
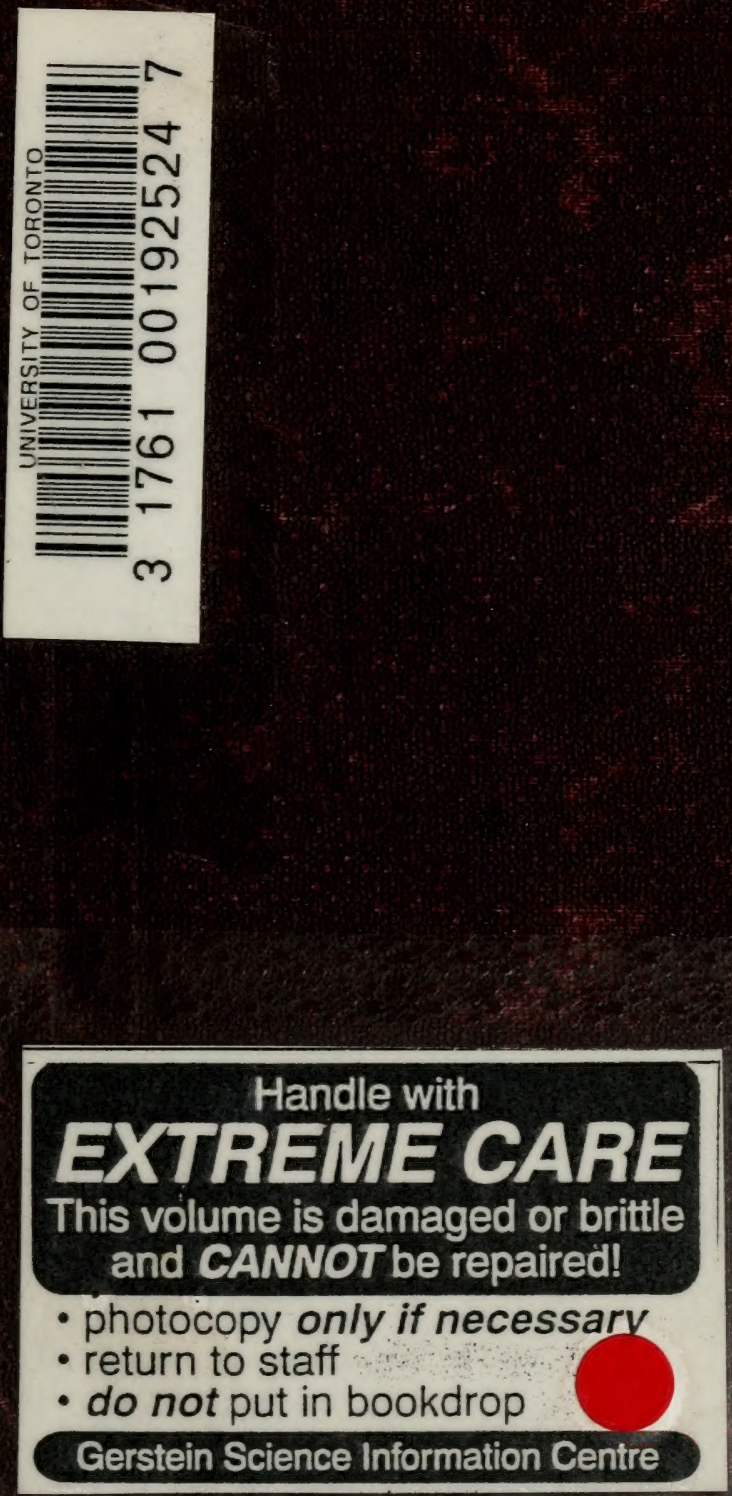


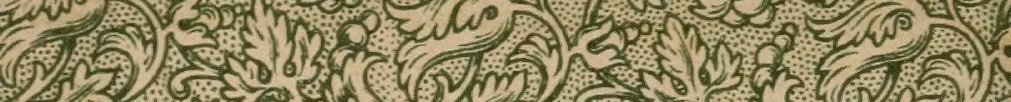

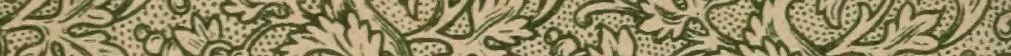
4.

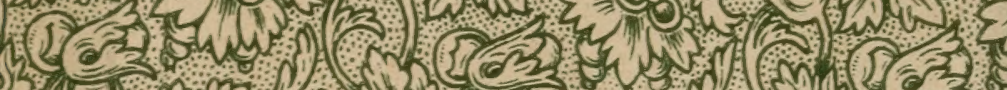
(2)

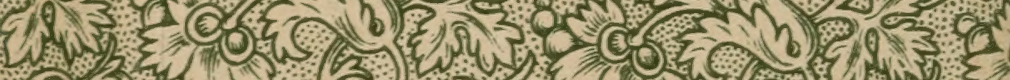

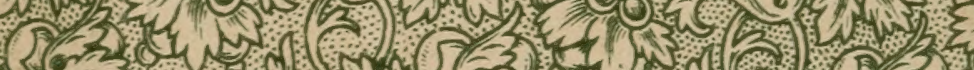
(1) 2.5.

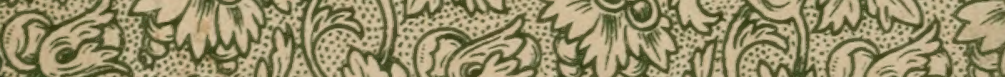

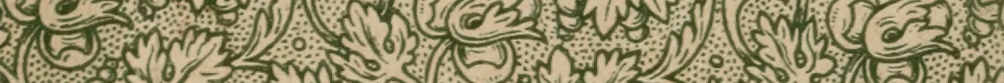

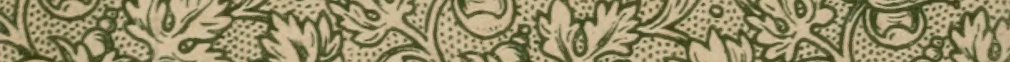
15. 3 - 5 .

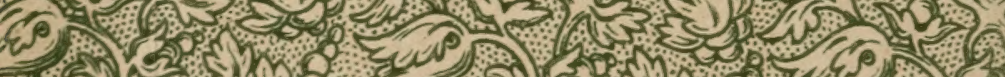
25) (5)

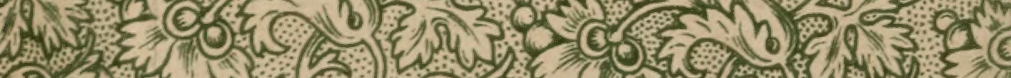

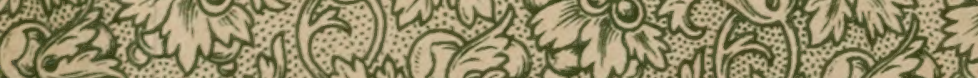

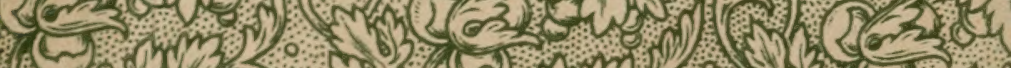

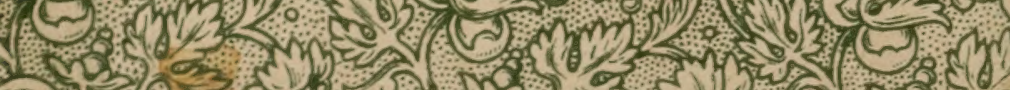

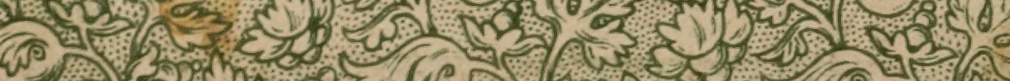











\section{0 *}

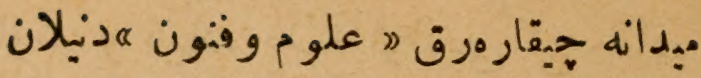

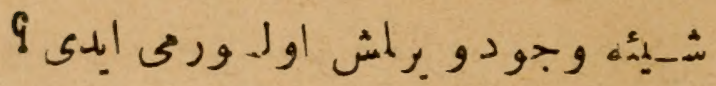

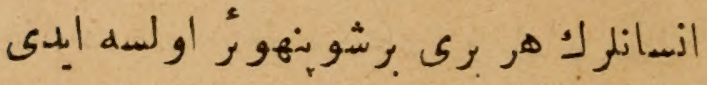

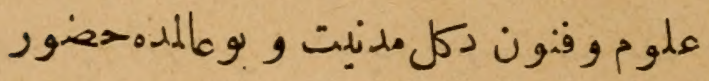

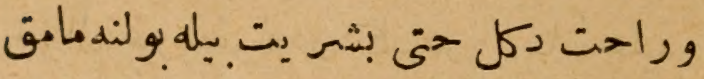

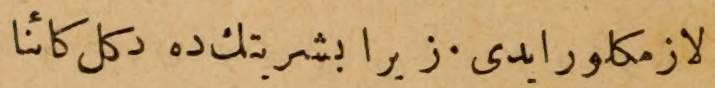

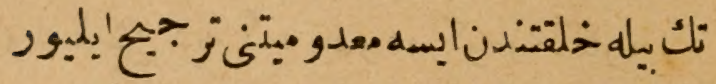

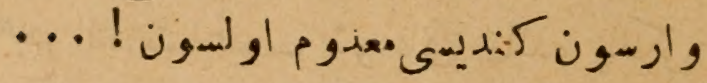


10\%

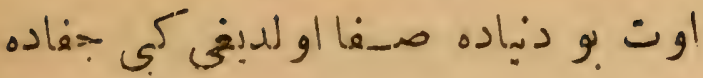

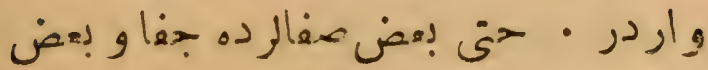

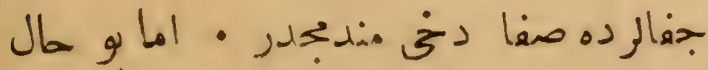

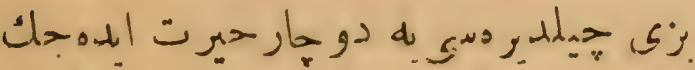

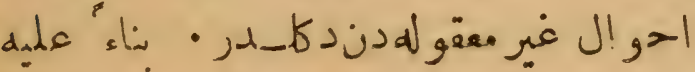

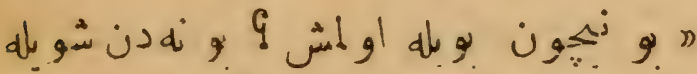

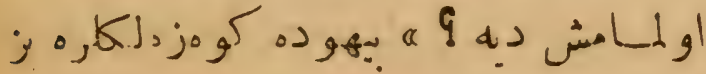

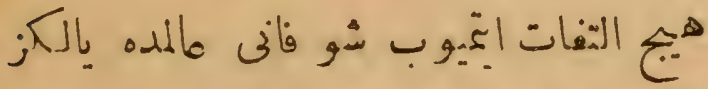

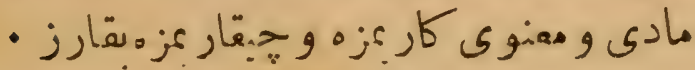

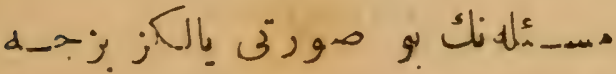

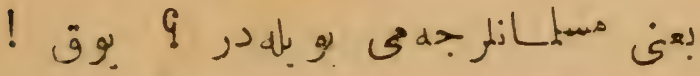

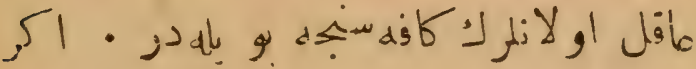

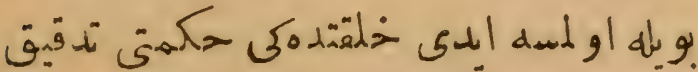

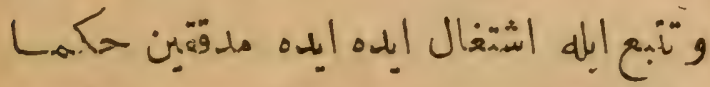
3. 


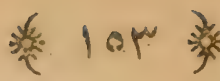

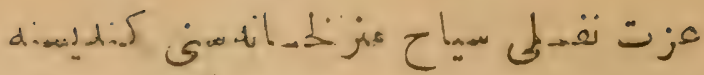

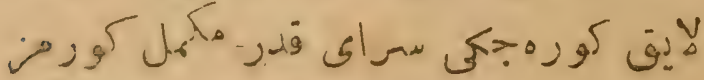

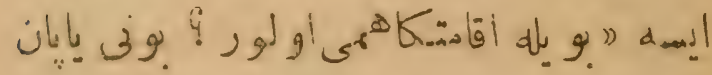

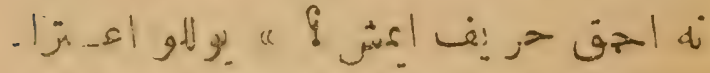

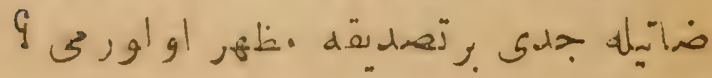

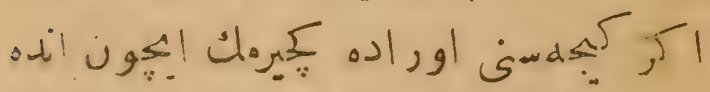

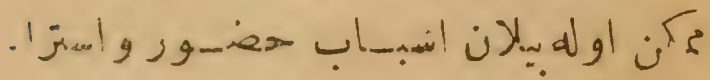

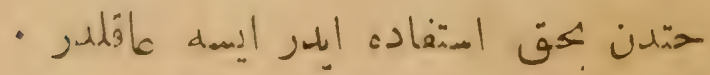

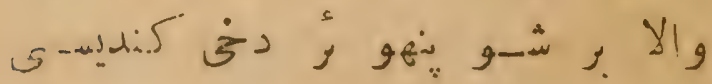
اولور الدور

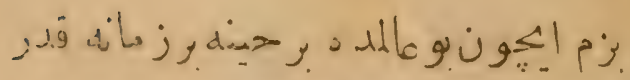

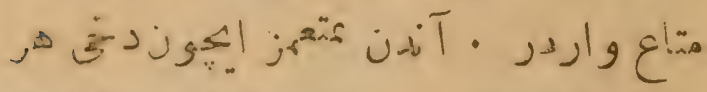

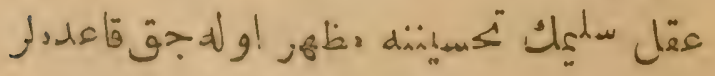

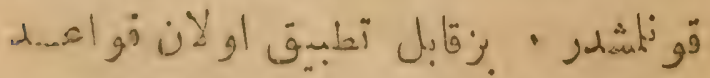

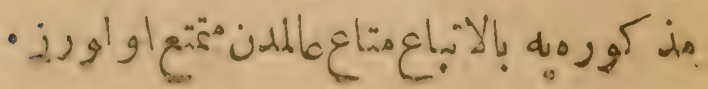




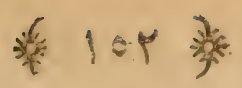

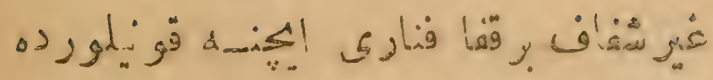

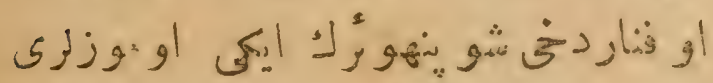

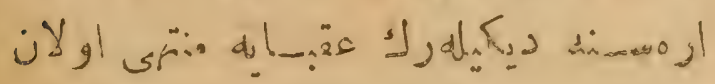

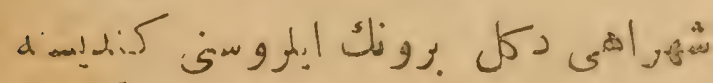
كم q

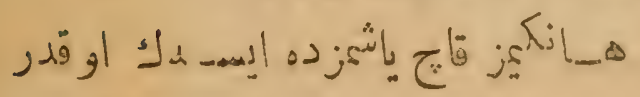

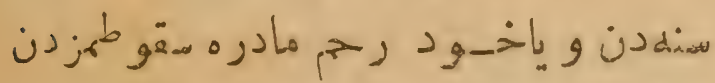

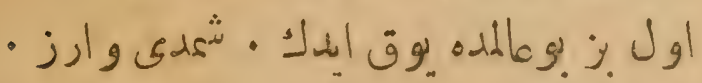

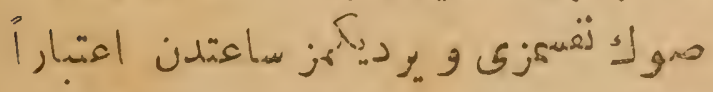

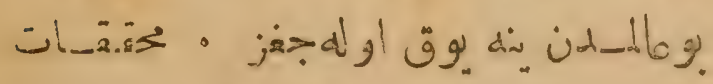

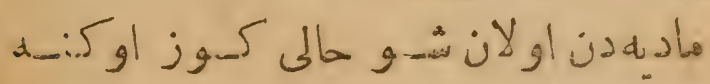

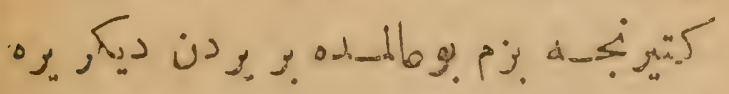

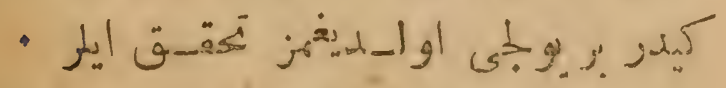
\% 
粉 101 標

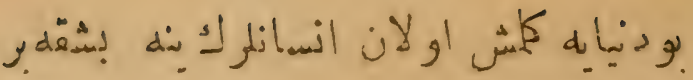

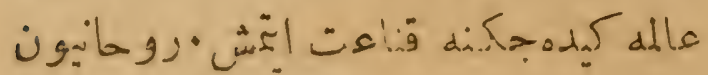

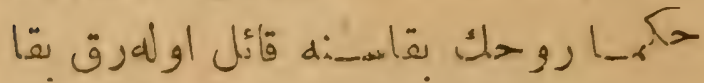

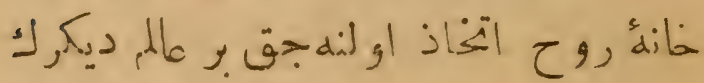

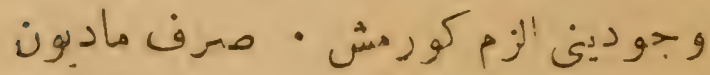

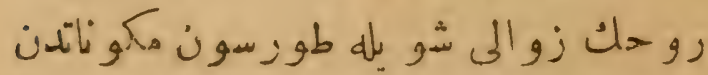

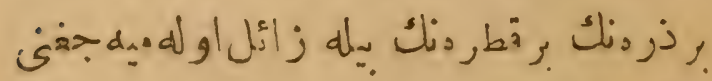

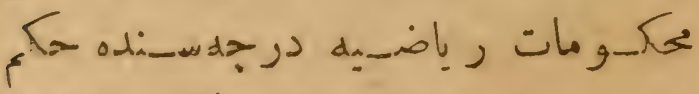

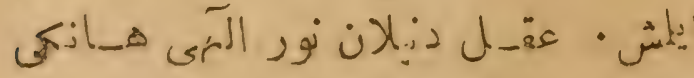
寉

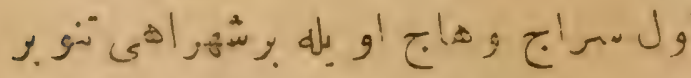

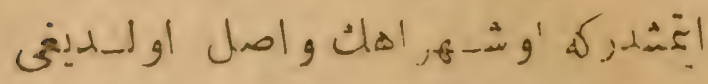

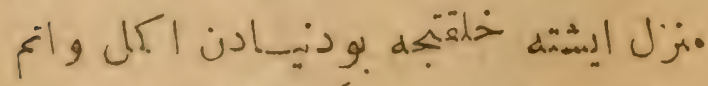

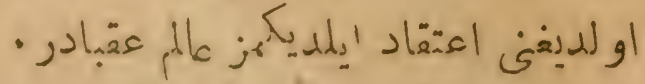

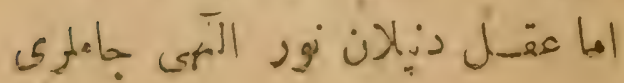


10.

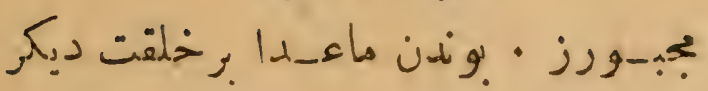

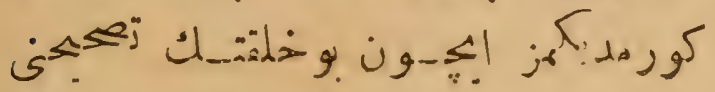

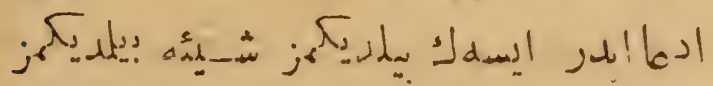

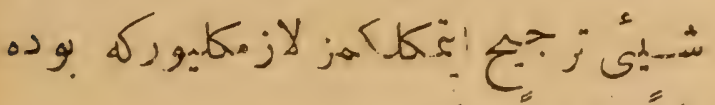
- كاًاً

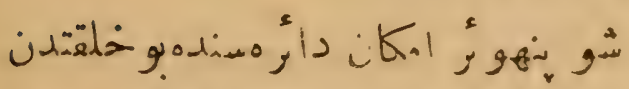

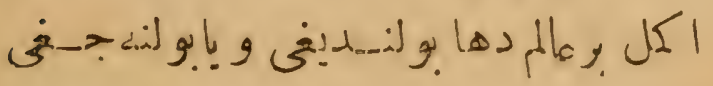

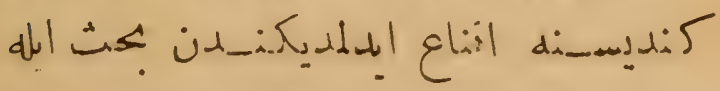

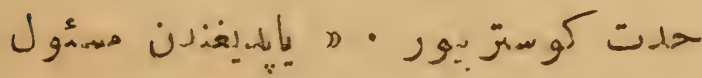

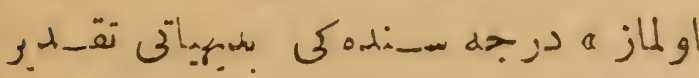

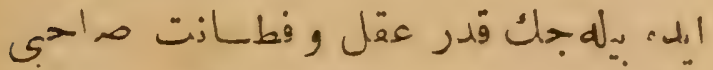

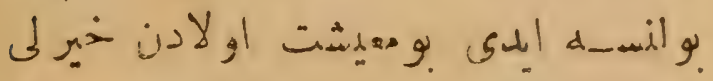

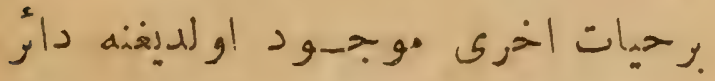

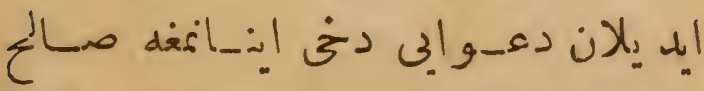

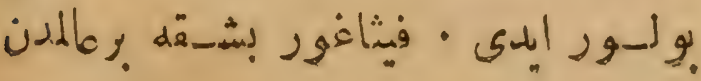


类 $1\{9$

b-

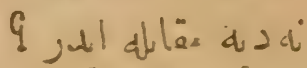

a a a

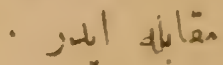

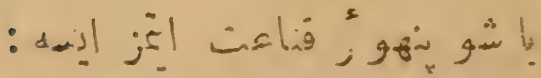

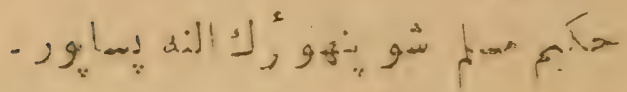

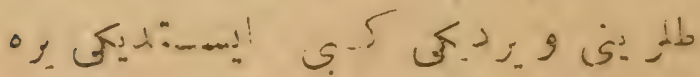

كو

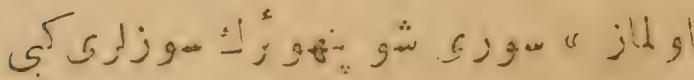

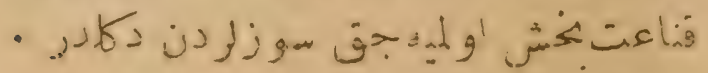

jyim

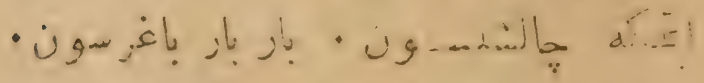

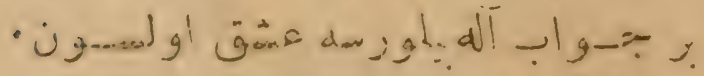

-

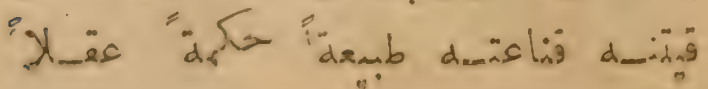


瓷 $1 \leqslant \Lambda$

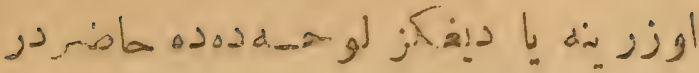

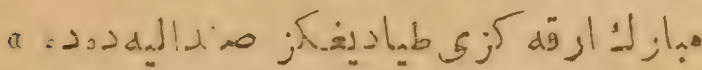

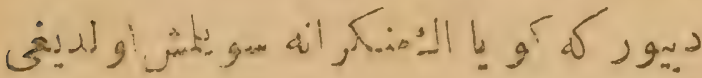

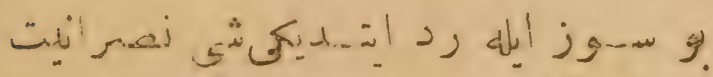
و وقبول , و

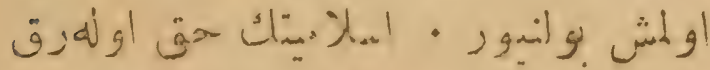

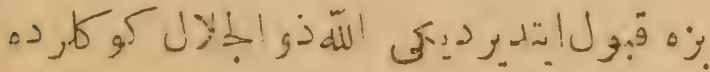

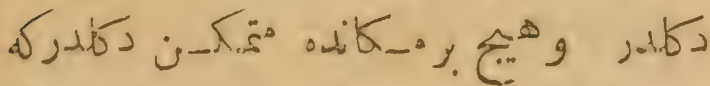

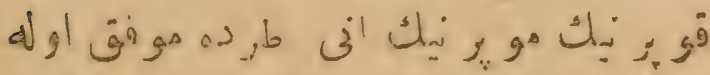
。

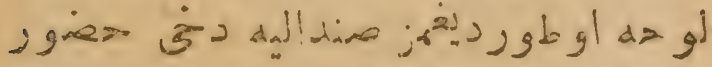

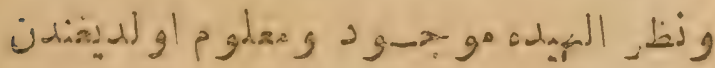

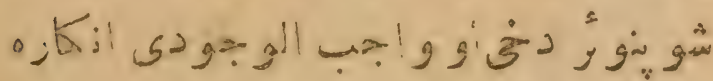

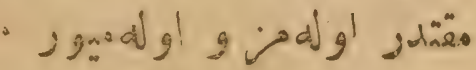

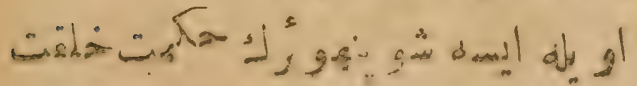


او منيحى درجهده اولهرق بردمديانت

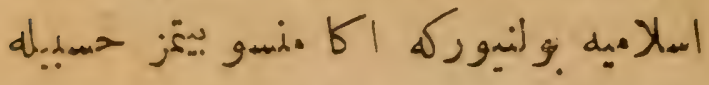

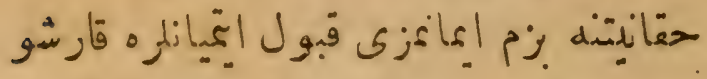

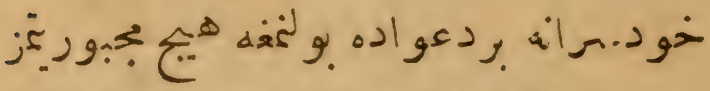

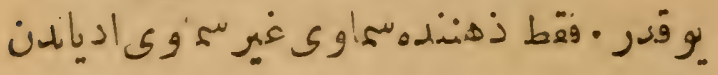

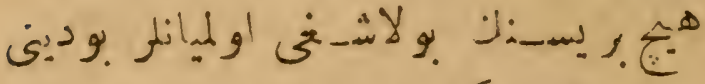

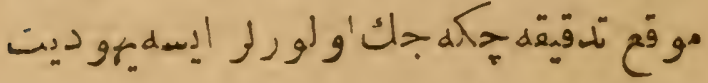

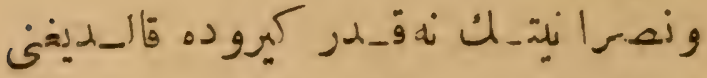

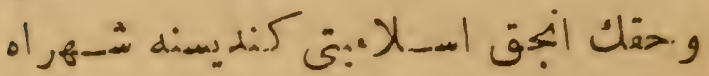

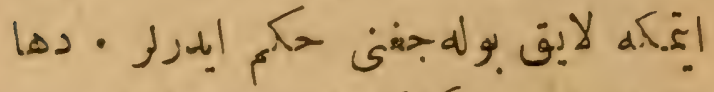

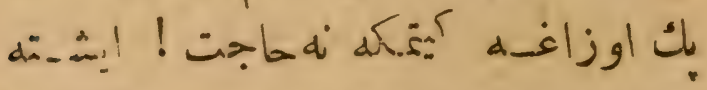

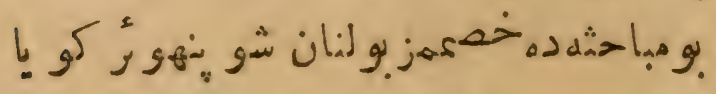

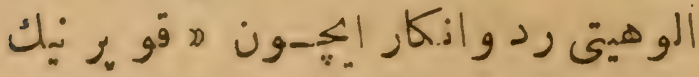

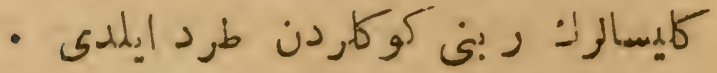

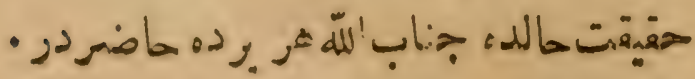


絭 129 泰

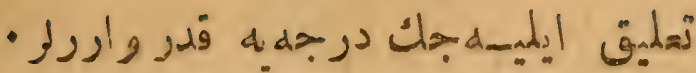

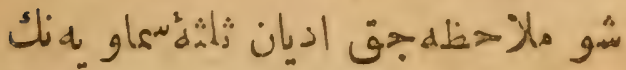

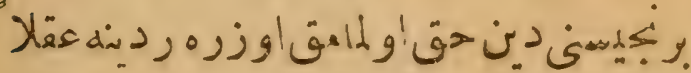

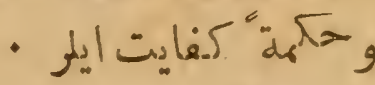

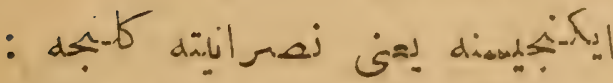

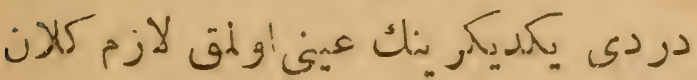

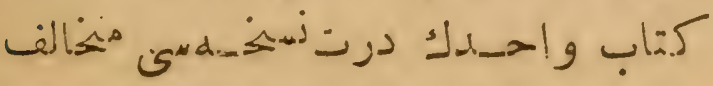

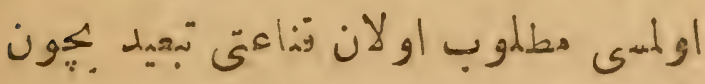

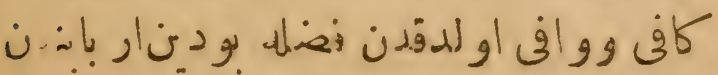

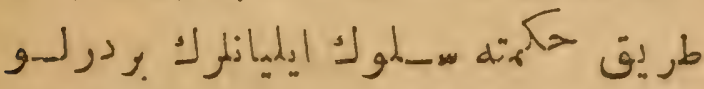

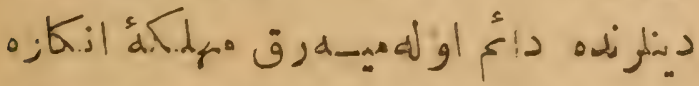

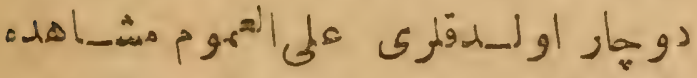

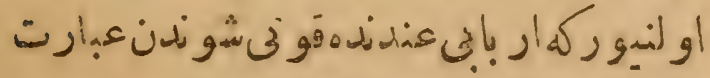

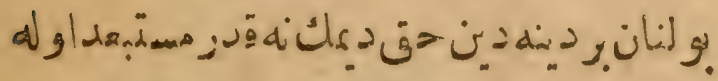

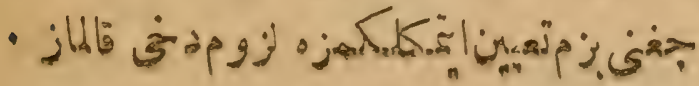




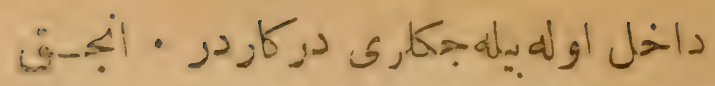

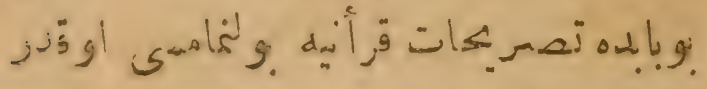

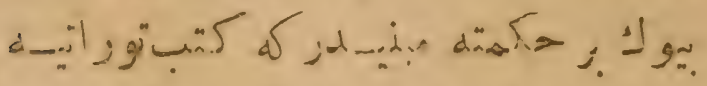

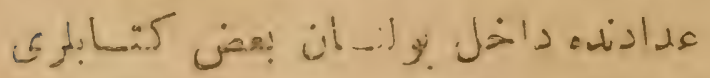

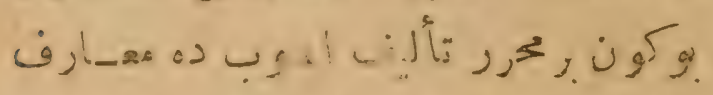

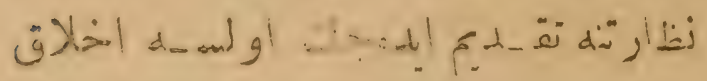

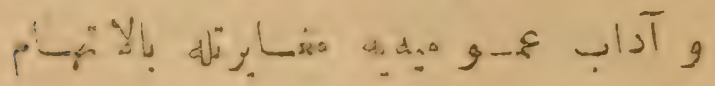
- ز

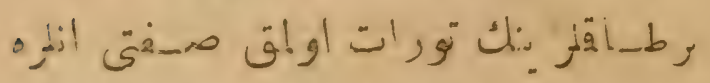

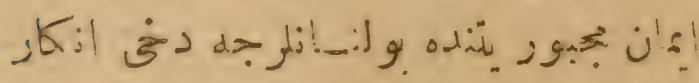

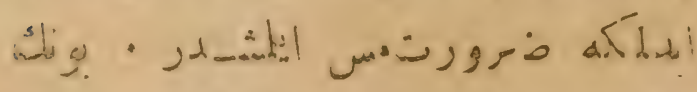
وز

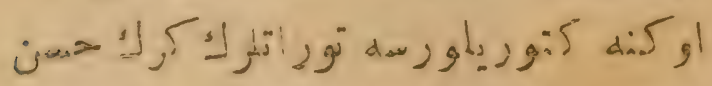

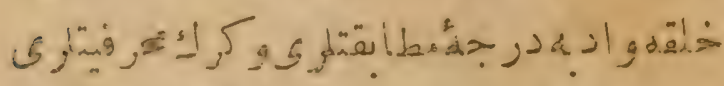
dis zab 


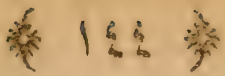

w

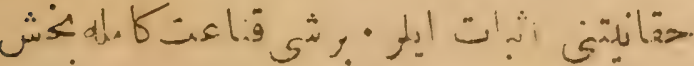

¿े

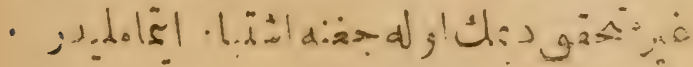

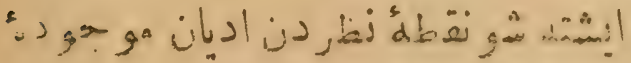

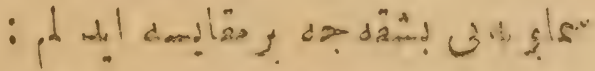

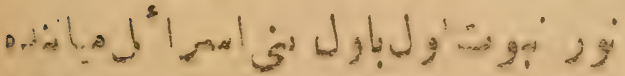

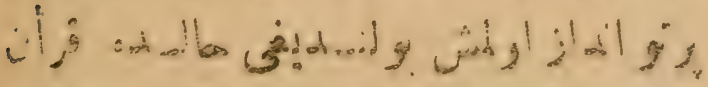

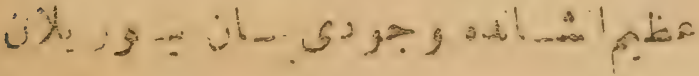

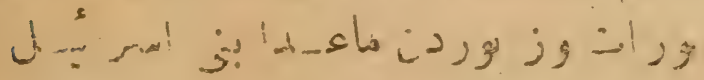

2-

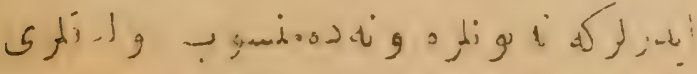

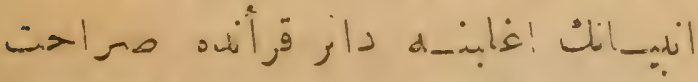

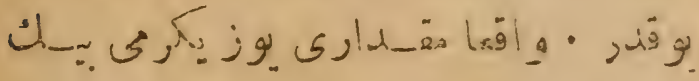

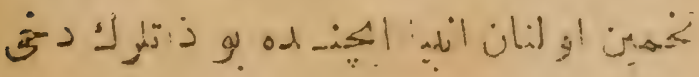




\section{1 $1 \leqslant p$}

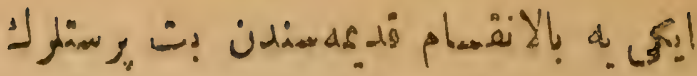

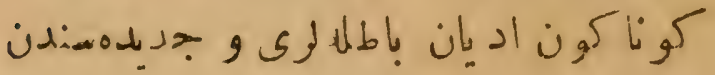

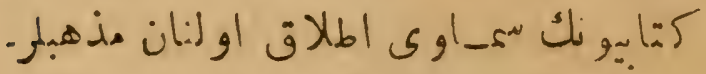

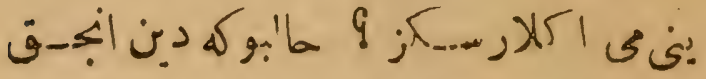

راه

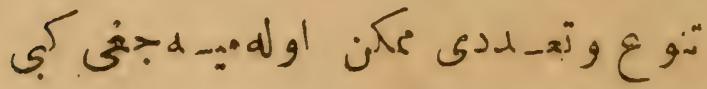

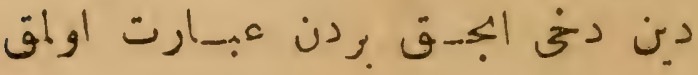

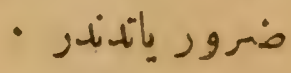

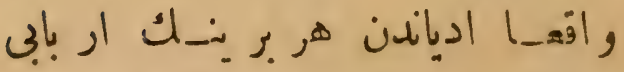

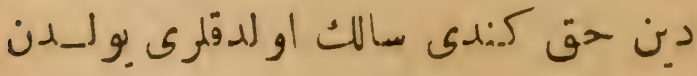

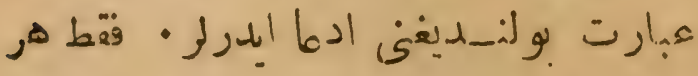

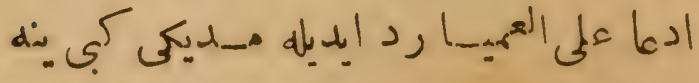

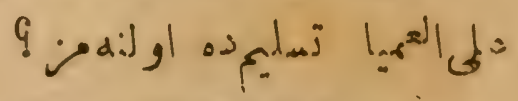

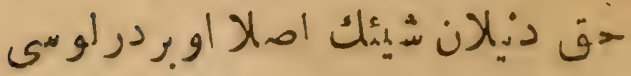

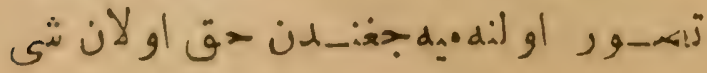


$1 \xi ץ$

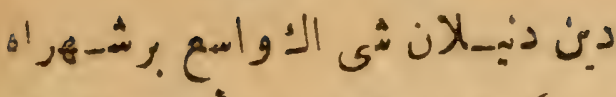

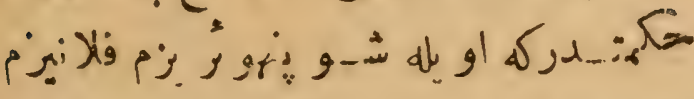

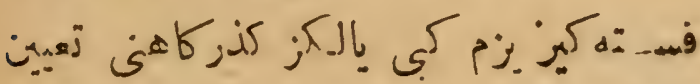

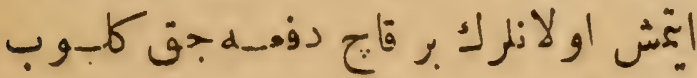

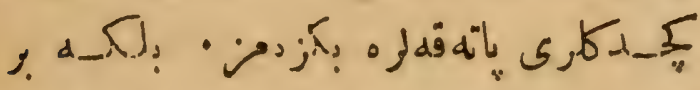

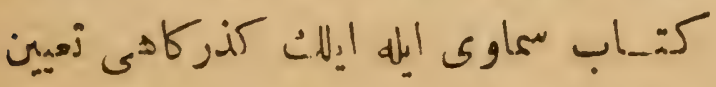

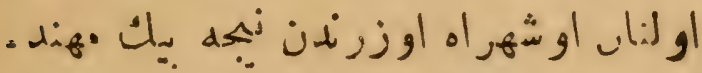

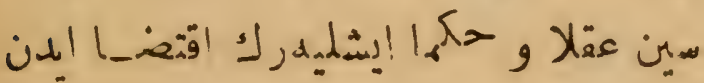

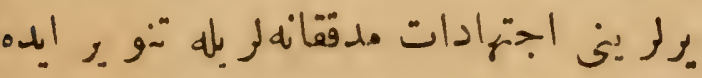

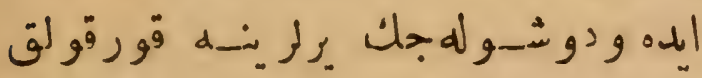

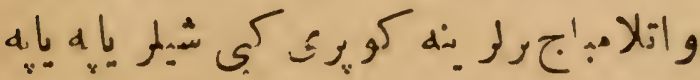

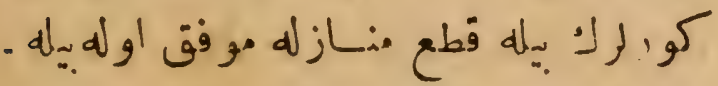

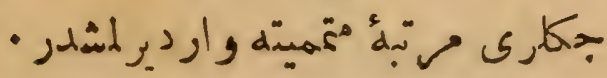

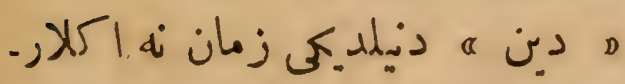

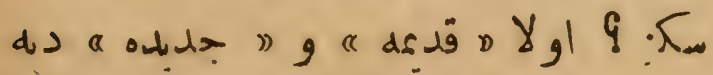


181

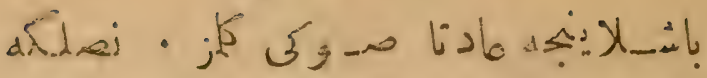

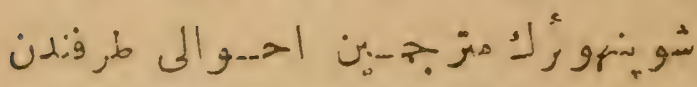

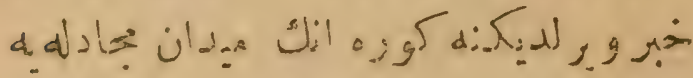

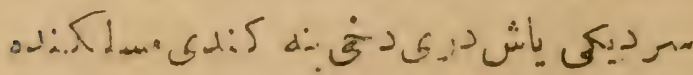
S.

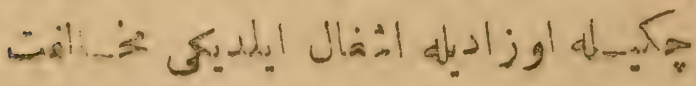

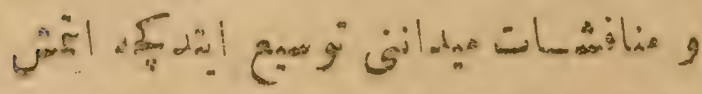

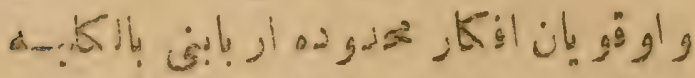
ن

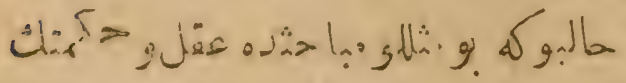

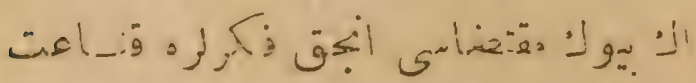

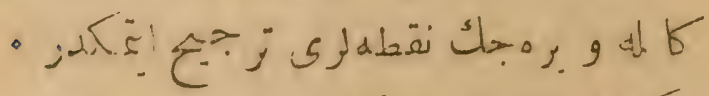

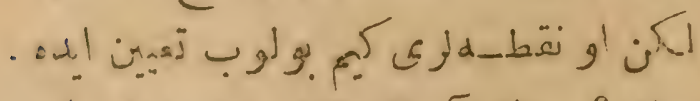
جله

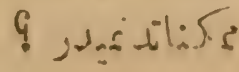


$1 \varepsilon \cdot$

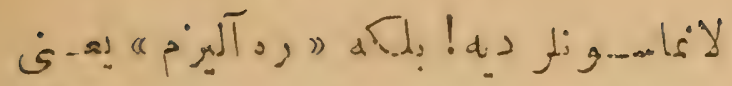

d

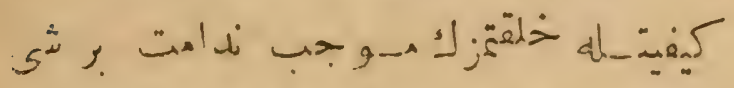

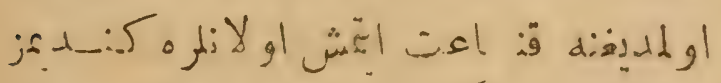

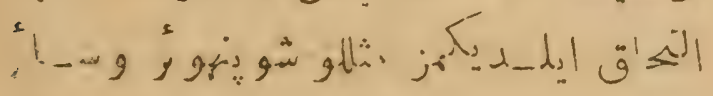

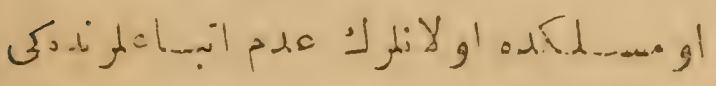

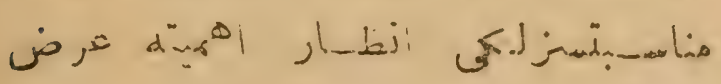

-

$ث$

-

a

.

و . ش

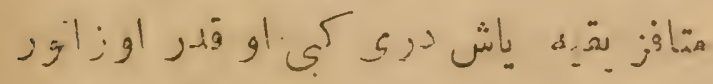

5 ibi-1. 


\section{$14 \mathrm{q}$}

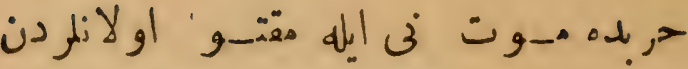

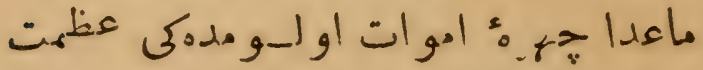

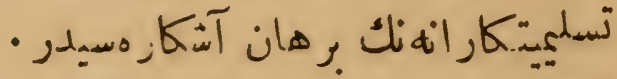

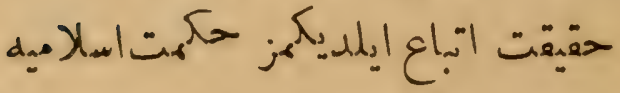

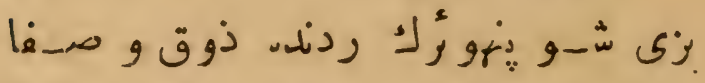

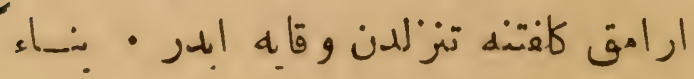

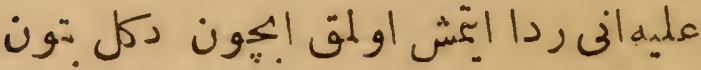

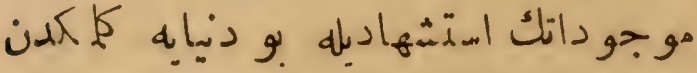

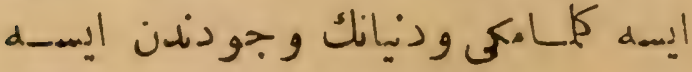

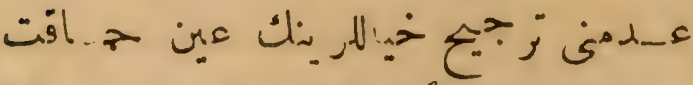

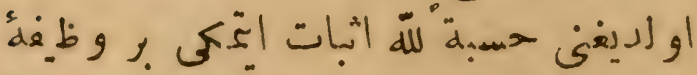

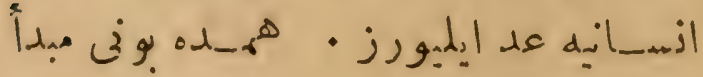

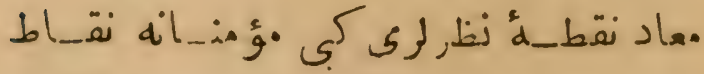

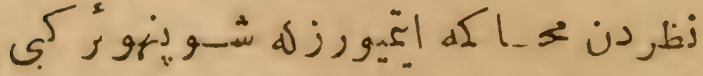

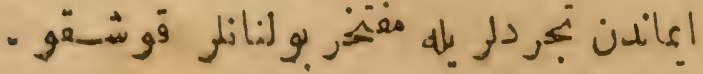


$\operatorname{lr} \Lambda$

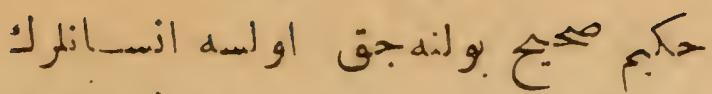

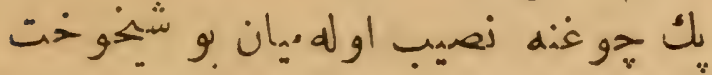

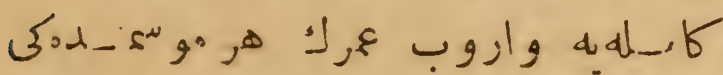

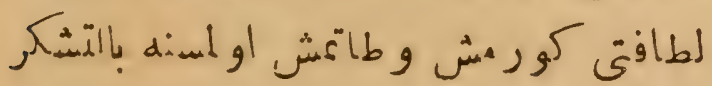

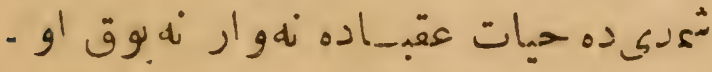

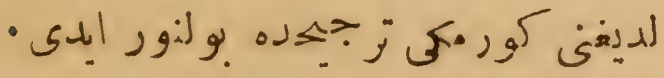

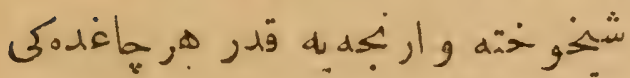

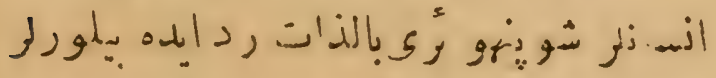

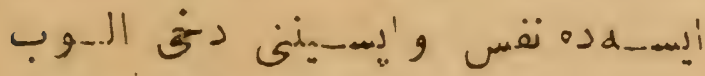

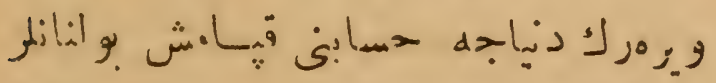

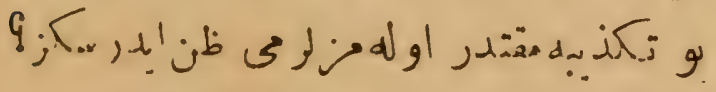

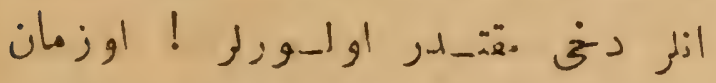

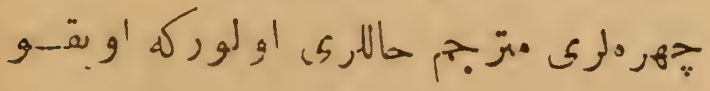

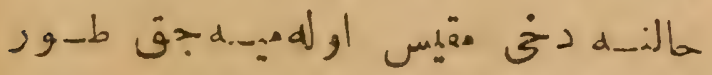

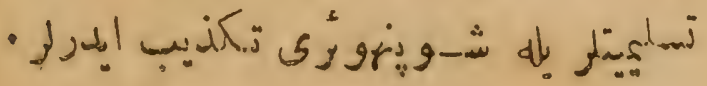


药

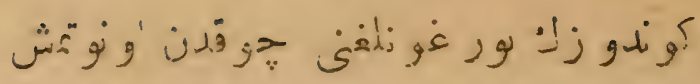

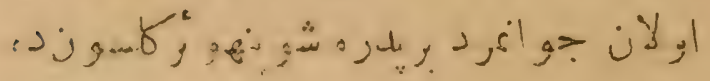

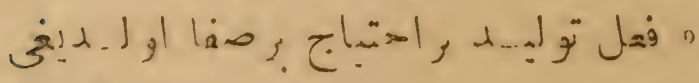

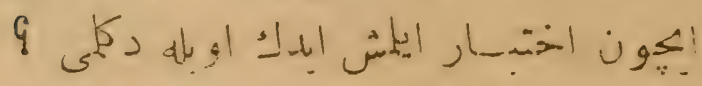

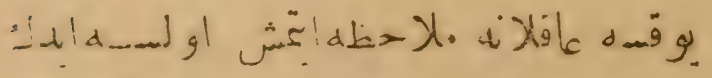

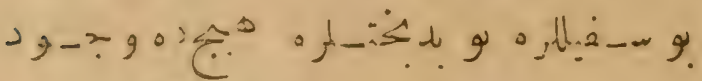

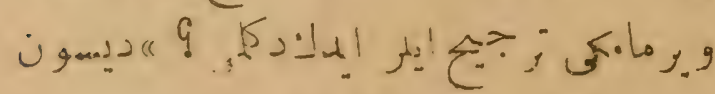

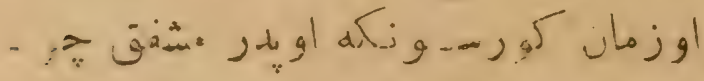

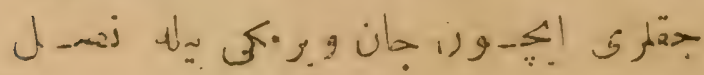

;

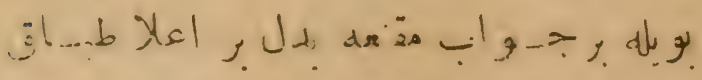

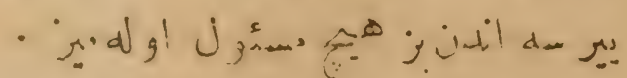

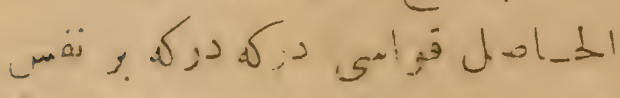

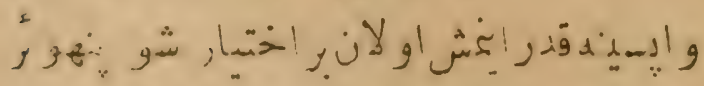

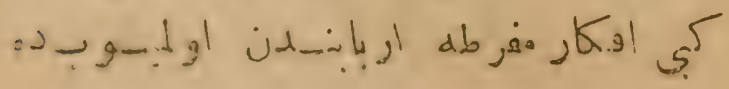


先 1 m

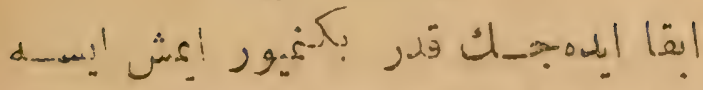

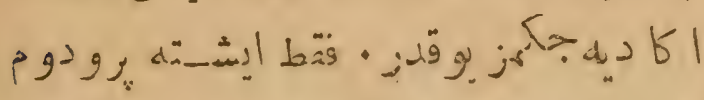

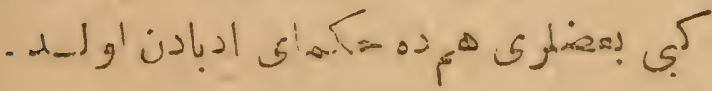
كتز

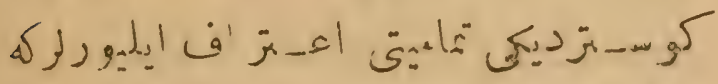

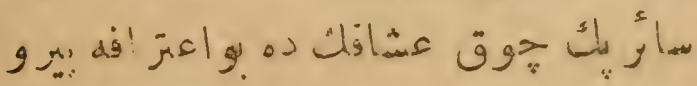

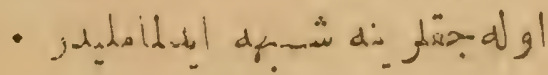

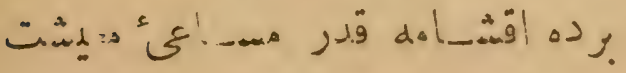

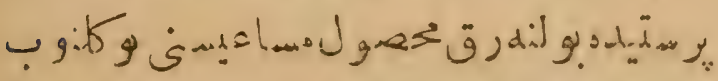

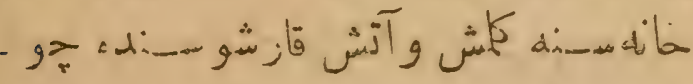

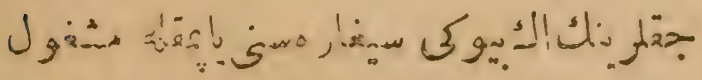

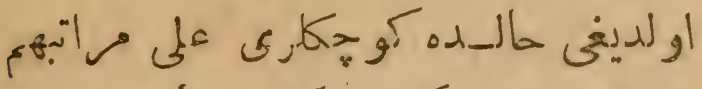

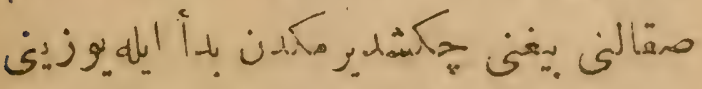

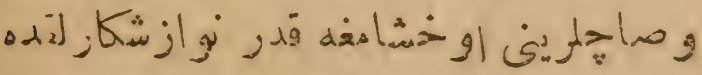

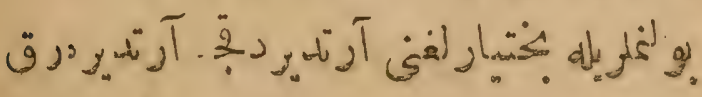


1 $10_{0}$

ز زمان ك ن

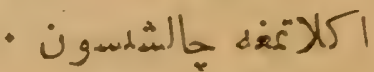

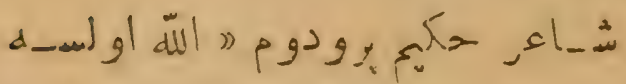

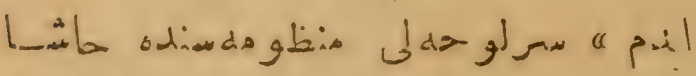

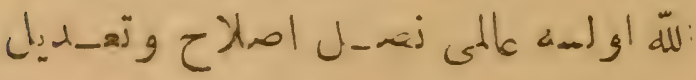

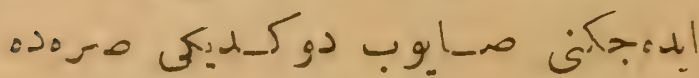

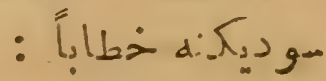

Je le laisserais la même si j’étais Dieu.

9. لئن

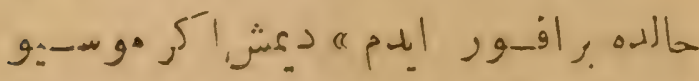
ش bا 


\section{1 世经}

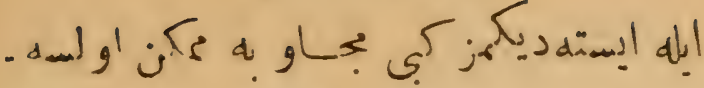

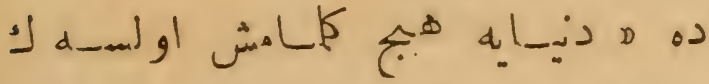

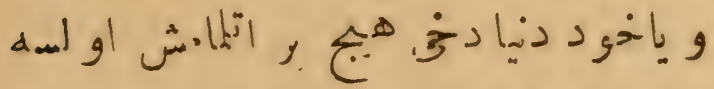

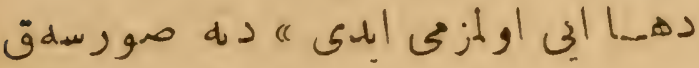

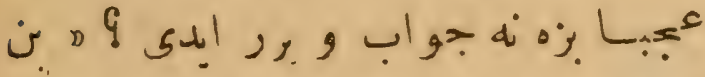

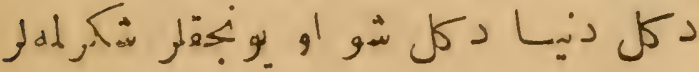

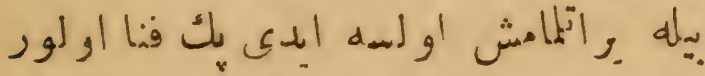

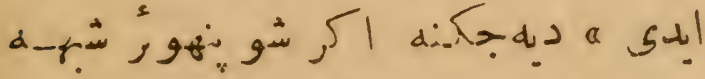

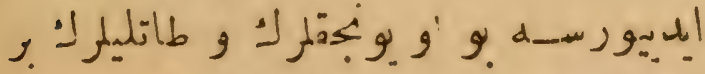

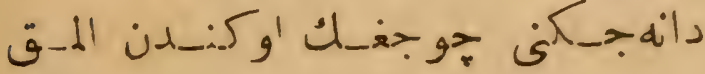

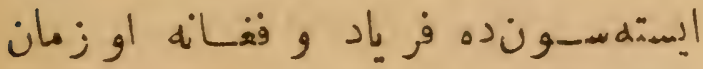
باقتسون السته

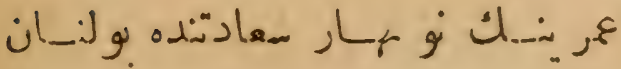

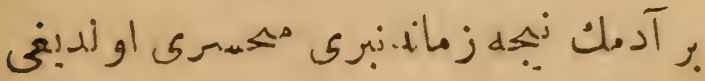

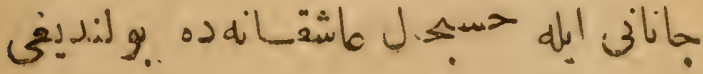


采似莎

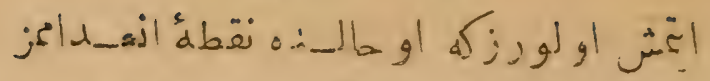

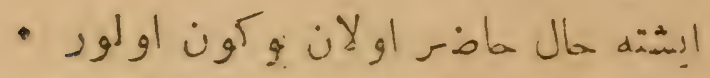

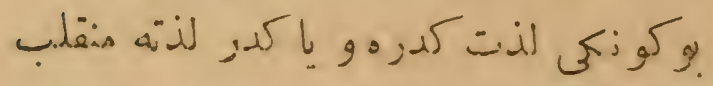

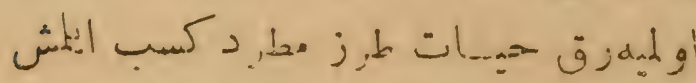

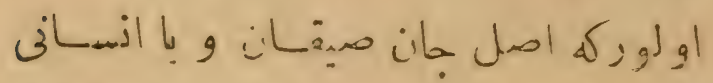

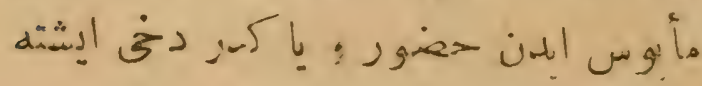

•

ज小

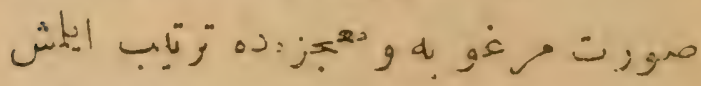

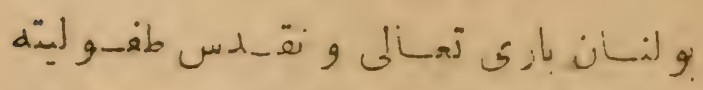

نا

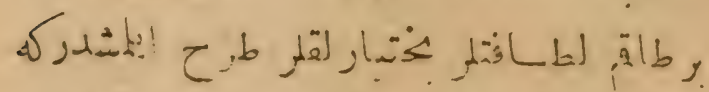

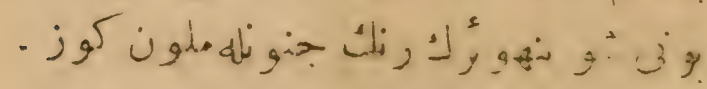

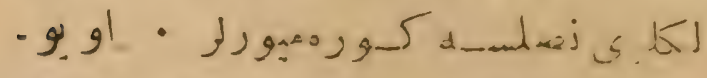

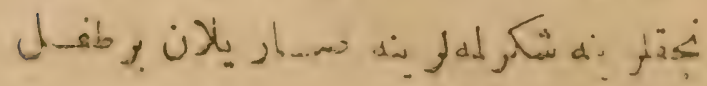


lor

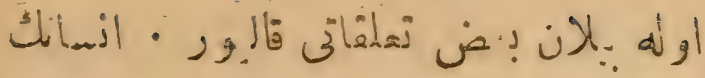

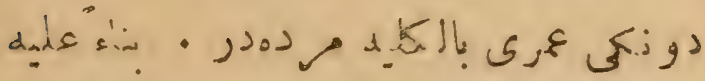

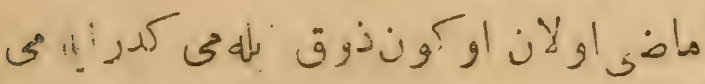

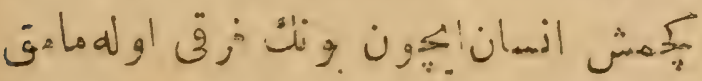
!

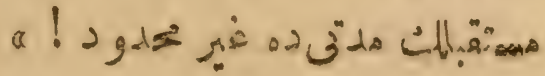
"و

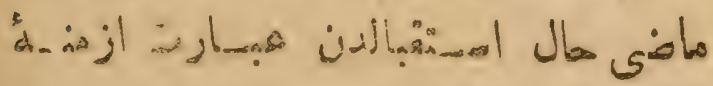
ن

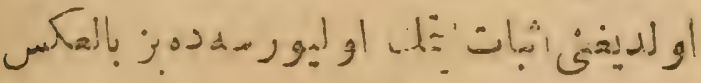

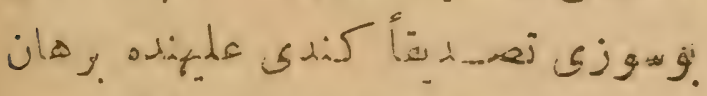

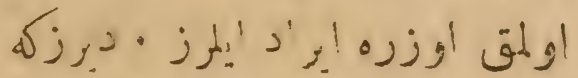

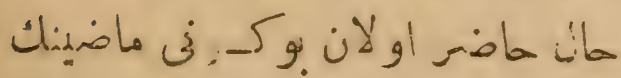

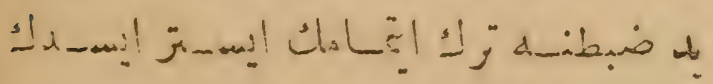

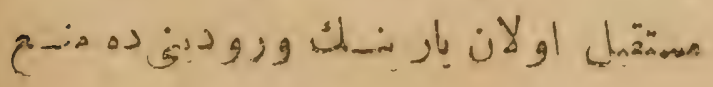




\section{$|m|$}

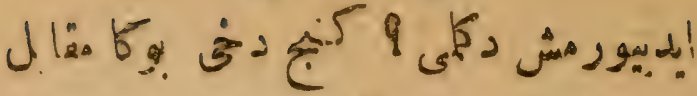

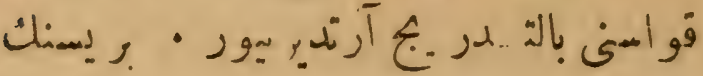

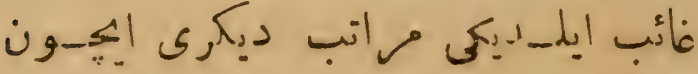

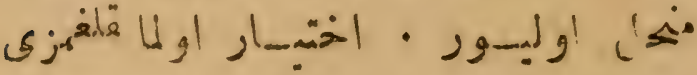

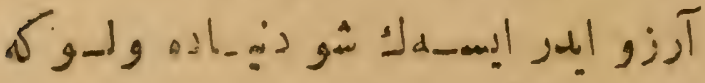

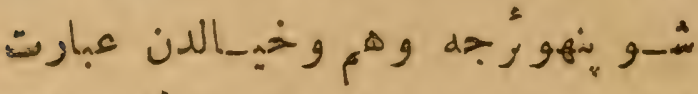

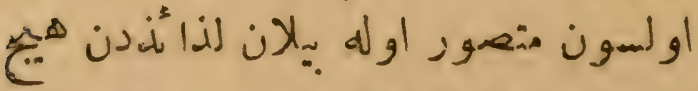

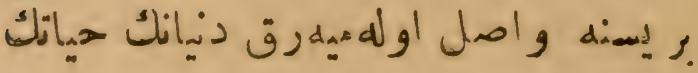

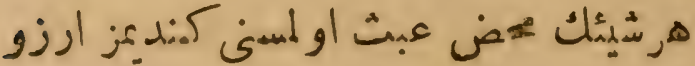

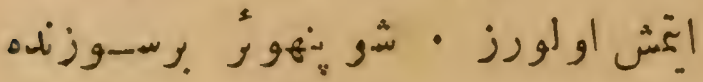
د.2.

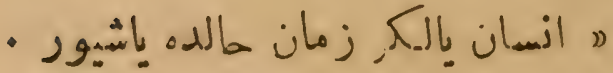

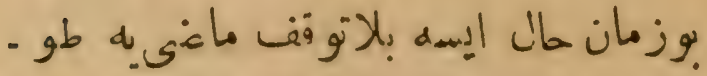

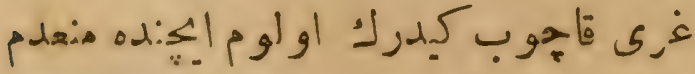

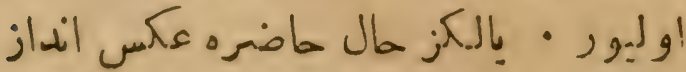




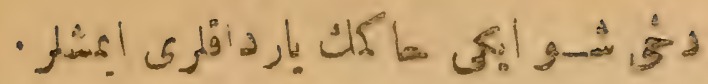

Sod_is

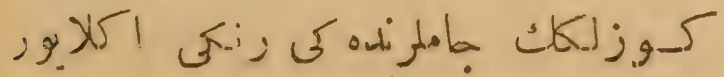

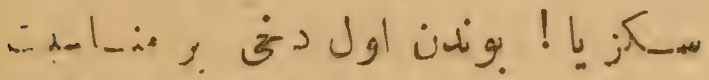

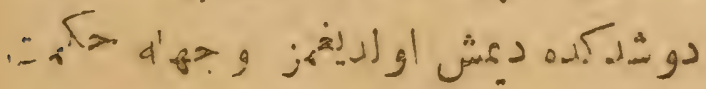

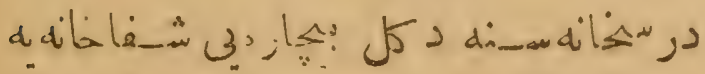

- bojolig:

حال هر هis

لز

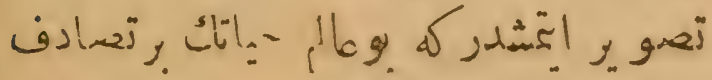

.

خاق ادار

I)

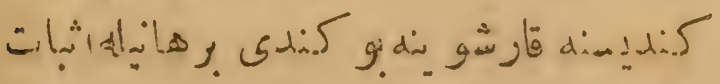

إ 
拳 1199

" 39 S

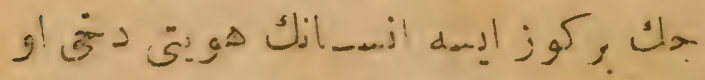

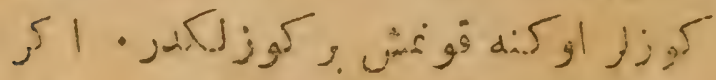

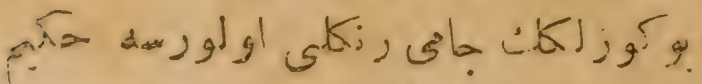

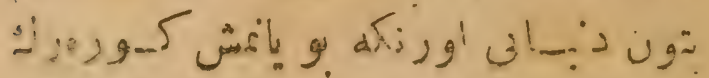

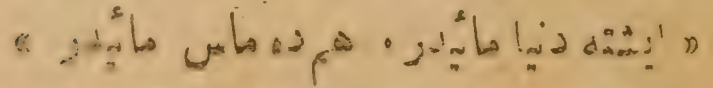

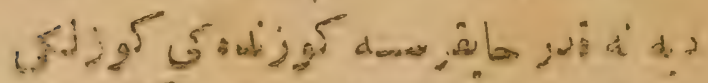

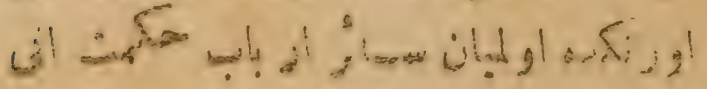

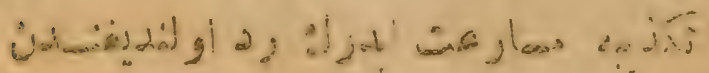

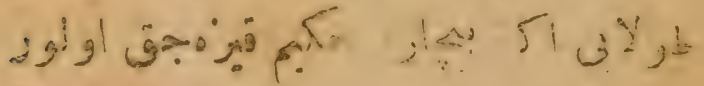

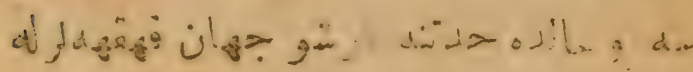

- is

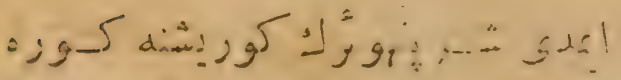

r $=$ ت

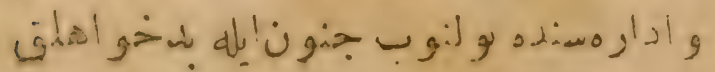




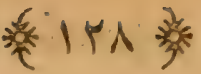

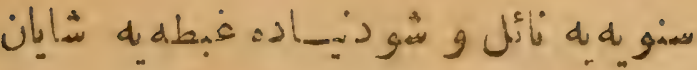
iو

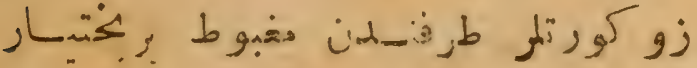
إيك

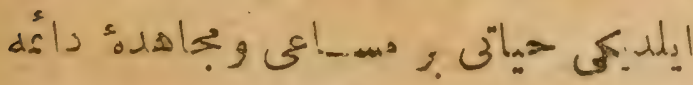

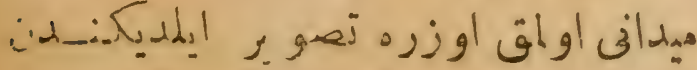

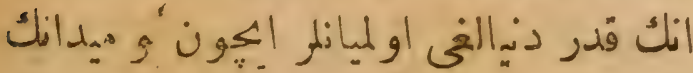

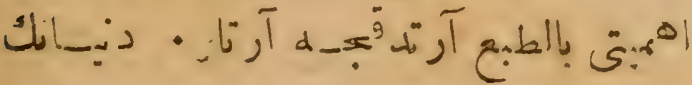

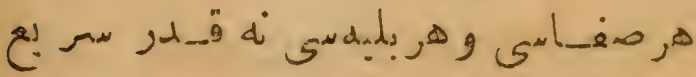

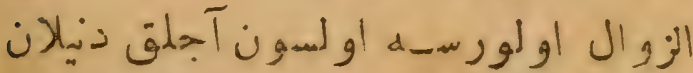

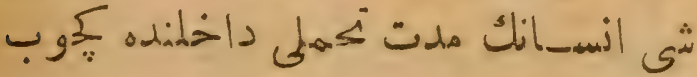

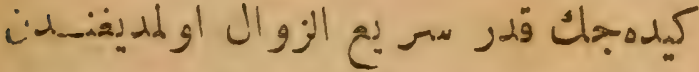
D هار ها! - jovis a sol. 
IrV

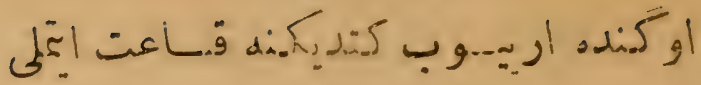
-

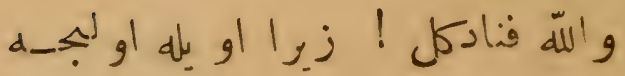

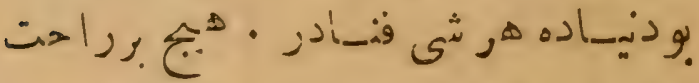

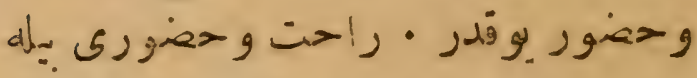

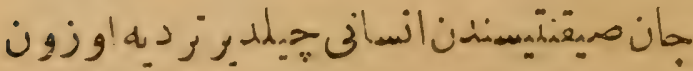

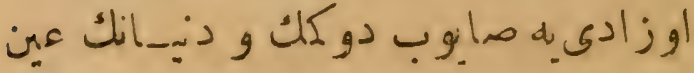

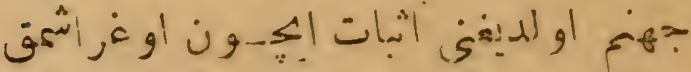

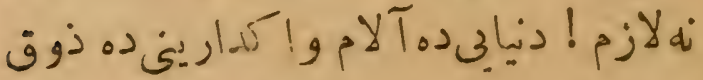

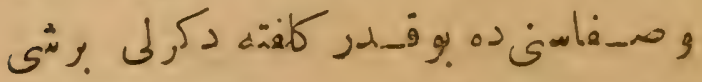

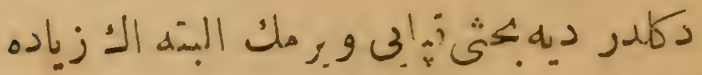

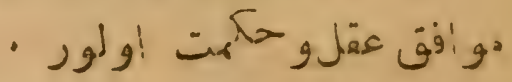
هis

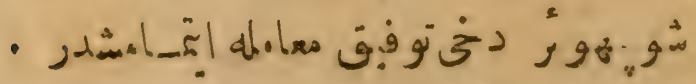

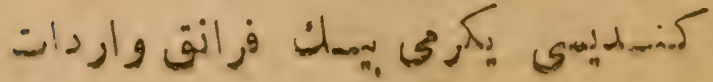




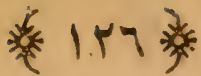

واروب كمنديسى دكل بو دنهـا بيله خحلدق

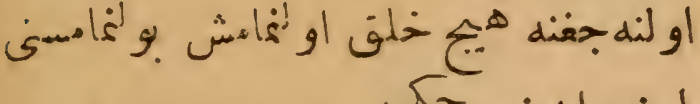

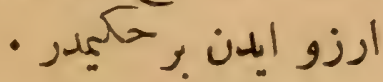

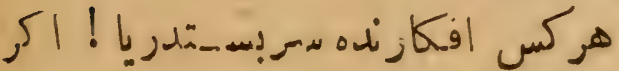

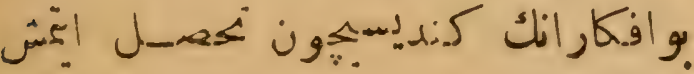

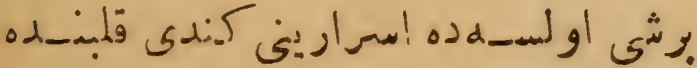

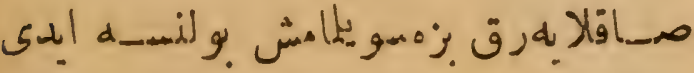

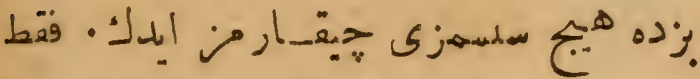

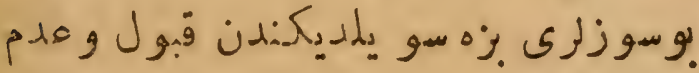

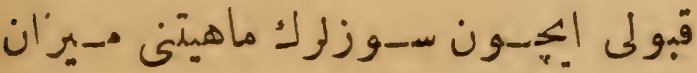

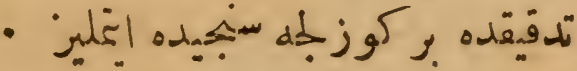

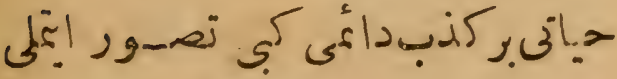

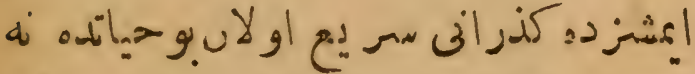

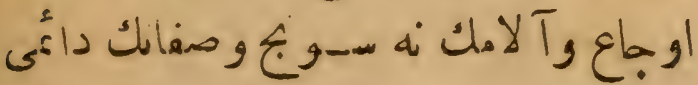

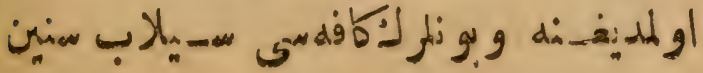


菜 190

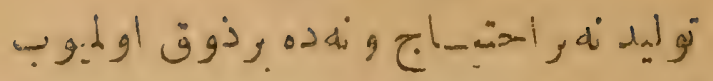

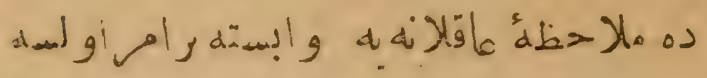

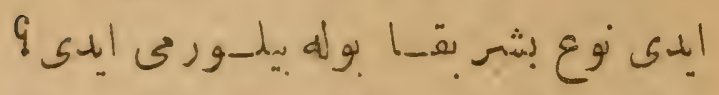

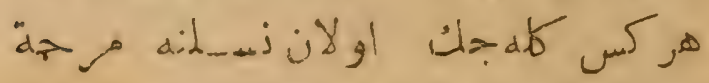

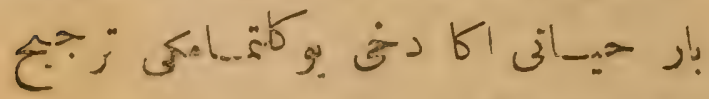

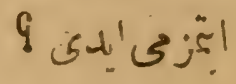

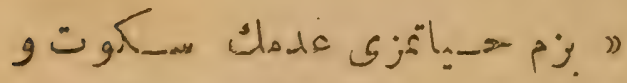

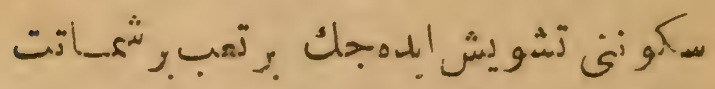

a ع ع

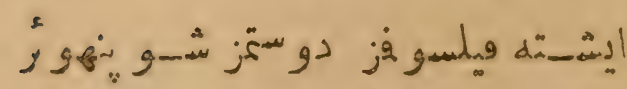

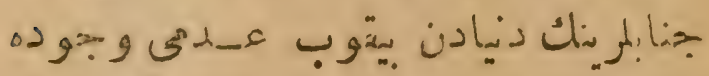

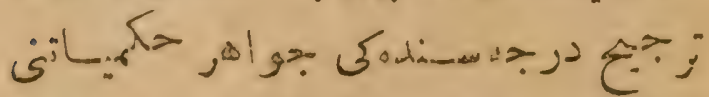

د

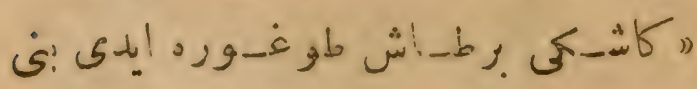

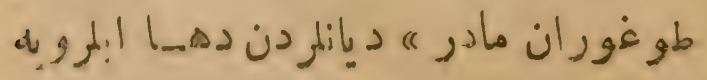




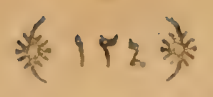

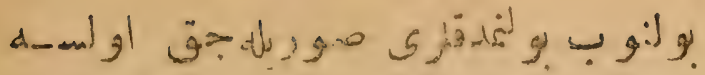

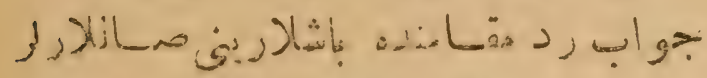
.

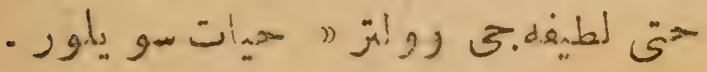

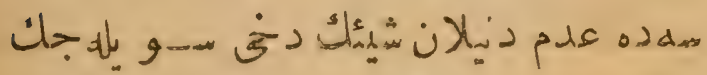

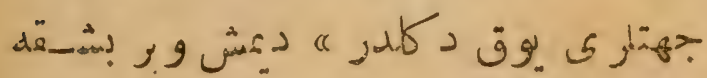

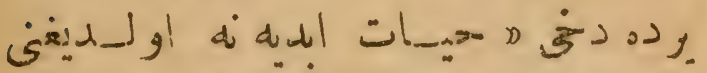

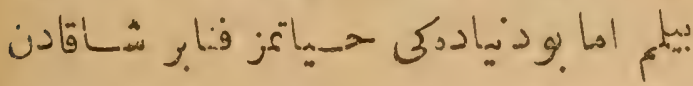

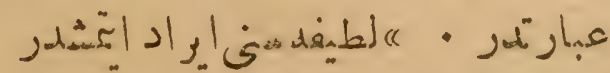

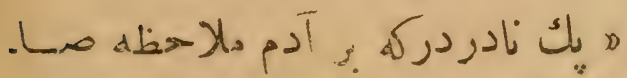

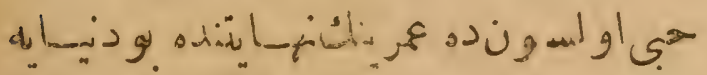

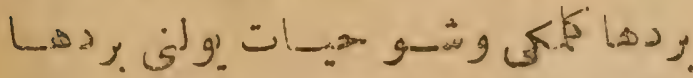

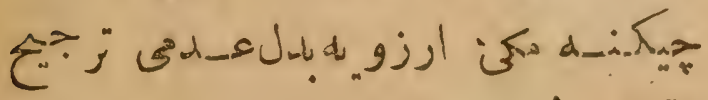
a! إتمدون

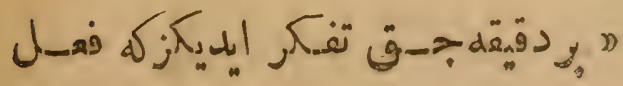


篦

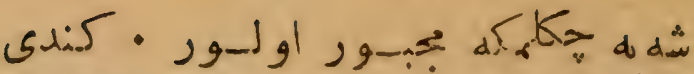

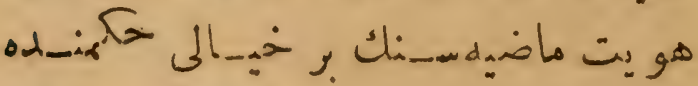

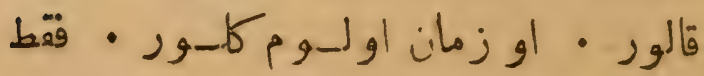

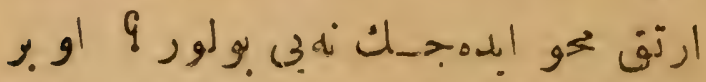

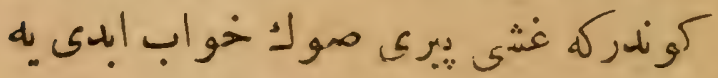

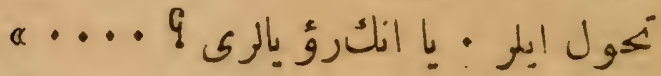

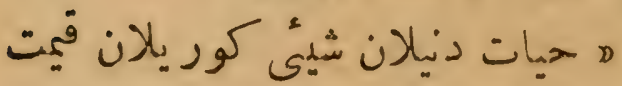

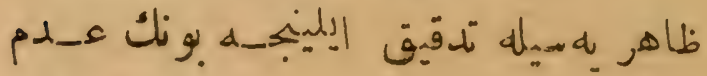

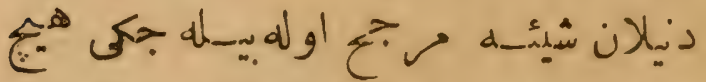

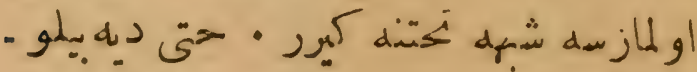

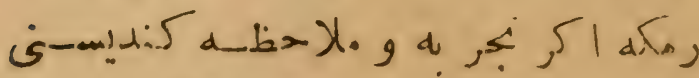

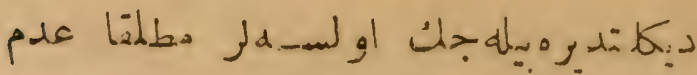

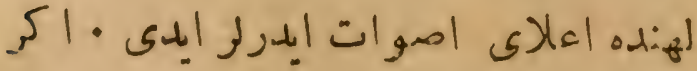

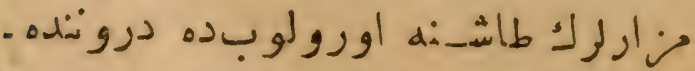

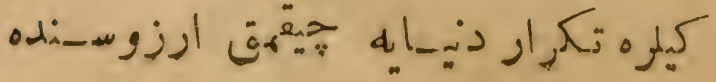


然 Irr

وديركه بودنيا نع_ادف البه خطانك تيكت

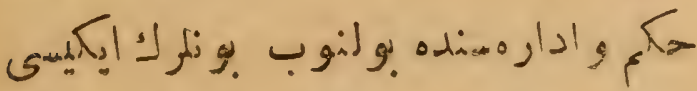

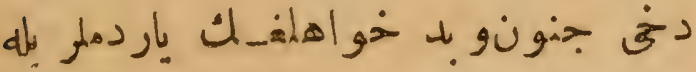

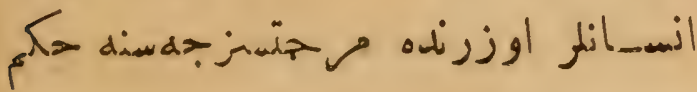
a a a مروزل ه اختيار اقت مالنده ارزولز وهو سملم

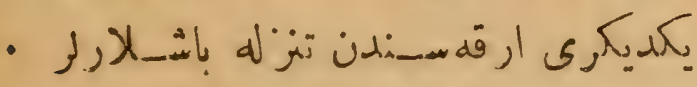

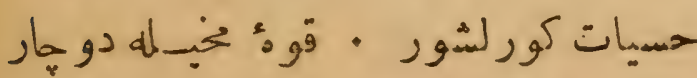

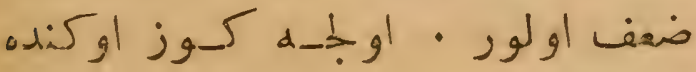

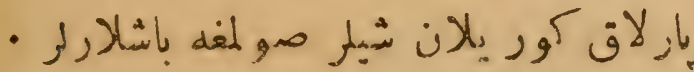

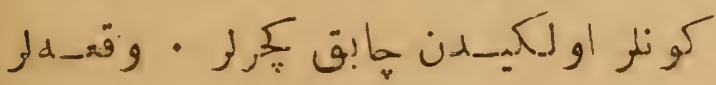

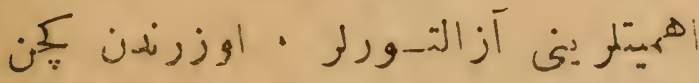

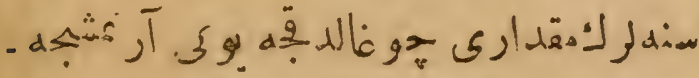

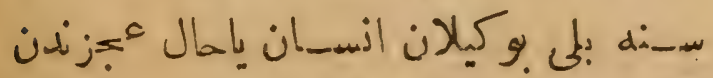
- 


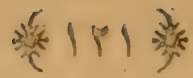

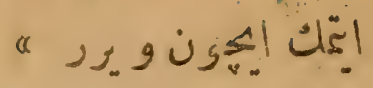

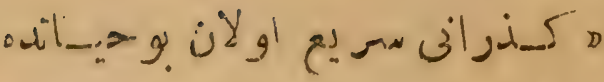

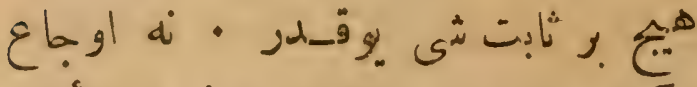

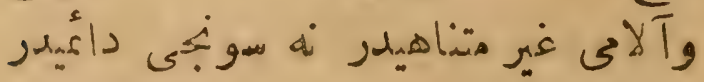

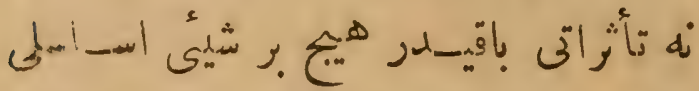

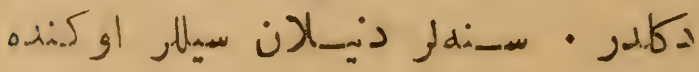

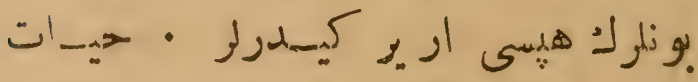

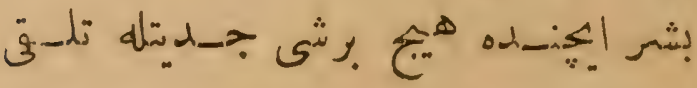
a

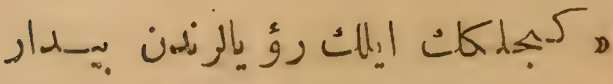

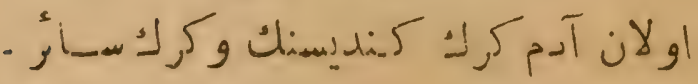

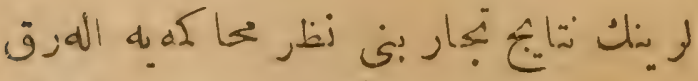

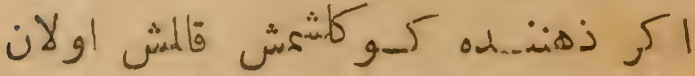

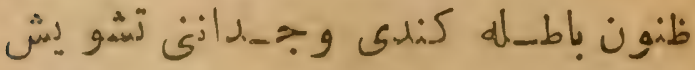

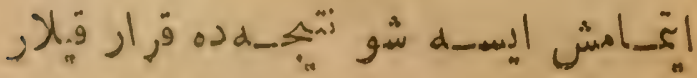




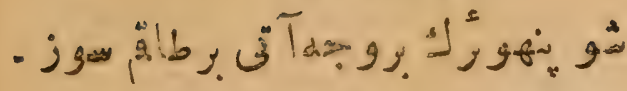

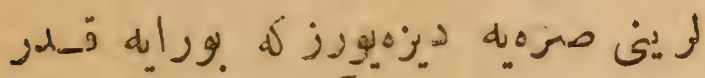

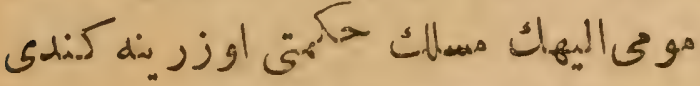

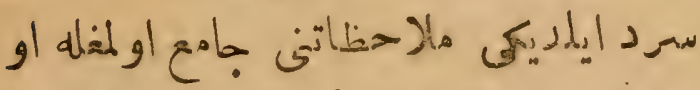

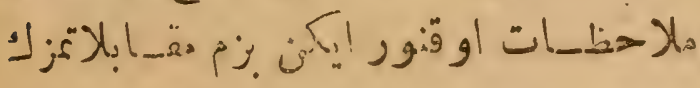

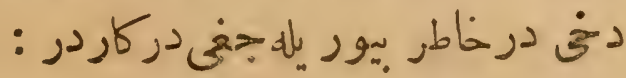

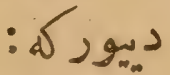

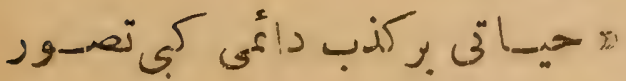

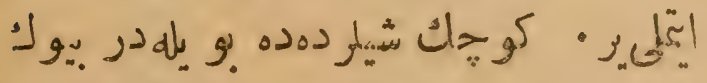

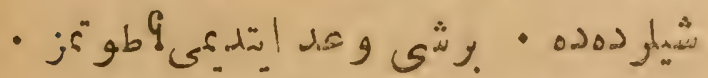

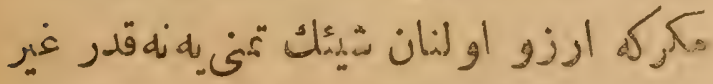

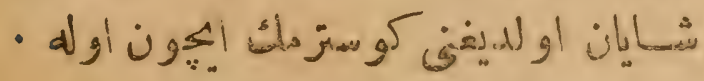
.

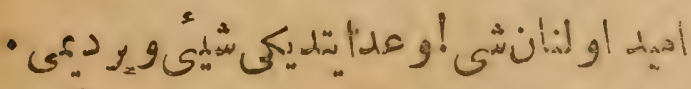

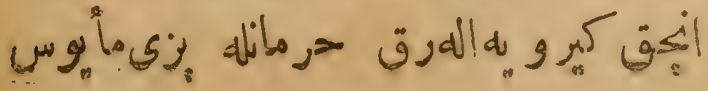




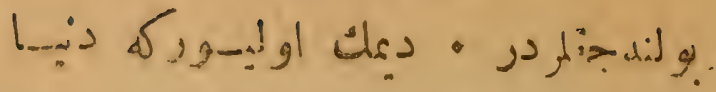

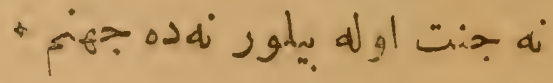

$$
\begin{aligned}
& \text { ! }
\end{aligned}
$$

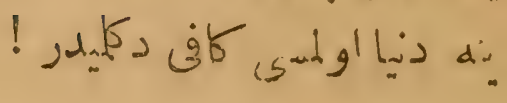

$$
\begin{aligned}
& \text { ثه } \\
& 5
\end{aligned}
$$

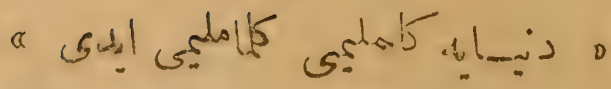

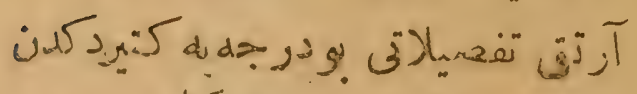

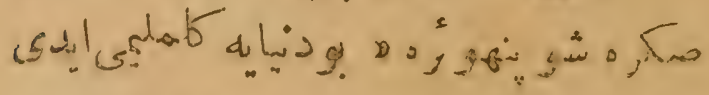

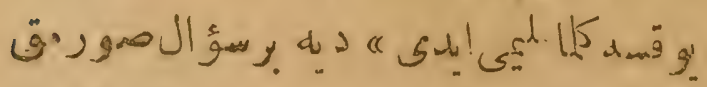

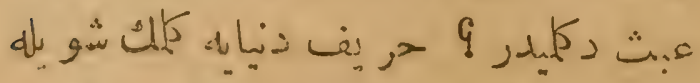

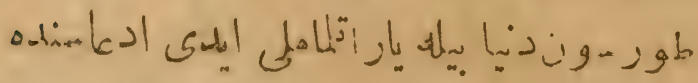

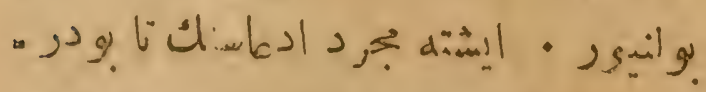

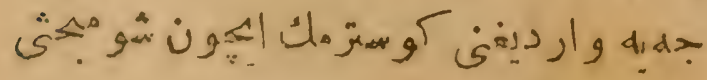

$$
\text { - }
$$




\section{染 111 絭}

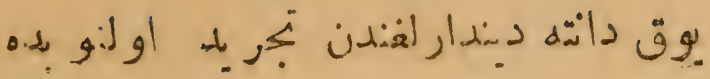

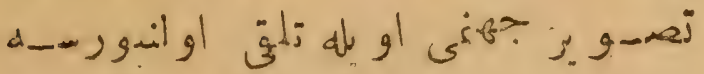

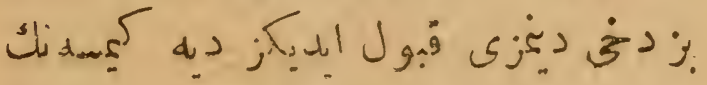

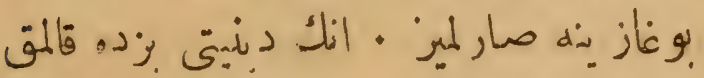

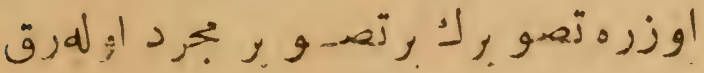

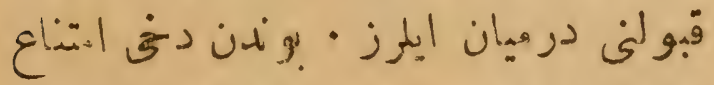

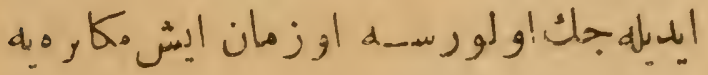

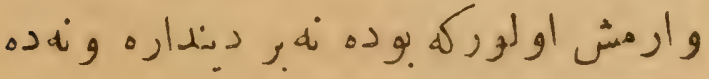

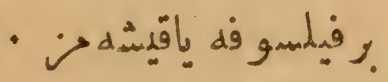

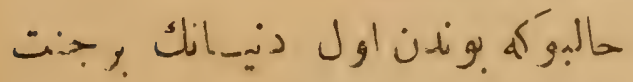

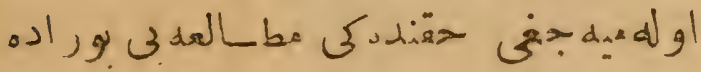

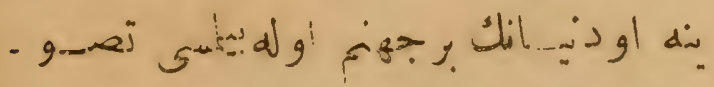

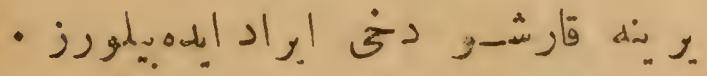

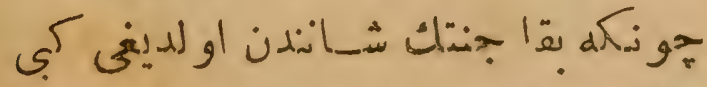

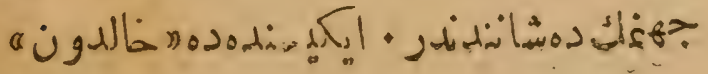




\section{菜 $11 \mathrm{~V}$ 秦}

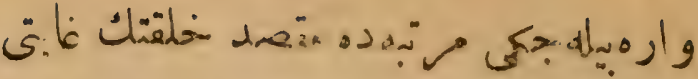

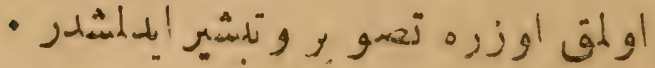

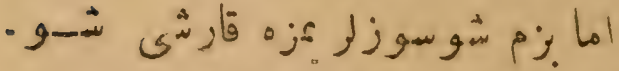

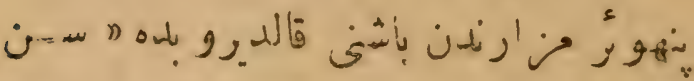

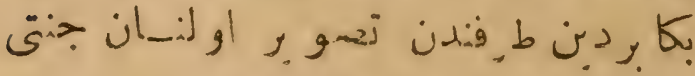

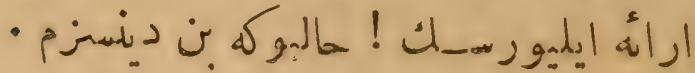

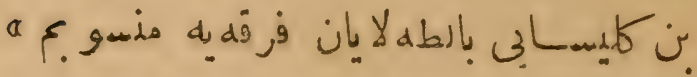

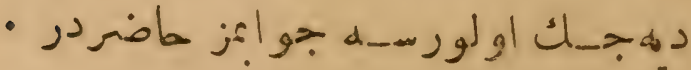

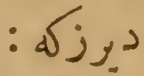

اكر دانتهـه برديندار اولمتق اوزره

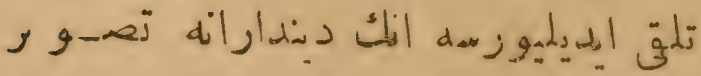

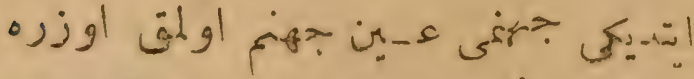

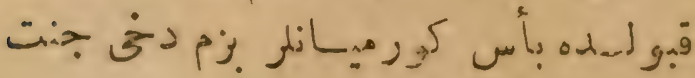

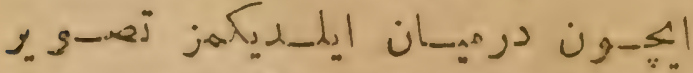

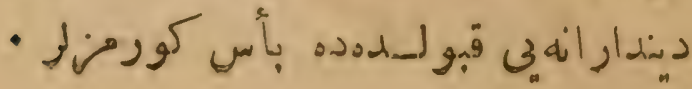


策 117 梁

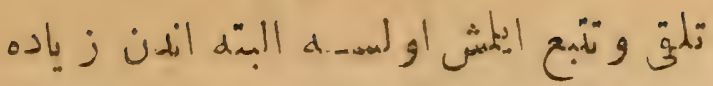
بك

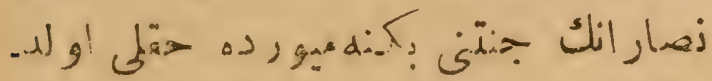

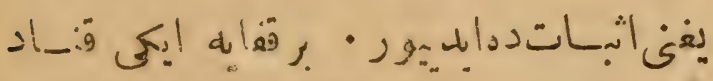

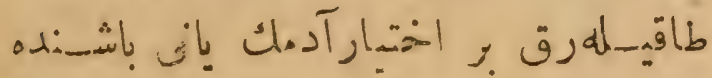

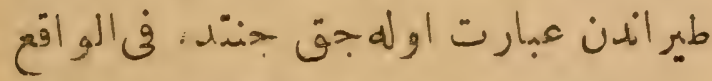

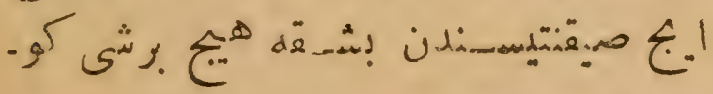

- ريل

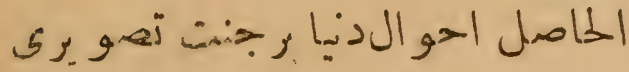

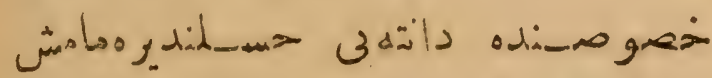

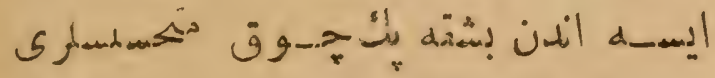

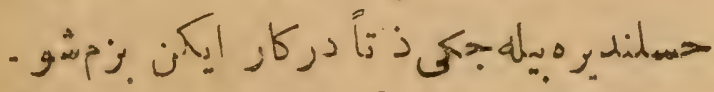

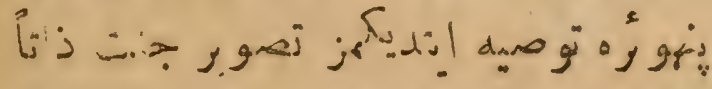

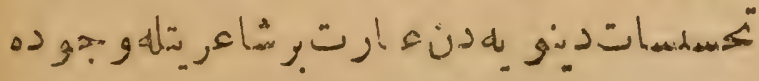

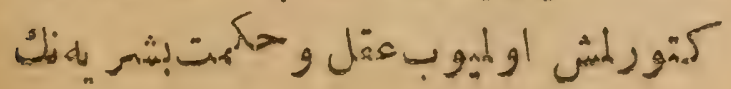




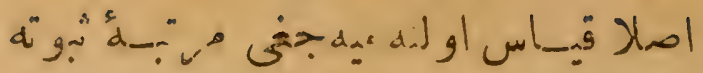

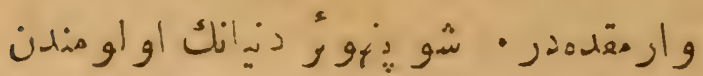

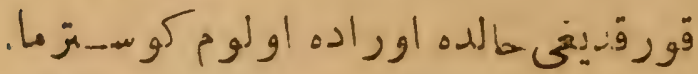

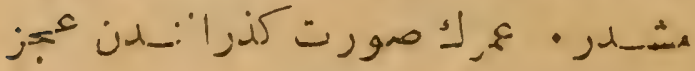

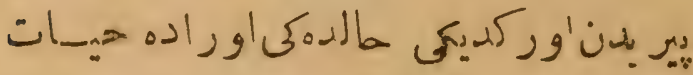

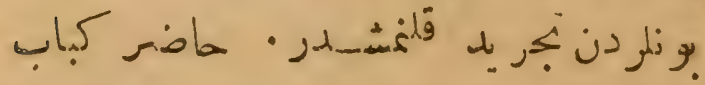

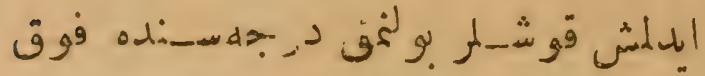

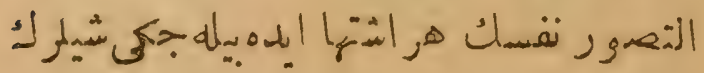

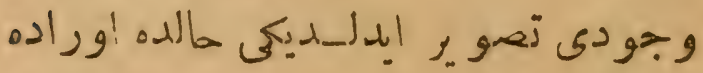

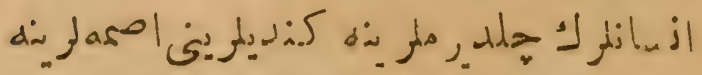

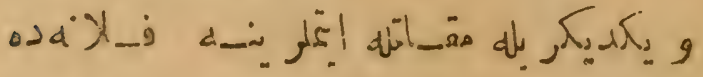

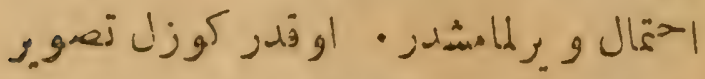

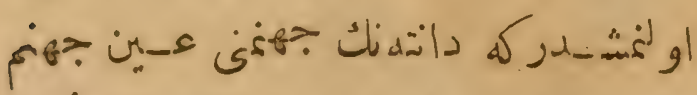

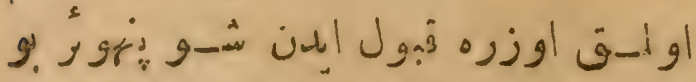

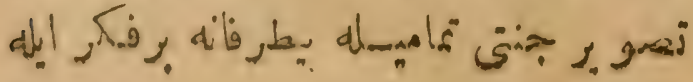




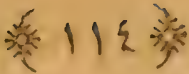

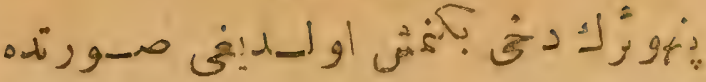

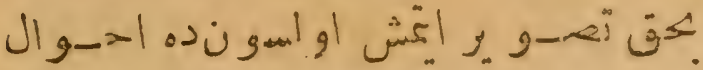

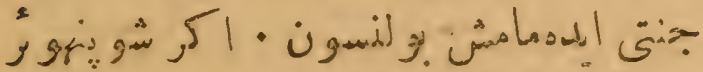

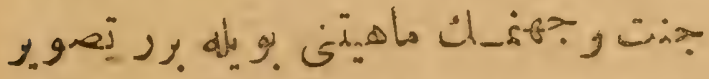

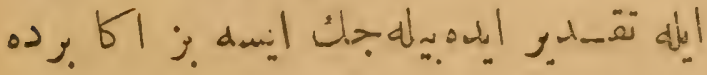

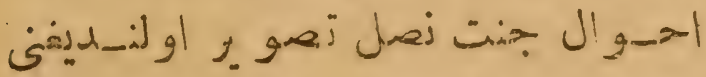

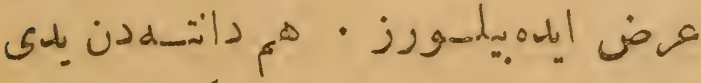

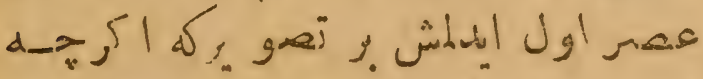

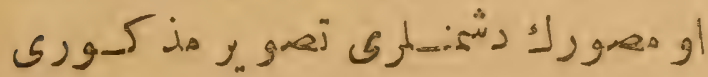

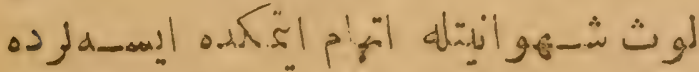

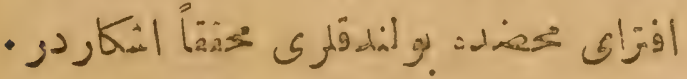

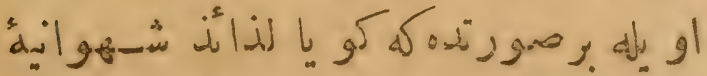

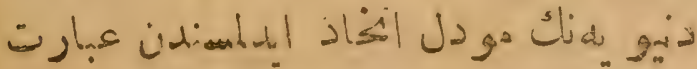

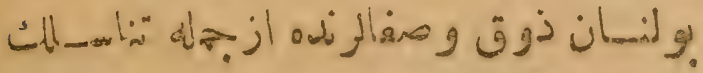

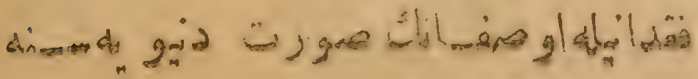




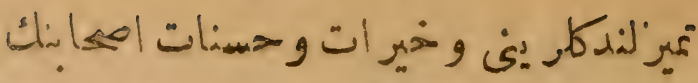

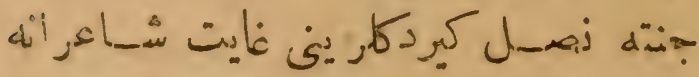

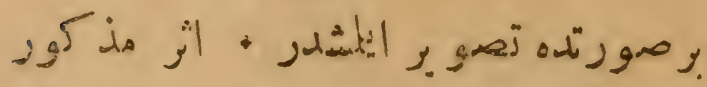

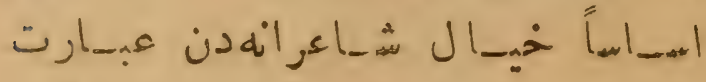

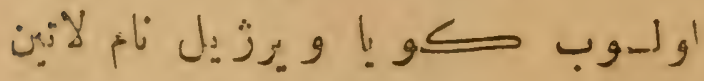
:

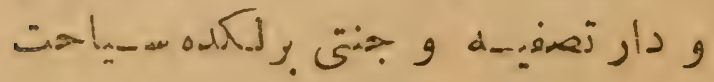

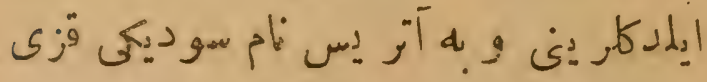

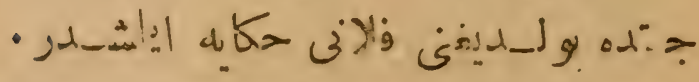

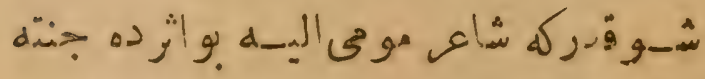

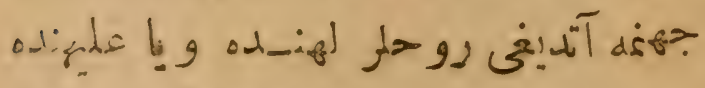

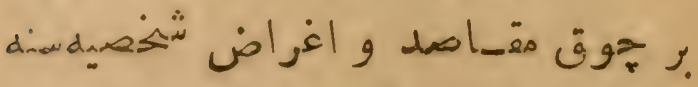

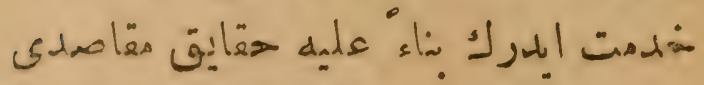

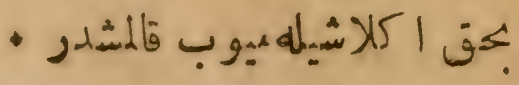

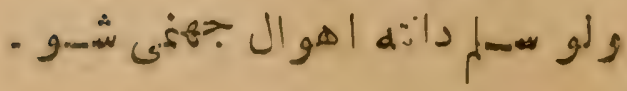




\section{稂 $11 p$ 类}

Lig

لم

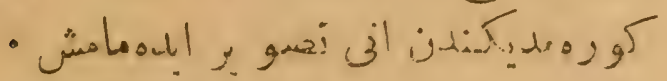

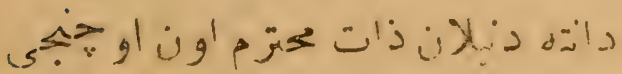

ن

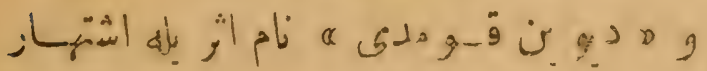

$$
\text { ألدن ذات }
$$

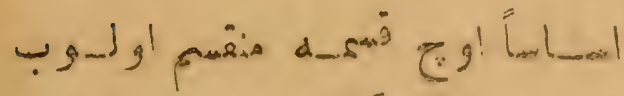

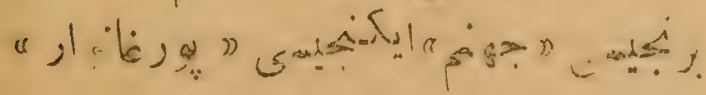

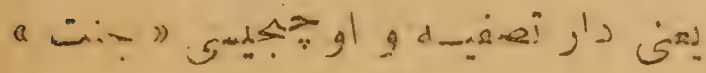

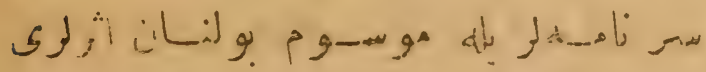

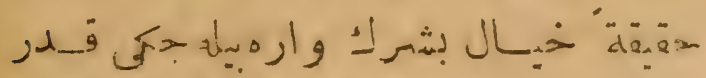

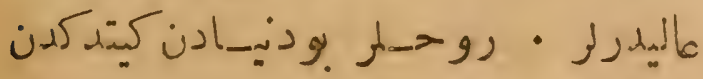

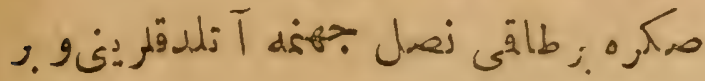
طاقّ 


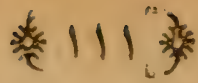

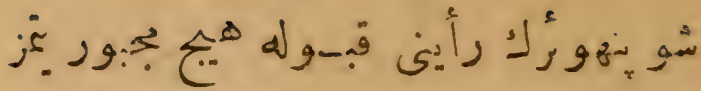
-

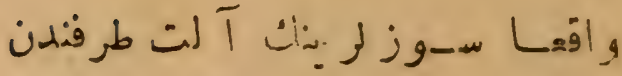

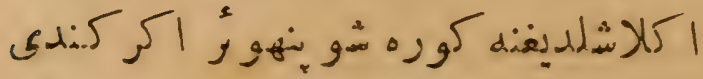

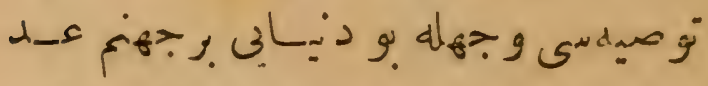

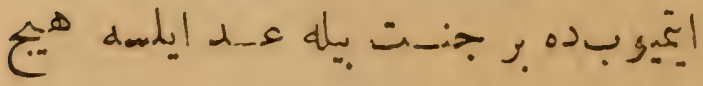

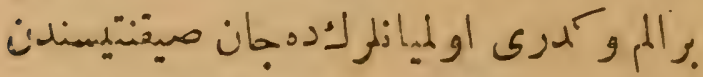

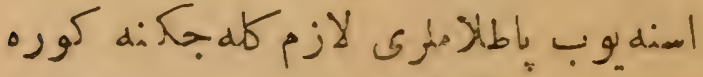

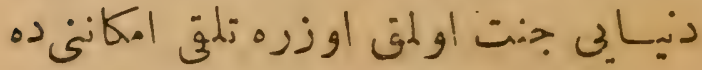

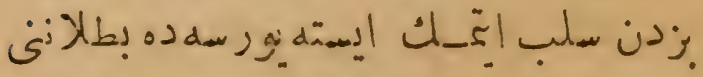

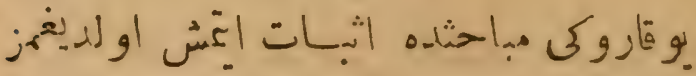

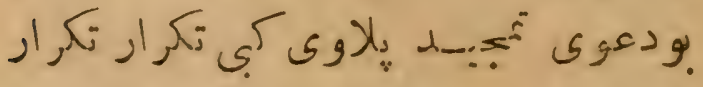

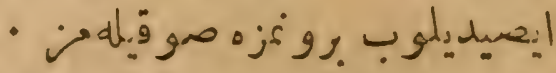

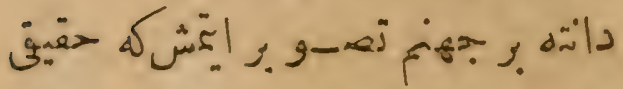

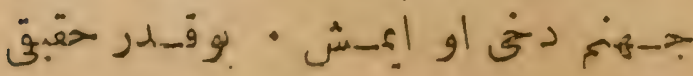




\section{点 $11 \cdot$ 奜}

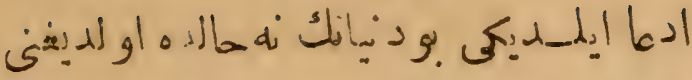

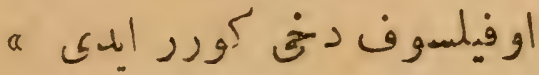

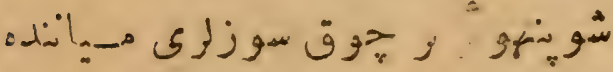

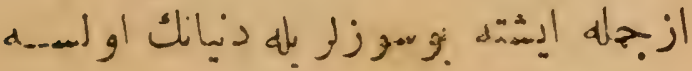

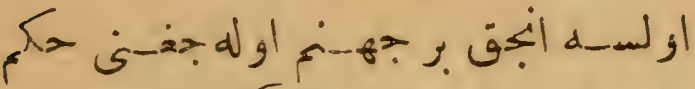

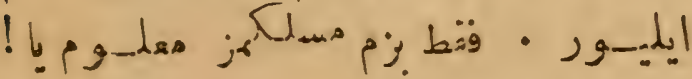

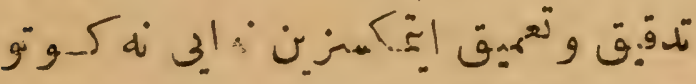

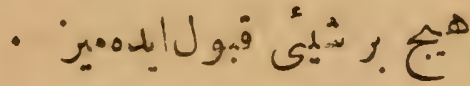

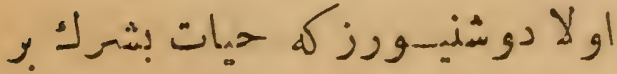

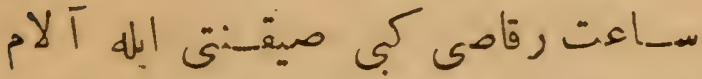

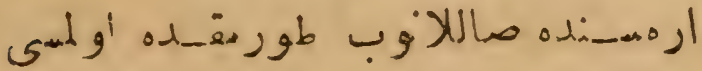

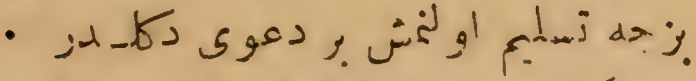

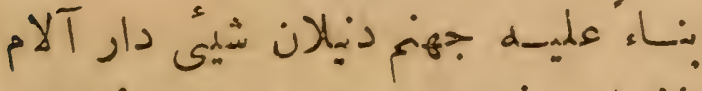

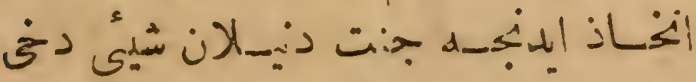

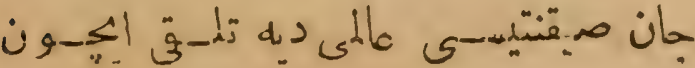




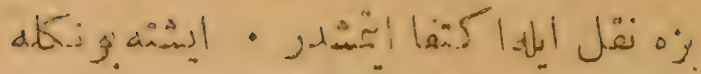

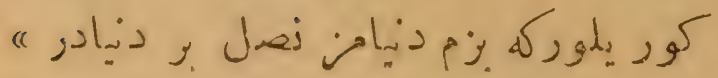

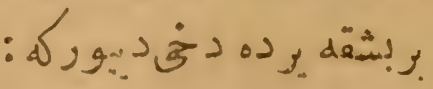

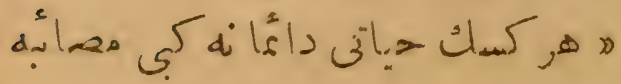

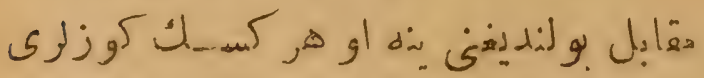

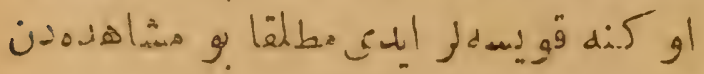

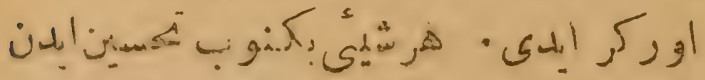

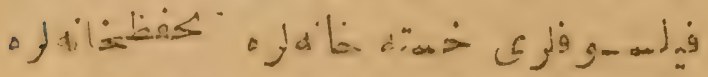

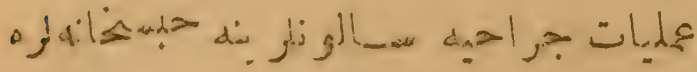
\&

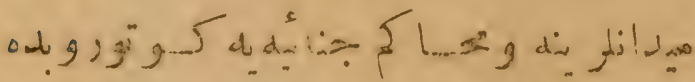

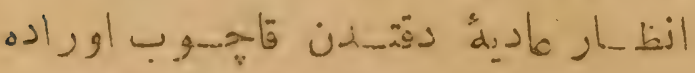

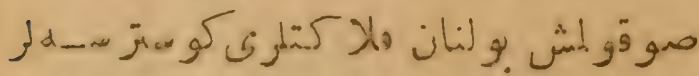

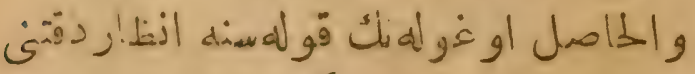

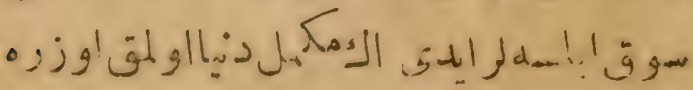




\section{慗 $1 \cdot 1$ 絭}

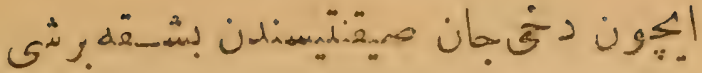
a

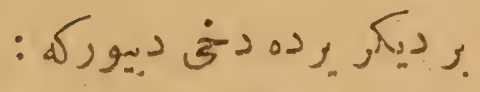

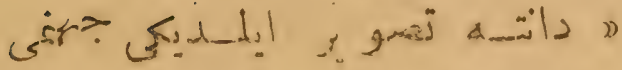

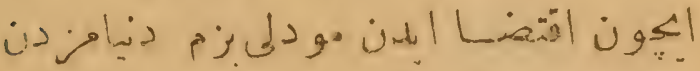

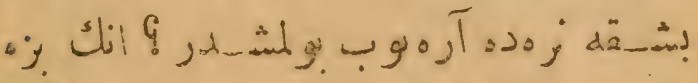

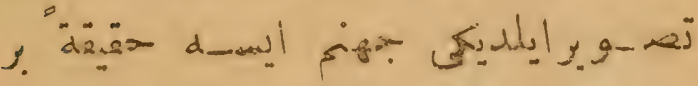

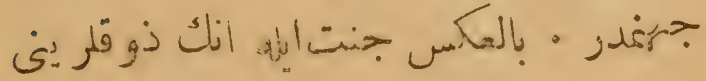

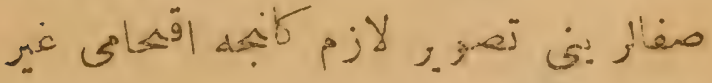

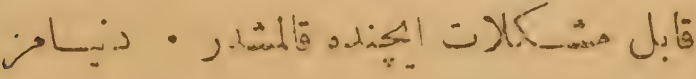

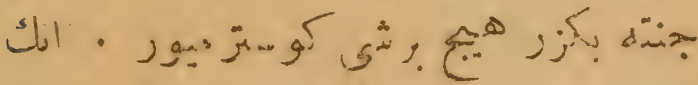
-

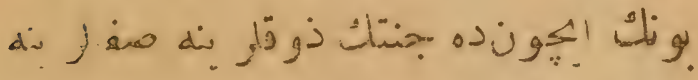

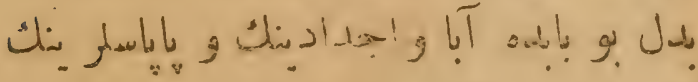

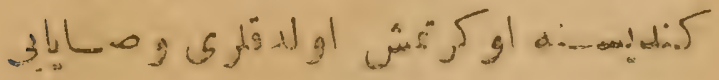




\section{㙩 1 V 港}

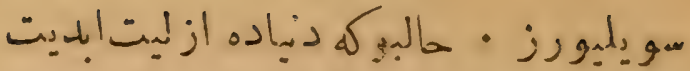

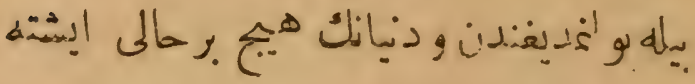

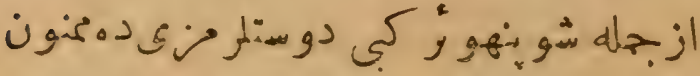

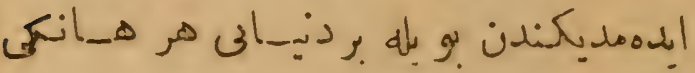

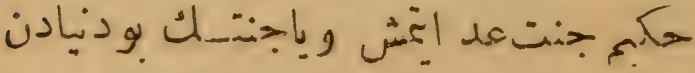

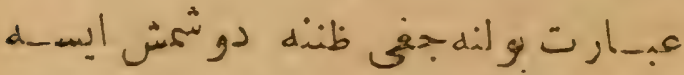

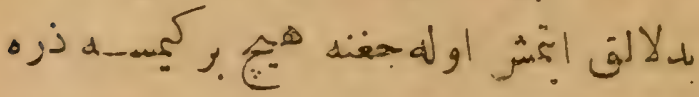
قد

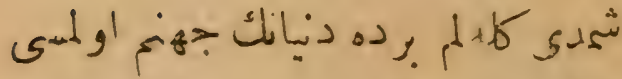

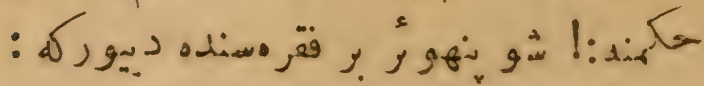

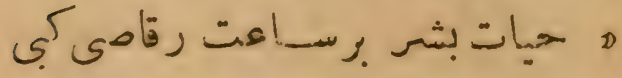

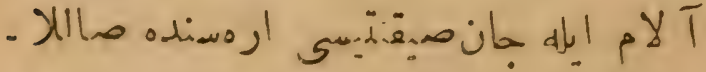

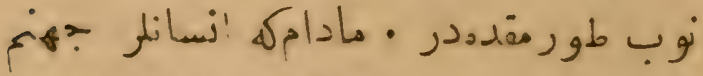

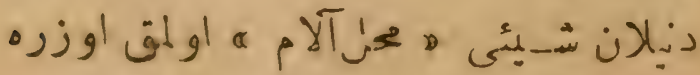

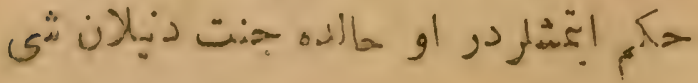




\section{然 $1 \cdot 7$ 絜}

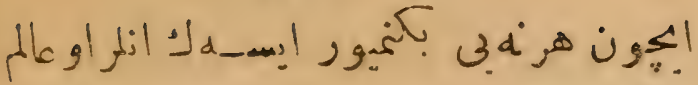

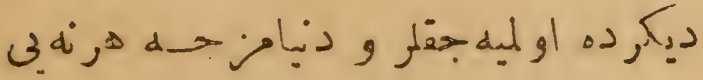

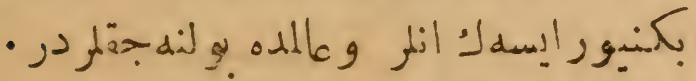

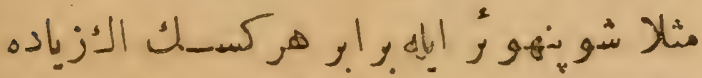

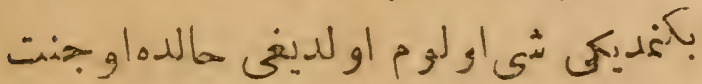

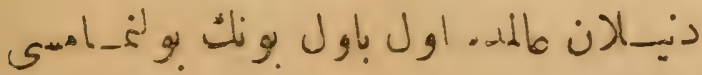

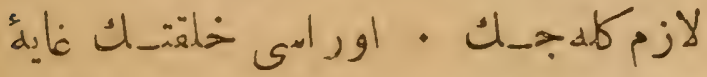

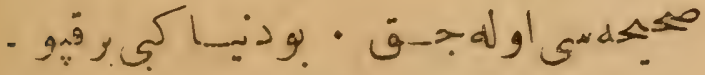

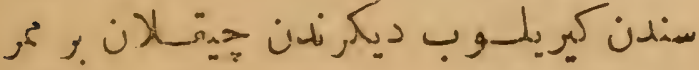

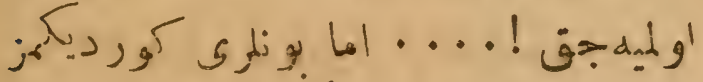

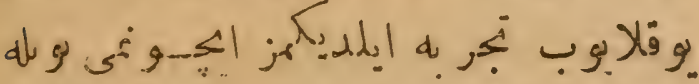

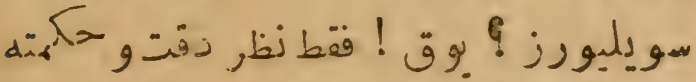

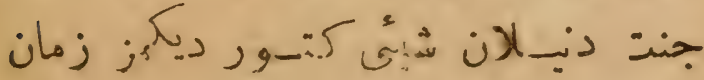

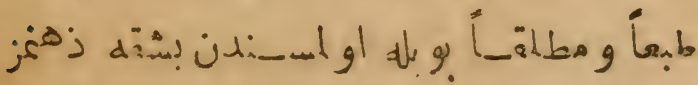
dو . 
棌 1.0

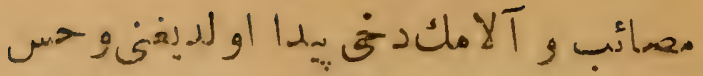
. :

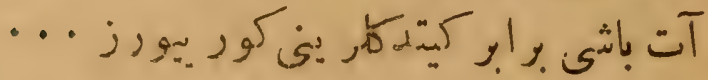

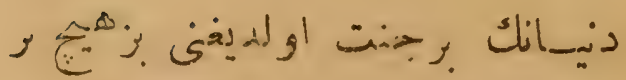

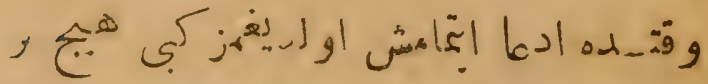

و وتمده د

- -

ن

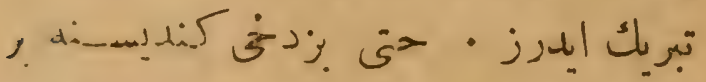

:

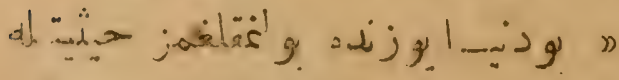

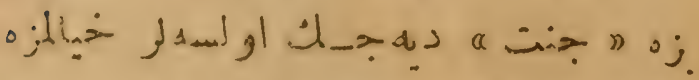

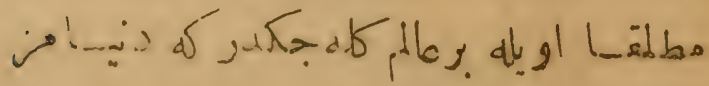




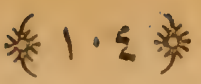

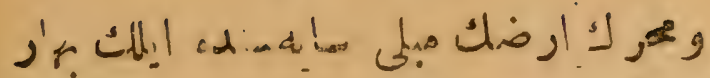

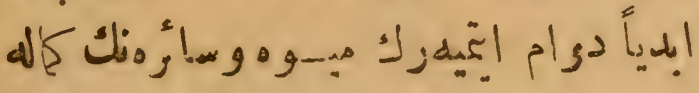

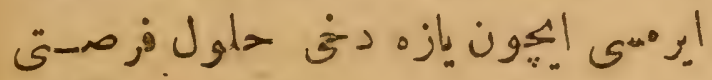

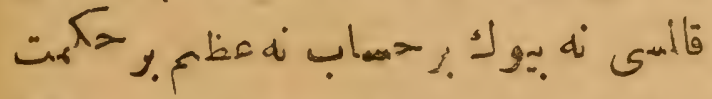

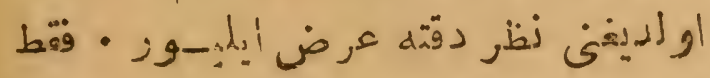

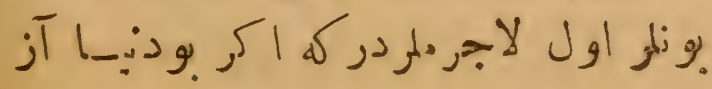

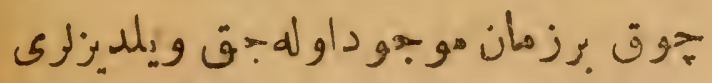

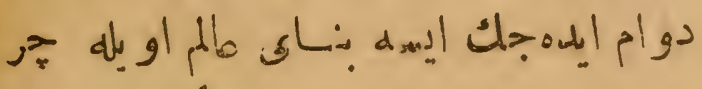

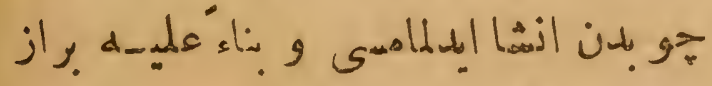

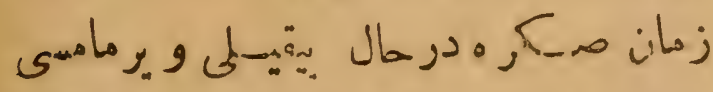

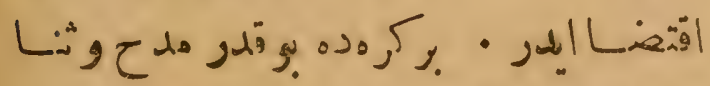

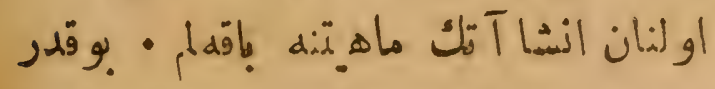

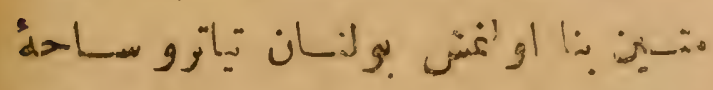

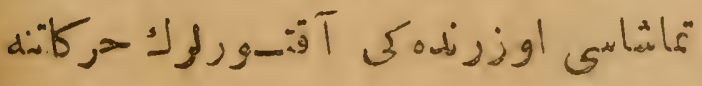

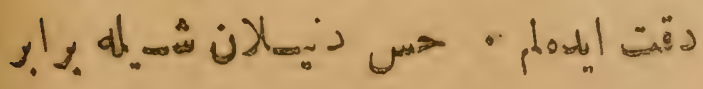


潘 ! 只

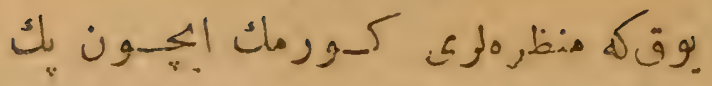

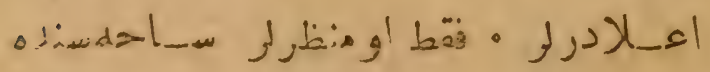

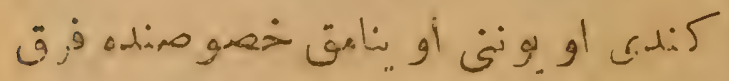

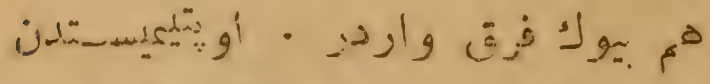

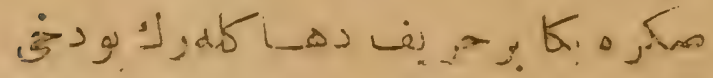

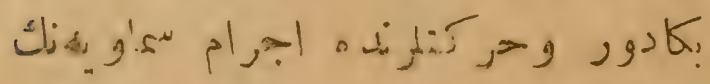

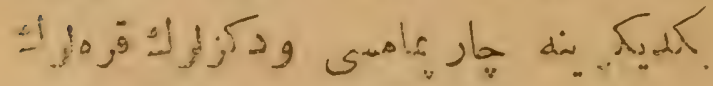

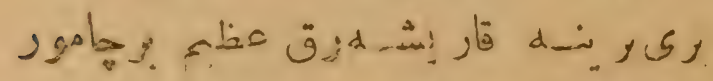
ن ن. ها

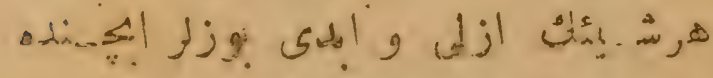

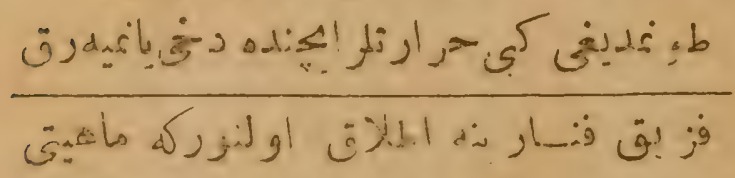

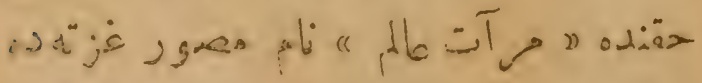

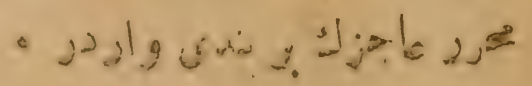




\section{1.r苏}

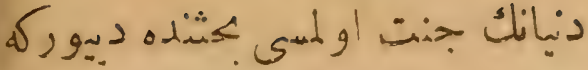

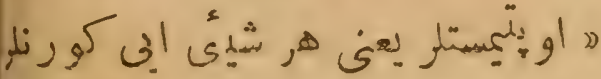

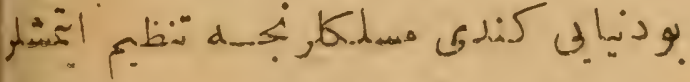

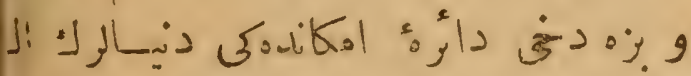

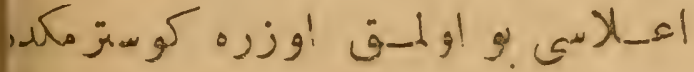

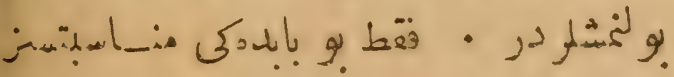

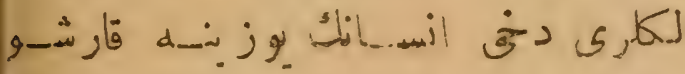

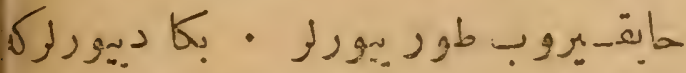

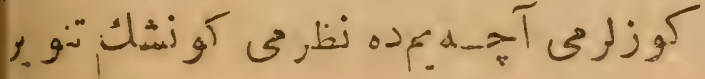

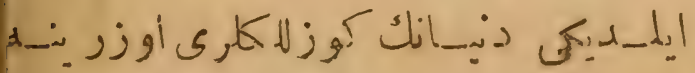

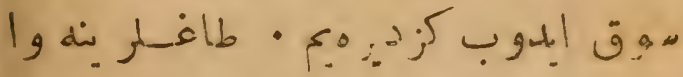

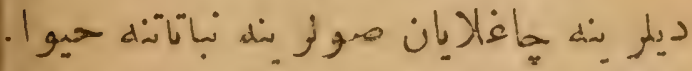

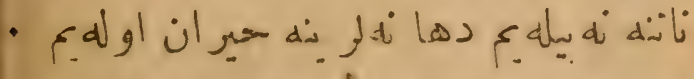

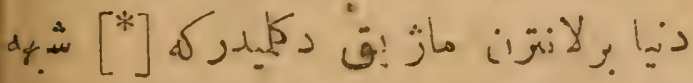

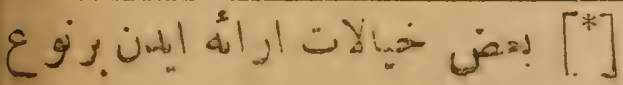




\section{类 1.1 器}

\section{ثي}

\section{to}

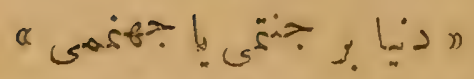

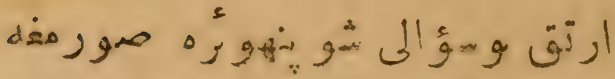

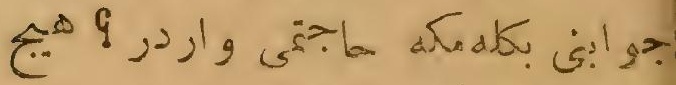

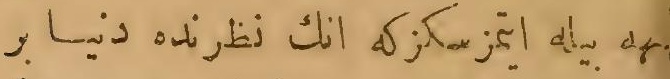

و

.

ظ

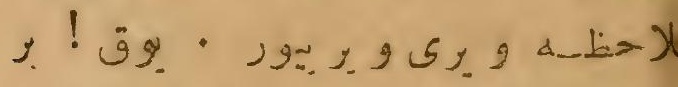

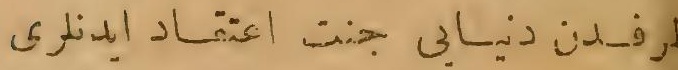

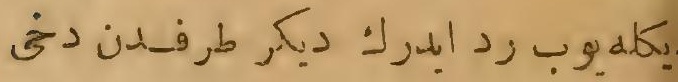

"

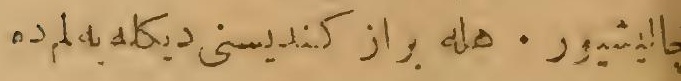

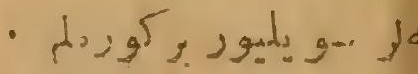




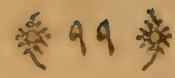

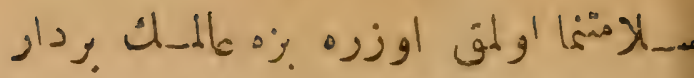

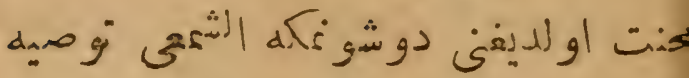

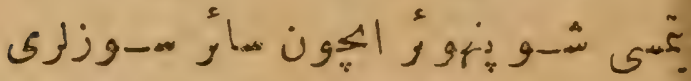

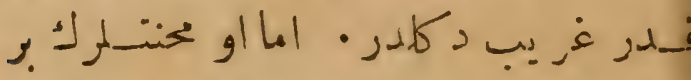
•

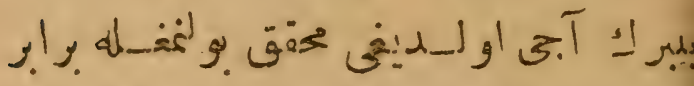

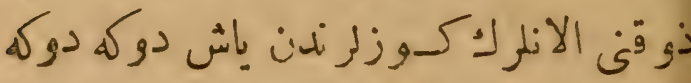

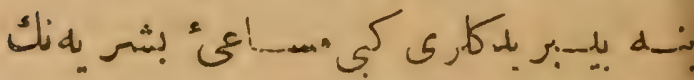

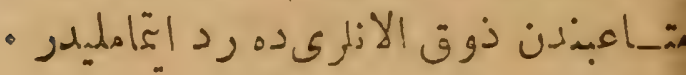

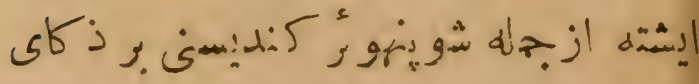

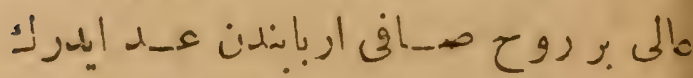

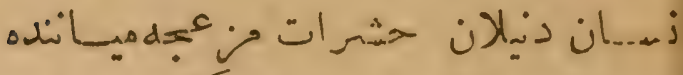

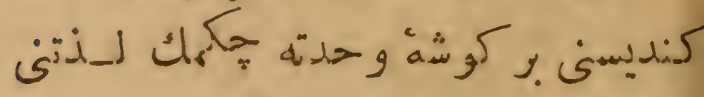

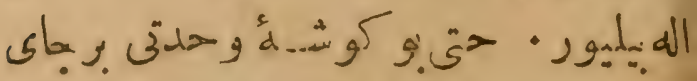

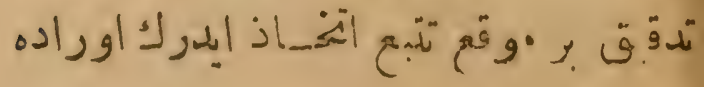


类人新

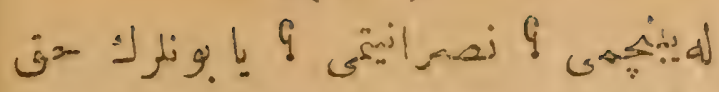

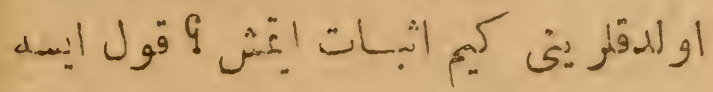

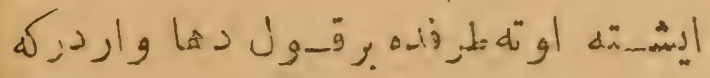

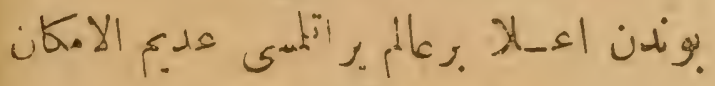

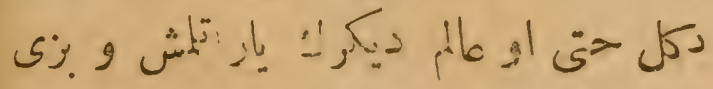
:

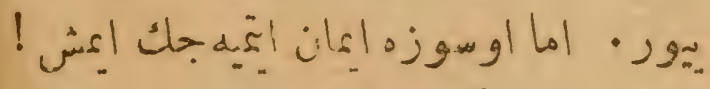

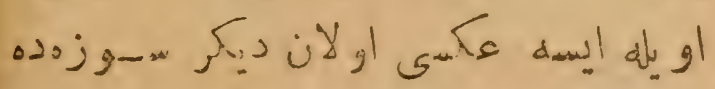

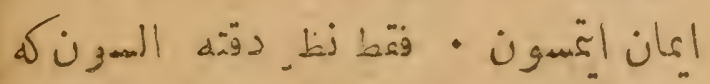

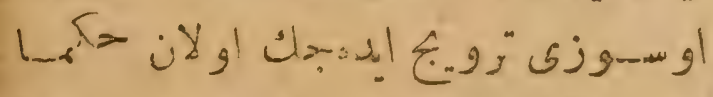

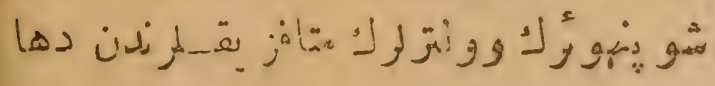

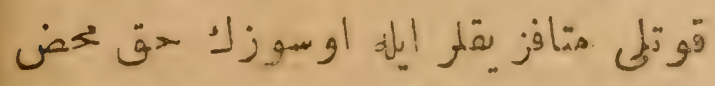

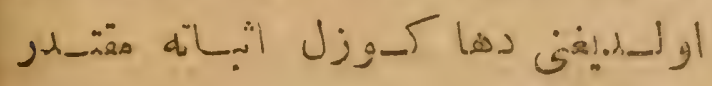

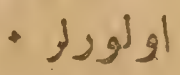

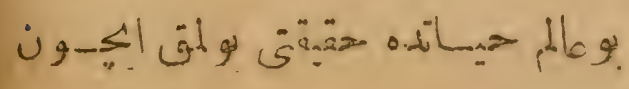




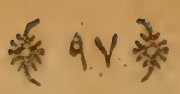

lol

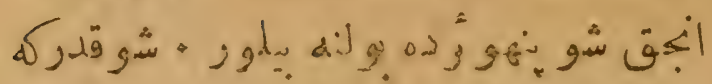

جاب هاب

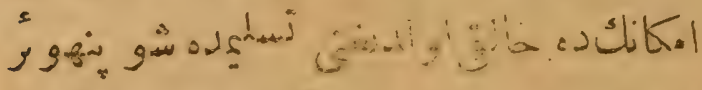

ب.

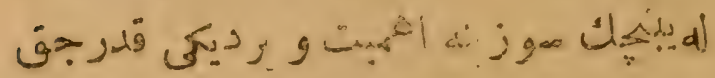

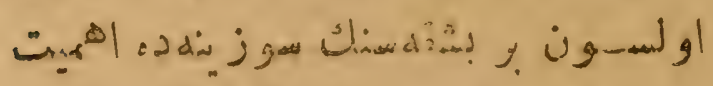

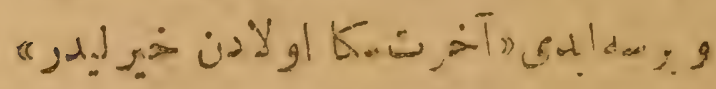

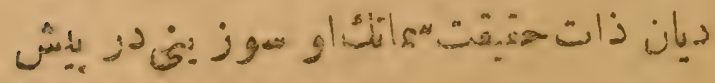

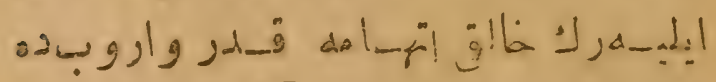

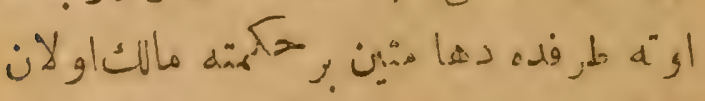

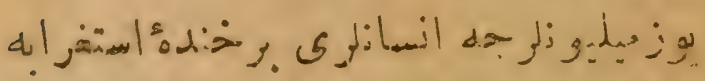

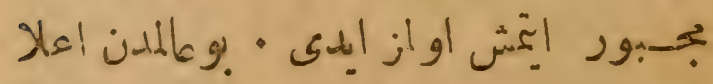

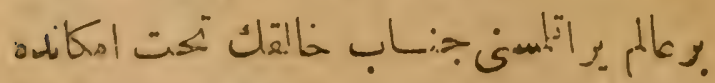

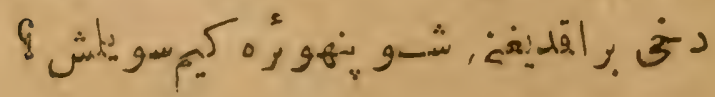




\section{7 .}

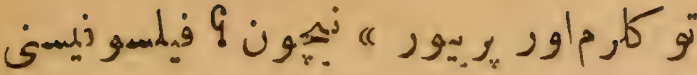

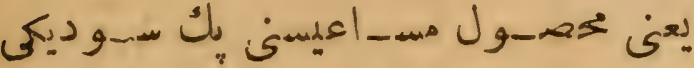

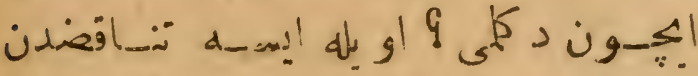

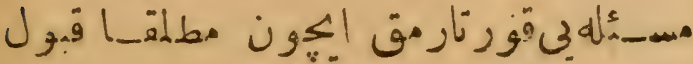

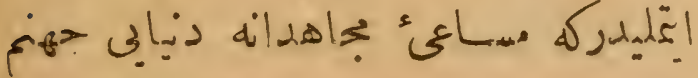

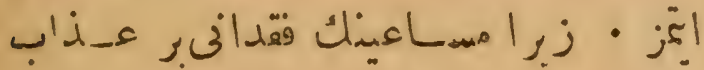

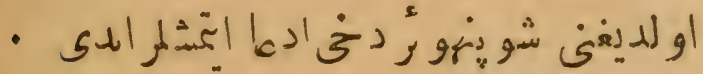

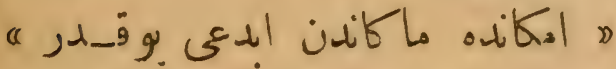

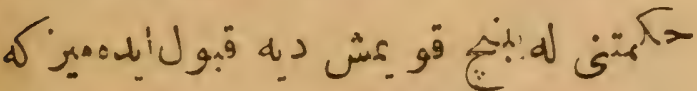

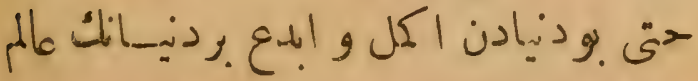

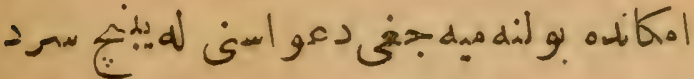

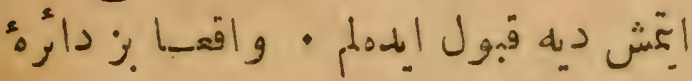

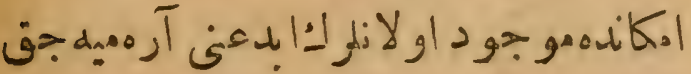

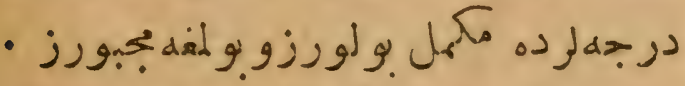

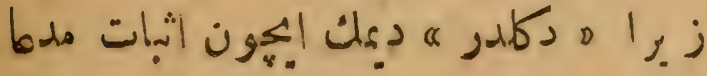




\section{染90}

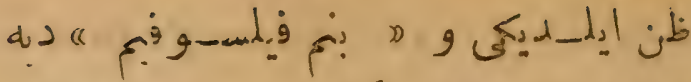

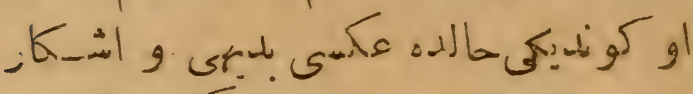

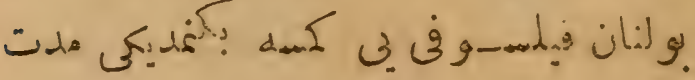

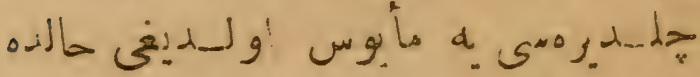

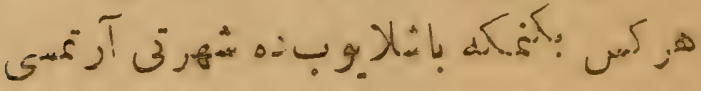

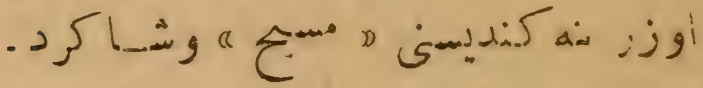

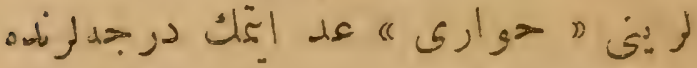

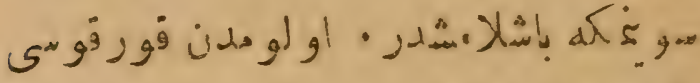

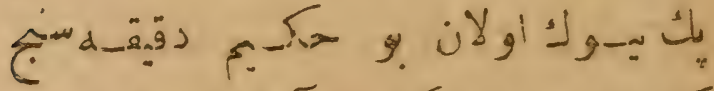

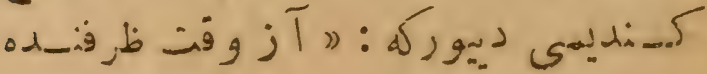

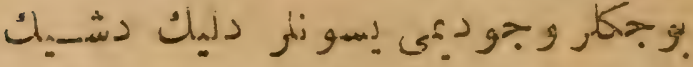

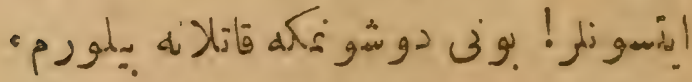

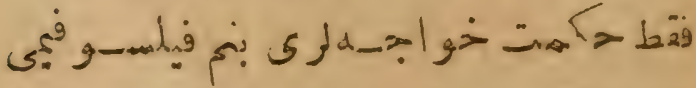

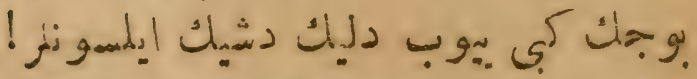

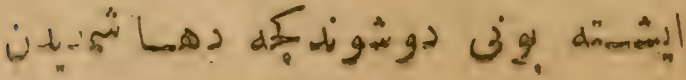




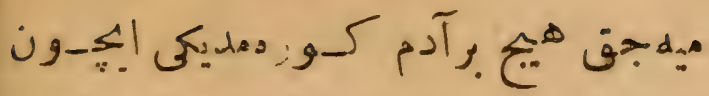

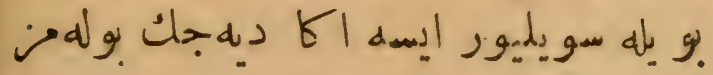

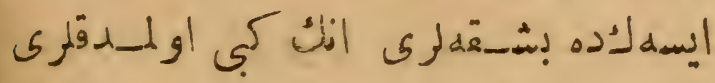

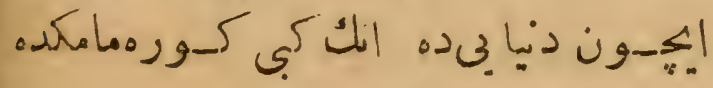

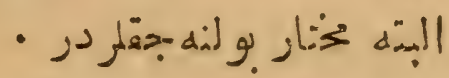

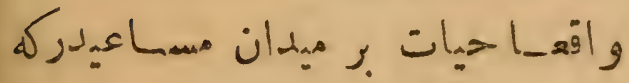

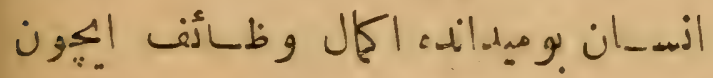

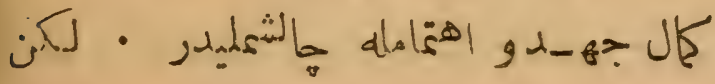

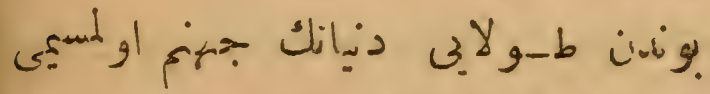

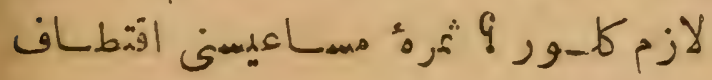

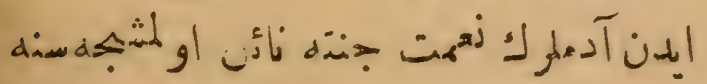

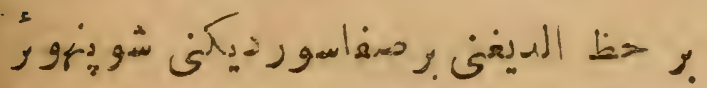

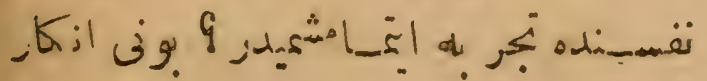

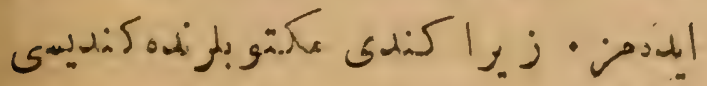

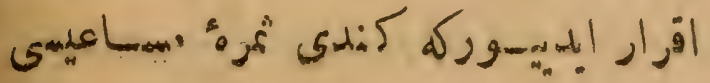




\section{qu}

ك

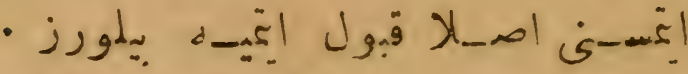

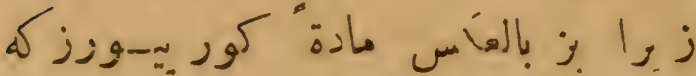

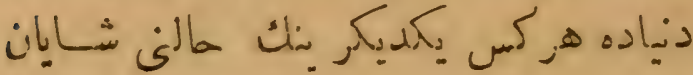

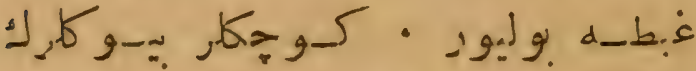

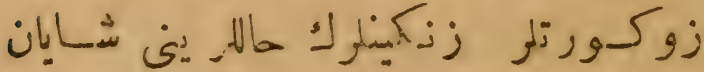

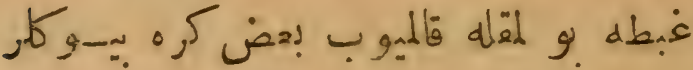

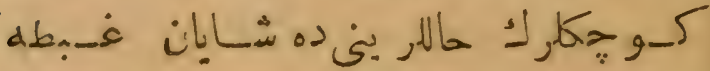

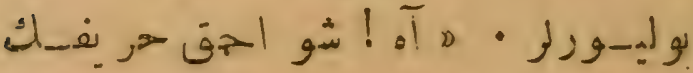

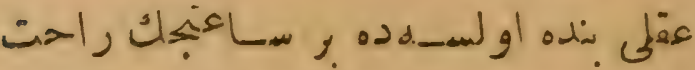

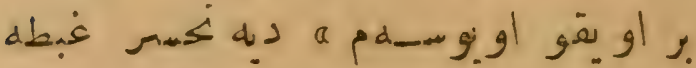

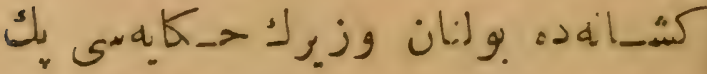

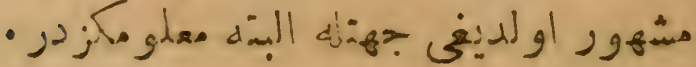

E

- dil gl dris dilla 


\section{ar 絭}

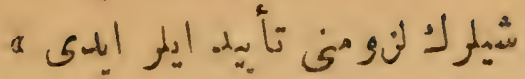

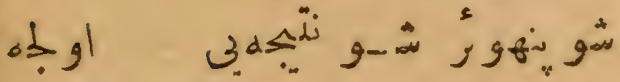

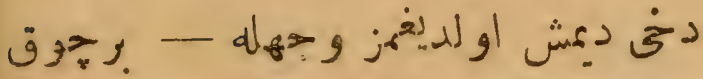

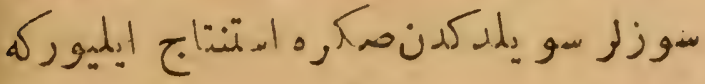

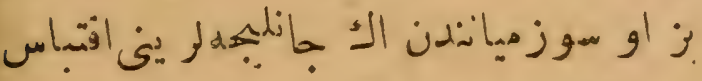

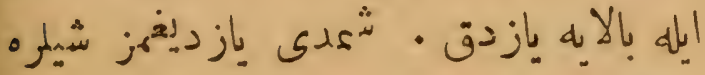

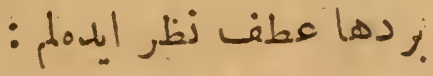

اولا هر كسلك نه فدر آجينه جق مالده.

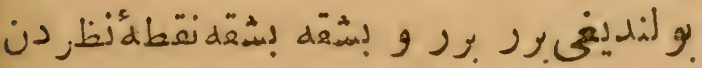

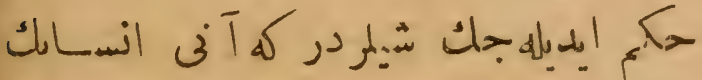

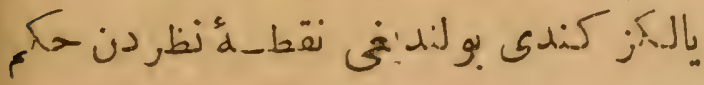

|

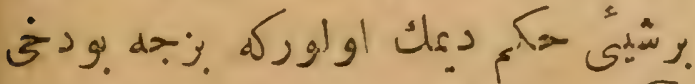

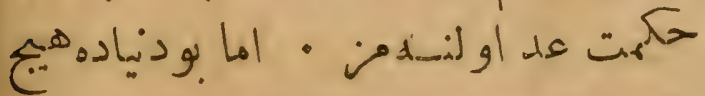

- 
率9!㴒

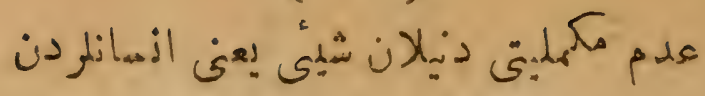

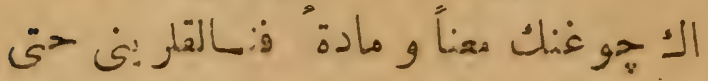

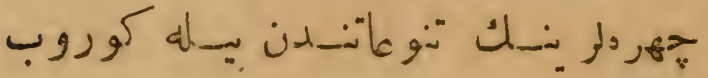
و

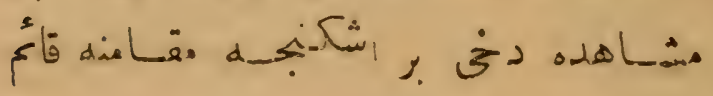
اولور

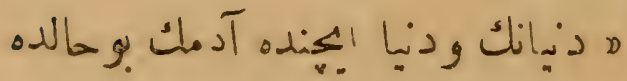

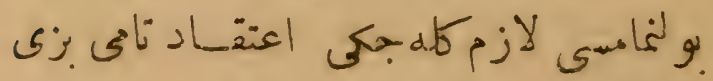

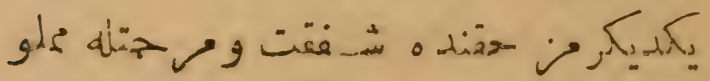

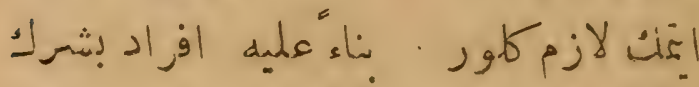

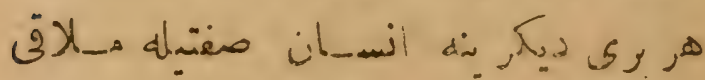

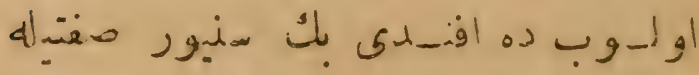

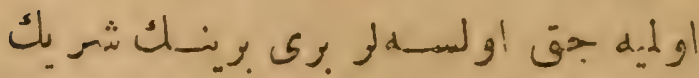

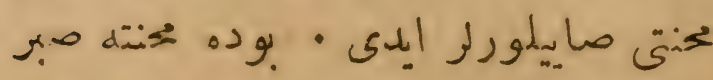

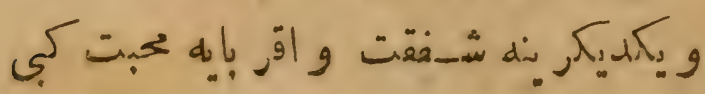


桨 $9 \cdot$ 桨

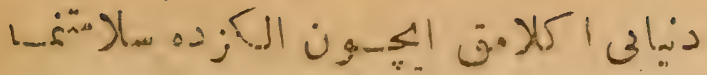

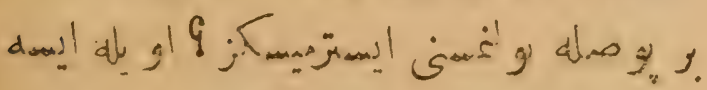

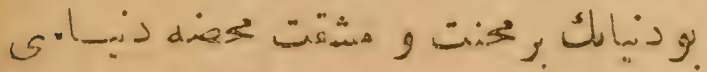

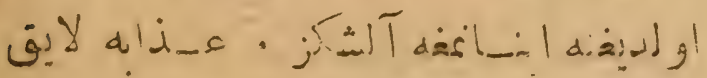

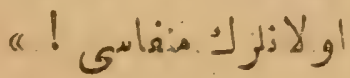

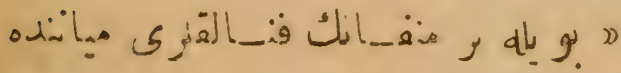

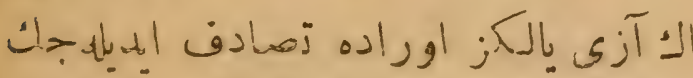

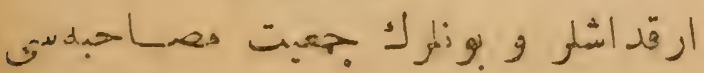

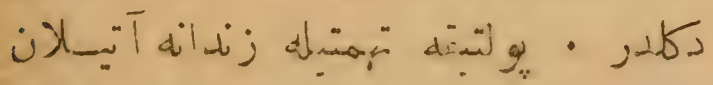

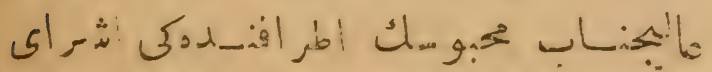

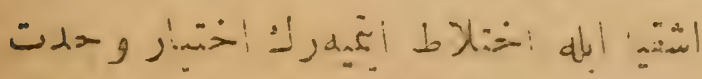

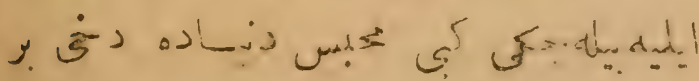

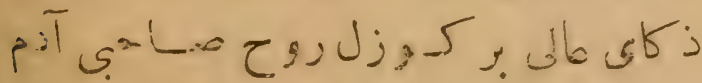

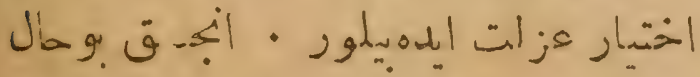

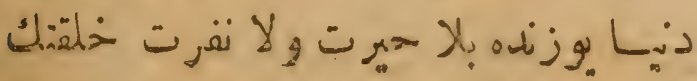


19 类

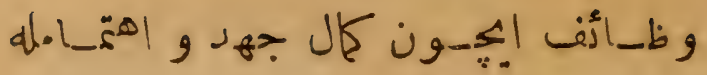

ه بإثميدر

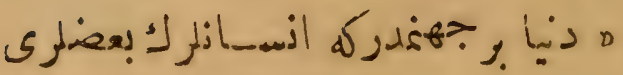

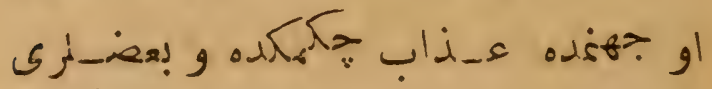

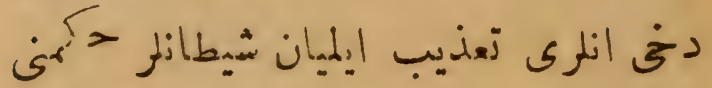

a المقدهر

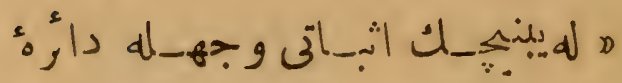

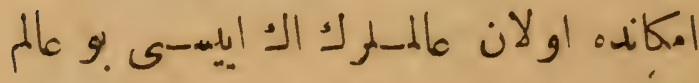

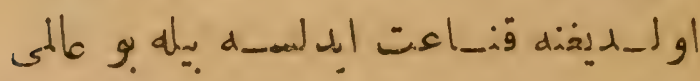

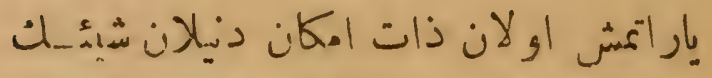

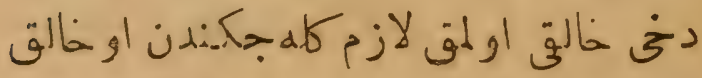

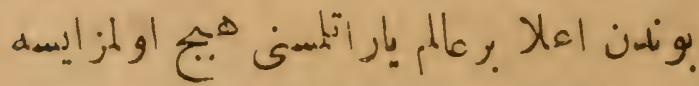

" ه

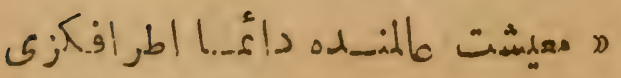

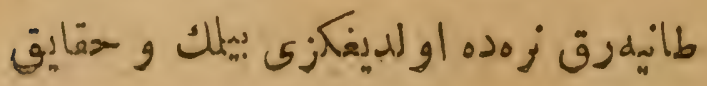




\section{冺絭}

و دنياده حنغوور وراحت تمكن

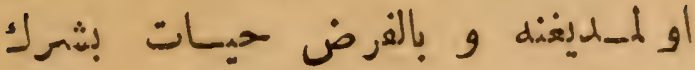

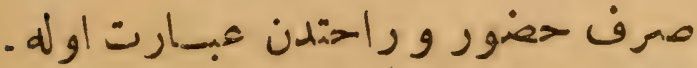

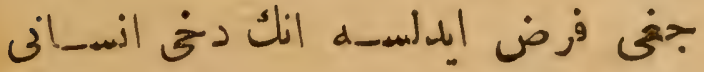

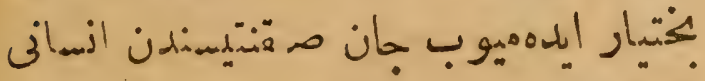

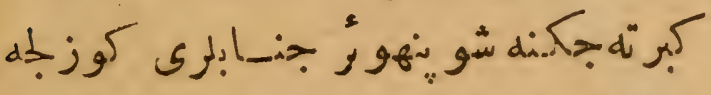

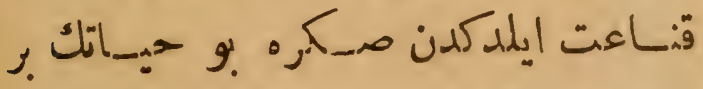

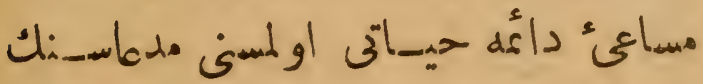

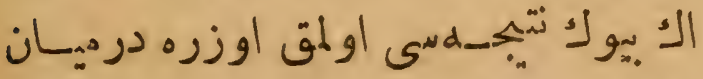

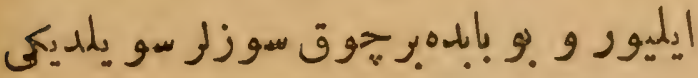

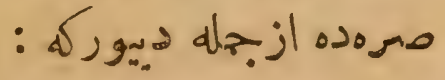

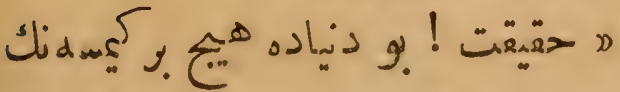

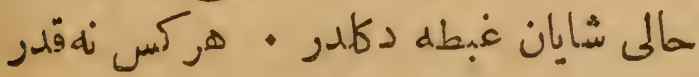

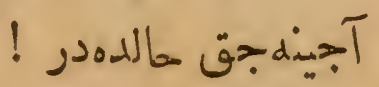

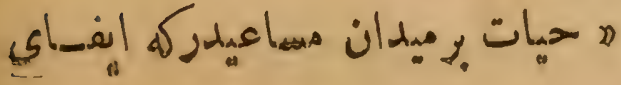


蔡ハ乷

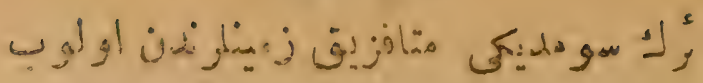

هـ

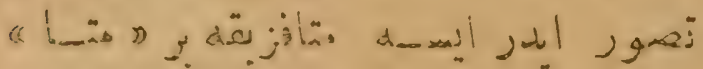

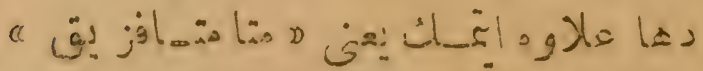

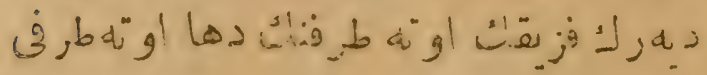

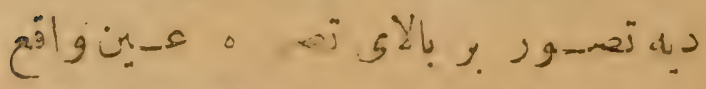

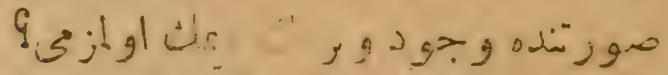

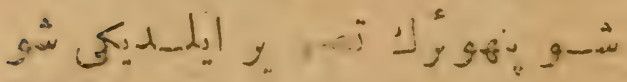

F.

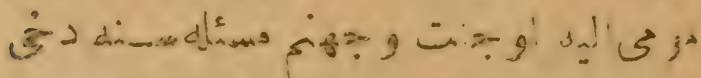

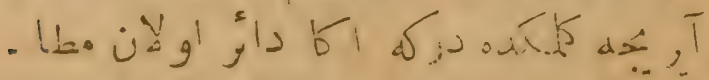

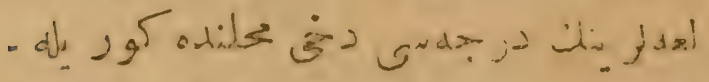

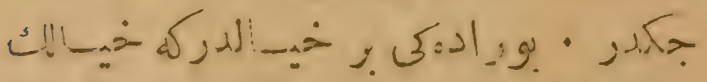

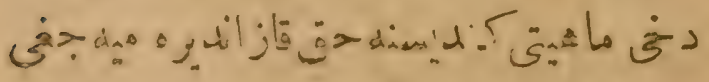

- jodarasalitas dniand 
资 17 䊅

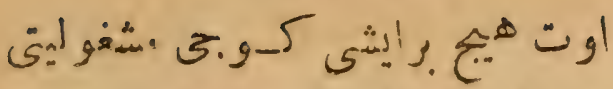
نे

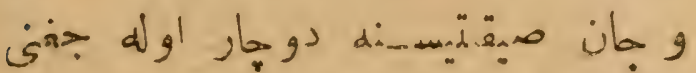
3و محه

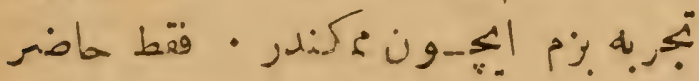

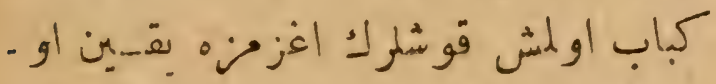

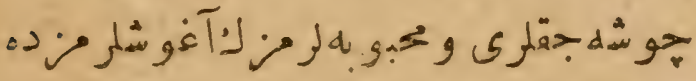

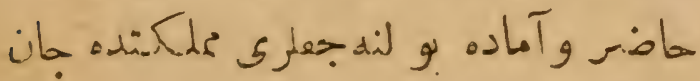

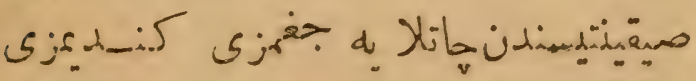

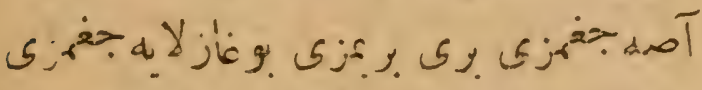

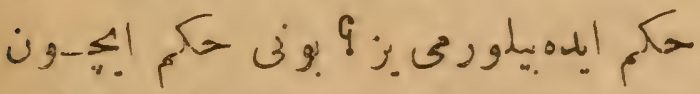

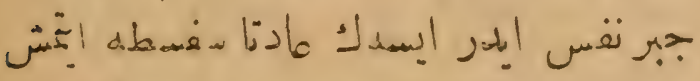

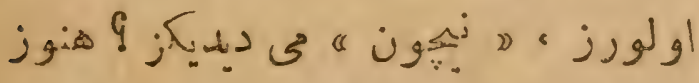

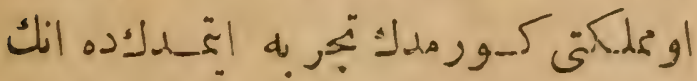

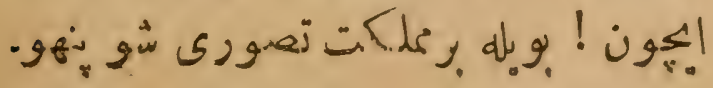




\section{0}

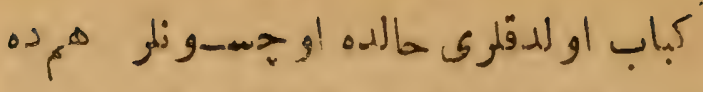

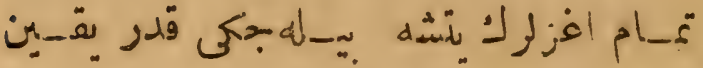

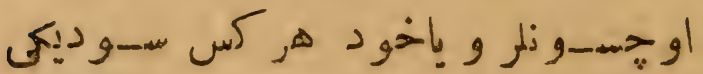

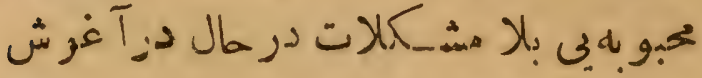

ابلهى وير سون او حالمه كوردرلكه انسانلر

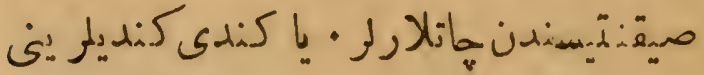

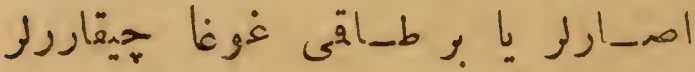

مبكديكرئى .

كاك

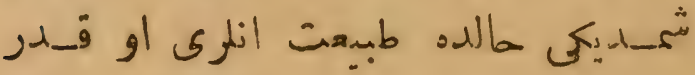

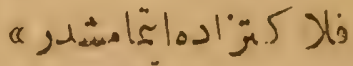

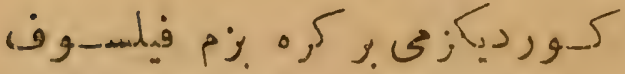

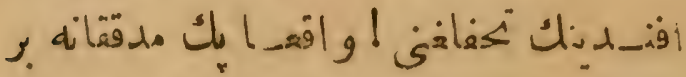

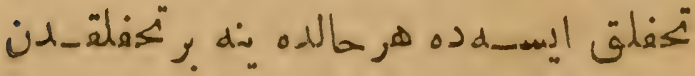

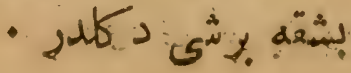




\section{漟}

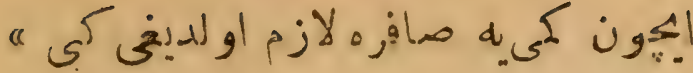

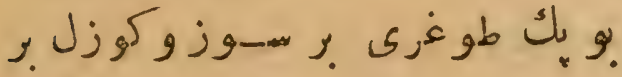

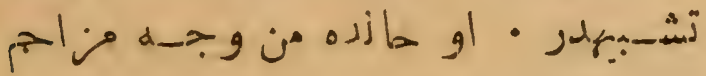

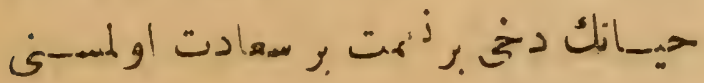

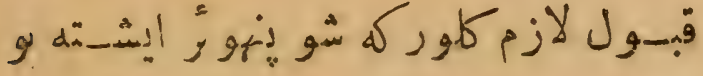

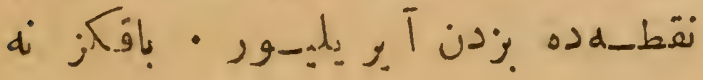
"جيجور :

ه إعدى شبها موقكه هيان هر انسانك

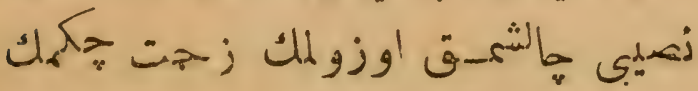

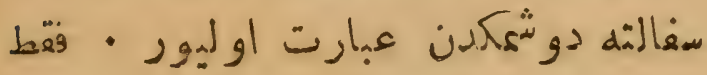

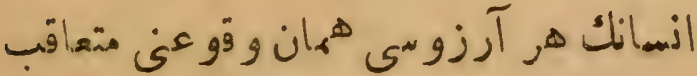

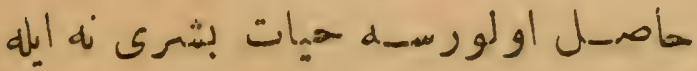

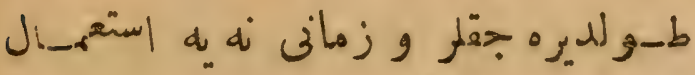

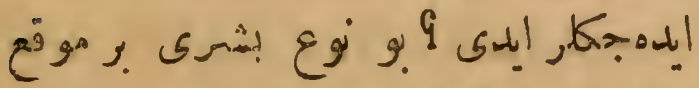

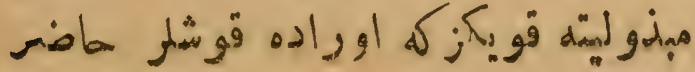




\section{潘}

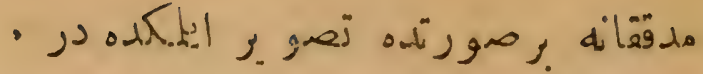

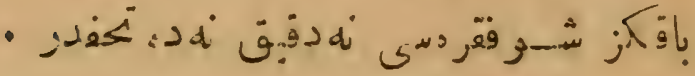
$:$ S.

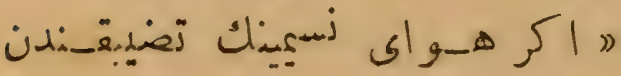

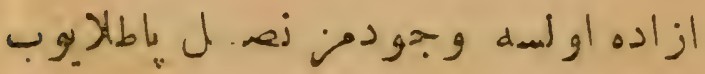

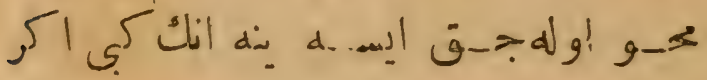

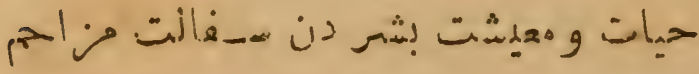

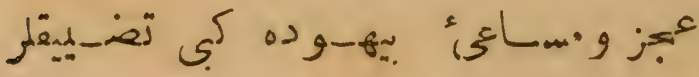

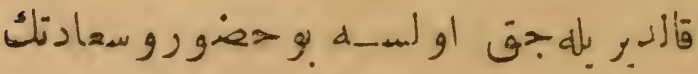

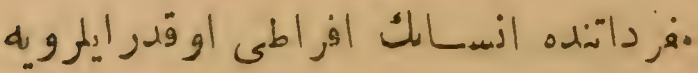

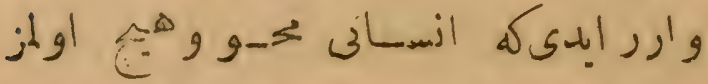

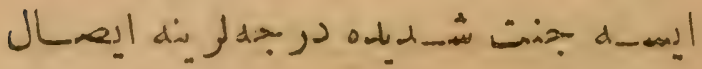

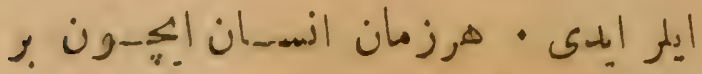

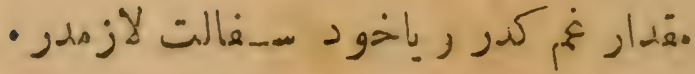
(5) 


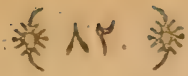

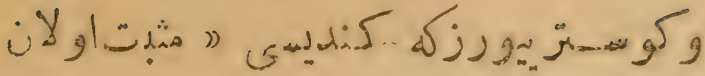

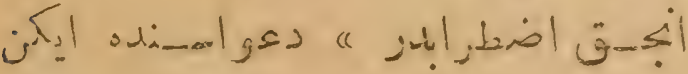

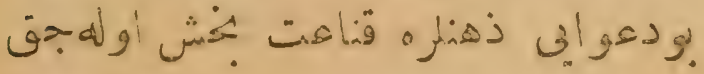

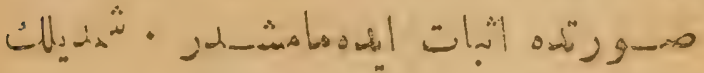

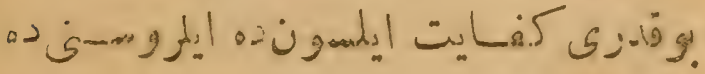

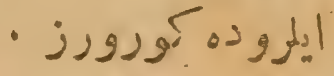

ث

$$
P
$$

a G.

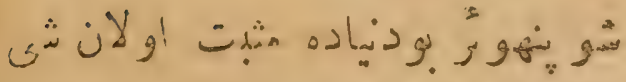

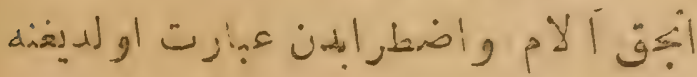

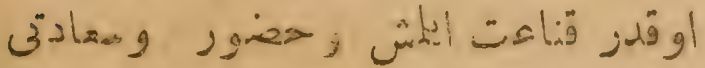

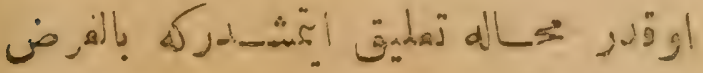

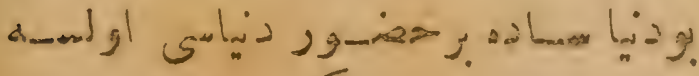

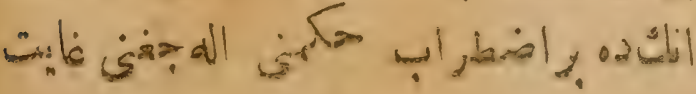




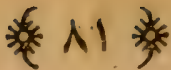

إندن بر حيو انك حال سـمادتى تمام يارى

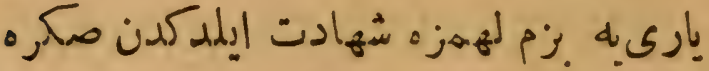

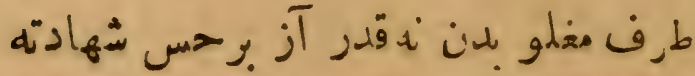

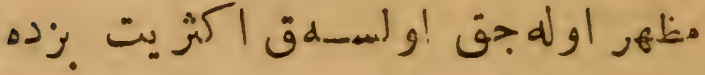

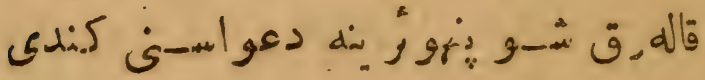

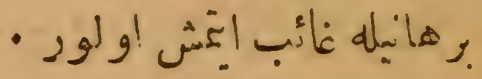

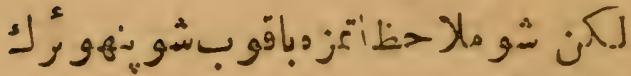

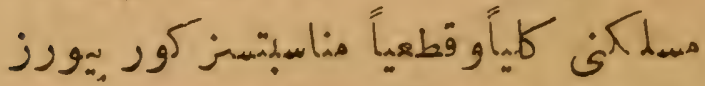

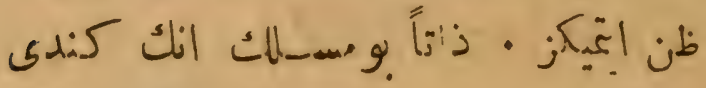

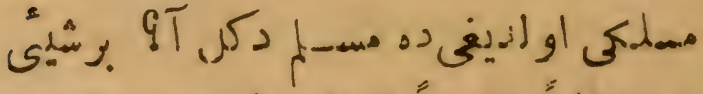

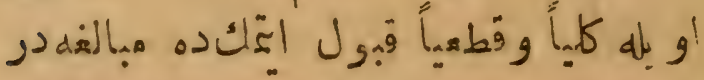

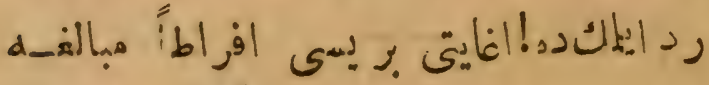

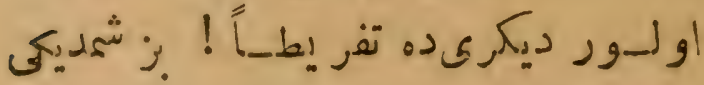

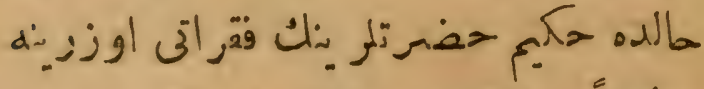

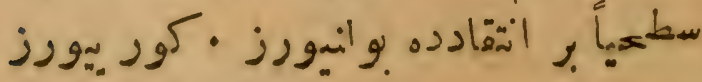


亚入・桨

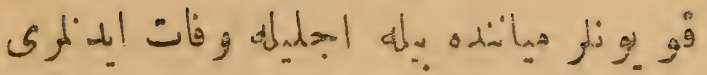

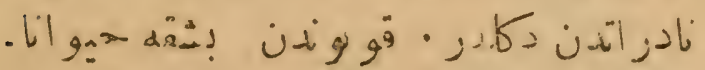

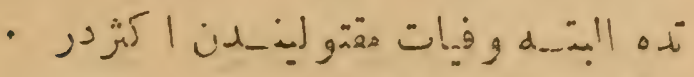
定

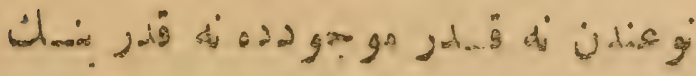

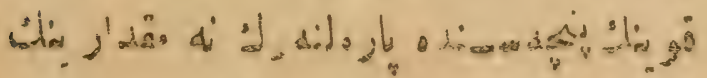

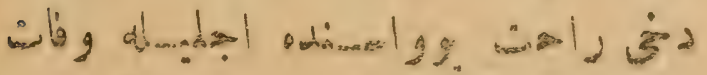

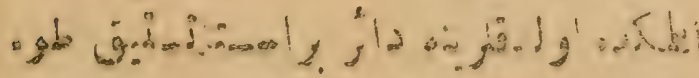

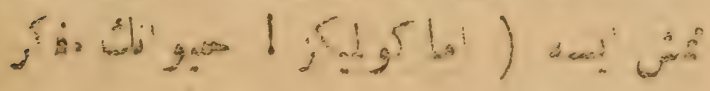

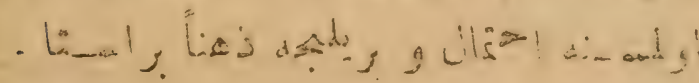
(q 9 (5)

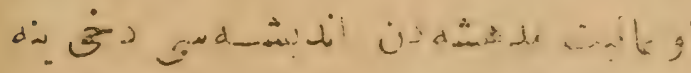

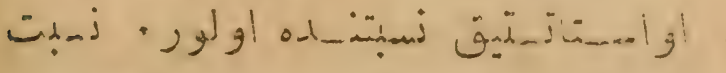
هis ل 
•

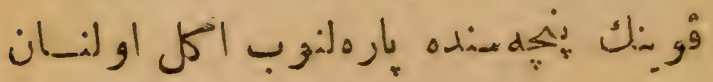

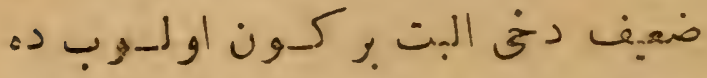

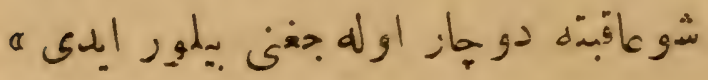

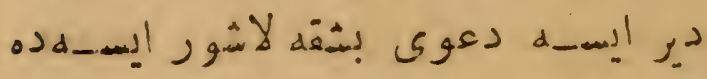

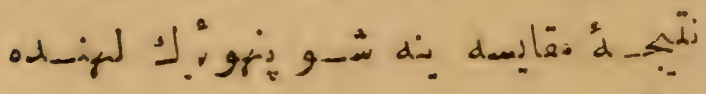

$$
\text { - }
$$

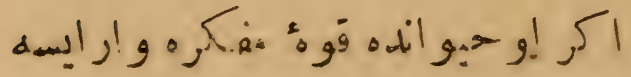

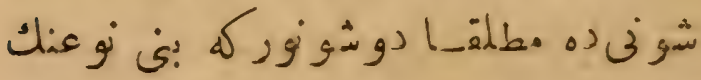

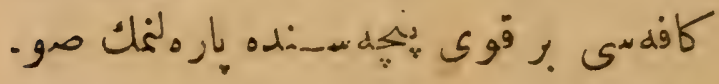

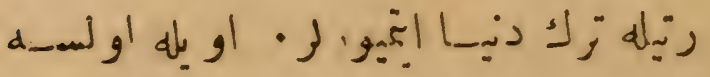

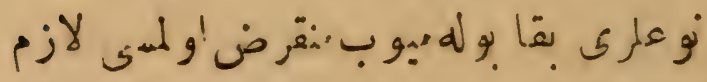

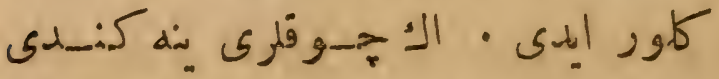

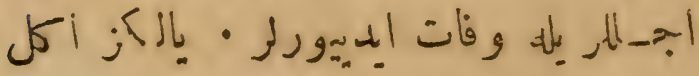

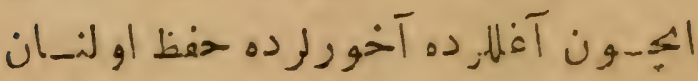




\section{絭 YA 拳}

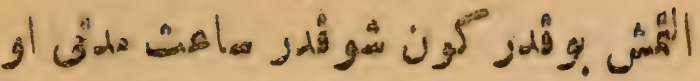

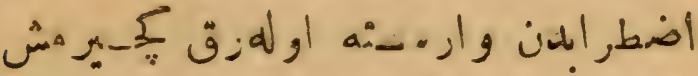

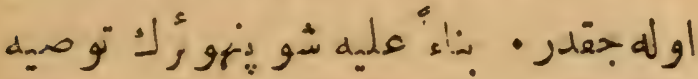

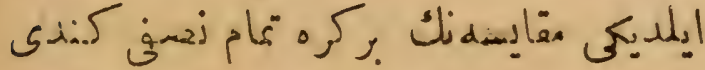

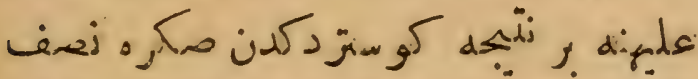

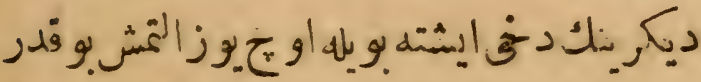

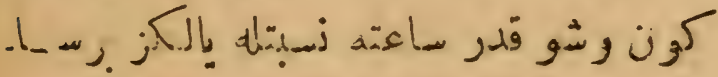

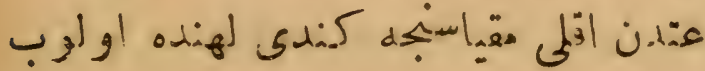

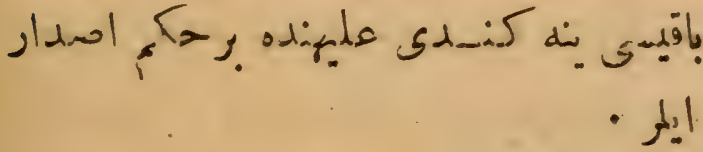

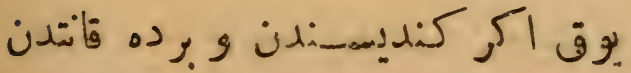

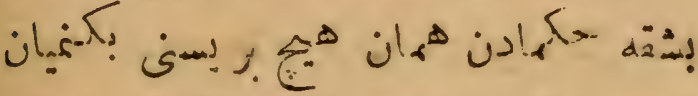

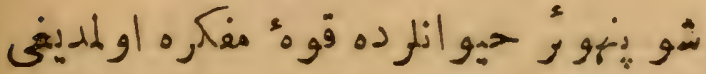

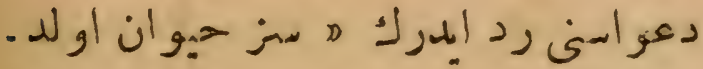

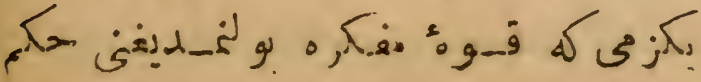




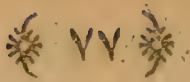

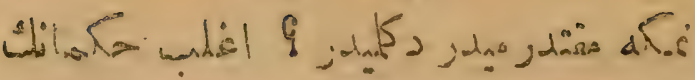

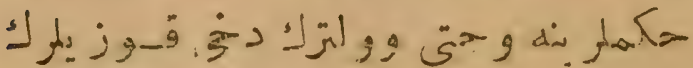

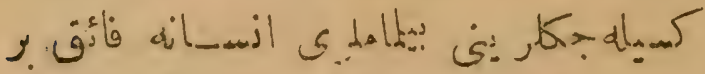

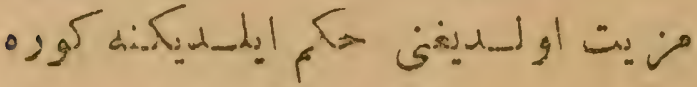

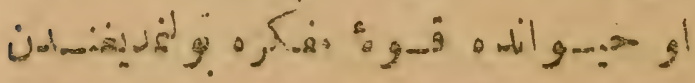
bان

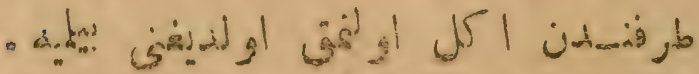

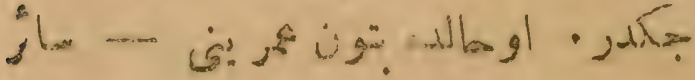

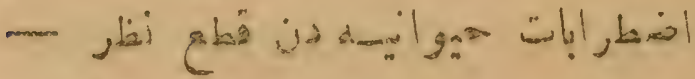
. 0 .

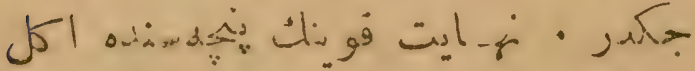

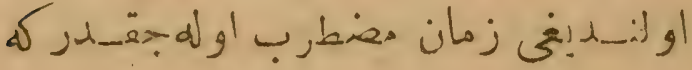

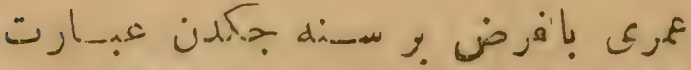

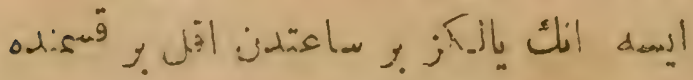

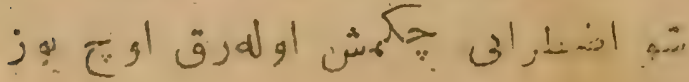


棌 $\mathrm{YO}$

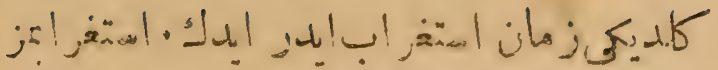

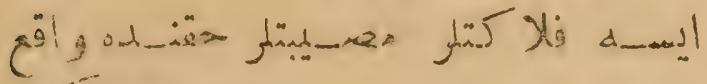
ال اوله

! stue dul slail

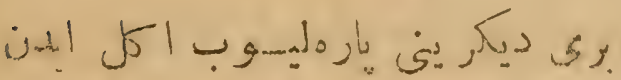

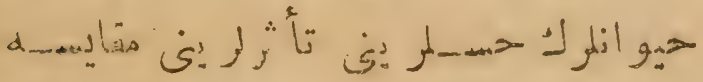

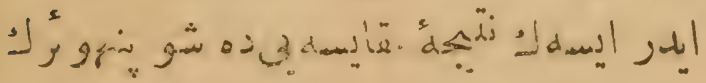

s.j.

بار

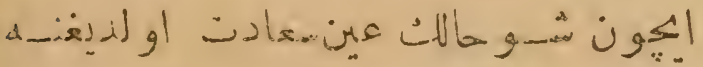

-

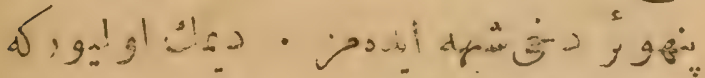

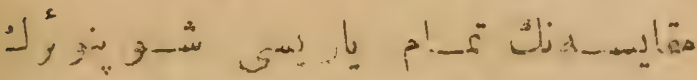

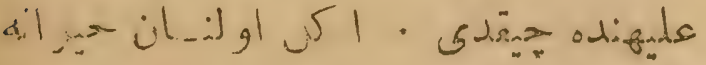

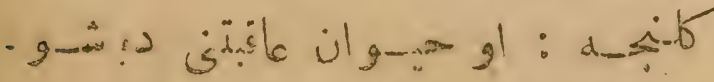




\section{Vo}

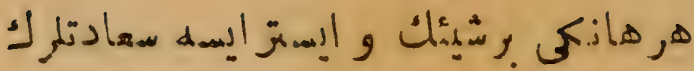

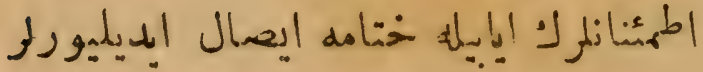

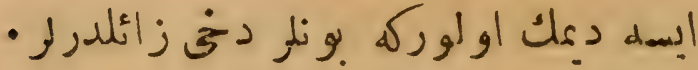

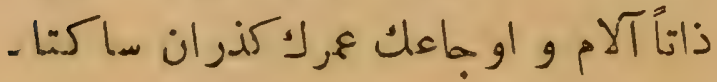
نهسني اخلال إبدجبك مادثاتدن اولديغني

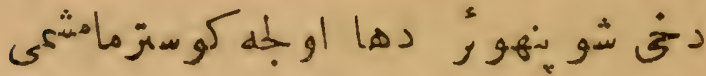

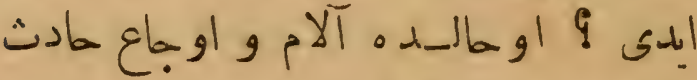

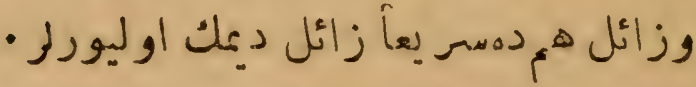

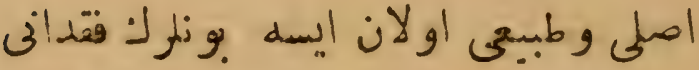

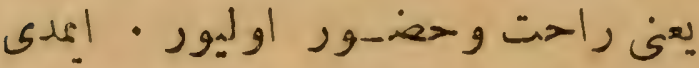
اصلم وطبيحى اولانان دها ـثبت ومادث

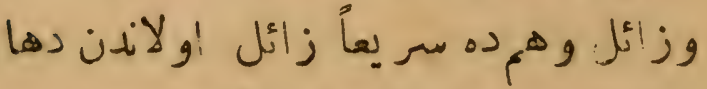

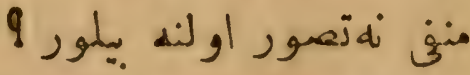

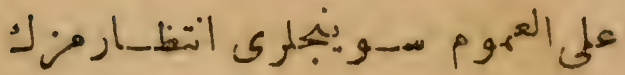

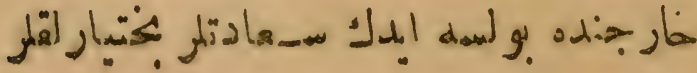




$$
\begin{aligned}
& \text { : } V \varepsilon
\end{aligned}
$$

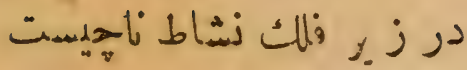

$$
\begin{aligned}
& \text { رتص .ره در د كان تمدباب }
\end{aligned}
$$

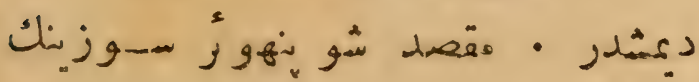

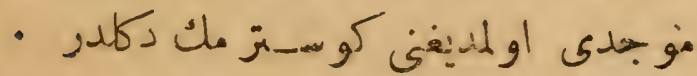

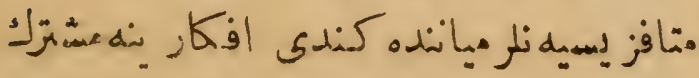

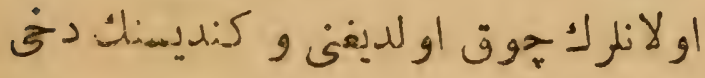

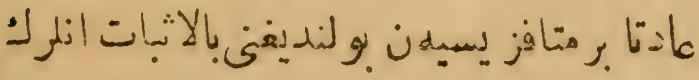

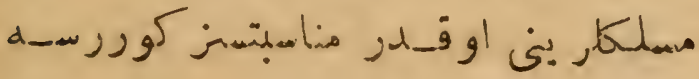

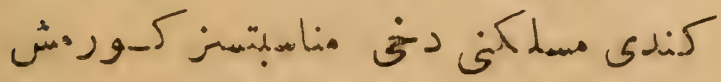

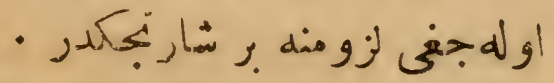

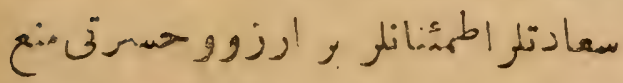

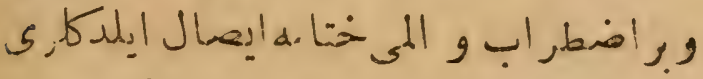

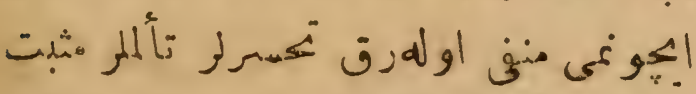

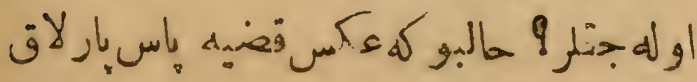

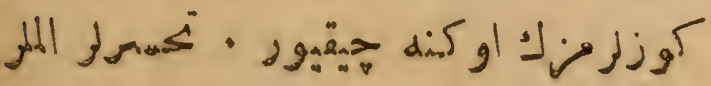




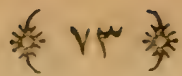

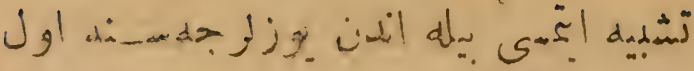

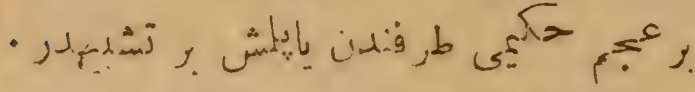

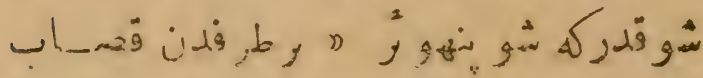

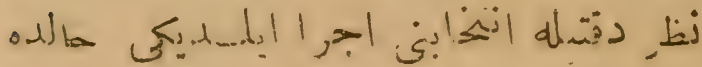
هاء

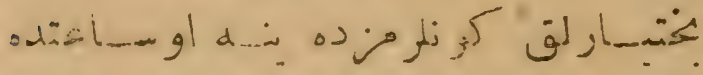

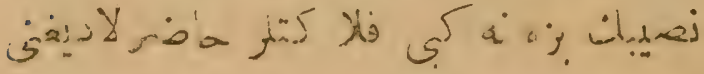
"

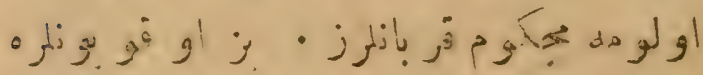

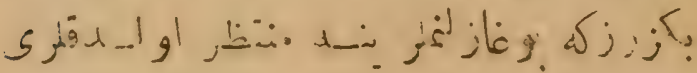
حالده

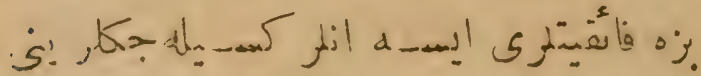

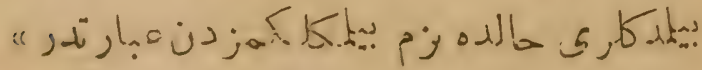

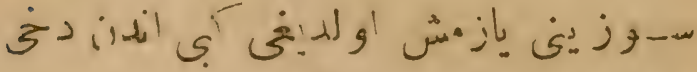

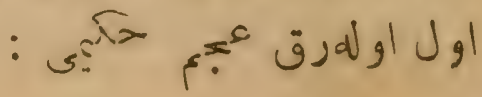




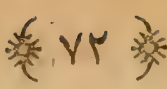

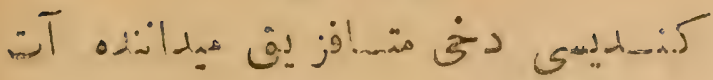

ا

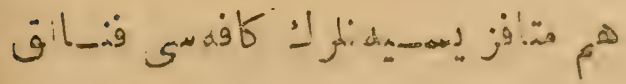
的

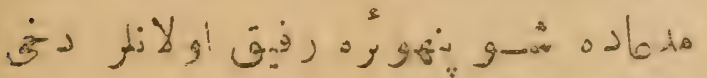

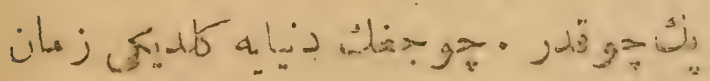

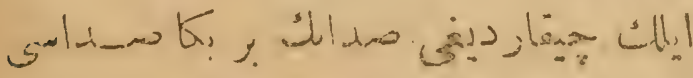

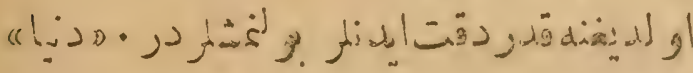

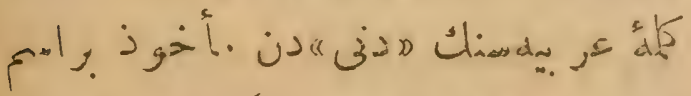

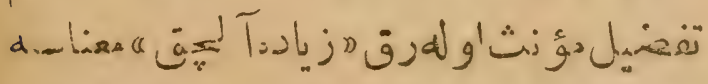

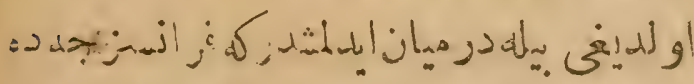
"ce bas monde " " ici bas"

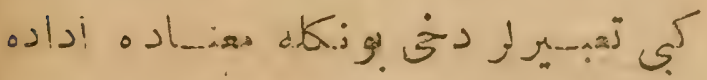

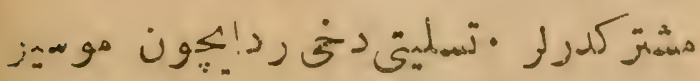

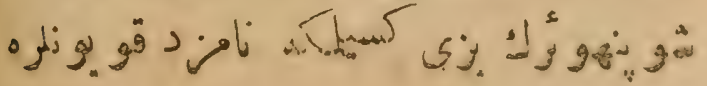




\section{港 VI}

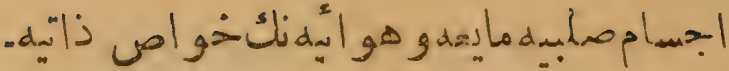

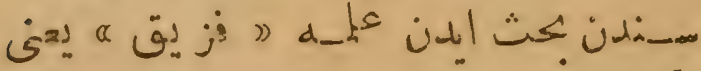

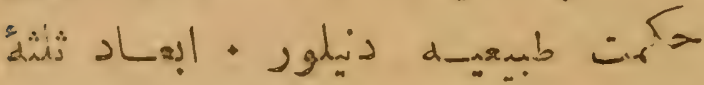

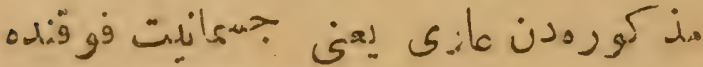

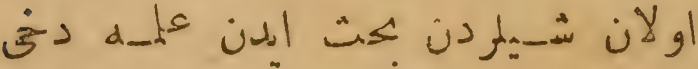

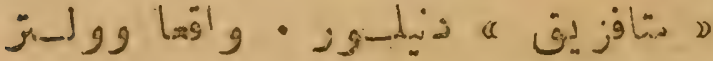

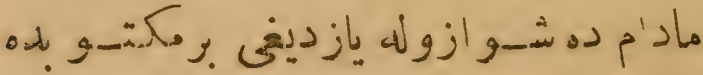

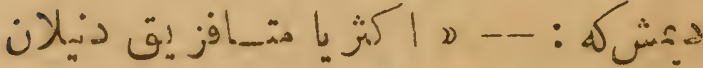

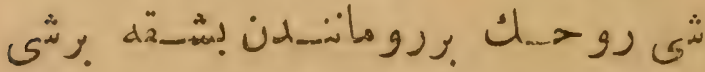

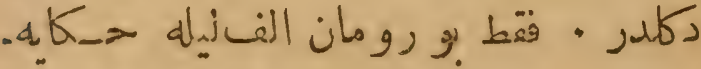

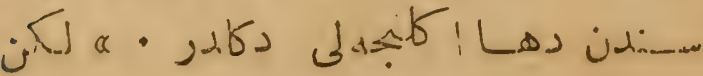

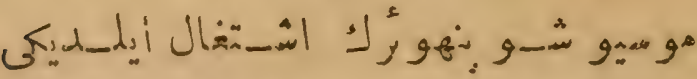

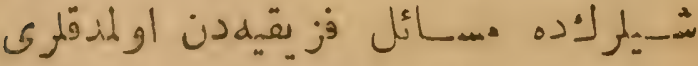

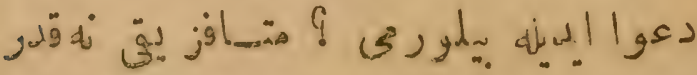

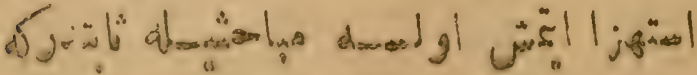




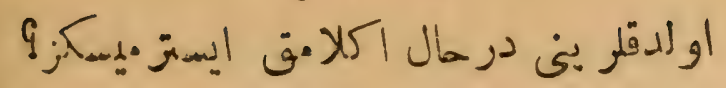

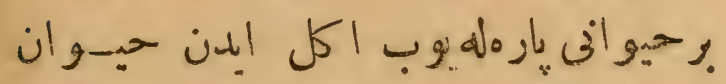

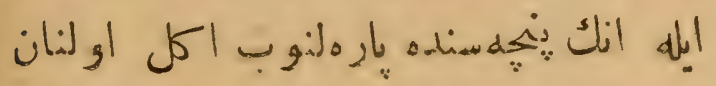

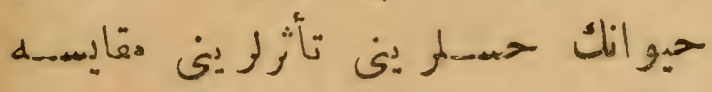
a

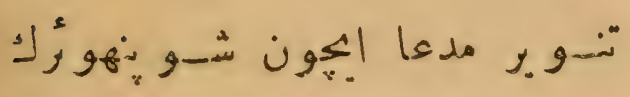

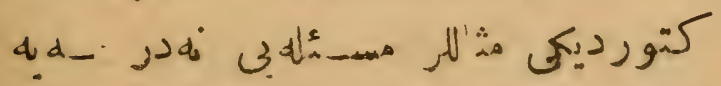

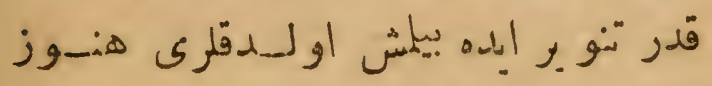

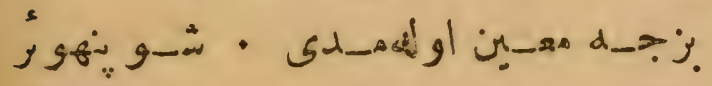

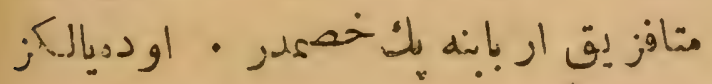

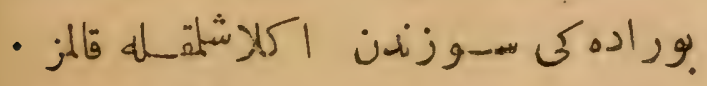

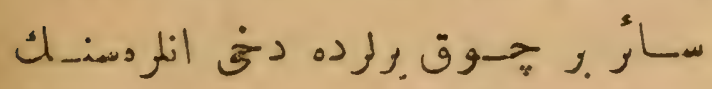
اعتر اض فرلاتور حتون

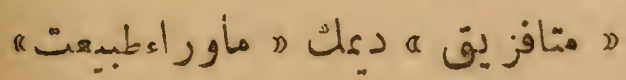

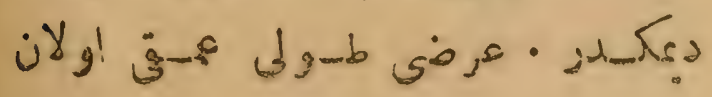


然 19 桨

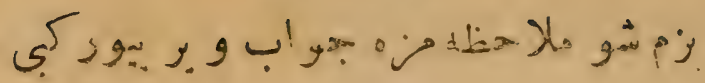

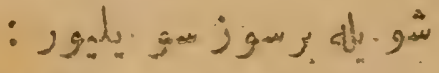

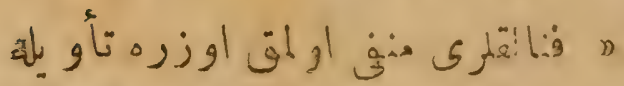

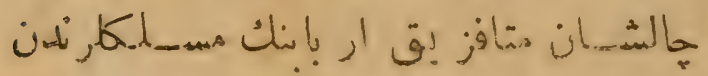

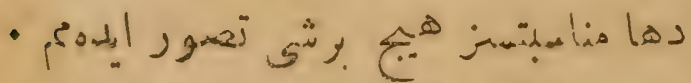

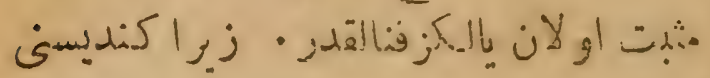

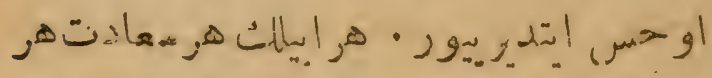

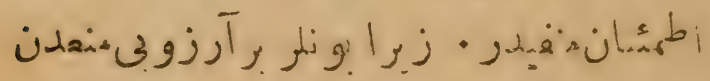

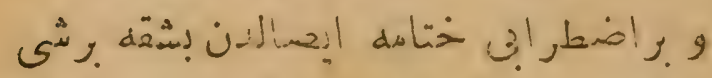

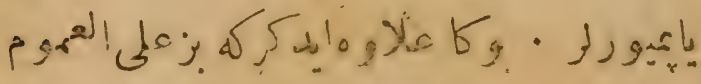

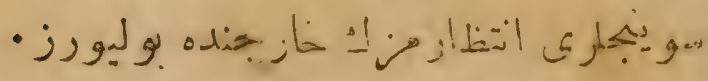

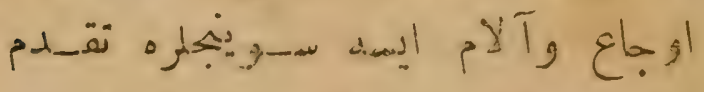

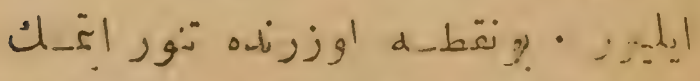

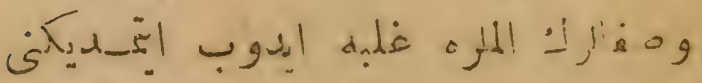

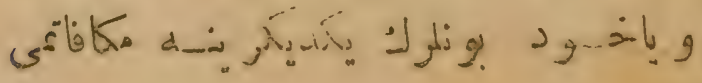




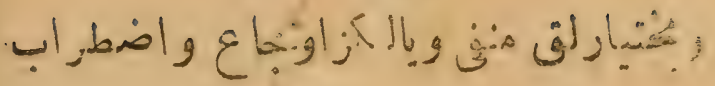

a gatis.

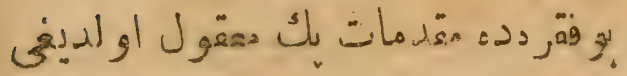

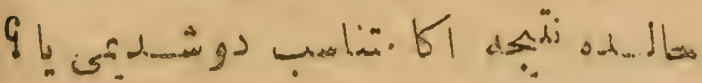

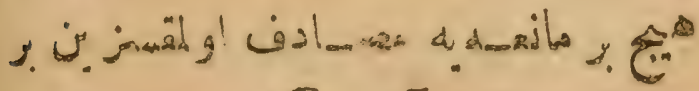

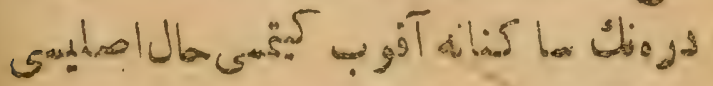

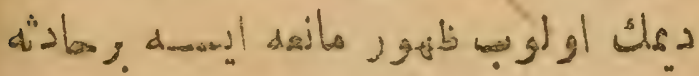

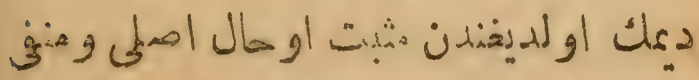

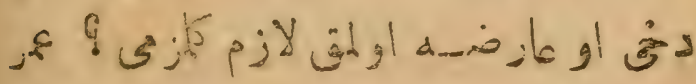

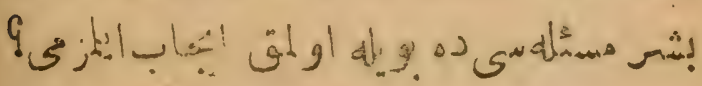

زاتاً

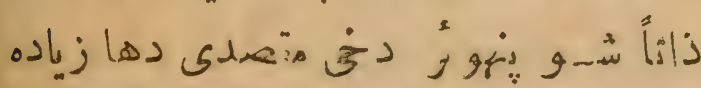

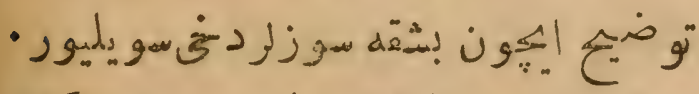

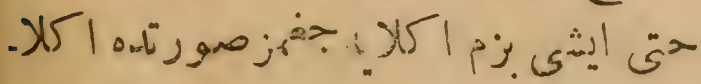

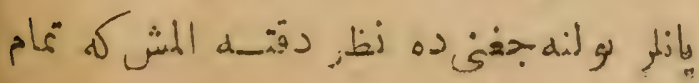




\section{荌 94}

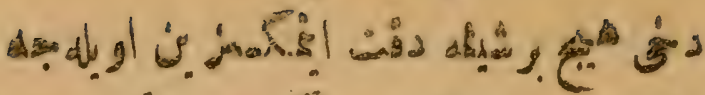

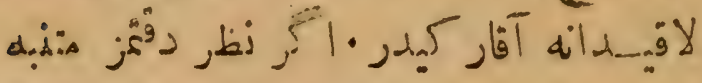

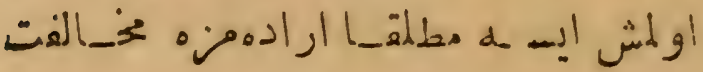

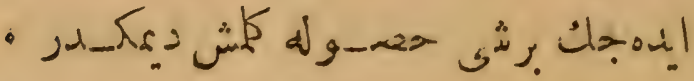

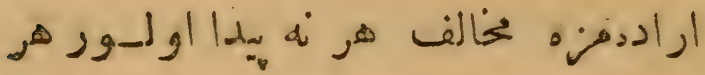

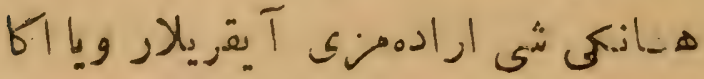

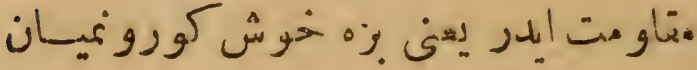

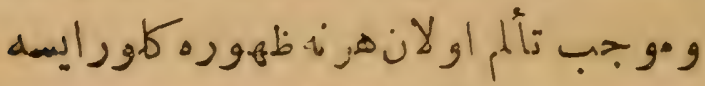

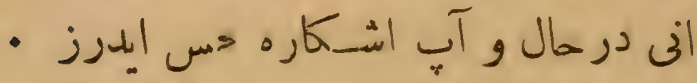

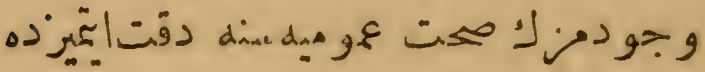

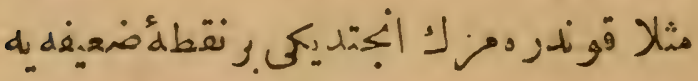

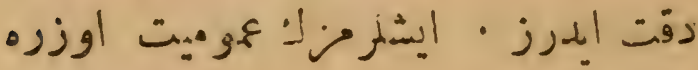

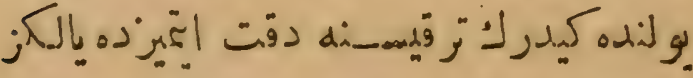

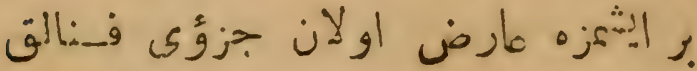

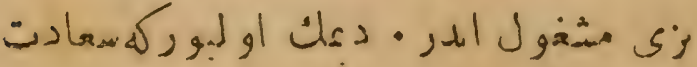




\section{7}

4. $3+x_{6} 0$

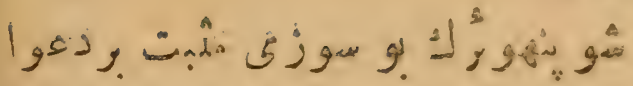

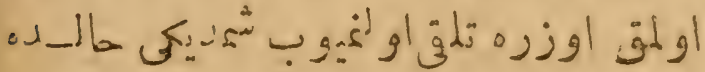

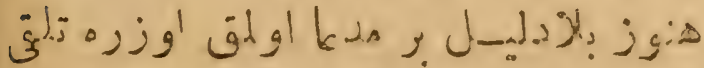

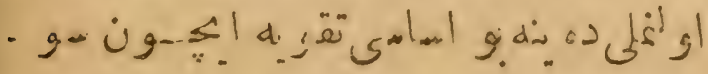

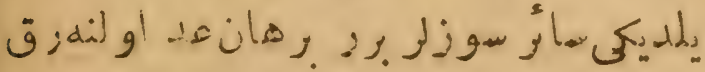

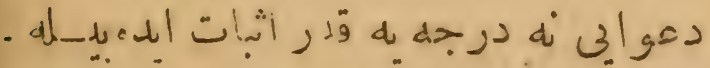

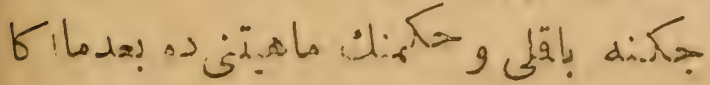

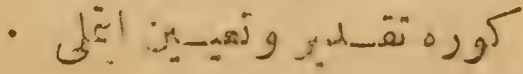

$$
\begin{aligned}
& \text { شو: }
\end{aligned}
$$

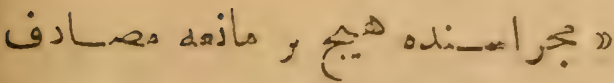

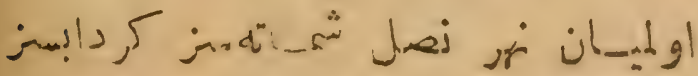

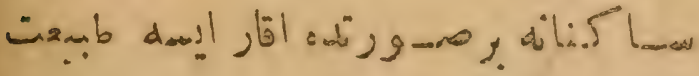

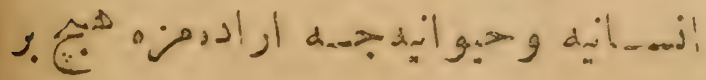

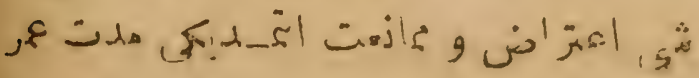




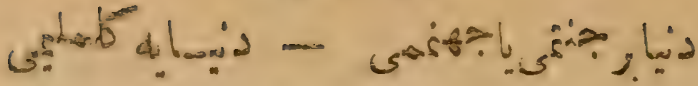

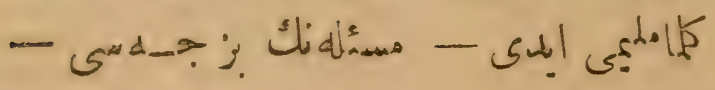

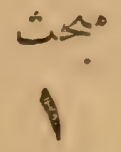

व ${ }^{2}$ का

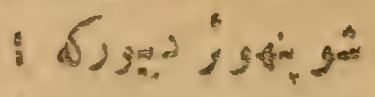

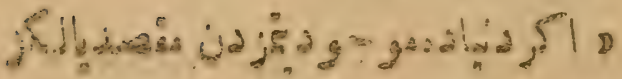

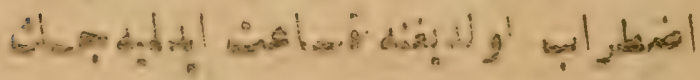

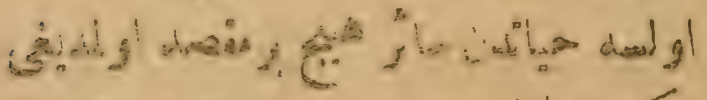

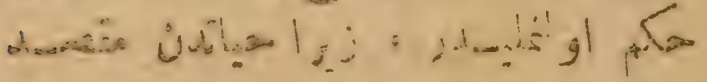

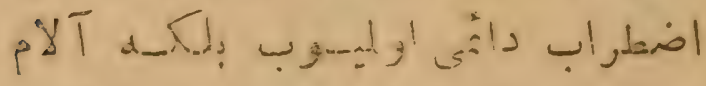
واكل

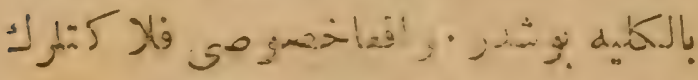

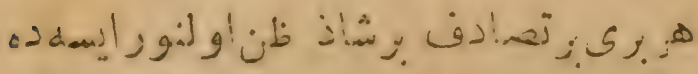
ه 
染征梁

كو

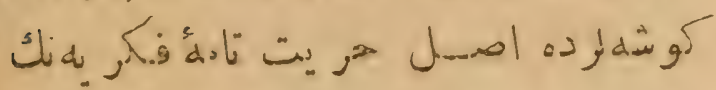
نامل

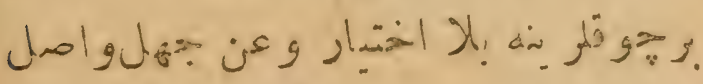
و

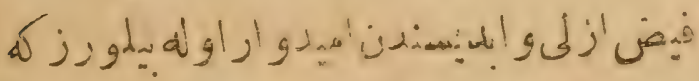

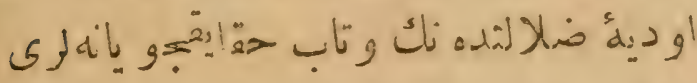

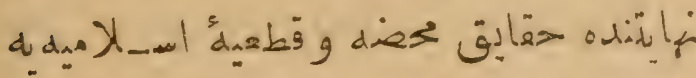

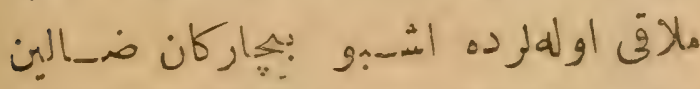

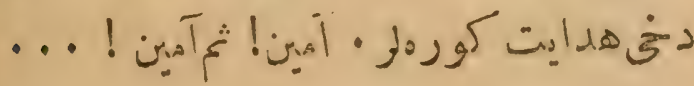

-

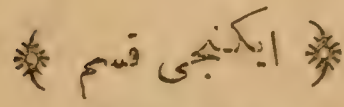

a dingister

ن-

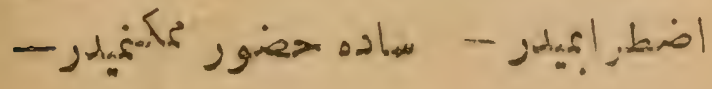


先

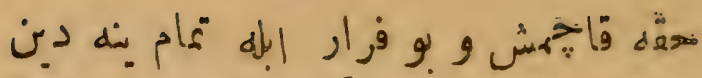

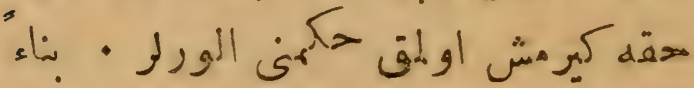

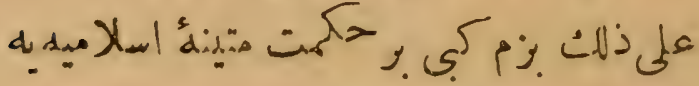

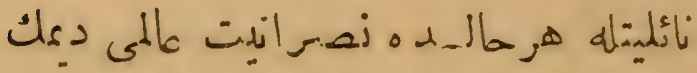

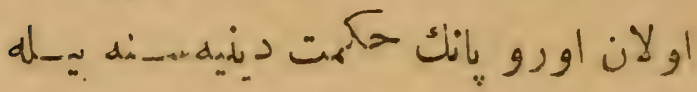

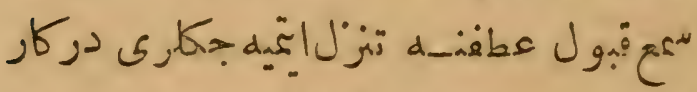

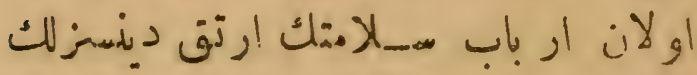

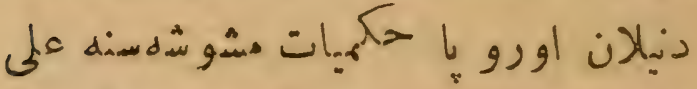

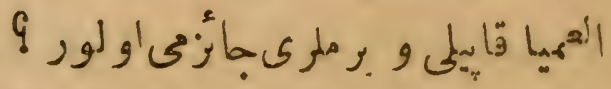

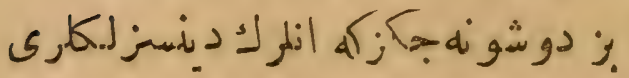

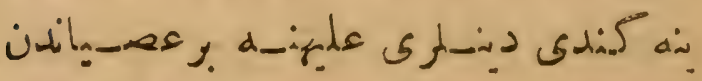

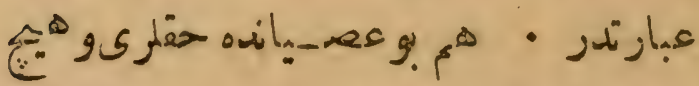

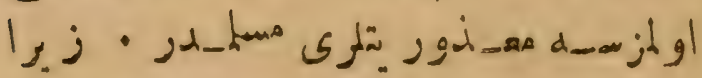

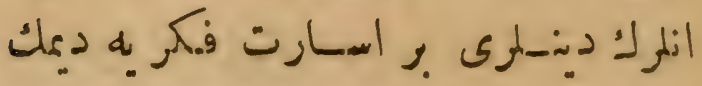

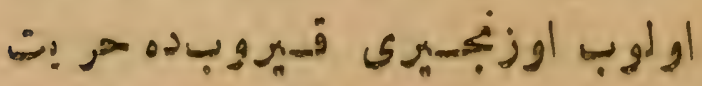




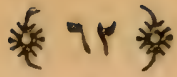

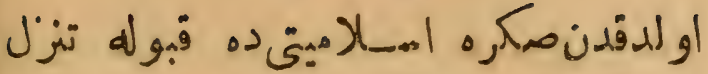

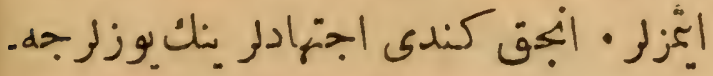

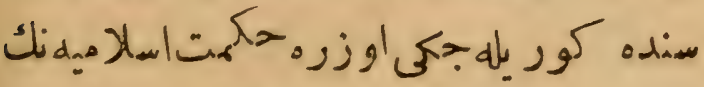

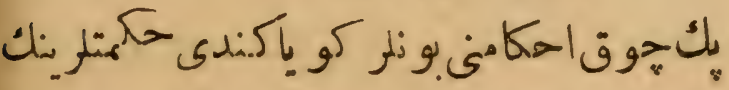
اس-لمى اولمق اوزره قبول إتيكدهدر لركه

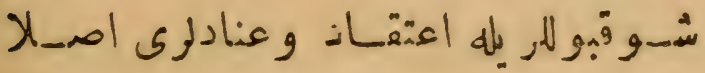

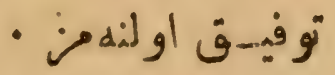

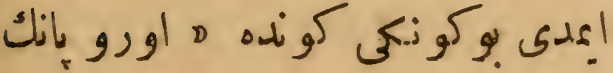

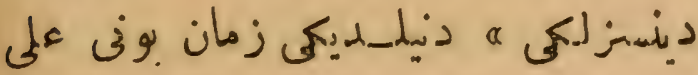

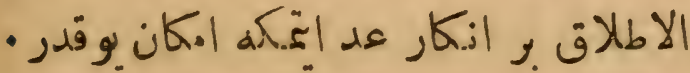

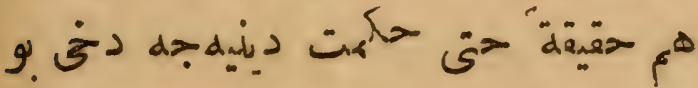
اهكان يوفـدر • زيرا دياتندن الوهيتدن

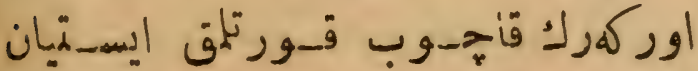

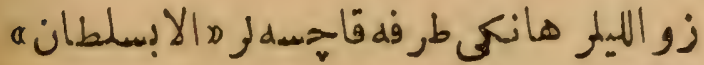

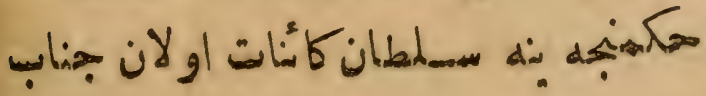




\section{秋}

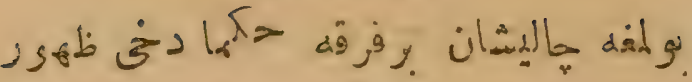

إبرلُ ديا:تى عبـاتى الوهيتى فـالانى

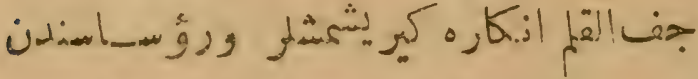

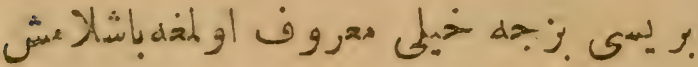

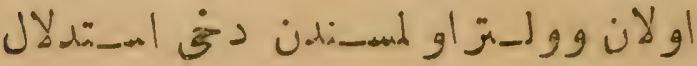

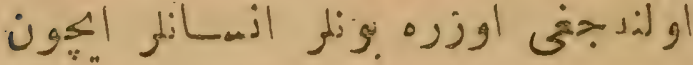

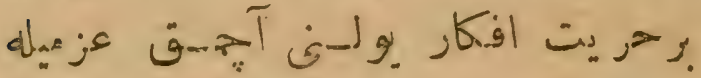

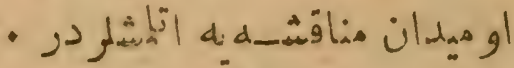

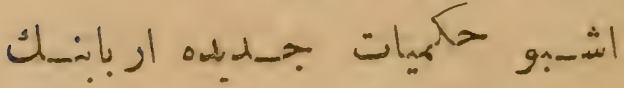

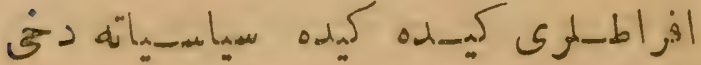

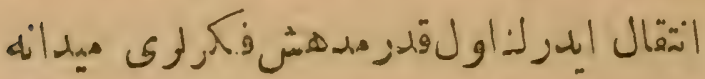

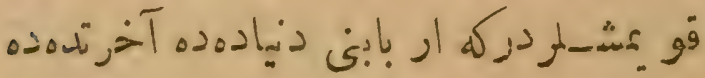

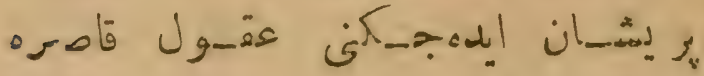

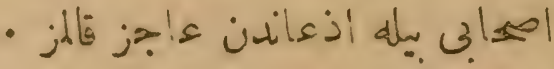

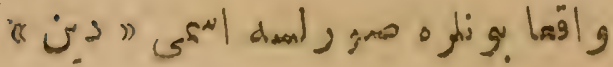




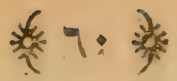

ن

. dب.

$$
\text { • }
$$

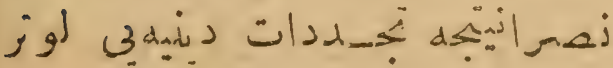

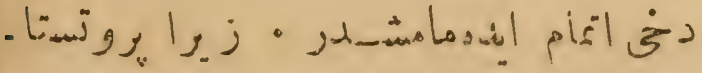

زلق هذهن

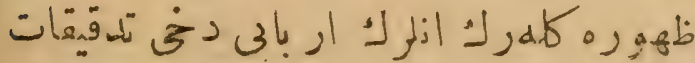

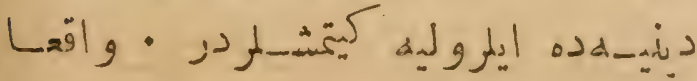

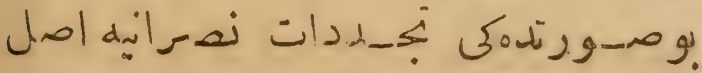

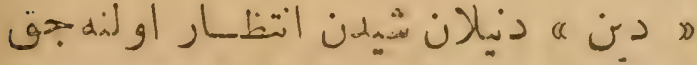

حتمنت

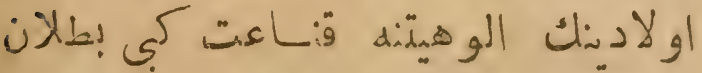

dglosd_on a

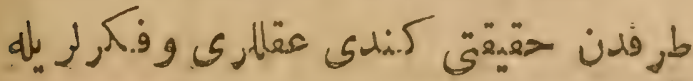




\section{类09}

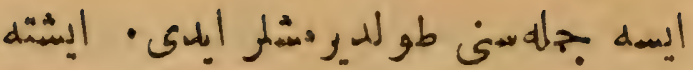

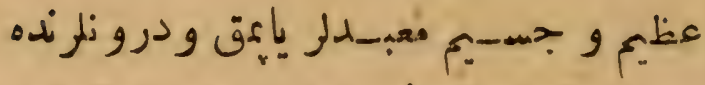

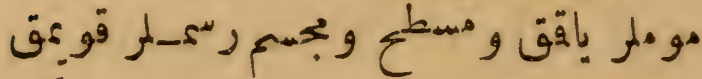

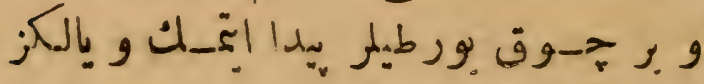

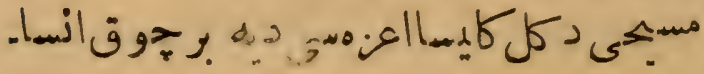

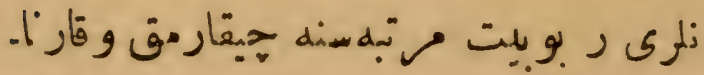

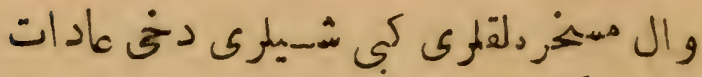

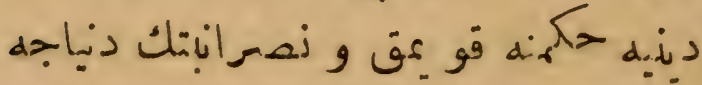

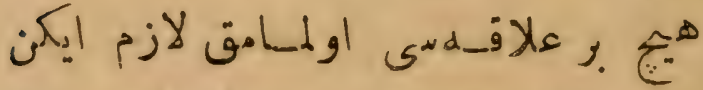

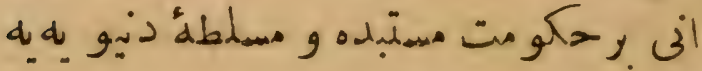

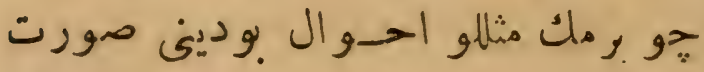

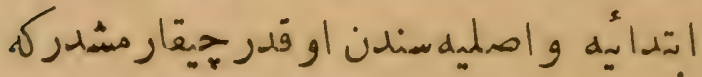

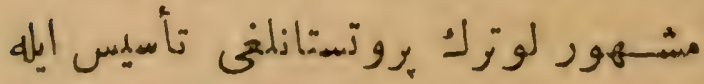

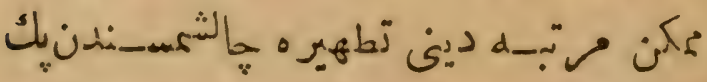

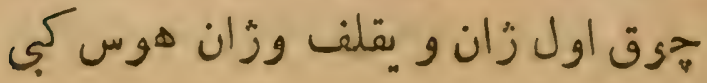




\section{棌的}

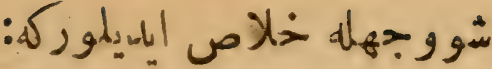

عن اصل يمو ديلكمن عبارت .ولنان

نصرانيت يموديلك عالمi_ده مظهر حسن

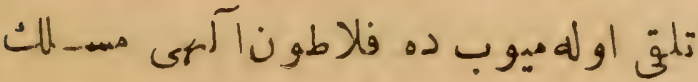

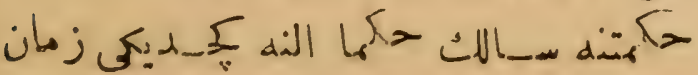

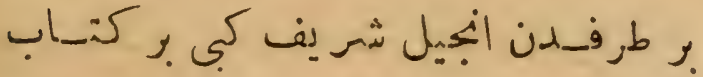

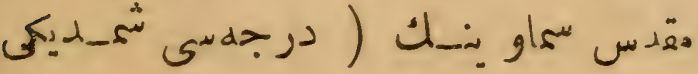

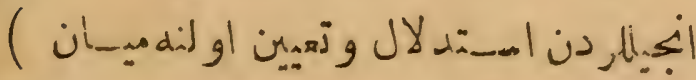

ارشادو ديكر طرفندن فلاطو يملرك اكمال

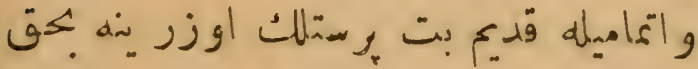

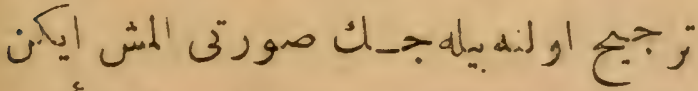

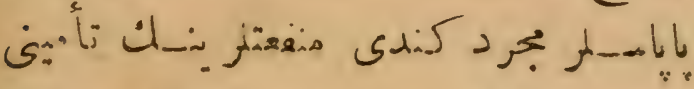

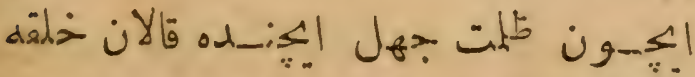

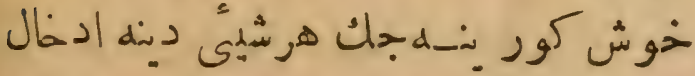

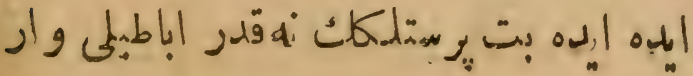


听慗

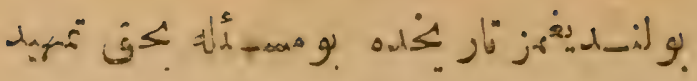

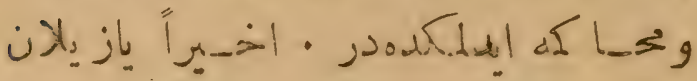

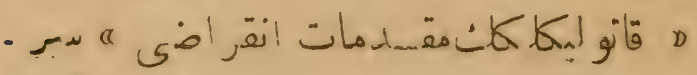

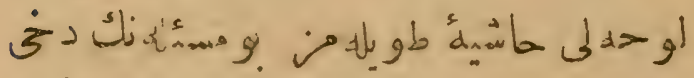

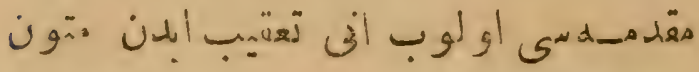

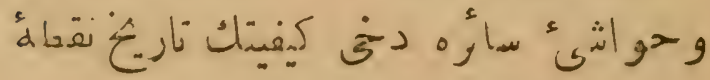

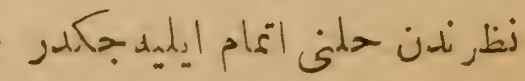

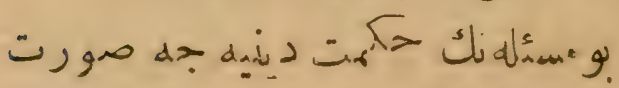

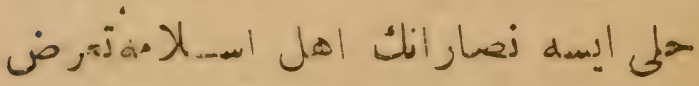

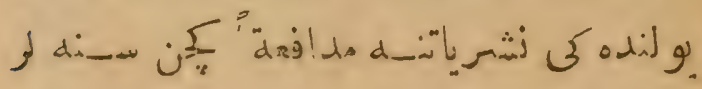

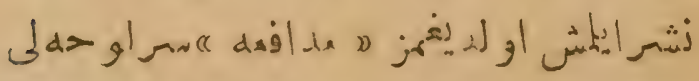

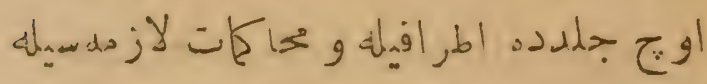
كور ديلور

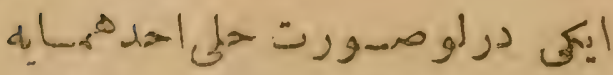

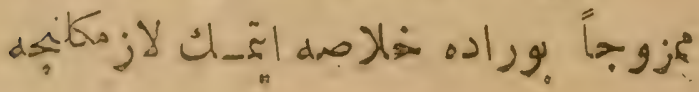


棌09获

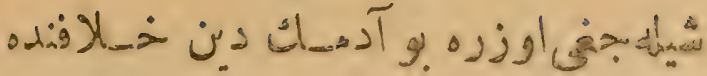

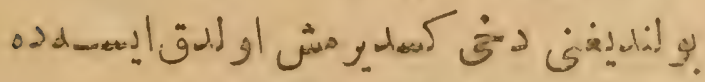
d.

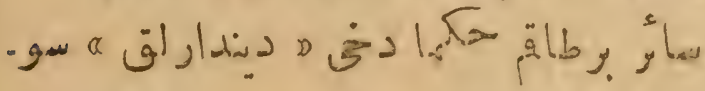
ه

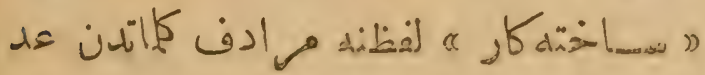

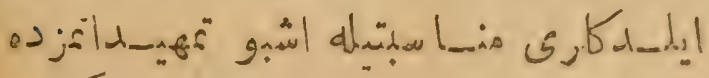

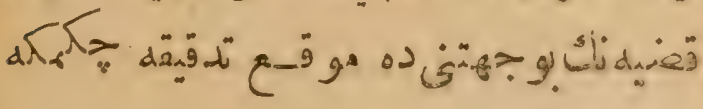

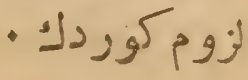

$\dot{H}$

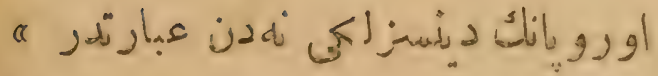

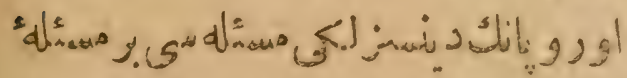
Sردd_

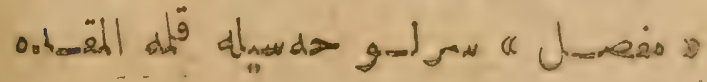


䇣00

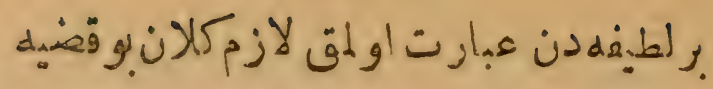

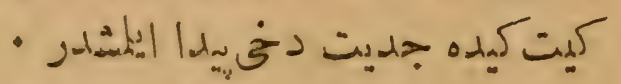

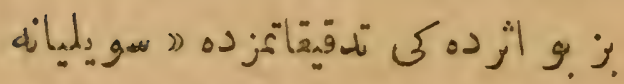

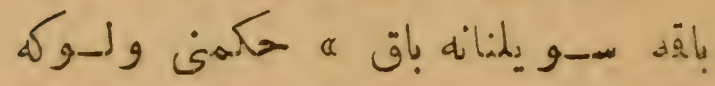

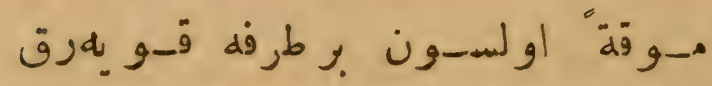

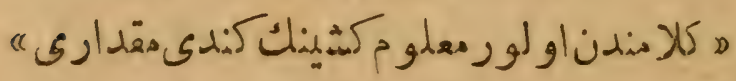

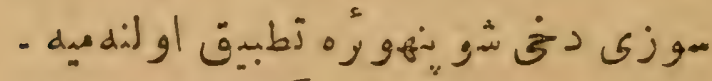

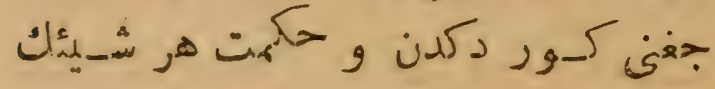

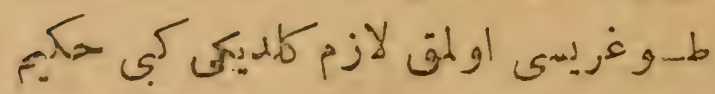

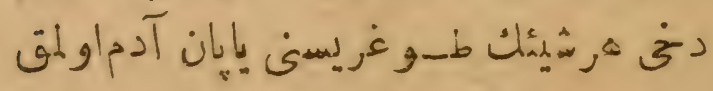

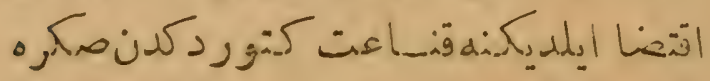

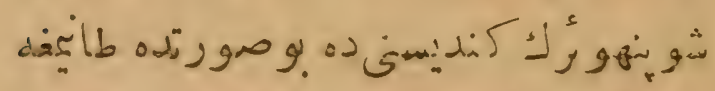

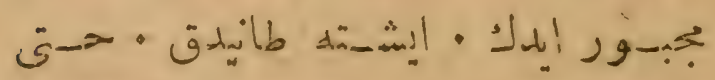

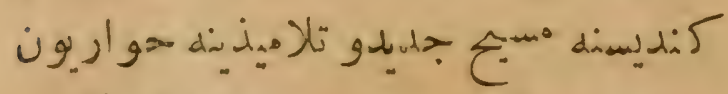

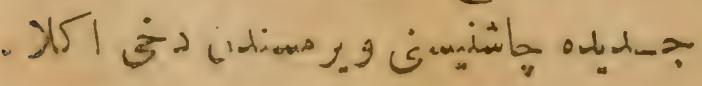




\section{吃慗}

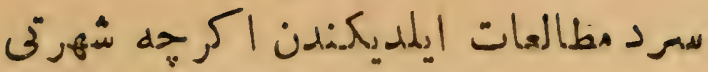
براز كم قالمش ايسهده اوقدر بيو مشيدركه

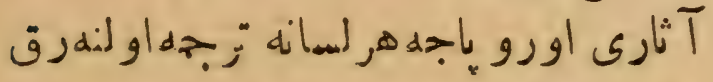

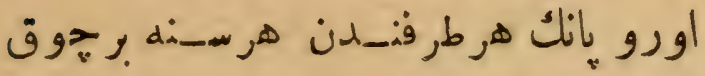

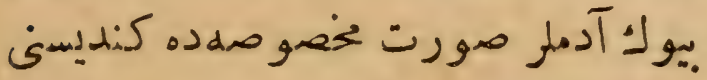

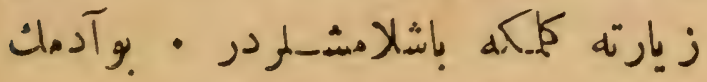

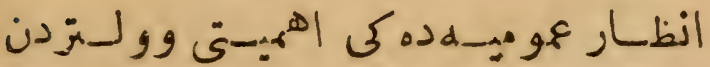

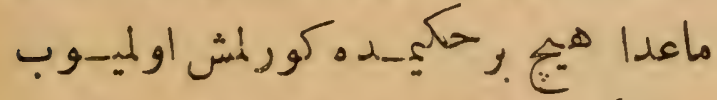

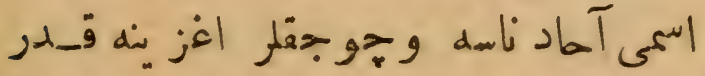

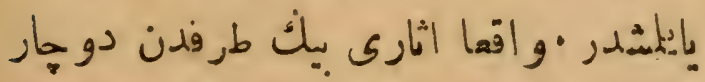

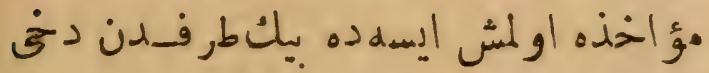

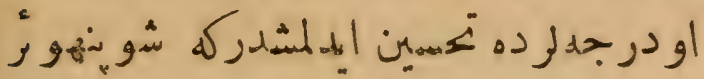

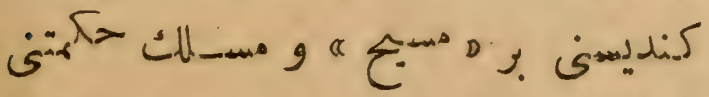

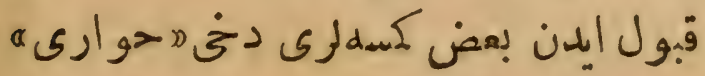

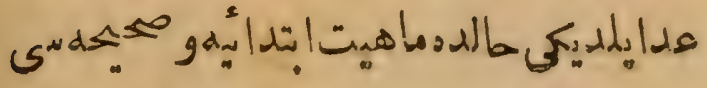


然 or 棠

قالهد

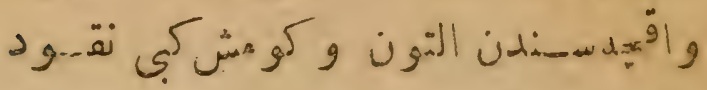

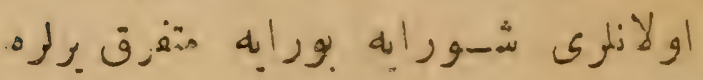

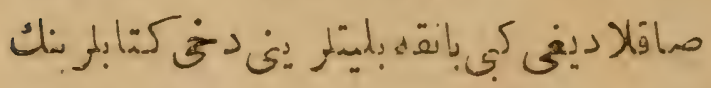

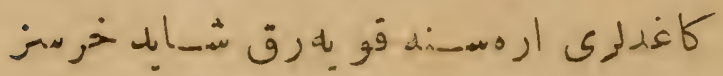

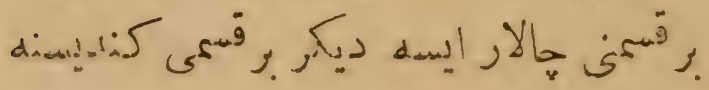

قوله

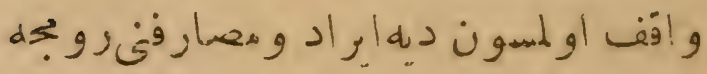

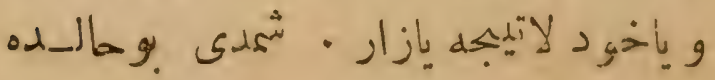

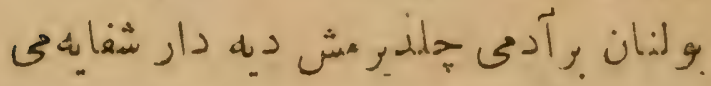

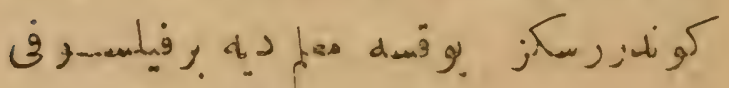

q

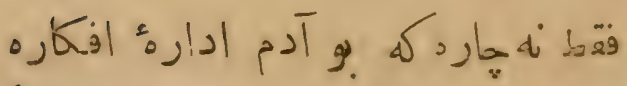

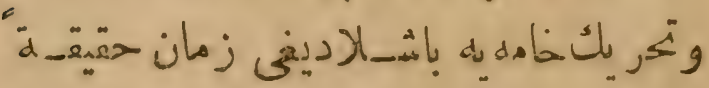

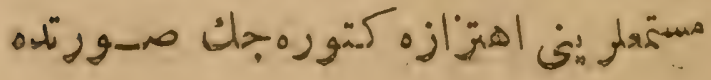




\section{染 or 婆}

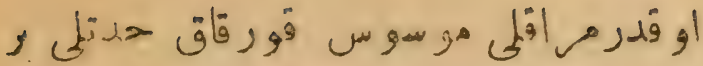

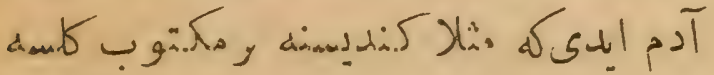

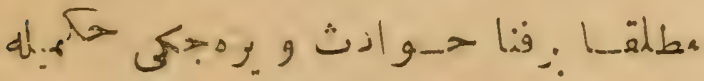

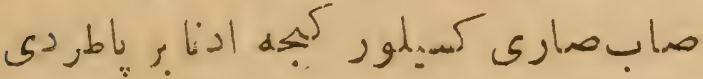

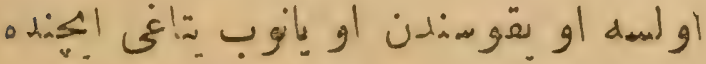

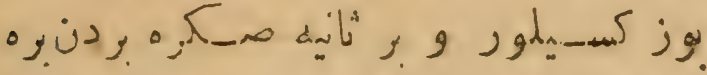

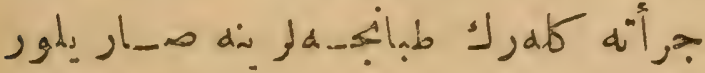

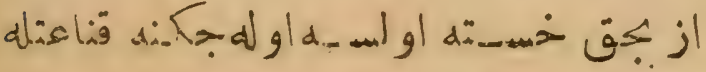

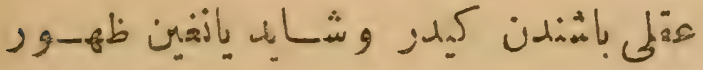

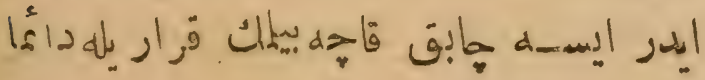

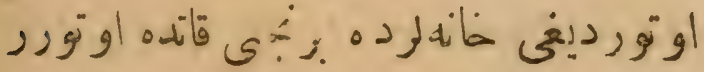

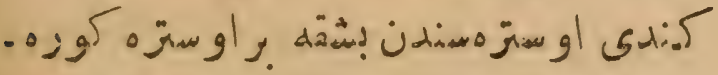

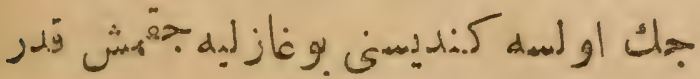

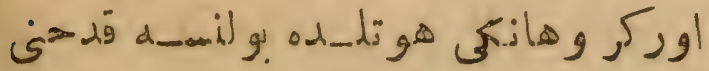

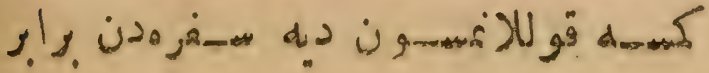




\section{1 桨}

كور ماك دماك اولوركها اودنى ص-باحلمين

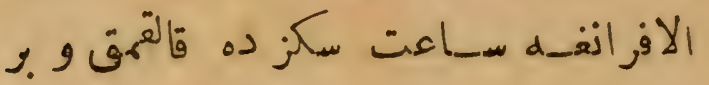

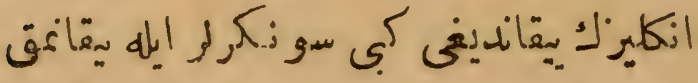

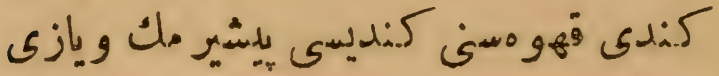

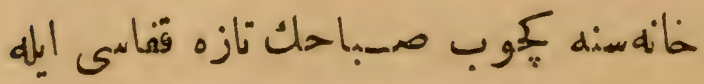

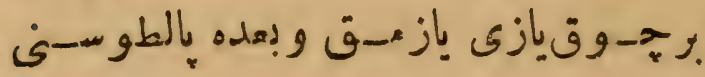

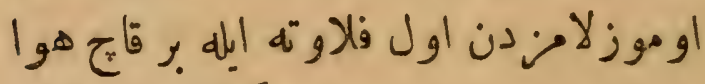

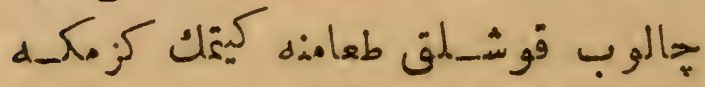

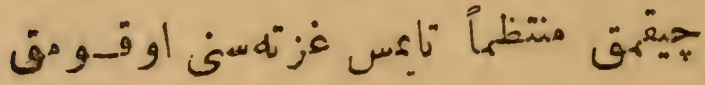

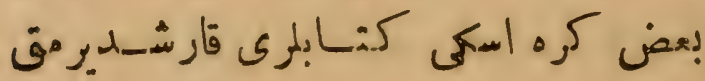

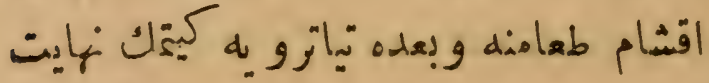

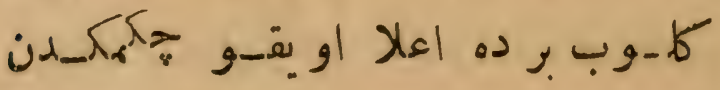
- عبارتمدوب

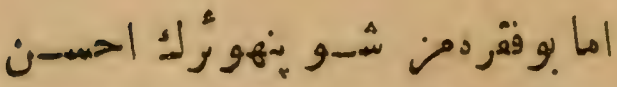

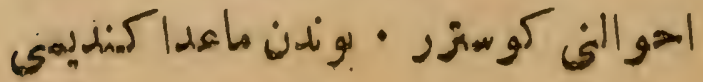


采 0 . 数

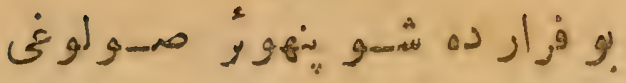

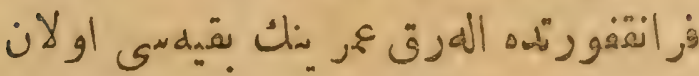

مكرمى طقوز

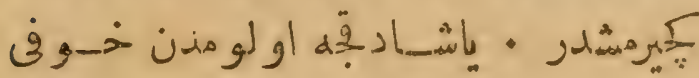

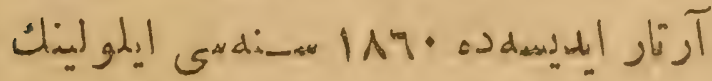

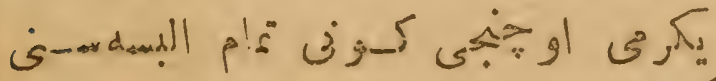

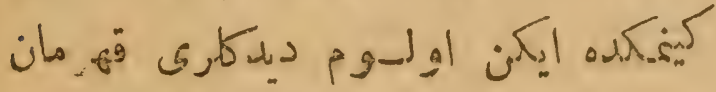

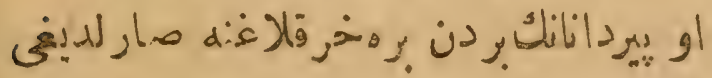

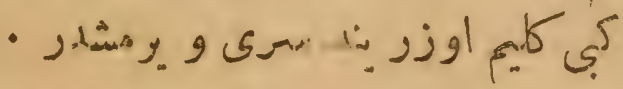

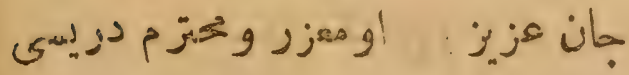

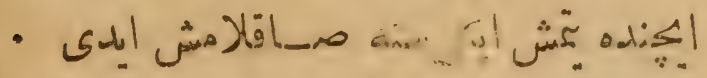

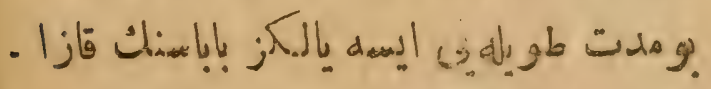

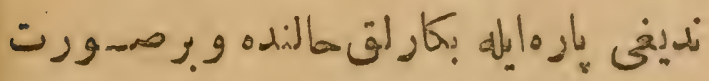

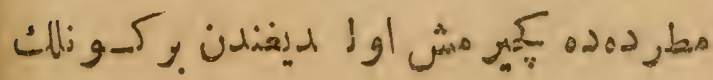

(i) 


\section{染 $\{9$ 荻}

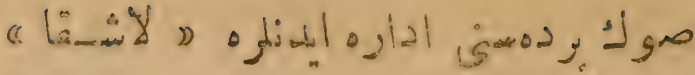

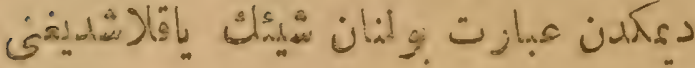

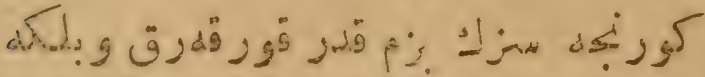

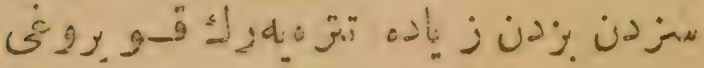

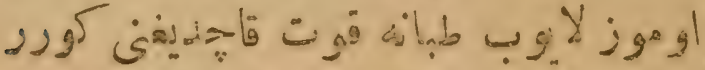

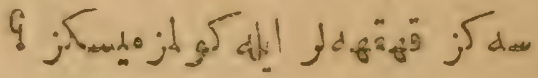

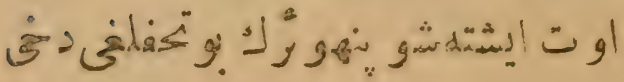
ا

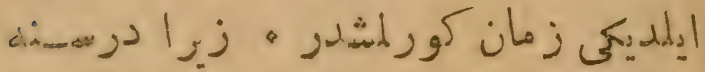

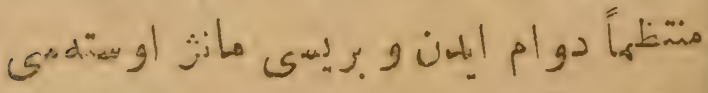

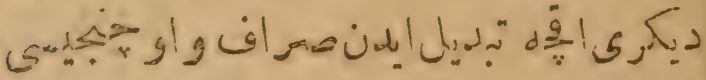

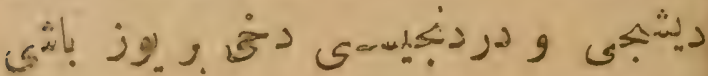

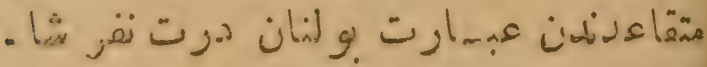

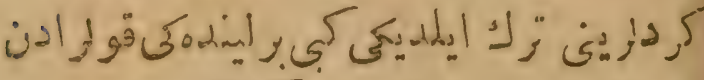
- رئم 
漛纳奜

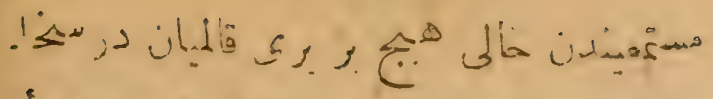

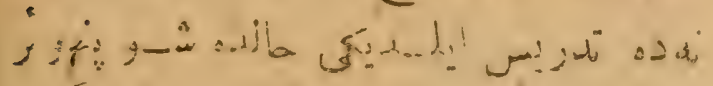

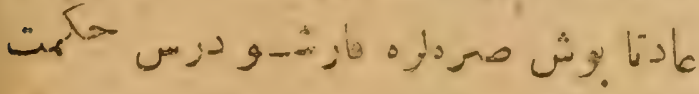

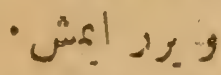

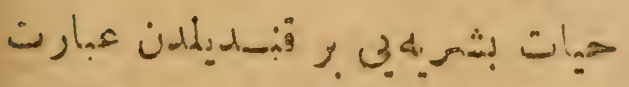
كورن إنه

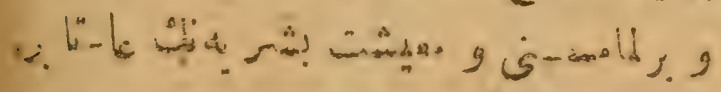

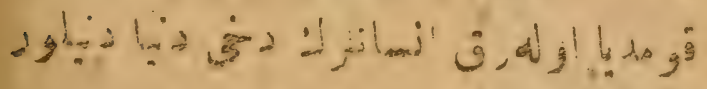

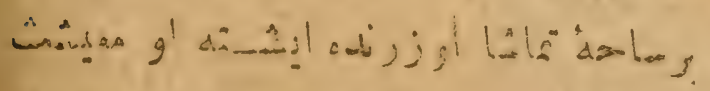

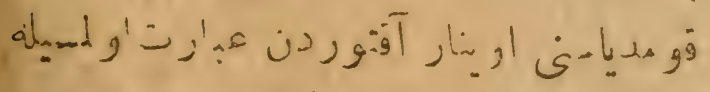

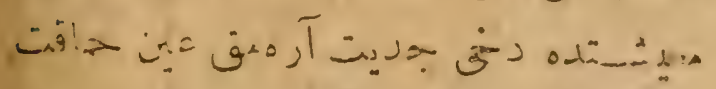

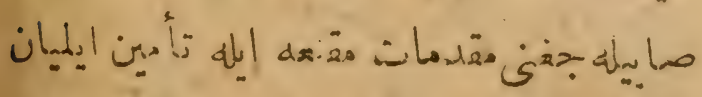

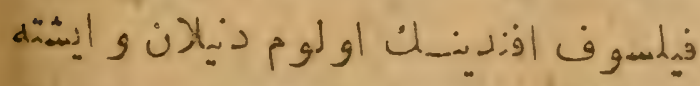

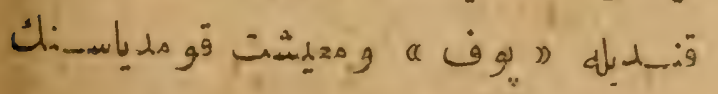




\section{渠 \{V 紫}

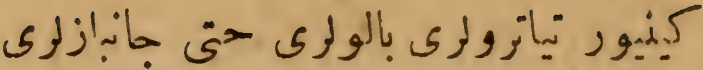

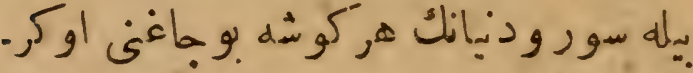

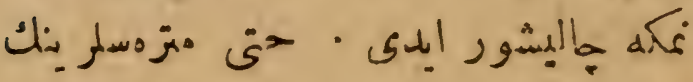

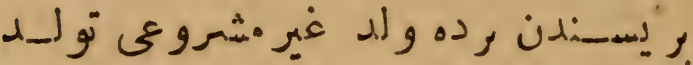

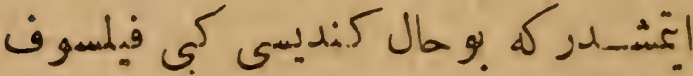

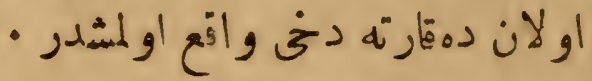

هر زمده بولنسه ذوق وصنا معتادى

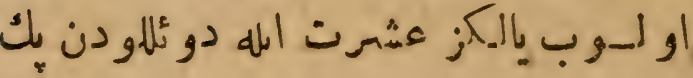

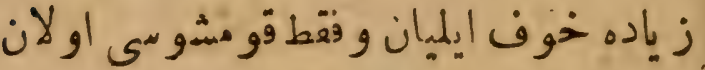

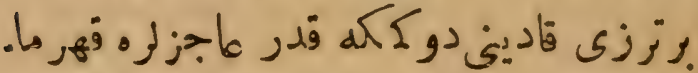

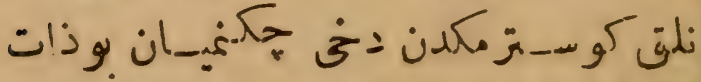

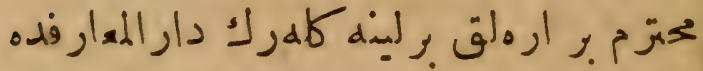

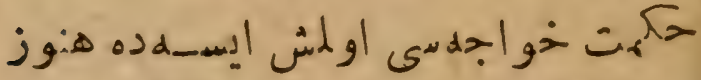

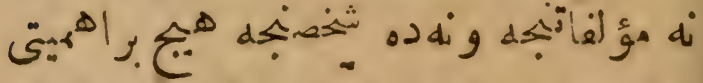

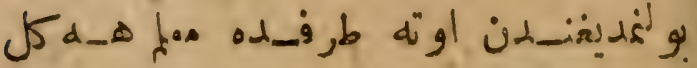




\section{粗}

ماحعل اقتدار ابدرك عم معدنيات نباتات

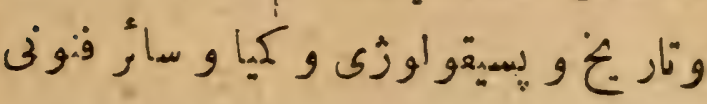

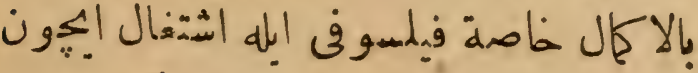

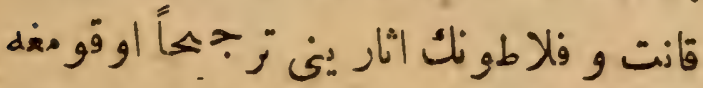

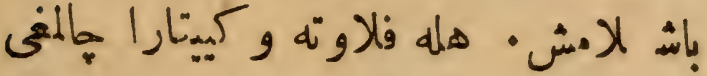

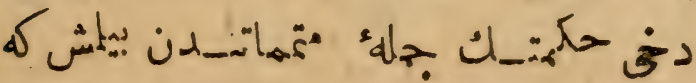

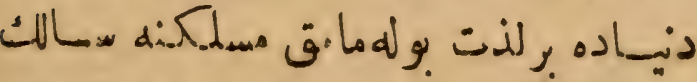

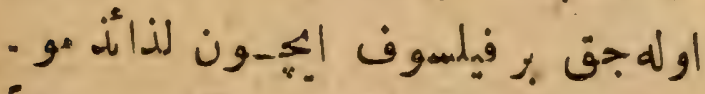

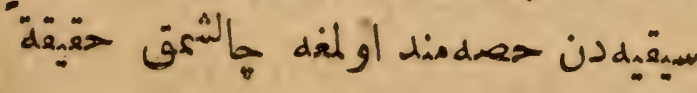

$$
\text { غر مدر }
$$

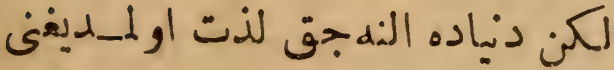

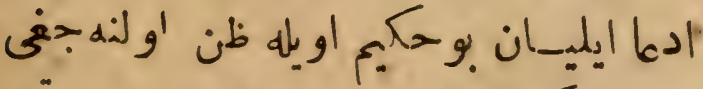

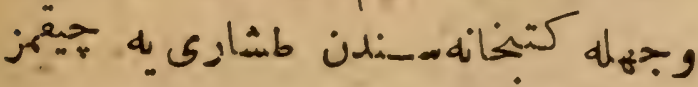

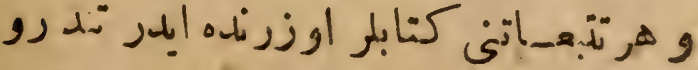

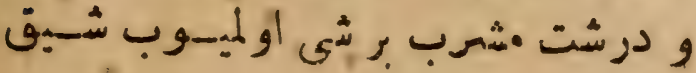




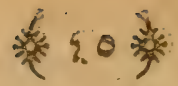

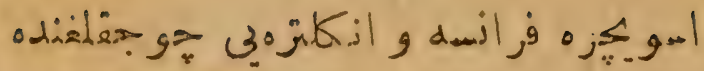

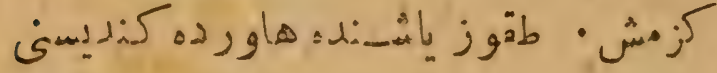

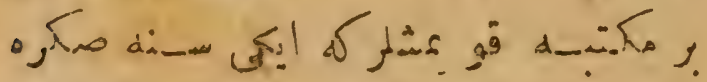

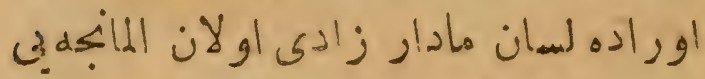

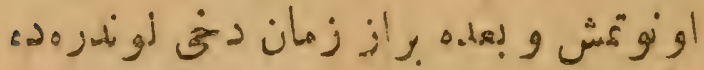

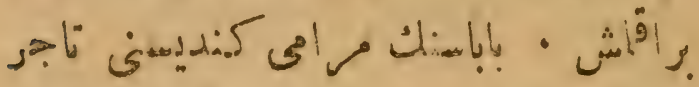

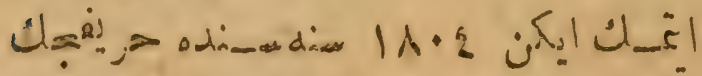

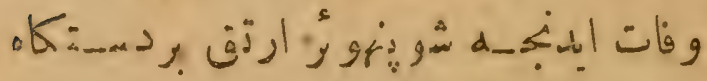

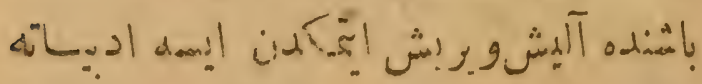

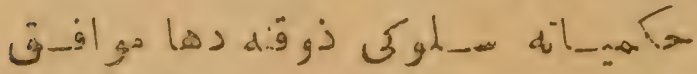

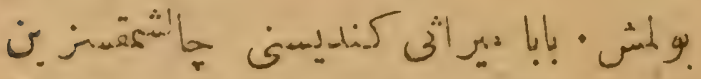

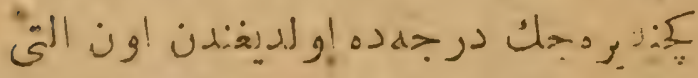

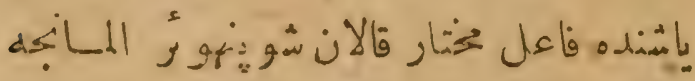

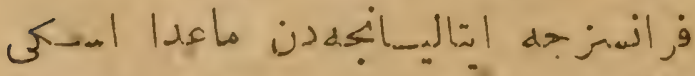

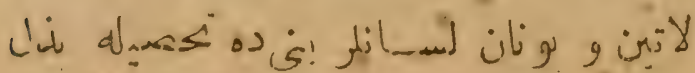


染 $\{$ 染

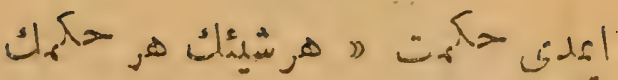

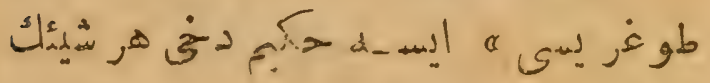

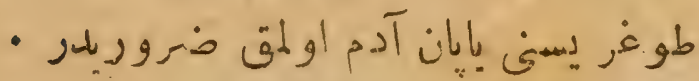

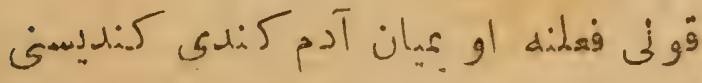

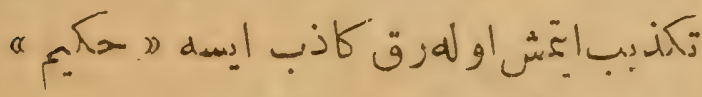

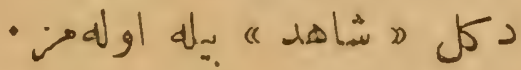

مي

\&

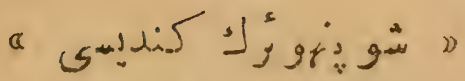

.

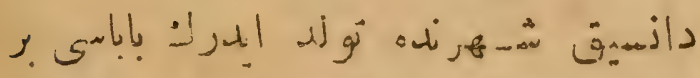

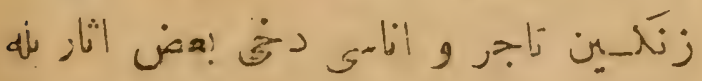

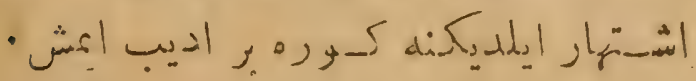

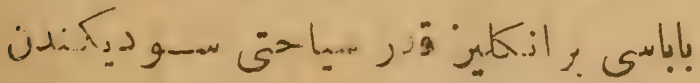

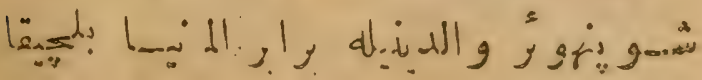




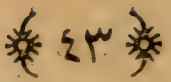

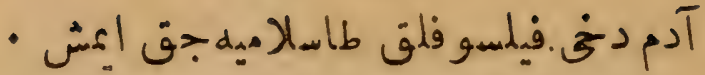

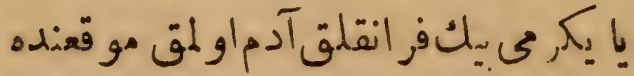

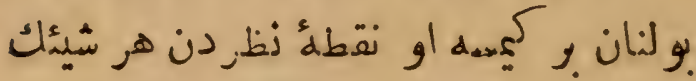

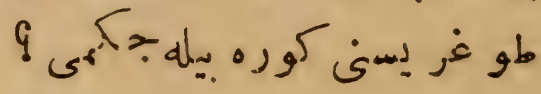

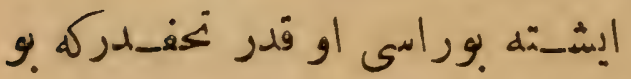

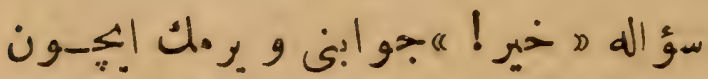

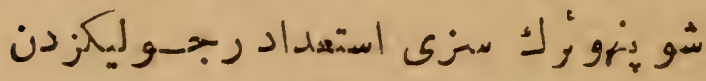

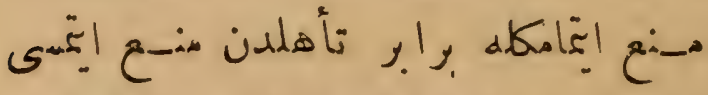

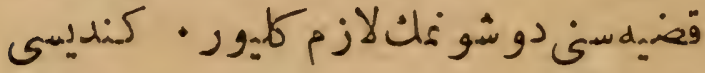

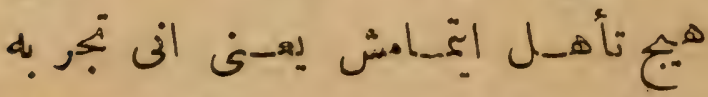

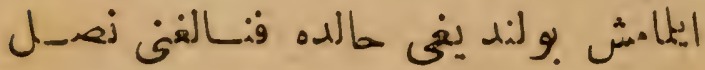

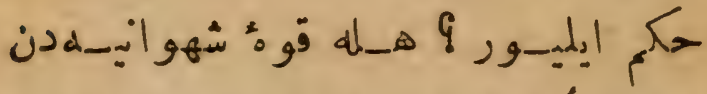

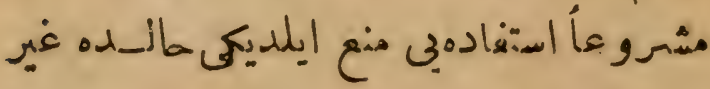

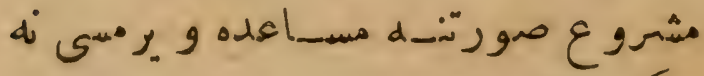
q 


\section{实}

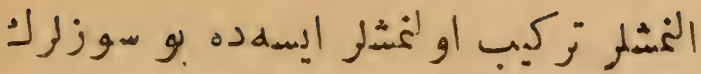

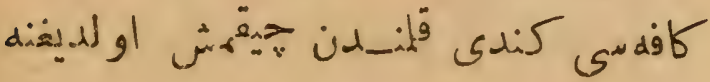

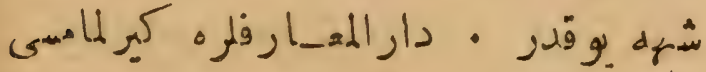

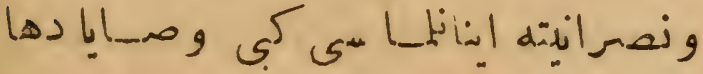

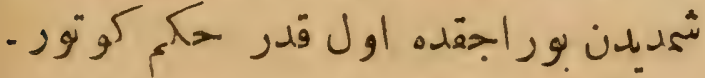

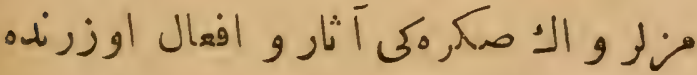

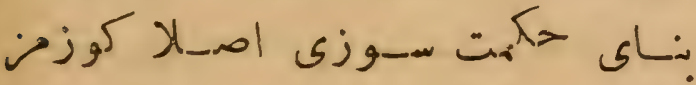

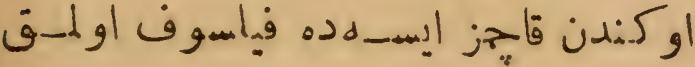

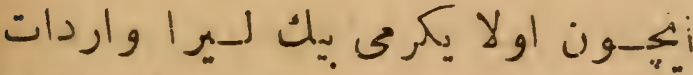

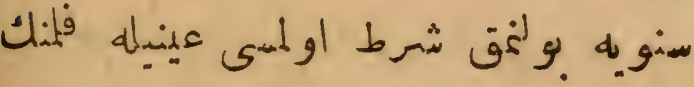

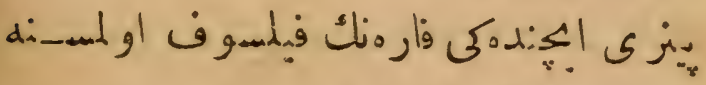

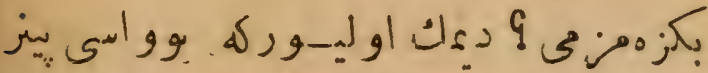

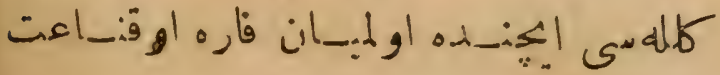

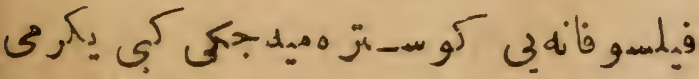

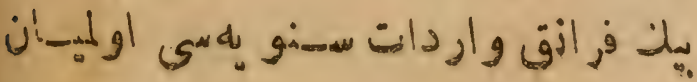


篹々1 媇

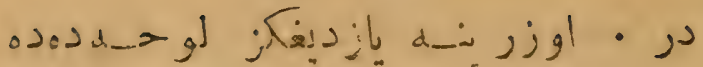

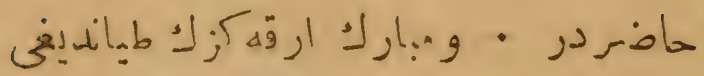

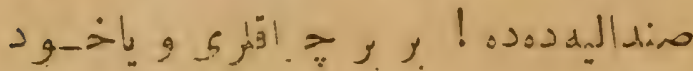

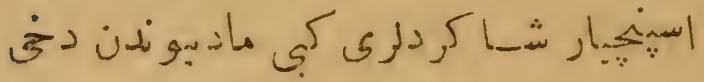

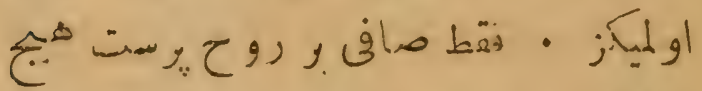

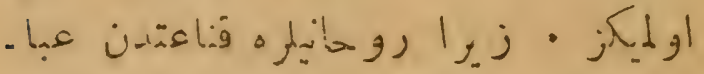

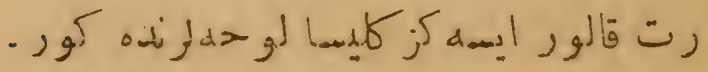

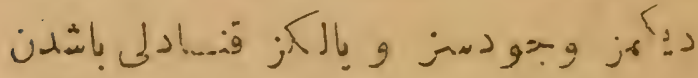

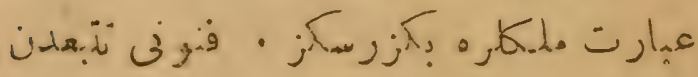

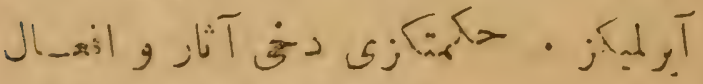

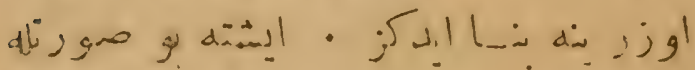

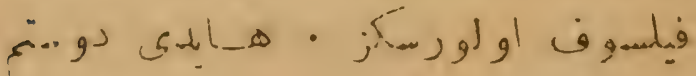

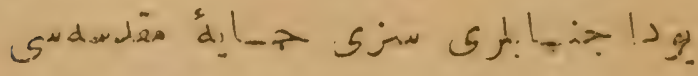

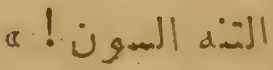

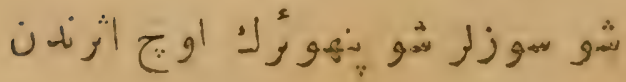




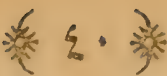

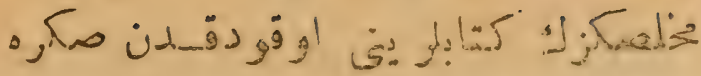

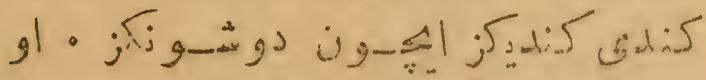

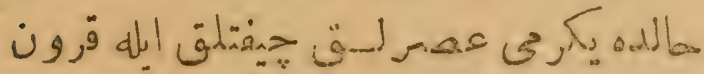

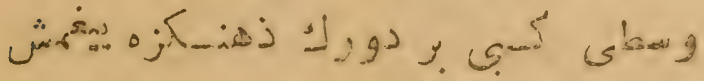

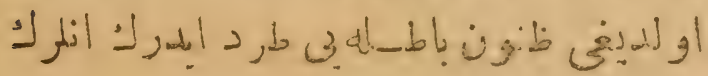

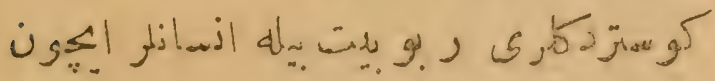

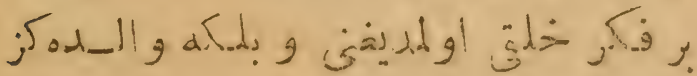

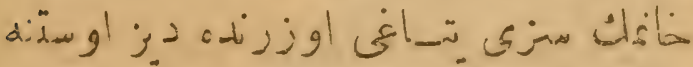
s) g م:

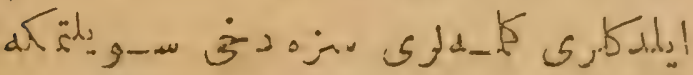

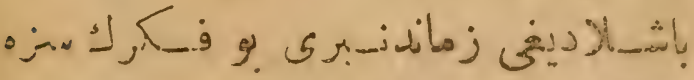

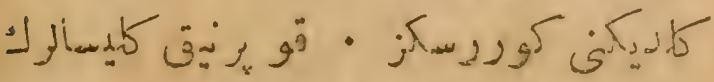

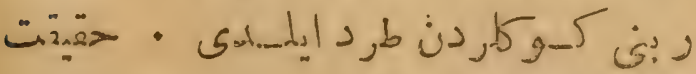

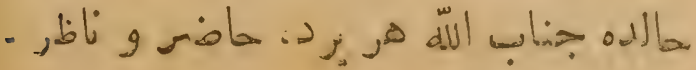




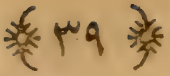

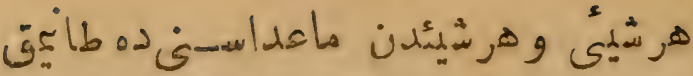

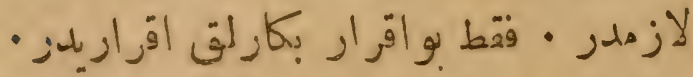

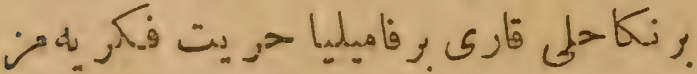

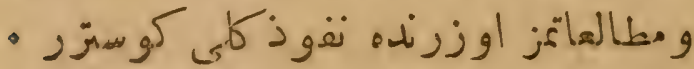

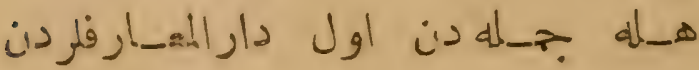

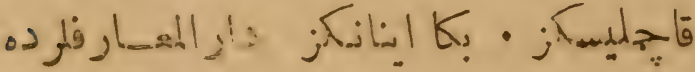

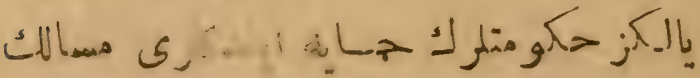

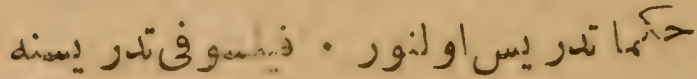
ن

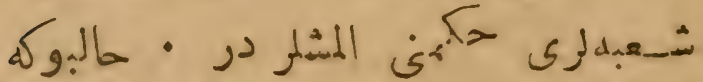

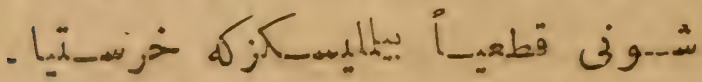

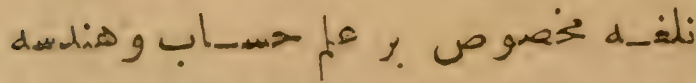

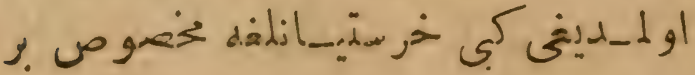

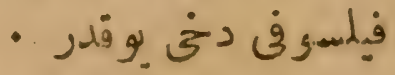

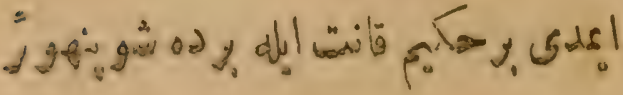




\section{以漟}

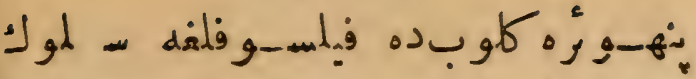

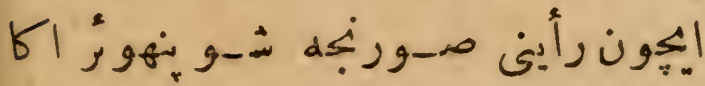

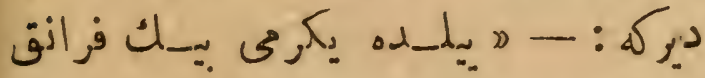

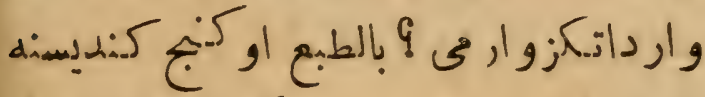

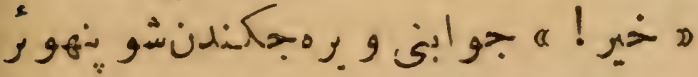

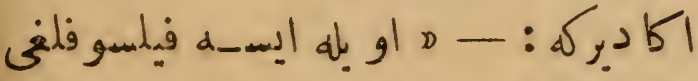

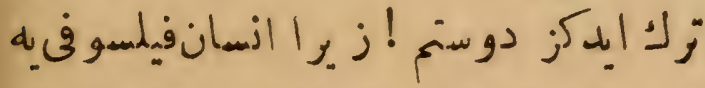

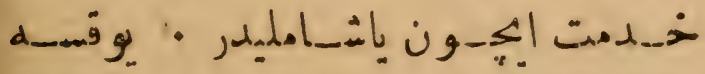

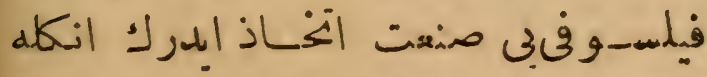

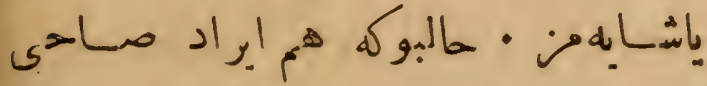

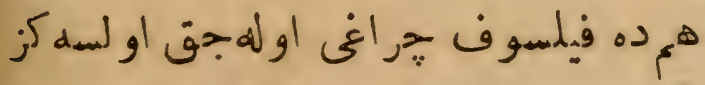

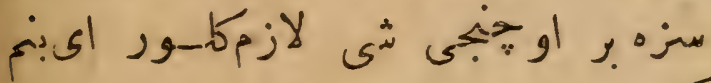

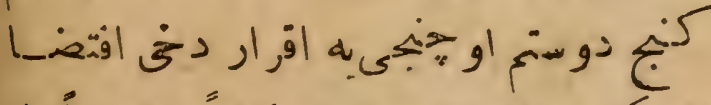

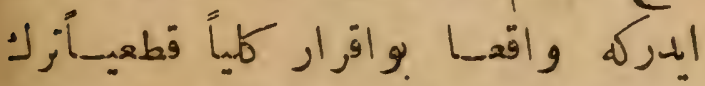

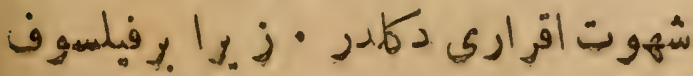


采 $\mathrm{y}$

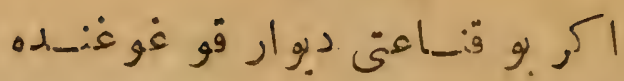

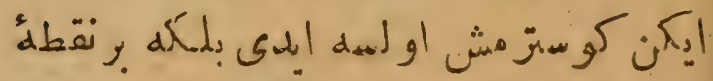

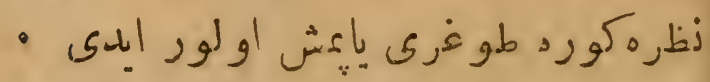

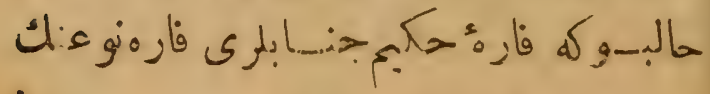

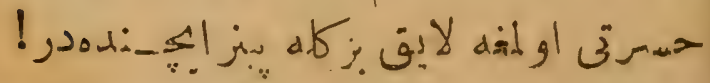

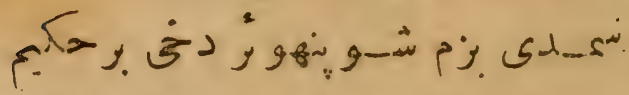

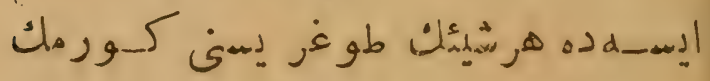

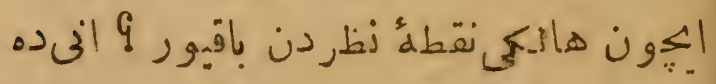

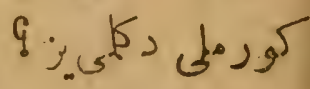

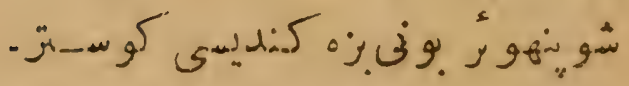

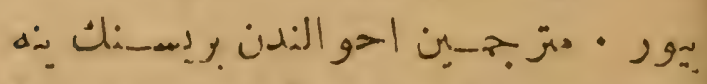

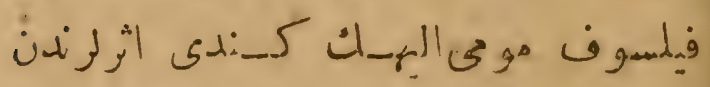

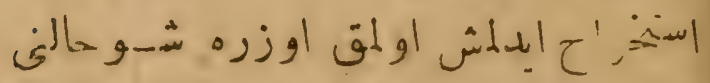

:

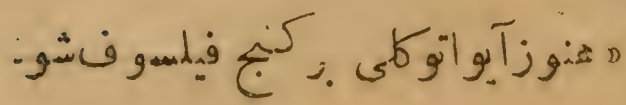


案 pon

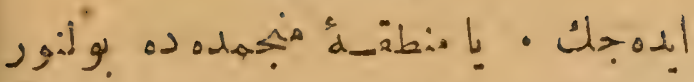

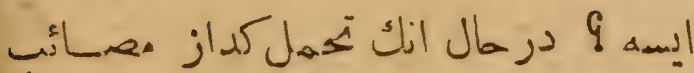

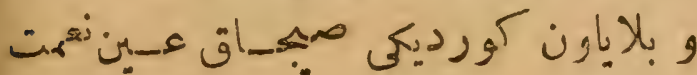

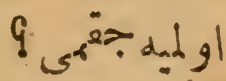

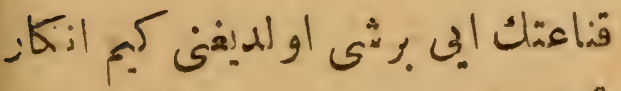

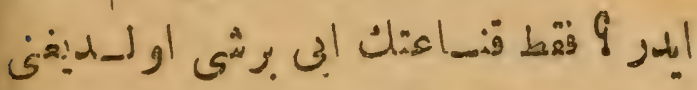

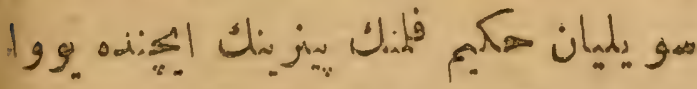

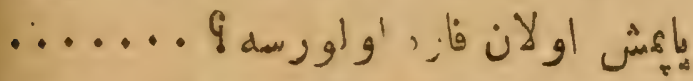

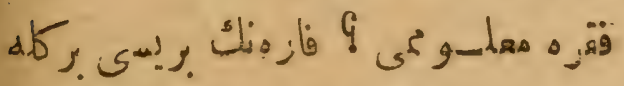

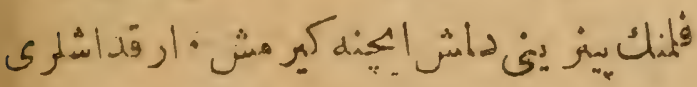

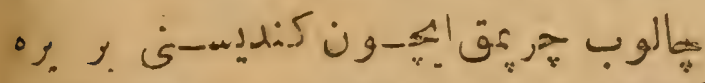

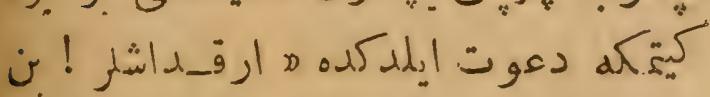

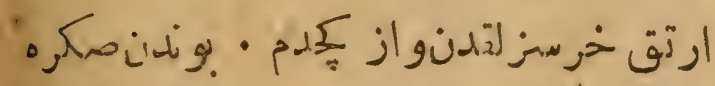

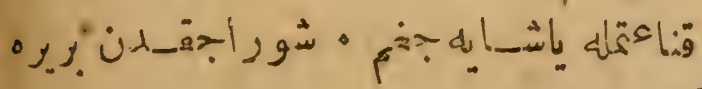

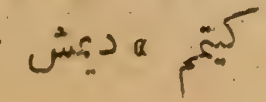




\section{*o}

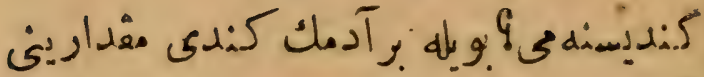

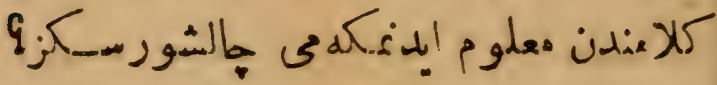

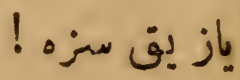

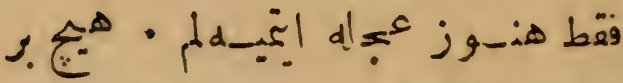

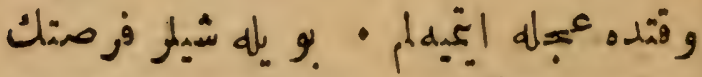

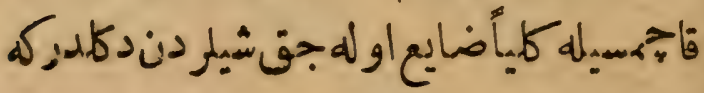

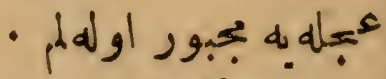

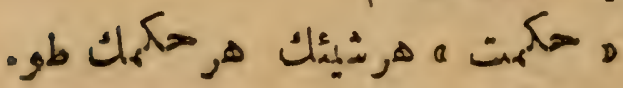

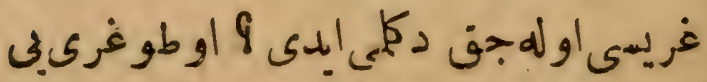

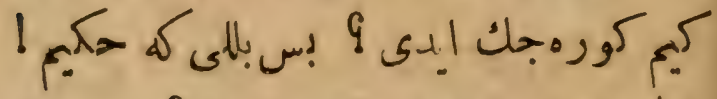

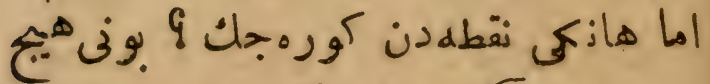

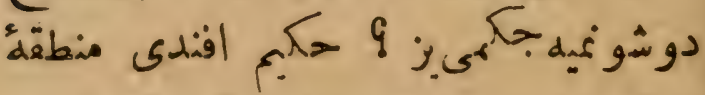

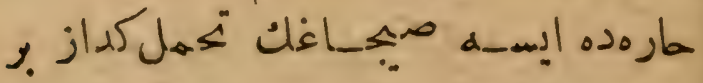

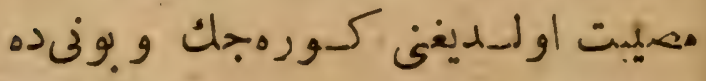

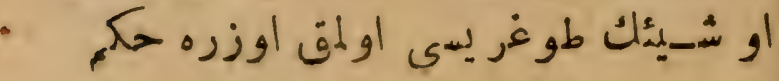




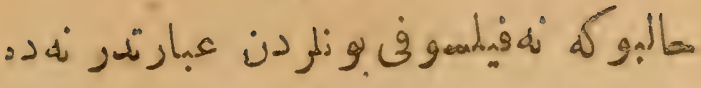

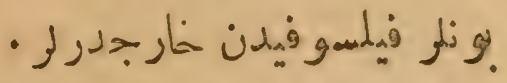

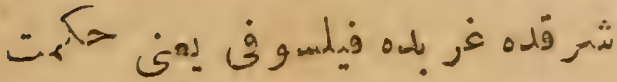

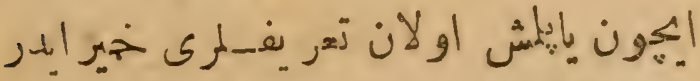

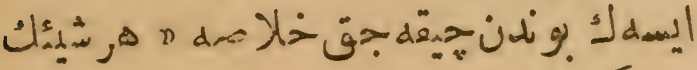

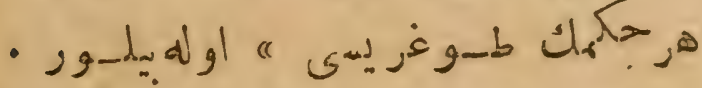

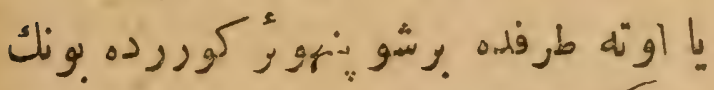

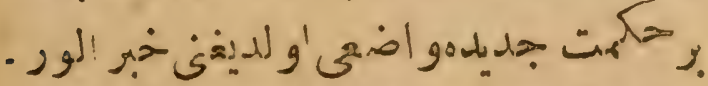

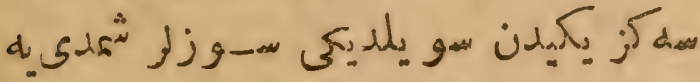

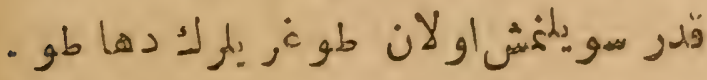

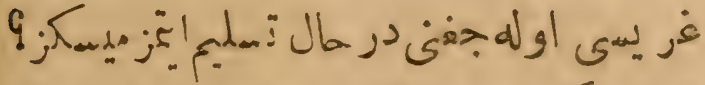

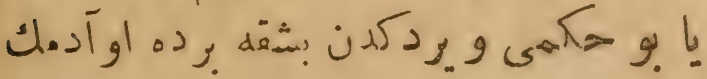

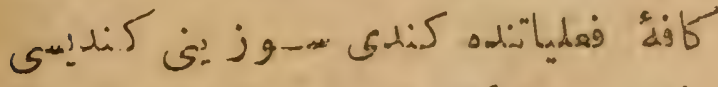

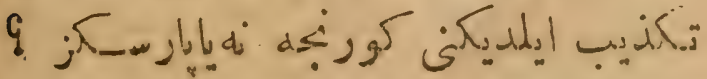

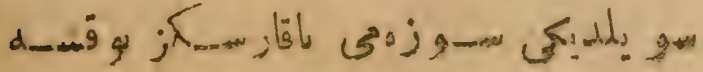


* pro

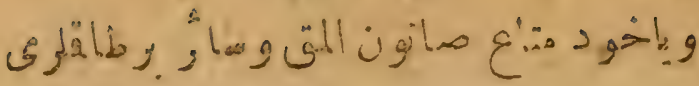

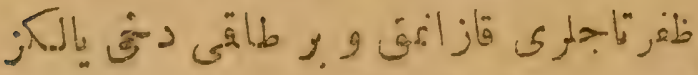

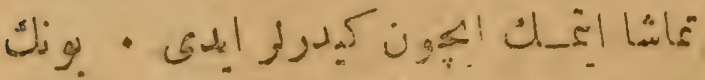

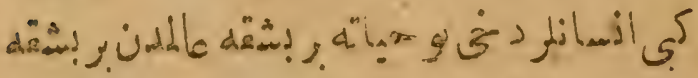

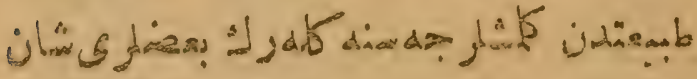

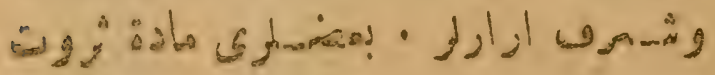

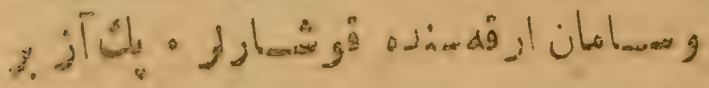

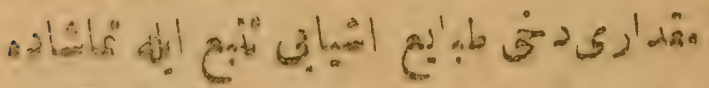

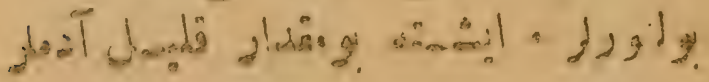

$$
\text { a jos dis gandis }
$$

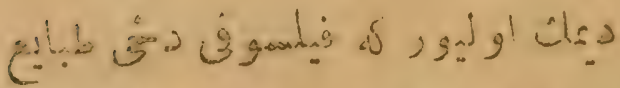

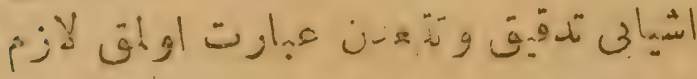

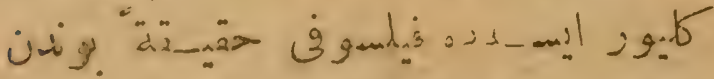

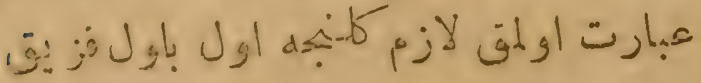

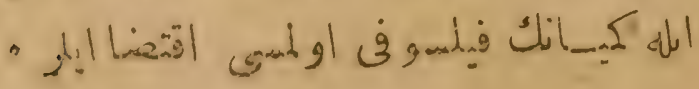




\section{菜rr}

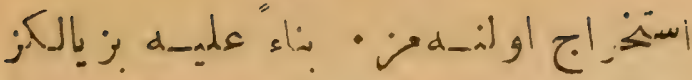

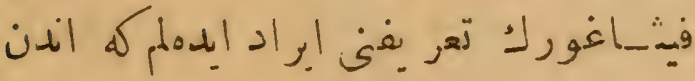

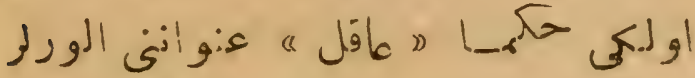

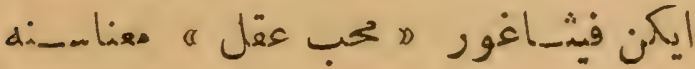
بm

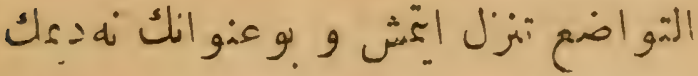

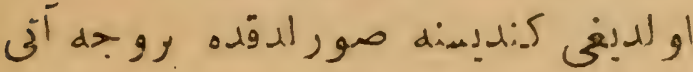

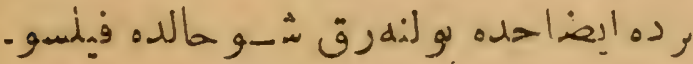

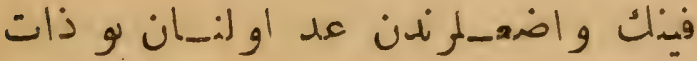

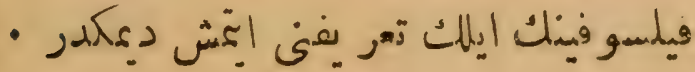

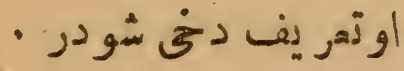

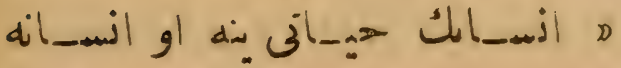

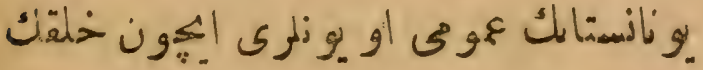

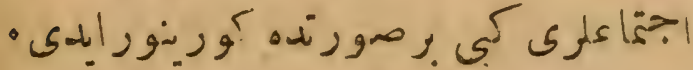

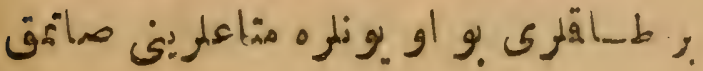




\section{潘}

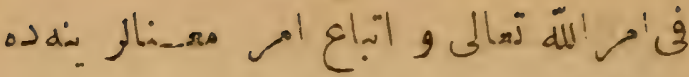

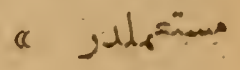

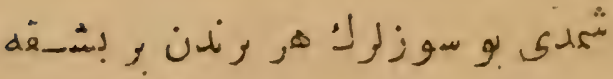

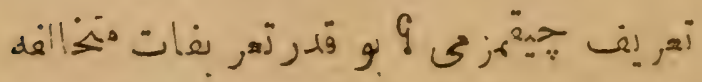

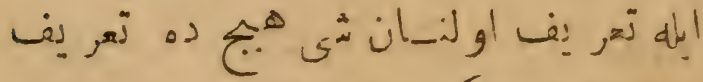

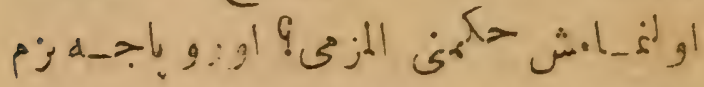

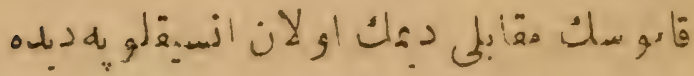

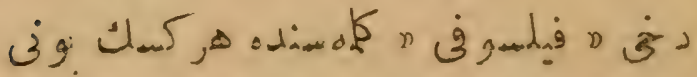

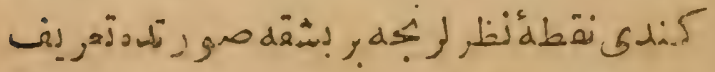

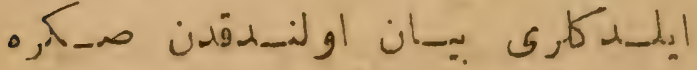

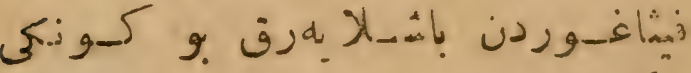
كَ

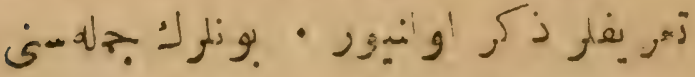

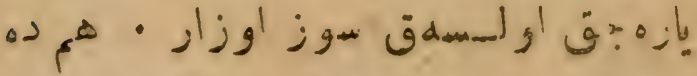

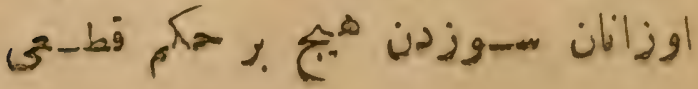


棌

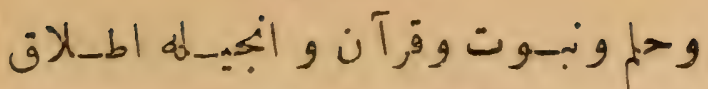

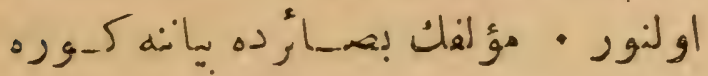

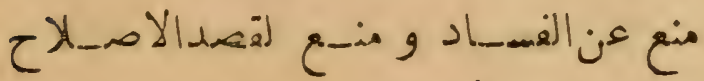

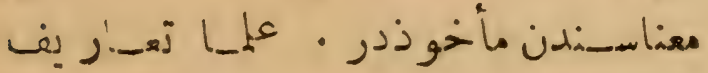

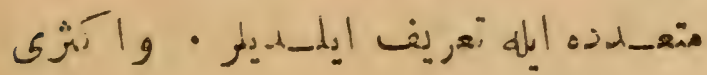

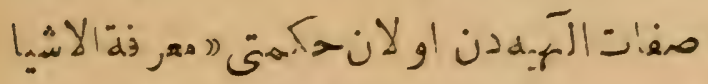

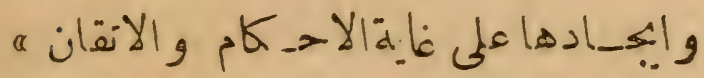

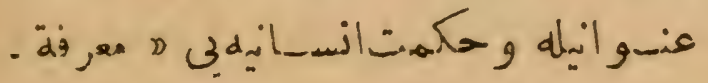

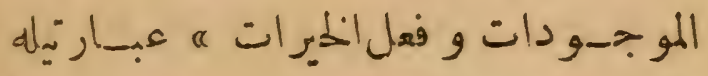

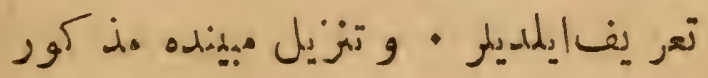

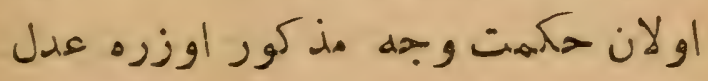

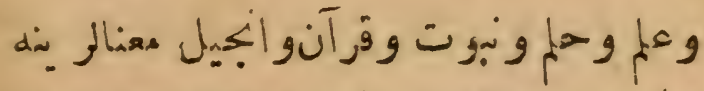

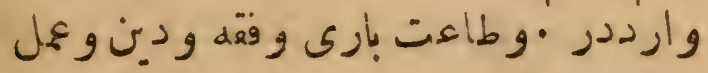

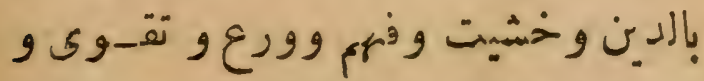

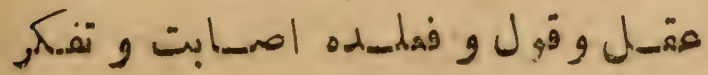


秦阳秦

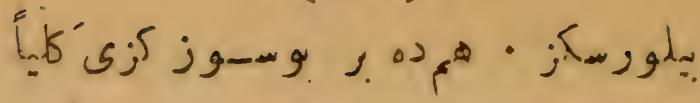

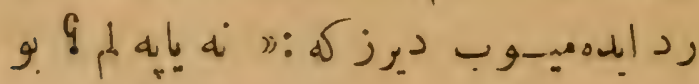

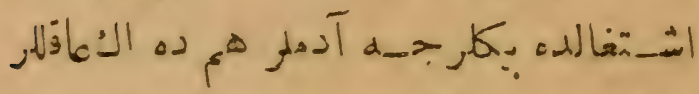

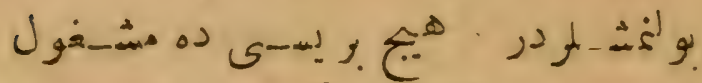

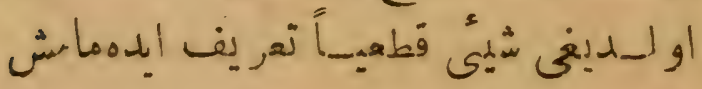

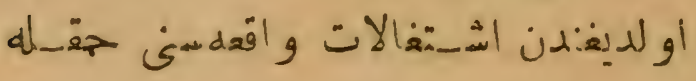

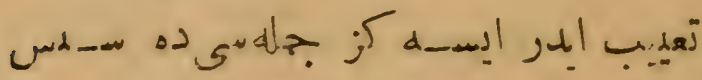

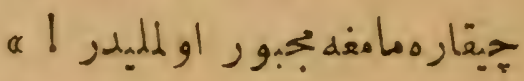

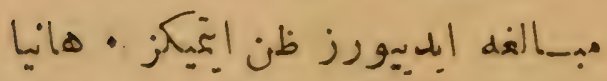

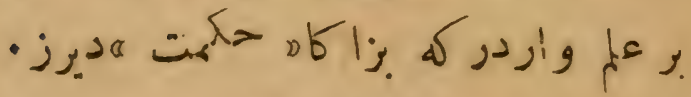

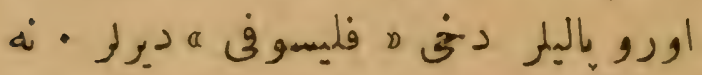

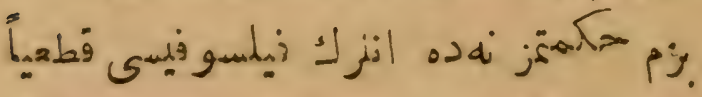

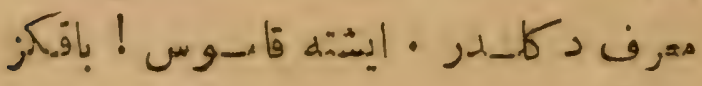
:

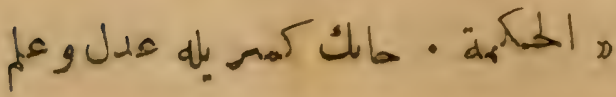


繁忪

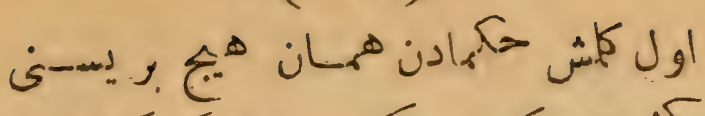

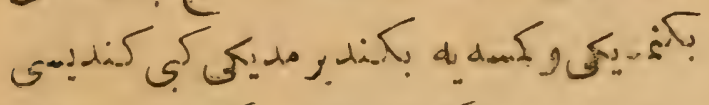

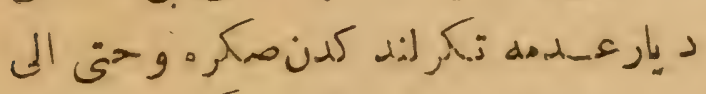

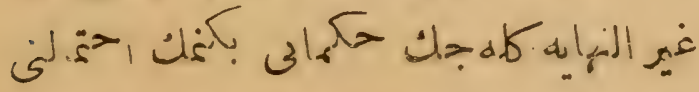

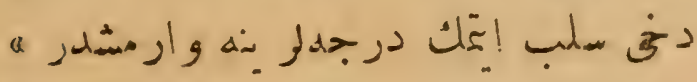

- زर्ष

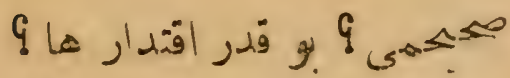

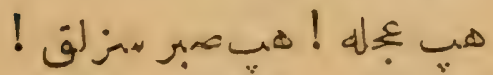

ميحث

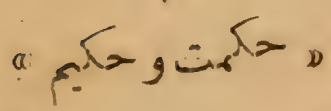

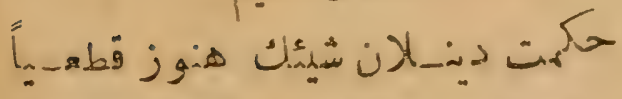

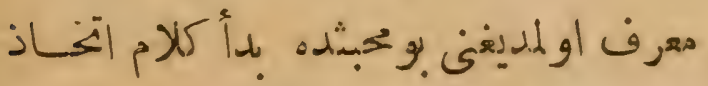

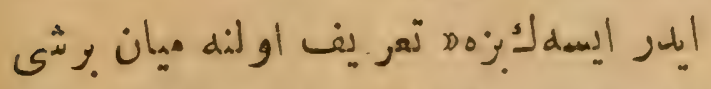

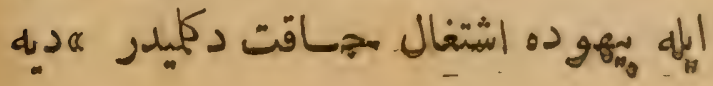




\section{絭 rV灙}

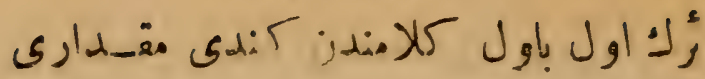

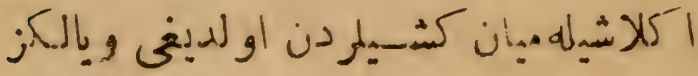

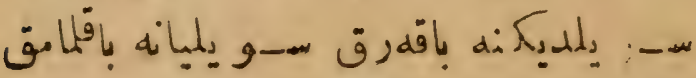

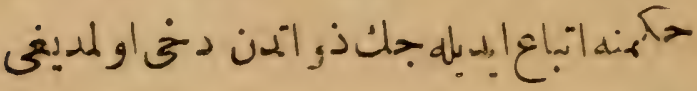

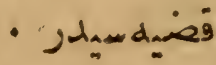

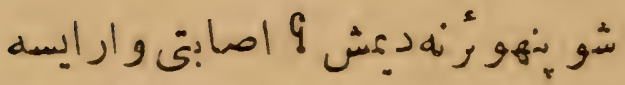

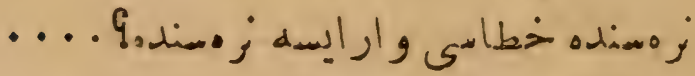

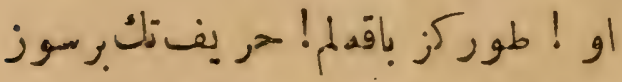

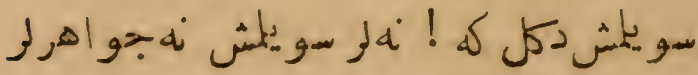

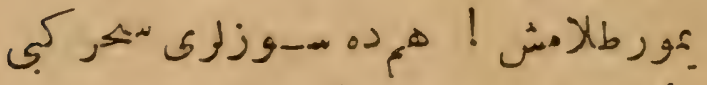

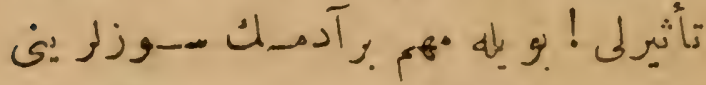

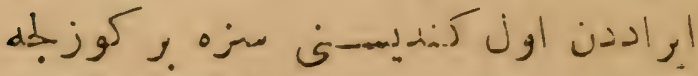

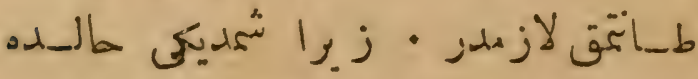

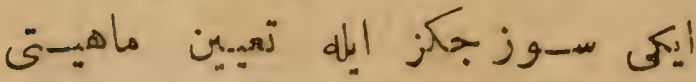
. 
采以率

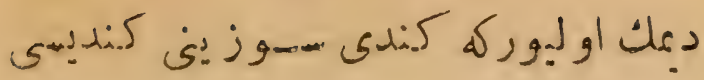

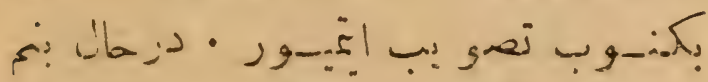

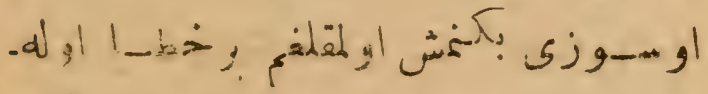

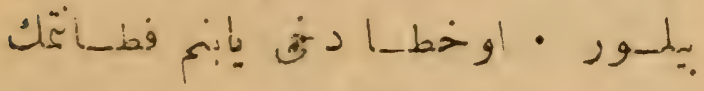

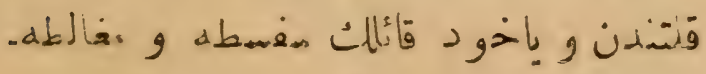

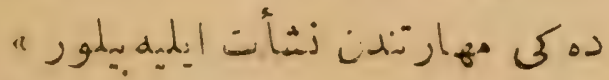

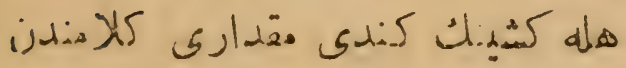

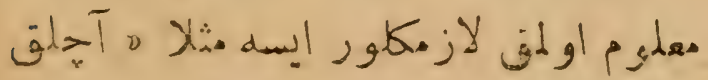

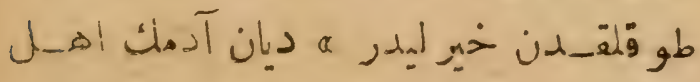

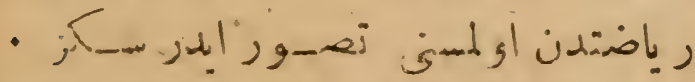

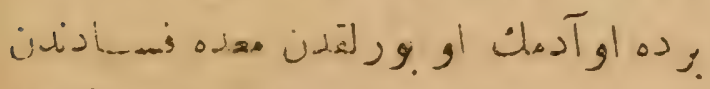

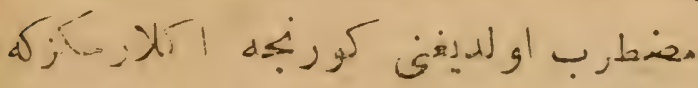

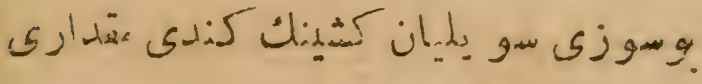

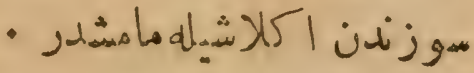

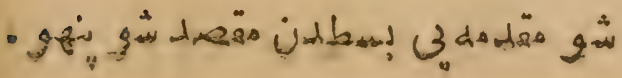


棌 ro

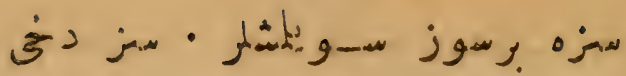

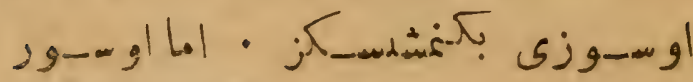

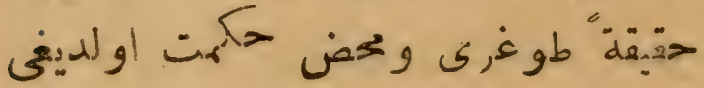

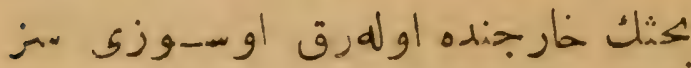
كind -d.

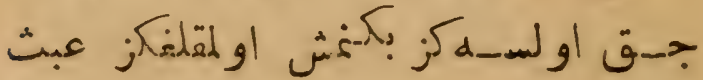

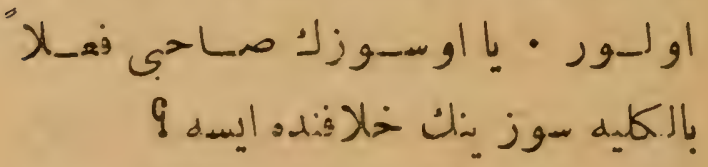

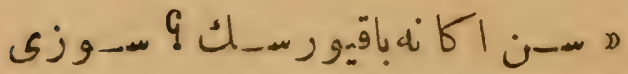

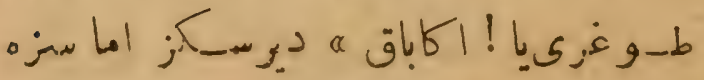

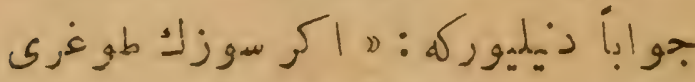

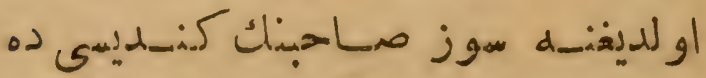

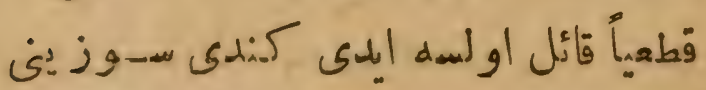

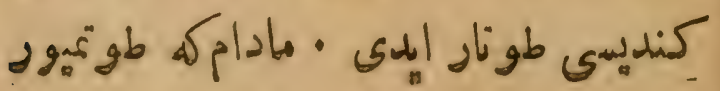




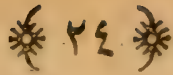

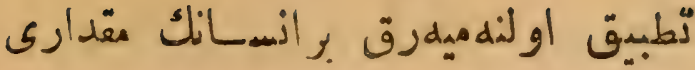

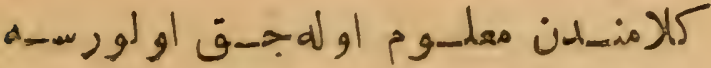

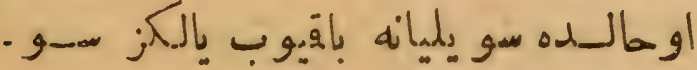

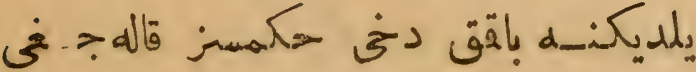

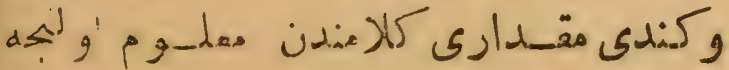

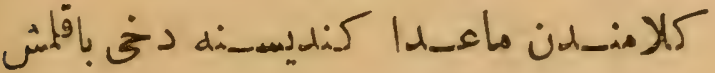

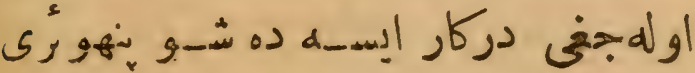

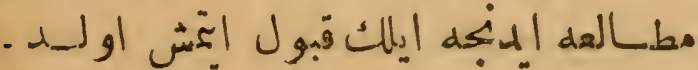

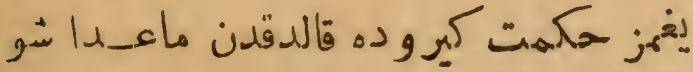

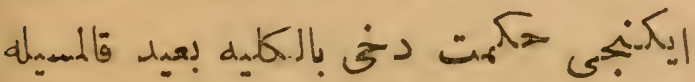

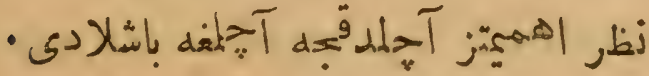

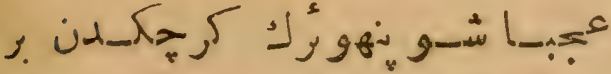

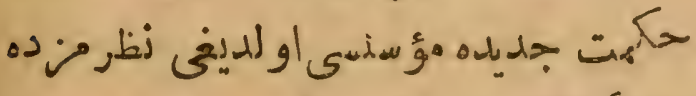

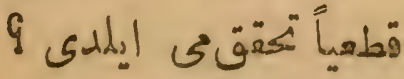

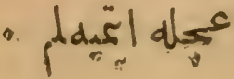




\section{染落}

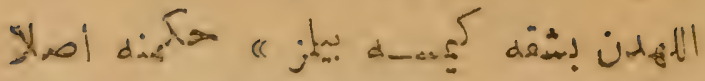

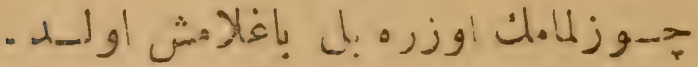

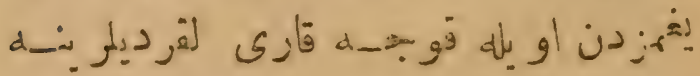

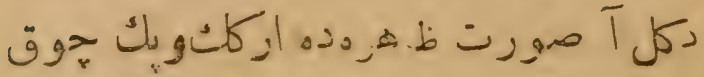

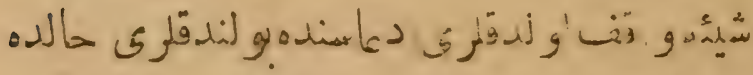

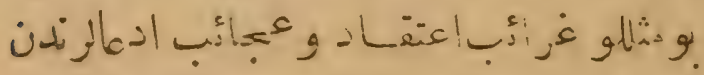

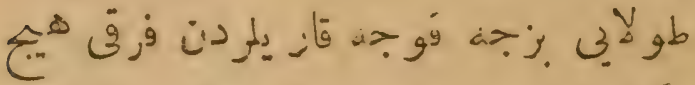

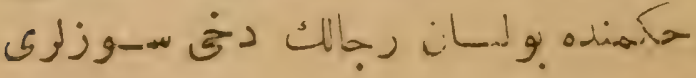

$$
\text { - أونارهن }
$$

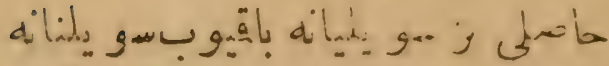

אᄌ

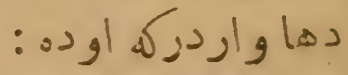

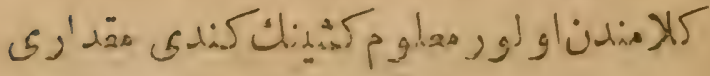
صور مد 


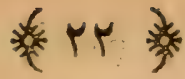

\section{in \\ P}

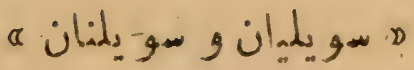

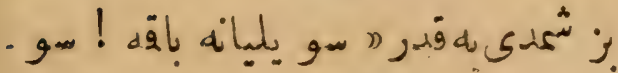

.

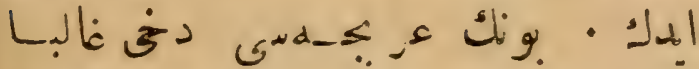

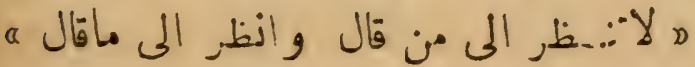

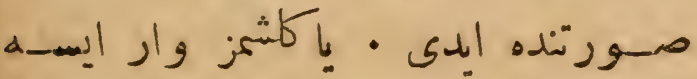

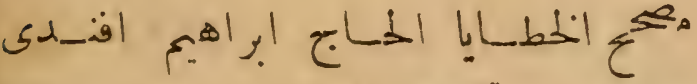

$|x| g \mid g$

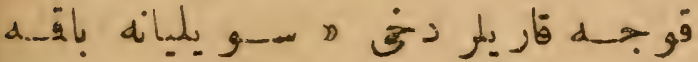

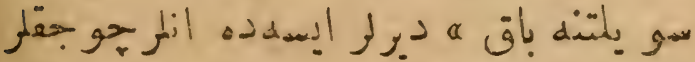

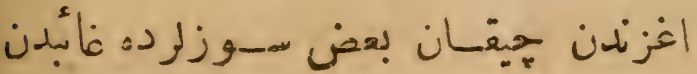

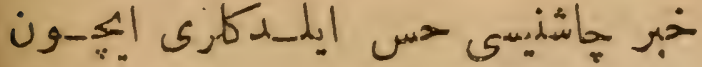

فائب 


\section{-}

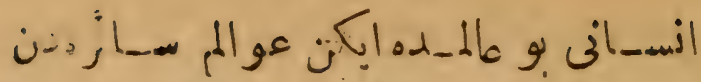

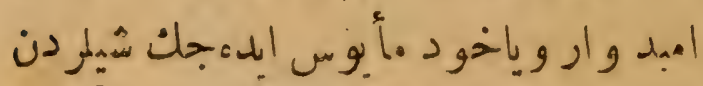

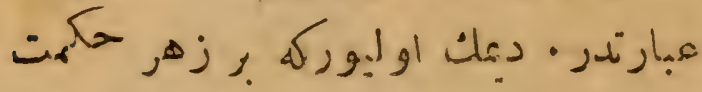

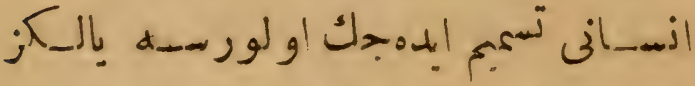

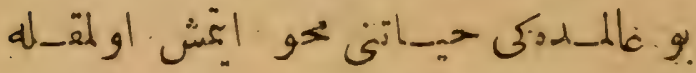

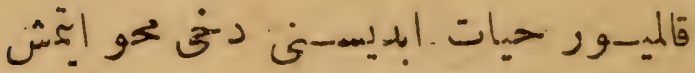

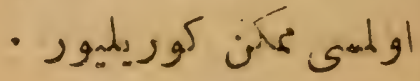

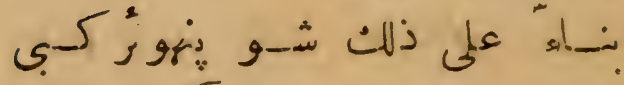

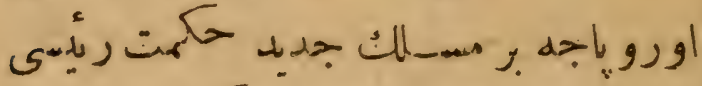

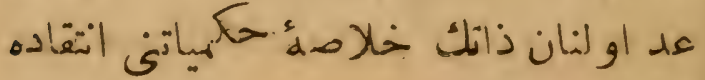

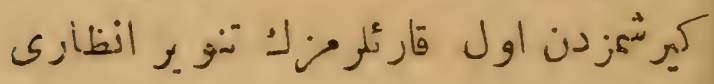

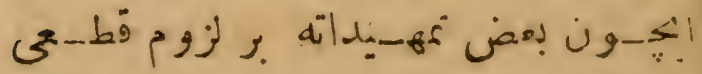

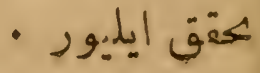




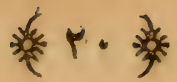

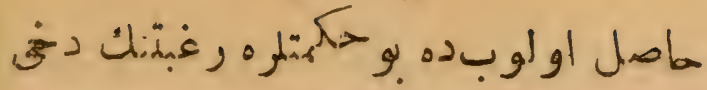

اندن صكرم معبوله كمش او لديغنه اهنيت

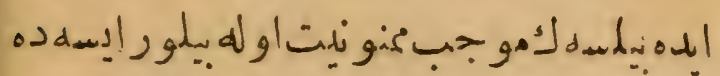

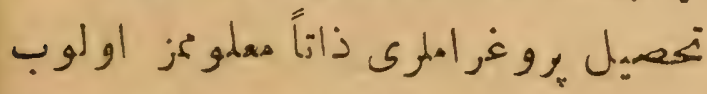

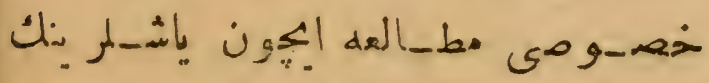

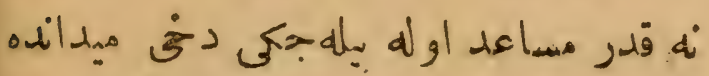

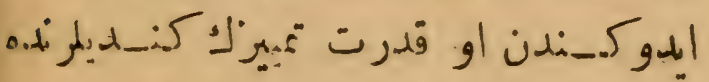

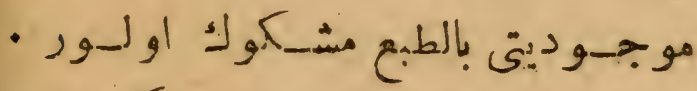

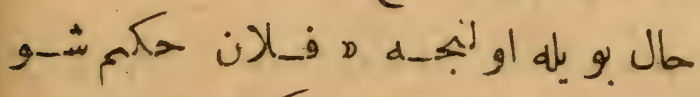

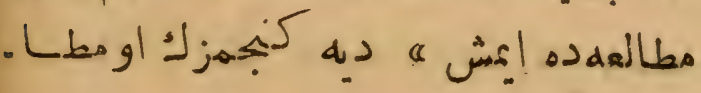

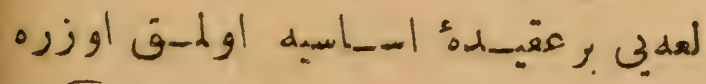

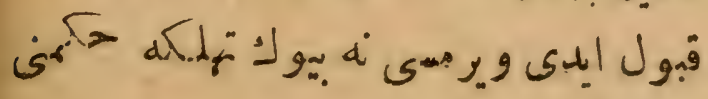

الوورو

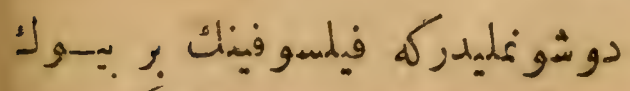

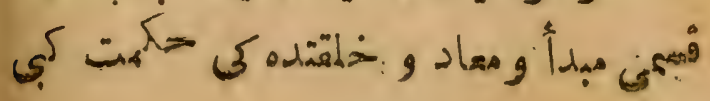




\section{9 楼}

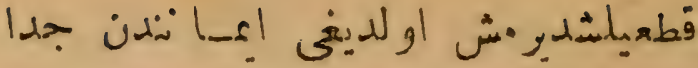

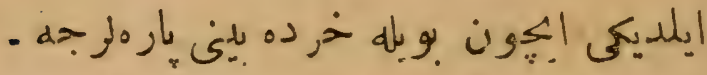

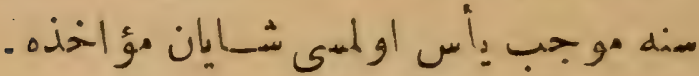
d

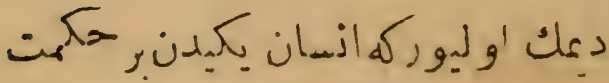

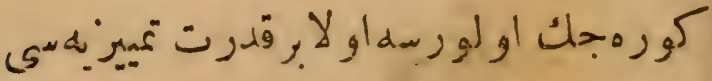

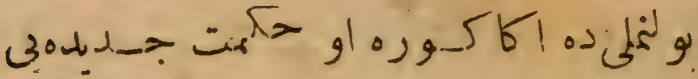

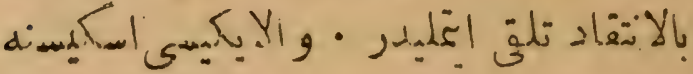

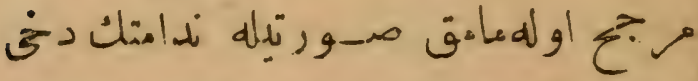

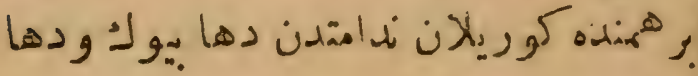

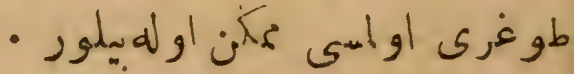

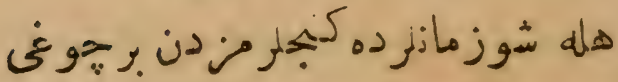

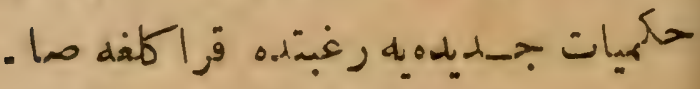

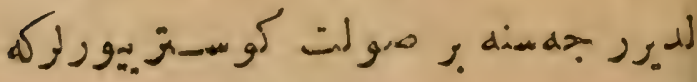

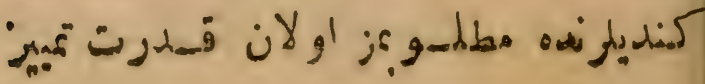




\section{菜 1.1 . 谈}

م آد و

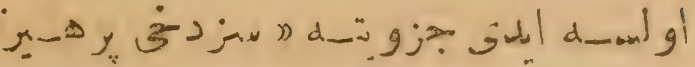

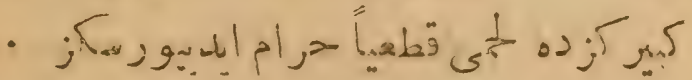

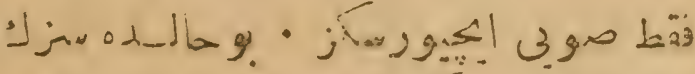

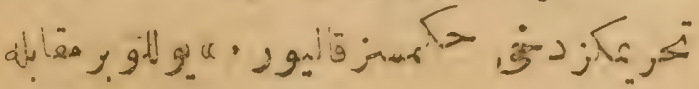

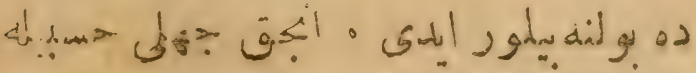
-

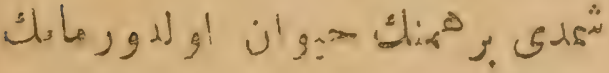
ع

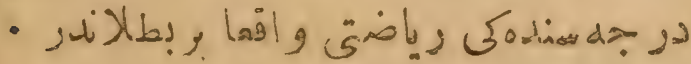

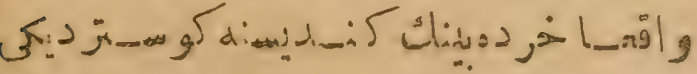

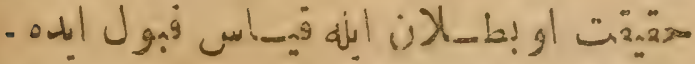

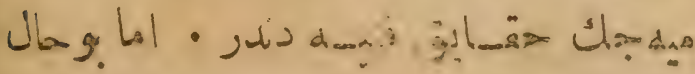

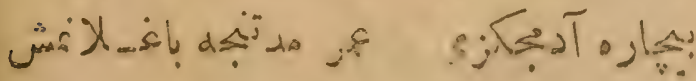
is 


\section{棌}

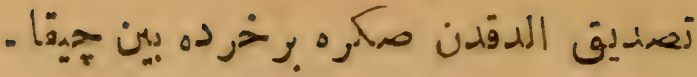

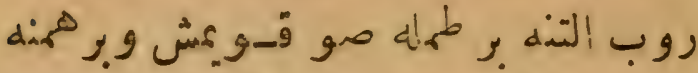

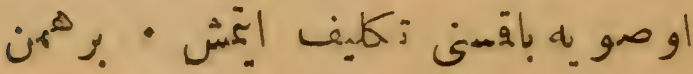

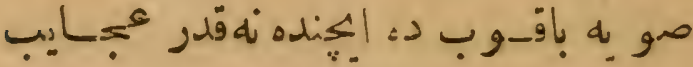

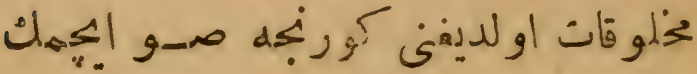

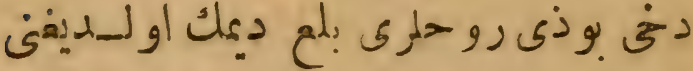

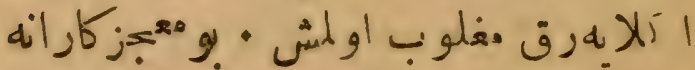
آلت وركوز

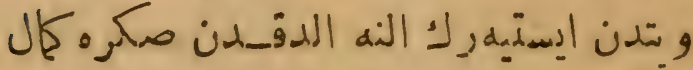

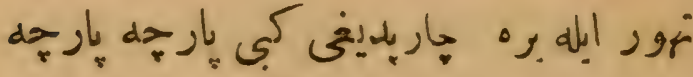

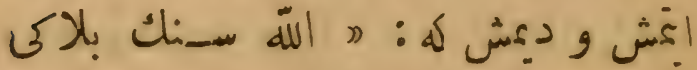

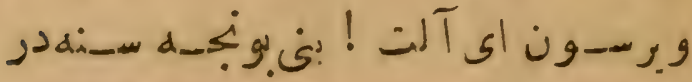

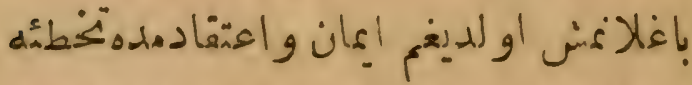

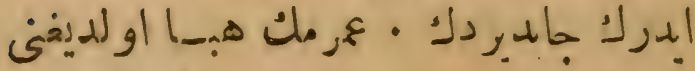

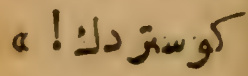




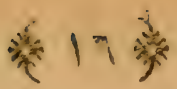

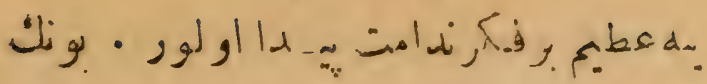

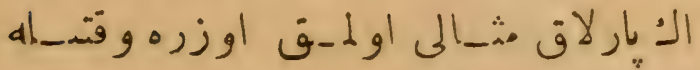

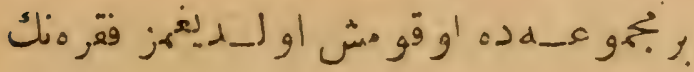

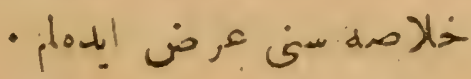

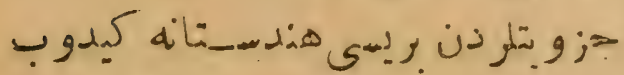

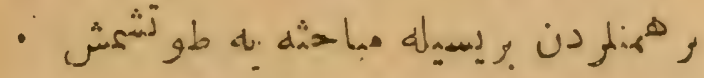

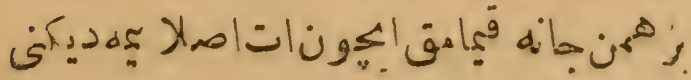

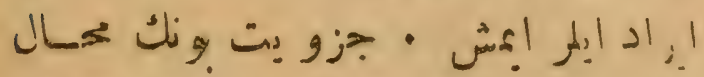
إl لدj:

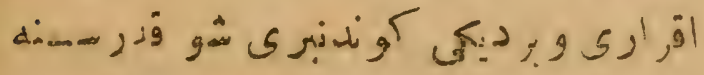
ن

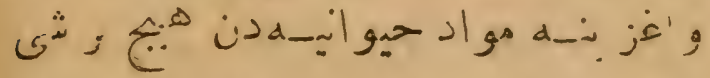

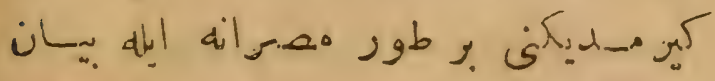
a

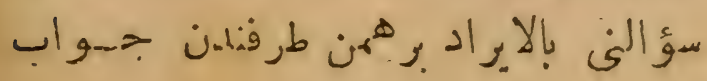


10

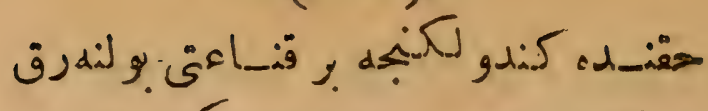

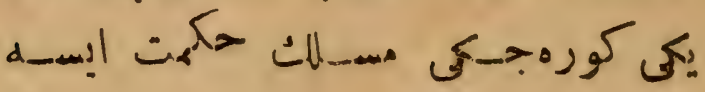

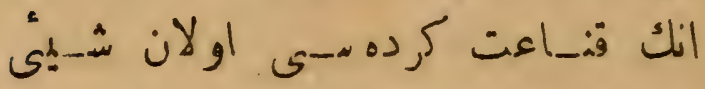

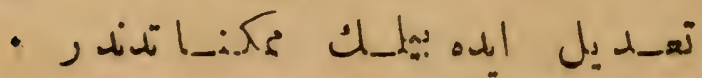

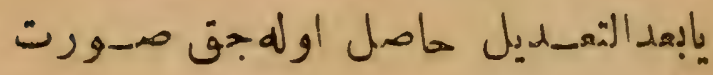

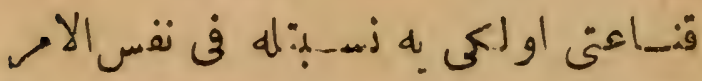

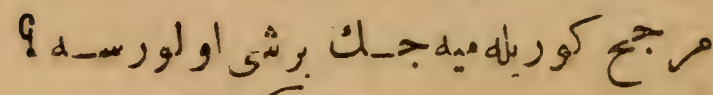

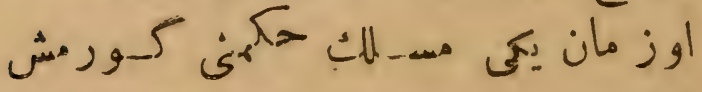

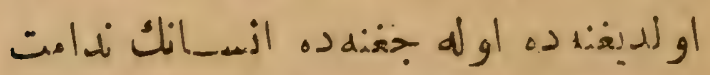

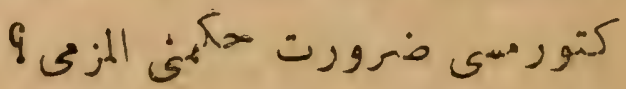

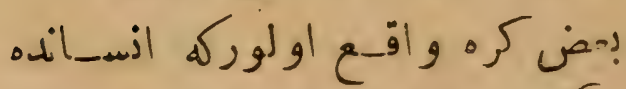

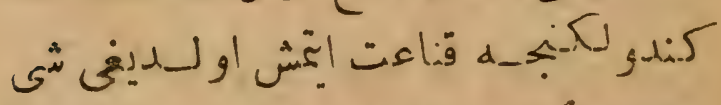

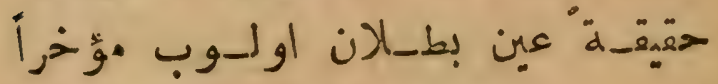

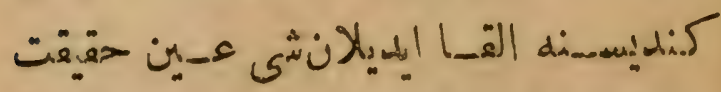

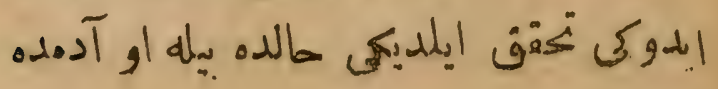




\section{is}

ايمدى فلان يرده شئو يله بروفيلمبوف

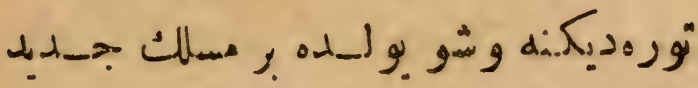

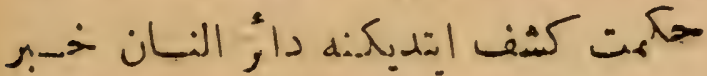

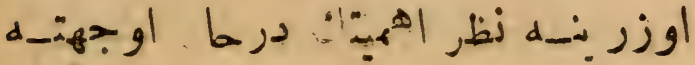

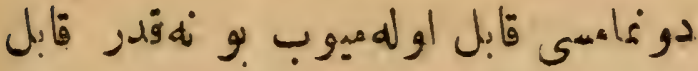

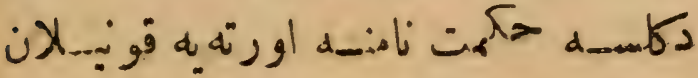

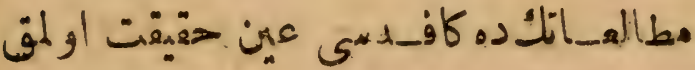

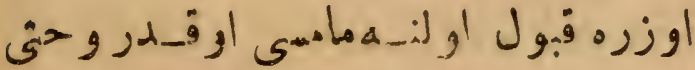

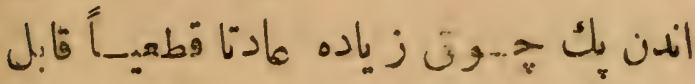

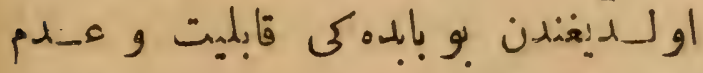

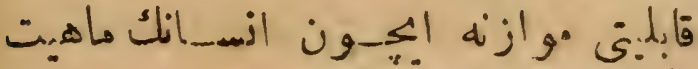

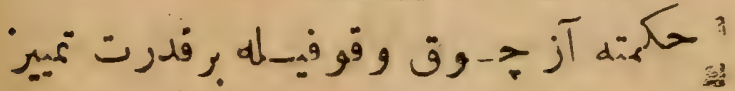
•

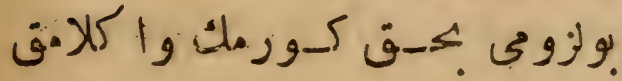

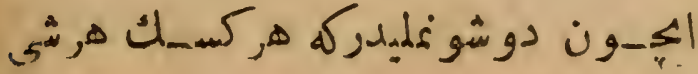




\section{类 $11 \%$}

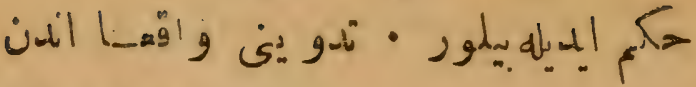

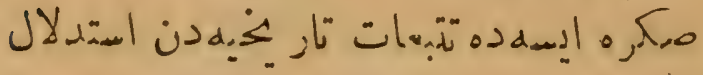

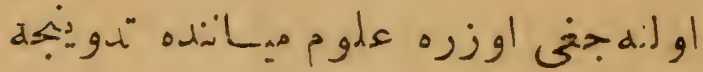

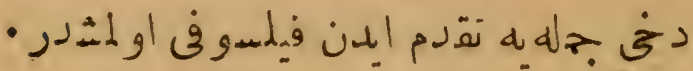

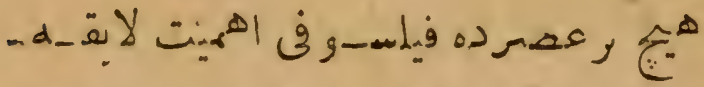

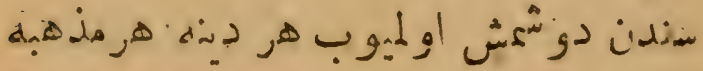

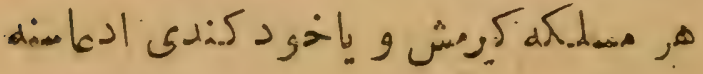

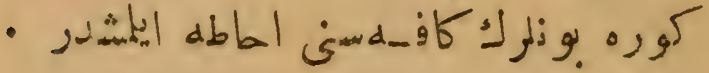

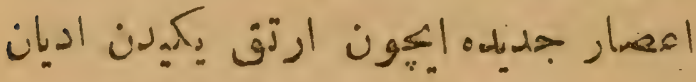

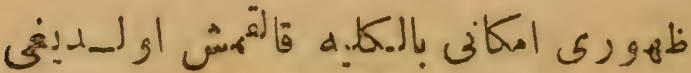

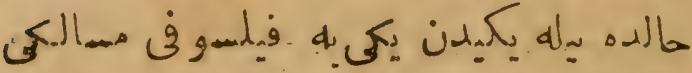

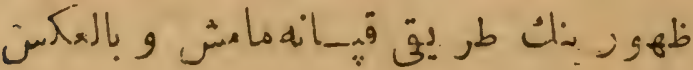

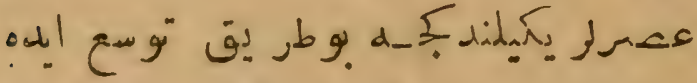

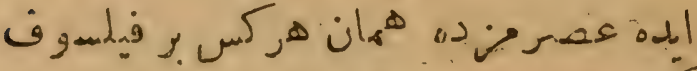
- ' 
ش

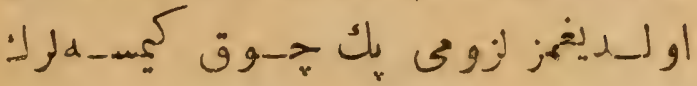

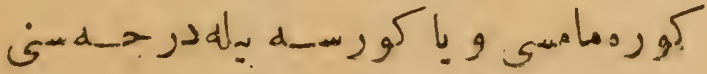

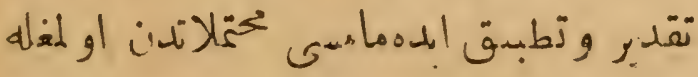

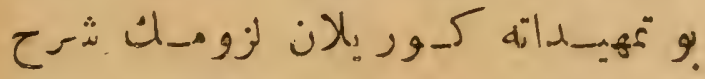

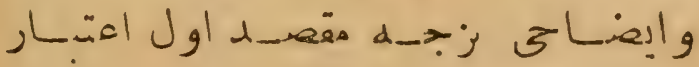
اولتمثندز

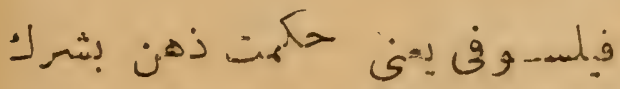

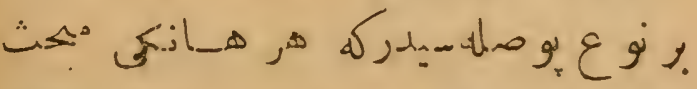

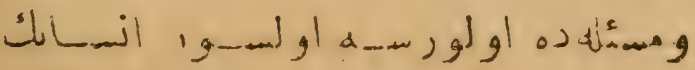

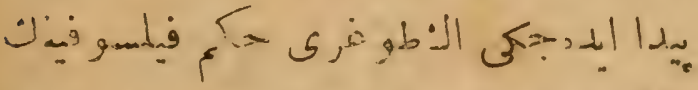
دلأنس

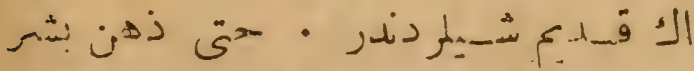

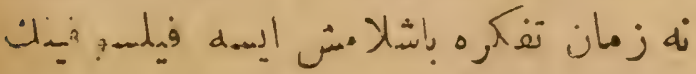

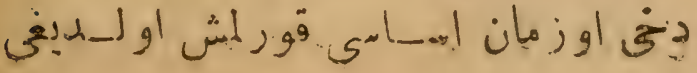




\section{娄 11 等}

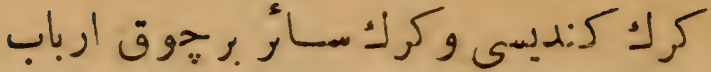

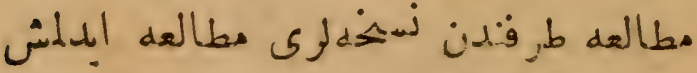

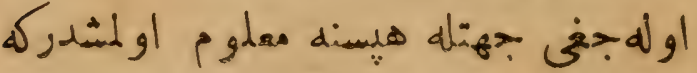

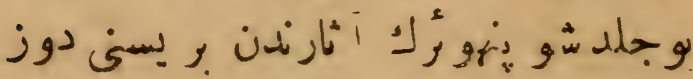

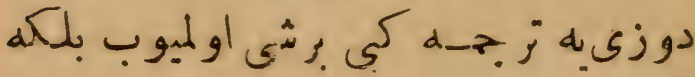

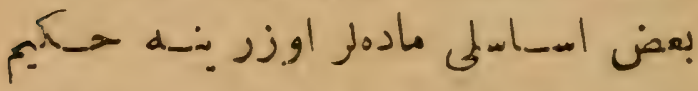

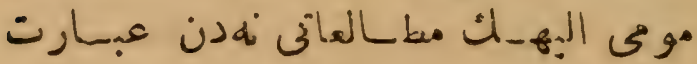

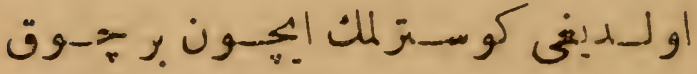

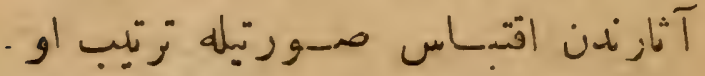

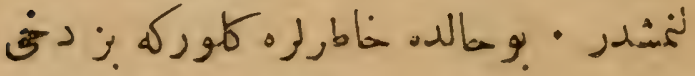

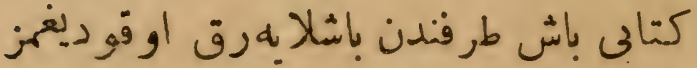

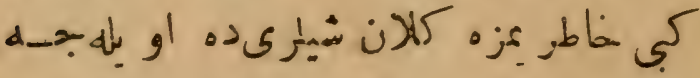

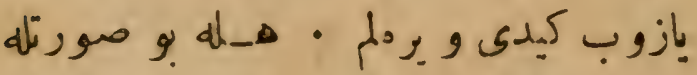

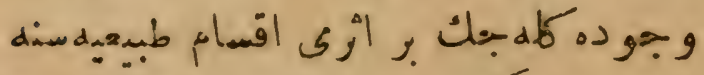

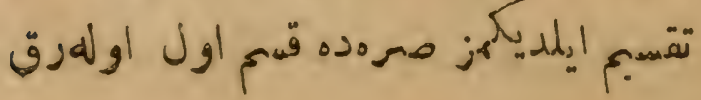




\section{1. 㴒}

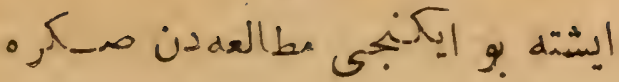

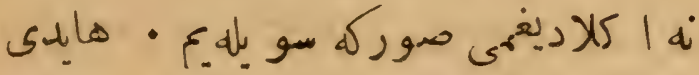

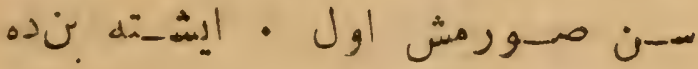
سويليورم: :

酥

$$
\text { a }
$$

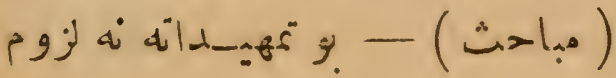

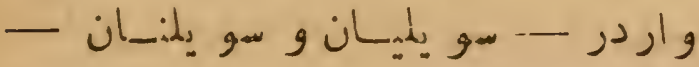

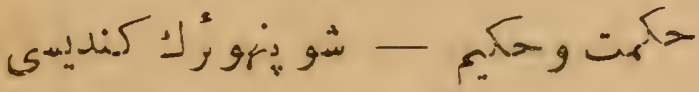

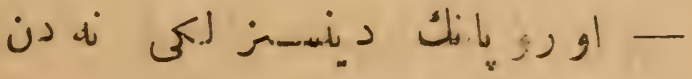

$$
\text { عبارتدزر - ع }
$$

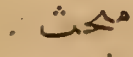

\section{1}

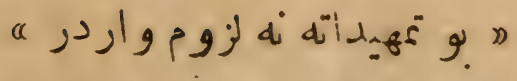

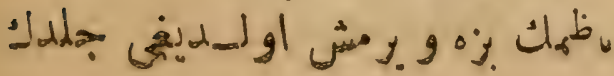


9

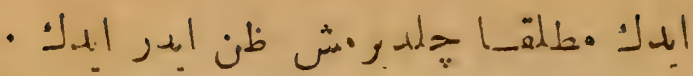

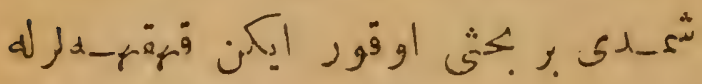

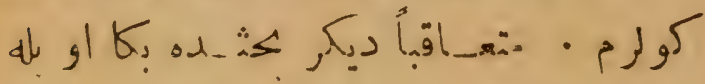

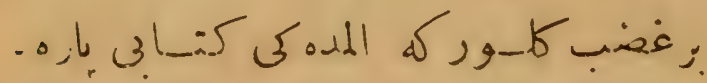
od,

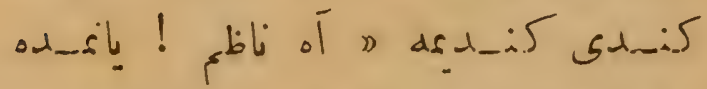

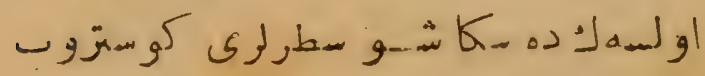

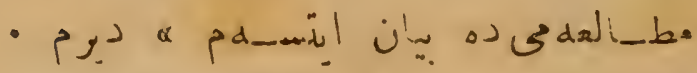

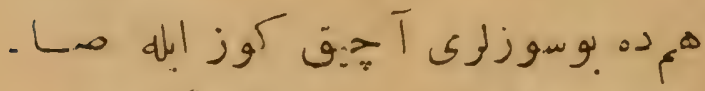

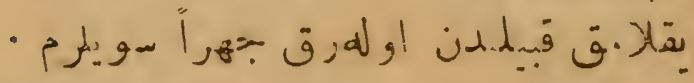

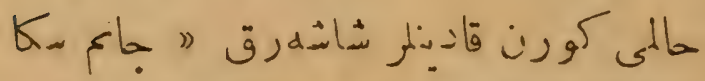

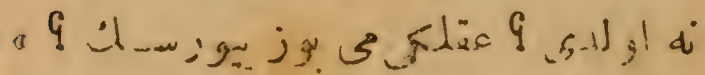

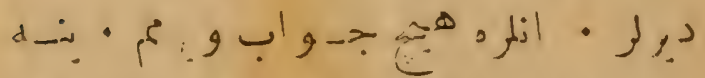

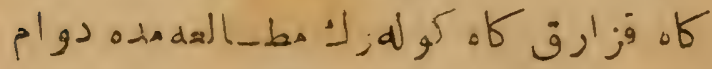

! 
ug

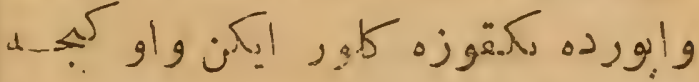

rro jädis

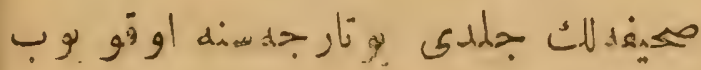

-

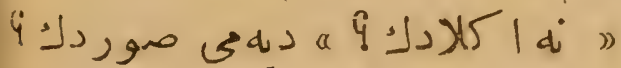

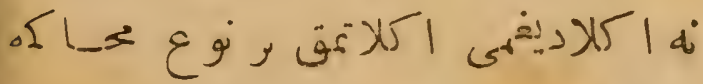

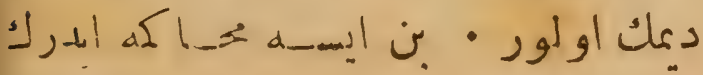

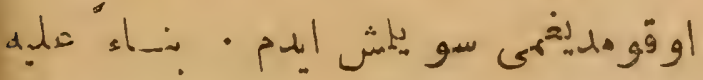

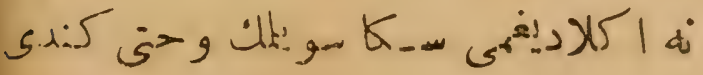

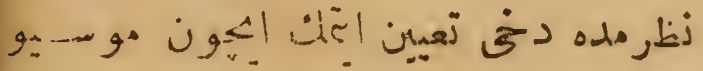

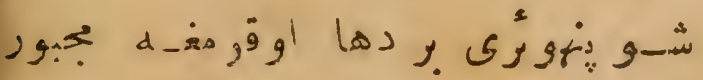

- 2 id

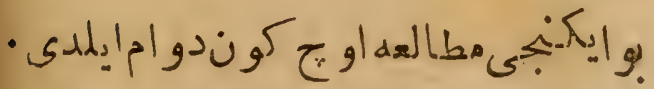

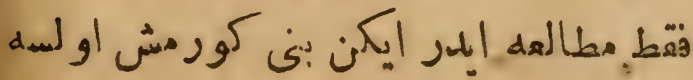




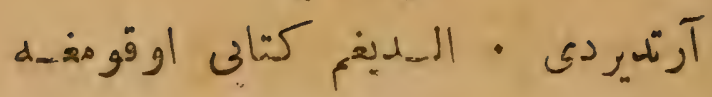

-

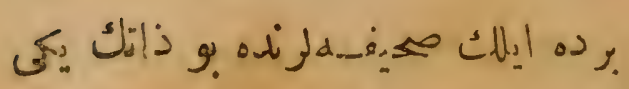

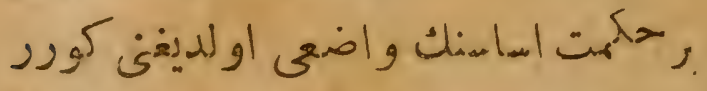

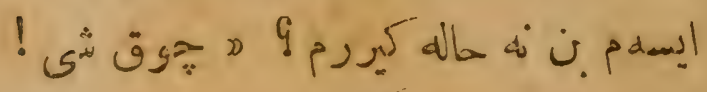

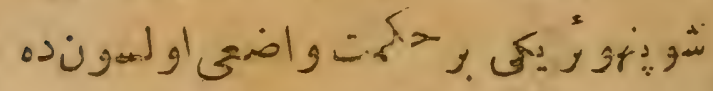

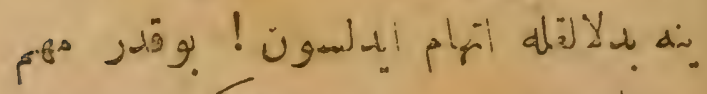

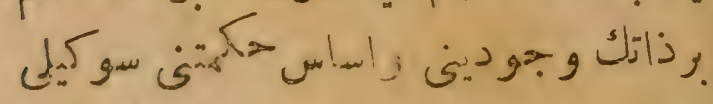

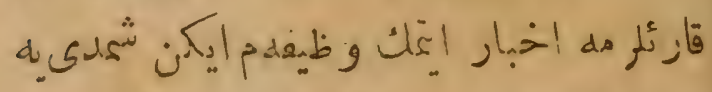

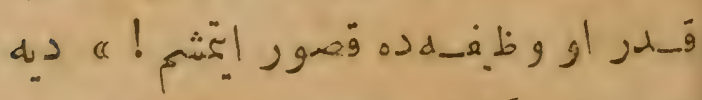

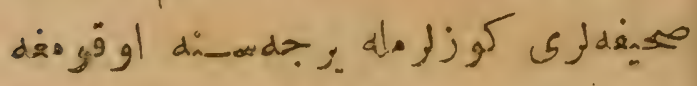

-

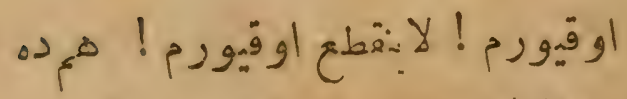

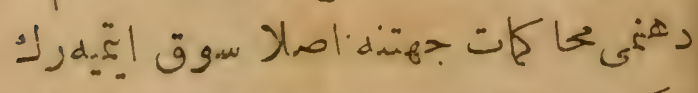

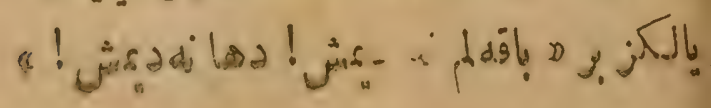




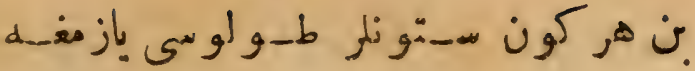

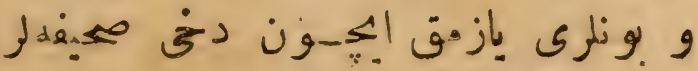

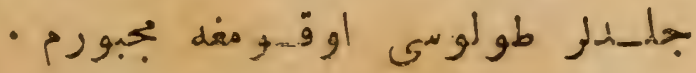

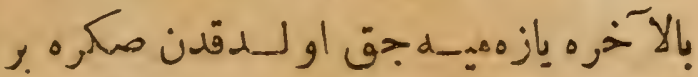

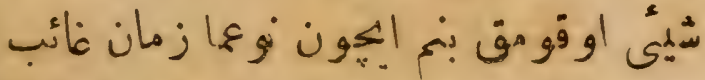

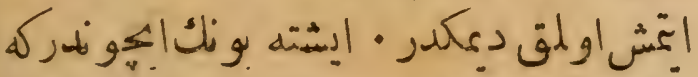

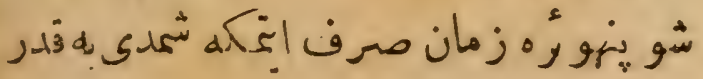

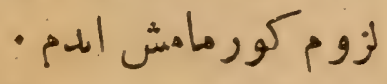

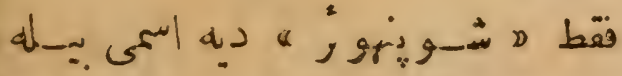

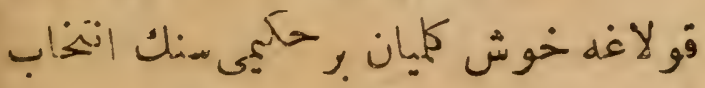

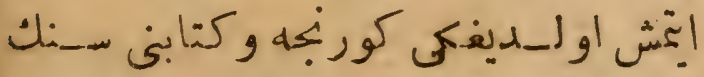

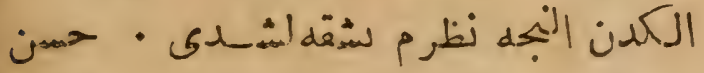

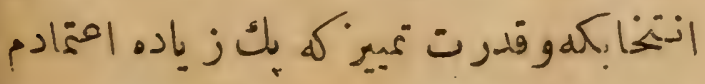

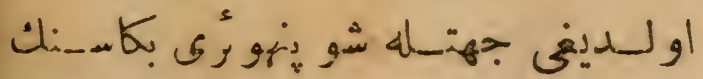

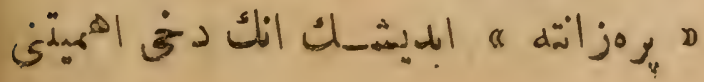


絭

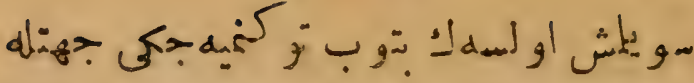

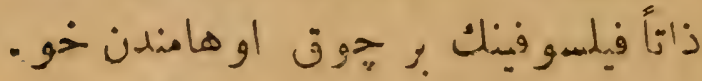

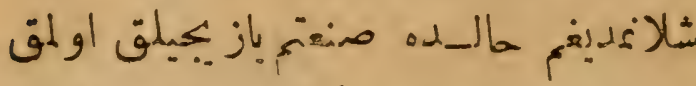

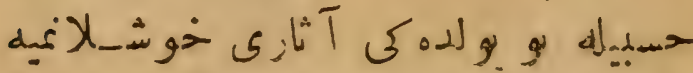

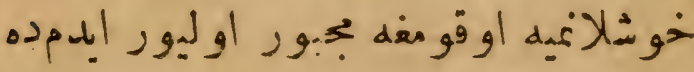

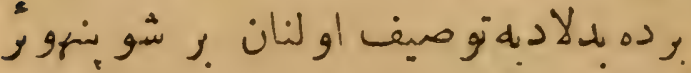

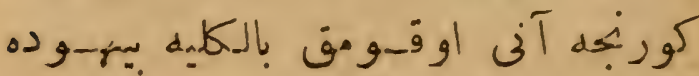

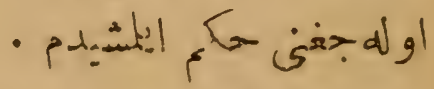

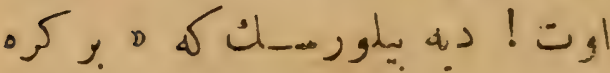

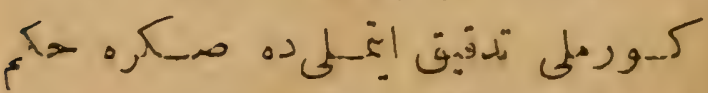

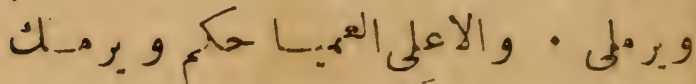

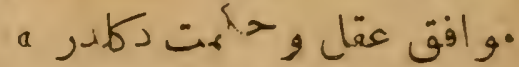

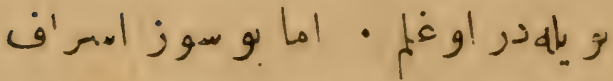

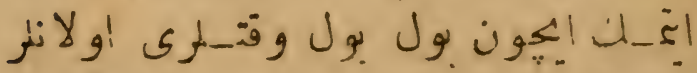

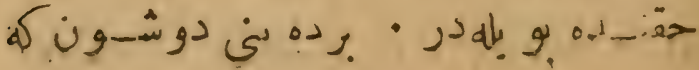




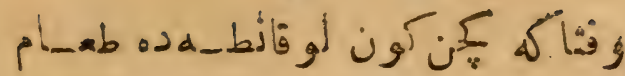

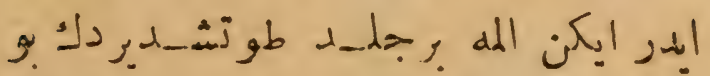

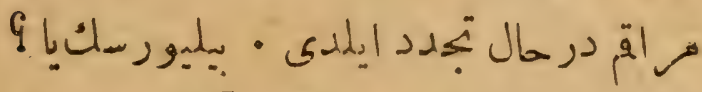

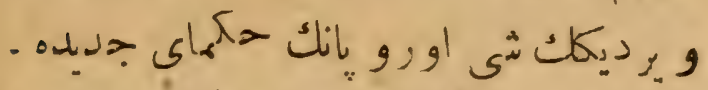

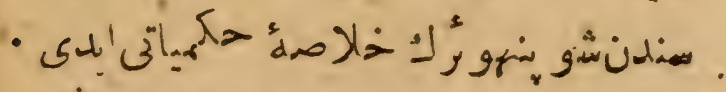

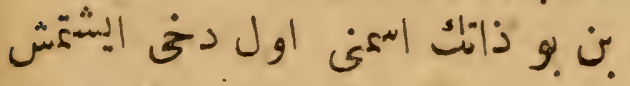

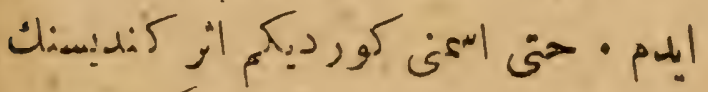

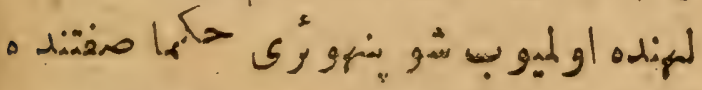

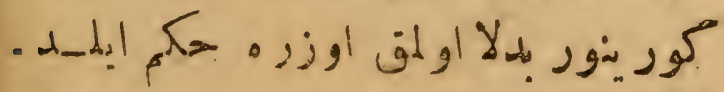

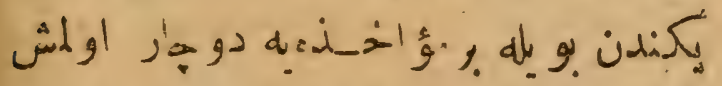

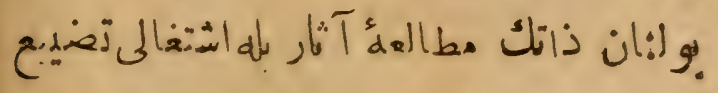

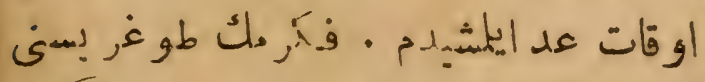

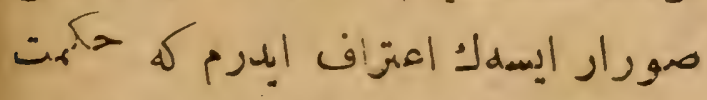

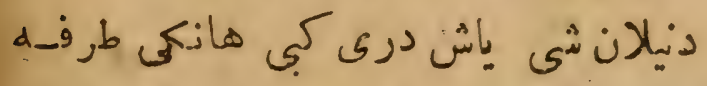

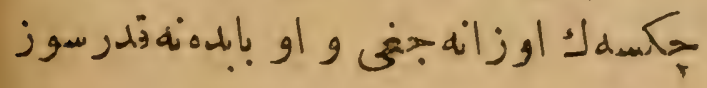




\section{r w}

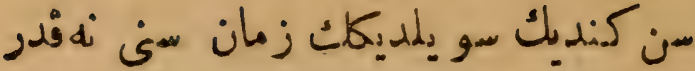

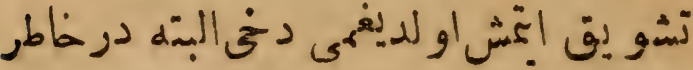

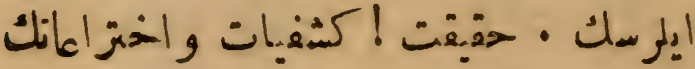

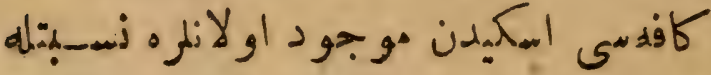

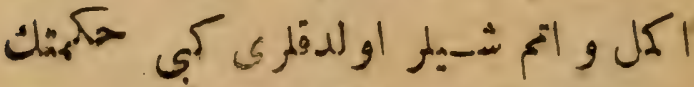

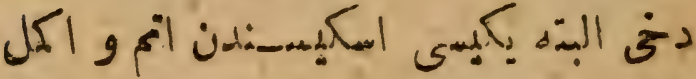

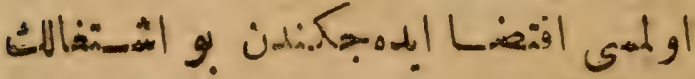

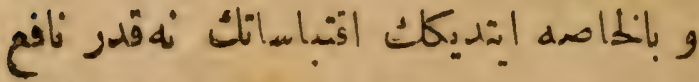

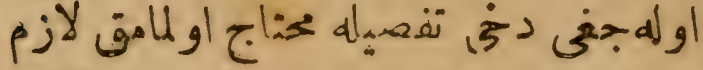

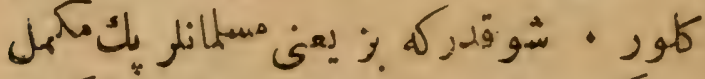
.

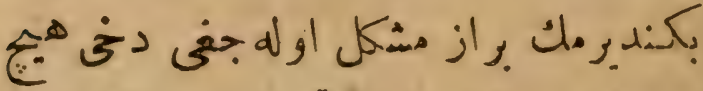

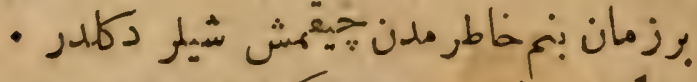

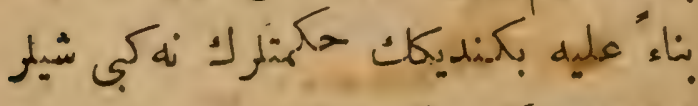

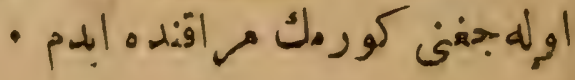




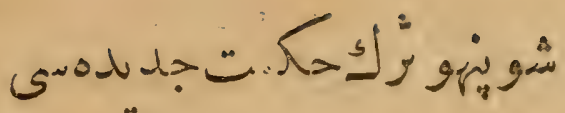

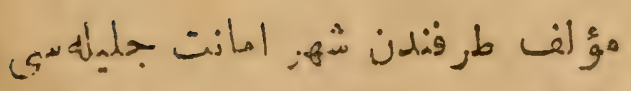

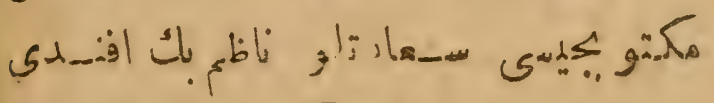

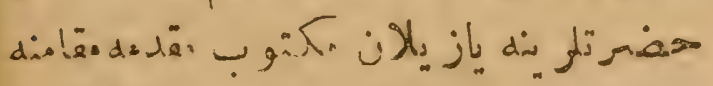

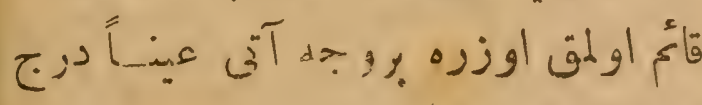

$$
\text { ا الون }
$$

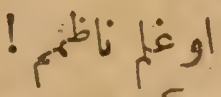

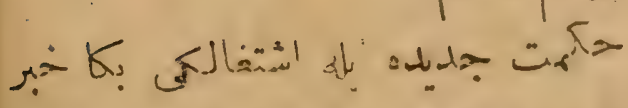

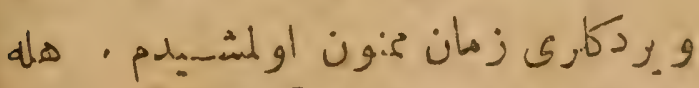

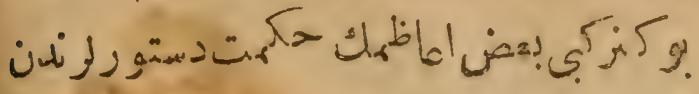

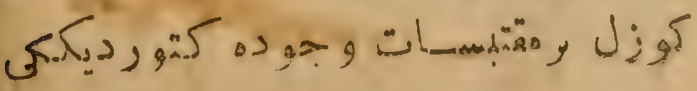


Aharet Mithat

شو:

Sopenhaüerin hikmet-i

cedideri

احهدمدحت

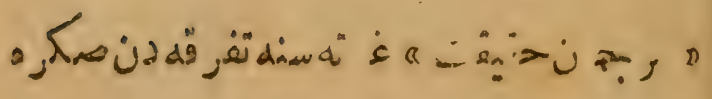

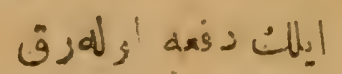

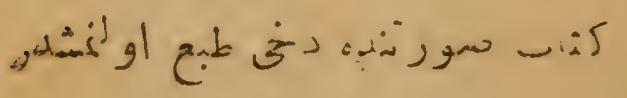

استابول

PFos 




\section{r.o}

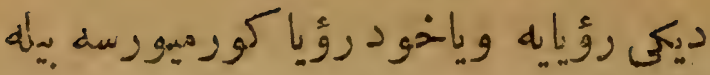

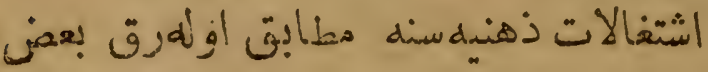

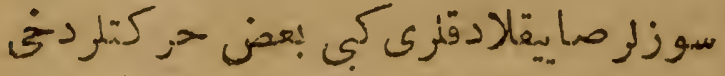

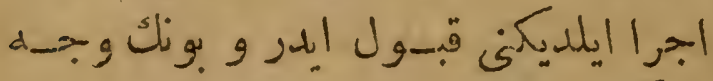

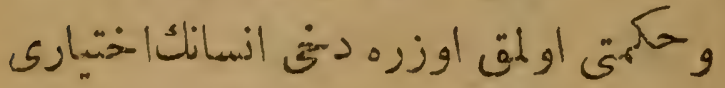

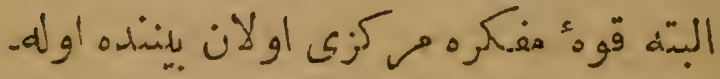

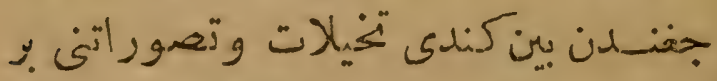

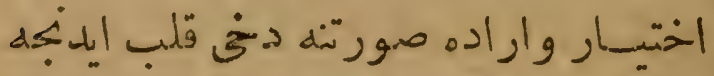

|

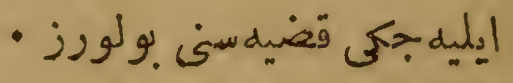

$$
\text { "दे" }
$$


r.E. 蔡

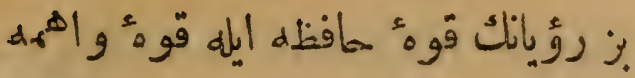

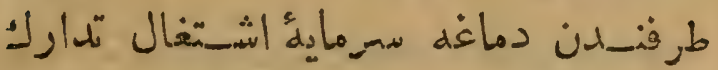

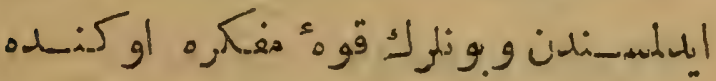

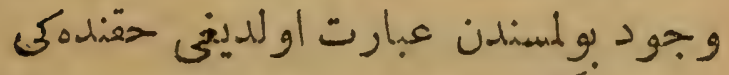

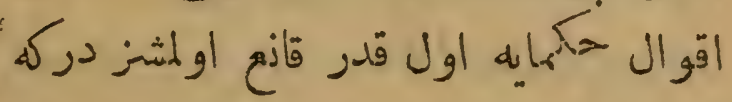

اسباب خارجيه دن تيمعل رؤياري ايله اذنسانه

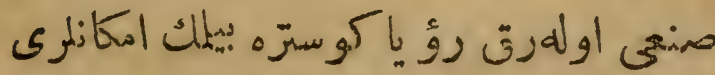

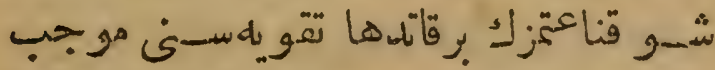

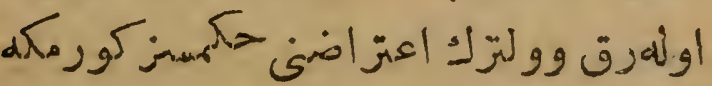

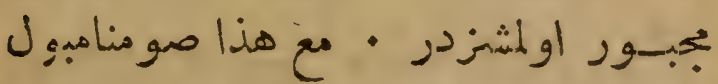

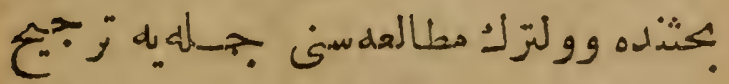

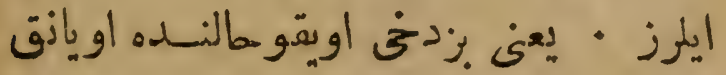

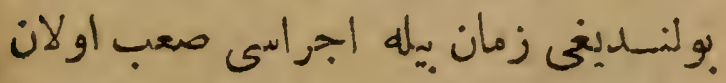

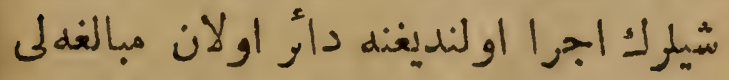

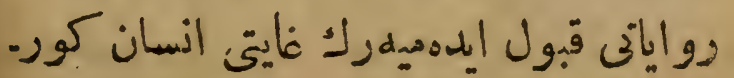




\section{rir}

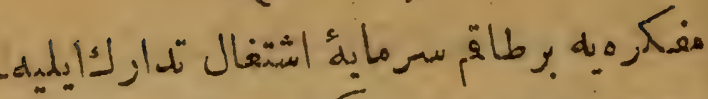

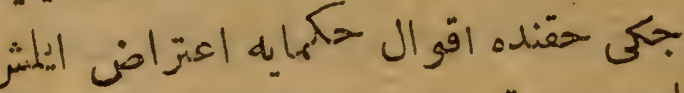

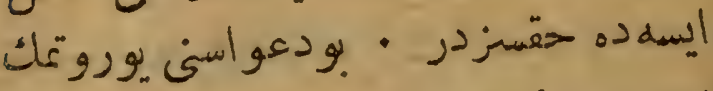

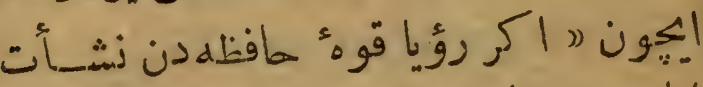

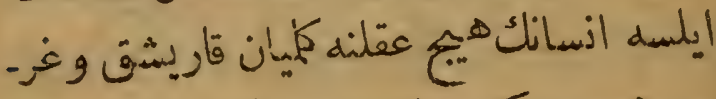

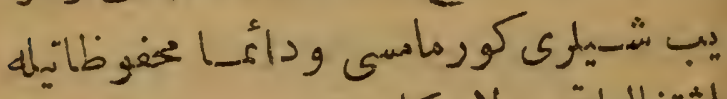

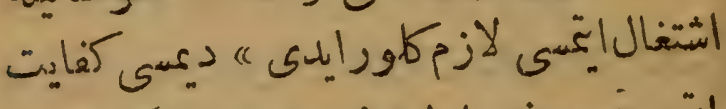

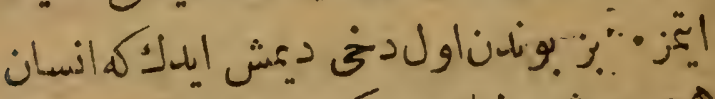

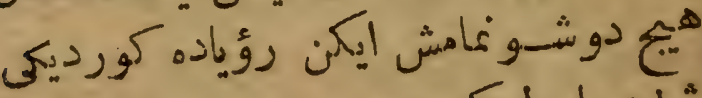

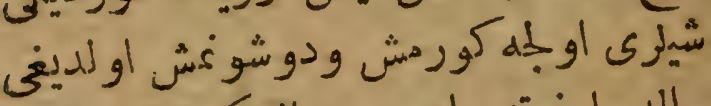

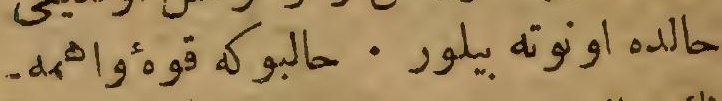

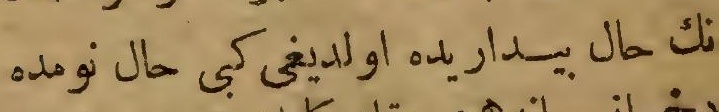

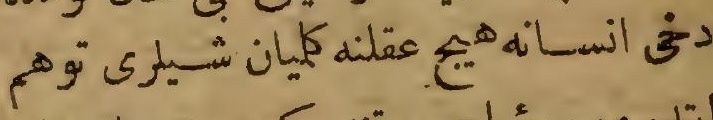

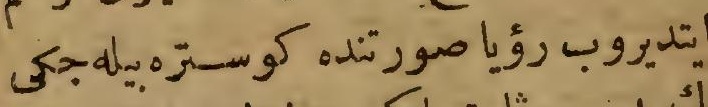

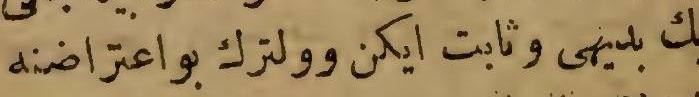

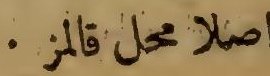




\section{卷 $\cos$}

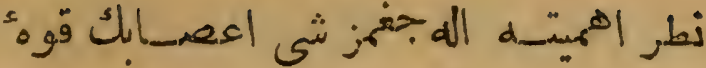

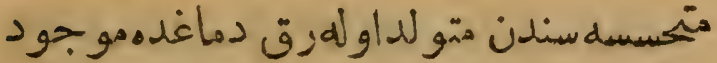

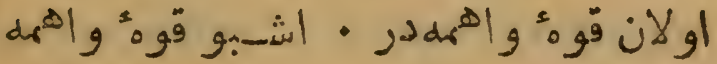

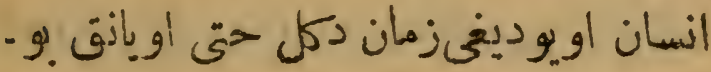

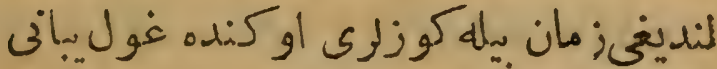

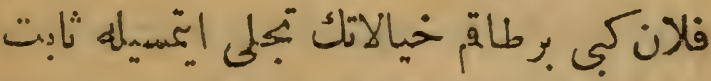

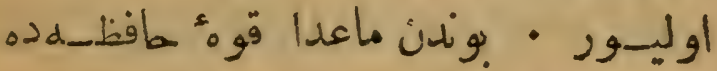

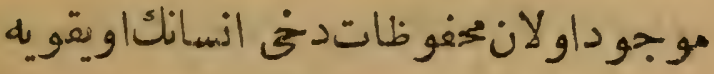

وارمسيله زائلاولميوب بالعكسن اويقومانيليل

حو اس ظاهره تعطبل خدمت إيلدكارى زمان

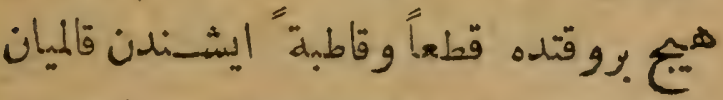

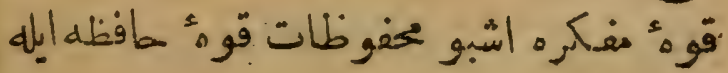

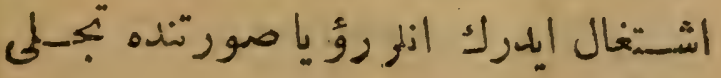

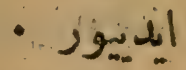

وولتر قوه؛ مافظه رؤيا مالنـده قوه؛ 


\section{s.1}

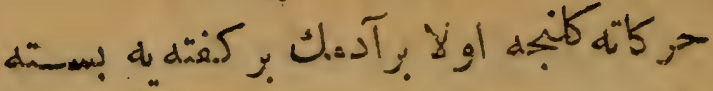

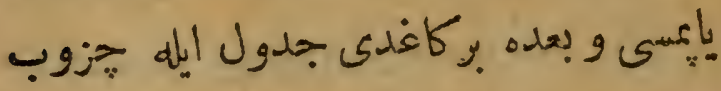

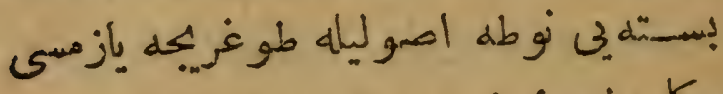

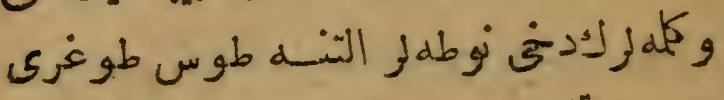

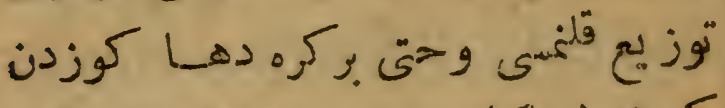

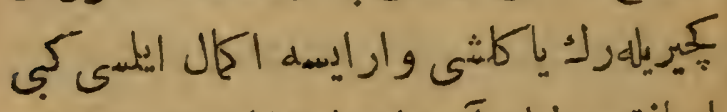

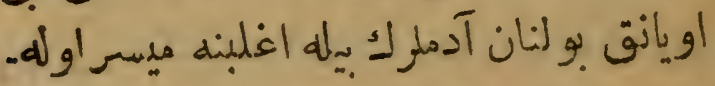

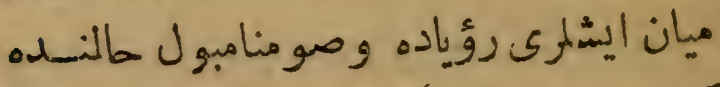

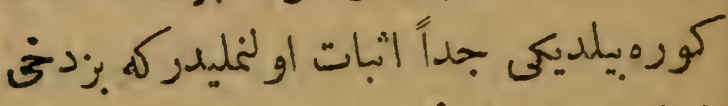

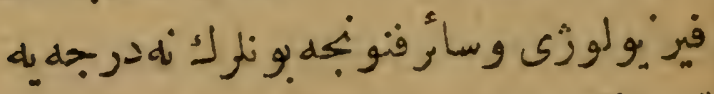

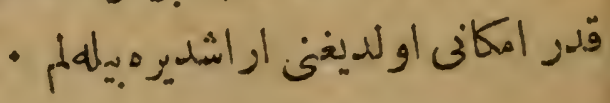

$$
\begin{aligned}
& \text { ميثى } \\
& \text { (c. d خلآ" }
\end{aligned}
$$

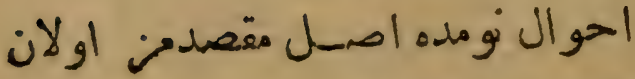

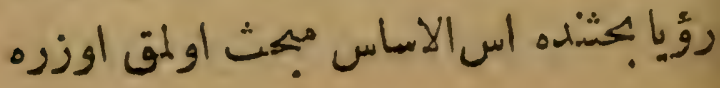




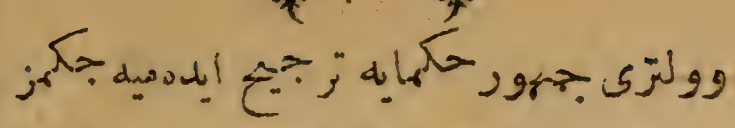

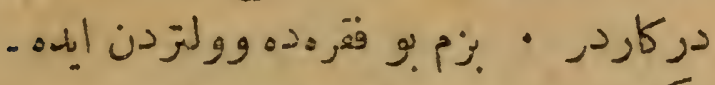

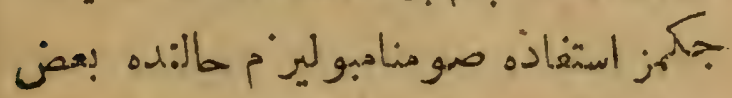

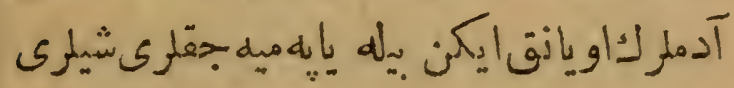

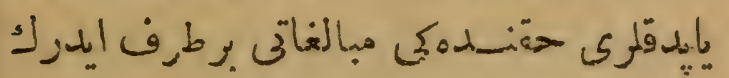

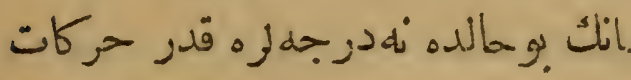

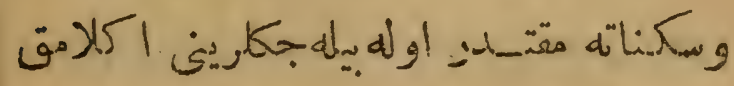
وحركات نوميهنك مو دورجهنى ايسه عادتا

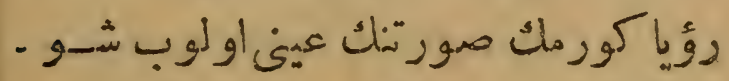

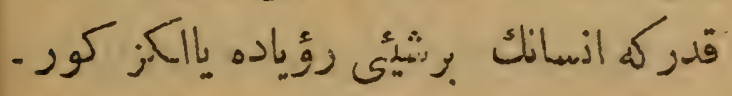

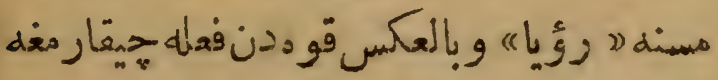

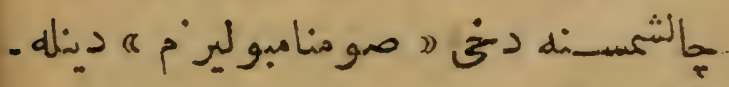

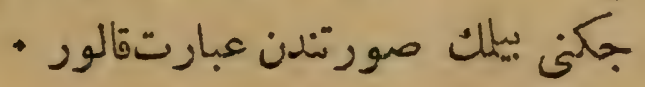

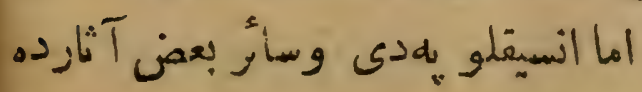

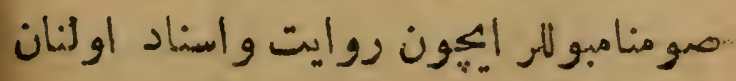


类 199

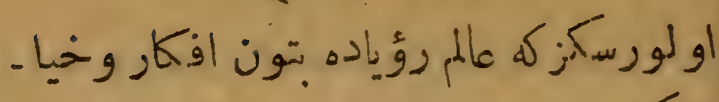

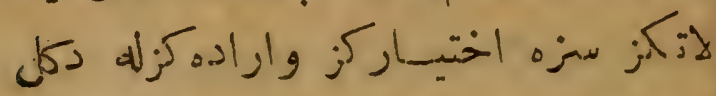

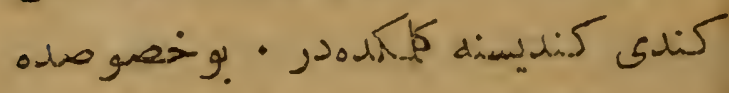

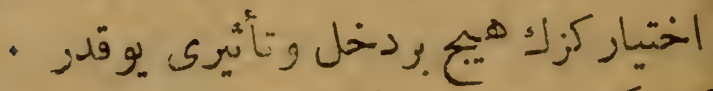

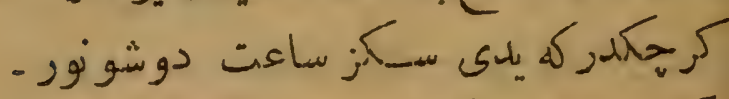

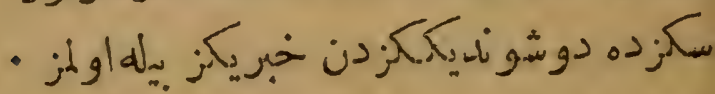

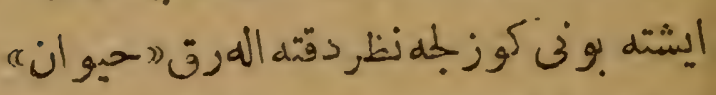

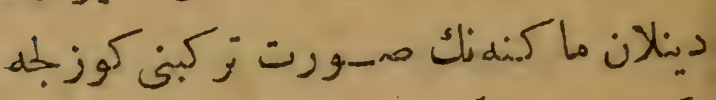

(c)

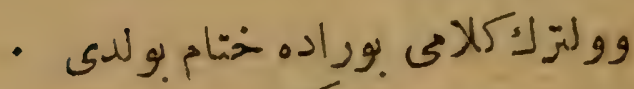

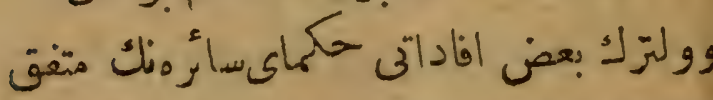

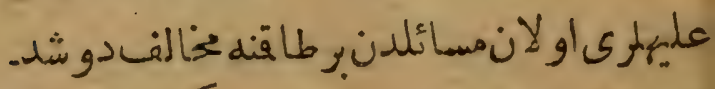

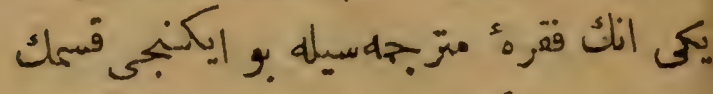

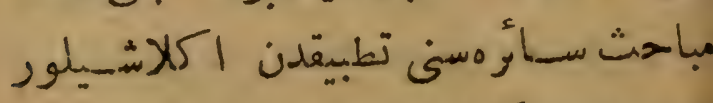

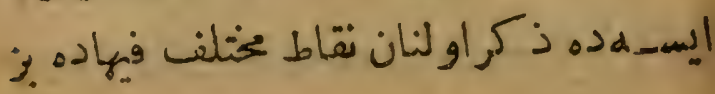




\section{类 191 等}

نيور? حتى بعضن كره روح ألك زيادهـصوت

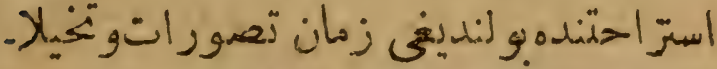

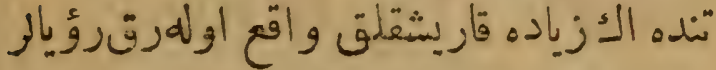

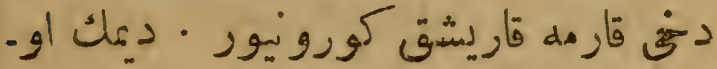

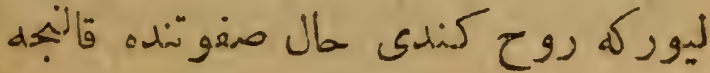

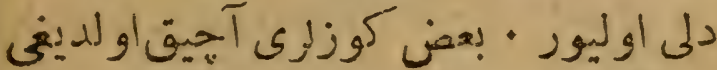

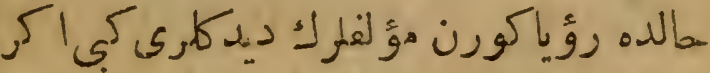

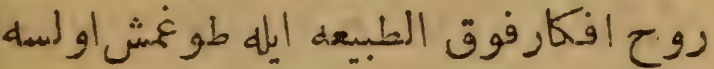

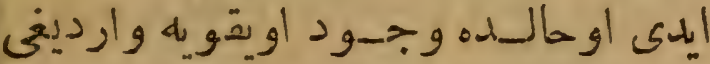
زمان مشهوداتنكدها زياده قوت وصنوتلهي

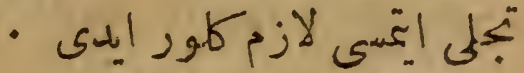

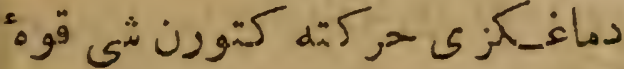

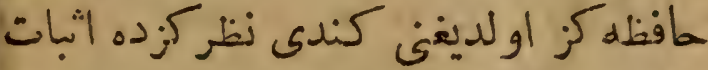
ائهو ن هانكى طريتى ملاحظه به كيتسه كز

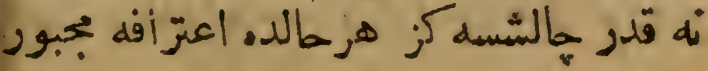




\section{4}

إيله اوغراشورلر · مويولمه أنسـانه حيرت

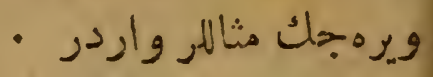

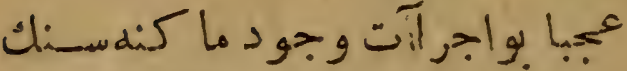

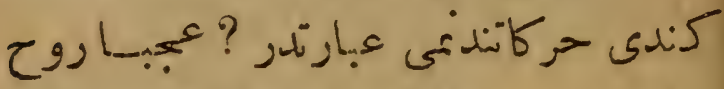

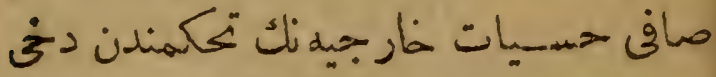

قورتمث اولديخى حالده كمندى حتوقيندن

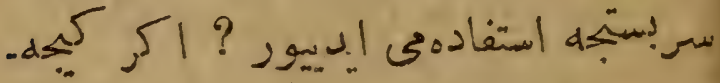

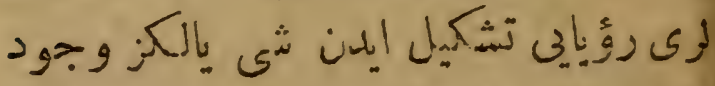

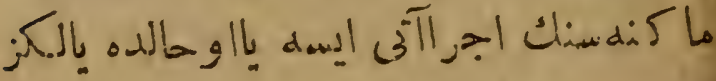

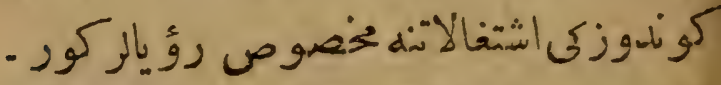

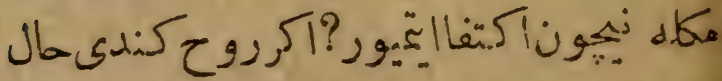

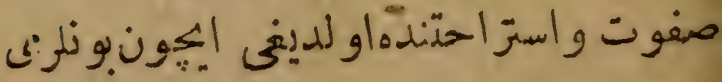

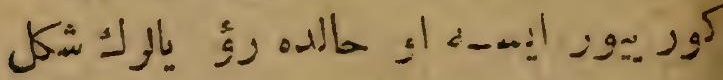

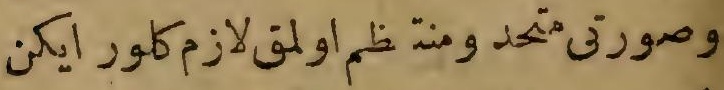

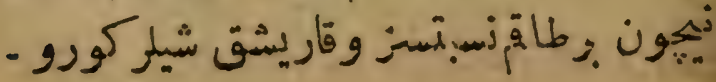




\section{慗 197 湾}

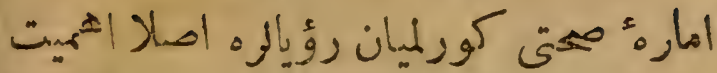

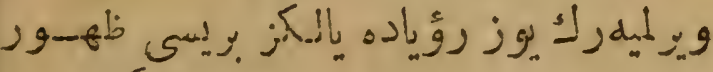

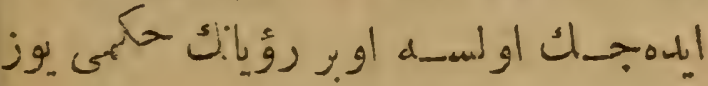

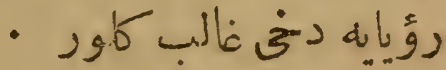

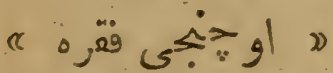

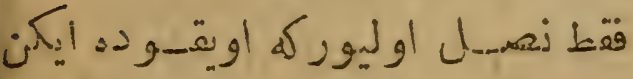

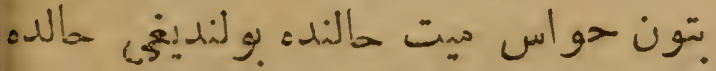
?

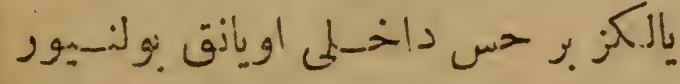
كوزلركز كوردمديكى وقو لاقلميكن: ايشتمديكي

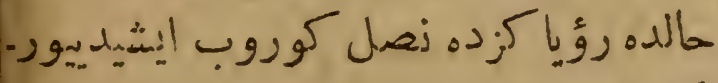

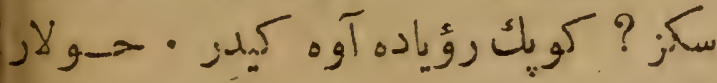

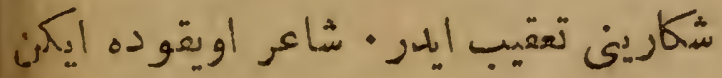

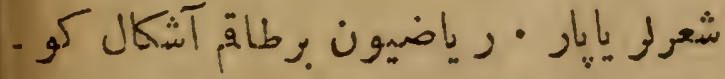

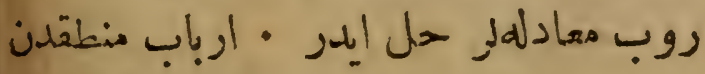

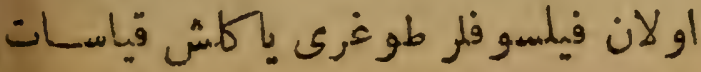




\section{0 (9)}

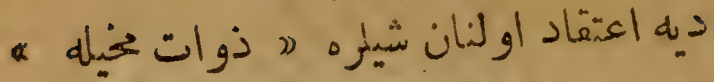

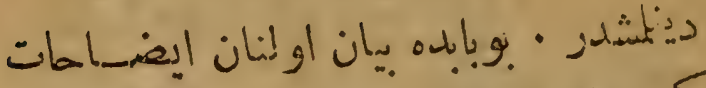

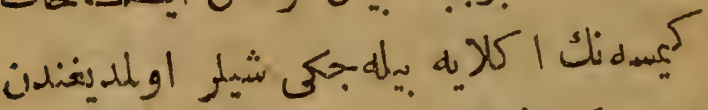

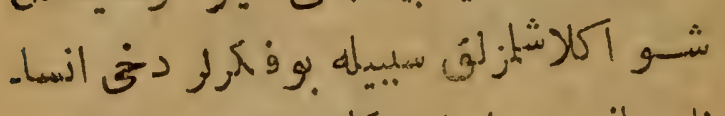

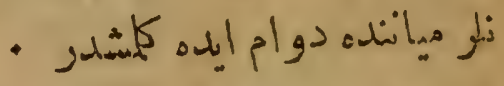

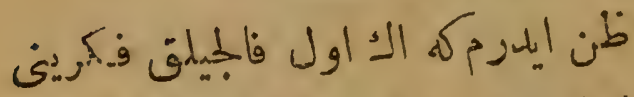

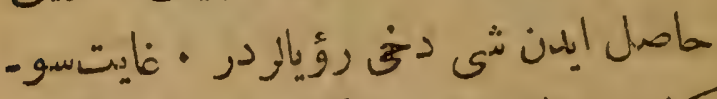

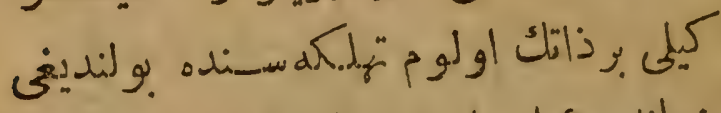

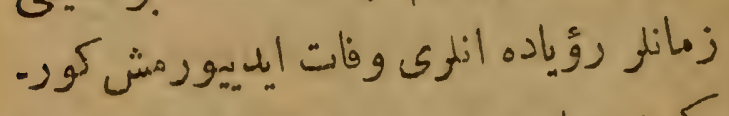

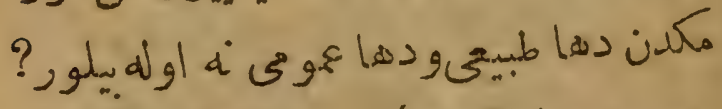

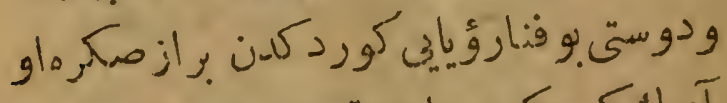

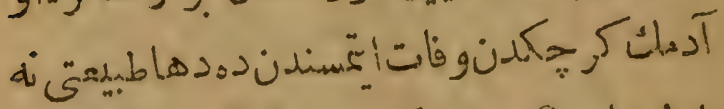

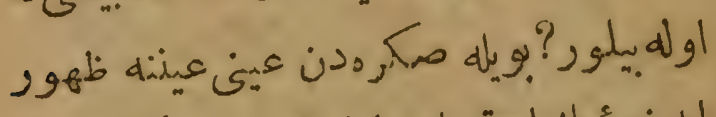

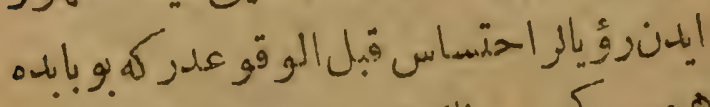

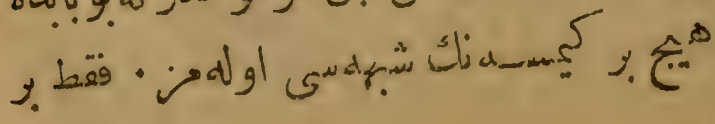




\subsection{4}

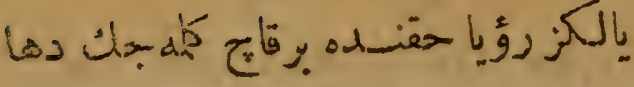

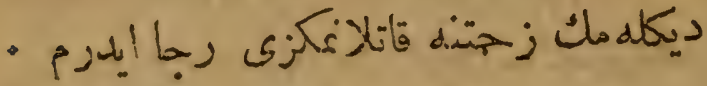

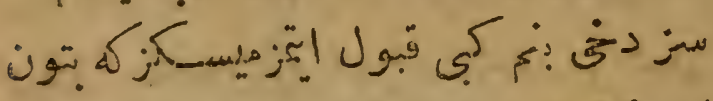

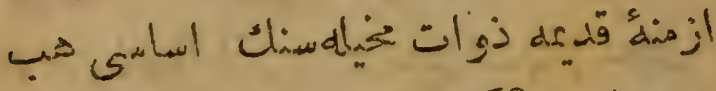

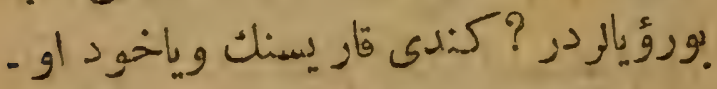

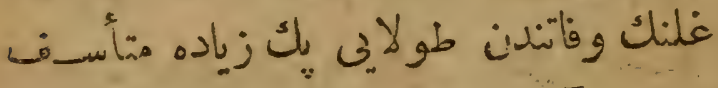

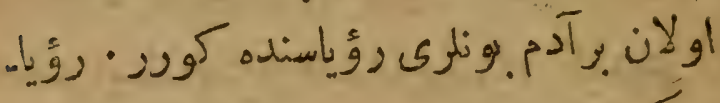

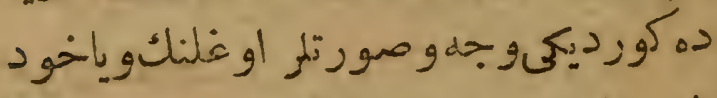

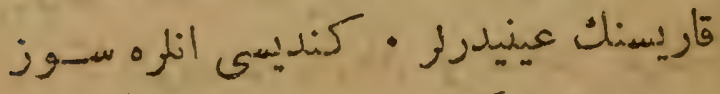

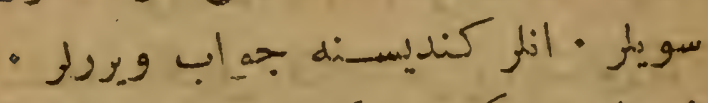

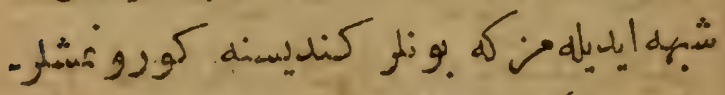

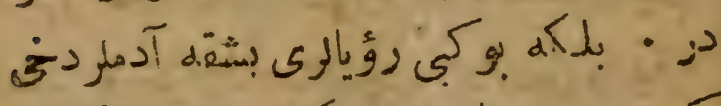

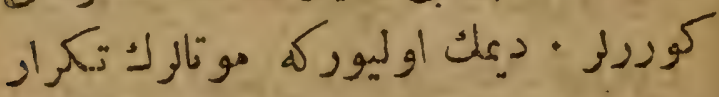

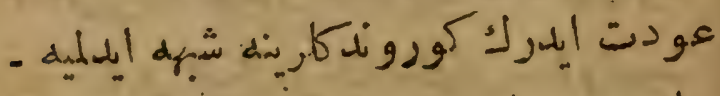

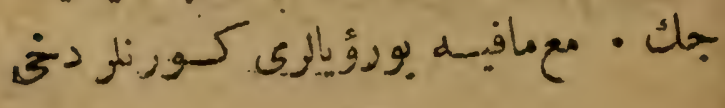




\section{慗 195}

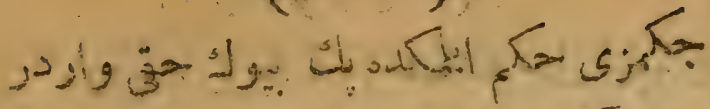

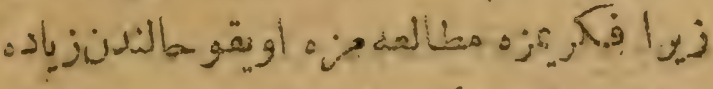

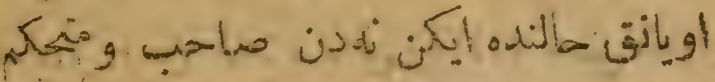
أ

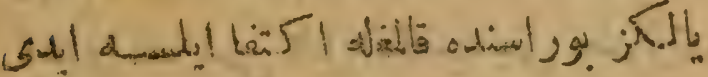

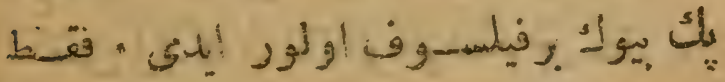

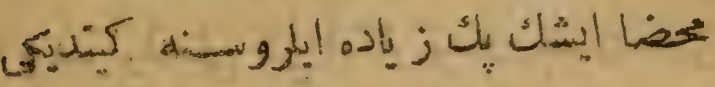
إيمون الدانمستدر

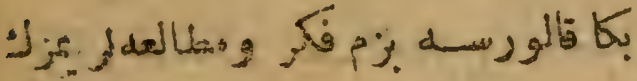

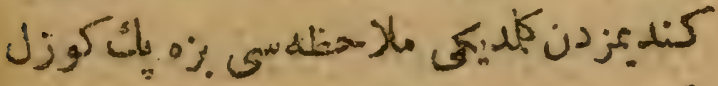

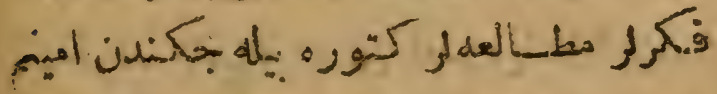

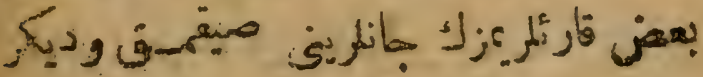

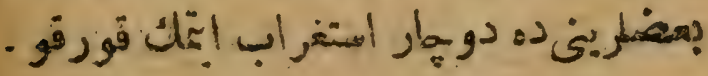

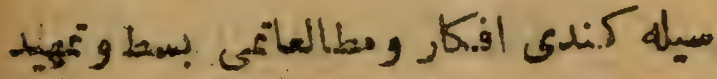
- foul 


\section{1 \%}

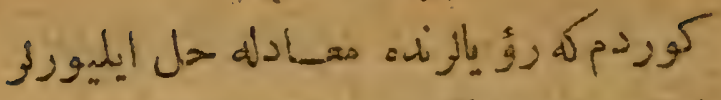

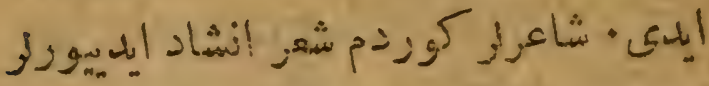

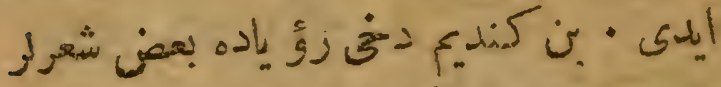

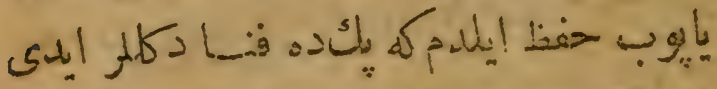

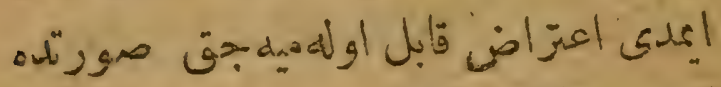

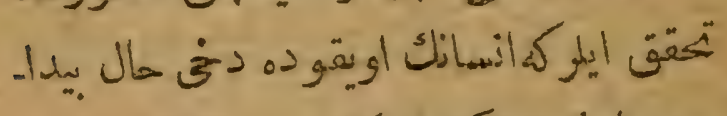

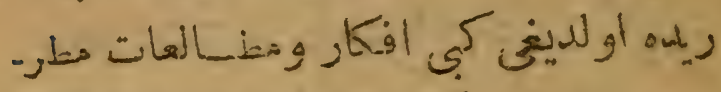

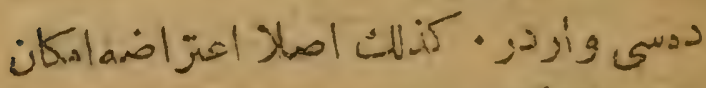

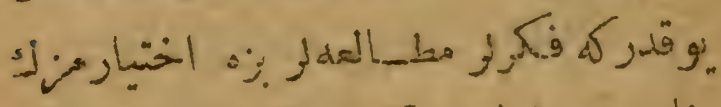

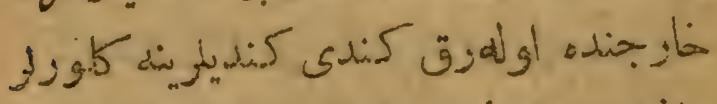

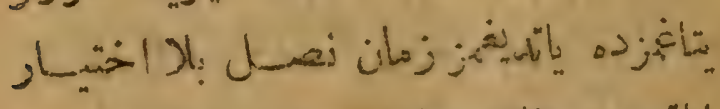

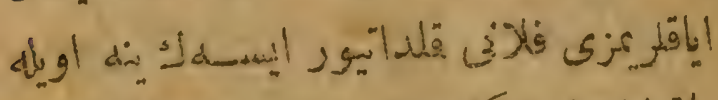

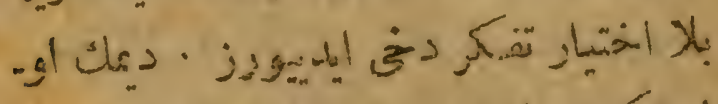

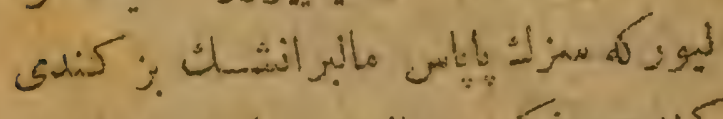

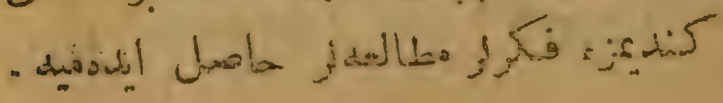




\section{9.}

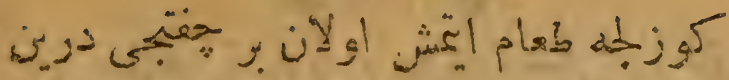

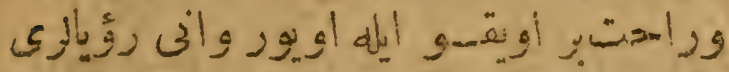

ئd

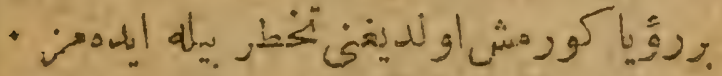

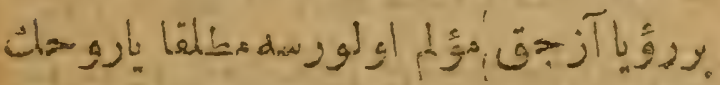

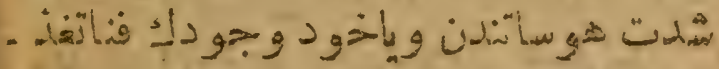

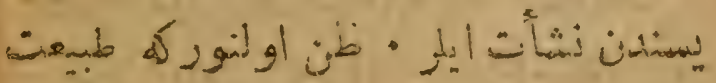

.

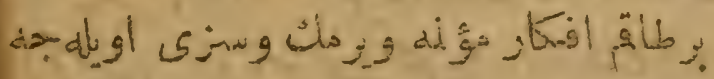

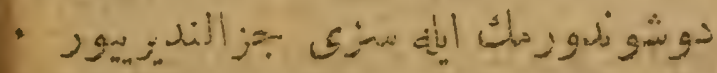

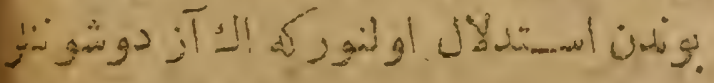

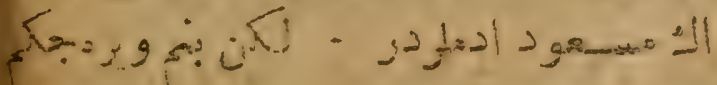

- jub a d a dij

\section{1}

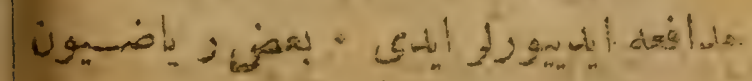




\section{A 率}

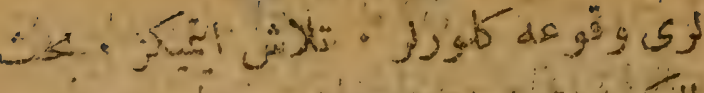

$$
\text { ! }
$$

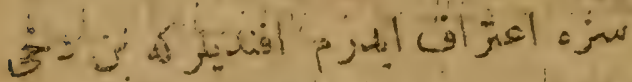

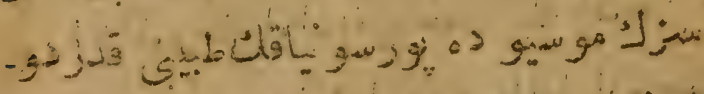

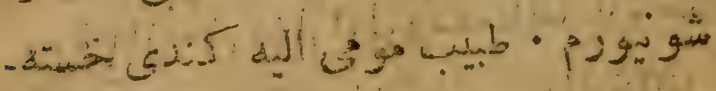

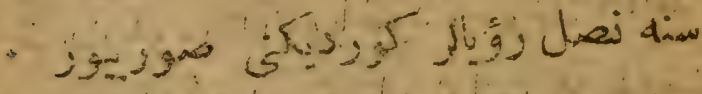

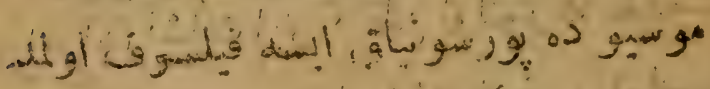

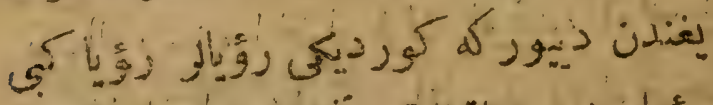

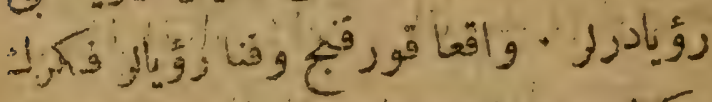

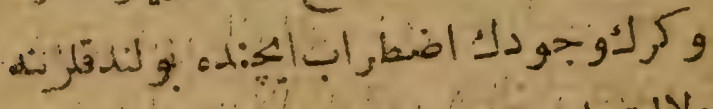

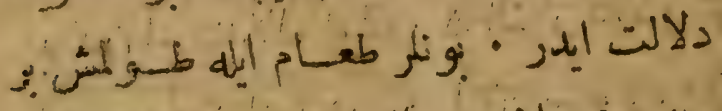

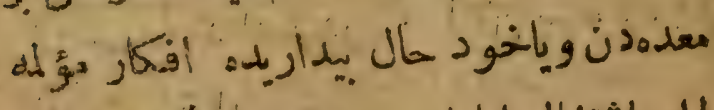

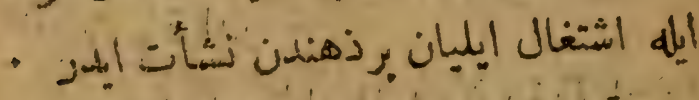

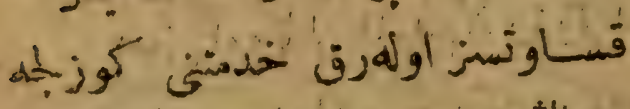

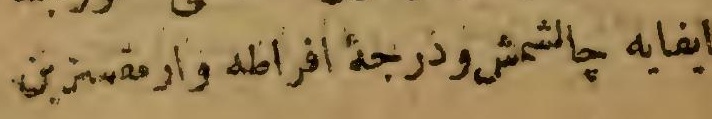


بز

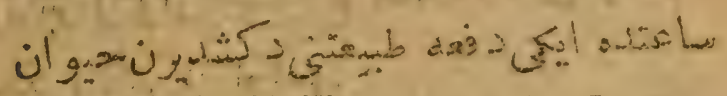
? गd

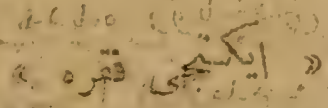

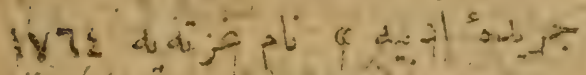

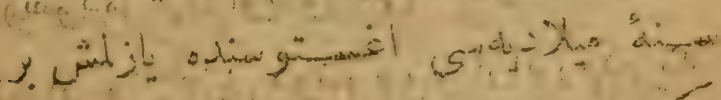
: j.jos

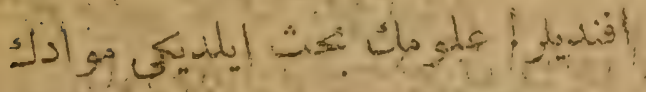

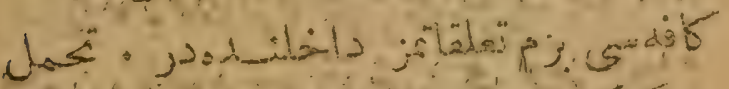

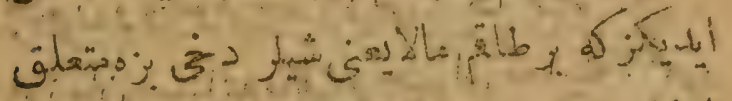

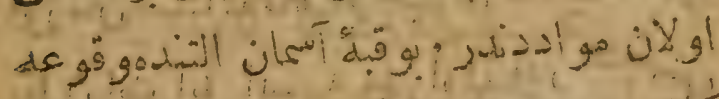
da

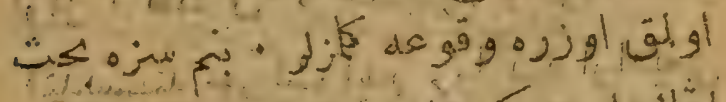
| - في و و 


\section{inr}

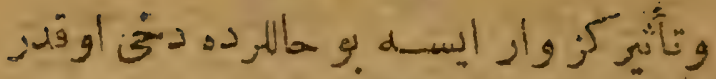

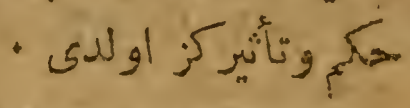

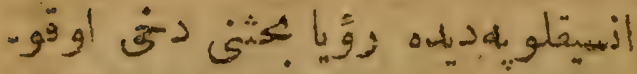

3.

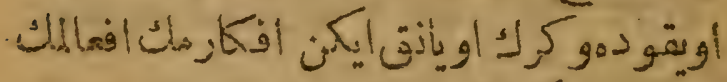

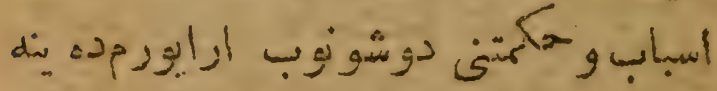

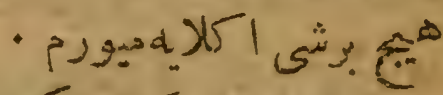

.

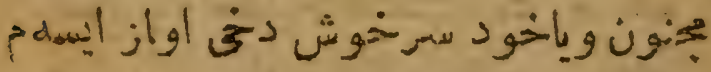

اوزمان

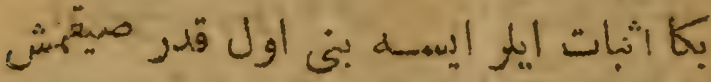

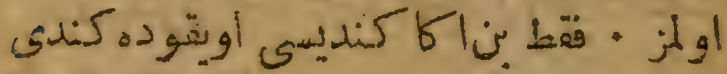

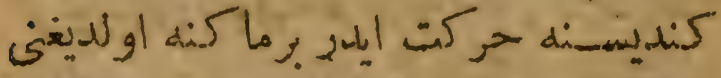

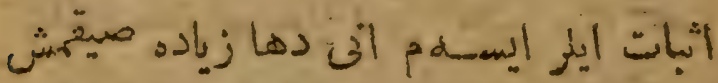

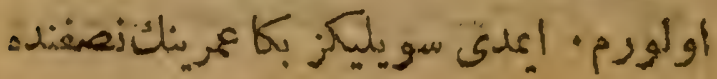




\section{7}

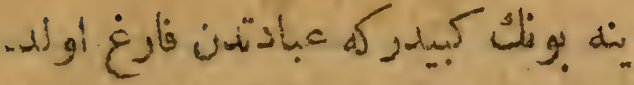

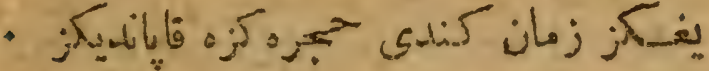

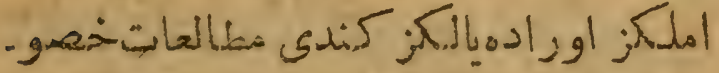

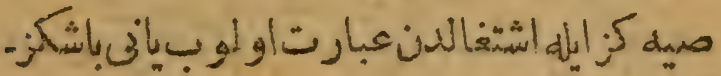

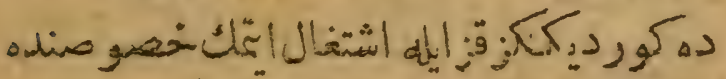

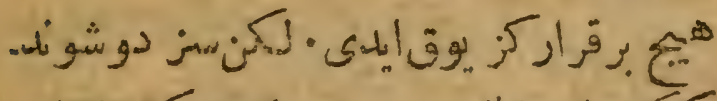

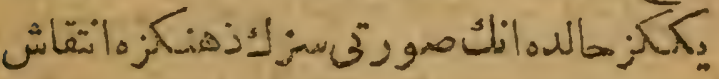

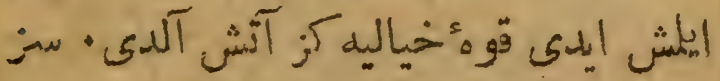

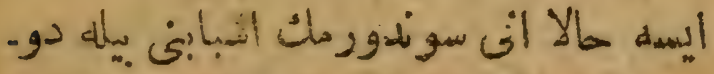

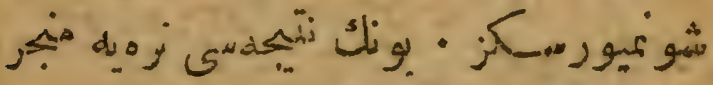

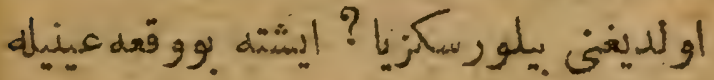

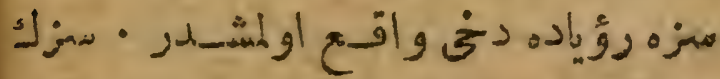

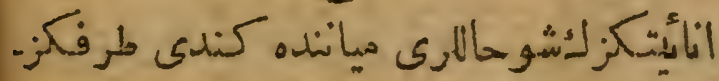

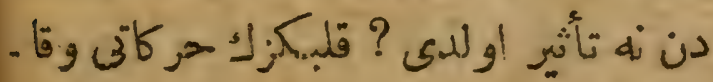

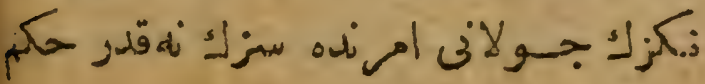




\section{0 亲}

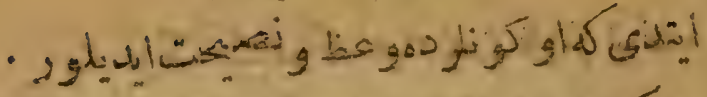

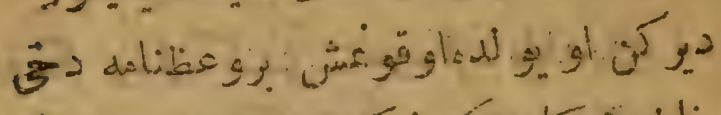

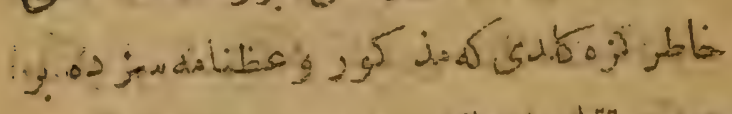

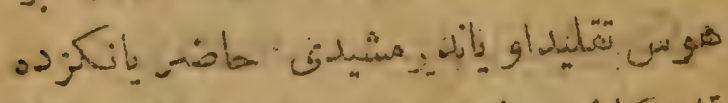
or

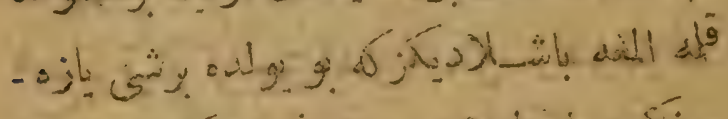

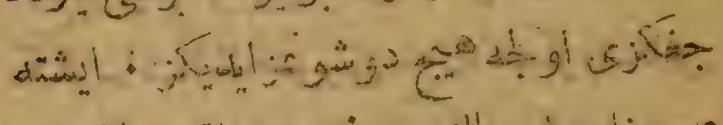
ज ज ن

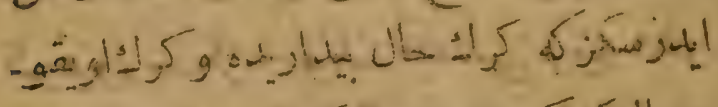
كئم

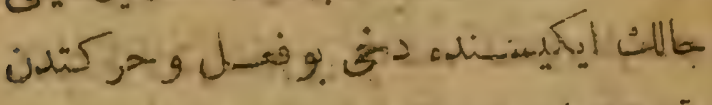

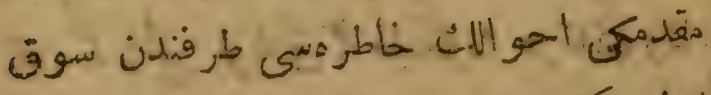
! : 


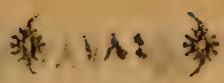

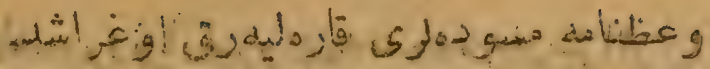

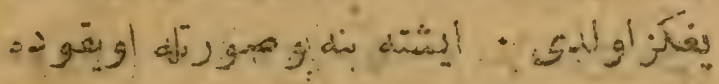

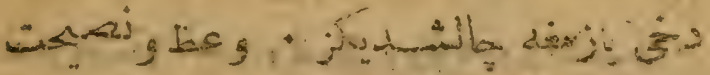
- Al b الم

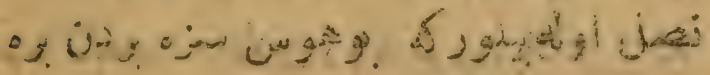
رو

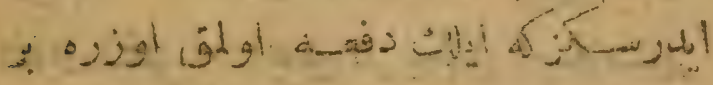

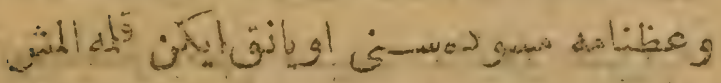

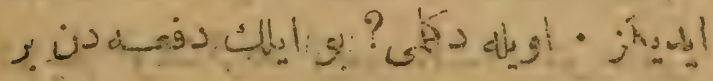

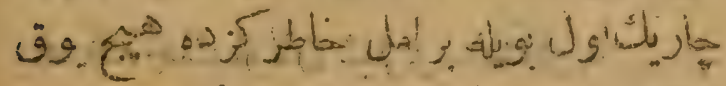
r.

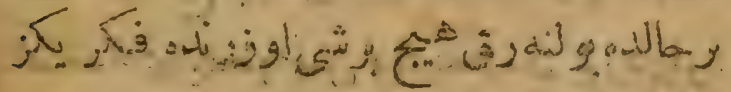

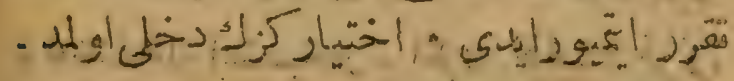

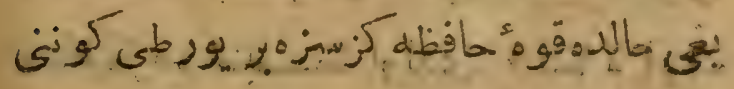

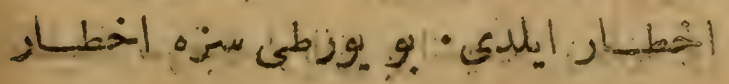




\section{* Ir}

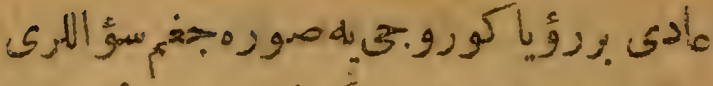

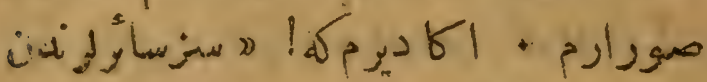

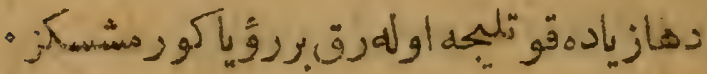

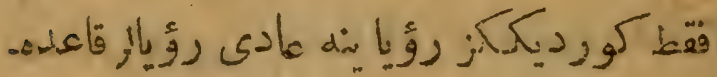

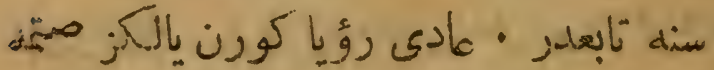

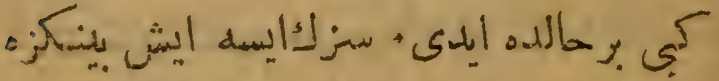

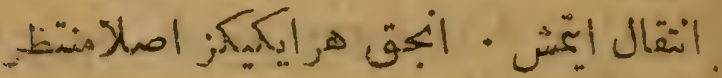

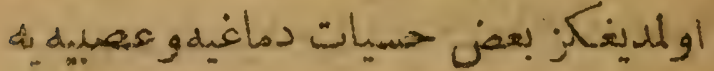

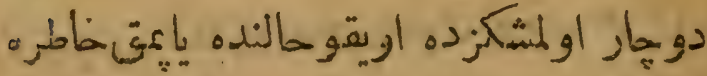
ه.

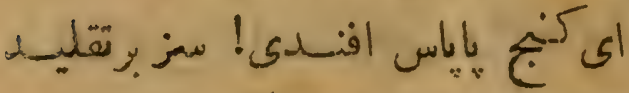

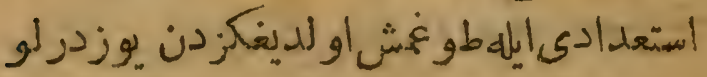

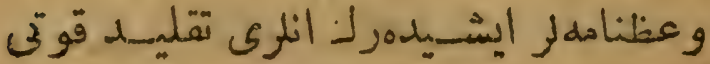

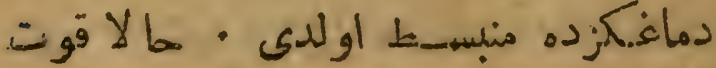

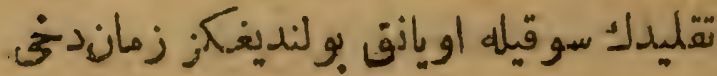




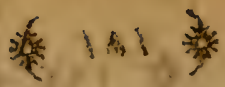

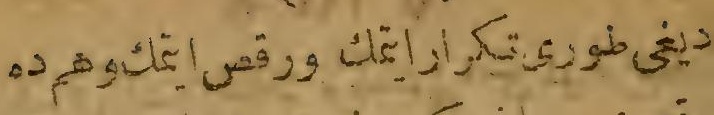

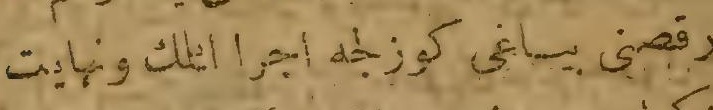

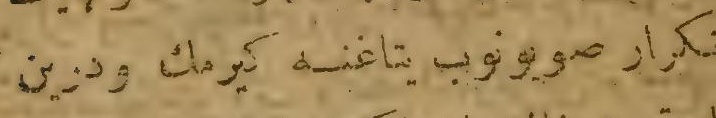
-

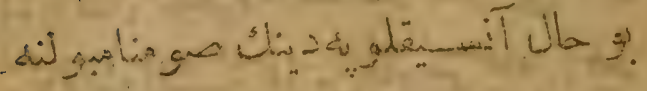

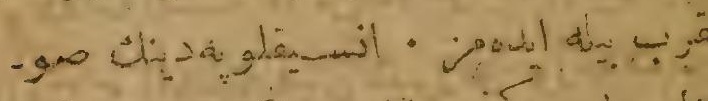

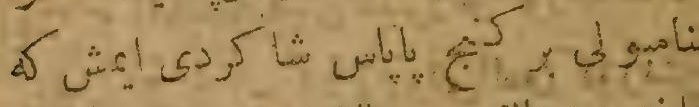

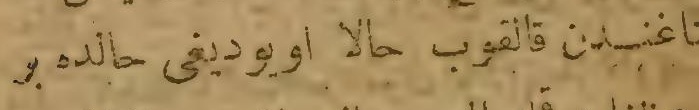

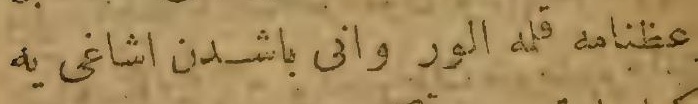
رونو ى

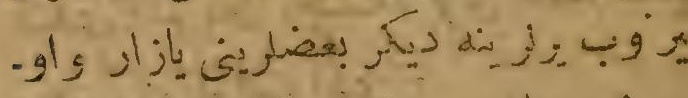

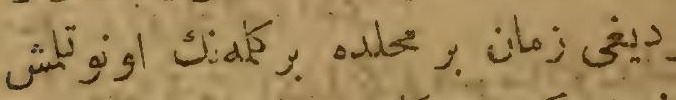

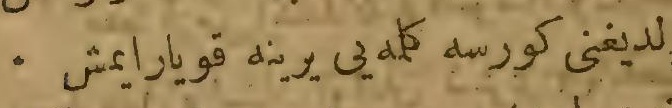

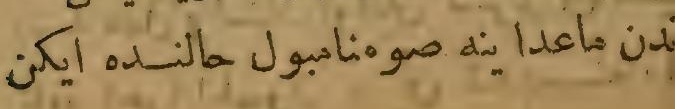




\section{$1 \mathrm{~A} \cdot \frac{\mathrm{k}}{3}$}

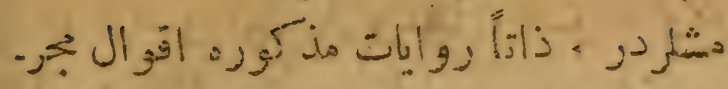

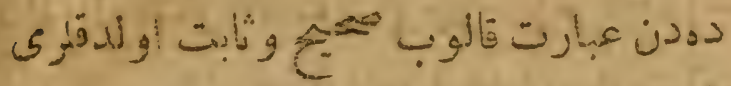

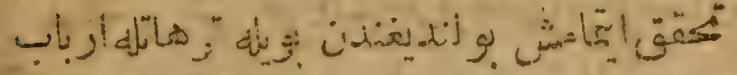

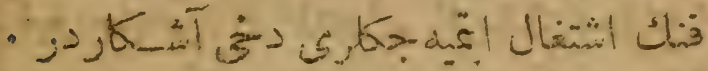

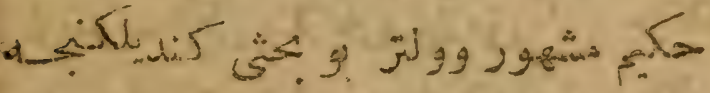

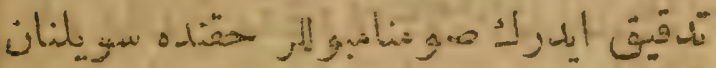

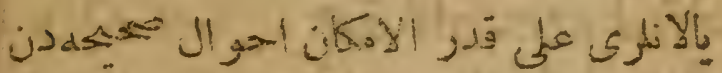

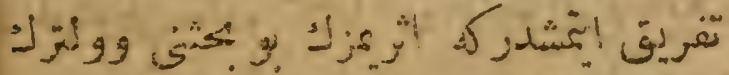

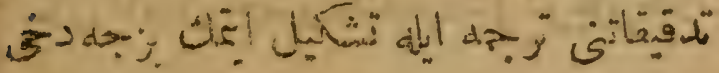

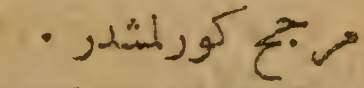
وولتز ديموركه:

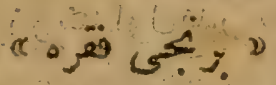

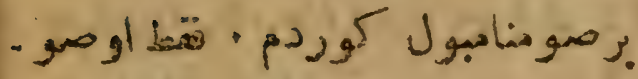

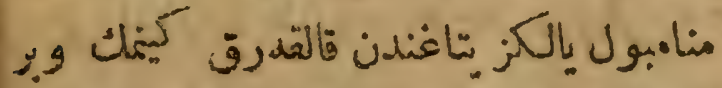

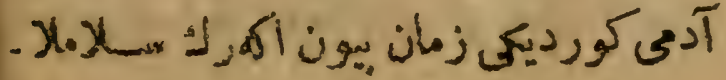




\section{V9}

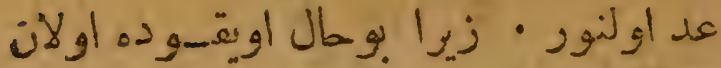

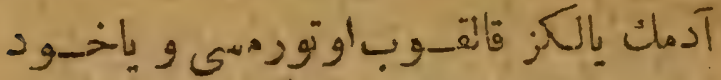

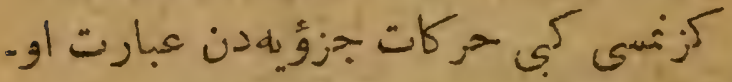

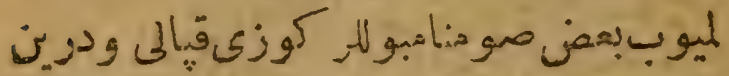

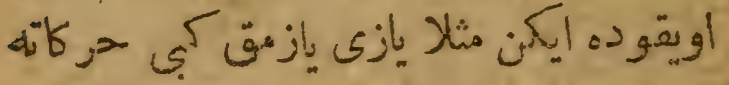

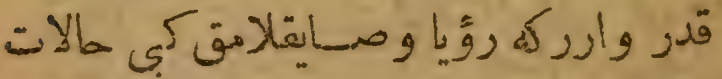

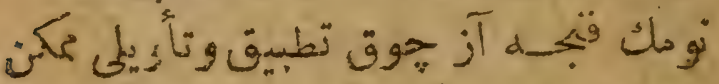

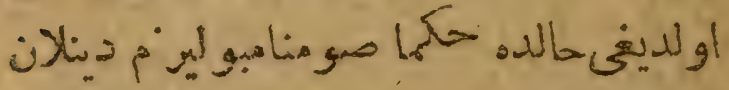

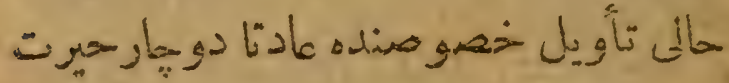

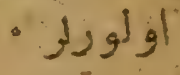

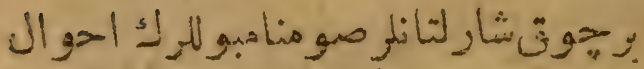

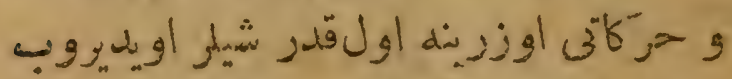

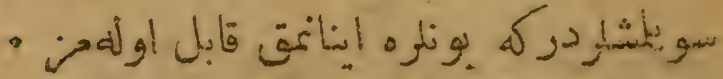

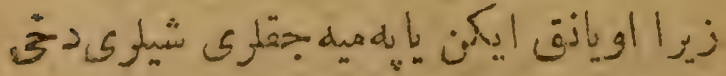

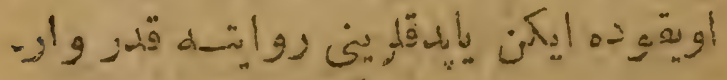




\section{WV W}

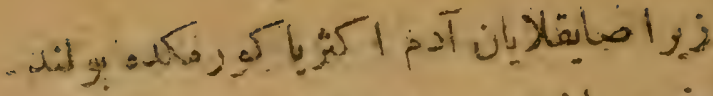

.

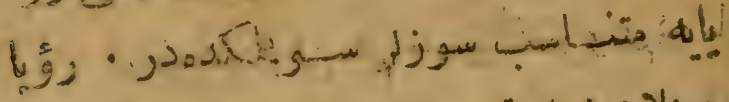
واه

5j

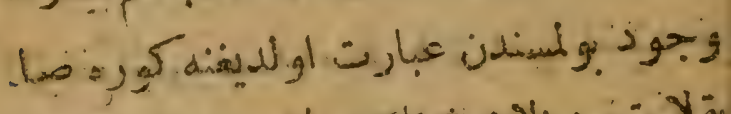

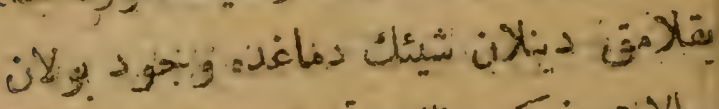

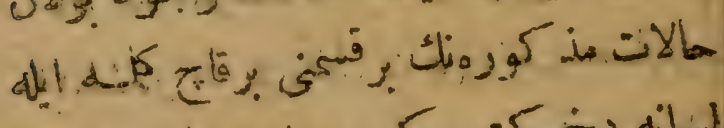

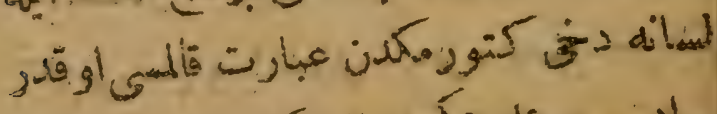

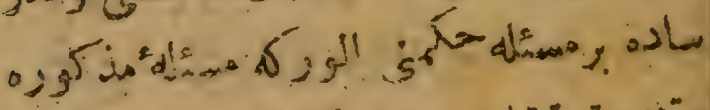

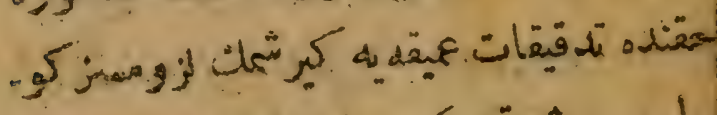

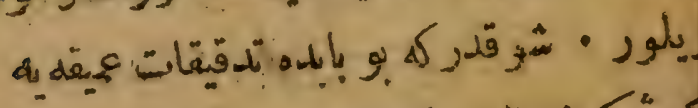

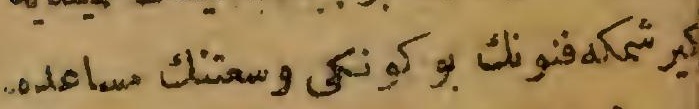
كى

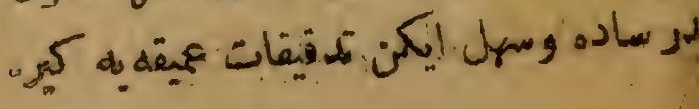


189

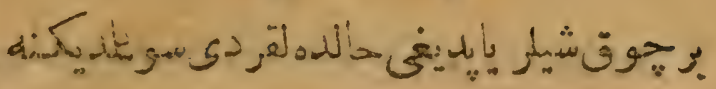

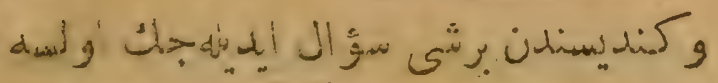

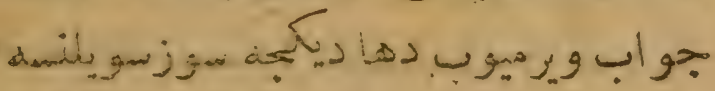

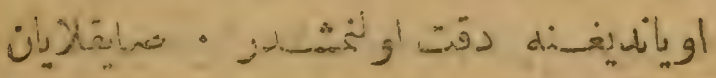

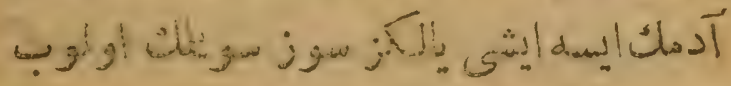
da

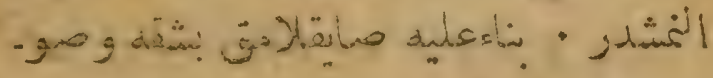

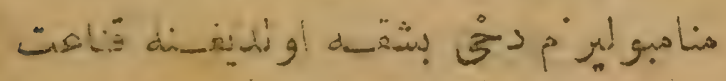

-

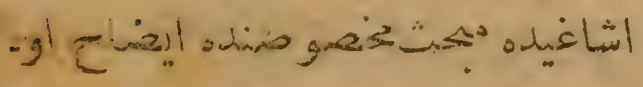

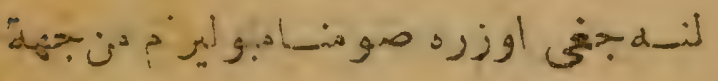

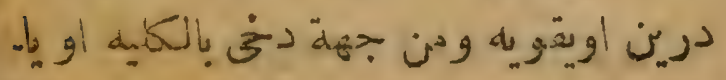

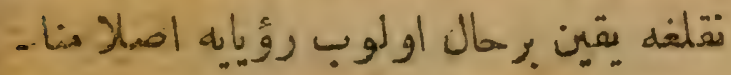

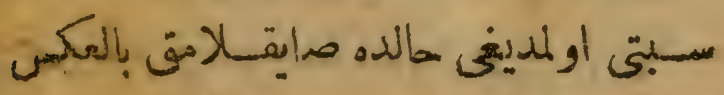

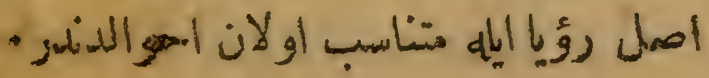




\section{IVo}

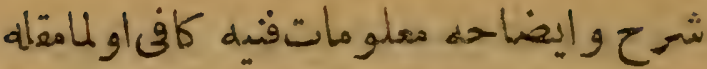

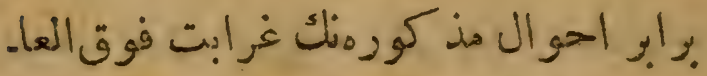

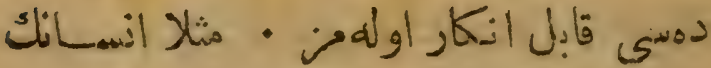

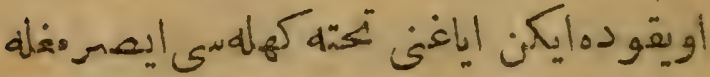

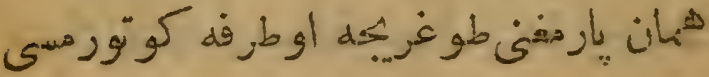

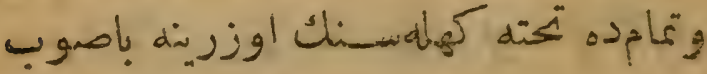

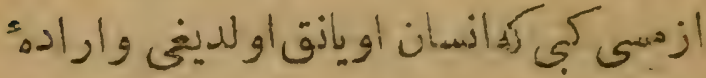

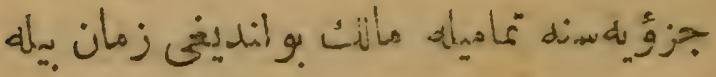

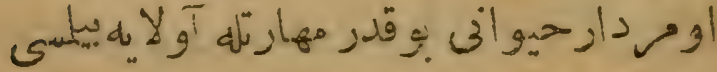

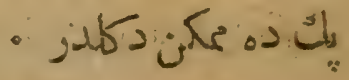

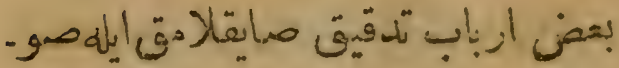

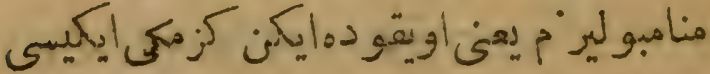

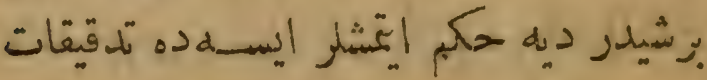

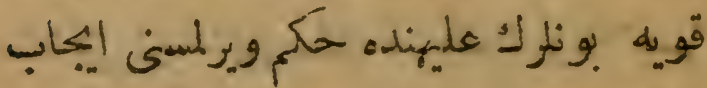

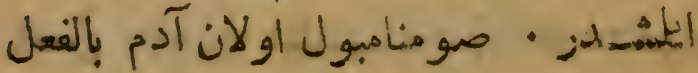




\section{IVE}

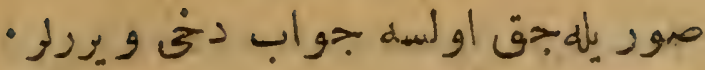

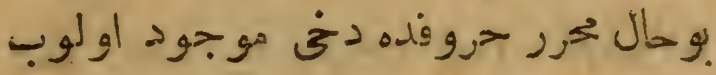

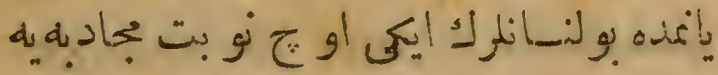

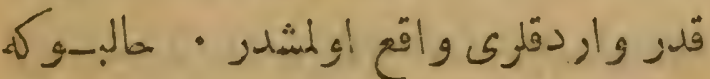

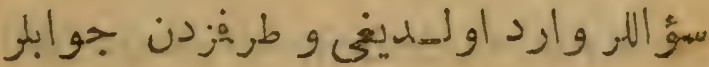

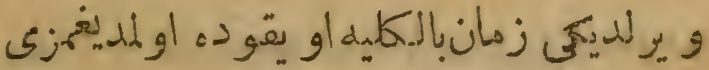

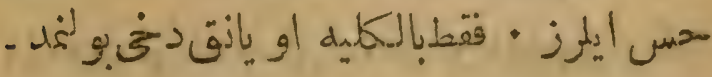

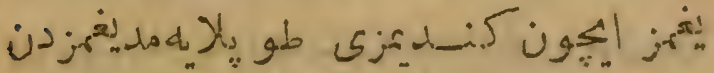

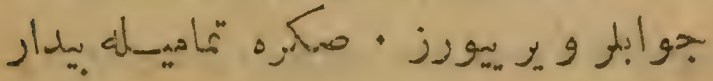

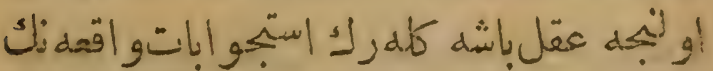

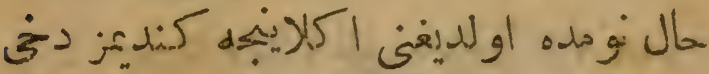

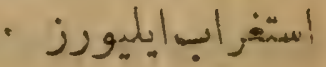

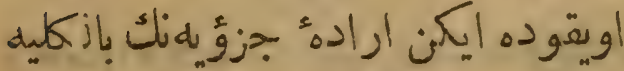

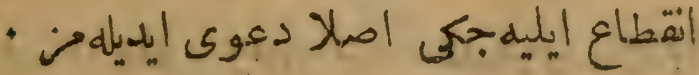

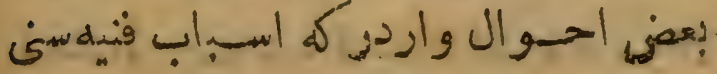




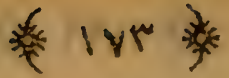

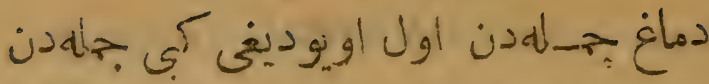

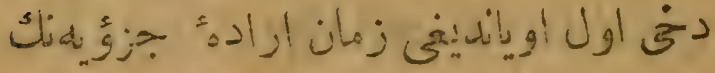

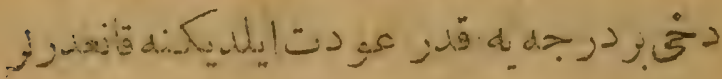

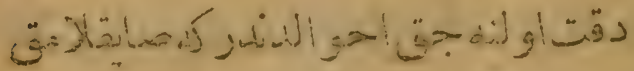

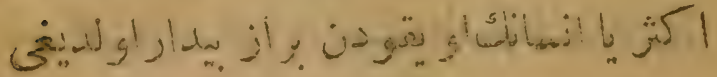

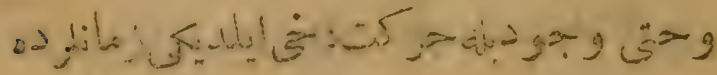

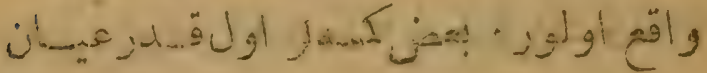

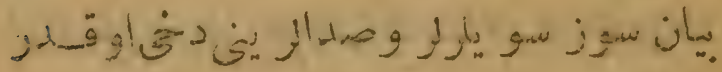

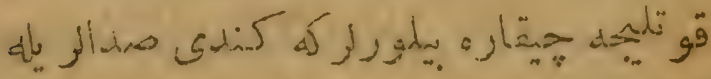

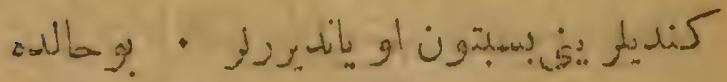

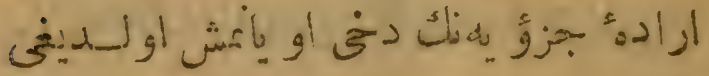

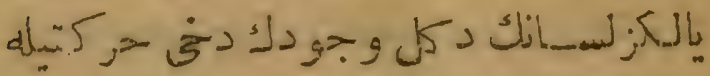

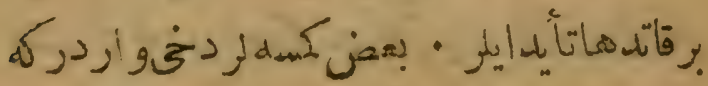

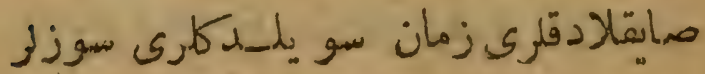

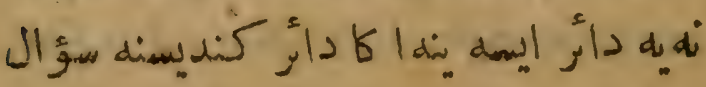


* ivr

9 هي

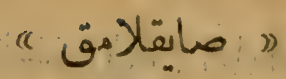

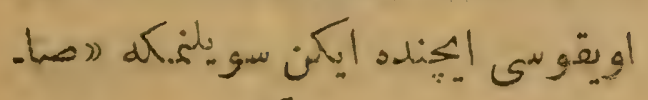

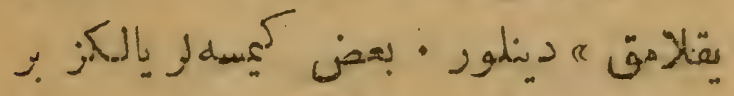

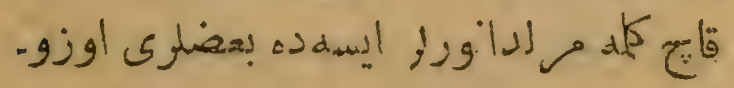

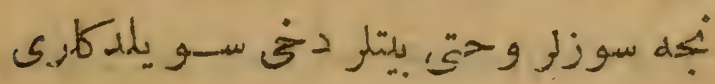

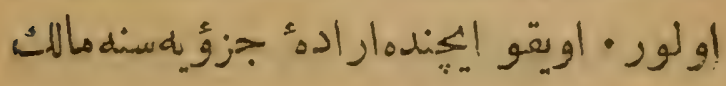

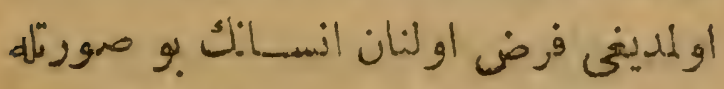

واسطة كلامى اولان لساني استحمال إتمّى إنى

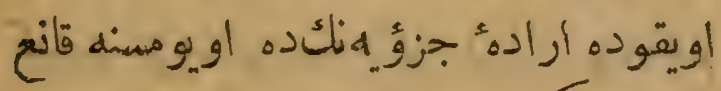

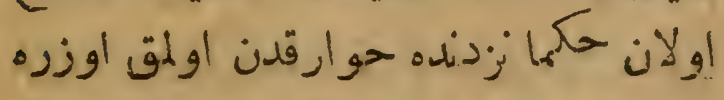

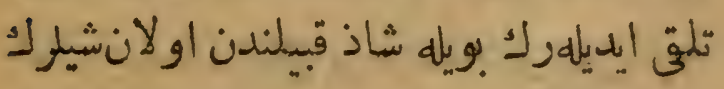

كيث كو تورمبه جحكلرينى درميان إيدرلر ايسه.

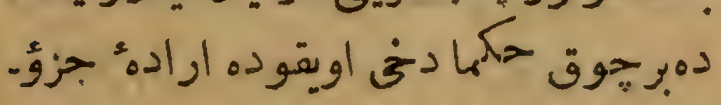

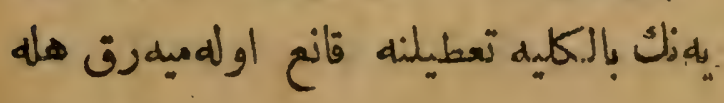




\section{|vi}

وقوتلى اولور ايسـه رؤياى ص-نمى ارأه

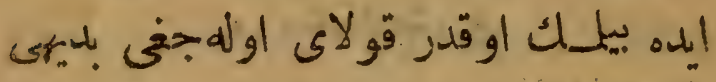
-

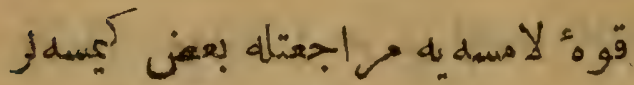

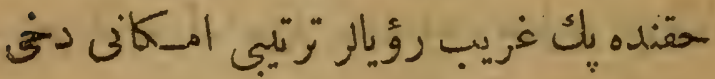

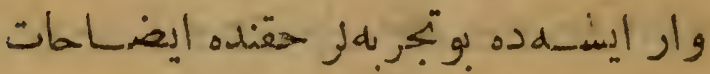

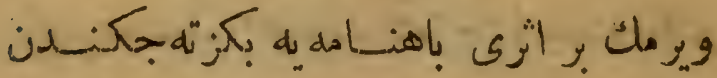

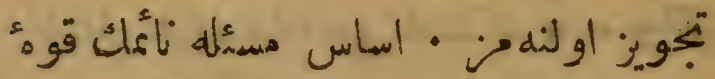

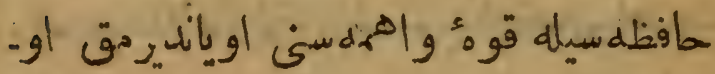

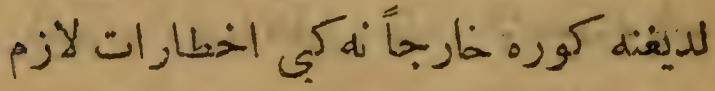

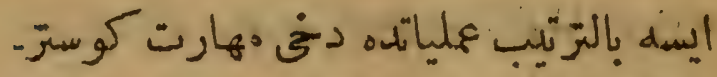

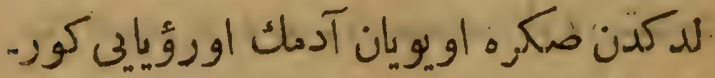
- 


\section{IV.}

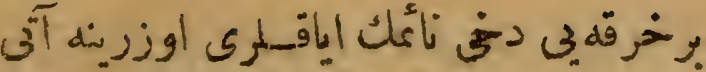

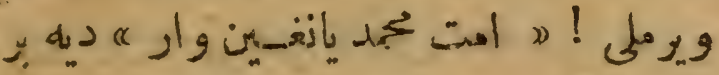

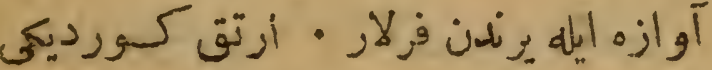

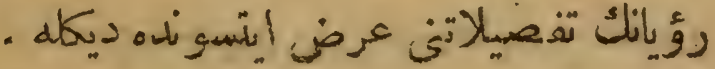

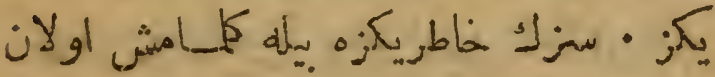

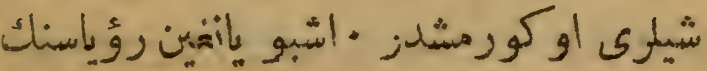

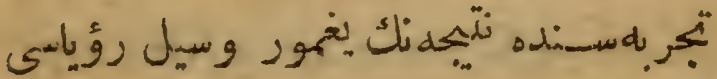

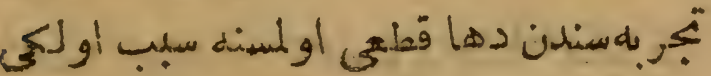

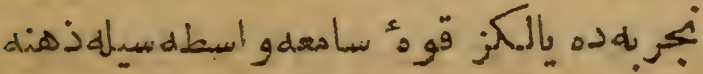

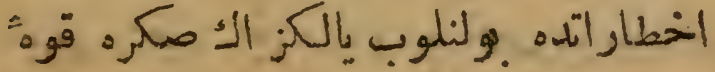

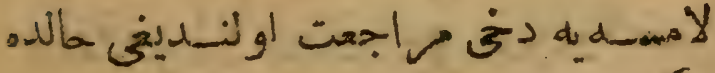

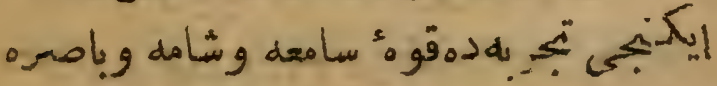

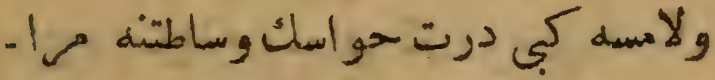

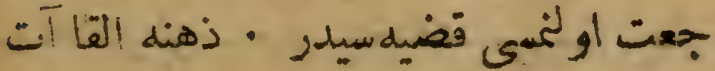

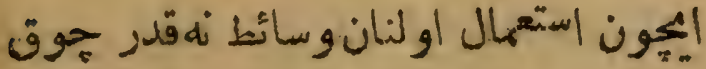




\section{类 179 䊅}

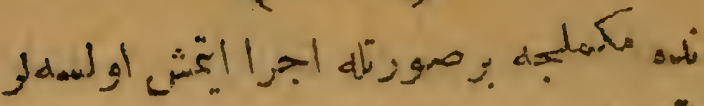

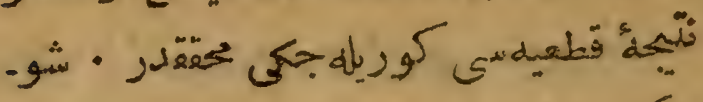

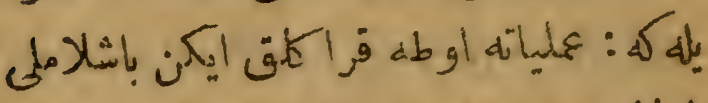

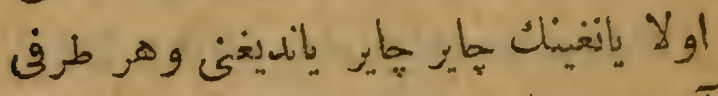

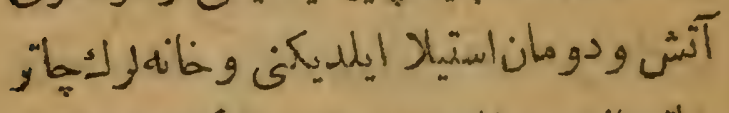

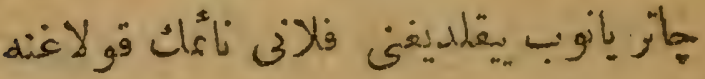

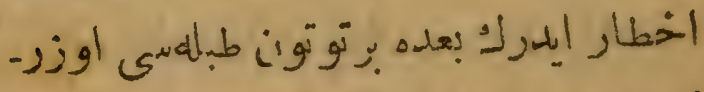

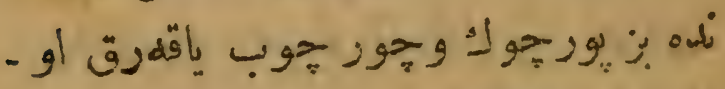

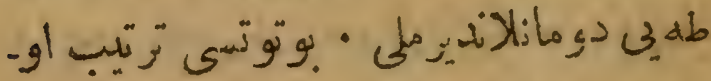

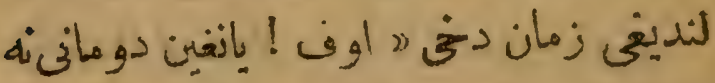

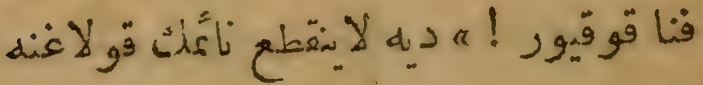

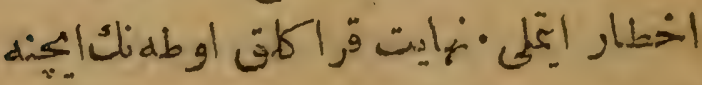

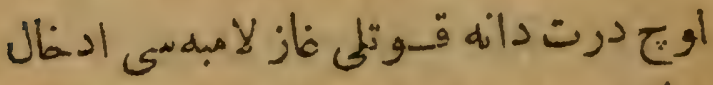

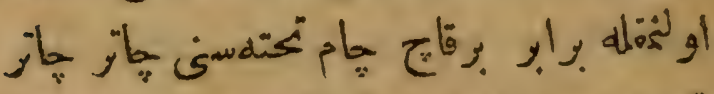

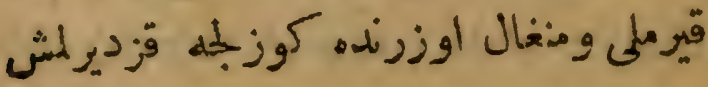




\section{7月}

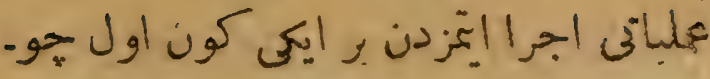

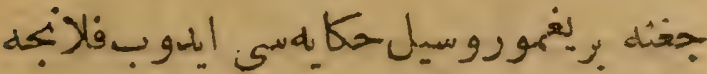

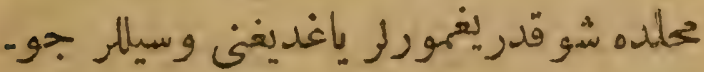

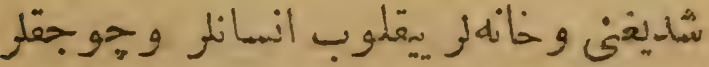

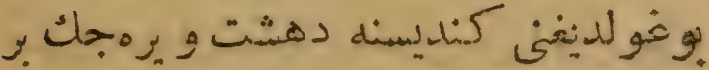

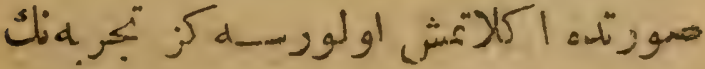

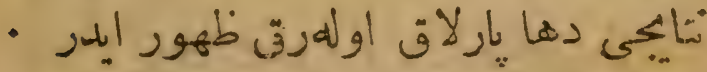

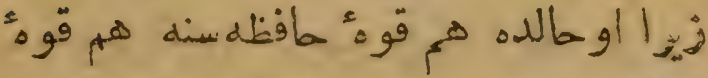

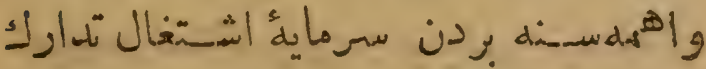

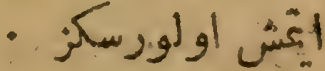

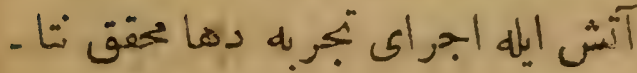

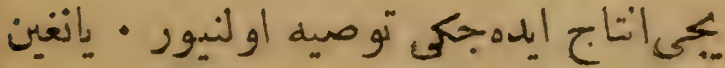

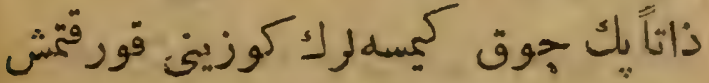

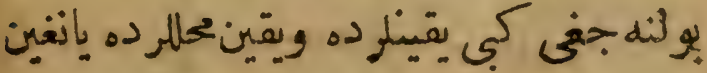

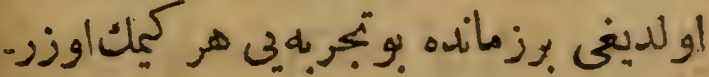




\section{IIV}

صو دوكملى •اويله برصوروتهه كه ماغلتيسى

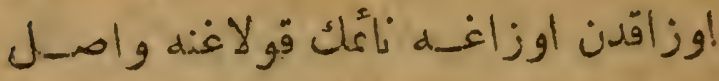

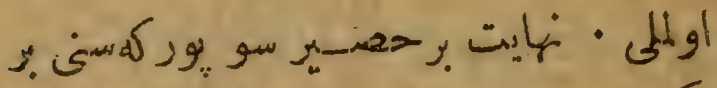

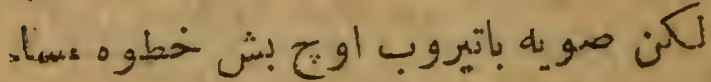

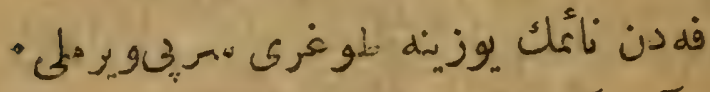

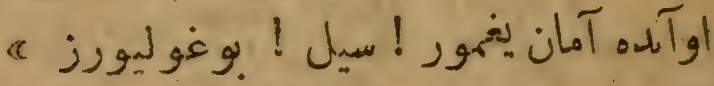

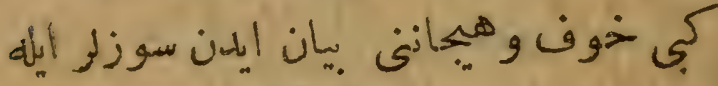

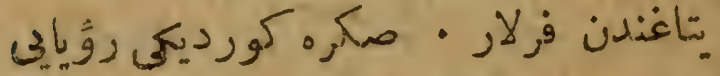

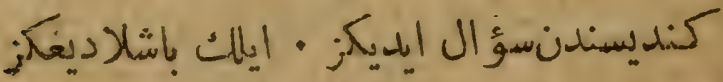

زماندنبرى هب رؤيا كورهشدر • حتى قوهة

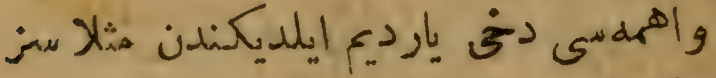

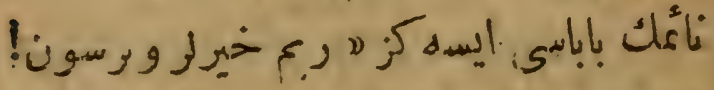

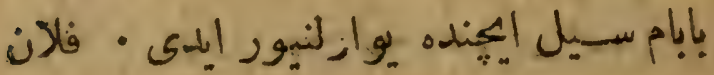

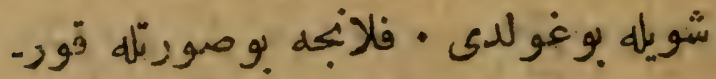

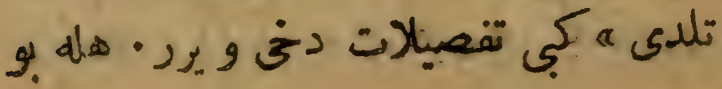




\section{7}

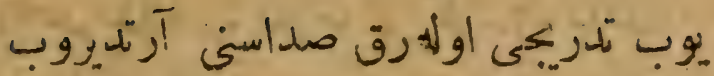

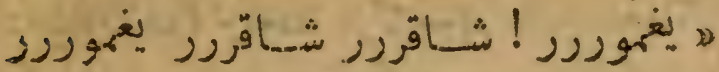

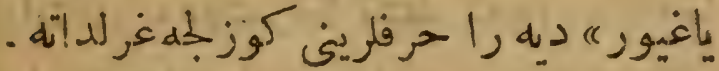

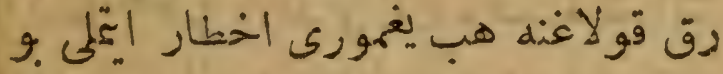

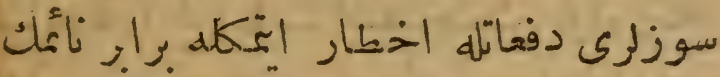

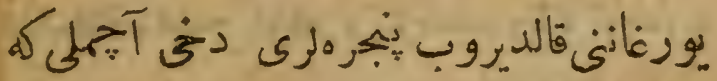

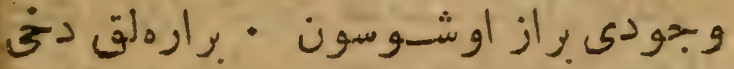

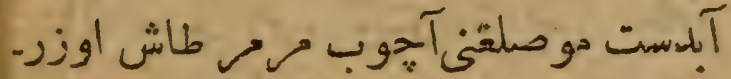

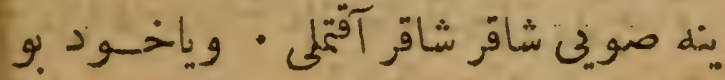

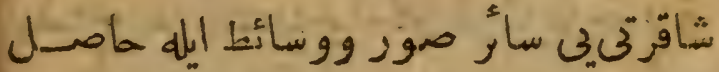

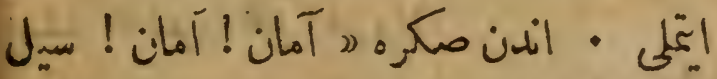

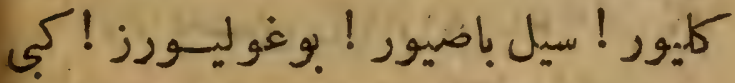

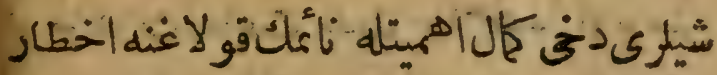

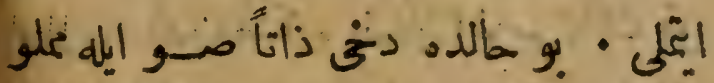

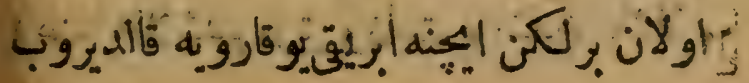




\section{0 䊅}

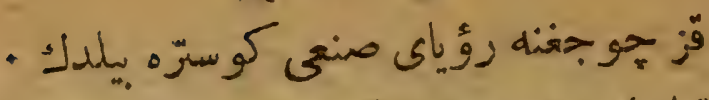

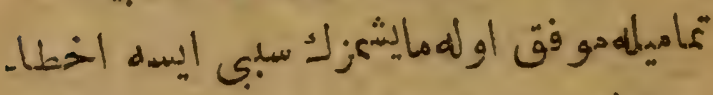

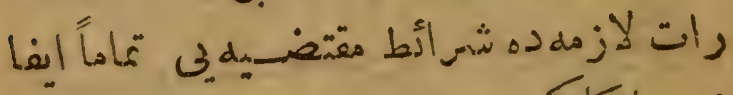

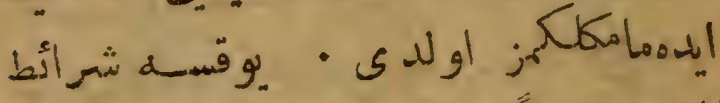

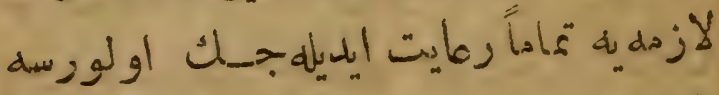

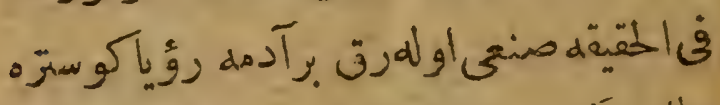

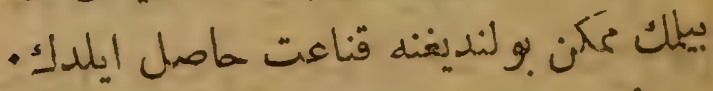

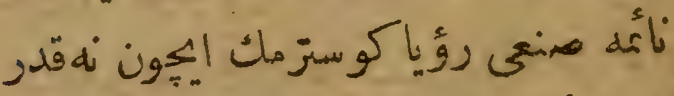

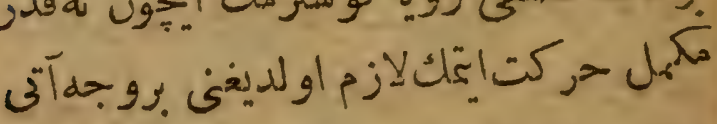

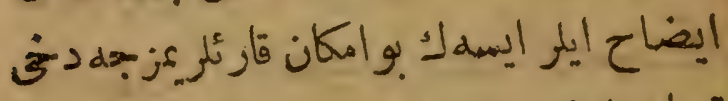

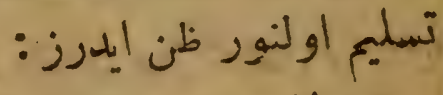

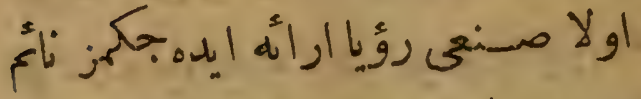

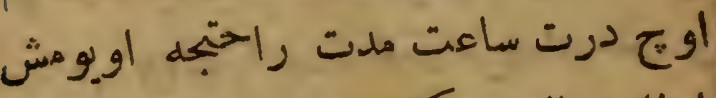

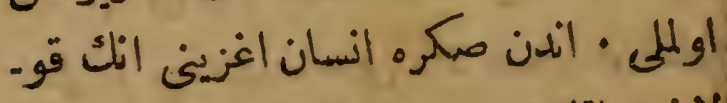

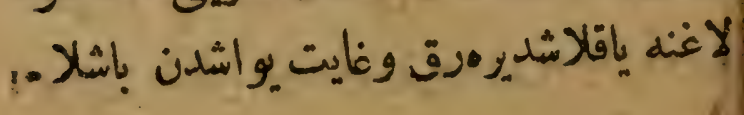


172 *

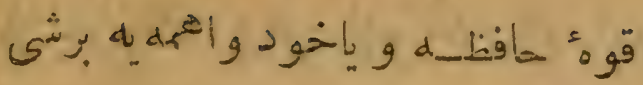

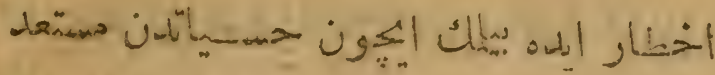

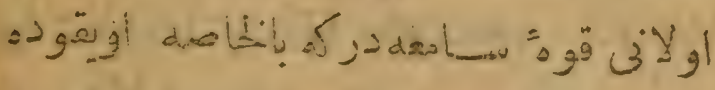

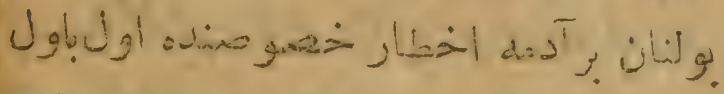

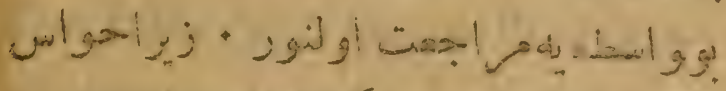

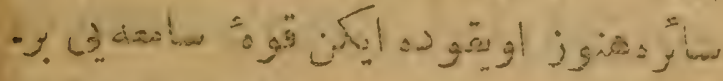

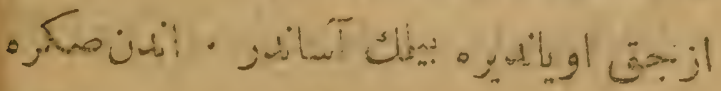

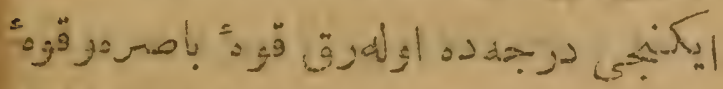

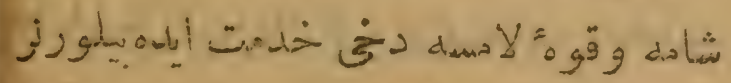

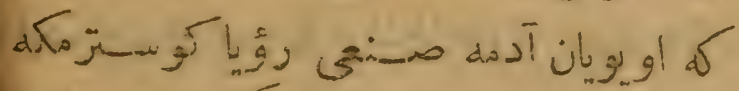

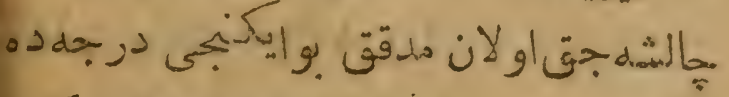

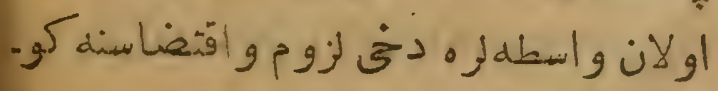

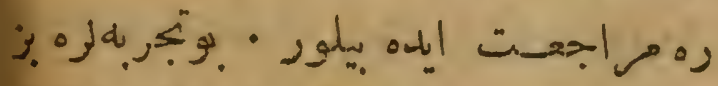

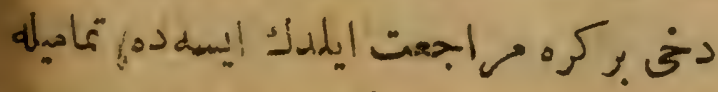

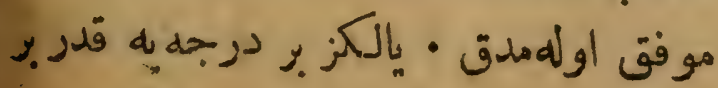




\section{$17 r$ 粉}

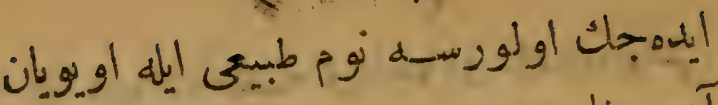

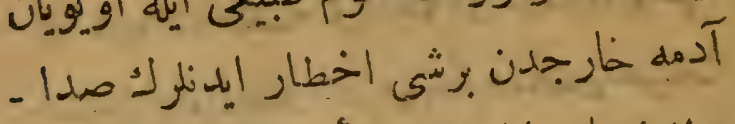

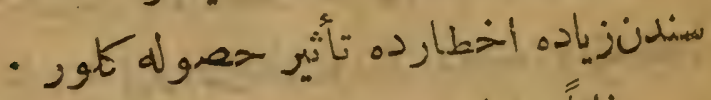

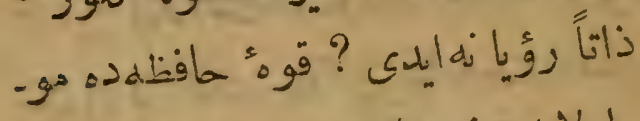

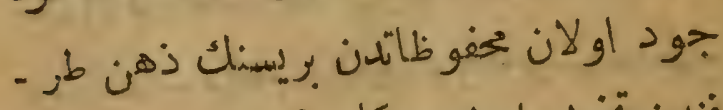

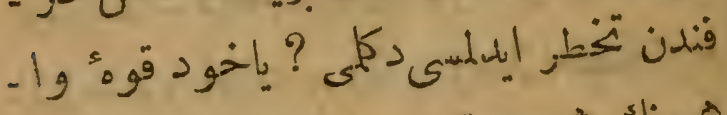

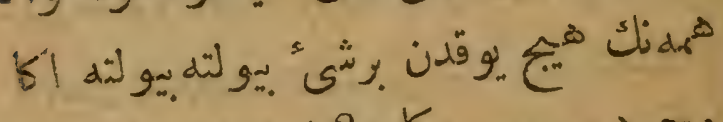

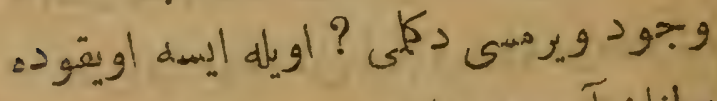

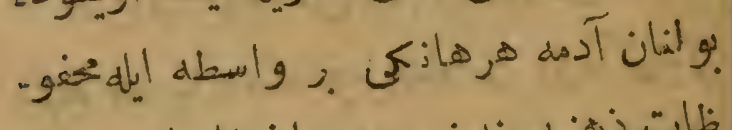

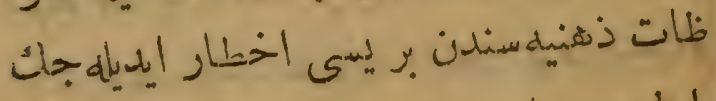

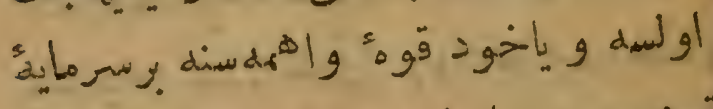

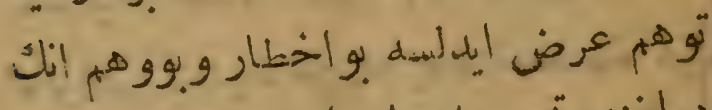

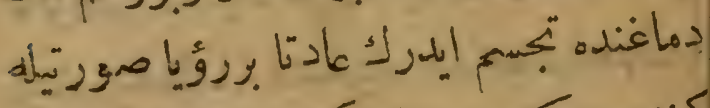

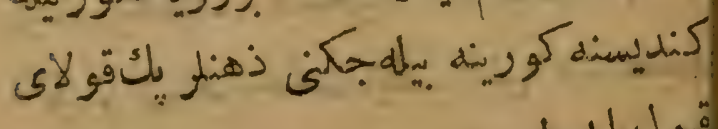

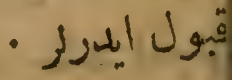


楚

$$
\text { A ش人웅 }
$$

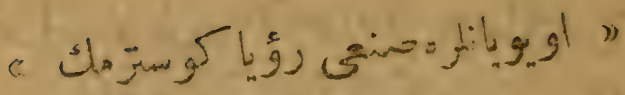

$$
\text { -? }
$$

-

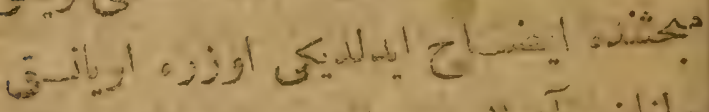

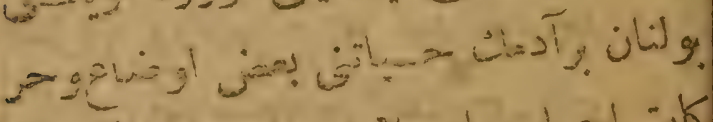
كأ

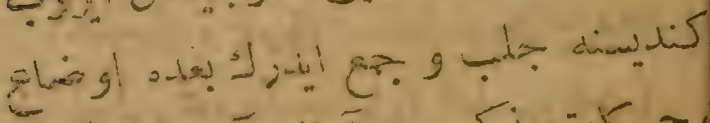

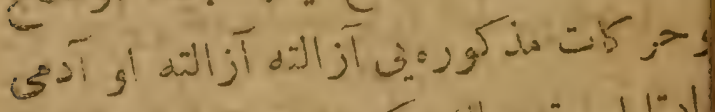

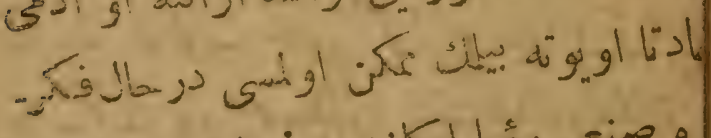
.

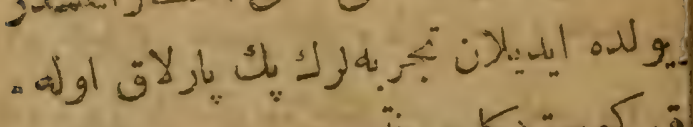

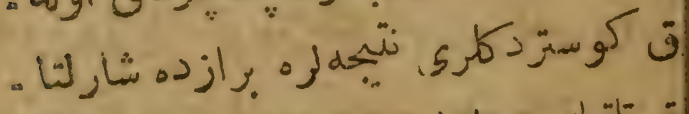

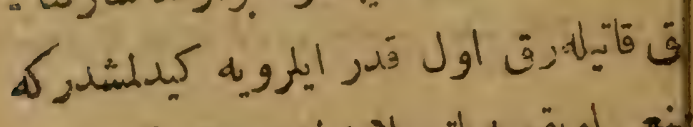

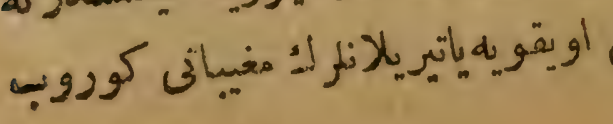


17

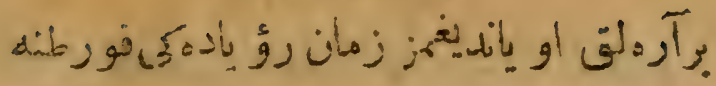

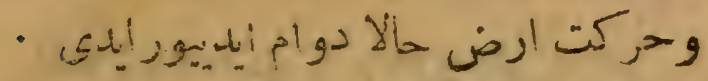

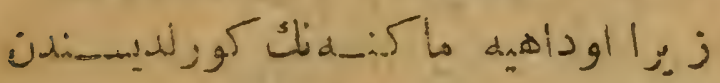

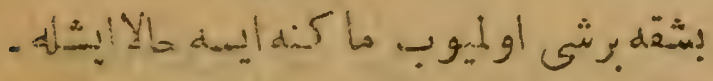

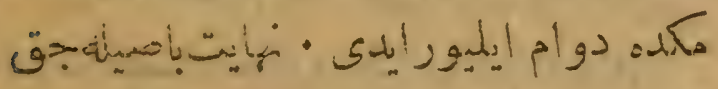

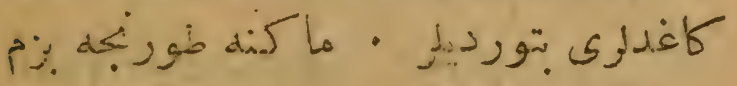

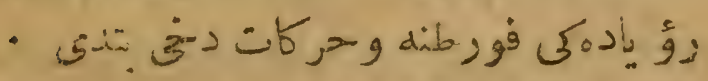

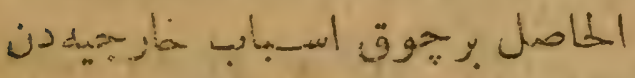

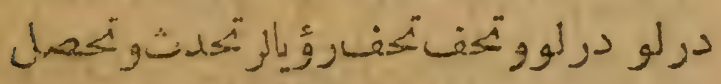

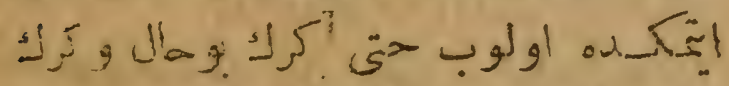

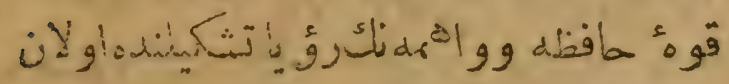

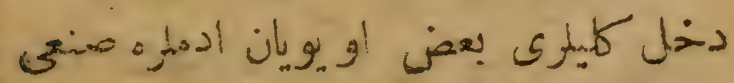

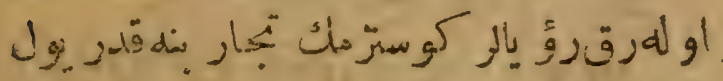

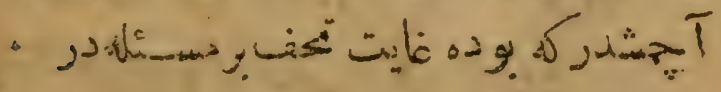




\section{9}

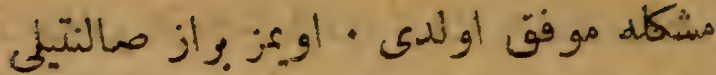

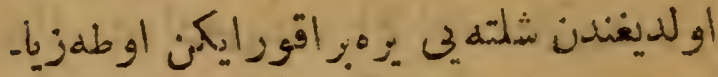

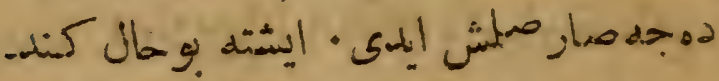

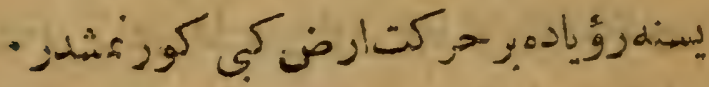

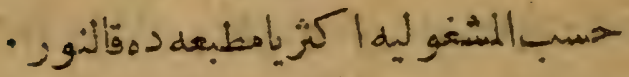

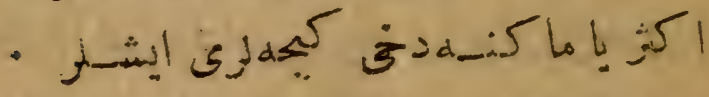

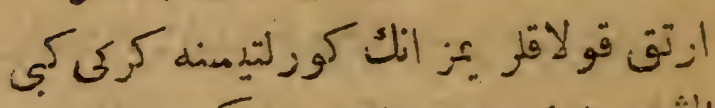

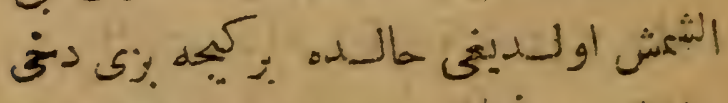

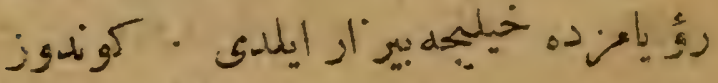

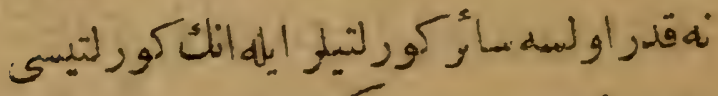

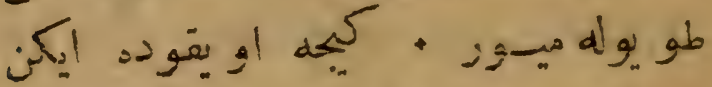

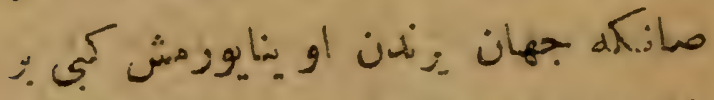

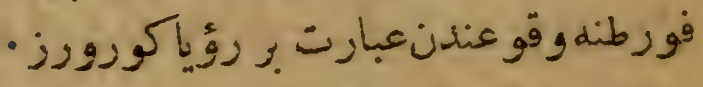

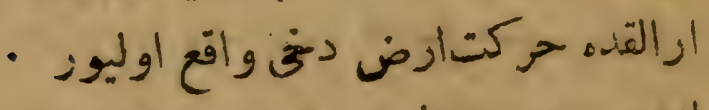

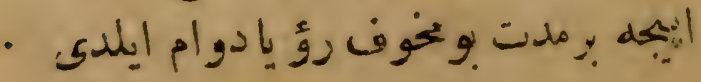


lon

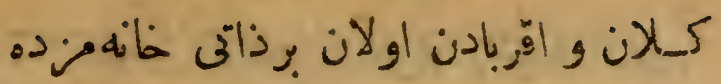

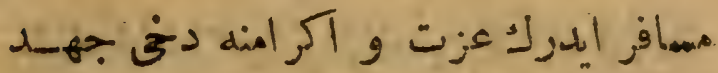

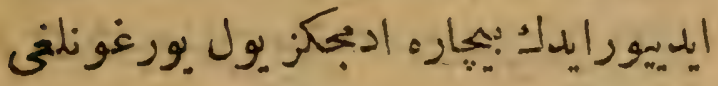

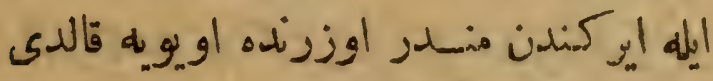

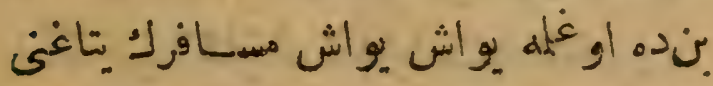

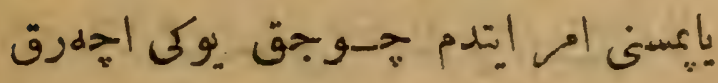

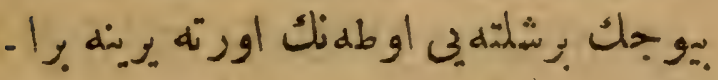

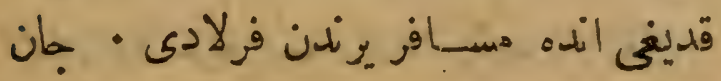

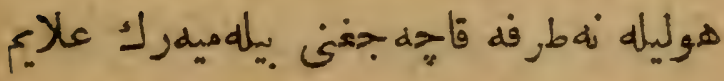

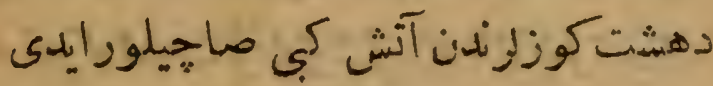

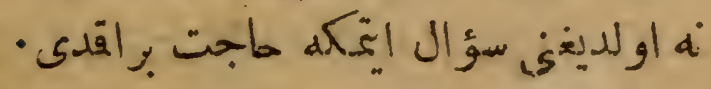

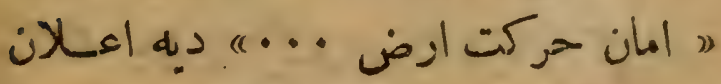

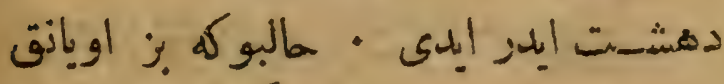

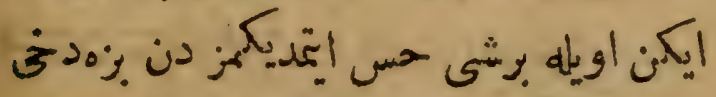

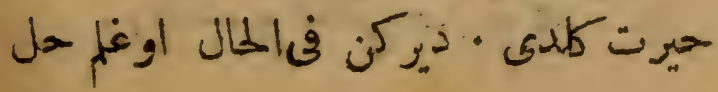




\section{$10 \mathrm{~V}$}

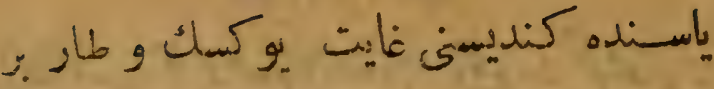

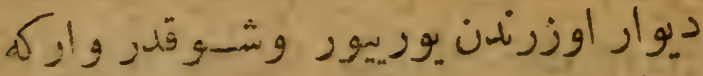

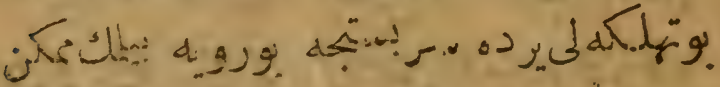

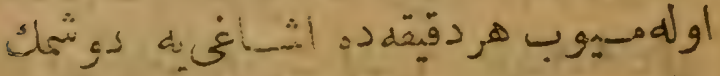

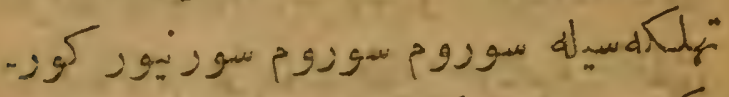

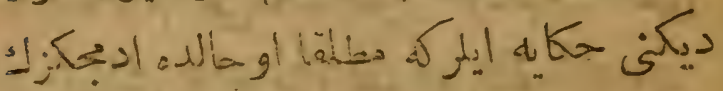

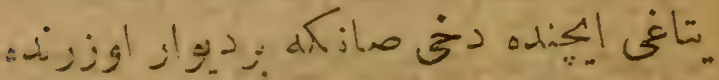

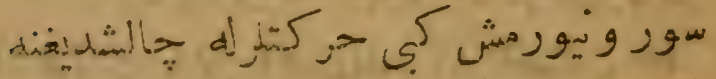

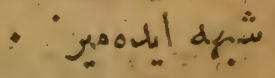

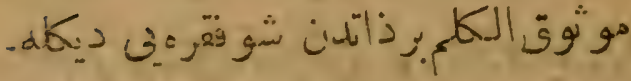

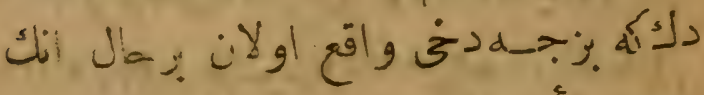

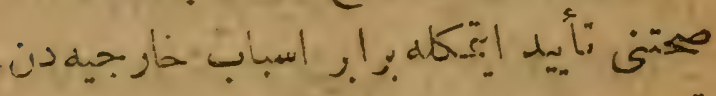

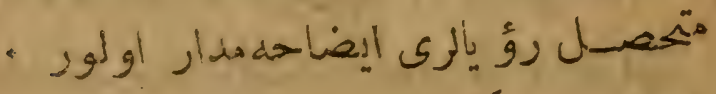

: اوذات ديدى

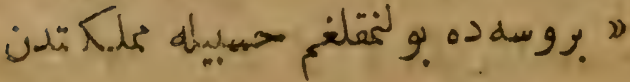




\section{7 *}

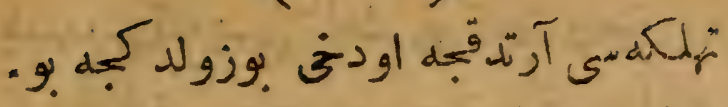

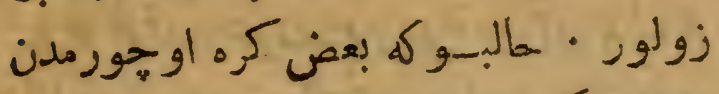

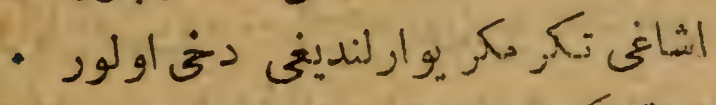

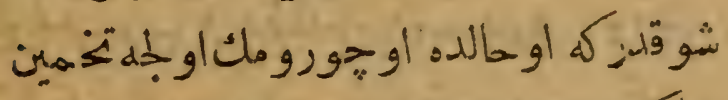

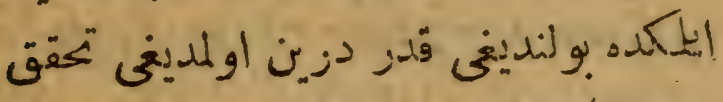

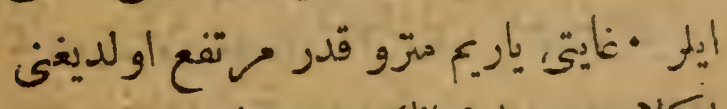

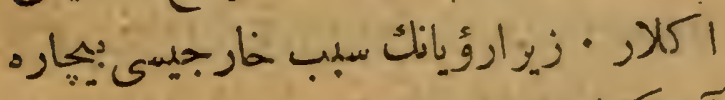

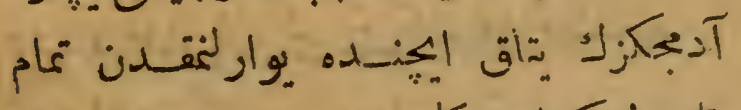

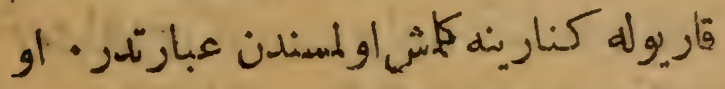

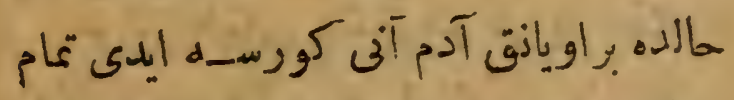

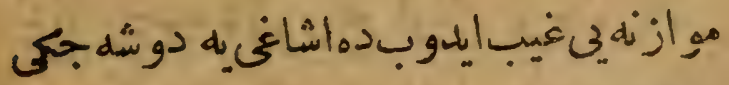

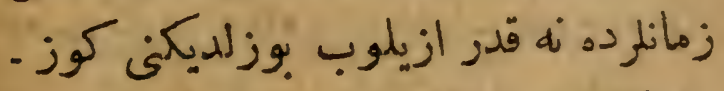

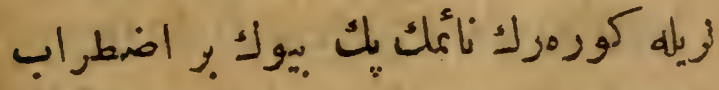

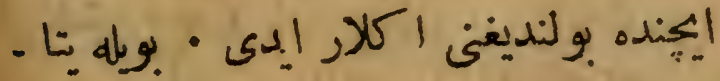

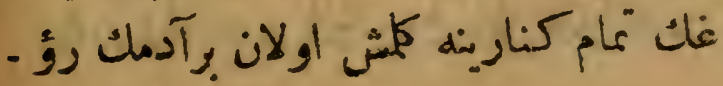




\section{$100 \%$}

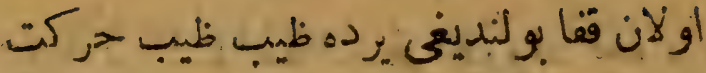

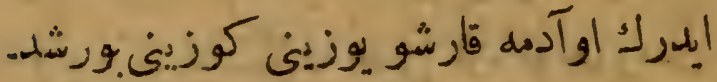

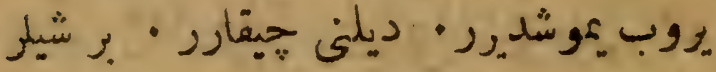

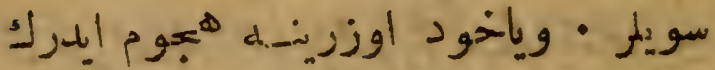

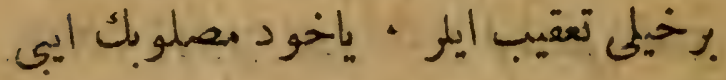

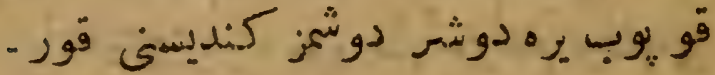

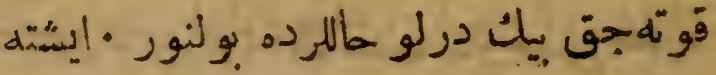

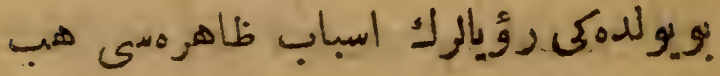

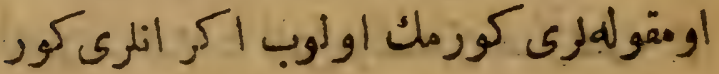

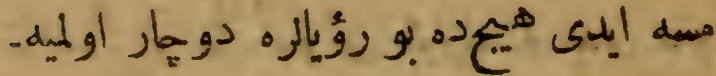

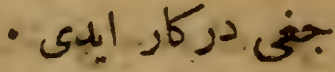

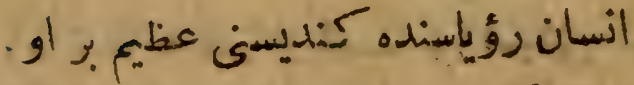

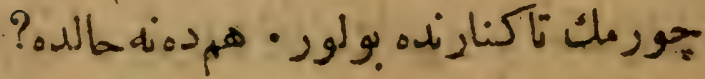

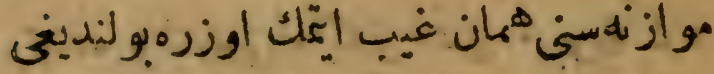

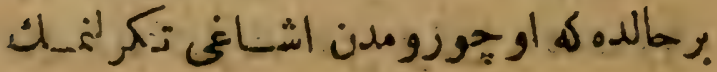




\section{$10: *$}

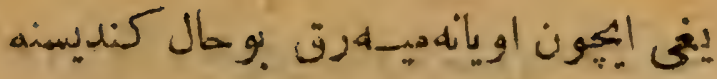

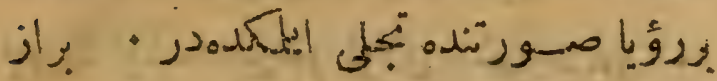

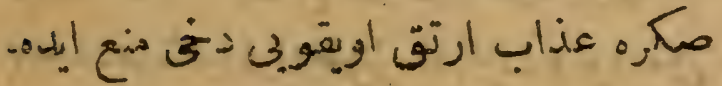

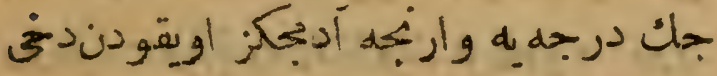

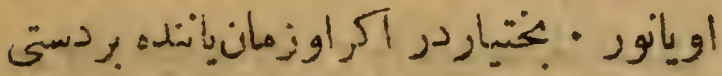

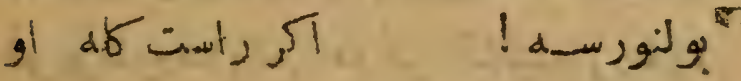
دستي وش أولور وياخود او جله دوريالهرك

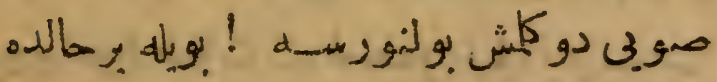

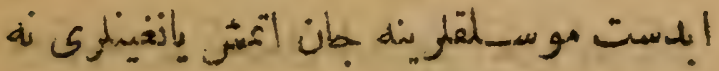

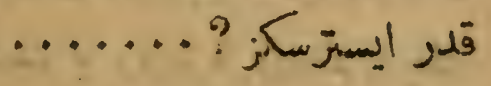

بعض قورقاق ركوز كوسنز ادملمر قوزر-

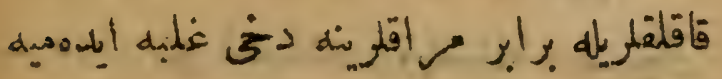

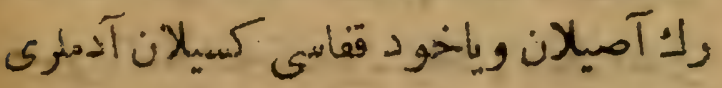

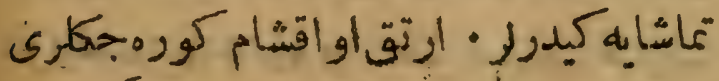

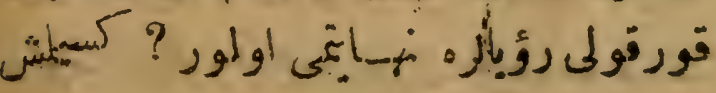




\section{0r}

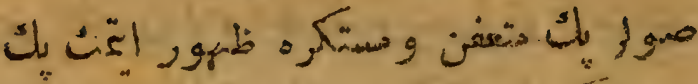

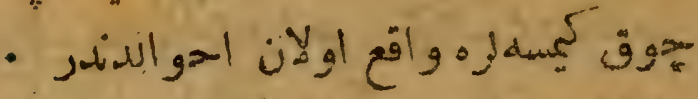

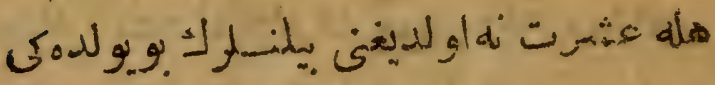

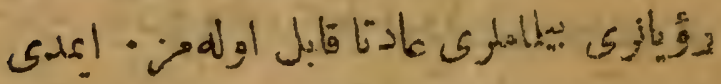

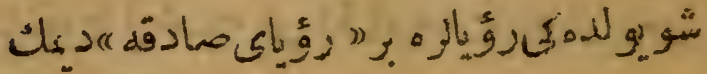

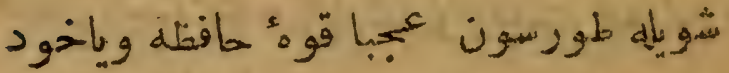

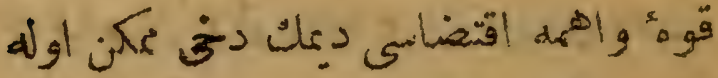

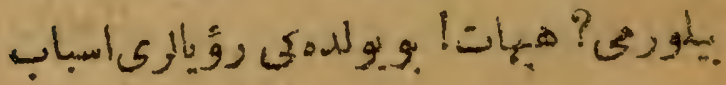

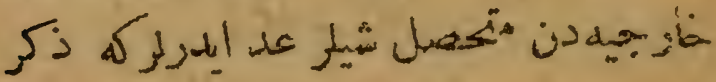

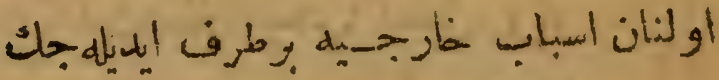

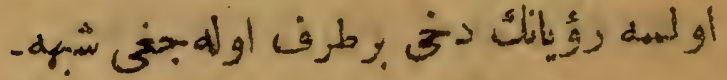

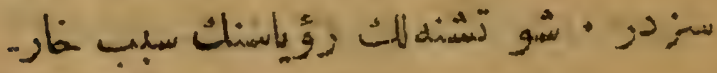

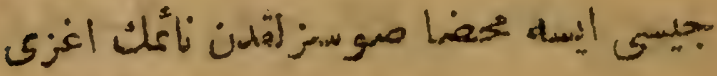

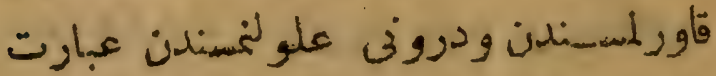

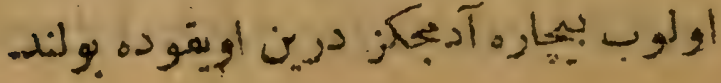




\section{* lor}

نادر اولهزق وقو عه كلموب رؤيازيمزلك الك جونى مخوظ ظات وياخود توهمات دماغيه.

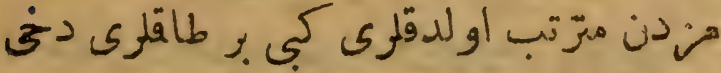

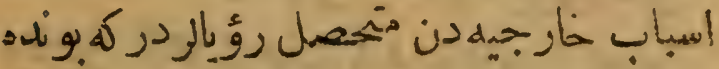

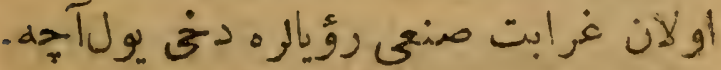

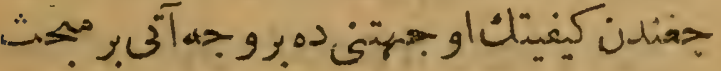

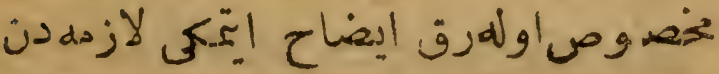
عد إيلبك V ثمث

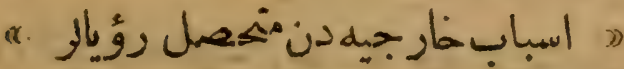

رؤياسندهبويوطم صو تحرى التخلكومثلا

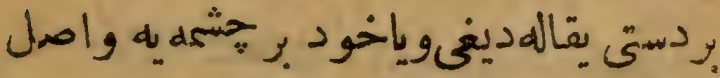

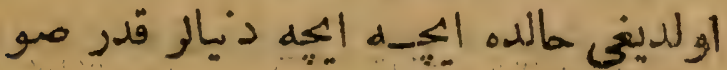
إهمهش ظن الملش ايكن ينه حرارتئ تسكين

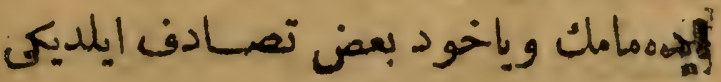




\section{1 (2)}

اما كبار كملينلك رؤيارى عبن حيقيقت

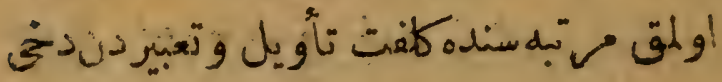

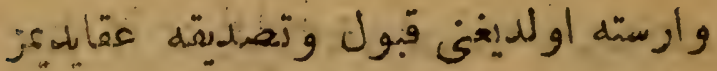

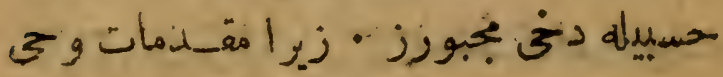

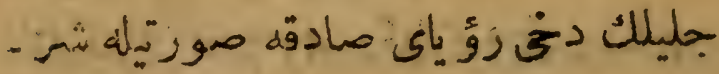

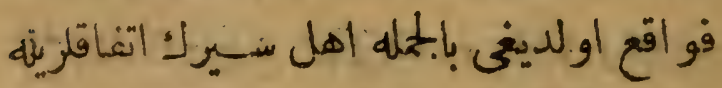

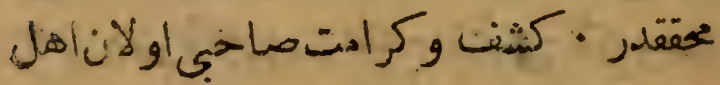

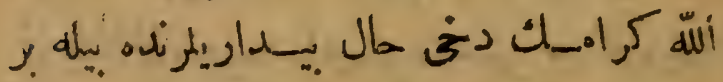

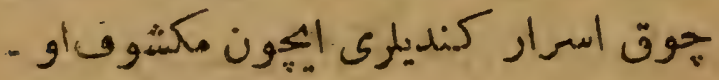

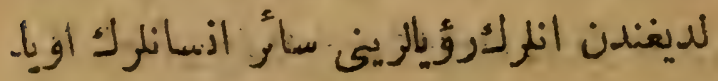

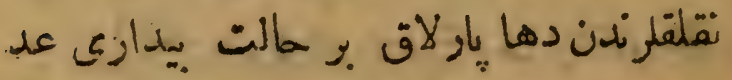

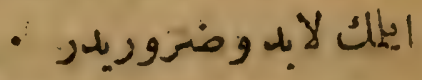

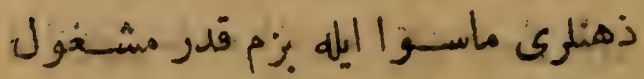

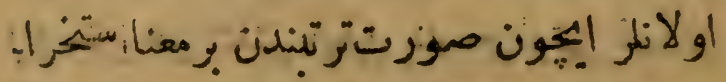

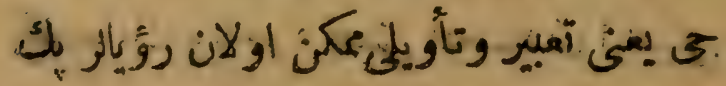




\section{$10 \cdot 3$}

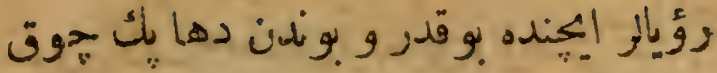

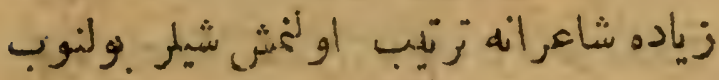

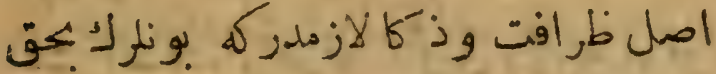
تأويلى هيسراولستون · وقعط نهقدر اولنسه

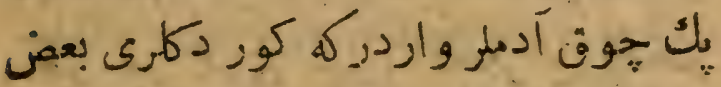

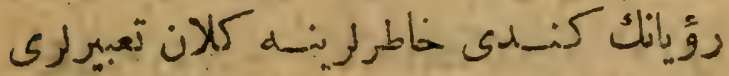

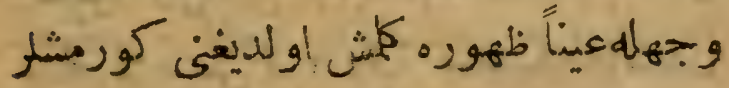

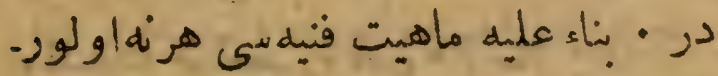

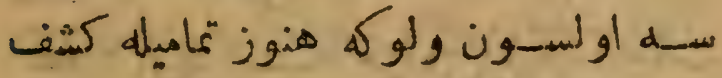

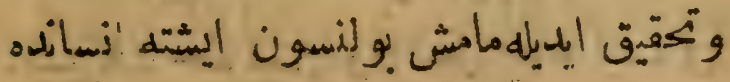

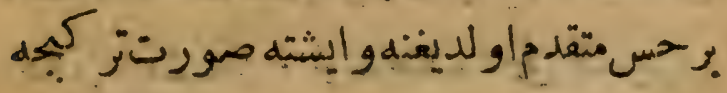
حاوىاولمبيخي مفهوم قابل تعبير اولانرؤيأى

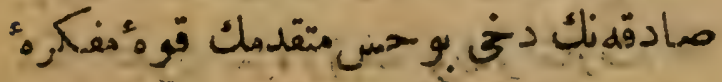

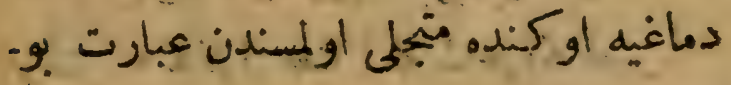

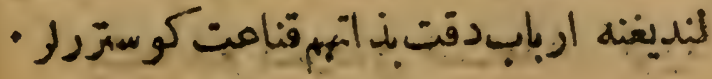




\section{9}

كورن ذات صلمحادناولهرق رؤياسنى كندى

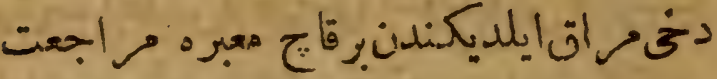

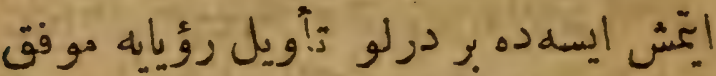

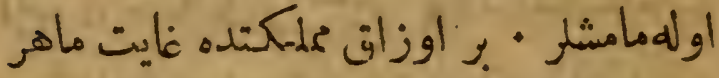

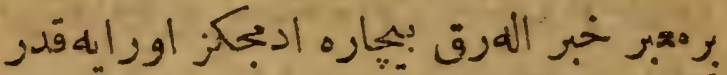

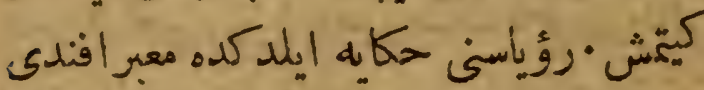

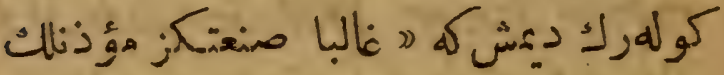

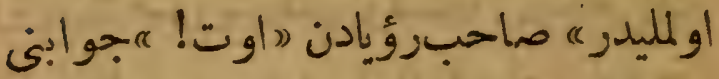

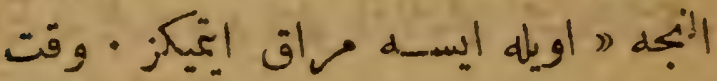

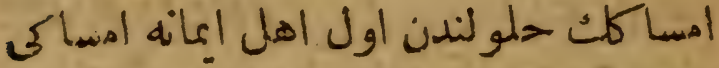

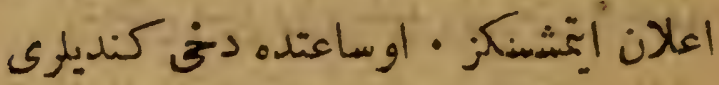

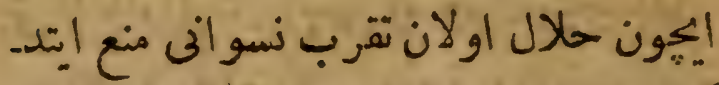

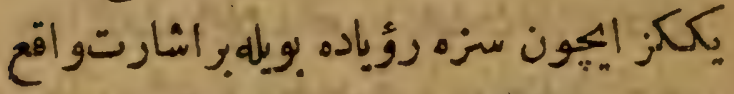

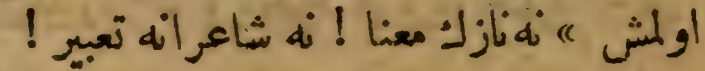

ايتّته طبع بشردمكى استصداده كوره 


\section{组}

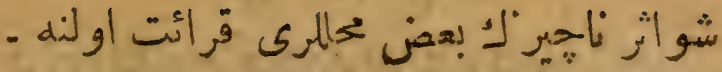

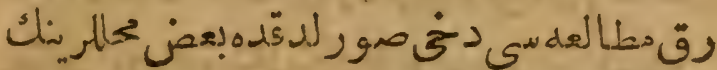

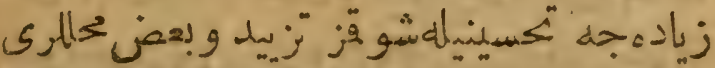

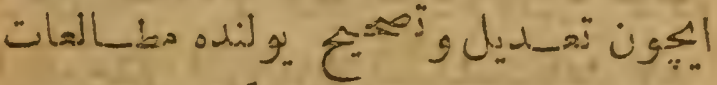

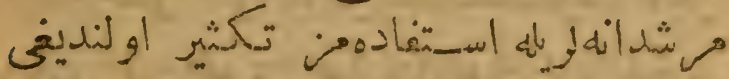

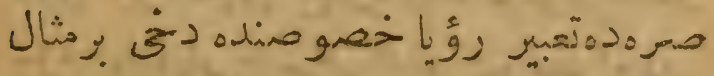

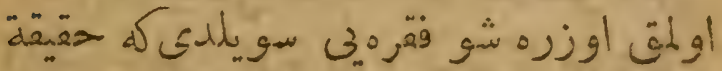

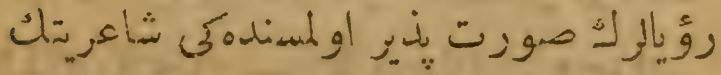

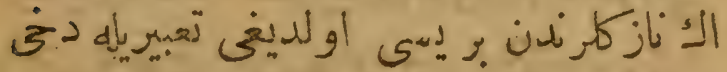

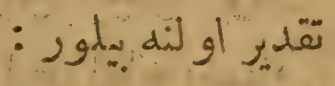

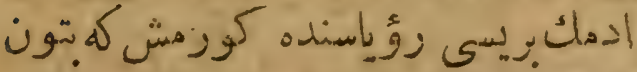

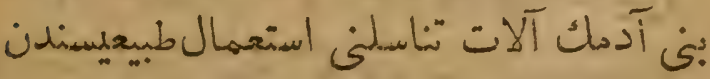

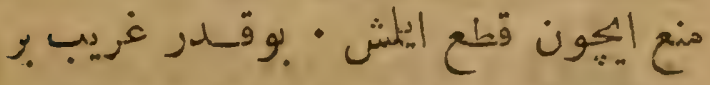
رؤيانك و همه و ياخود قوم" حافظله به تزعلق

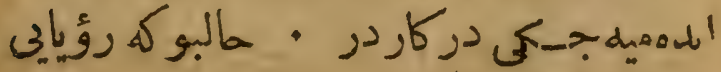




\section{I $12 v$}

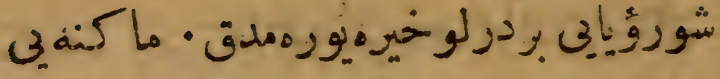

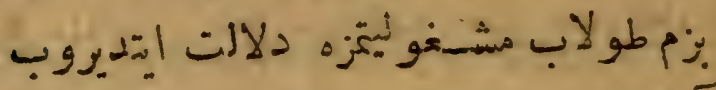

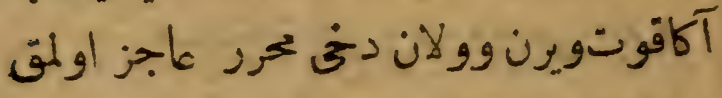

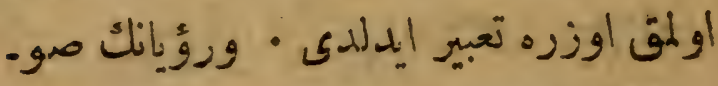

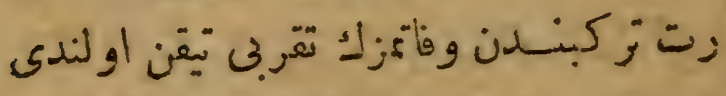

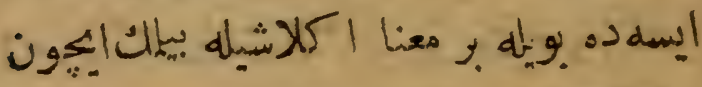

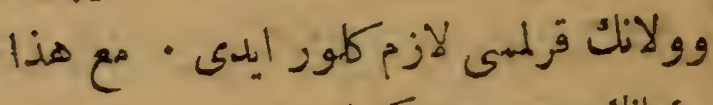

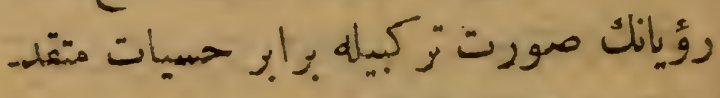

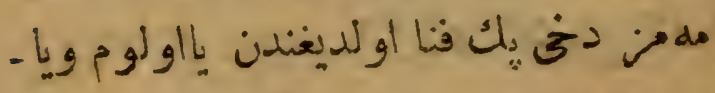

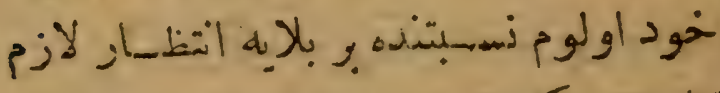

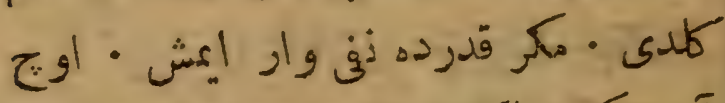

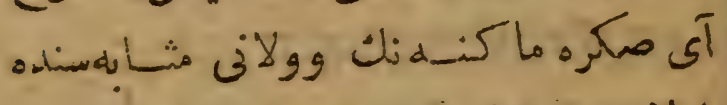

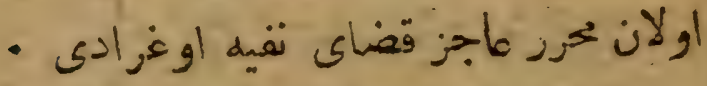

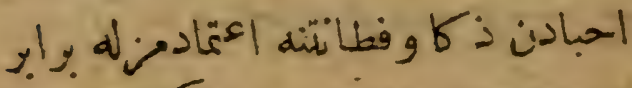

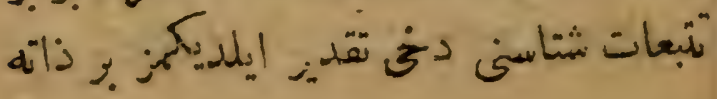




\section{$122 \%$}

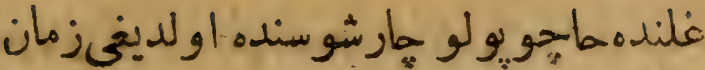

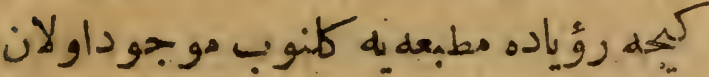

اوتج ماكنه ميانده يكى مبايعه إيلمسندنطو مطنو

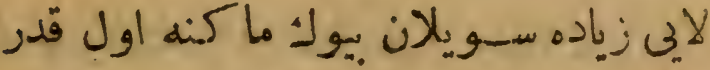

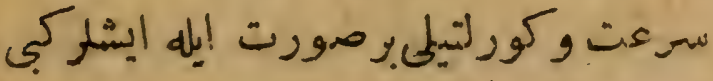

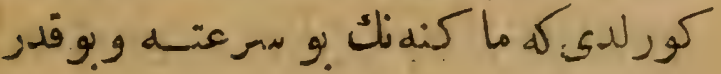

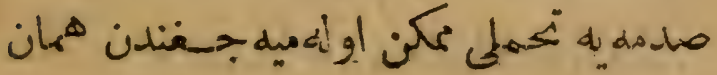

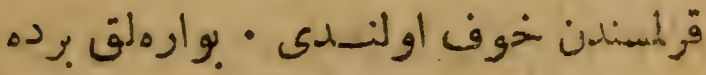

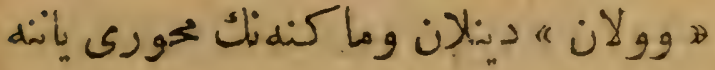

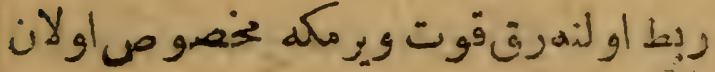

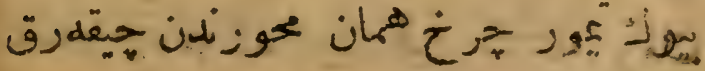

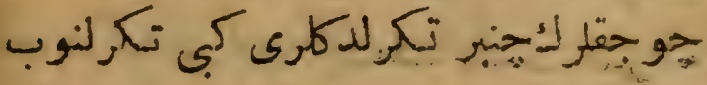

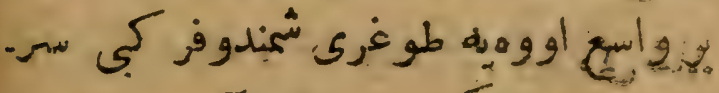

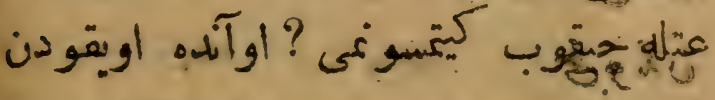
• 
120

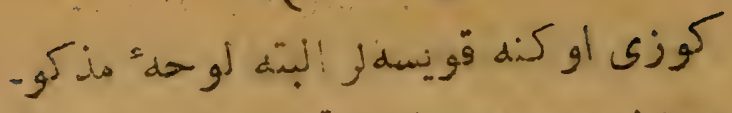

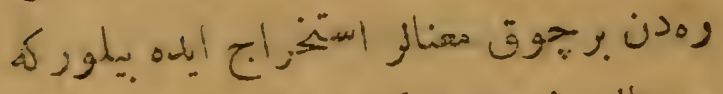

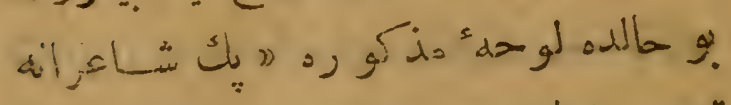

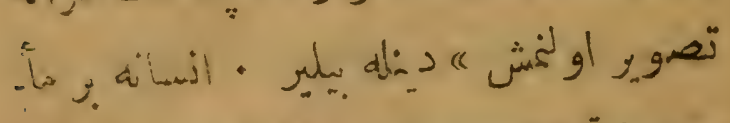

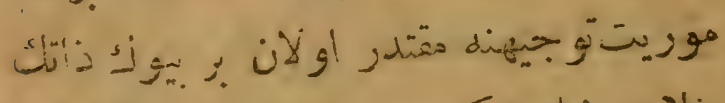

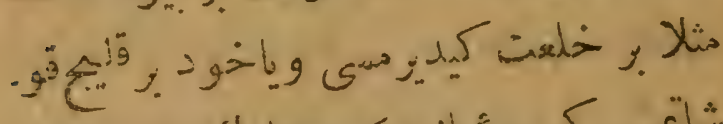

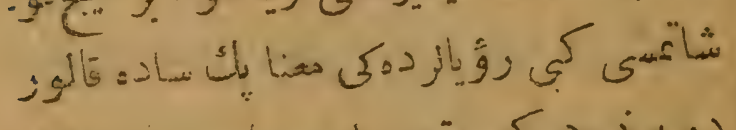

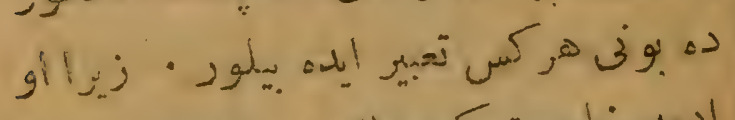

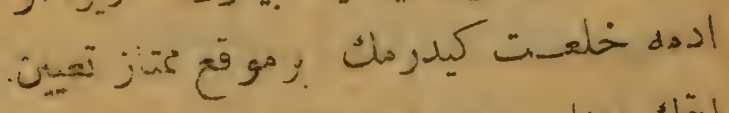

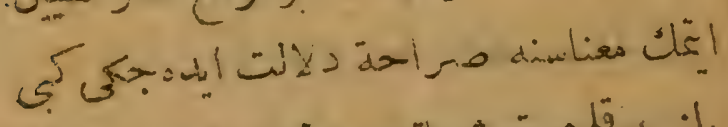

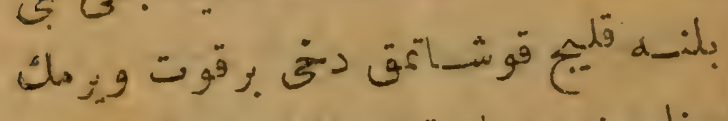

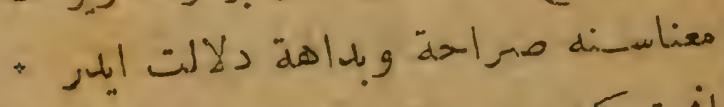

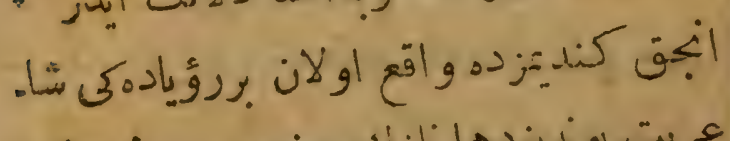

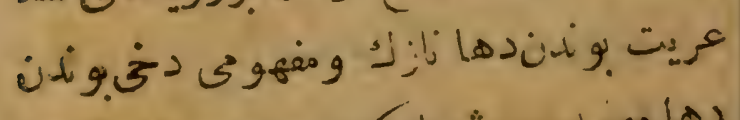

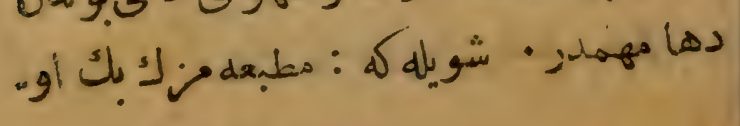
1. 


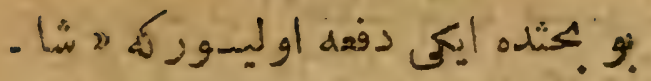

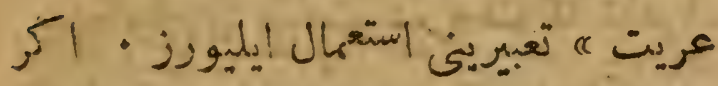

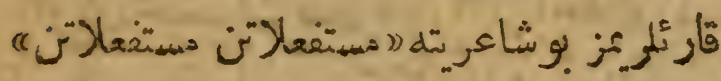

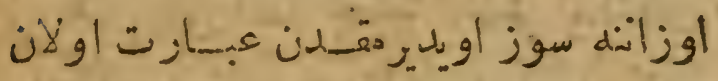

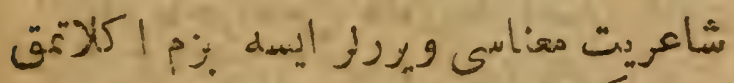

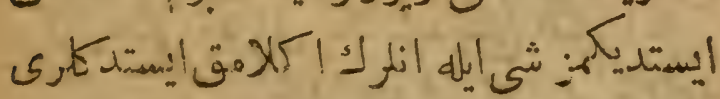

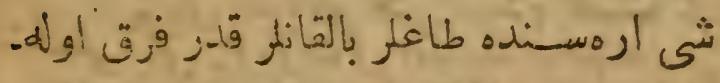

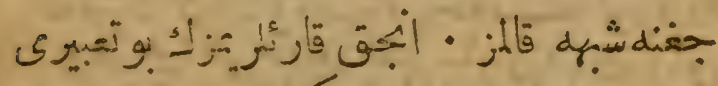

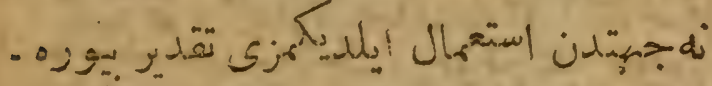

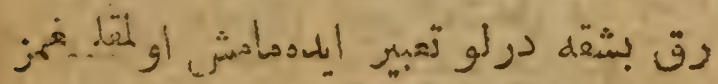

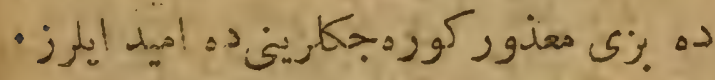

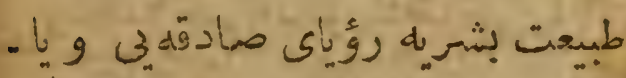

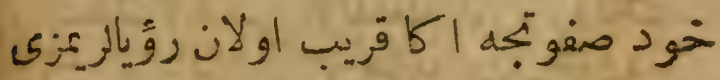

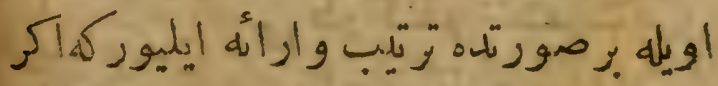

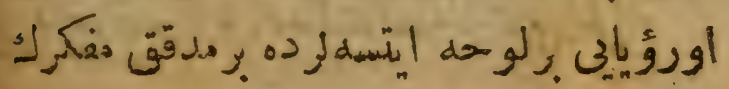




\section{* vir}

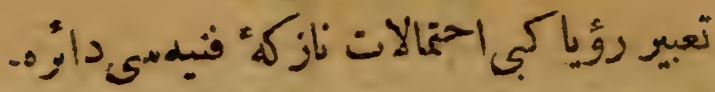

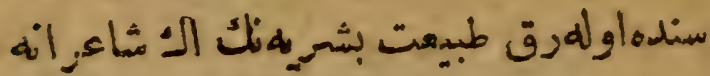

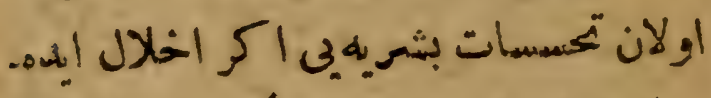

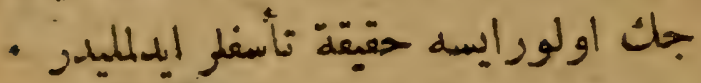

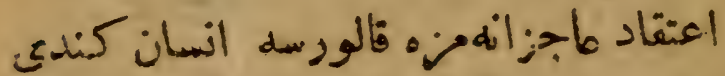

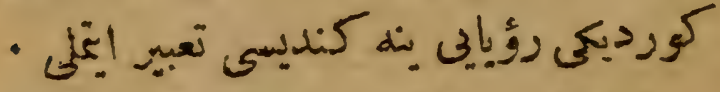

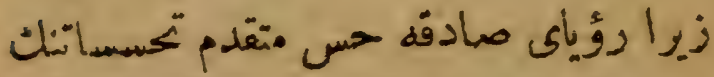

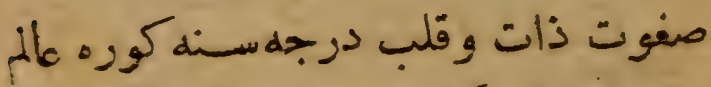

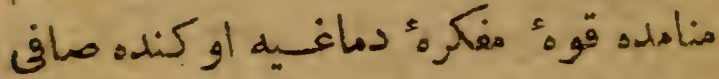

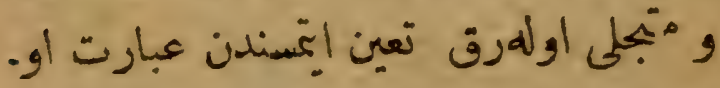

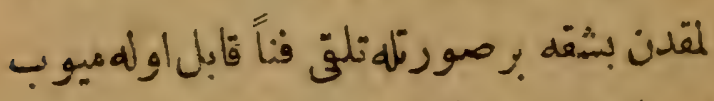

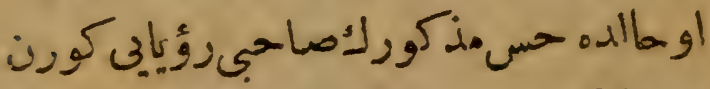

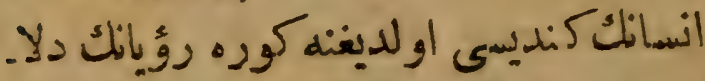

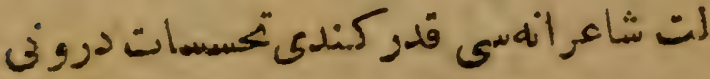

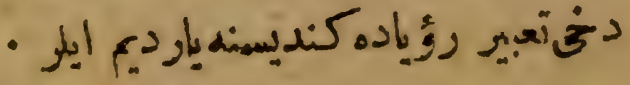




\section{2r}

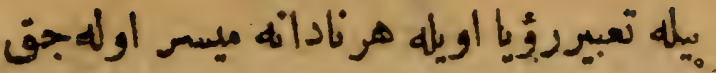

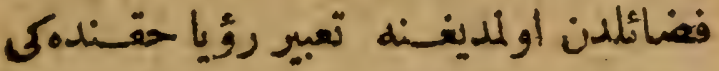

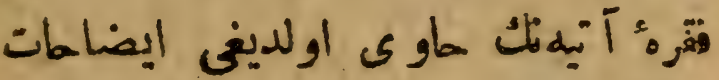

$$
\text { - دلالت اليرة }
$$

$$
\begin{aligned}
& 7 \text { ميحث } \\
& \text { ه آعبير زؤيا }
\end{aligned}
$$

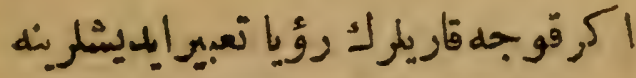

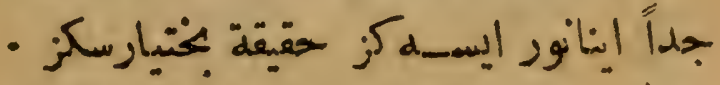

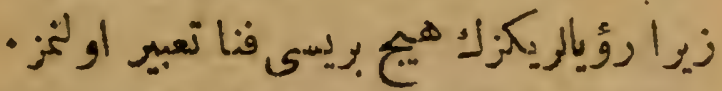

كربه كوروسه كز تير "لك ونهاست كورورسه.

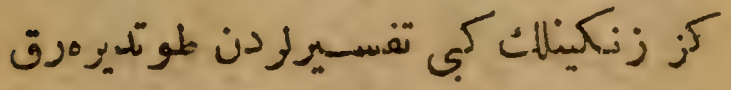

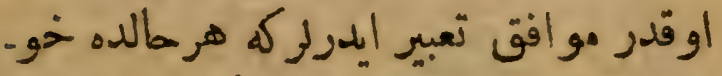

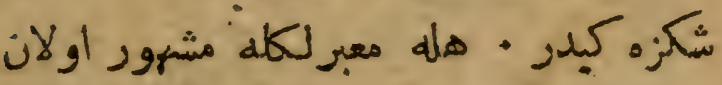

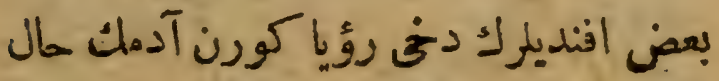

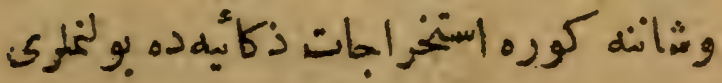




\section{$1 \leqslant 1 \%$}

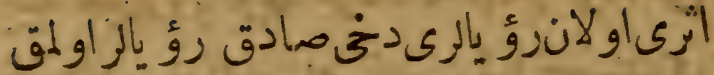

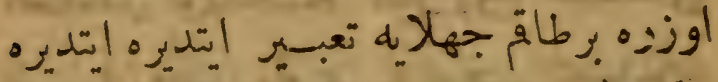

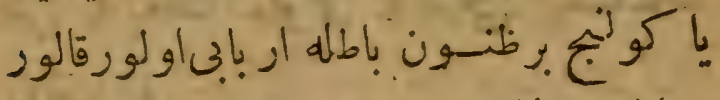

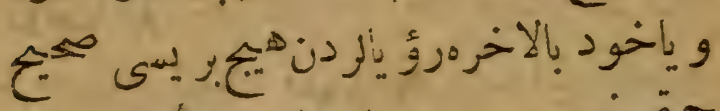

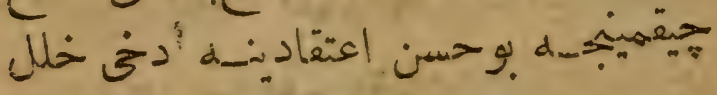

رؤياى صلدقه اليكزن انسانك هسكرات

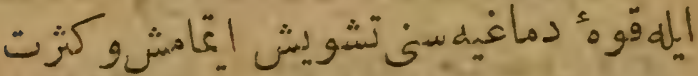

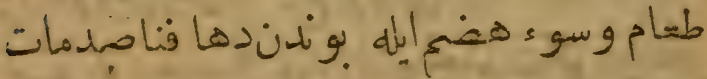

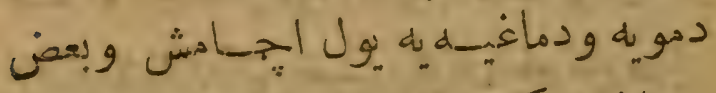

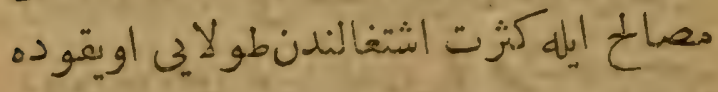

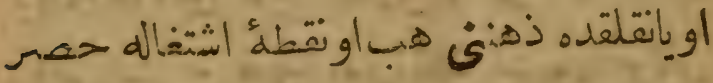

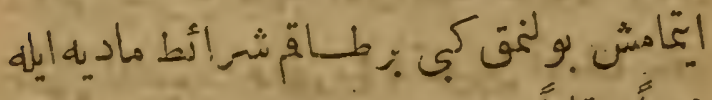

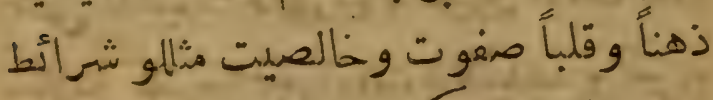

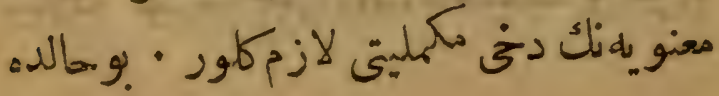




\section{$1 \varepsilon \cdot 3$}

مال بيدار يمزنكى تشو يش مال و بالمزمال

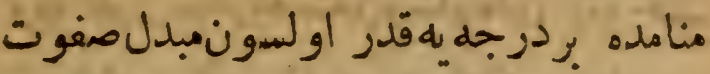

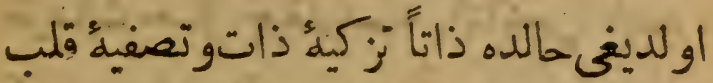

اتئشاولانكبارك مال منامدهى صفوتلرى

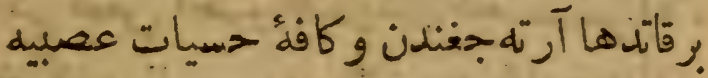

ايسه وجودلك أستزاحت وفككرك جيـادنى

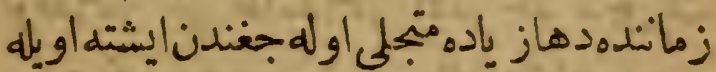

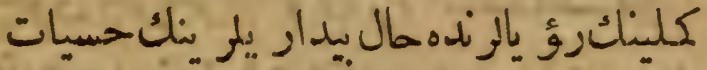

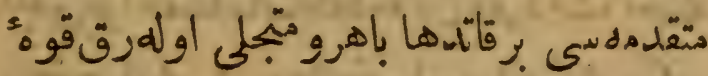

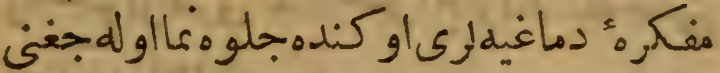

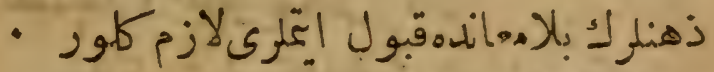

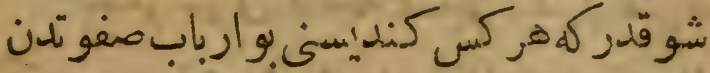

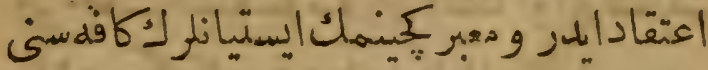

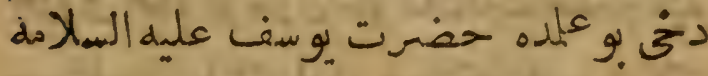

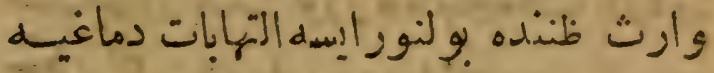




\section{irs}

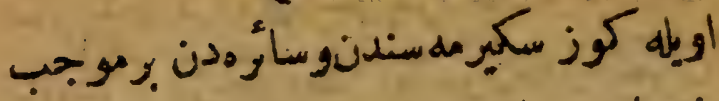

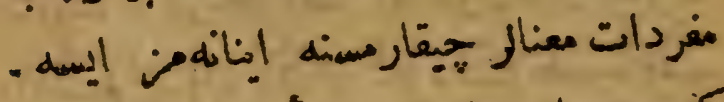

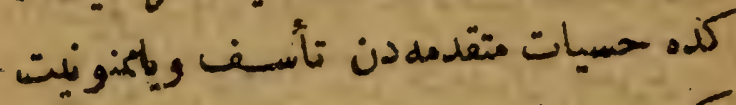

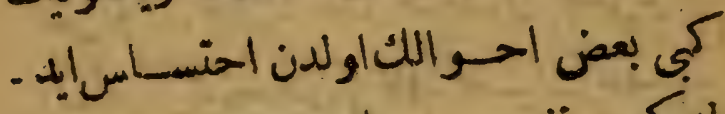

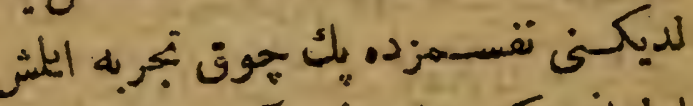

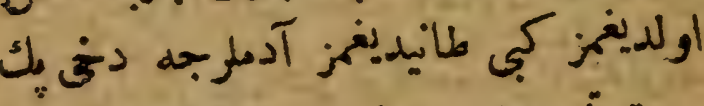

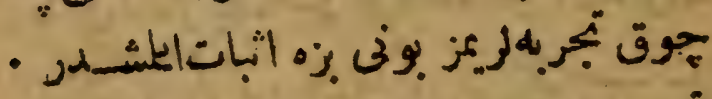

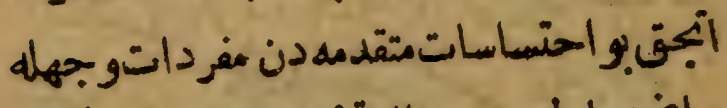

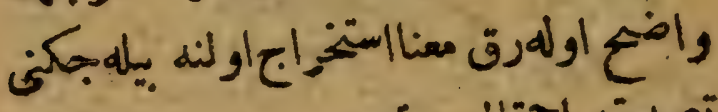

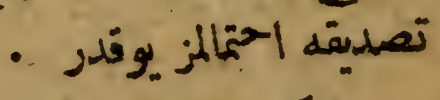

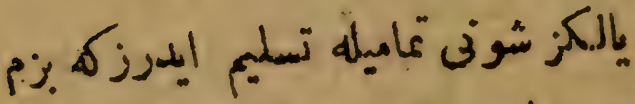

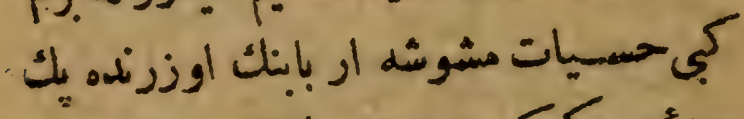

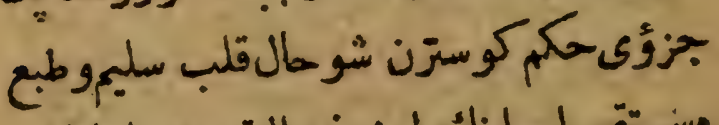

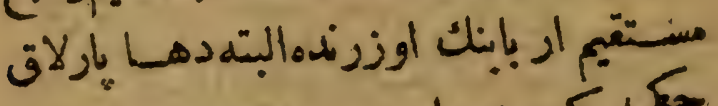

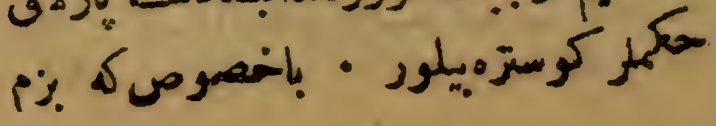




\section{IrA}

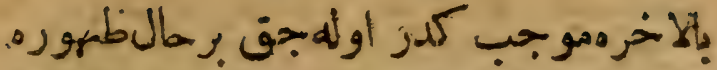

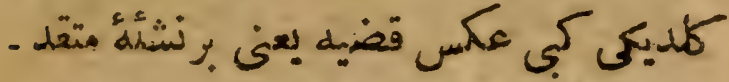

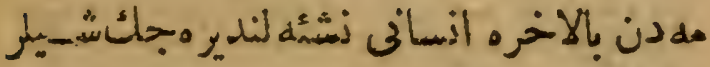

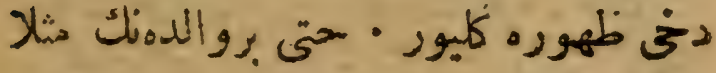

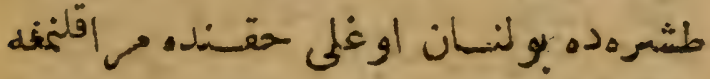

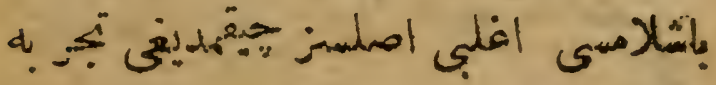

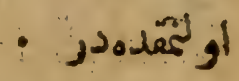

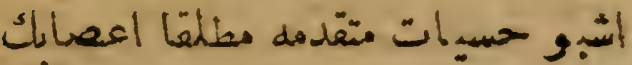

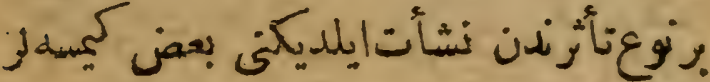

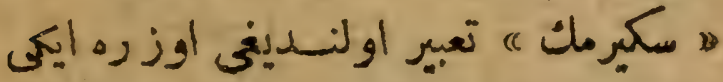

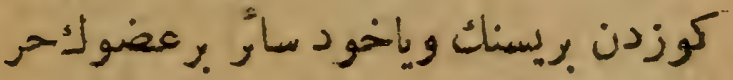

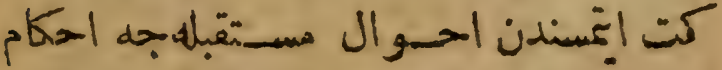

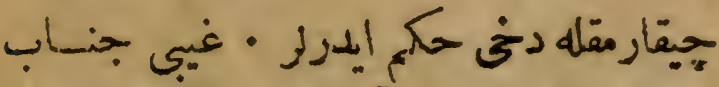

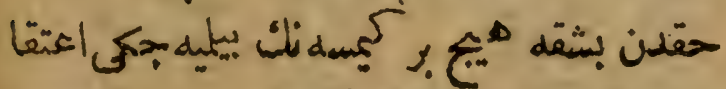

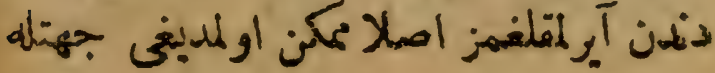




\section{irv}

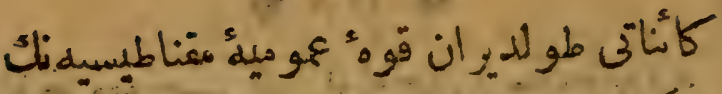

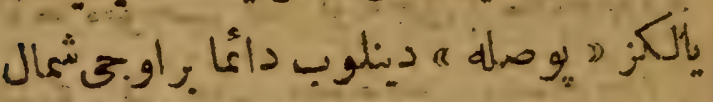

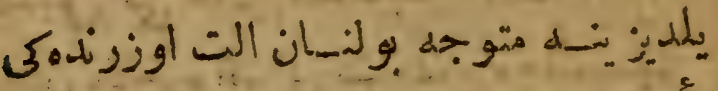

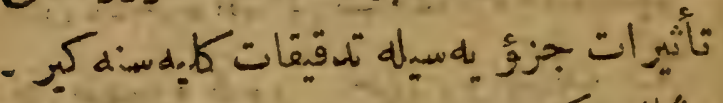

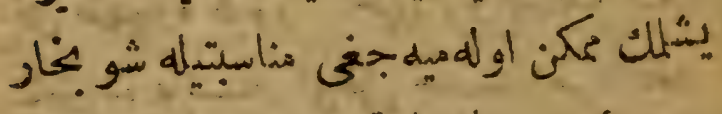

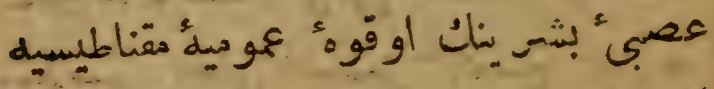

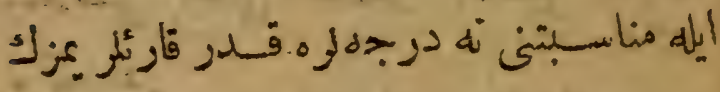

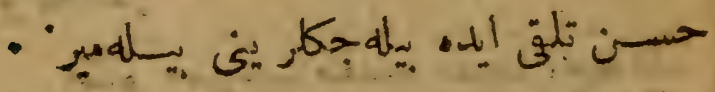

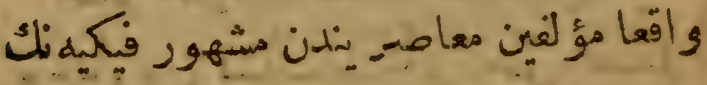

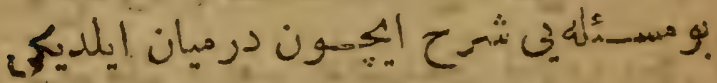

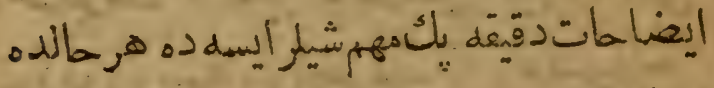

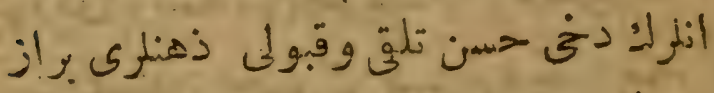

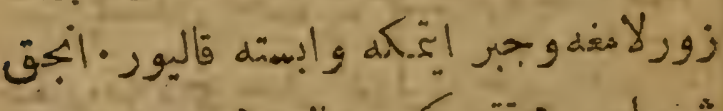

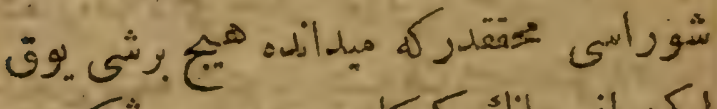

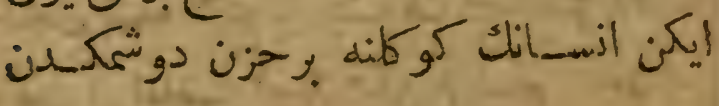




\section{* Irr}

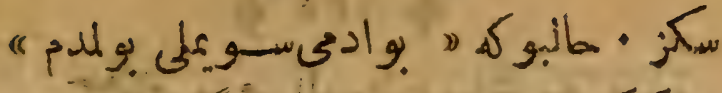

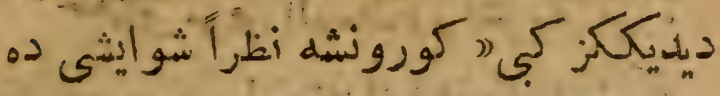

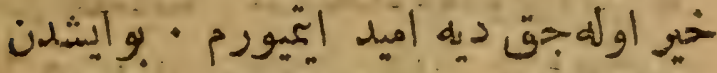

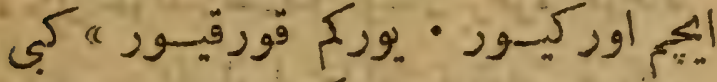

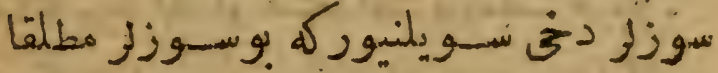

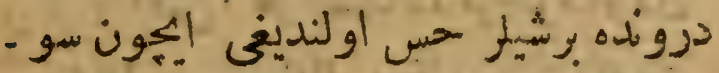

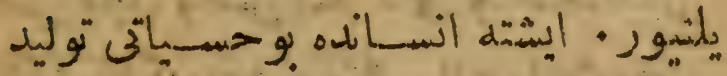

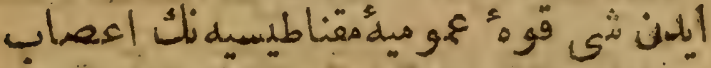

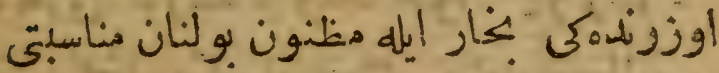
إمشّ إن

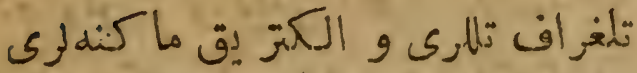

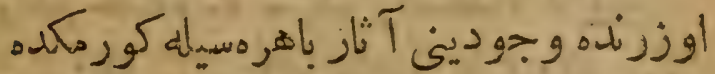

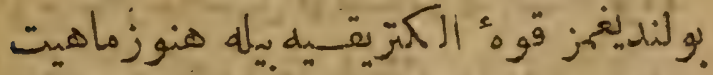

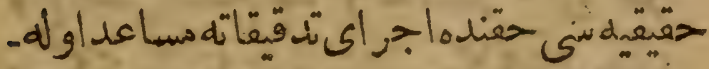

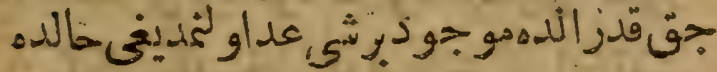




\section{Iro}

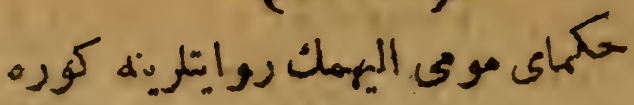

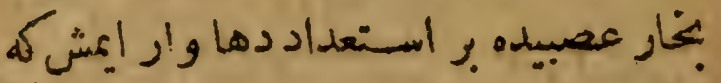

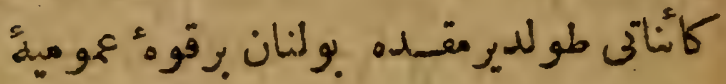

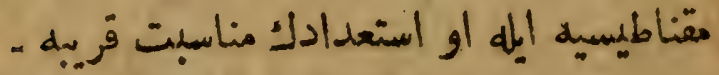

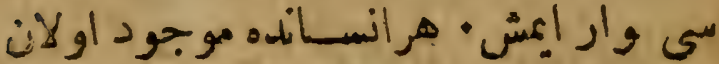
حس تمايل وحس تنافر دمثن بو أستعداددن

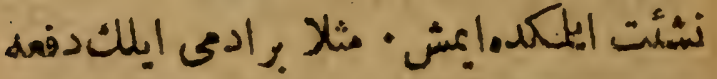

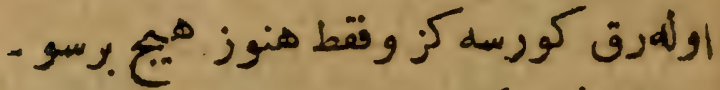

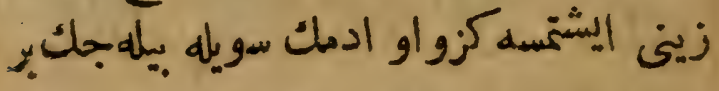

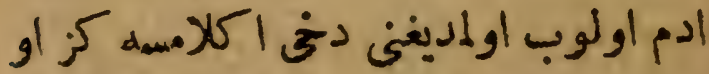

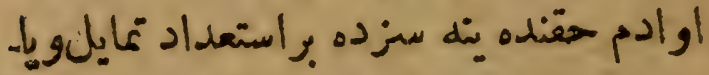

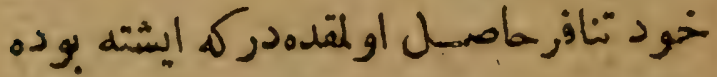
مرنو حسب منقدم عد اولتمقدهدر • زير اسو.

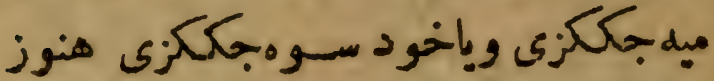

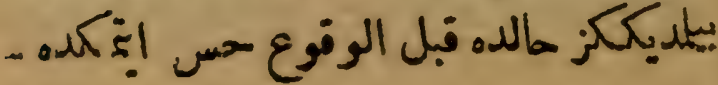




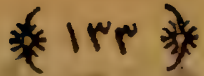

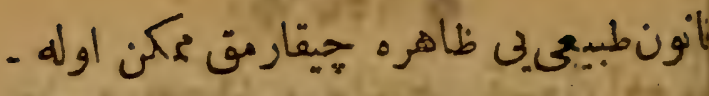

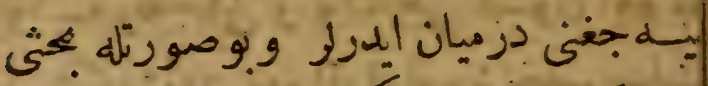

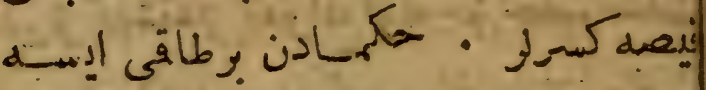

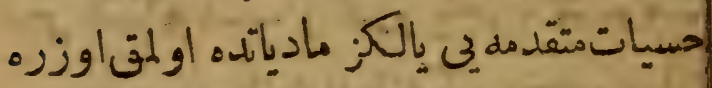

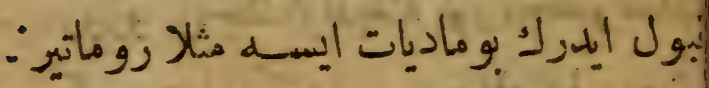

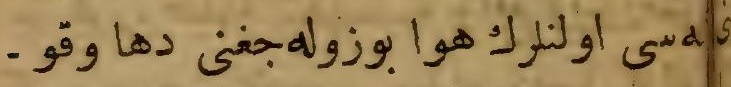

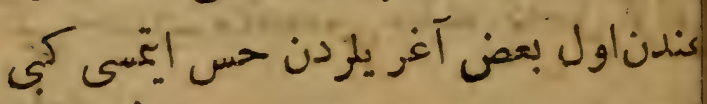

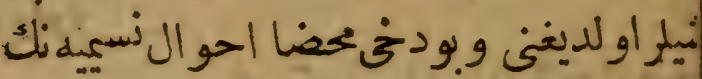
|

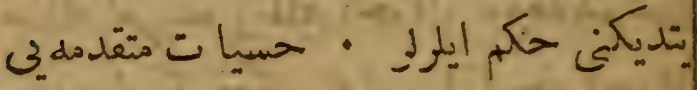

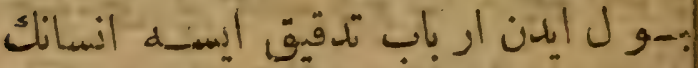

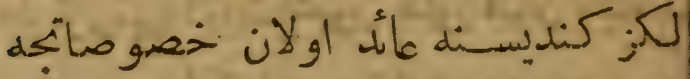

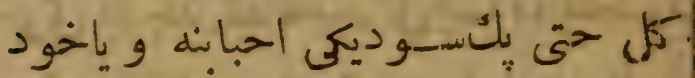

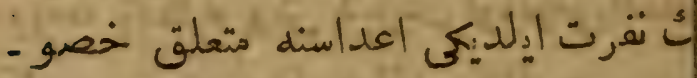

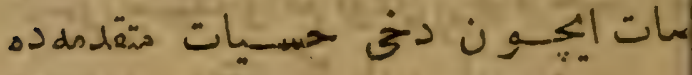




\section{* $|F| \%$}

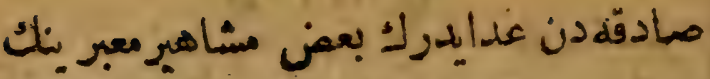

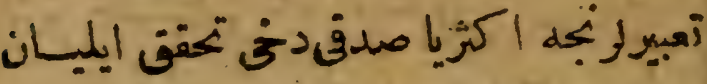

رؤيالرى ديكرمشهودات منامبـهدن ثقريت

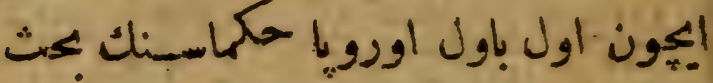

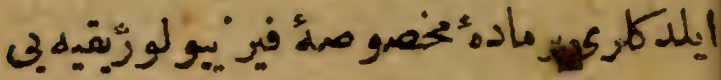

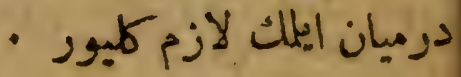

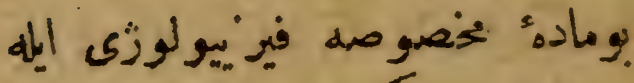

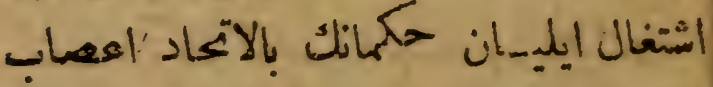

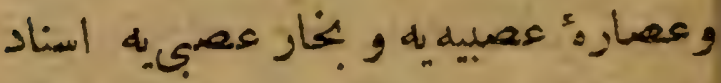

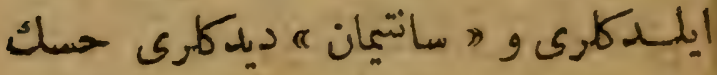

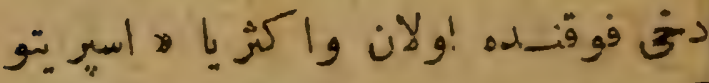

آليست

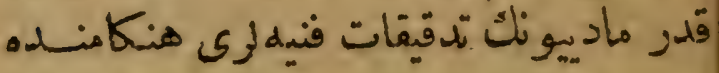

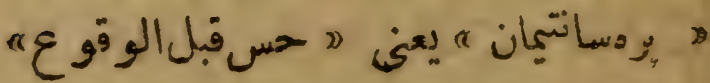

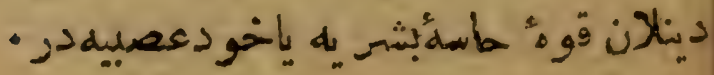




\section{ir. ir}

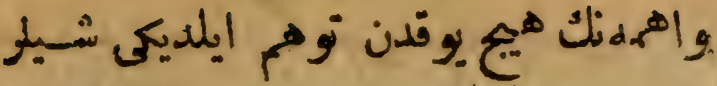

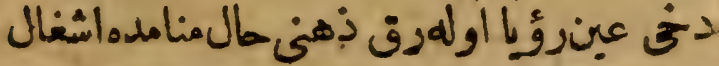

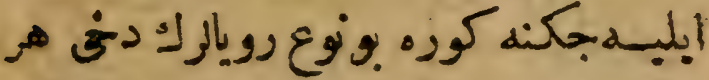
مالده انلرى كوزنلرك اسـتعداد وقابليت

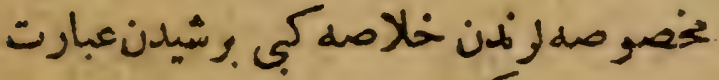

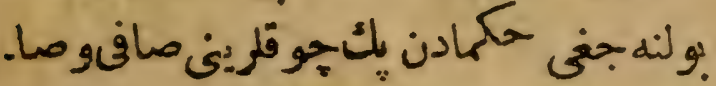

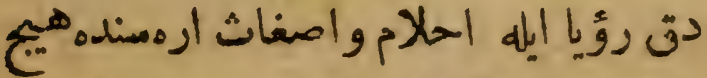

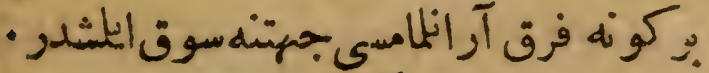
انبكت بومسئلده حكماى اسلاميه انلره تقدم وتقو تى إيدرك رؤيانك هـافنى وصادقنى

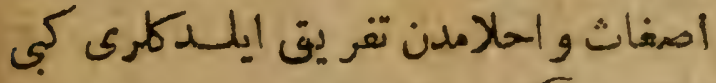

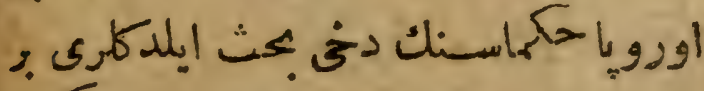

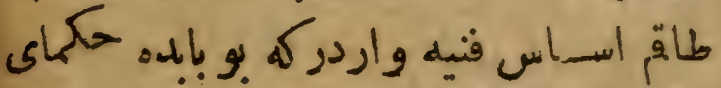

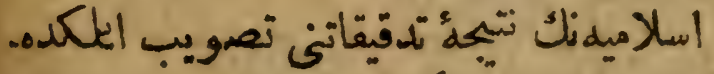

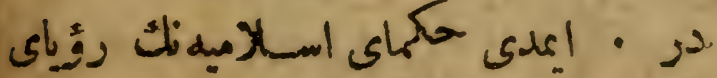




\section{9}

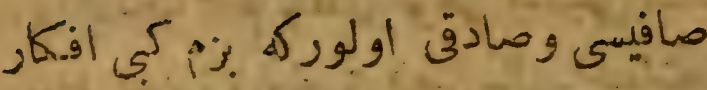

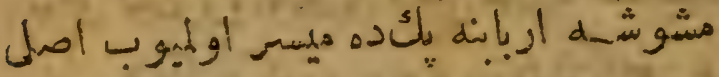

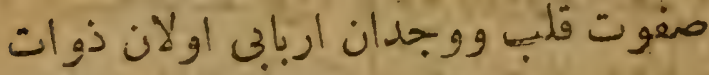

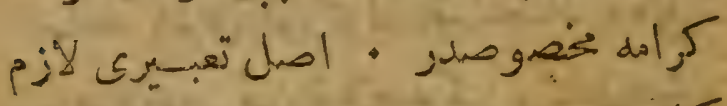

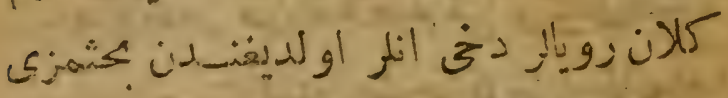

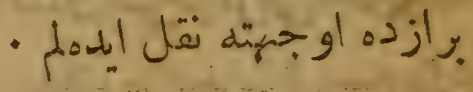
- ث

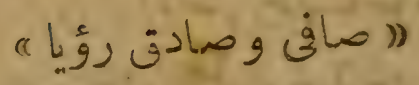

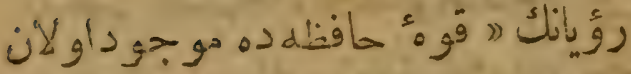

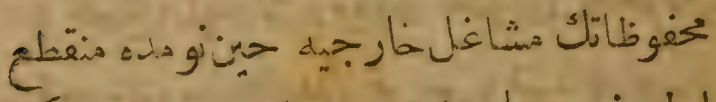

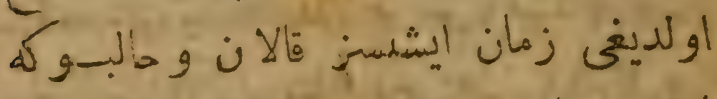

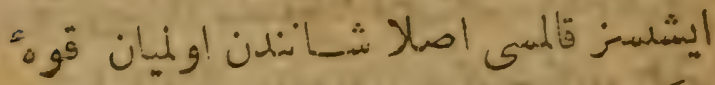

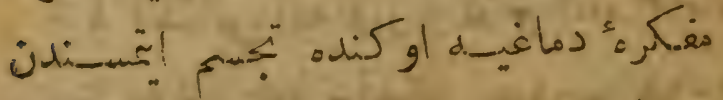

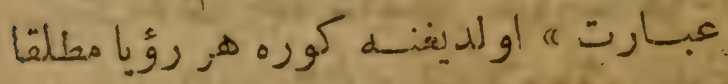
ماضى يه 


\section{潘 ISA}

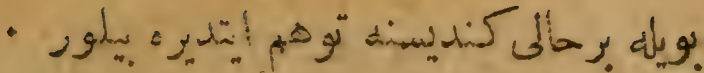

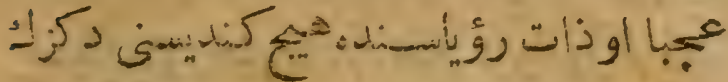

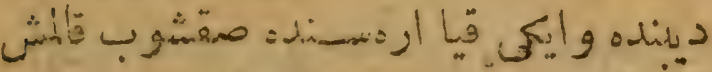

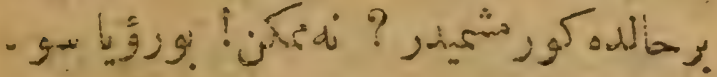

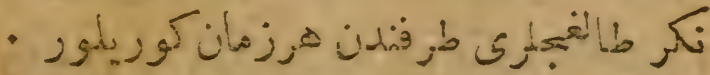

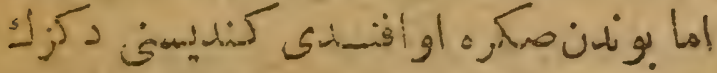

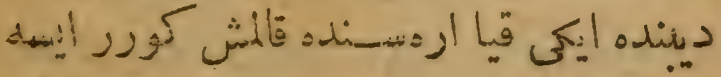

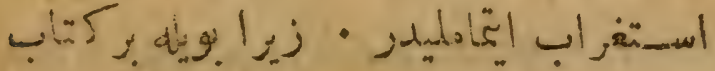

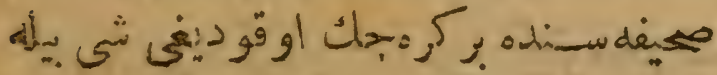

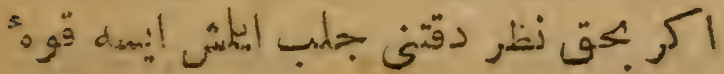

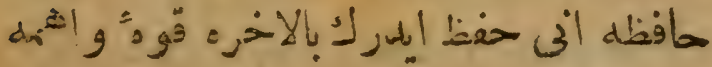

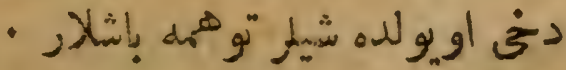

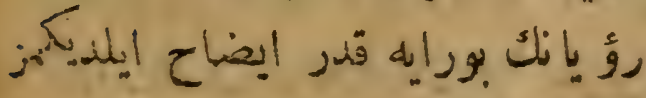

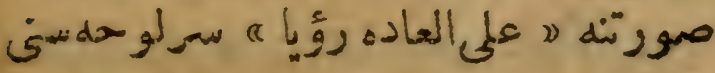

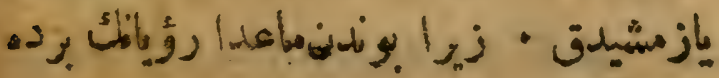




\section{liv}

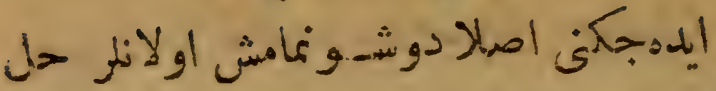

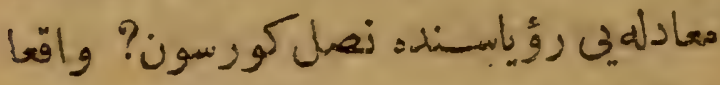

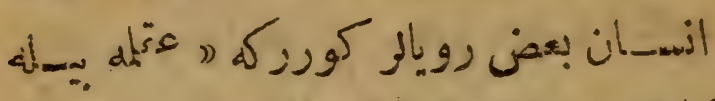

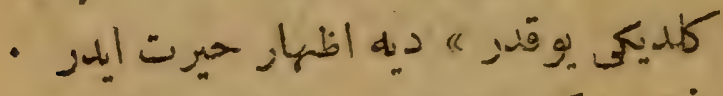

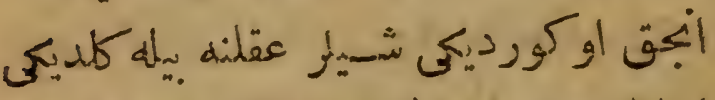

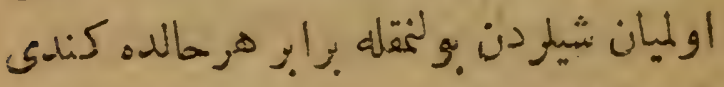

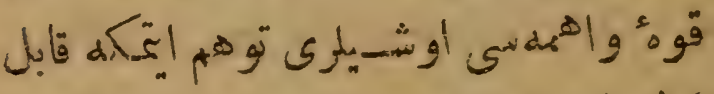

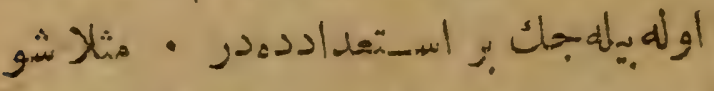

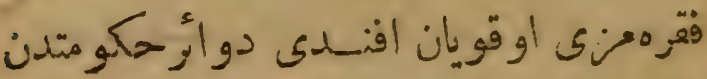

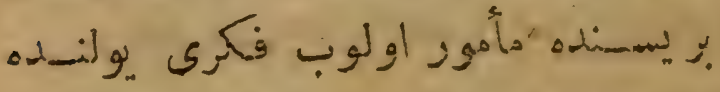

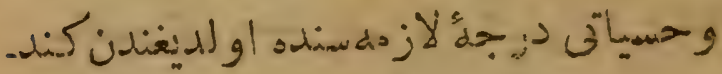

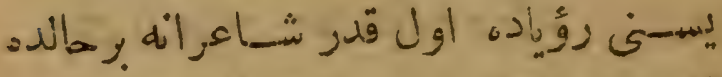

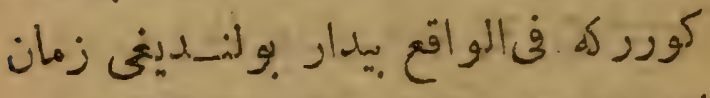

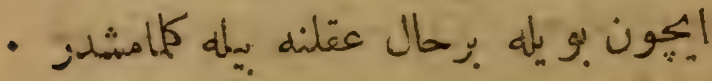

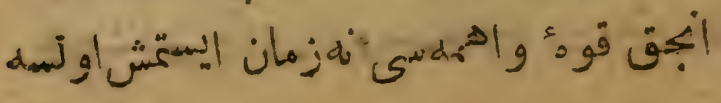




\section{7}

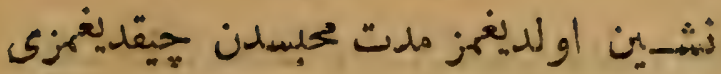

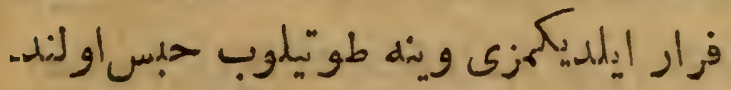

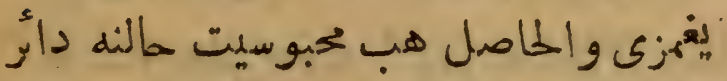

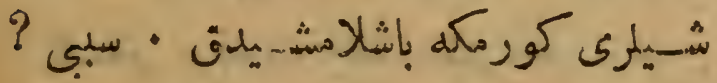

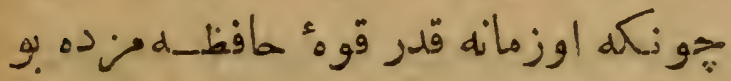

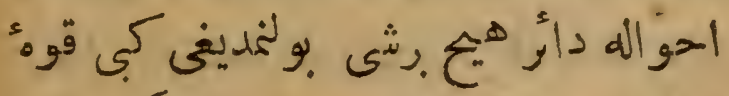
والهاه

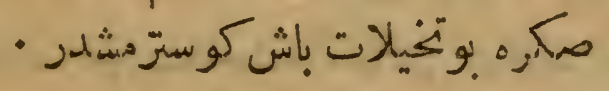

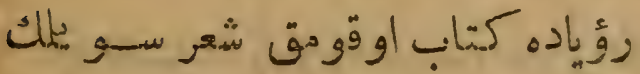

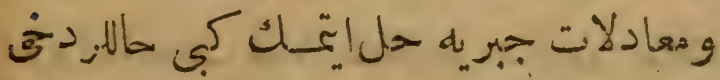

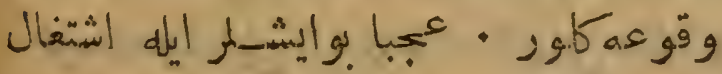

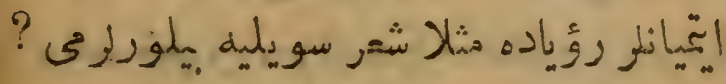

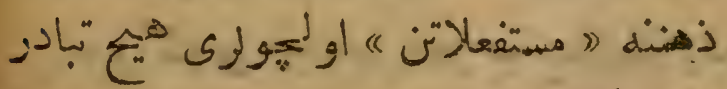

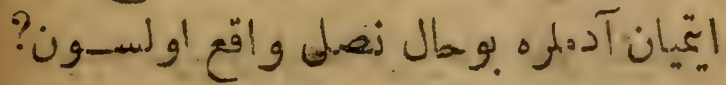

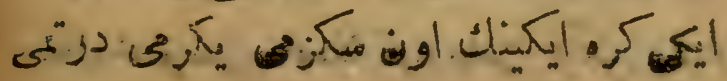




\section{0 柲}

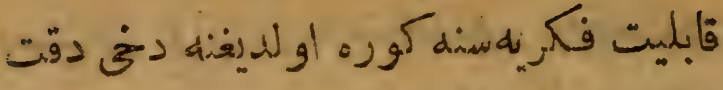

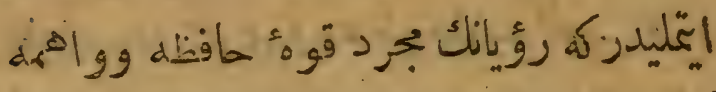

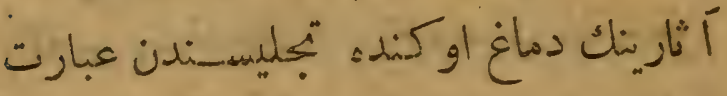

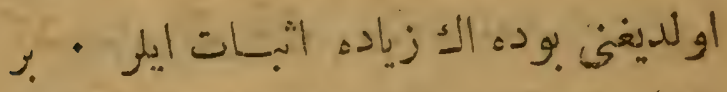

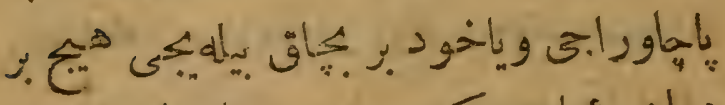

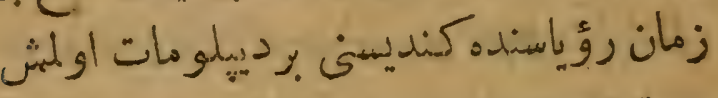

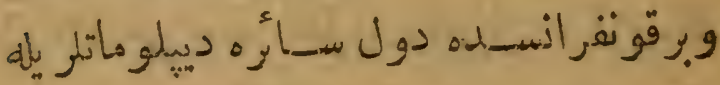

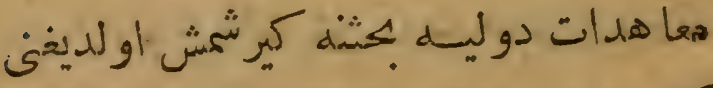

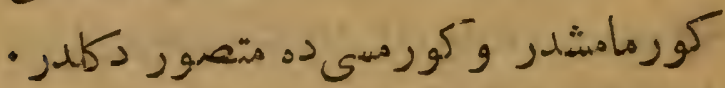

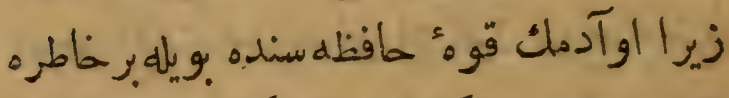

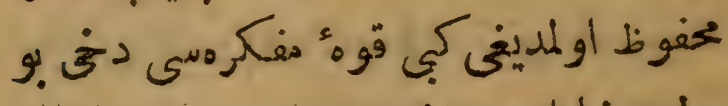

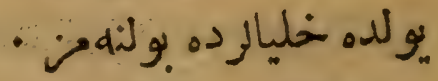

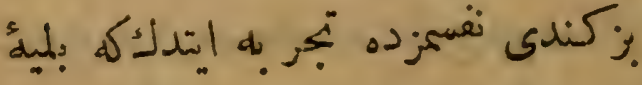
تقيـهـ دوهار اولديغمز زمانه قدر رؤيامزده

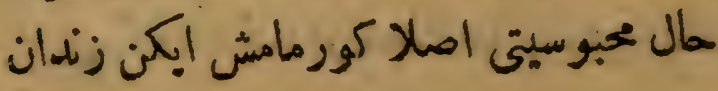




\section{2 潘}

بعض رؤيار كورديكنى فقط كورديكى شيسيل

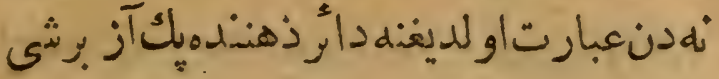

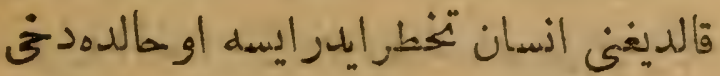

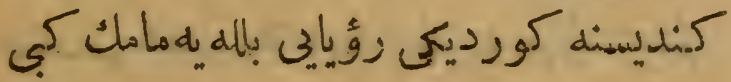

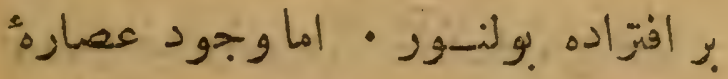

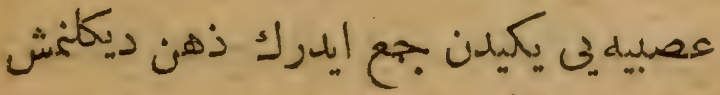

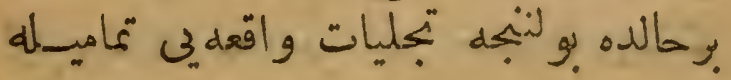

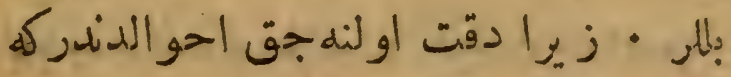

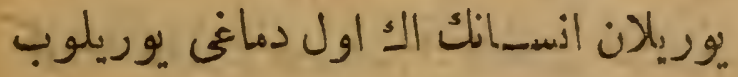

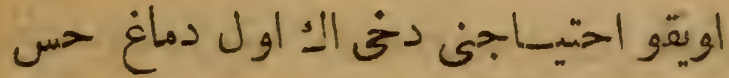

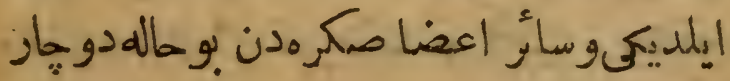

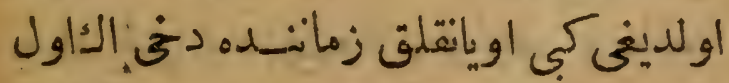

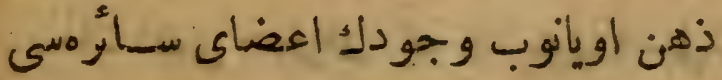

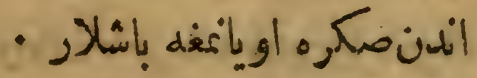

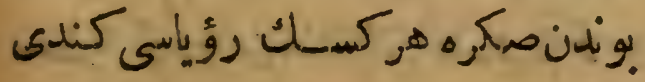




\section{$\operatorname{lrm}$}

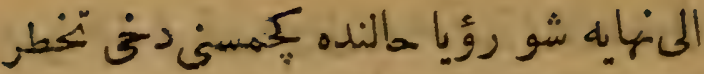

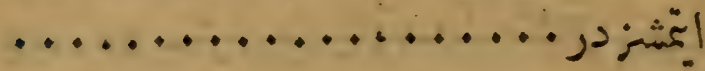

رؤيانك زمان وصورت وقورتى حقنده

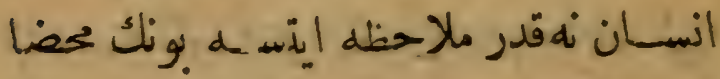

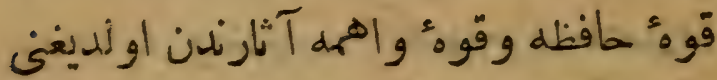

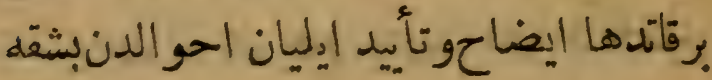

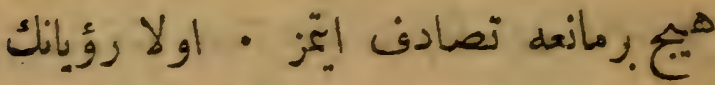

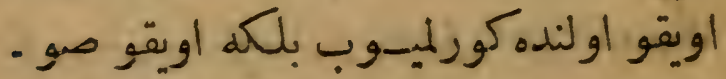

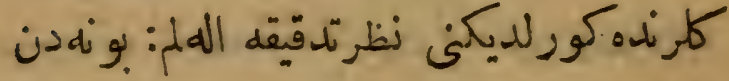

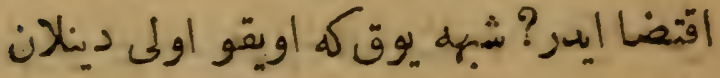

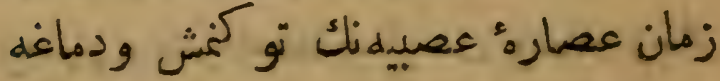

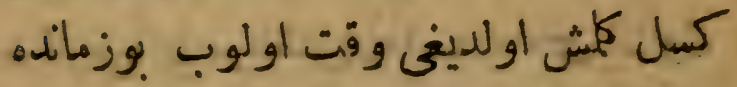

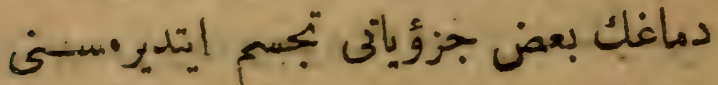
دنى انسان اونوتوركيدر • شونسيانْهابيه

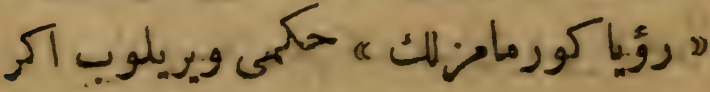




\section{irf}

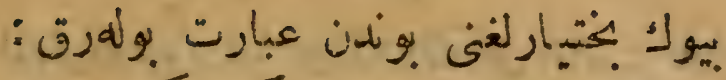

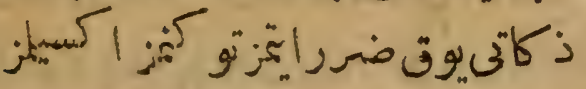

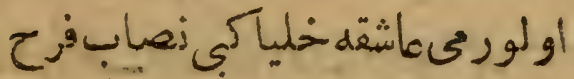

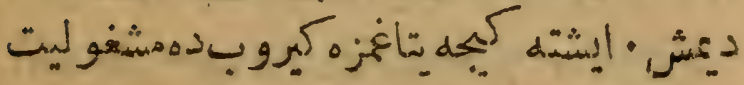

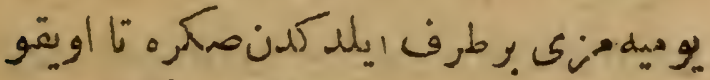

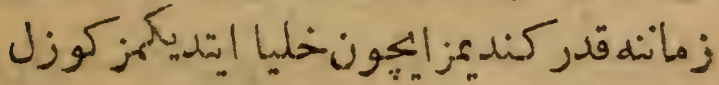

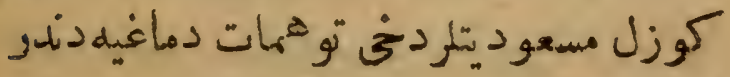

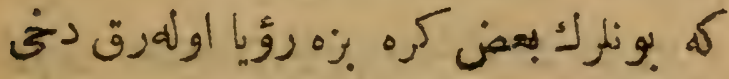

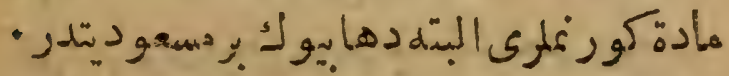

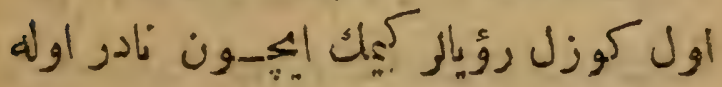

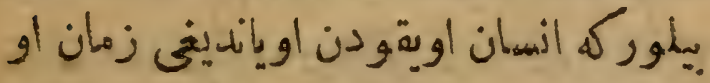

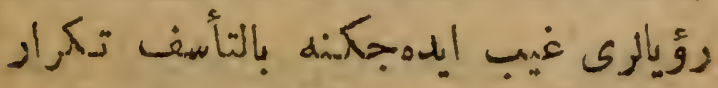

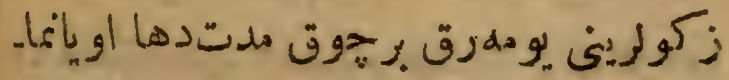

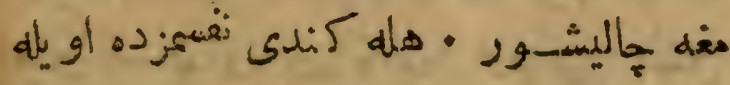

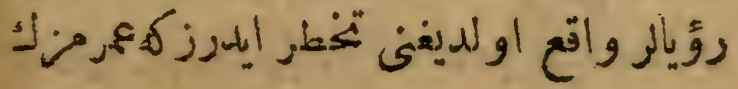




\section{1}

ئى

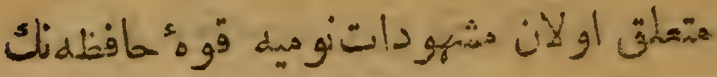

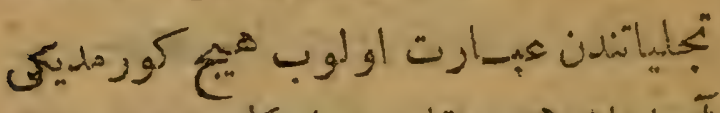

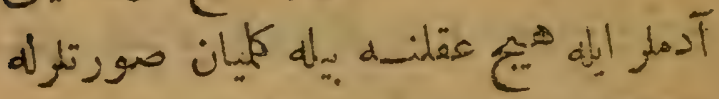

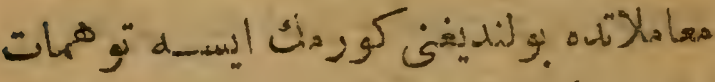

-

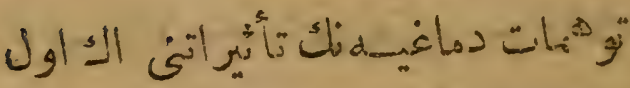

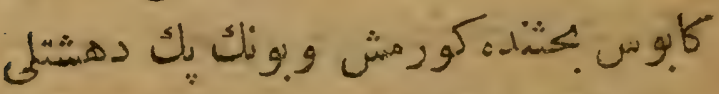

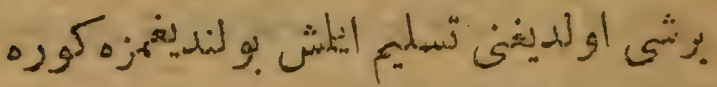

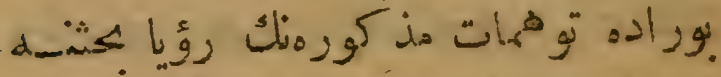

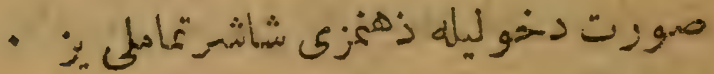

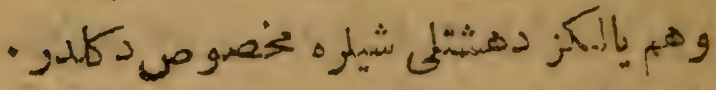

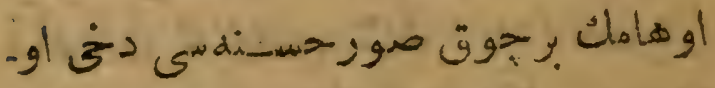

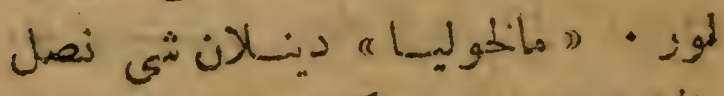

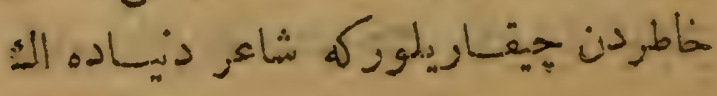




\section{8:}

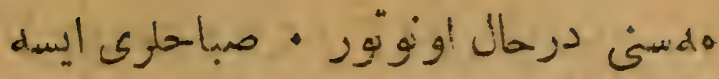

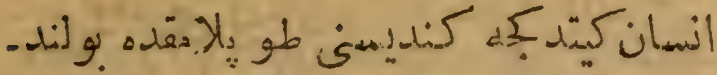

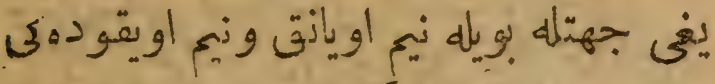

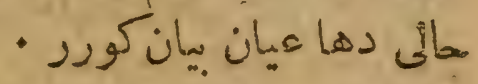

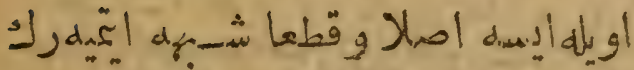

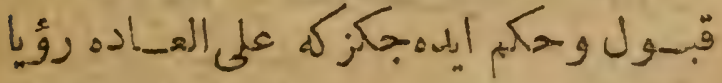

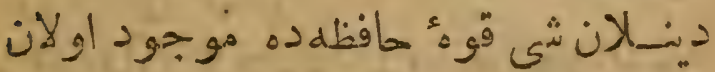

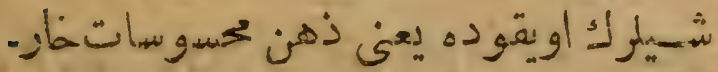

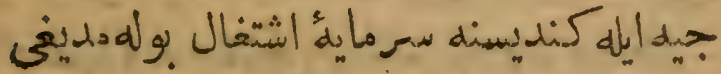

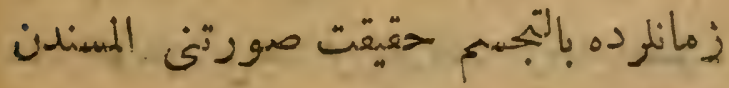

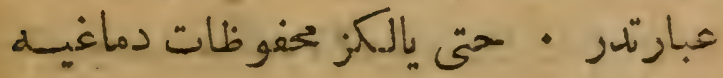

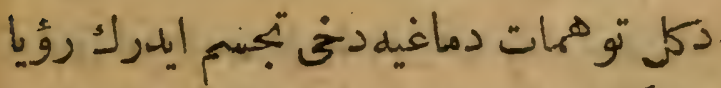

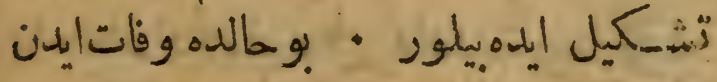

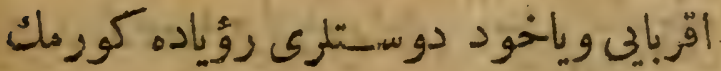

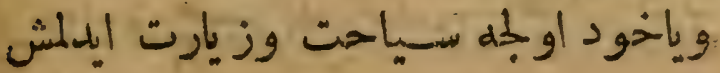




\section{9}

اولديغى زمانايله برده هنوز اويقودن أويا -

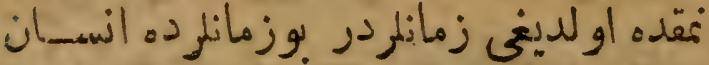

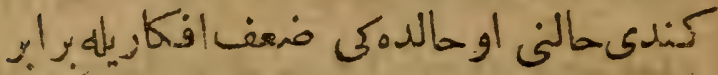

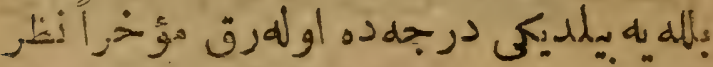

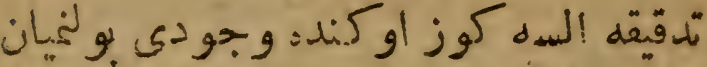

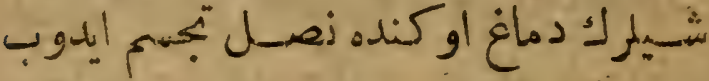

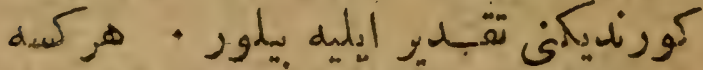

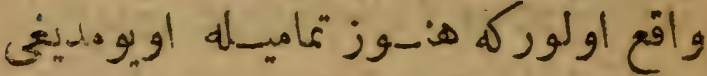

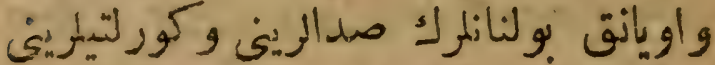

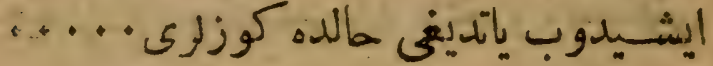

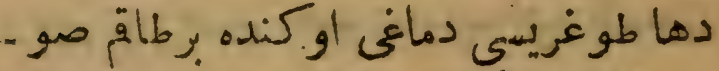

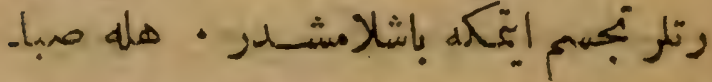

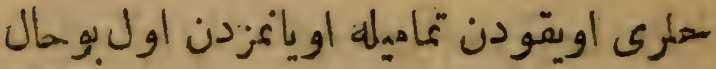

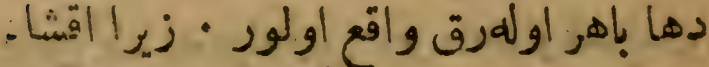

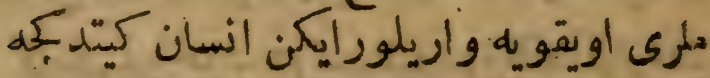

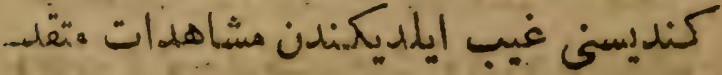




\section{1}

برشى واردردهموز آنيع كوريورجهيهات!

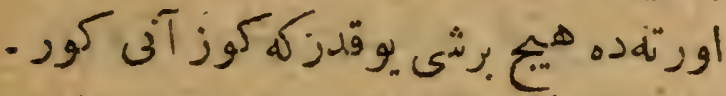

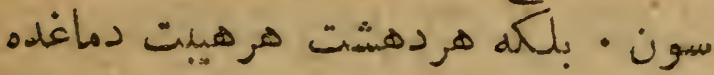

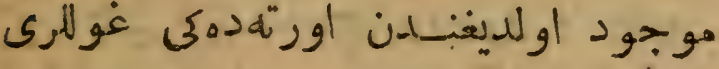

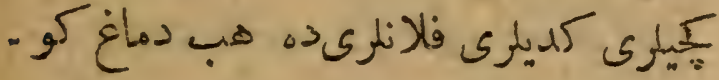
ريور

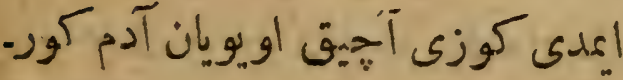

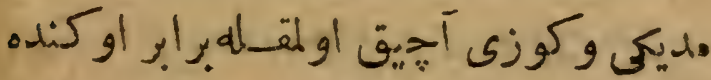

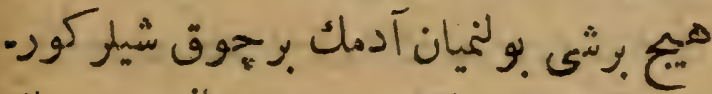

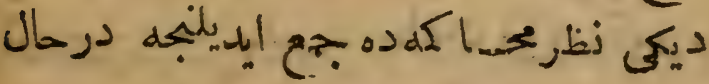

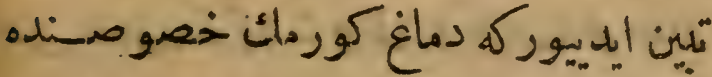

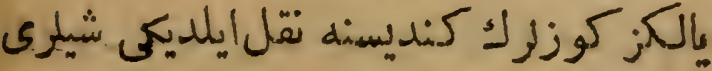

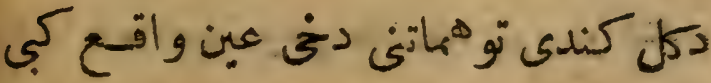

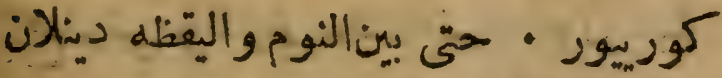

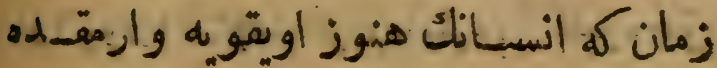




\section{V 数}

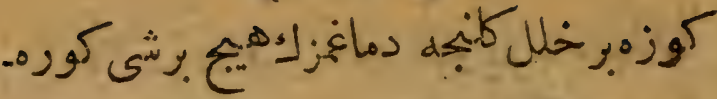

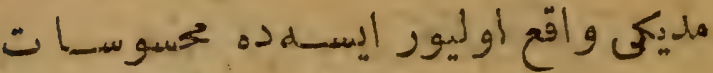

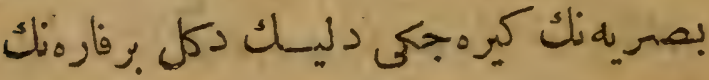

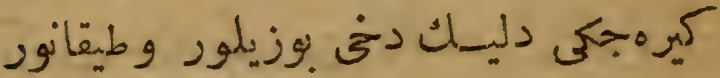

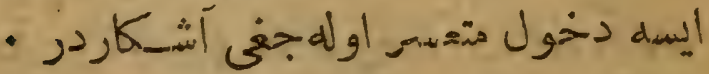

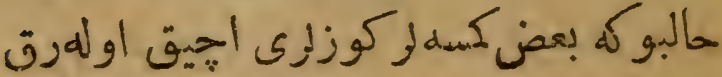

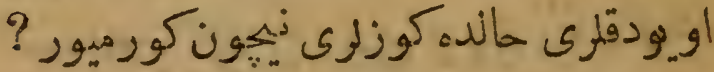

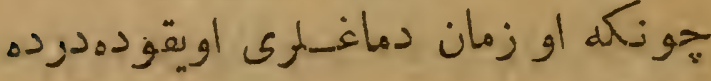

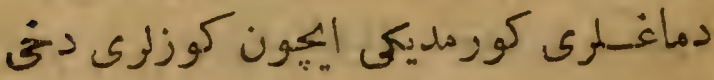

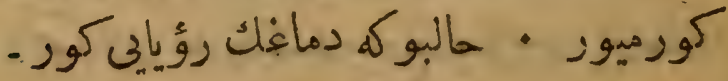

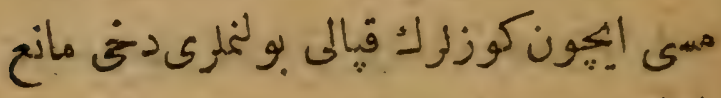
اولميور

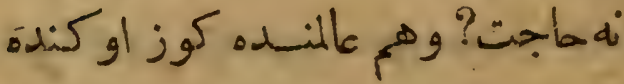

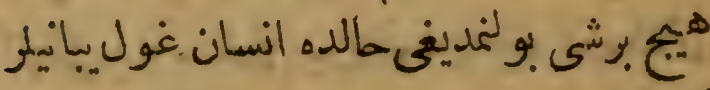

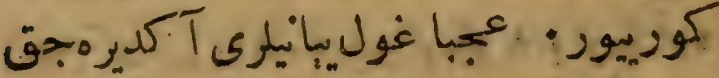




\section{$117 \%$}

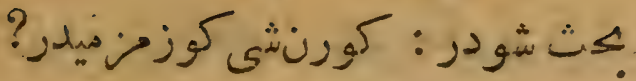

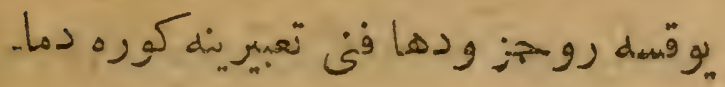

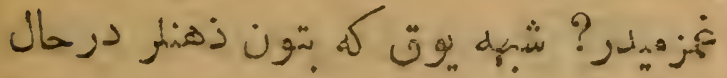

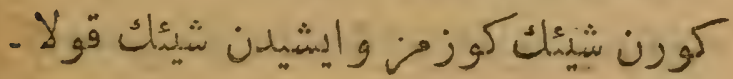

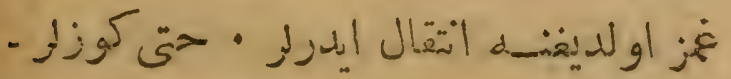

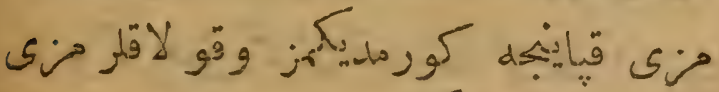

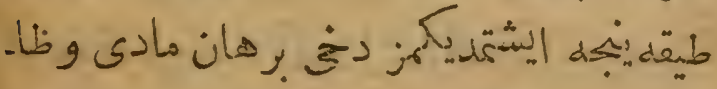

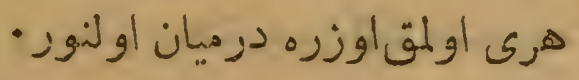

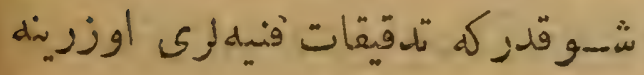

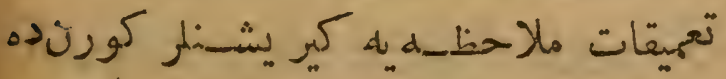

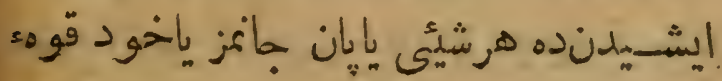

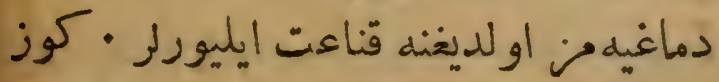

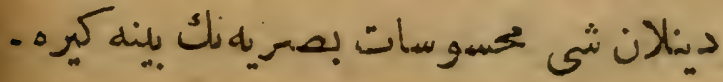

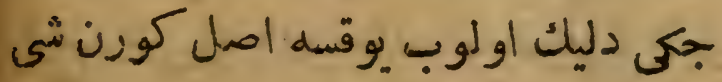

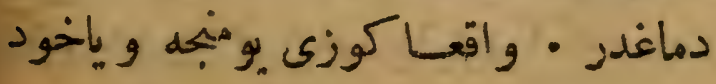


类 110

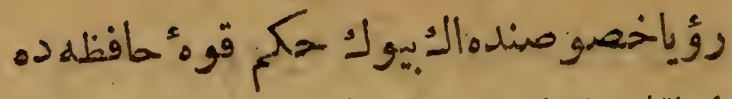

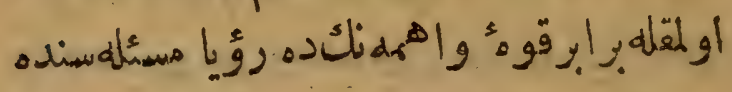

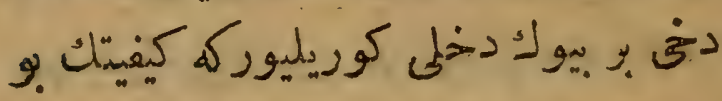

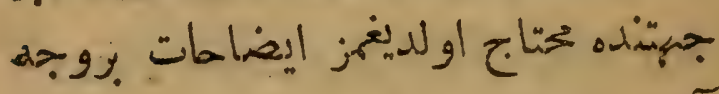

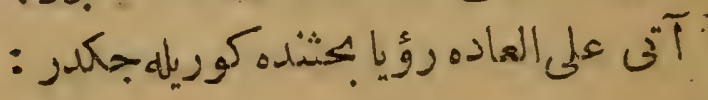
$\varepsilon$ ثمثرث

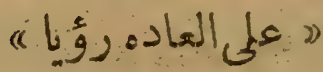

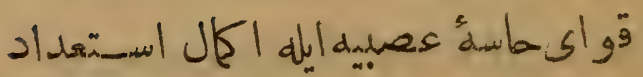

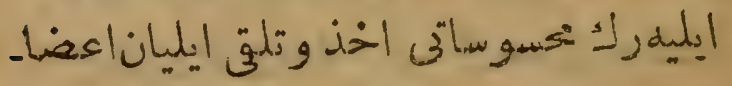

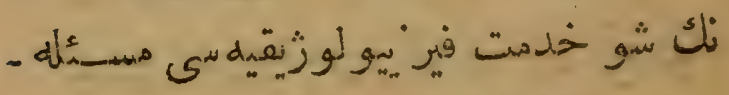

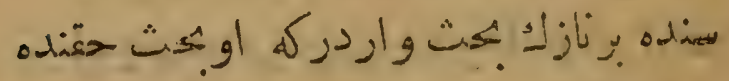

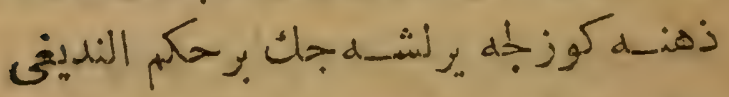

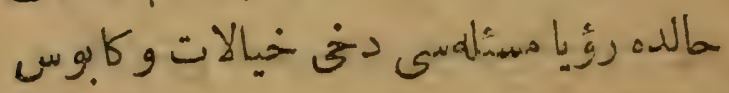

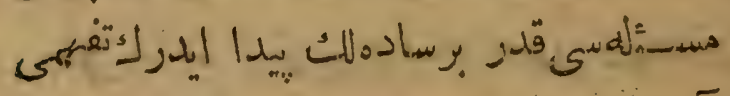
آسنان إولورن 
NIE

زير ابونلر وهملئه دكل بلكه مادة موجود

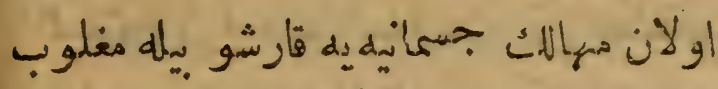

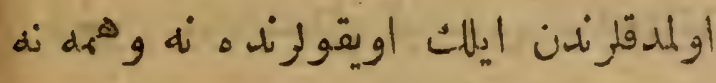

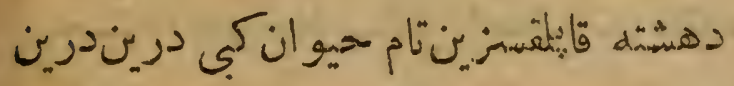

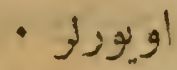

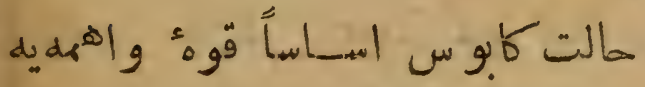

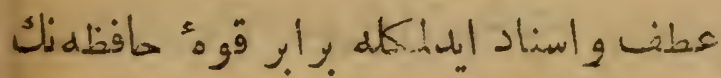

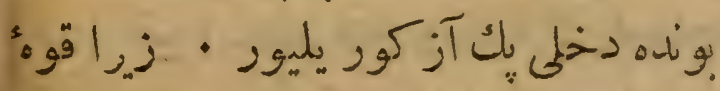

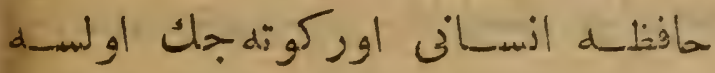

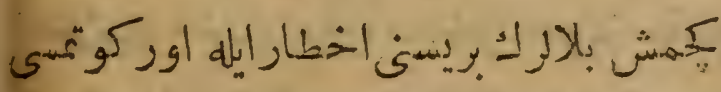

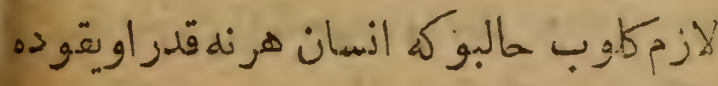

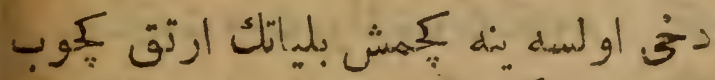

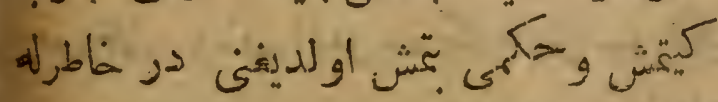

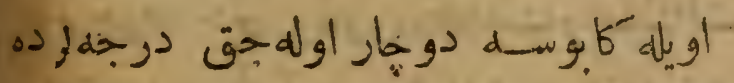

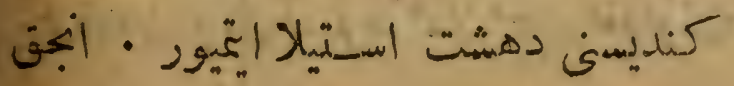




\section{䄅 $11 \mathrm{r}$}

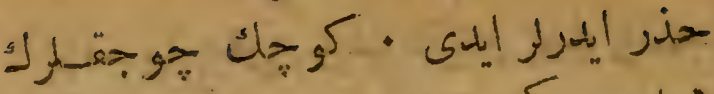

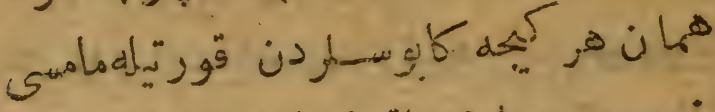

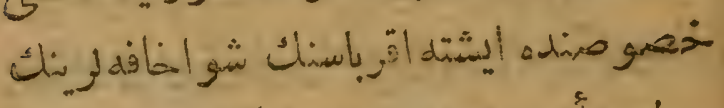

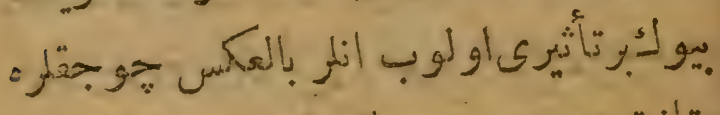

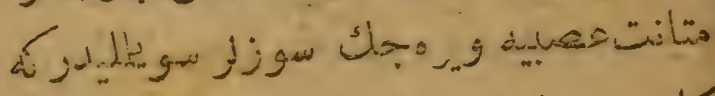

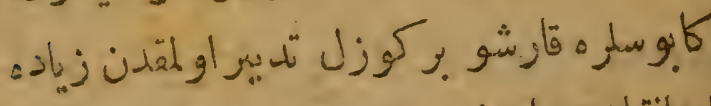

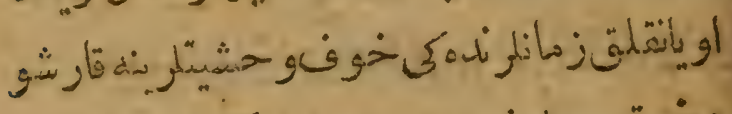

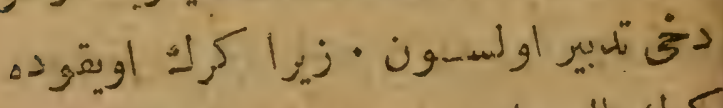

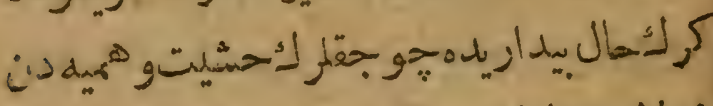

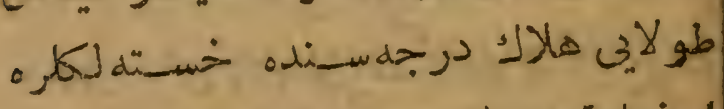

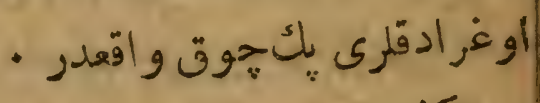

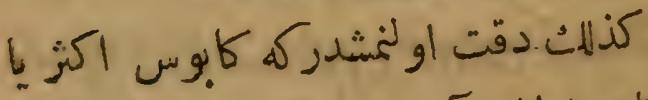

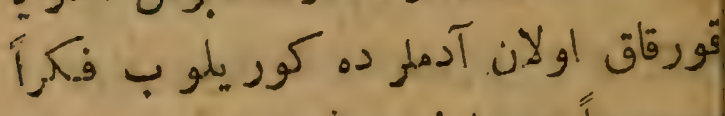

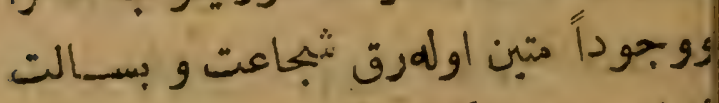

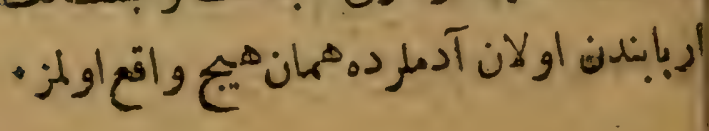




\section{5}

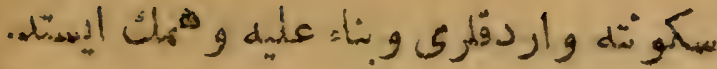

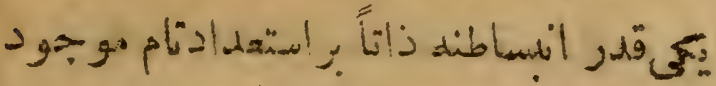

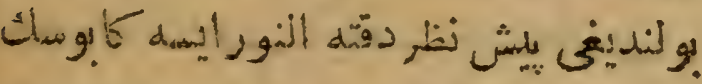

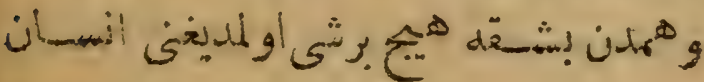

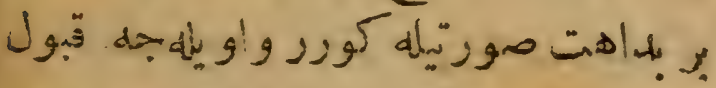

$$
\text { - }
$$

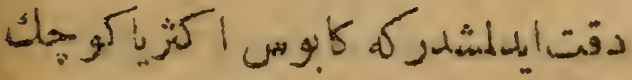

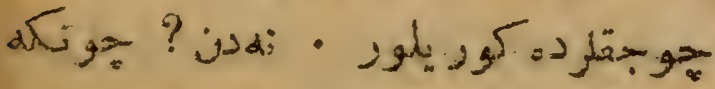

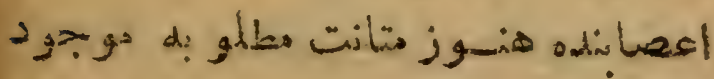

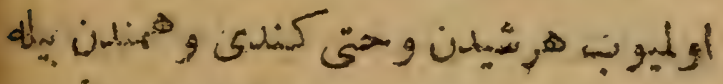

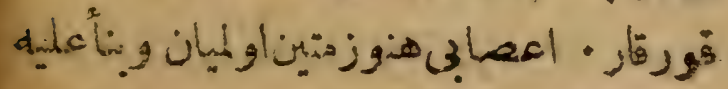

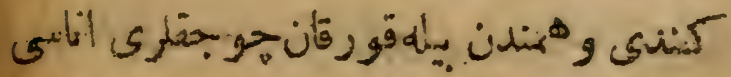

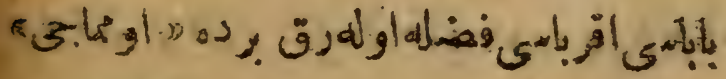

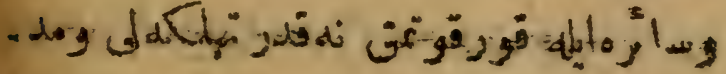

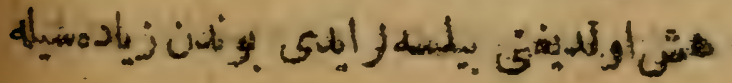




\section{* 111 絭}

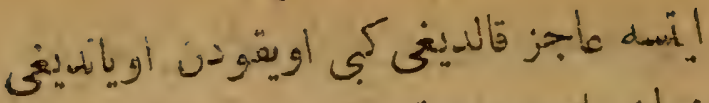

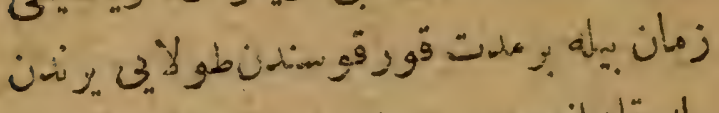

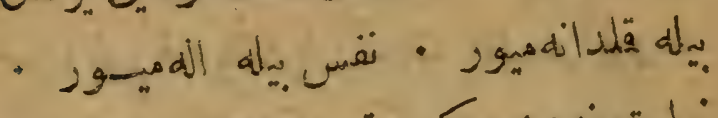

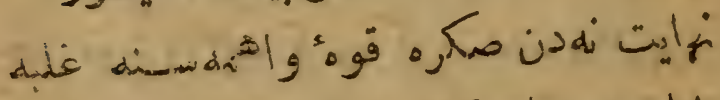

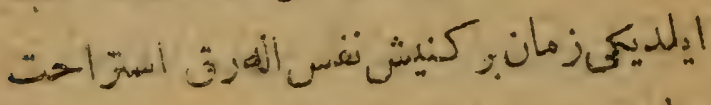
-

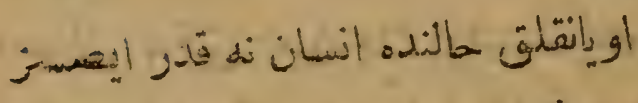

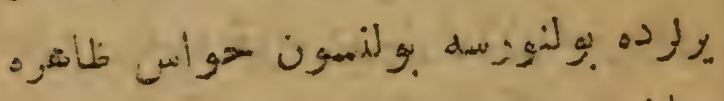

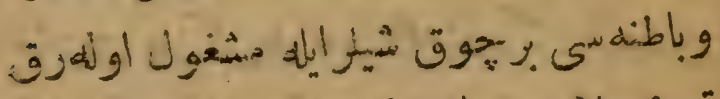

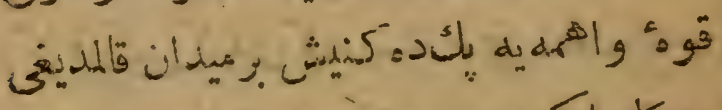

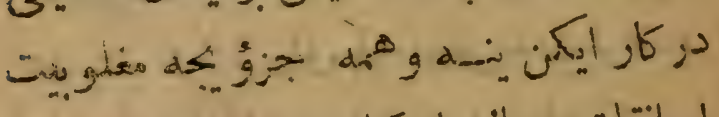

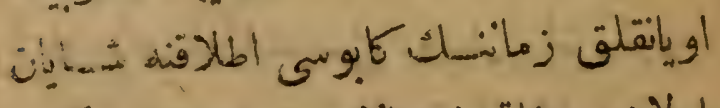

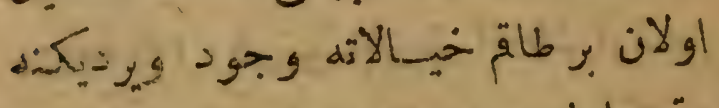

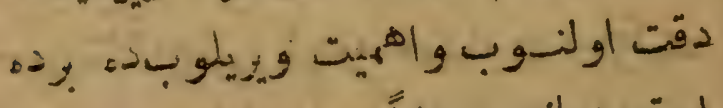

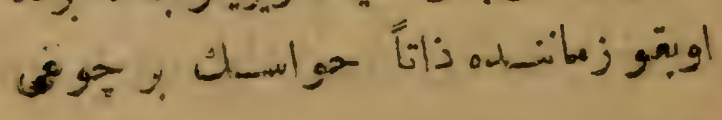


11.

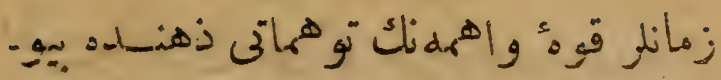

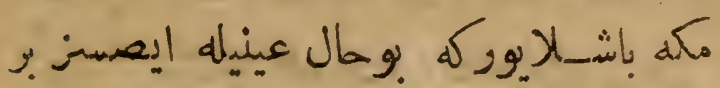

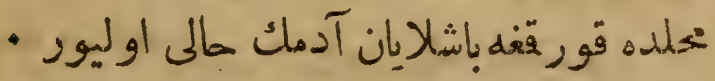

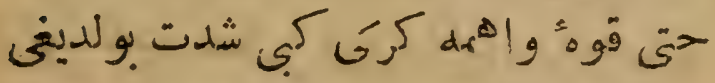

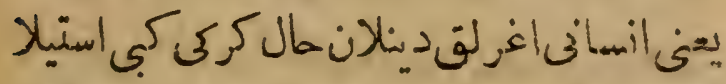

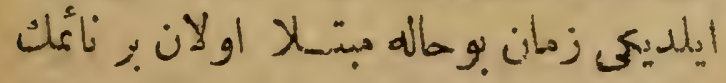

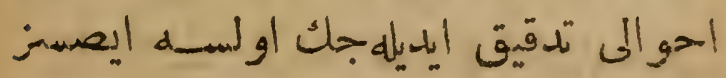

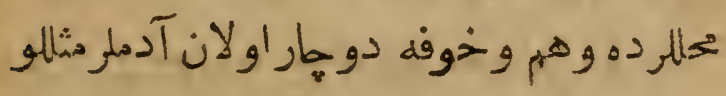

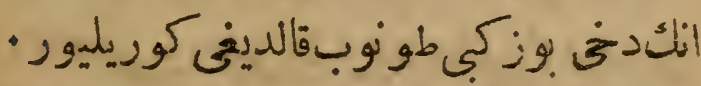

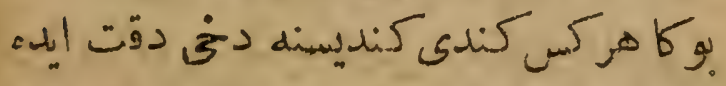

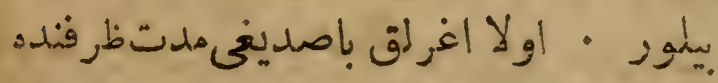

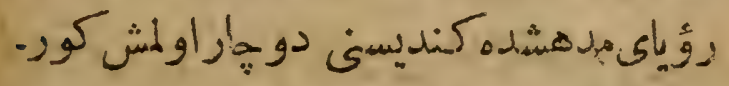

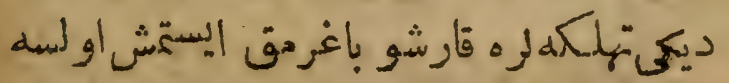

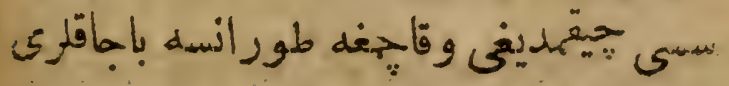

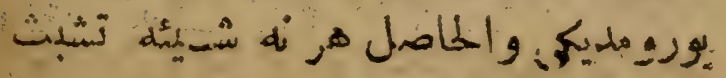




\section{9 )}

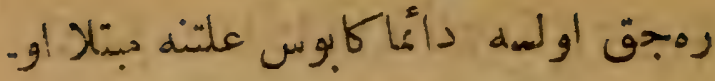

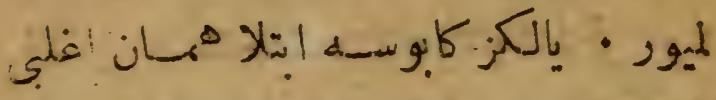

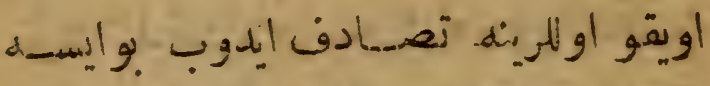

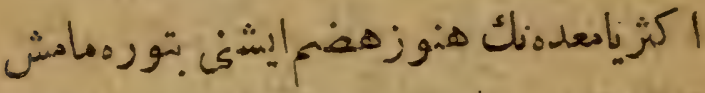

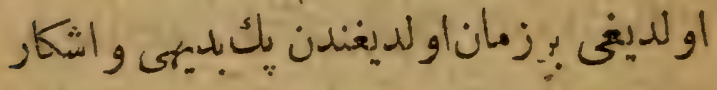

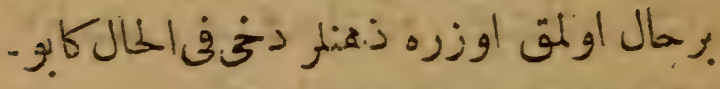

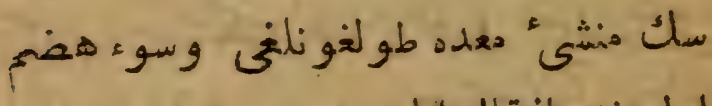

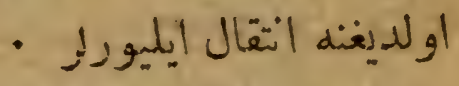

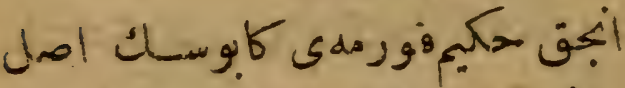

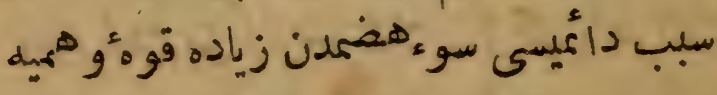
اولديغنه قناعت ايليور • اويقـونك ايلك فيك

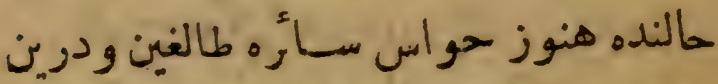

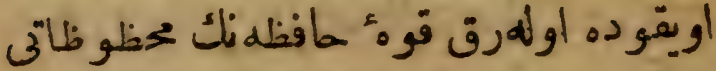

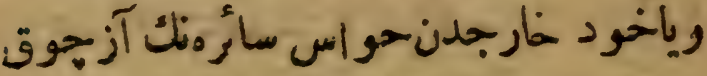

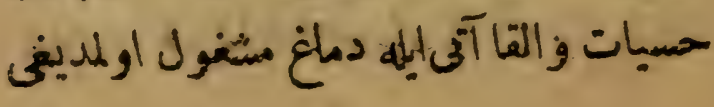




\section{$1 \cdot 1 \%$}

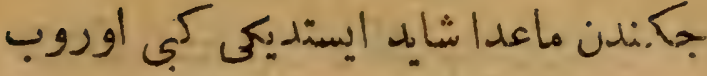

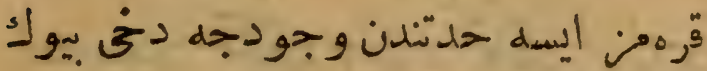

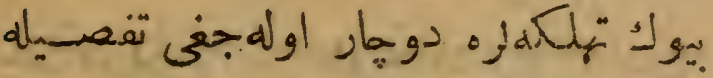

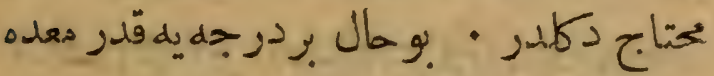

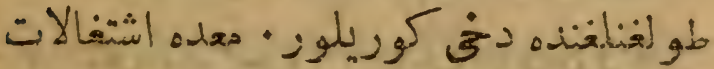

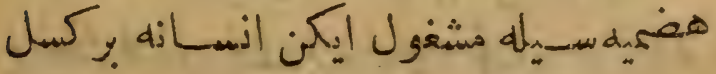

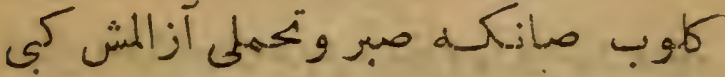

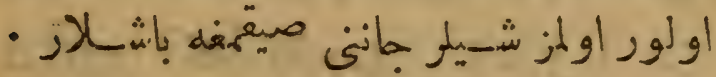

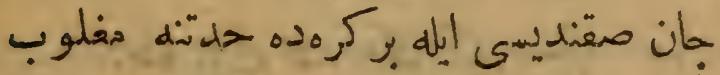

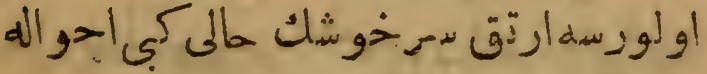

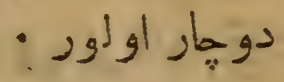

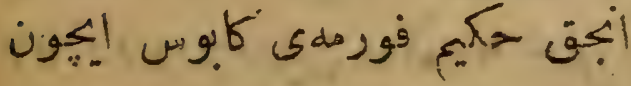

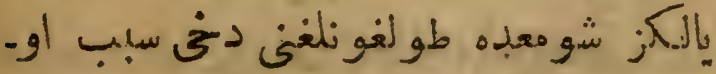

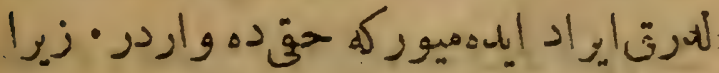
أنسان هرنه زمان هضمدن اول الو يقوية واله 


\section{$1 \cdot v$}

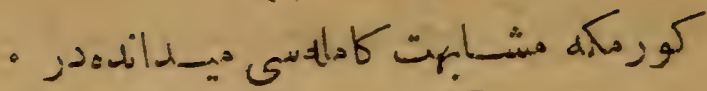

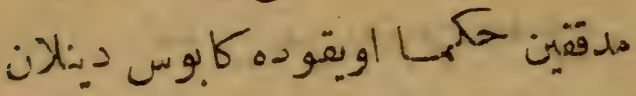

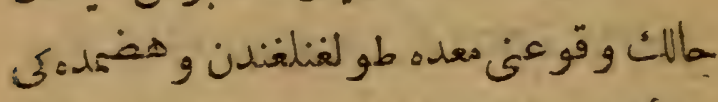

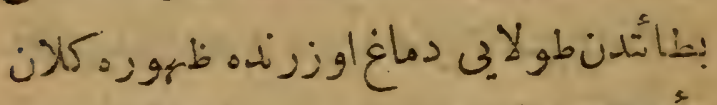

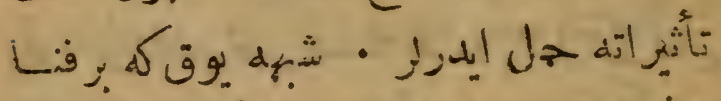

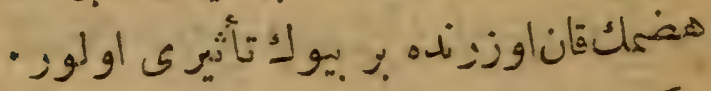

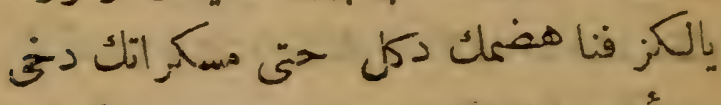

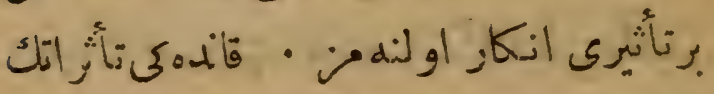

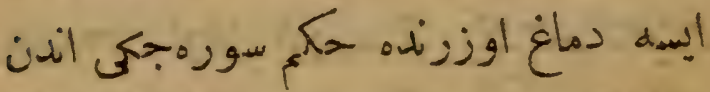

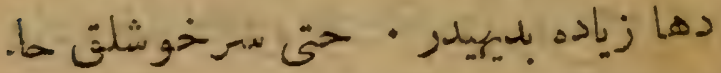

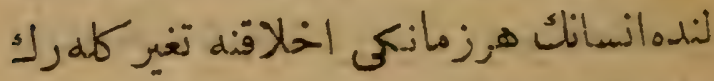

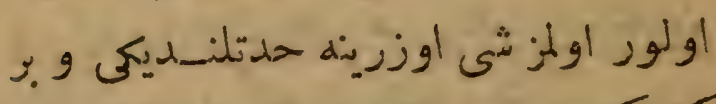

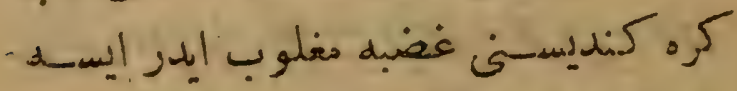

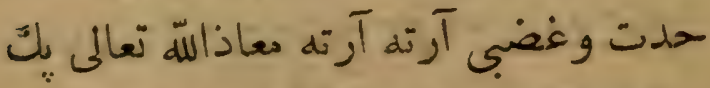

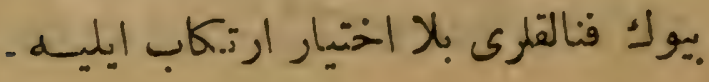




$$
\begin{aligned}
& 1.7 \% \\
& \text { 12 }
\end{aligned}
$$

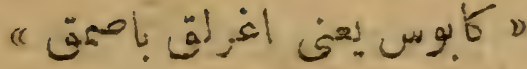

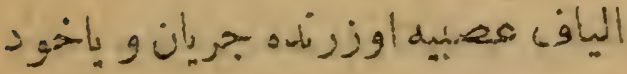

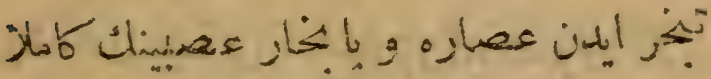

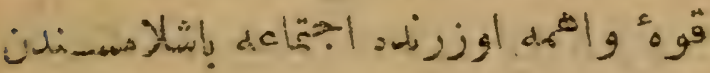

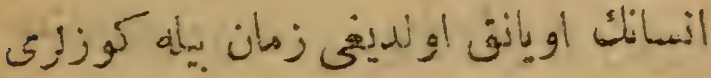

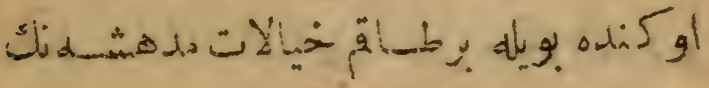

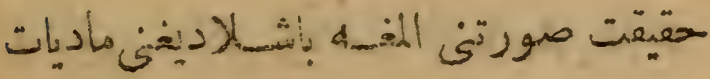

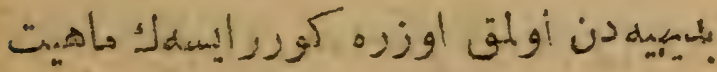

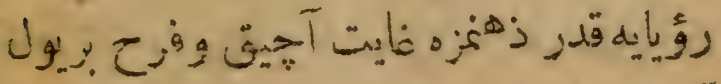

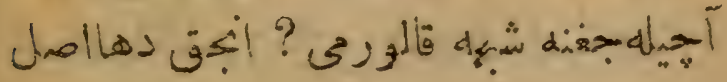

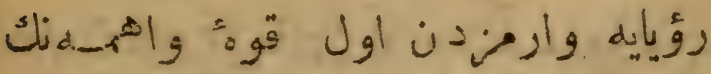

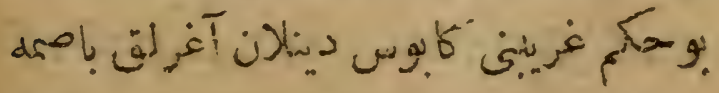

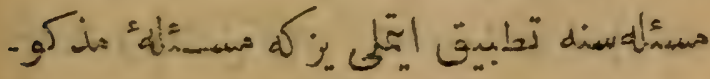

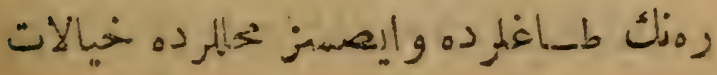




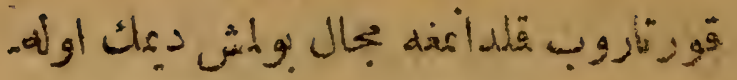

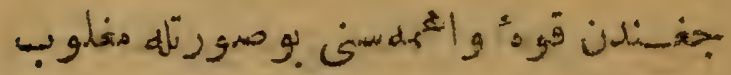

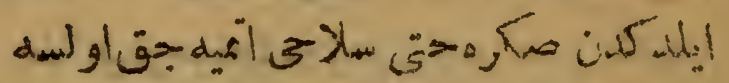

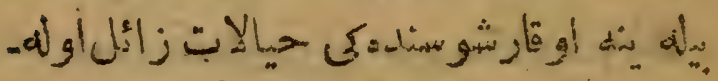

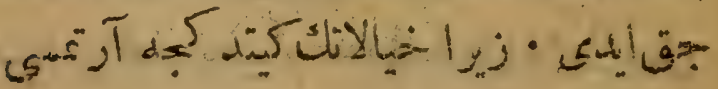

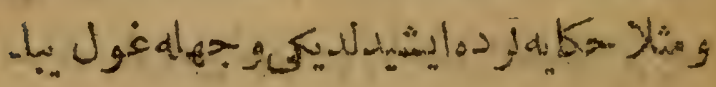

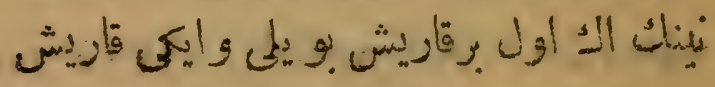
- Alla

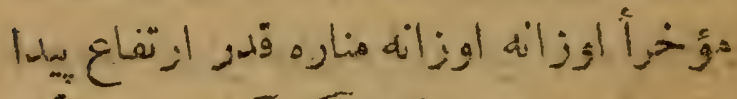

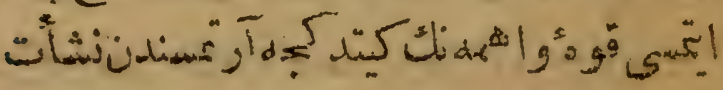

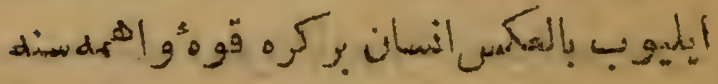

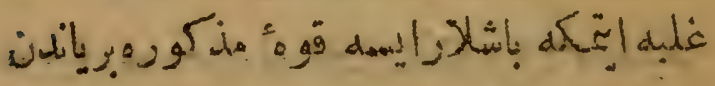
اكسمبله

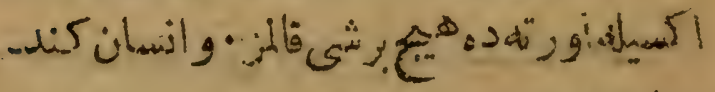
- 


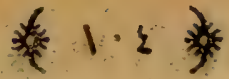

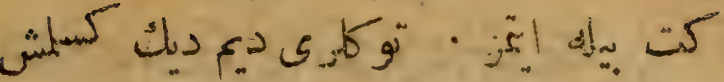

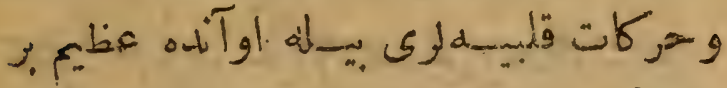

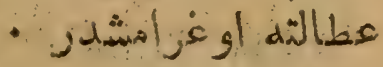

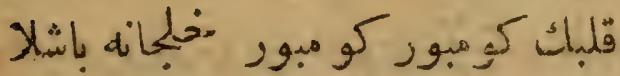

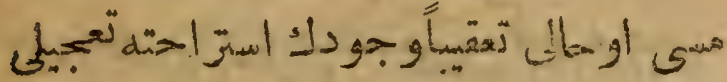

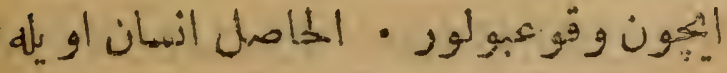

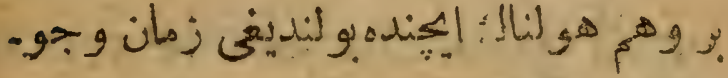

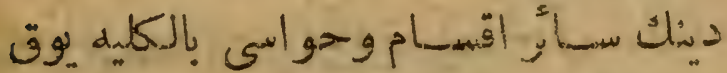

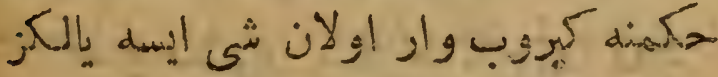
- و

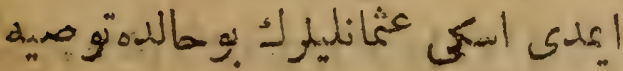

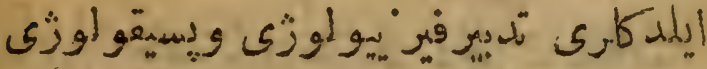

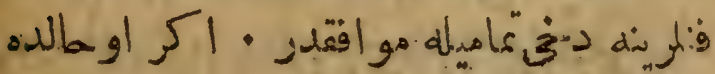

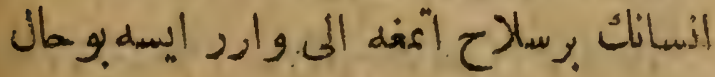

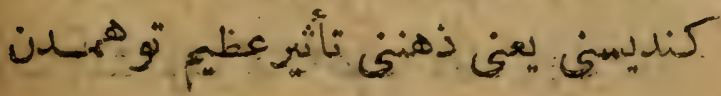




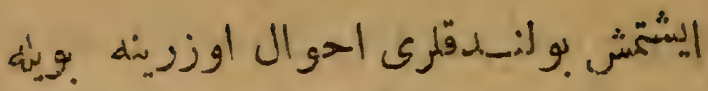

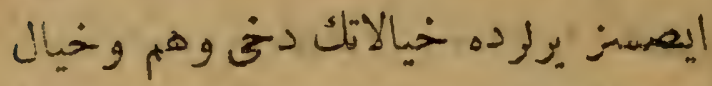

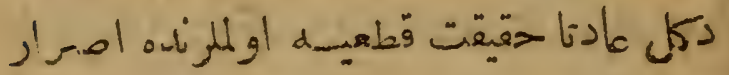

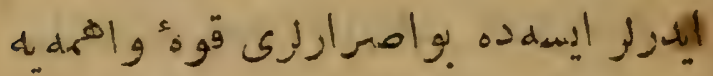

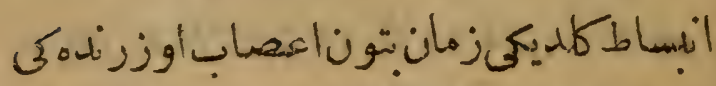

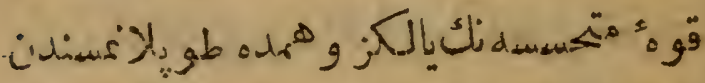

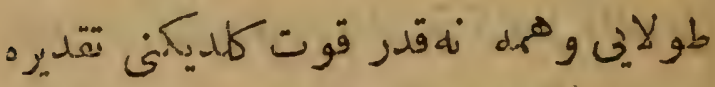

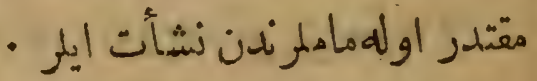

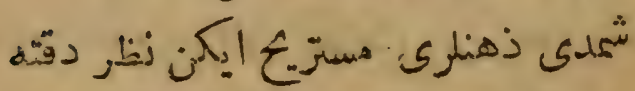

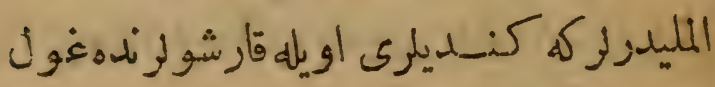

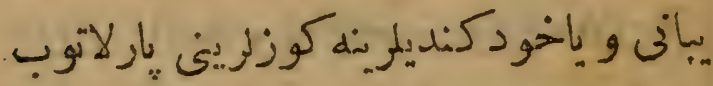

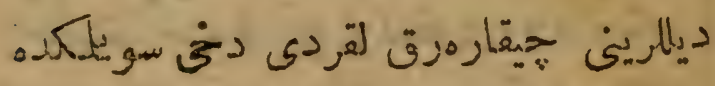

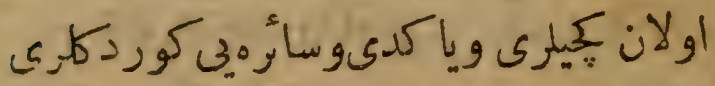

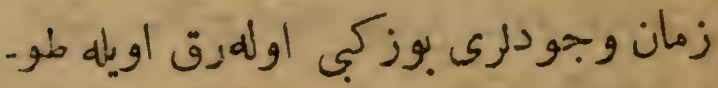

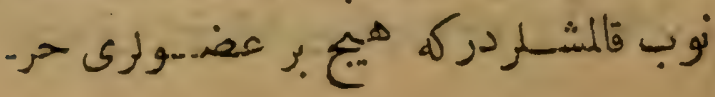




\section{1,r}

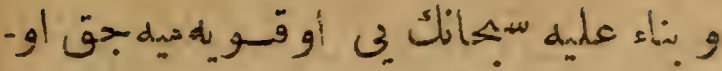

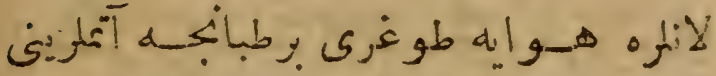

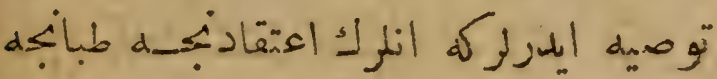

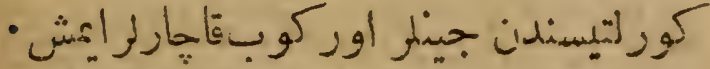

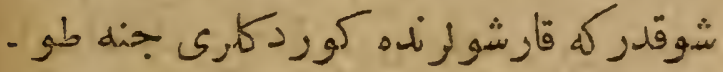

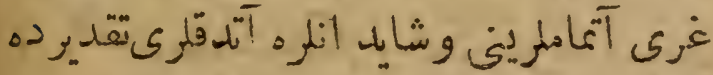

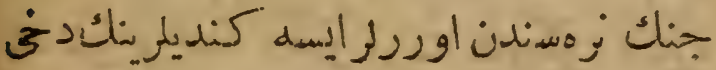

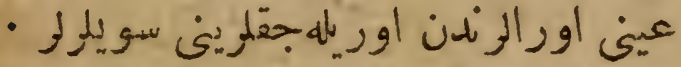

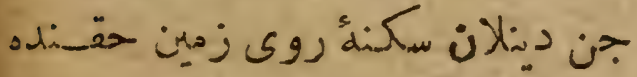

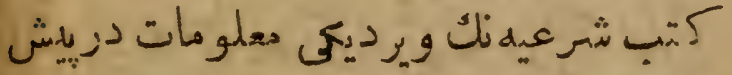

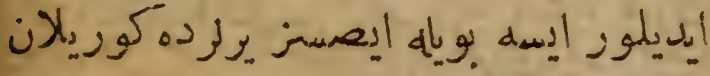

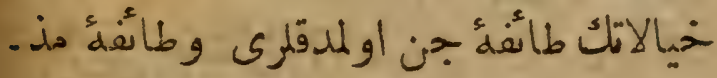

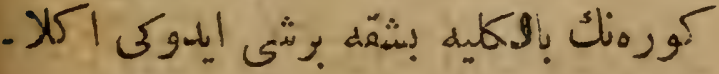

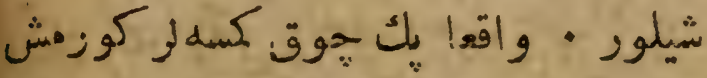

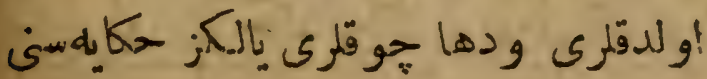




\section{1 *}

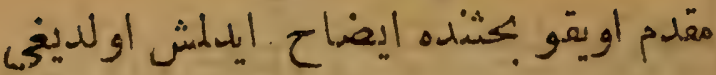

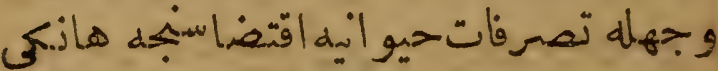

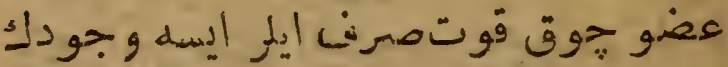

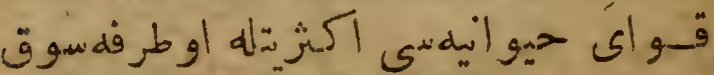

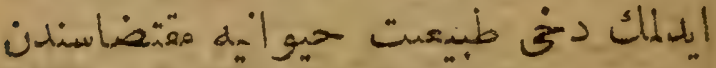

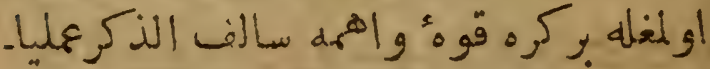

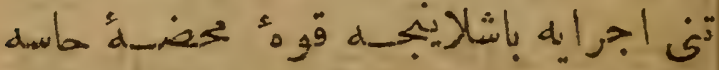

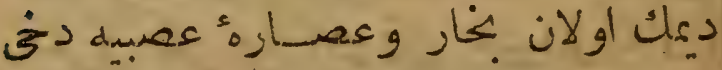

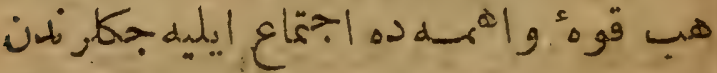

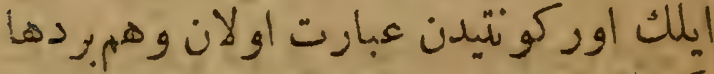

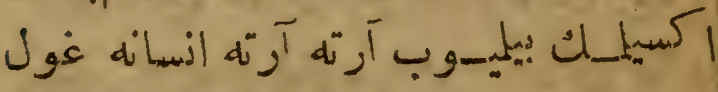

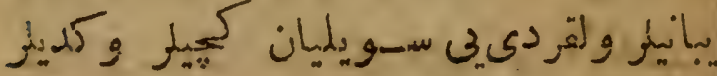
كوستز مكاك قدر آرتار

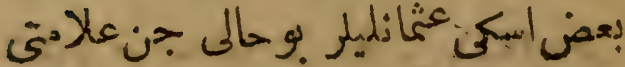
اولقق اوزره ححكم ايدرك اوقومق بيميانلره 


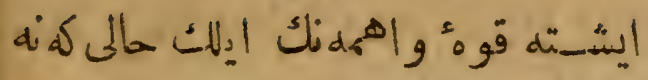

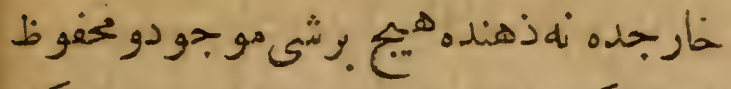

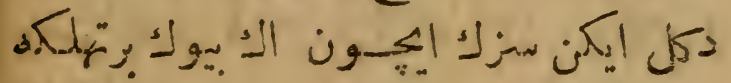

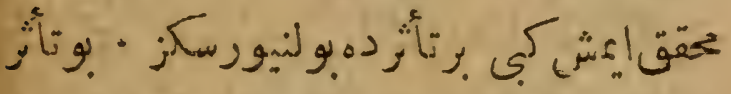

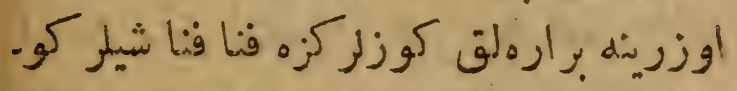

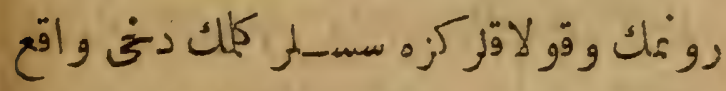

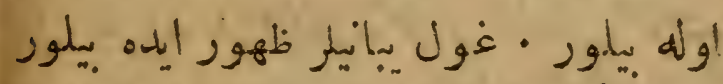

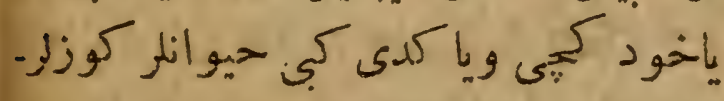

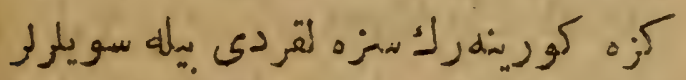

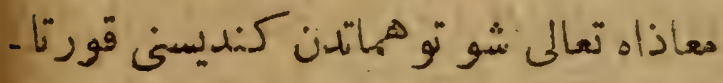

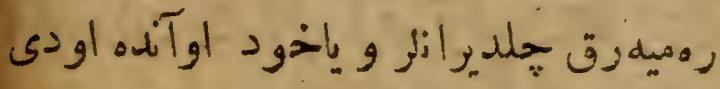

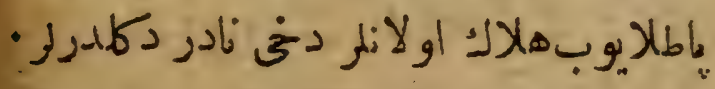

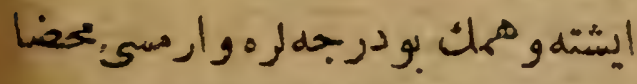

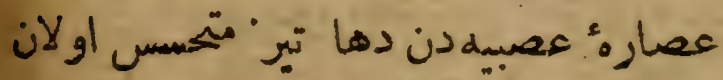

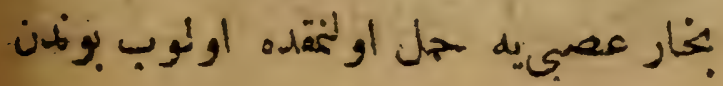




\section{9 \%}

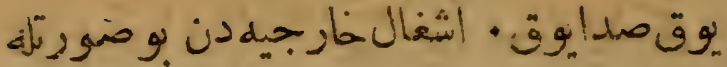

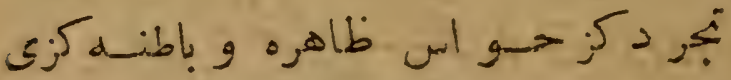

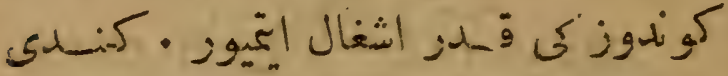

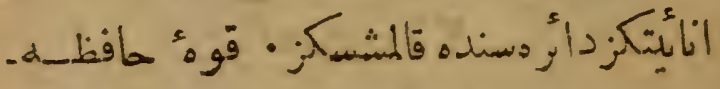

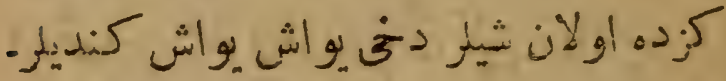

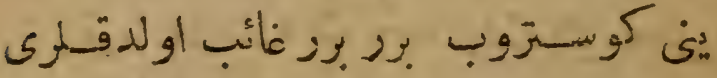

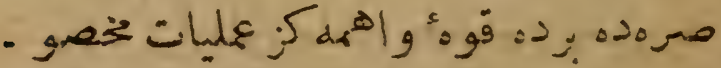

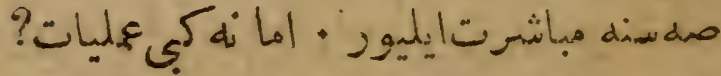

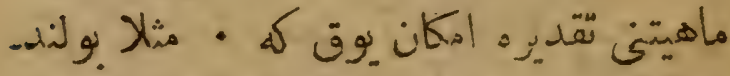

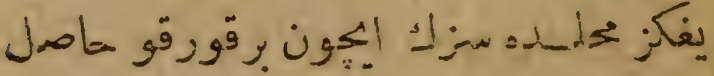

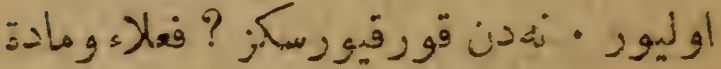

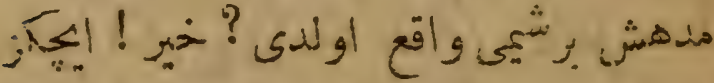

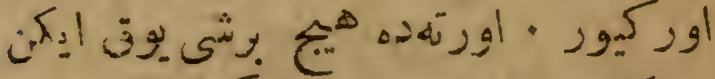

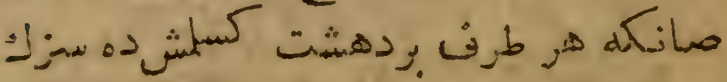

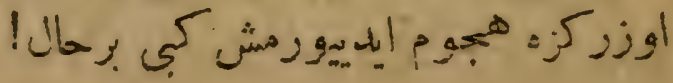


凑 9 人

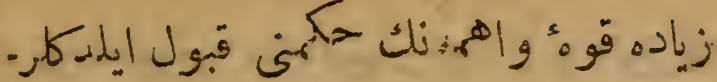

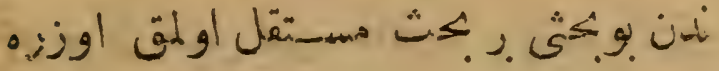

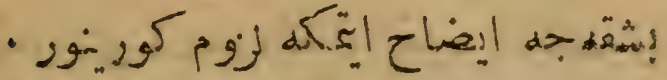
1 ثيم:

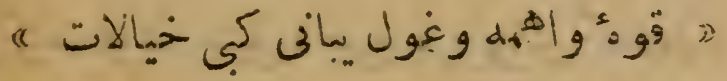

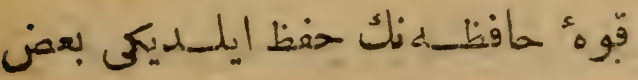

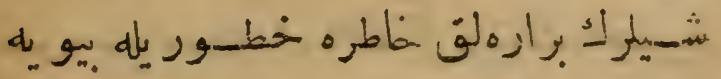

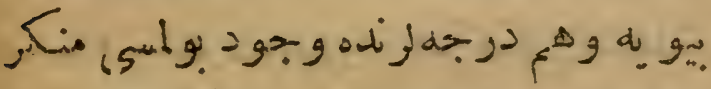

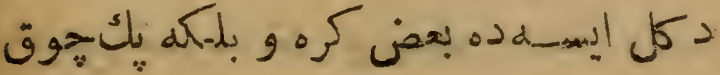

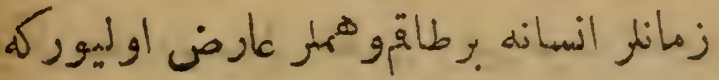

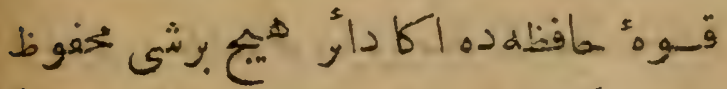

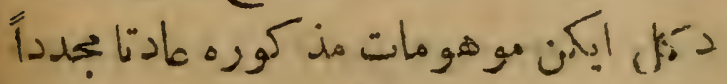

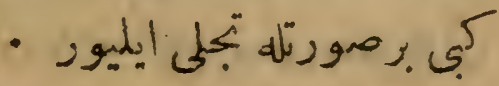

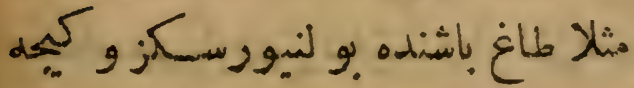

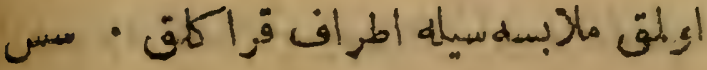




\section{$9 v$ 释}

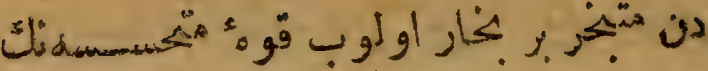

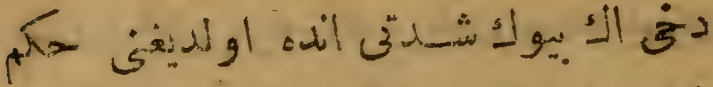

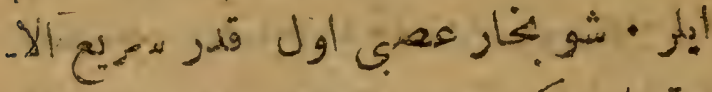

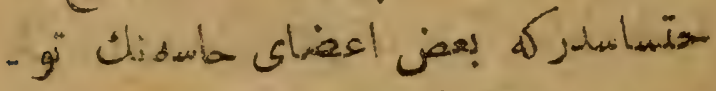

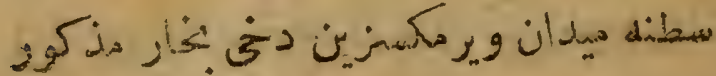

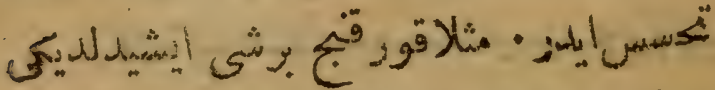

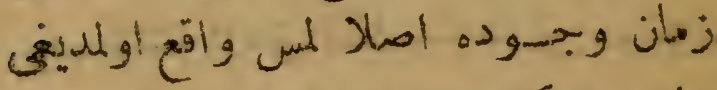
ك.

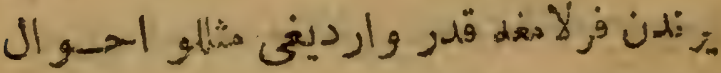

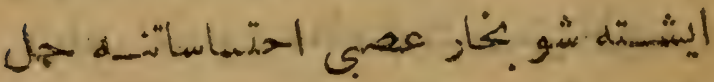

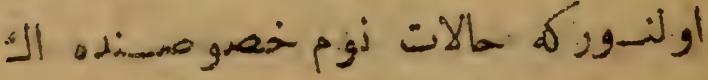

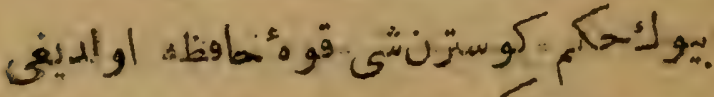

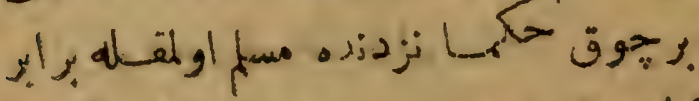

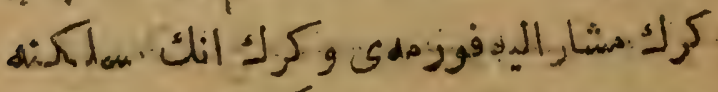

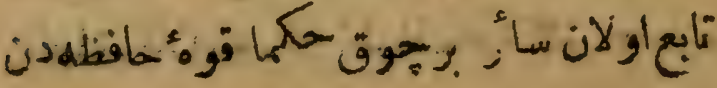


997 絭

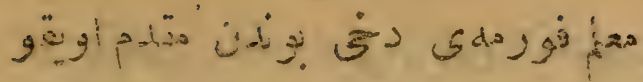

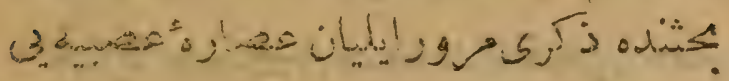

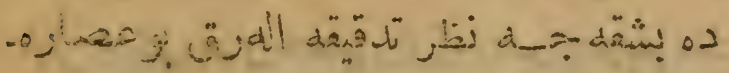

d...

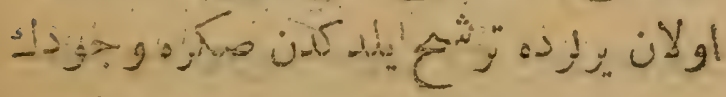

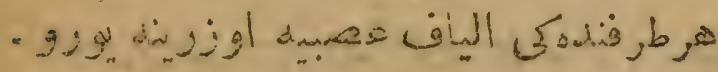

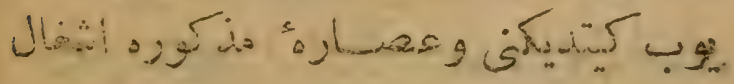

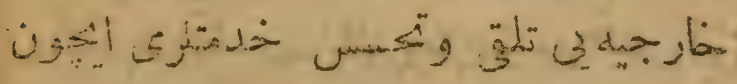

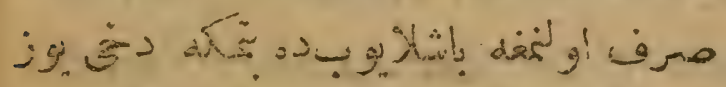

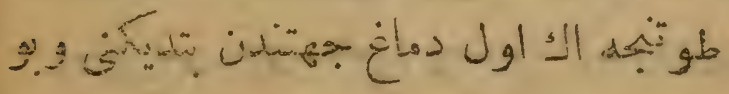

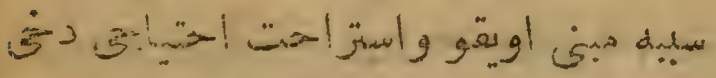

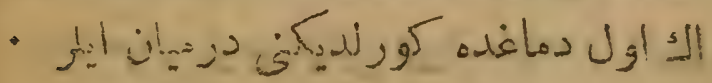

Q2

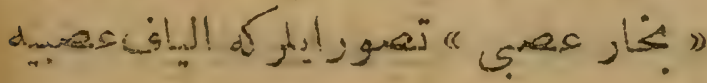

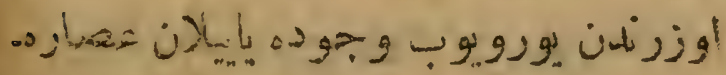




\section{0 繁}

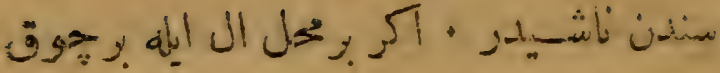

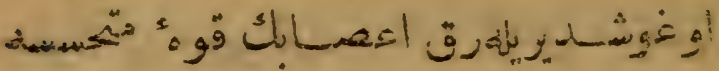

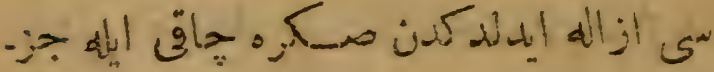

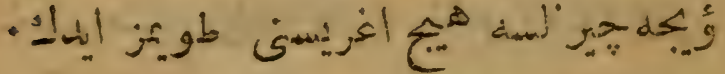

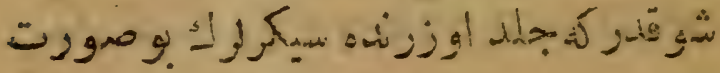

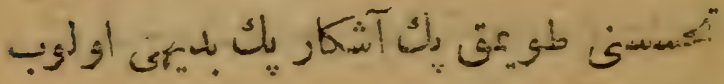

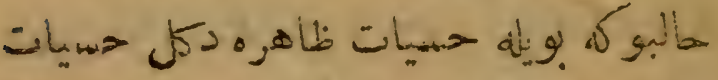
بان

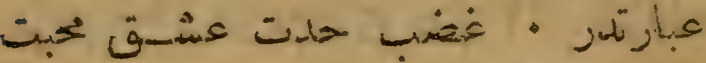

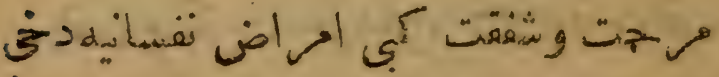

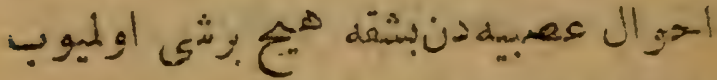

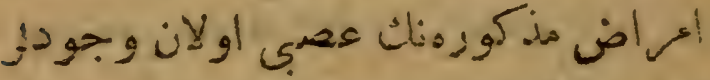

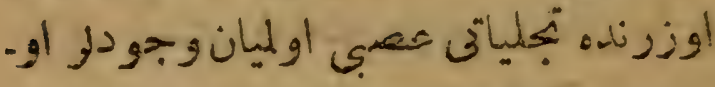

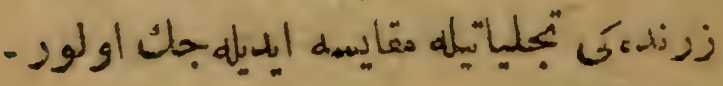

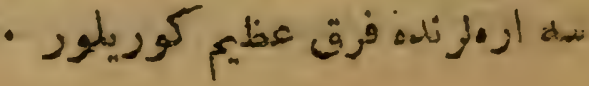




\section{2}

|ه:

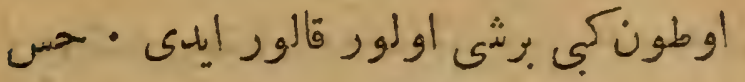

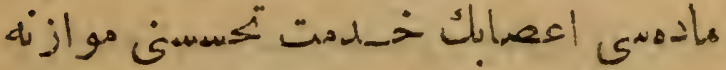

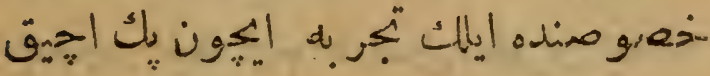

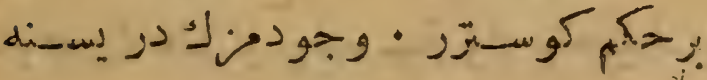

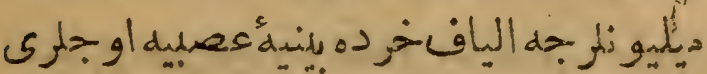

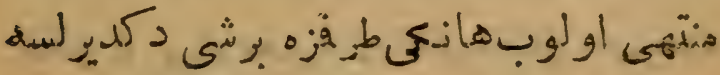

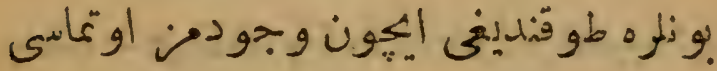

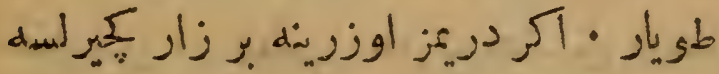

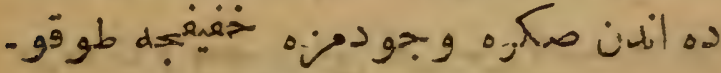

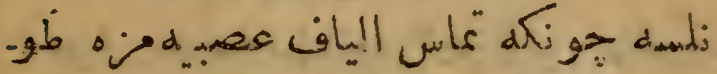

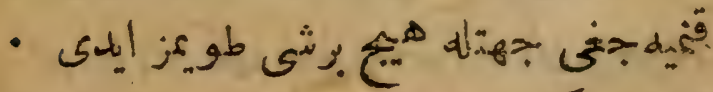

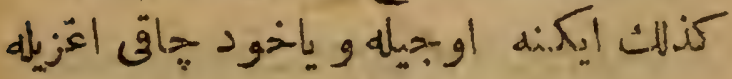

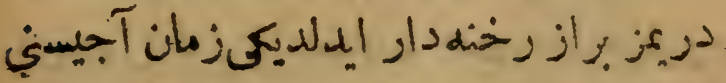

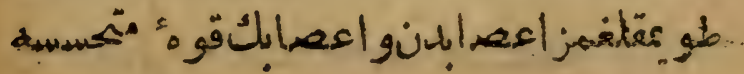




\section{繁 $4 \mathrm{r}$}

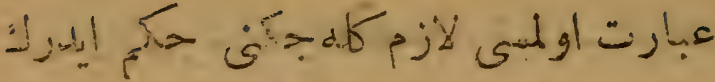

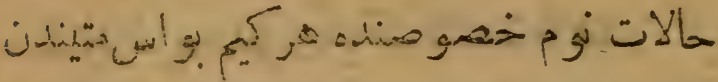

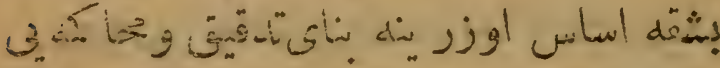

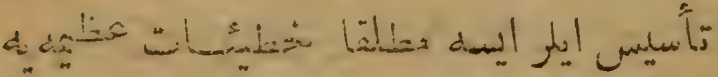

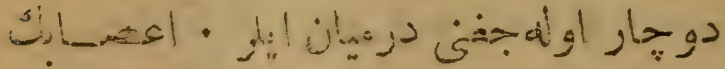

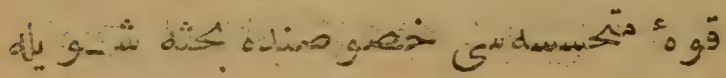

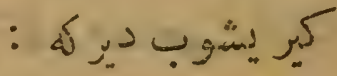

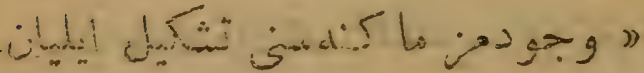

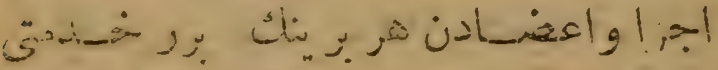

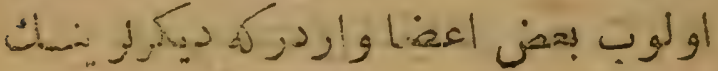

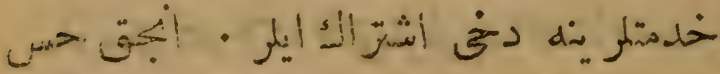

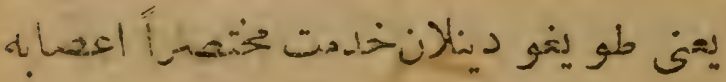

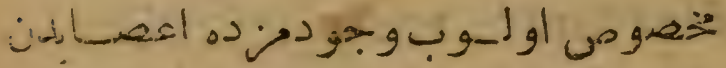

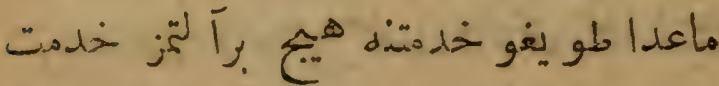

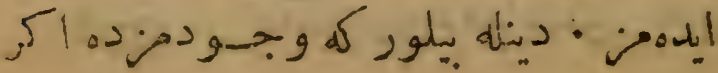


98 䊅

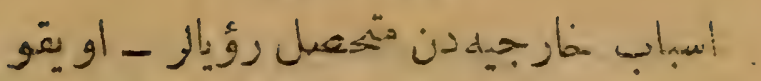

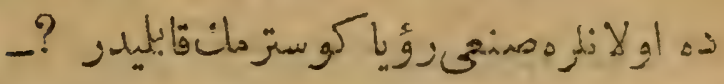

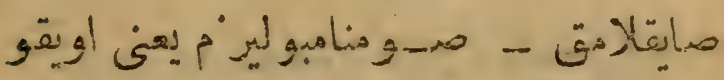
1 ثير

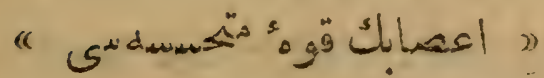

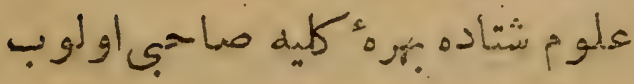

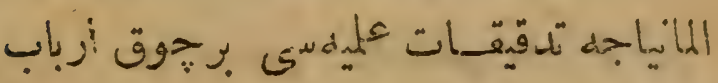

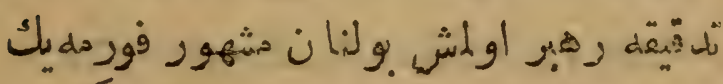

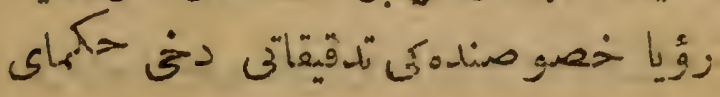

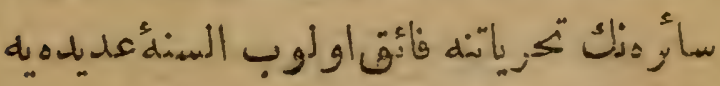

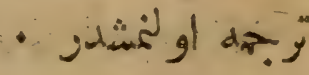

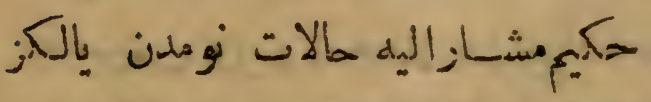

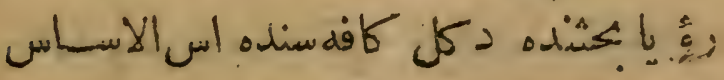

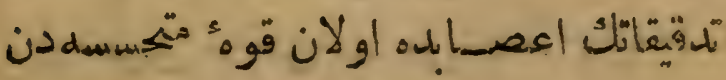




\section{1 类}

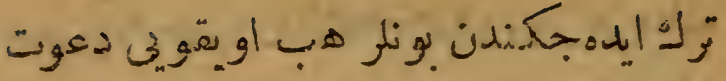

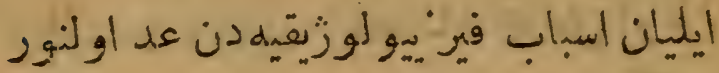

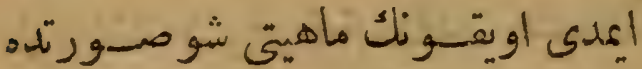

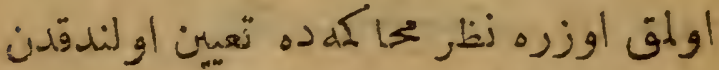

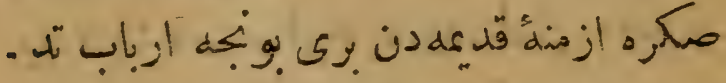

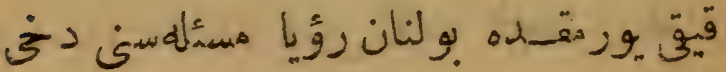

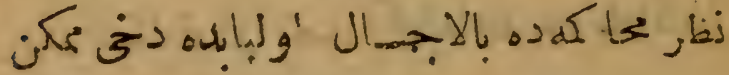

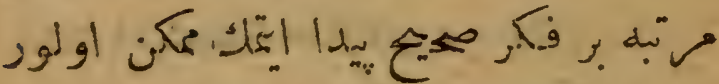

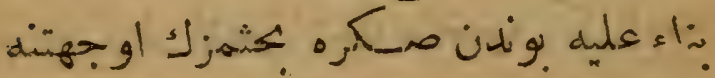

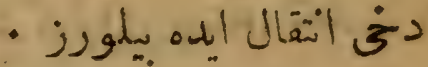

$$
\begin{aligned}
& \text { (نان (ن) }
\end{aligned}
$$

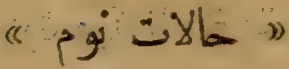

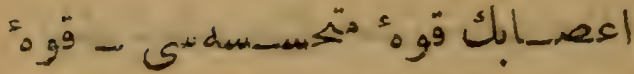

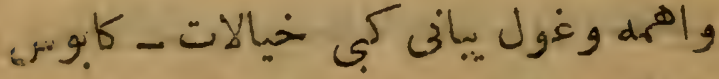

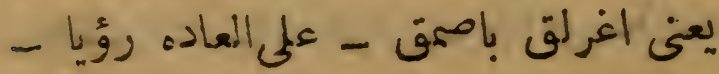


缕 9 . 淘

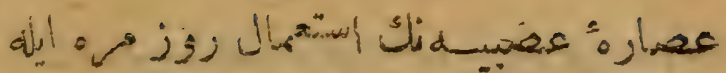

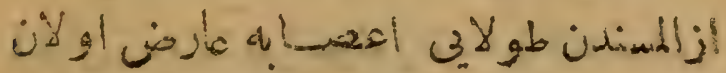

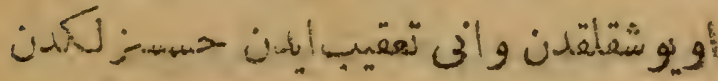

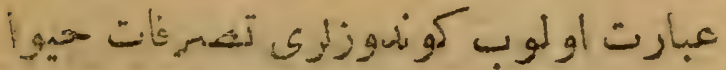

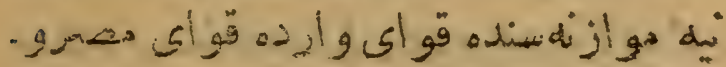

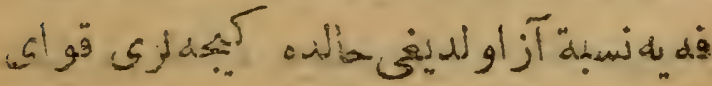

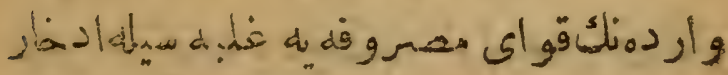

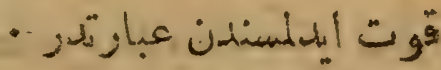

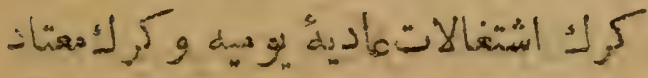

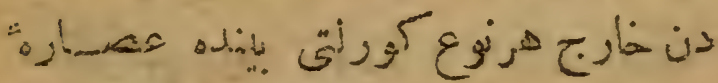

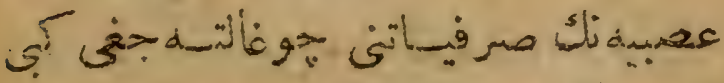

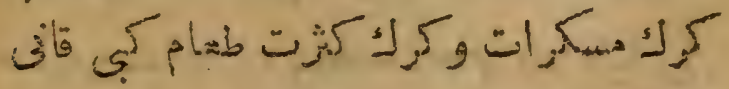

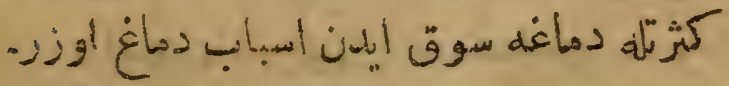

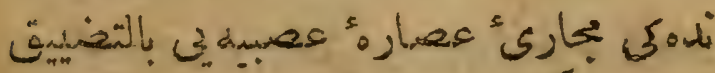

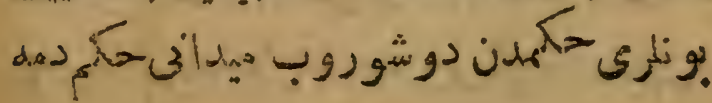




\section{AV慗}

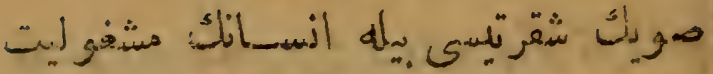

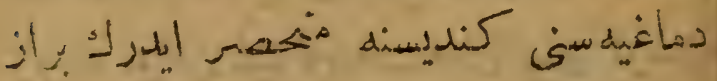

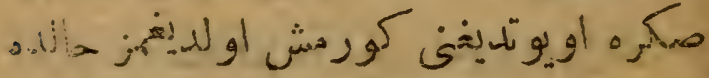

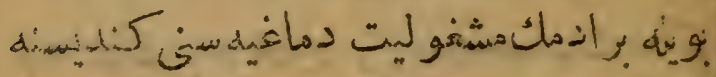

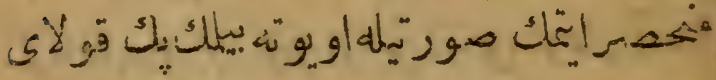

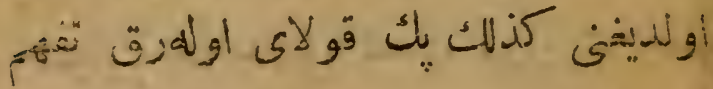

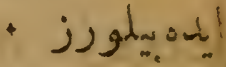

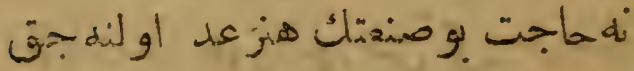

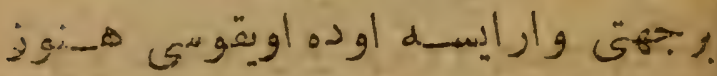

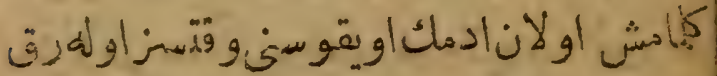

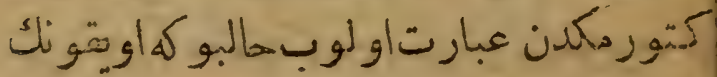

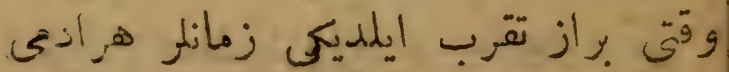

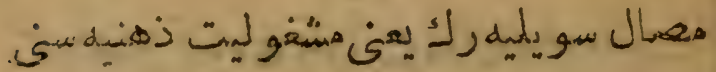

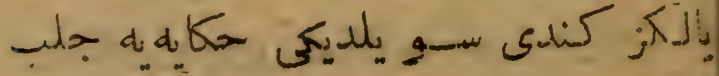

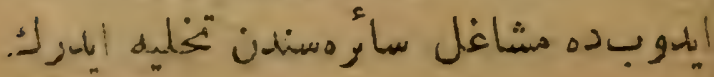




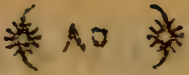

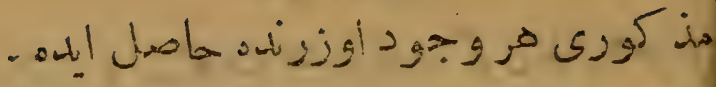

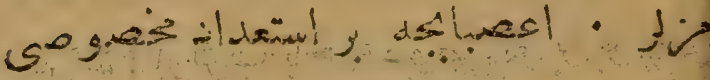

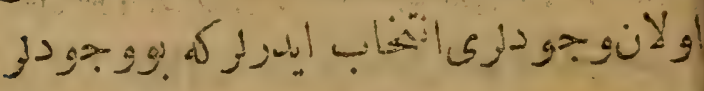

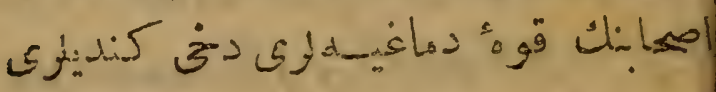

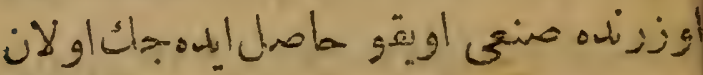

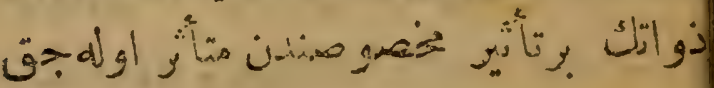

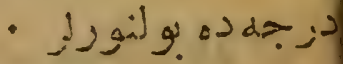

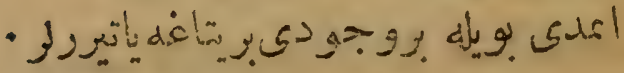

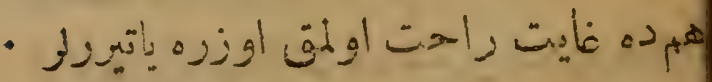

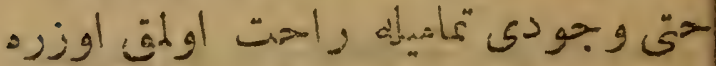

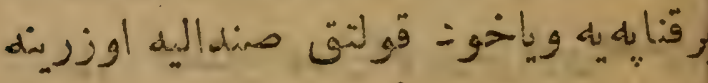

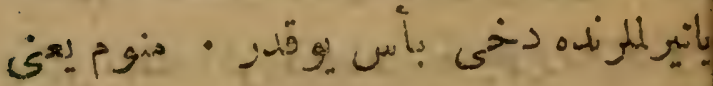

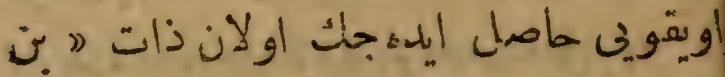

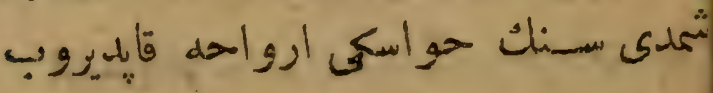

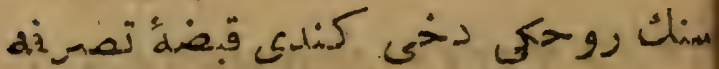




\section{慗的灙}

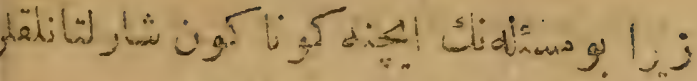

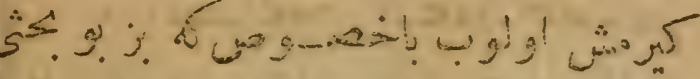

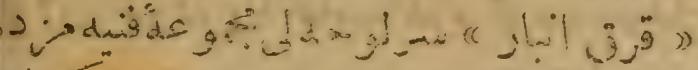

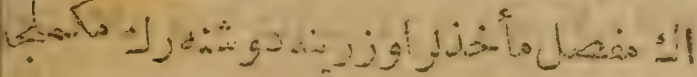

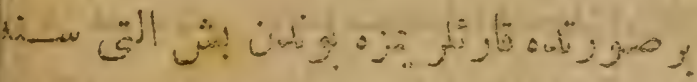

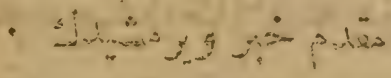

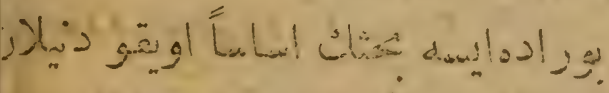

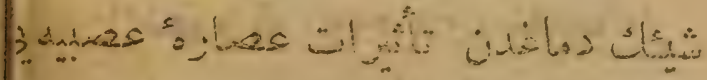
; d $\mid$ i ن ن

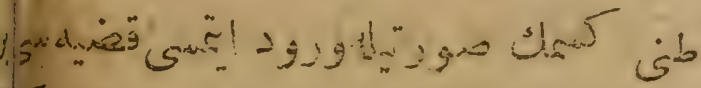

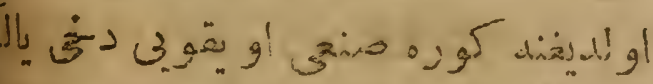

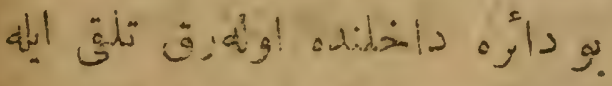
- jodidul

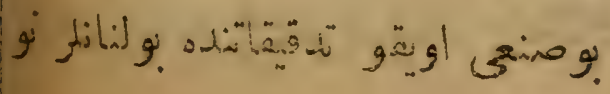




\section{* Ar 媇}

$$
\text { 1. ثم }
$$

$$
\text { " }
$$

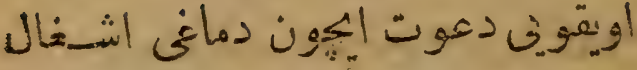

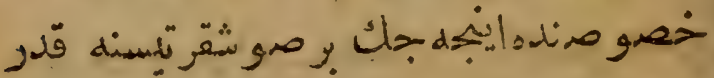

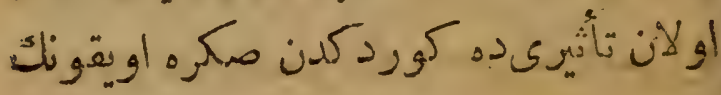

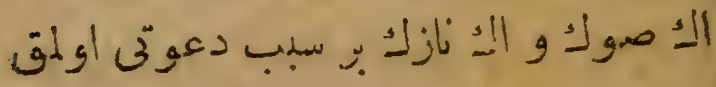

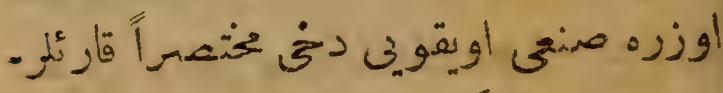

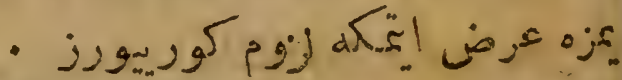

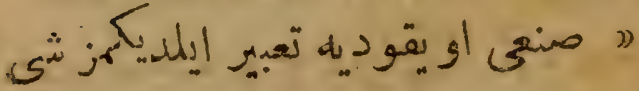

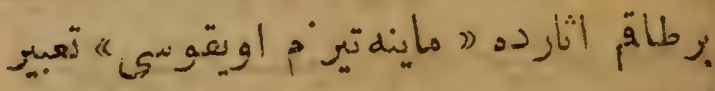

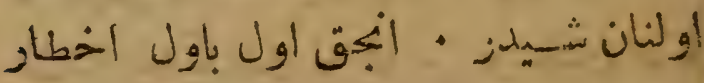

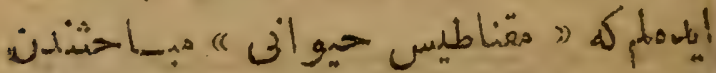

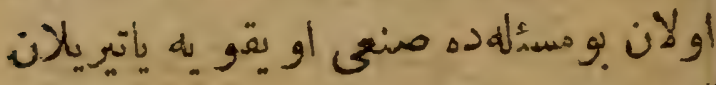

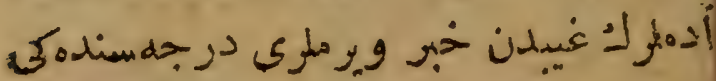

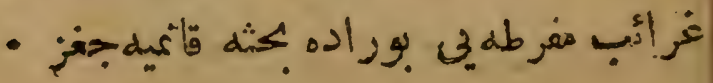




\section{ar}

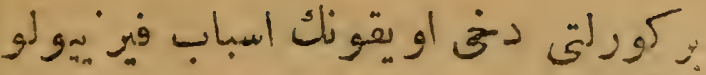

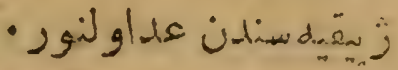

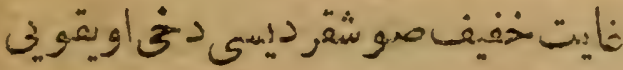

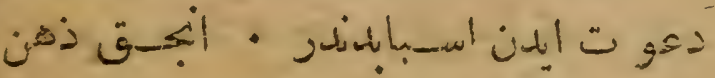

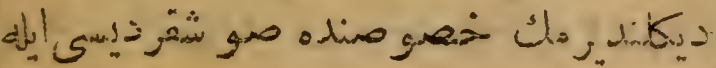

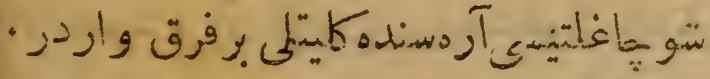

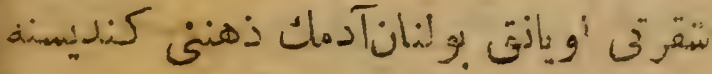

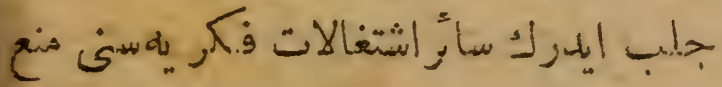

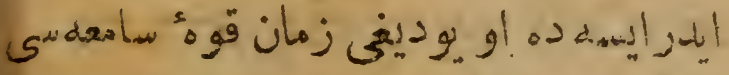

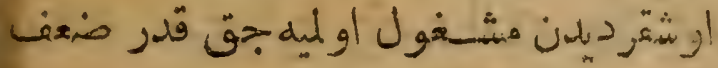

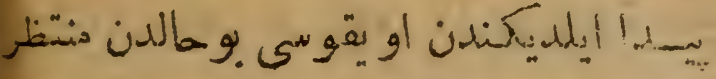

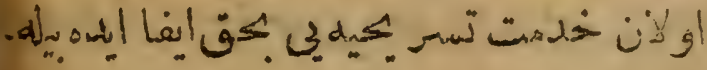

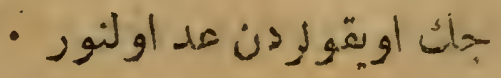




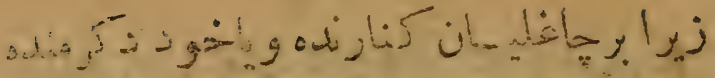

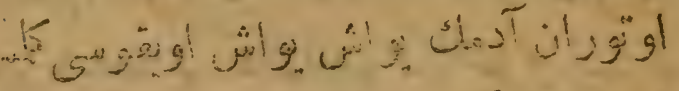

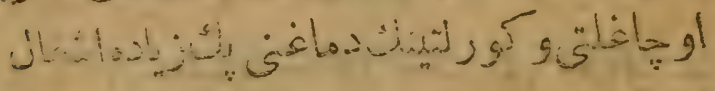

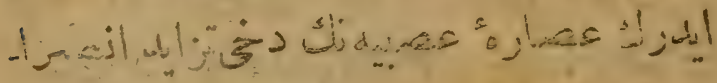

d

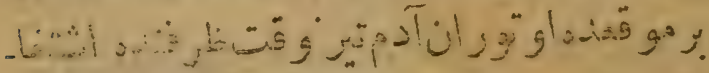

ن

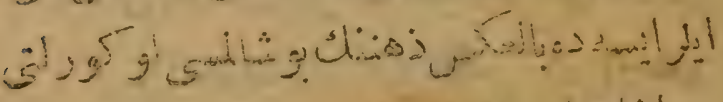

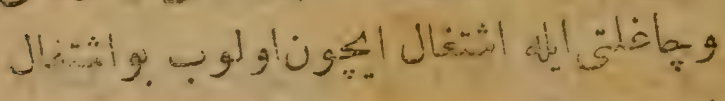

-

ذं d \&

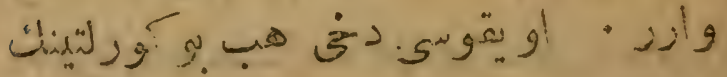

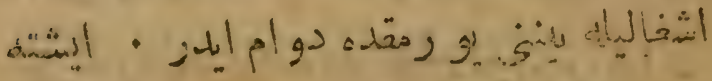

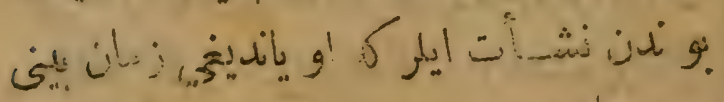

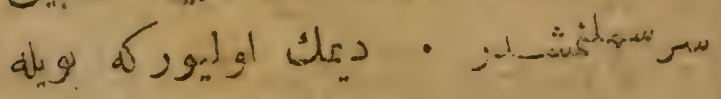




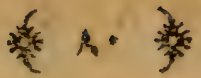

تj زور لاد"

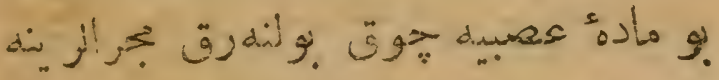

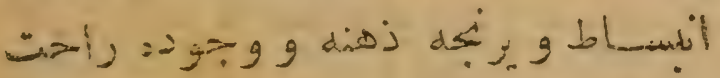
كاوب

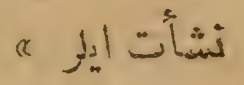

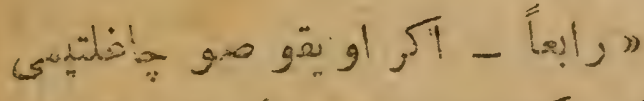

و و كرن

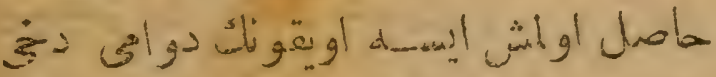

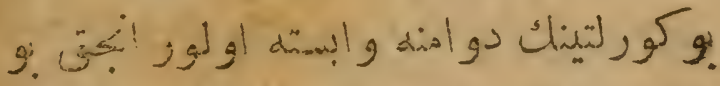

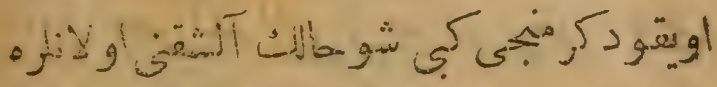

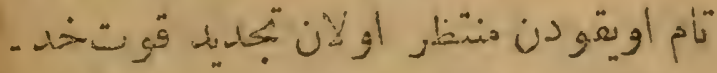

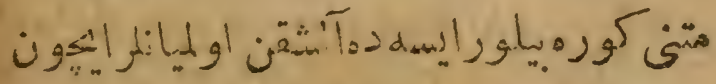

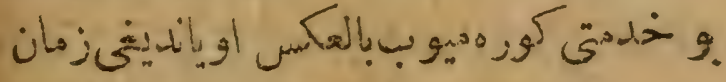

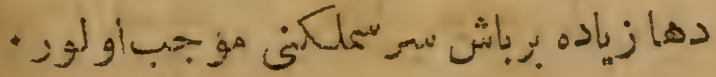




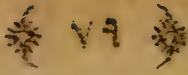

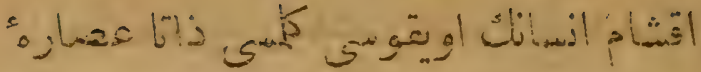

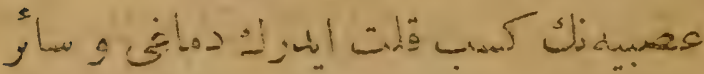

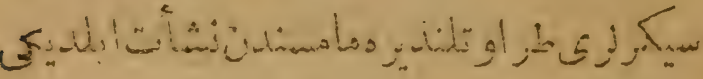

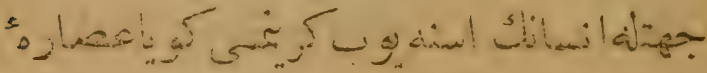
di jos

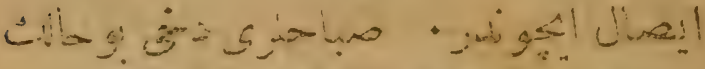

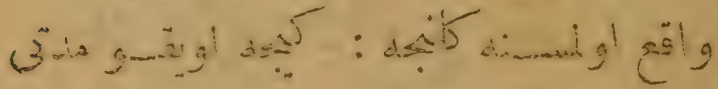
di d L L

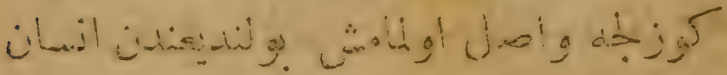

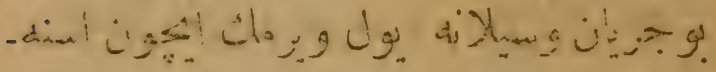

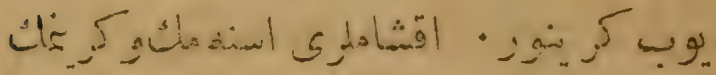

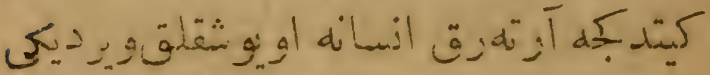
d-2.

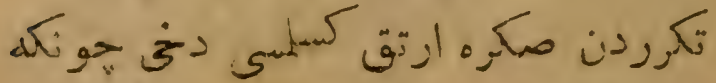

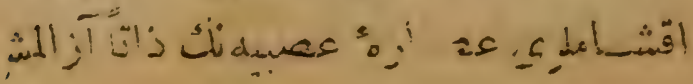


VA 类

d.

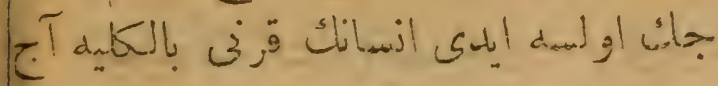

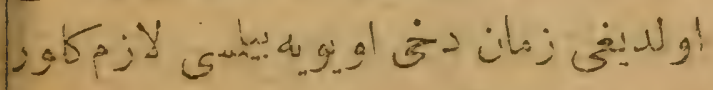

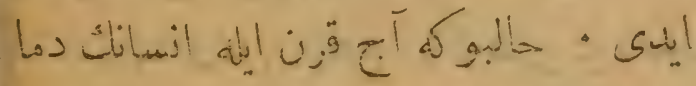

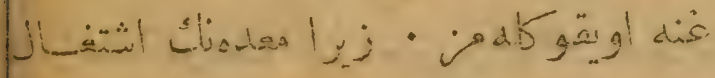

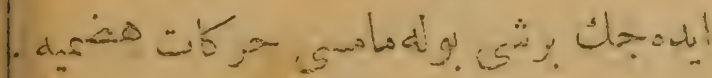

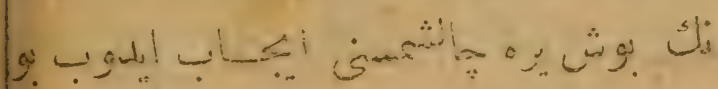

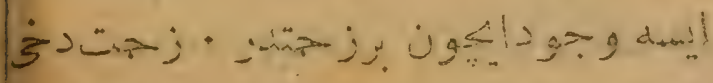

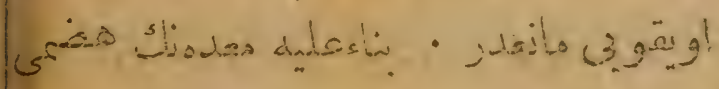

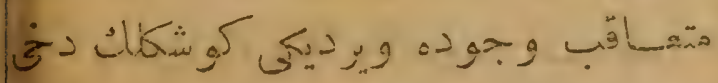

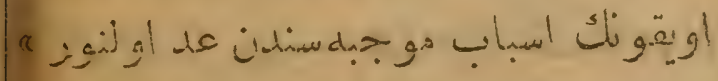

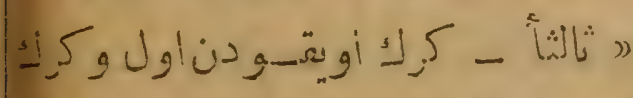

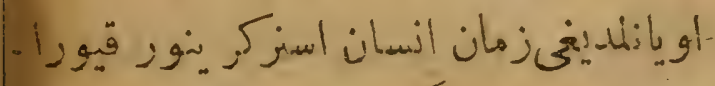

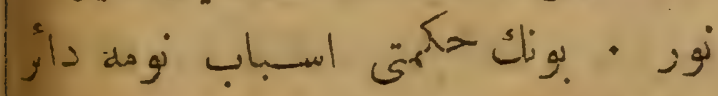

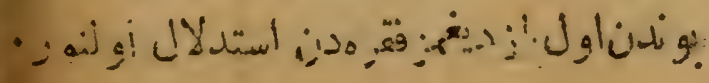




\section{VV 拳}

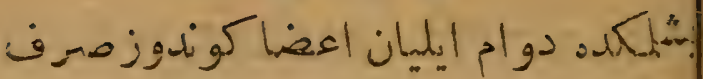

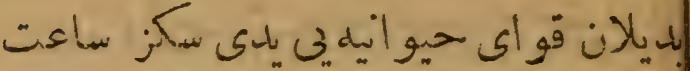

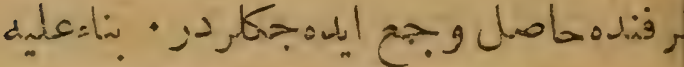

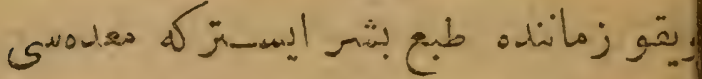

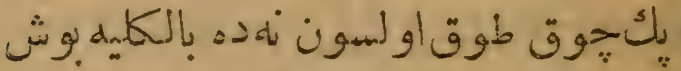

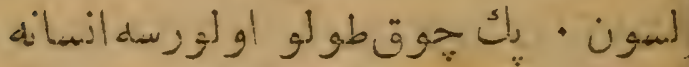

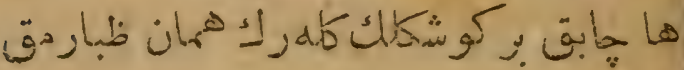

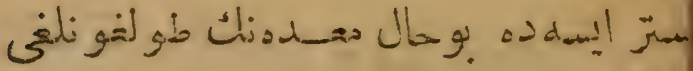

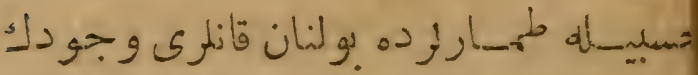

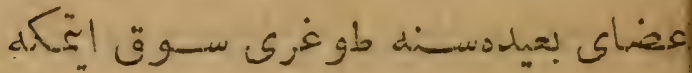

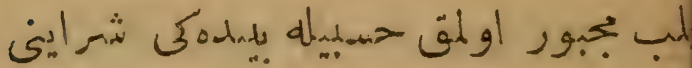

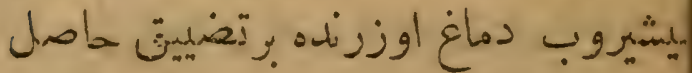

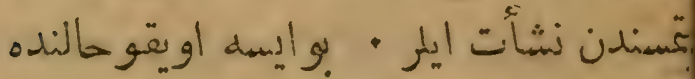
•

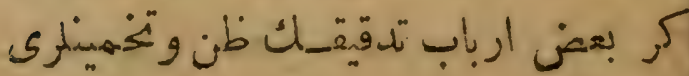


采 10 类

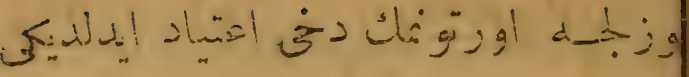

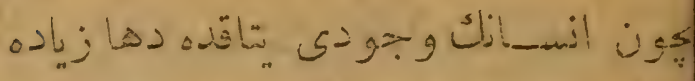

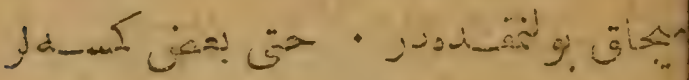

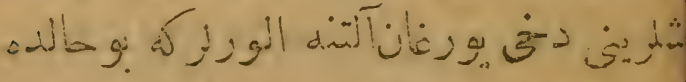
|ز

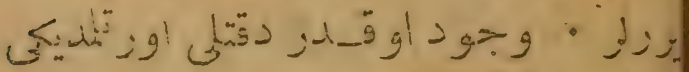
-

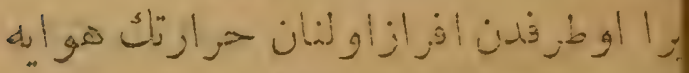

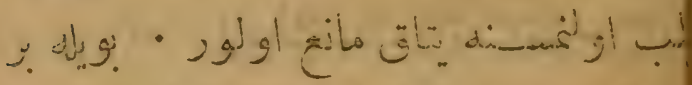

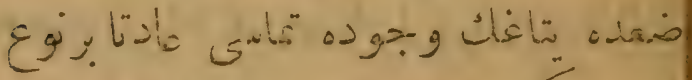

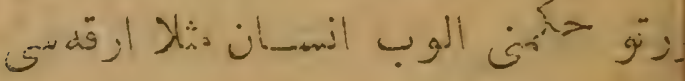

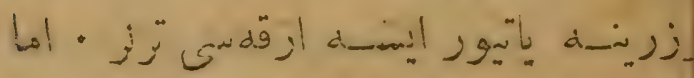

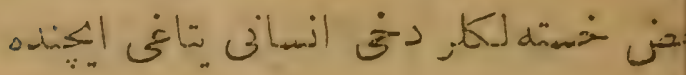

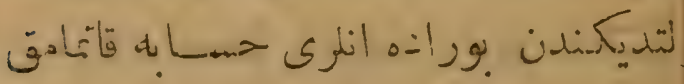

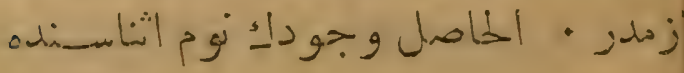




\section{难}

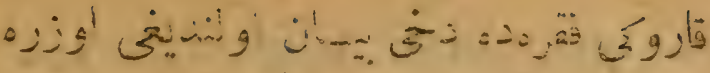
di

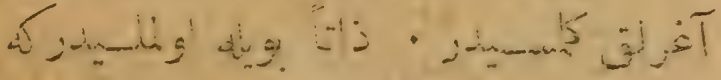

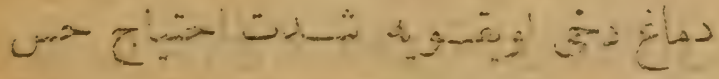

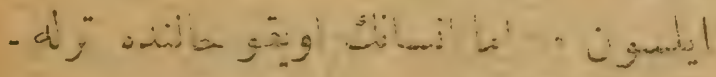

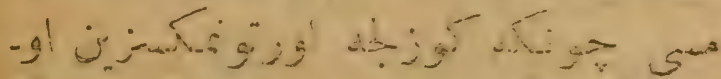

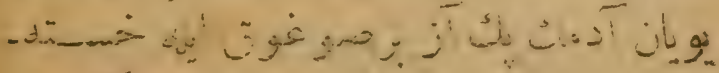
di ه

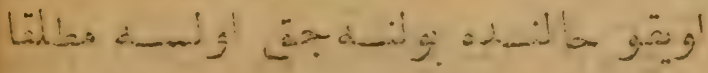

-

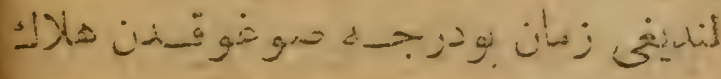
di

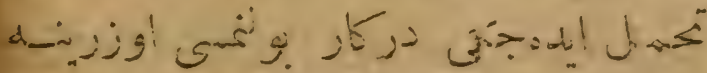

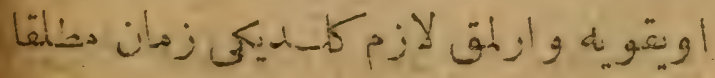




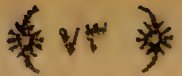

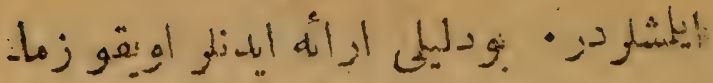

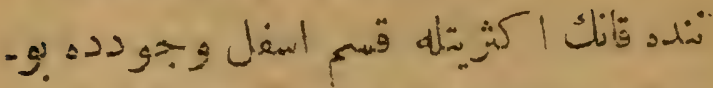

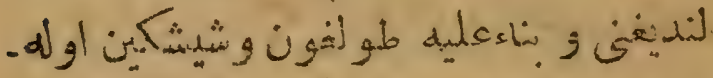

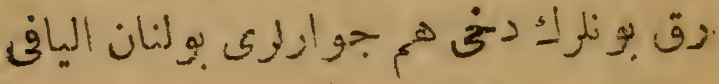

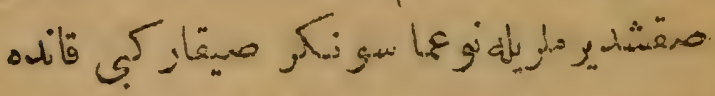

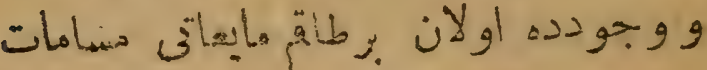

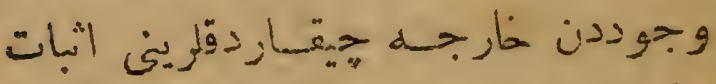

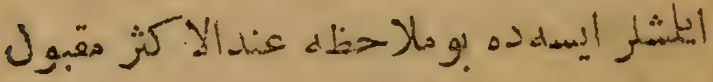

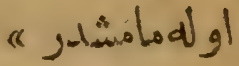

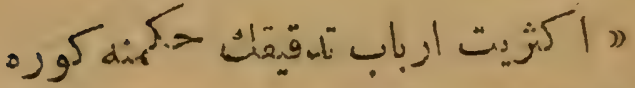

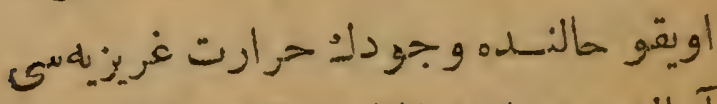

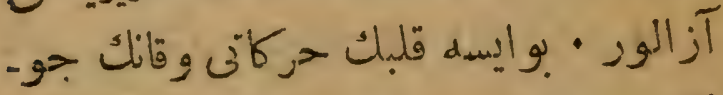

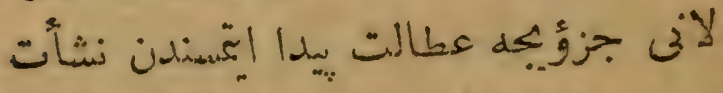

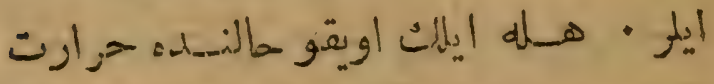

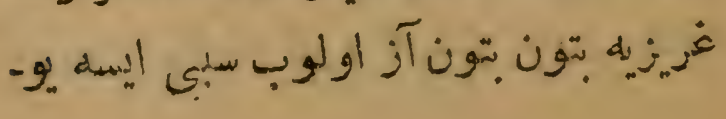


vr

9 مي

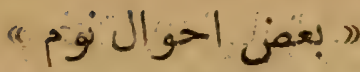

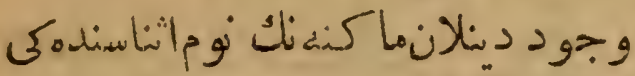

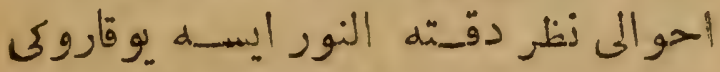

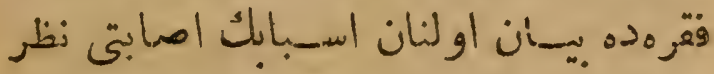

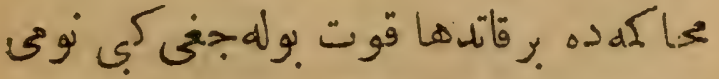

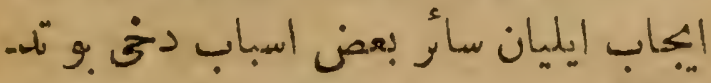

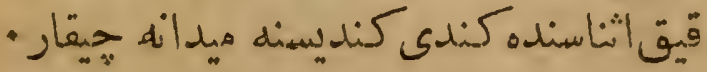
. : لمإl dol do

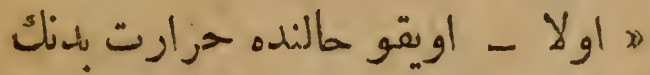

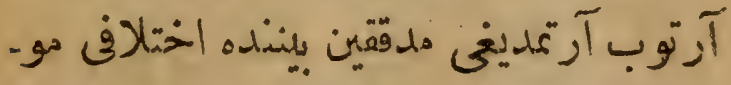

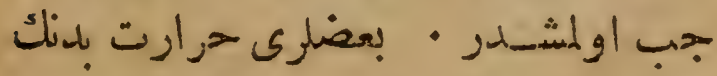

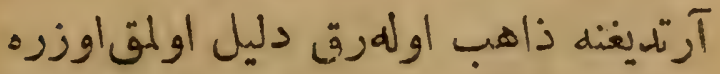

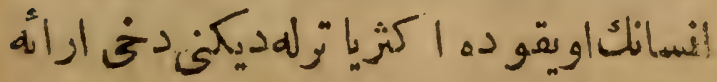




\section{类}

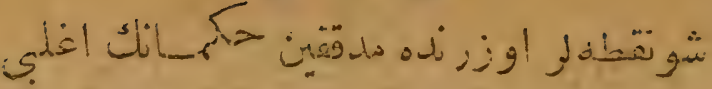

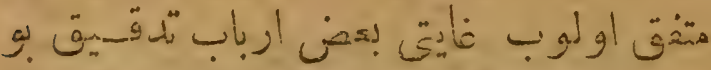

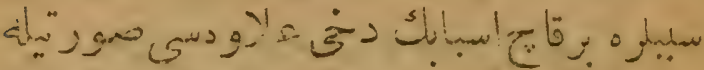
ثs

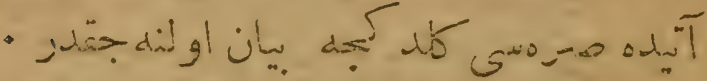

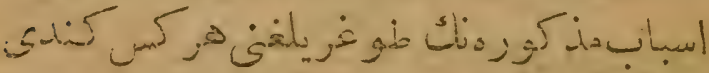

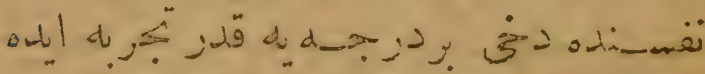
.

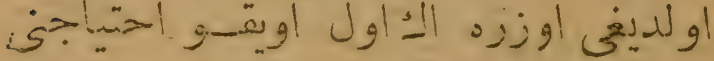

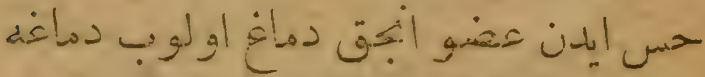

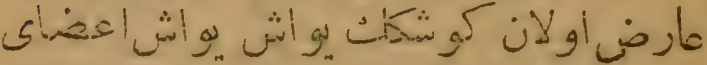

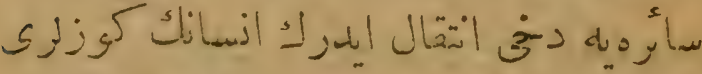

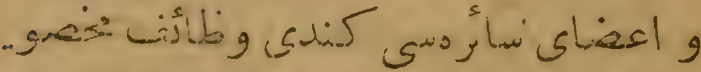

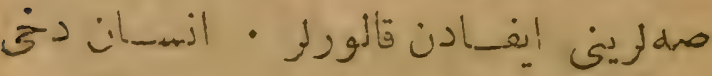

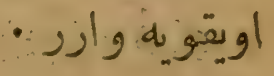




\section{*}

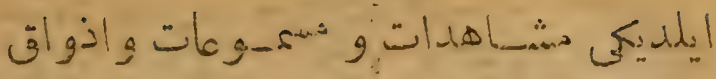

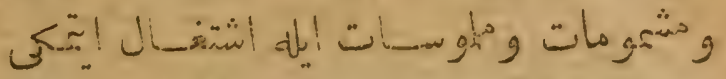

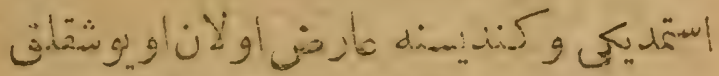

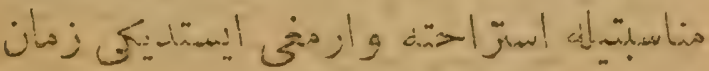
كو

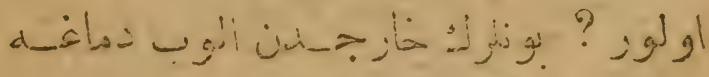
dغاغla

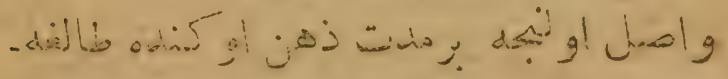

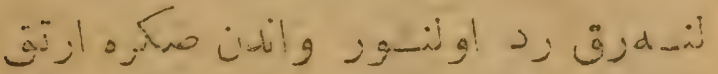

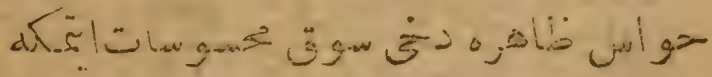

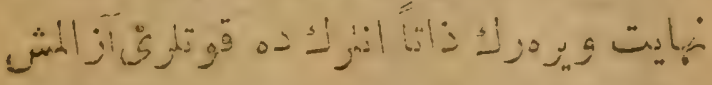

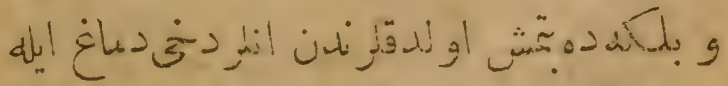

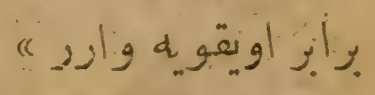

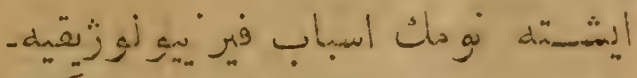

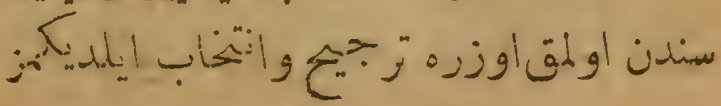




\section{* 79}

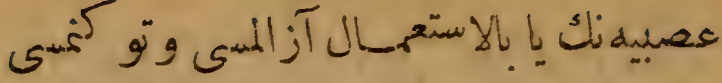

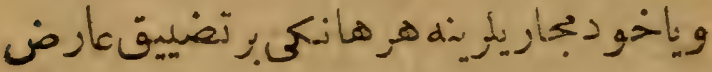

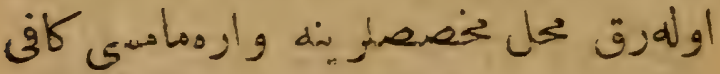

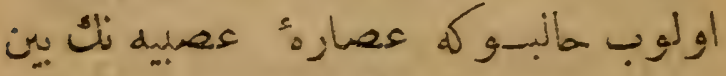

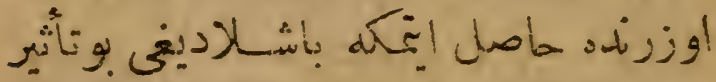

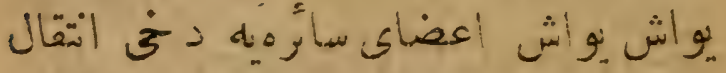

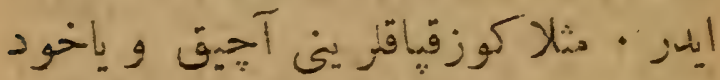

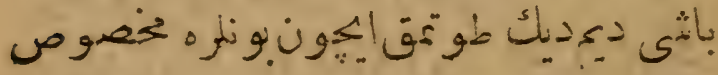
4.

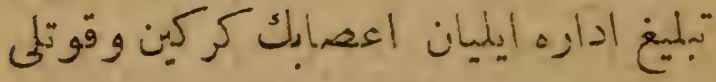

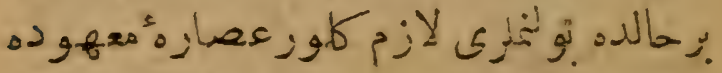

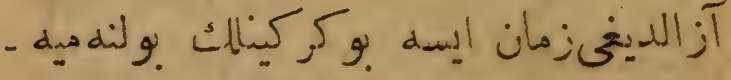

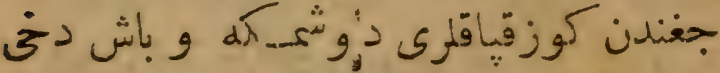

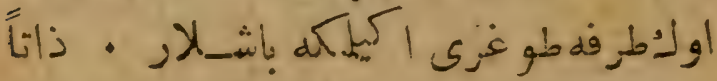

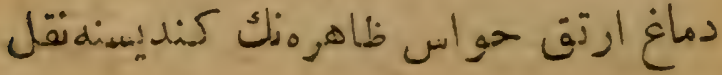




\section{絭 $71 \cdot$ 滦}

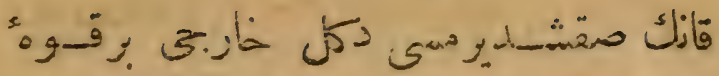

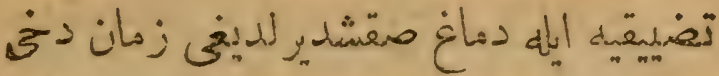

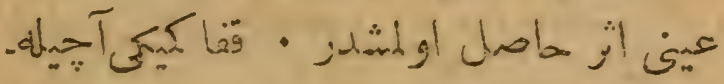

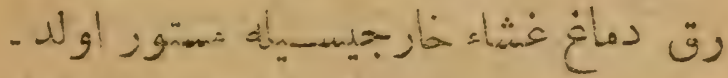

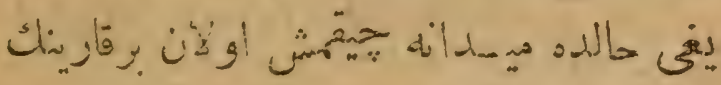

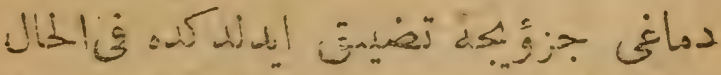

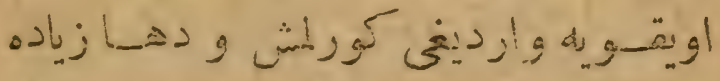

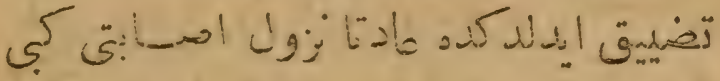

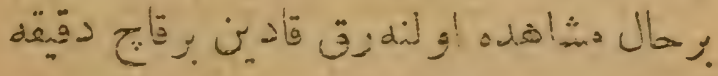

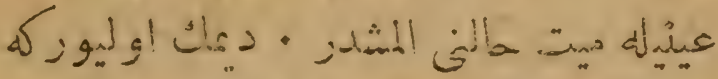

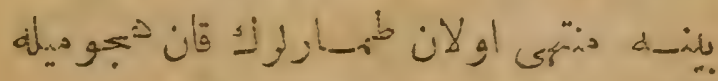

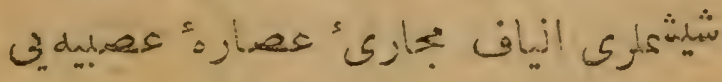

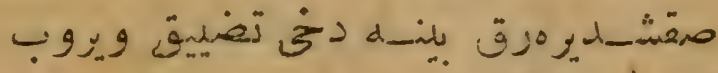

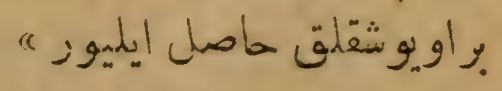

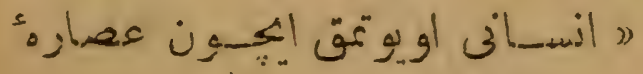


داغ do

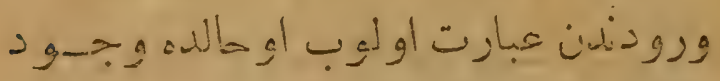

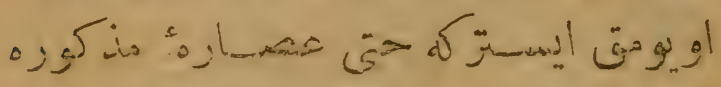
ن

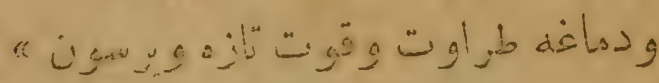

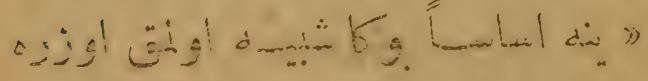

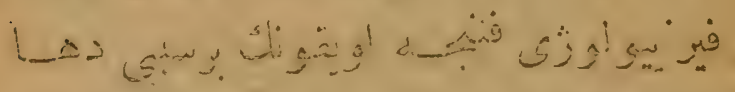
"s

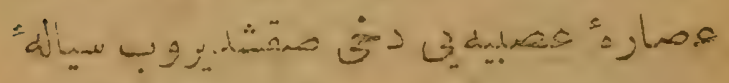

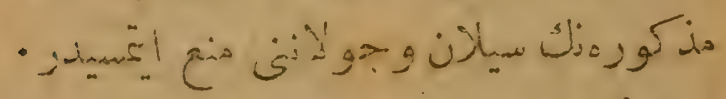

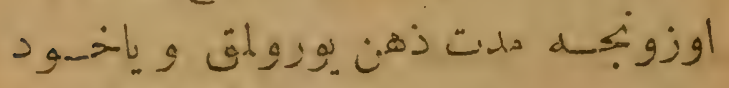

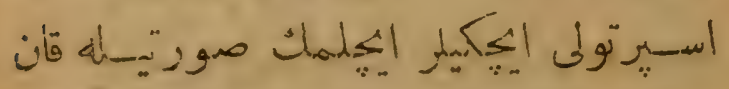

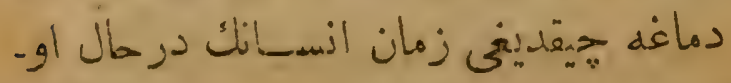

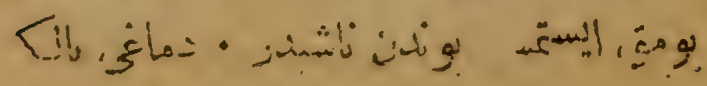


- با

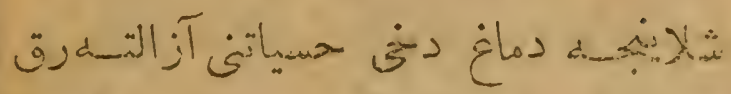

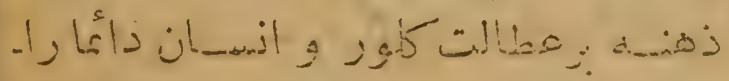

drojó

"

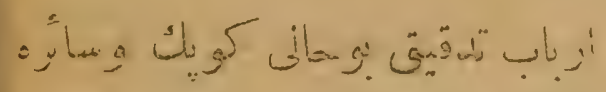

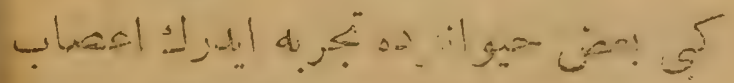

ibز ز

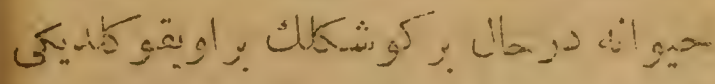

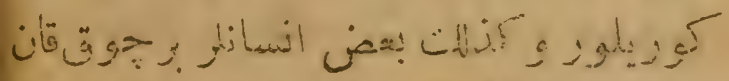

تnن

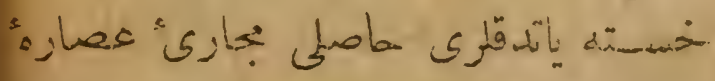

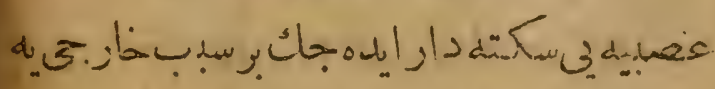

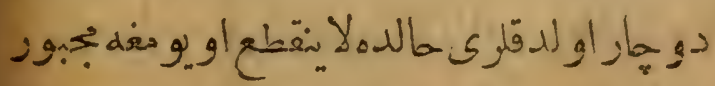

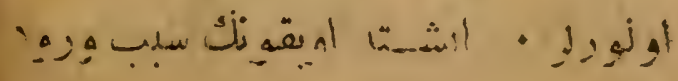




\section{0, 絭}

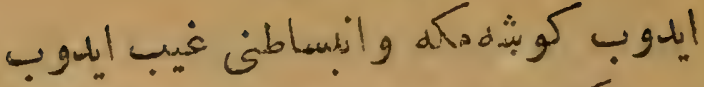

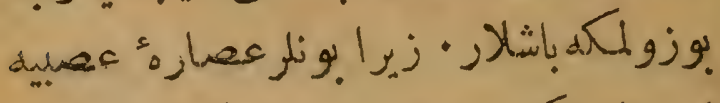

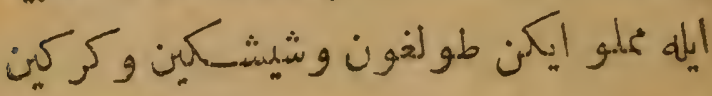

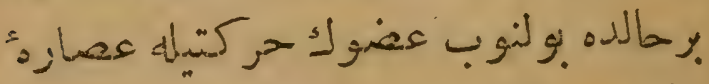

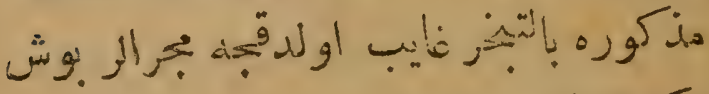

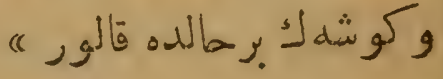

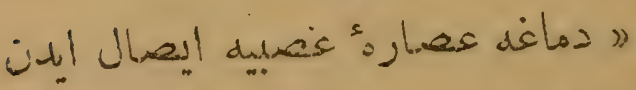

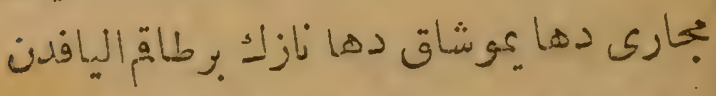

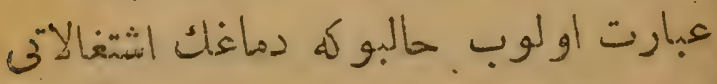

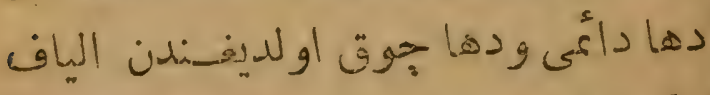

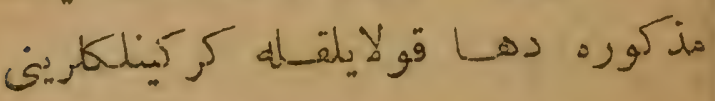

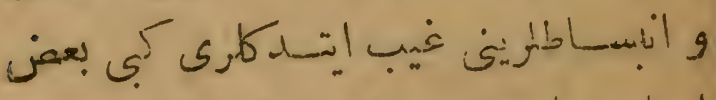

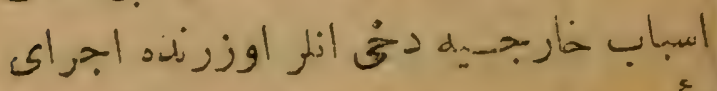

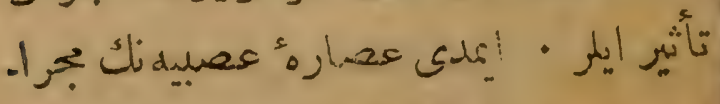

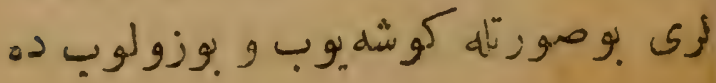


72

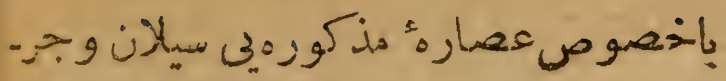

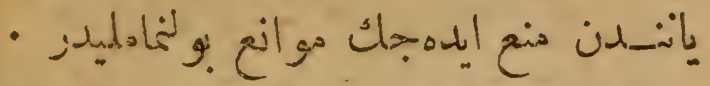

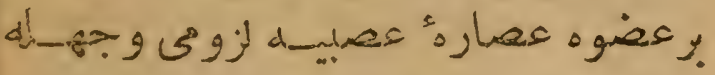

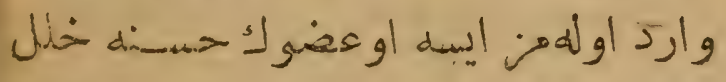

كلور •

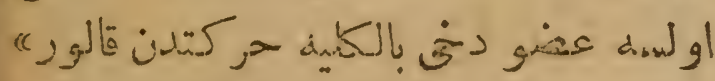

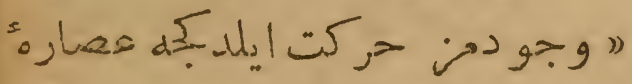

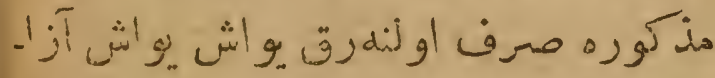

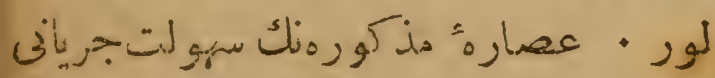

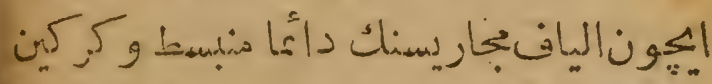

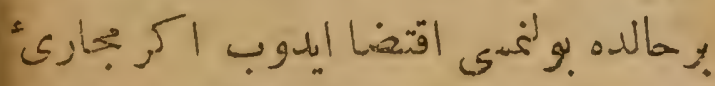

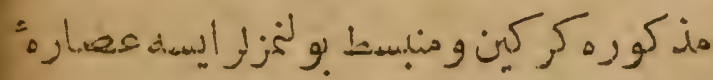

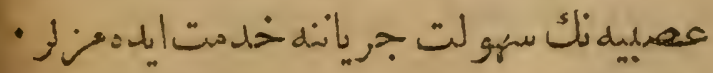

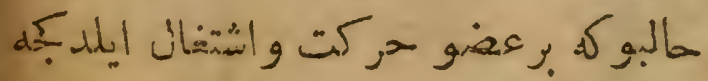

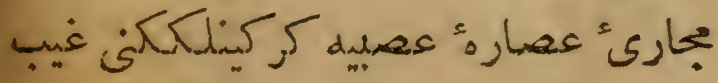




\section{( 7 r}

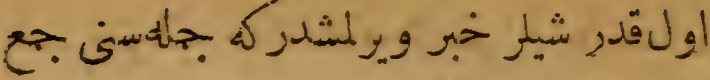

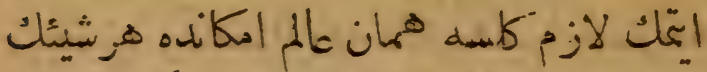

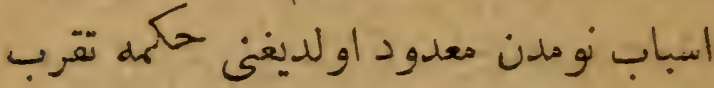

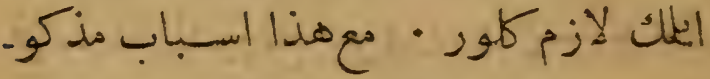

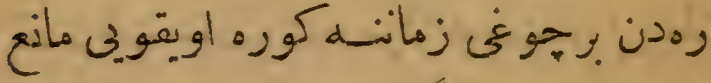

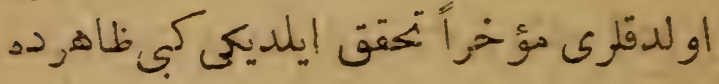

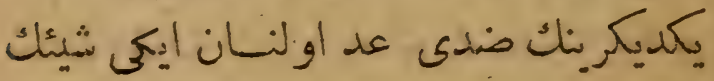

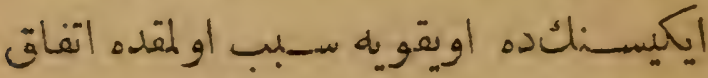

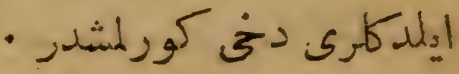

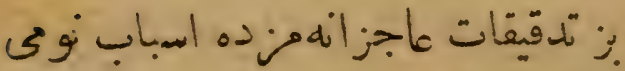

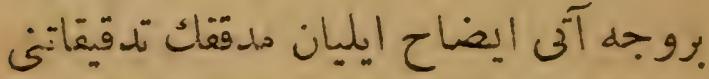
:

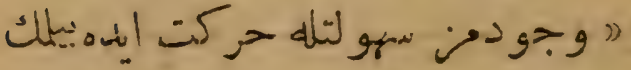

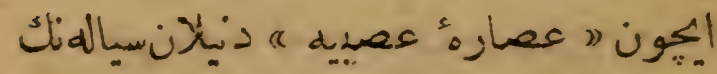

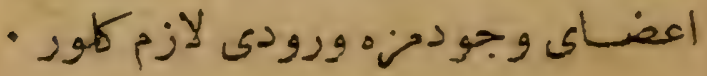




\section{盗 75}

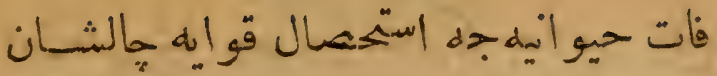

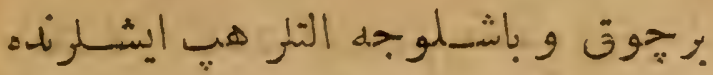

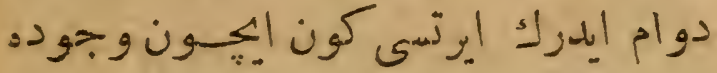

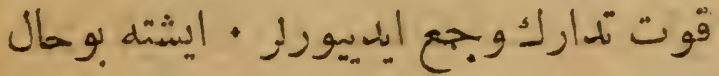

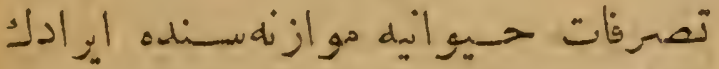

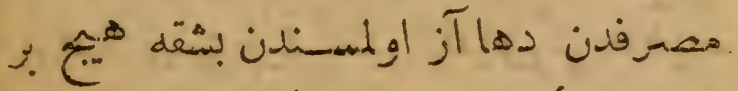

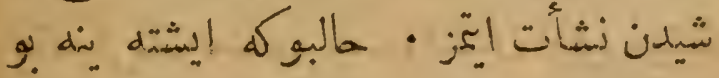

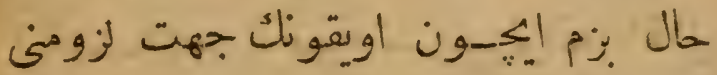

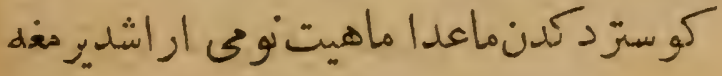

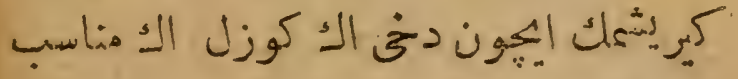

$$
\text { - والم آحار }
$$

\section{A مي}

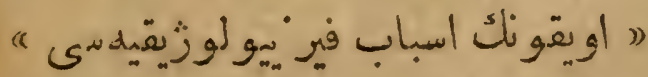

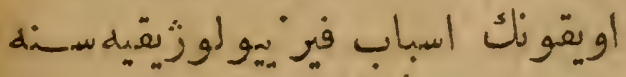

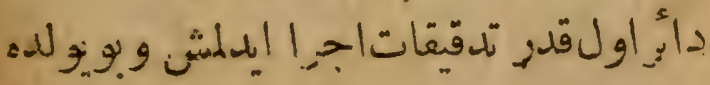




\section{1\%}

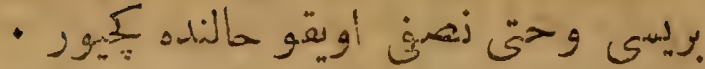

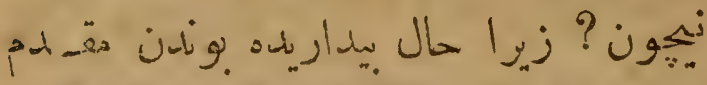

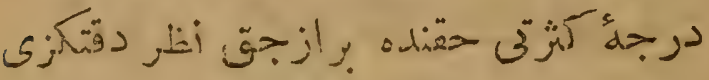

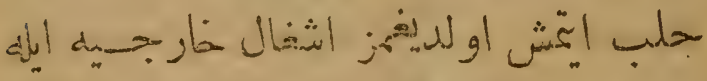

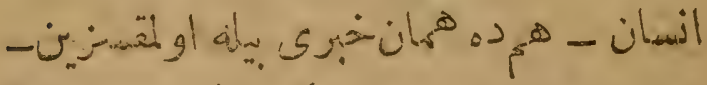

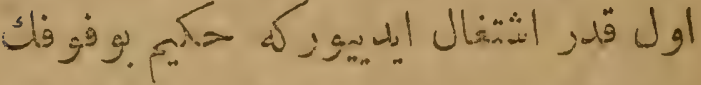

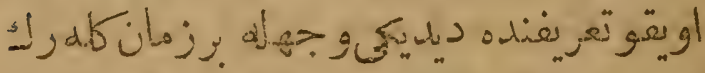

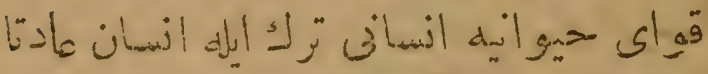

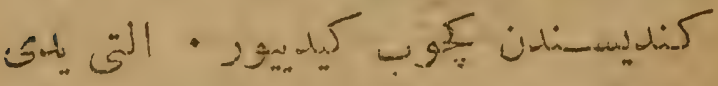

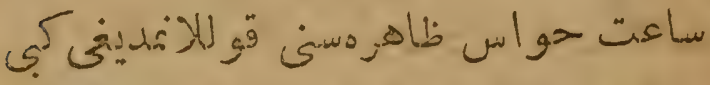

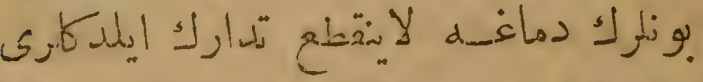

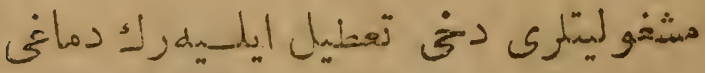

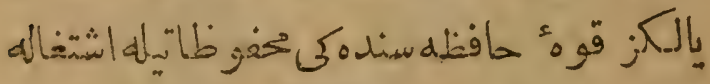

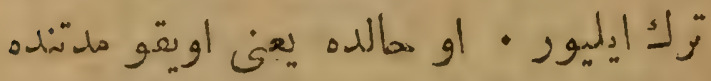

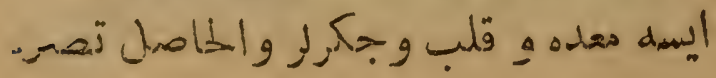




\section{7.}

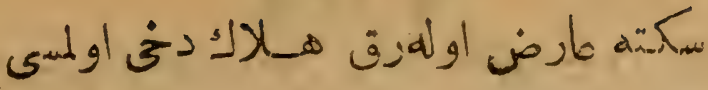

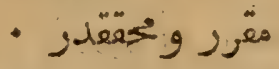

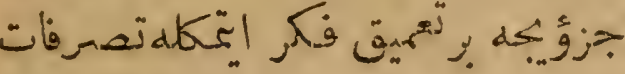

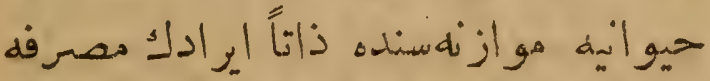

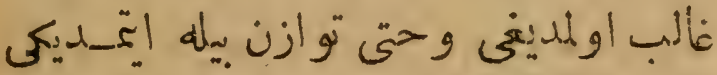

كوريلور • بلكمه براز دها تدقيقاته كيريشيله.

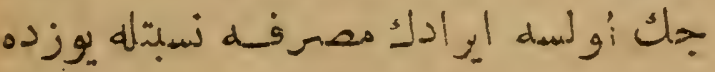

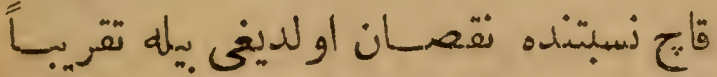

اولسون حساب اولنمق مككندز • .و موا.

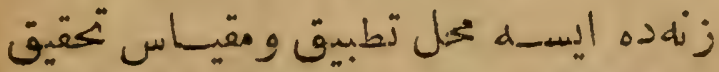

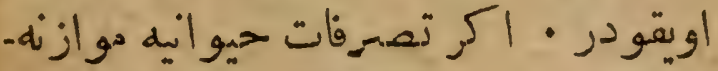

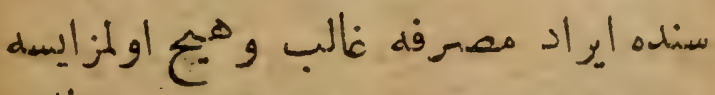

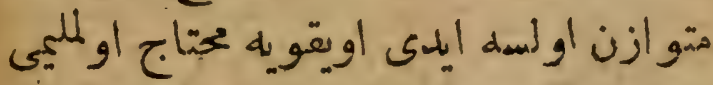

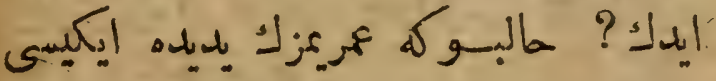

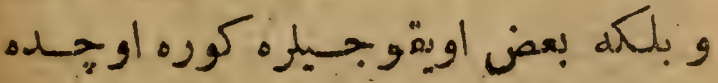




\section{*q}

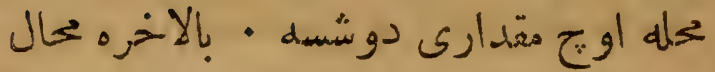

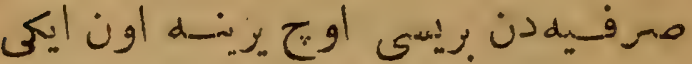

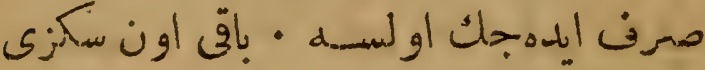

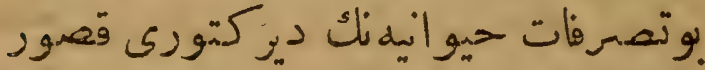

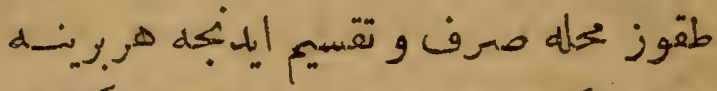

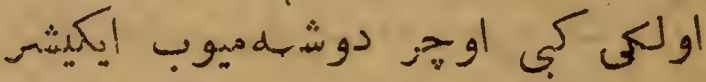

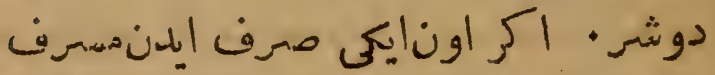

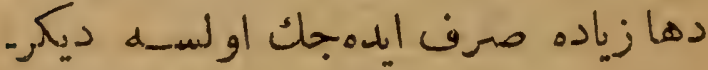

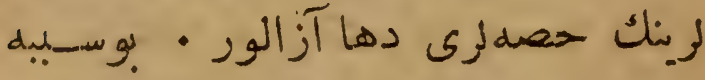

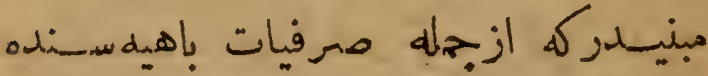

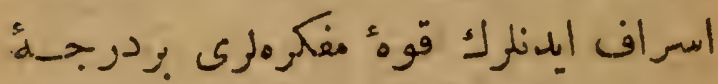

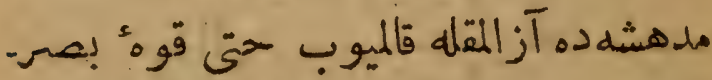

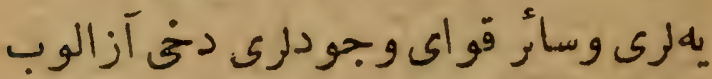
اكر اسرافات باهيه سنده دها ايلموريه كبدهـ

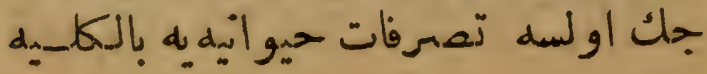


慗 0 人

كوريلور ايسسلده وجودينك جهات ساء

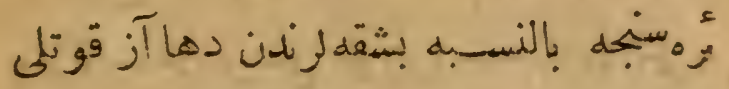

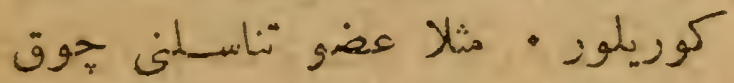

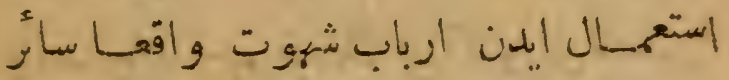

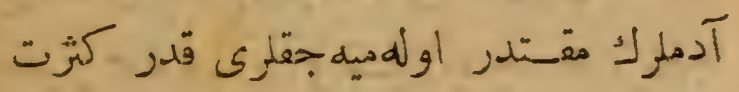

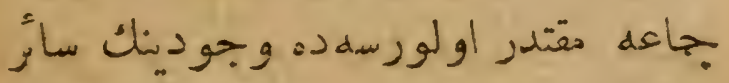

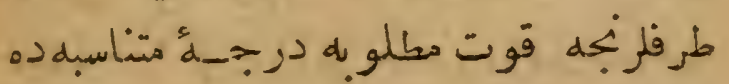

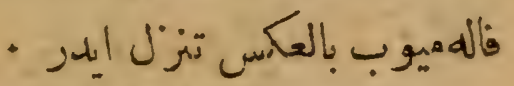

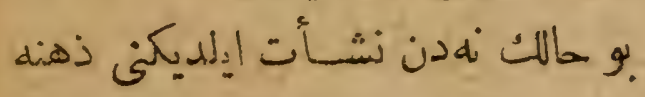

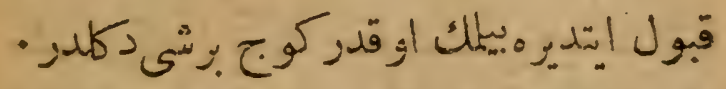

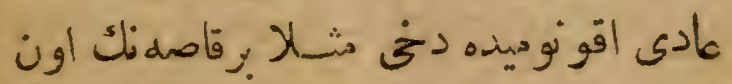

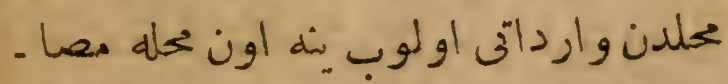

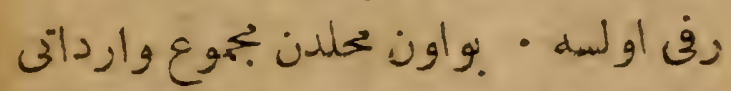

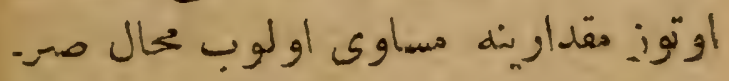

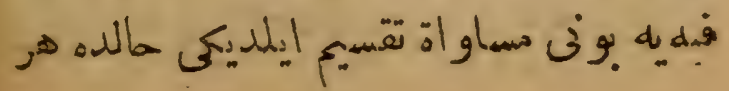




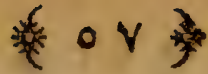

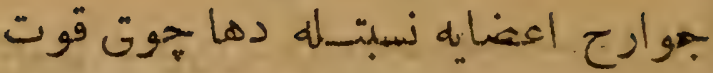

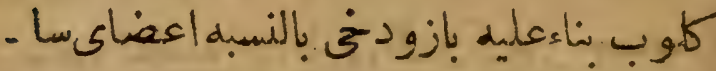

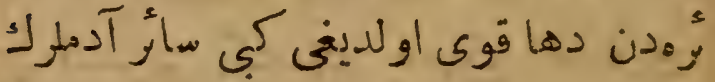

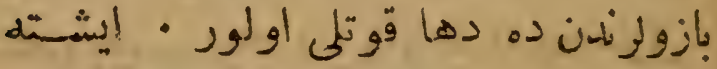

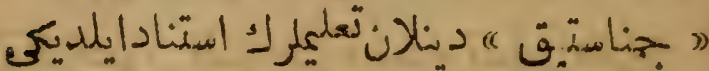

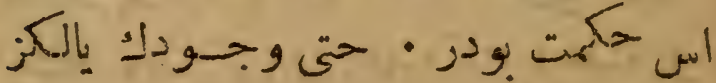

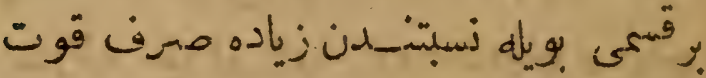

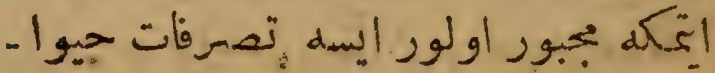

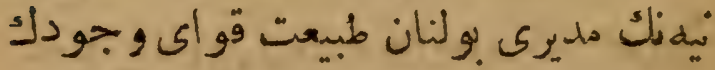

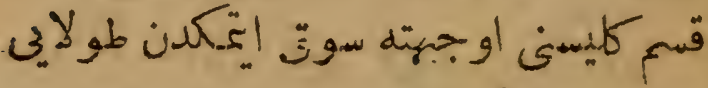

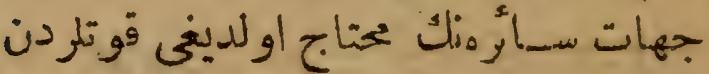

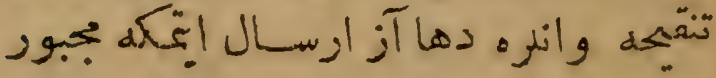

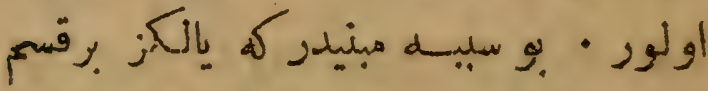

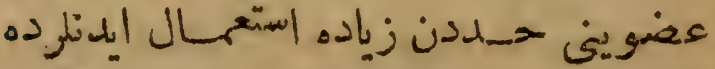

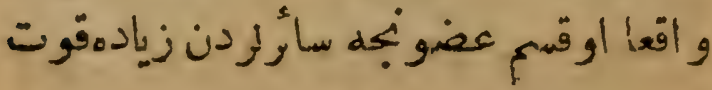




\section{or}

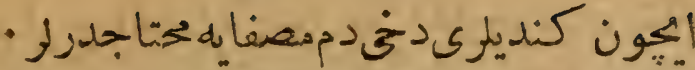

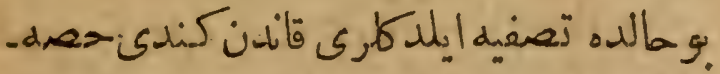

لرى فـدرين كمنديلرى صرف اليلدكارى

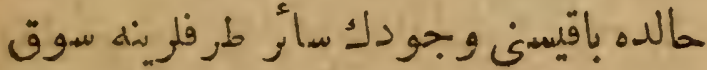

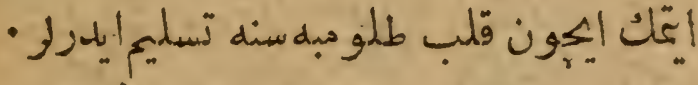

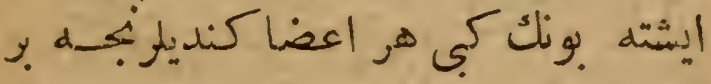

تصرف حمبوانى اير اد ومعسرفـه رعايت

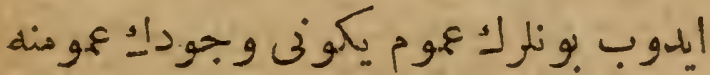

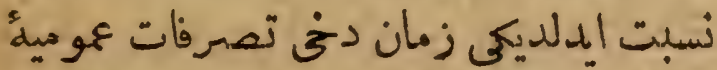

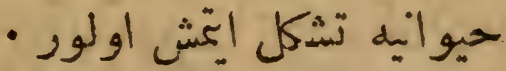

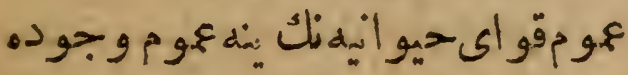

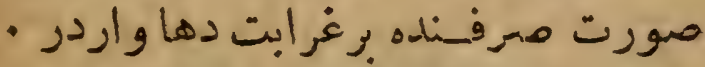

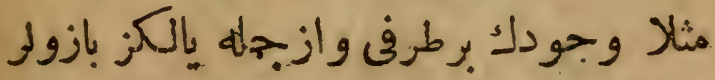
تحوق اشتغال اولنهرت هجوق قوت ضرفّه

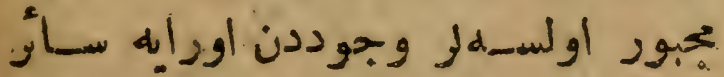


* 00

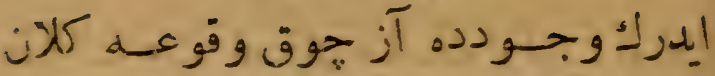

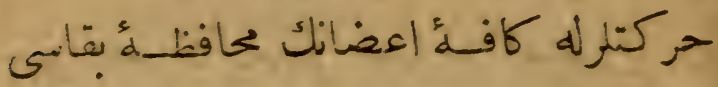

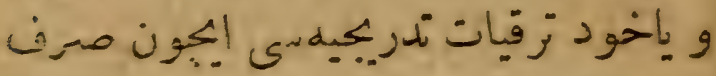

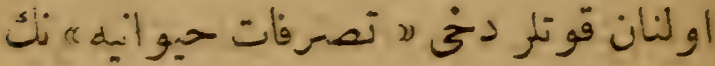

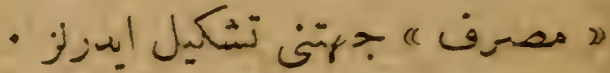

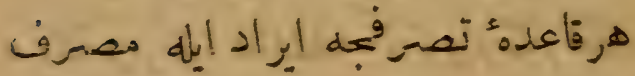

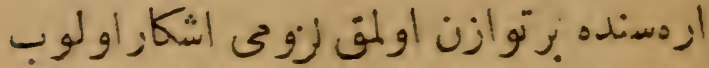

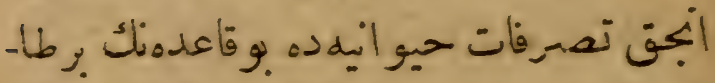

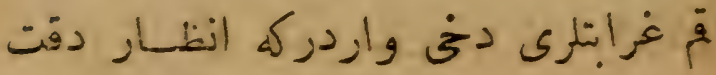
و اهمينى .ر صورت مغعورئهده كندى

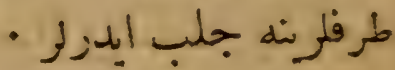
اولا اقليم بذنك هرجهتى بركرهكندي

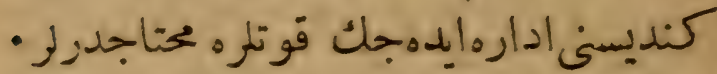

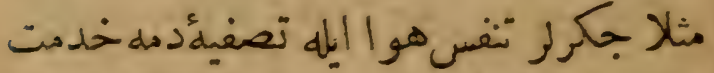

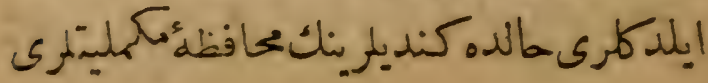


委 O\&

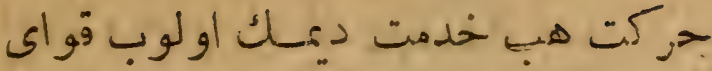

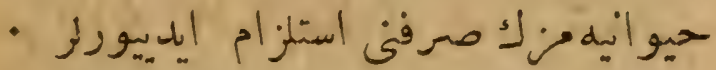

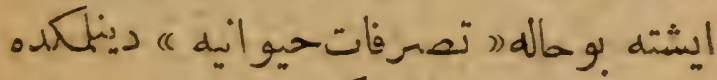
اولوب الثـتغال ايلديكمز اويتـو. بكثي ايله

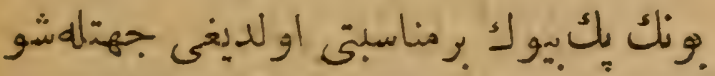

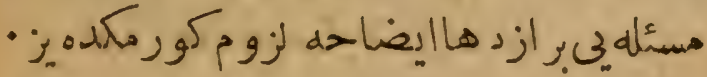

$$
v \text { مئن }
$$

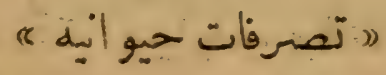

وجودلك برياندن معسدهيه القًا اولنهان

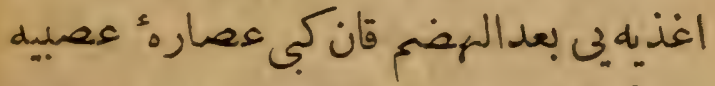

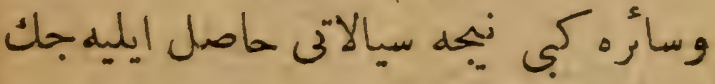

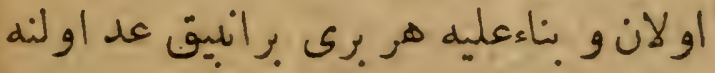

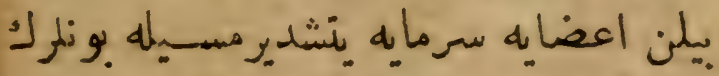
وجــوده كتوردكلرى قوتلر لا تصبرفات

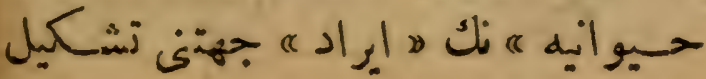


or

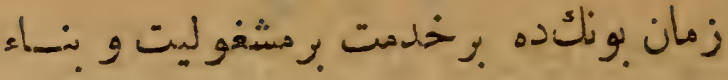

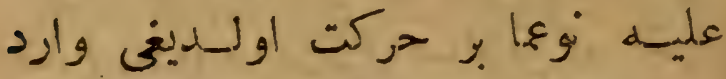

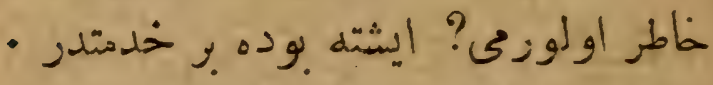

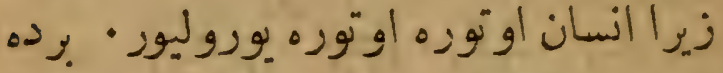

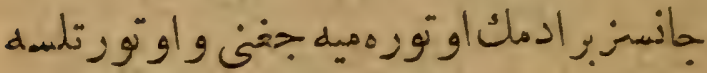

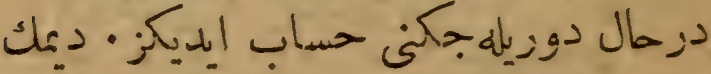

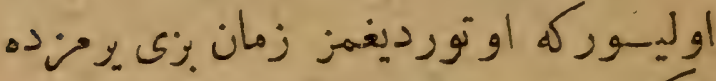

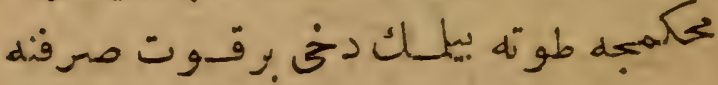

$$
\text { - وابستdدور }
$$

مالبوكه هيج بوحر كمز اولمديغىزمانل

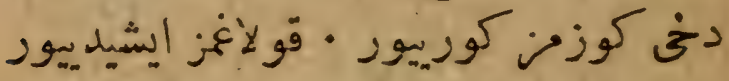

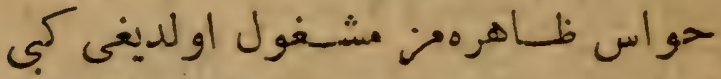

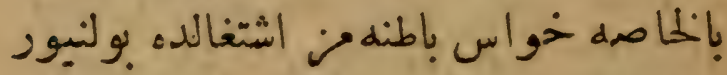

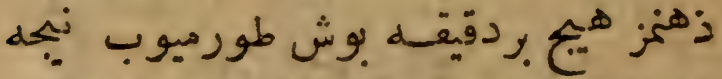

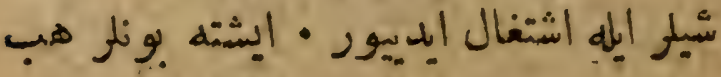




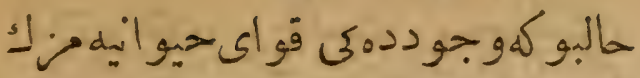

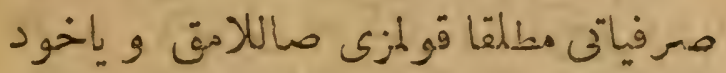

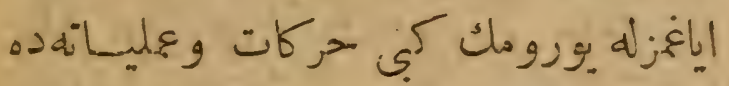

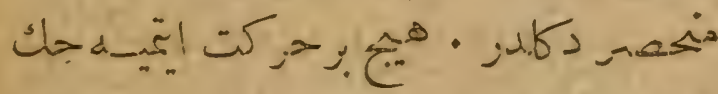

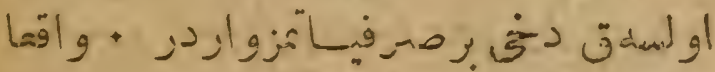

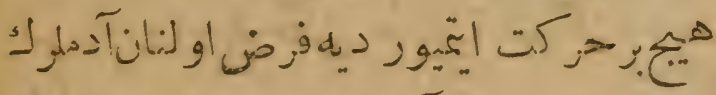

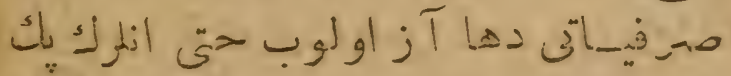

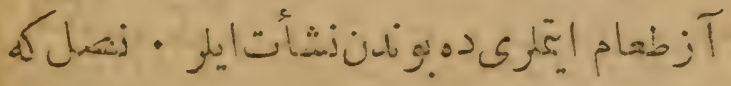

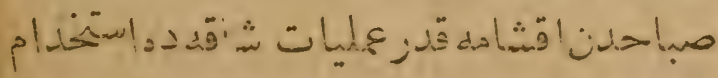

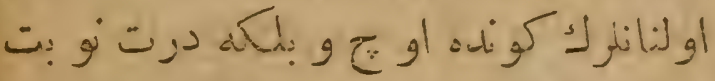

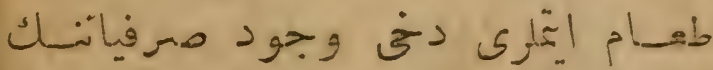

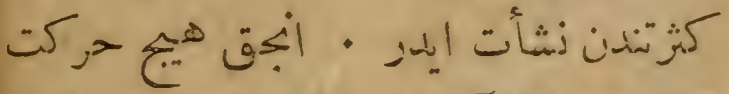

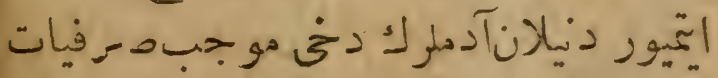

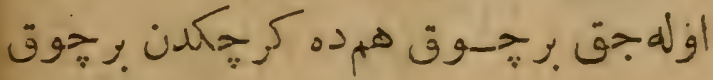

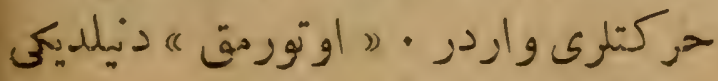




\section{3}

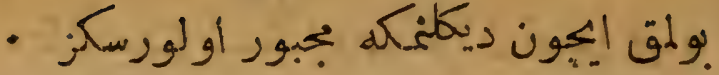

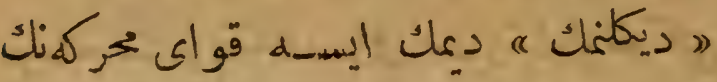

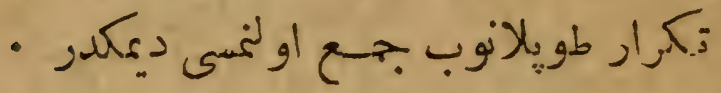

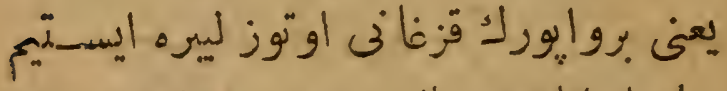

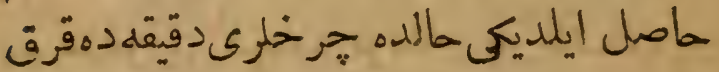

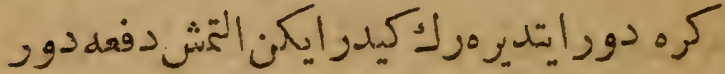

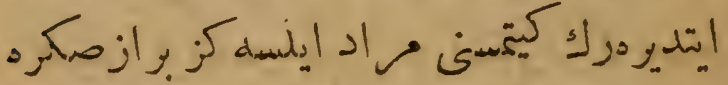

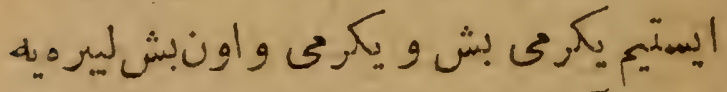

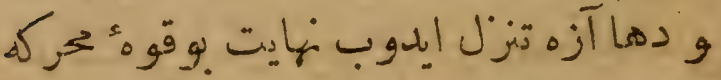

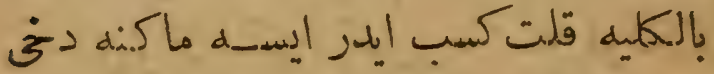

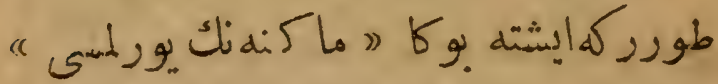

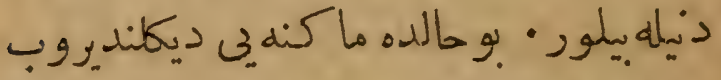

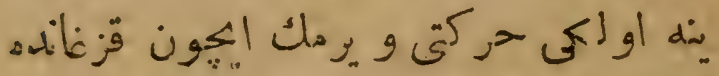

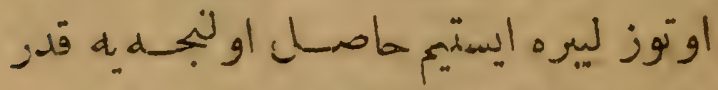

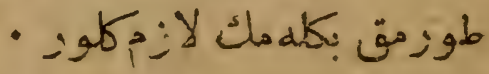




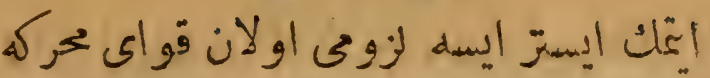

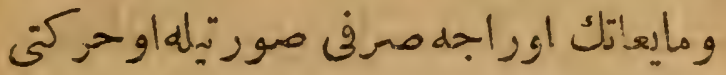

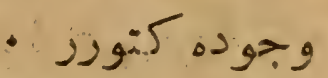

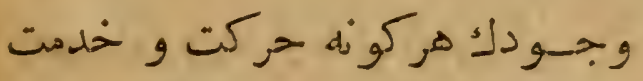

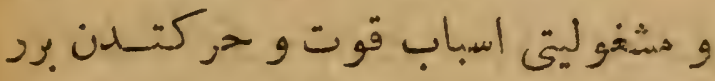

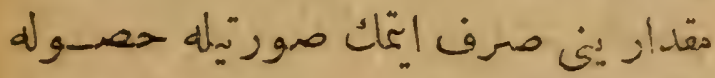

كلديكى اولقدد بلهيهى و آشيكاردزكه انسان

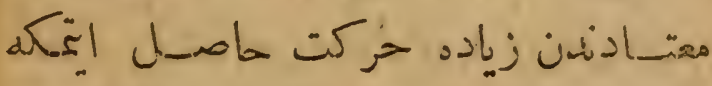

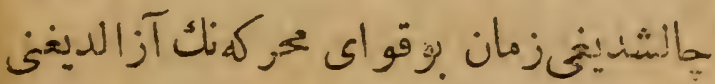

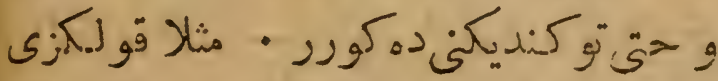

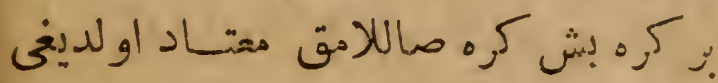

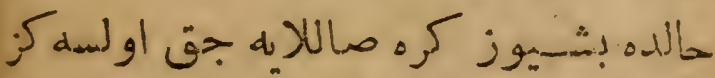

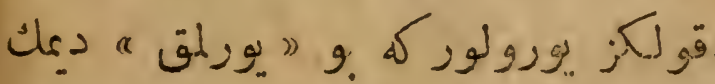

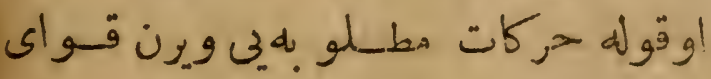

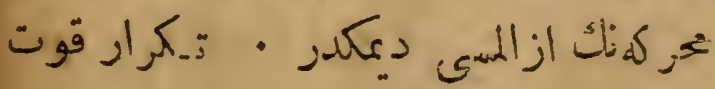




\section{\&9 类}

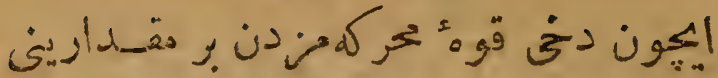

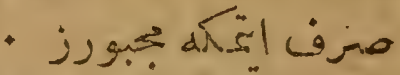

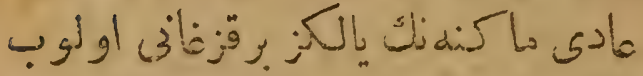

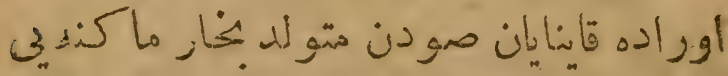

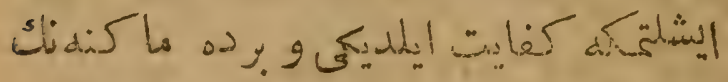

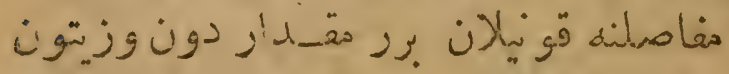

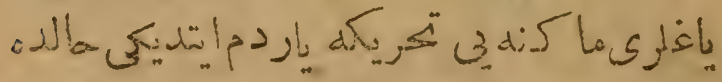

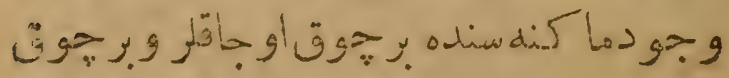

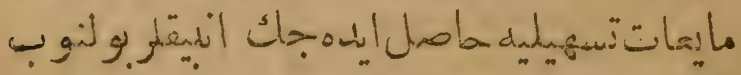

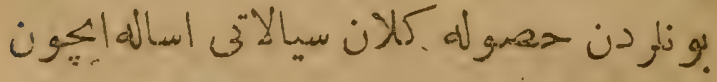

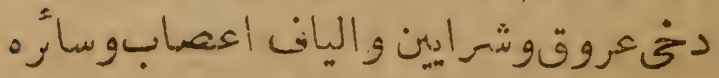

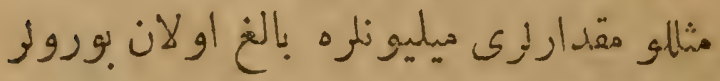

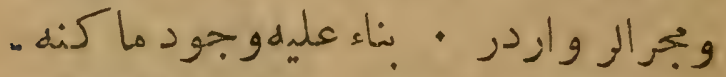

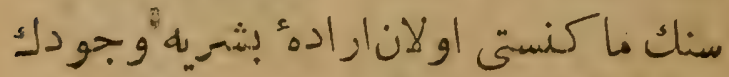

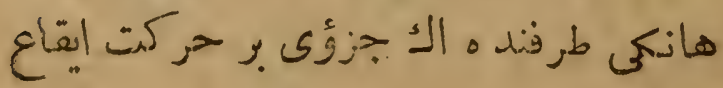

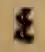




\section{缃笔}

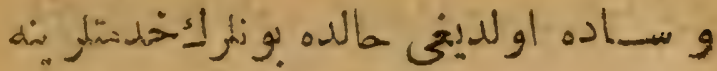

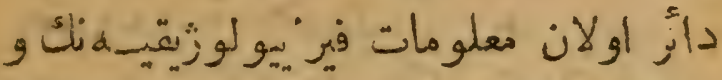

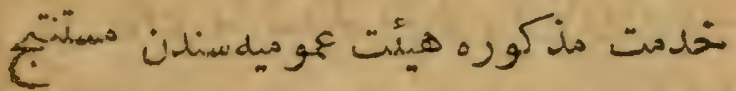

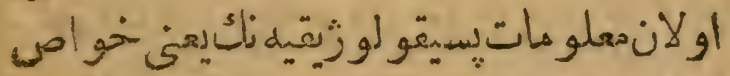

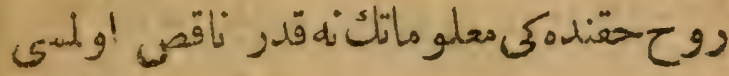

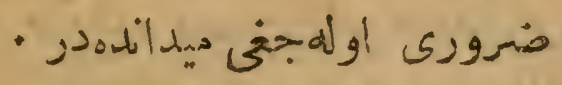

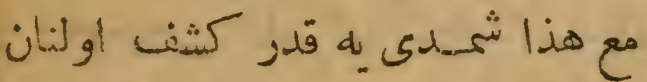

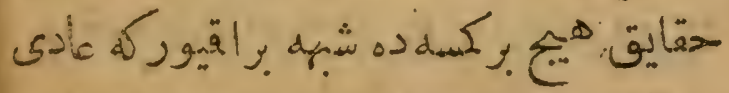

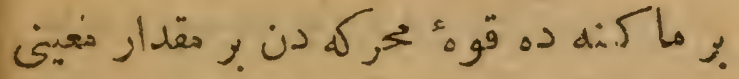

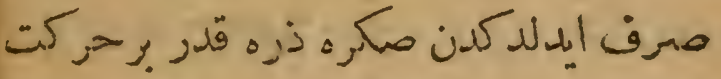

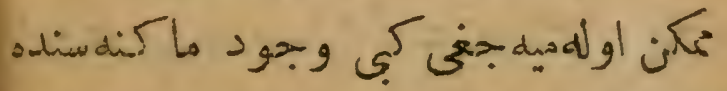

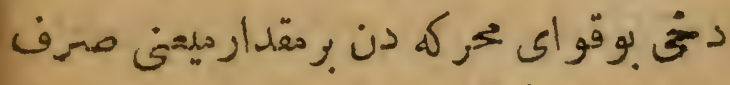

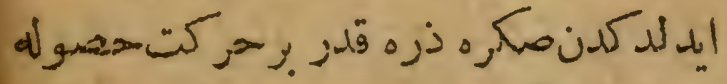

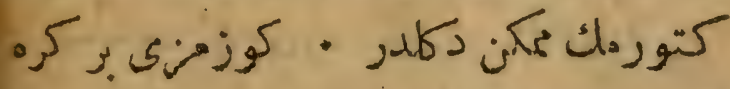

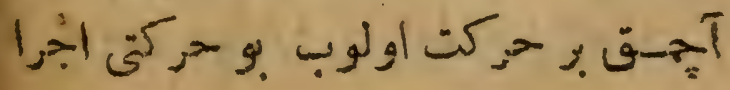




\section{\&V *}

وجود النمانه

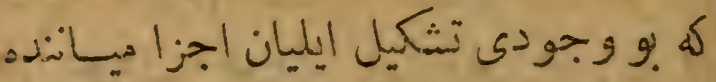

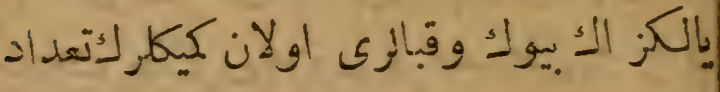

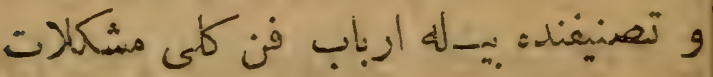

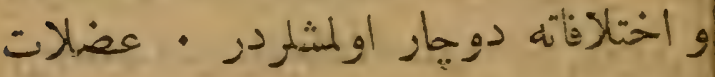

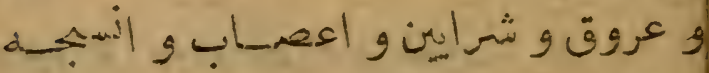

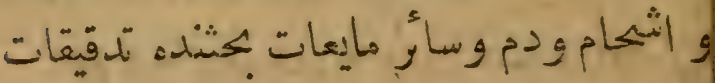

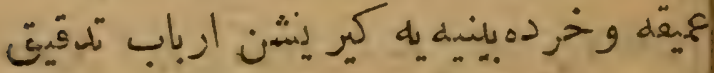

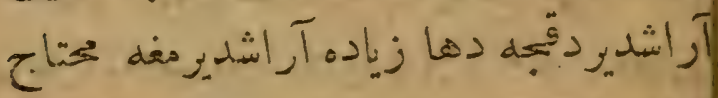

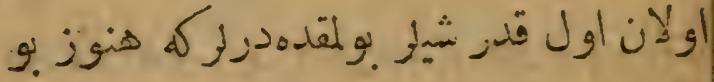

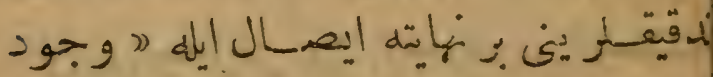

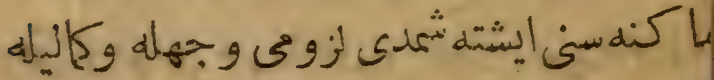

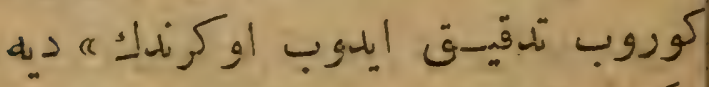

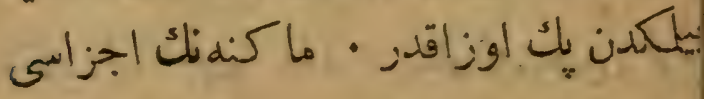

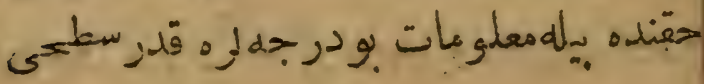




\section{7 潘}

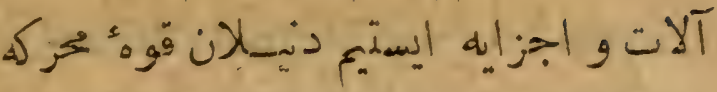

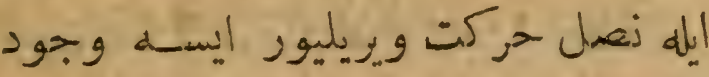

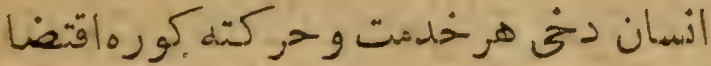

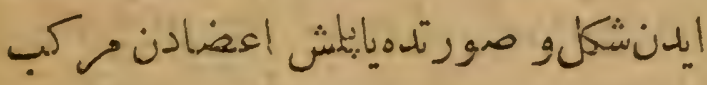

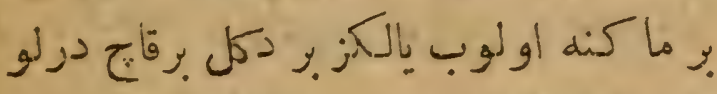

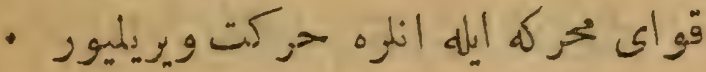

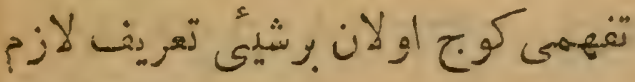

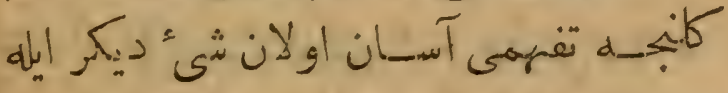

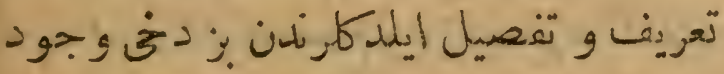

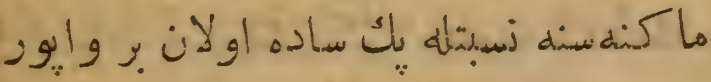

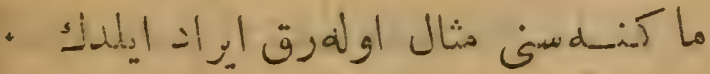

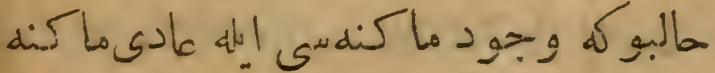

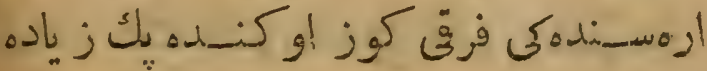

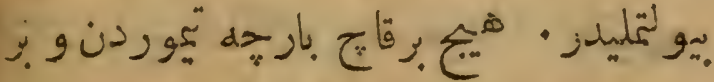

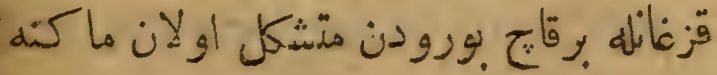


缕

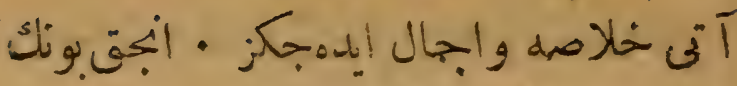

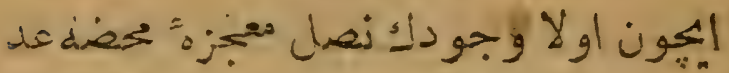

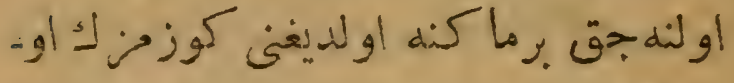

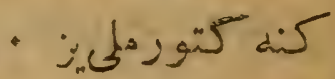

$9 ث$

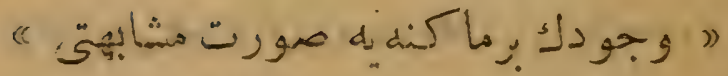

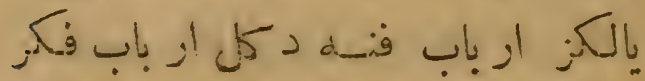

و وزكاله

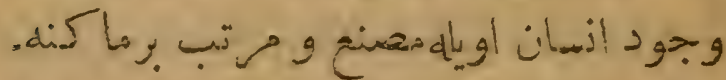

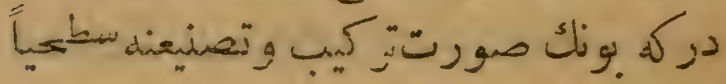

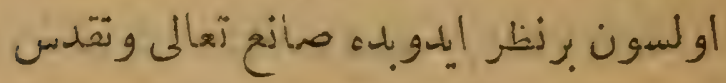

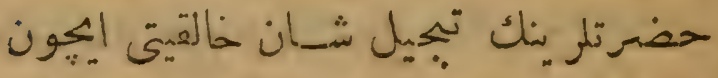

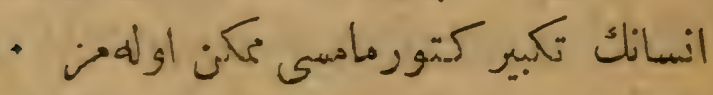

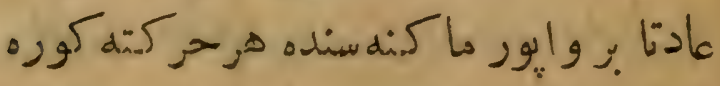

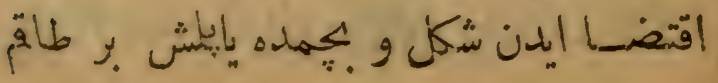




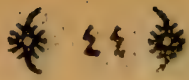

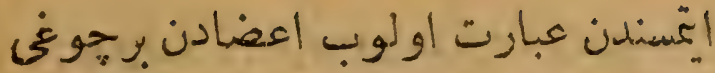

.

كندى خو اصنى ايناده وانسانكانانئي ليعنى

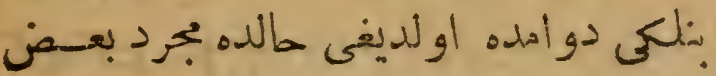

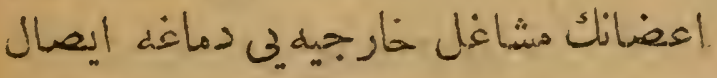

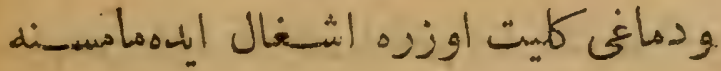

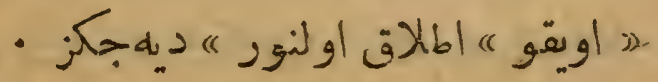

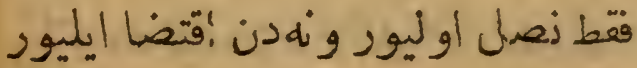

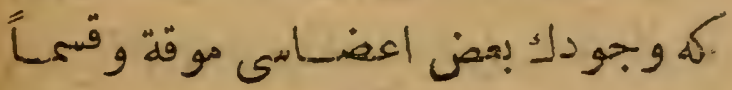

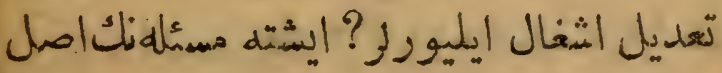

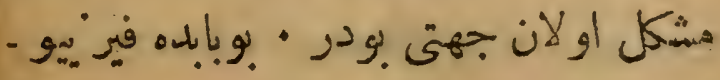

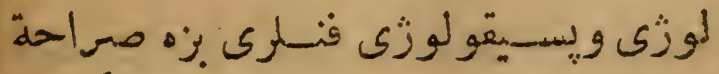

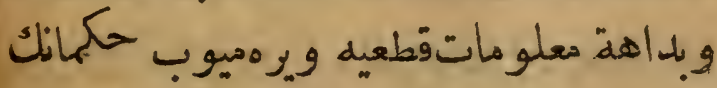

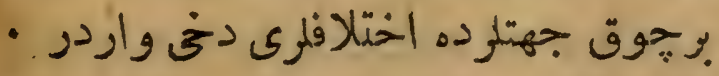

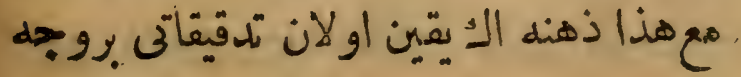




\section{*2r}

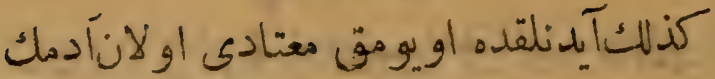

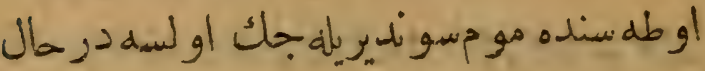

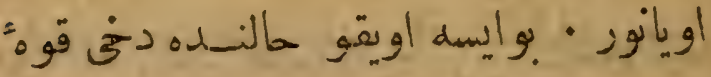

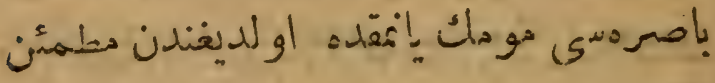

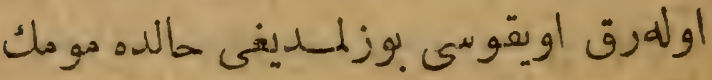

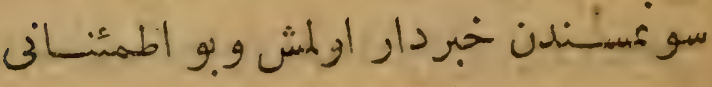

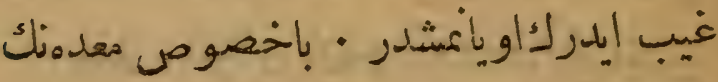

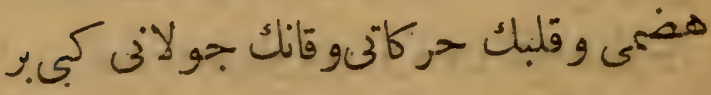

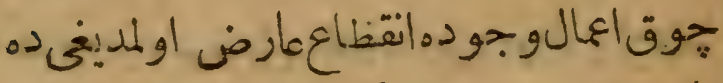

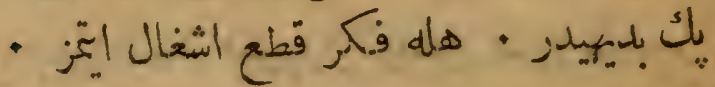

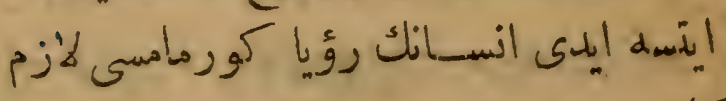

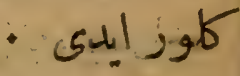

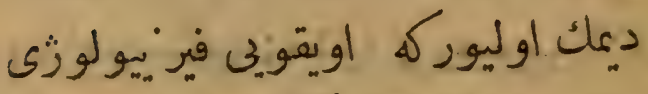

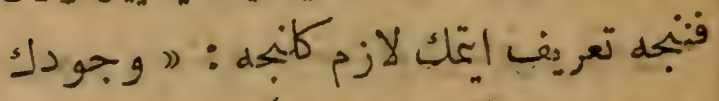

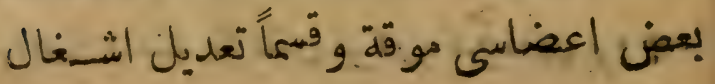




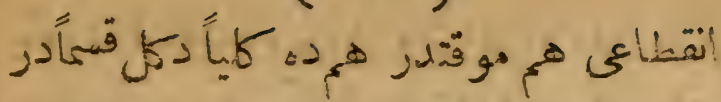

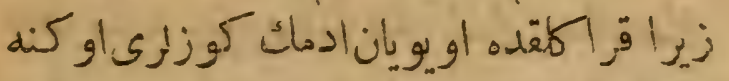

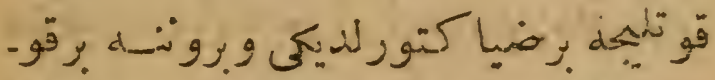

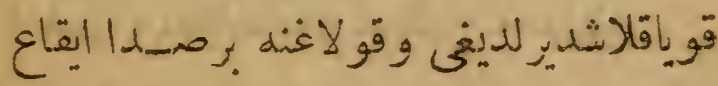

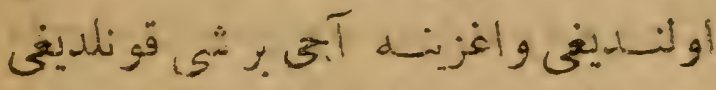

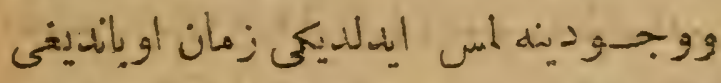

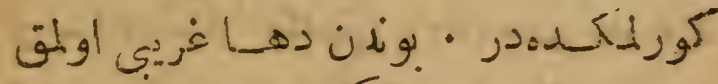

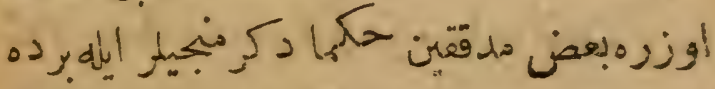

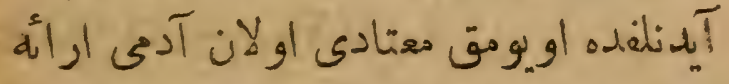

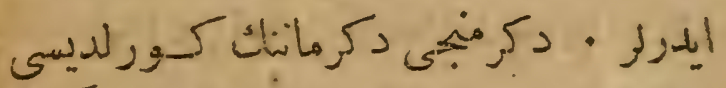

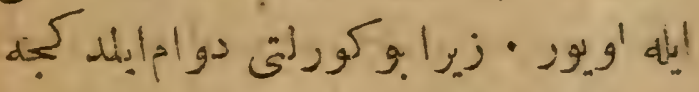

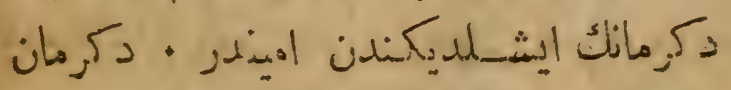

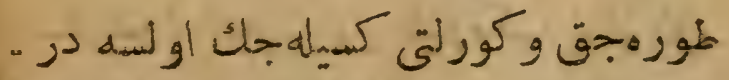

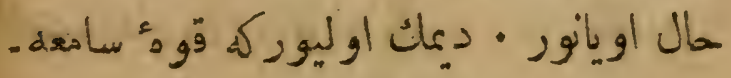

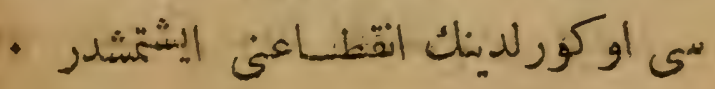




\section{番红等}

هلور ? مدتى نهقدز آز اولورسبـه أولسون

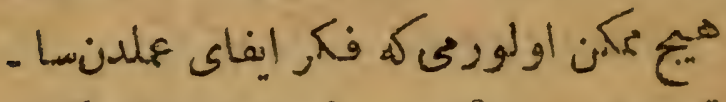

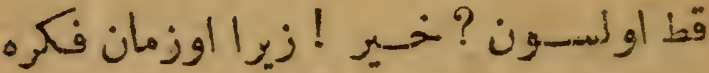

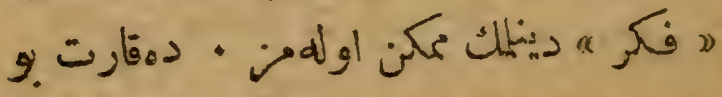

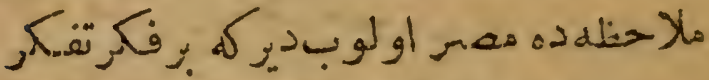

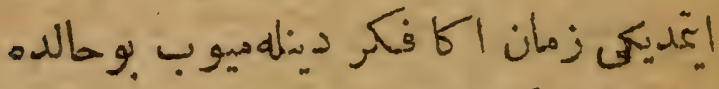

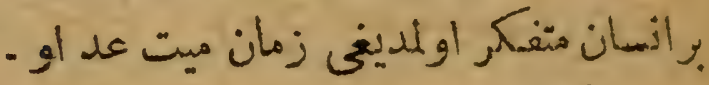

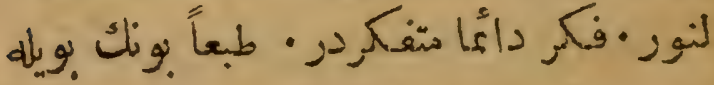

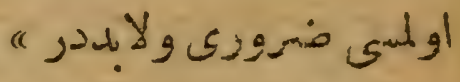

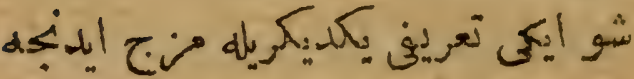

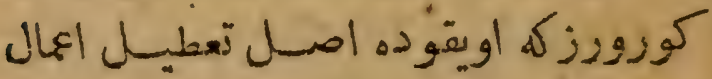

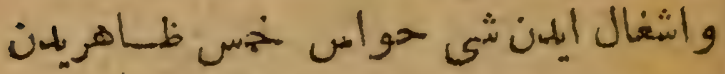

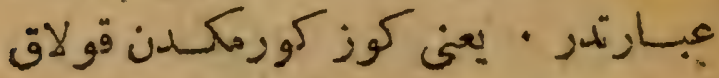

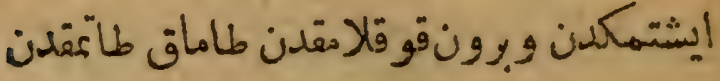

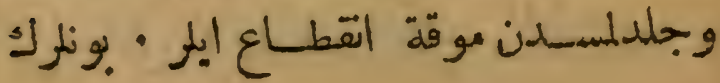




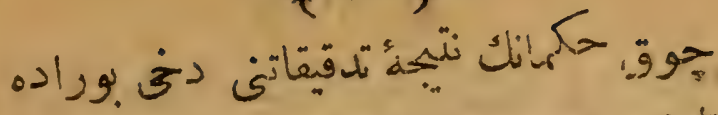

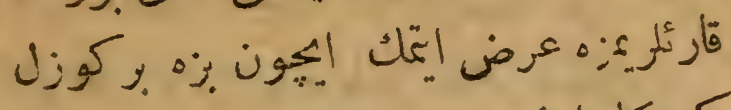

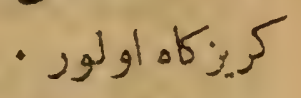

لهلوت ودمقارت نام خحكيمسلم اويقو

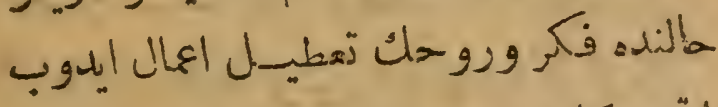

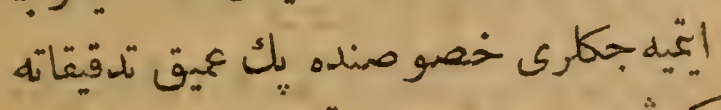

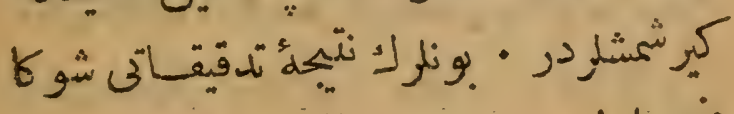

منير اولورن

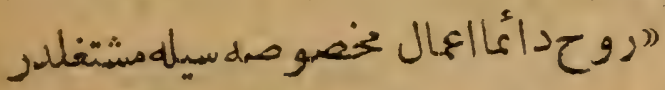

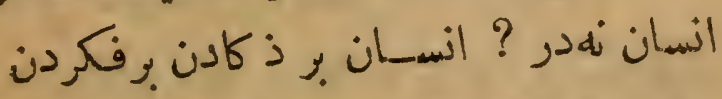

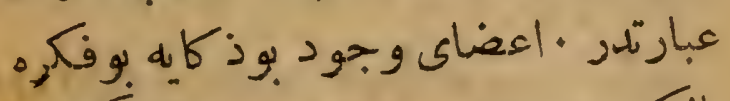

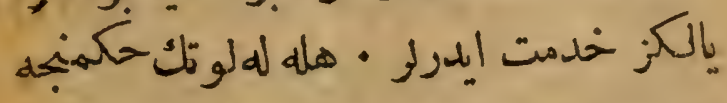

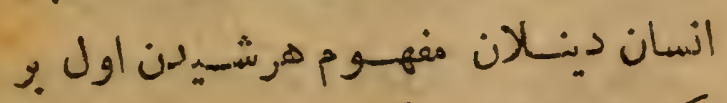

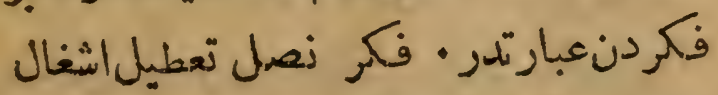

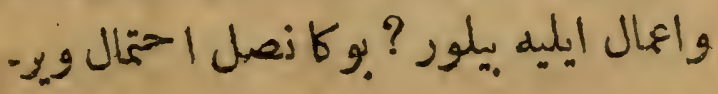




\section{(iq}

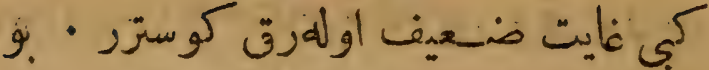

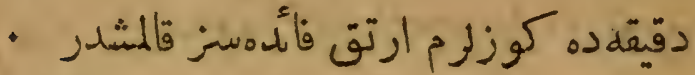

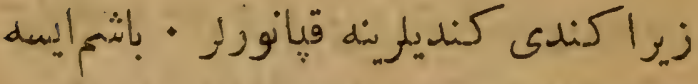

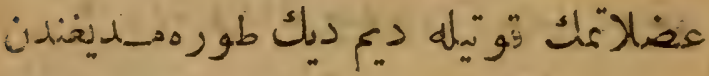
كمنديسنه طيانهجتبوير بولمق اوزره كو كسيم

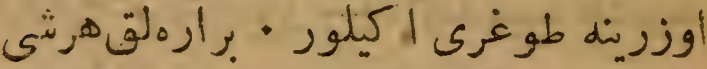

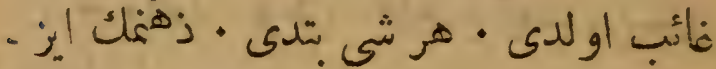

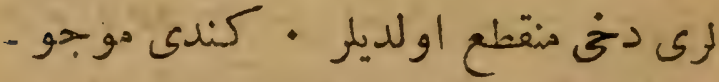

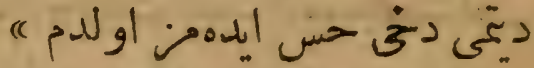

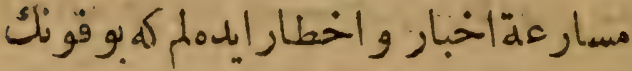

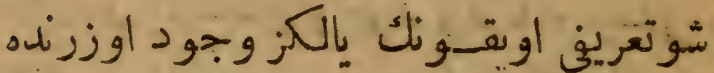

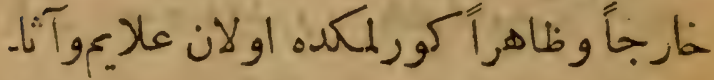
رندن خلاصهاليلمش برتعريف أولوب.ونده

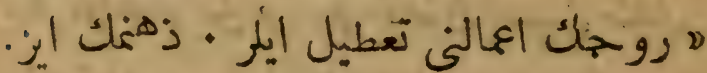

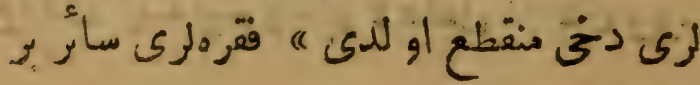




\section{漛 H 絭}

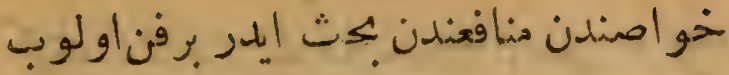

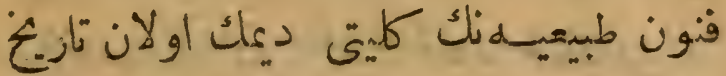

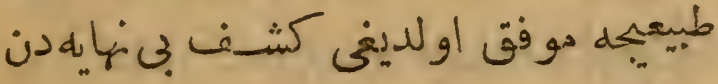

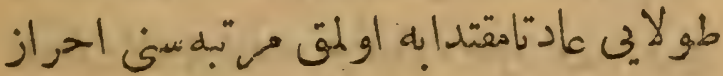

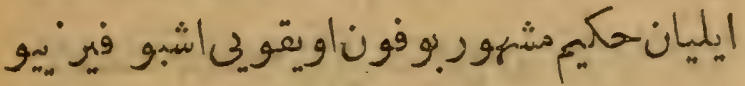

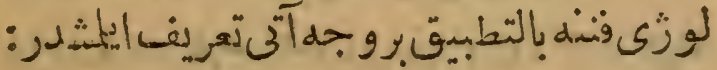

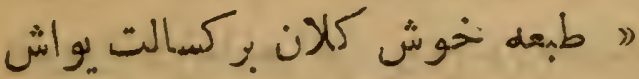

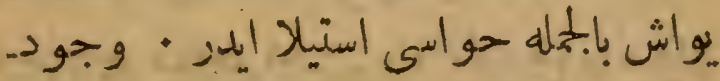

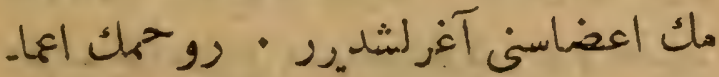

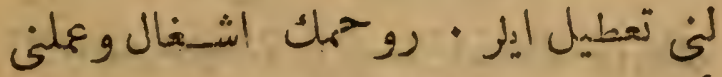

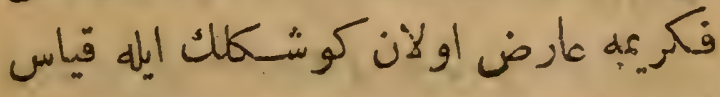

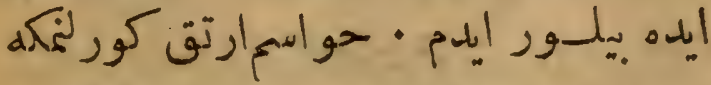

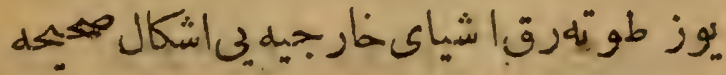

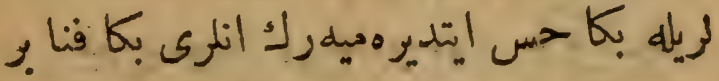

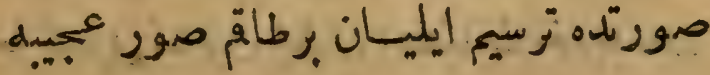




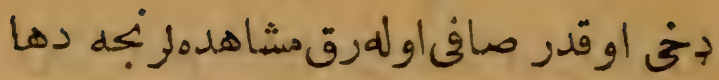

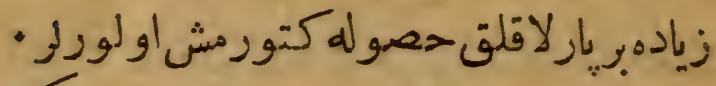

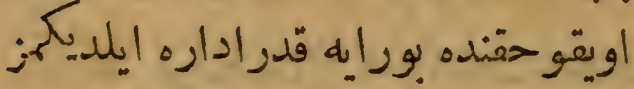

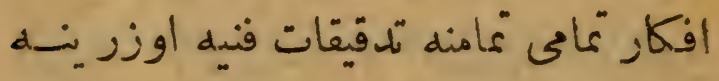

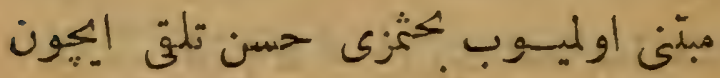

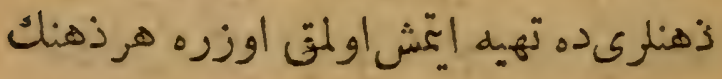

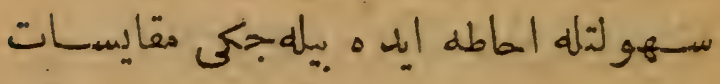

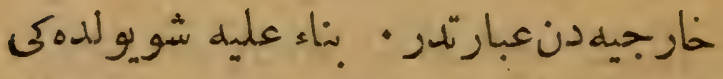

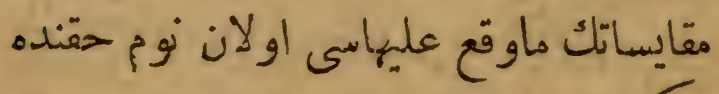

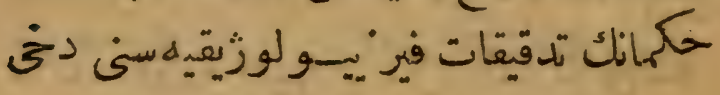

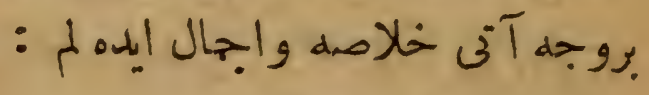
0.

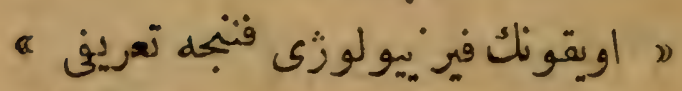

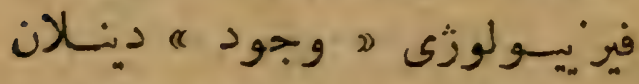

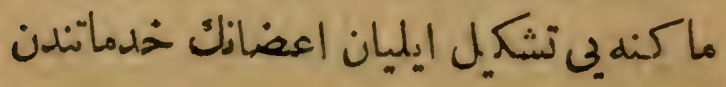




\section{rq}

هضم كندى اويقولرينى . ماله كأوس دينان

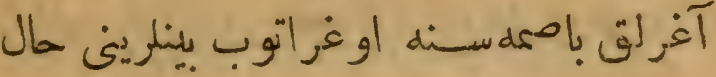

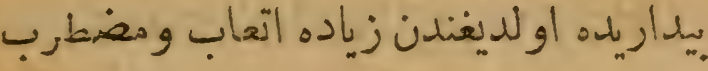

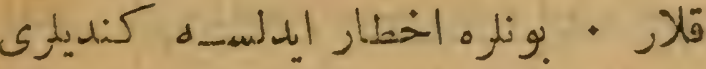

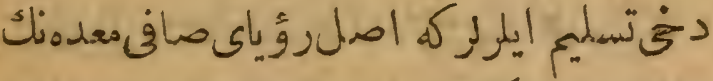

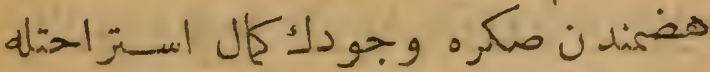

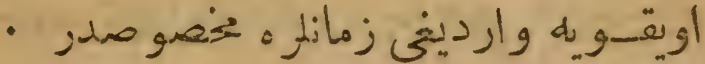

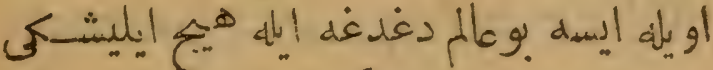

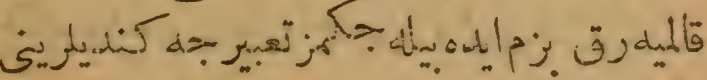

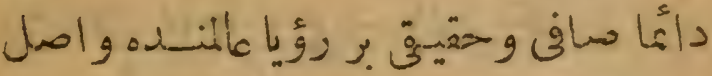

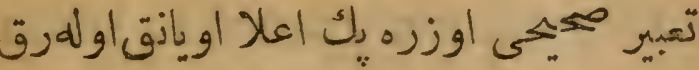

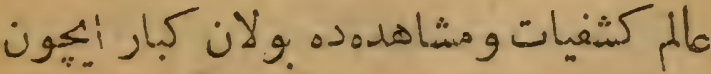

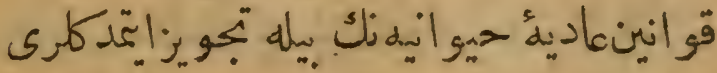

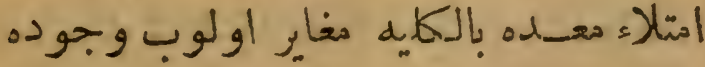

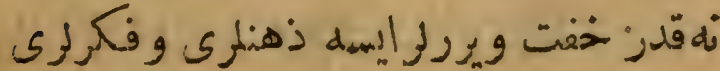




\section{娄 re}

تأليف وتخر يرده دنخ رعايت اولنان اصرو

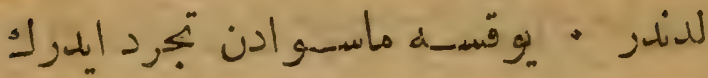

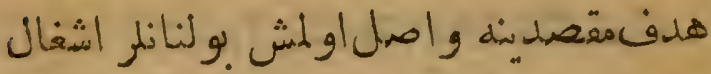

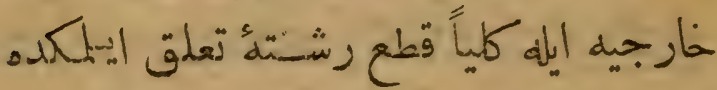

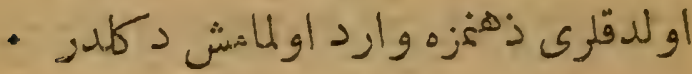

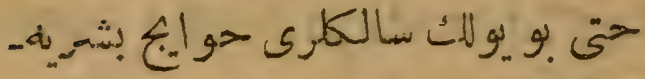

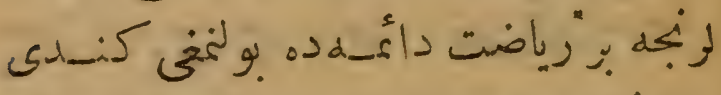

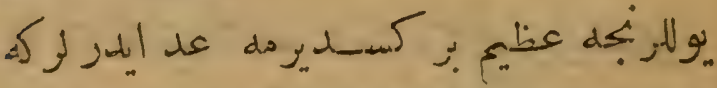

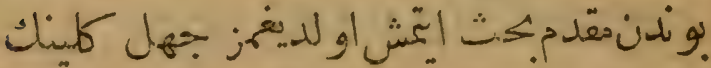

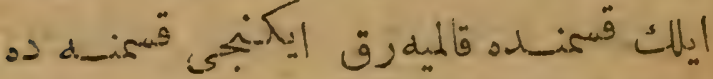

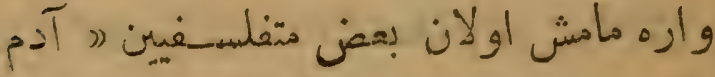

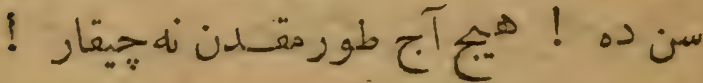

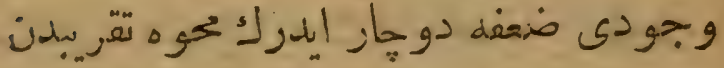

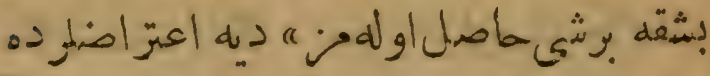

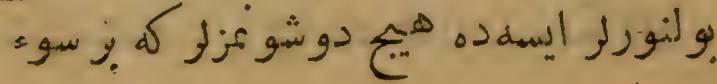


مكاشئه زمانلرى دنى عالم رؤيا ايدوكنى كوز

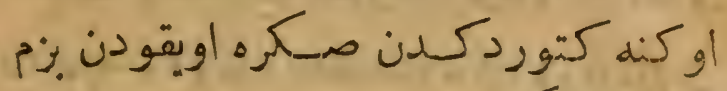

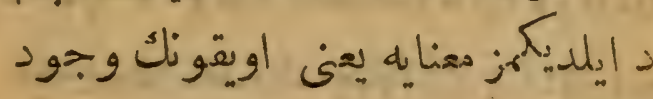

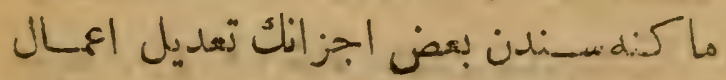

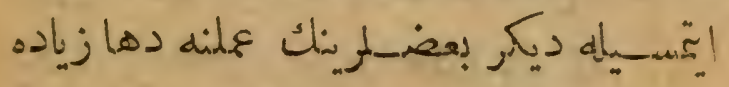

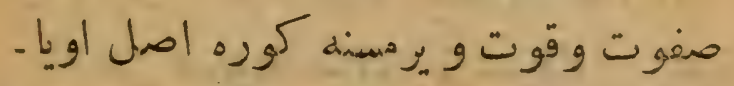

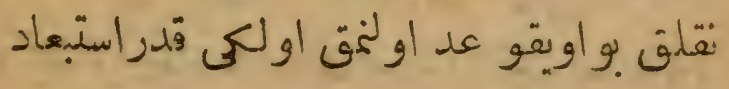

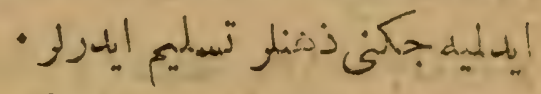

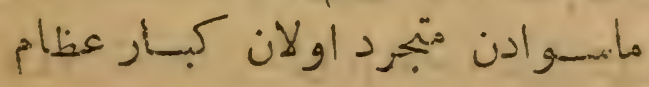

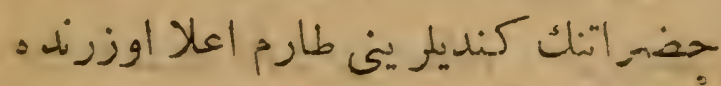

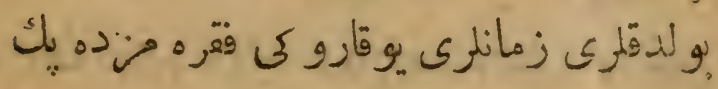

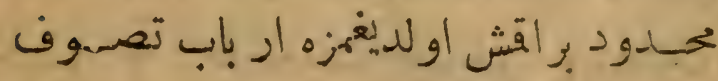

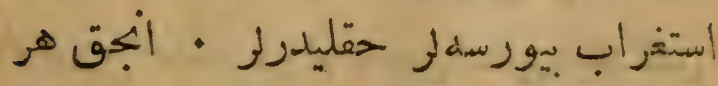

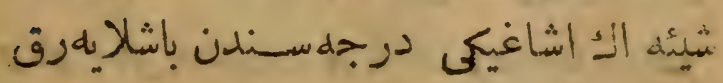

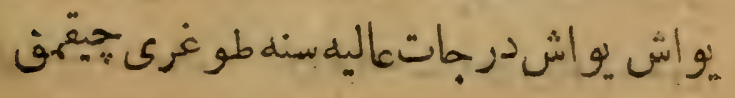




\section{wr}

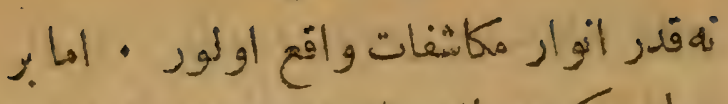

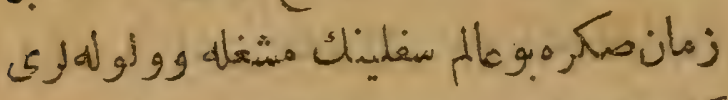

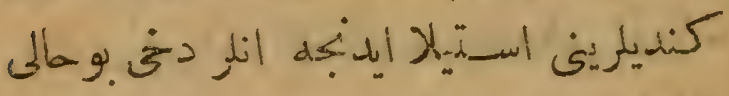

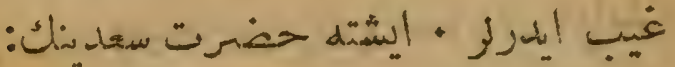

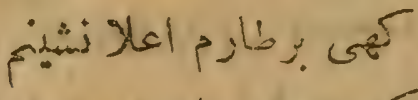

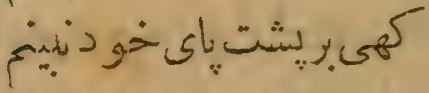

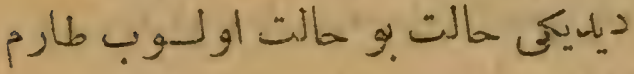

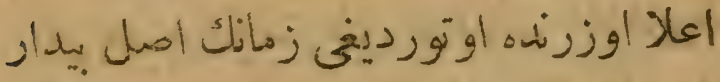

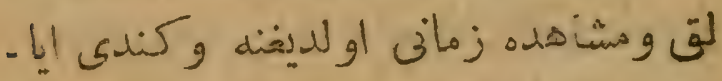

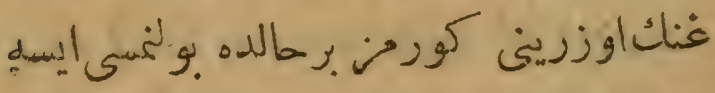
اصل اويتو دميك اوله جغنه ذهنلر كوزيله

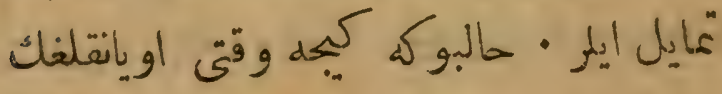

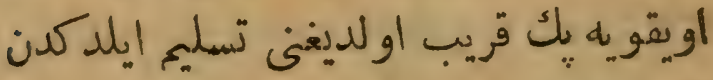
وهر ذهن صسافى ار بإنك بردربه به قدر

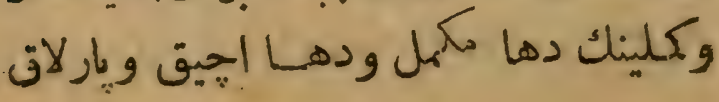




\section{*r}

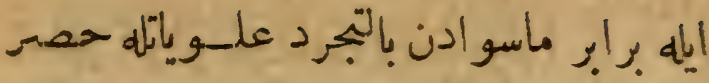

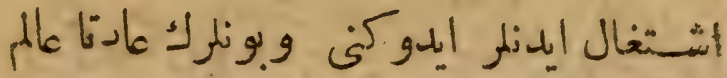

علوى ذوالعقولنه تقرب ايلديكنى اثبـات

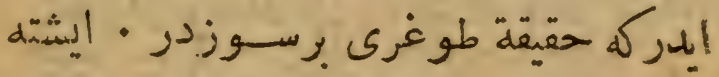

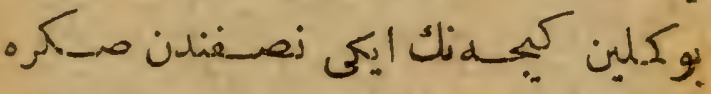

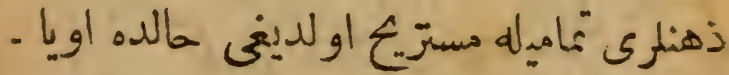

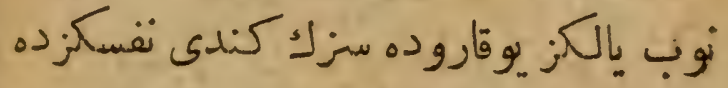

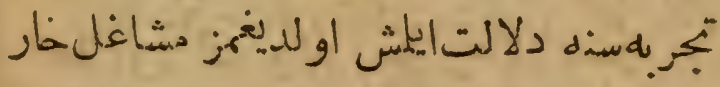

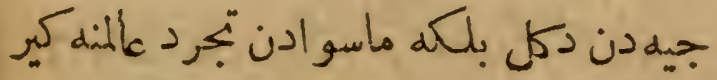

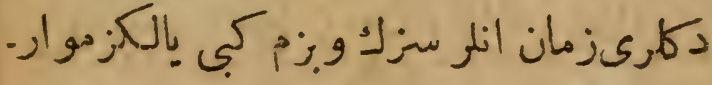

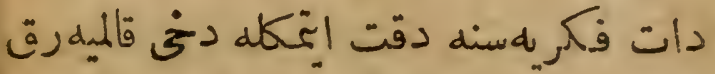

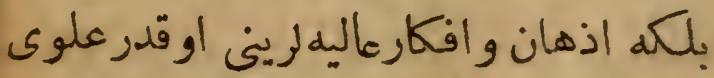

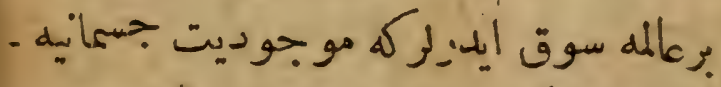

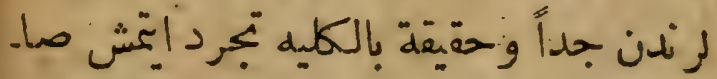

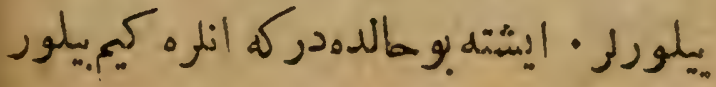




\section{类落}

هو اليد ثلمثه حقنده ثيان فكر ودطالعه ايلد.

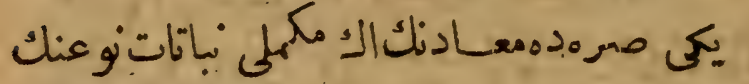

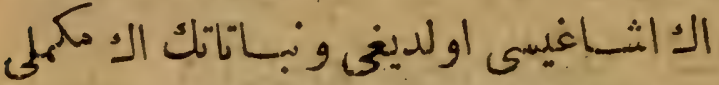

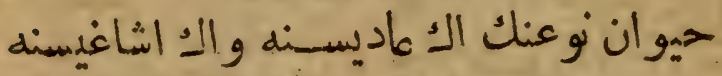

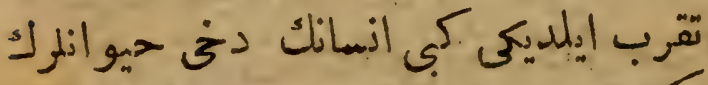

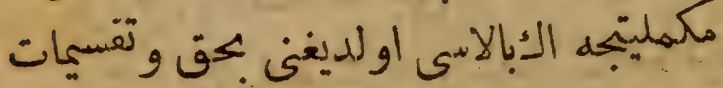

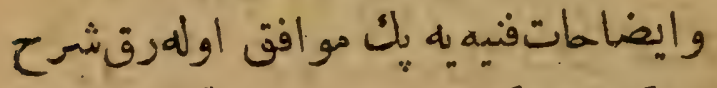

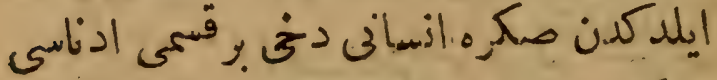

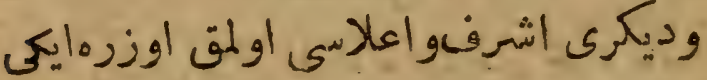

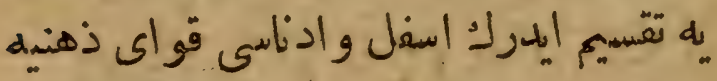

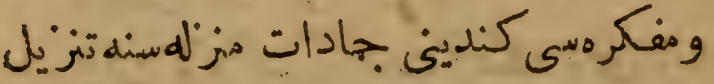

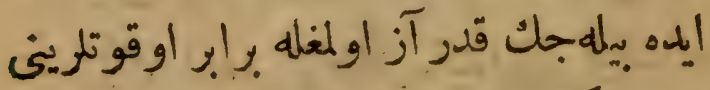

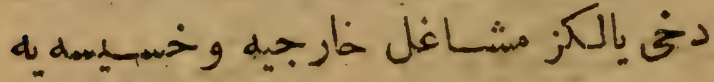

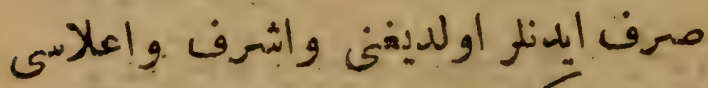

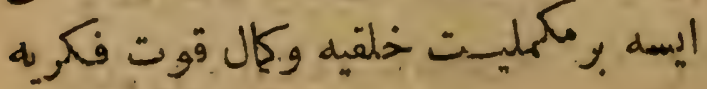




\section{r.}

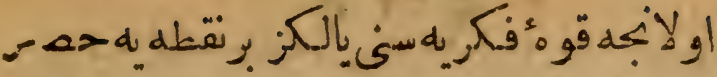

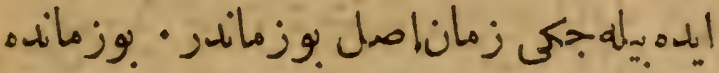

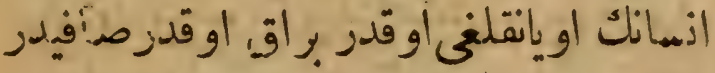

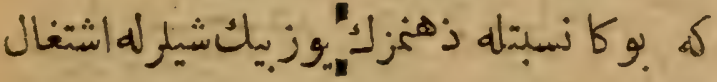

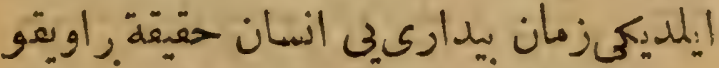

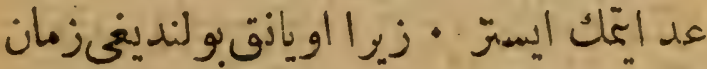

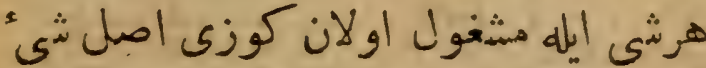

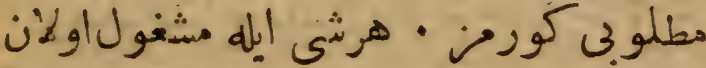

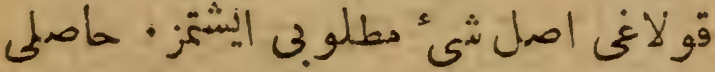

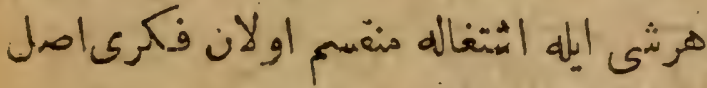

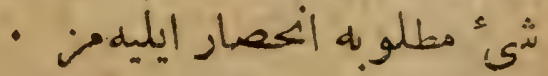
\& ثي

" ماسوادن تجرد وعالم مشاهده

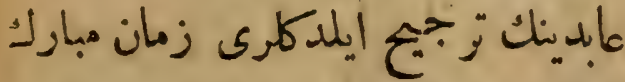

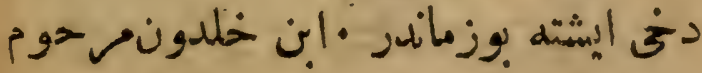




\section{(9)}

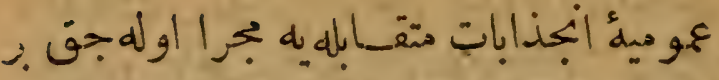

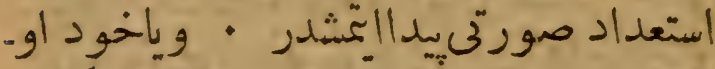

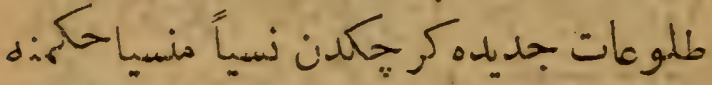

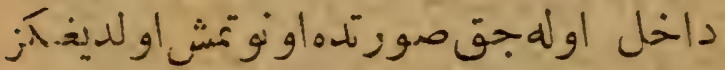
ورشى اولوب شمدى تهدديني طلو عات جديده

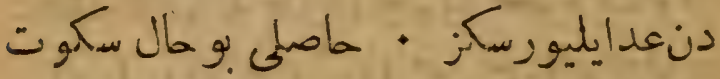

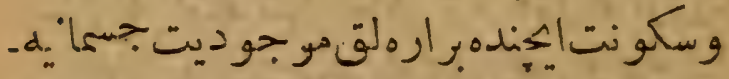

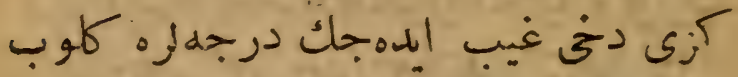

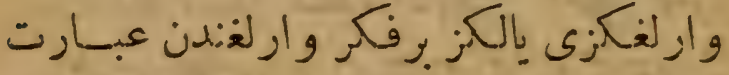

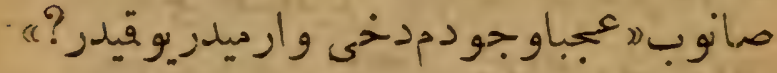

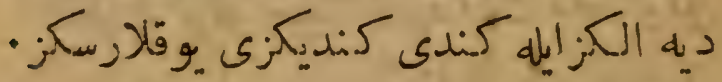
ياخود كندى صداكزله كندى موجود .

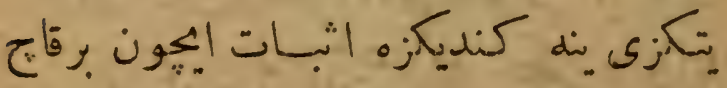

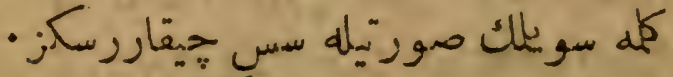

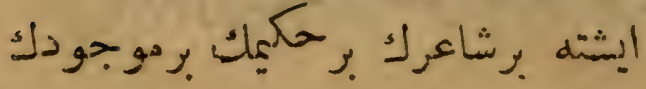




\section{rᄉ}

اولمديغنـدن يواش يواش كنديكزى ك:دي

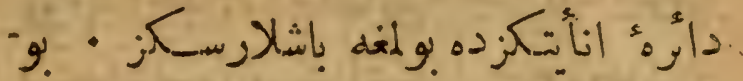

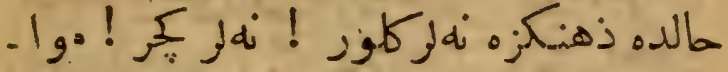

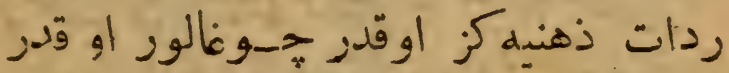

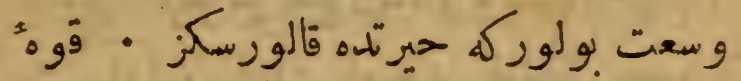

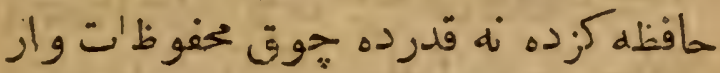

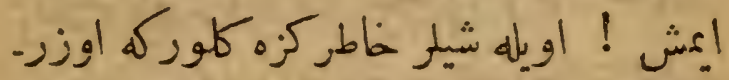

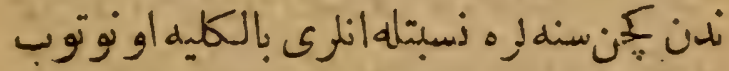

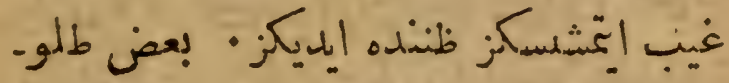

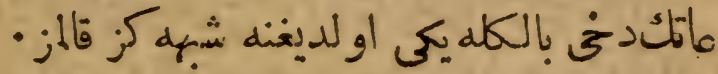

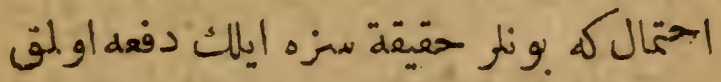

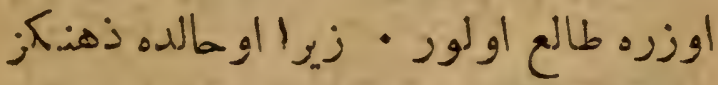

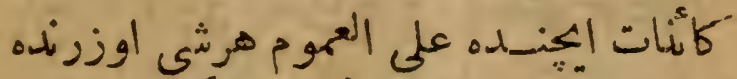

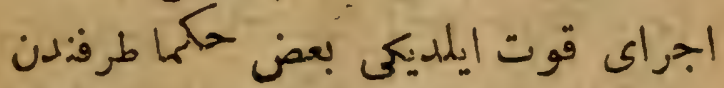

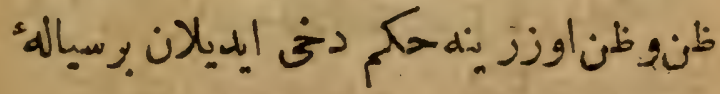




\section{rV}

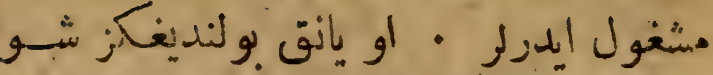

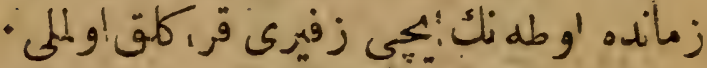

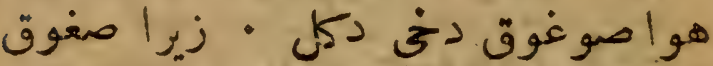

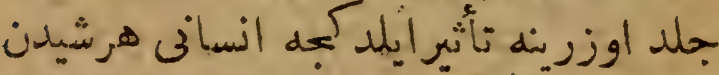

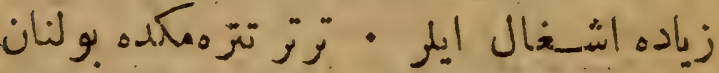

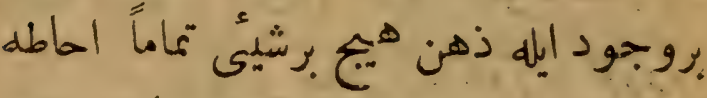

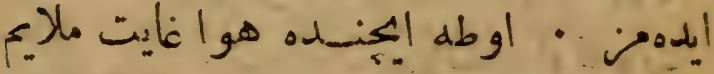

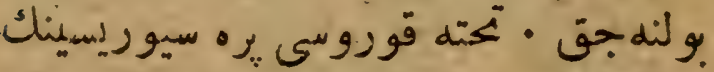

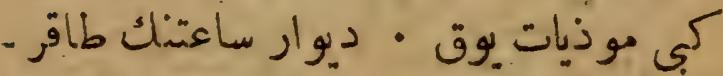

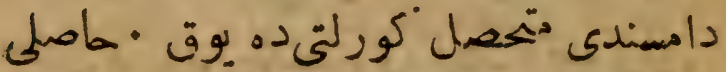

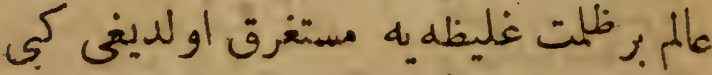

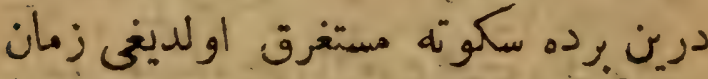

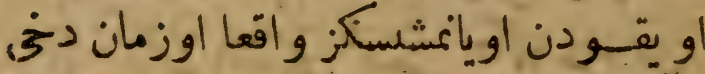

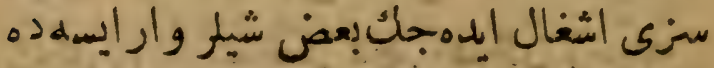

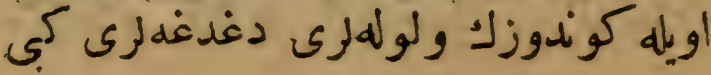




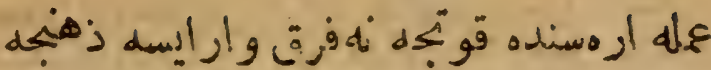

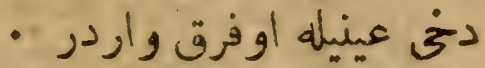

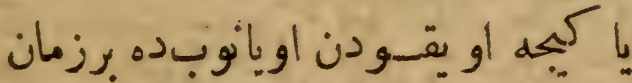

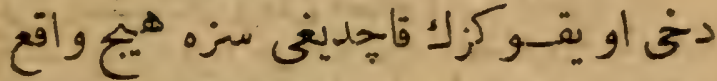

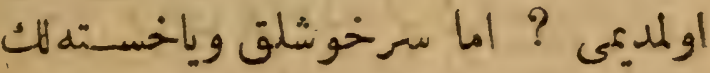

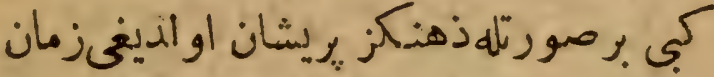

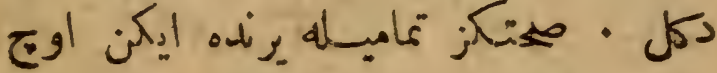

درنت ساءت أويودقدن صكره اويانمشمسكز

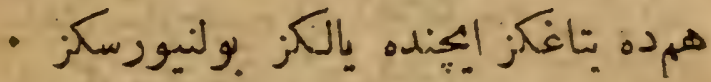

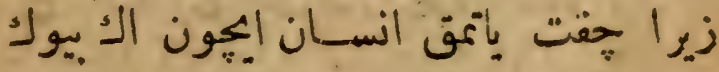

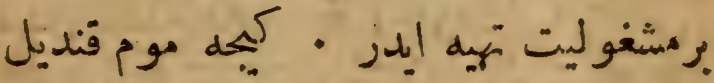

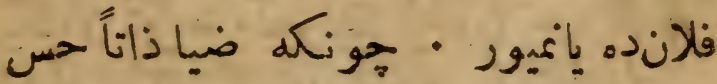

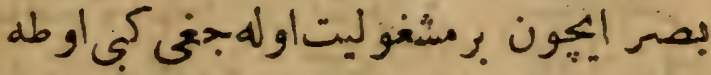

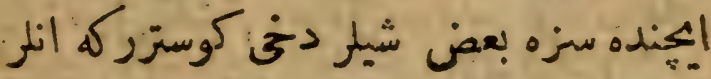

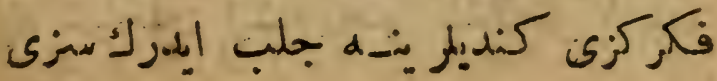




\section{稌}

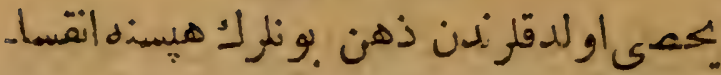

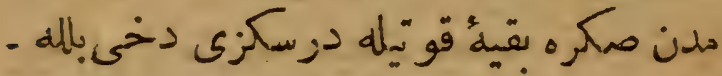

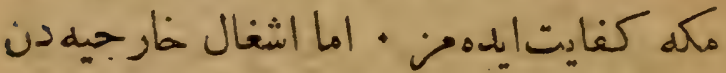

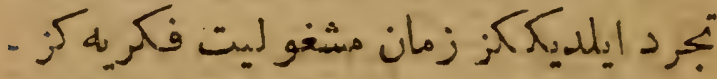

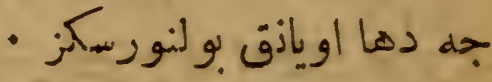

هله صباح وقتى هرزمانه زتجيم إيل

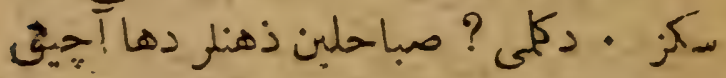

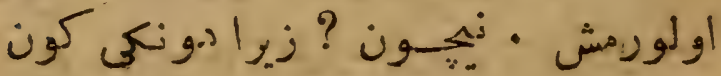

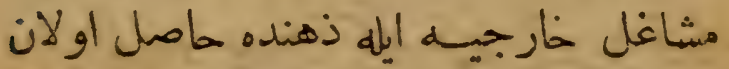

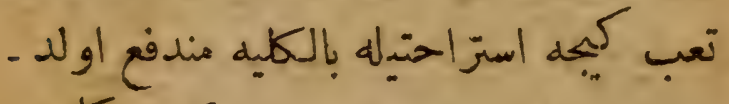

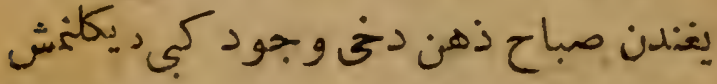

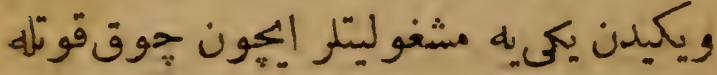

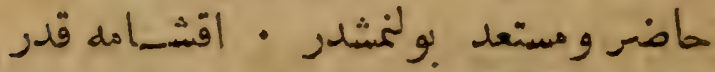

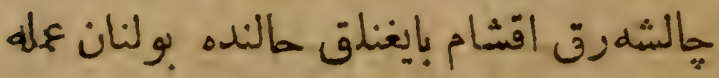

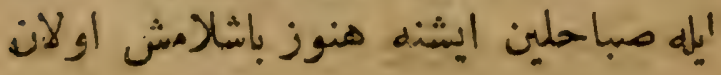


(r)

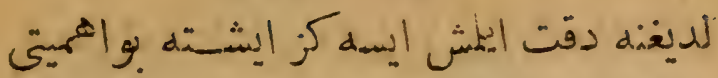

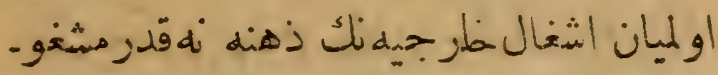

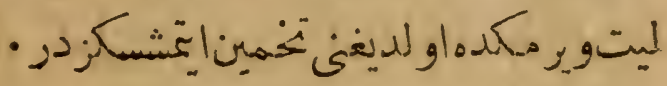

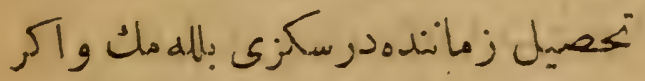

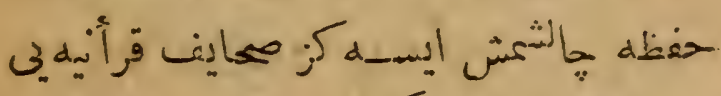

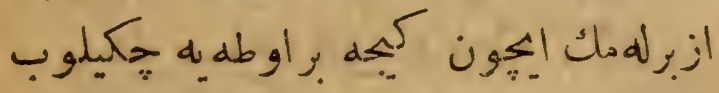

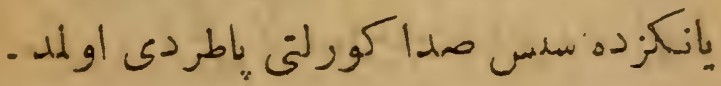

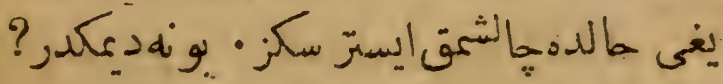

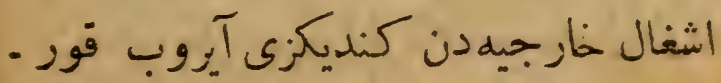

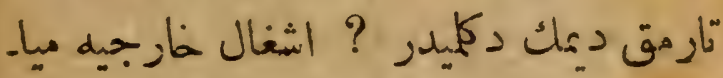

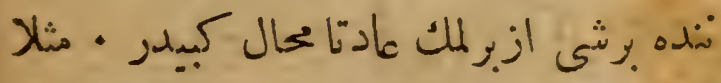

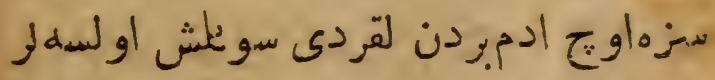

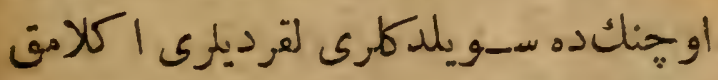

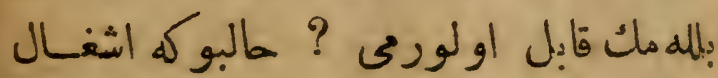

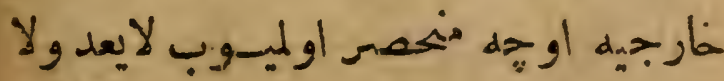




\section{r r}

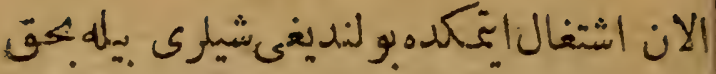

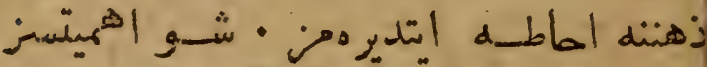

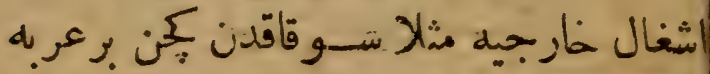

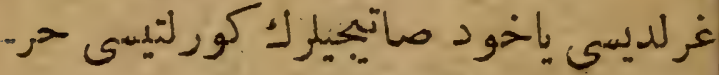

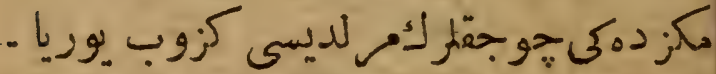

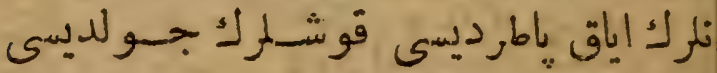

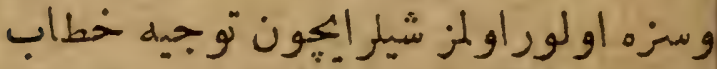

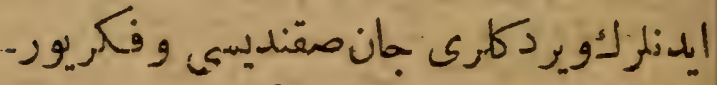

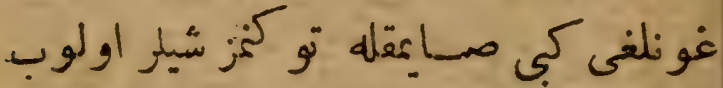

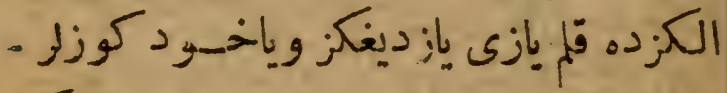

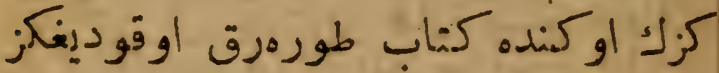

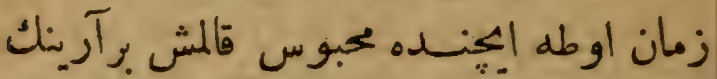

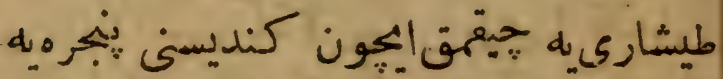

هاريه هاز يه ويزلدأمسى سزه نهقدر كوزل

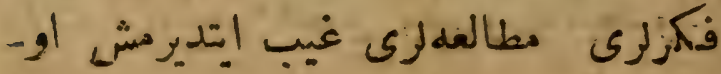




\section{re}

ذهنكزده يوقدر • عهبا انمر ذاتاً ذهنكزده

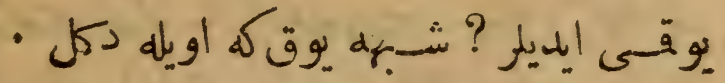

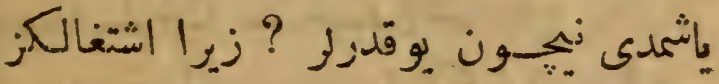

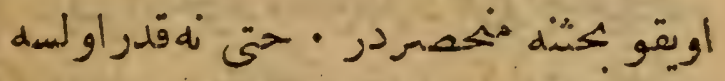

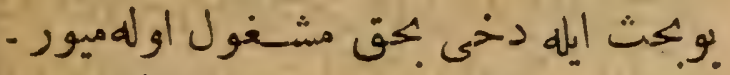

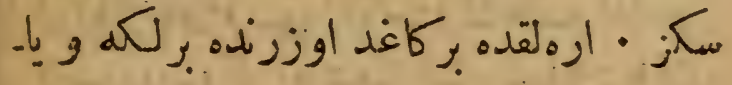

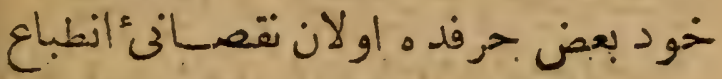

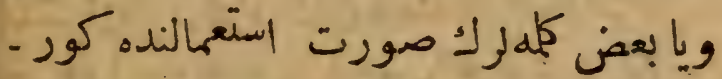

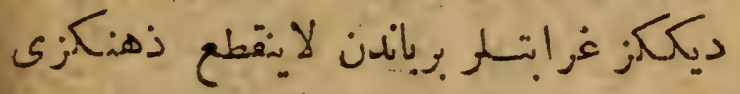

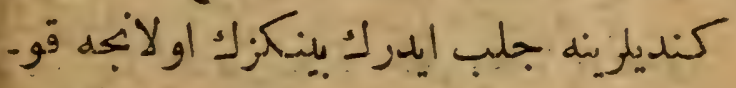
تى .وبكثه صرف إتكاتكدن سمزى منع إيليور

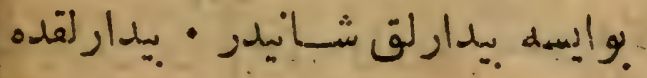

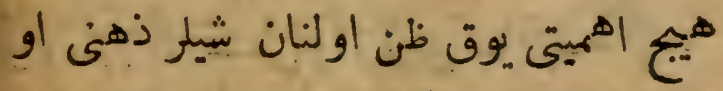

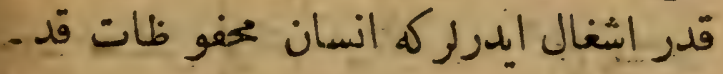

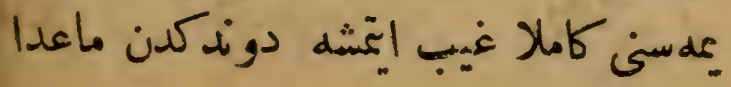




\section{ri}

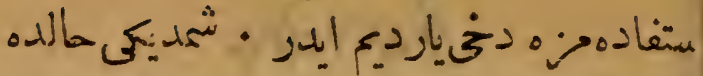

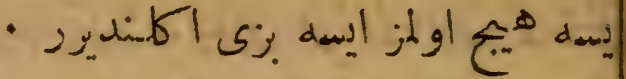
rي

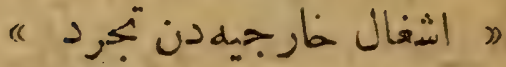

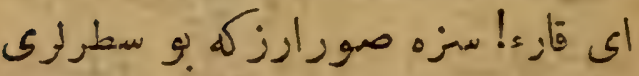

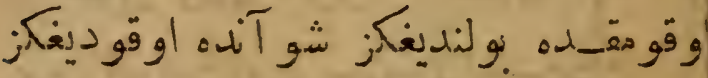

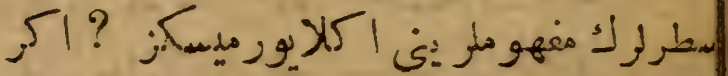

كلاهيور ايسه كز انىده اثبات مدعائيه برهان

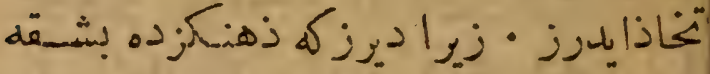

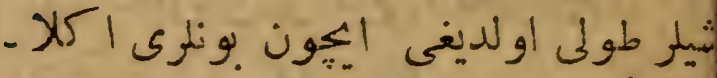

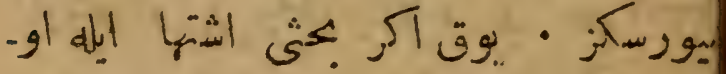

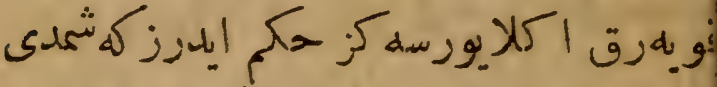

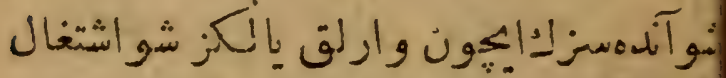

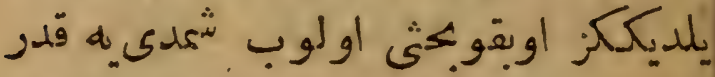

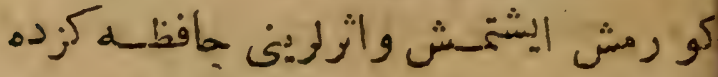

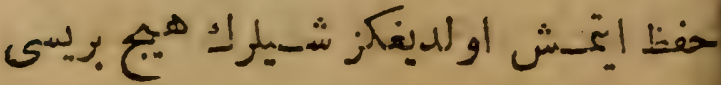


ووملاحظه من اويقويى همان هيج برمناسبتى

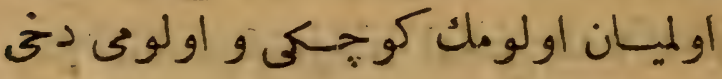

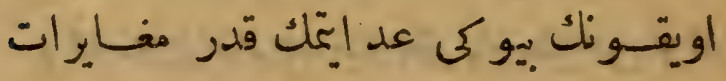

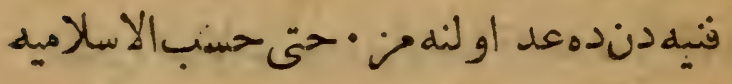

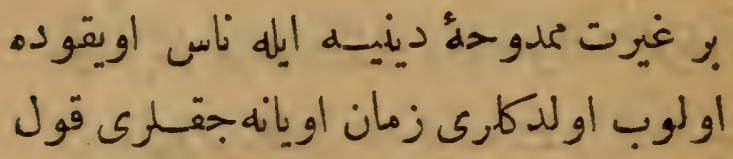

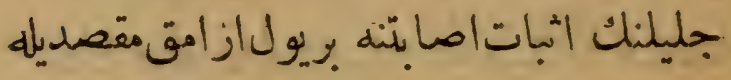

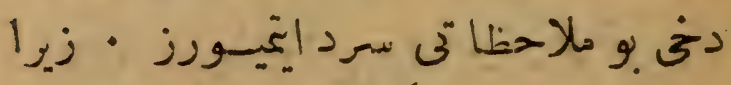

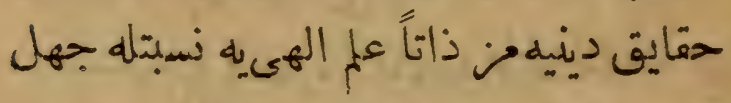

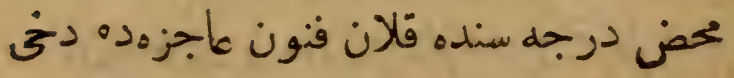

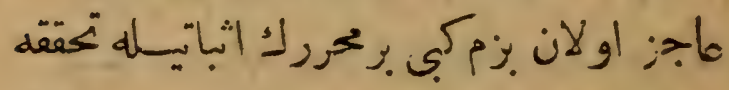

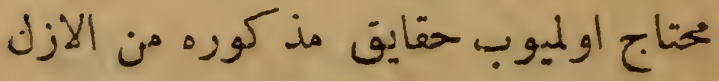

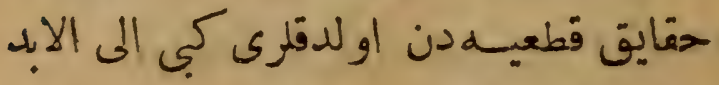

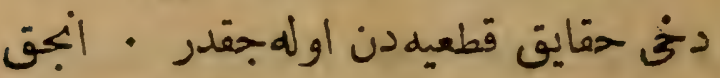

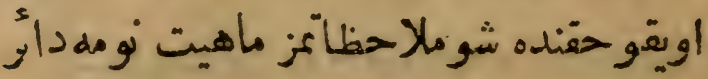




\section{IA}

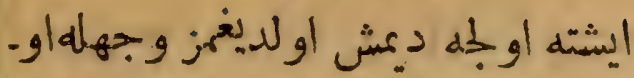

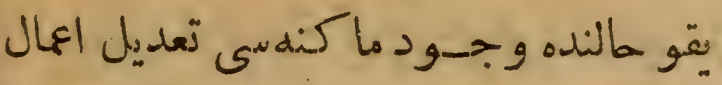

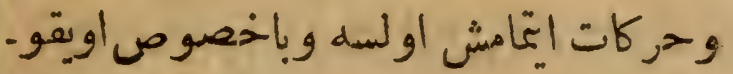

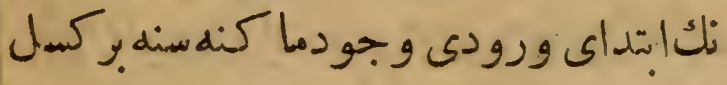

عارض اولمق صورتبله وقوعبو لمسه اويقو -

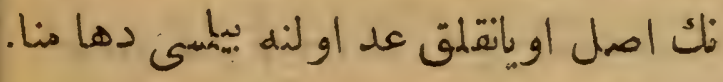

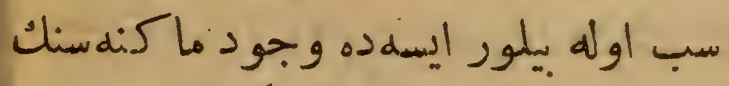

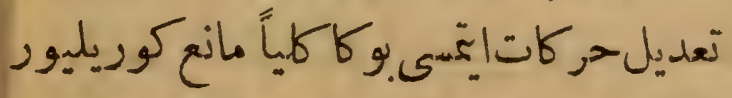

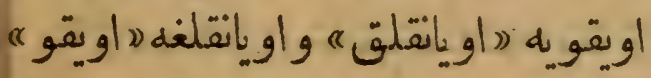

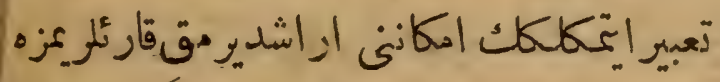

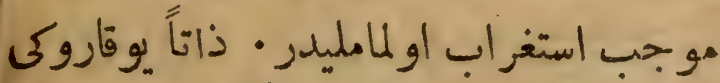

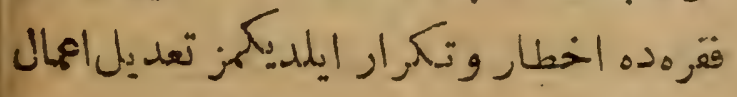

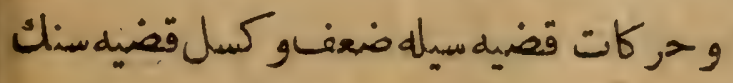

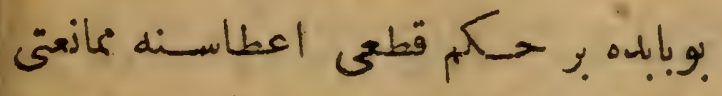

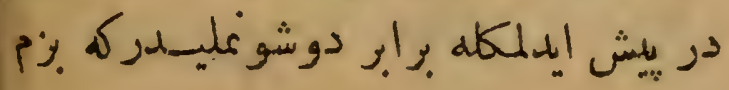




\section{IV}

ميدارلقدر ه ديه مبلور ايدلك · زيرا اويانقلق

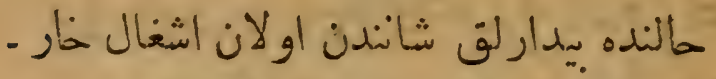

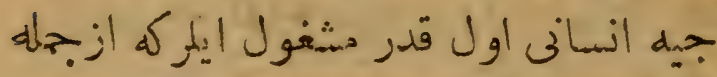

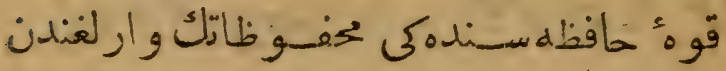

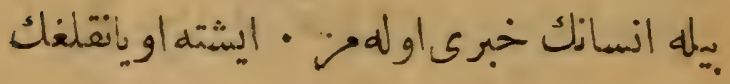

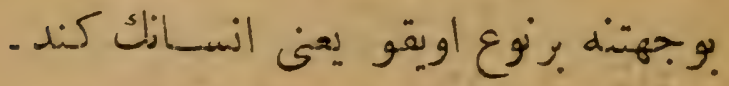

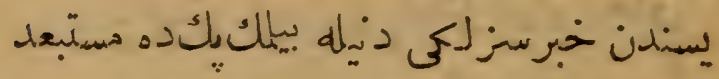

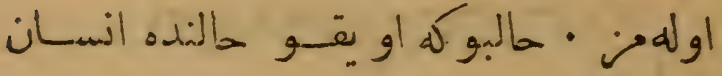
كندى انائتت خصعو صيه سنه دها زيادهياقلا.

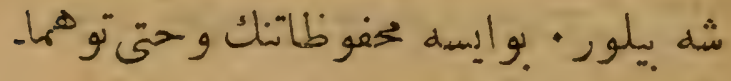

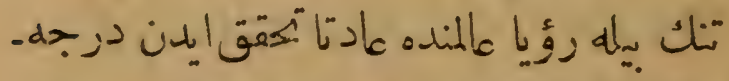

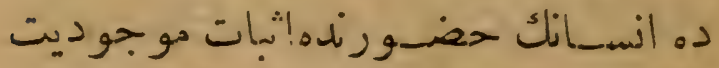

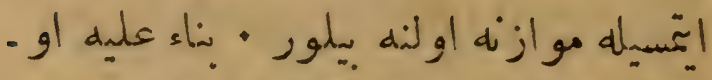

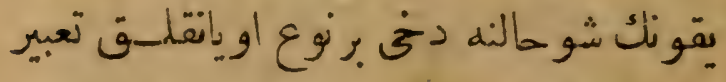
•الونه 


\section{粪 17 弯}

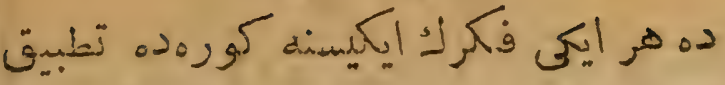

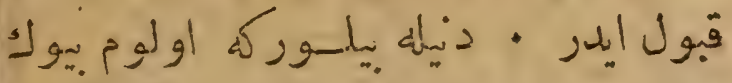

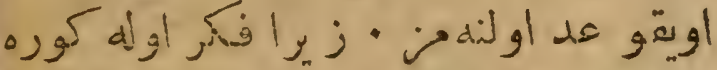

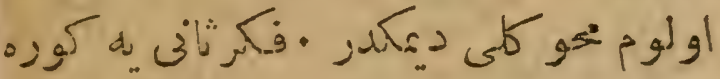

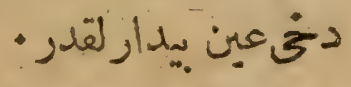

$$
5 \stackrel{*}{*}
$$

أويقو اصل او يانقلق واو يلتقلق

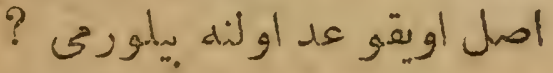

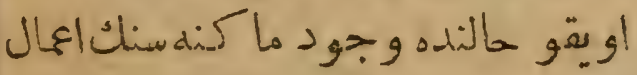

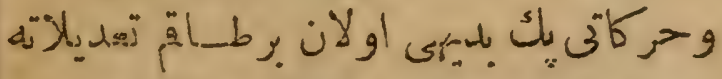

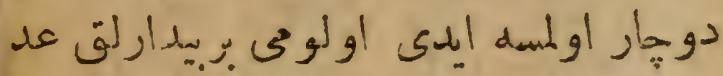

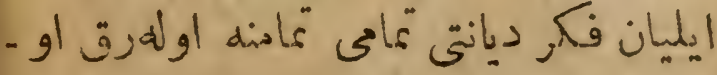

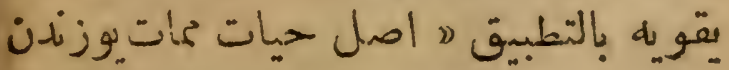

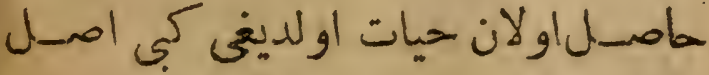

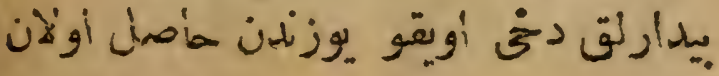




\section{0 絭}

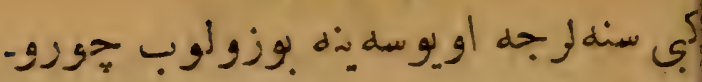

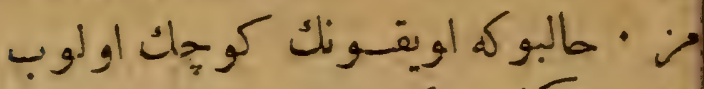

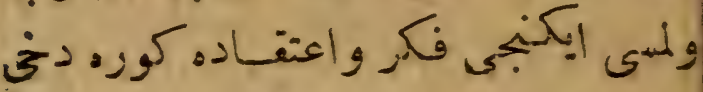

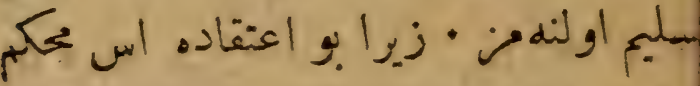

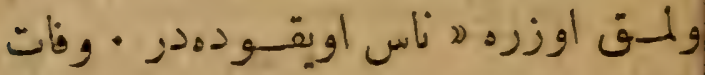

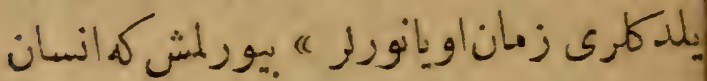

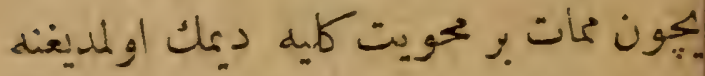

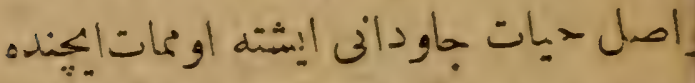

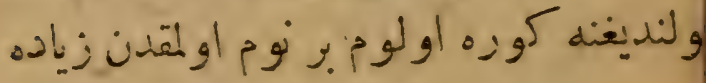

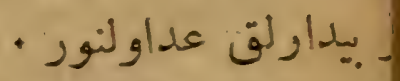

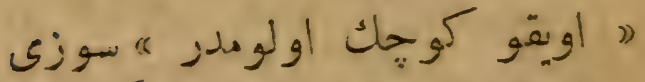

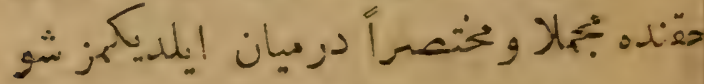

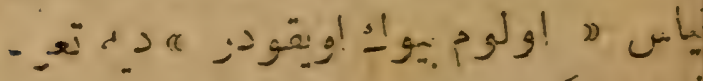

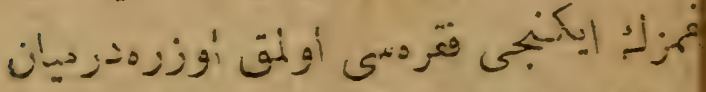

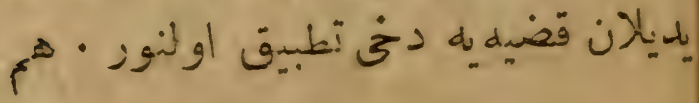




\section{在 16 娄}

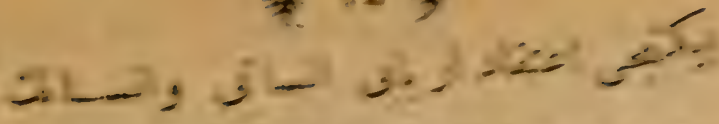

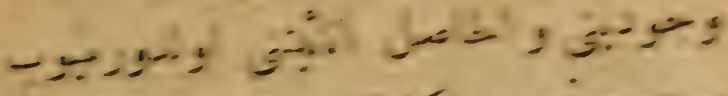
$4 x^{2}-120, \pm \leq-2+2 y=$

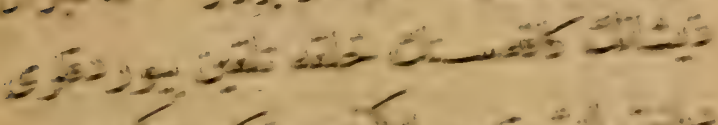

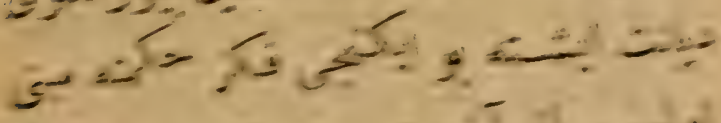

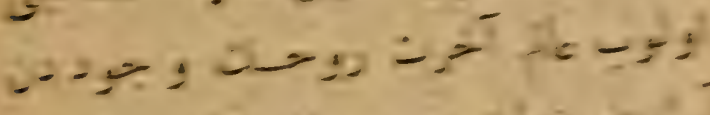

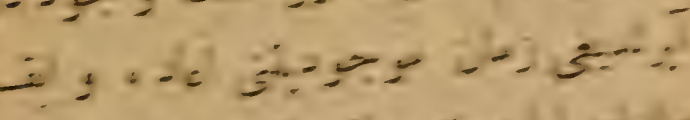

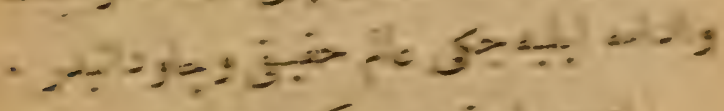

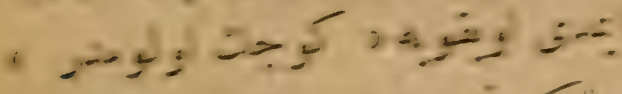

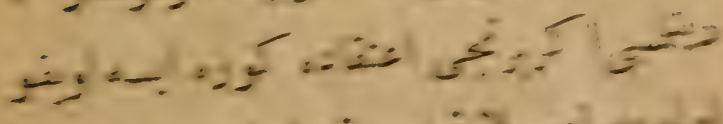

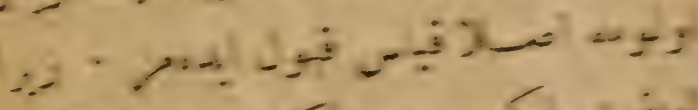

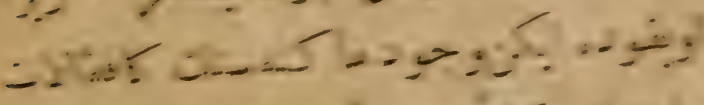

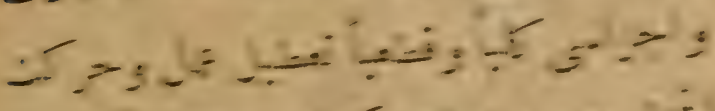
भे

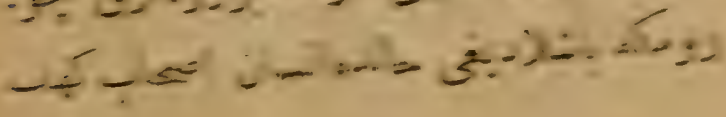


ir

عندن و.ناء عليه بقاي وجودمه لازم كلان

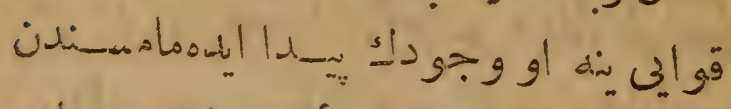

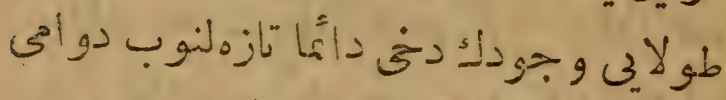

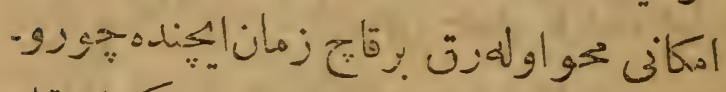

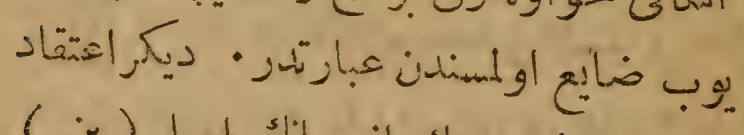

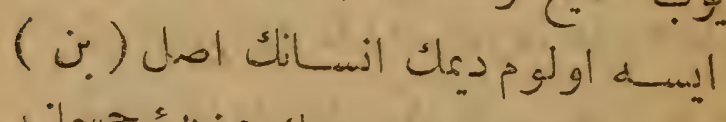

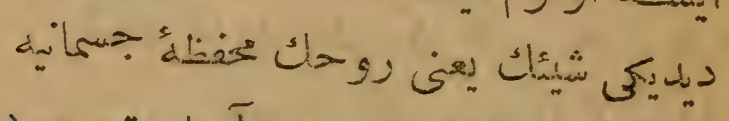

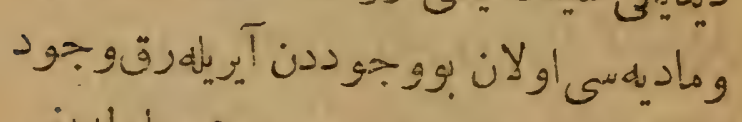

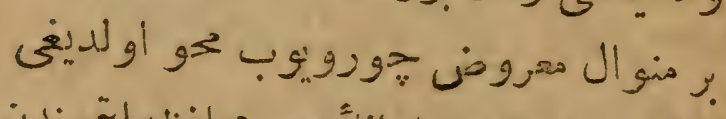

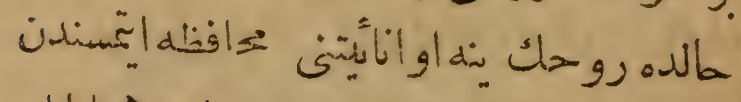

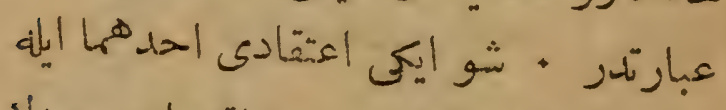

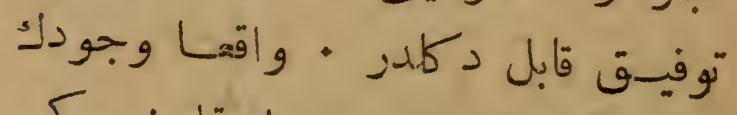

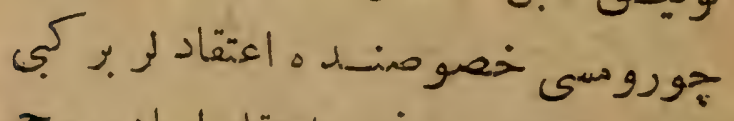

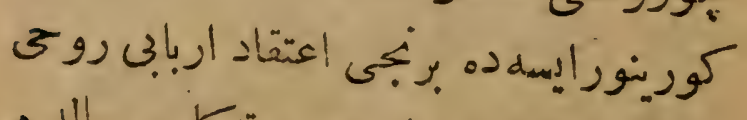

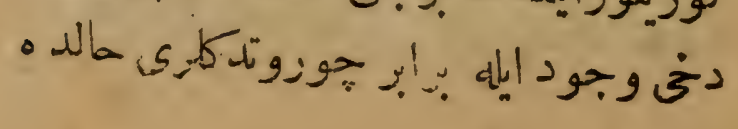


ir

كلينى نوع بشر اليكون مكن وحتى ماصل

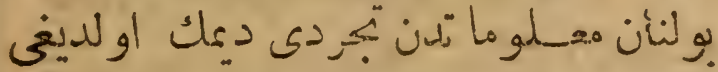

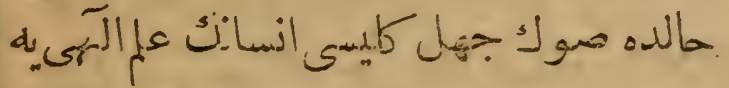

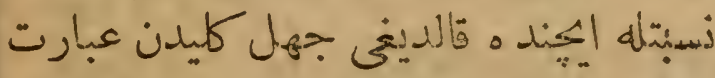

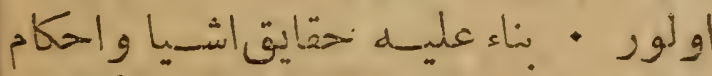

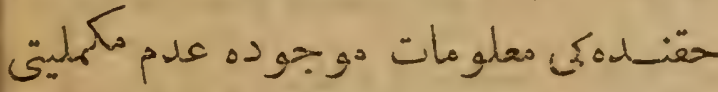

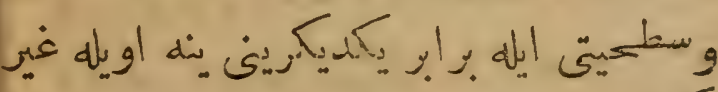

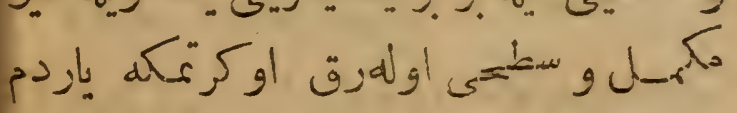

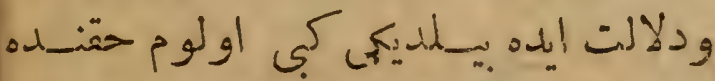

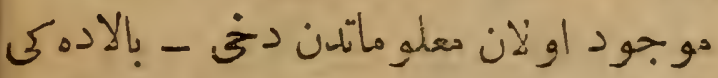
تعريف اقتضانينه - اويقويى ده استدلاله

- جالشهه بِّورز

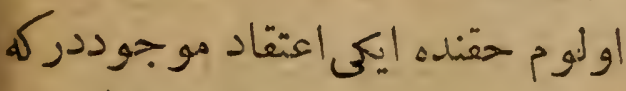

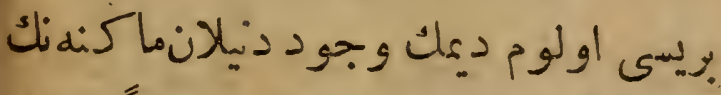

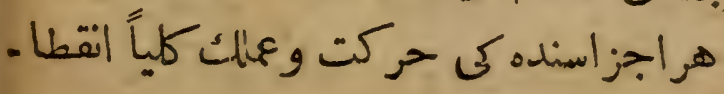




\section{1 粼}

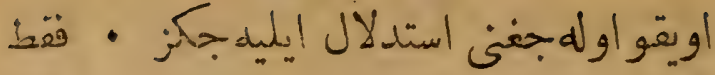

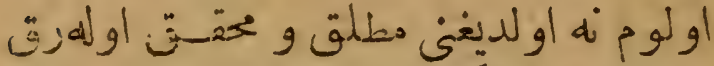

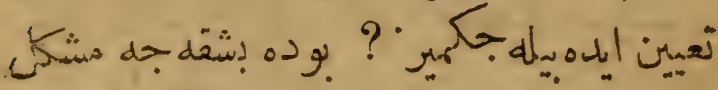

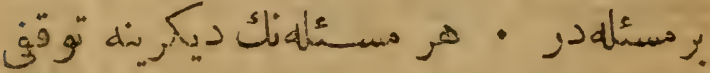

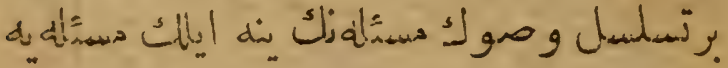

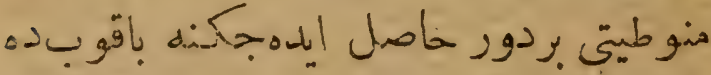

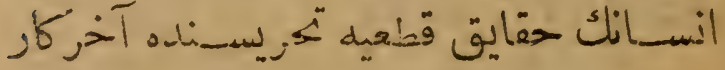

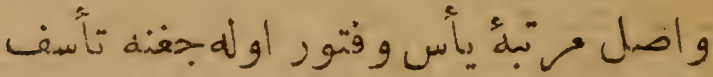

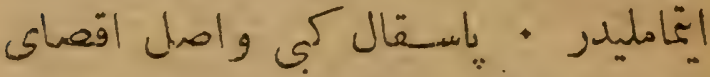

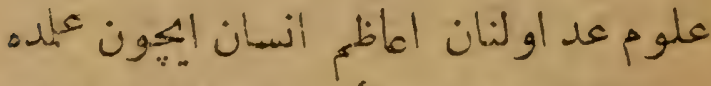

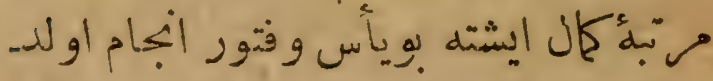

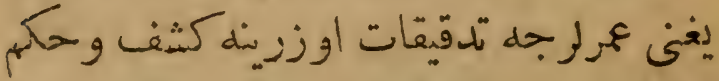

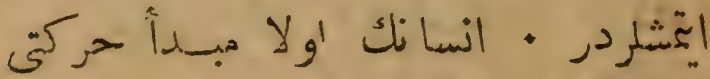

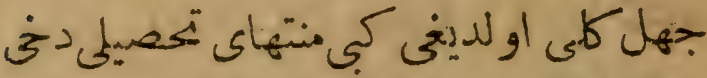

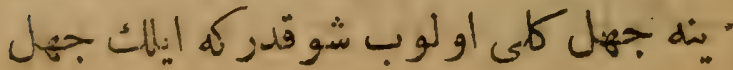




\section{1. 䊅 \\ i $\stackrel{3}{*}$}

- اويقو اليله أولوم اره سنده كى نسلت

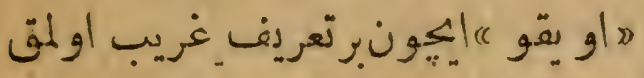

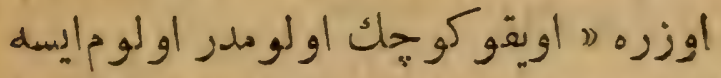

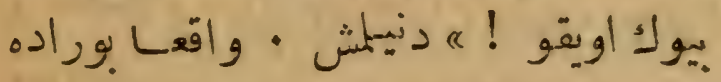

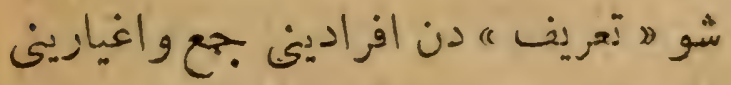

-

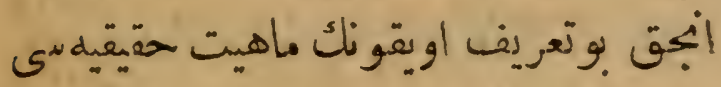

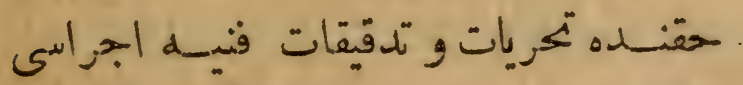

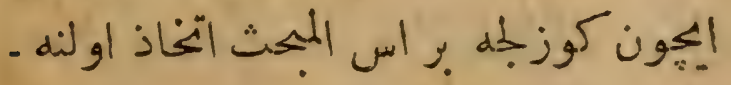

$$
\text { . }
$$

" اويتو كو جكاك اولو مدر " دنبليكى

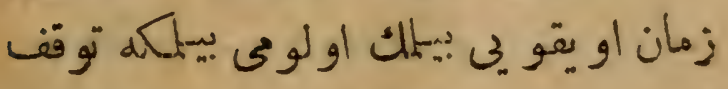

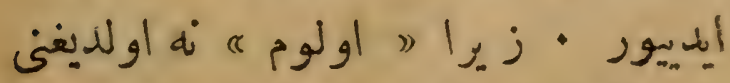
. 


\section{9 泌}

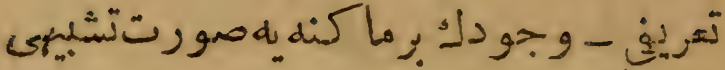

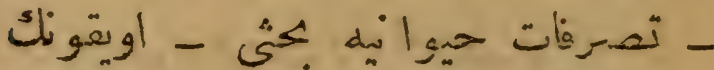

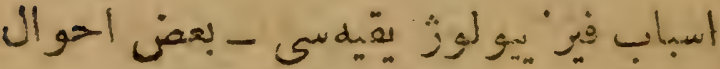

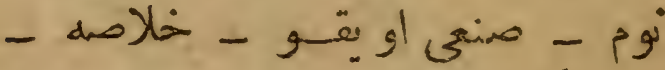

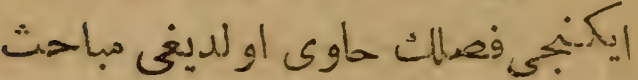

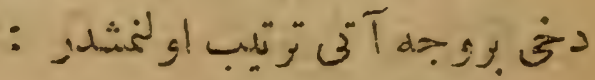

: قو - قو

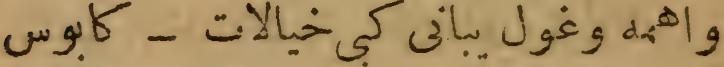

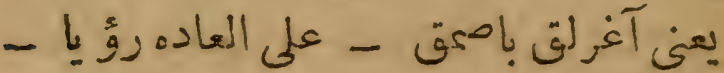

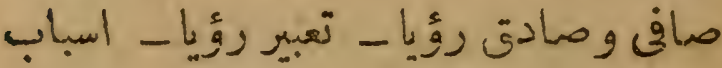

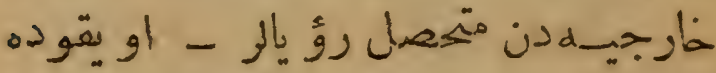

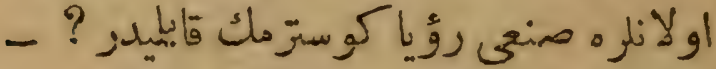

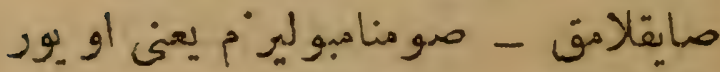

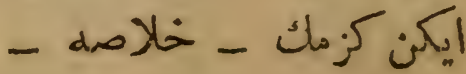
(J) ) 


\section{A 洗}

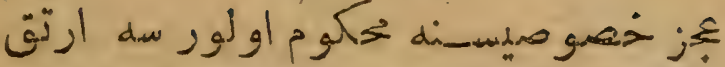

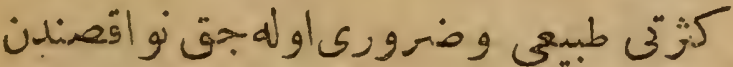

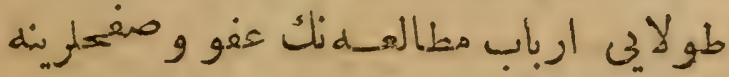

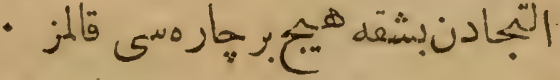

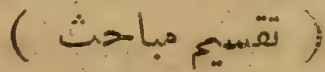

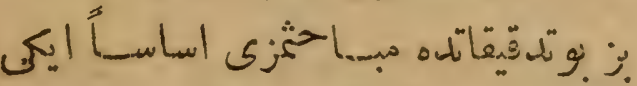

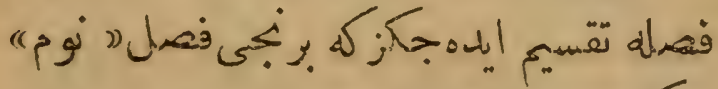

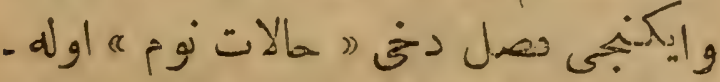

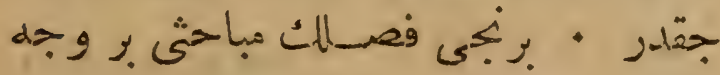

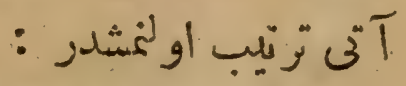

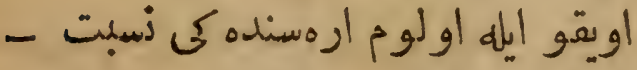

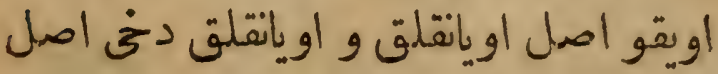

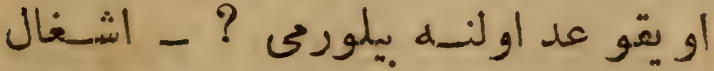

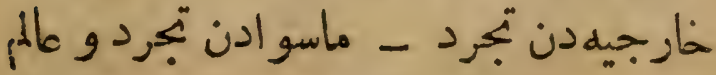

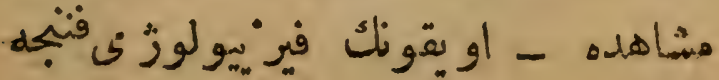




\section{V}

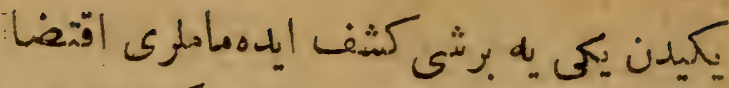

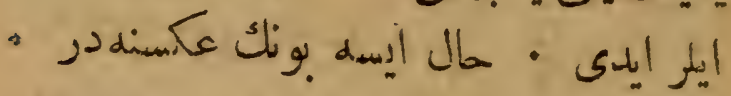

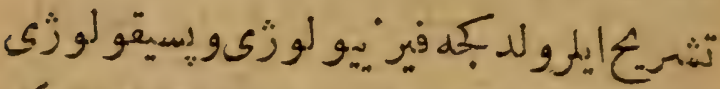

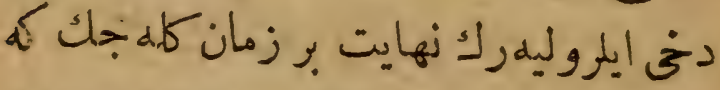

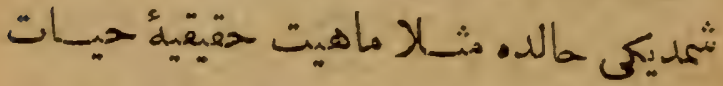

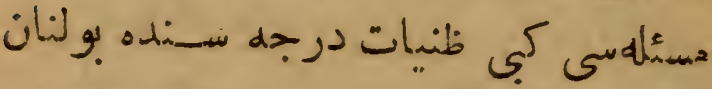

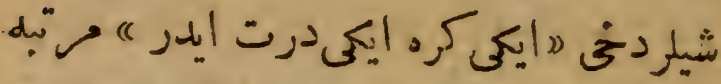

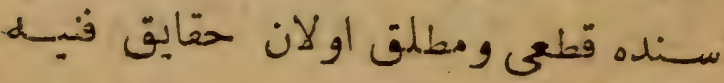

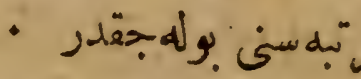

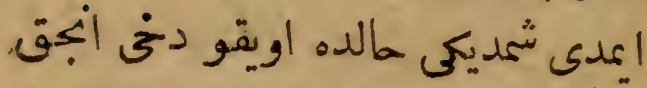

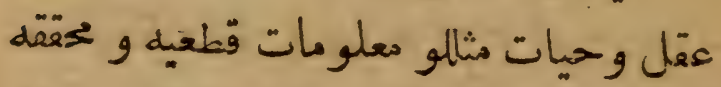

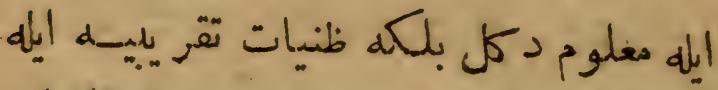

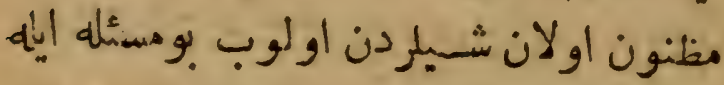

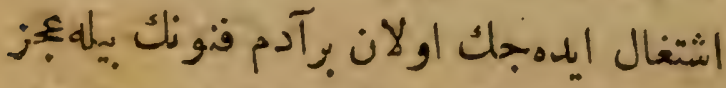

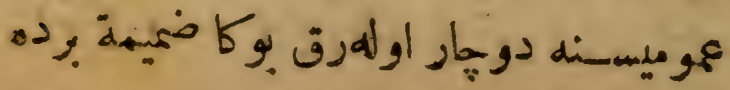




\section{7}

لـ ده .و فنلر لك هنوز شوكى مسائل دقيقهده

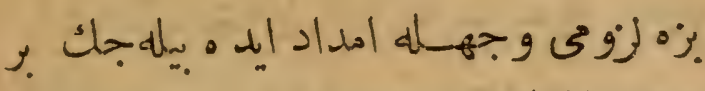

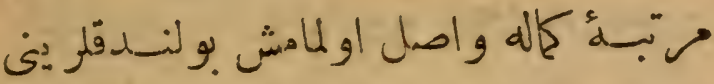

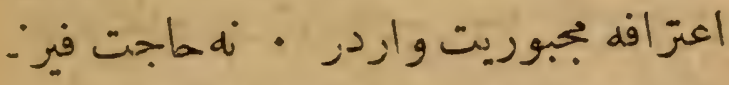

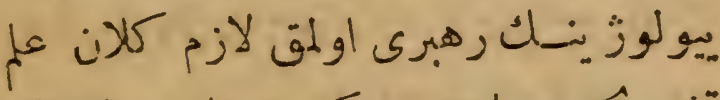

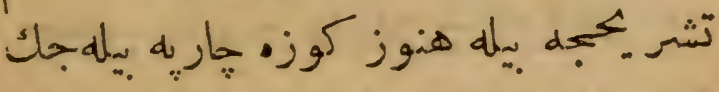

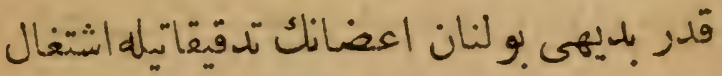

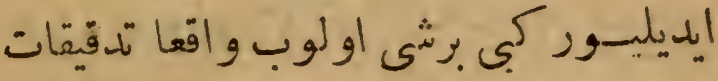

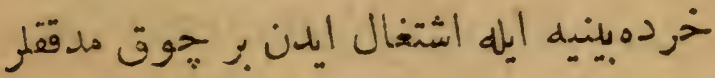

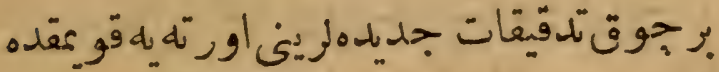

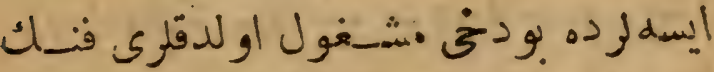

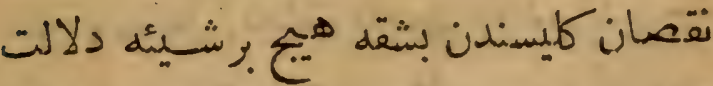

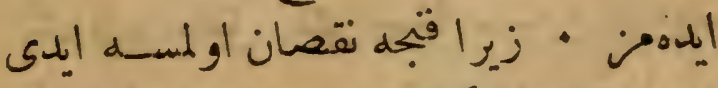

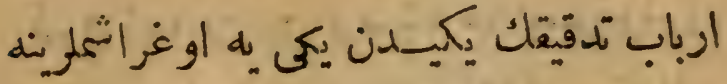

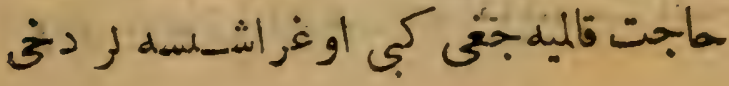




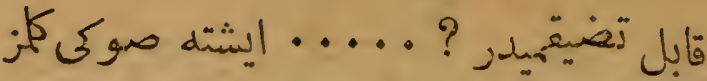

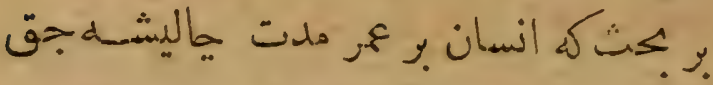

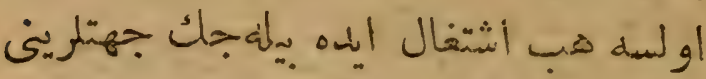

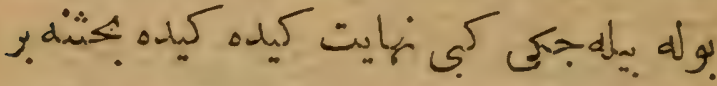

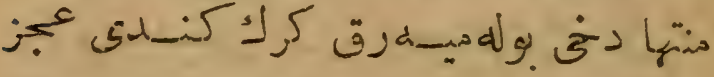

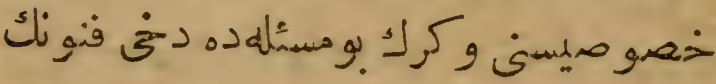

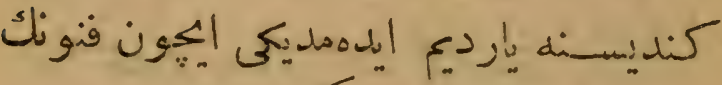

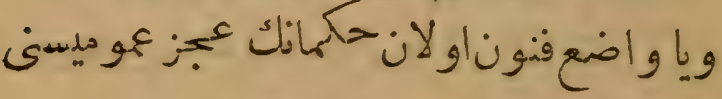

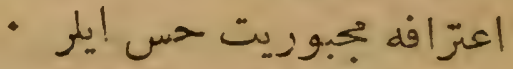

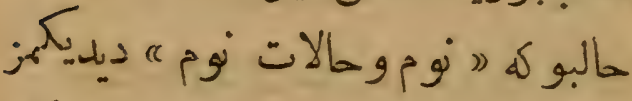

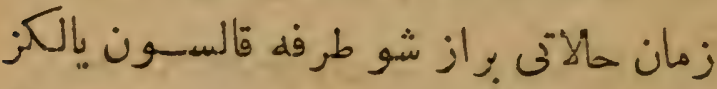

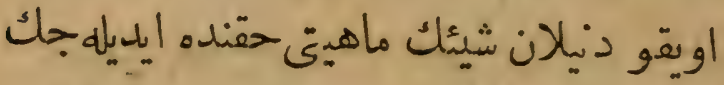

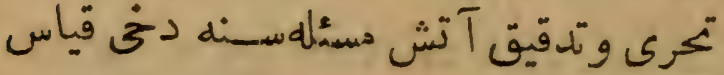

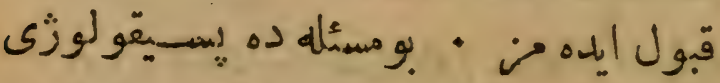

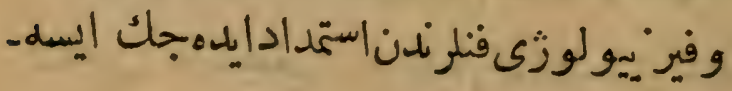




\section{纟染}

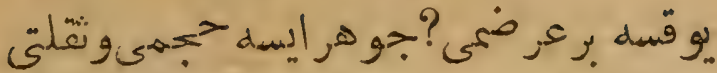

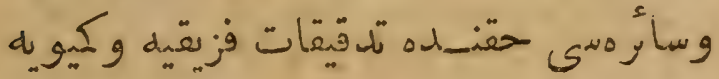

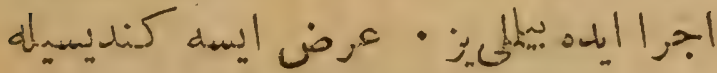

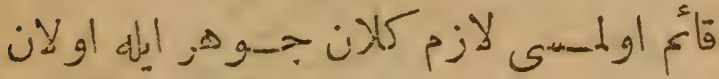

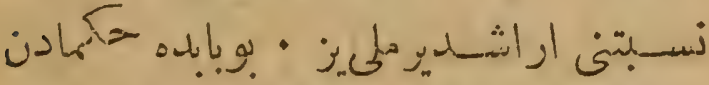

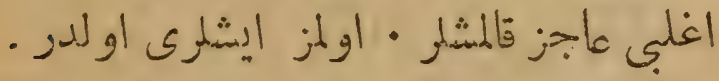

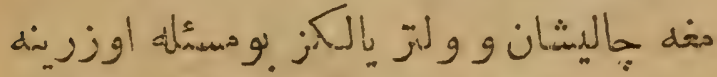

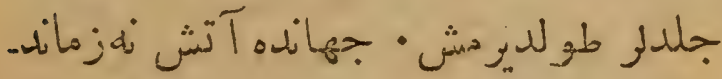

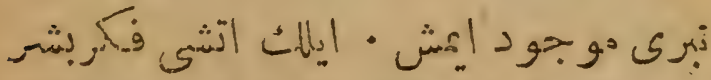

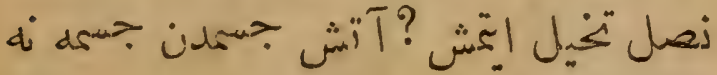

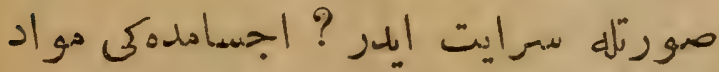
مشتعله احتراقى حالنده او اجسام اوزرندهنه

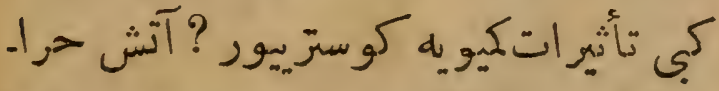
رتدمى عبارتدر? حرارت طوس طوغريمه

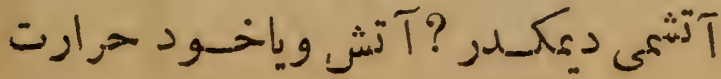




\section{r}

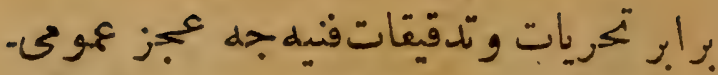

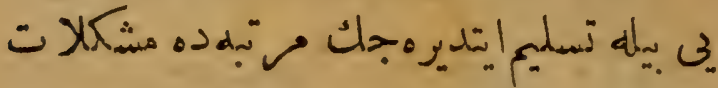

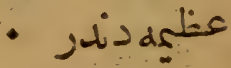
مقتحت بعض شيلم واردركه سطيكياتده

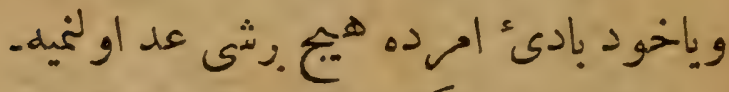

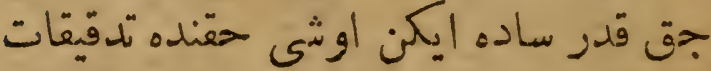

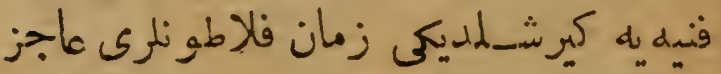

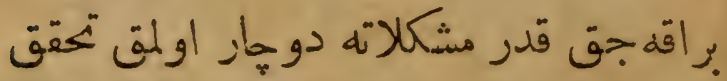

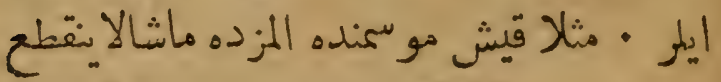

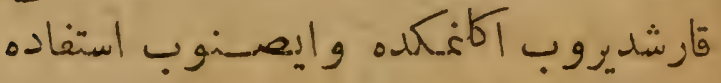

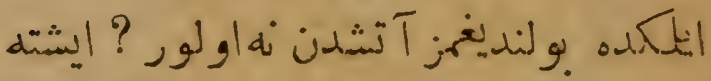

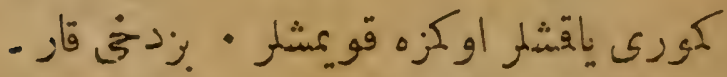

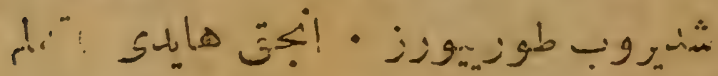

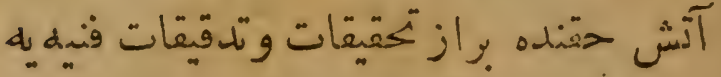

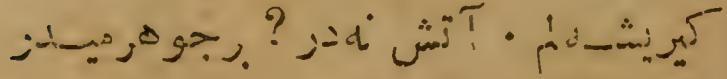




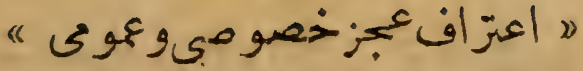

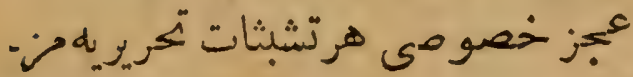

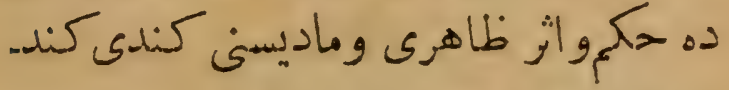

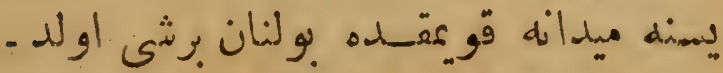

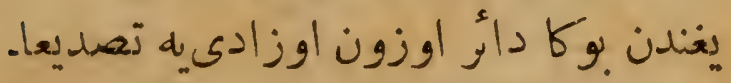

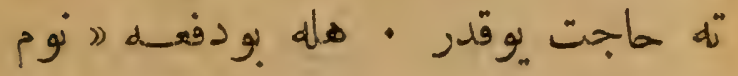

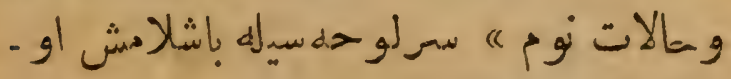

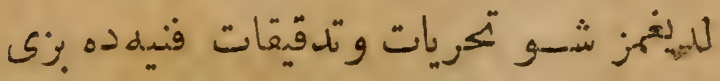

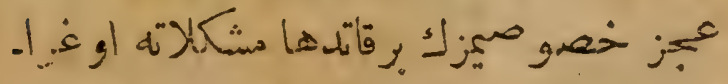

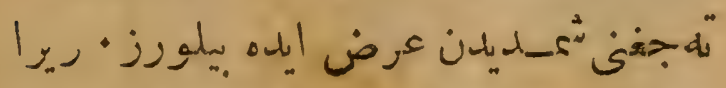

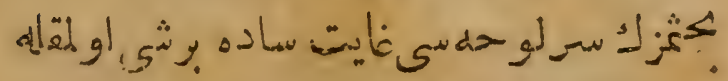




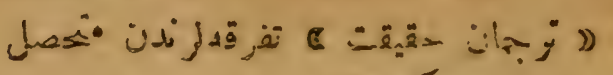

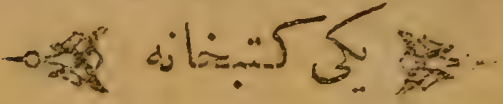

Thmet Mithat

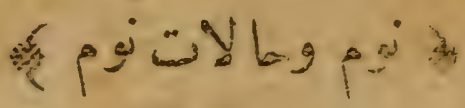

$a_{203}=0$

Nevin vehälät-1 neum.

محرزي

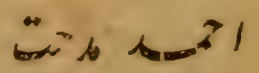

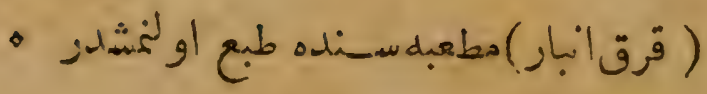

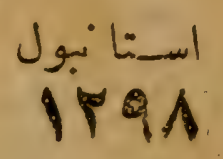


. 




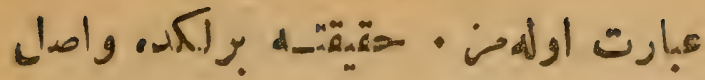

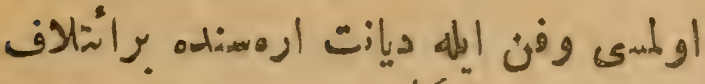

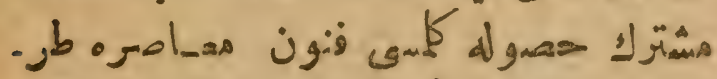

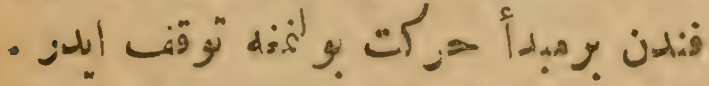
:كر كاجزانهمه كموره ف:ون هاضرهن

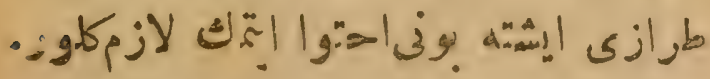

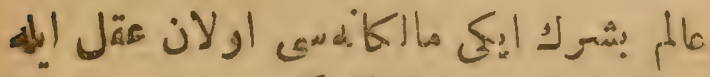
إحis

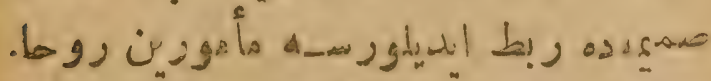

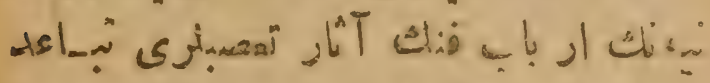

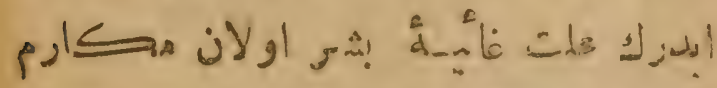

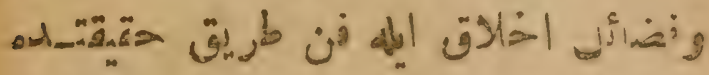

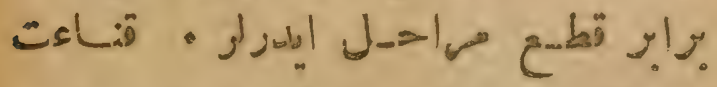

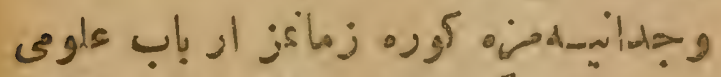
| |fis!

$$
\text { وندن عهارندر. }
$$


vo

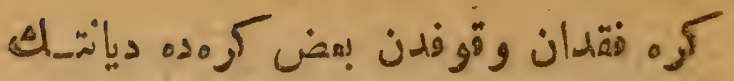

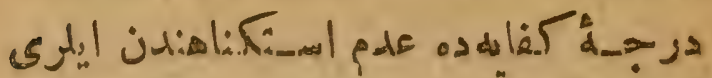

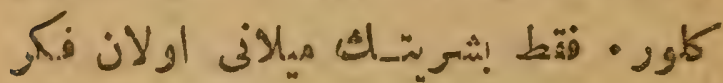

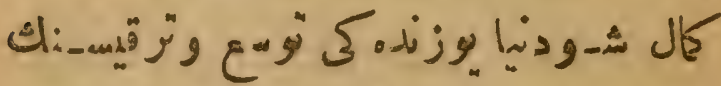

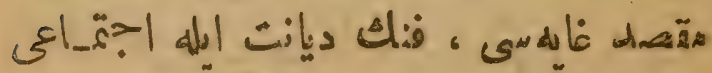

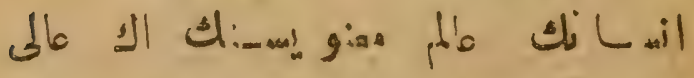

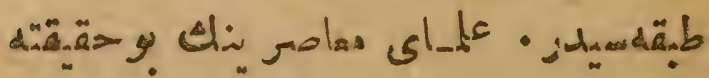

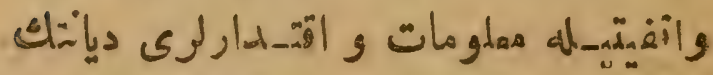

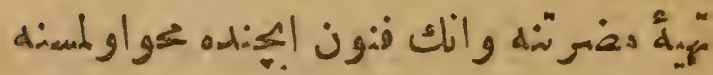

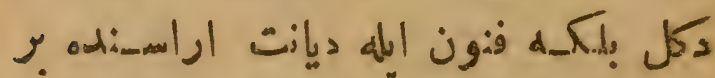

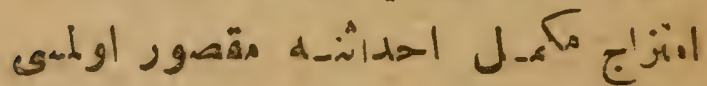

-

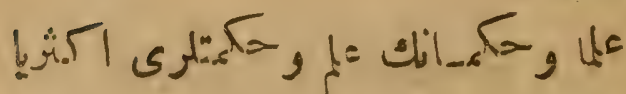

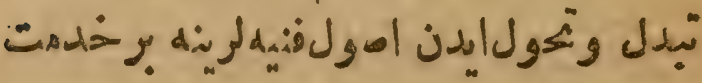

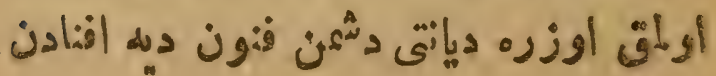


$V \leq$

أمهاو

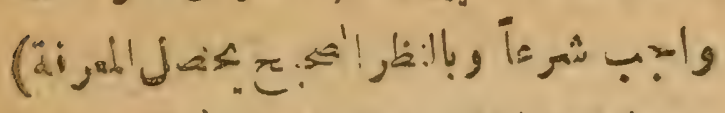
|

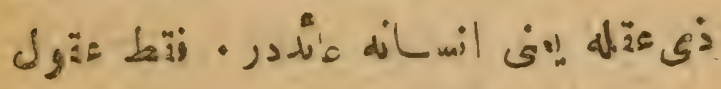

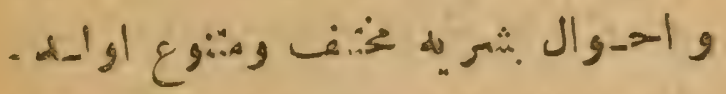

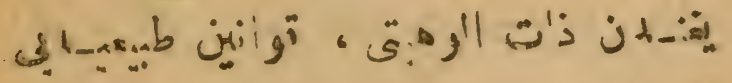

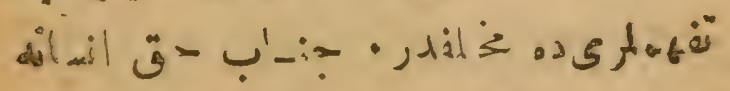

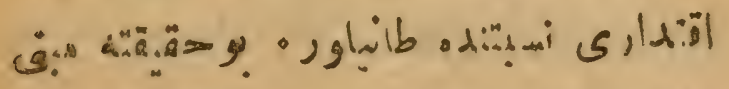

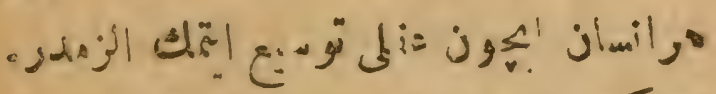

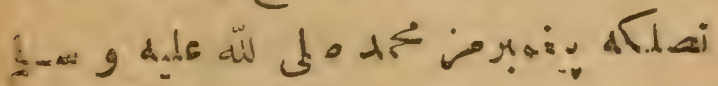

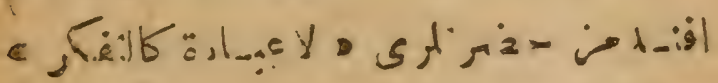

•وردم:

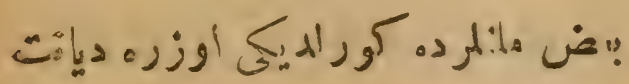

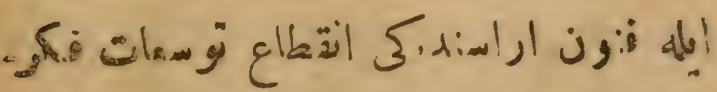

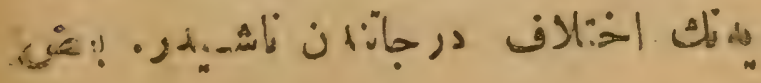




\section{* $V^{\mathrm{w}}$}

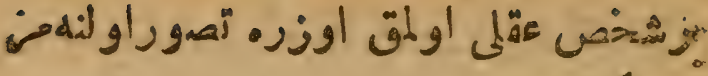
ن.

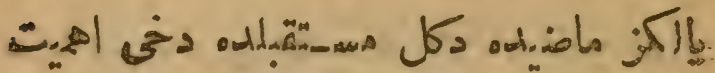

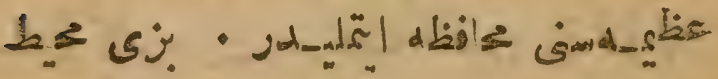

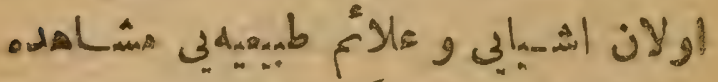

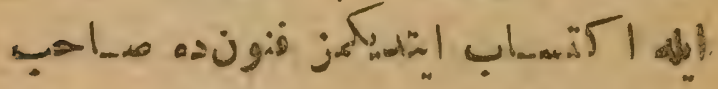

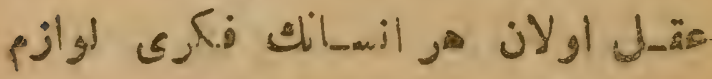

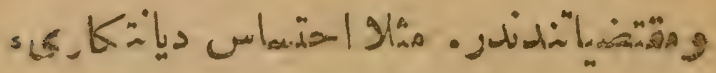

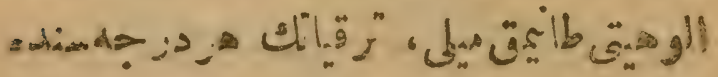

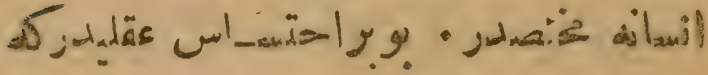

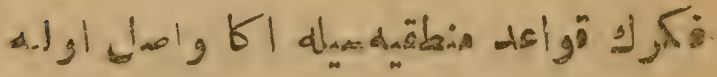
-

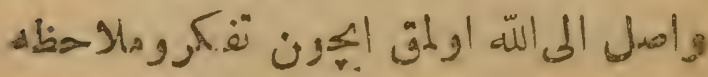

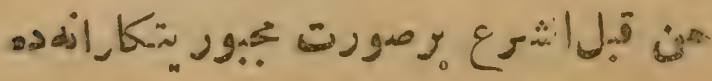




\section{乘 Vr}

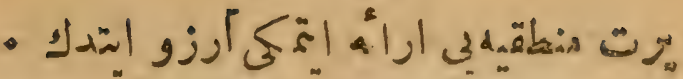

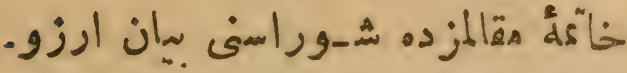

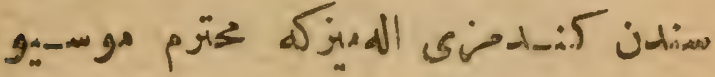
فان كب

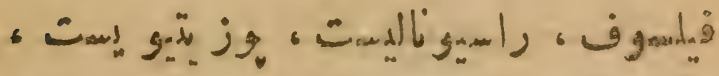

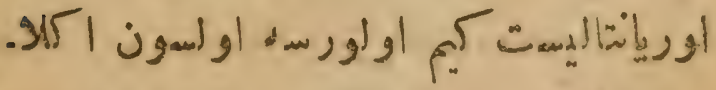

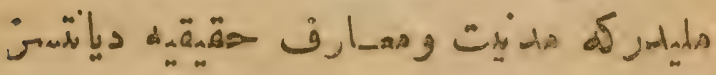

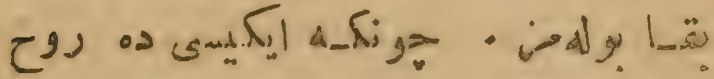

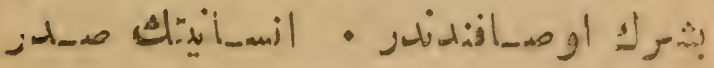

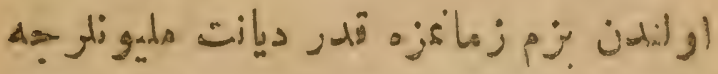

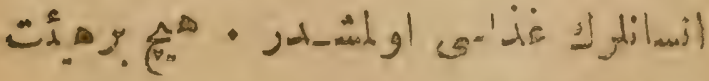
-

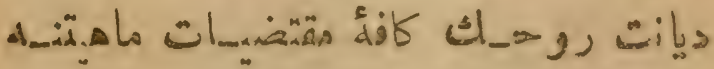
دونش في

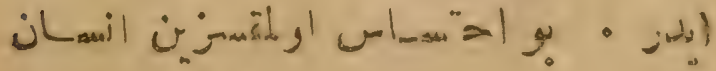




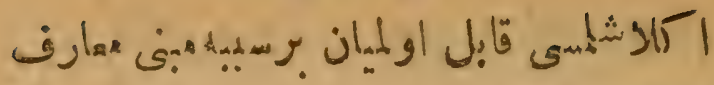

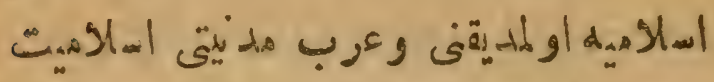

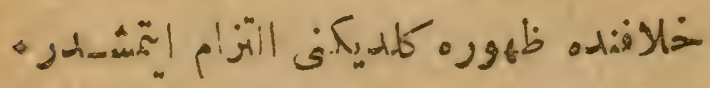

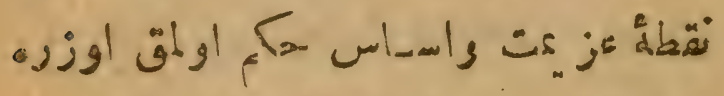

जو

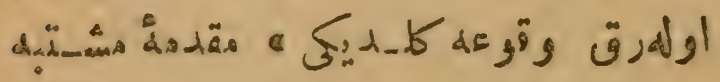

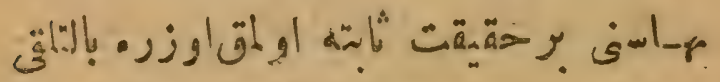

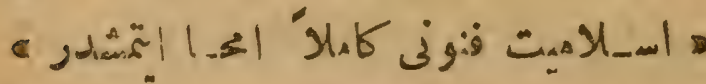

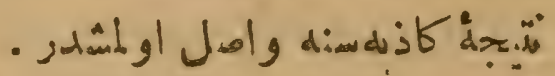

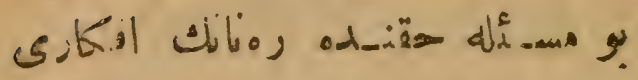

نأن

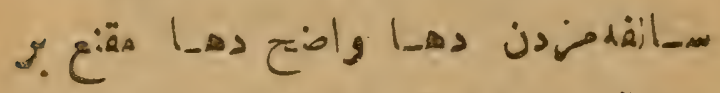

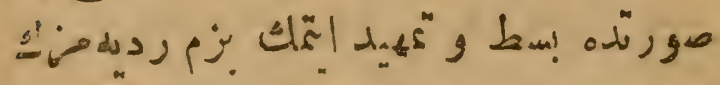

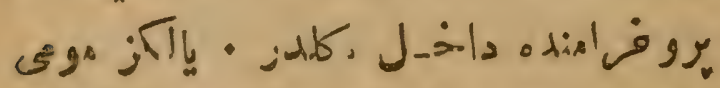

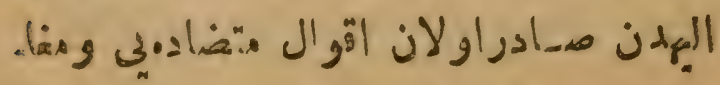




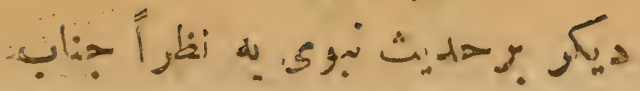

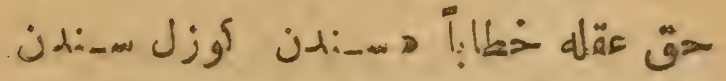

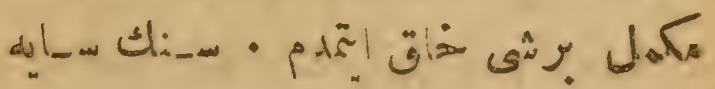

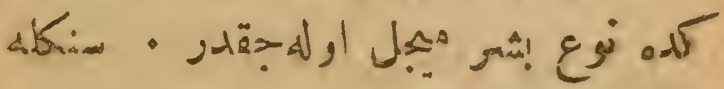

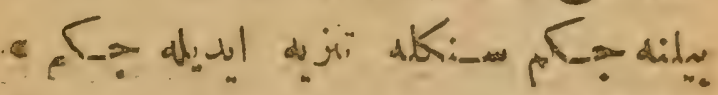

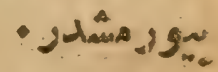

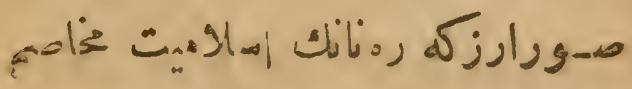

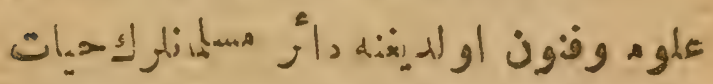

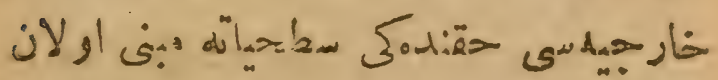

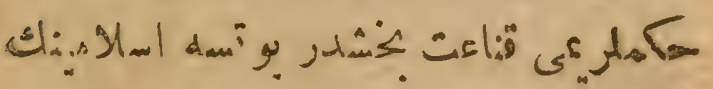

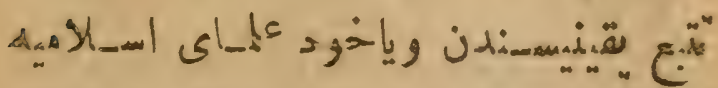

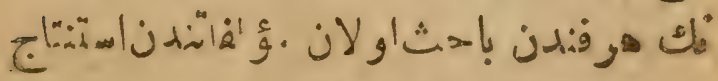

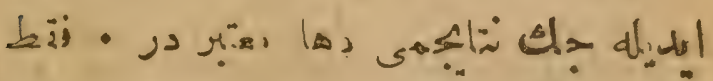
s

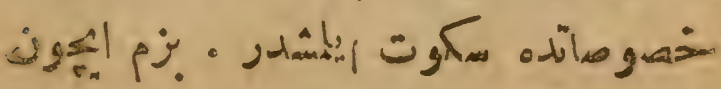




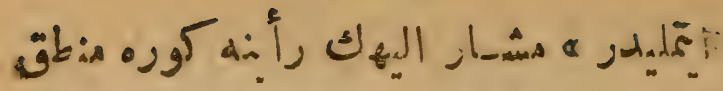

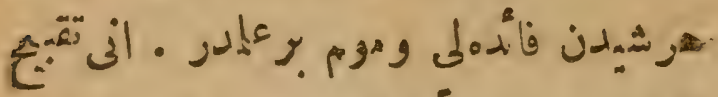

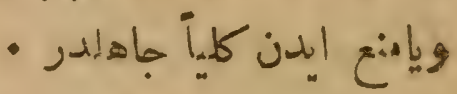

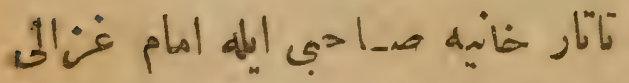

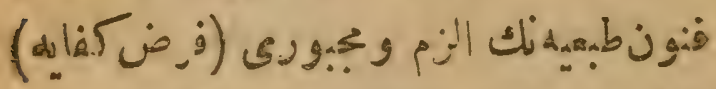

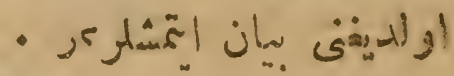

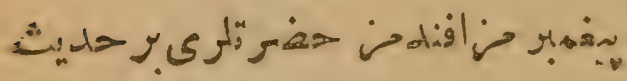

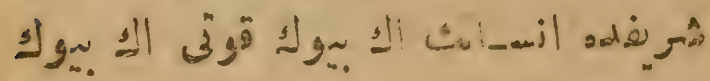

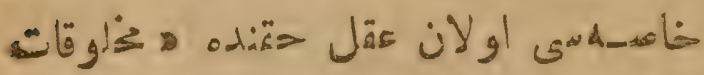

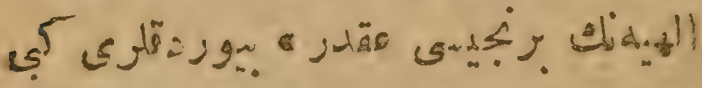

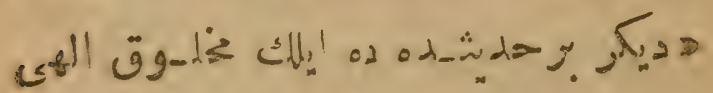

Aا

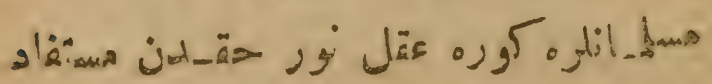

•ونورن 


\section{(41)}

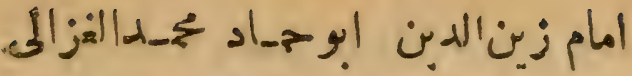

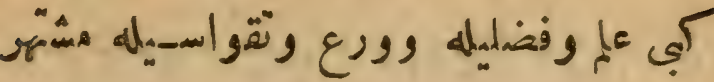

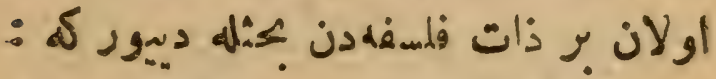

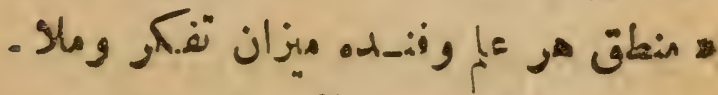

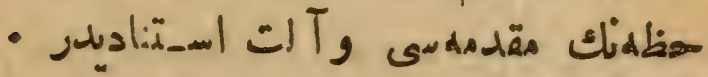

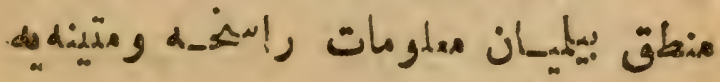
صاحب أولهن

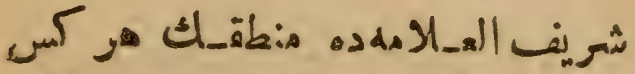

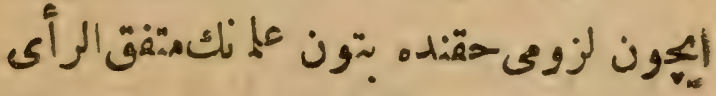

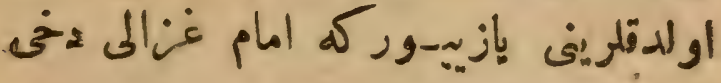

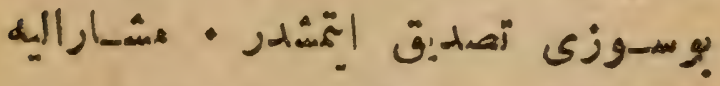

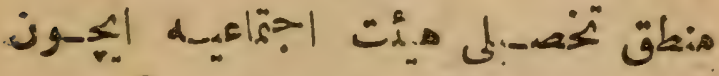

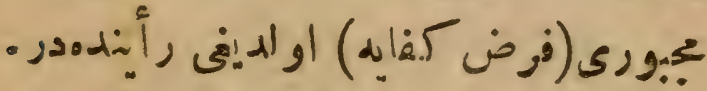

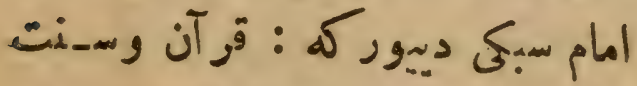

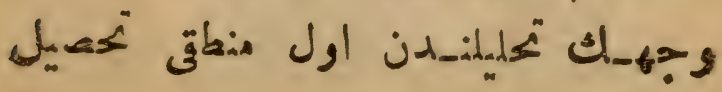




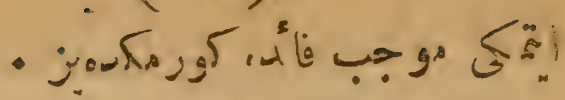

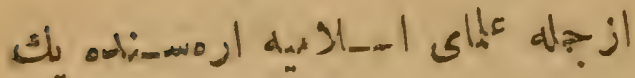

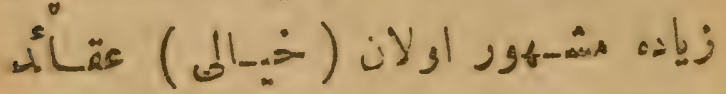

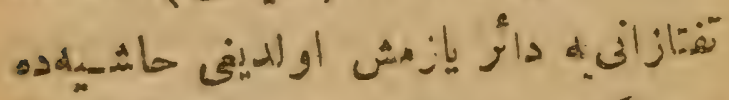

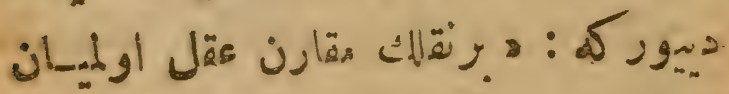

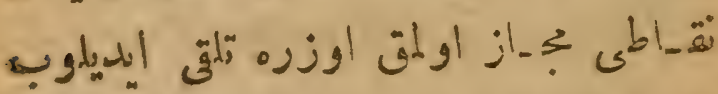

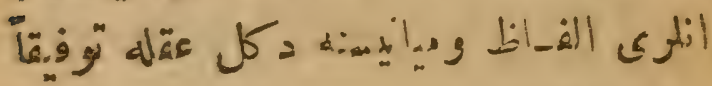

c

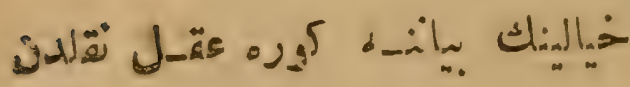

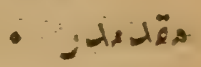

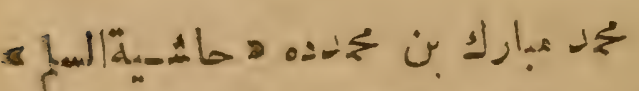

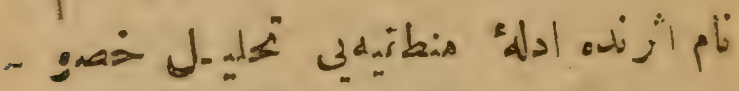

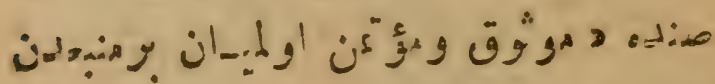

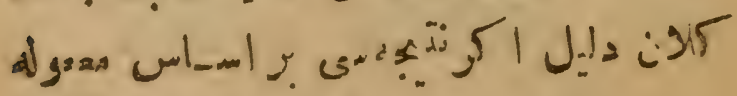

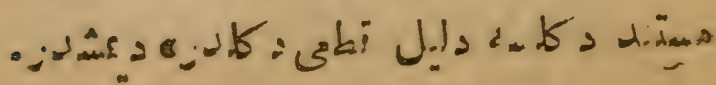




\section{9\%}

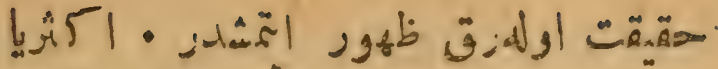

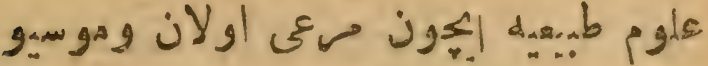

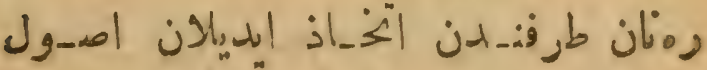

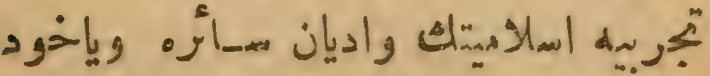

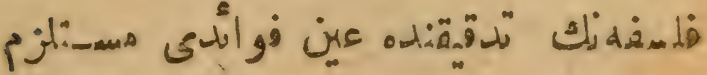

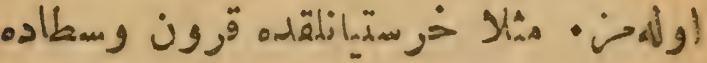

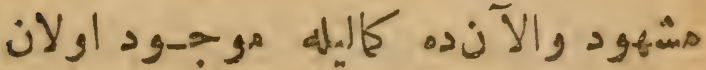

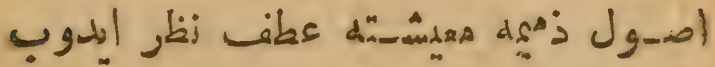

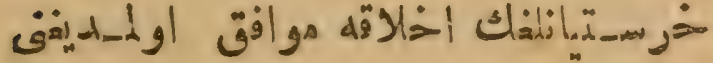

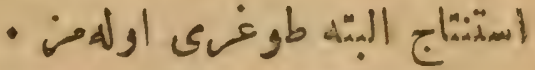
al |

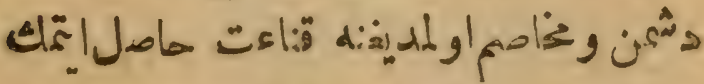

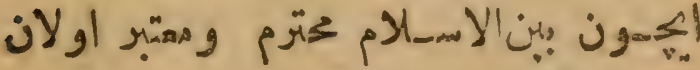

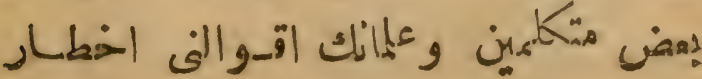




\section{$90 \%$}

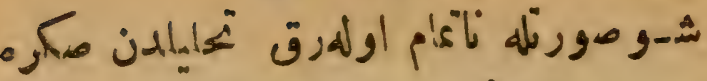

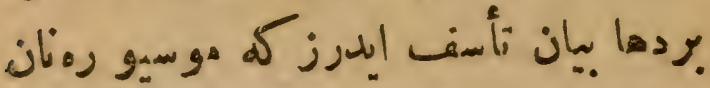

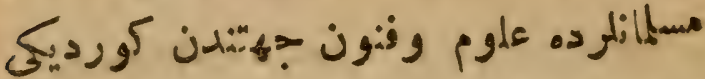

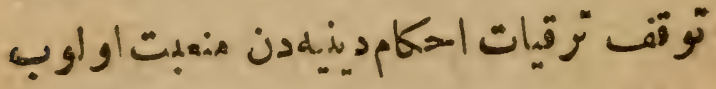

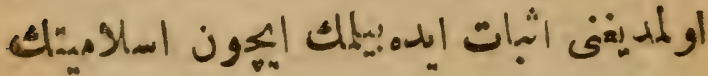

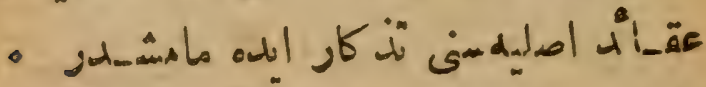

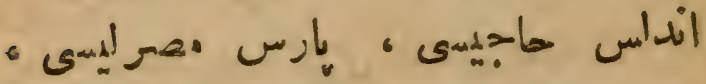

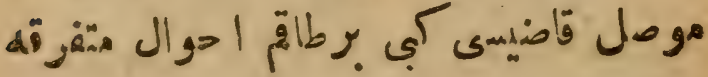

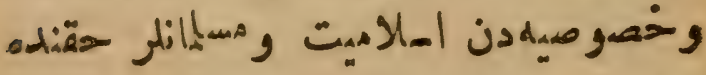

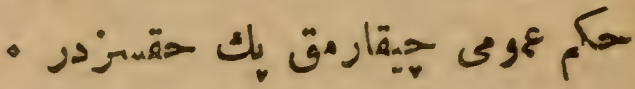

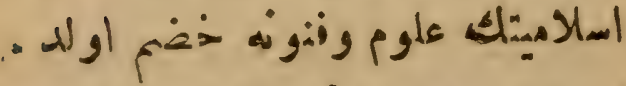

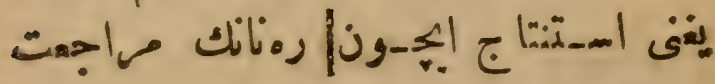

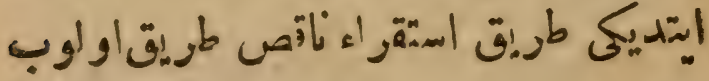

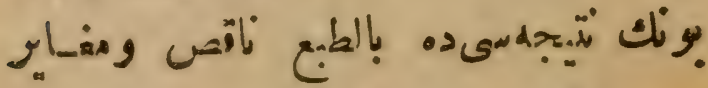
$r$ 


\section{8}

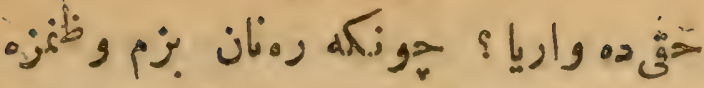

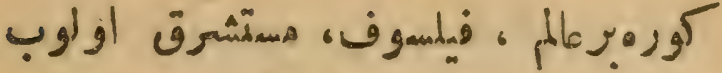

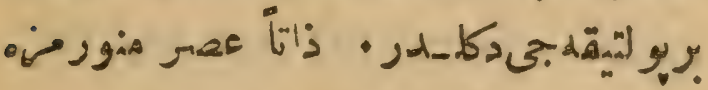

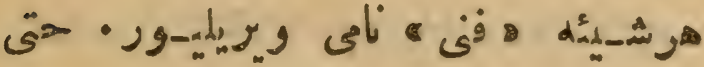

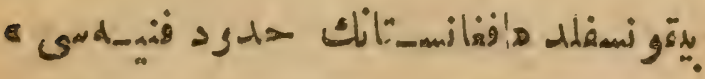

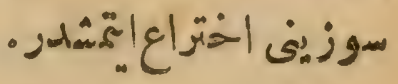

ربنان بوفاضى كي كندى نقطة نظرندن

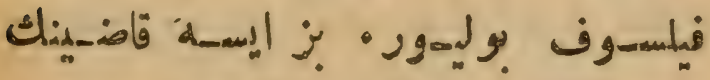

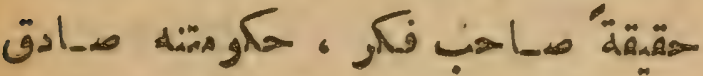
ومAm

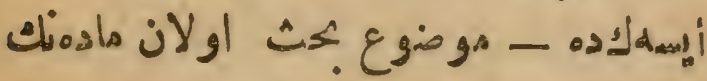

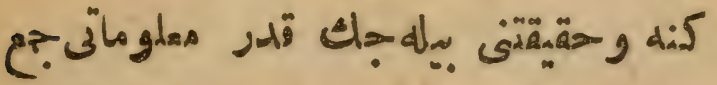

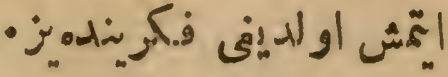

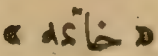

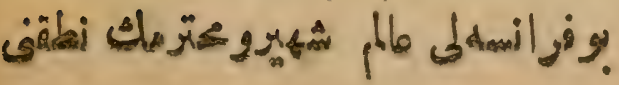




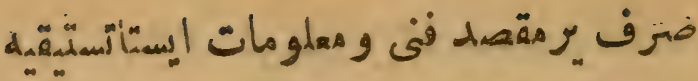

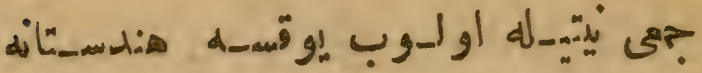

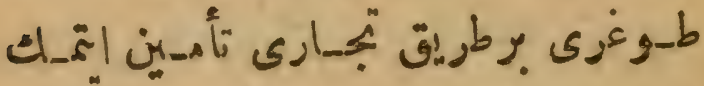

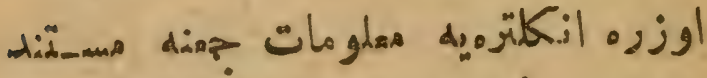

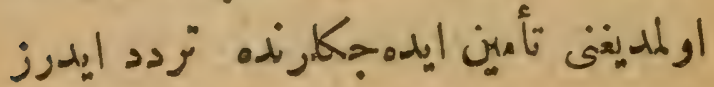

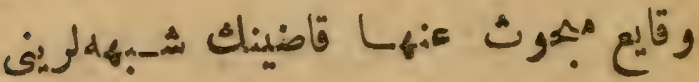

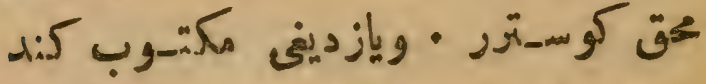

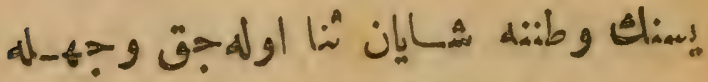
صلا:ت ارتّاطنى كو سمتردم

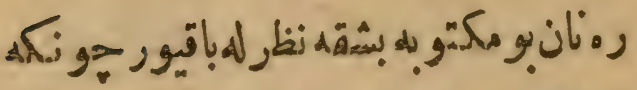

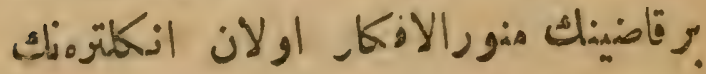

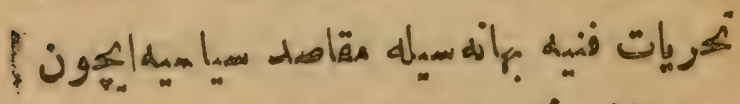

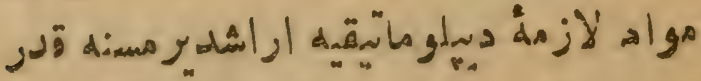

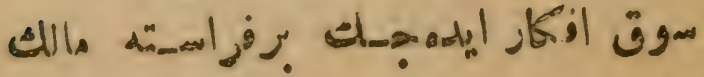

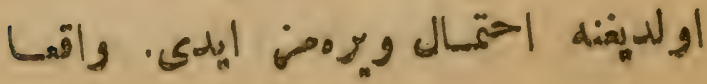




\section{\% or 离}

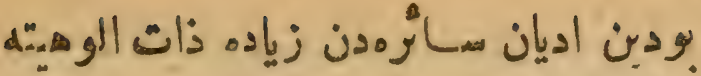

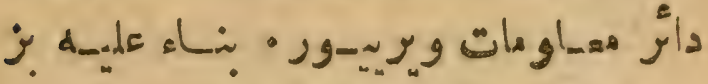

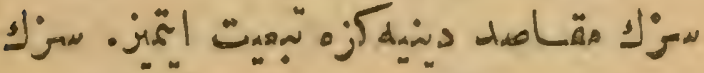

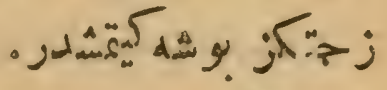

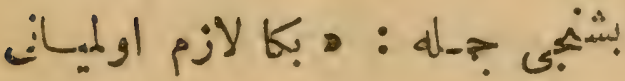

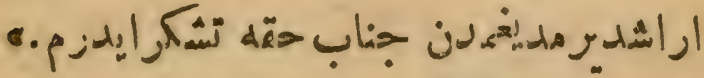

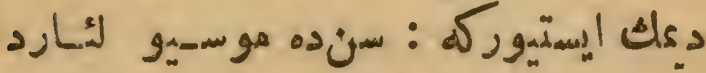

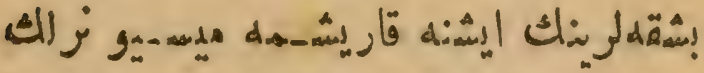

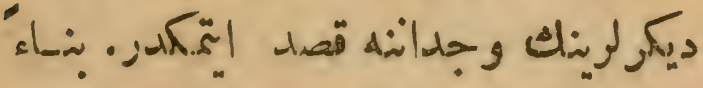
-

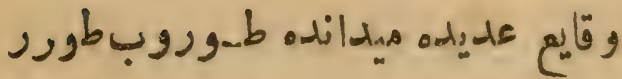

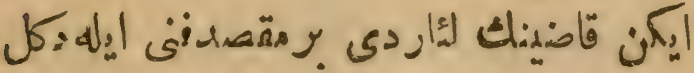

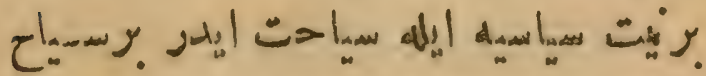

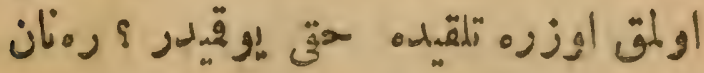

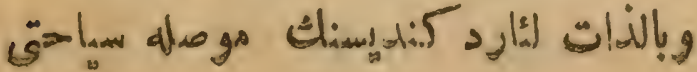


41

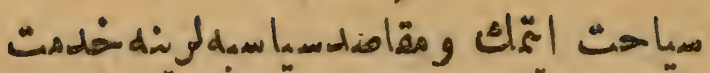

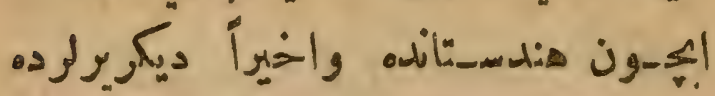

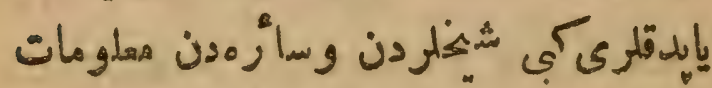

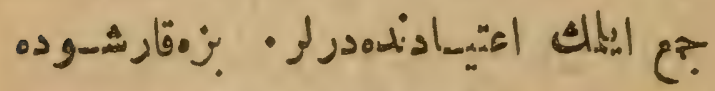
اوصور نله

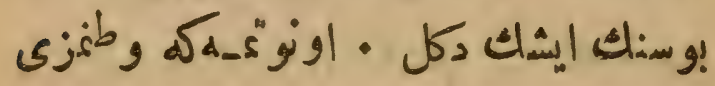

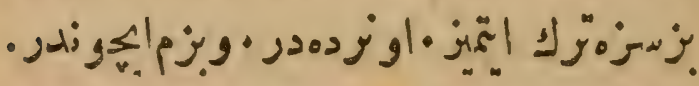

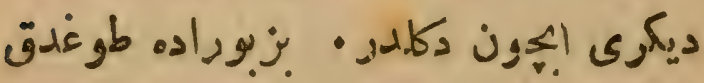

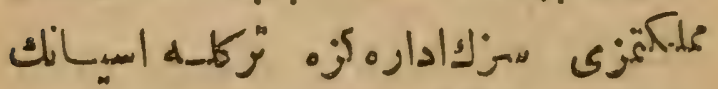

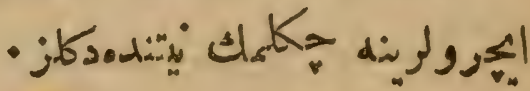
afll!

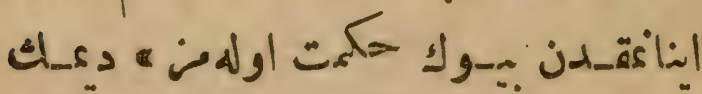

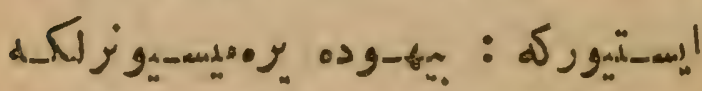

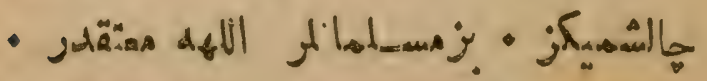

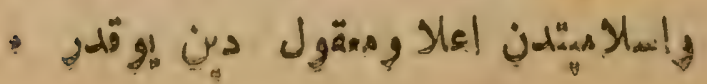




\section{7.}

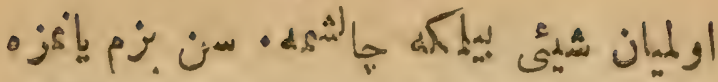

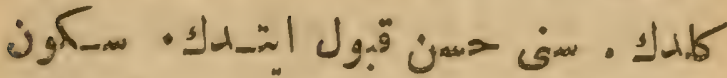

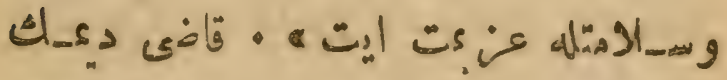

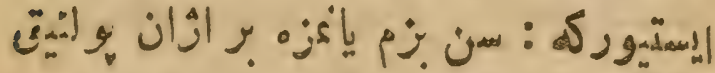

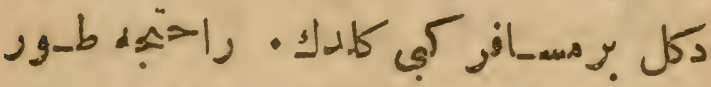

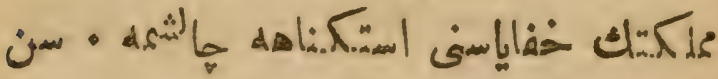

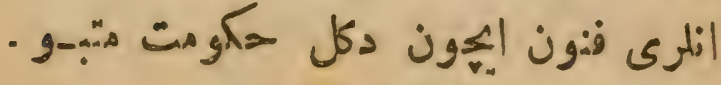
ن

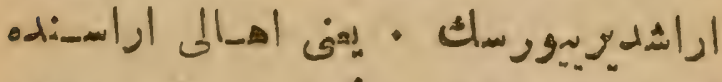

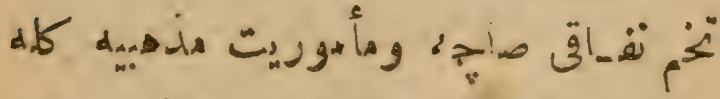

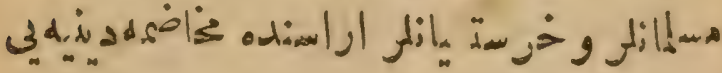

$$
\text { تحربك ايتمه }
$$

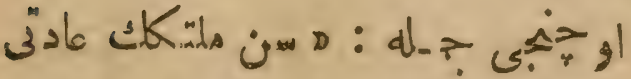

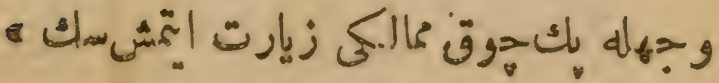

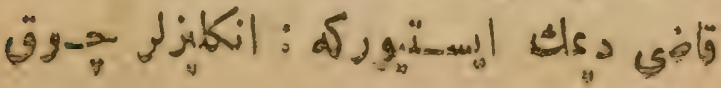




\section{塯 99}

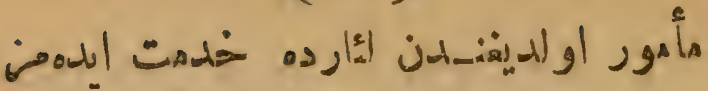

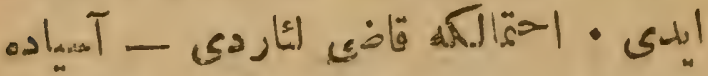

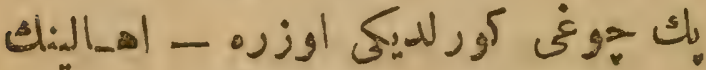

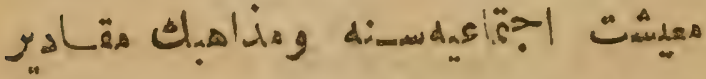

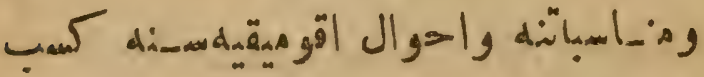

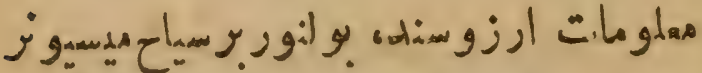

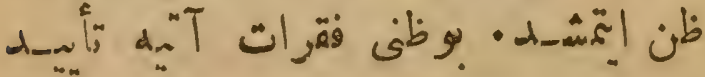

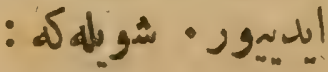

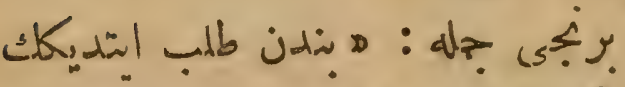

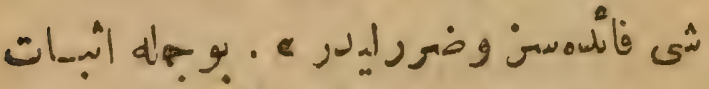

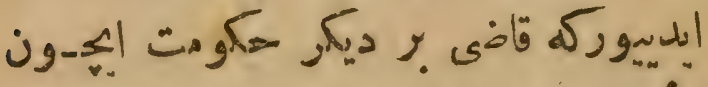

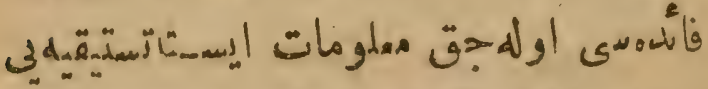

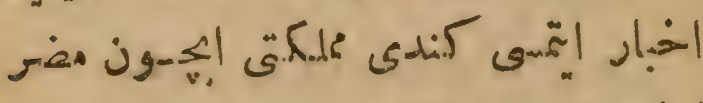

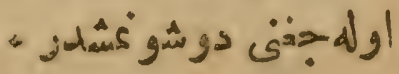

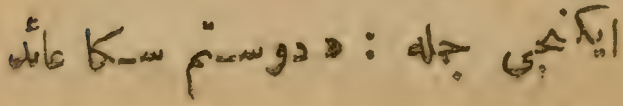




\section{变 01}

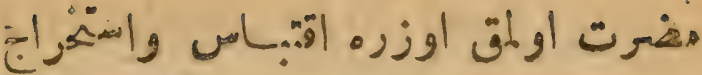

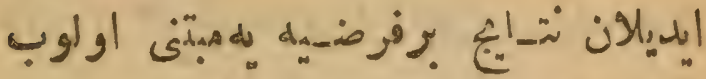

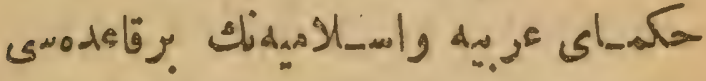

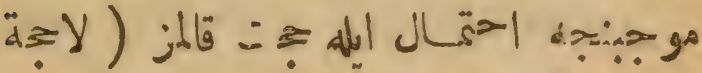

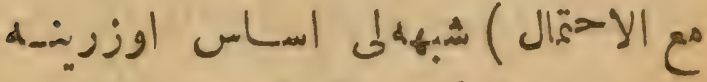
مؤس سمس اولان

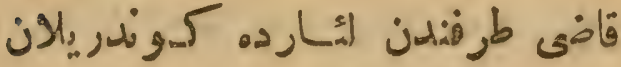

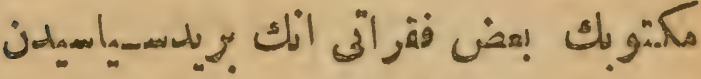

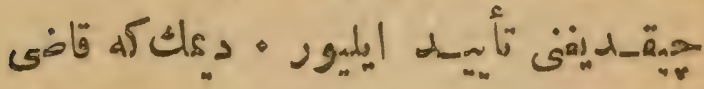

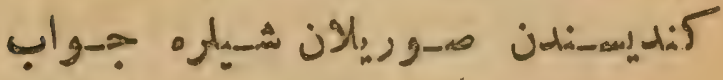

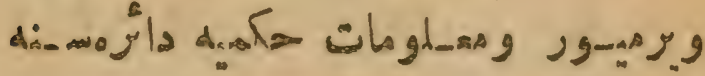

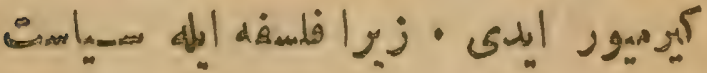

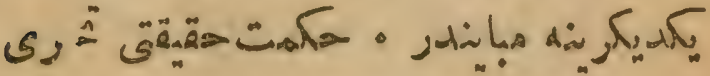

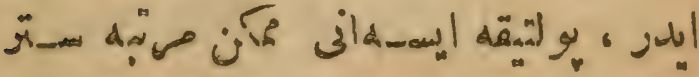

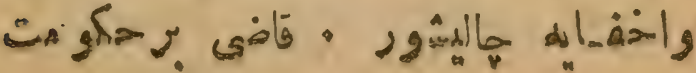


vo

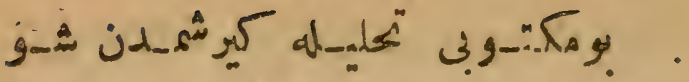

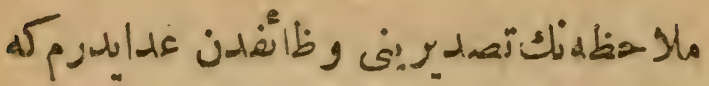

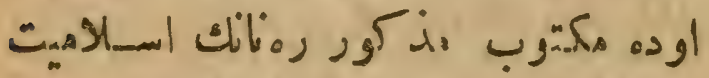

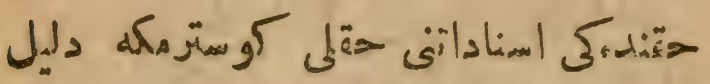

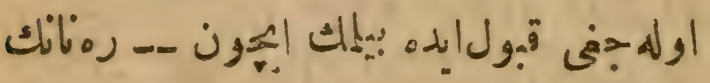

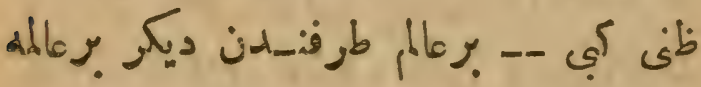

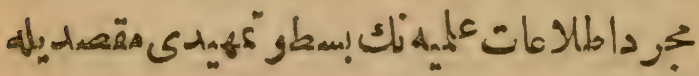

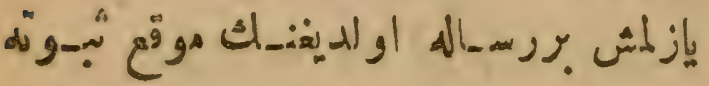

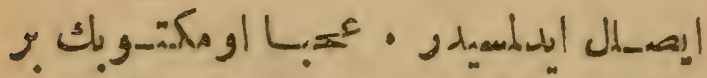

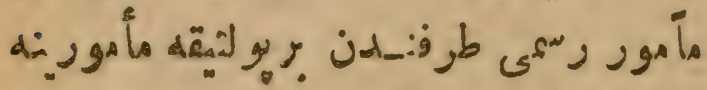

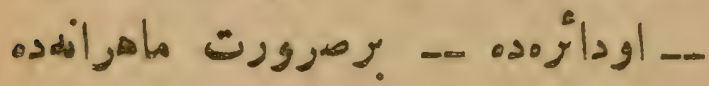

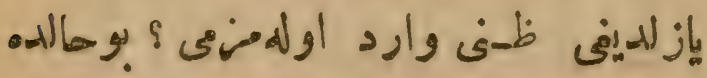

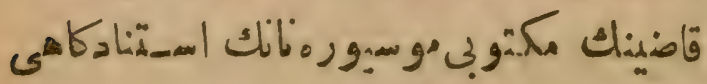

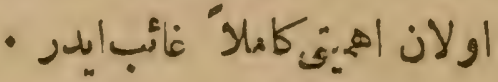

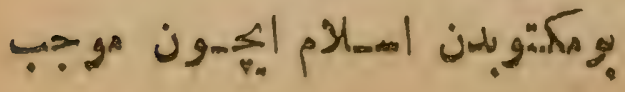




\section{स०१方}

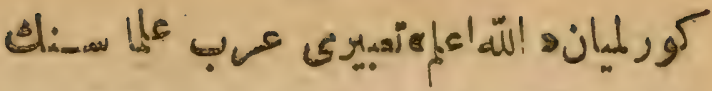

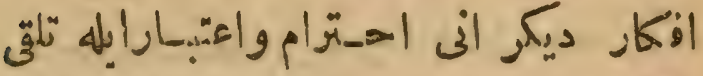

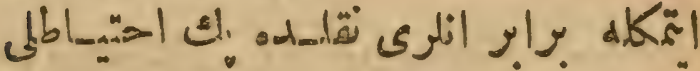

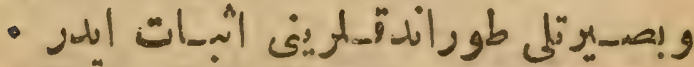

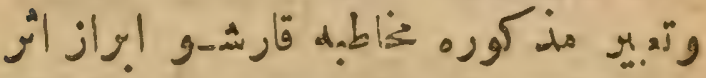

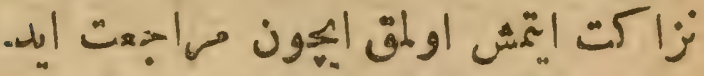

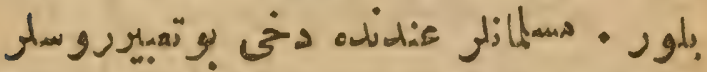

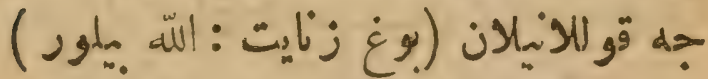
-

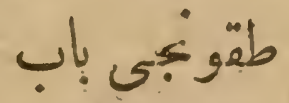

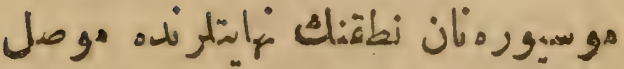

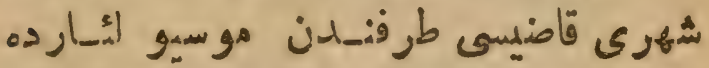

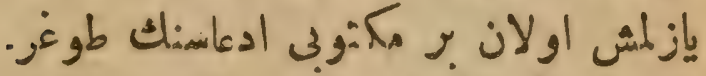

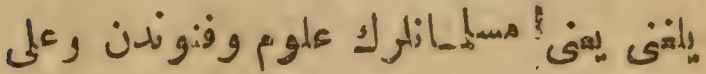

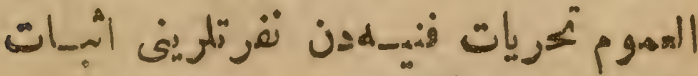
- 


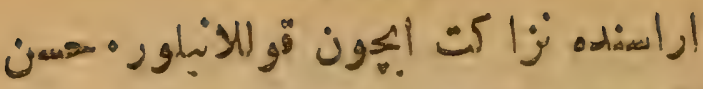

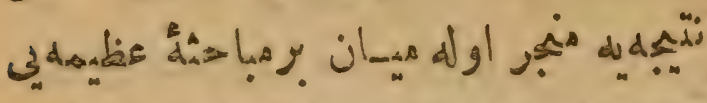

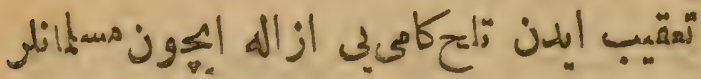

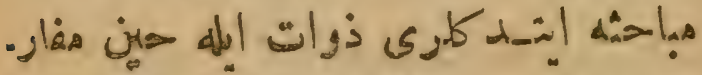

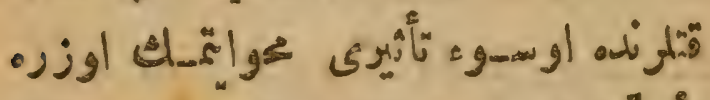

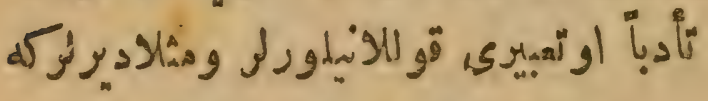

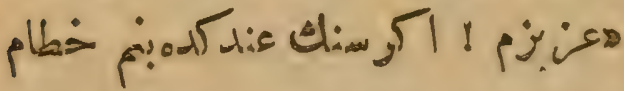

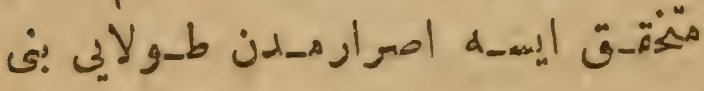

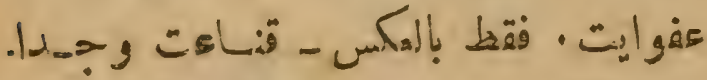

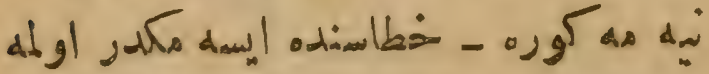

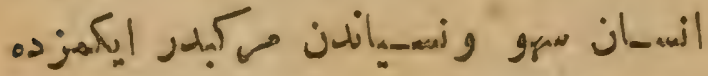

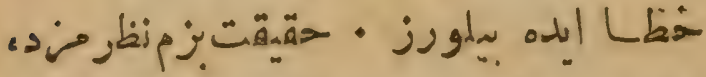

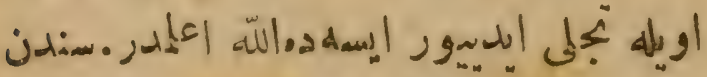

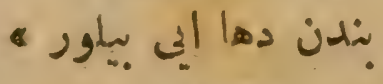
宝 


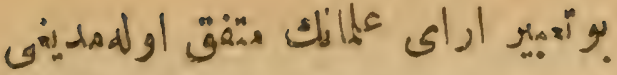

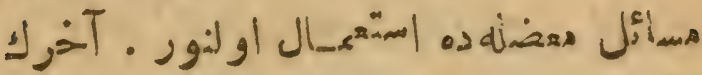

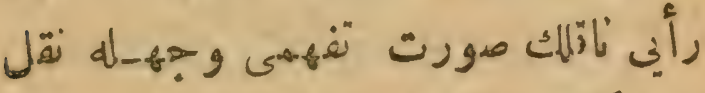

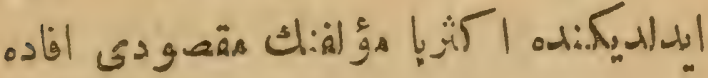

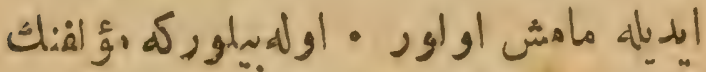

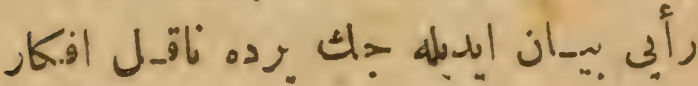

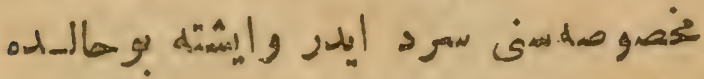

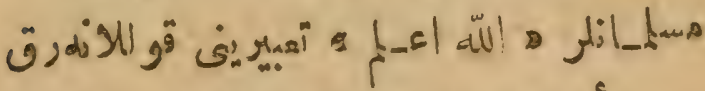

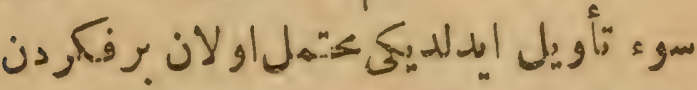

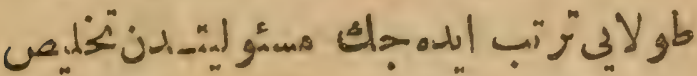

:

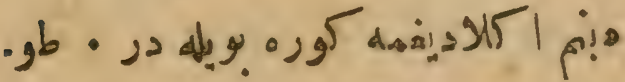

غرى

ه

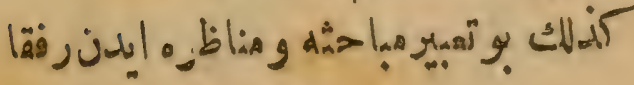


or

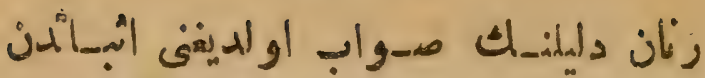

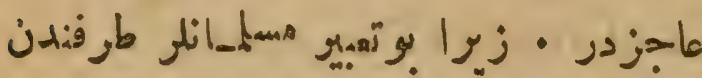

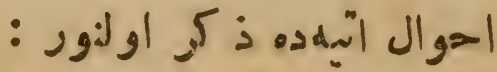

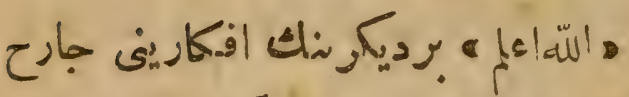

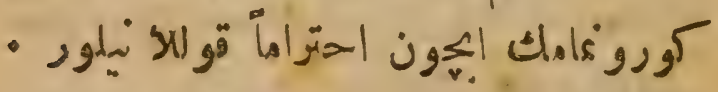

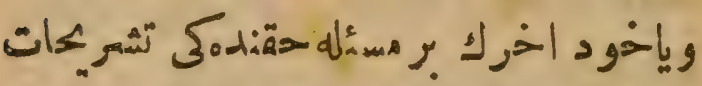

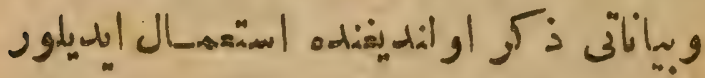

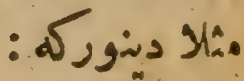

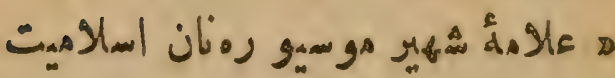

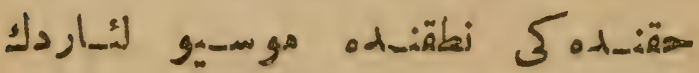

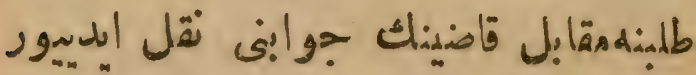

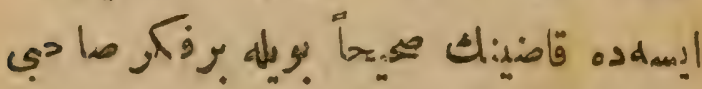

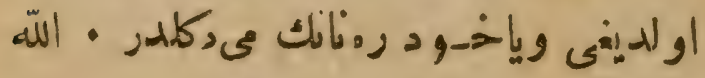

a $\mid$ | $\mid$ 


$$
\begin{aligned}
& \text { (6p) } \\
& \text { \{ سكابز }
\end{aligned}
$$

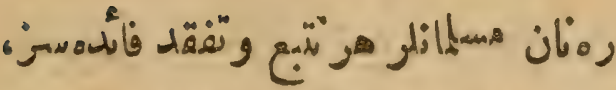

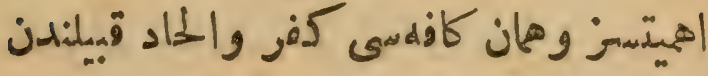

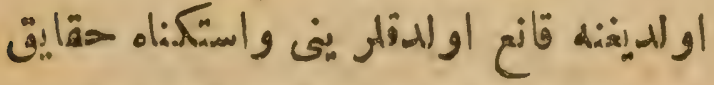

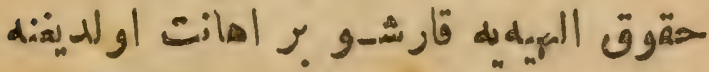

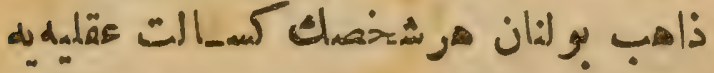
كرفتـار اولهرق صحت ووضوح ايله ضضكر

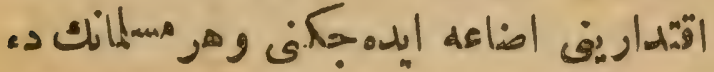

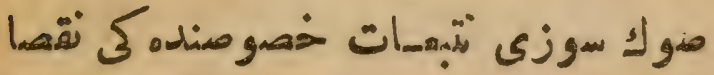

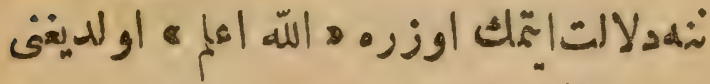

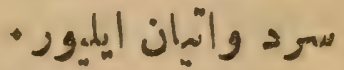

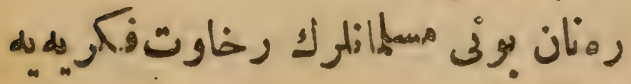

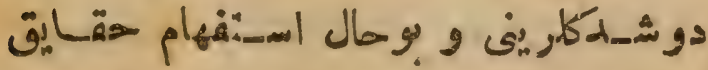

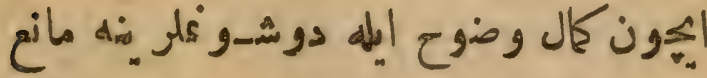

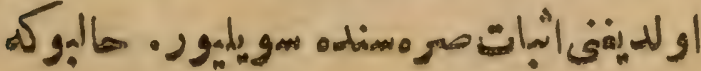




\section{$01 \%$}

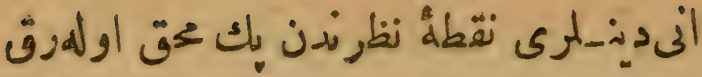
-

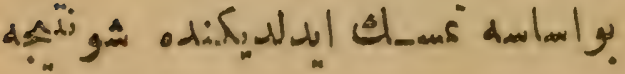

$$
\text { : }
$$

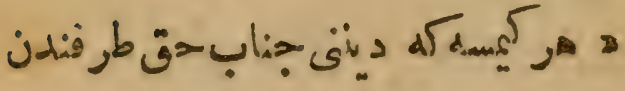

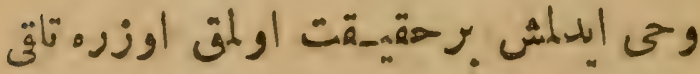

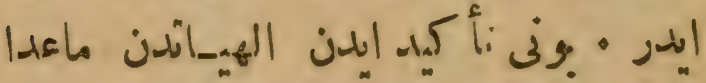

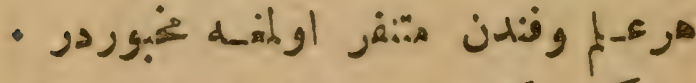

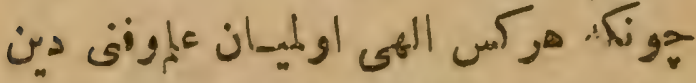

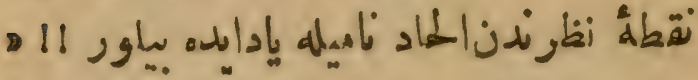

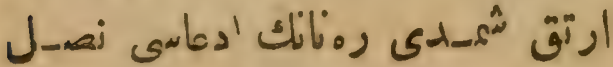

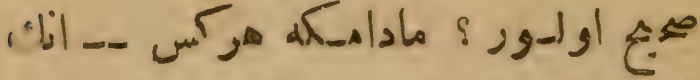

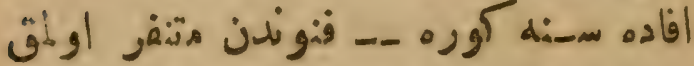

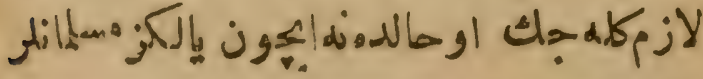

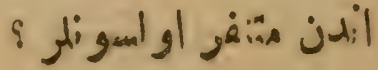




\section{0.}

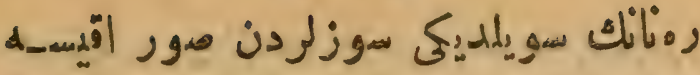
: 1 - رalis (P

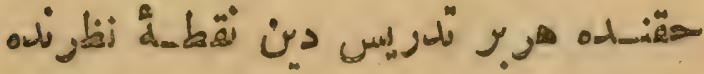
- هليدj

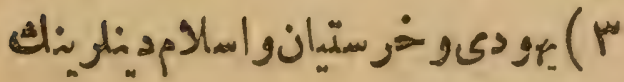

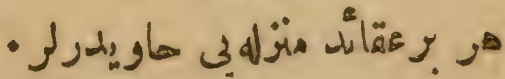

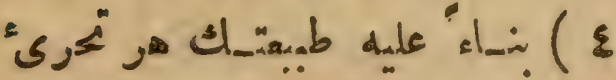

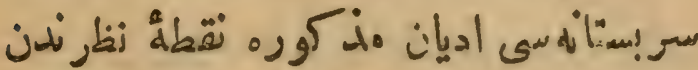

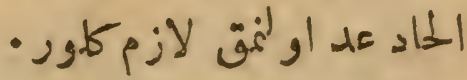

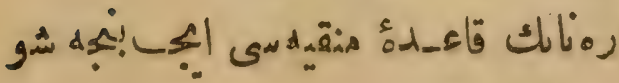

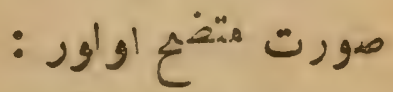

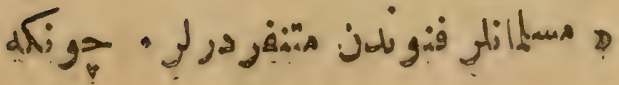




\section{\& 89}

-

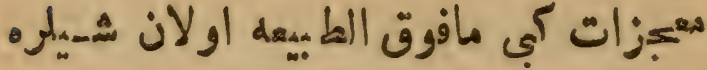

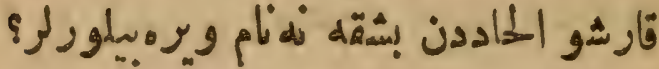

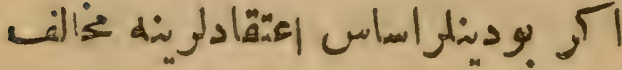

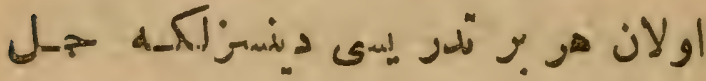

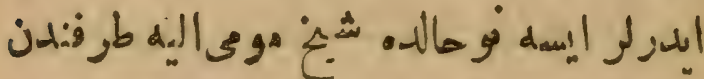

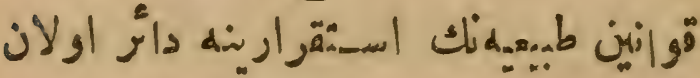

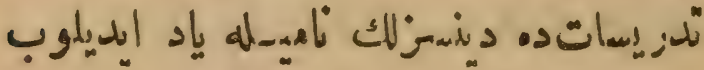

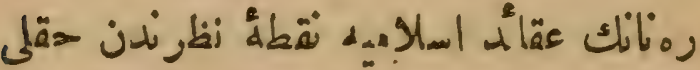

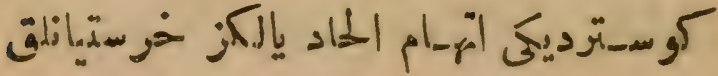

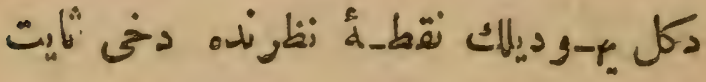

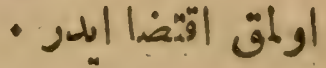

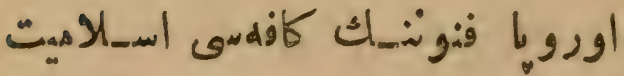

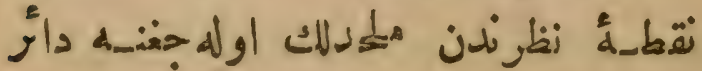

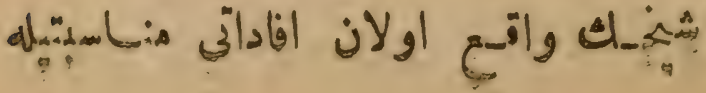




\section{1)}

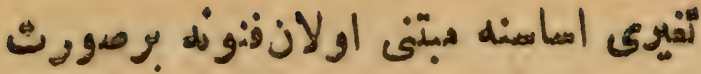

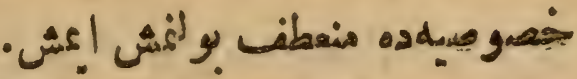

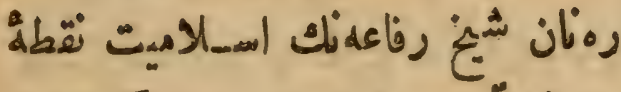

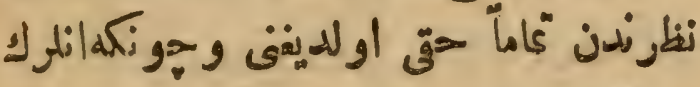

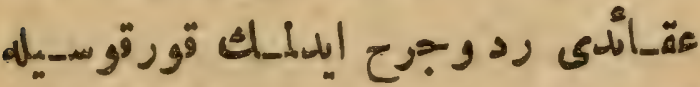

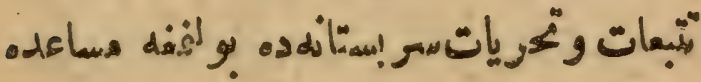
-

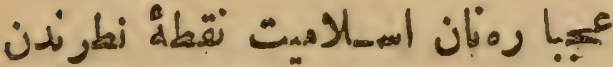

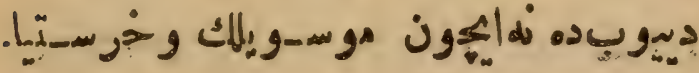

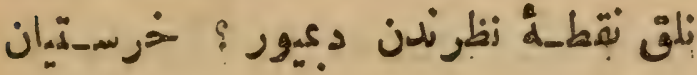

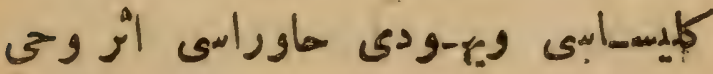

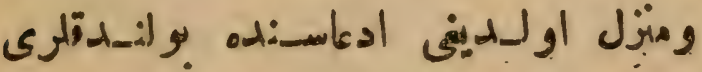

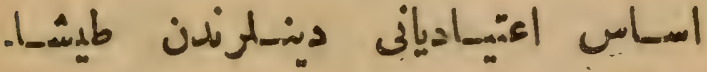

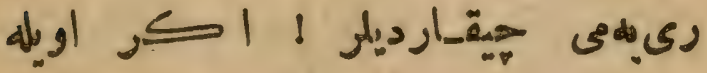

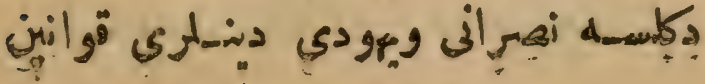


\&V

كافة

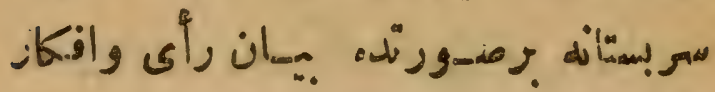

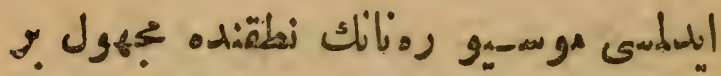

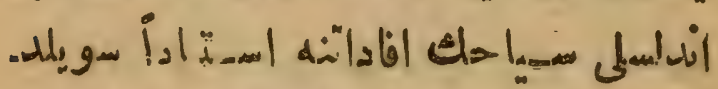

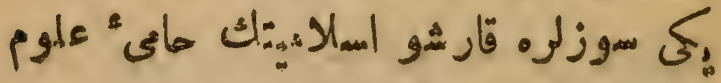

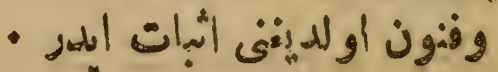

بان.

:

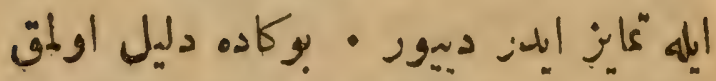

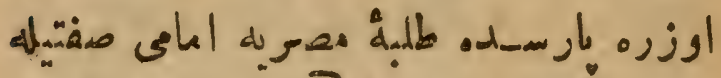

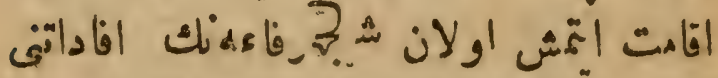

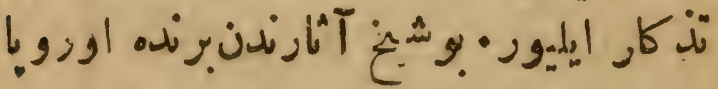

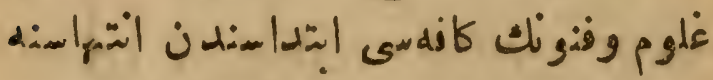

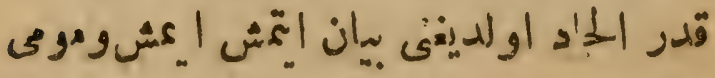

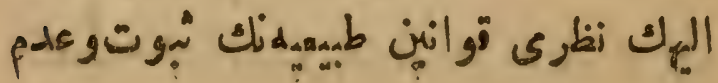




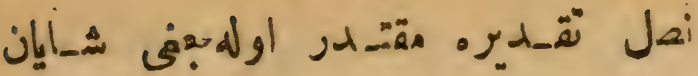

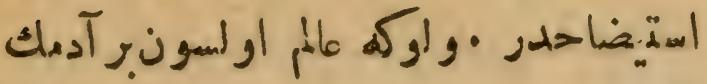

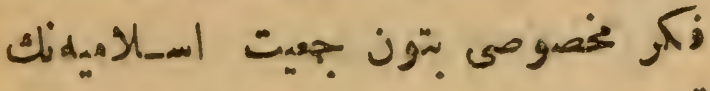

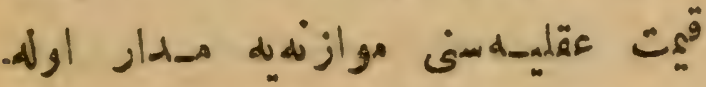

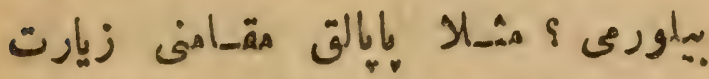

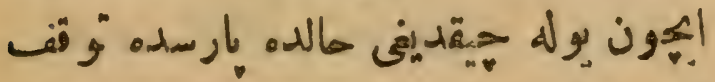

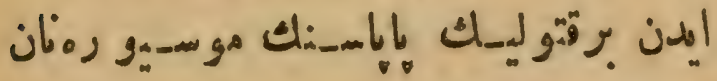

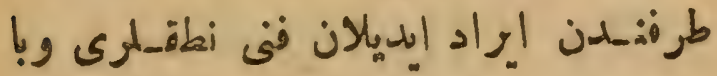

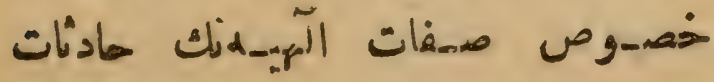

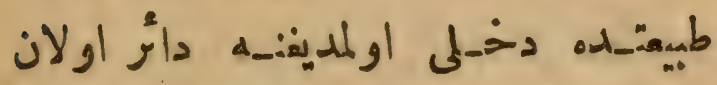

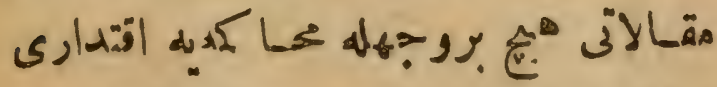

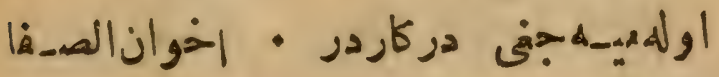

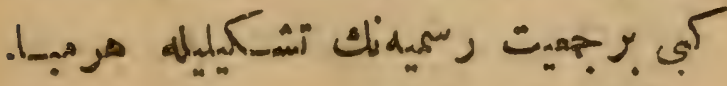
، آلهُ

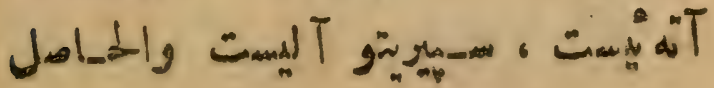




\section{0}

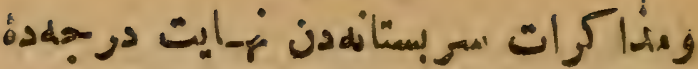

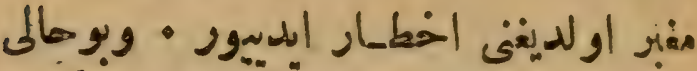

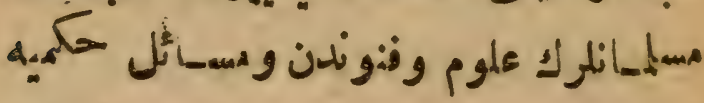

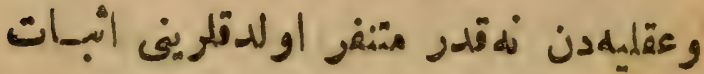

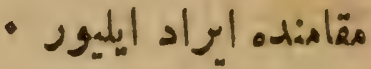

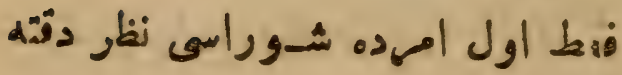

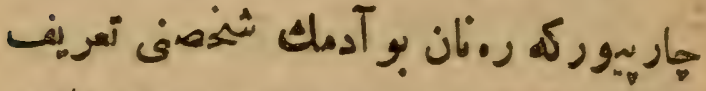

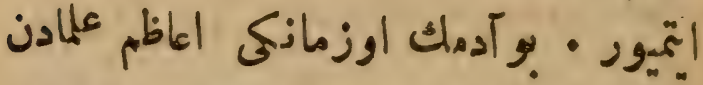

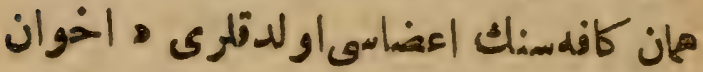

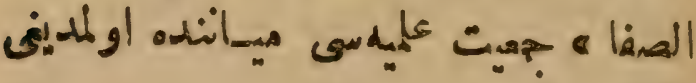
-

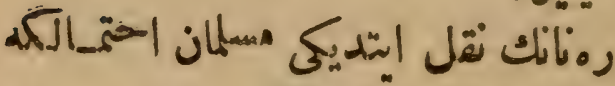

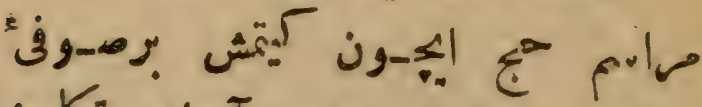

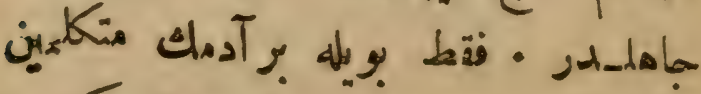

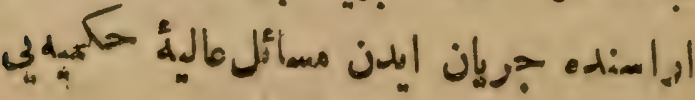




\section{क \& \&}

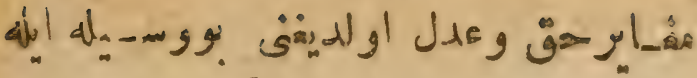
-

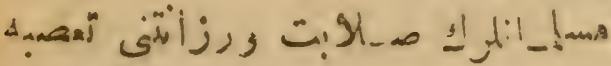

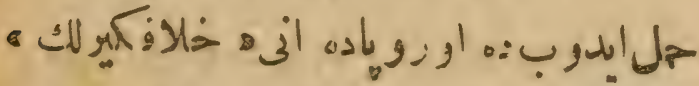

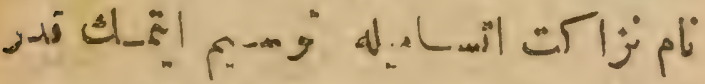

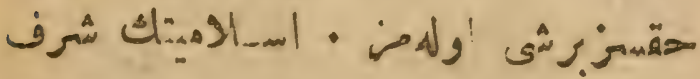

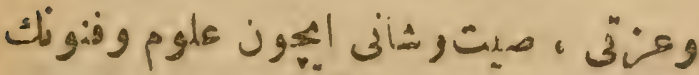

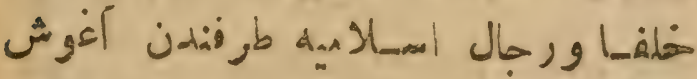

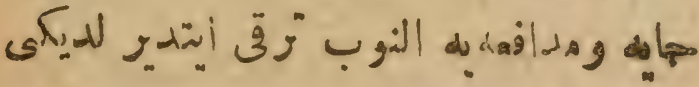

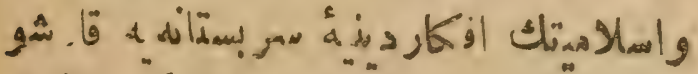

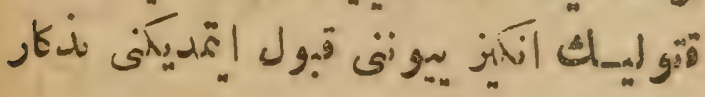
- إيمك كافيدر التصنى باب

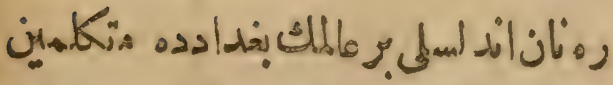

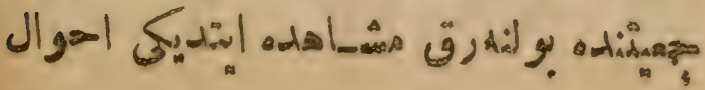




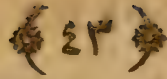

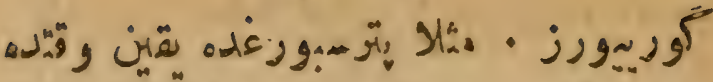

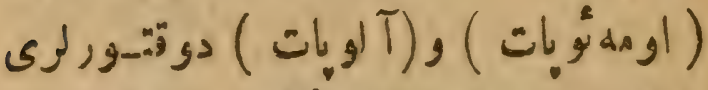

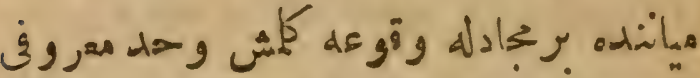

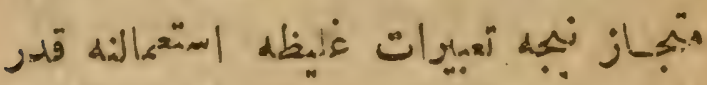

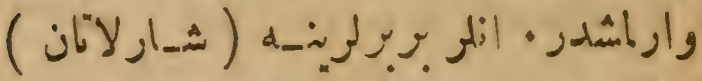

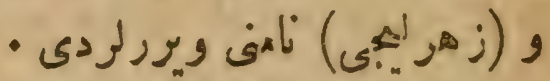

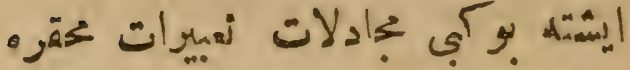

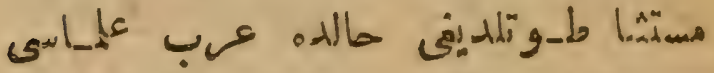

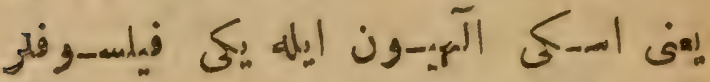
- آره

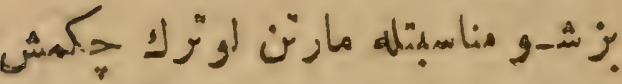

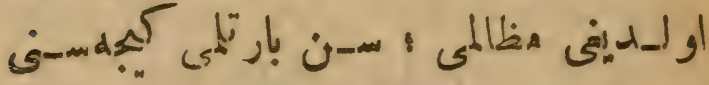

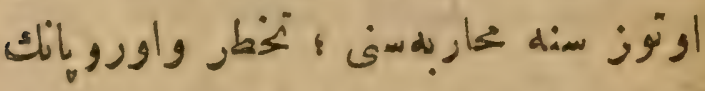

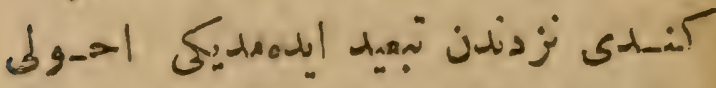

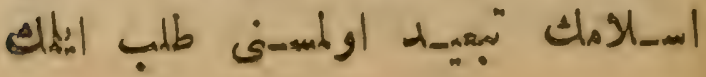


(s)

車

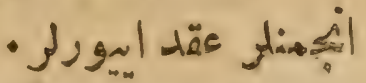

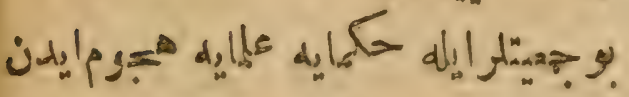

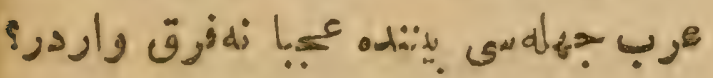

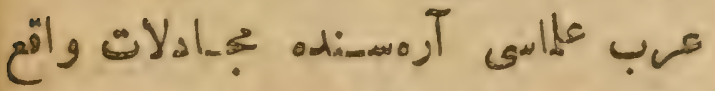

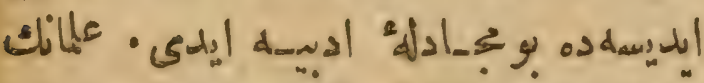

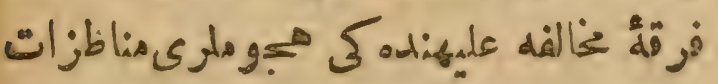

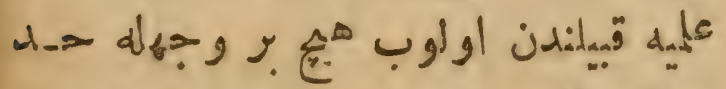

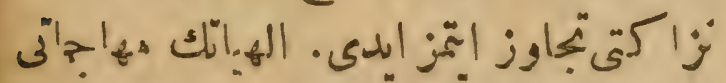

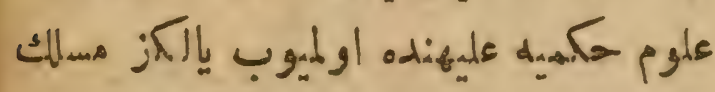

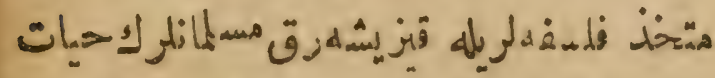

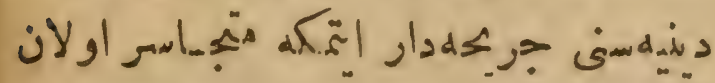

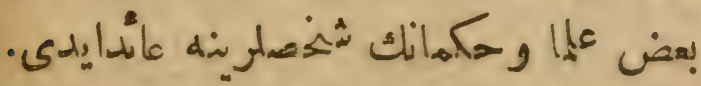

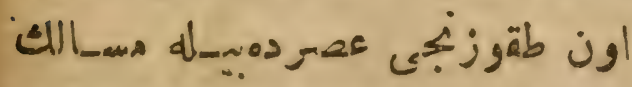

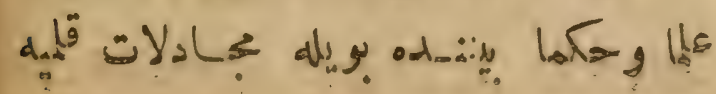


8)

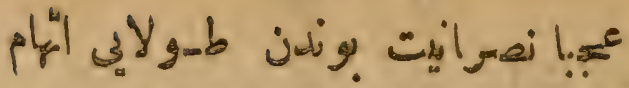

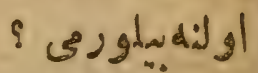

هو

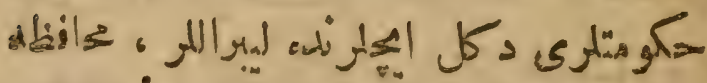

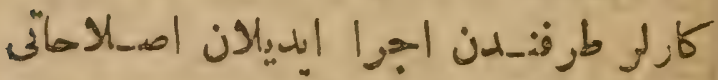

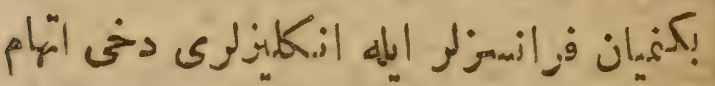

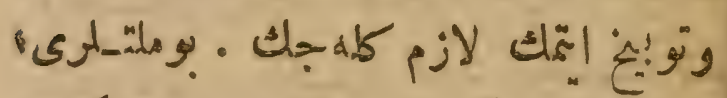

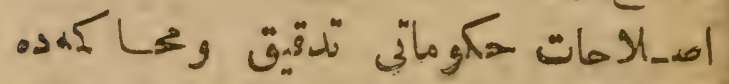

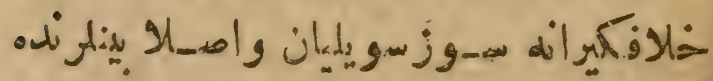

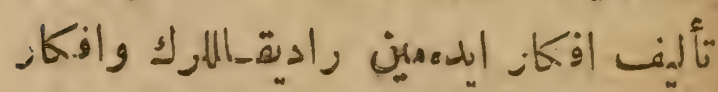

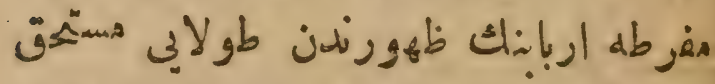

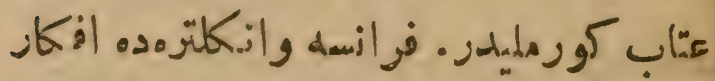

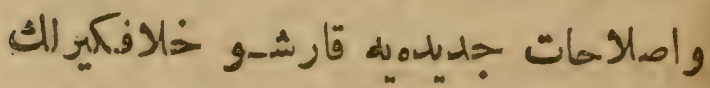

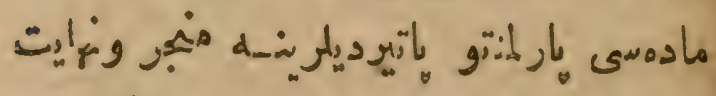

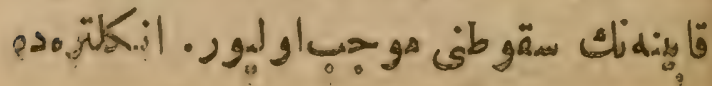




\section{转就}

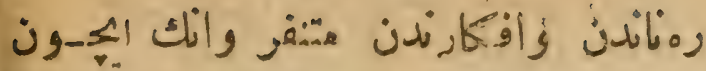

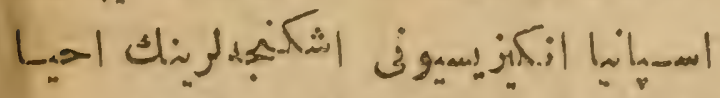

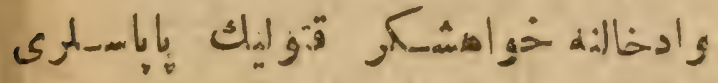

و

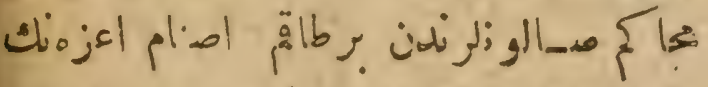

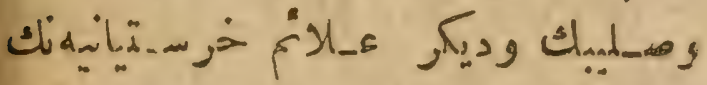

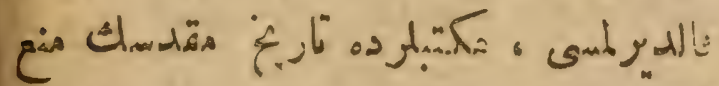

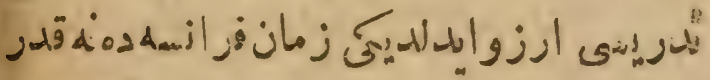

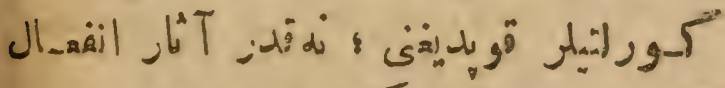

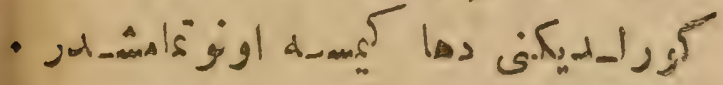

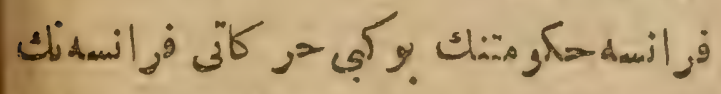

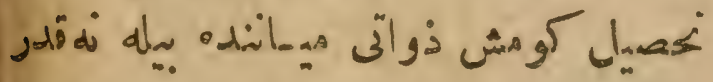

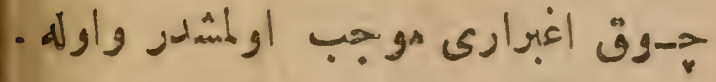

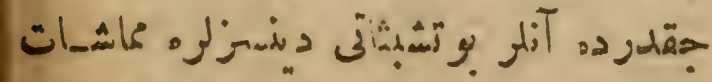

- اتمك ن 


\section{\&q}

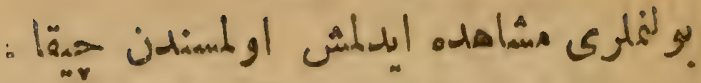

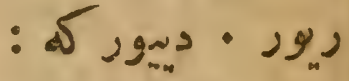

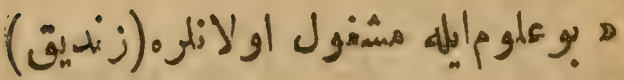

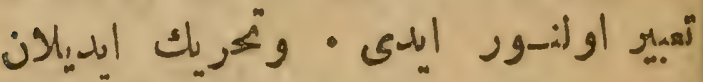

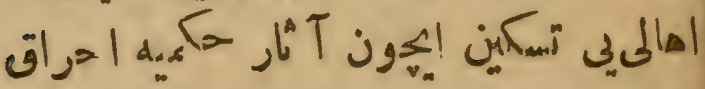

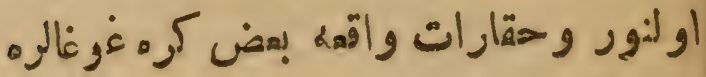

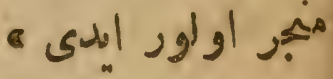

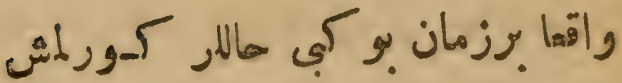

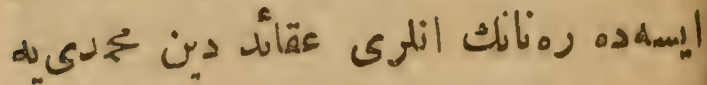

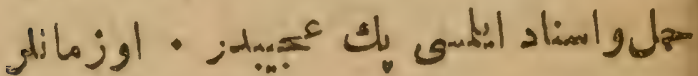

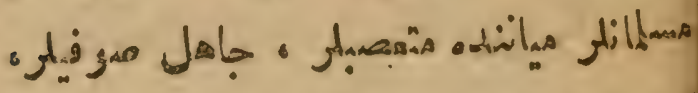

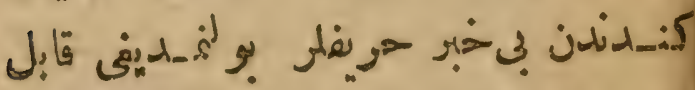

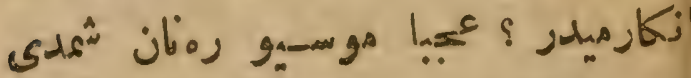

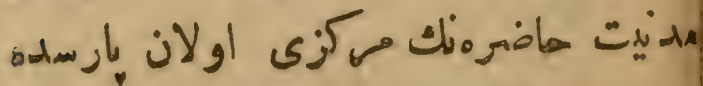

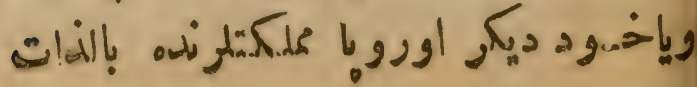




\section{*}

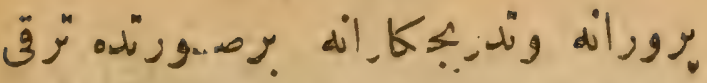

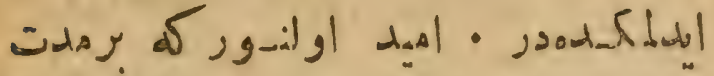

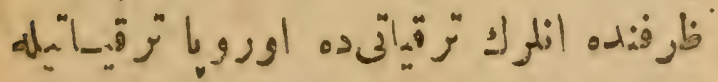

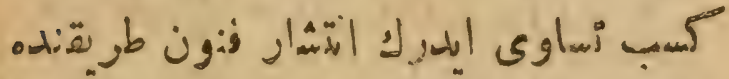

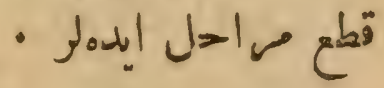

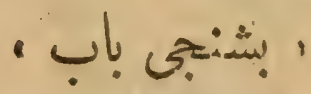

رأن

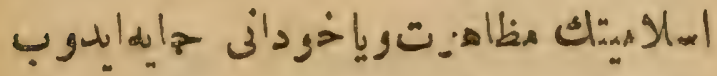

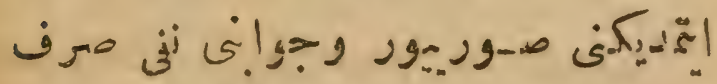

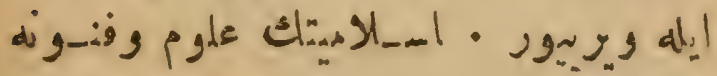

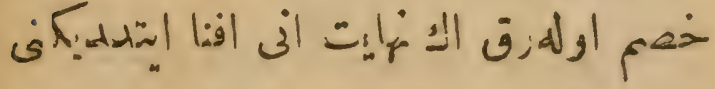

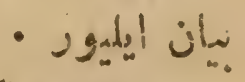

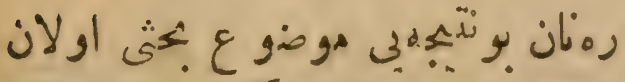

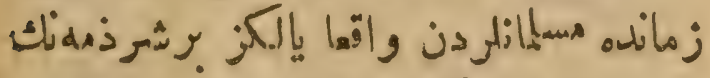

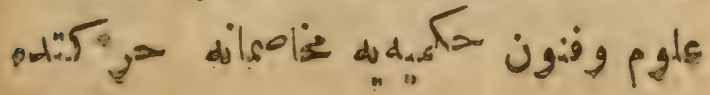




\section{TV}

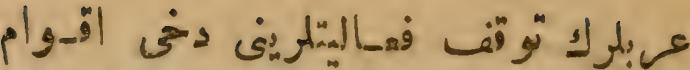

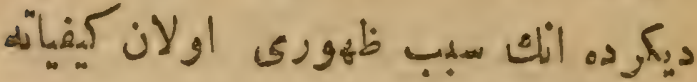

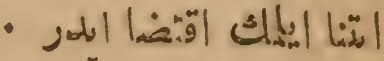

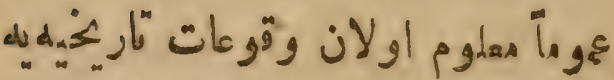

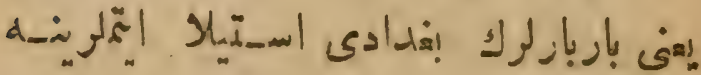

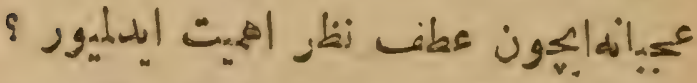

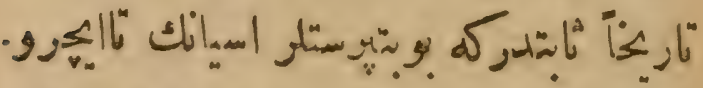

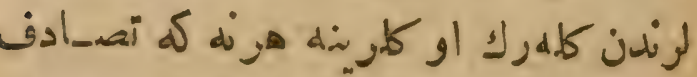

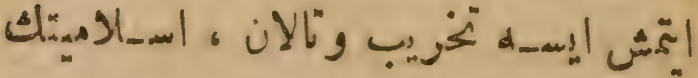

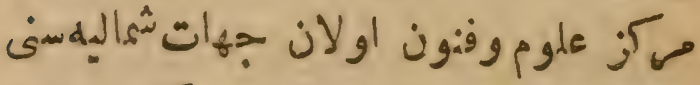

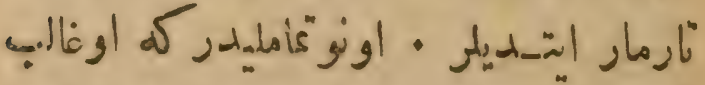

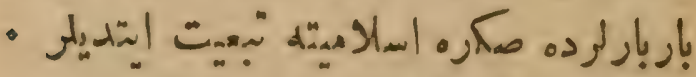

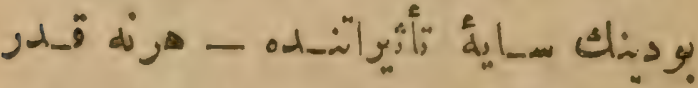

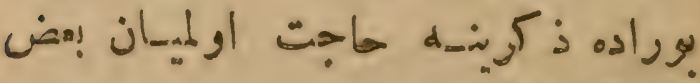

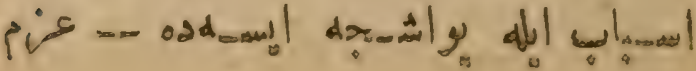




\section{胺}

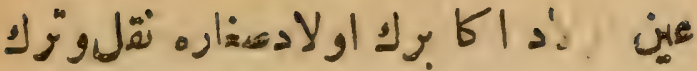

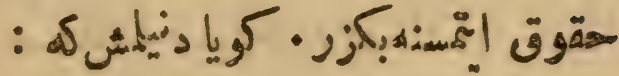

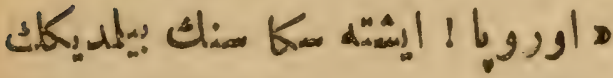

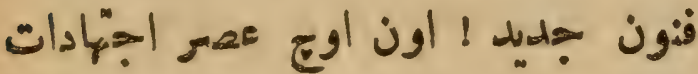
عقلي_dدن غافل اولـوب كوشـهُ رخاوتده

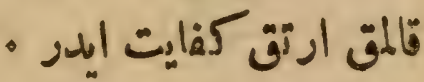

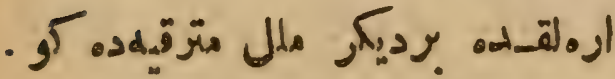

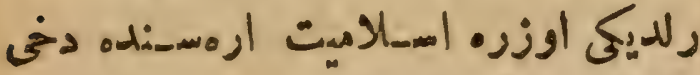

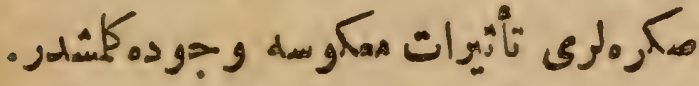

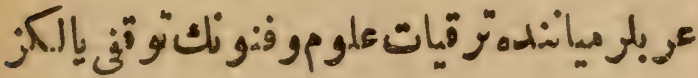

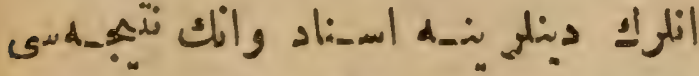

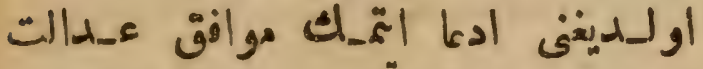

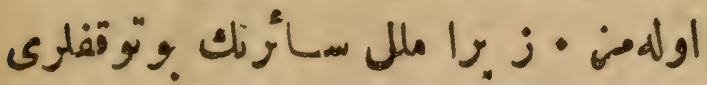

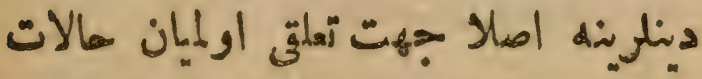

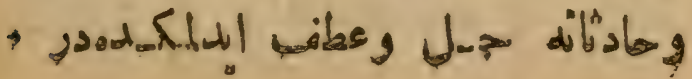




\section{wo \\ صادر اولان شوسوزلردر : صوران}

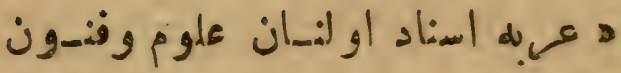

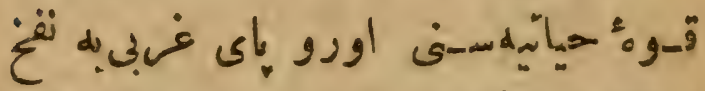

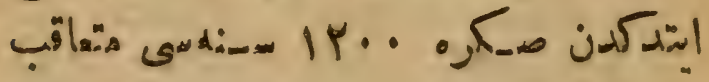

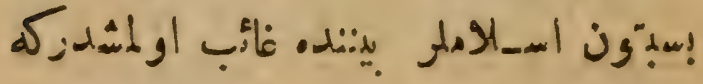

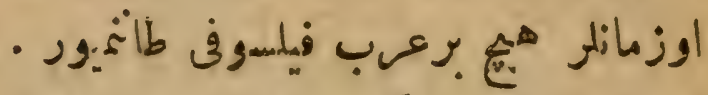

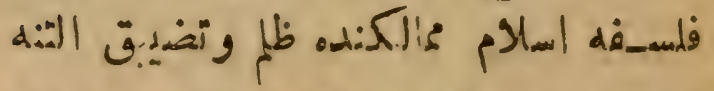

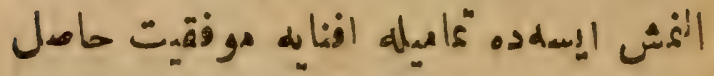
|

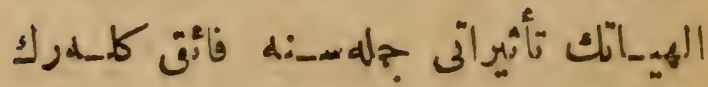

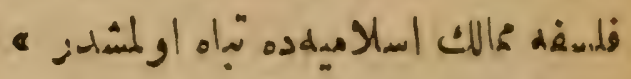

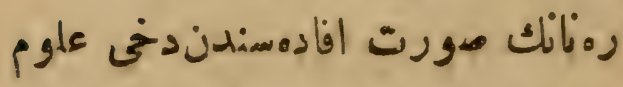

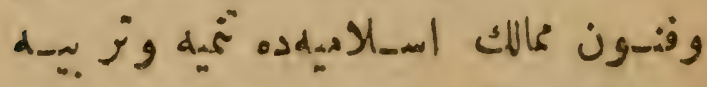

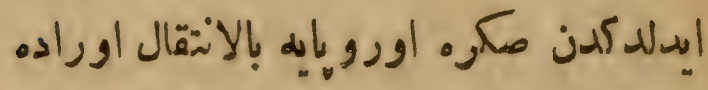

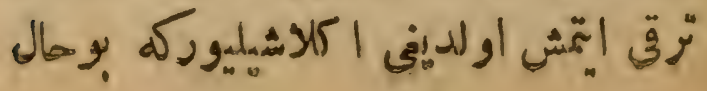




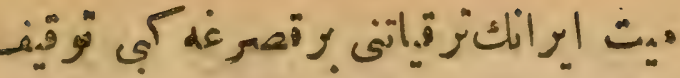

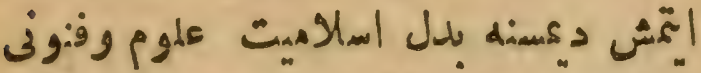

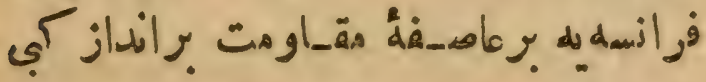

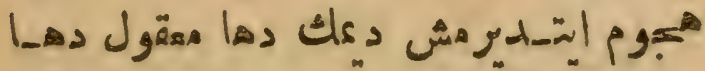

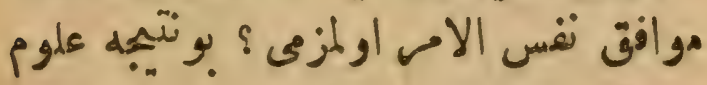

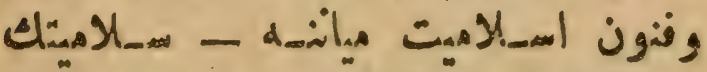

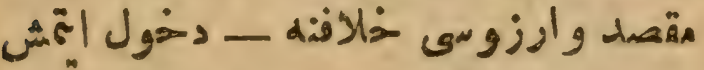

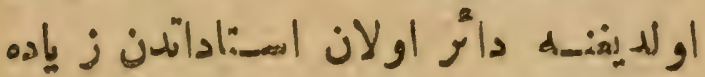

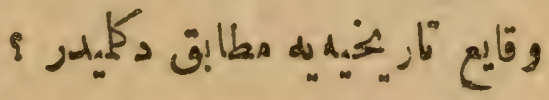

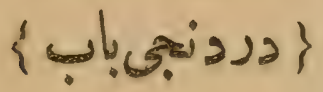

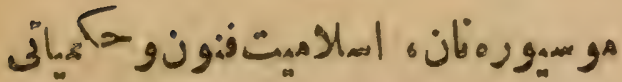

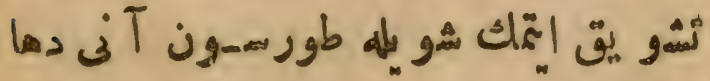

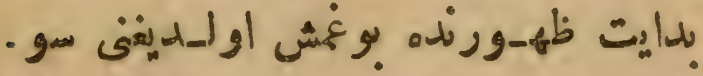

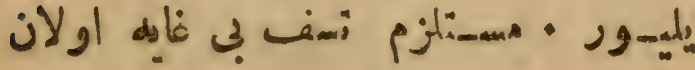

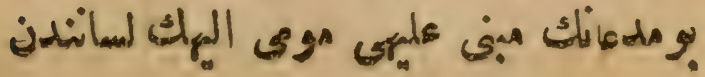




\section{6rip}

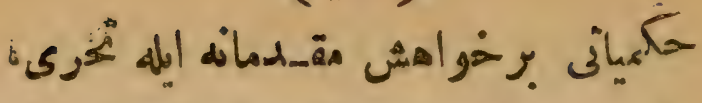

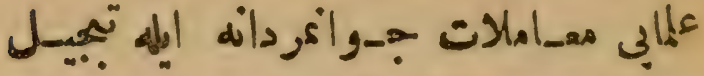

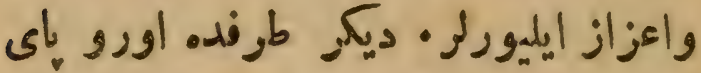

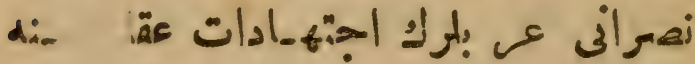

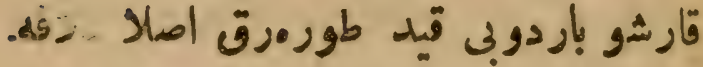

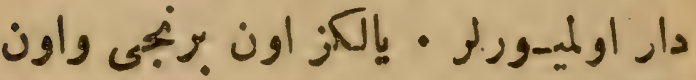

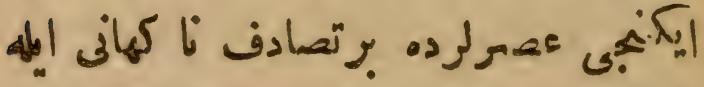
فنون فرانسه فزيهياب دهول اوليورد

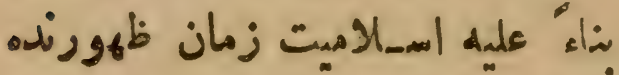
وى هر "وده عسلوم وفن-ونى آراهش

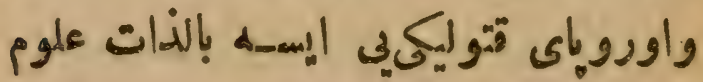

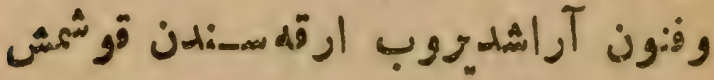

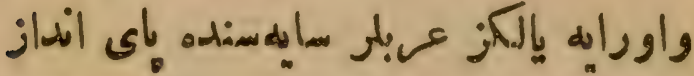

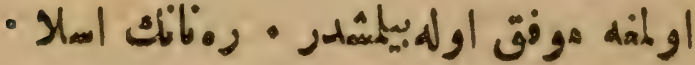




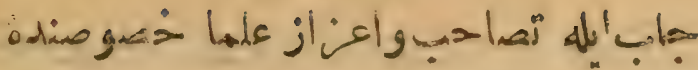

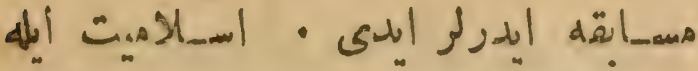

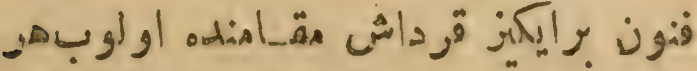

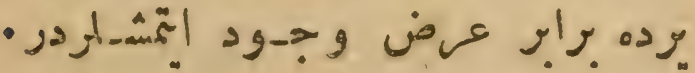

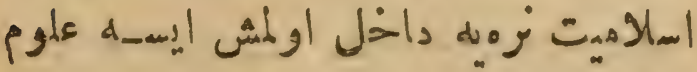

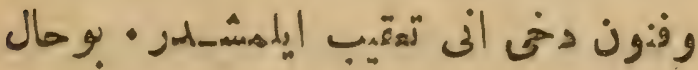

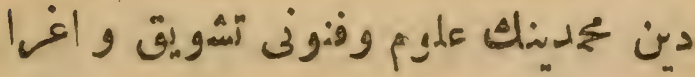

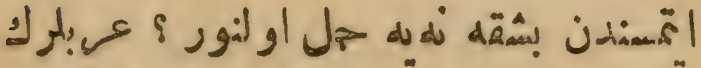

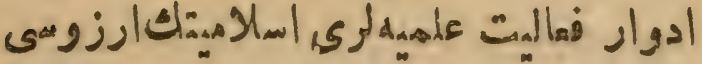

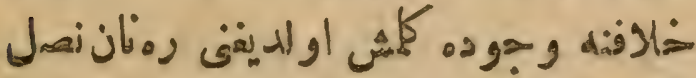

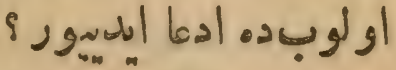

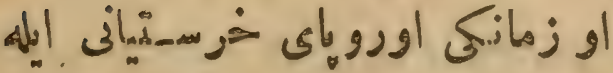

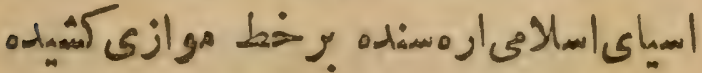

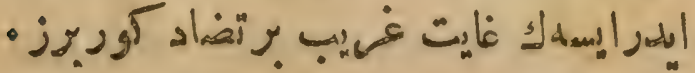

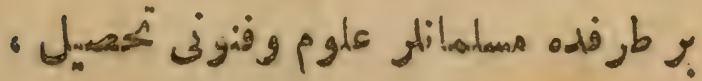




\section{要客

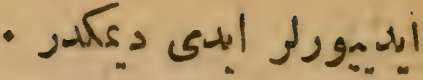

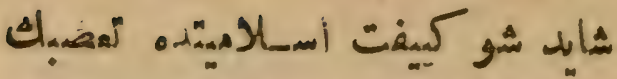

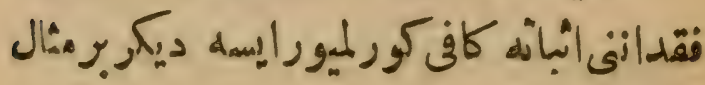

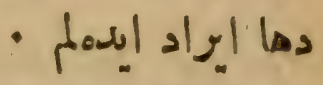

ره

حابه إتد كلرى إيهون المنصور ، هارون

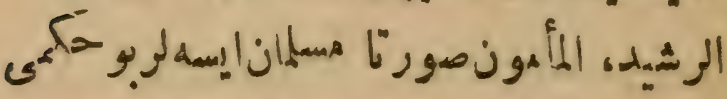

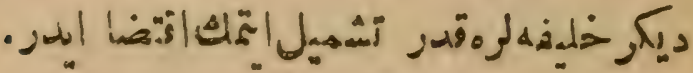

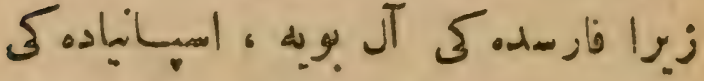

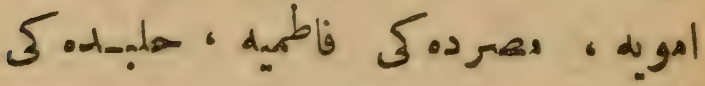

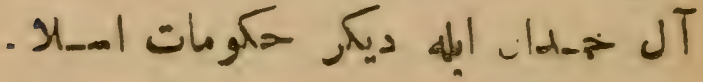

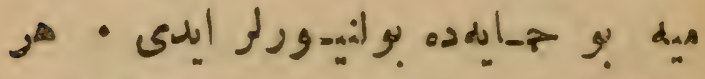

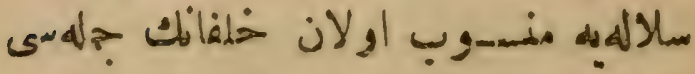
-

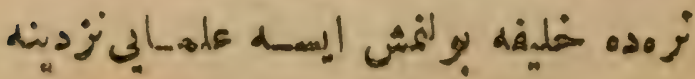




\section{草榢}

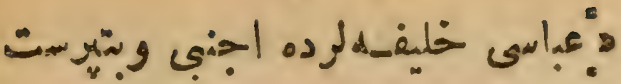

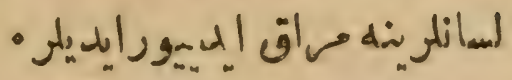

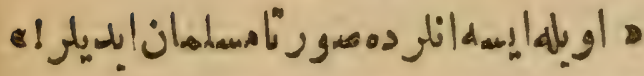

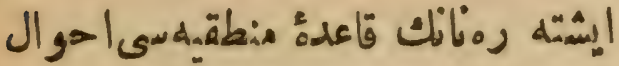

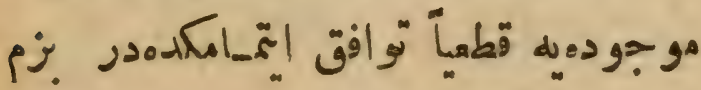

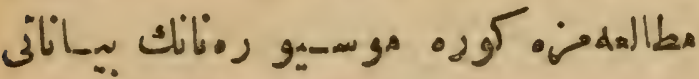

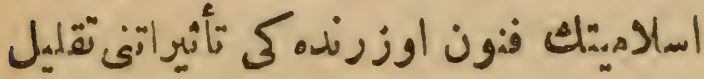

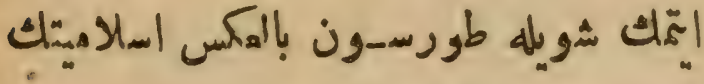
-

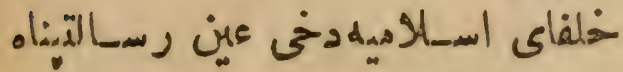

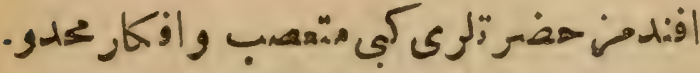

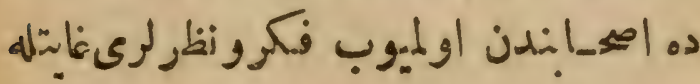

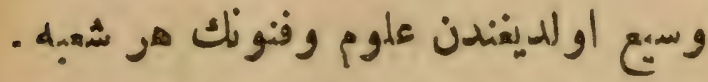

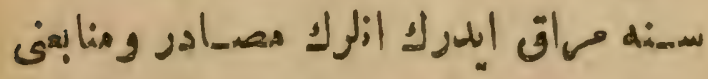

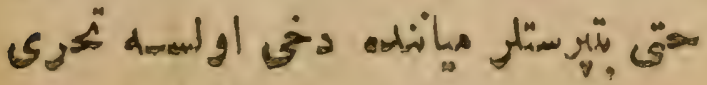




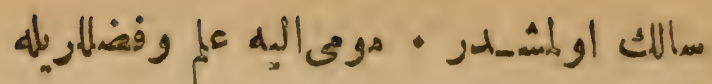

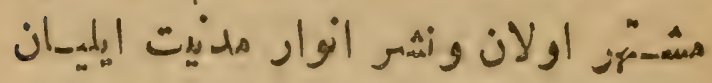

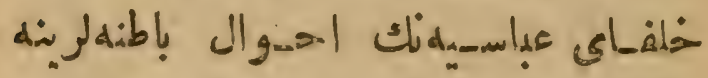

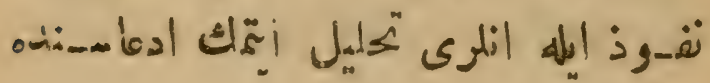

• بوليوز

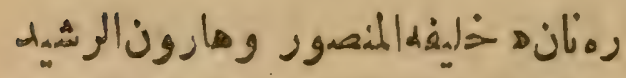

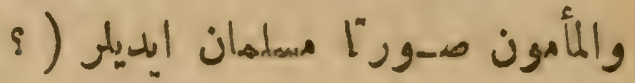

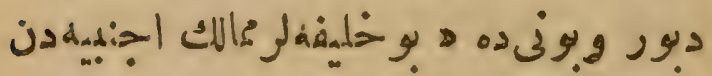

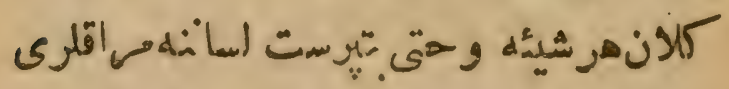

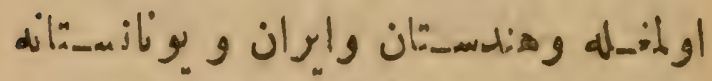

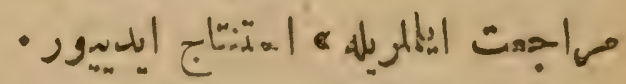

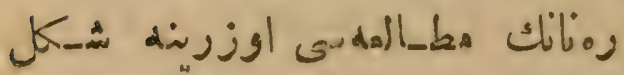

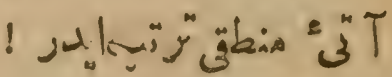

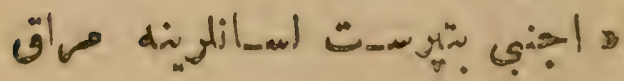
- Jjugario do 
(4)

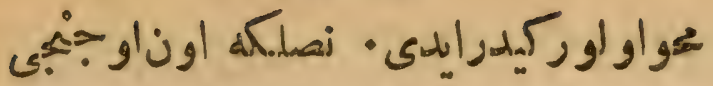

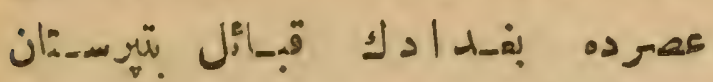

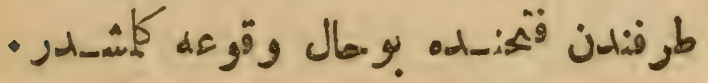

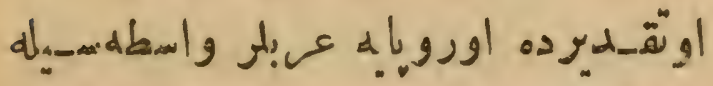

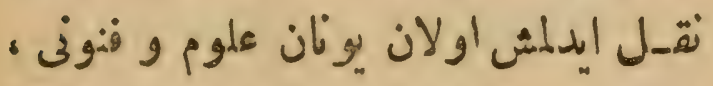

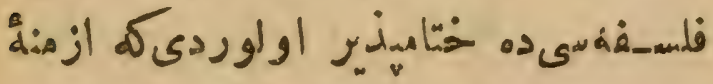

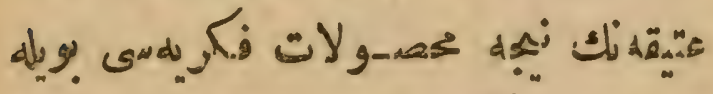

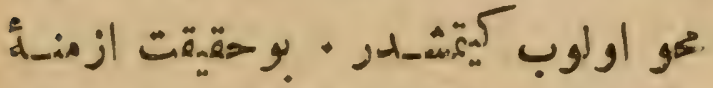

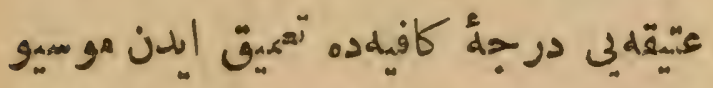

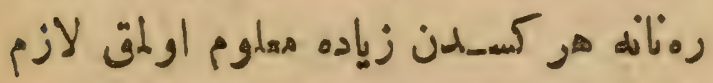

كلور

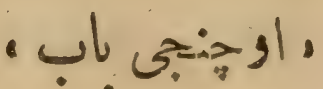

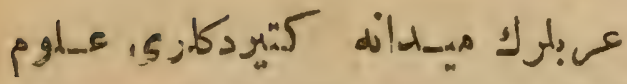

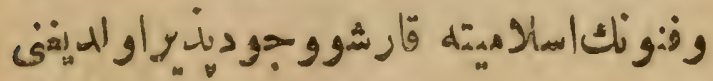

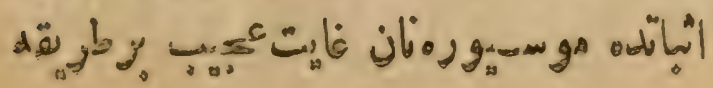




\section{4rv}

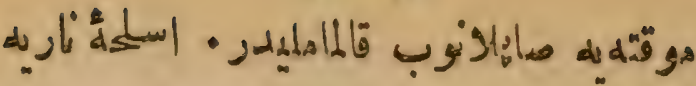

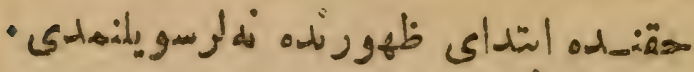

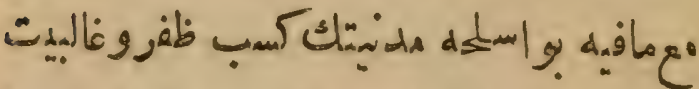

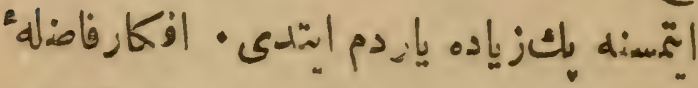

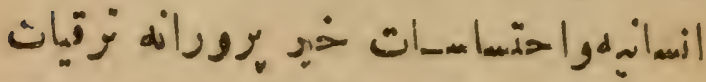

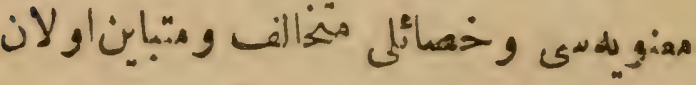

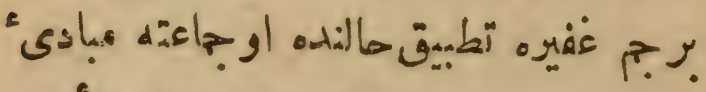

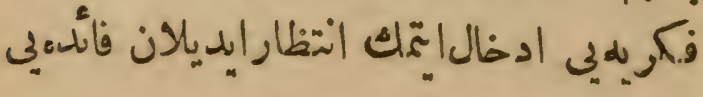

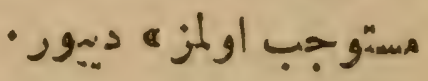

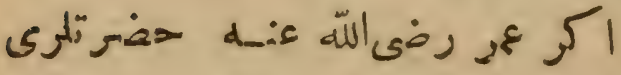

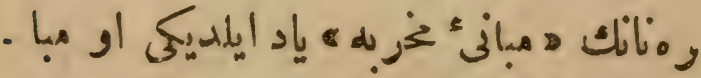

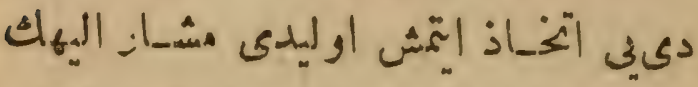

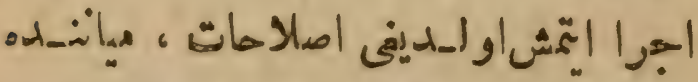

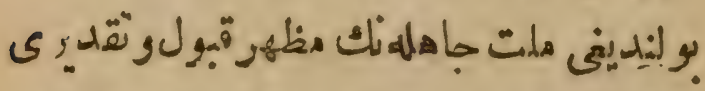

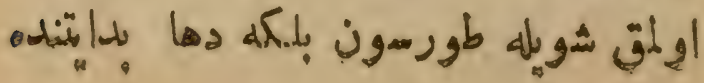




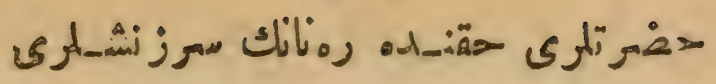

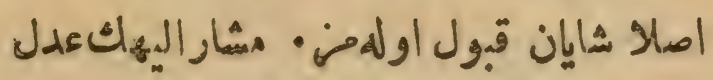

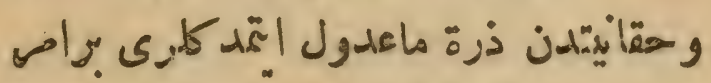

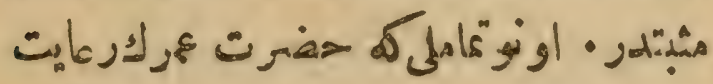

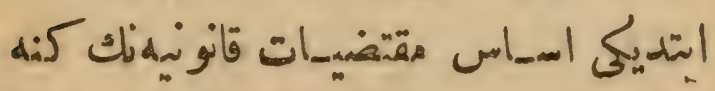

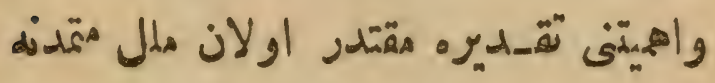

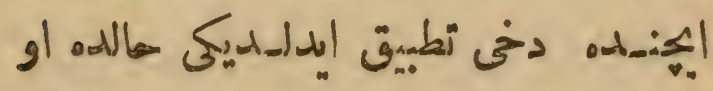

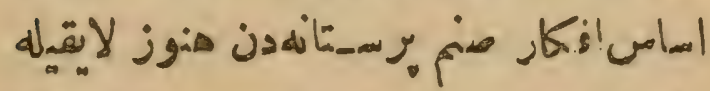

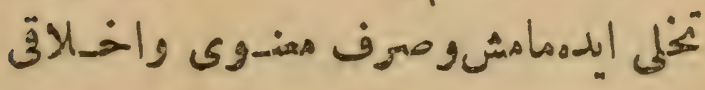

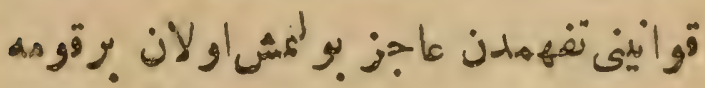

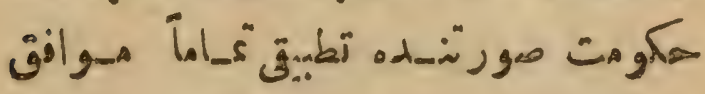

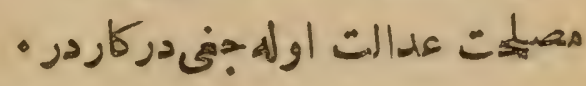

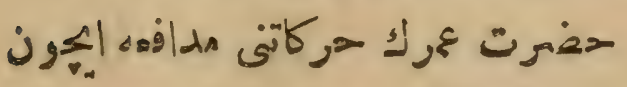

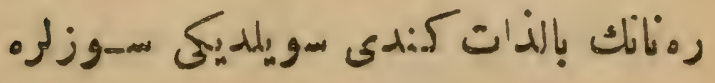

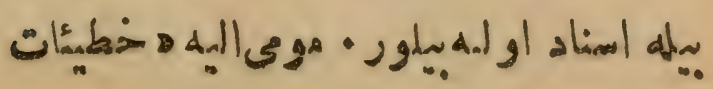




\section{ró}

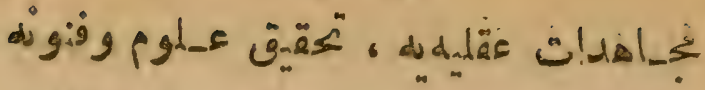

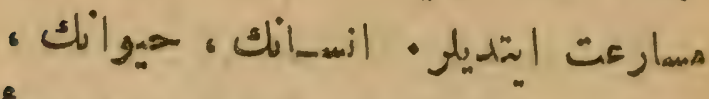

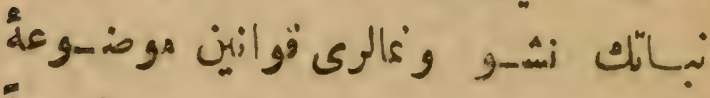

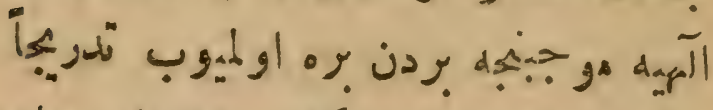

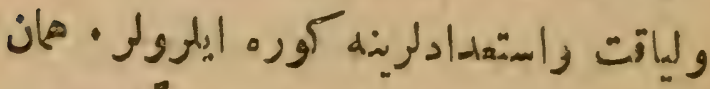

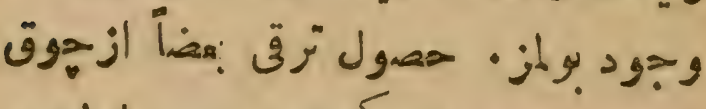

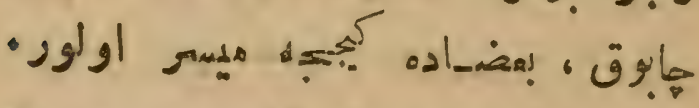

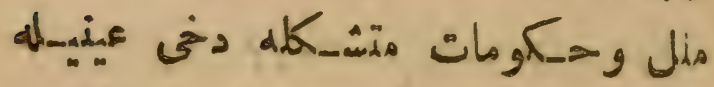

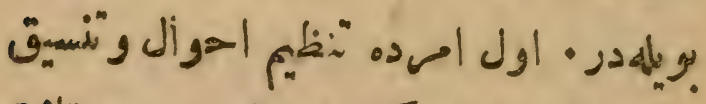

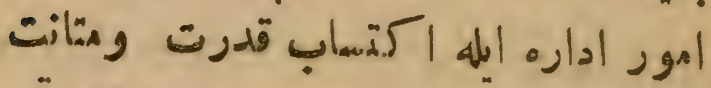

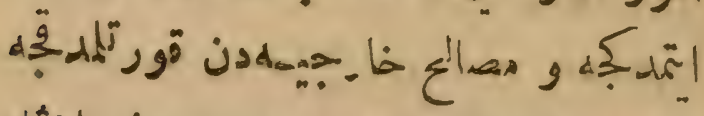

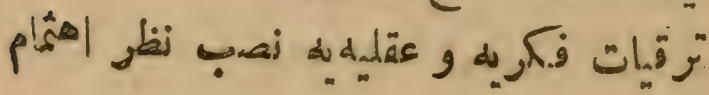
اتمكه وقتبوله

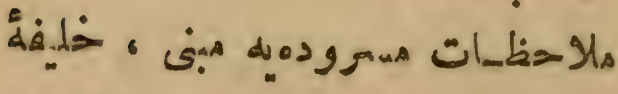

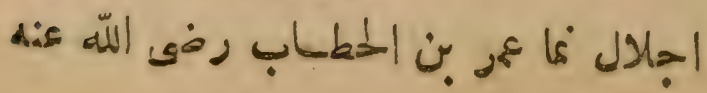




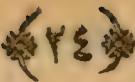

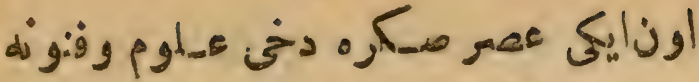

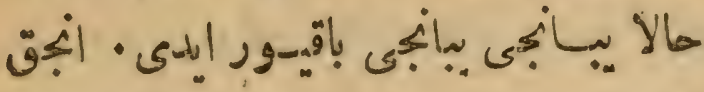

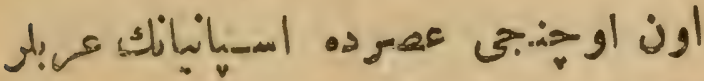

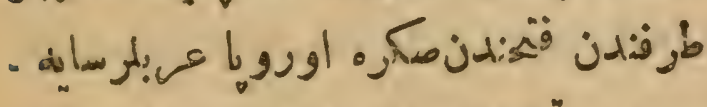

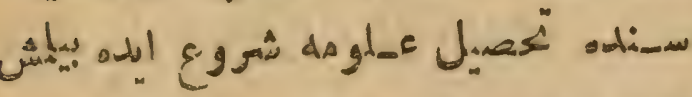

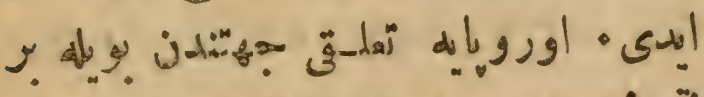

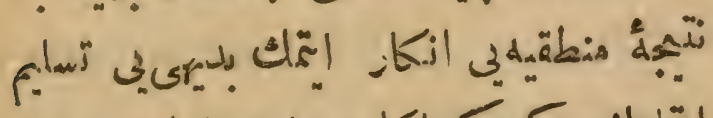

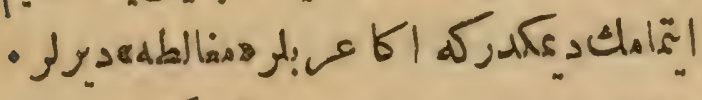

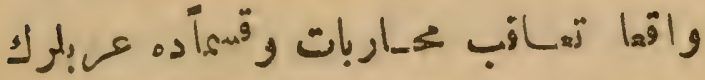

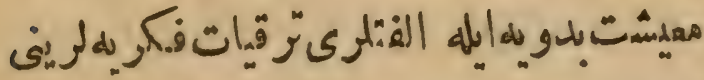

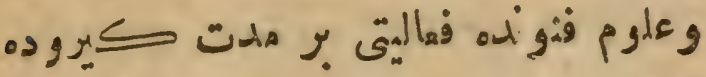

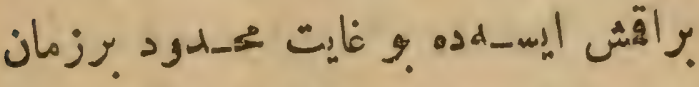

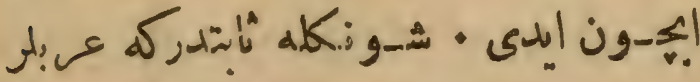

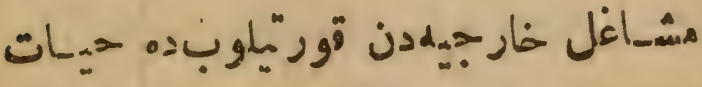

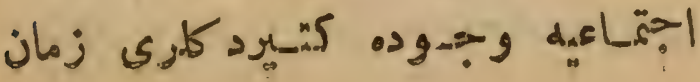




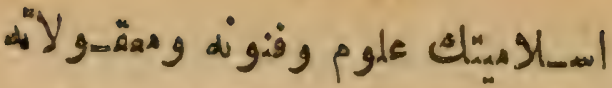

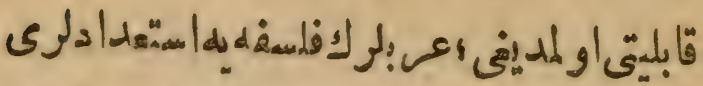
ث

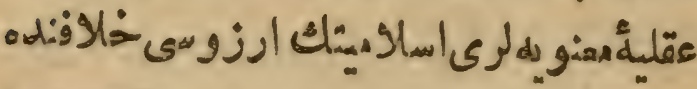

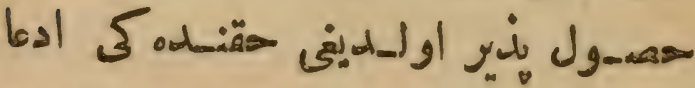
dis

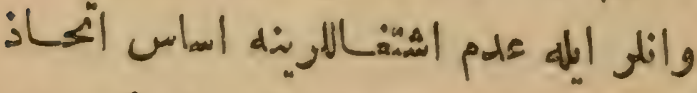

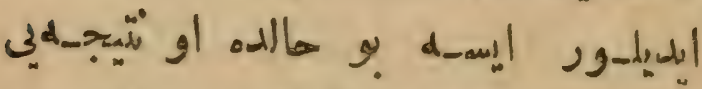

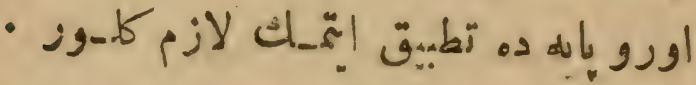

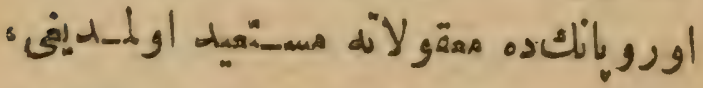

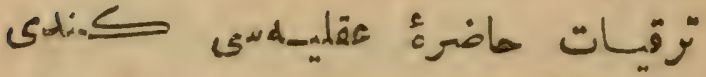

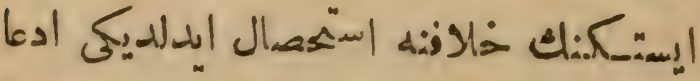

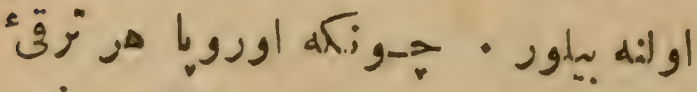

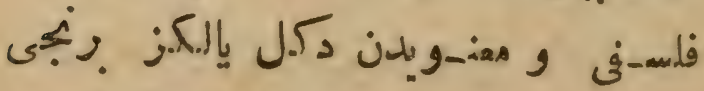

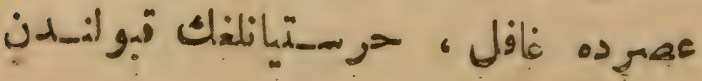




\section{\&rros}

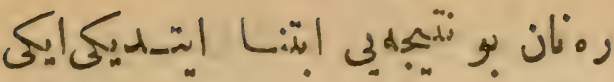

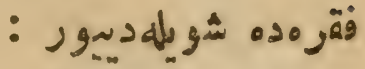

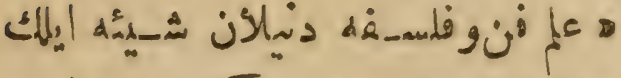

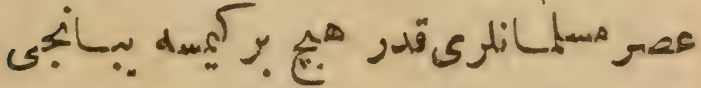
a $v 415$

- Dع بلو اصل

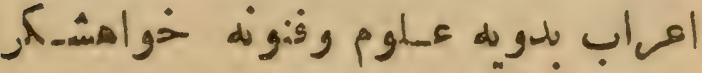

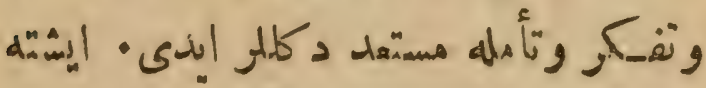

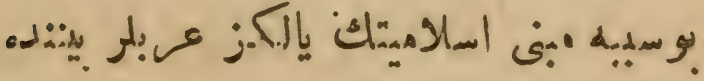

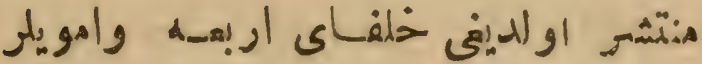

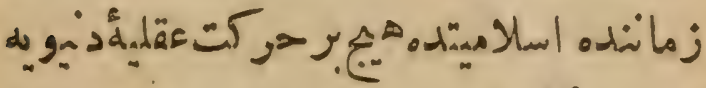
disdin Vo.

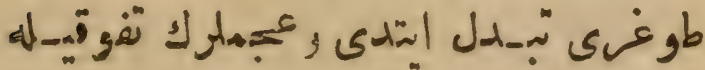
: axitr diss 


\section{保}

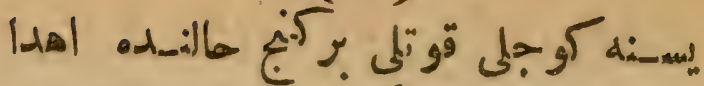

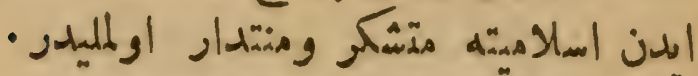

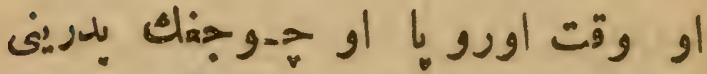

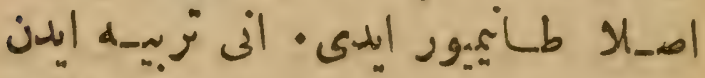

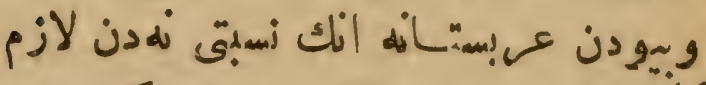

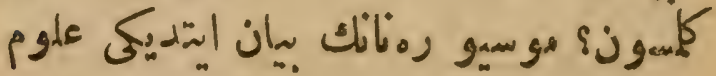

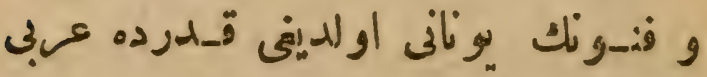

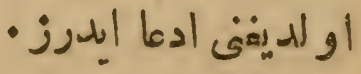

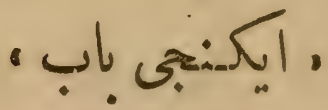

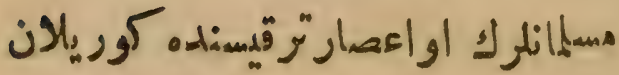

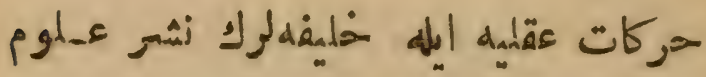

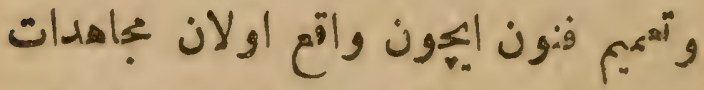

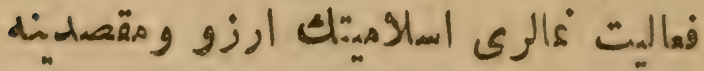

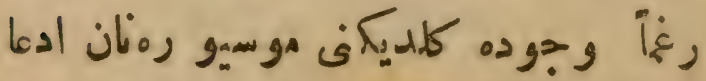




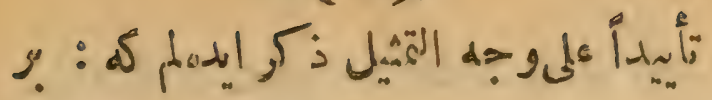

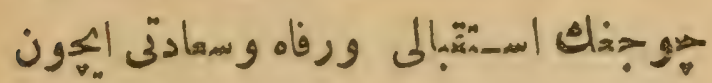

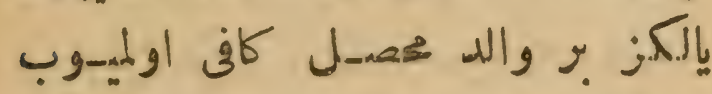

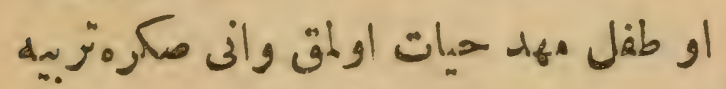

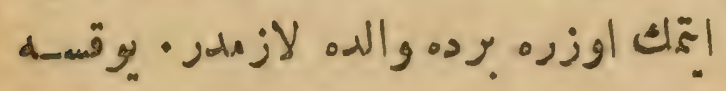

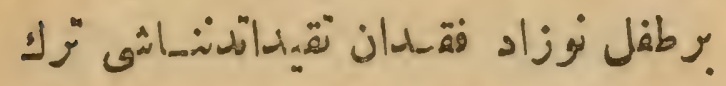

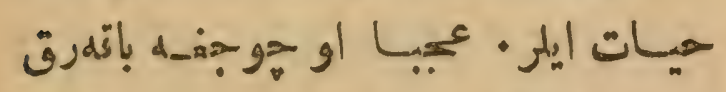

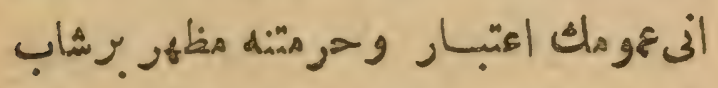

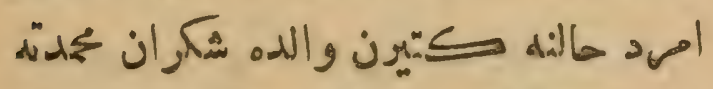

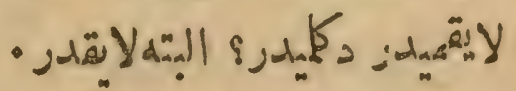
.

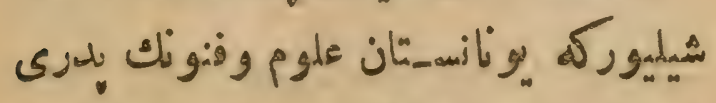

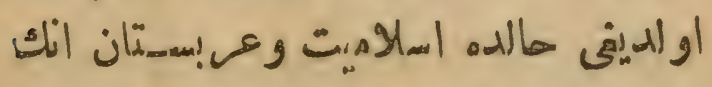

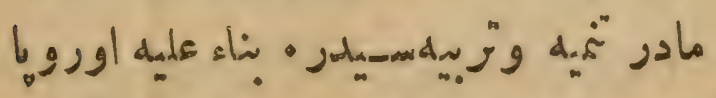

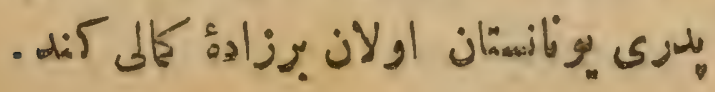




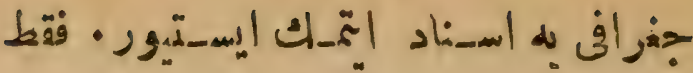

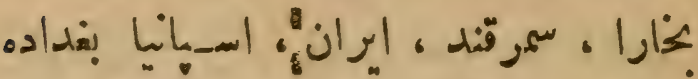

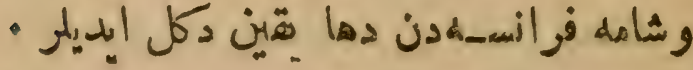

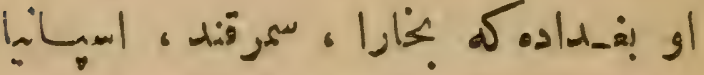

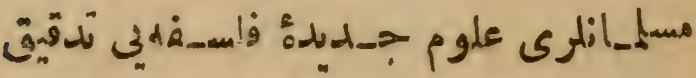

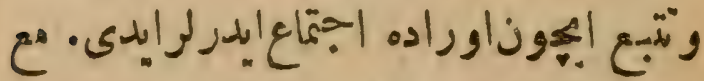

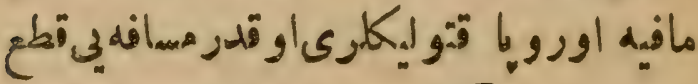

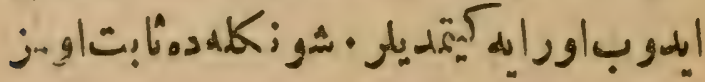

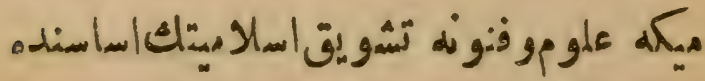

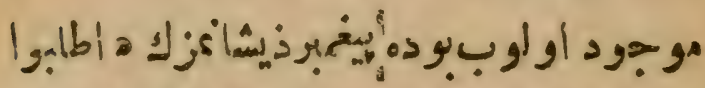

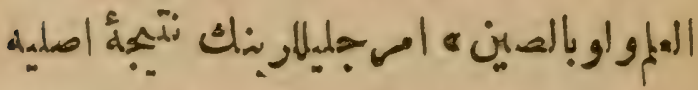

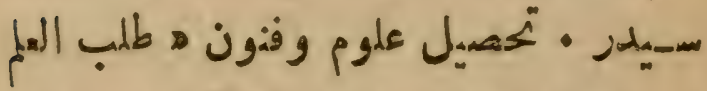

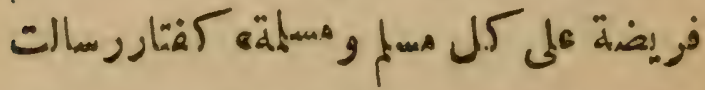
•

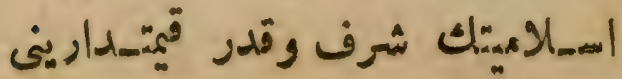




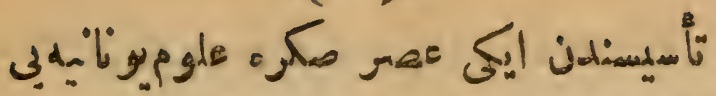

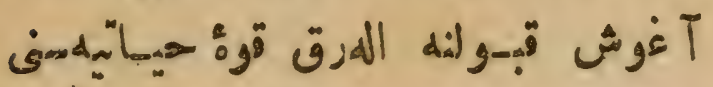
|

- آمش

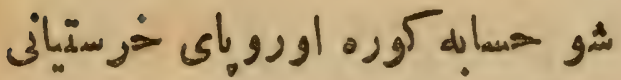

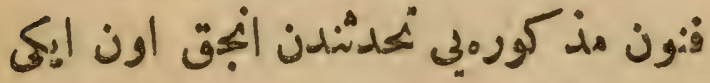

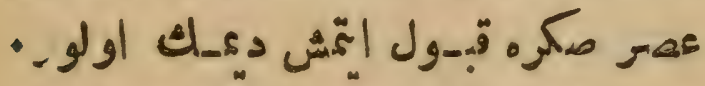

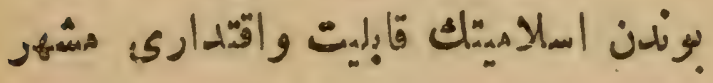

بله

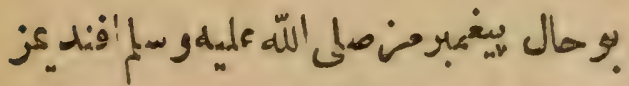

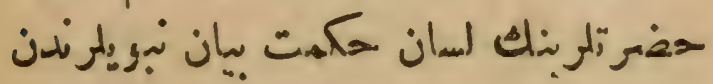

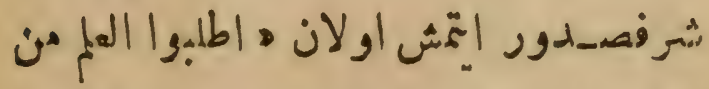

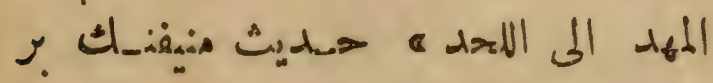

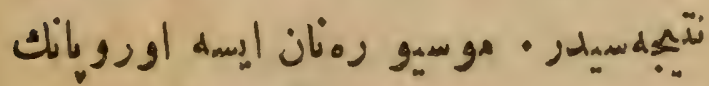

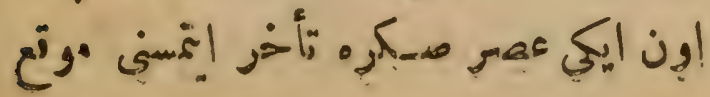




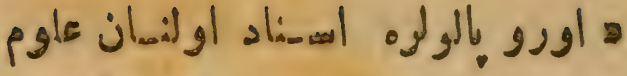

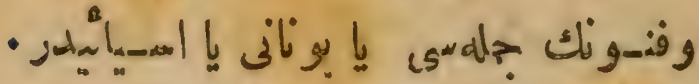

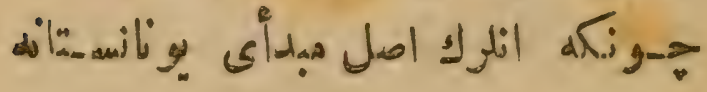

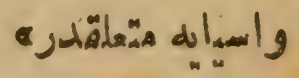

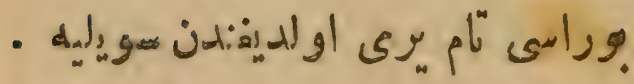

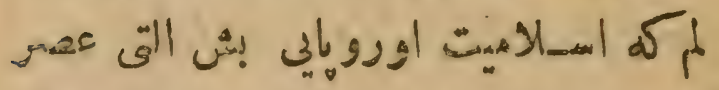

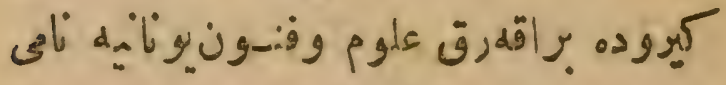

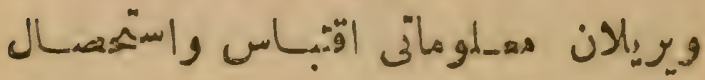

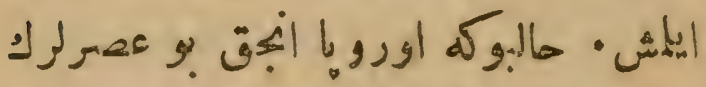

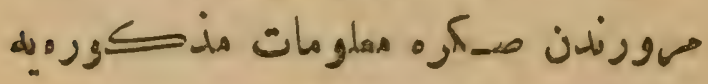

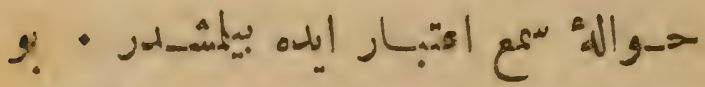

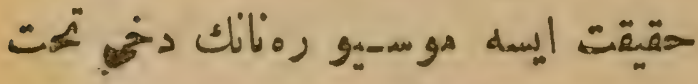

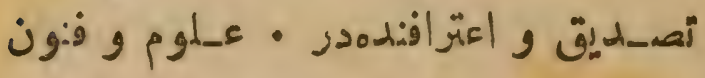

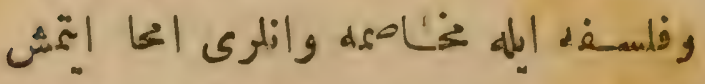

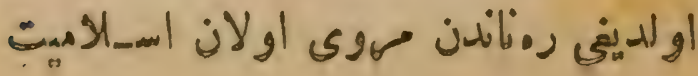




\section{(19)}

اوروبإيه نسبت ايتّديكى علوم وفنونه دار

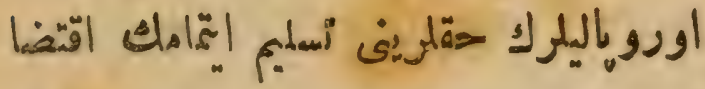

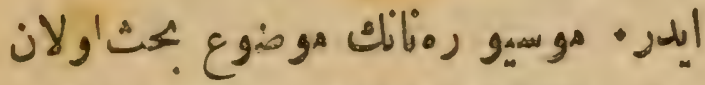

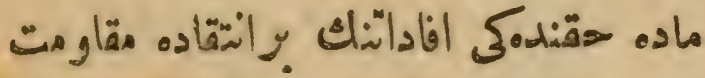

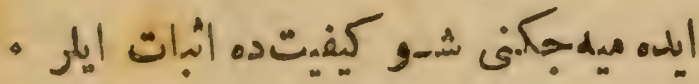

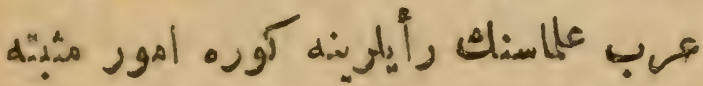

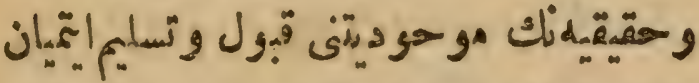

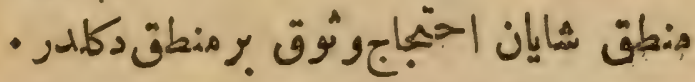

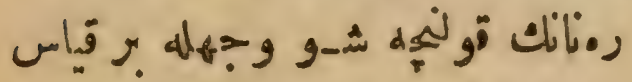

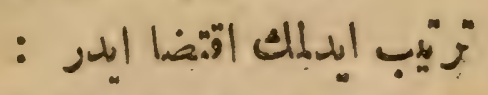

هوبلره اسناد اولن علوم وفنونك

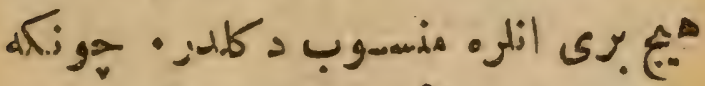

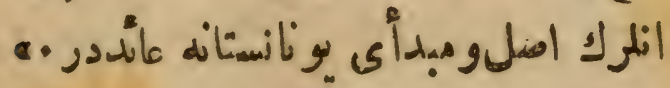

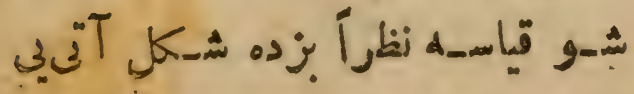

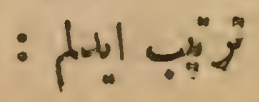




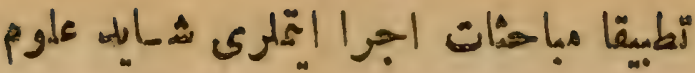

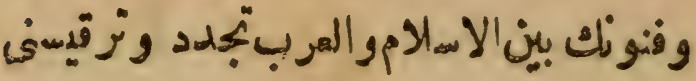

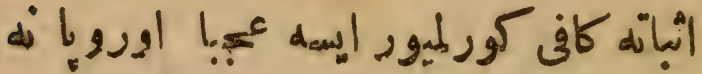

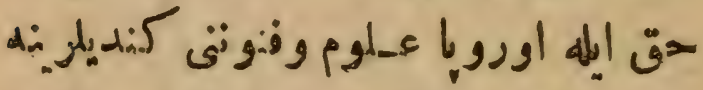

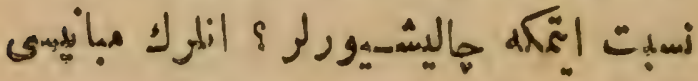

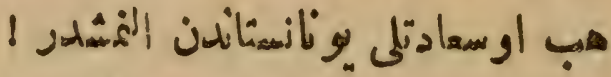

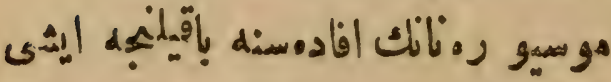

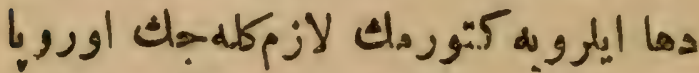

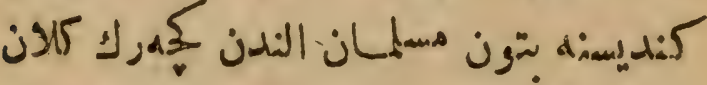

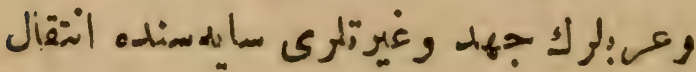

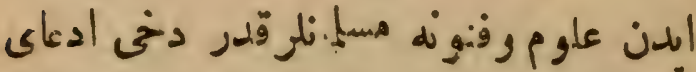

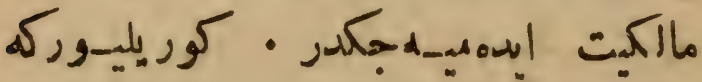
- مصني

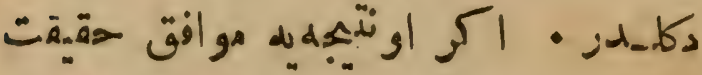

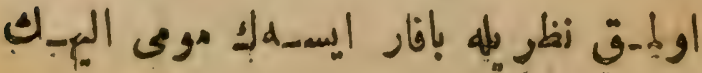




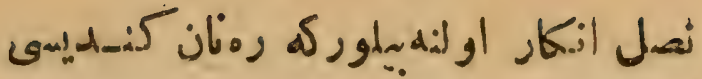

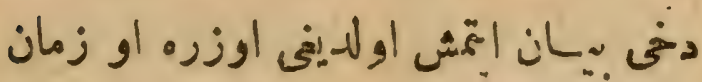

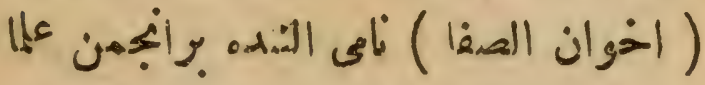

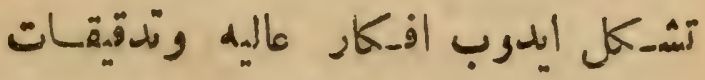

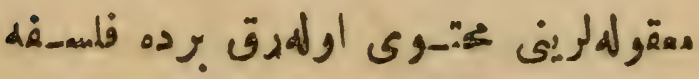

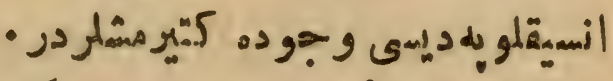

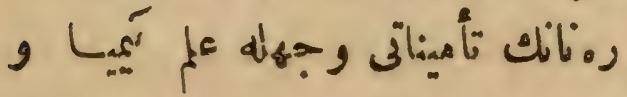

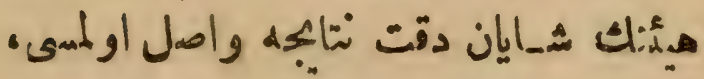

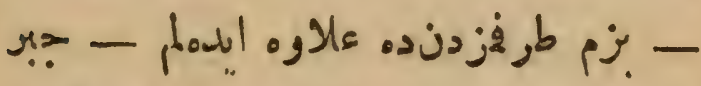

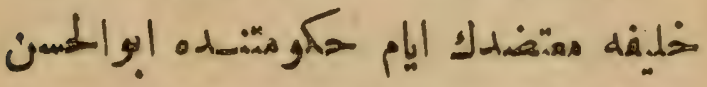

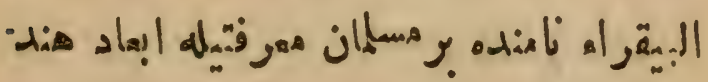

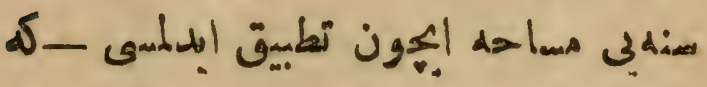

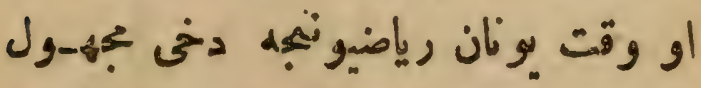

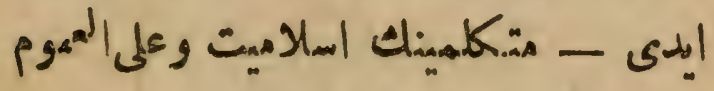

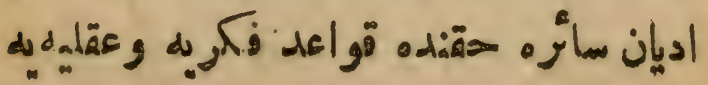


انلم يدندهى فنونك اسـاسى يونانسماندن

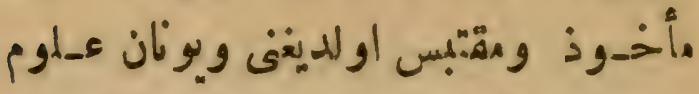

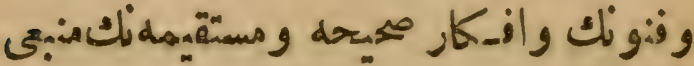

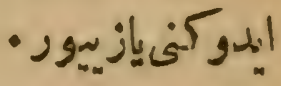

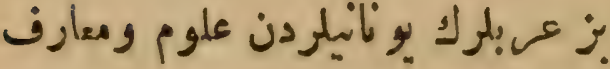

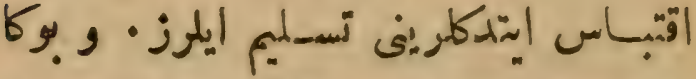

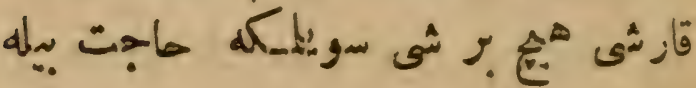

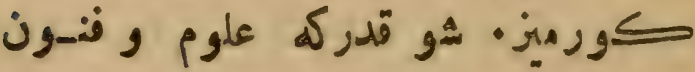

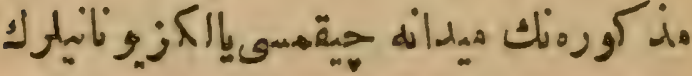

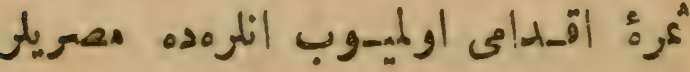

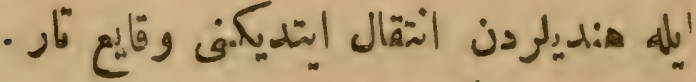

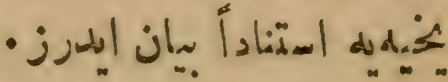

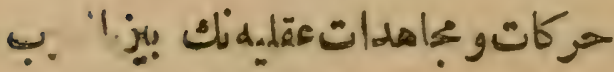
اجرأى حكم إتمش اوالمدئى او |

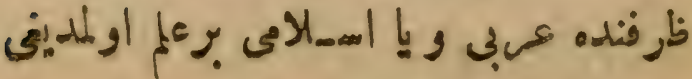




\section{कirs \\ با.}

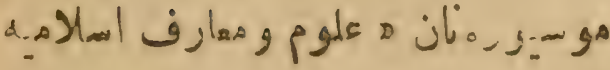

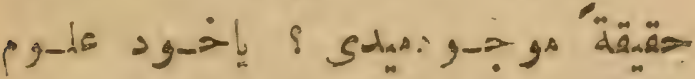

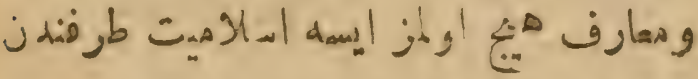

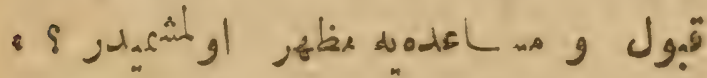

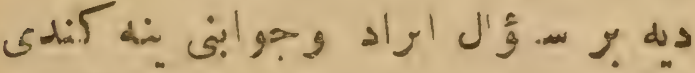

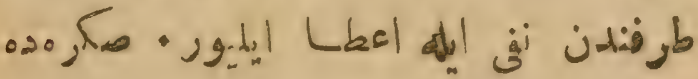
.

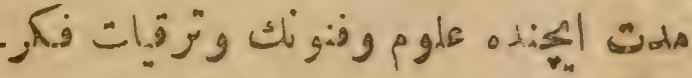

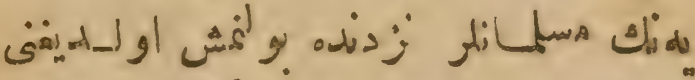

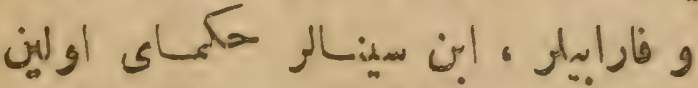

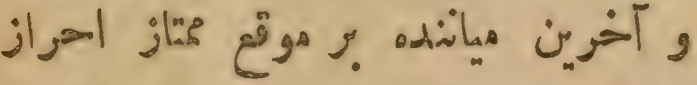

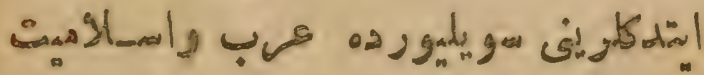

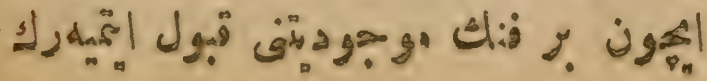




\section{$11 \%$}

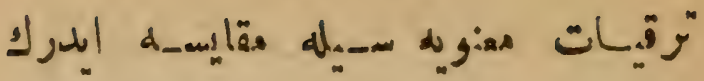

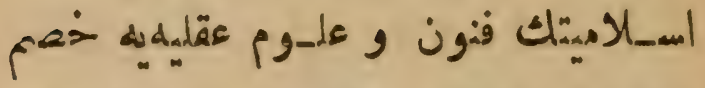

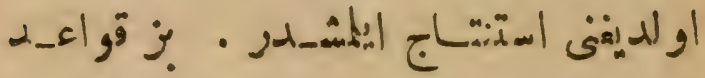

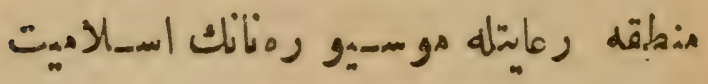

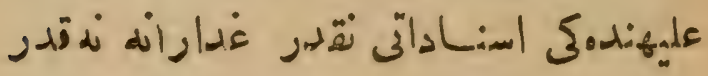

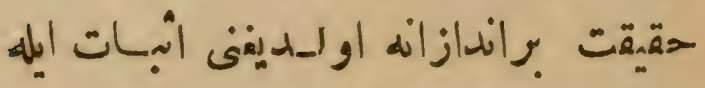

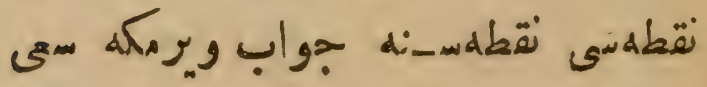

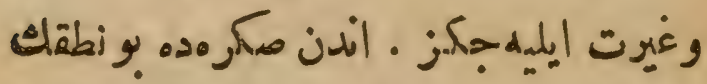

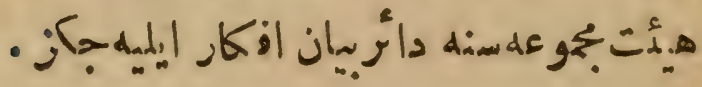




\section{1.}

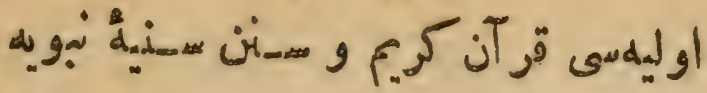

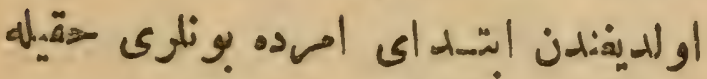

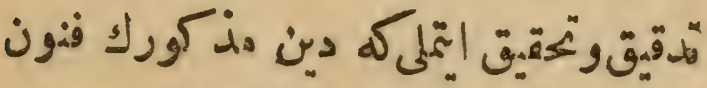

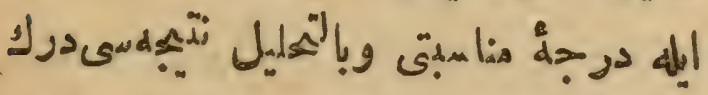

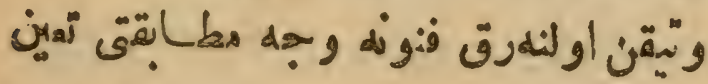

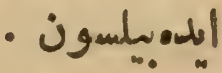

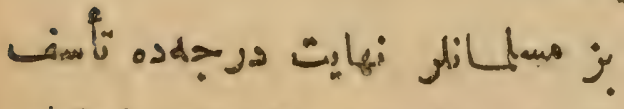

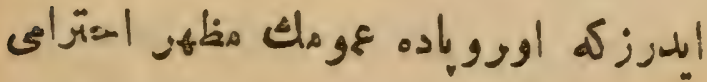

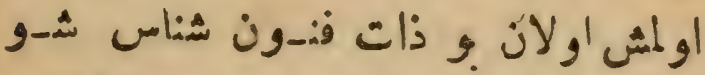

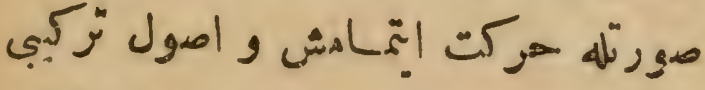

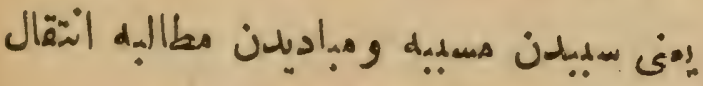

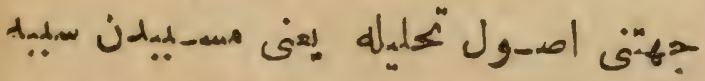

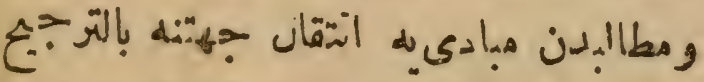

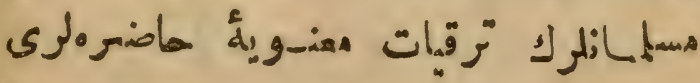

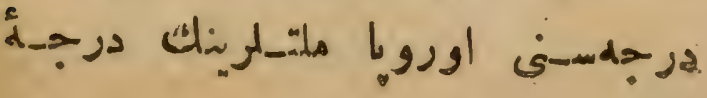




\section{9}

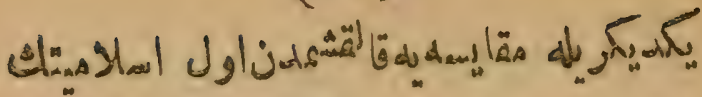
كاهي

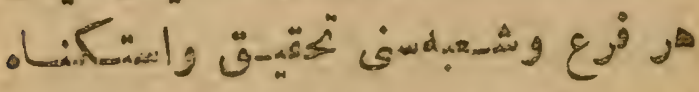

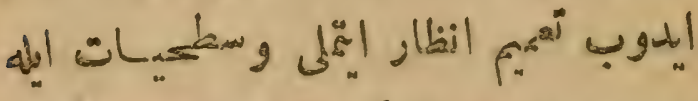

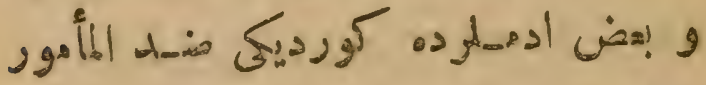

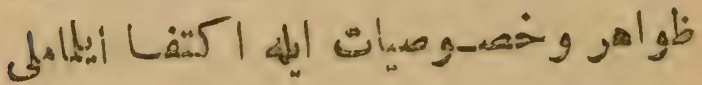

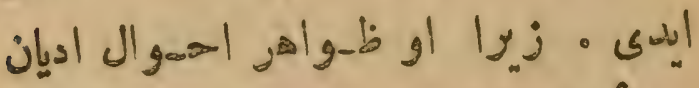

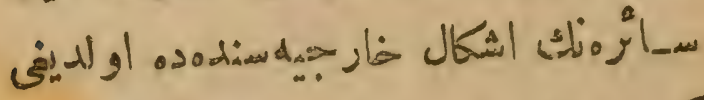

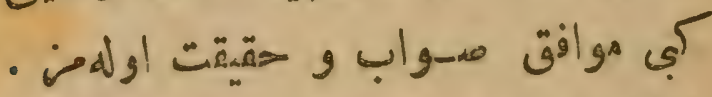
،

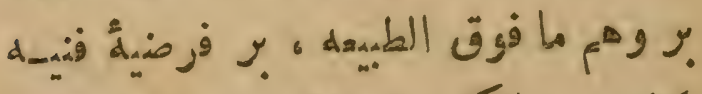

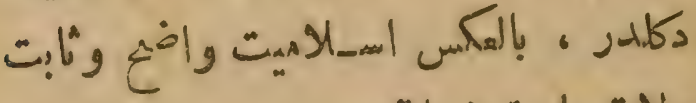

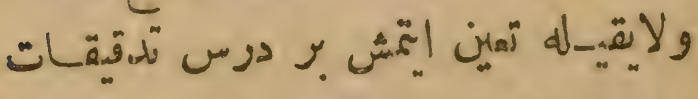

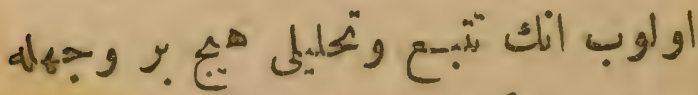

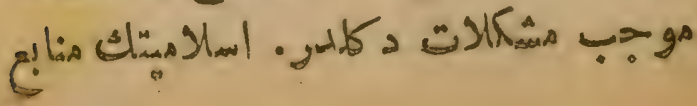




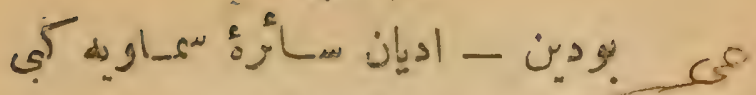

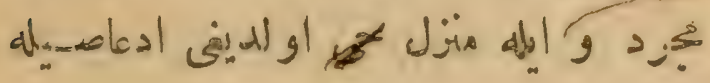

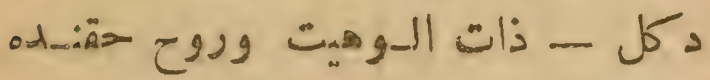

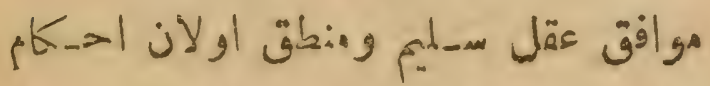

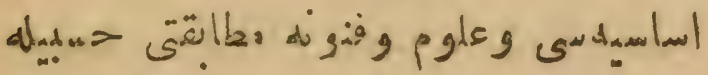

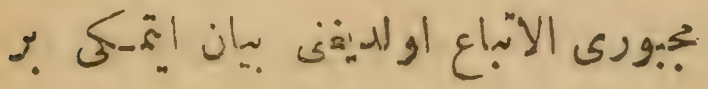

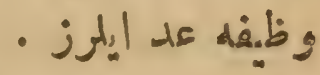

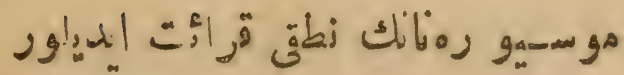
إيكن

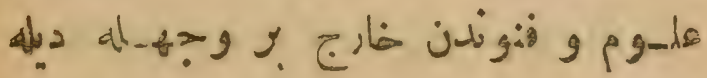

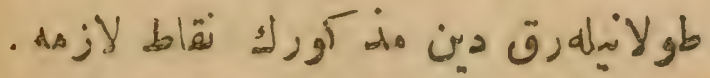

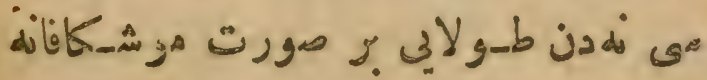
و

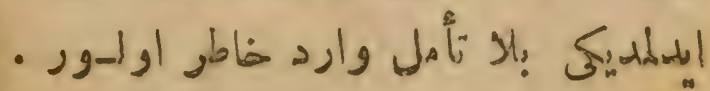
ات ات | 


\section{Y}

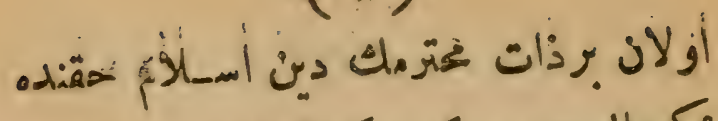

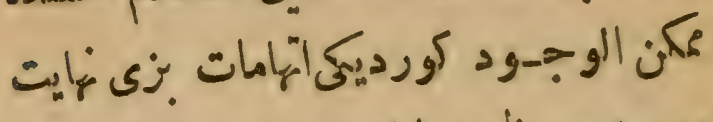
دو جلده دخون إيلدى • اودين الـ معتول

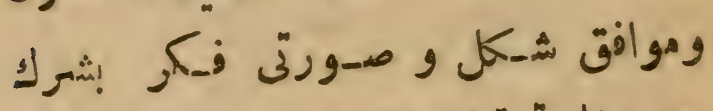

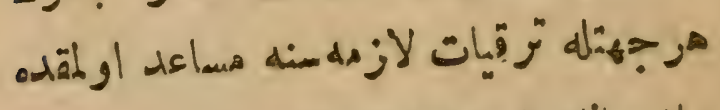

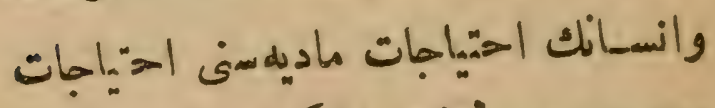

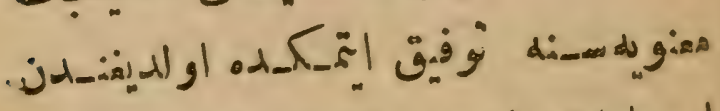

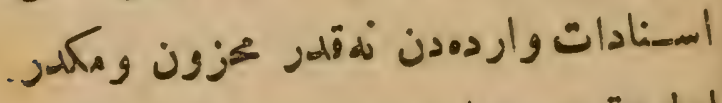

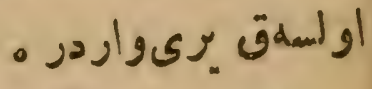

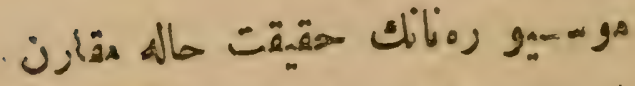

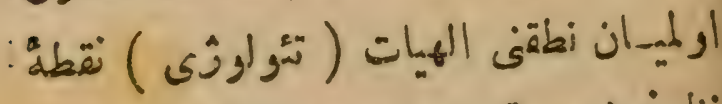

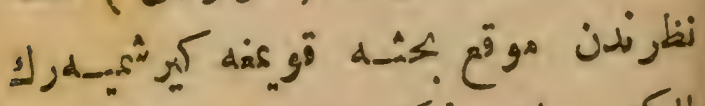

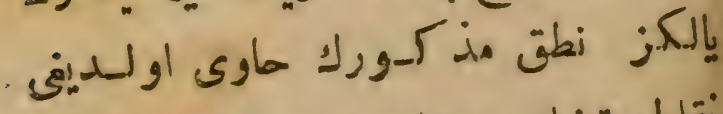

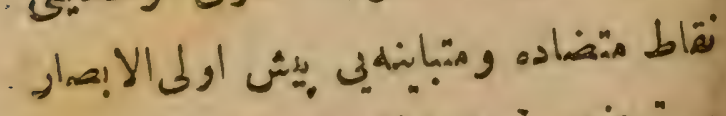

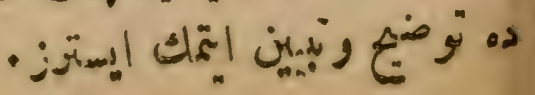




\section{0 .}

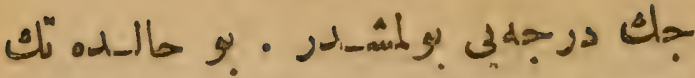

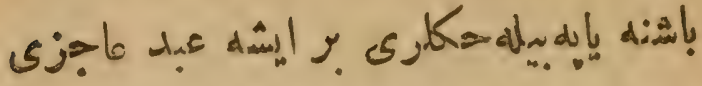

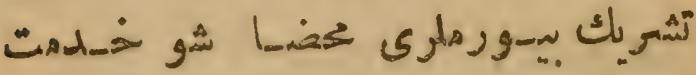

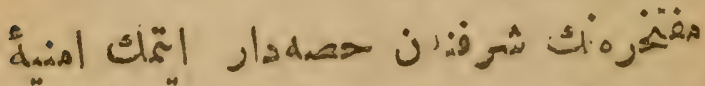

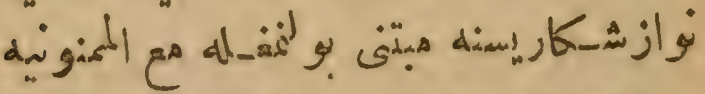

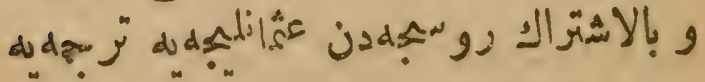

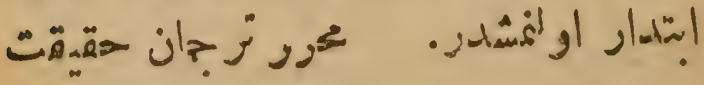

$$
\text { | اجلd }
$$




\section{的}

وبو إيش_ه عبد عاجزلكه هشـاركمى آرزو

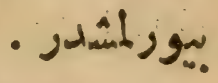

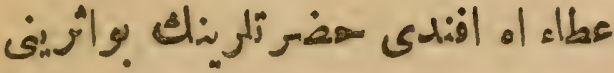

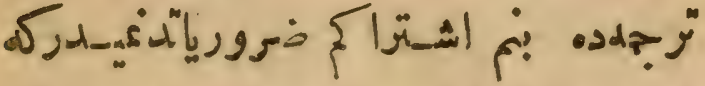

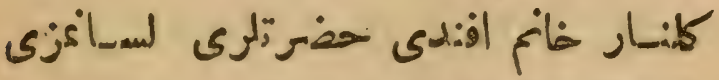

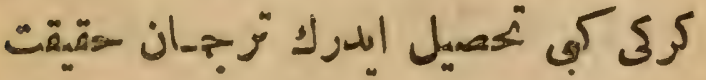

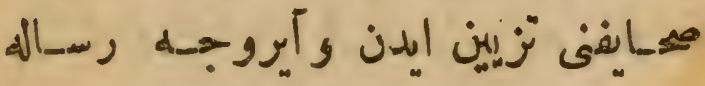

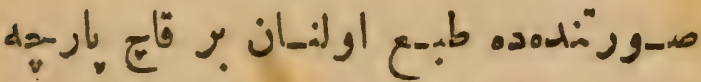

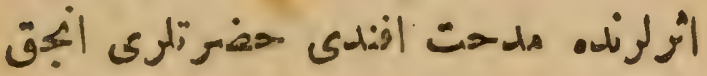

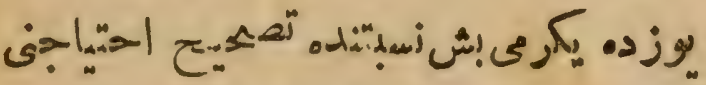

كوروب أعتباف إتمشاو الهقّلمى حال_يده

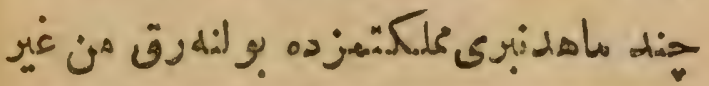

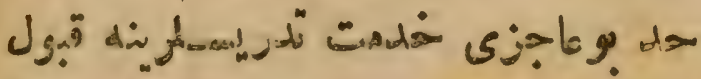

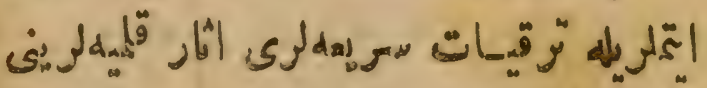

. 


\section{w}

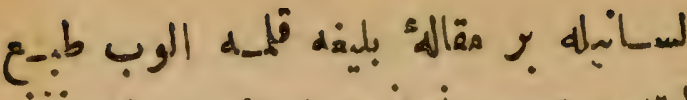

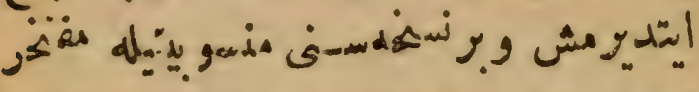

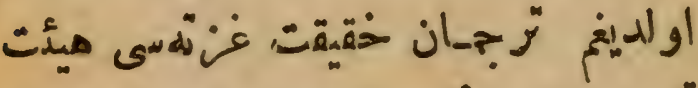

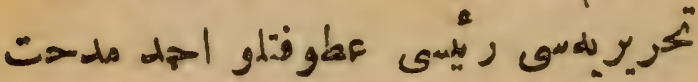

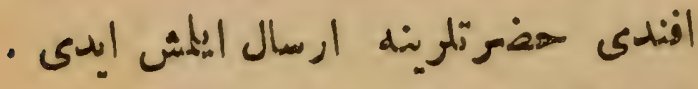

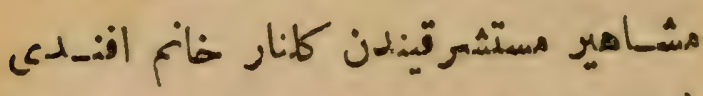

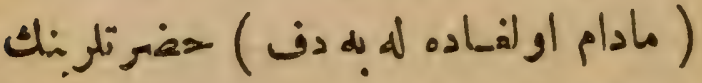

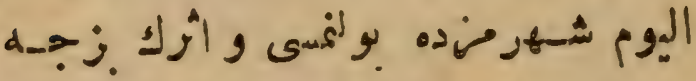

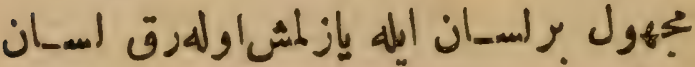

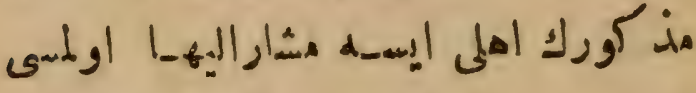

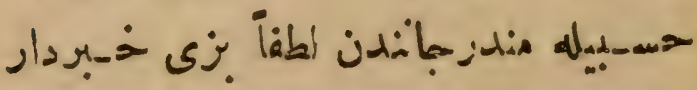

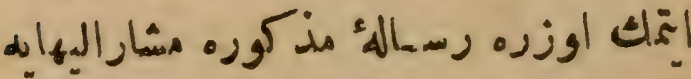

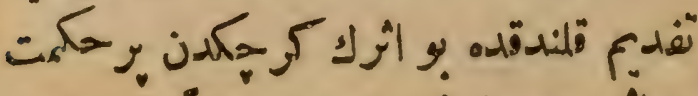

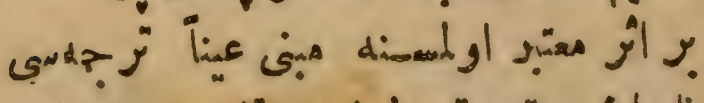
فأله" 


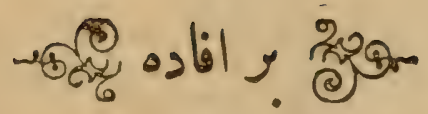

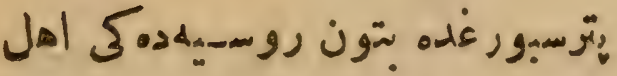

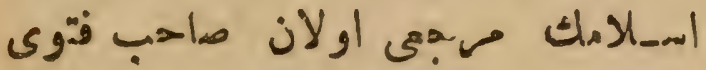

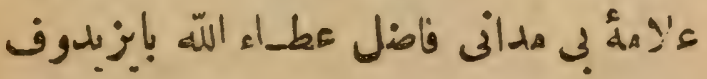

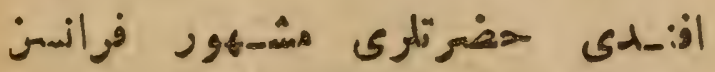
فيلسوفى ارهنست رونأك الس_الاهيت علوم

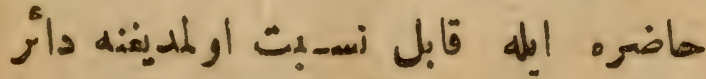

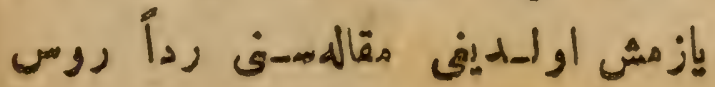


Bäyexidóf, "Atāan ultak

(3)

Redd-i

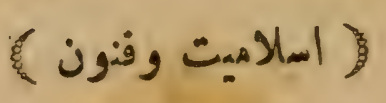

Rěnān

مؤلفي

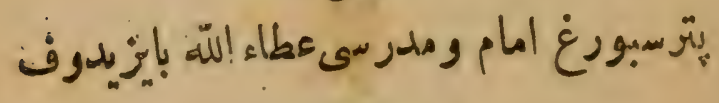

$\rightarrow-\infty \times 0000$

مترجملى

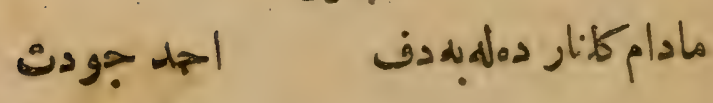

معارف نظارت جليلهستك رنصتيل

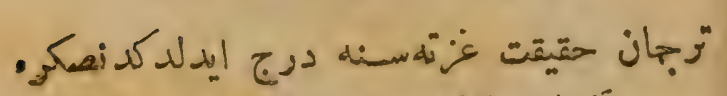
كتاب شكلند، دنى طبع اولندى إيد

استانبول

$|F|$ 


\section{$-197-$}

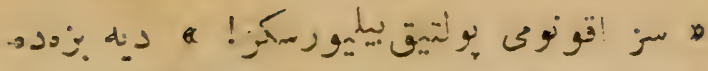

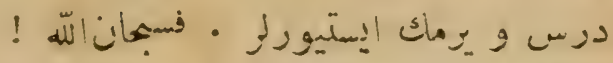

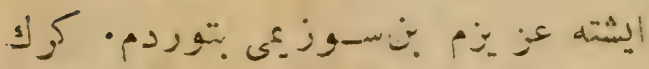

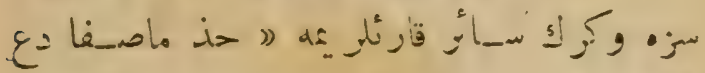

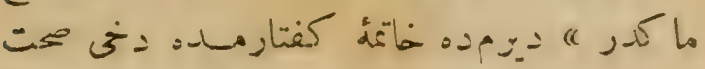

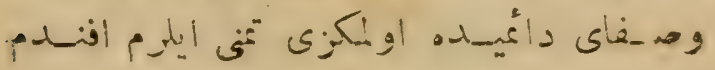
إن | 


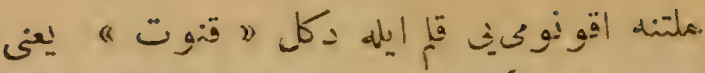

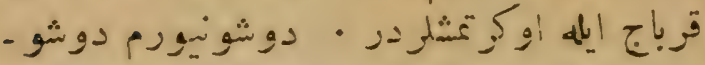

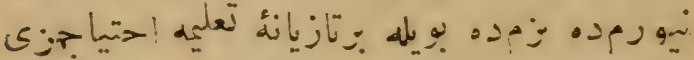

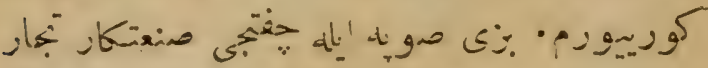

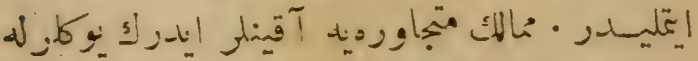

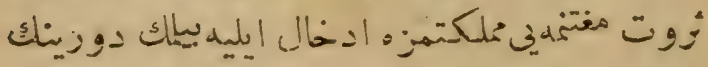

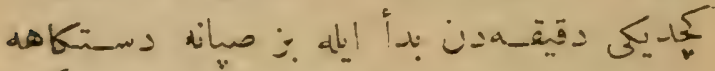

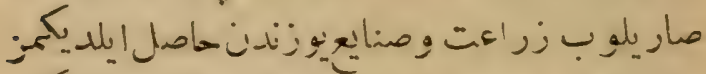

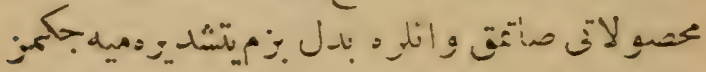

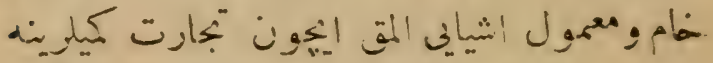

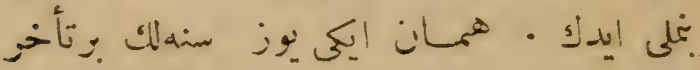

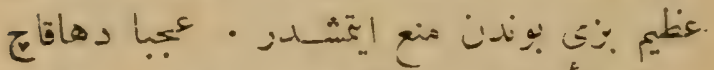

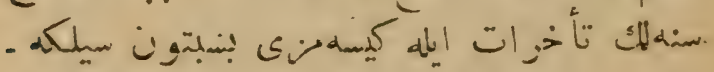

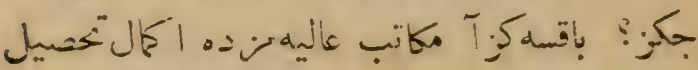

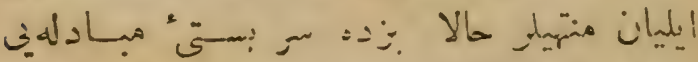

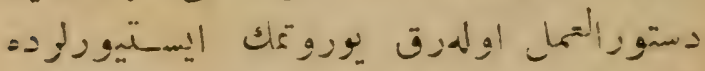

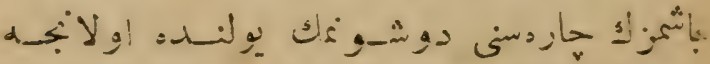

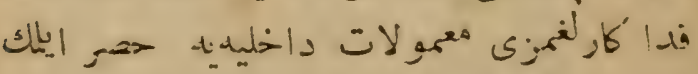

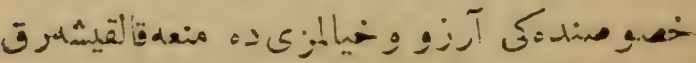




\section{-195--}

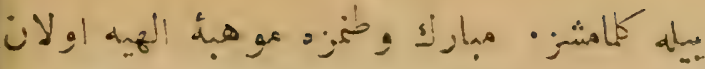

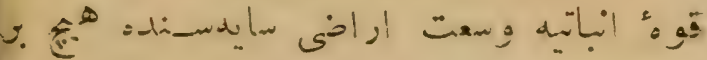

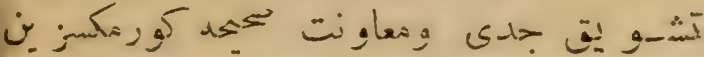

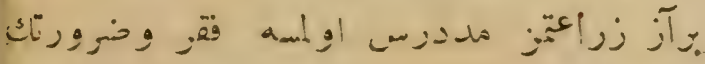

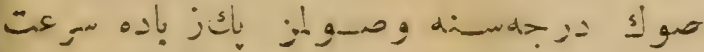

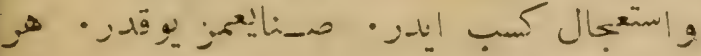

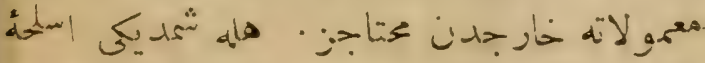

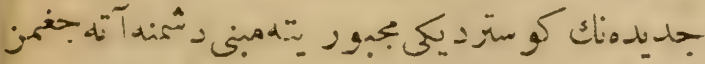

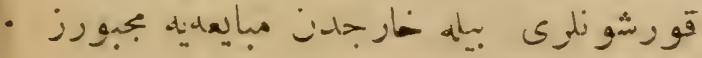

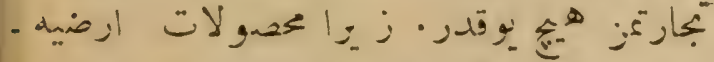

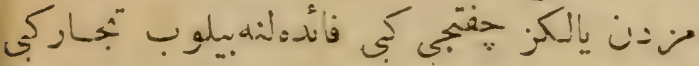

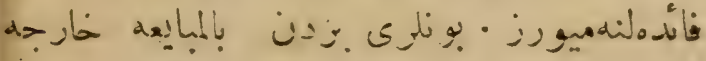

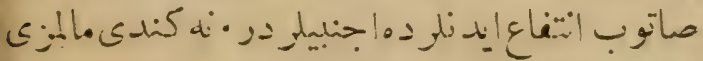

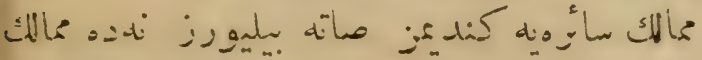

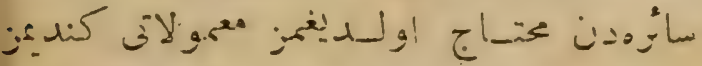

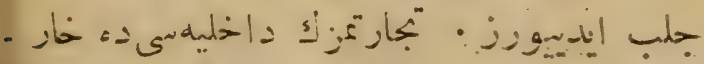

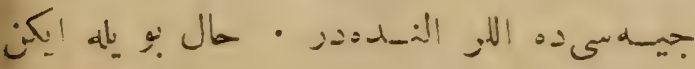

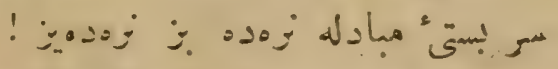

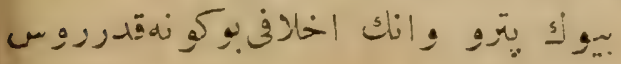




\section{$-19 r$}

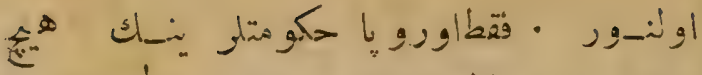

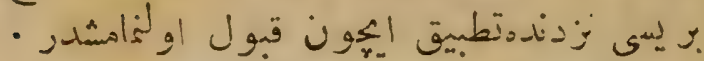

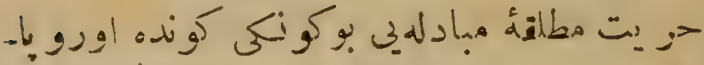

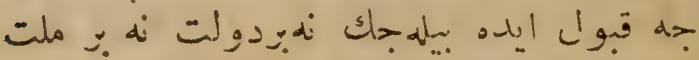

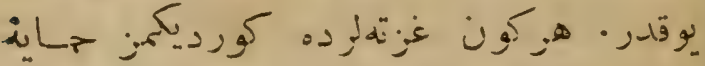

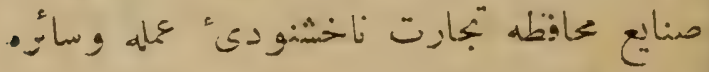

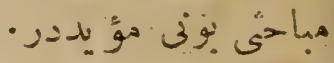

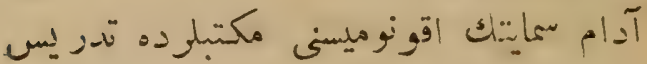

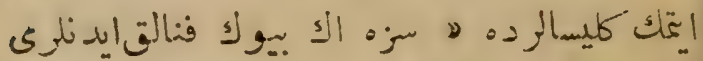

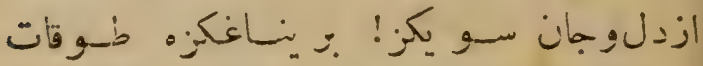

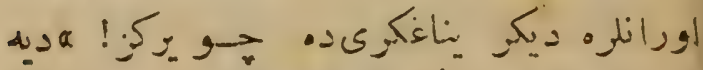

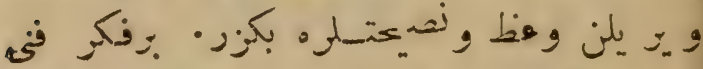

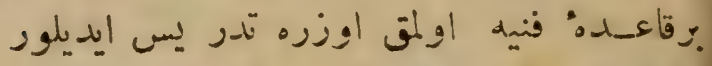

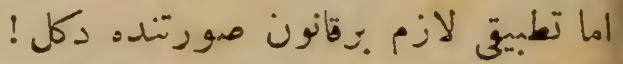

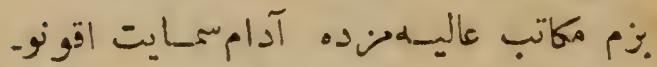

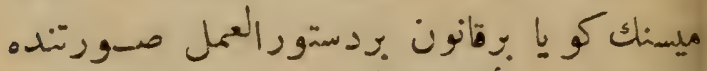

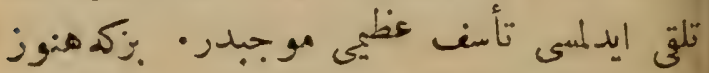

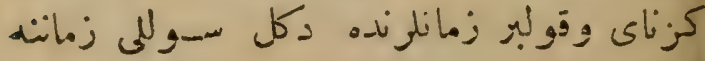




\section{$-194-$}

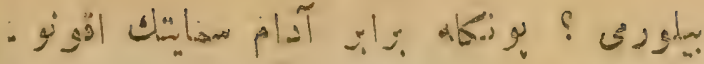

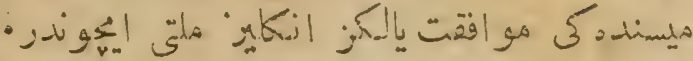

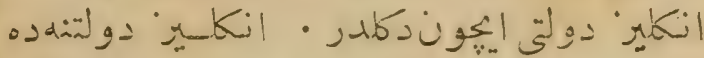

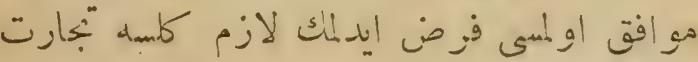

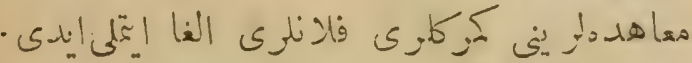

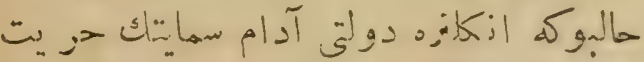

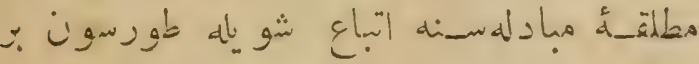

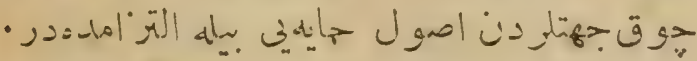

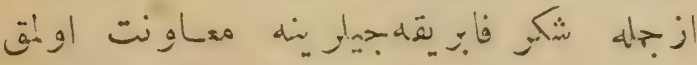

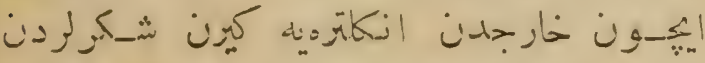

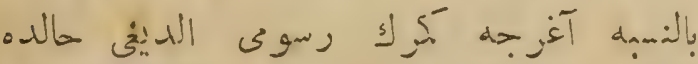

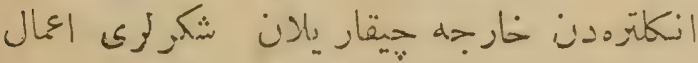

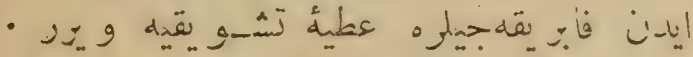

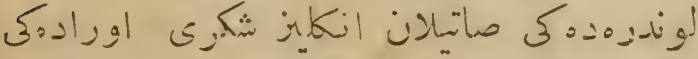

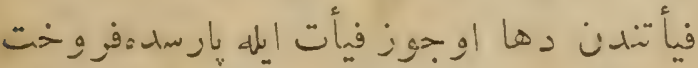

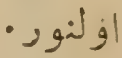

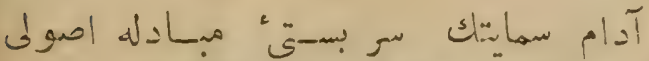

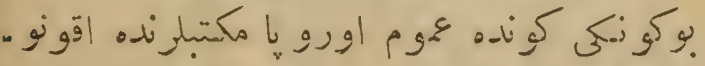

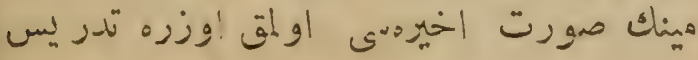


$-191-$

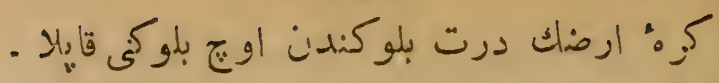

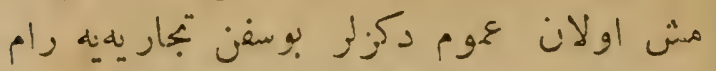

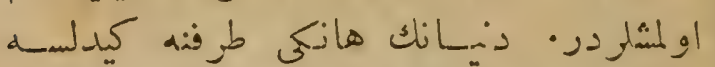

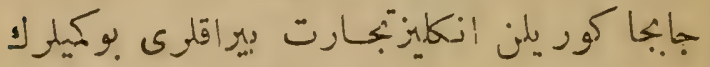

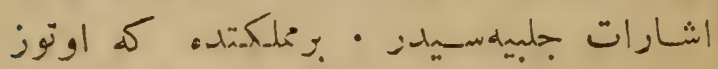

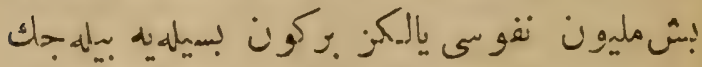

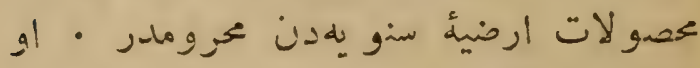

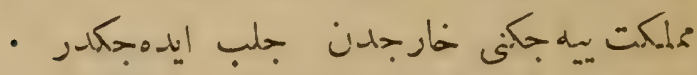

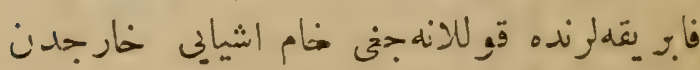

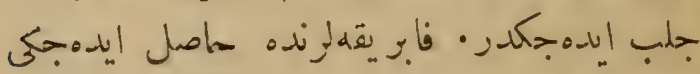

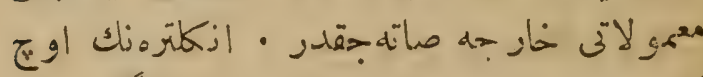

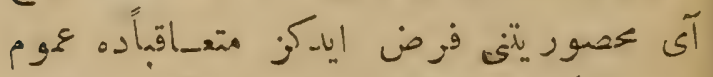

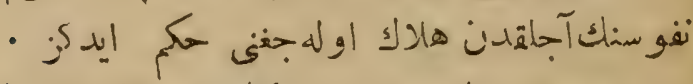

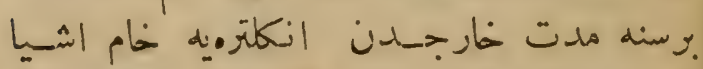

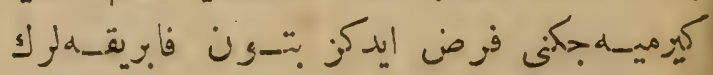

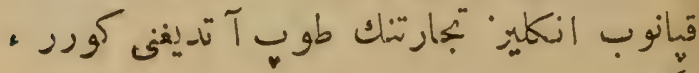
مَّكن.

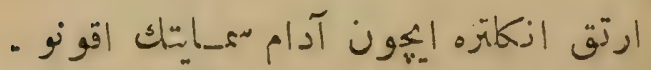

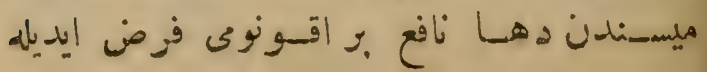


$-19 \cdot-$

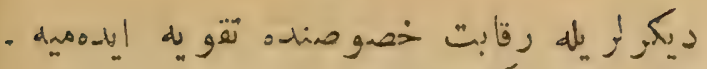

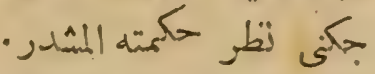

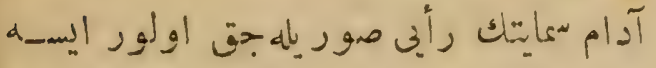

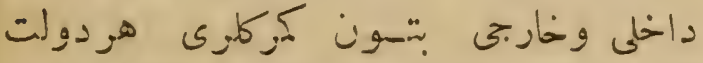

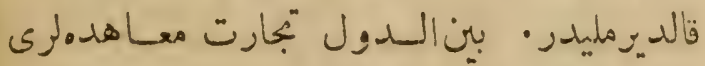

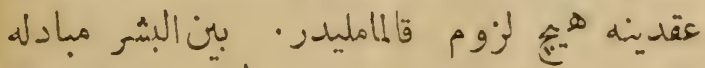

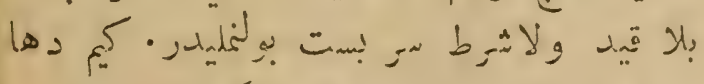

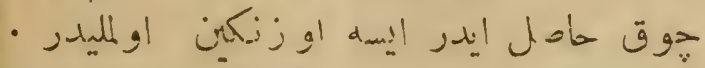

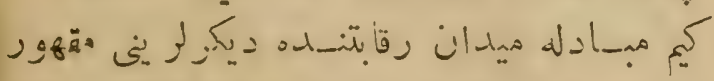

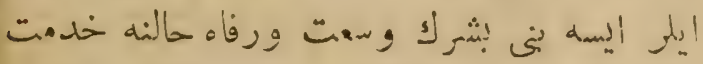

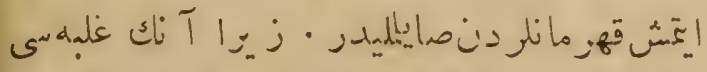

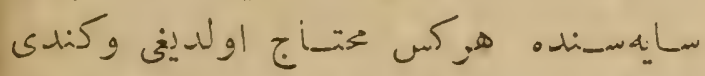

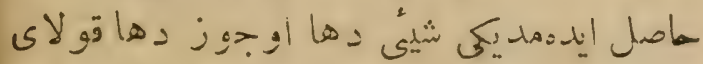

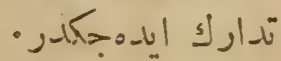

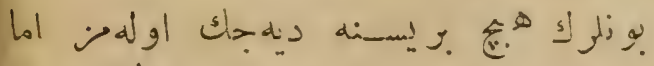

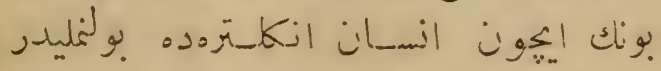

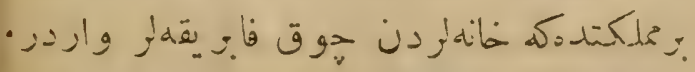

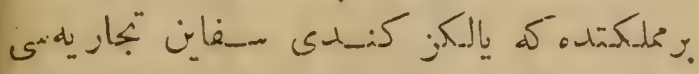

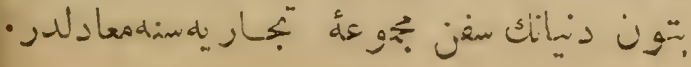


$-119-$

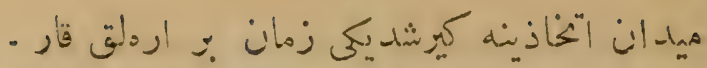

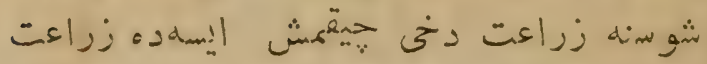

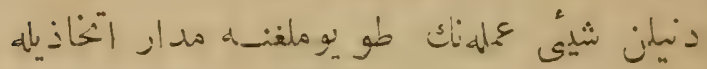

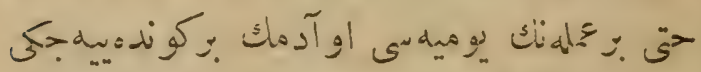

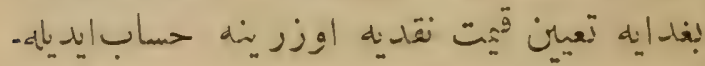

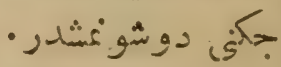

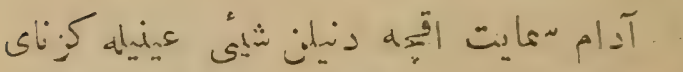

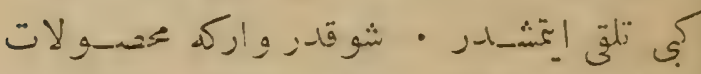

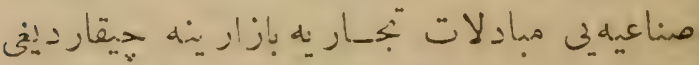
ن

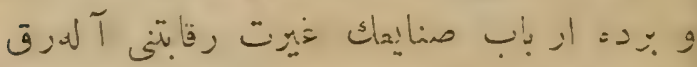

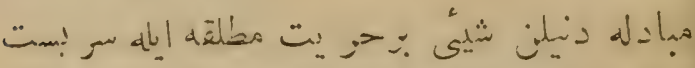

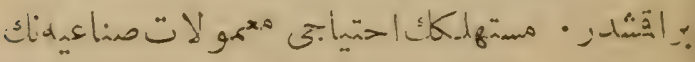

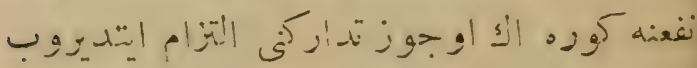

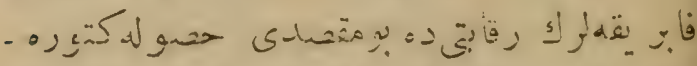

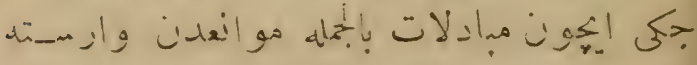

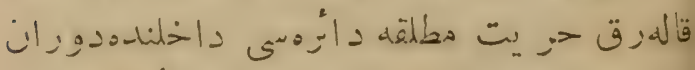

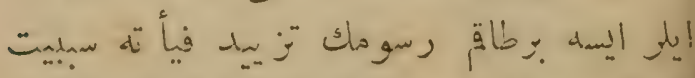

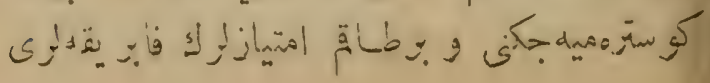




$$
-1 \lambda \Lambda-
$$

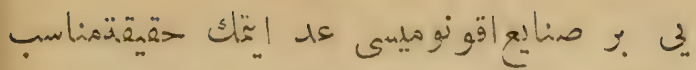

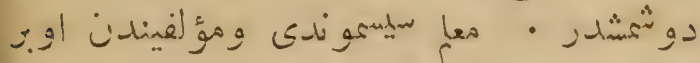

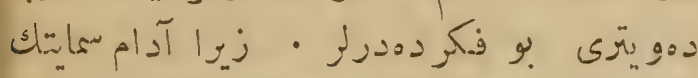

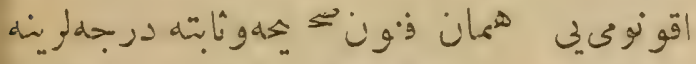

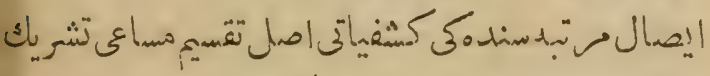

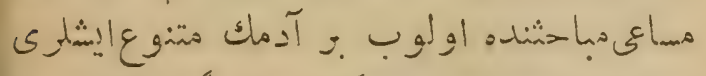

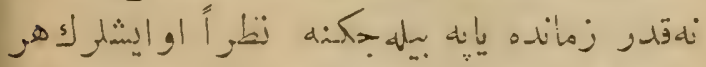

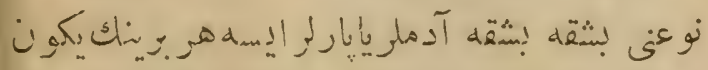

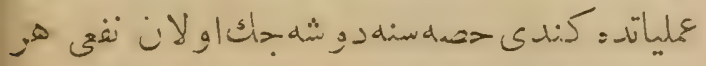

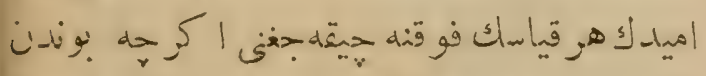

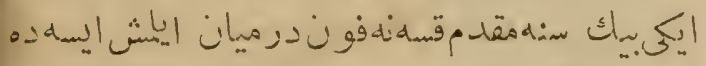

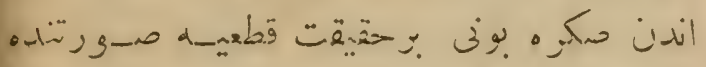

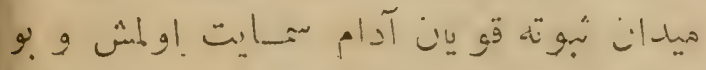

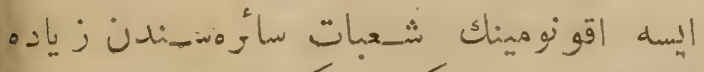

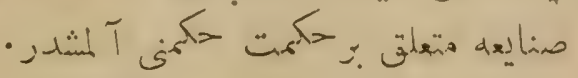

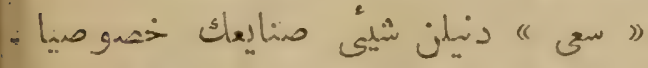

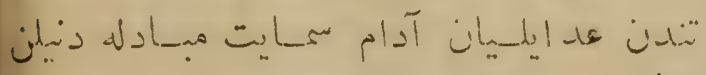

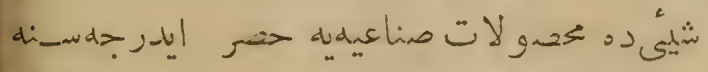

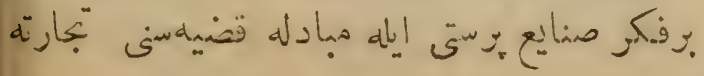




\section{$-\operatorname{lnV}=$}

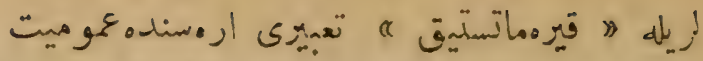

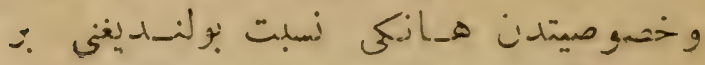

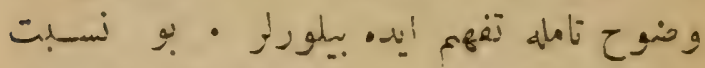

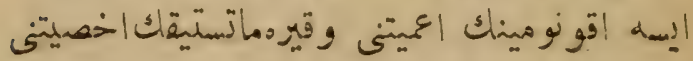

$$
\text { كوسترد · تونم }
$$

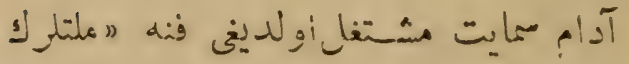

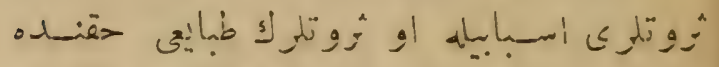

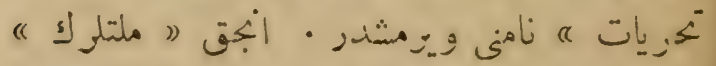

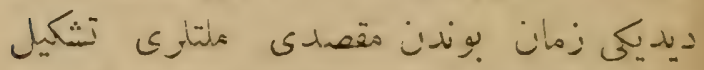

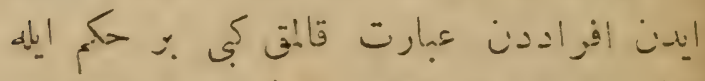

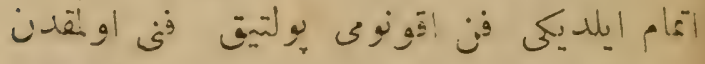

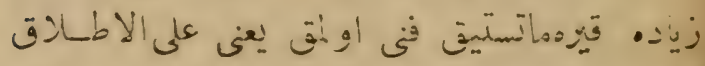

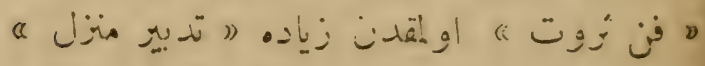

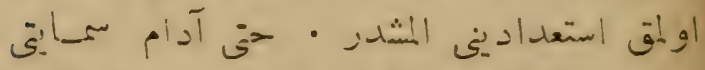

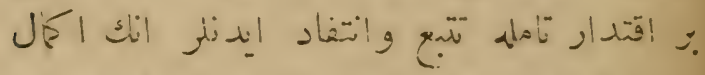

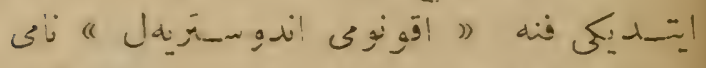

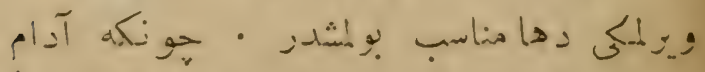

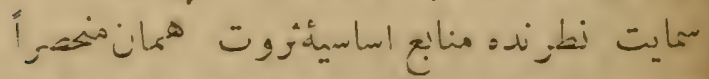

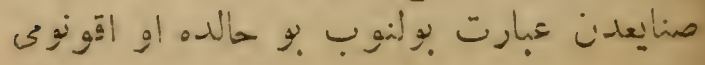




\section{$=1119-$}

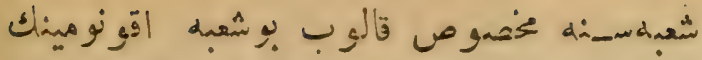

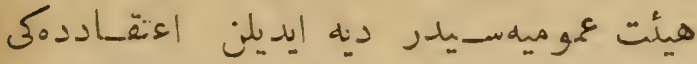

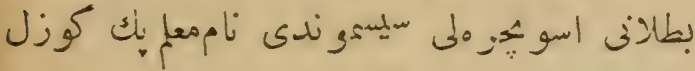

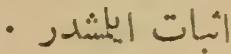

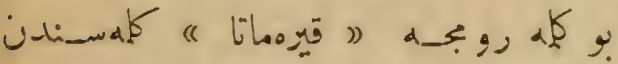

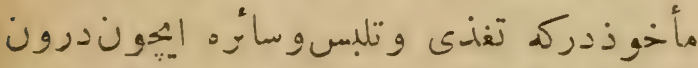

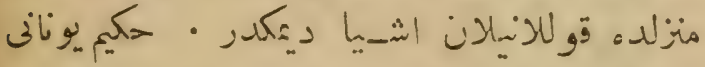

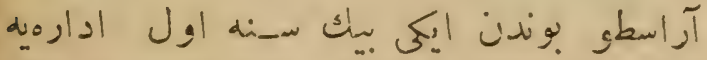

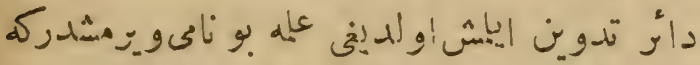

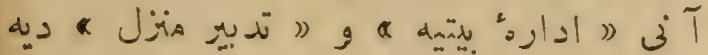

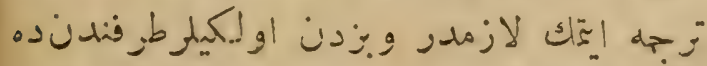

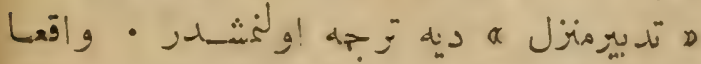

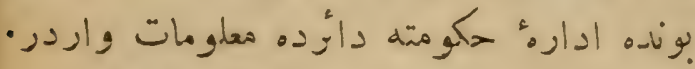

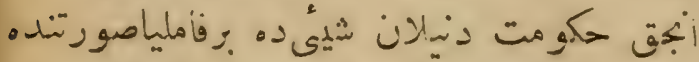

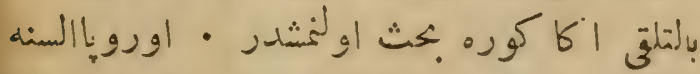

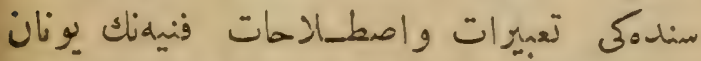

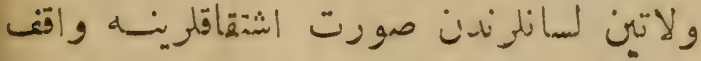

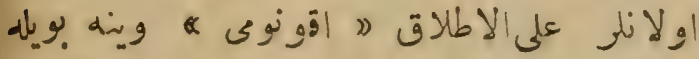

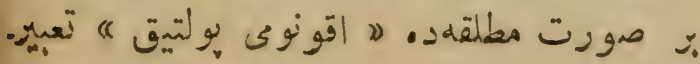




\section{-idón.}

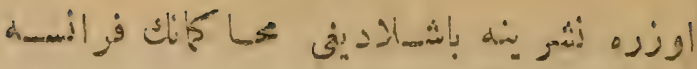

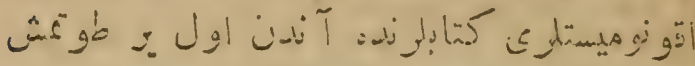

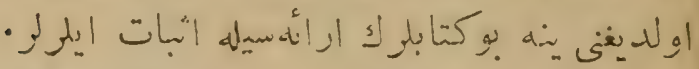

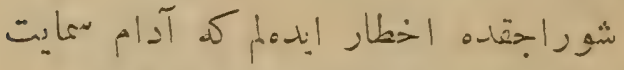

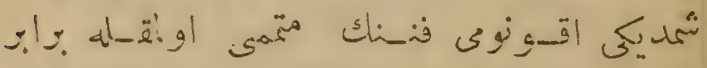

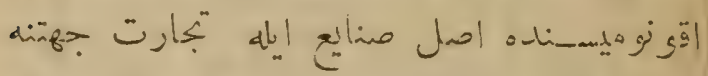

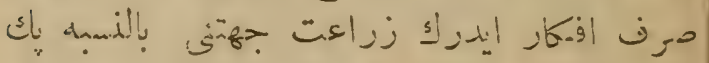

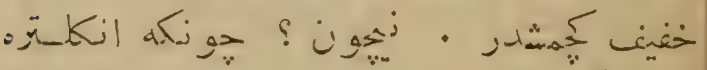

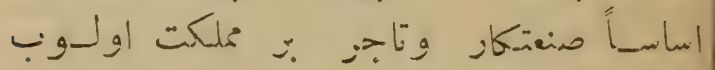

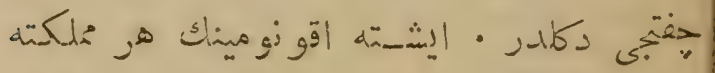

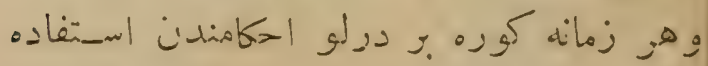

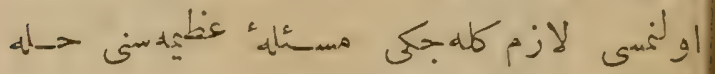

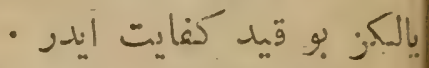

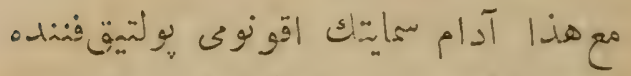

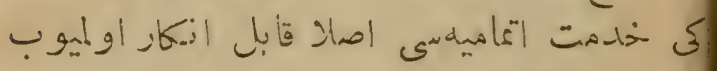

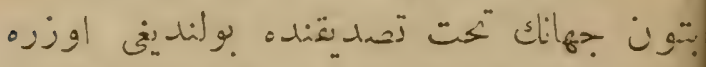

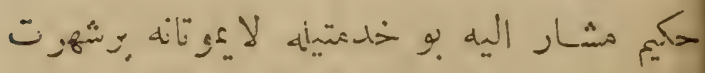

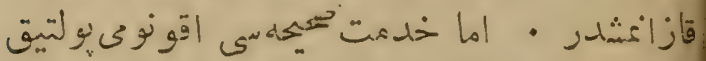

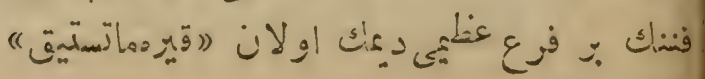




\section{$-1 \mathrm{~s}-$}

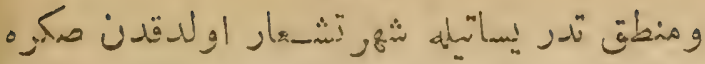

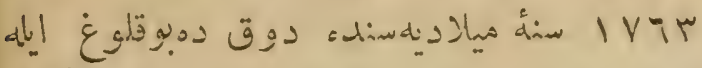

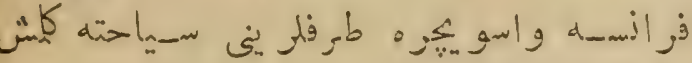

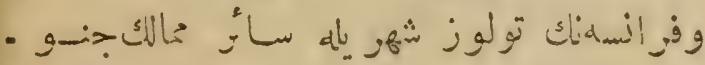

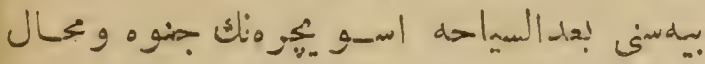

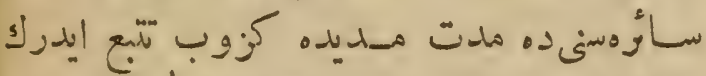

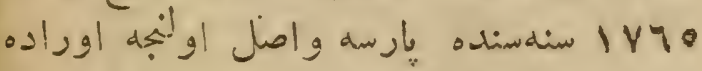

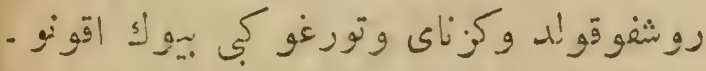

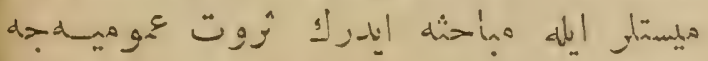

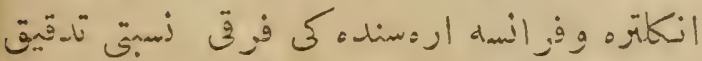

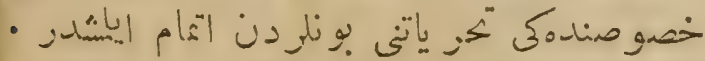

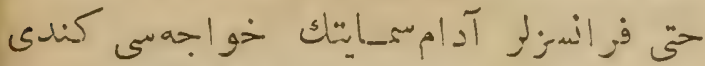

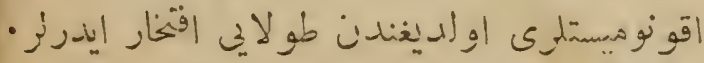

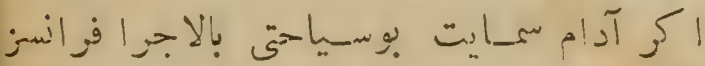

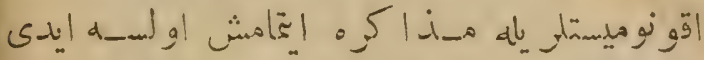

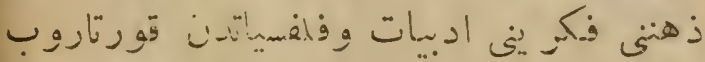

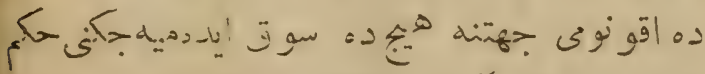

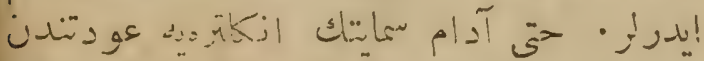

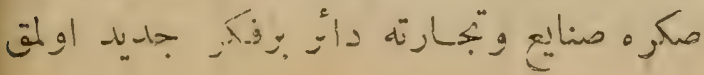




\section{$-11 \mu^{M}$}

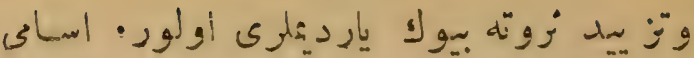

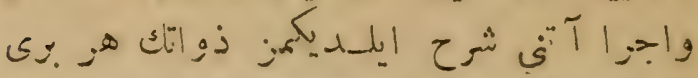

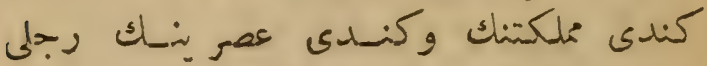

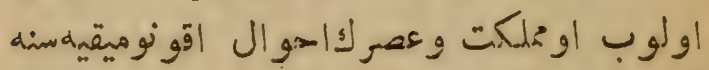

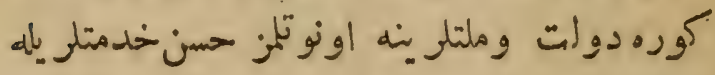

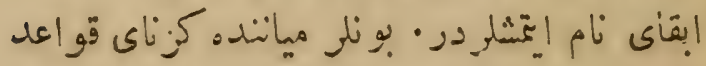

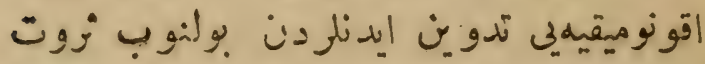

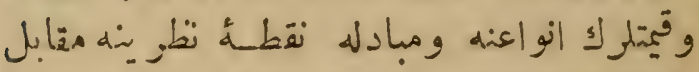

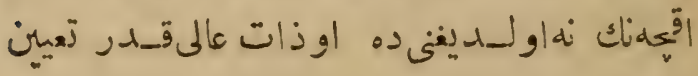
•

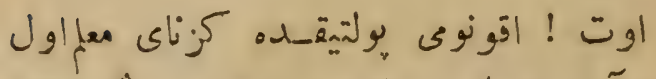

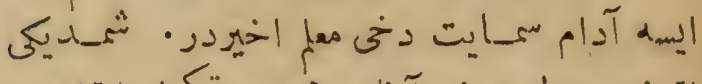

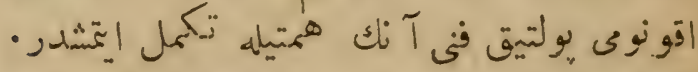

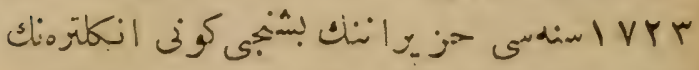

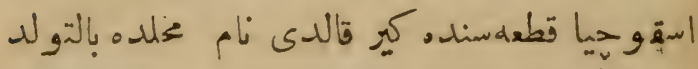

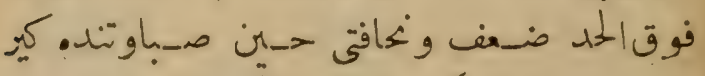

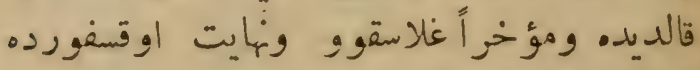

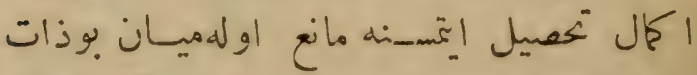

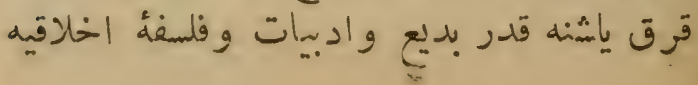




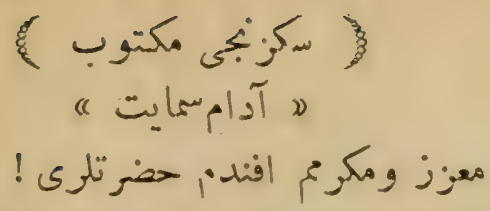

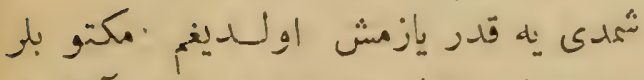

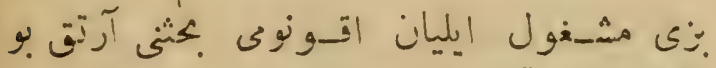

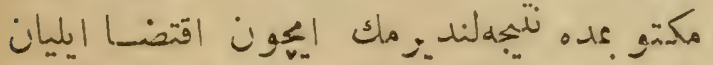

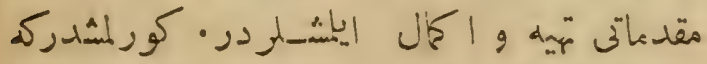

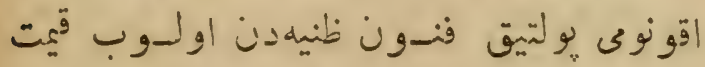

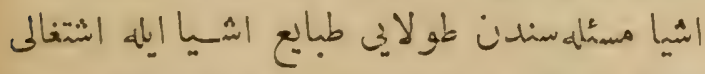

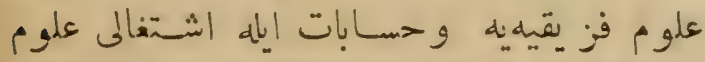

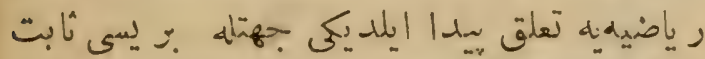

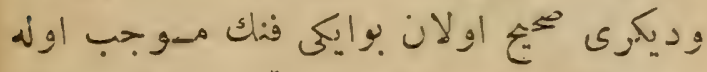

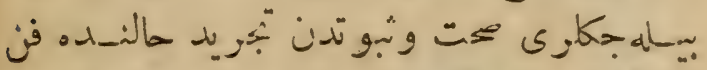

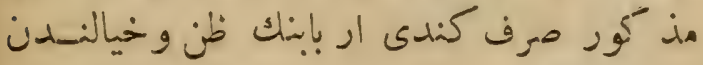

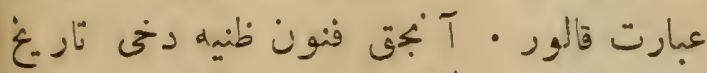

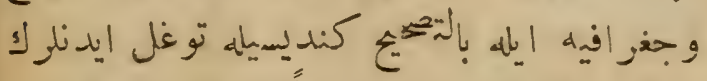

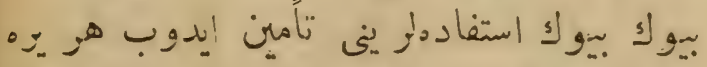

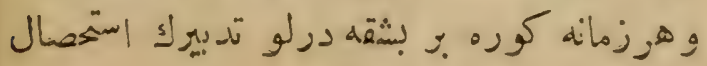


$-|\lambda|-$

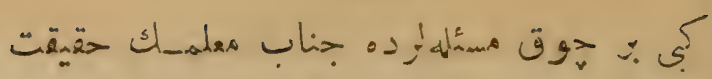

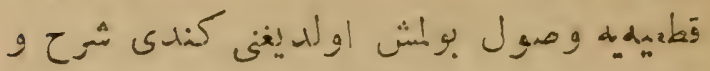
-

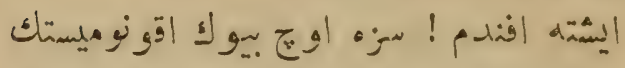

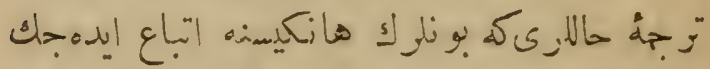

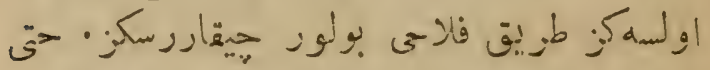

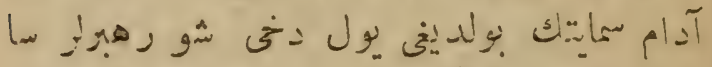

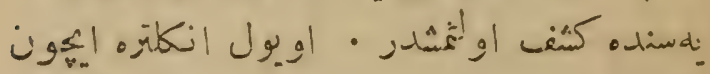

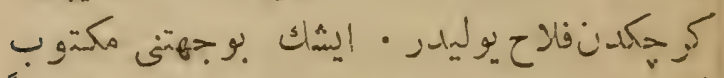

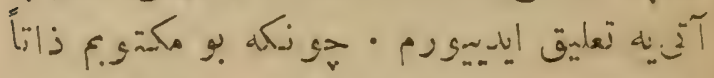

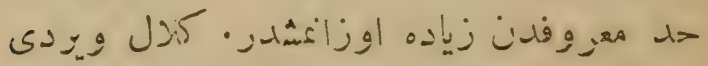

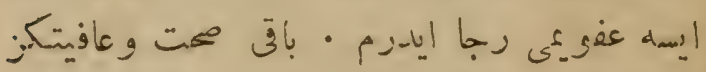

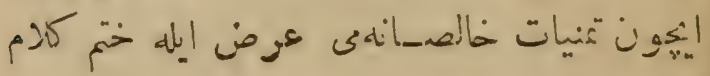

-

آحي

$-0$ 


\section{$-11 \cdot-$}

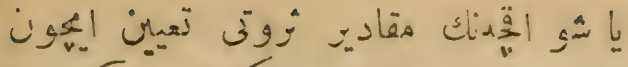

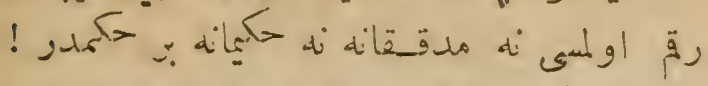

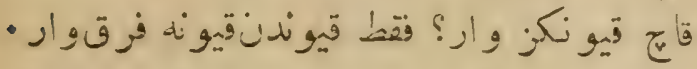

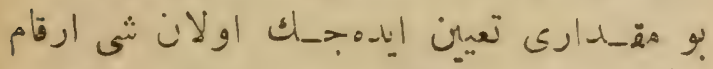

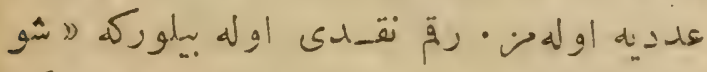

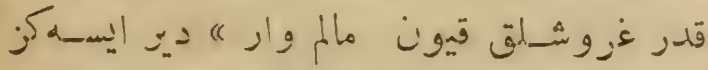

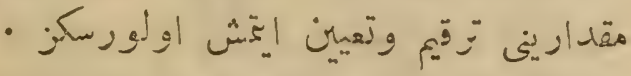

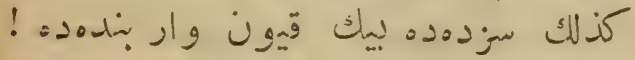

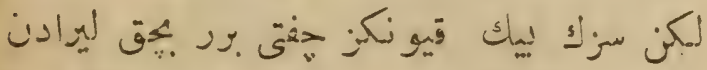

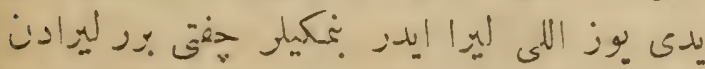

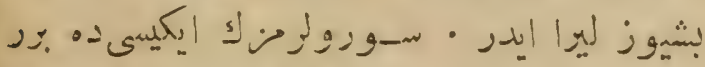

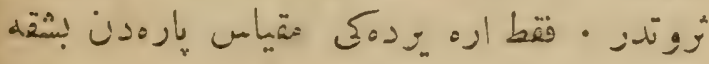

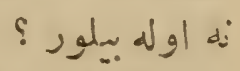

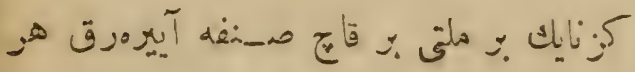

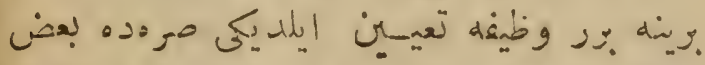

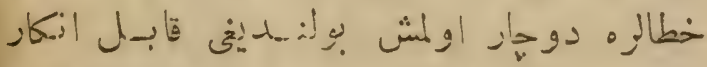

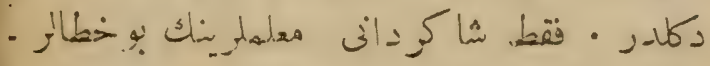

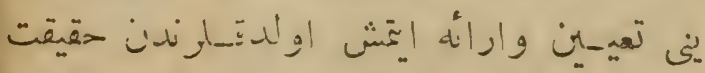

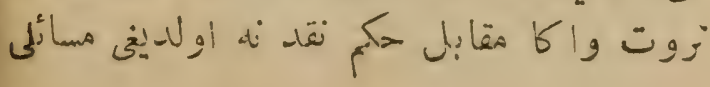




\section{$-1 \times 9$}

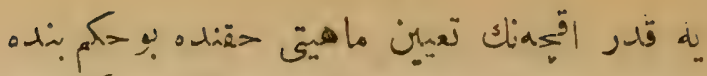

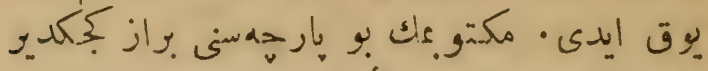

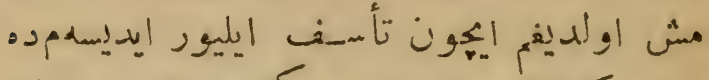

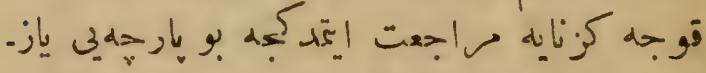

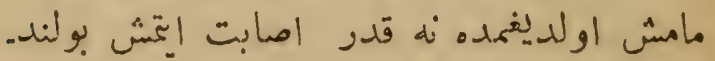

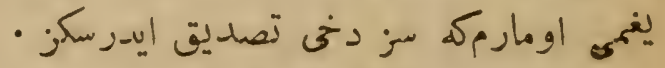

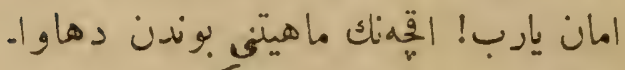

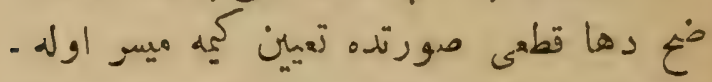

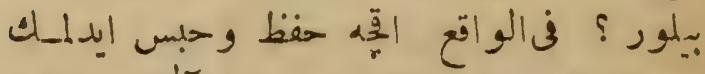

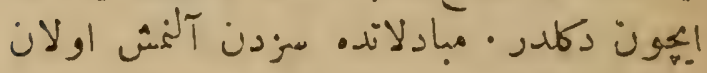

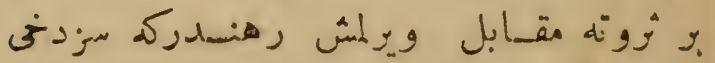

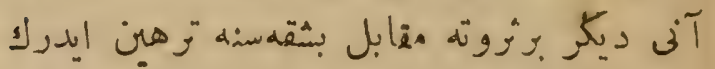

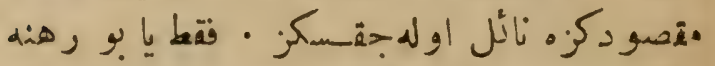

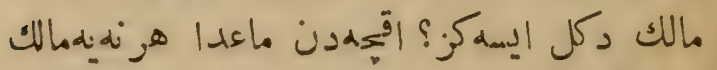

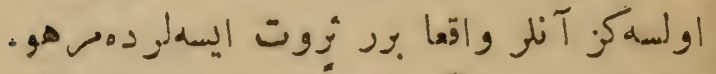

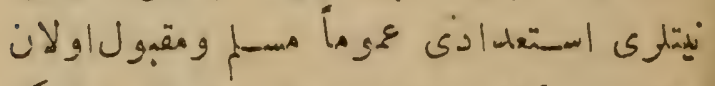

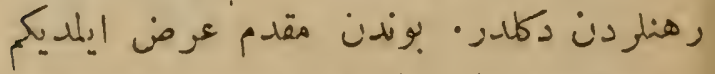

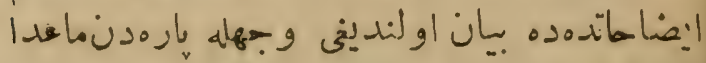

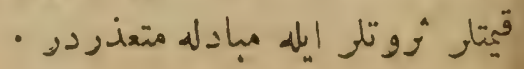




\section{$-\mid V \lambda-$}

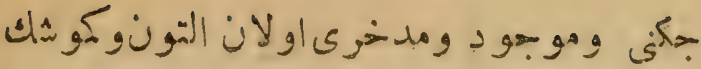

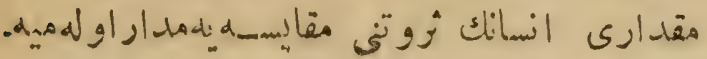

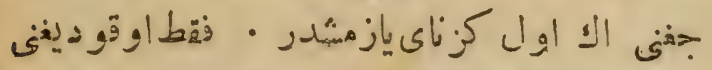

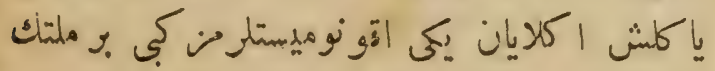

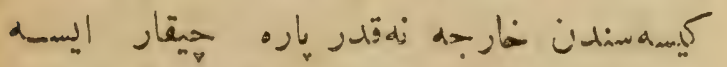

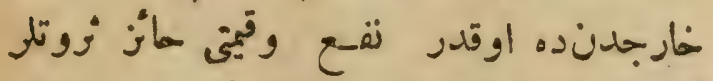

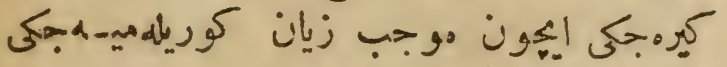

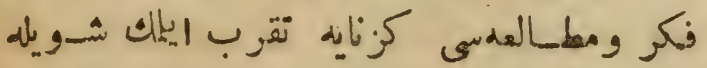

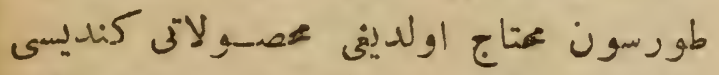

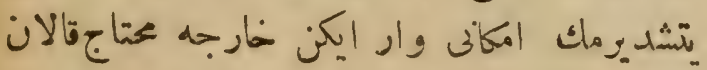

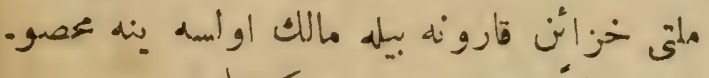

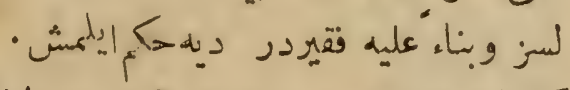

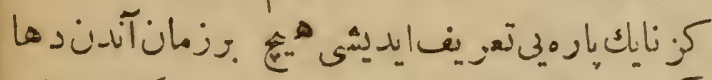

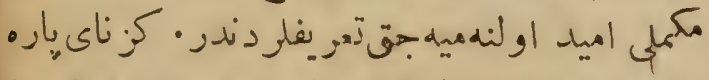

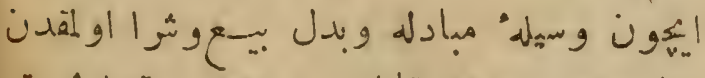

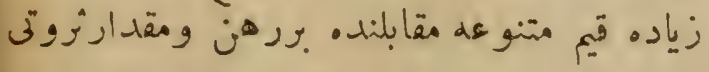

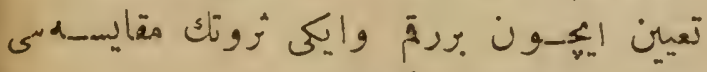

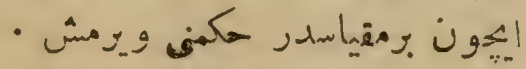

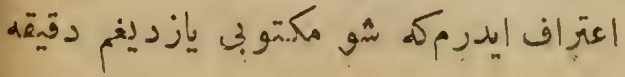




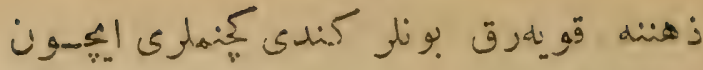

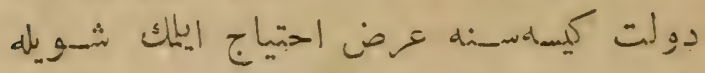

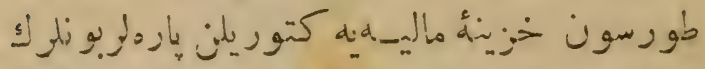

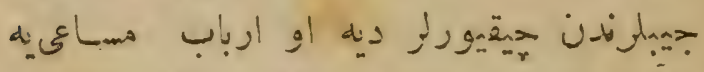

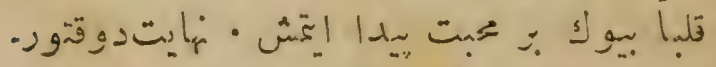

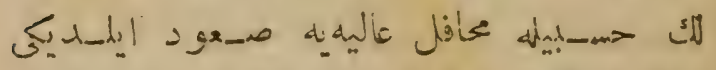

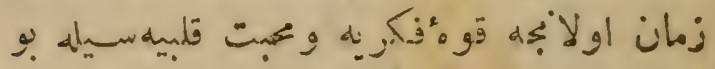

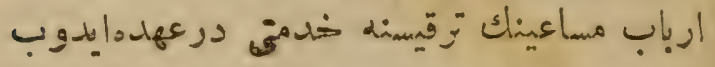

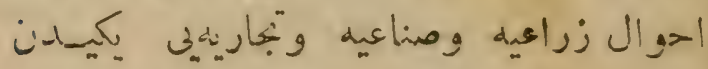

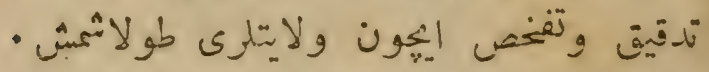

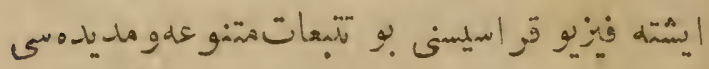

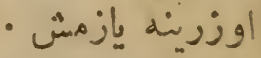

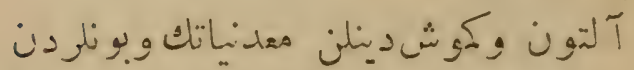

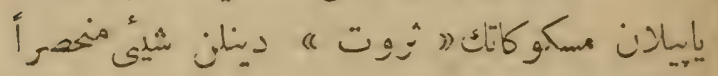

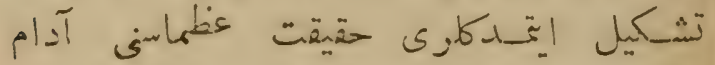

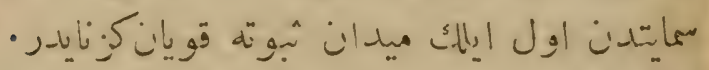

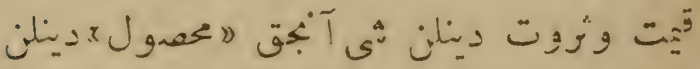

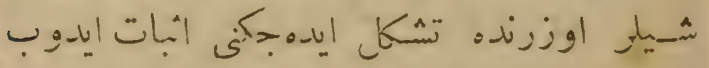

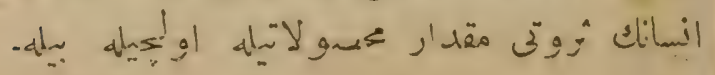




\section{$-1 \mathrm{~V} 7-$}

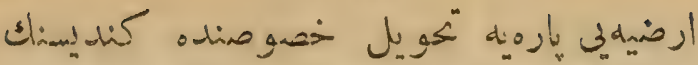

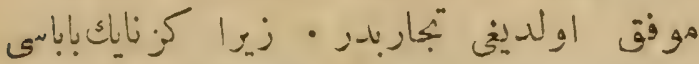

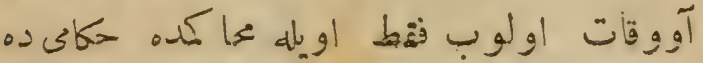

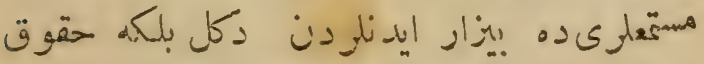

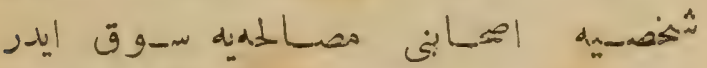

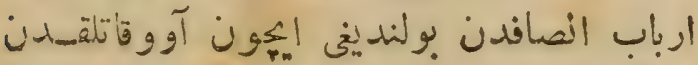

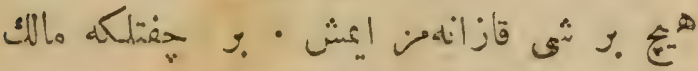

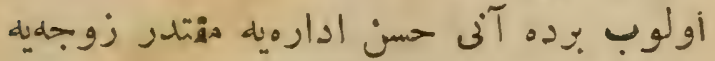

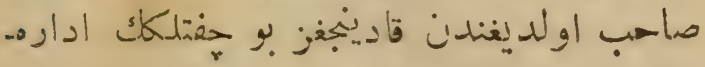

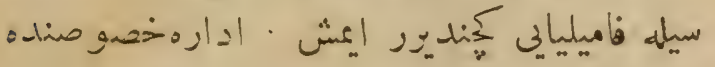

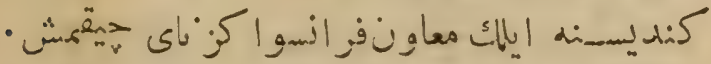

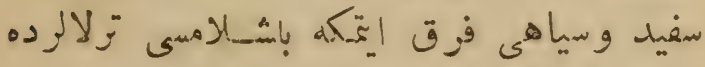

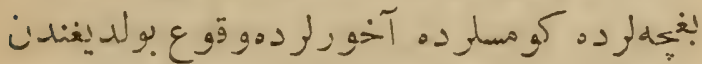

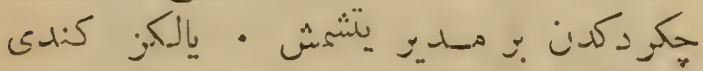

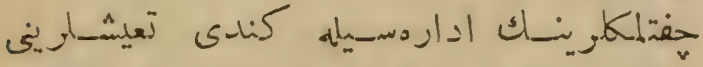

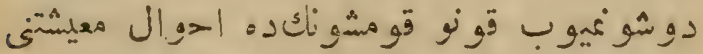

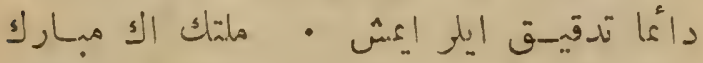

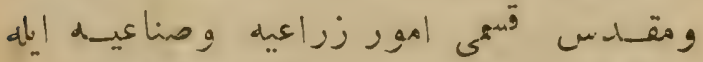

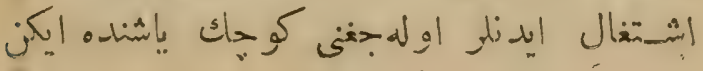




\section{$-1 V_{0}$}

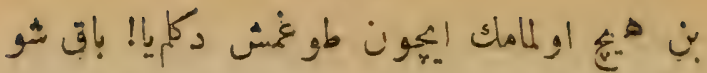

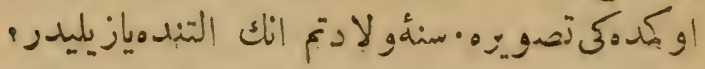

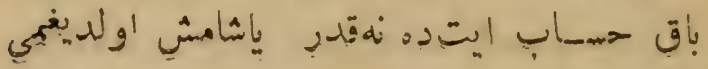
! 1

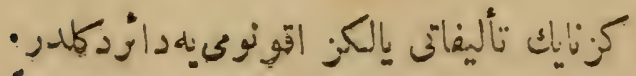

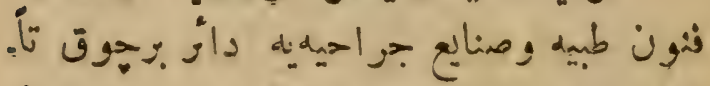

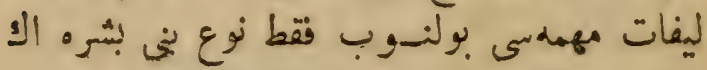

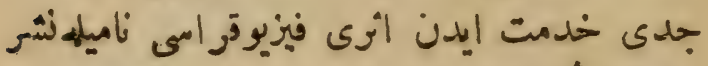

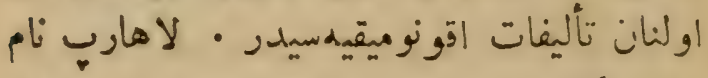

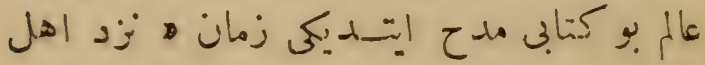

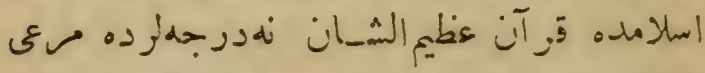

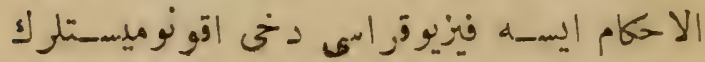

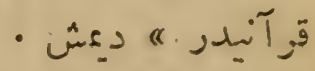

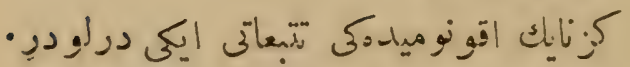

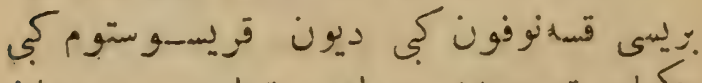

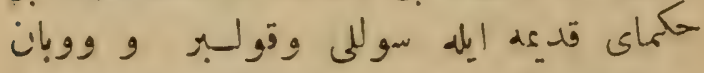

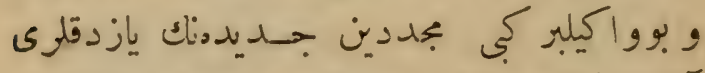

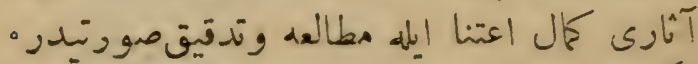

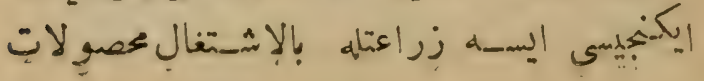




\section{$-1 V \varepsilon-$}

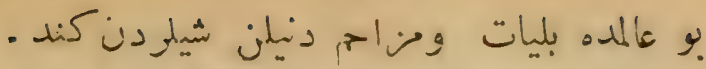

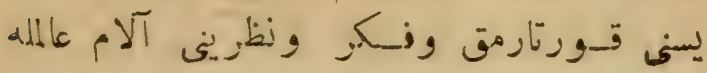

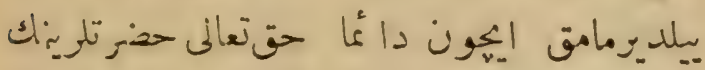

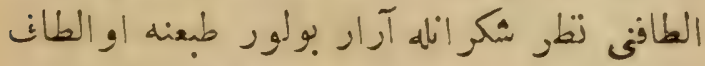

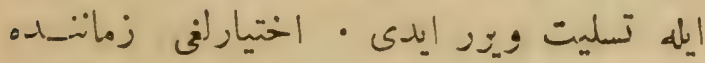

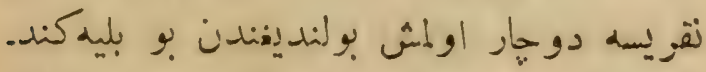

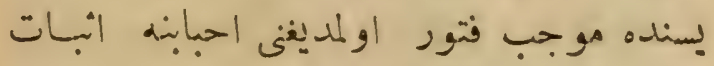

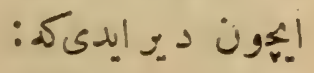

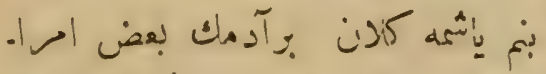

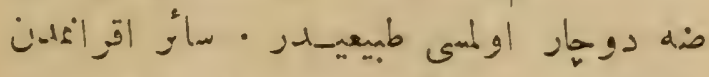

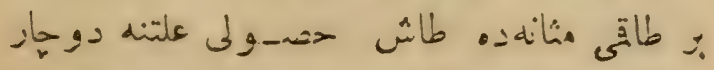

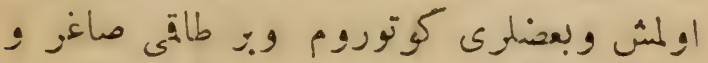

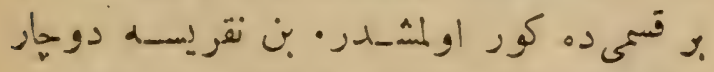

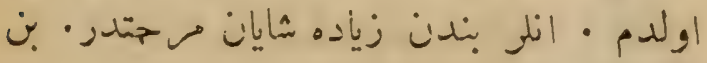

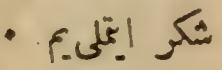

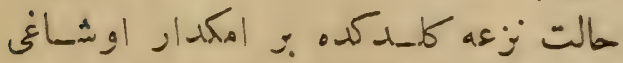

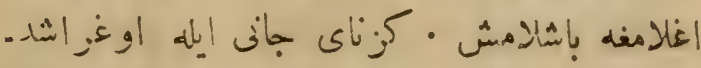

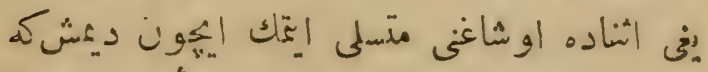

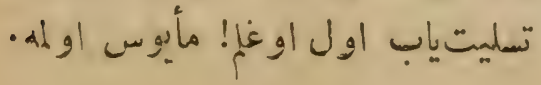




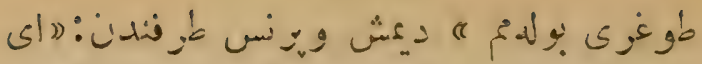

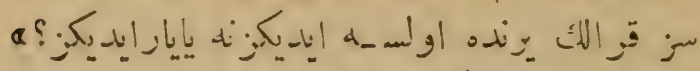

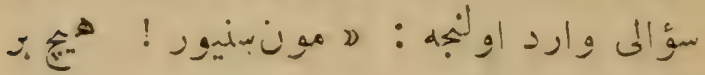

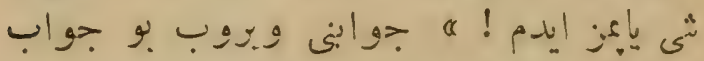

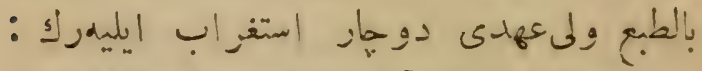

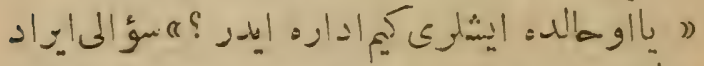

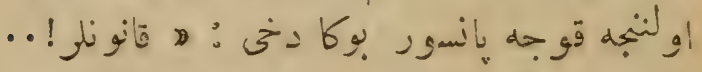
• ج....

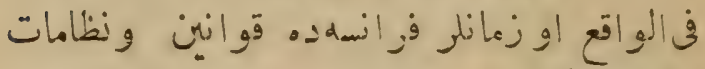

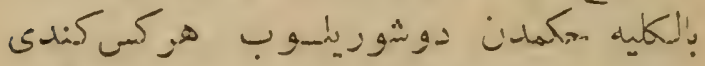

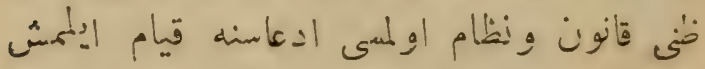

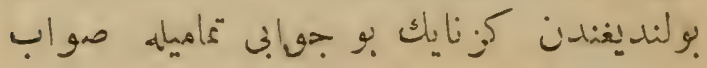
- إن

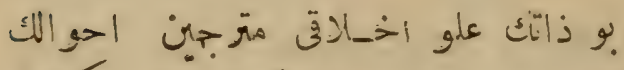

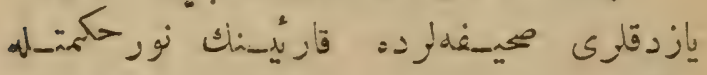

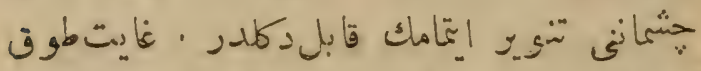

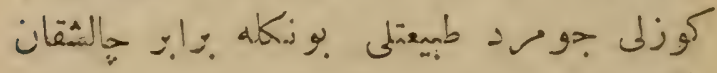

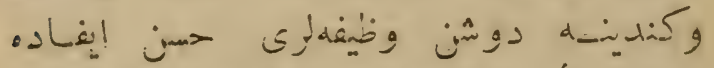

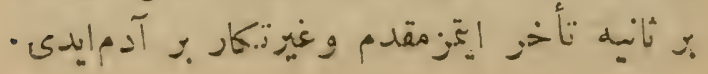




\section{$-1 \mathrm{k}-$}

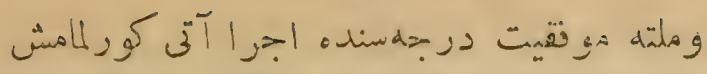

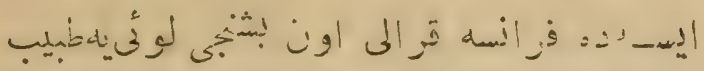

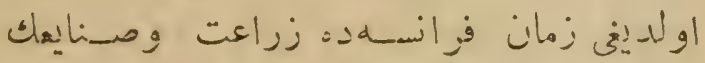

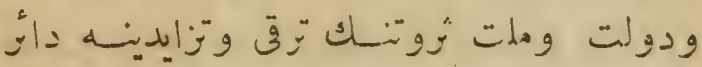

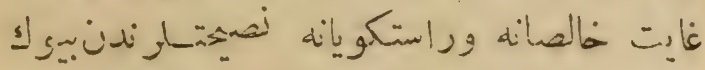

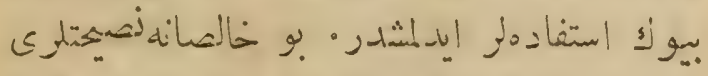

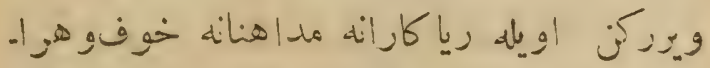

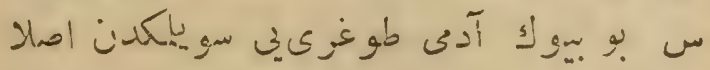

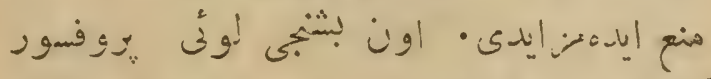

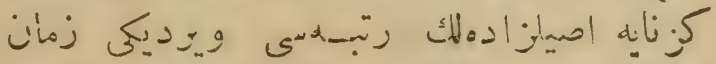

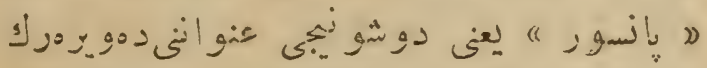

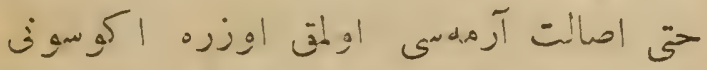

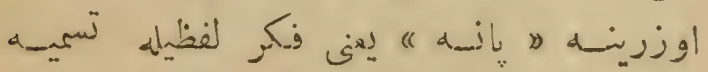

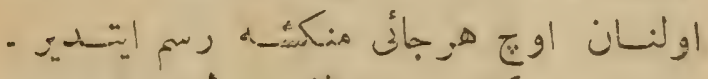

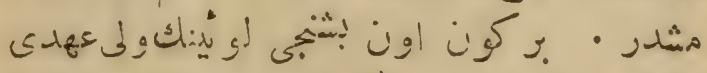

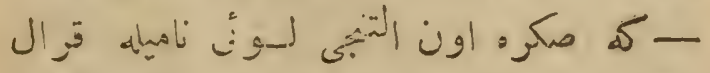

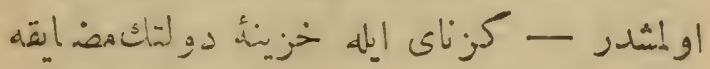

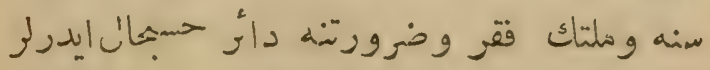

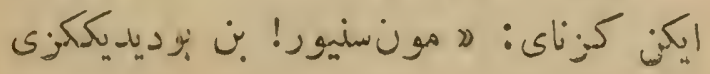




\section{- IVI-}

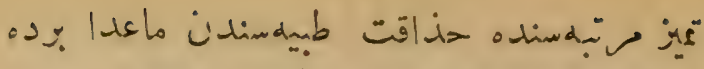

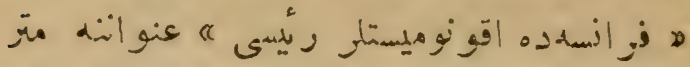

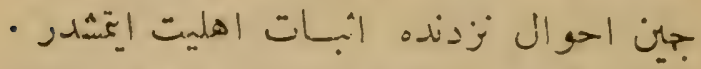

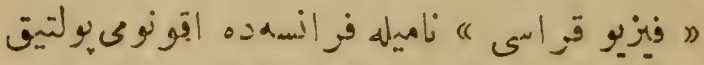

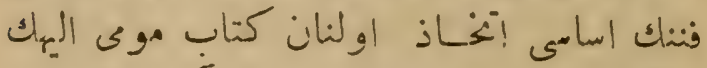

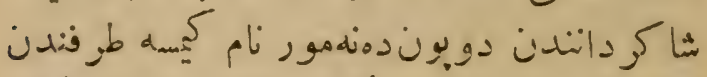

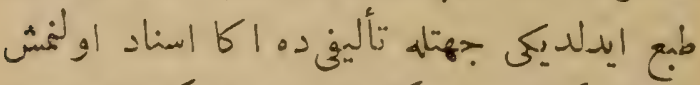

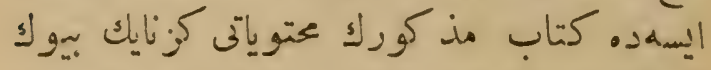

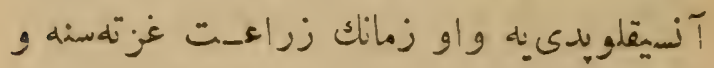

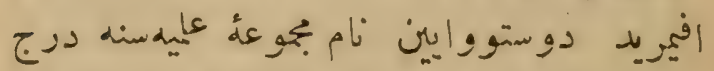

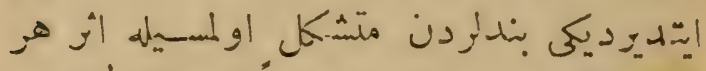

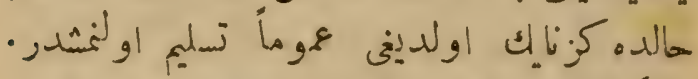

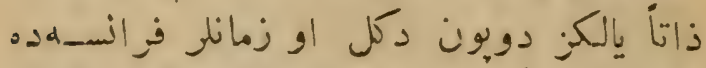

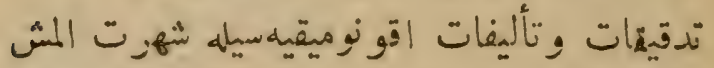

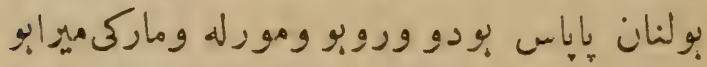

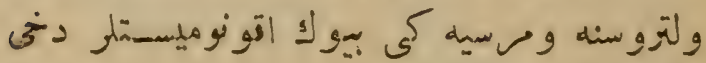

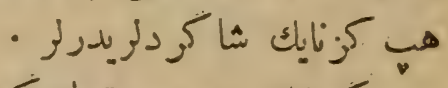

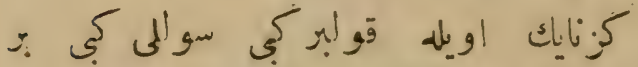

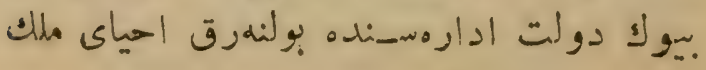




\section{$-I V:-$}

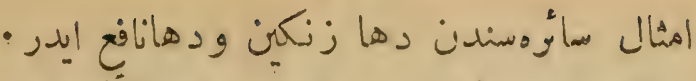

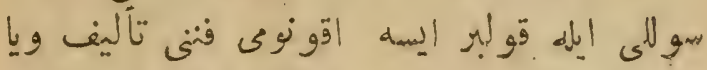

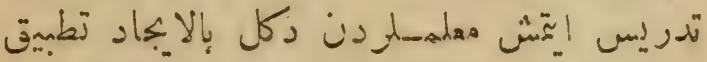

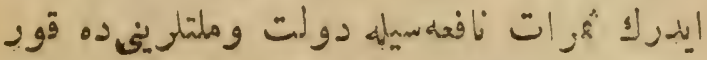

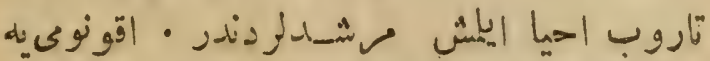

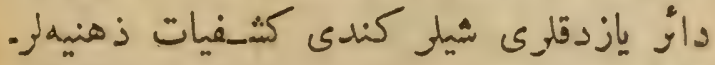

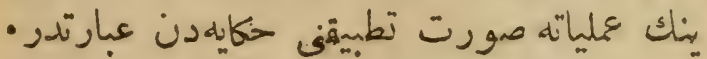

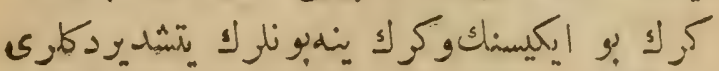

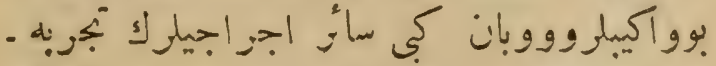

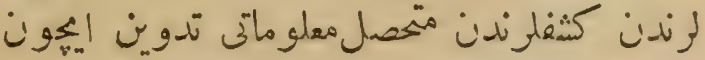

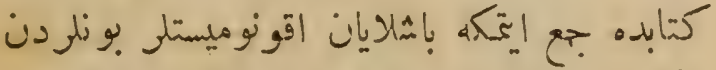

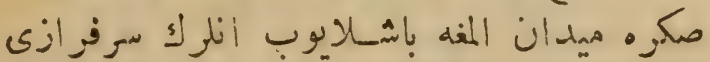

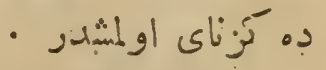

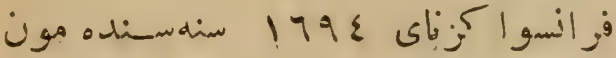

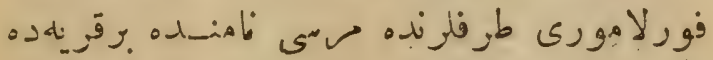

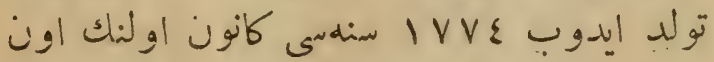

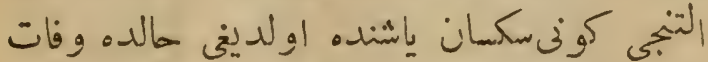

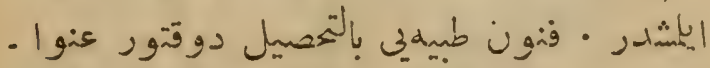

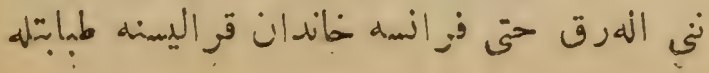




\section{$-199-$}

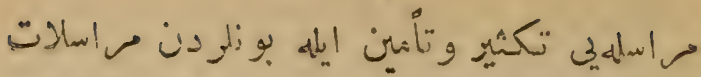

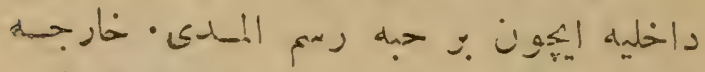

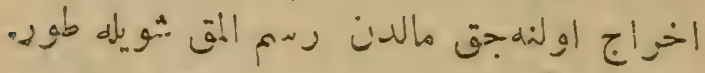

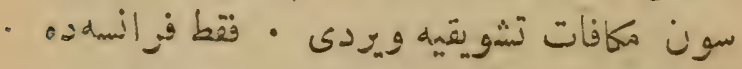

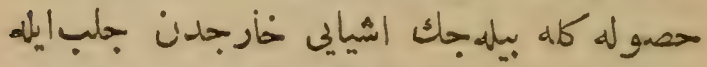

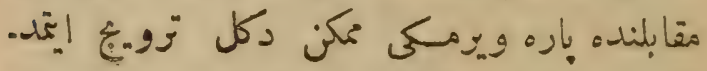

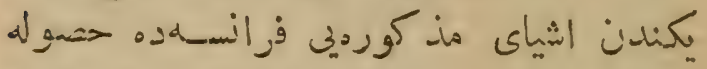

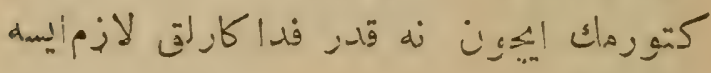

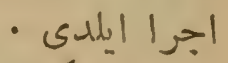

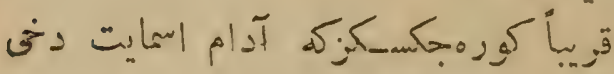

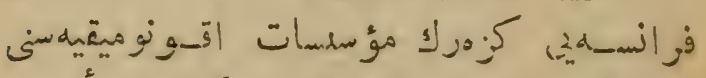

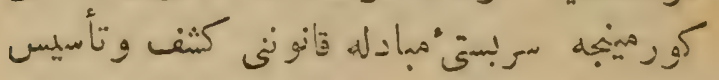

- ايدمدى

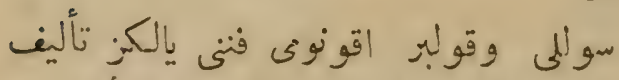

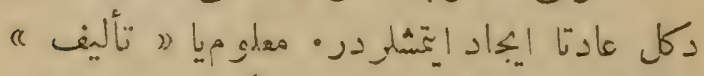

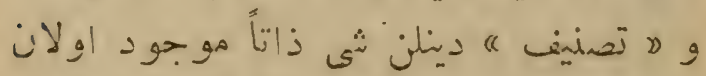

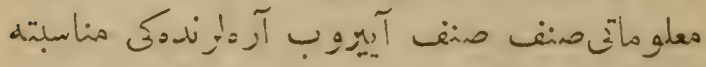

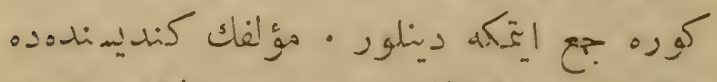

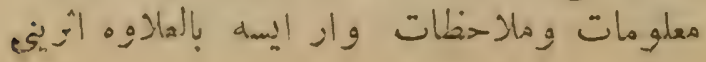


$-191-$

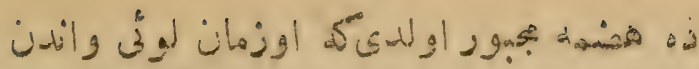

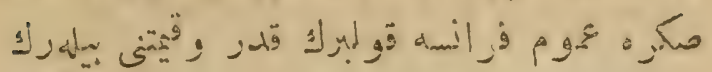

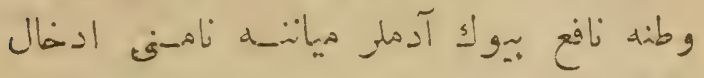
إبلديلر

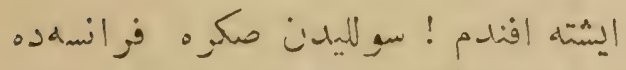

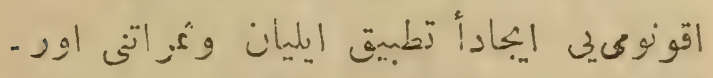

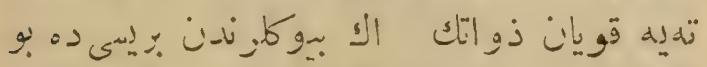

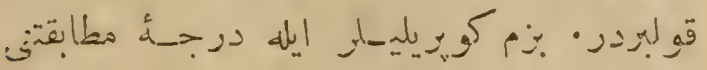

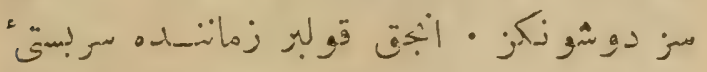

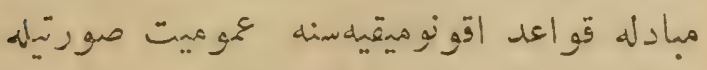

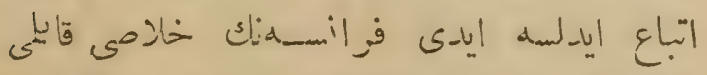

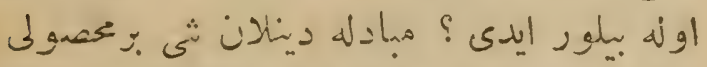

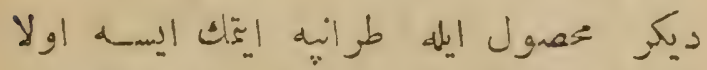

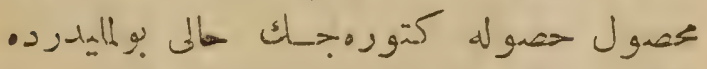

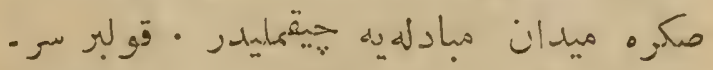

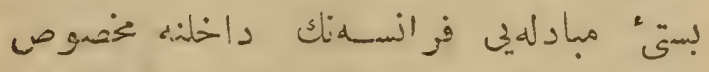

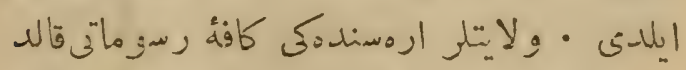

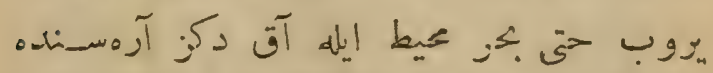

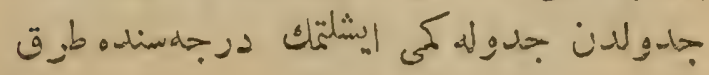


ميليون ليورا قزانديومشيدر ه جوابنى ويزبهد

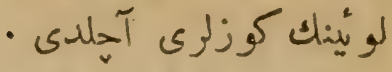

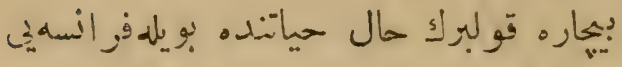

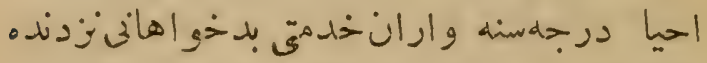

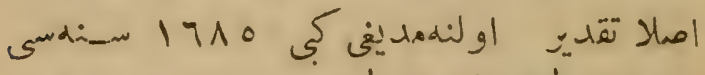

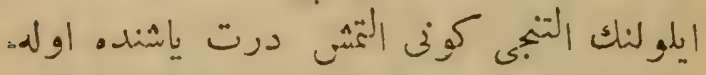

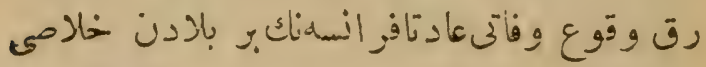

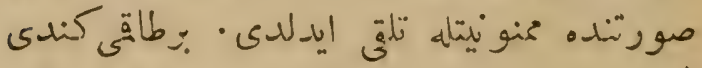

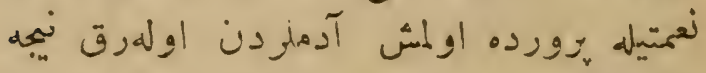

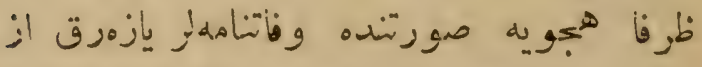

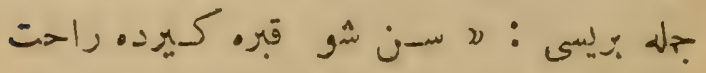

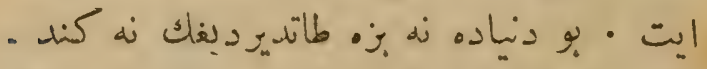

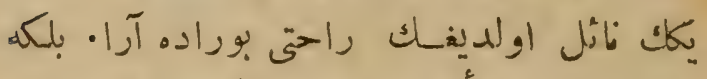

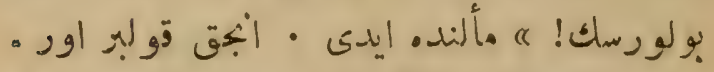

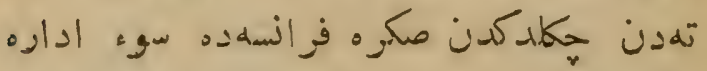

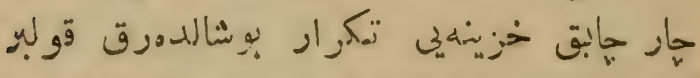

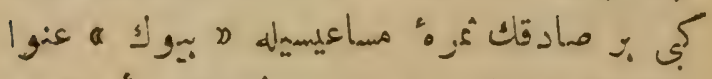

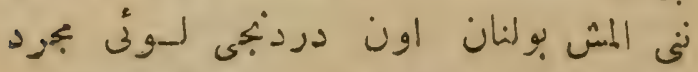

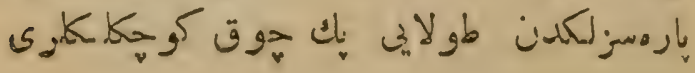




\section{$-177-$}

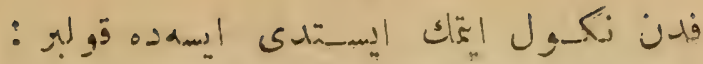

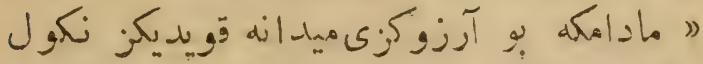

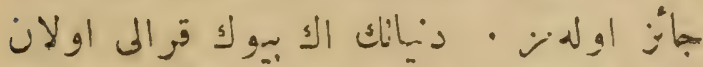

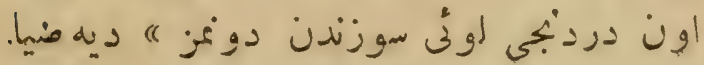

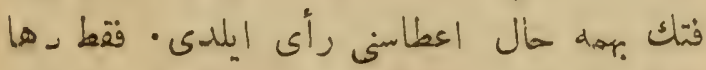

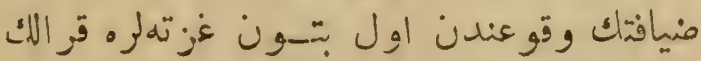

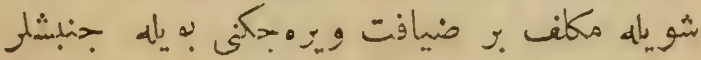

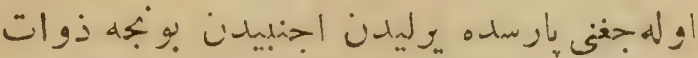

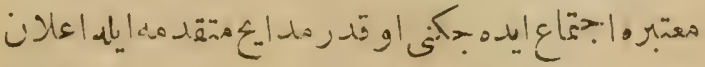

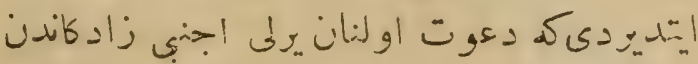

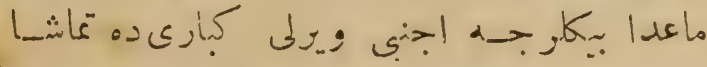

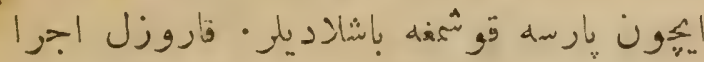

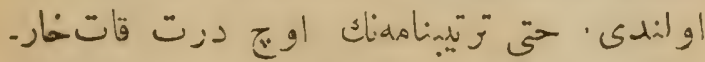

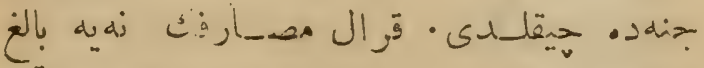

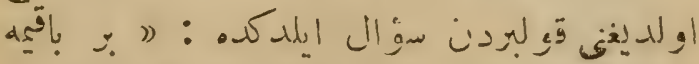

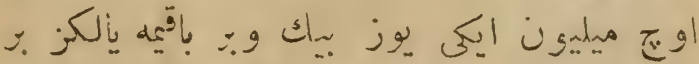

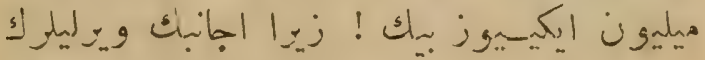

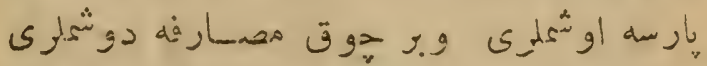

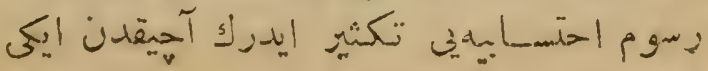




\section{$-190-$}

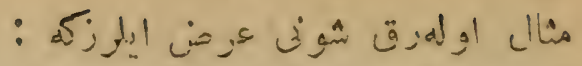

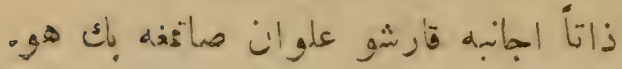

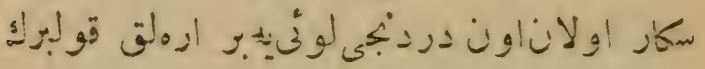

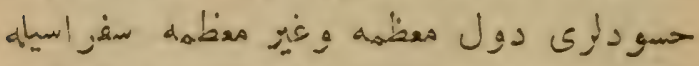

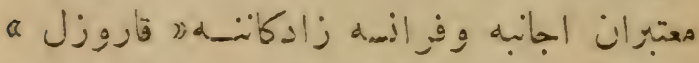

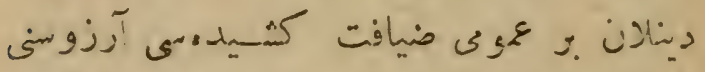

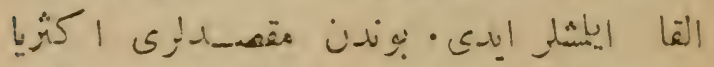

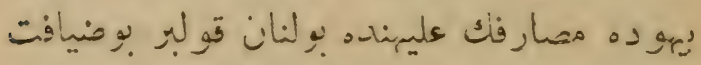

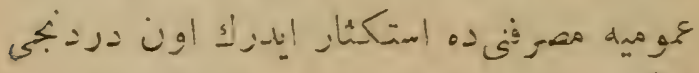

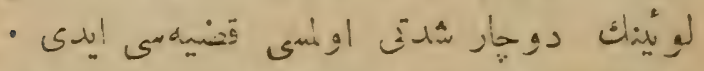

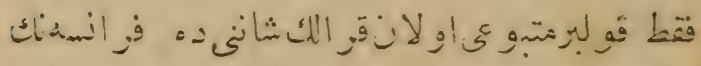

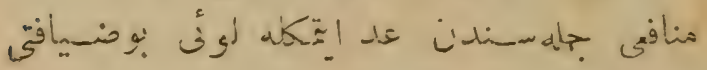

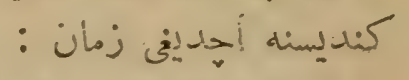

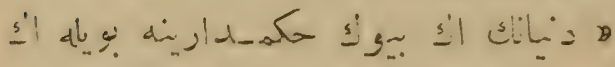

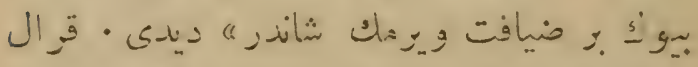

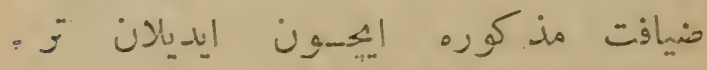

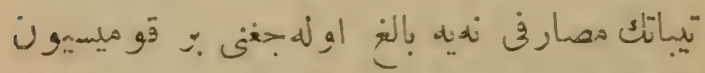

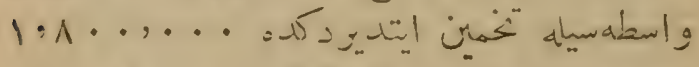

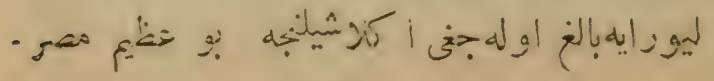


$-17 \varepsilon-$

-

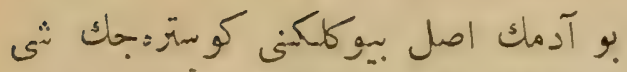

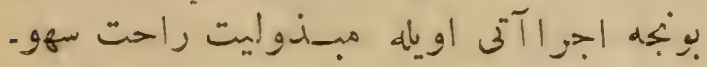

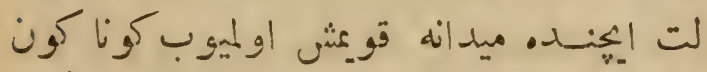

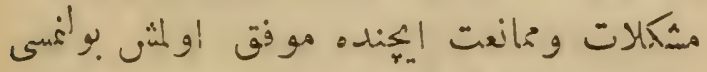

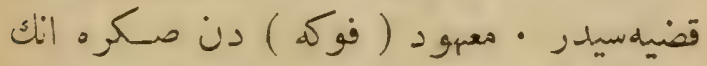

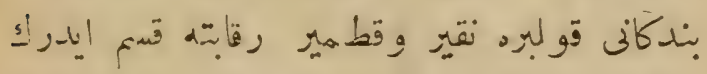

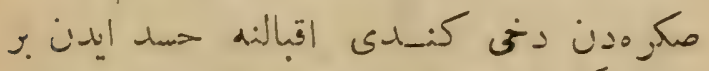

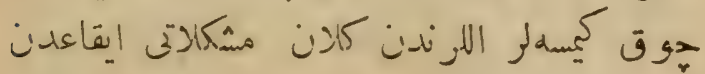

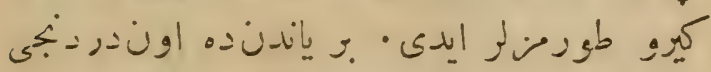

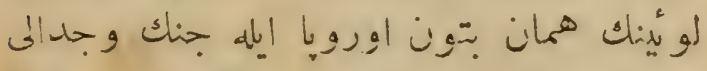

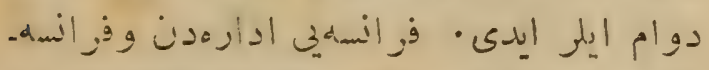

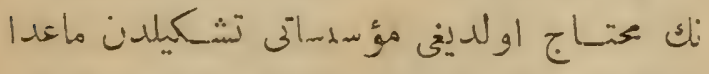

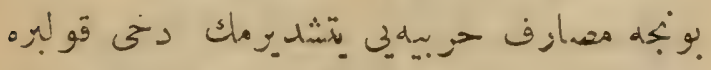

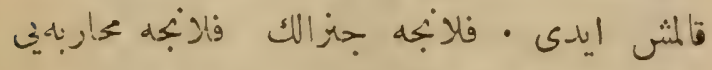

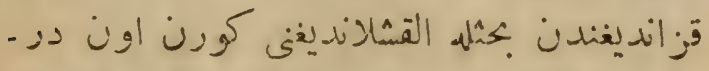

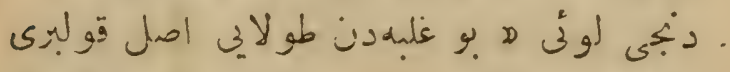

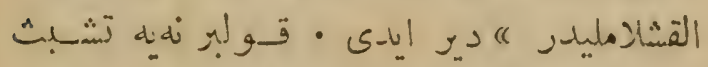

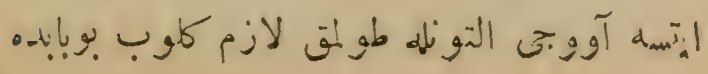




\section{$-17 \mu$}

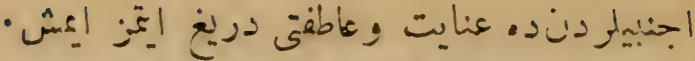

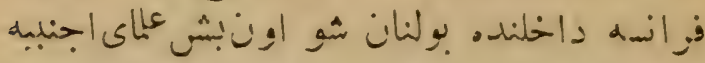

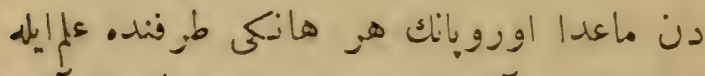

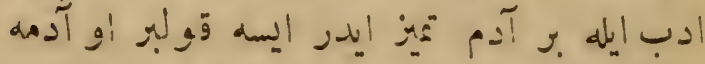

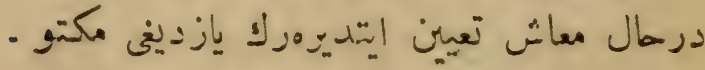

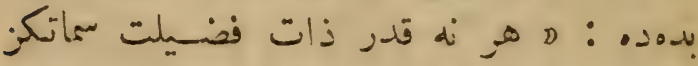

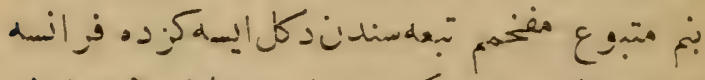

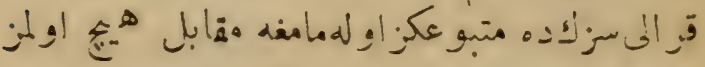

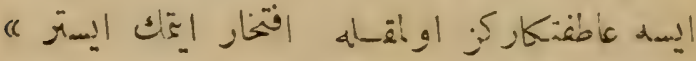

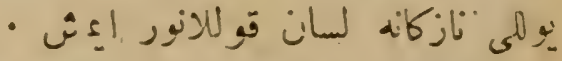

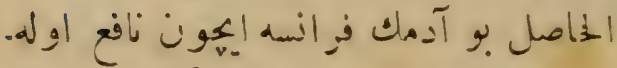

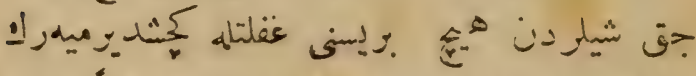

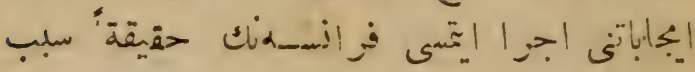

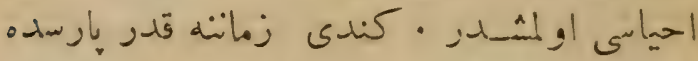

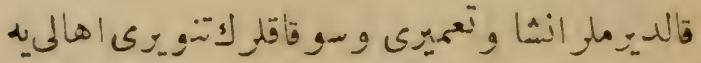

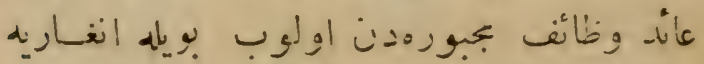

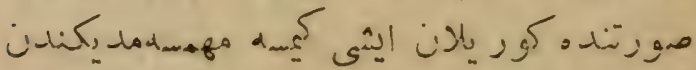

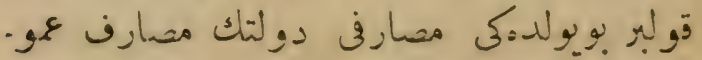

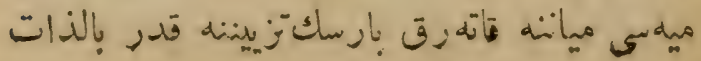




\section{$-194-$}

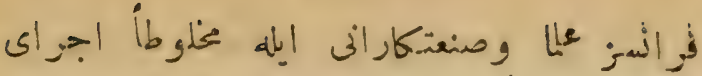

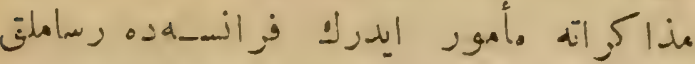

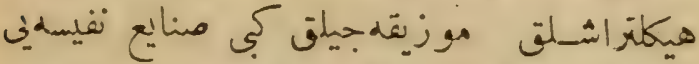

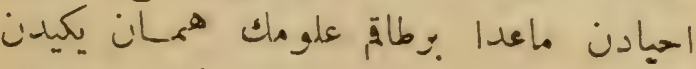

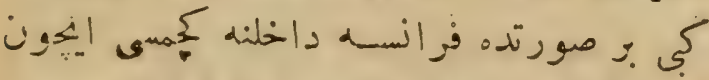

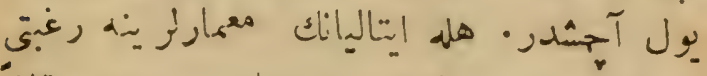

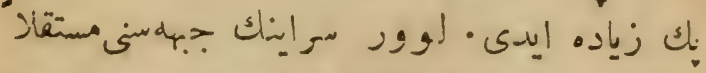

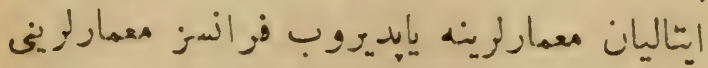

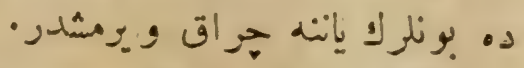

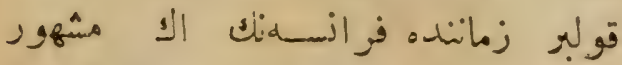

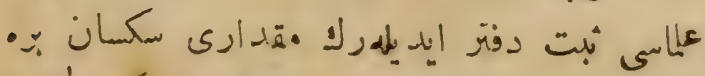

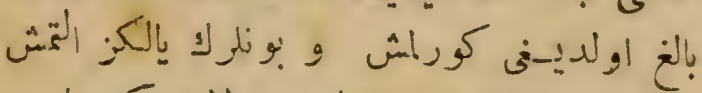

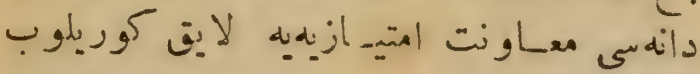

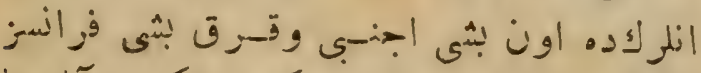

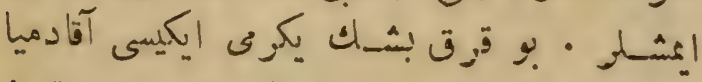

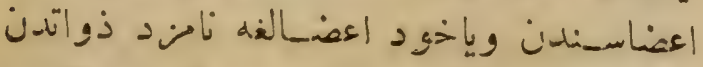
اولوب باقيسى كندى بأشلرينه جلإليشور علمادن

ارباب فضيتلـدن اولدقدن مـكمه قولبر

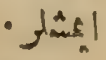




\section{$-17 i-$}

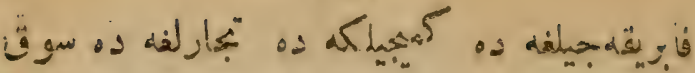

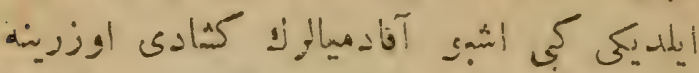

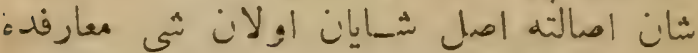

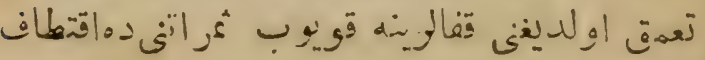

آقالدميا كتخانه سنى وجوده كتورمكه اول

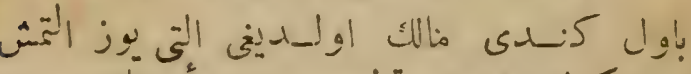

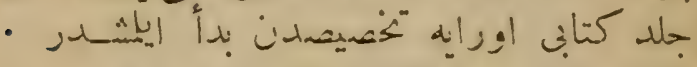

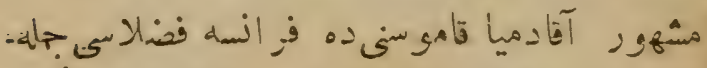

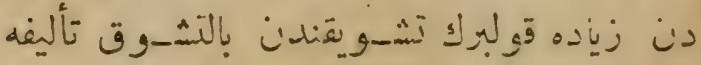

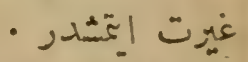

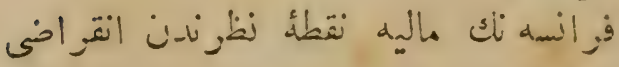

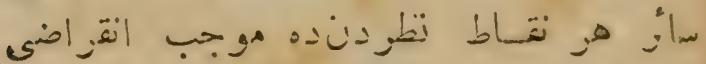

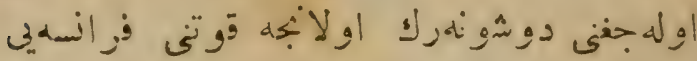

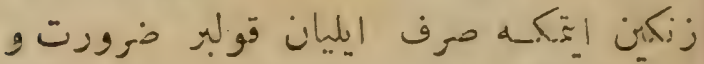

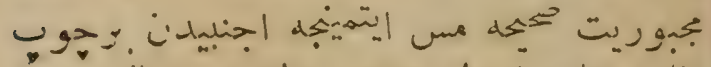

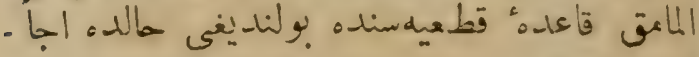

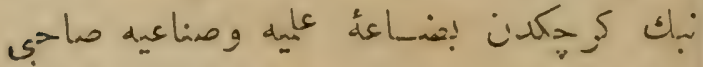

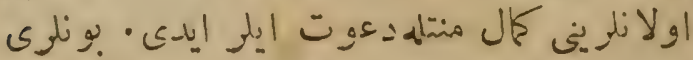


$-19:-$

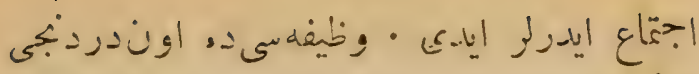

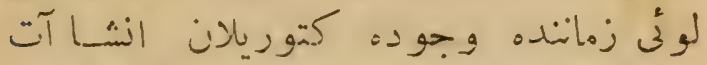

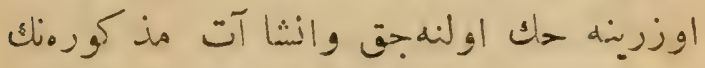

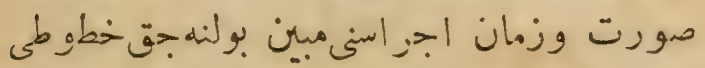

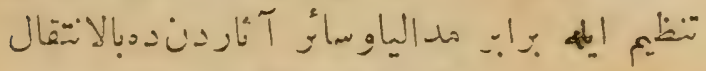

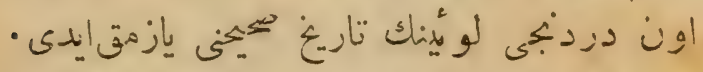
المرل 1797

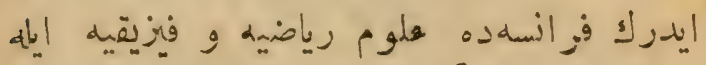

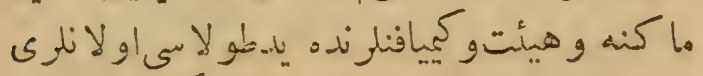

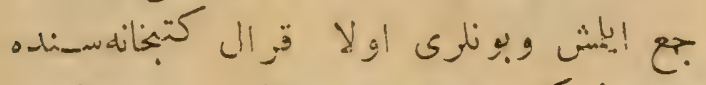

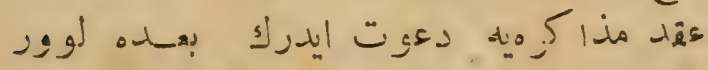

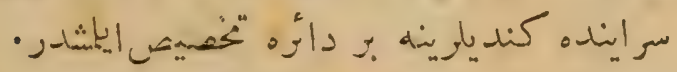

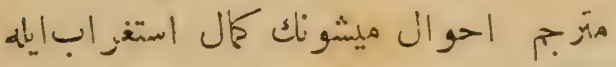

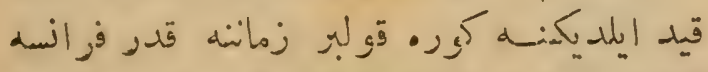

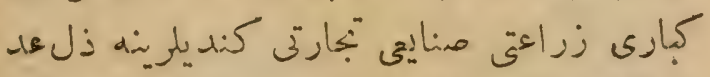

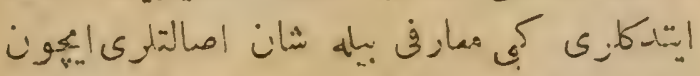

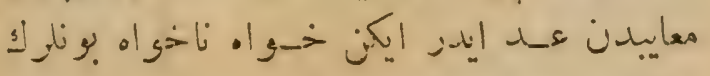

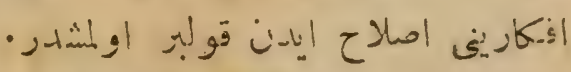

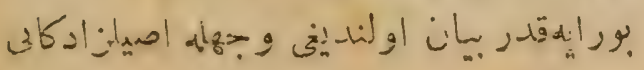




\section{$-104$}

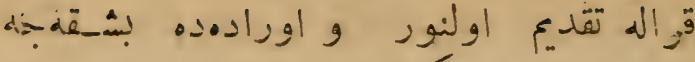

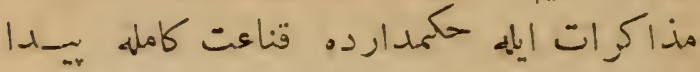

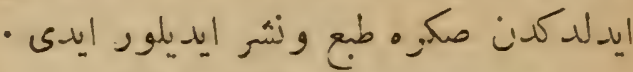

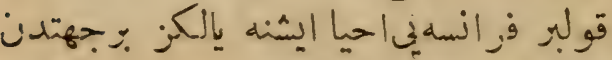

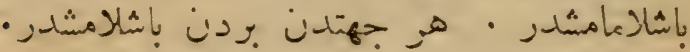

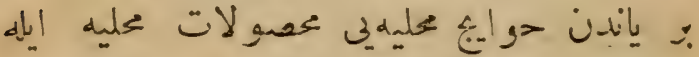

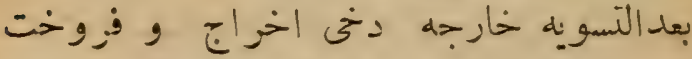

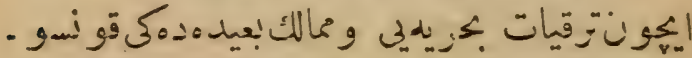

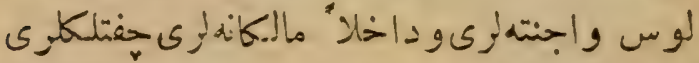

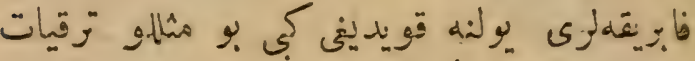

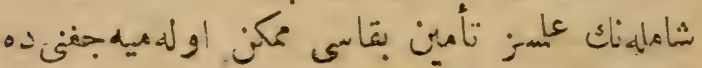

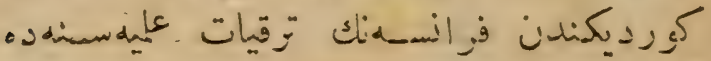

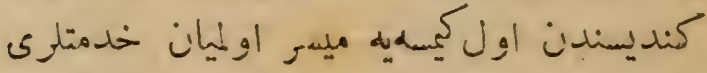

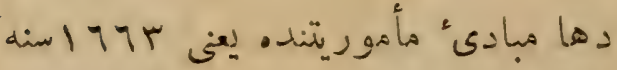

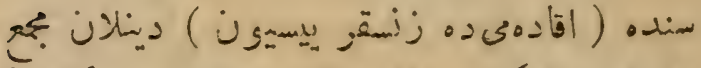

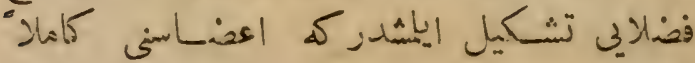

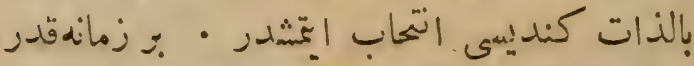

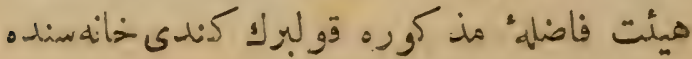


$-101-$

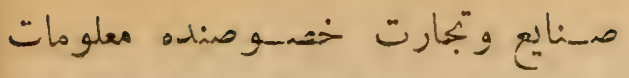

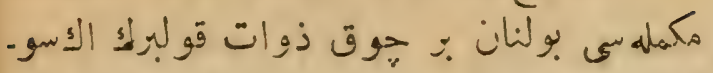

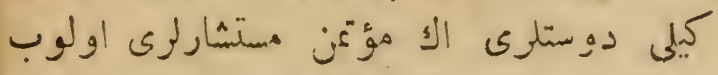

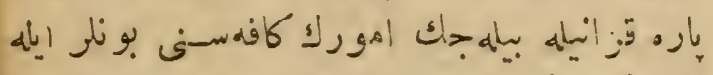

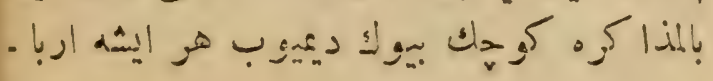

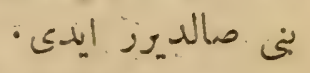

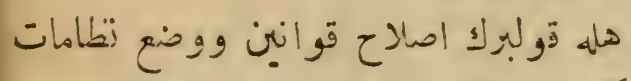

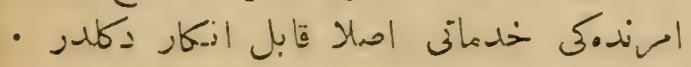

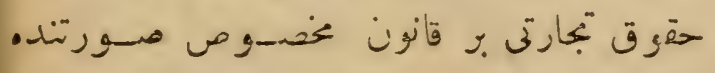

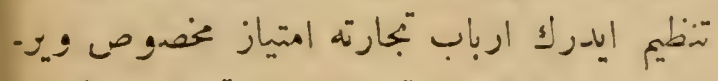

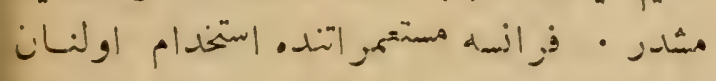

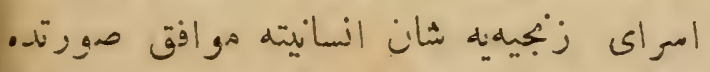

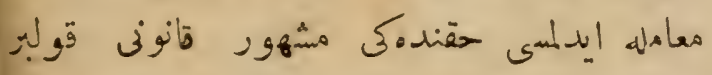

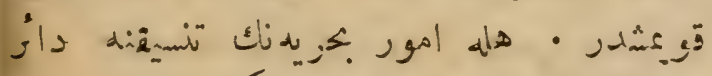

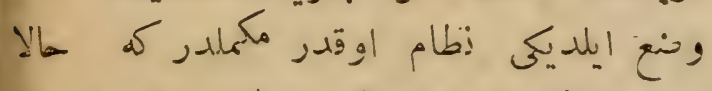

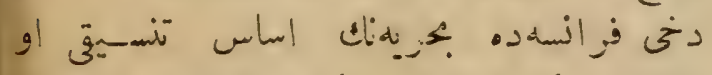

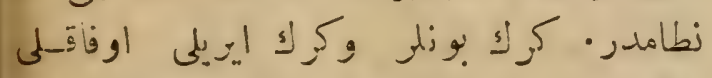

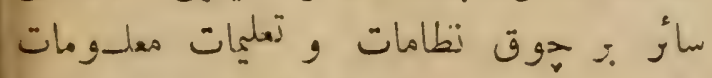

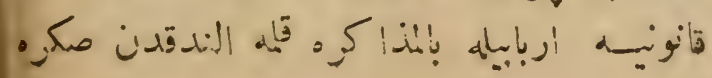




\section{$-10 \mathrm{~V}--$}

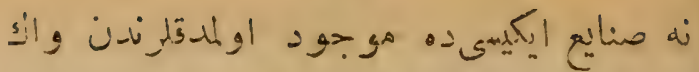

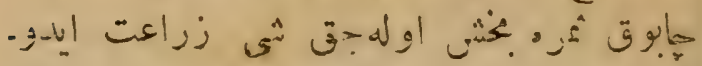

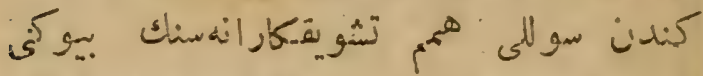

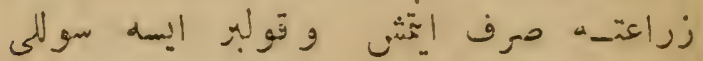

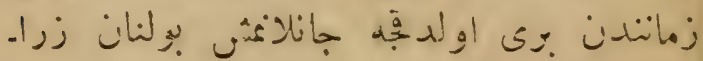

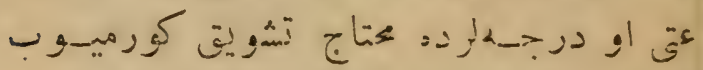

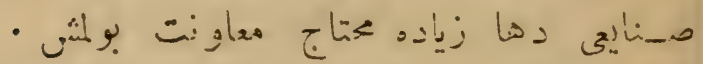

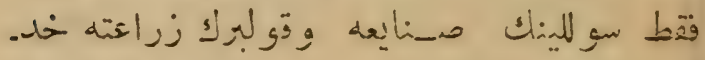

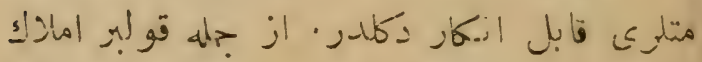

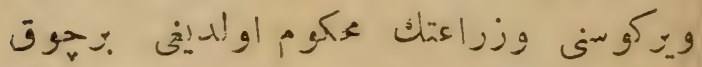

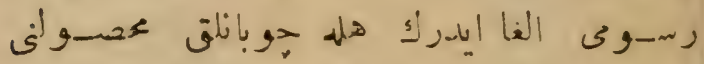

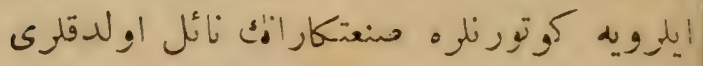

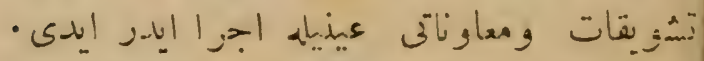

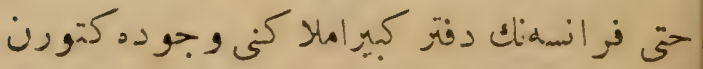

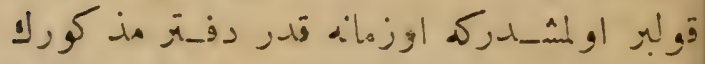

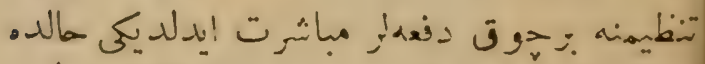

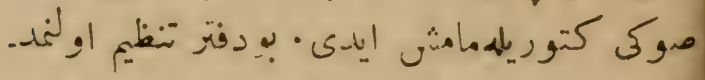

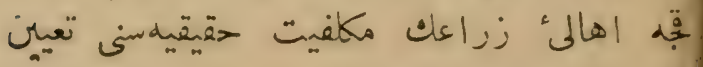
• 


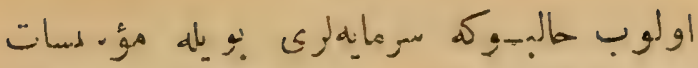

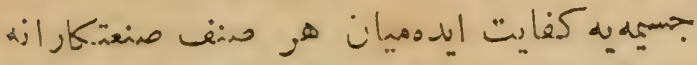

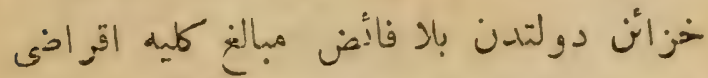

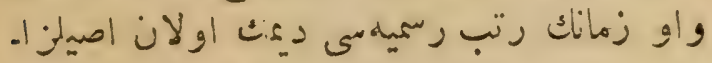

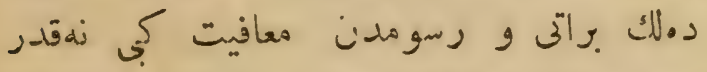

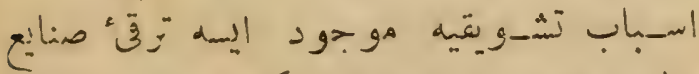

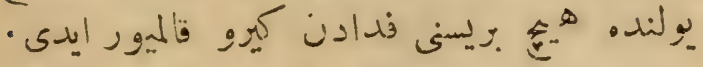

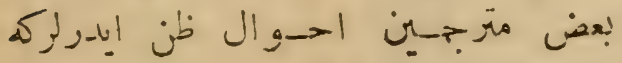

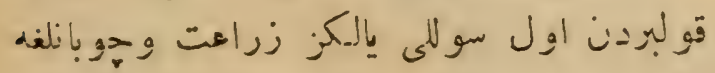

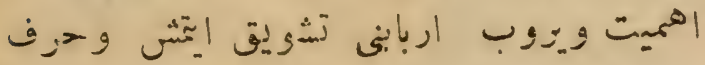

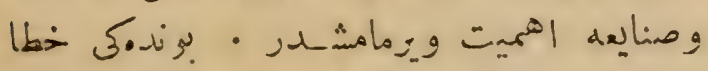

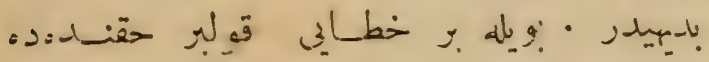

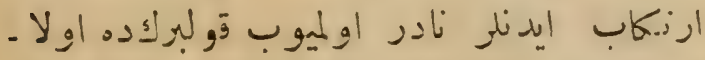

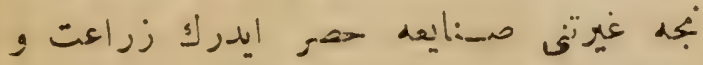

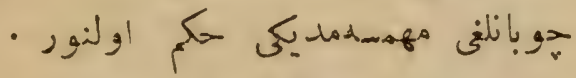

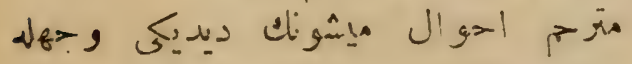

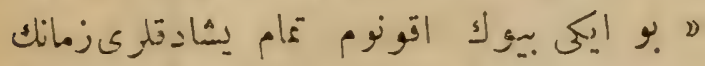

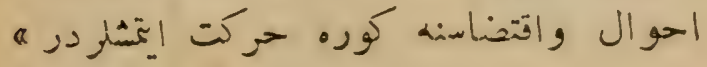

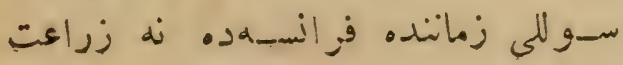




\section{$-100-$}

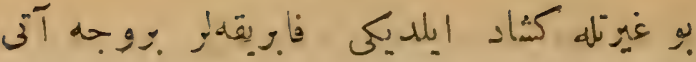

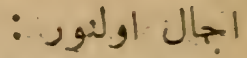

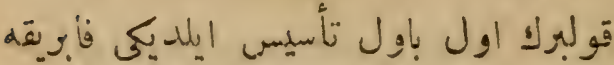

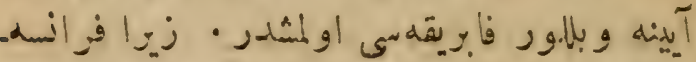

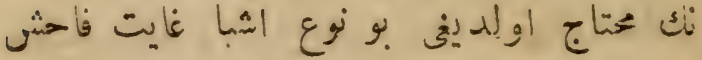

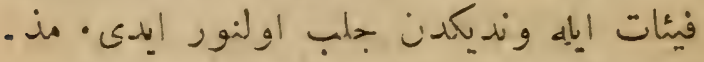

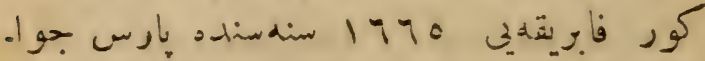

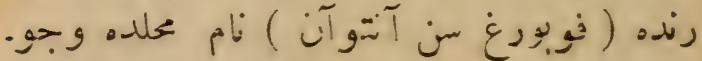

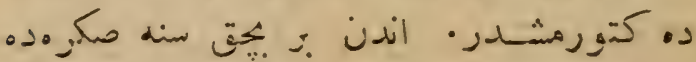

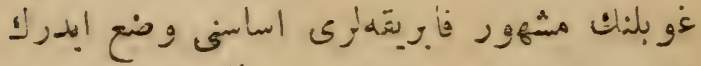

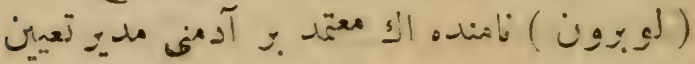

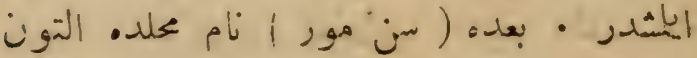

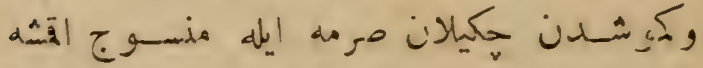

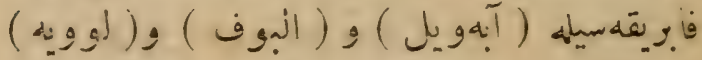

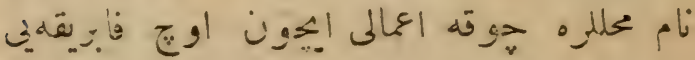
-

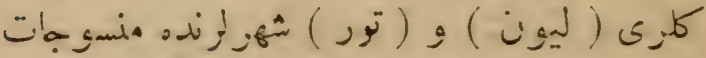

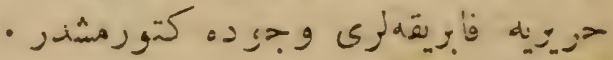

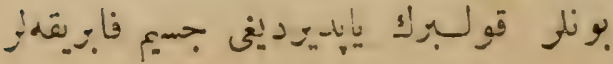




\section{- $10\{-$}

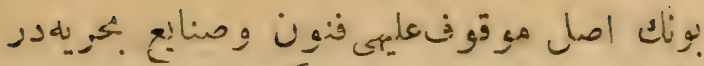

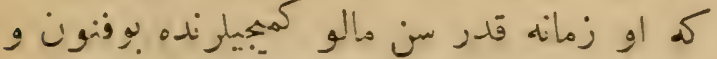

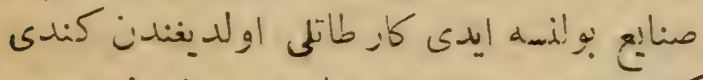

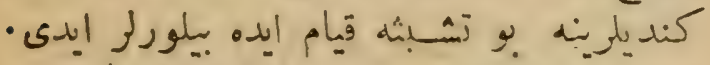

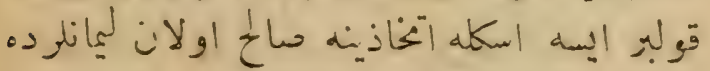

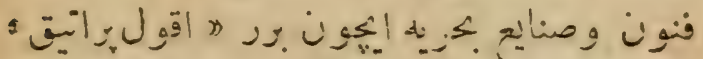

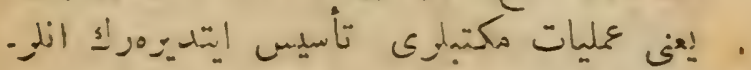

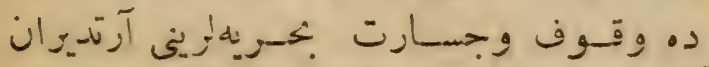

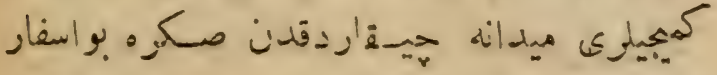

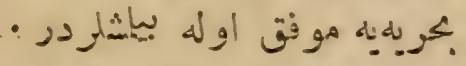

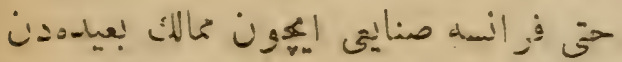

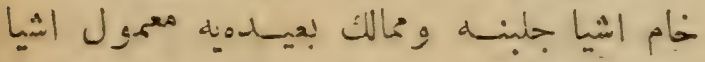

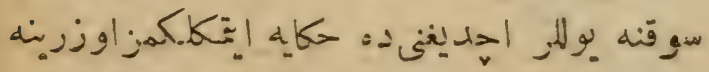

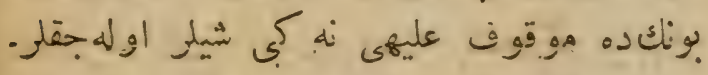

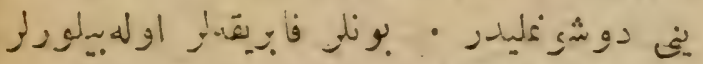

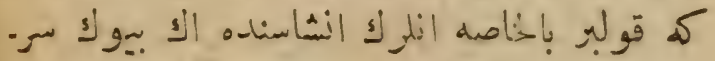

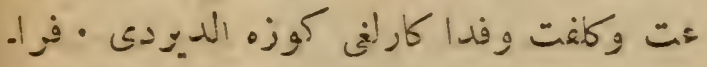

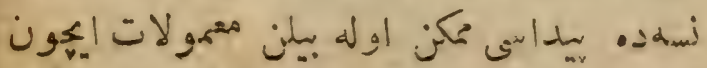

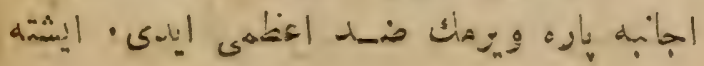




\section{- ior-}

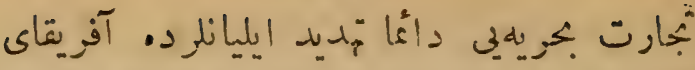

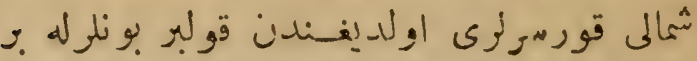

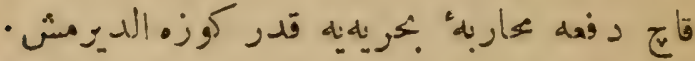

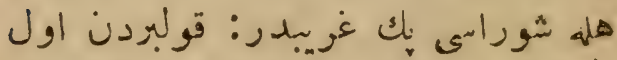

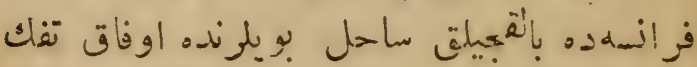

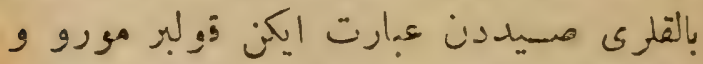

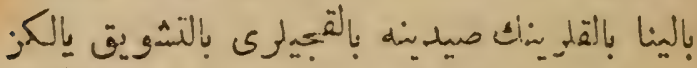

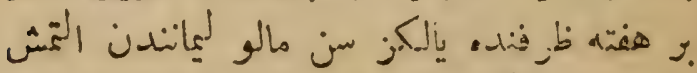

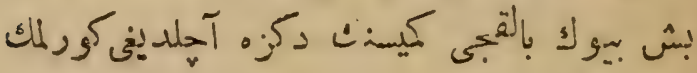

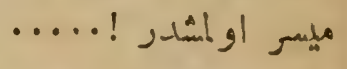

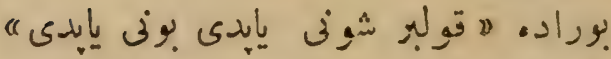

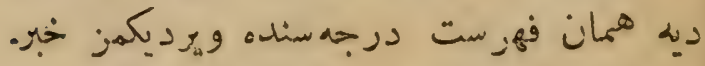

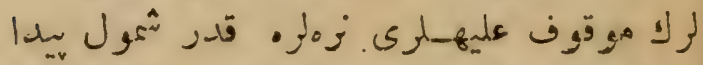

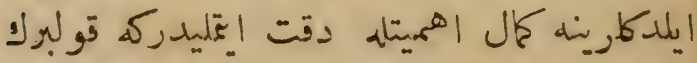

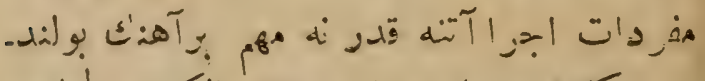

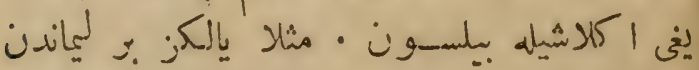

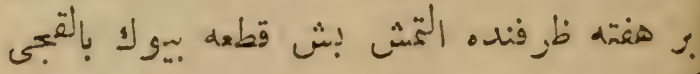

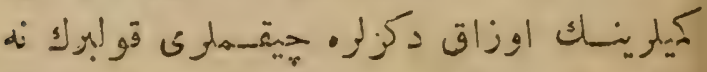

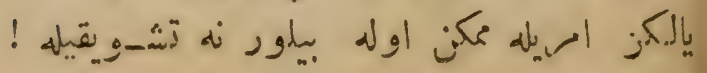




\section{$-104-$}

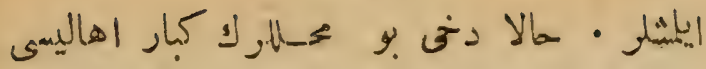

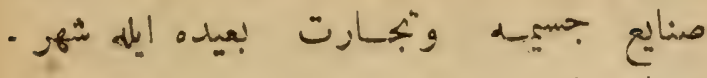

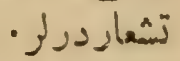

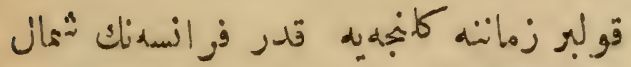

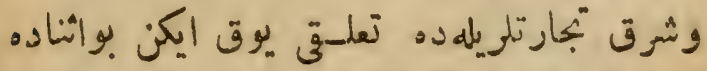

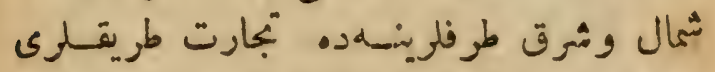

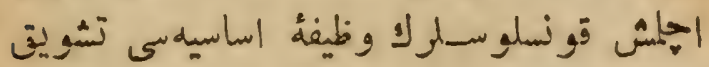

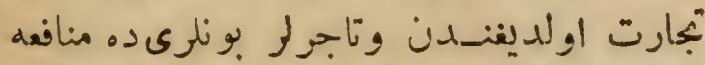

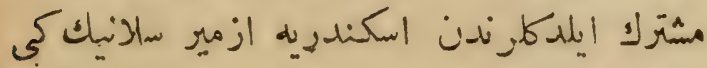

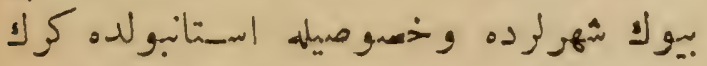

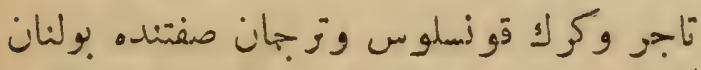

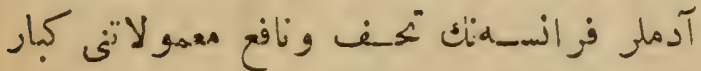

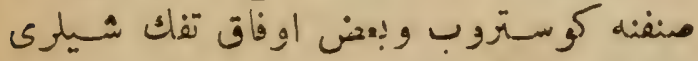

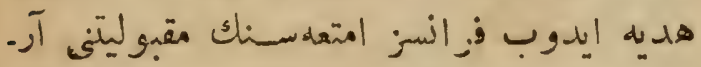

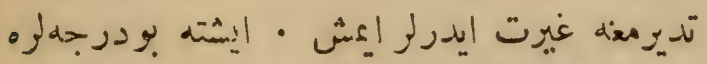

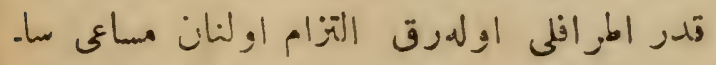

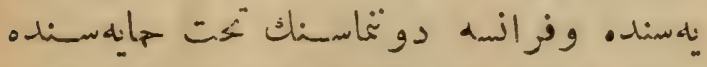

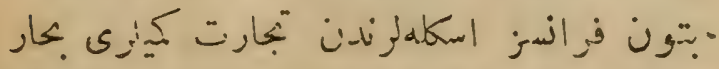

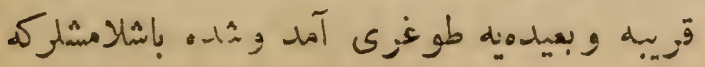




\section{$-101-$}

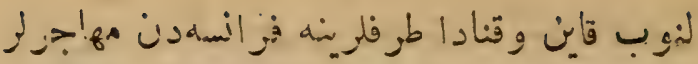

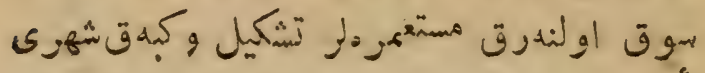

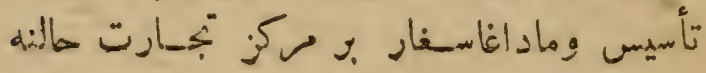

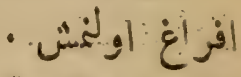

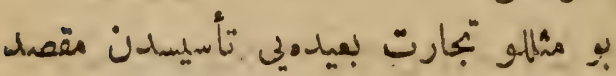

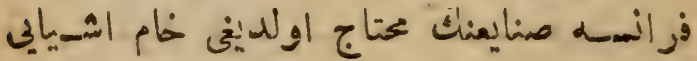

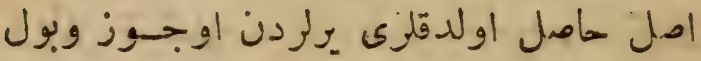

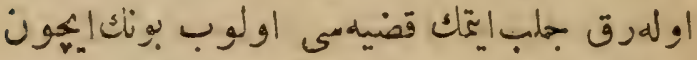

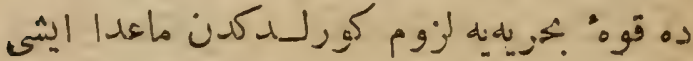

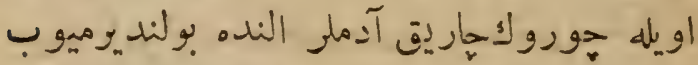

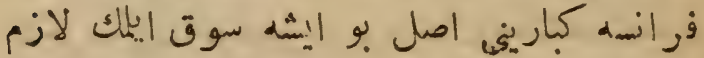

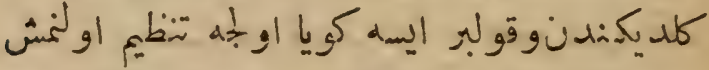

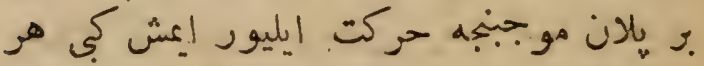

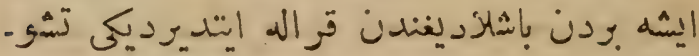

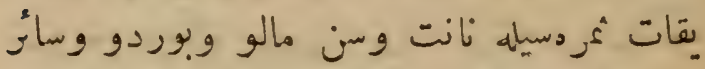

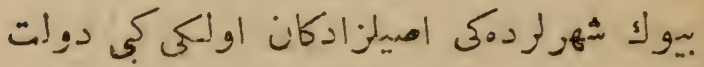

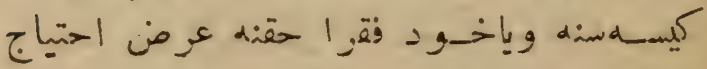

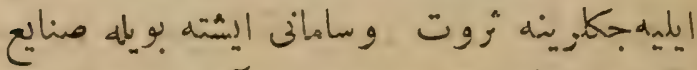

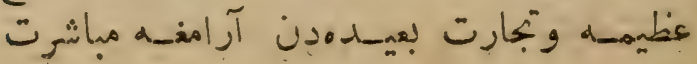




\section{$-10$}

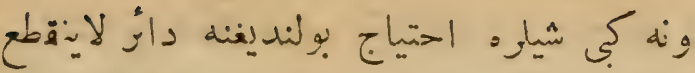

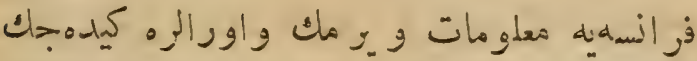

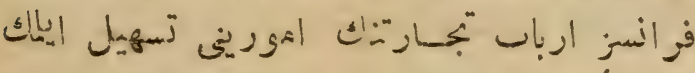

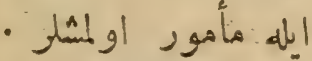

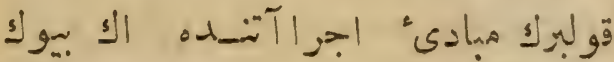

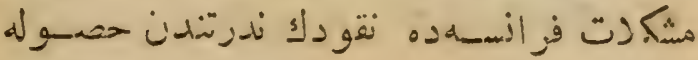

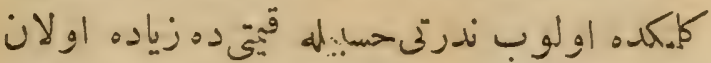

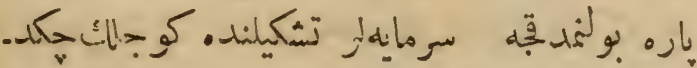

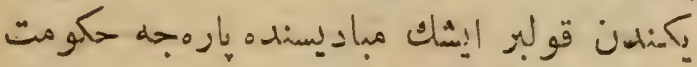

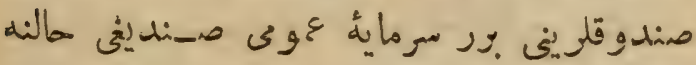

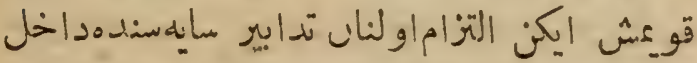

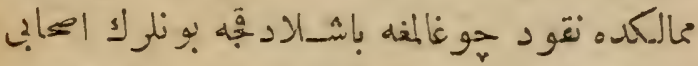

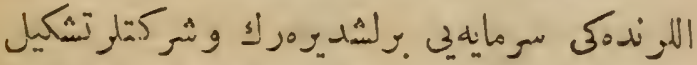

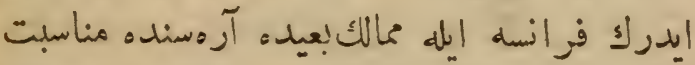

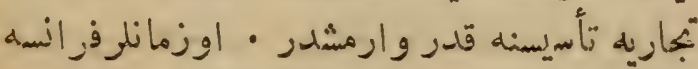

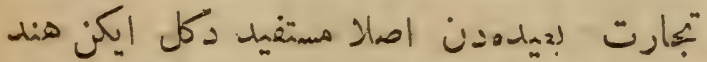

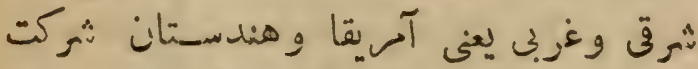

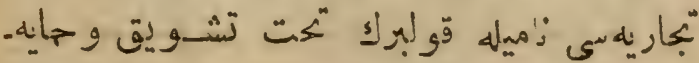

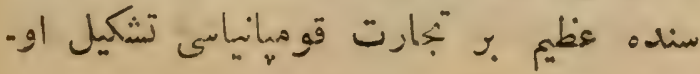




\section{$-1 \leqslant 9-$}

زراءت وصنايعه صـورت تعلق ودرجه منا :

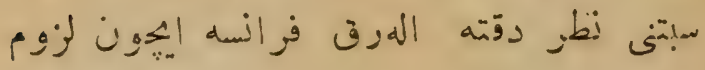

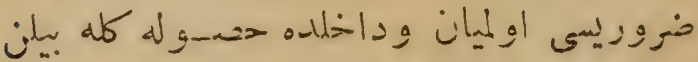

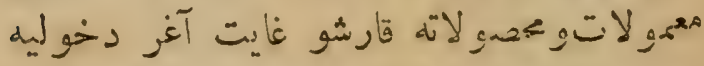

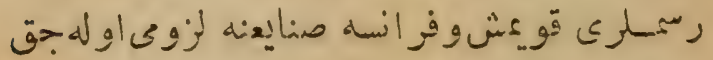

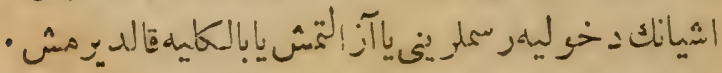

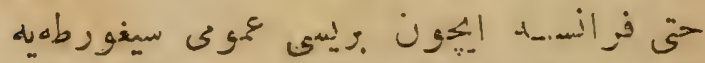

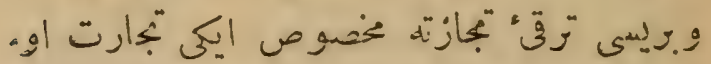

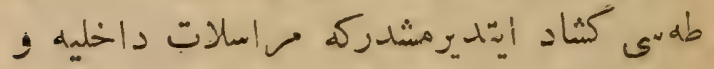

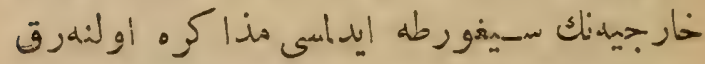

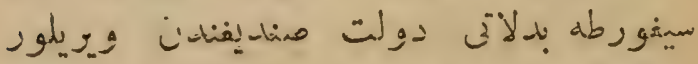

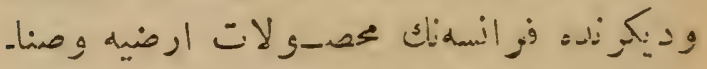

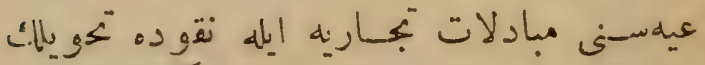

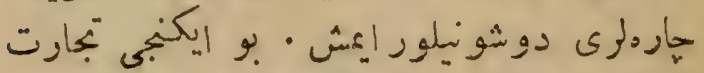

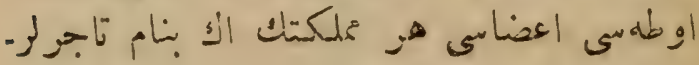

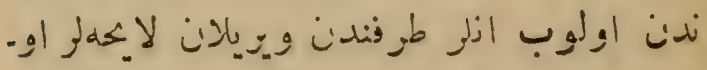

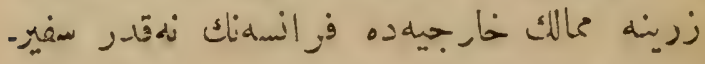

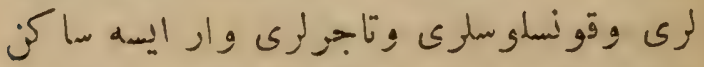

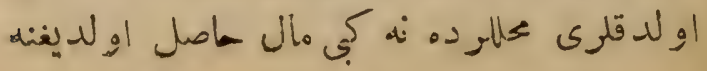




\section{$-1 \leqslant \lambda-$}

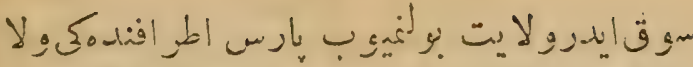

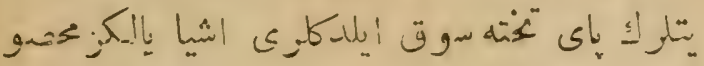

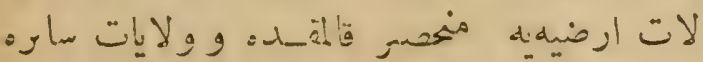

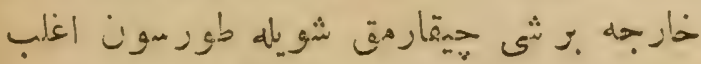

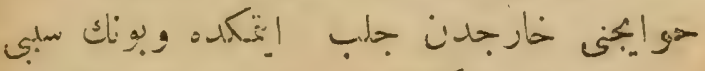

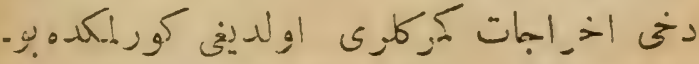

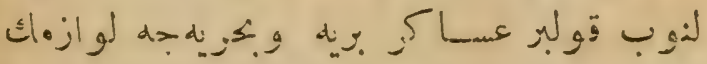

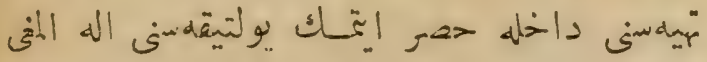

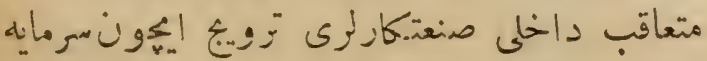

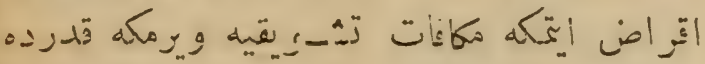

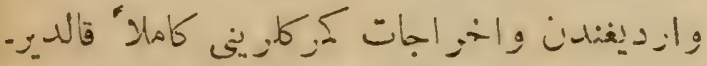

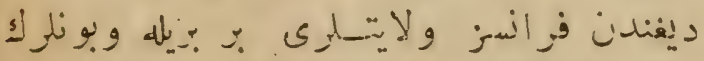

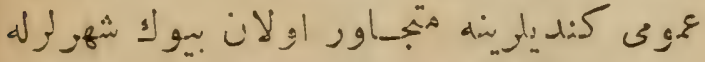

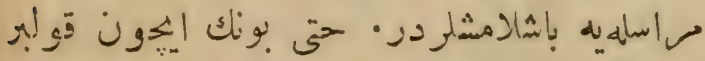

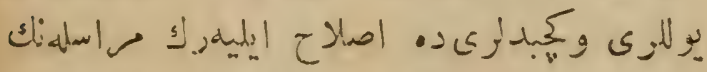

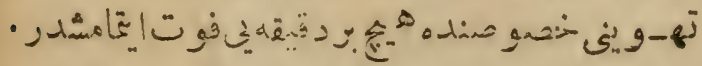

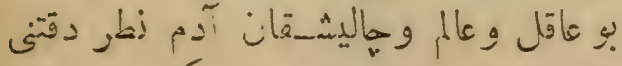

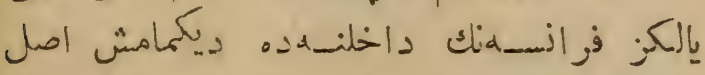

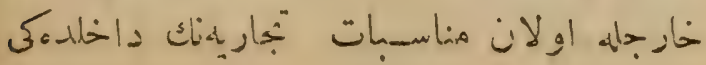


$-1 \leqslant \gamma-$

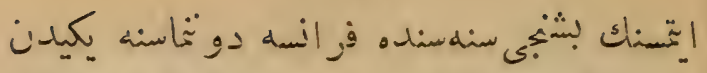

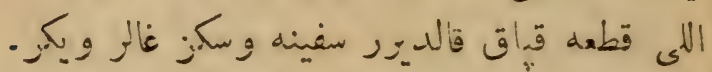

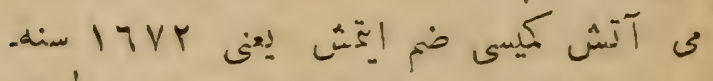

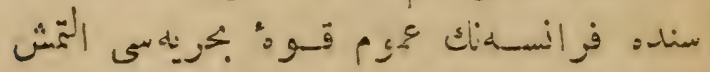

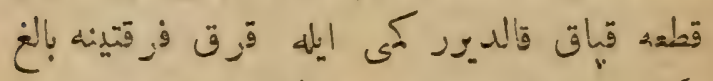

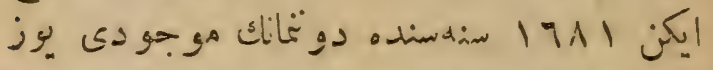

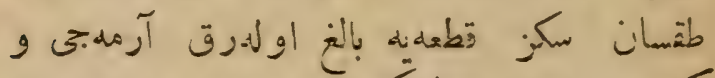

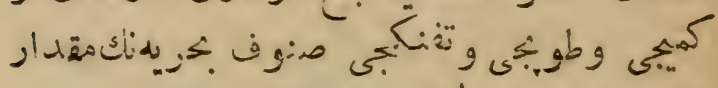

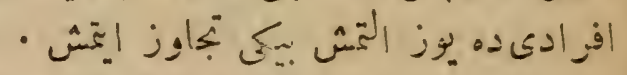

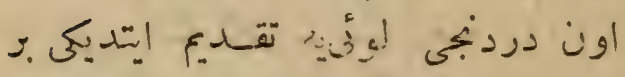

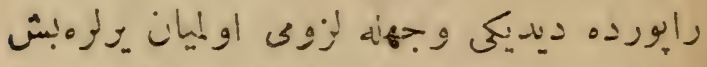

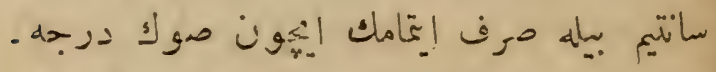

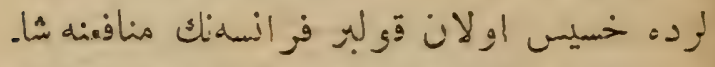

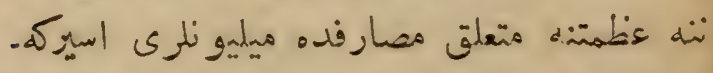

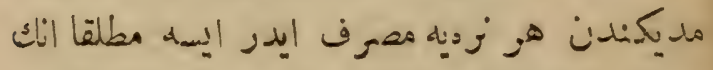

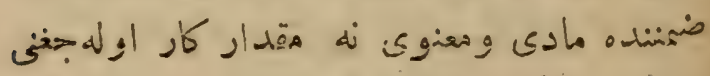

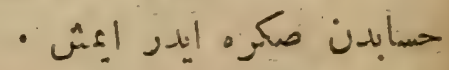

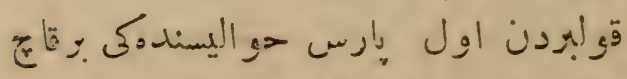

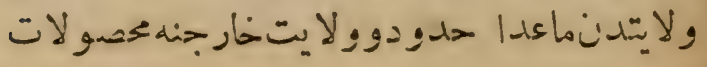




\section{$-1 \xi 7-$}

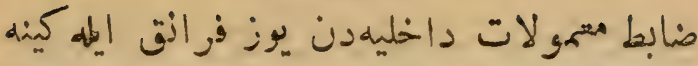

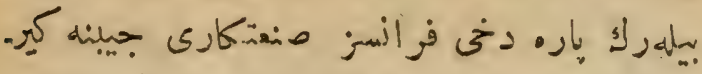

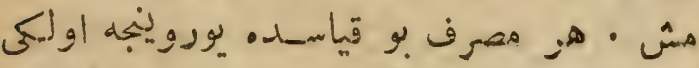

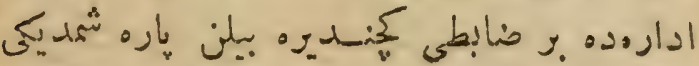

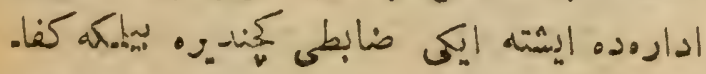

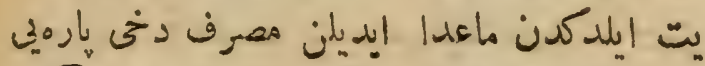

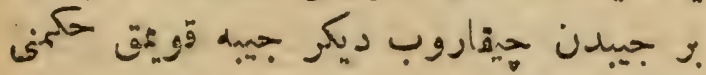

- المش

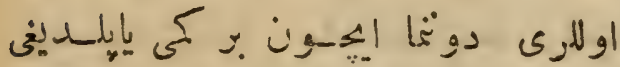

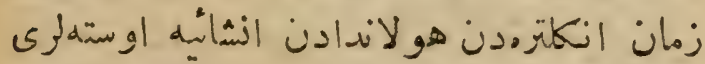

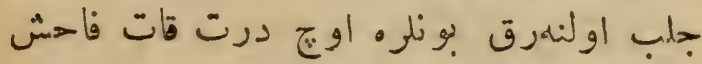

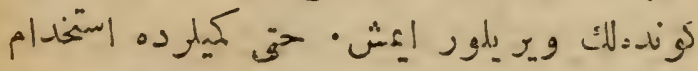

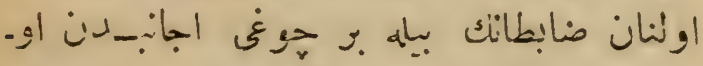

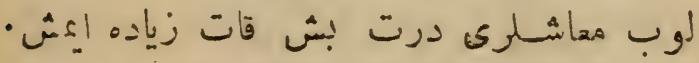

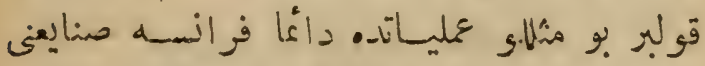

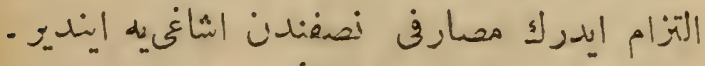

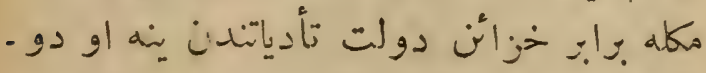

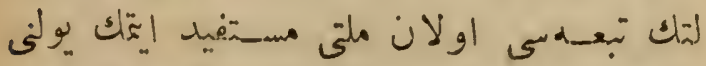

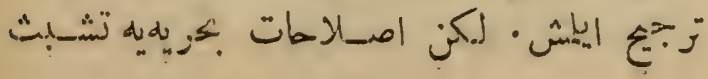




\section{$-1 \leqslant 0-$}

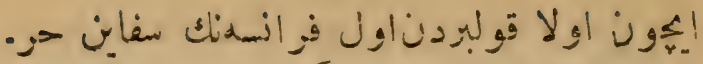

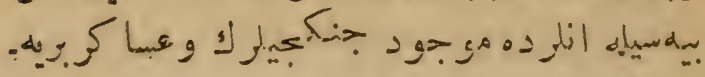

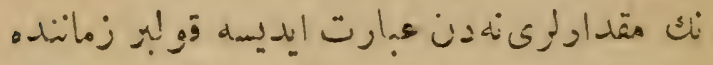

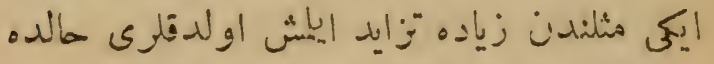

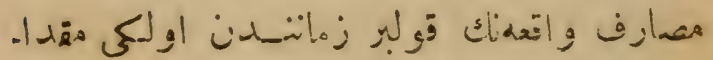

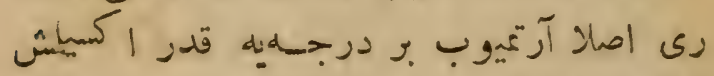

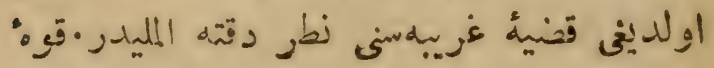

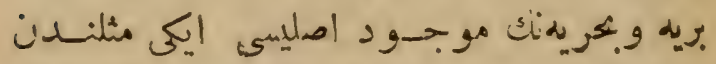

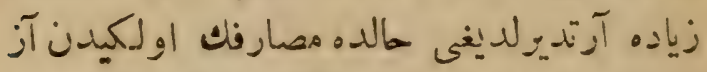

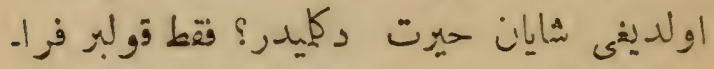

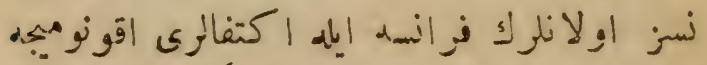

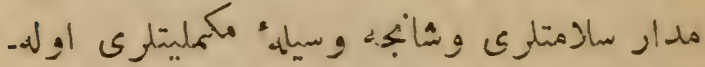

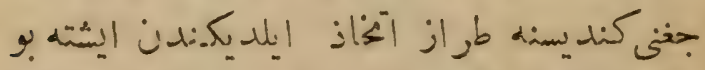

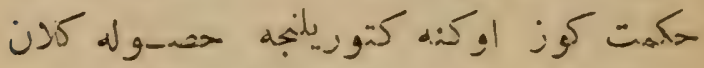

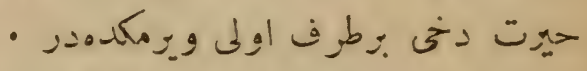

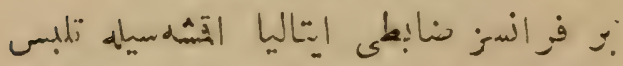

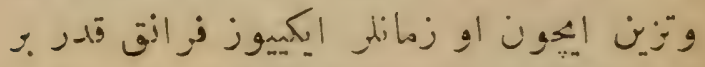

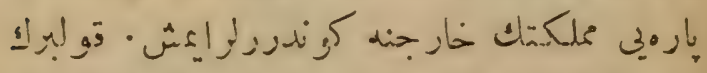

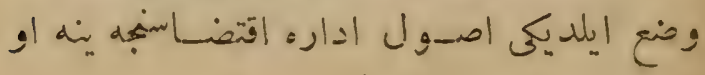




\section{$-1 \leqslant \leqslant-$}

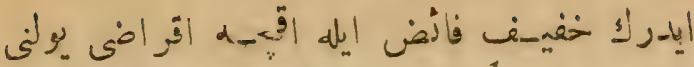

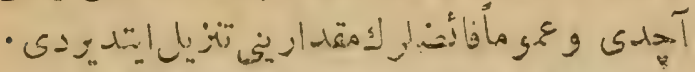

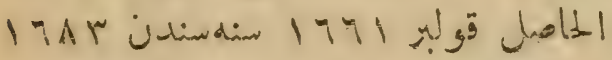

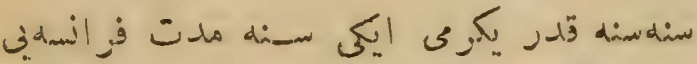

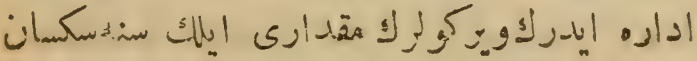

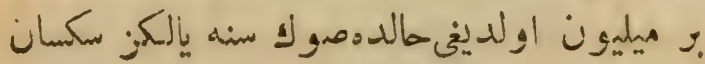

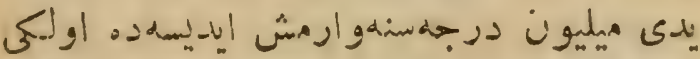

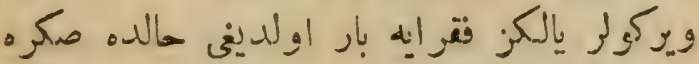

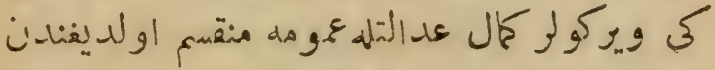

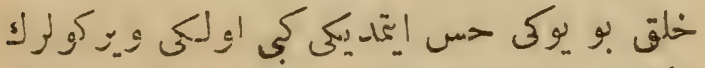

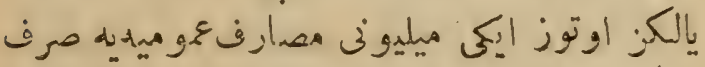

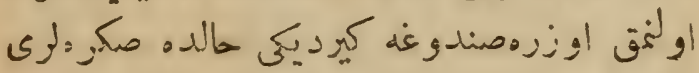

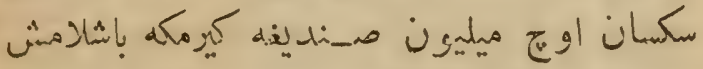

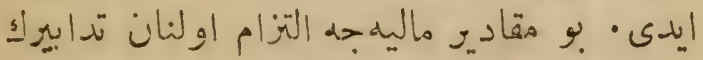

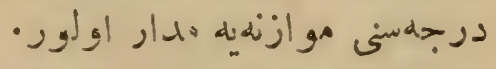

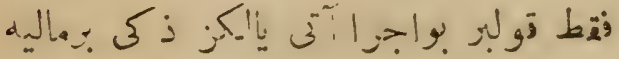

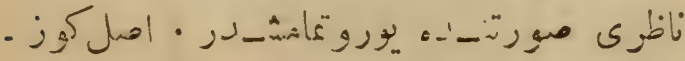

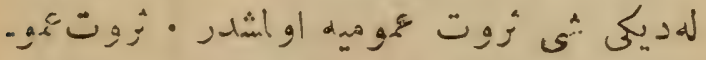

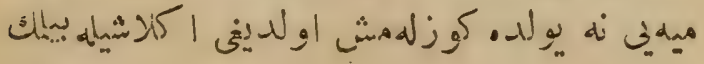




\section{$-1 \varepsilon \mu$}

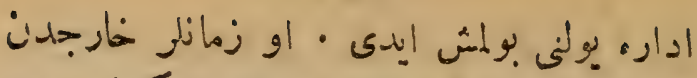

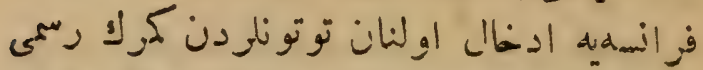

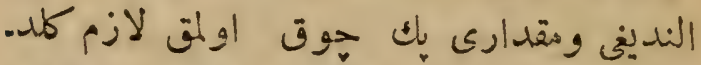

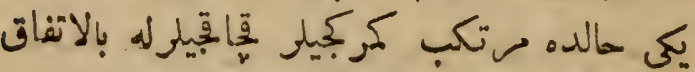

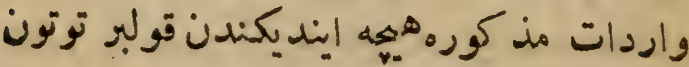

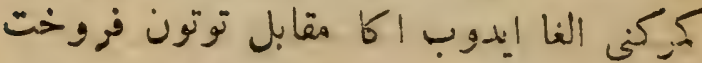

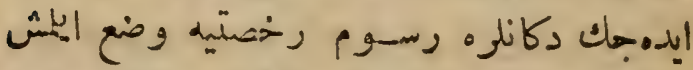

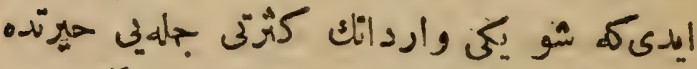

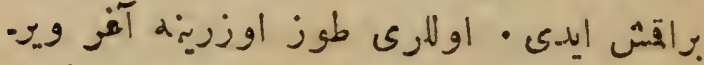

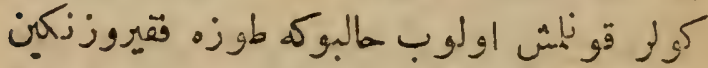

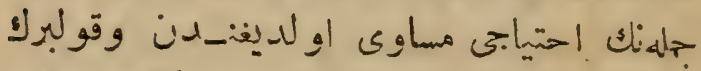

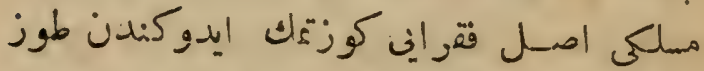

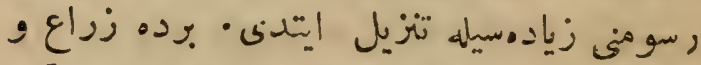

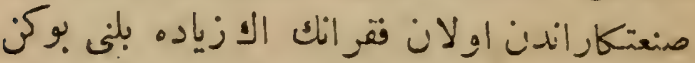

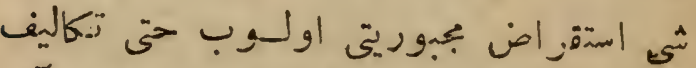

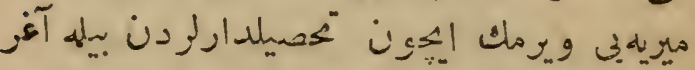

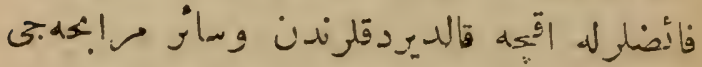

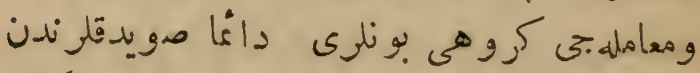

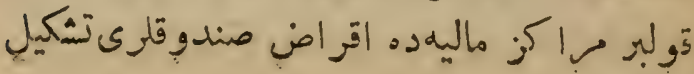




\section{$-1 \leqslant r-$}

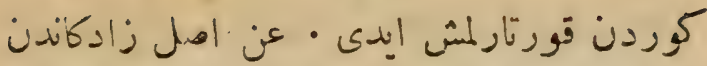

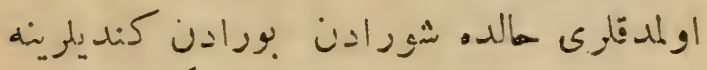

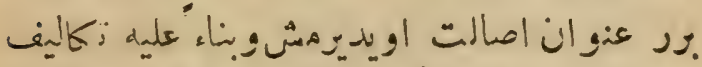

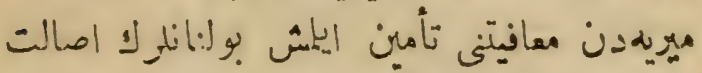

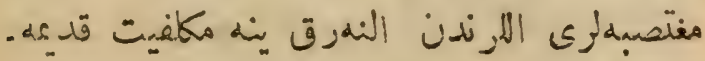

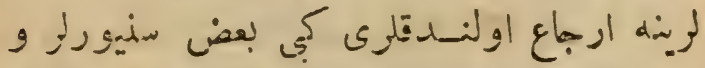

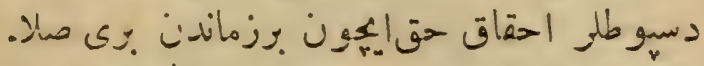

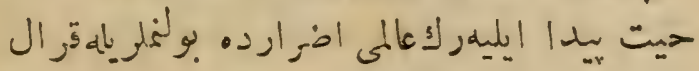

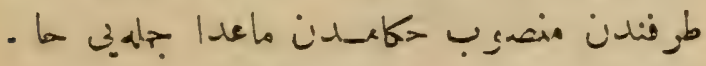

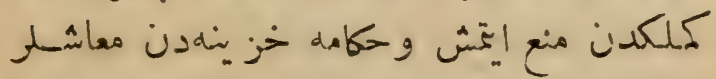

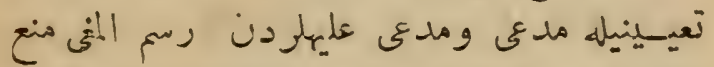

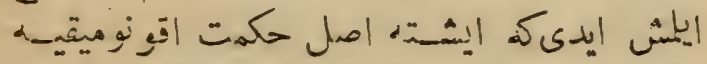

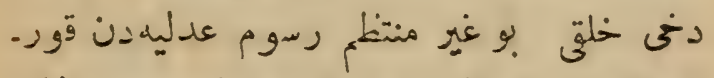

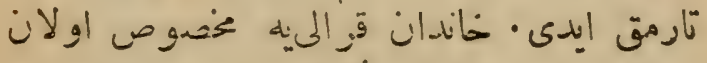

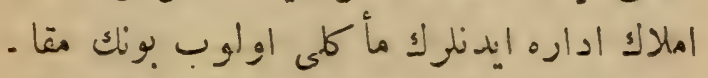

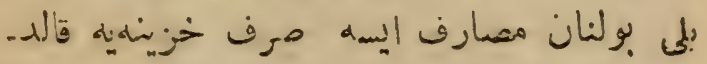

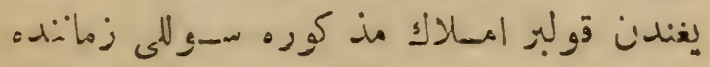

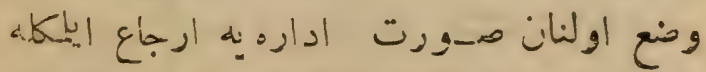

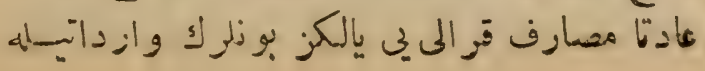




\section{$-1 \leq 1-$}

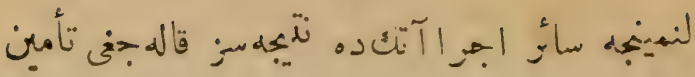

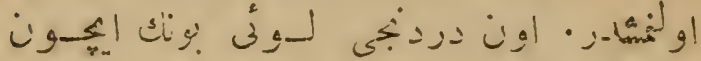

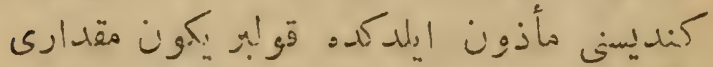

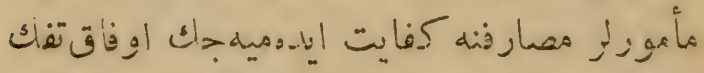

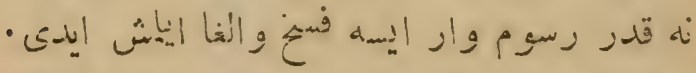

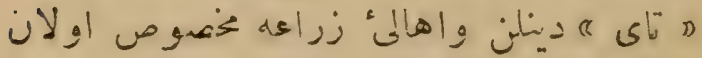

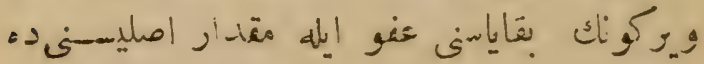

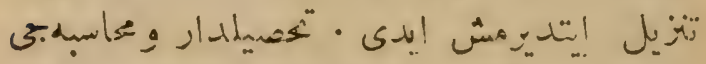

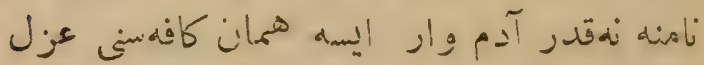

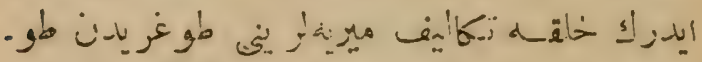

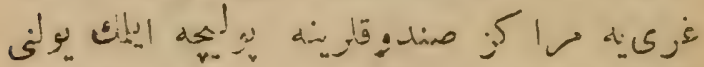

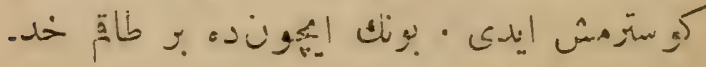

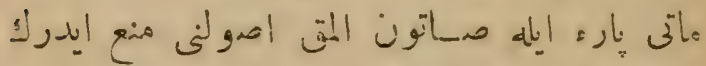

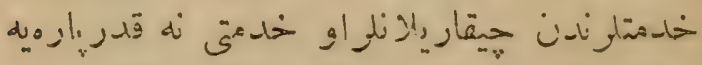

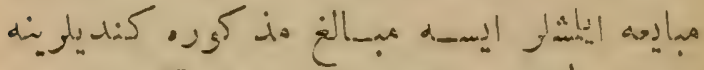

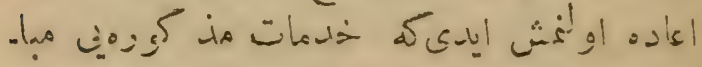

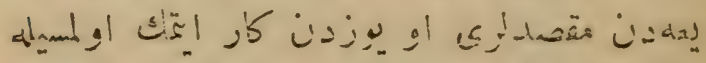

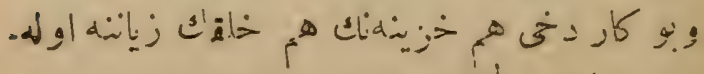

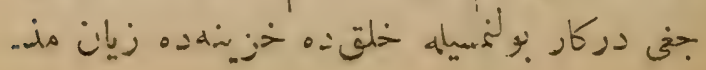




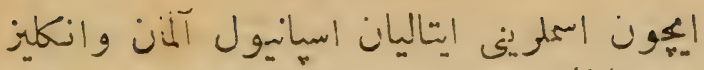

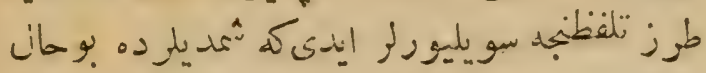

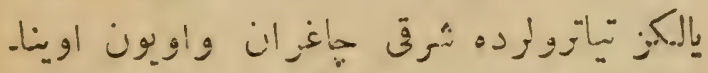

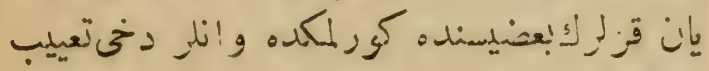

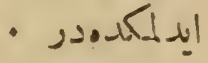

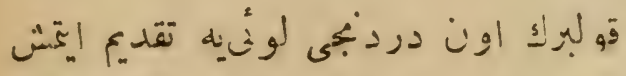

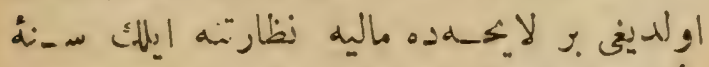

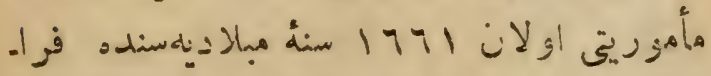

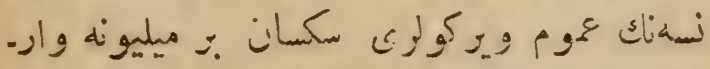

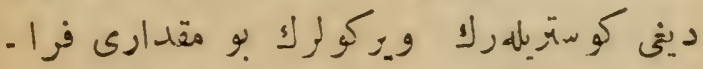

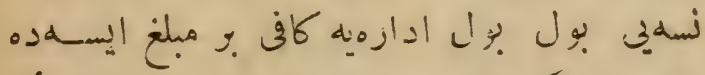

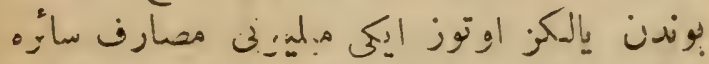

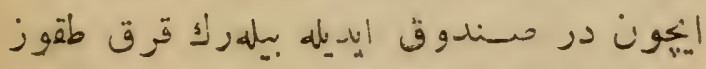

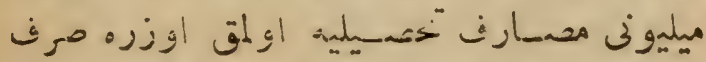

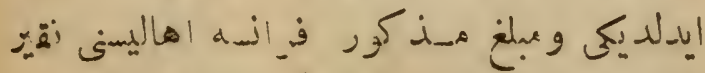

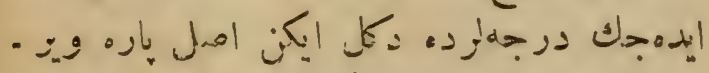

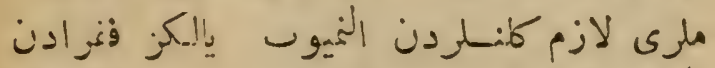

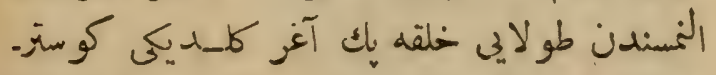

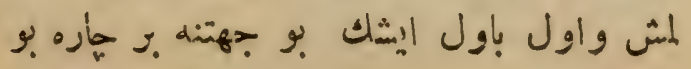




\section{- Irq-}

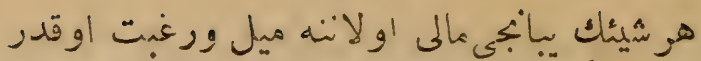

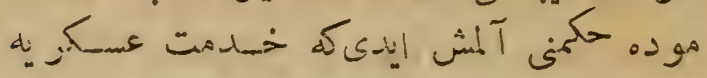

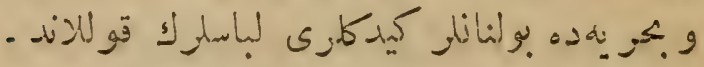

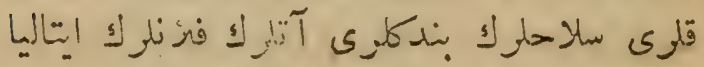

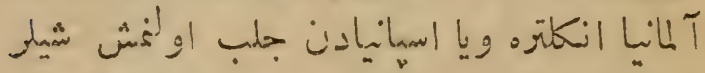

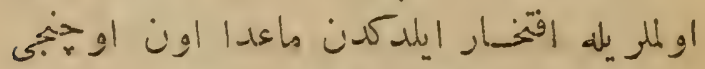

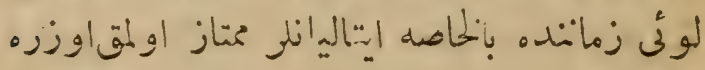

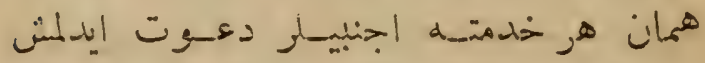

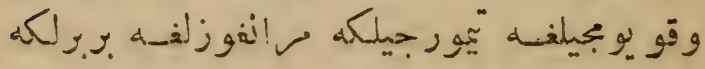

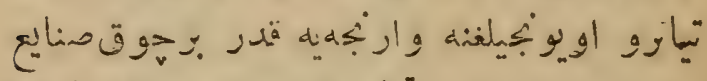

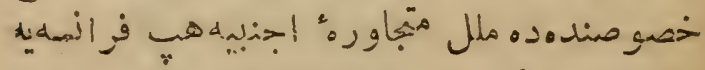

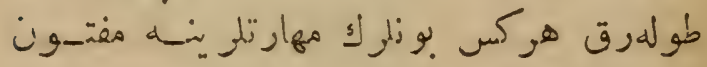

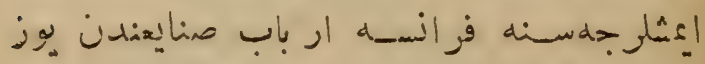

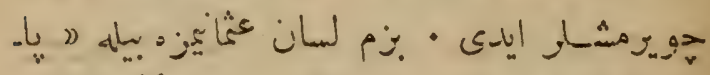

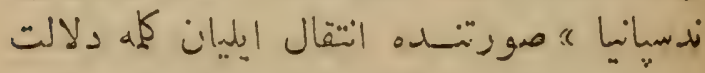

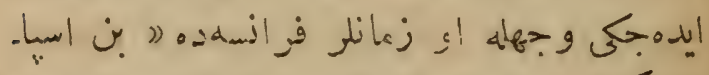

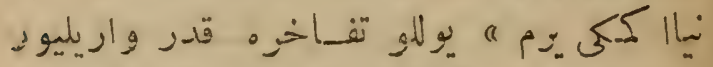

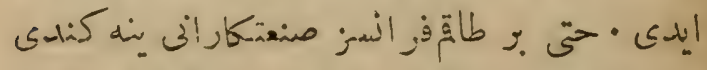

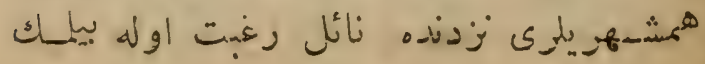




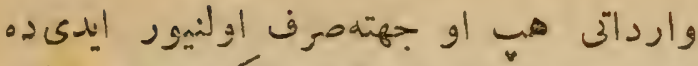

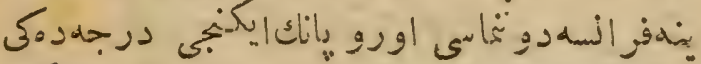

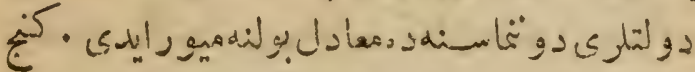

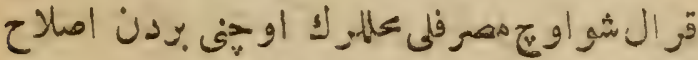

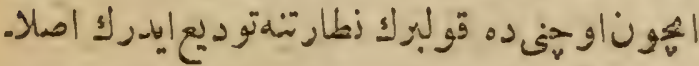

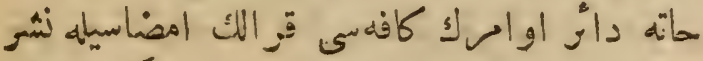

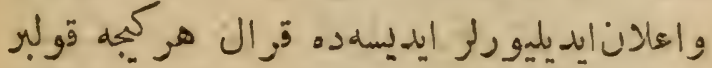

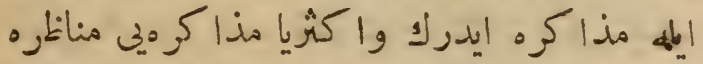

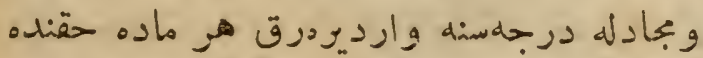

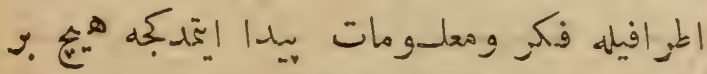

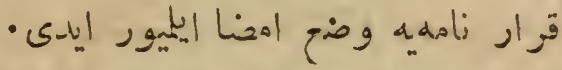

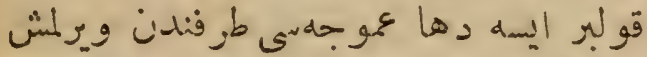

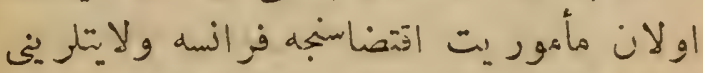

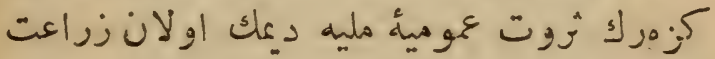

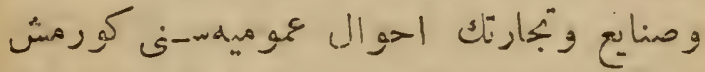

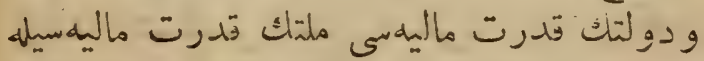

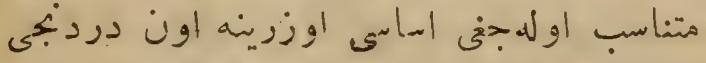

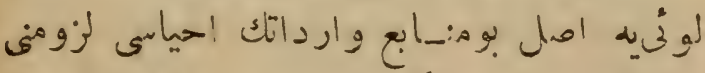

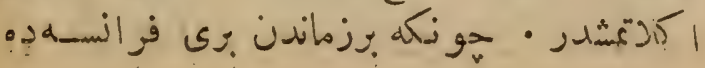




\section{$-1 \mu \gamma-$

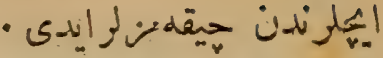

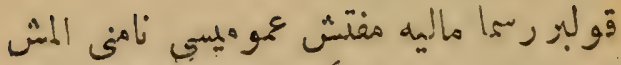

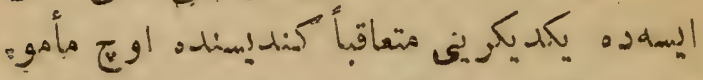

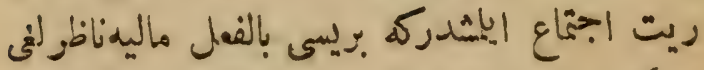

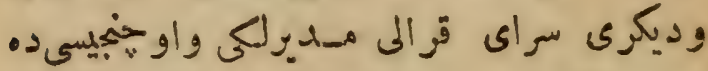

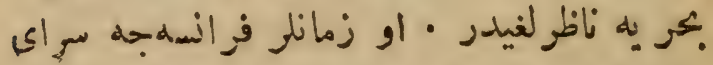

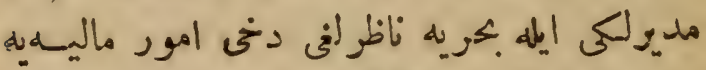

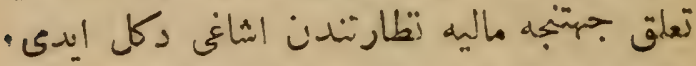

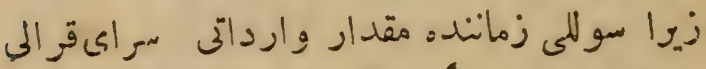

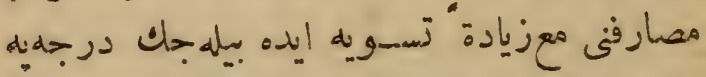

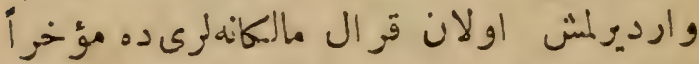

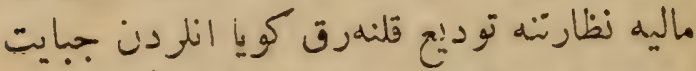

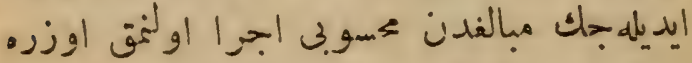

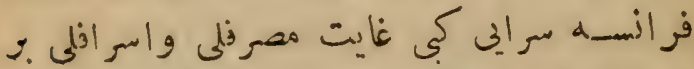

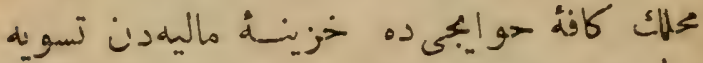

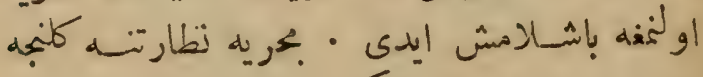

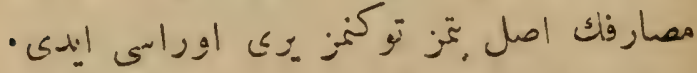

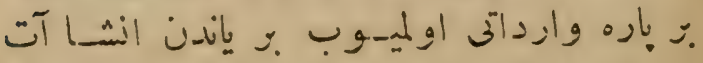

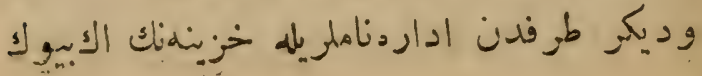




\section{-irin.}

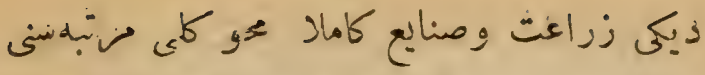

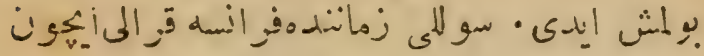

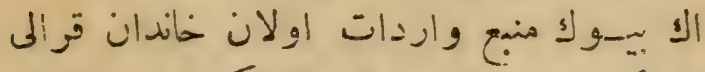

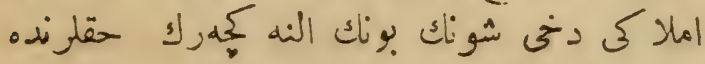

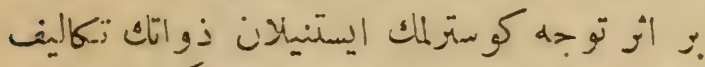

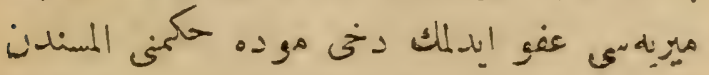

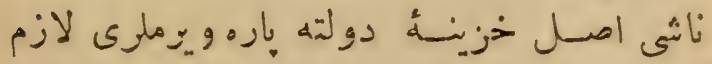

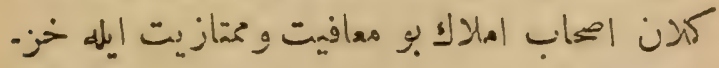

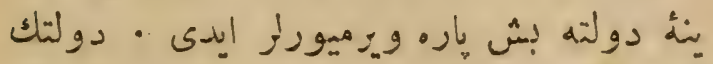

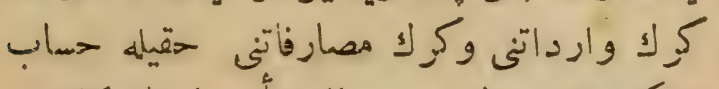

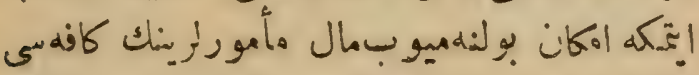

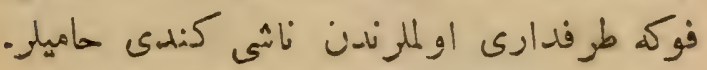

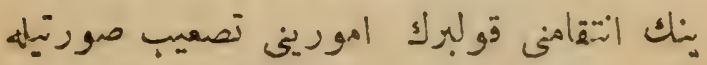

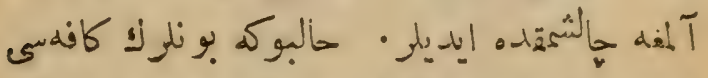

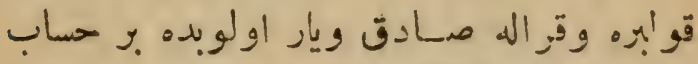

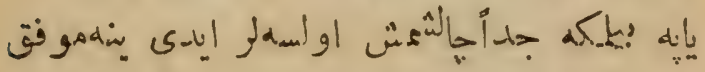

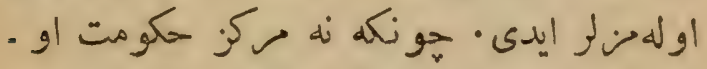

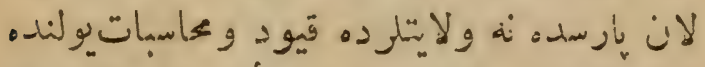

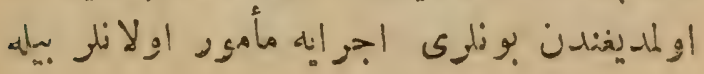




\section{$-1+0$}

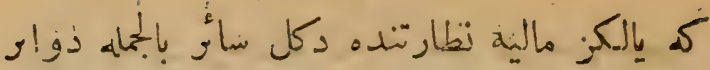

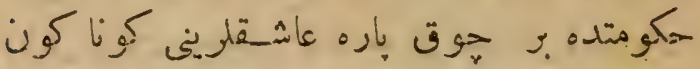

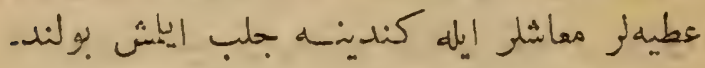

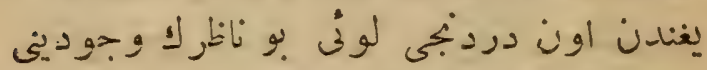

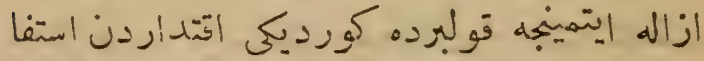

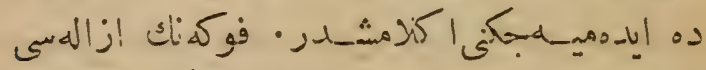

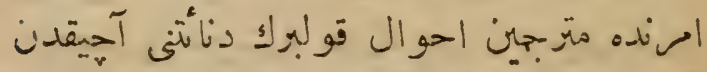

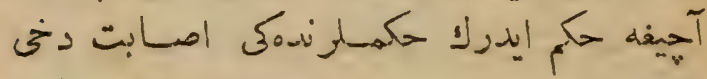

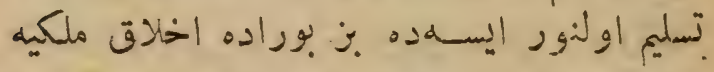

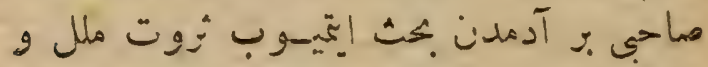

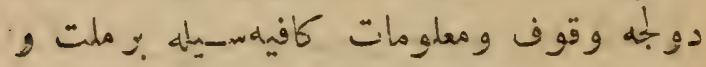

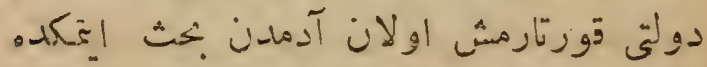

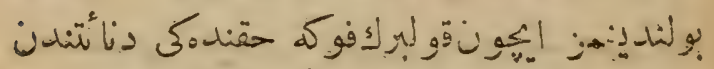

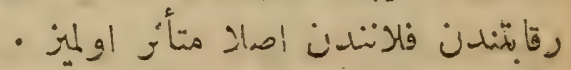

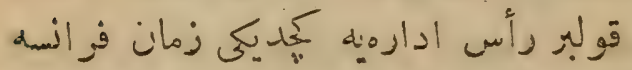

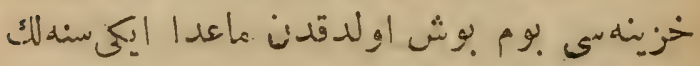

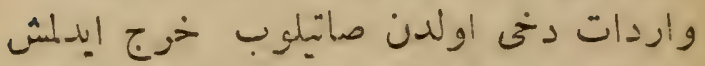

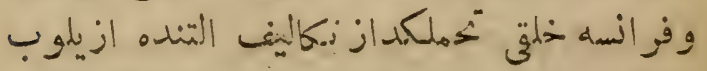

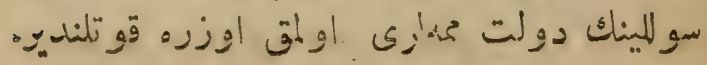


آلهرق قاردينال مازارن آرتق .و دهـا خلاص

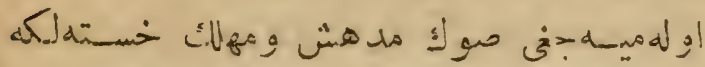

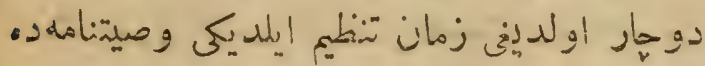

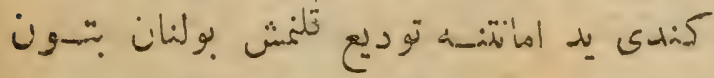

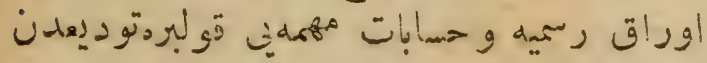

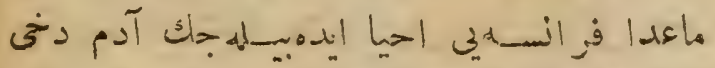

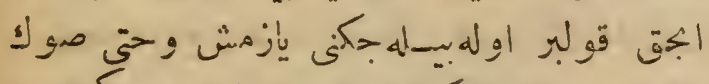

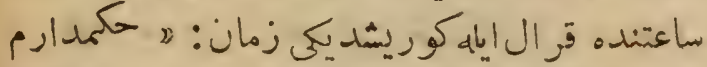

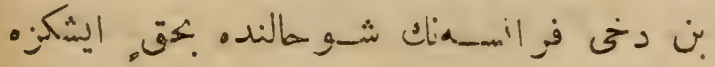

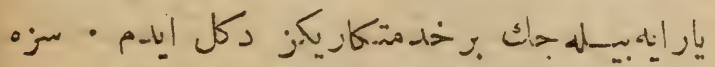

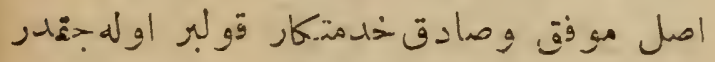

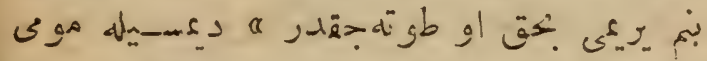

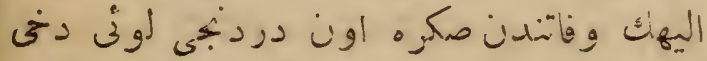

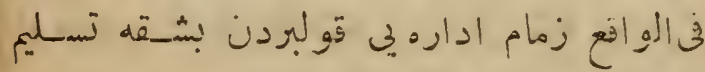

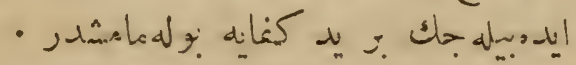

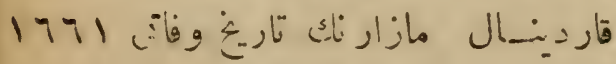

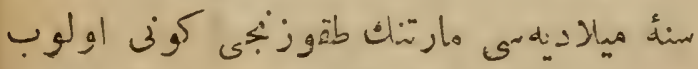

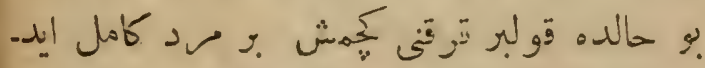

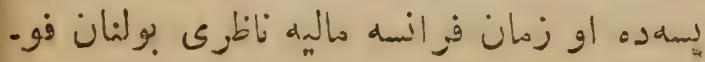


列 دئك اولانا

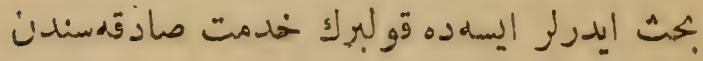

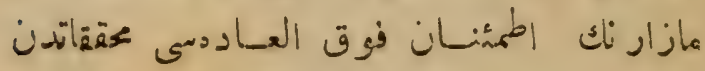

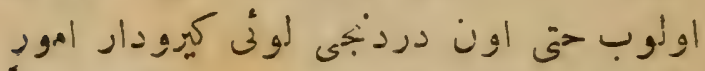

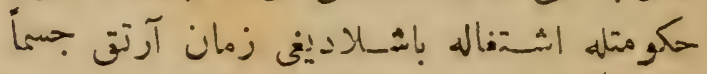

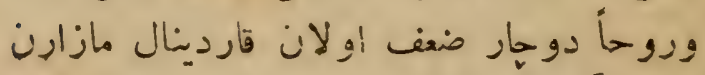

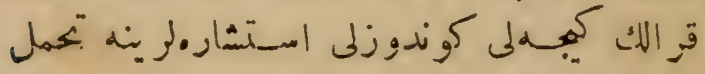

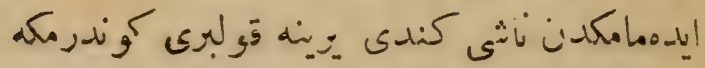

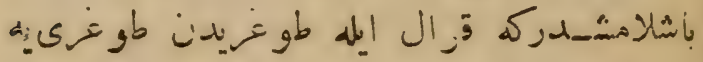

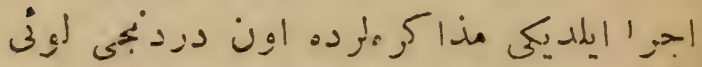

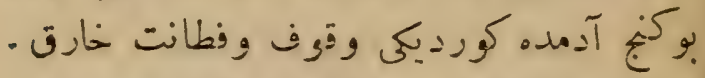

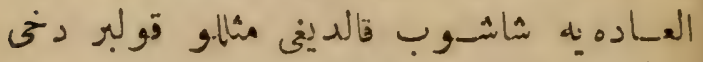

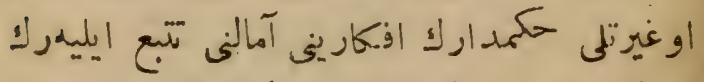

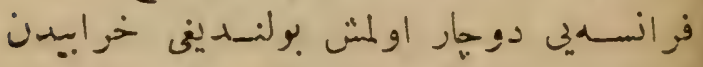

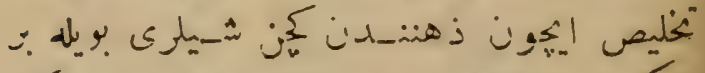

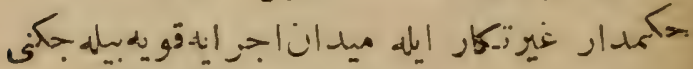

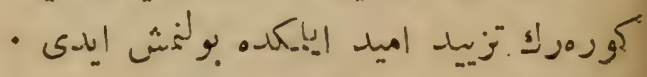

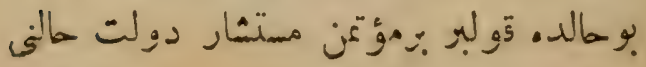




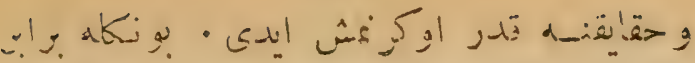

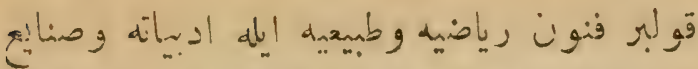

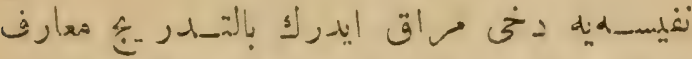

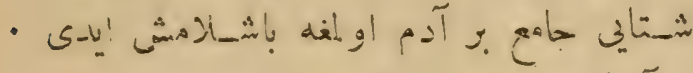

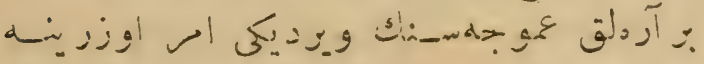

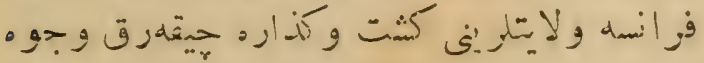

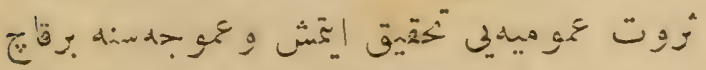

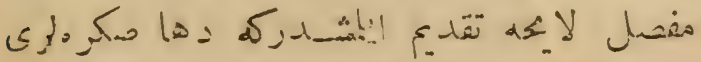

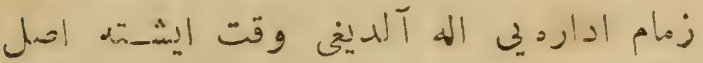

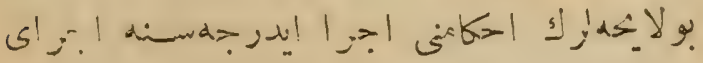

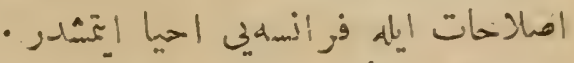

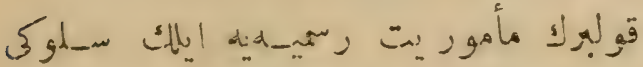

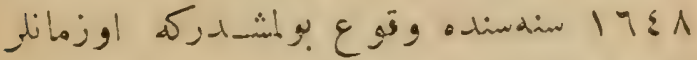

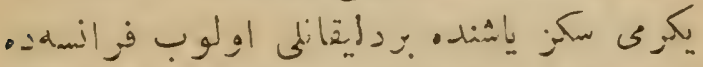

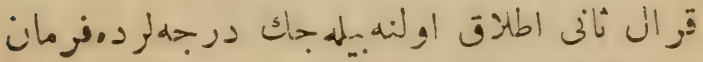

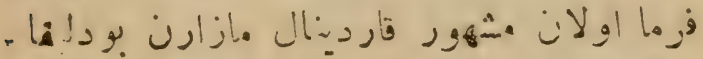

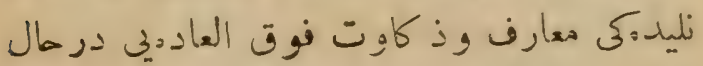

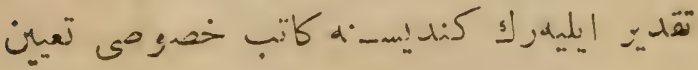

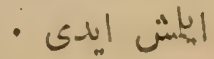




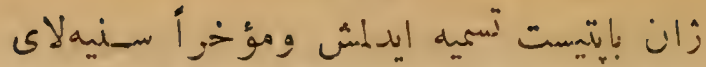

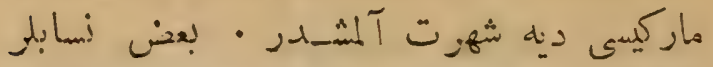

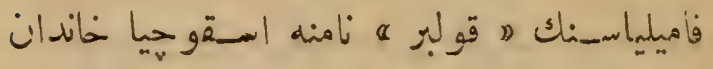

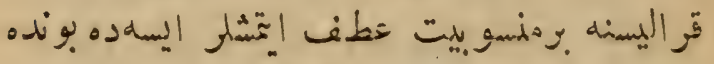

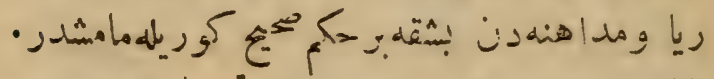

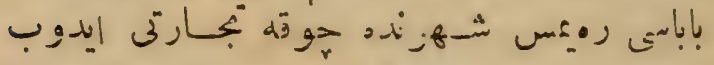

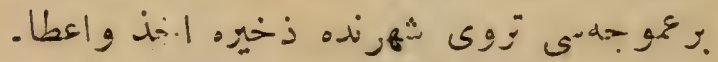

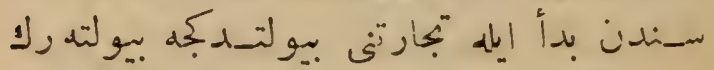

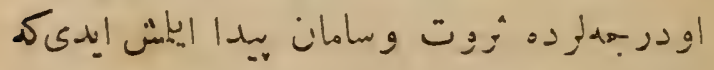

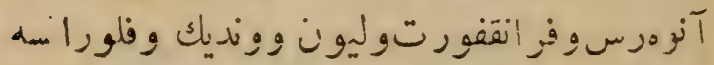

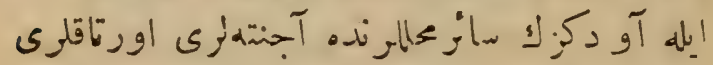

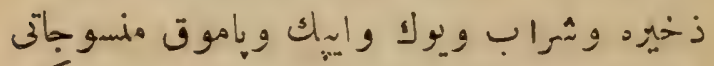

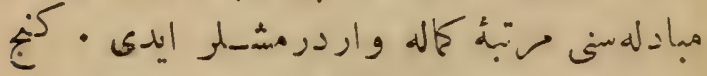

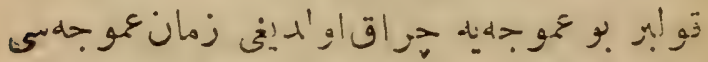

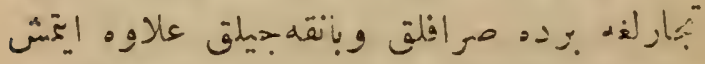

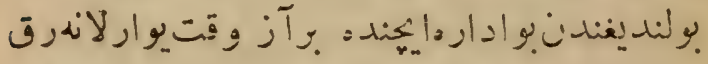

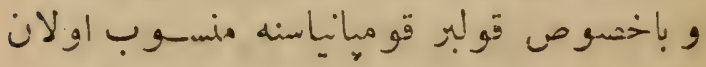

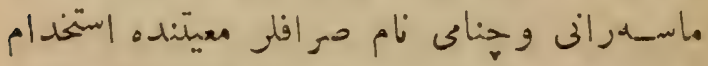

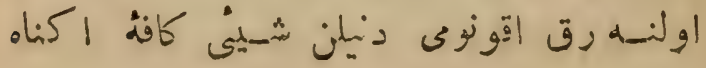




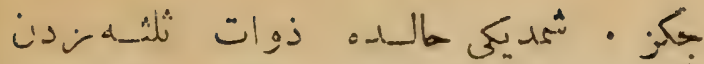

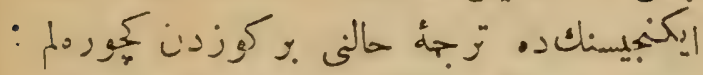

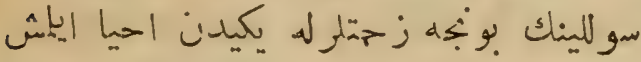

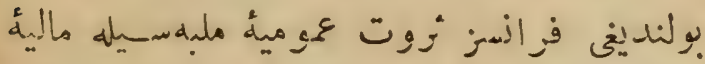

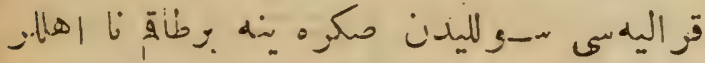

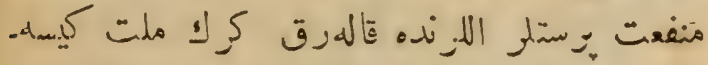

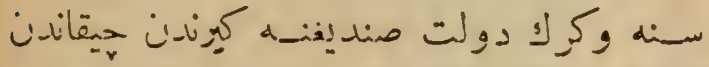

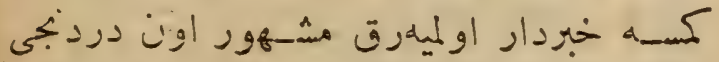

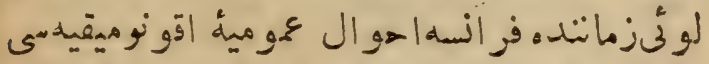

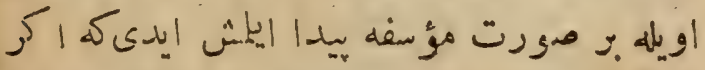

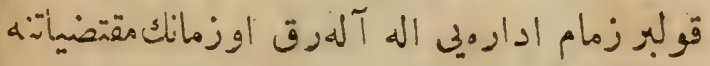

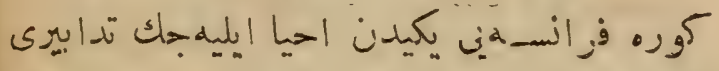

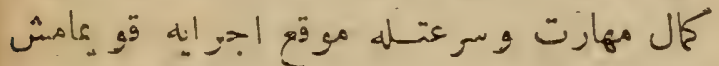

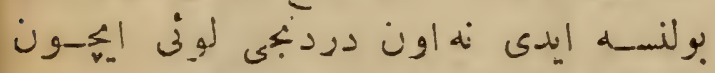

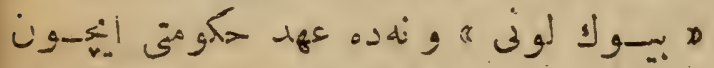

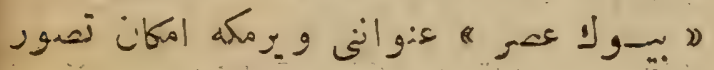

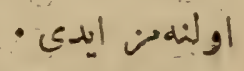

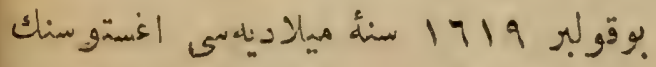

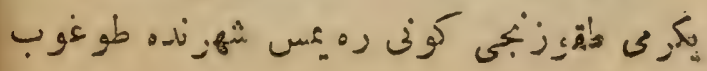




\section{$-1+9-$}

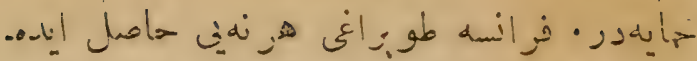

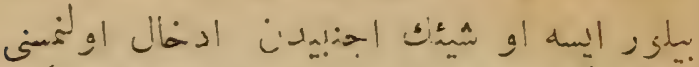

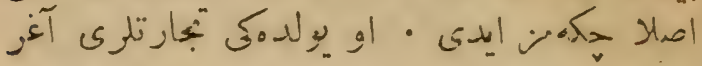

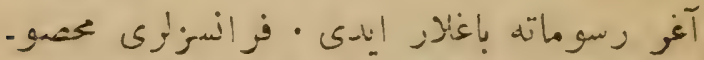

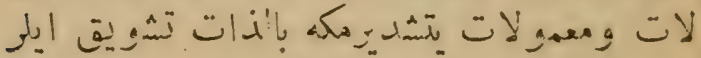

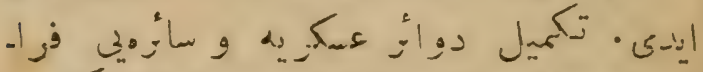

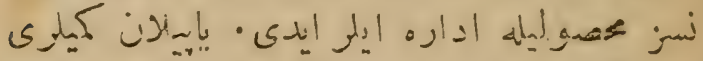

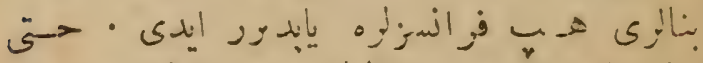

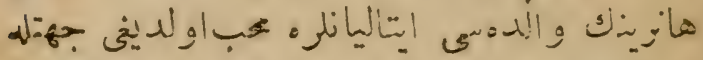

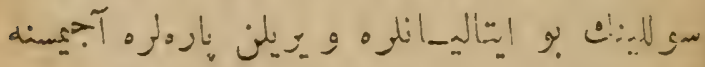

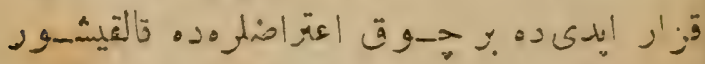

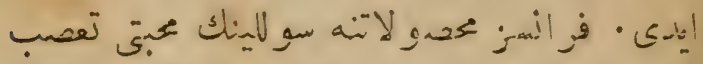

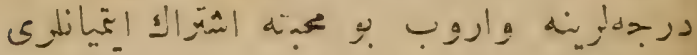

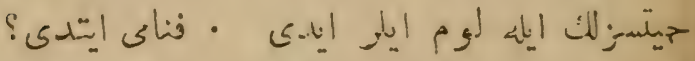

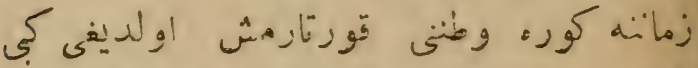

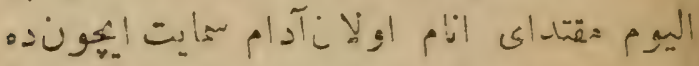

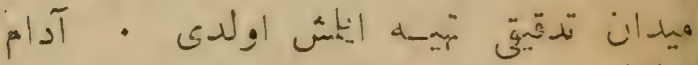

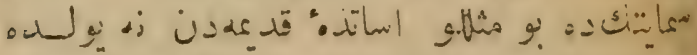

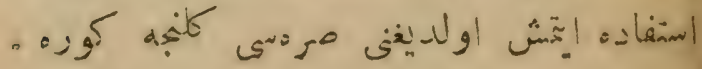




\section{- IrA-}

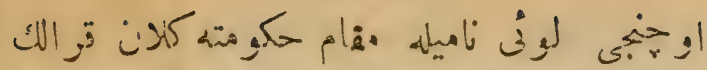

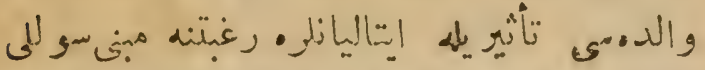

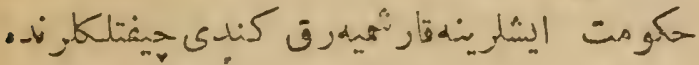

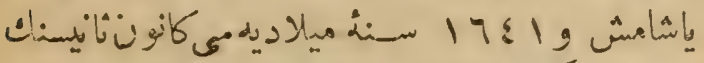

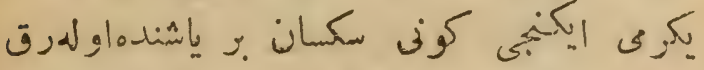

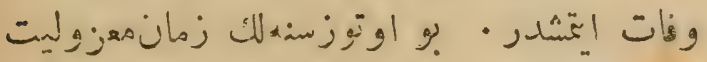

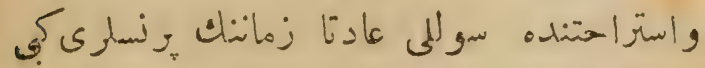

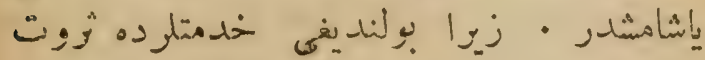

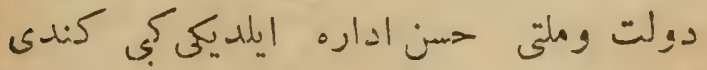

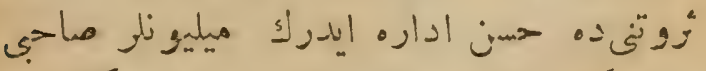

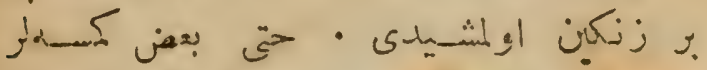

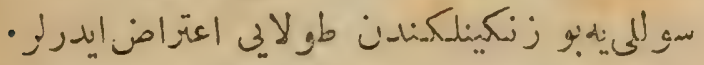

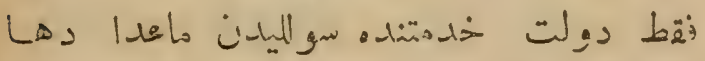

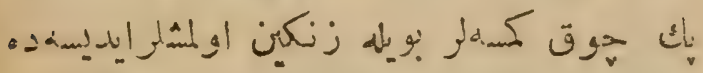

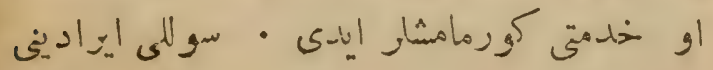

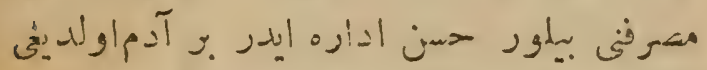

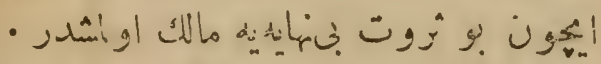

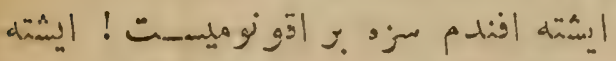

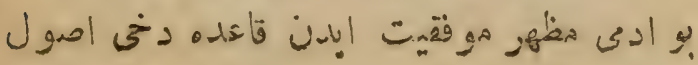




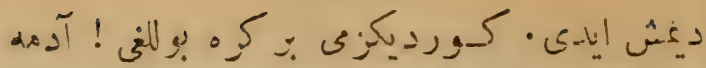

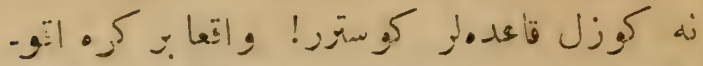

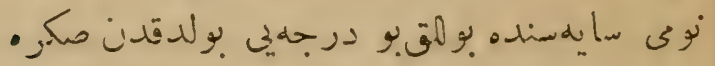

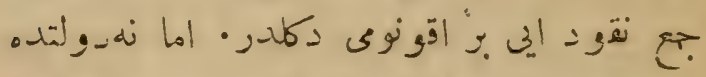

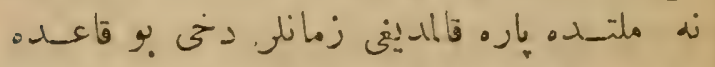

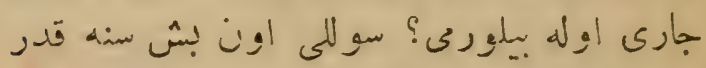

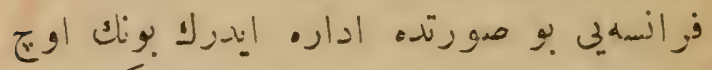

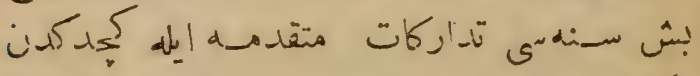

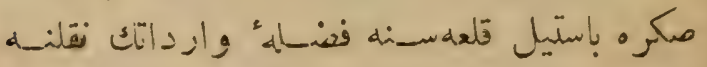

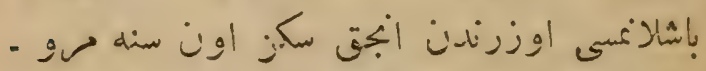

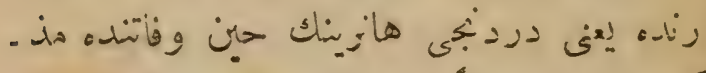

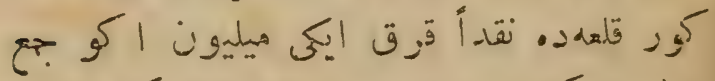

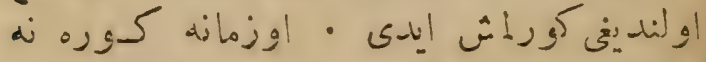

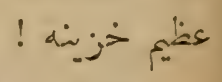

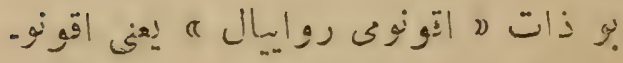

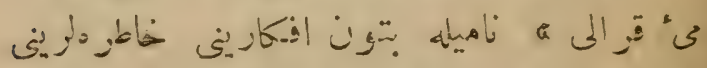

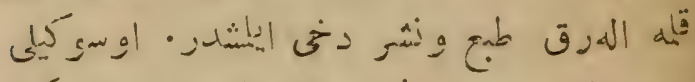

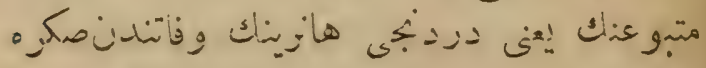

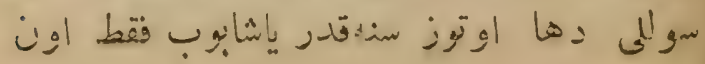


$-157-$

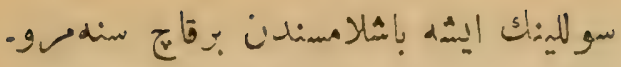

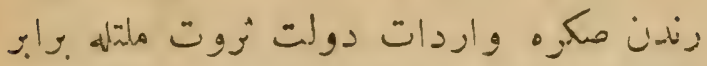

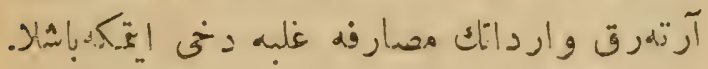

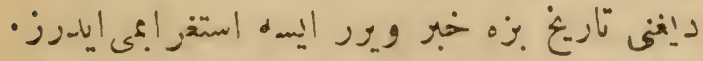

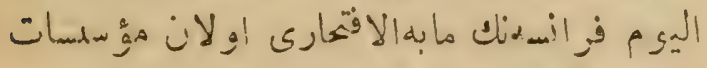

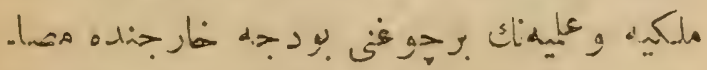

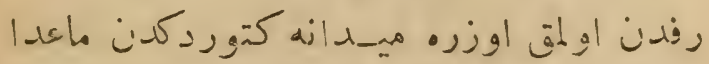

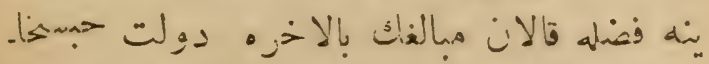

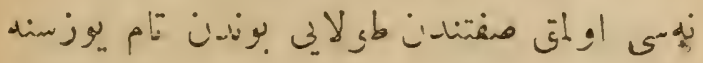

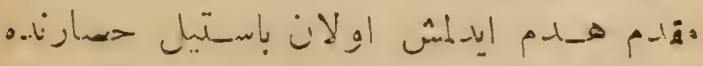

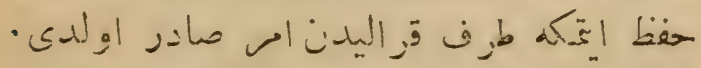

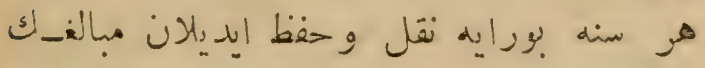

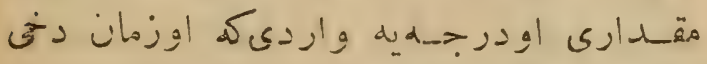

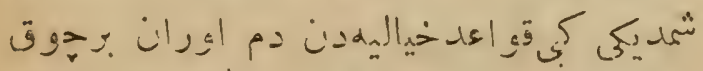

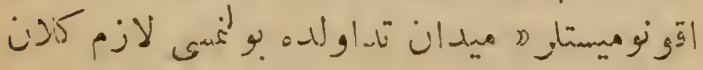

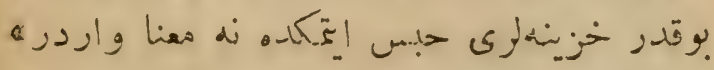

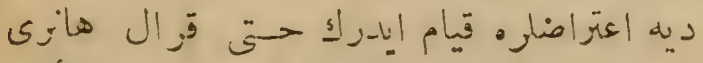

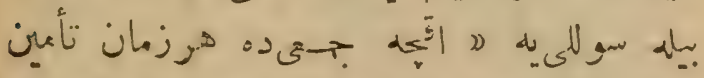

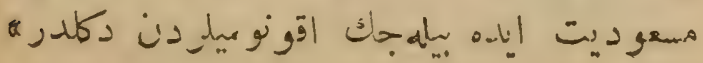


$-150-$

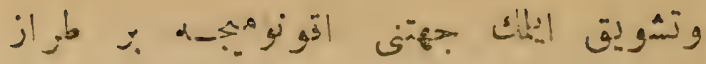

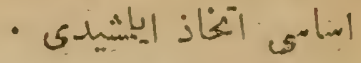

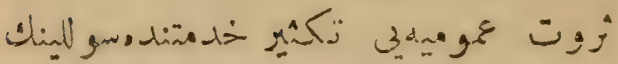

-

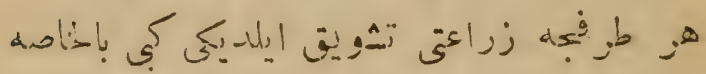

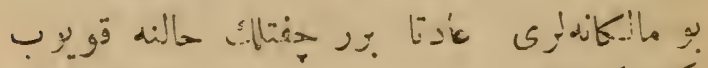

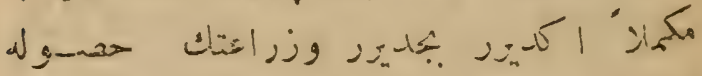

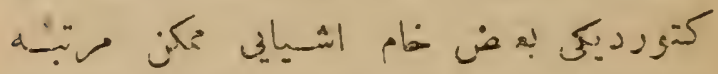

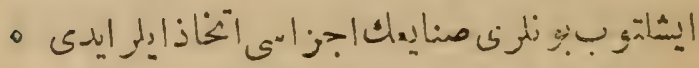

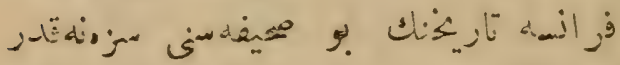

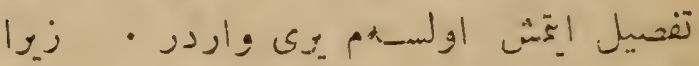

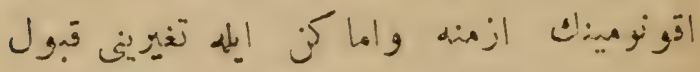

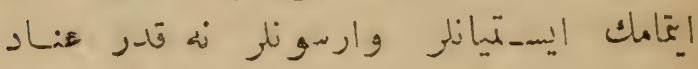

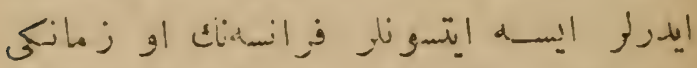

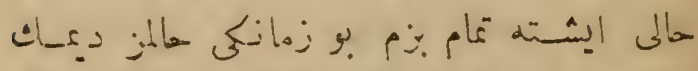

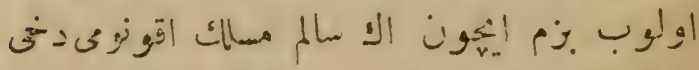

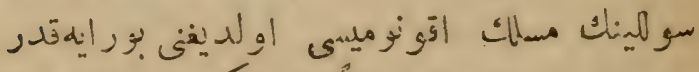

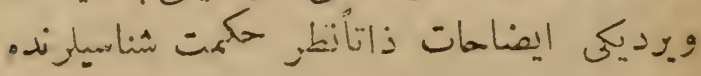

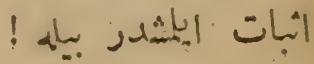


$-1+\xi-$

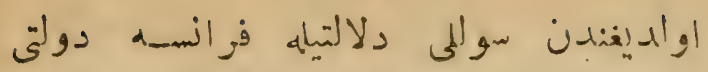

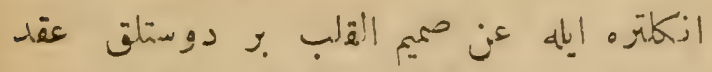

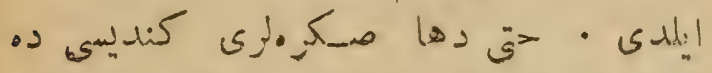

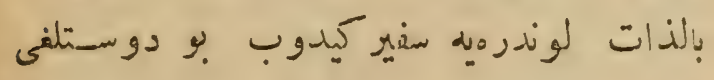

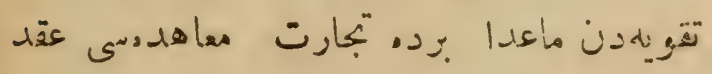

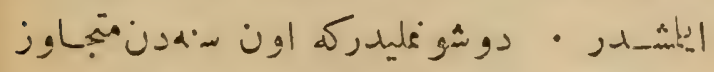

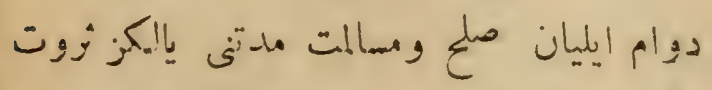

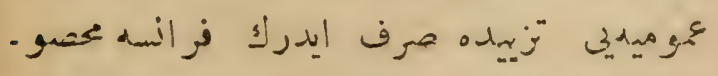

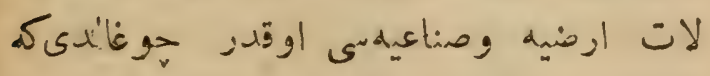

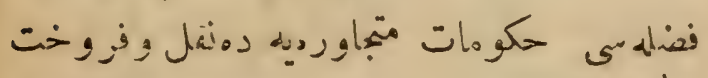

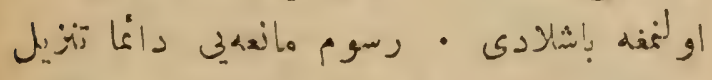

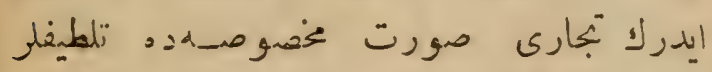

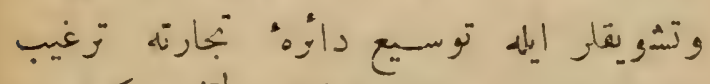

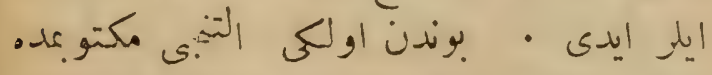

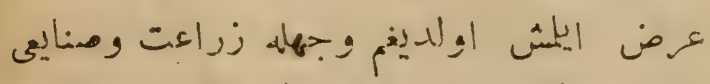

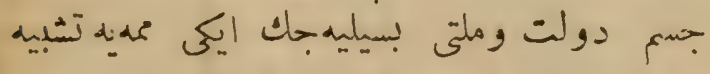

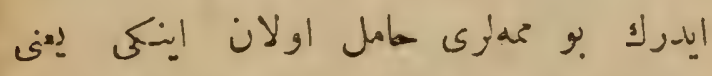

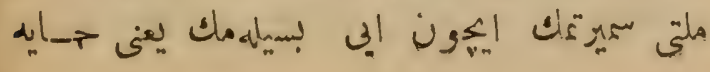




\section{$-19 p-$}

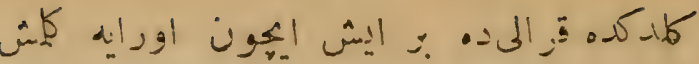

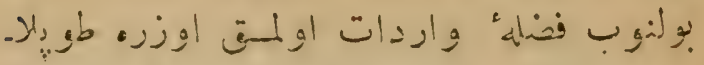

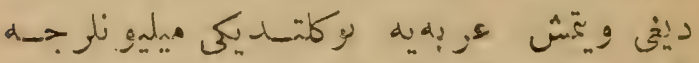

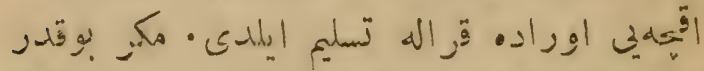

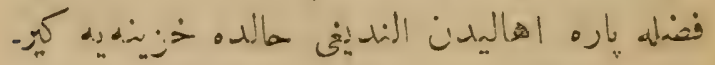

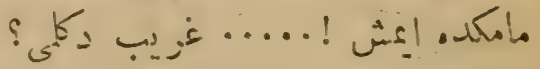

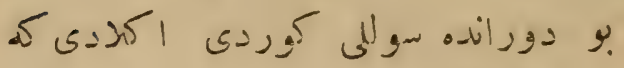

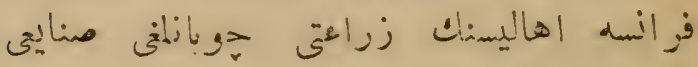

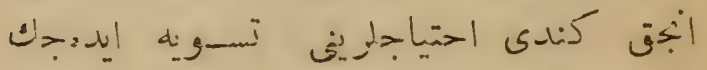

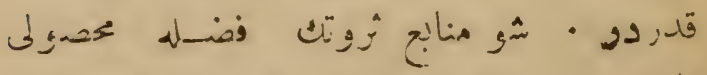

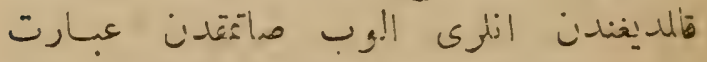

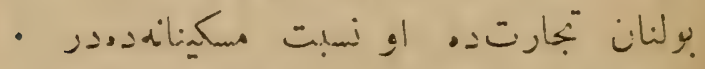

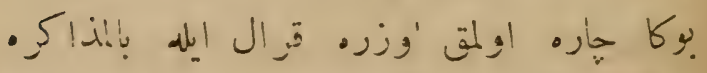

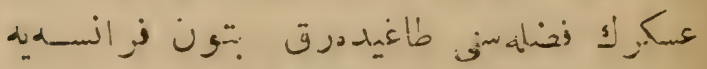

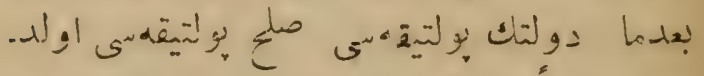

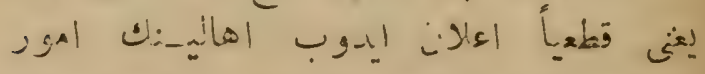

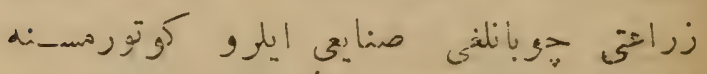

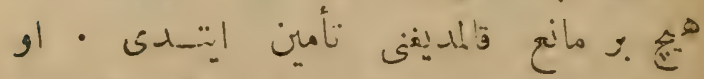

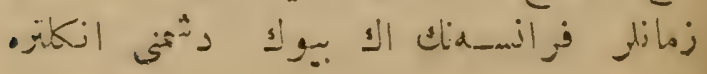


- Ir P -

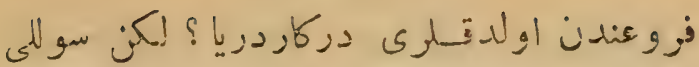

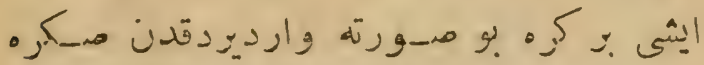

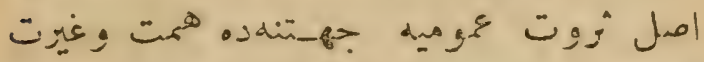

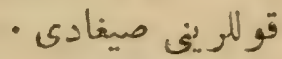

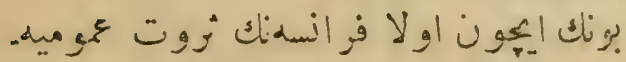

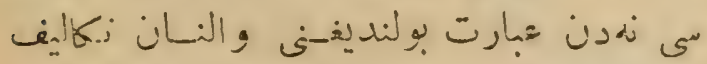

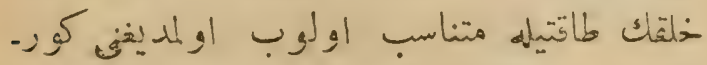

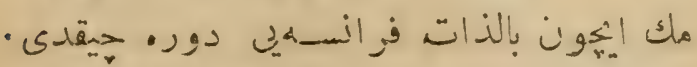

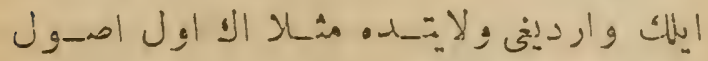

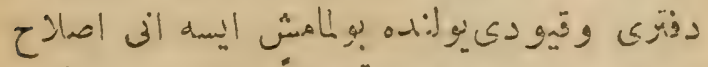

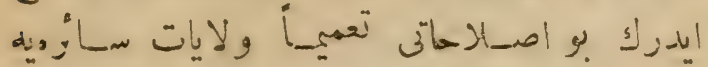

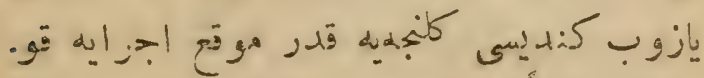

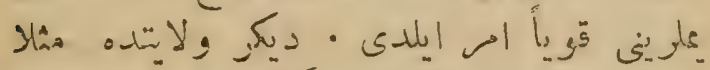

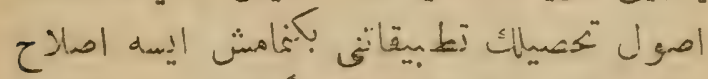

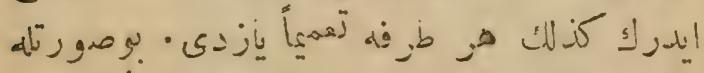

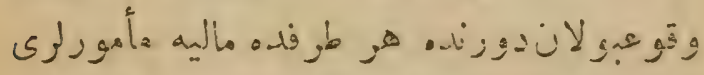

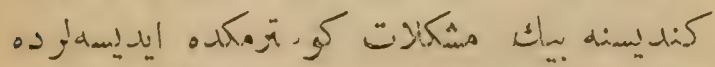

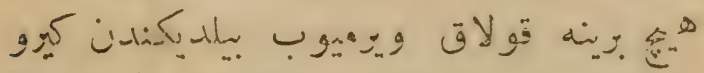

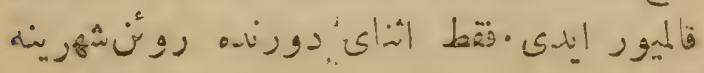




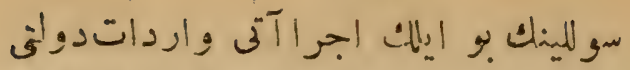

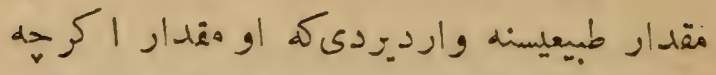

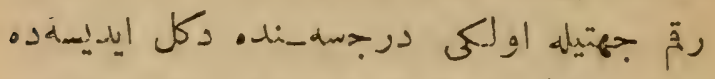

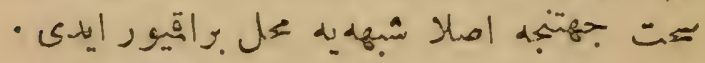

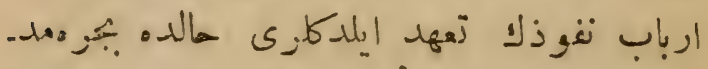

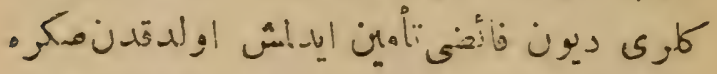

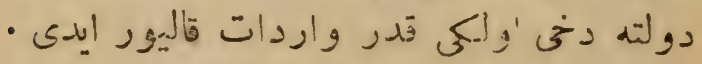

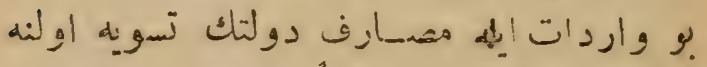

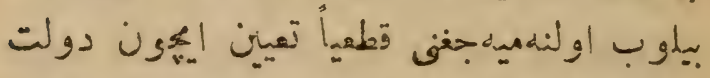

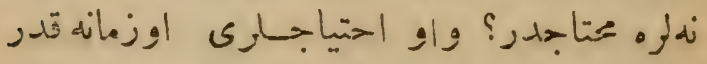

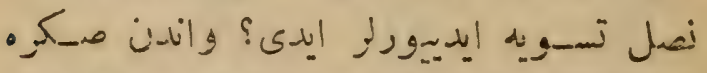

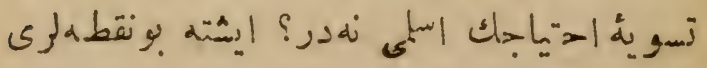

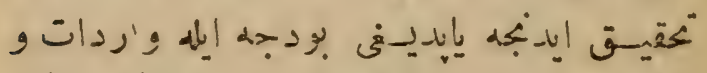

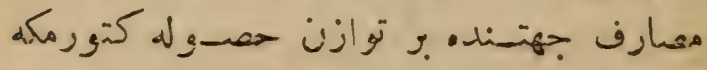

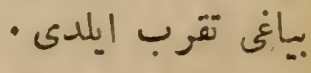

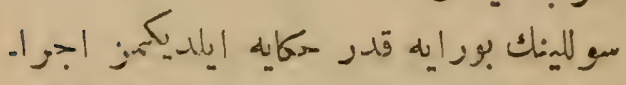

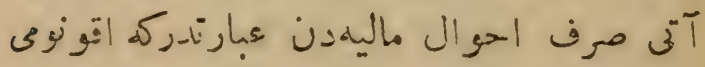

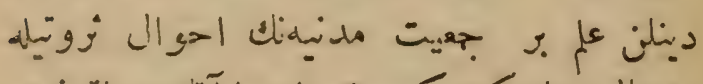

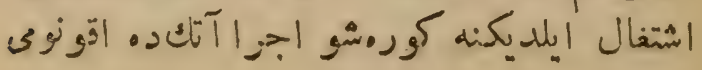




\section{$-1 \mu \cdot-$}

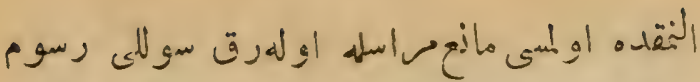

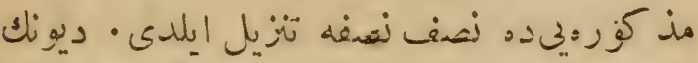

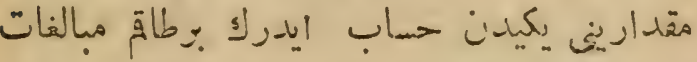

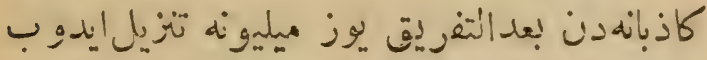

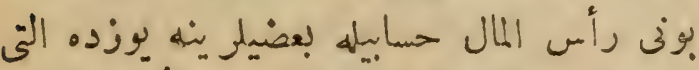

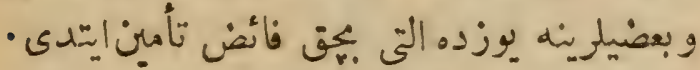

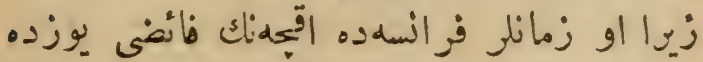

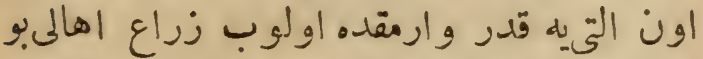

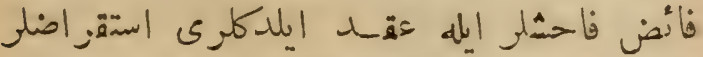

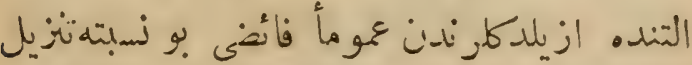

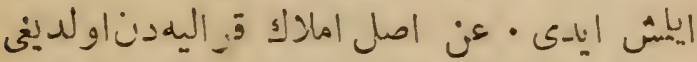

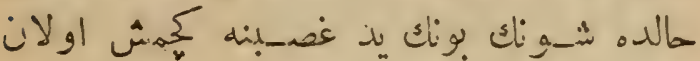

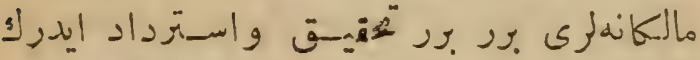

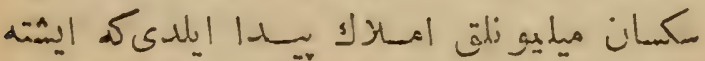

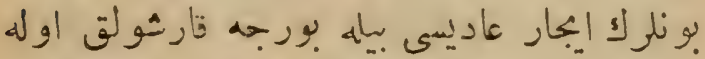

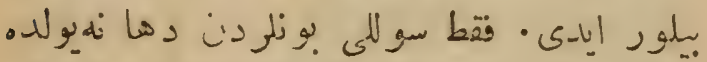

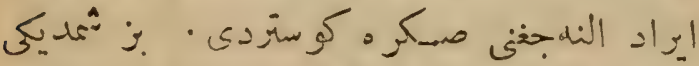

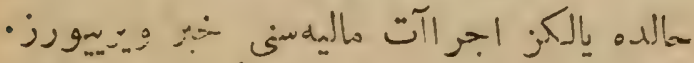

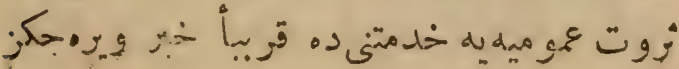


$-119-$

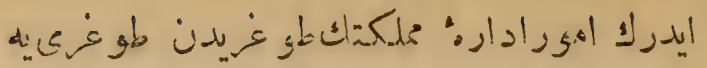

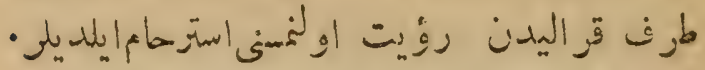

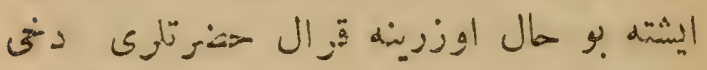

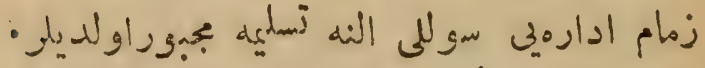

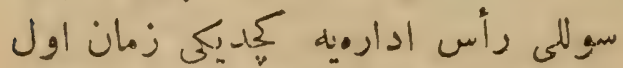

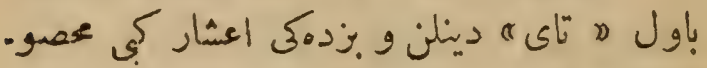

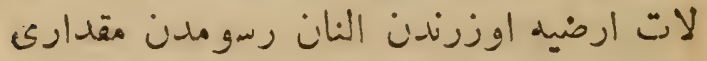

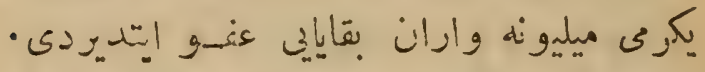

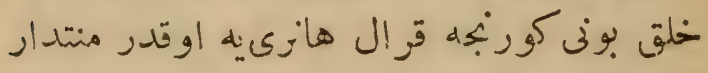

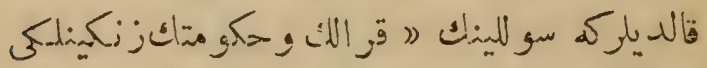

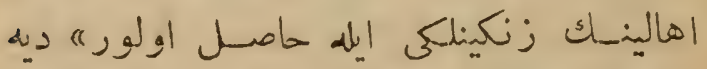

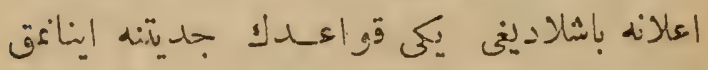

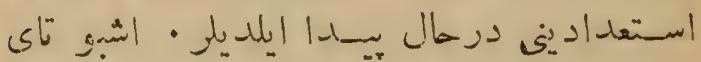

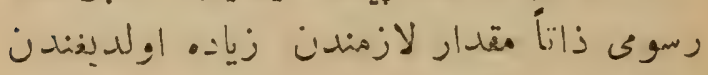

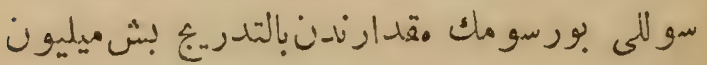

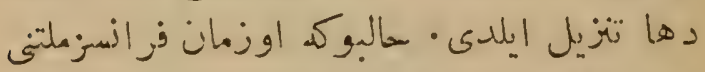

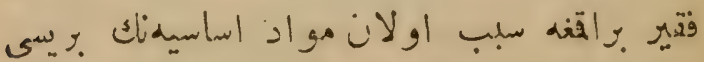

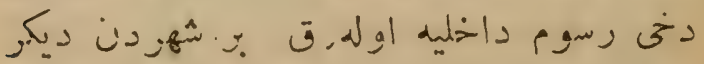

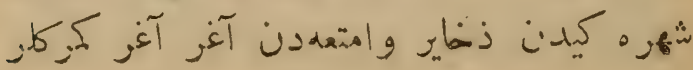




$$
-111-
$$

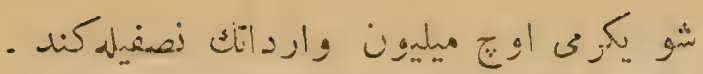

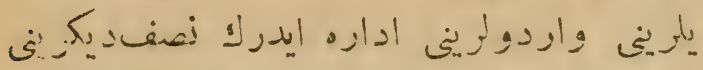

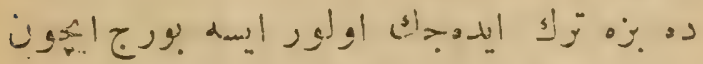

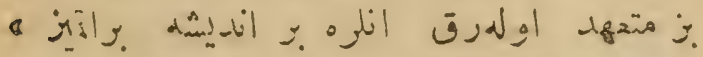

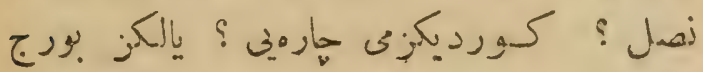

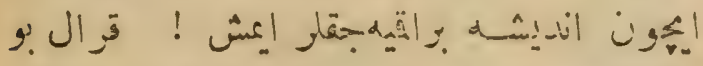

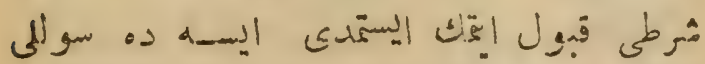

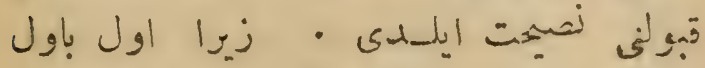

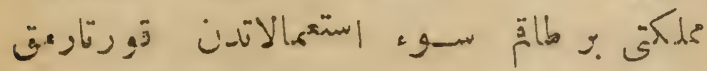

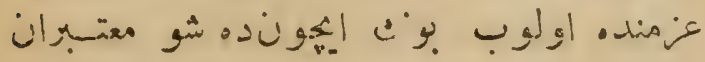

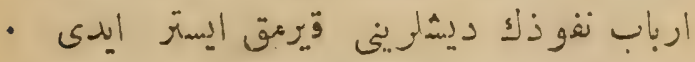

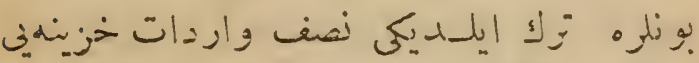

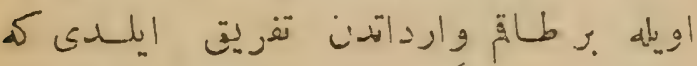

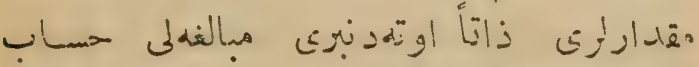

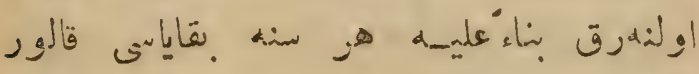

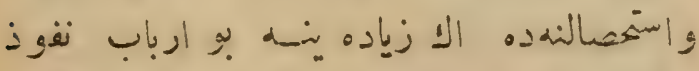

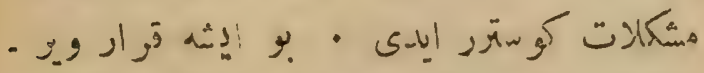

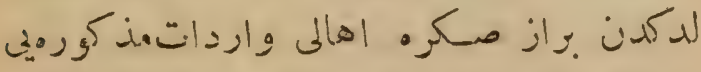

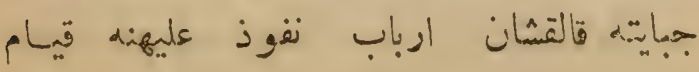


$-118-$

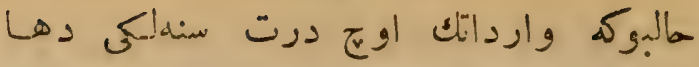

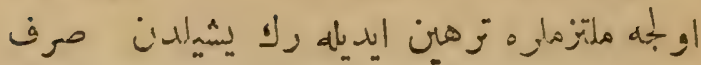

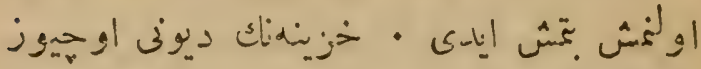

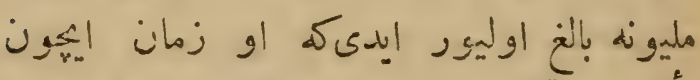

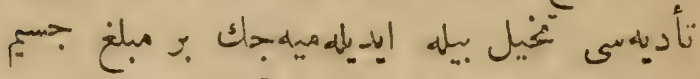

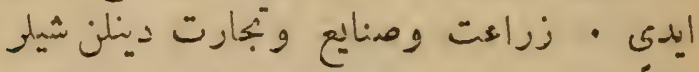

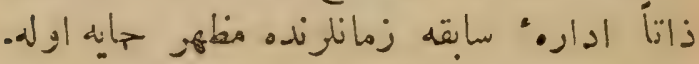

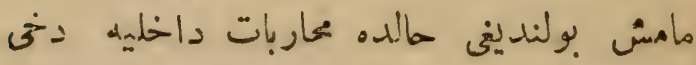

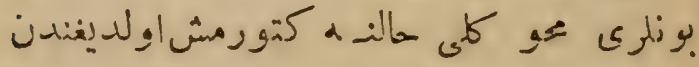

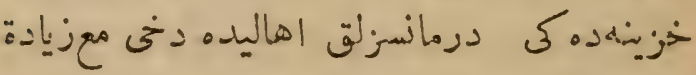

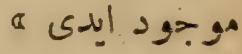

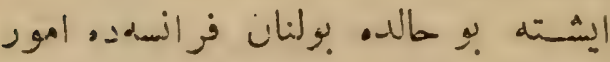

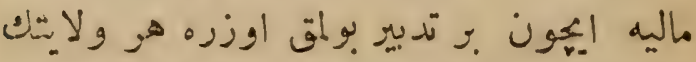

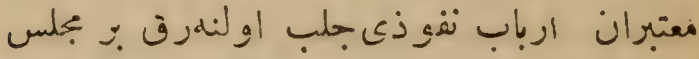

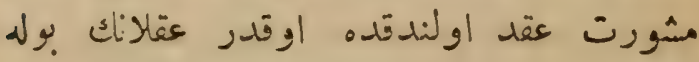

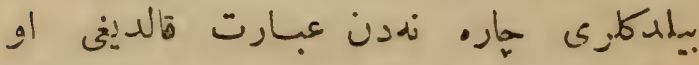

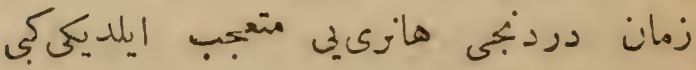

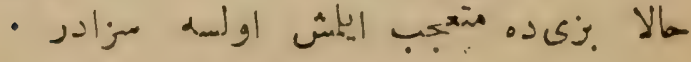

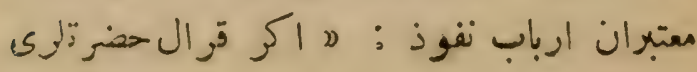


$-119$

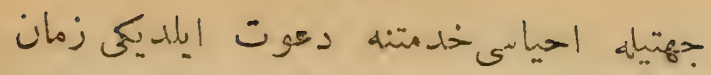

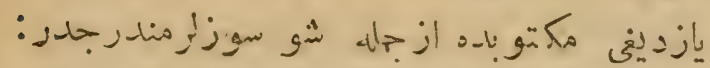

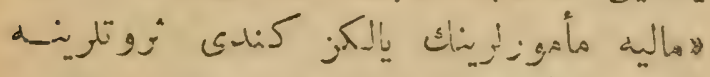

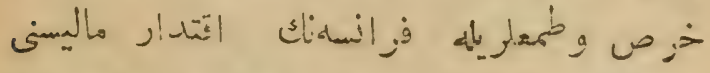

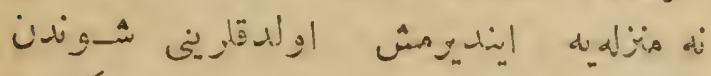

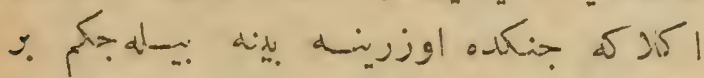

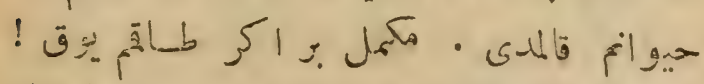

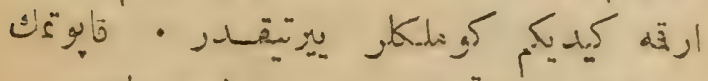

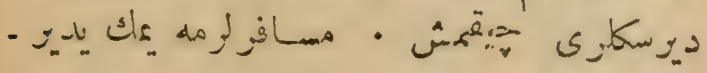

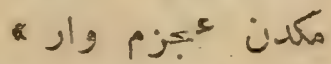

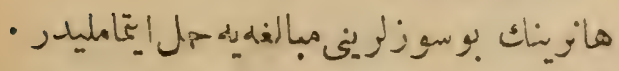

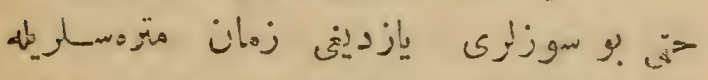

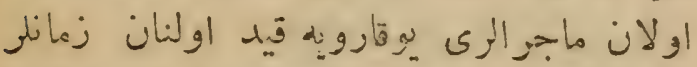

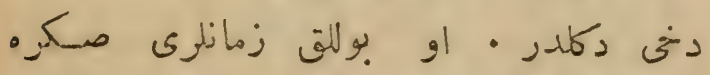

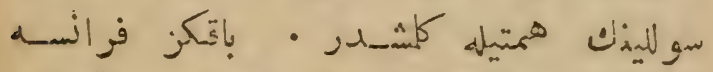

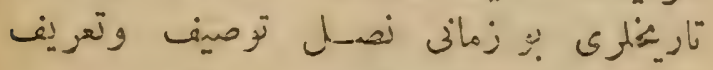

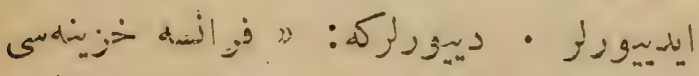

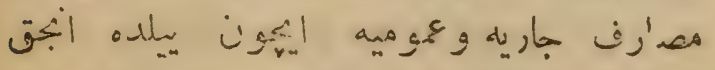

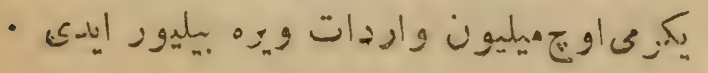


$-110-$

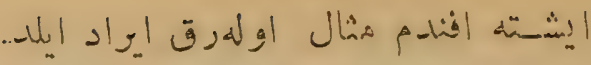

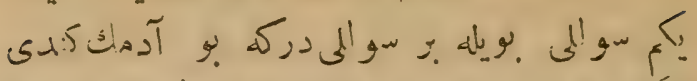

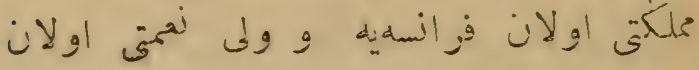

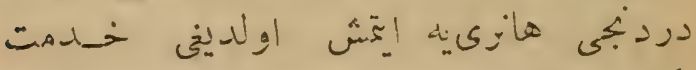

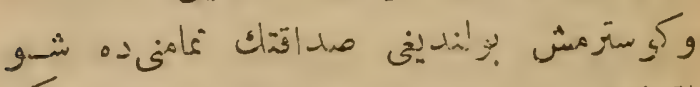

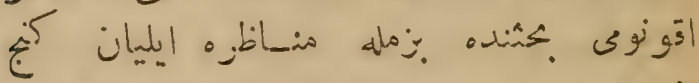

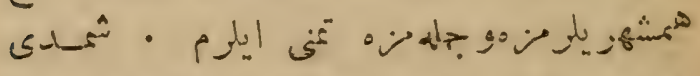

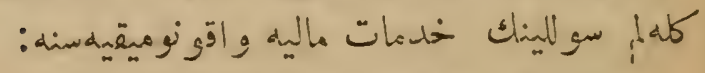

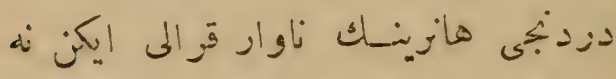

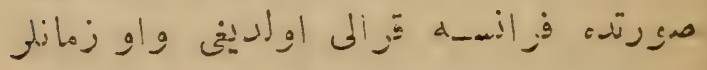

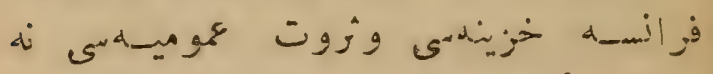

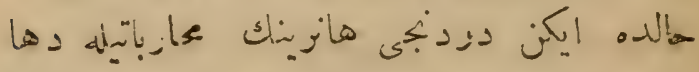

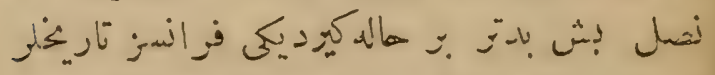

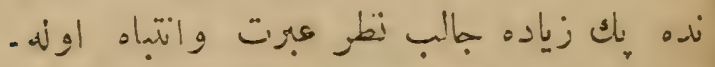

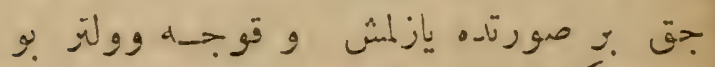

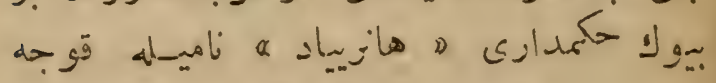

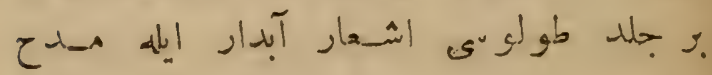

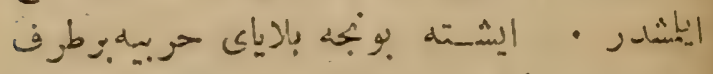

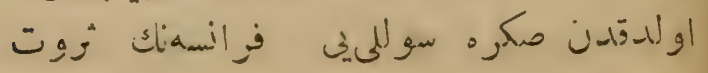


$-11 \varepsilon-$

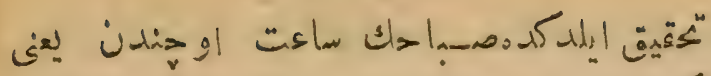

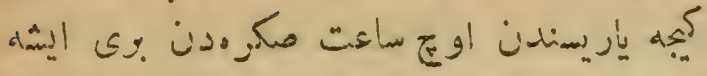

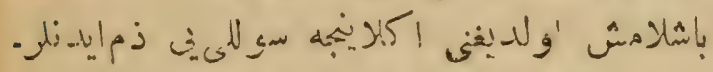

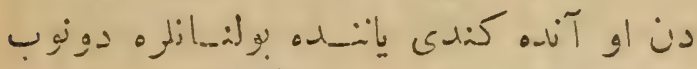

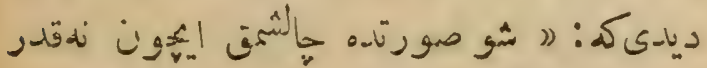

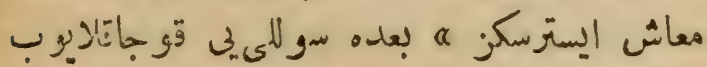

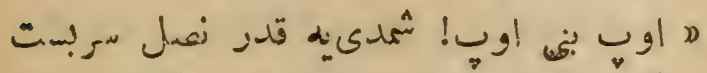

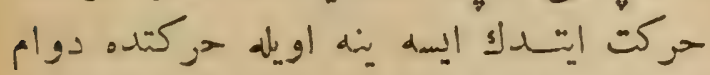

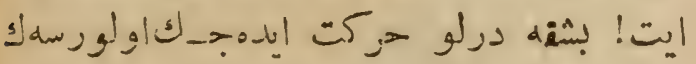

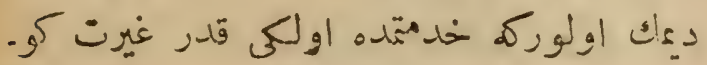

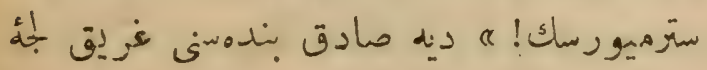

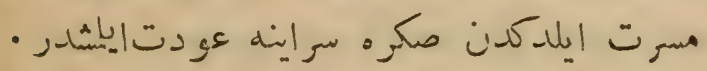

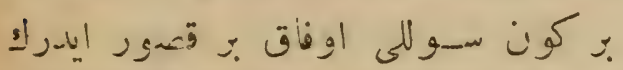

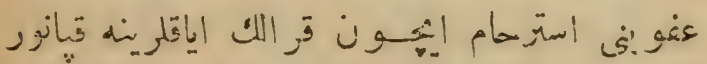

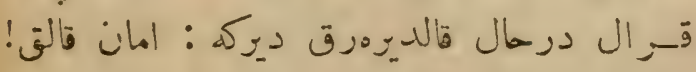

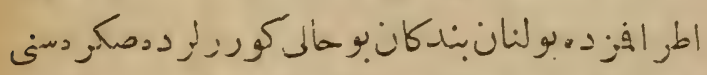

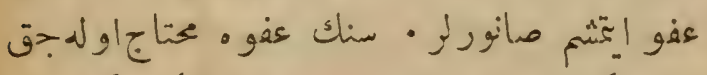

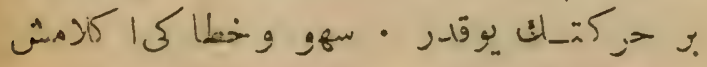

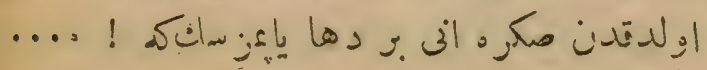




\section{$-114-$}

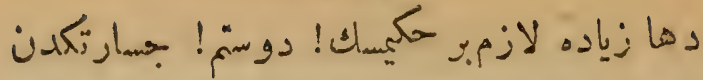

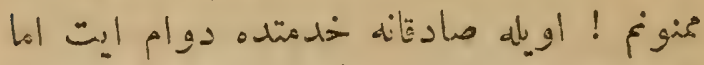

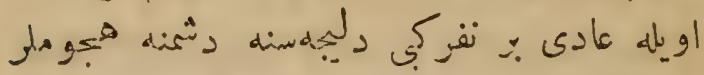

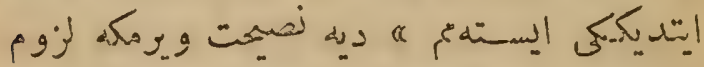

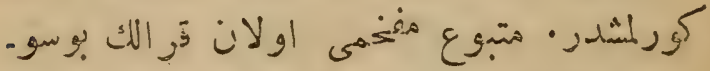

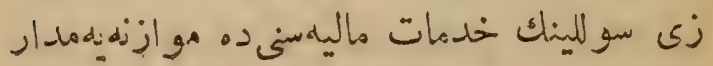

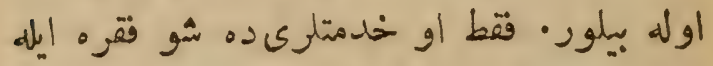
موازنه إيتليدر:

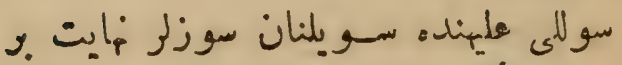

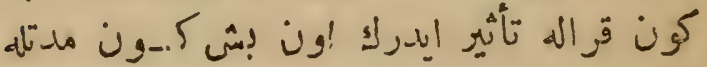

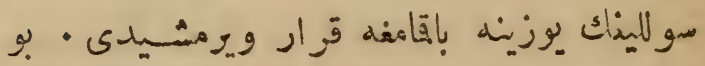

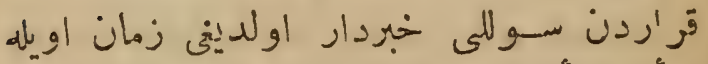

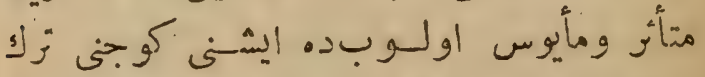

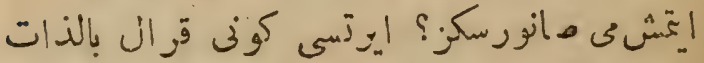

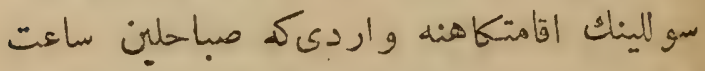

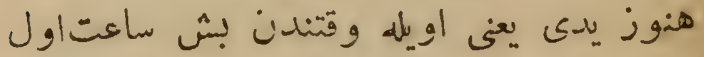

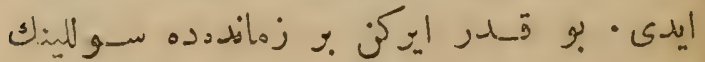

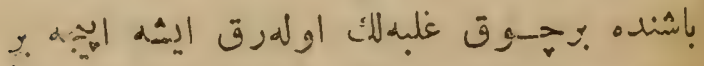

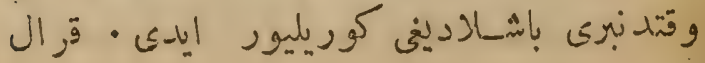




\section{$-114-$}

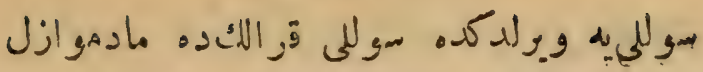

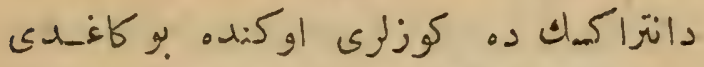

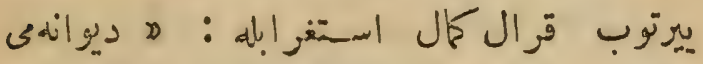

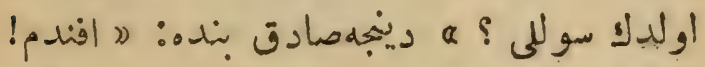

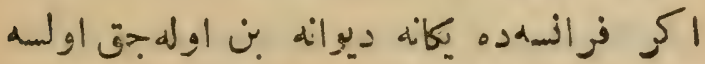

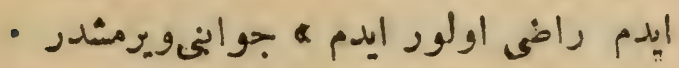

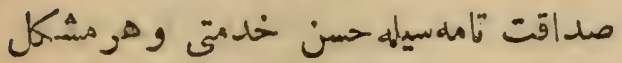

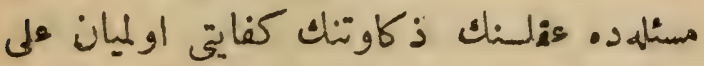

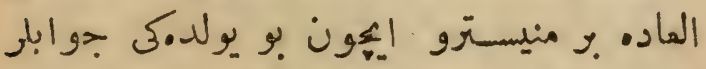

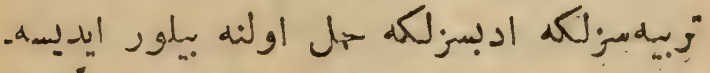

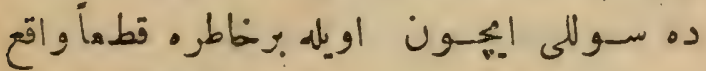

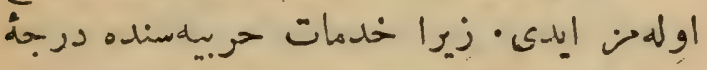

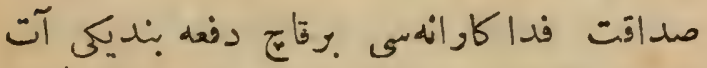

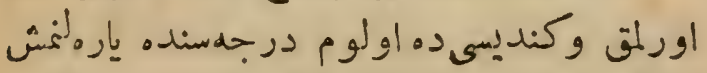

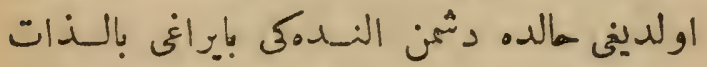

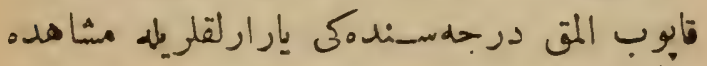

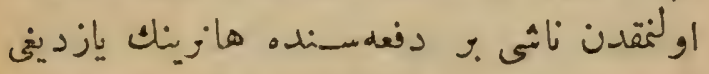

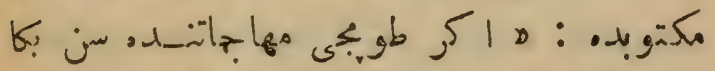

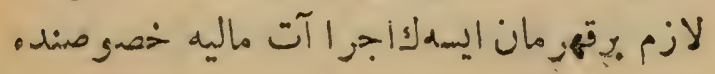




\section{$-111-$}

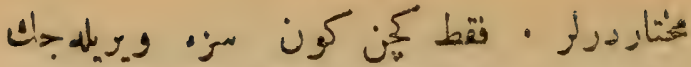

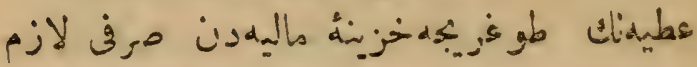

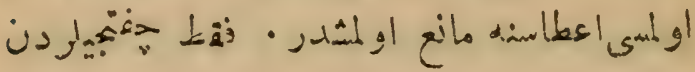

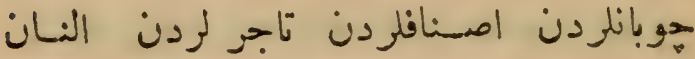

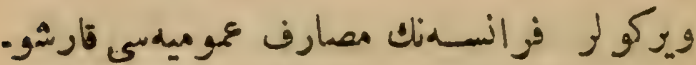

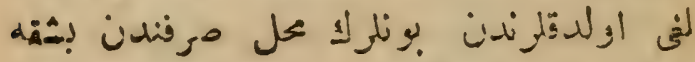

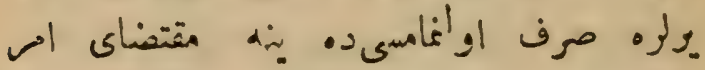

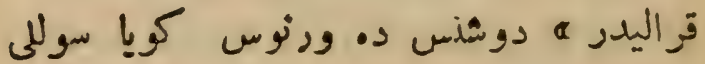

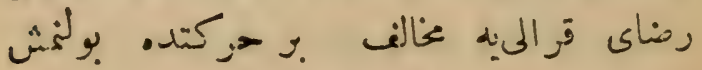

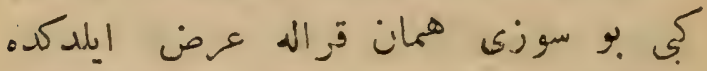

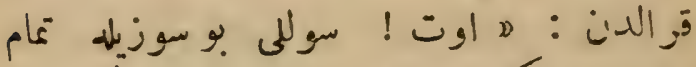

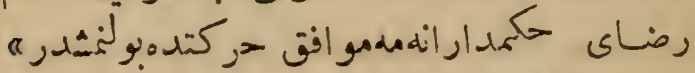

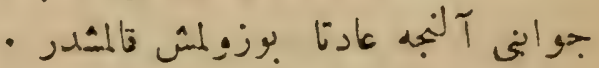

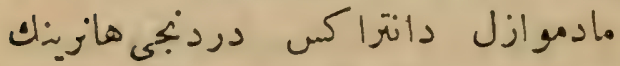

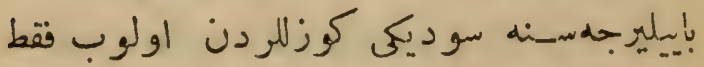

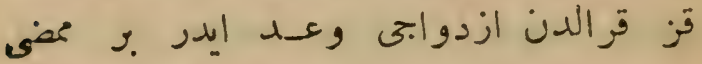

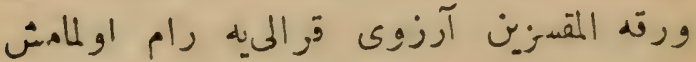

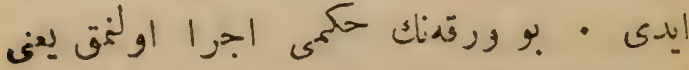

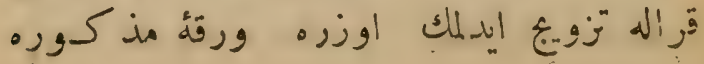




\section{$-11 \cdot$}

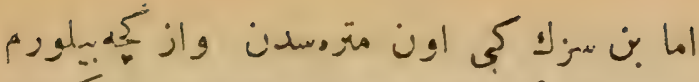

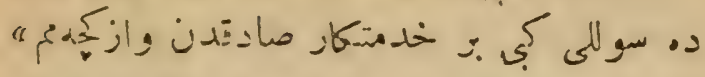

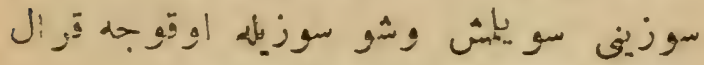

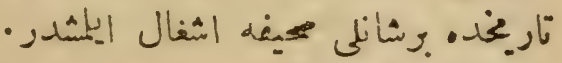

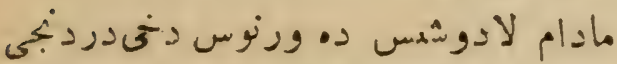

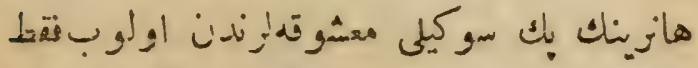

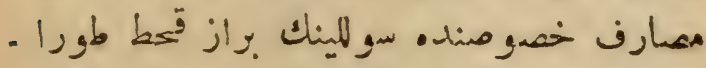

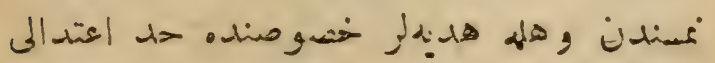

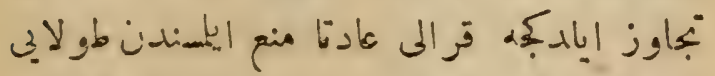

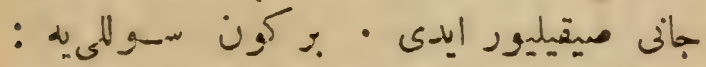

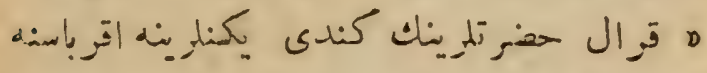

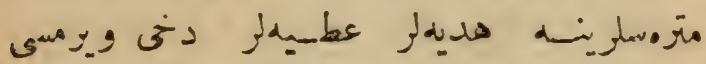

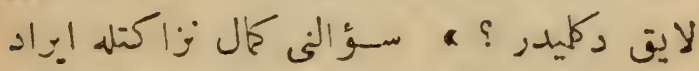

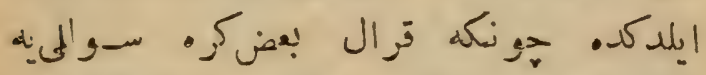

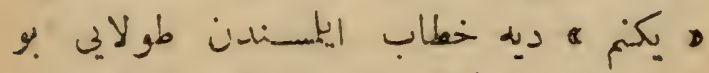

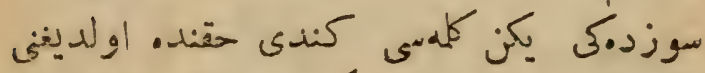

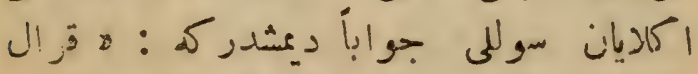

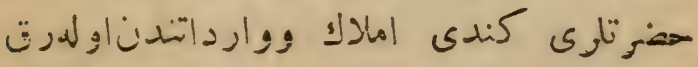

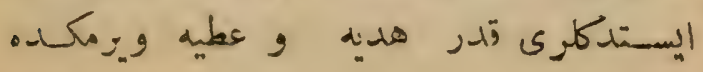




\section{$-1 \cdot 9$}

نقو ذلى اوقدرزياده ايدىكمايستدكلرى آدملرى

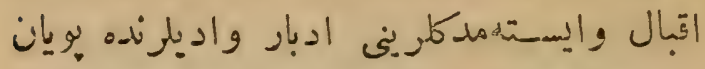

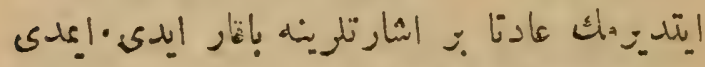

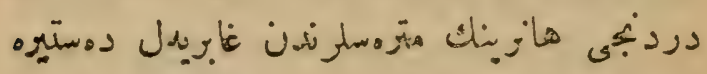

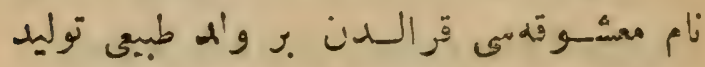

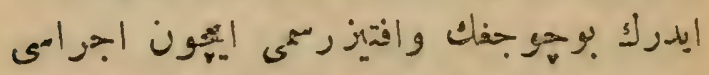

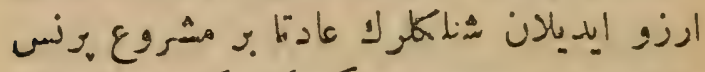

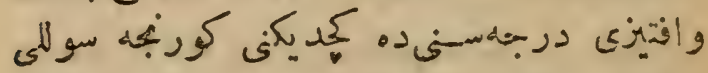

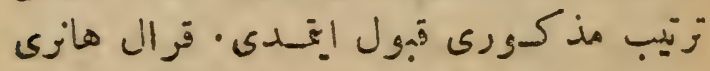

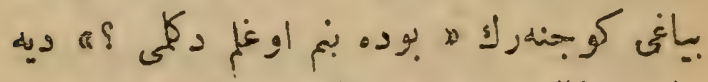

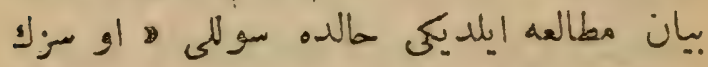

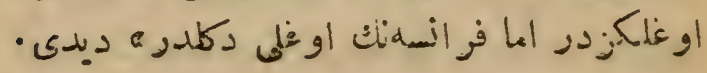

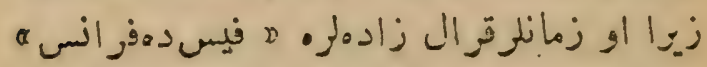

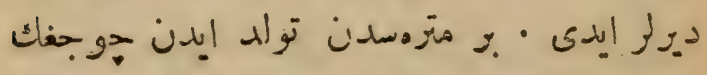

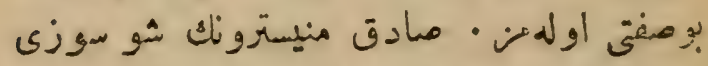

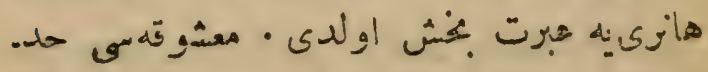

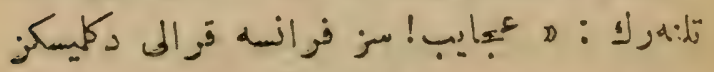

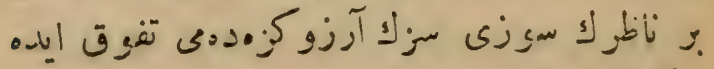

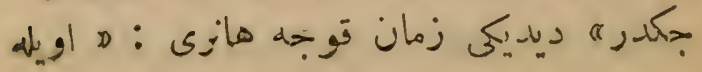




\section{$-1 \cdot 1-$}

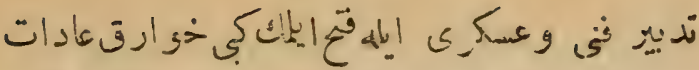

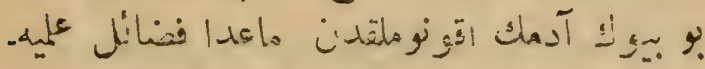

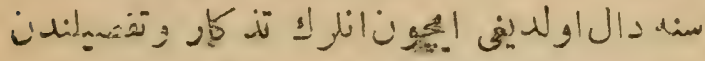

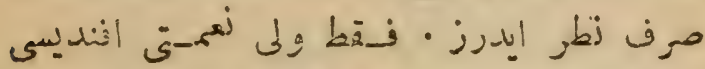

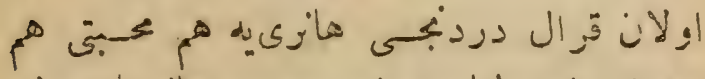

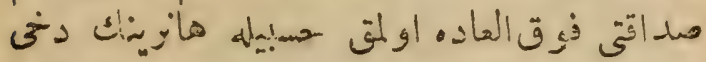

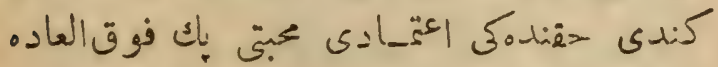

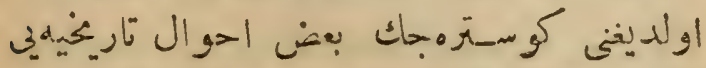

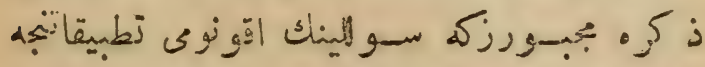

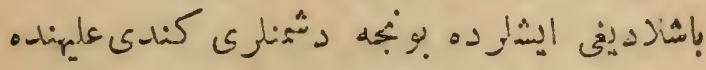

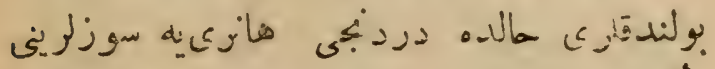

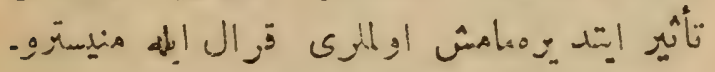

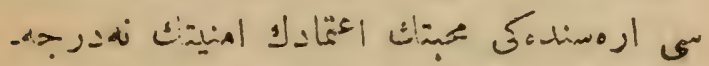

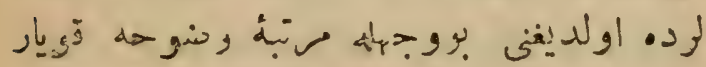

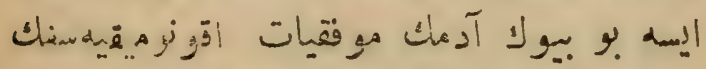

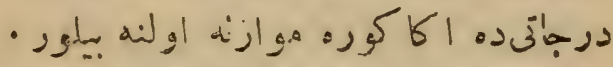

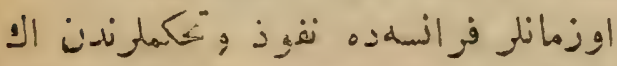

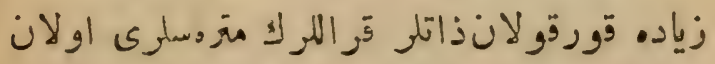

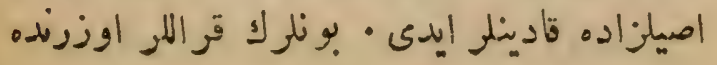




\section{$-1 \cdot V-$}

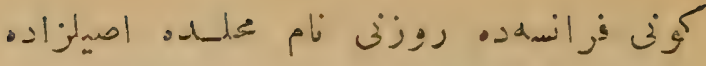

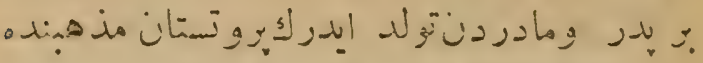

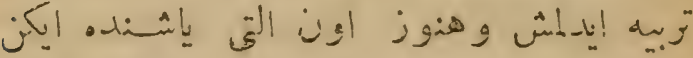

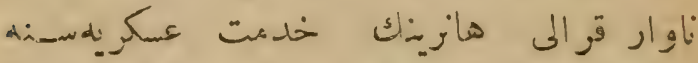

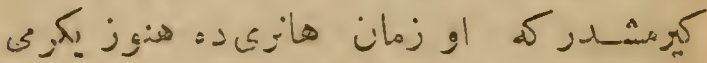

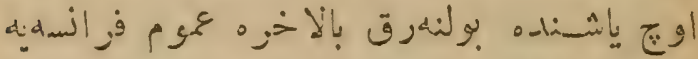

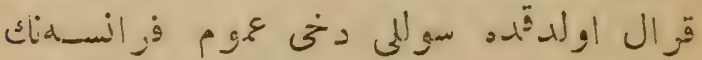

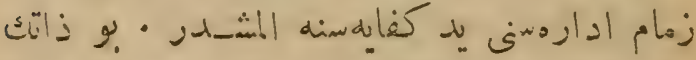

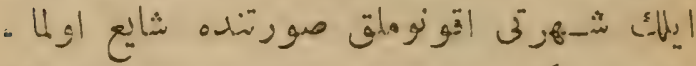

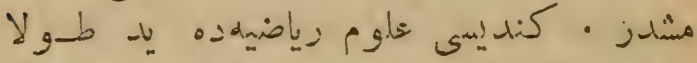

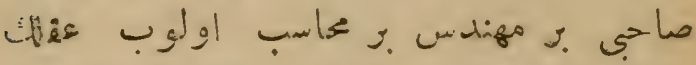

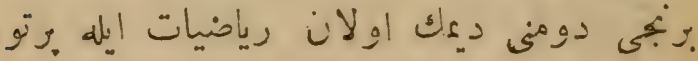

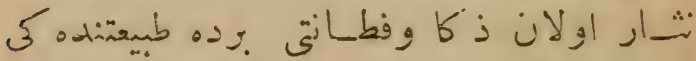

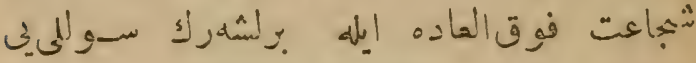

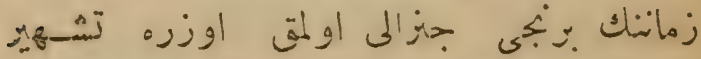

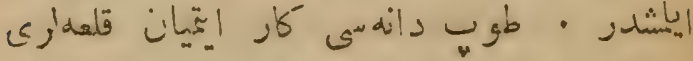

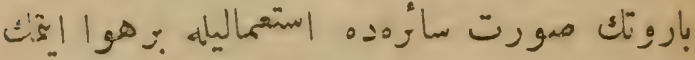

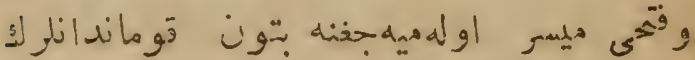

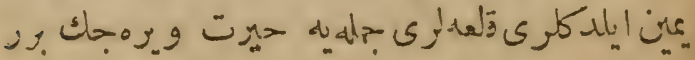




$$
-1 \cdot 9-
$$

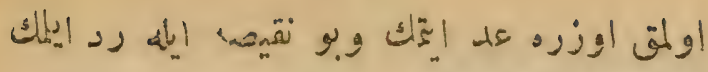

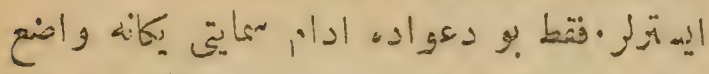

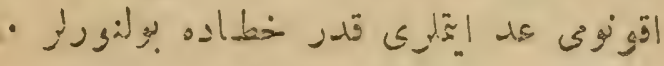

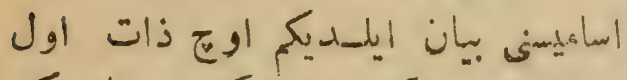

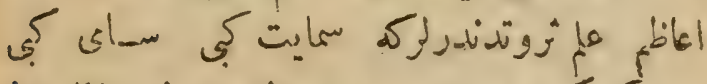

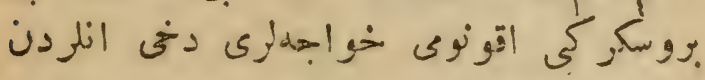

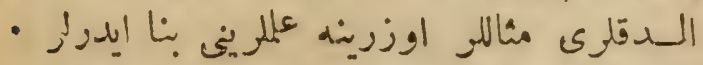

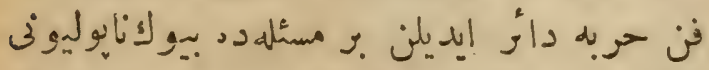

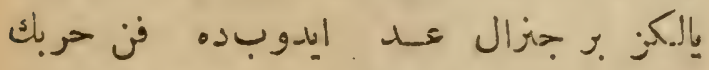

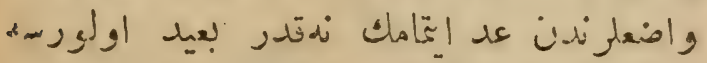

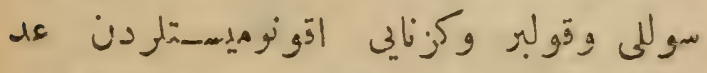

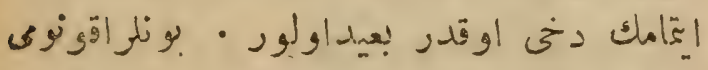

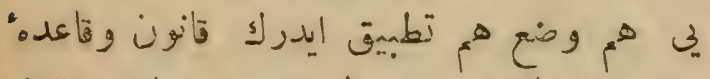

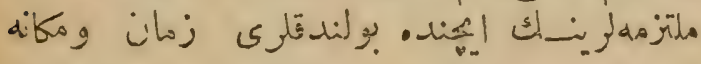

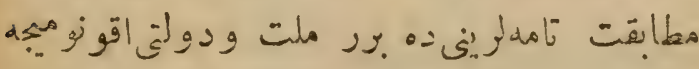

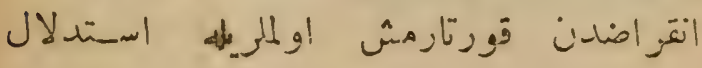

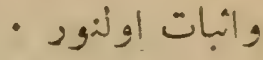

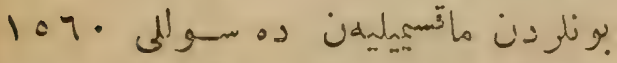

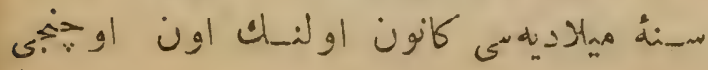




\section{$-1.0$}

البت بو نقيصه عد إتمزسكز •جيو نكمه مبادلهدينلن

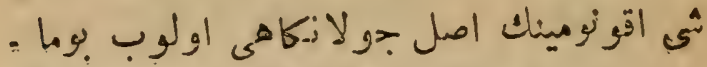

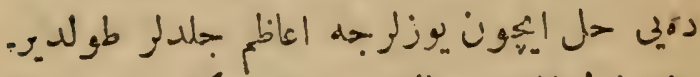

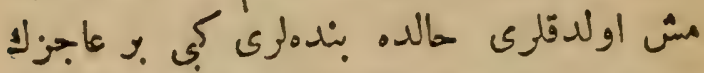

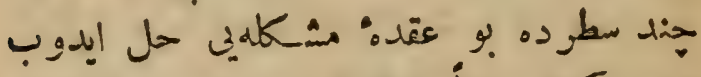

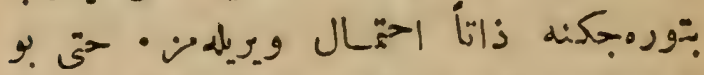

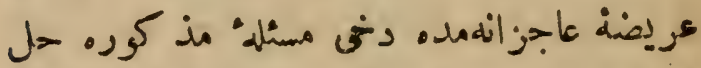

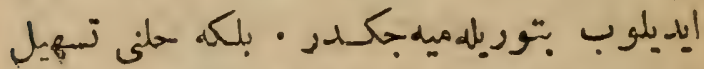

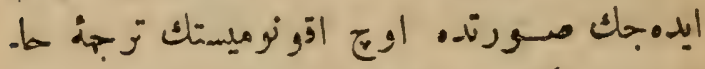

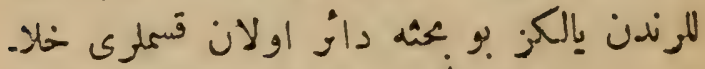

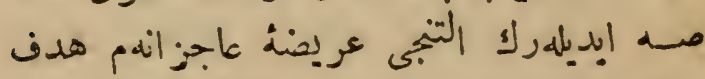

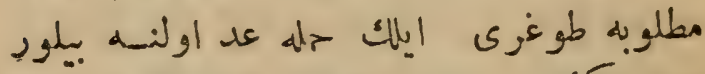

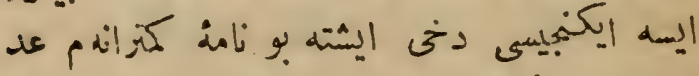

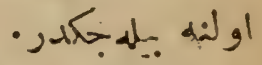

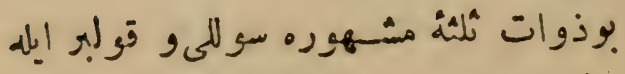

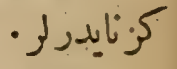

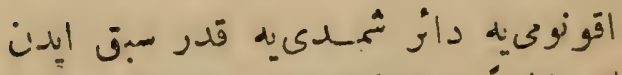

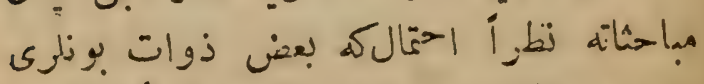

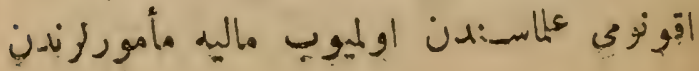


$-1 . \xi-$

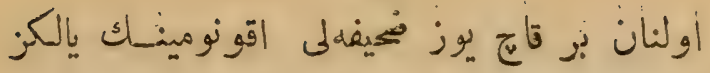

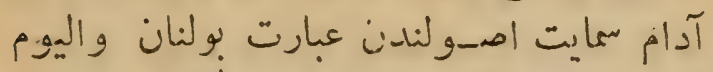

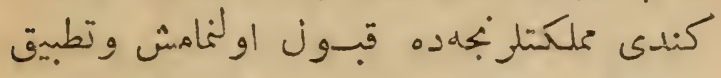

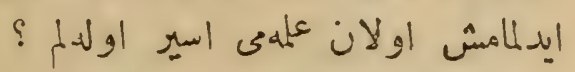

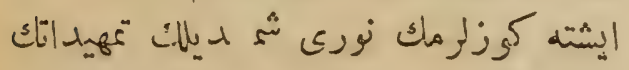

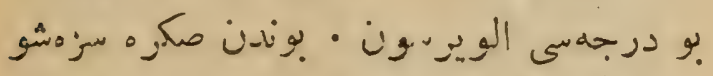

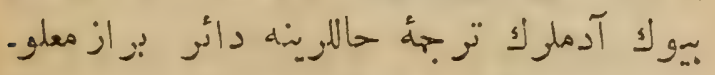

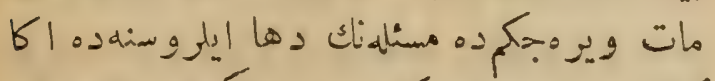

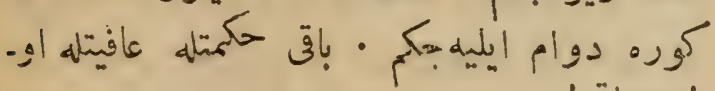
له سرنبانق!

احد مدحت

بـ

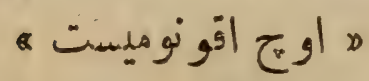

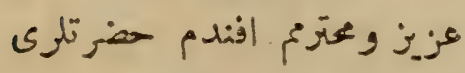

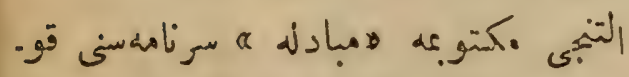

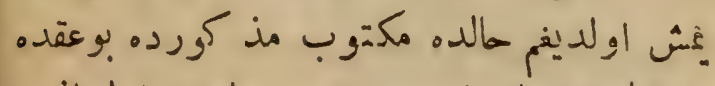

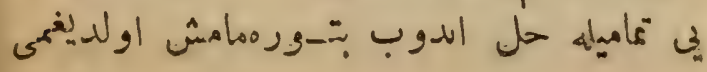




\section{$-1 \cdot r$}

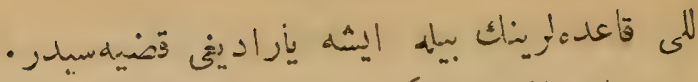

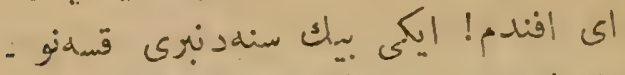

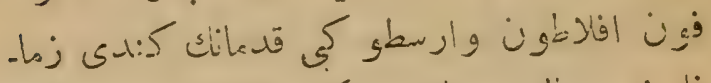

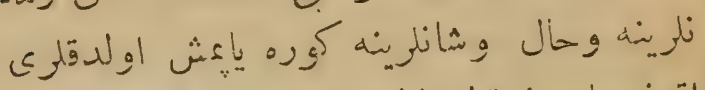

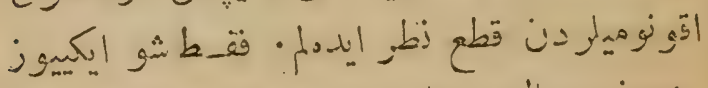

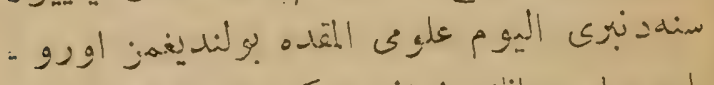

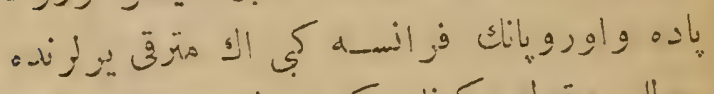

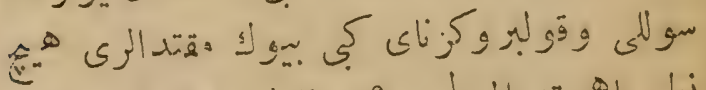

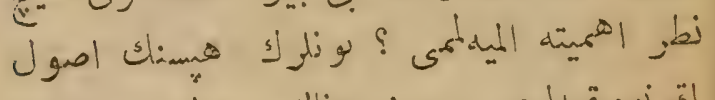

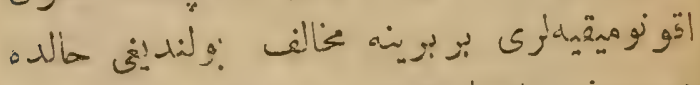

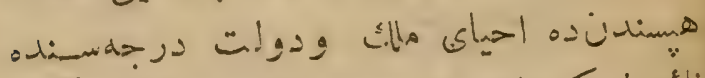

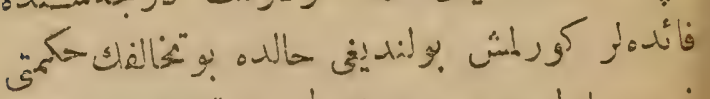

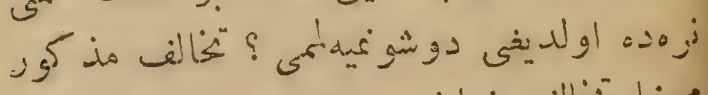

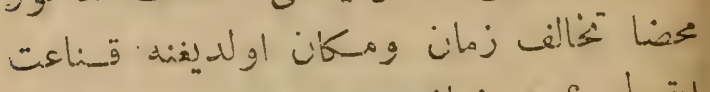

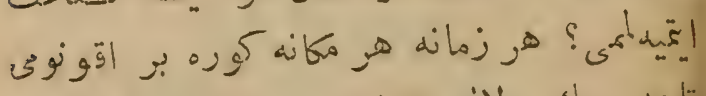

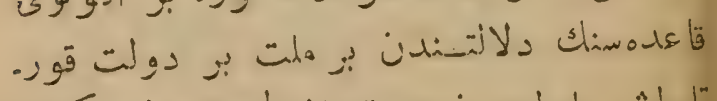

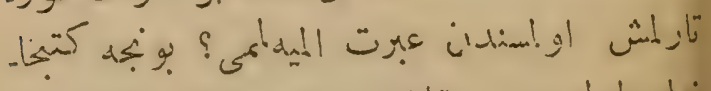

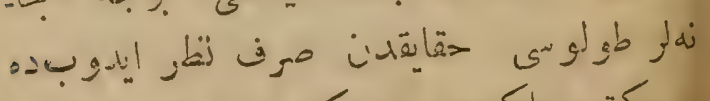

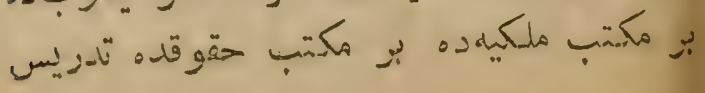




\section{$-1 \cdot r-$}

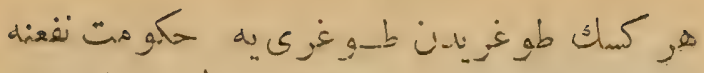
اليشليه ج大كلرى

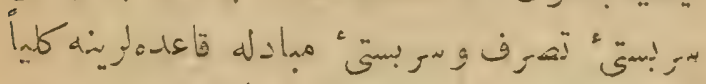

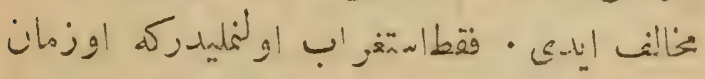

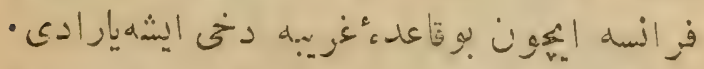

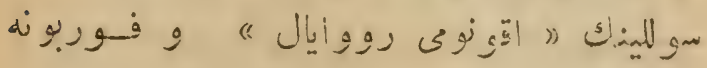

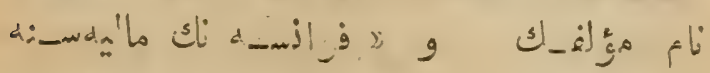

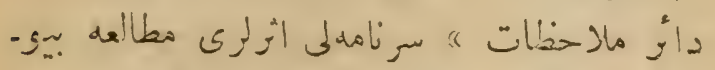

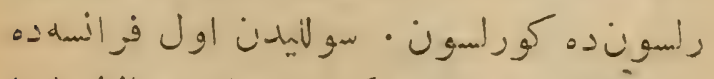

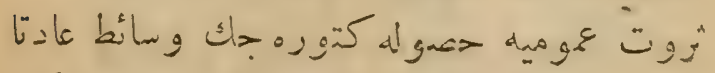

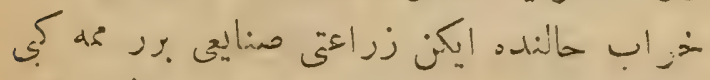

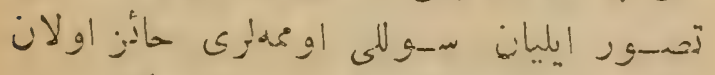

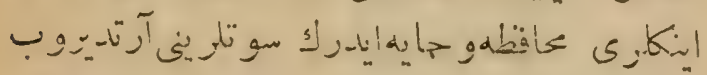

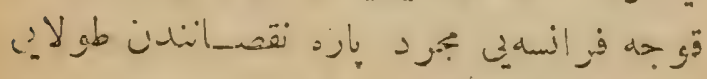

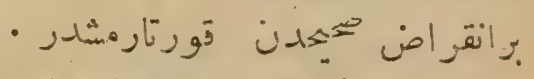

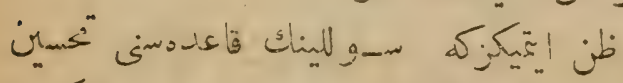

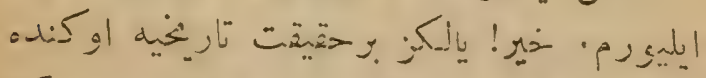

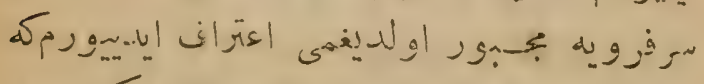

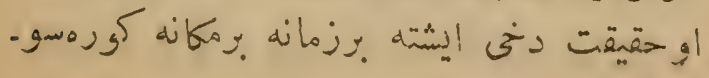




\section{$-1 \cdot 1$}

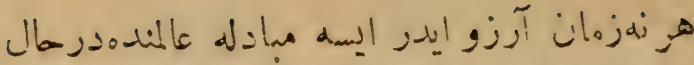

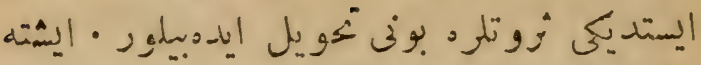

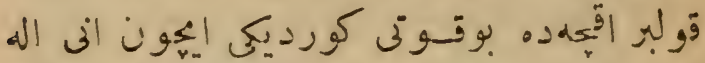

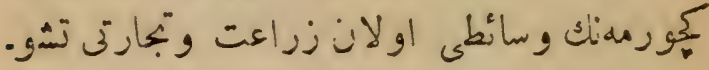

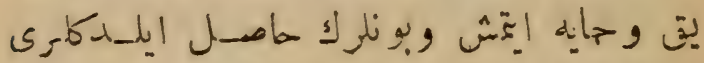

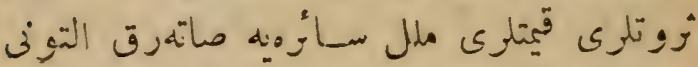

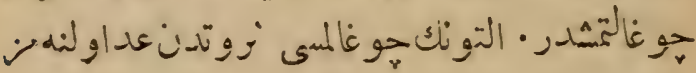

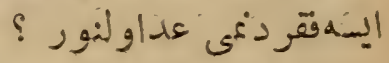

قولبر دوخى اساس مسلكينده سو للى بيه مخا.

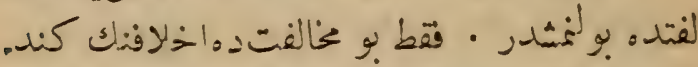

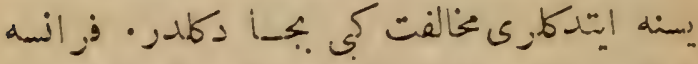

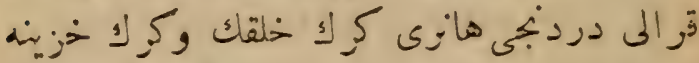

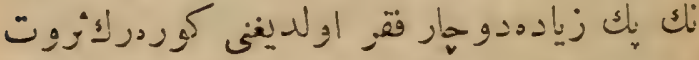

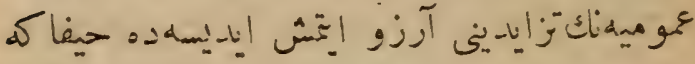

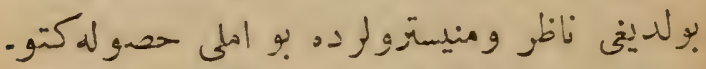

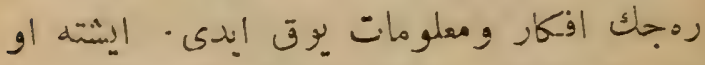

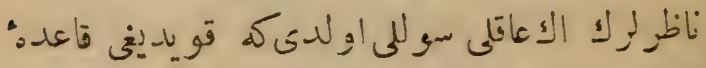

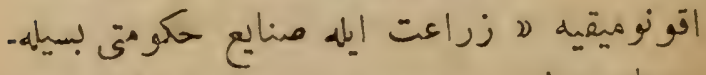

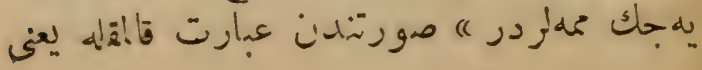




\section{$-1 \cdots-$}

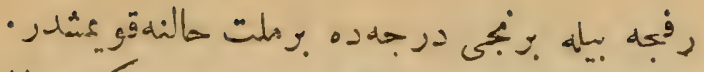

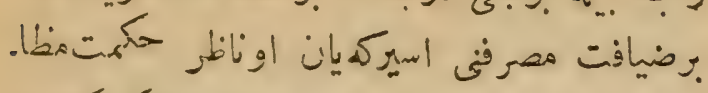

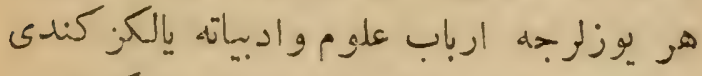

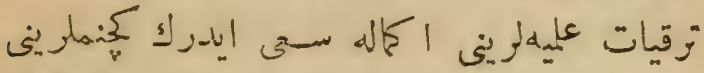

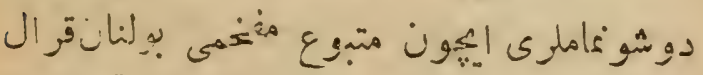

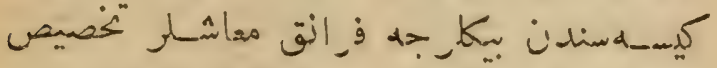

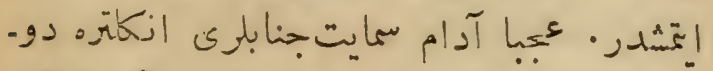

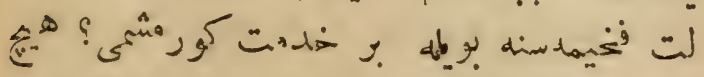

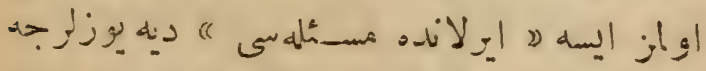

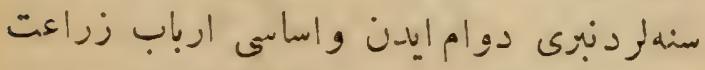

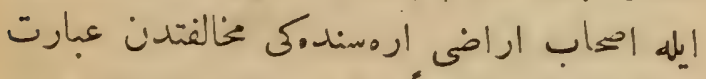

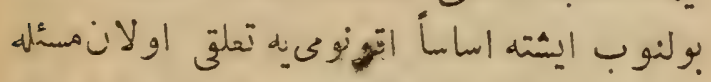

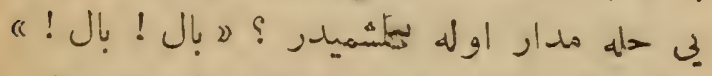

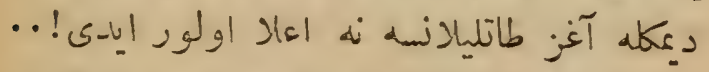

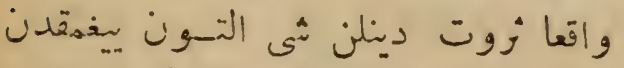

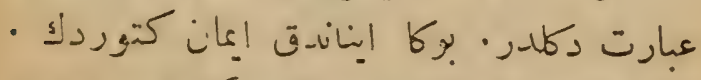

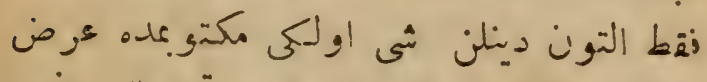

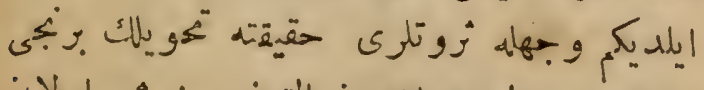

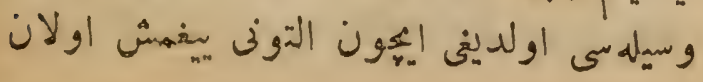




\section{- $99-$}

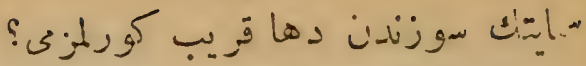

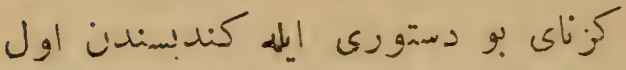

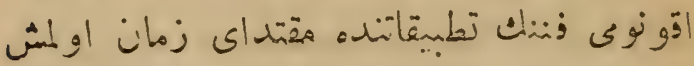

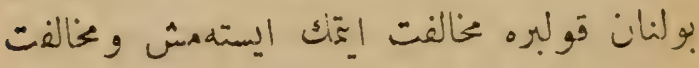

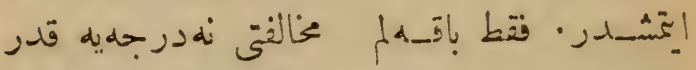

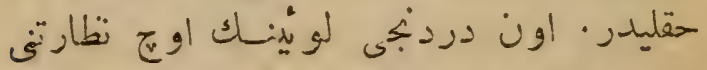

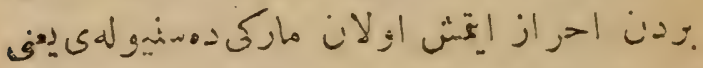

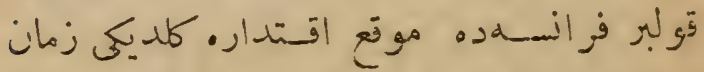

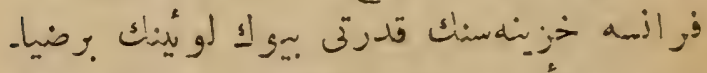

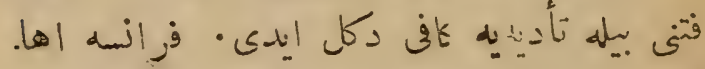

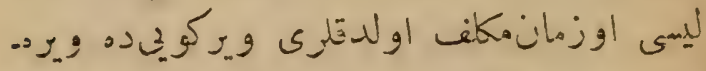

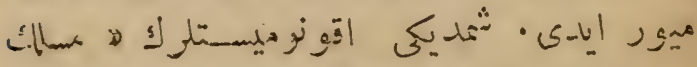

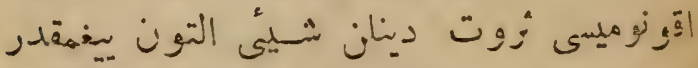

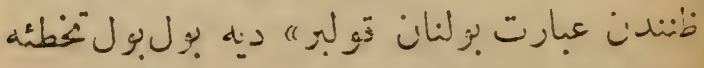

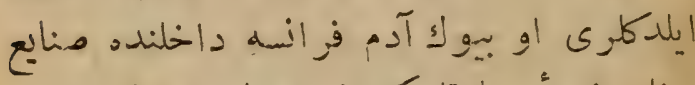

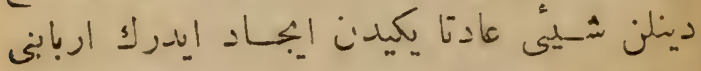

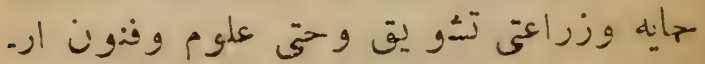

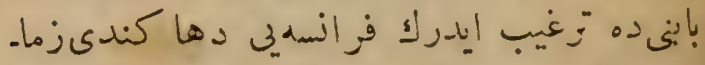

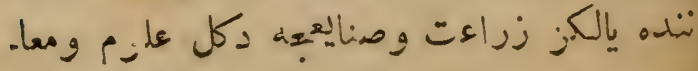


- $91-$

غالطر دولتلرنده قالمش ايسه ايثته بو سـوز

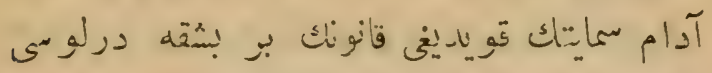

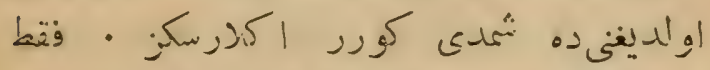

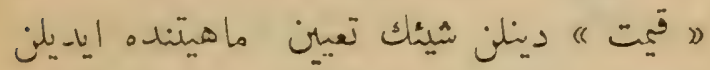

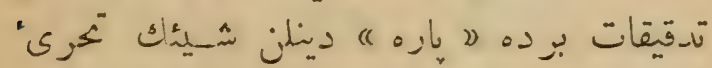

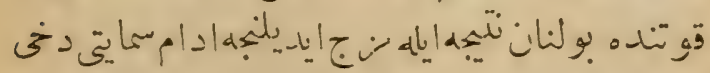

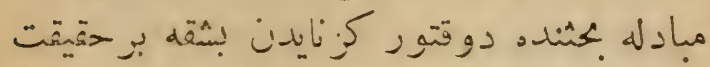

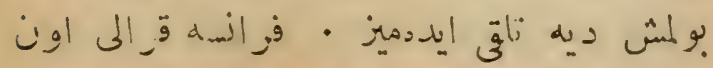

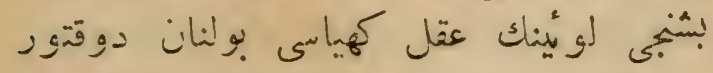

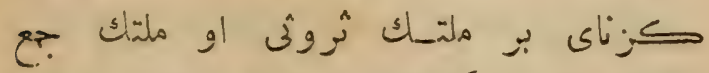

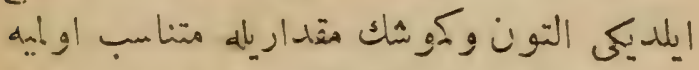

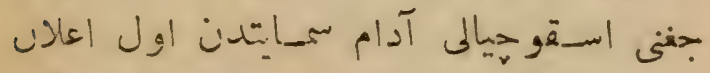

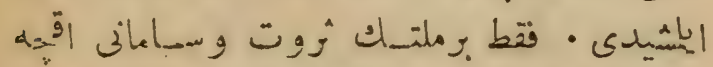

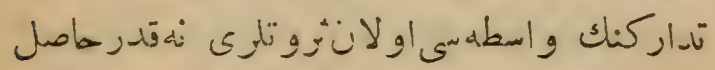

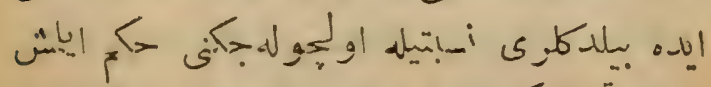

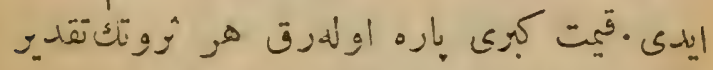

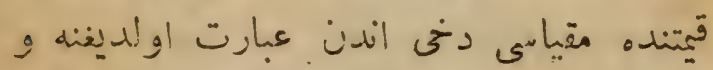

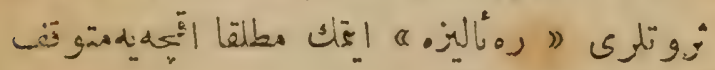

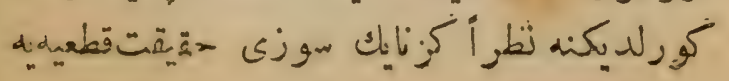




\section{- $q v$ -}

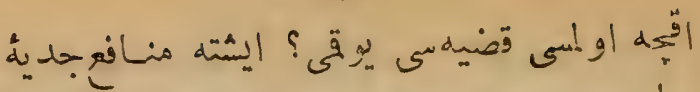

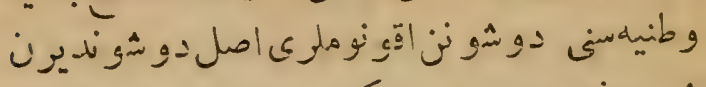

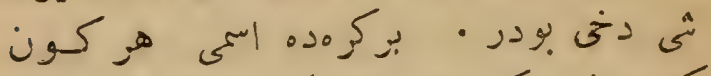

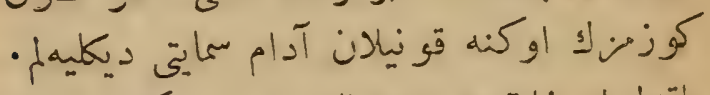

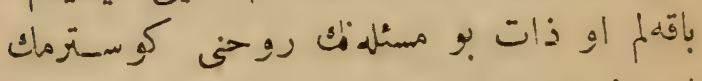

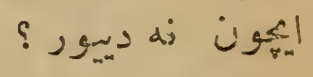

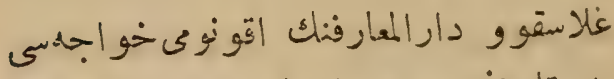

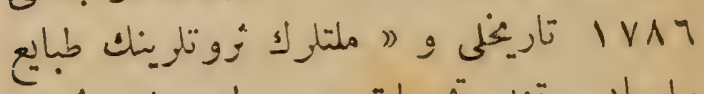

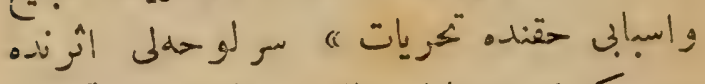

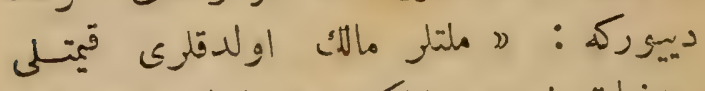

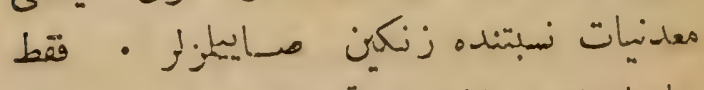

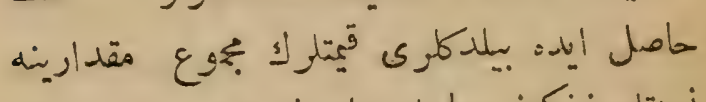

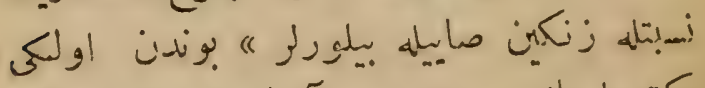

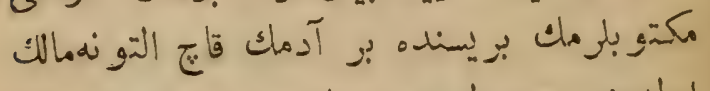

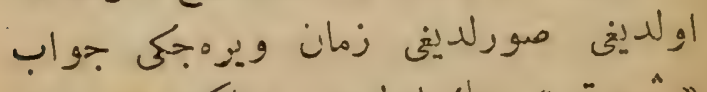

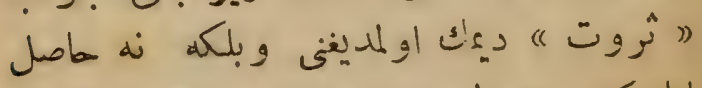

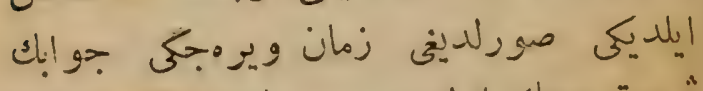

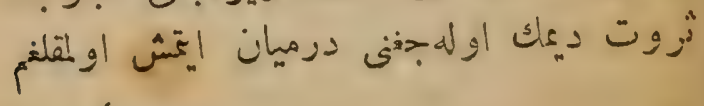




\section{$-89$}

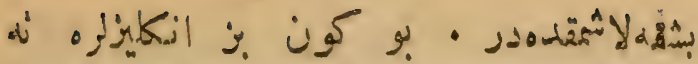

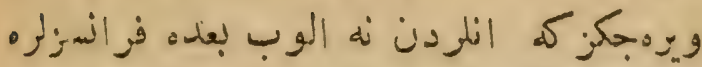

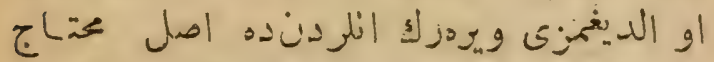

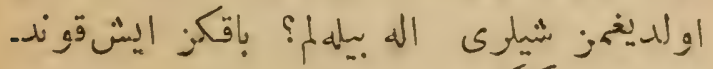

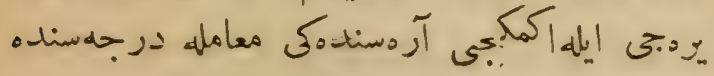

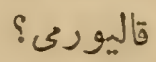

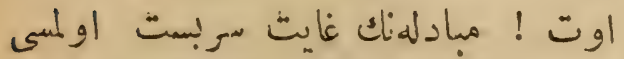

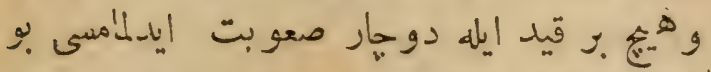

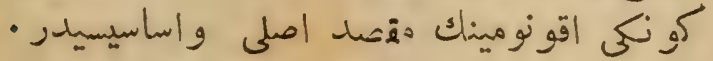

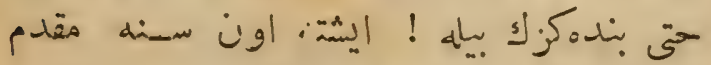

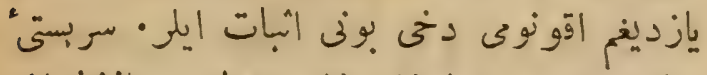

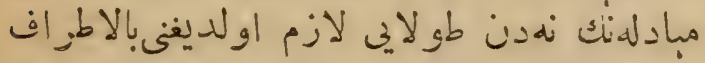

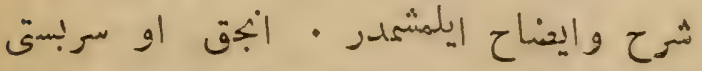

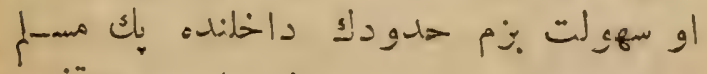

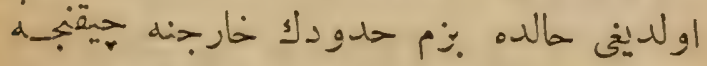

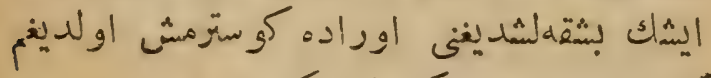

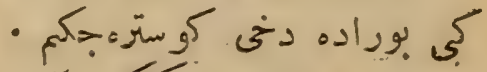

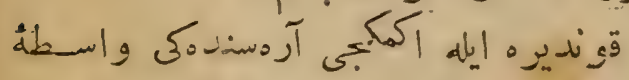

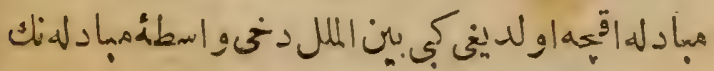


$-90-$

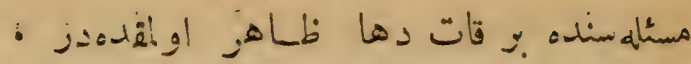

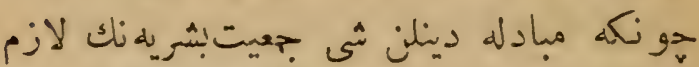

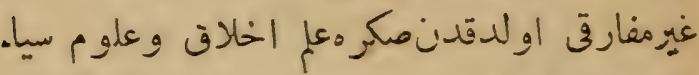

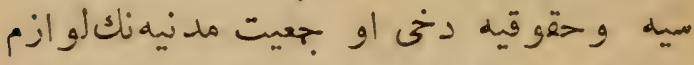

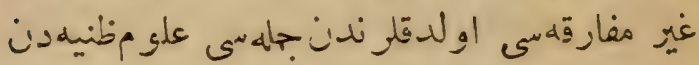

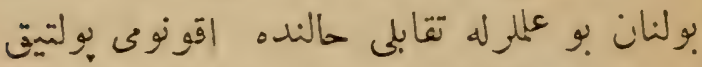

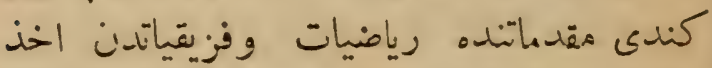

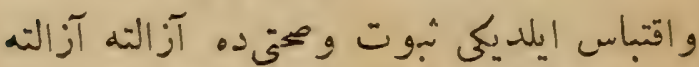

•

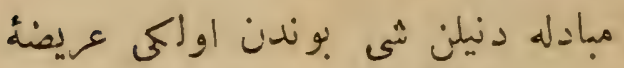

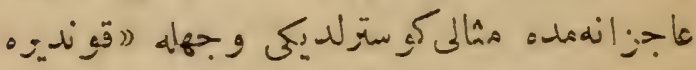

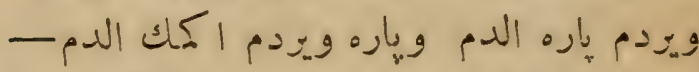

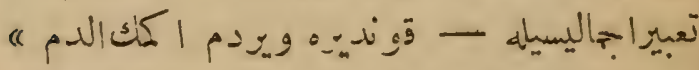

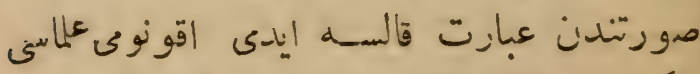

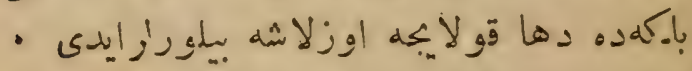

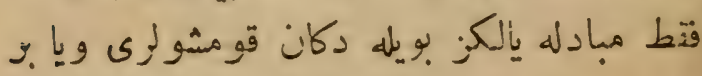

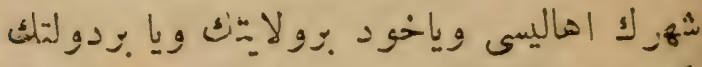

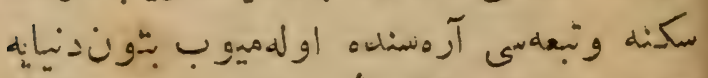

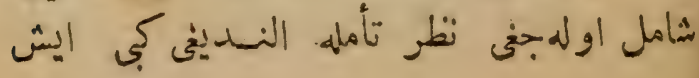




\section{- $9 \varepsilon-$}

دن عبارتندر • زيرا مهاذله سوز جعيت مدنيه

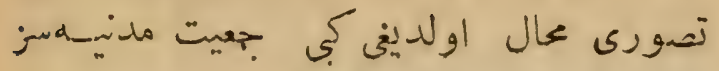

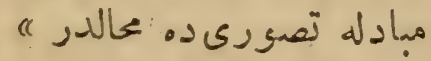

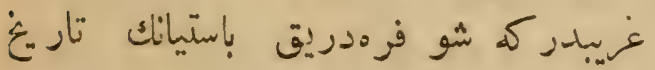

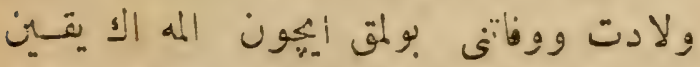

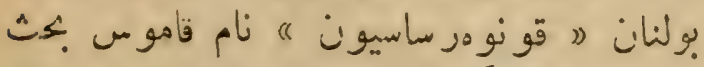

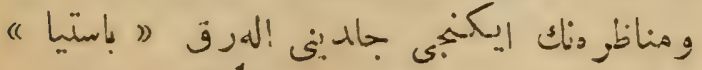

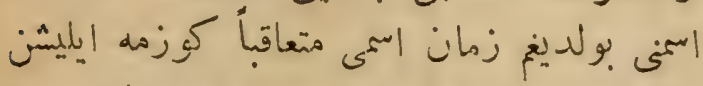

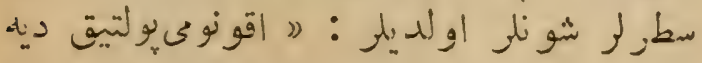

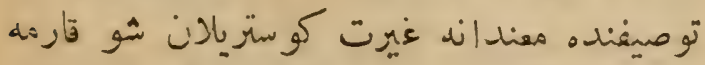

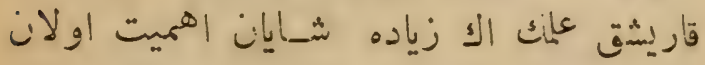

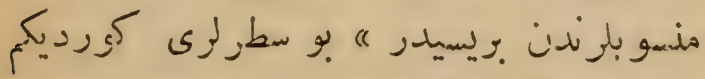

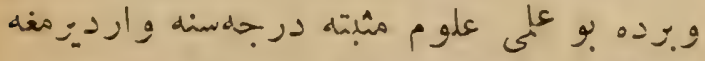

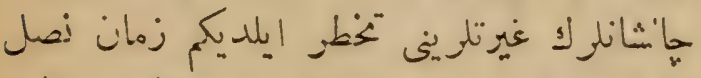

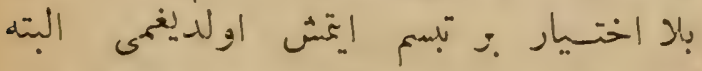

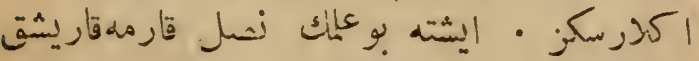

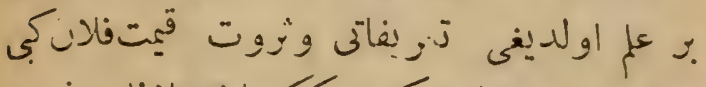

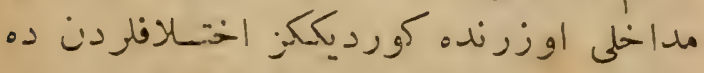

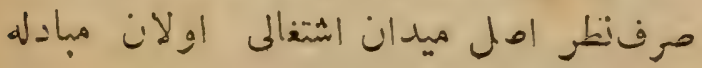




\section{$-q \pi-$}

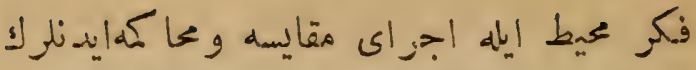

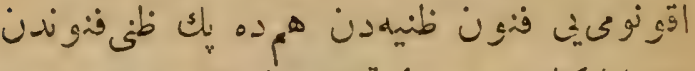

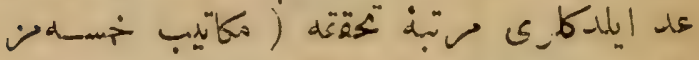

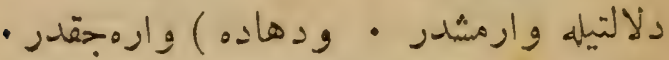

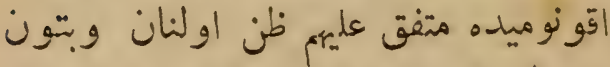

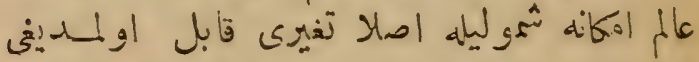

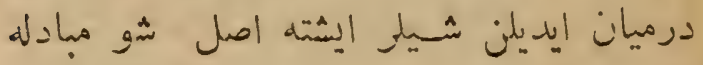

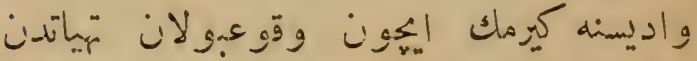

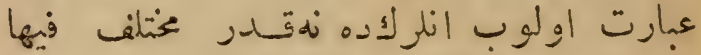

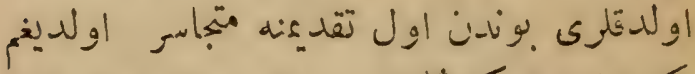

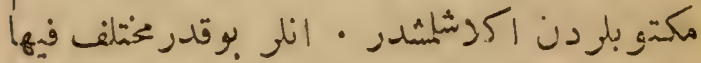

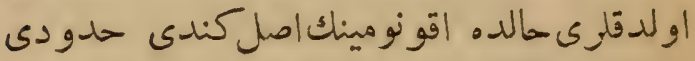

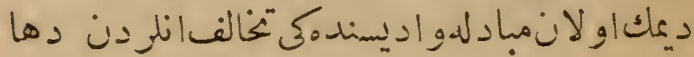

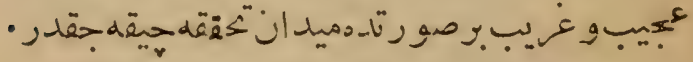

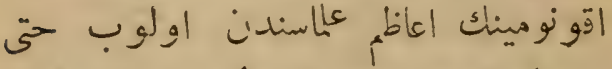

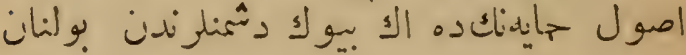

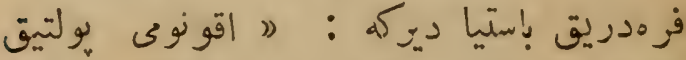

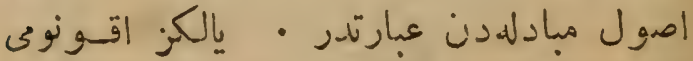
بوليقيق دكل جعيت مدنيه وانسانيد بيله مهادله 
- ar -

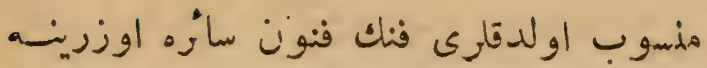

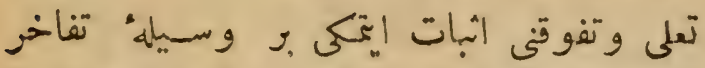

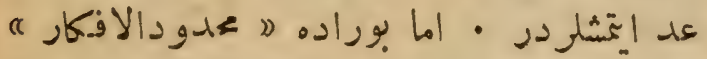

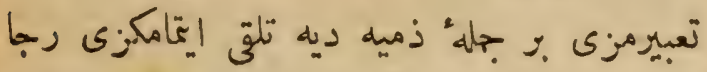

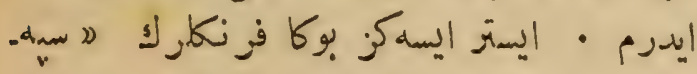

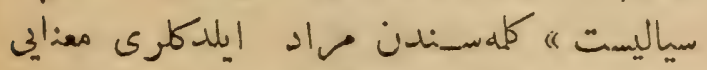

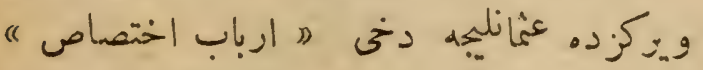

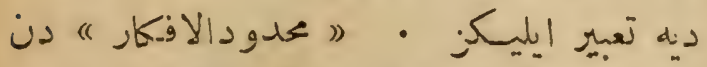

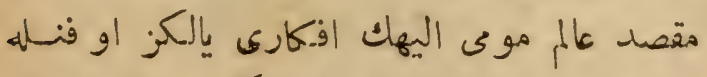

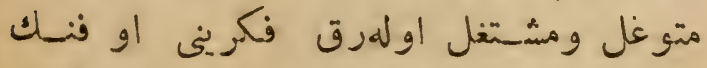

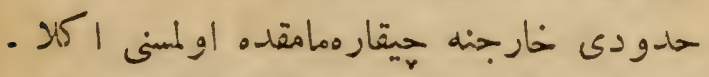

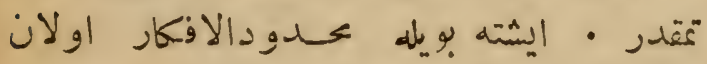

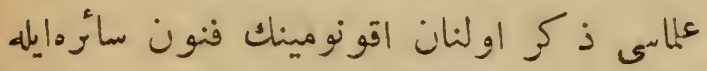

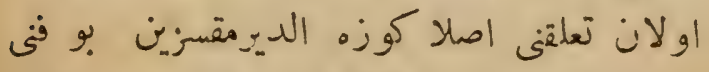

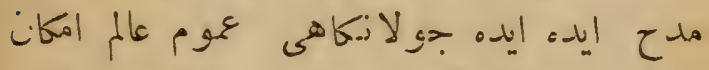

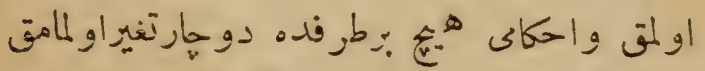

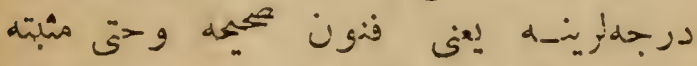

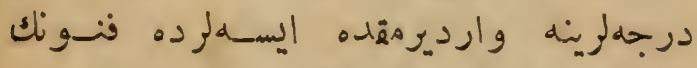

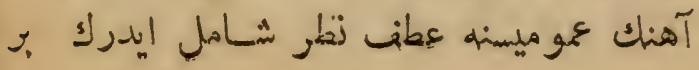


$-91-$

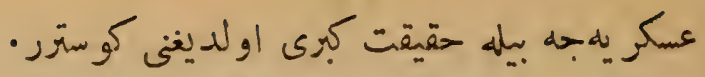

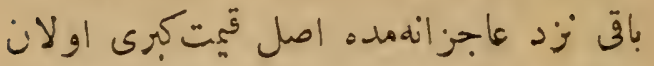

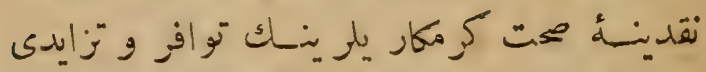

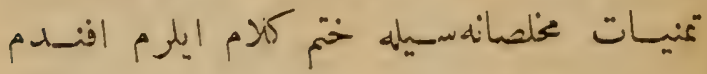

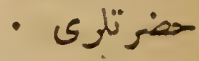

الحdo

التجنى a disto

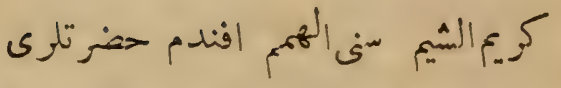

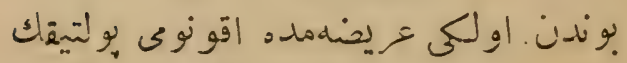

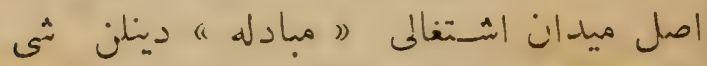

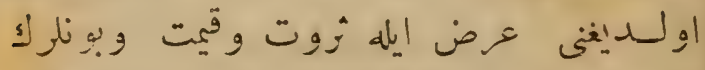

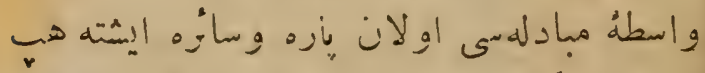

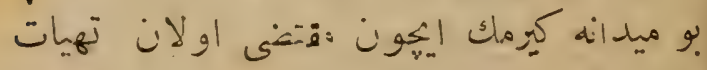

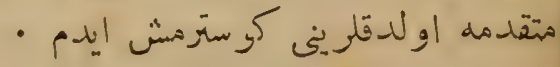

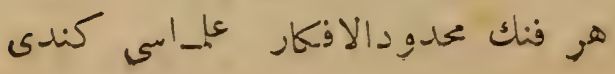




\section{- $9 \cdot-$}

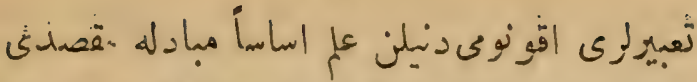

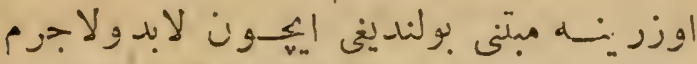

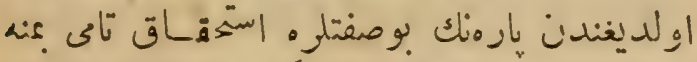

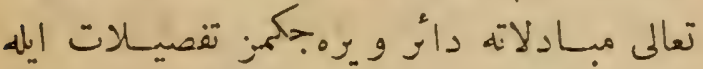

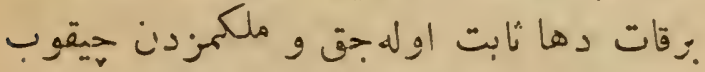

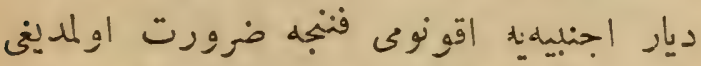

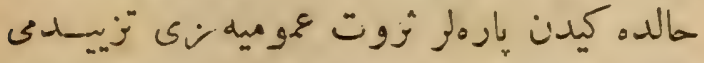

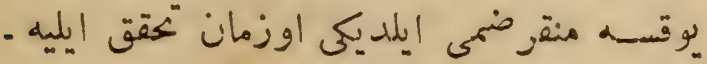
•

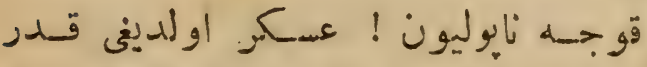

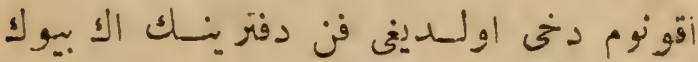

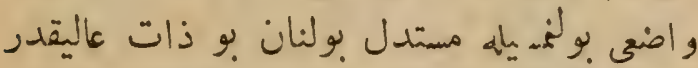

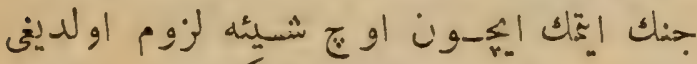

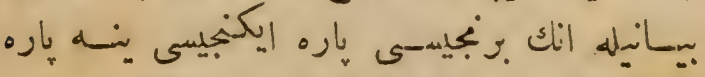

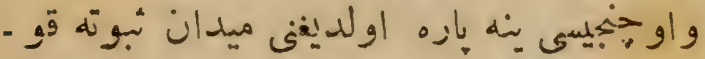

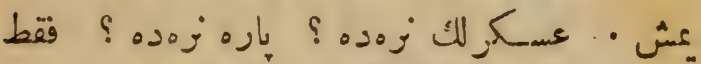

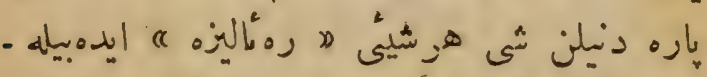

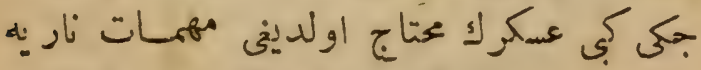

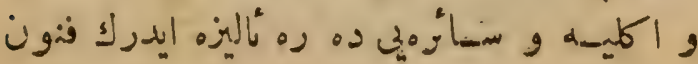




\section{- 19}

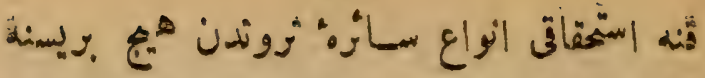

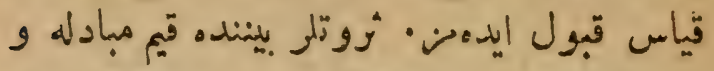

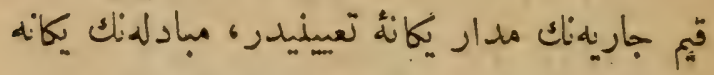

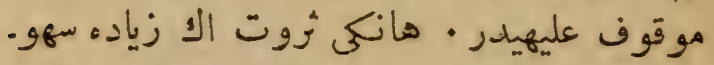

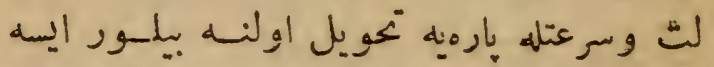

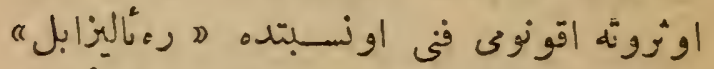

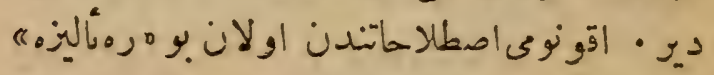

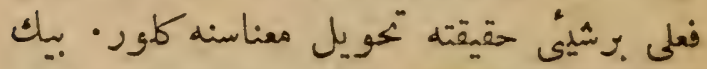

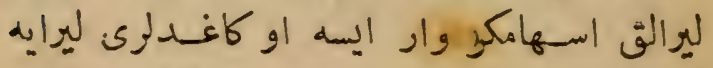

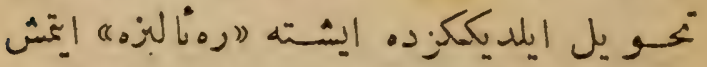

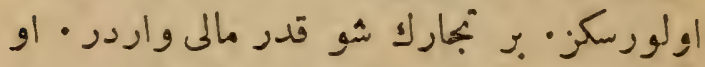

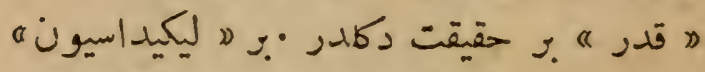

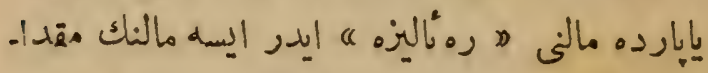

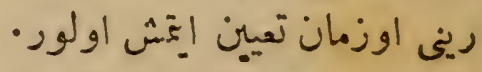

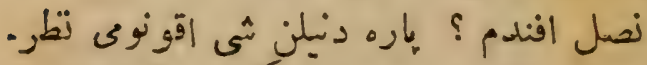

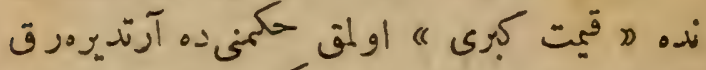

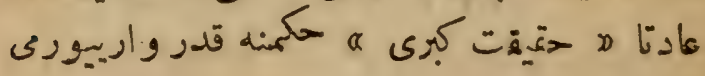

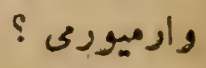

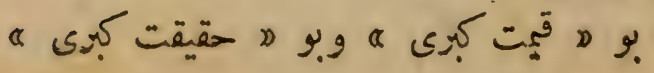




\section{$-\lambda \lambda$}

وبو تمدر فلانجه عناصرى حاوى اولان سبهدرد

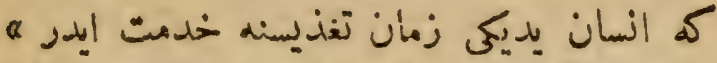

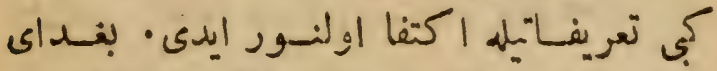

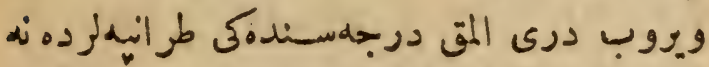

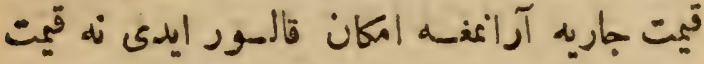

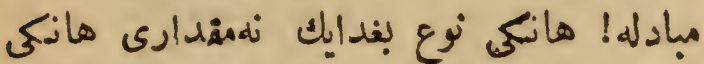

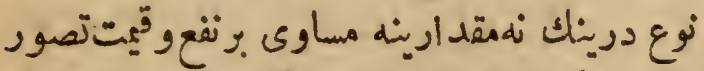

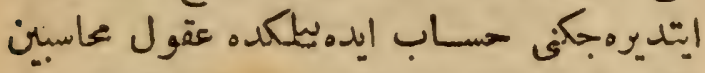

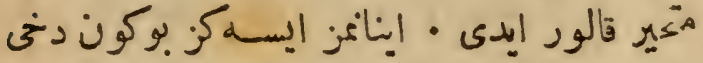

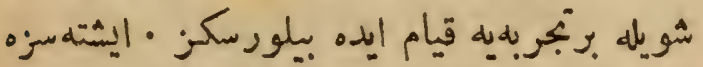

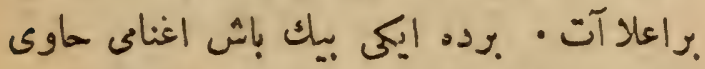

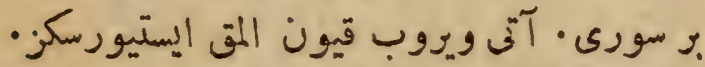

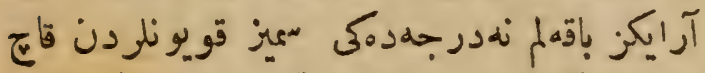

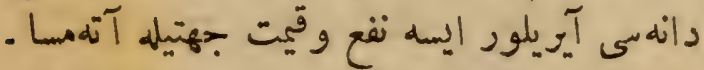

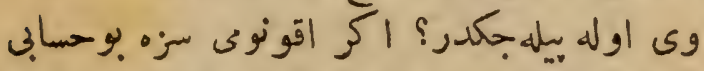

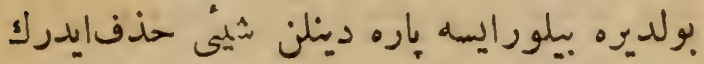

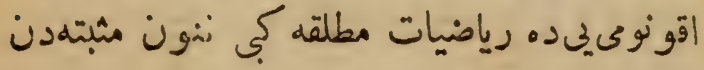
عد ايلرز - عارئن باره قيت كبرادر افندمن! ”زوت ه اطلاه 


\section{$-\lambda Y-$}

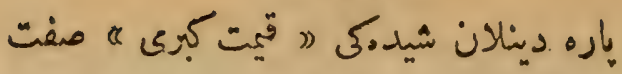

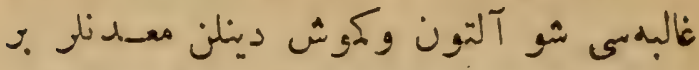

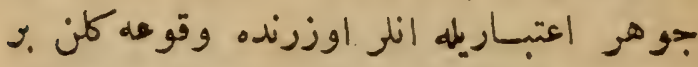

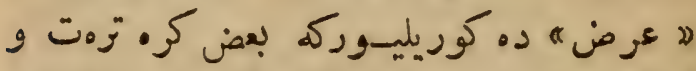

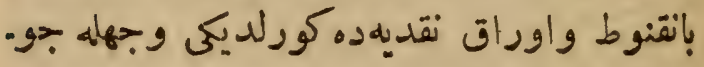

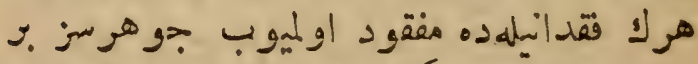

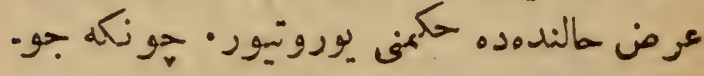

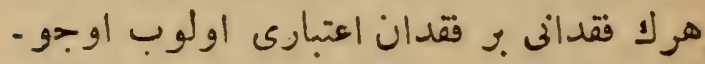

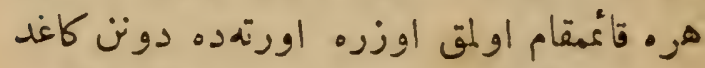

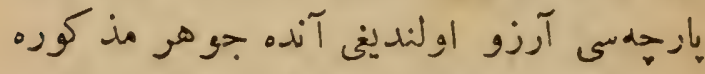

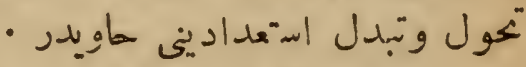

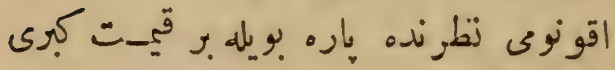

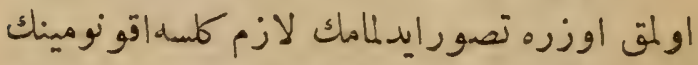

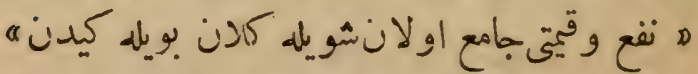

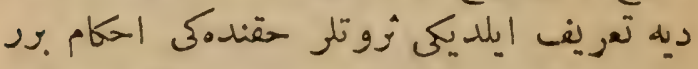

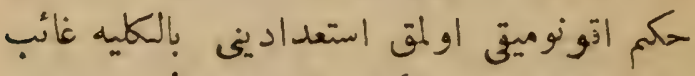

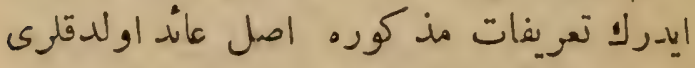

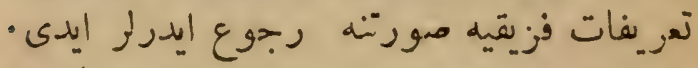

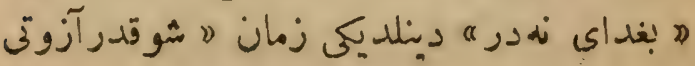




\section{$-\lambda 9-$}

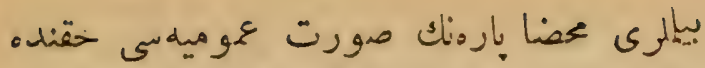

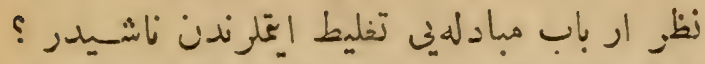

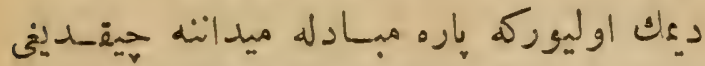

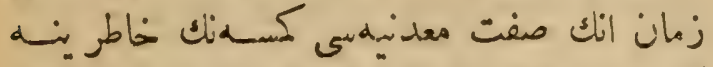

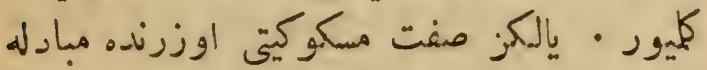

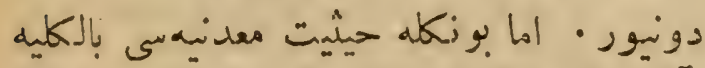

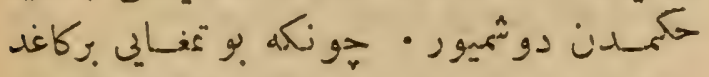

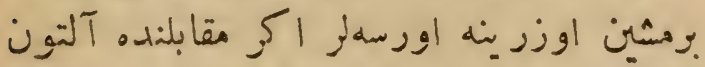

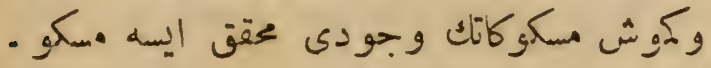

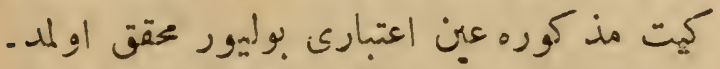

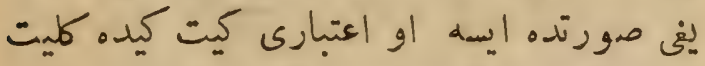

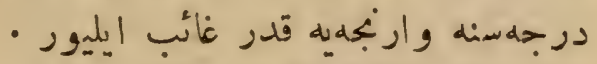

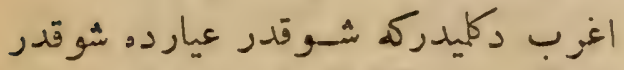

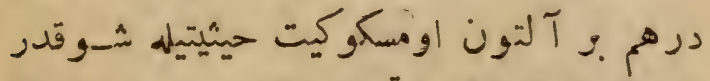

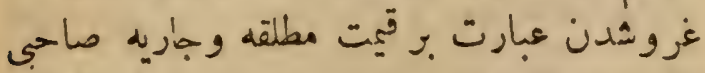

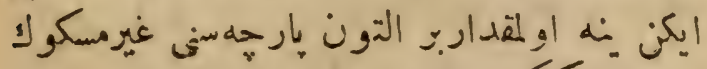

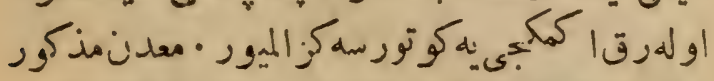

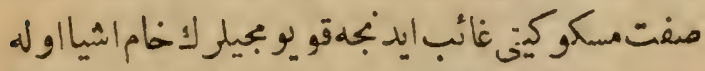

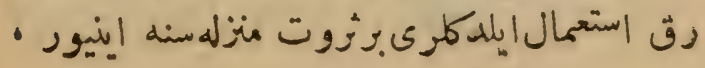




\section{$-\lambda \dot{\theta}-$}

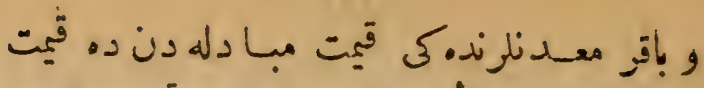

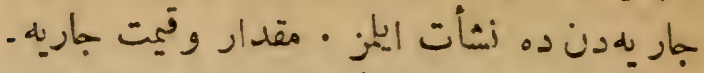

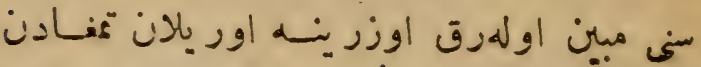

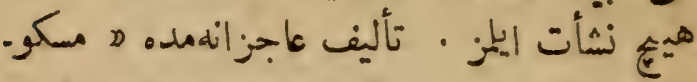

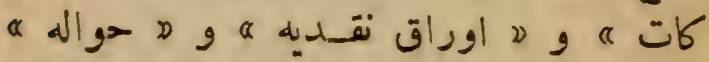

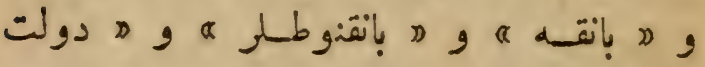

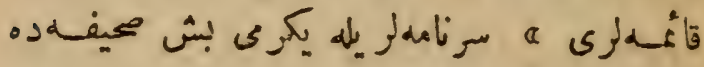

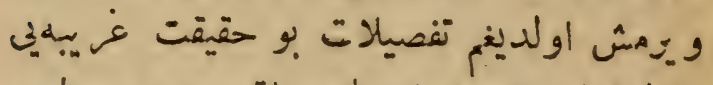

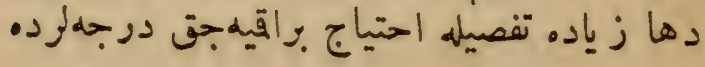

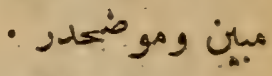

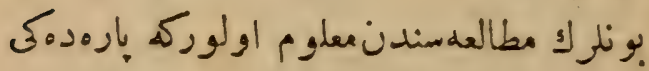

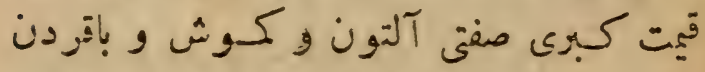

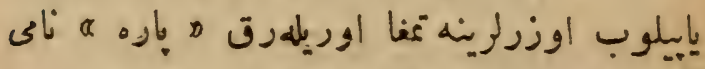

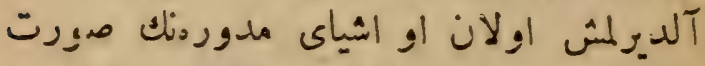

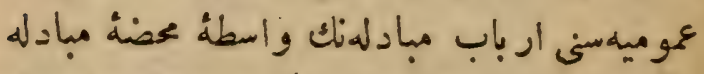

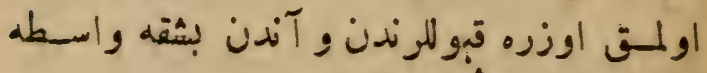

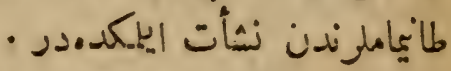

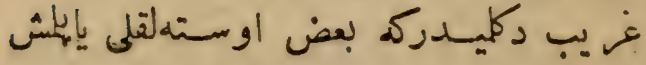

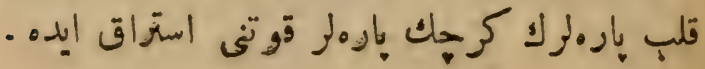




\section{$-16-$}

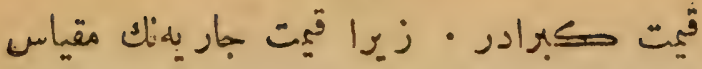

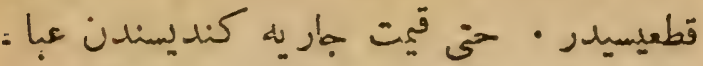

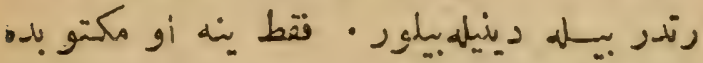

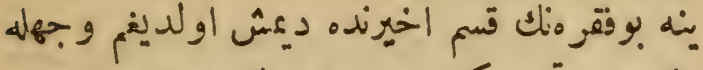

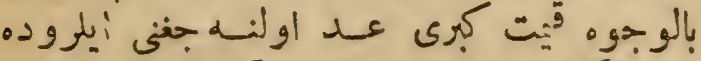

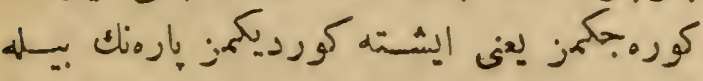

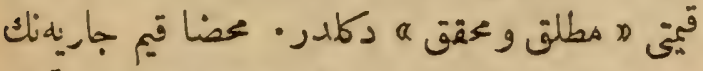

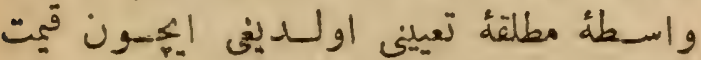

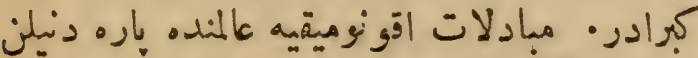

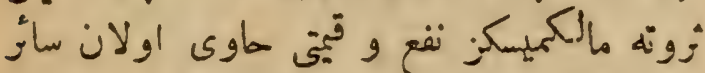

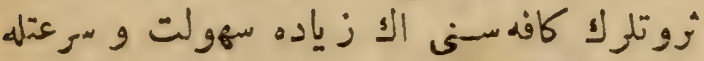

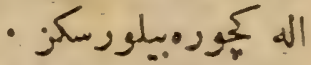
بارناك بو يله قيمت كبرى اولمسى هان اولدينى

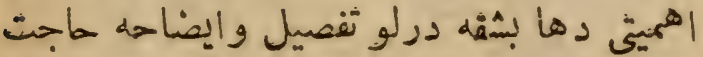

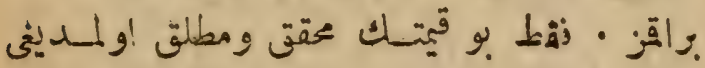

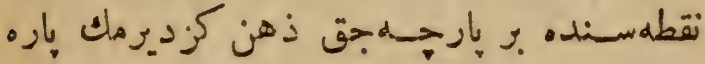

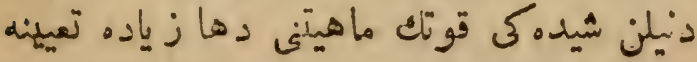
-

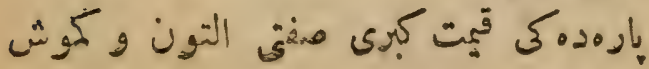




\section{- $\lambda \dot{~}$}

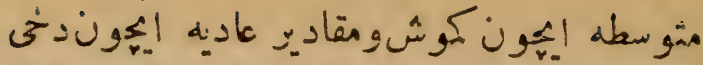

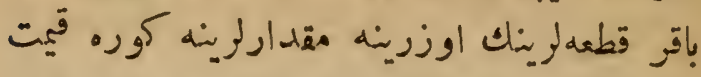

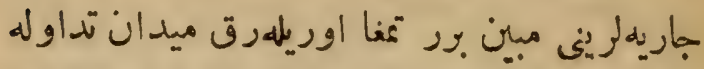

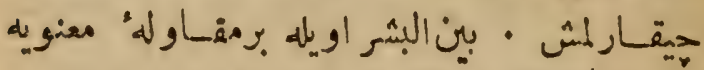

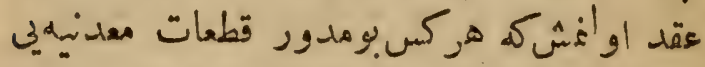

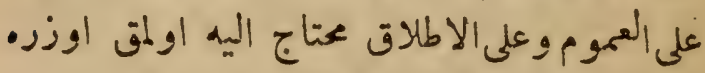

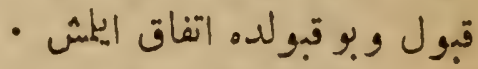

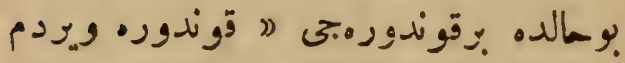

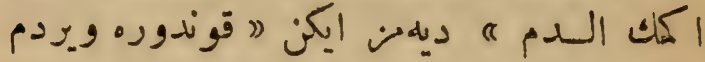

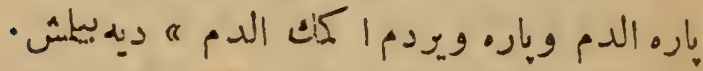

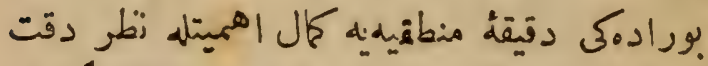

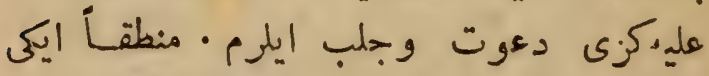

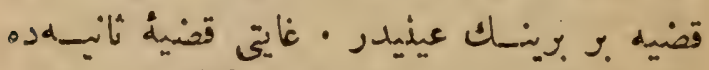

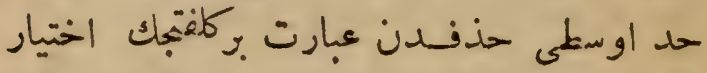

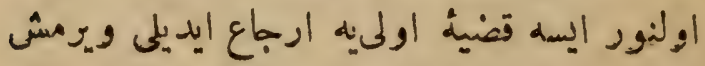
اولودن اونور البي

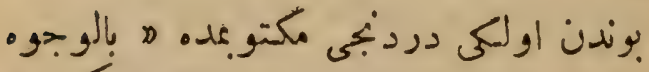

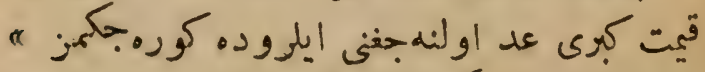

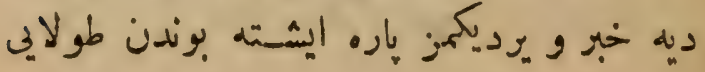




\section{- $\lambda r$}

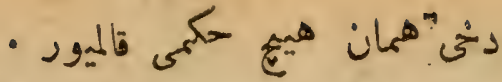

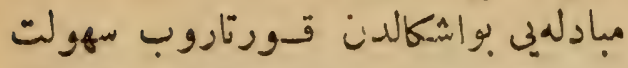

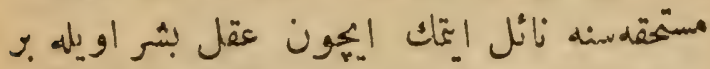

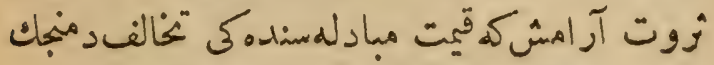

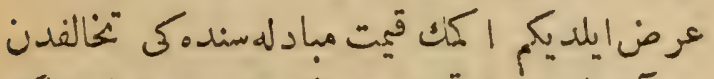

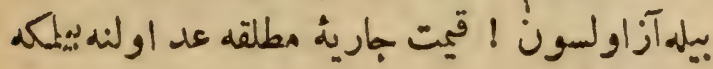

$$
\text { استحقاق كورلسون! }
$$

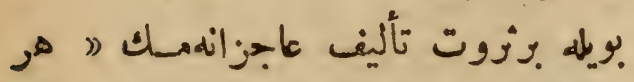

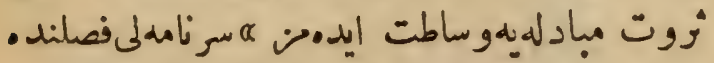

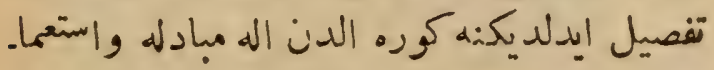

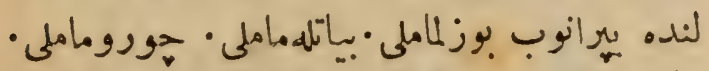

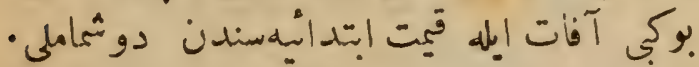

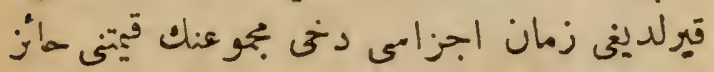

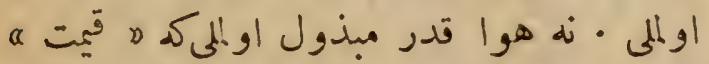

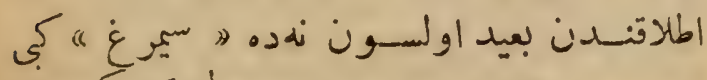

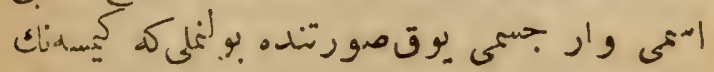

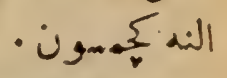

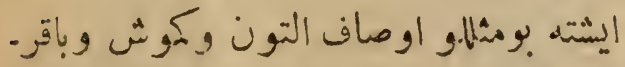

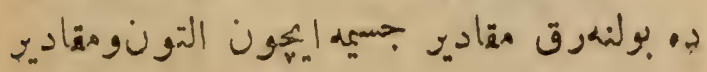




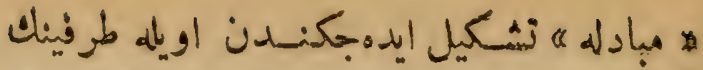

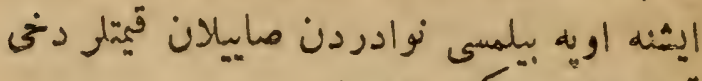

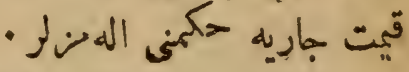

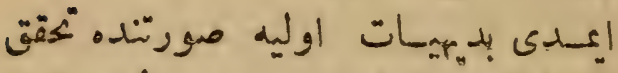

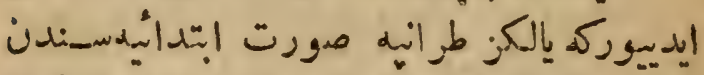

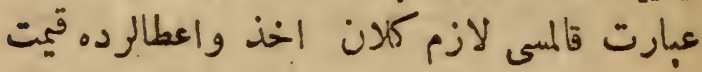

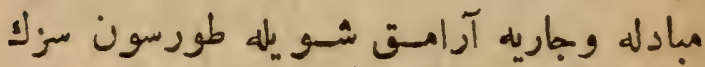

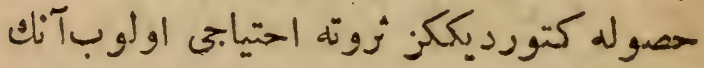

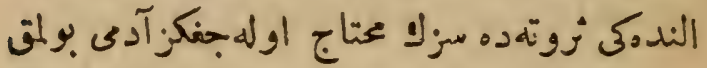

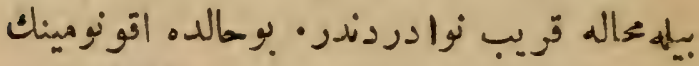

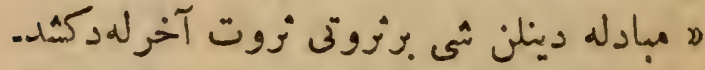

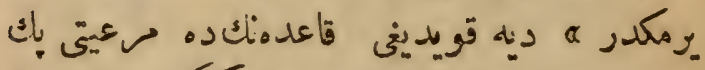

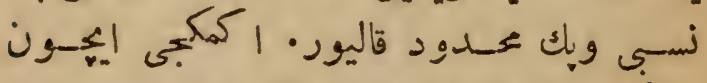

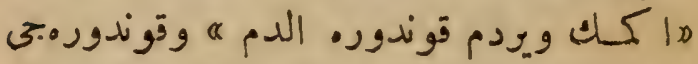

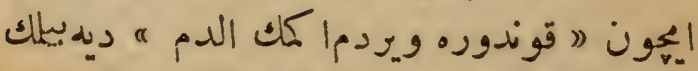

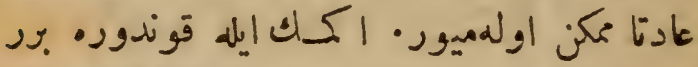

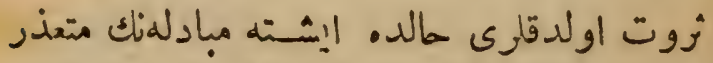

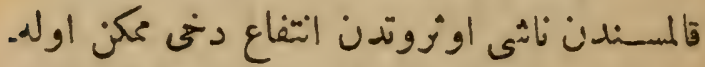

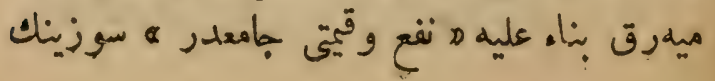




\section{$-\lambda \cdot-$}

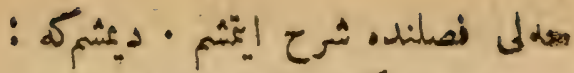

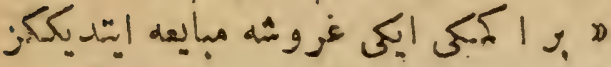

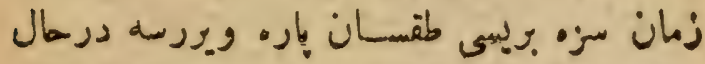

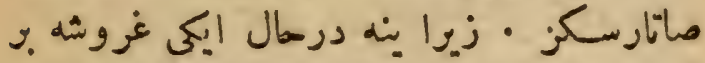

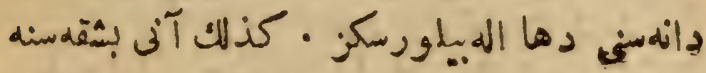

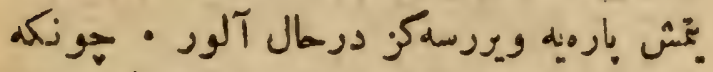

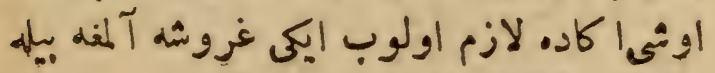

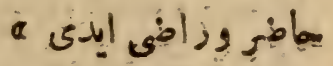

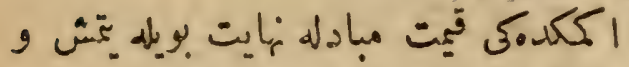

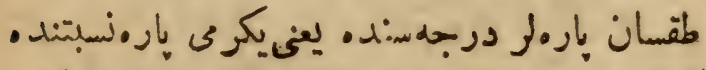

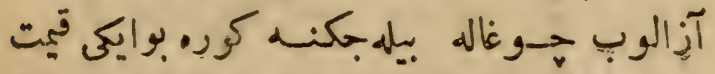

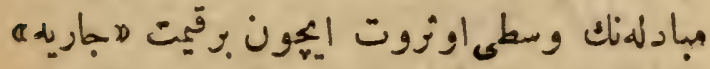

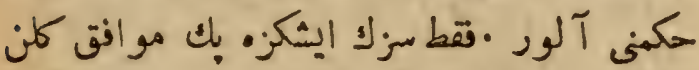

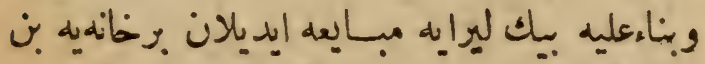

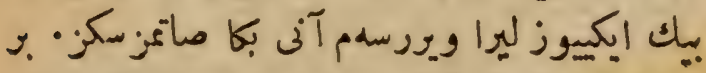

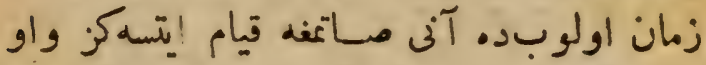

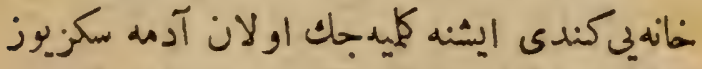

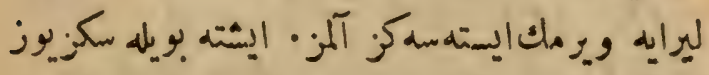

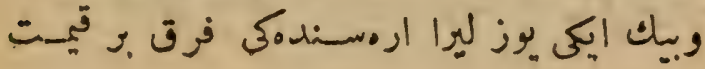




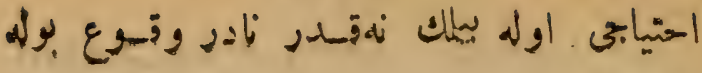

$$
\text { بلموز }
$$

شوندرت قيمتلر إيمون بالطبع إيى مودرث

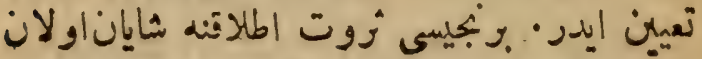

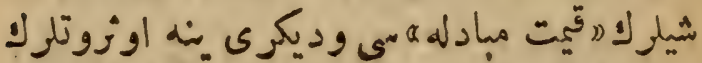

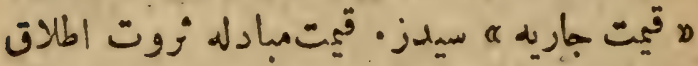

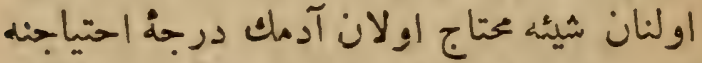

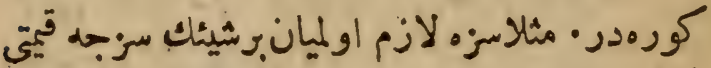

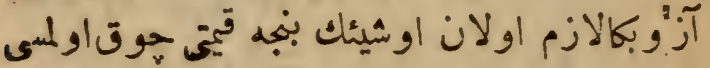

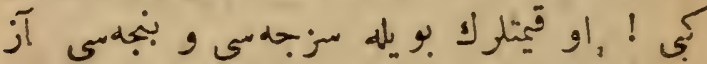

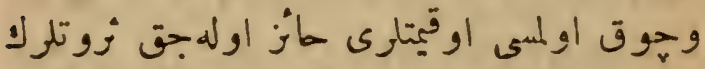

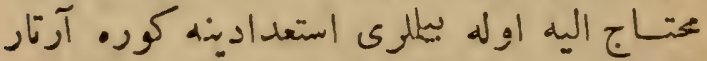

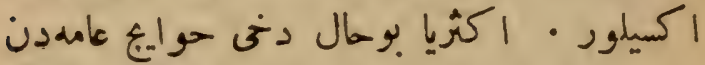

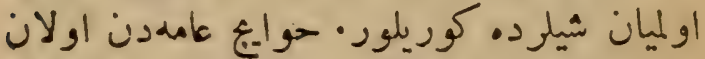

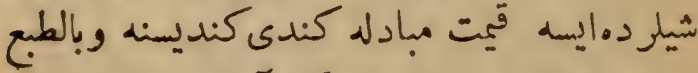

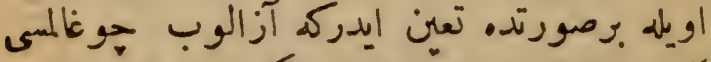

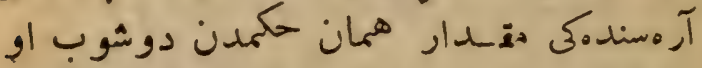

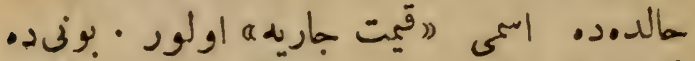

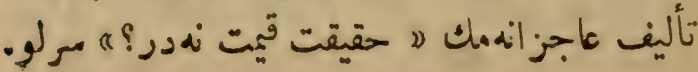




\section{$-\mathrm{V \lambda}$}

ه مثلا بو قوندورهبى اكككه يحت'ج إيسهد.

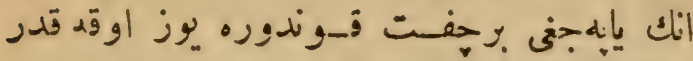

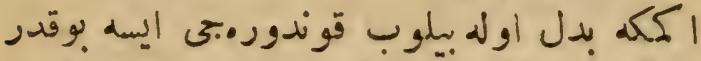

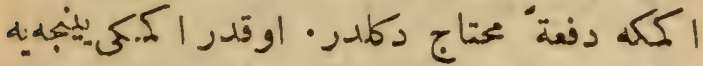

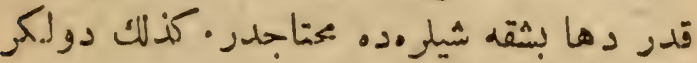

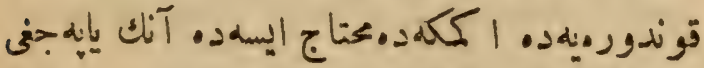

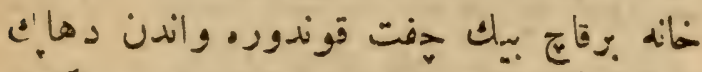

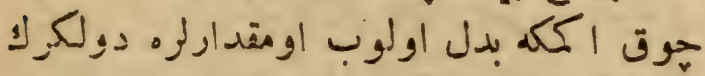

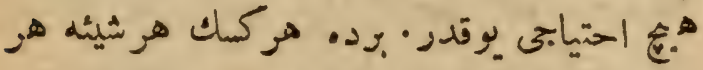

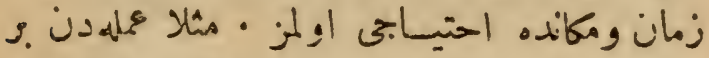

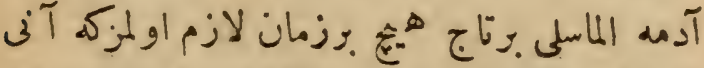

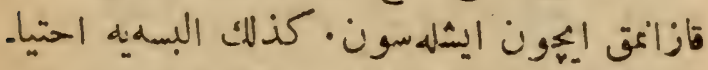

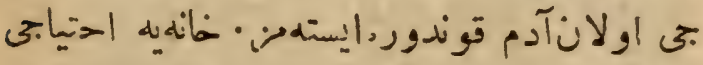

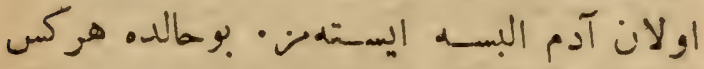

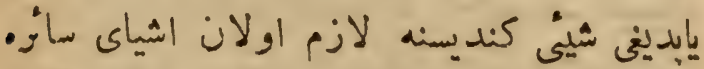

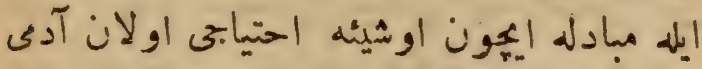

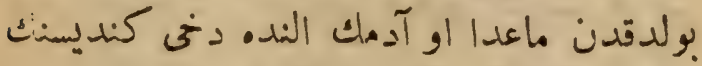

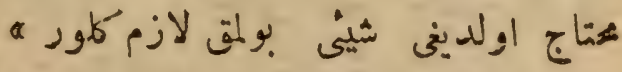

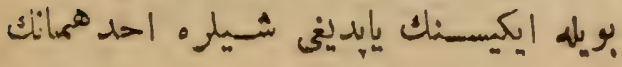




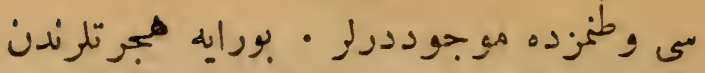

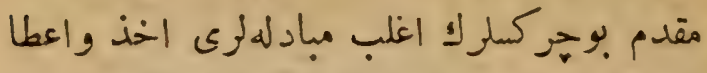

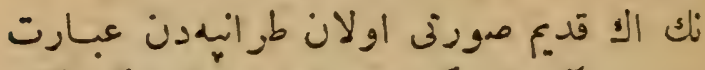

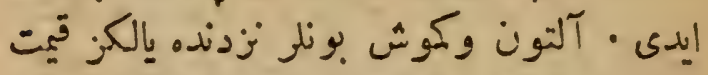

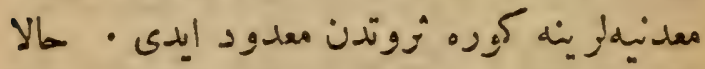

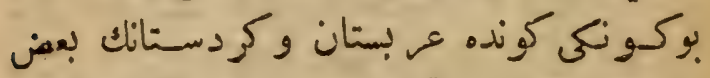

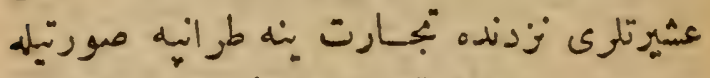

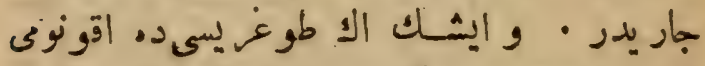

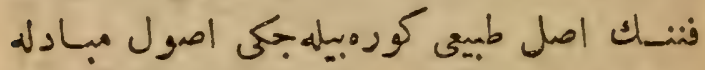

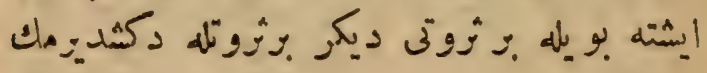

ديكدر - دئه بو

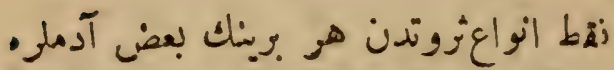

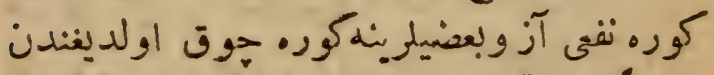

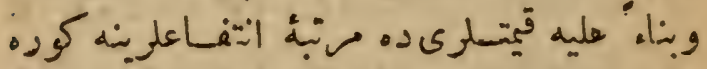

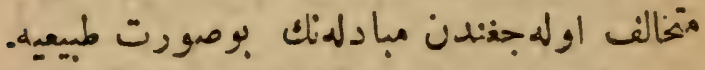

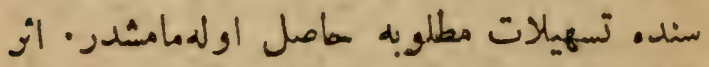

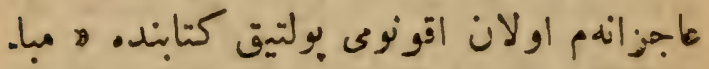

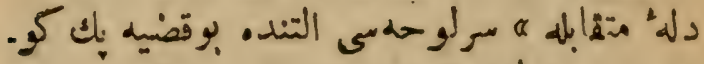

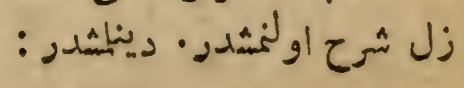




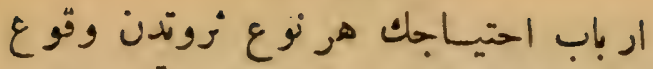

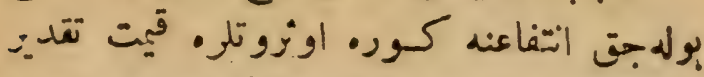

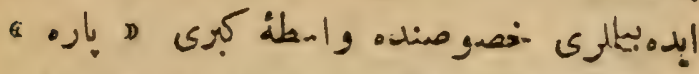

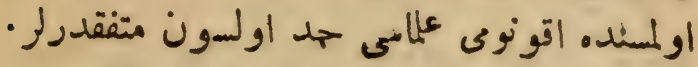

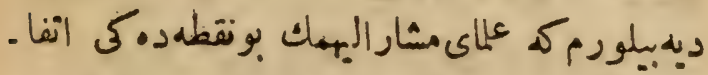

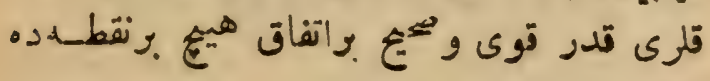

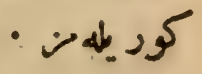

اقونوى حكماسندن ساى و.رووسكر ورومى نكى

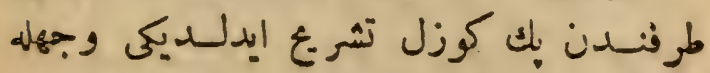

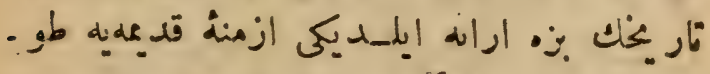

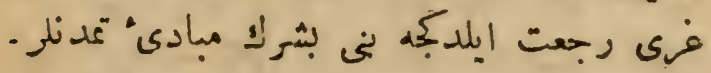

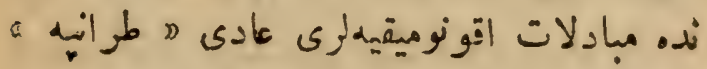

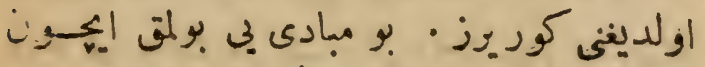

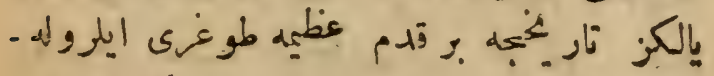

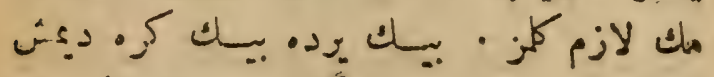

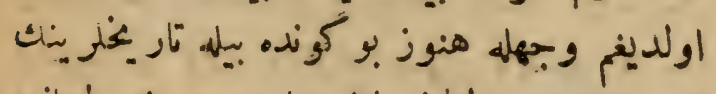

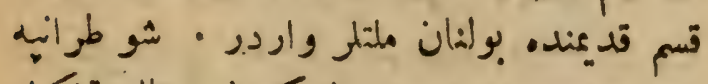

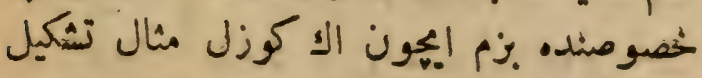

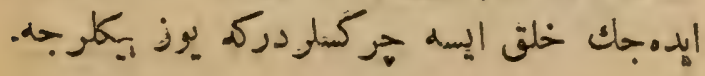




\section{- yo}

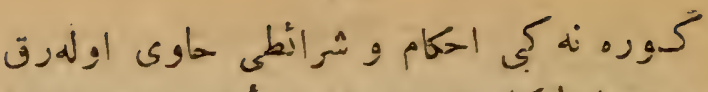

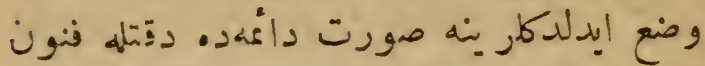

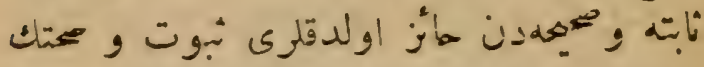

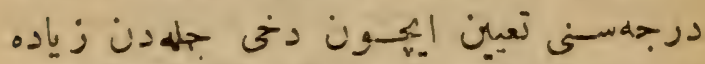

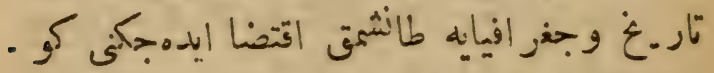

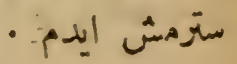

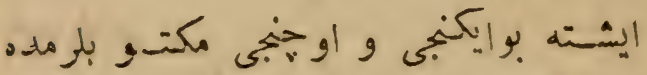

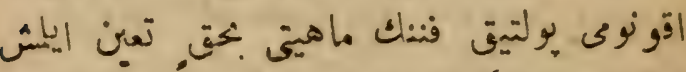

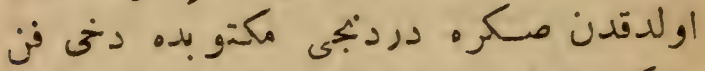

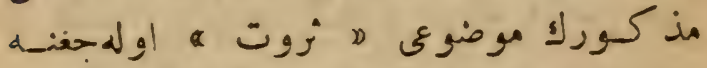

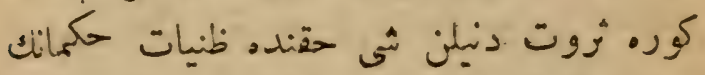

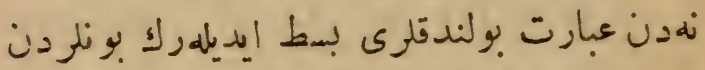

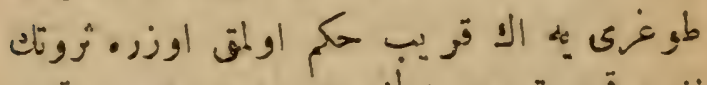

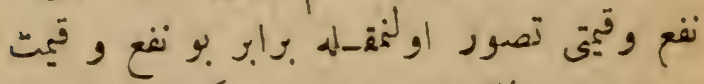

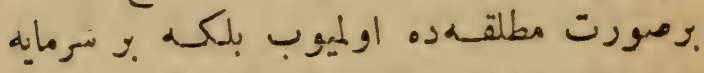

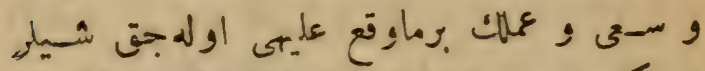

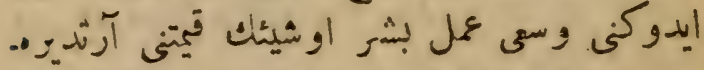

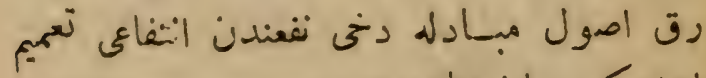

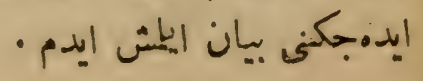




\section{$-V_{\varepsilon}-$}

家

$$
\text { a " }
$$

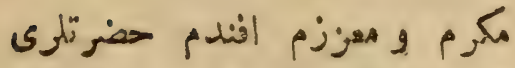

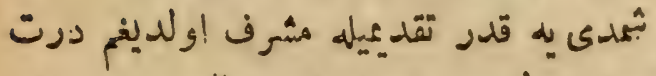

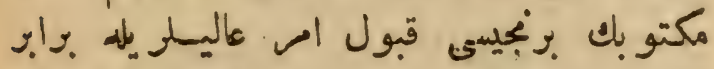

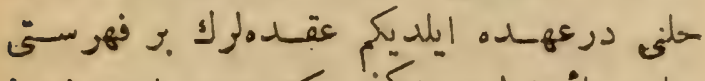

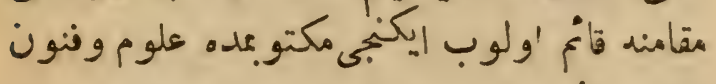

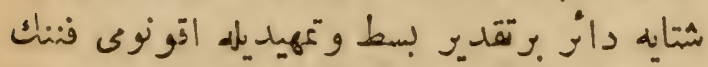

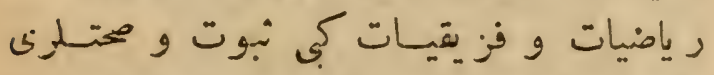

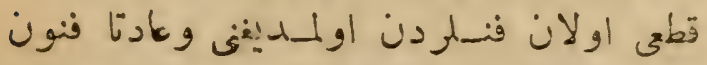

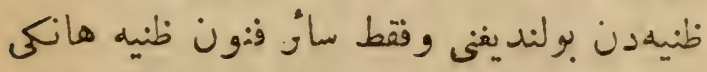

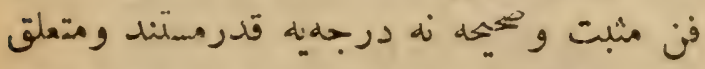

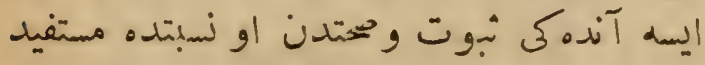

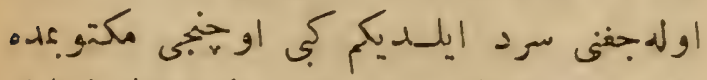

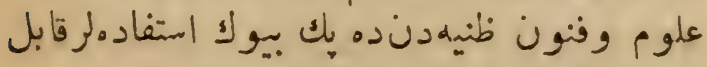

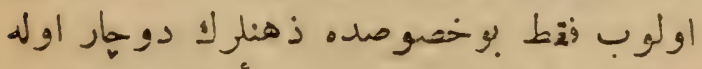

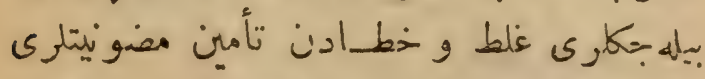

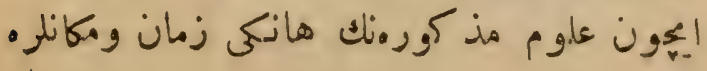




\section{$-\mathrm{V}^{\mathrm{N}}-\mathrm{m}$}

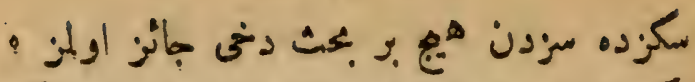

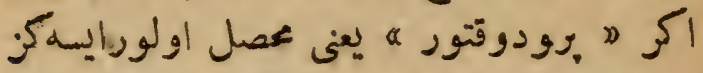

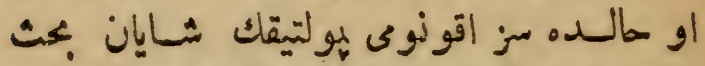

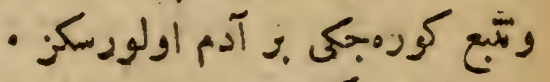

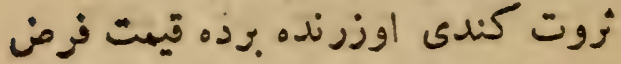

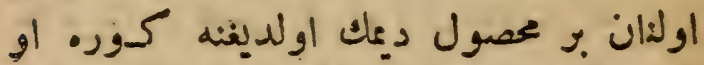

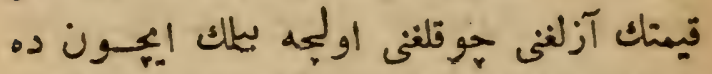

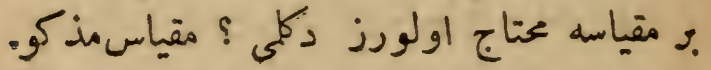

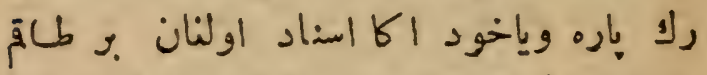

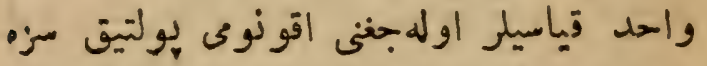

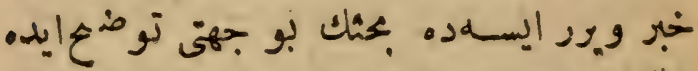

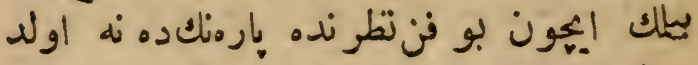

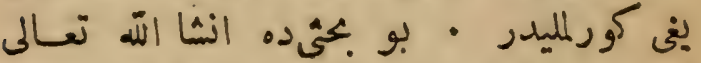

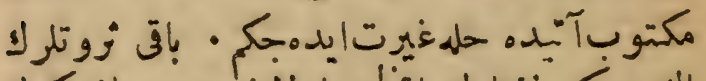

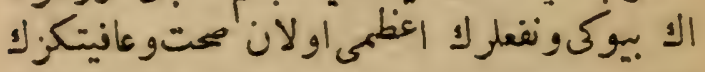

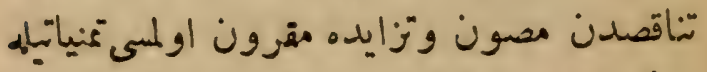

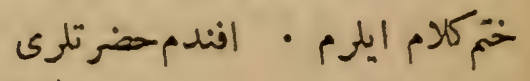
احدهدحت 


\section{- Yr}

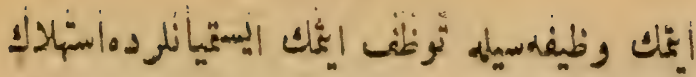

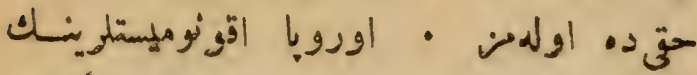

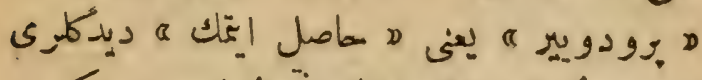

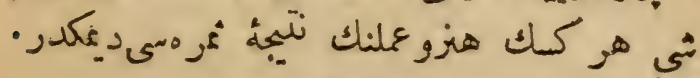

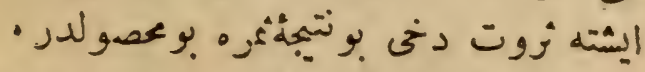

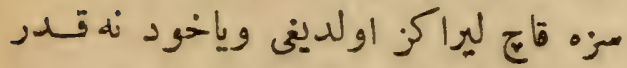

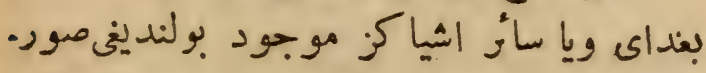

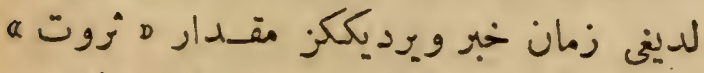

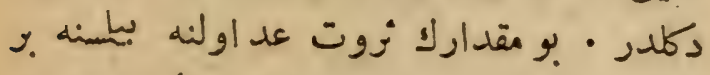

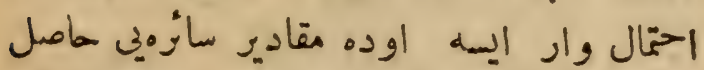

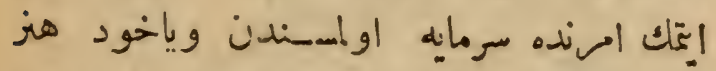

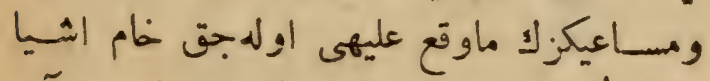

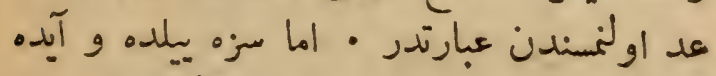

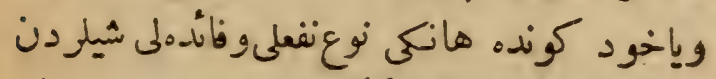

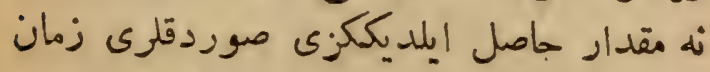

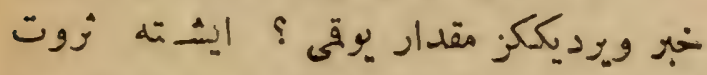

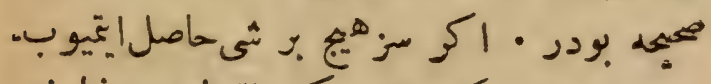

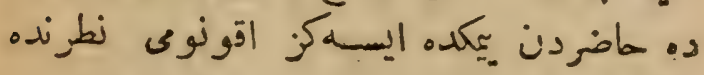

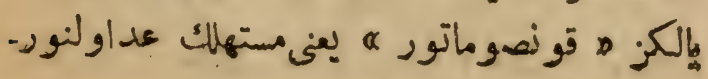


$-v i=$

دنبلن شيده نقع وقيت تصور اولنمق لزوهيهله

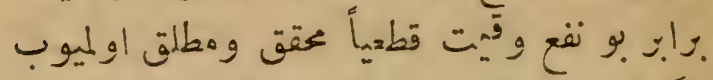

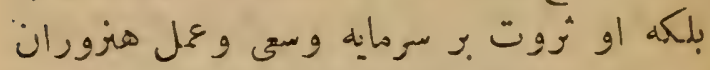

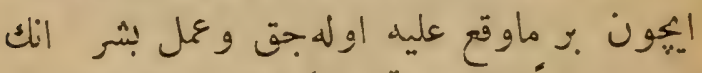

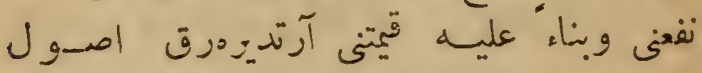

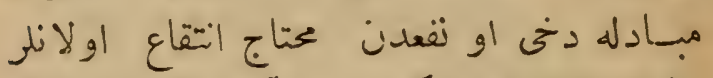

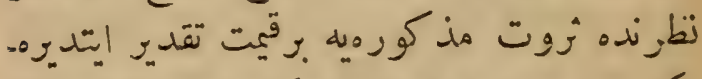

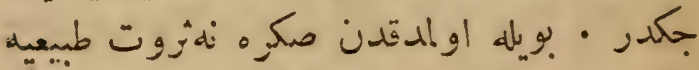

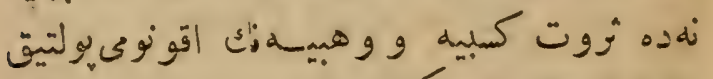

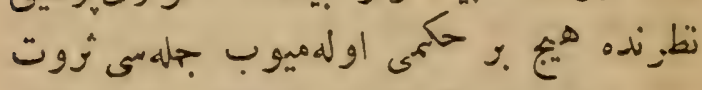

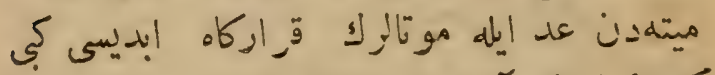

كوشهُ نسيانه آتيلى ويونل موتلرك

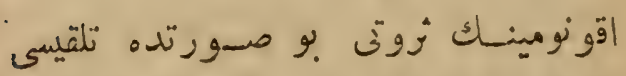

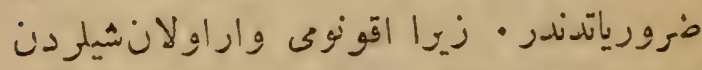

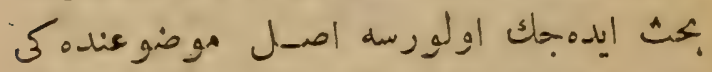

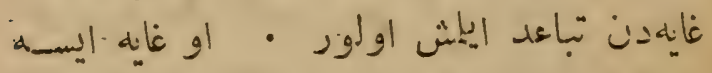

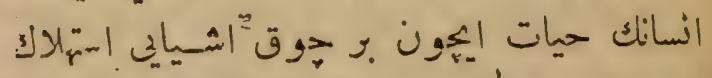

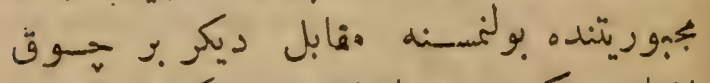

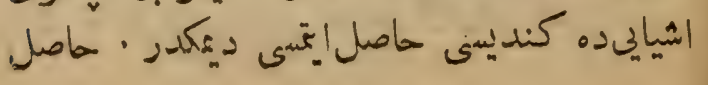




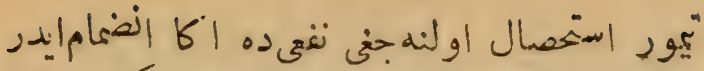

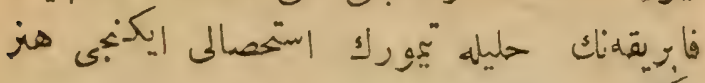

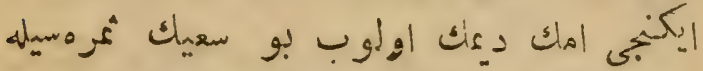

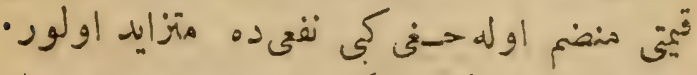

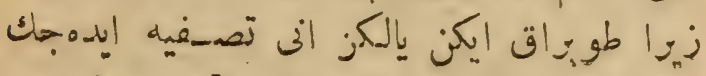

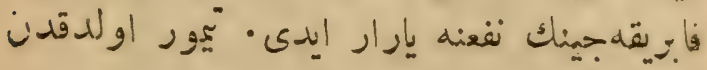

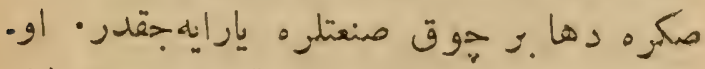

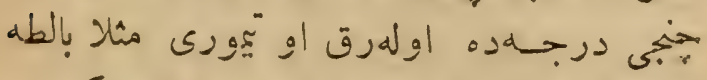

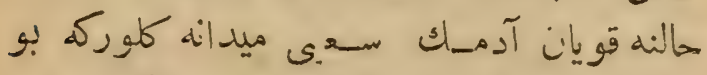

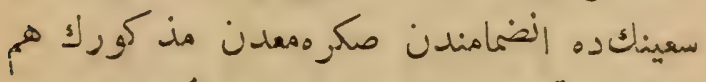

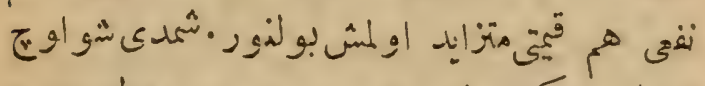

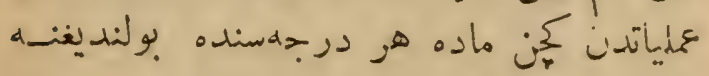

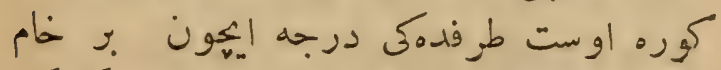

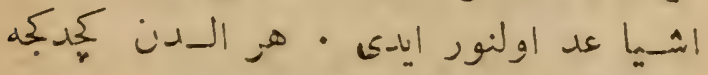

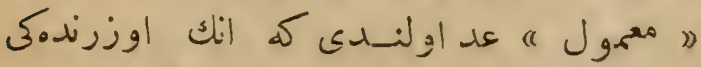

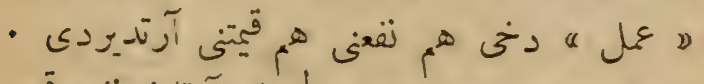

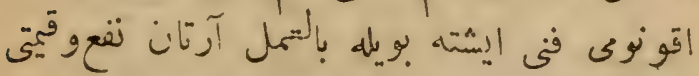

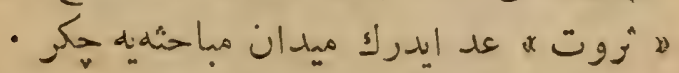

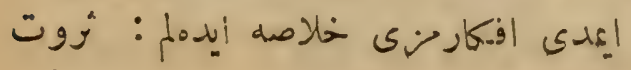




\section{$-.9-$}

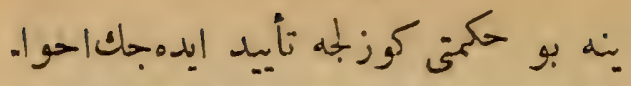

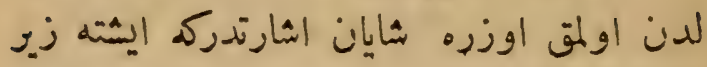

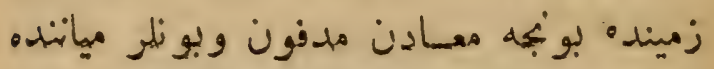

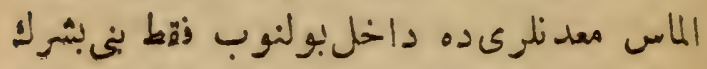

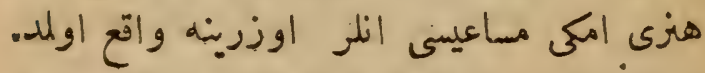

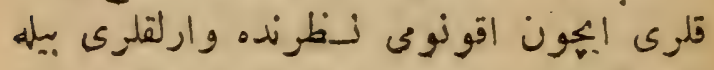

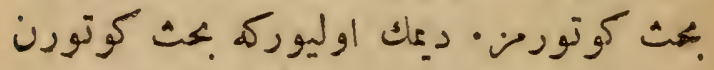

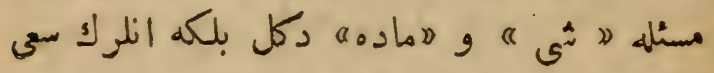

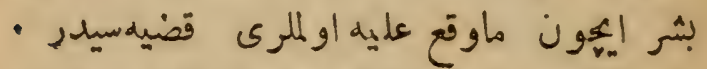
زوت دينلن شيئك بوبله مساعئ بشريديه

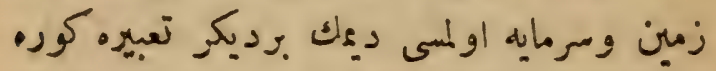

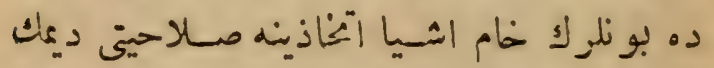

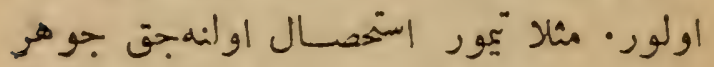

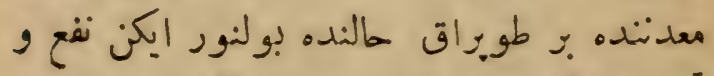

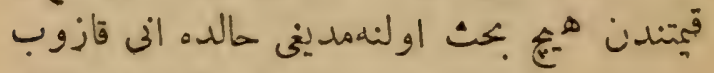

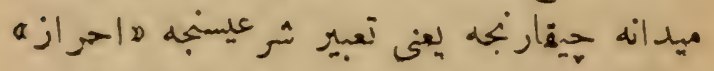

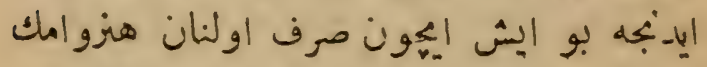

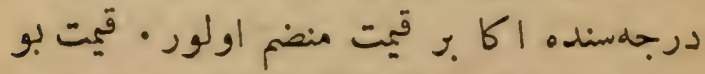

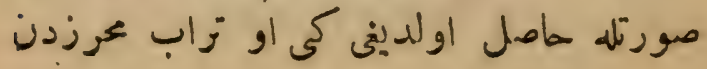




\section{$-71-$}

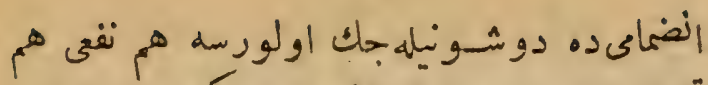

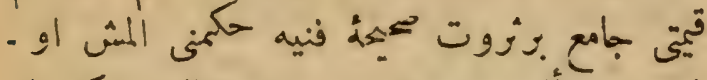

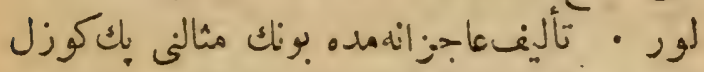

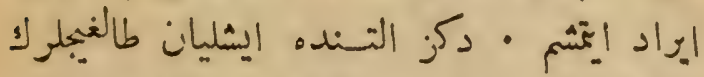

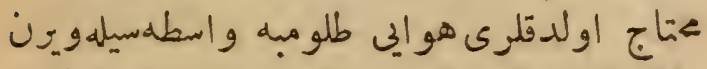

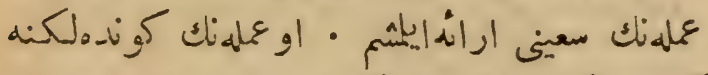

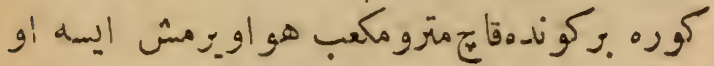

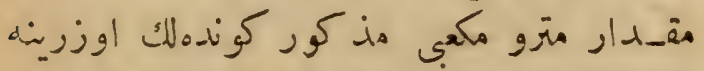

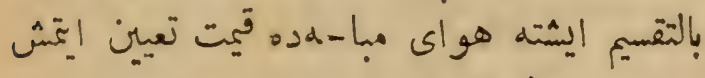

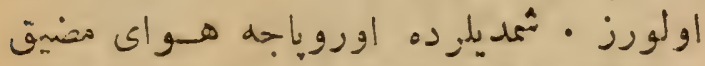

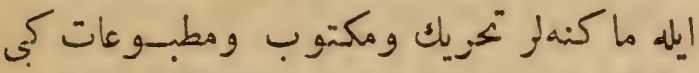

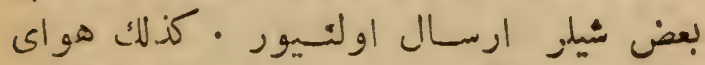

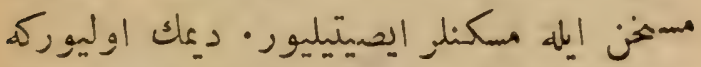

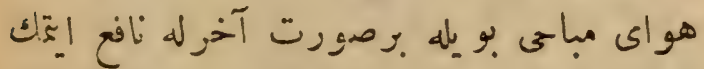

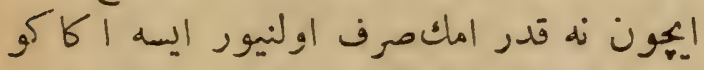

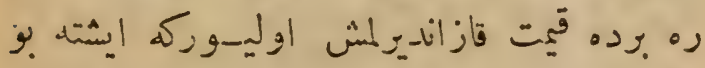

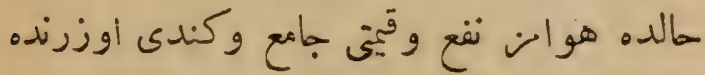

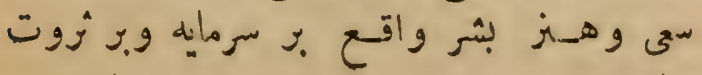




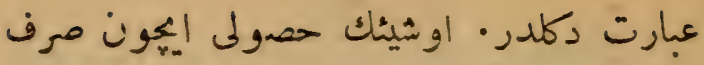

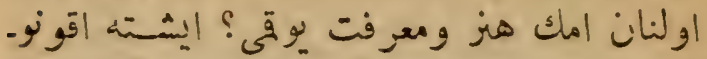

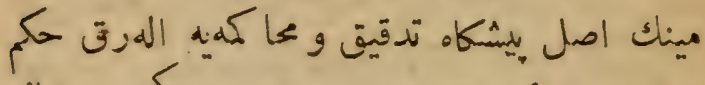

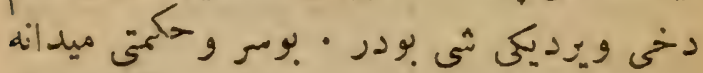

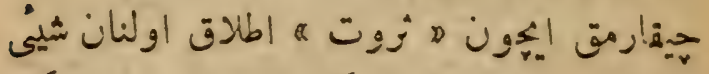

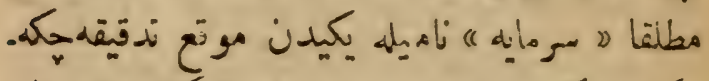

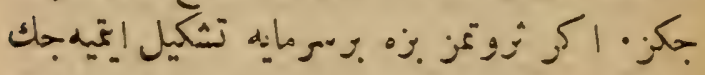

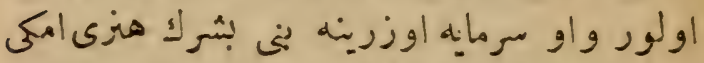

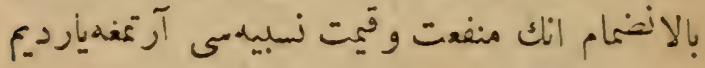

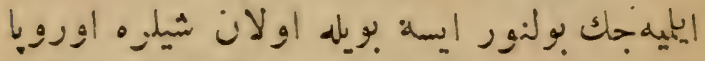

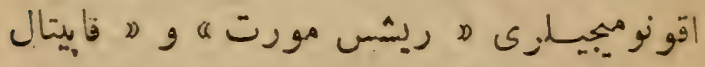

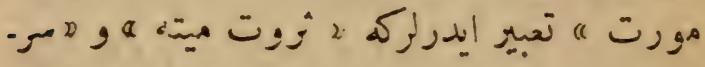

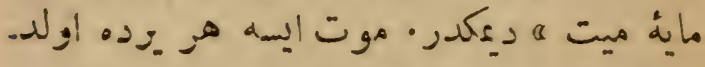

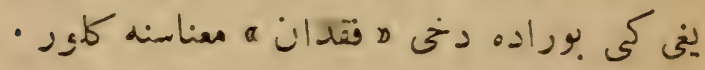

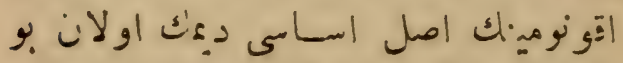

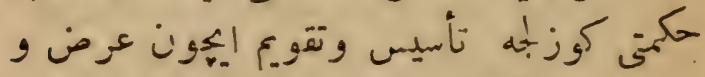

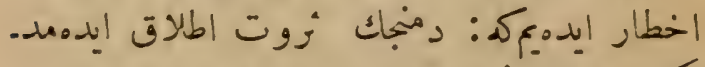

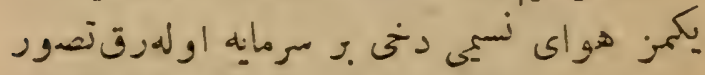

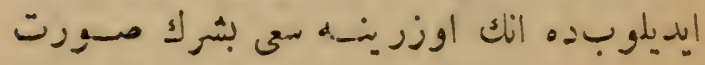




\section{$=99-$}

وقيمتسز اولان ثي اوزرنده بزاستعنداد مبادله

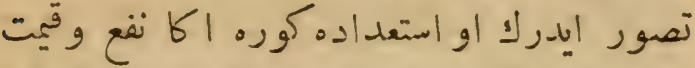

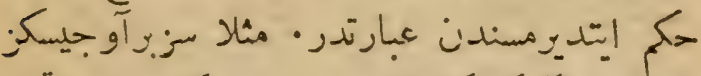

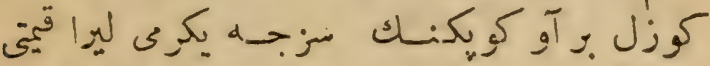

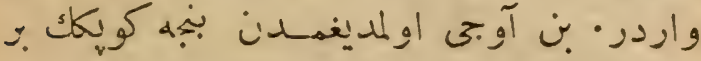

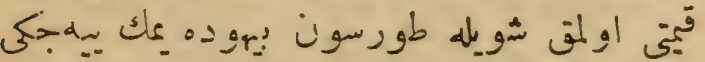

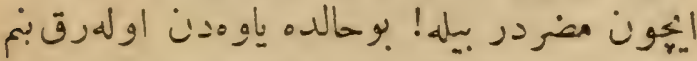

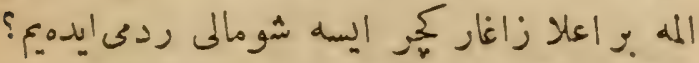

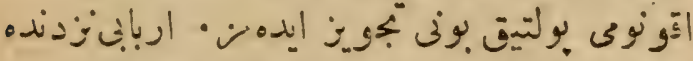

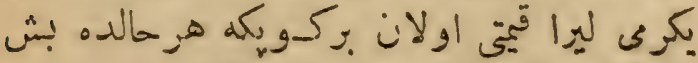

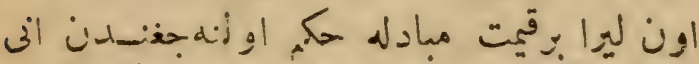

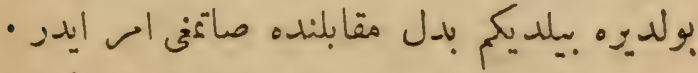

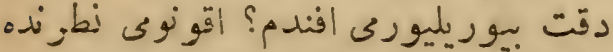

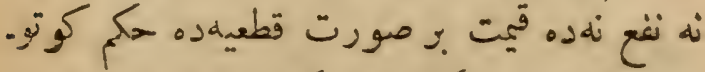

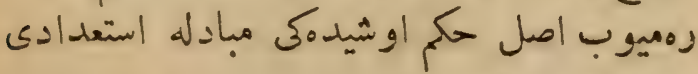

$$
\text { اوزرينه ويريليور. }
$$

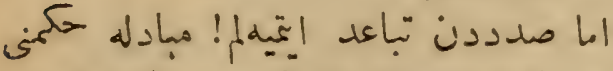

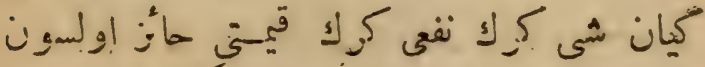

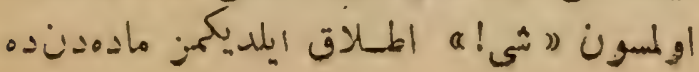




\section{$=40-$}

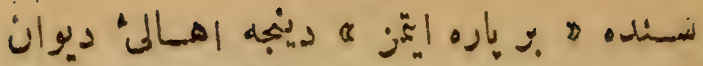

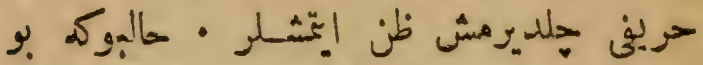

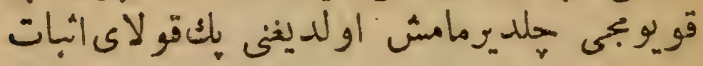

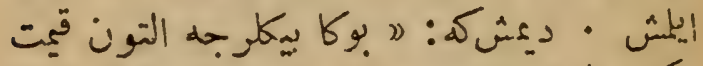

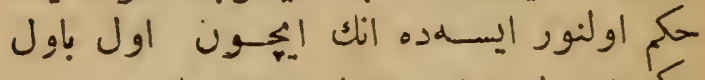

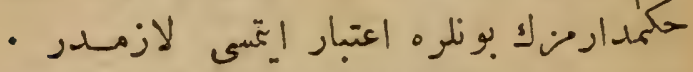

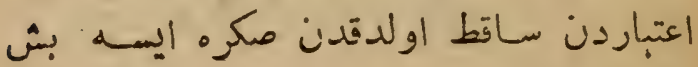

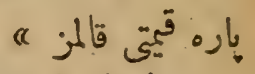

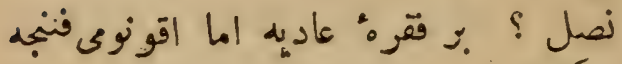

$$
\text { نهدر حكمّانه ؟ }
$$

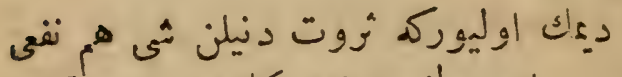

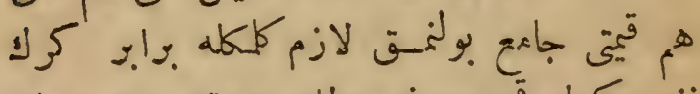

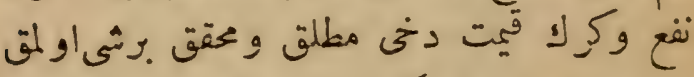

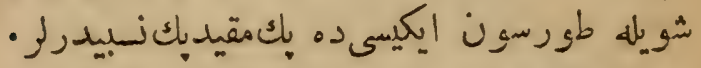

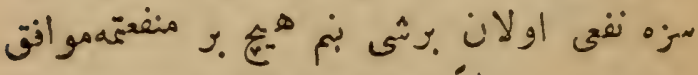

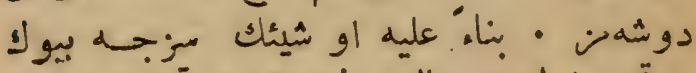

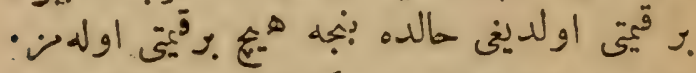

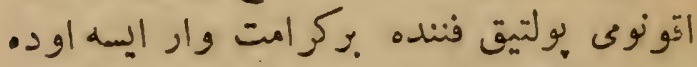

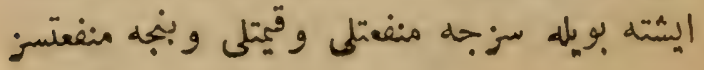
$r$ 


\section{- -}

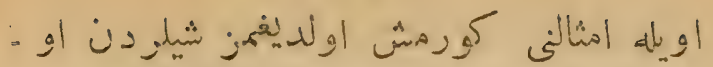

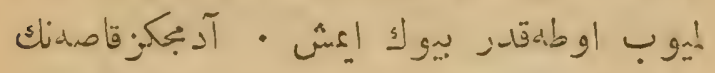

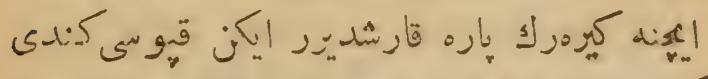

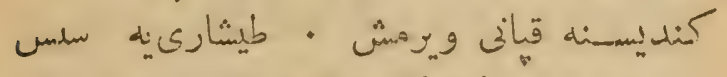

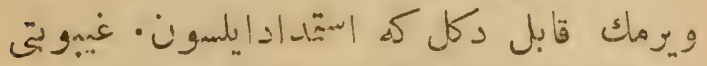

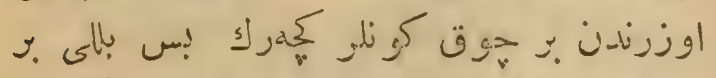

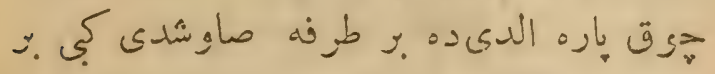

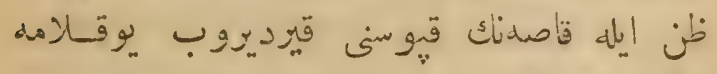

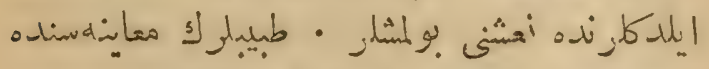

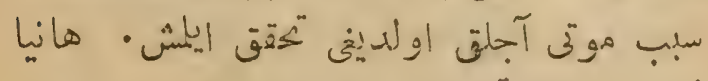

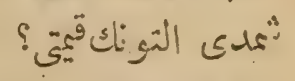

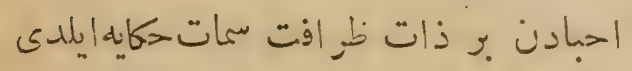

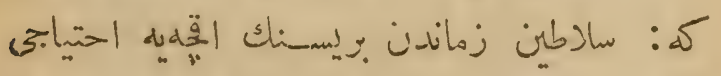

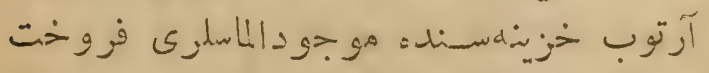

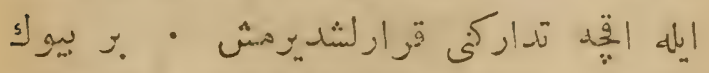

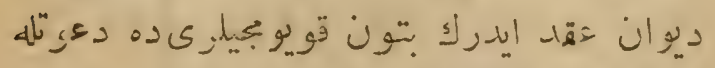

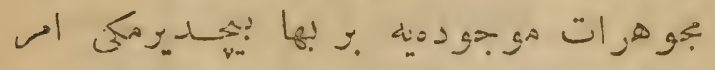

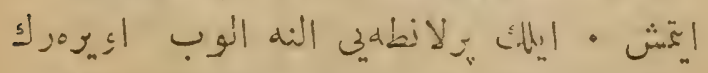

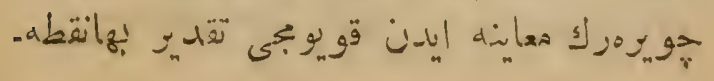




\section{-}

آدام اسمايت طزفدارانى زوتاك تعريفنة

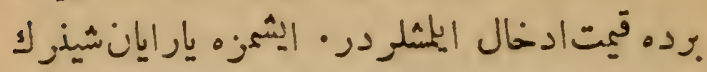

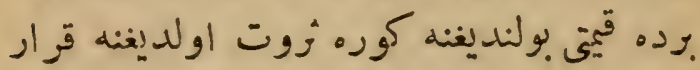

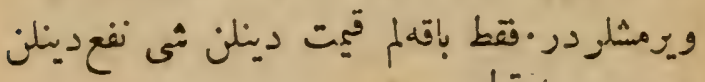
شيدن دها قطعيدر؟

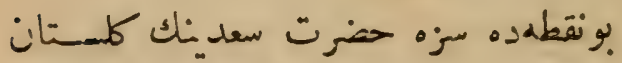

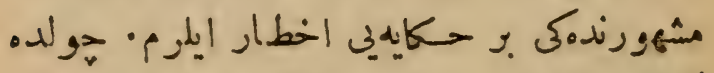

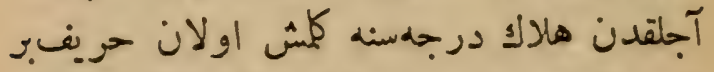

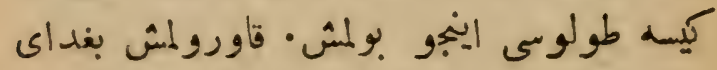

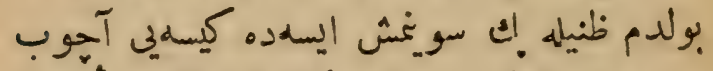

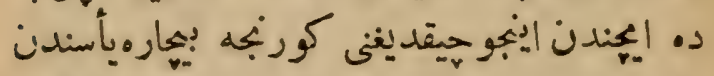

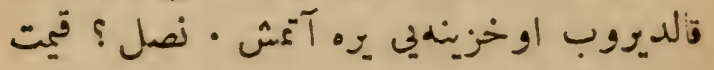
زمهده قالدى ؟ بالوجو. قيمت كبرى عد اولنه بنى إيلروده

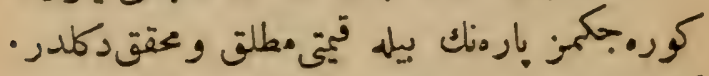

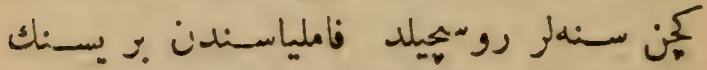

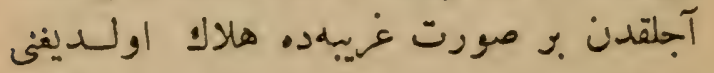

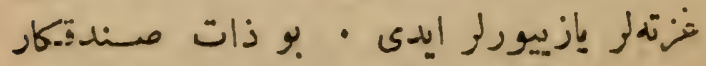

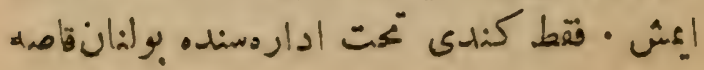


- $-7 r-$

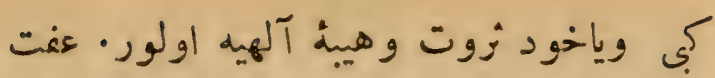

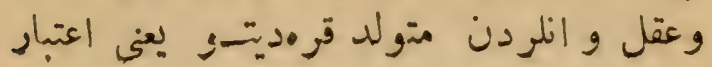

"

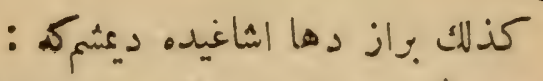

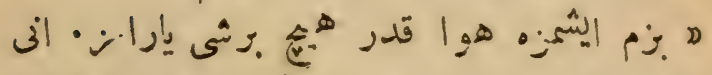

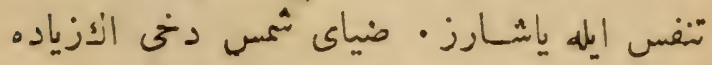

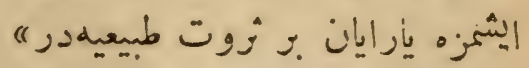

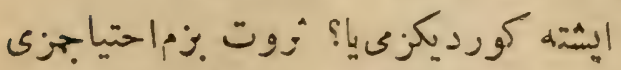

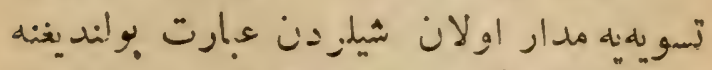

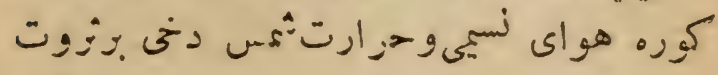

• 2

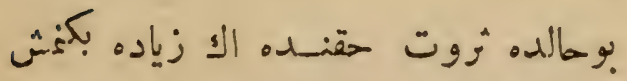

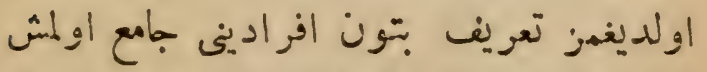

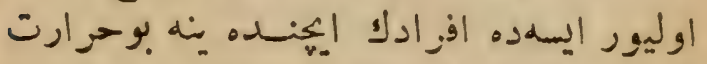

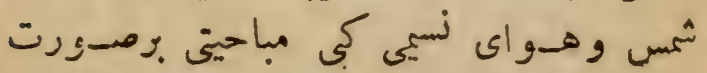

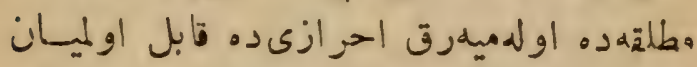

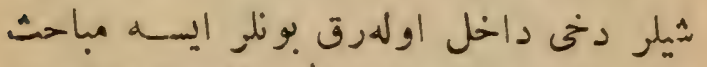

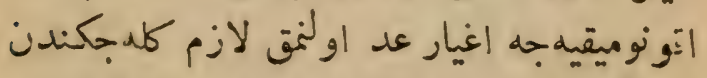

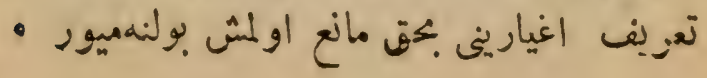




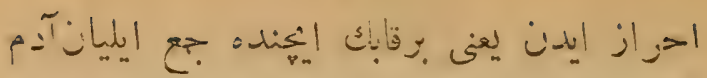

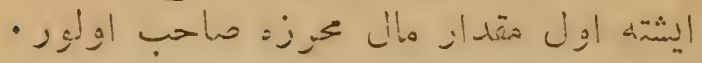

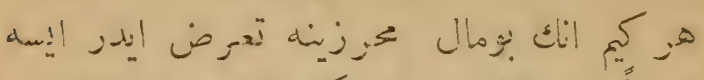

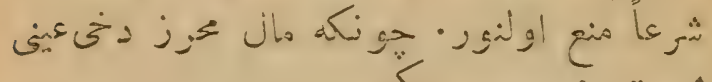

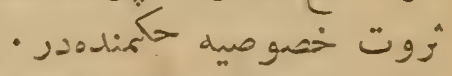

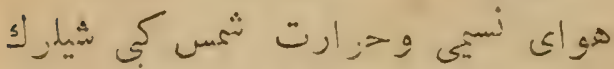

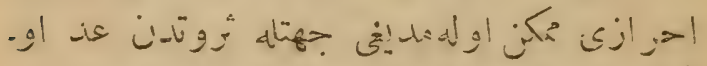

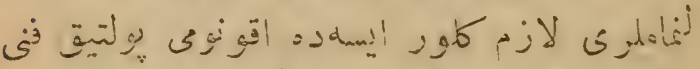

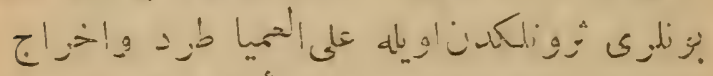

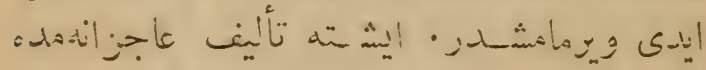

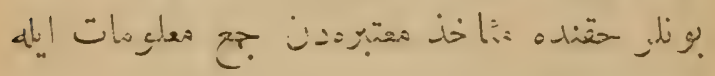
شويله ديثشيم:

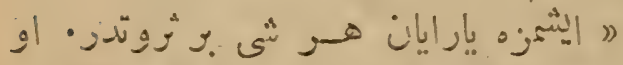

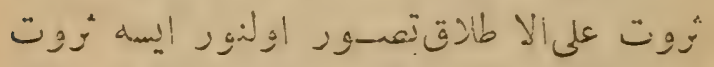

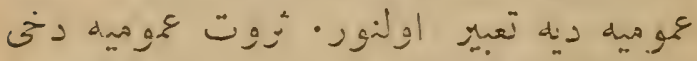

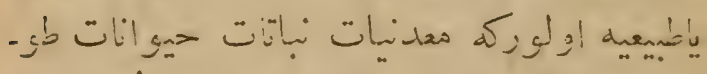

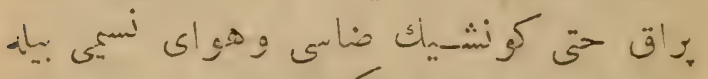

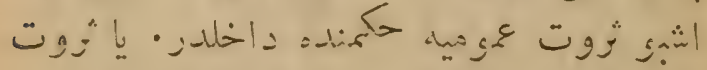

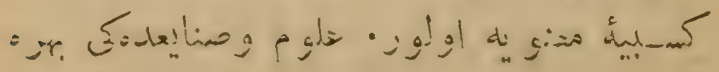




\section{$-9 \cdot$}

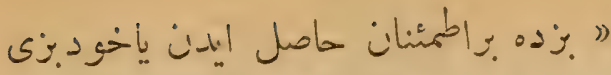

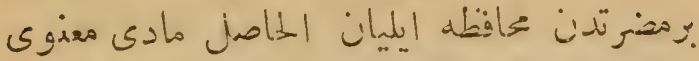

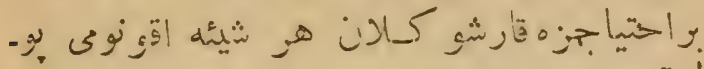

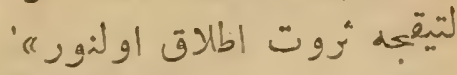

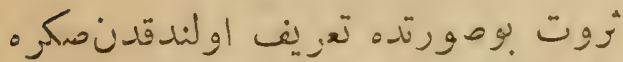

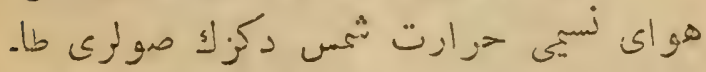

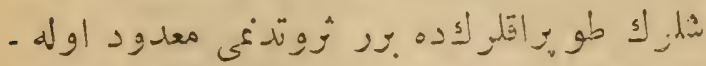

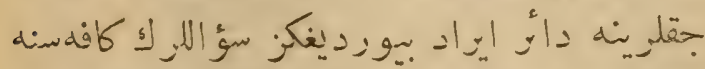

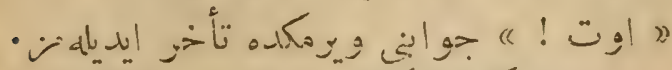

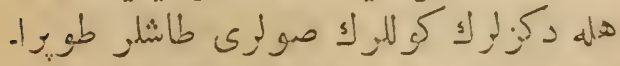

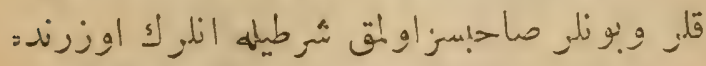

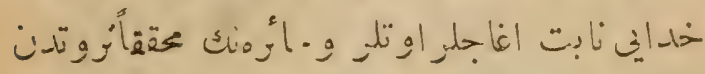

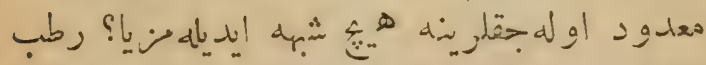

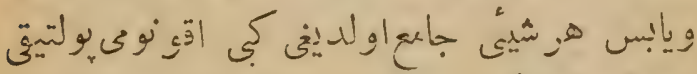

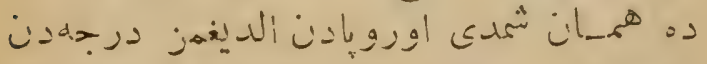

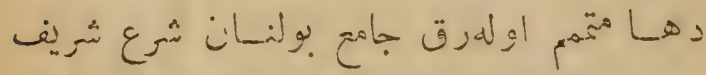

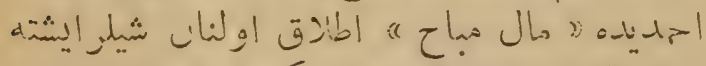

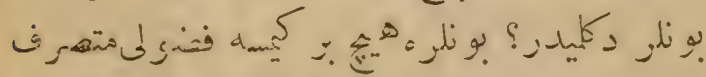

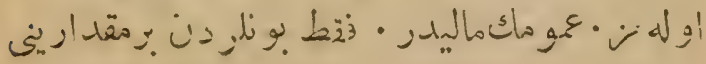




\section{- 09}

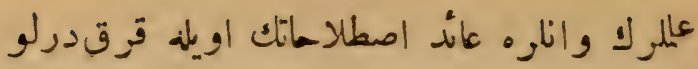

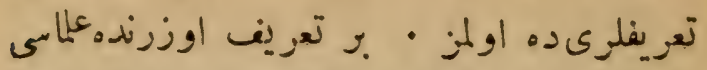

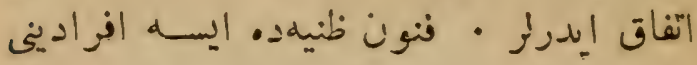

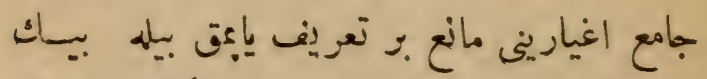

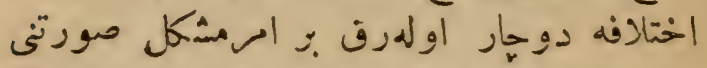

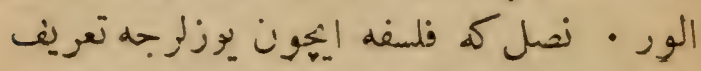

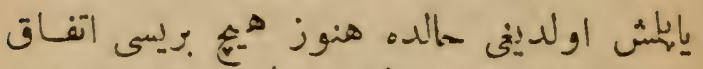

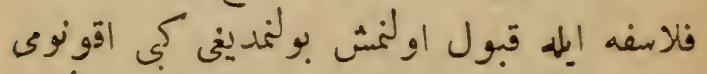

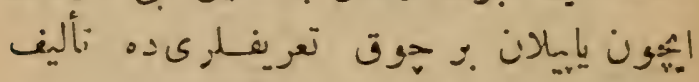

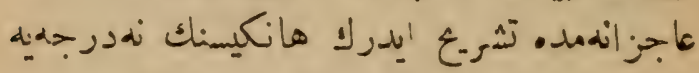

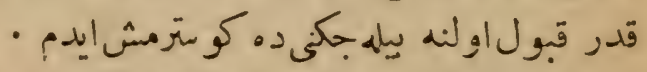

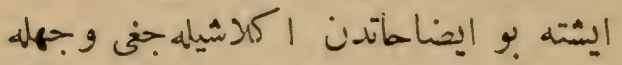

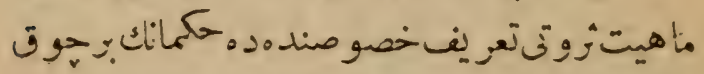

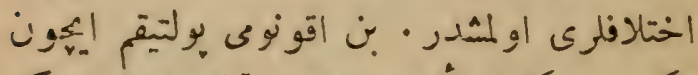

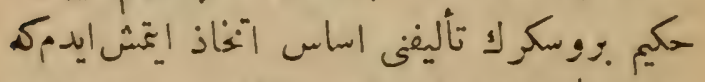

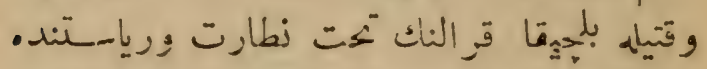

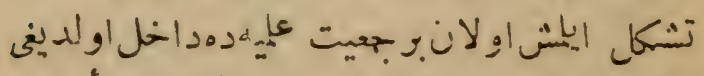

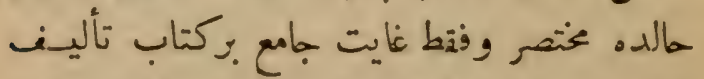

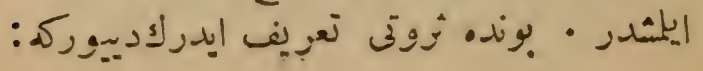




\section{- $\partial \lambda-$}

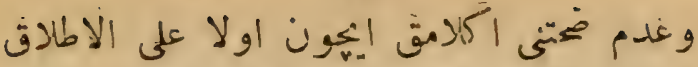

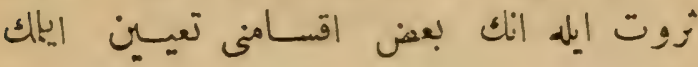
لازمدز الهات

معلوم حكمت ملزوملرى اولديني اوزره

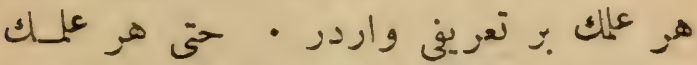

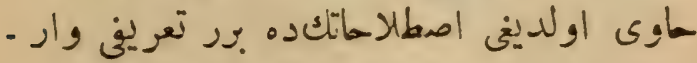

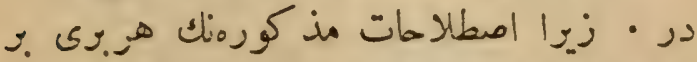

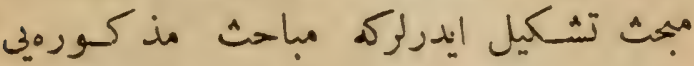

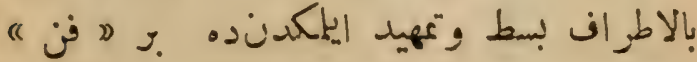

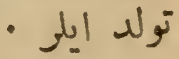

تعريفلر لك اغيارينى مانع افراندينى جامهـع

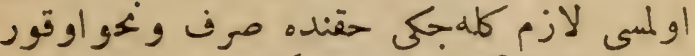

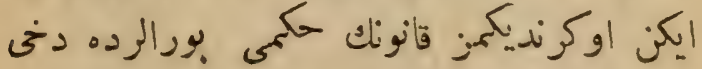

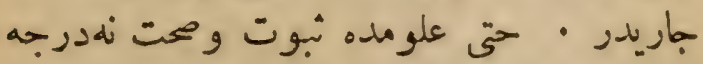

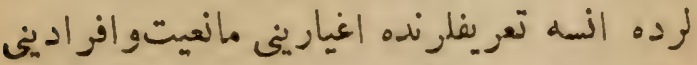

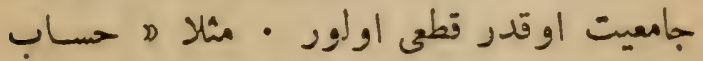

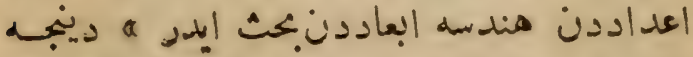

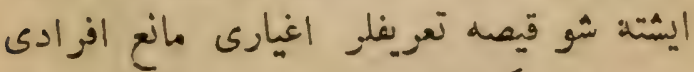

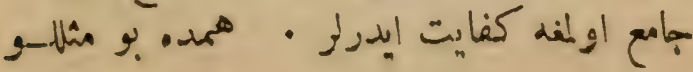


- ò

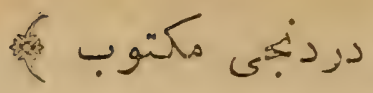
«

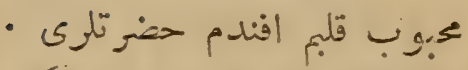

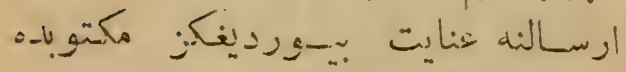

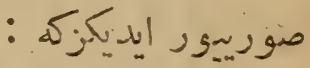

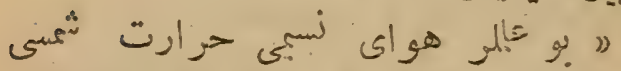

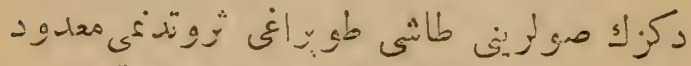

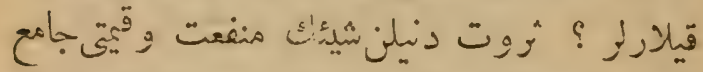

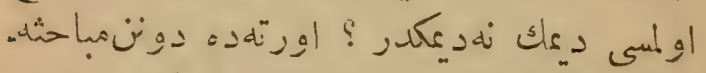

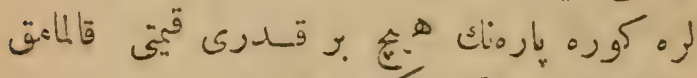

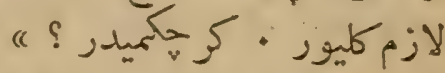

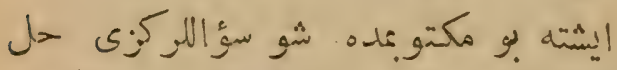

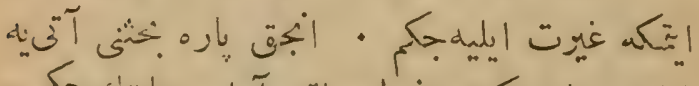

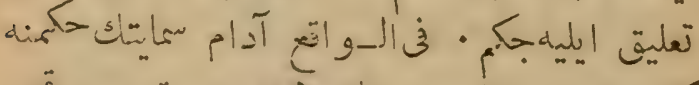

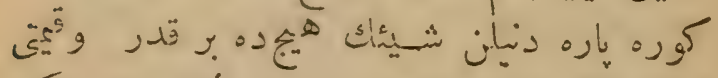

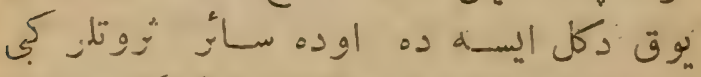

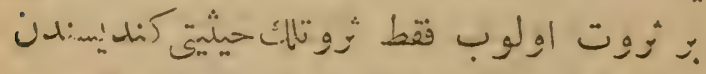

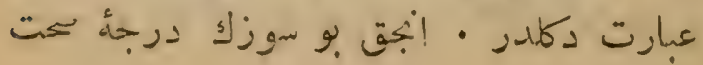




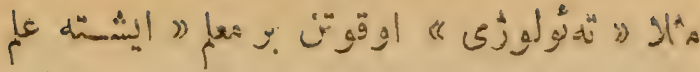

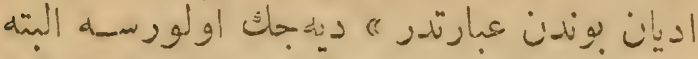

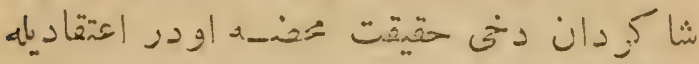

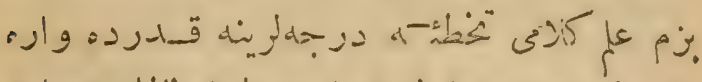

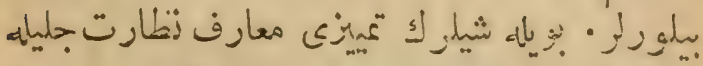

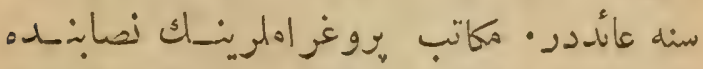

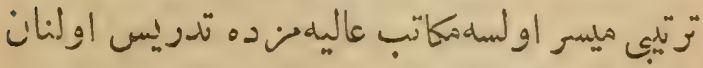

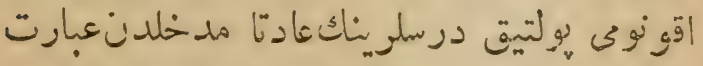

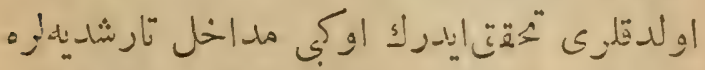

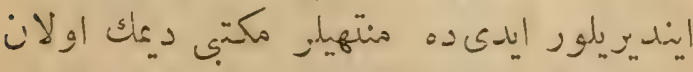

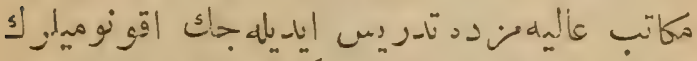

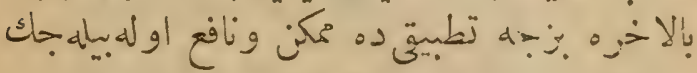

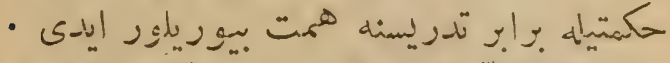

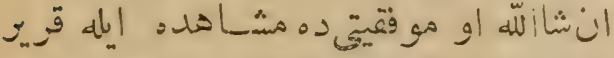

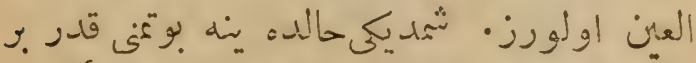

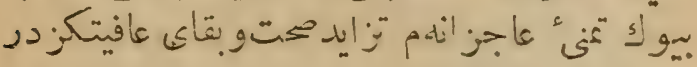

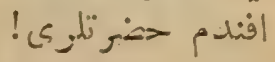
احد مدحت 


\section{- 00}

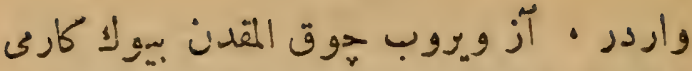

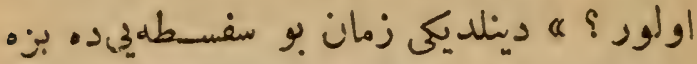

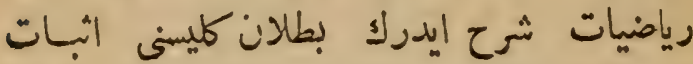

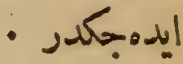

منه تعالى بوندن صكر مكى مكتو. بلر مده سؤ ا.

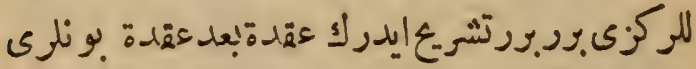

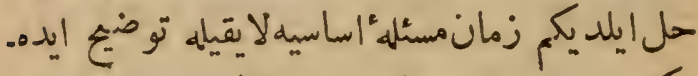

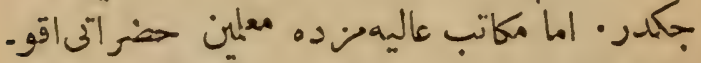

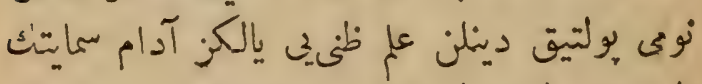

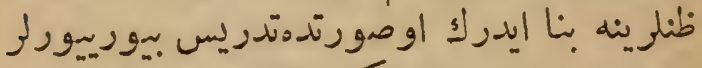

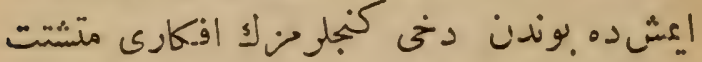

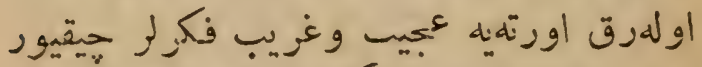

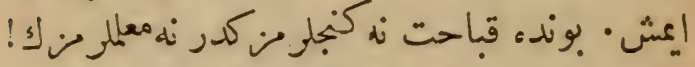

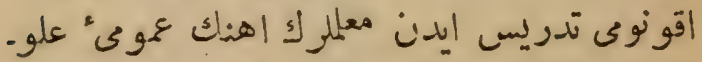

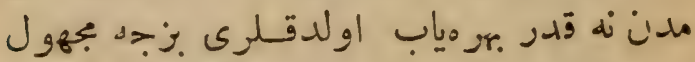

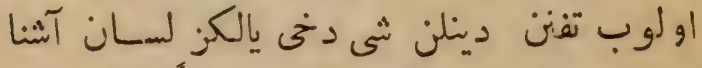

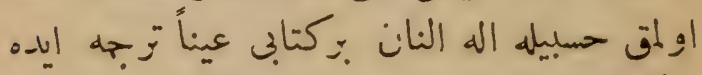

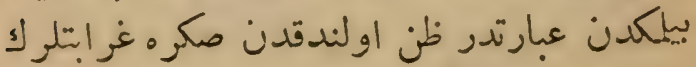

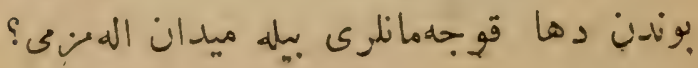




\section{- 0 -}

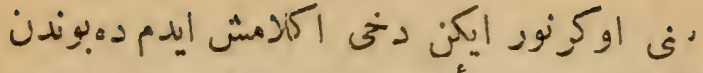

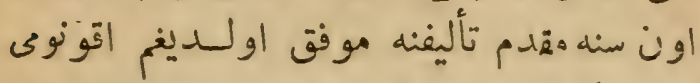

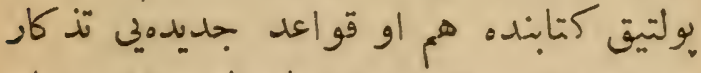

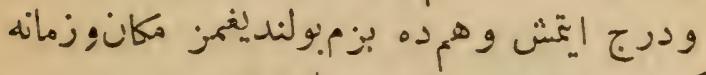

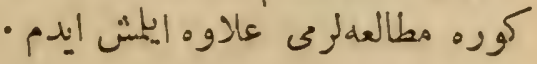

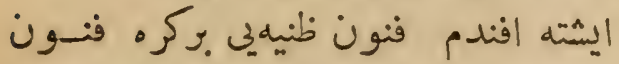

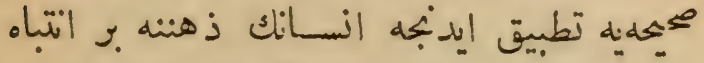

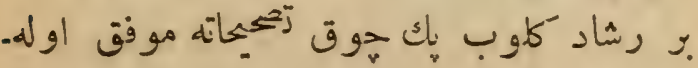
جنى كمى بونلرى .رده فنون رياضيسهيه تطبيق

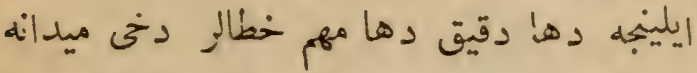

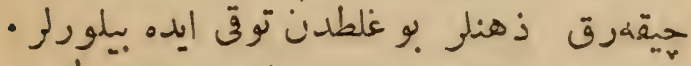

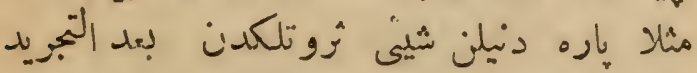

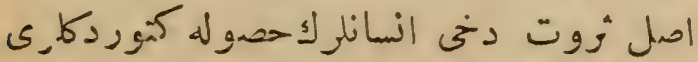

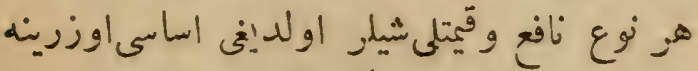

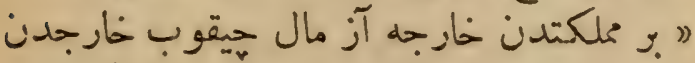

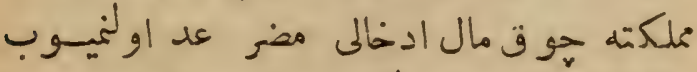

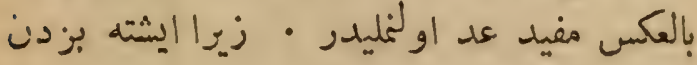

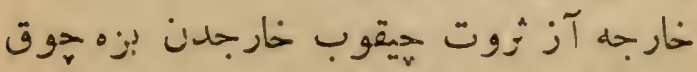

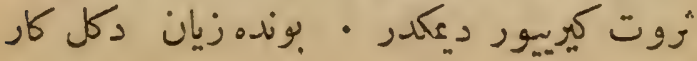




\section{- or -}

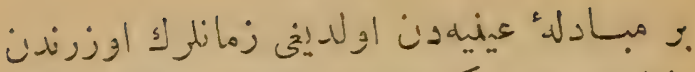

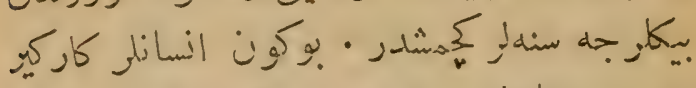

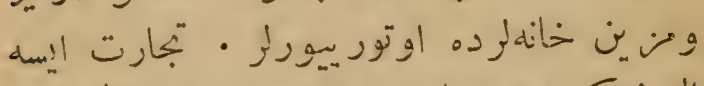

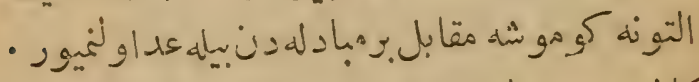

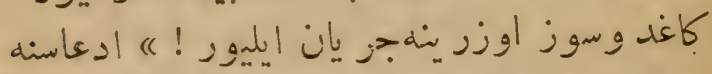

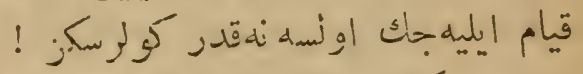

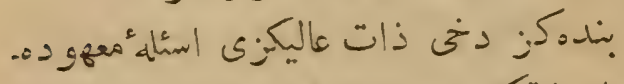

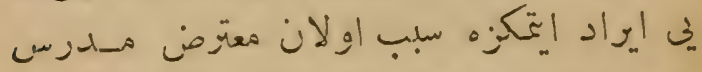

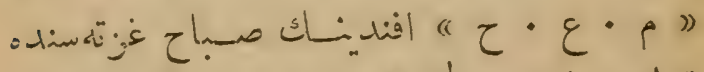

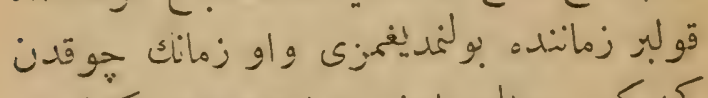

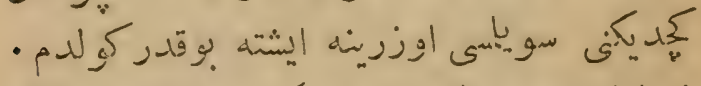

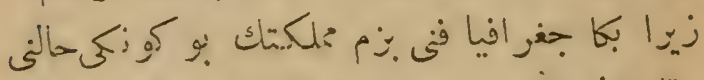

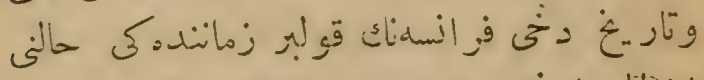

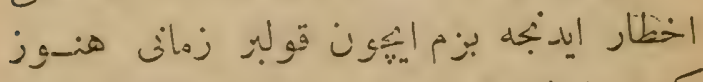

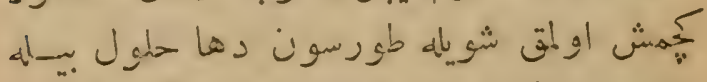

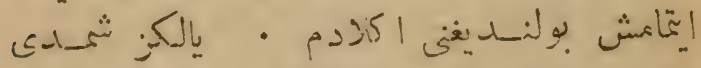

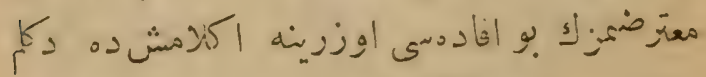

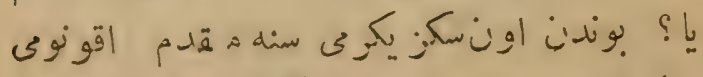

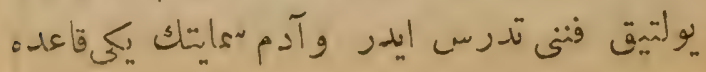


$-O \psi-$

دان

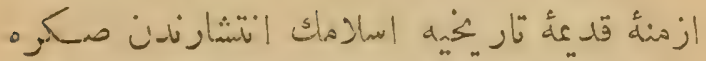

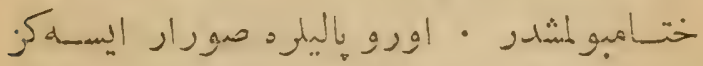
كVT

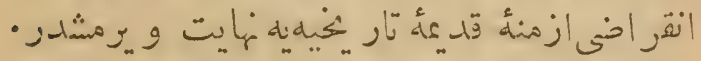

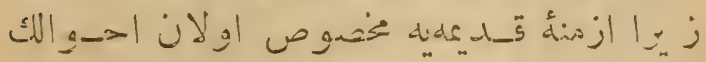

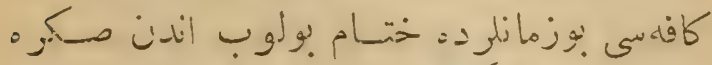

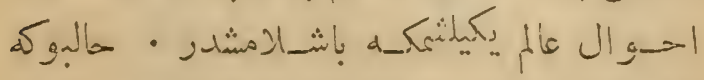

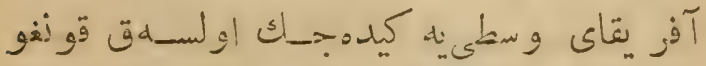

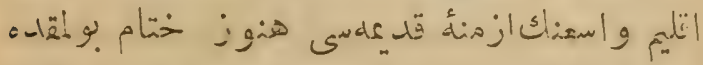

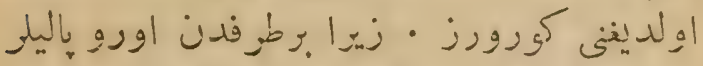

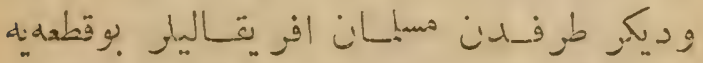

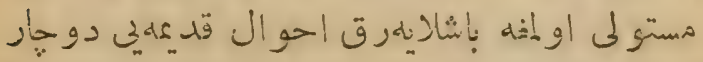

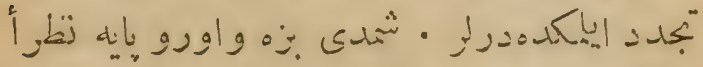

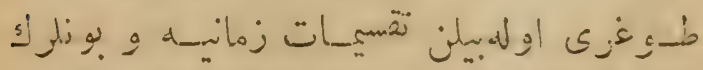

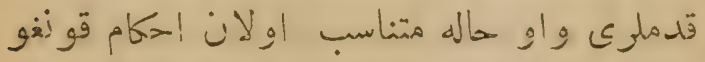

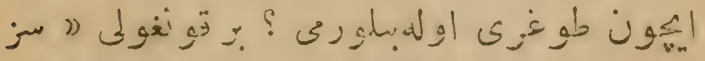

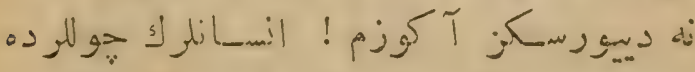

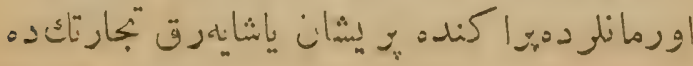




\section{- $01-$}

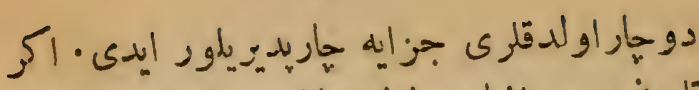

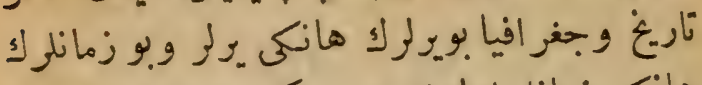

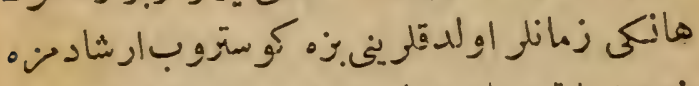

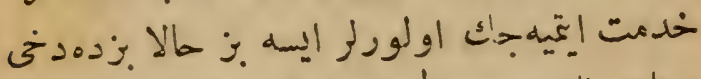

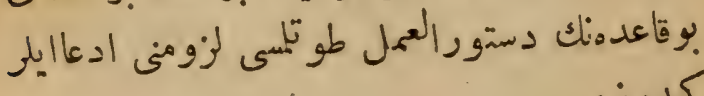
كيدرز •

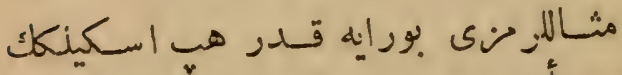

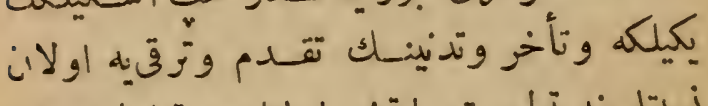

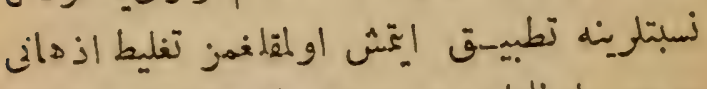

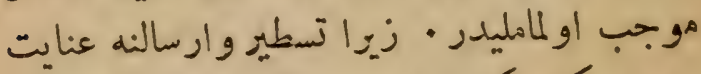

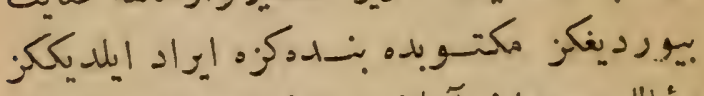

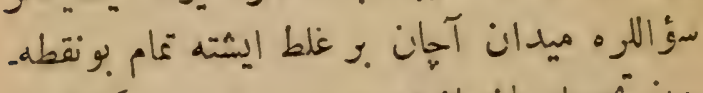

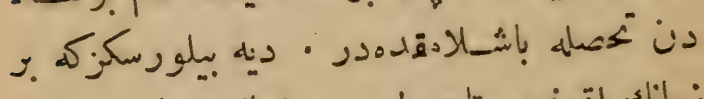

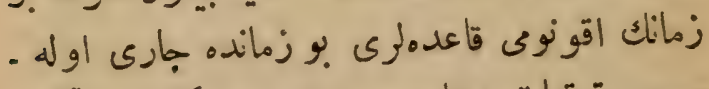

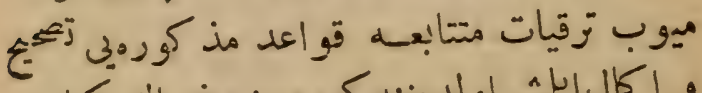

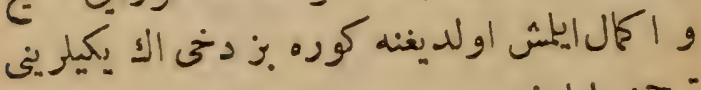

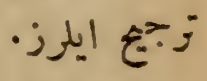

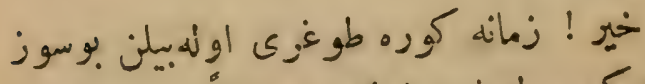

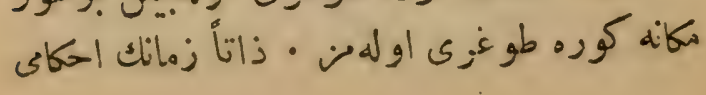




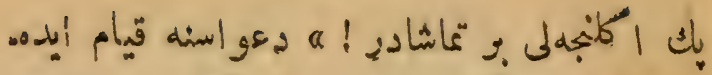

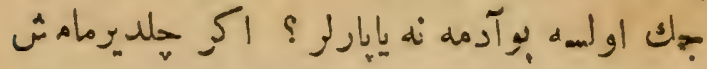

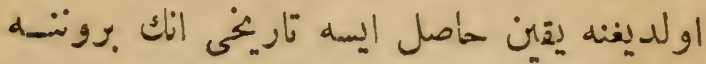

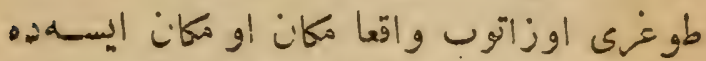

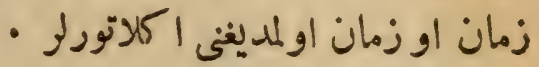

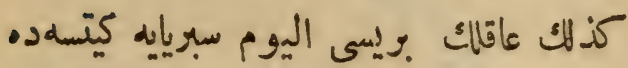

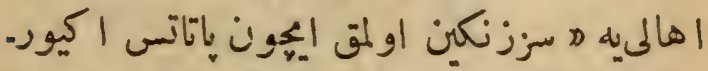

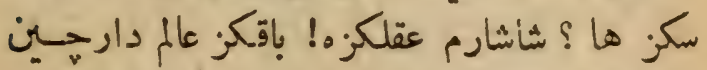

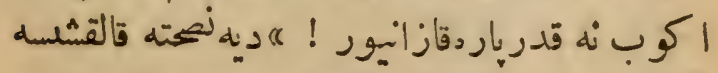

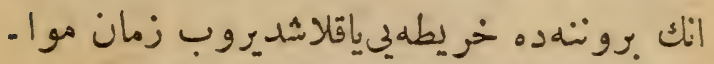

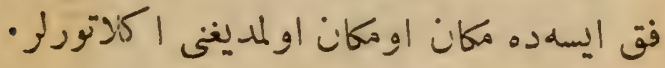

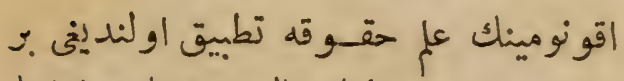

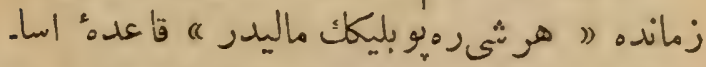

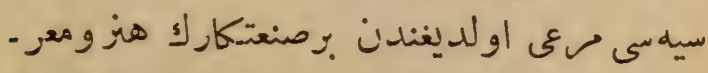

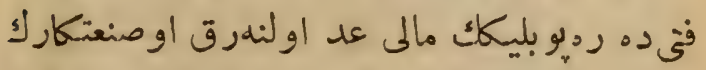

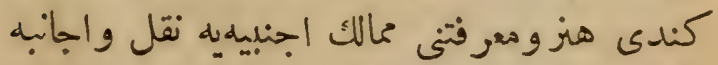

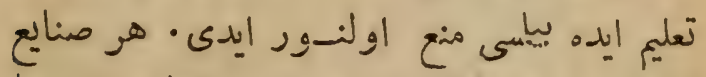

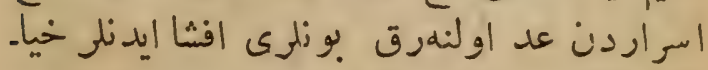

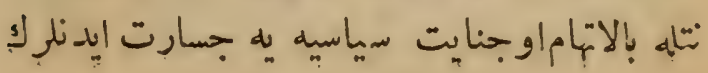




\section{- 29}

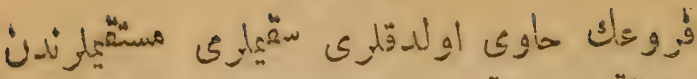

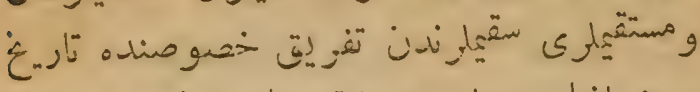

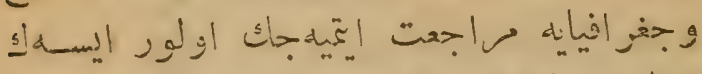

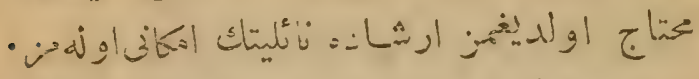

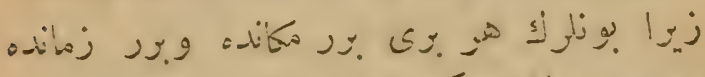

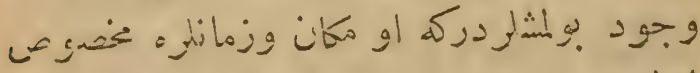

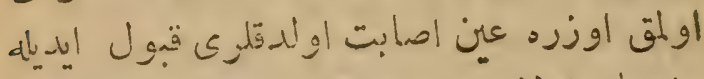

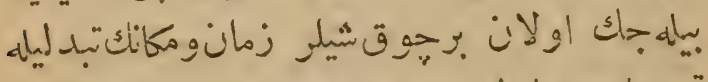

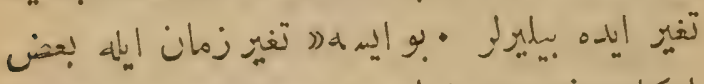

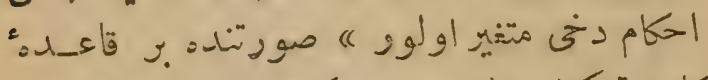

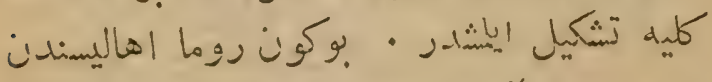

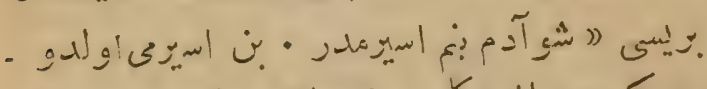

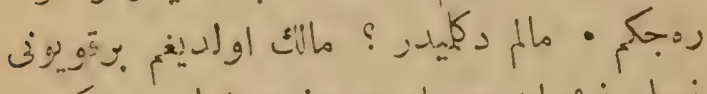

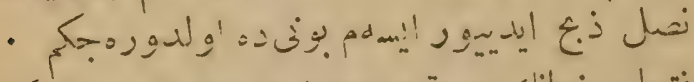

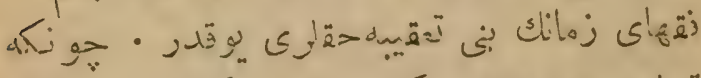

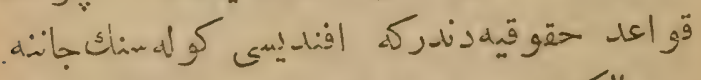

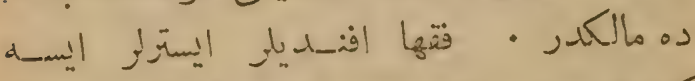

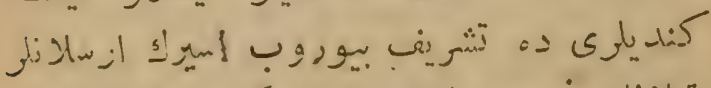

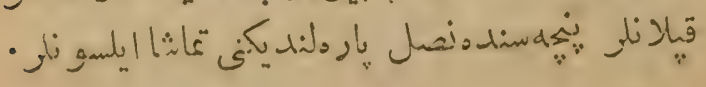




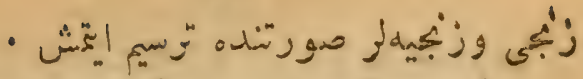

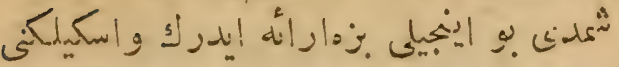

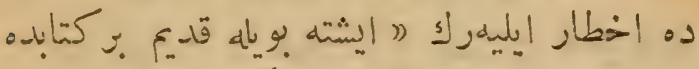

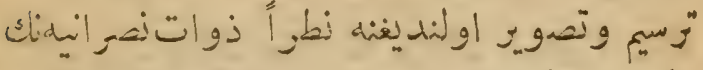

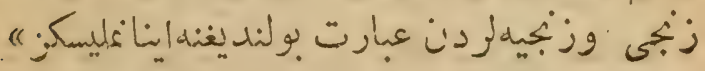

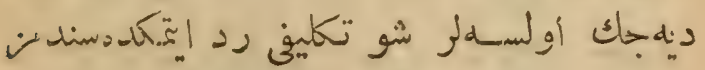

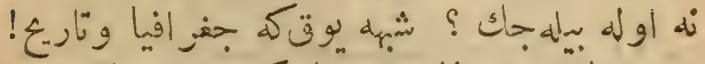

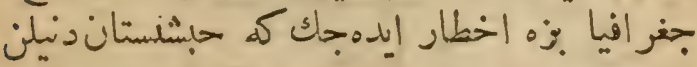

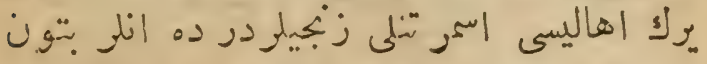

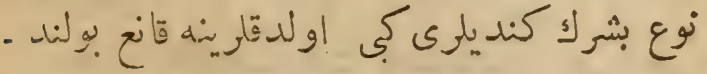

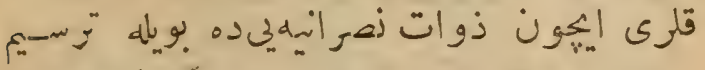

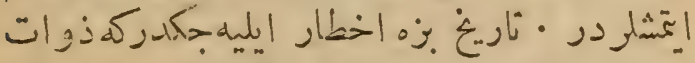

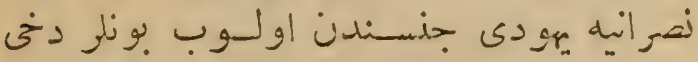

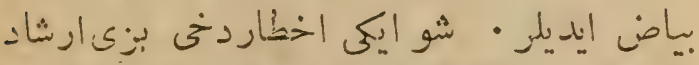

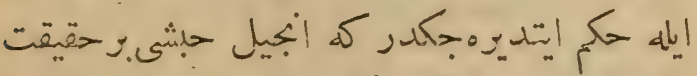

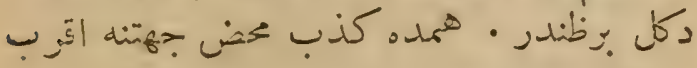

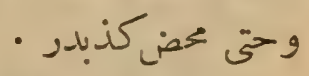

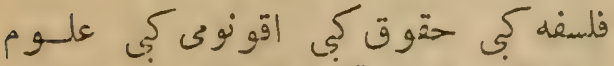

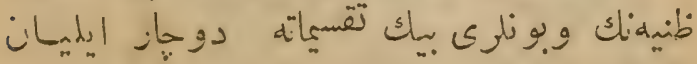




\section{$-\varepsilon Y-$}

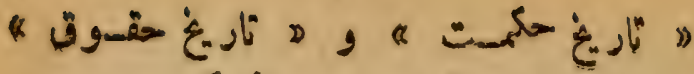

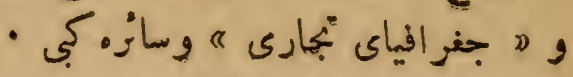

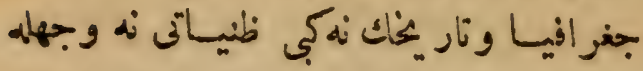

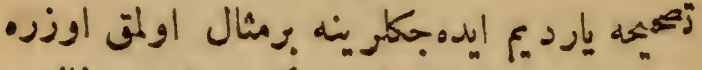

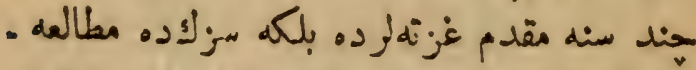

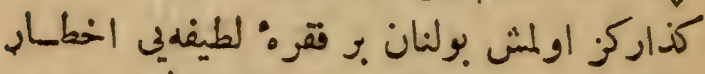

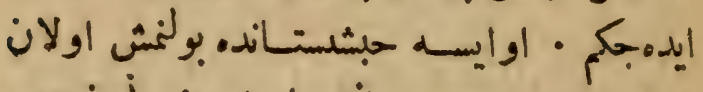

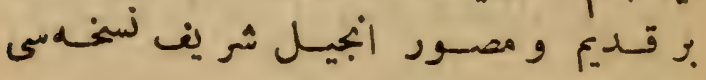

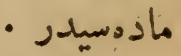

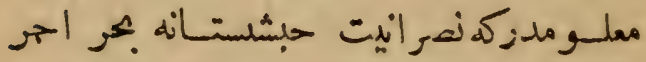

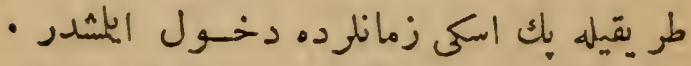

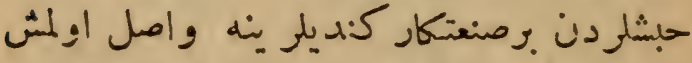

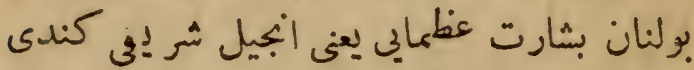

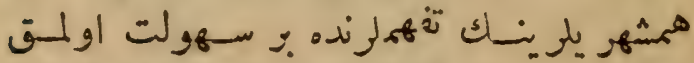

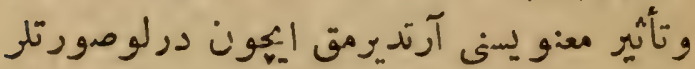

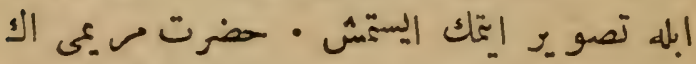

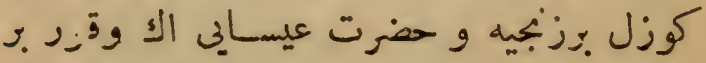

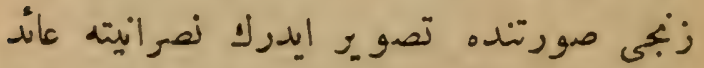

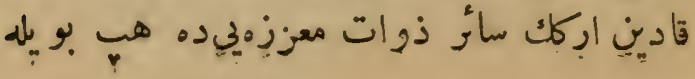




\section{$--\leqslant 0$}

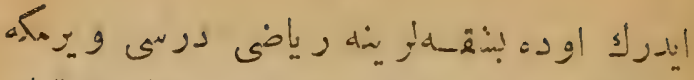

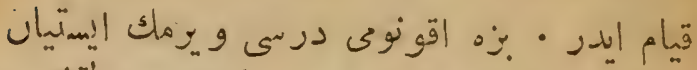

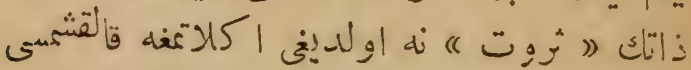

ايمدى ظن دينان ش-مأك جغز افياكي علوم

$$
\text { ! } 5
$$

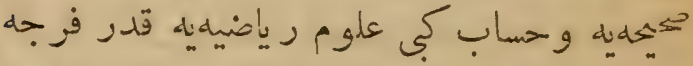

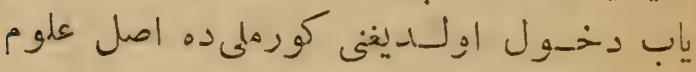

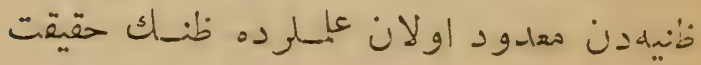

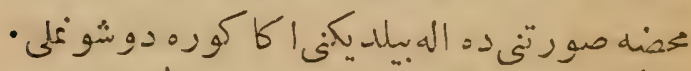

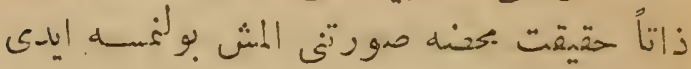

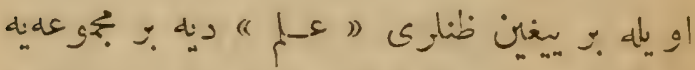

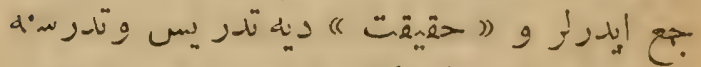

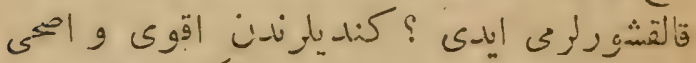

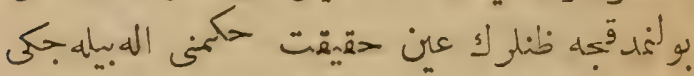

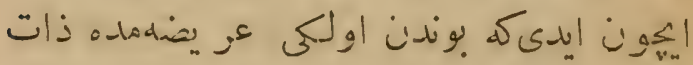

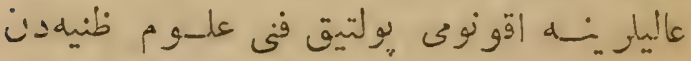

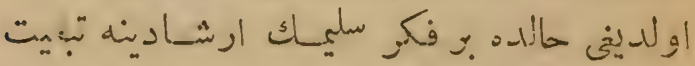

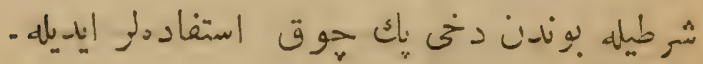
- 


\section{$-2 \xi$}

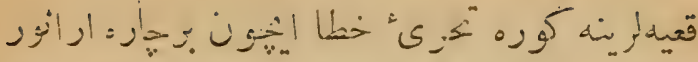

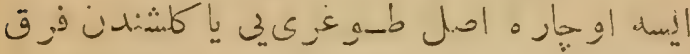

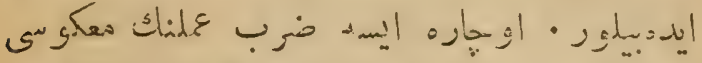

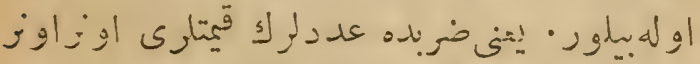

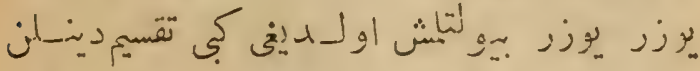

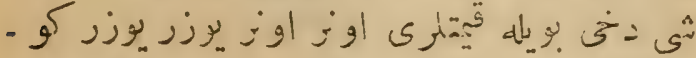

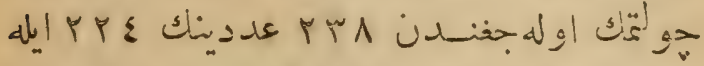

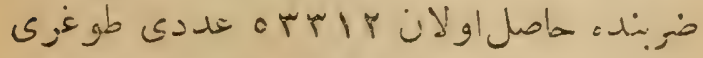

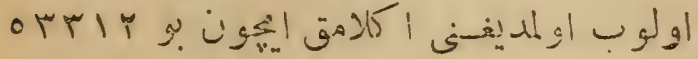

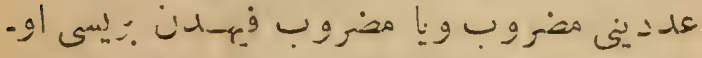

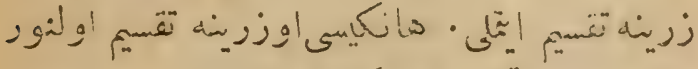

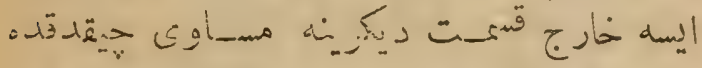

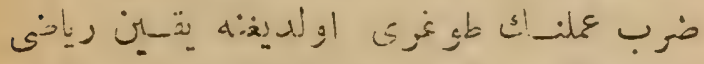

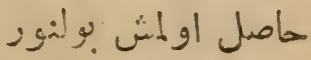

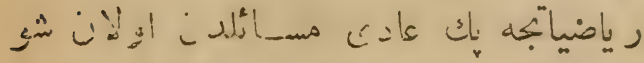

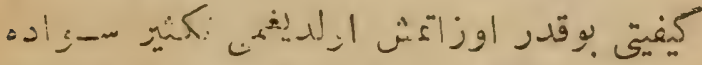

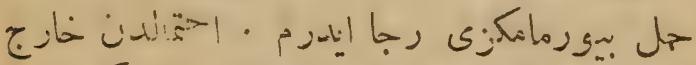

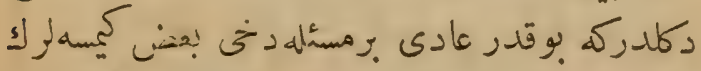

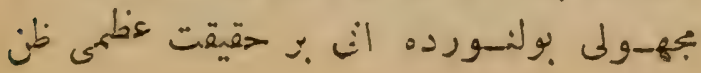




\section{$-\varepsilon r-$}

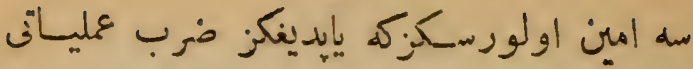

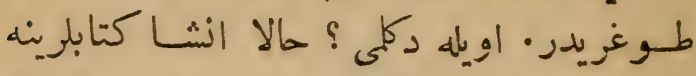

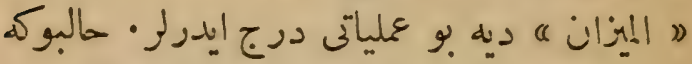

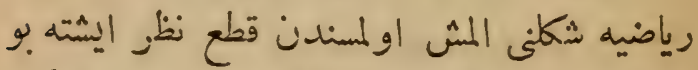

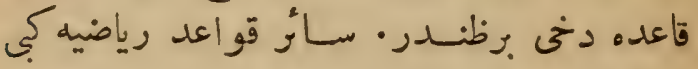

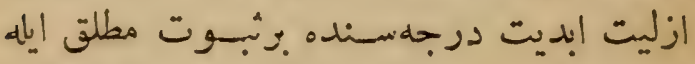

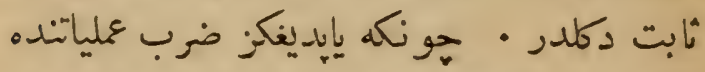

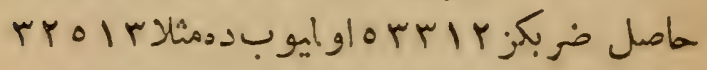

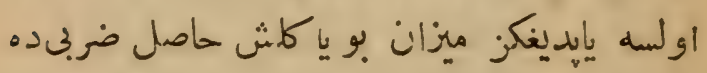

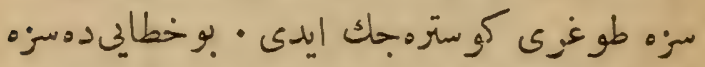

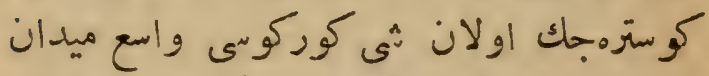

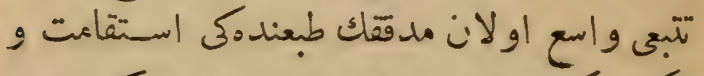

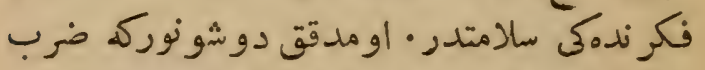

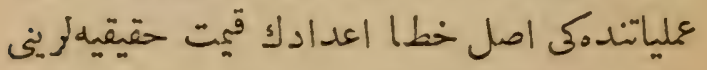

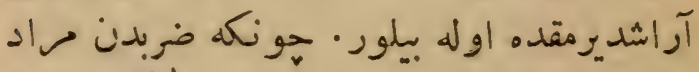

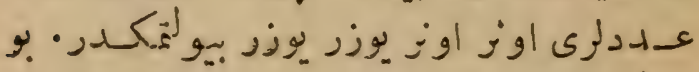

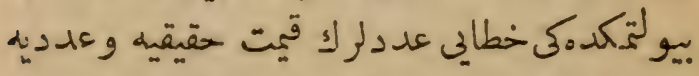

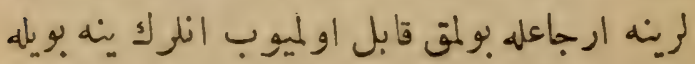

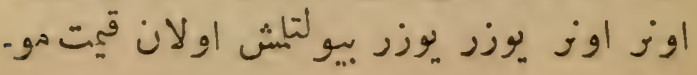




\section{$-\xi r-$}

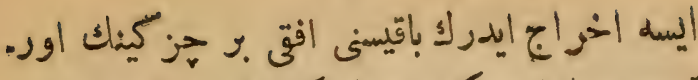

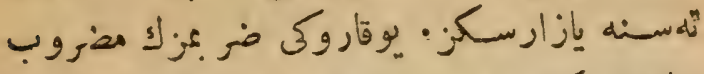

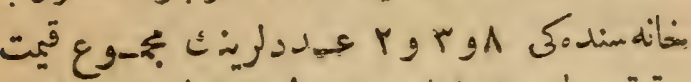

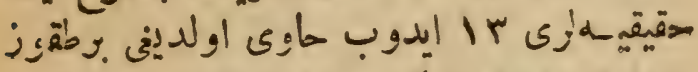

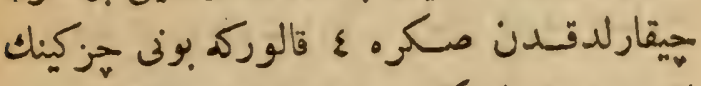

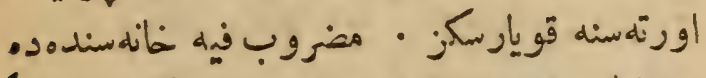

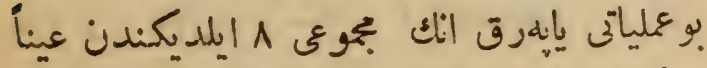

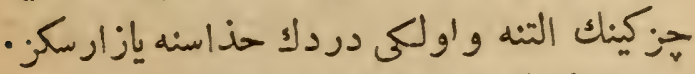

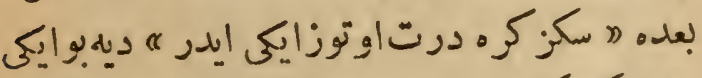

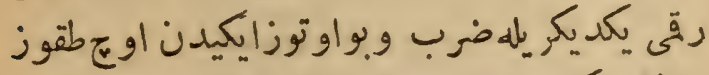

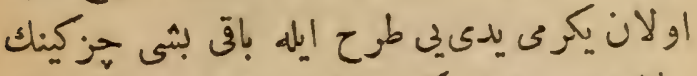

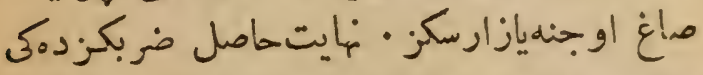

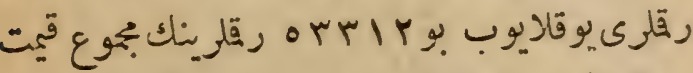

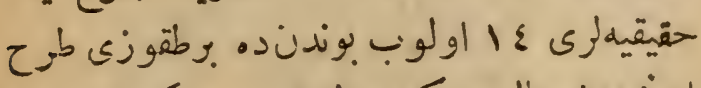

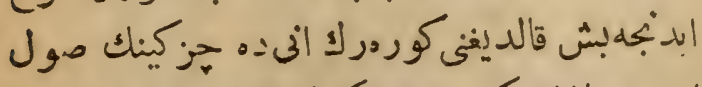

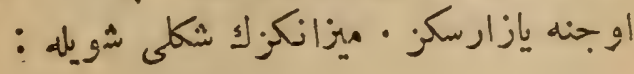

$\frac{0 \leqslant 0}{1}$

اولود • إيكي اوجدهكي رقملر بربوينكينىاولور 
$-\leqslant 1-$

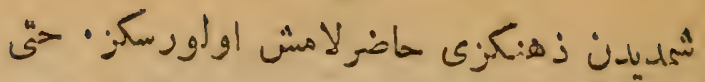

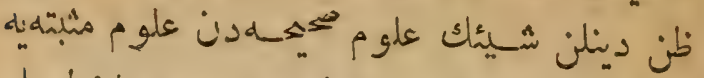

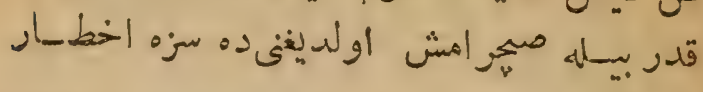

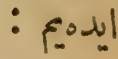

مفتاح رياضيات اولان أعال عادئة حسابه

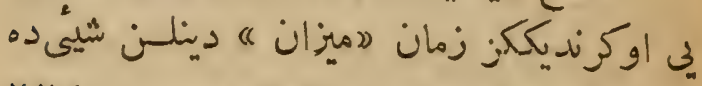

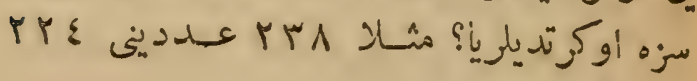

عددي إيله شويلهجه :

THA

TYE

gor

$\varepsilon V Y$

$\frac{\varepsilon V Y}{\text { orrir }}$

ديه فرب إيلديككززمان حاصل إيلديككز

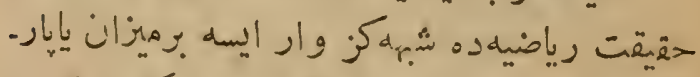

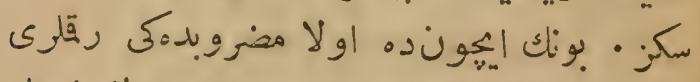

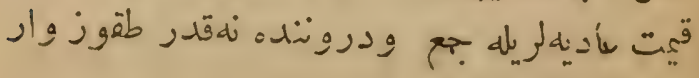




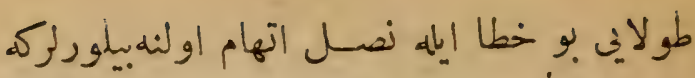

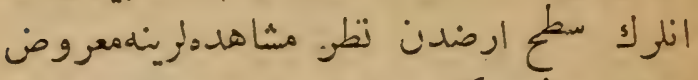

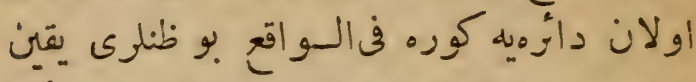

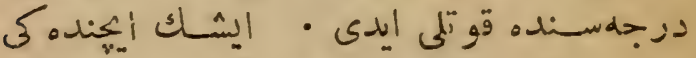

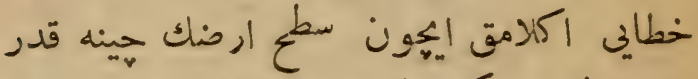

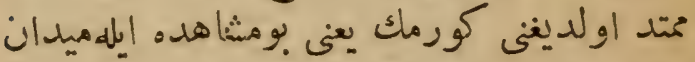

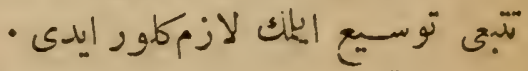

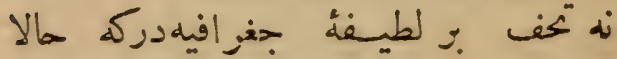

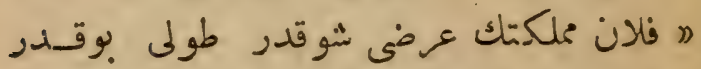

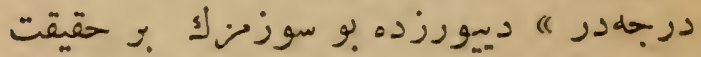

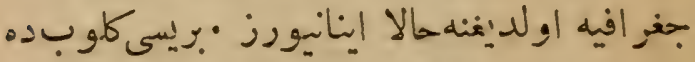

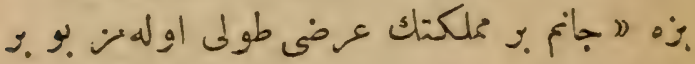

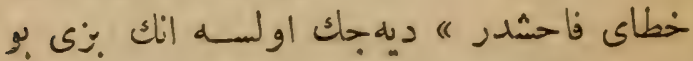

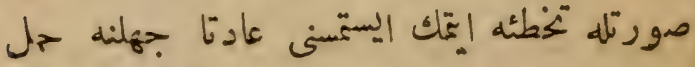

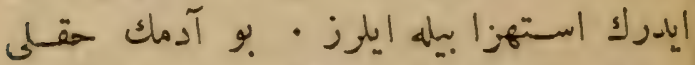

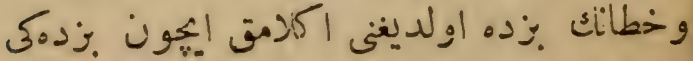

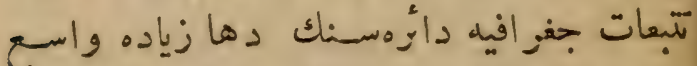

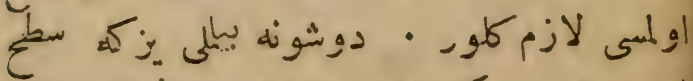

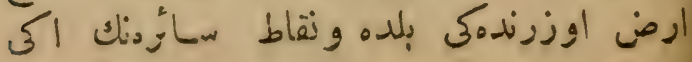




\section{$-\mu \nu$}

ذهنلرده حصوله كمش .ب حكم ناتمام اولهوب

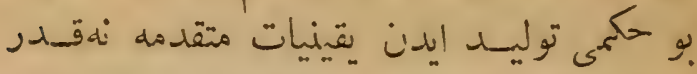

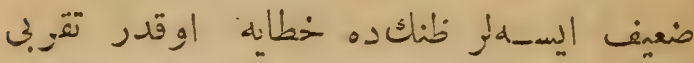

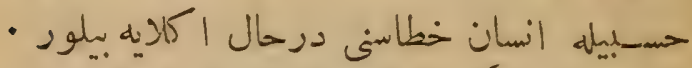

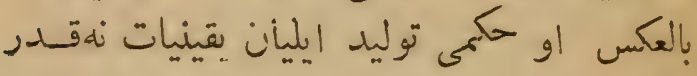

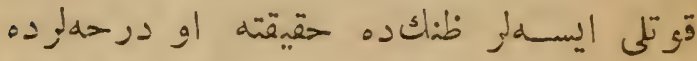

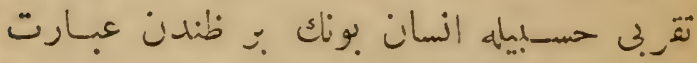

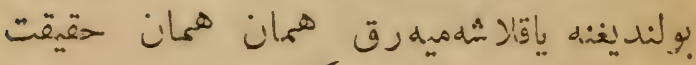

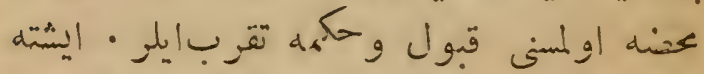

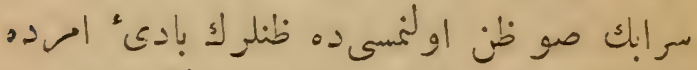

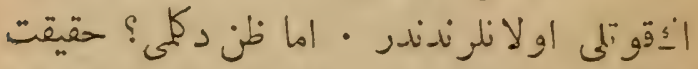

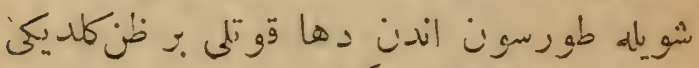

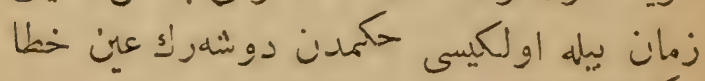

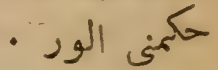

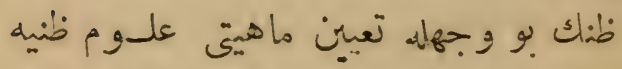

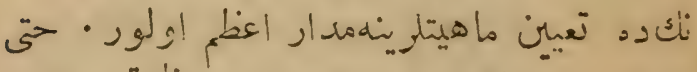

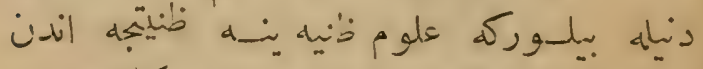

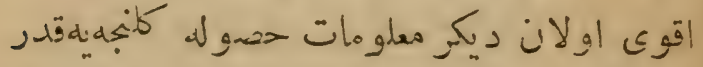

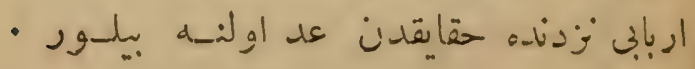


فنلز عادتا فنون ظنيهدن معدود اوله فمقلرينى

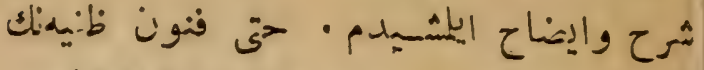

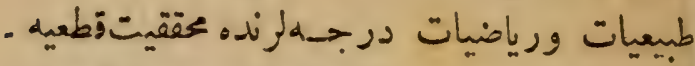

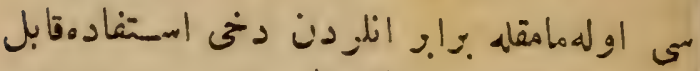

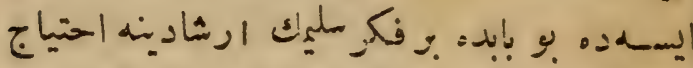

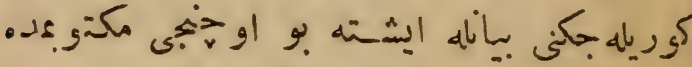

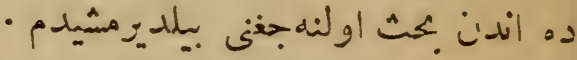

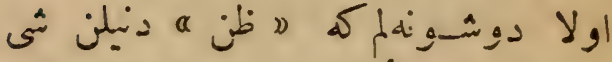

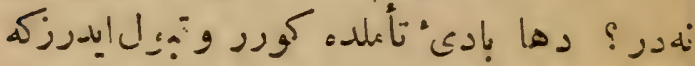

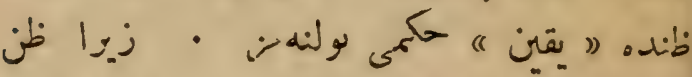

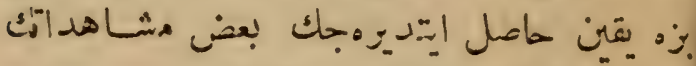

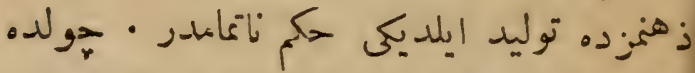

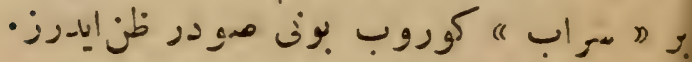

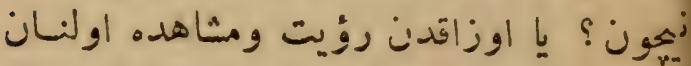

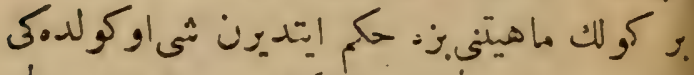

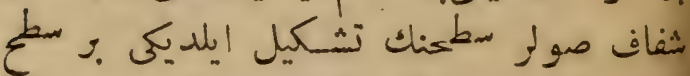

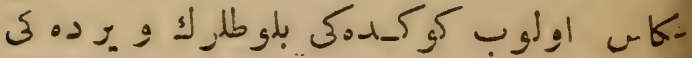

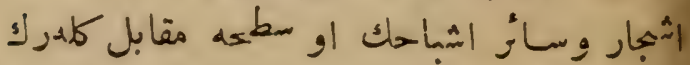

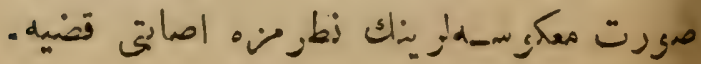




\section{- w}

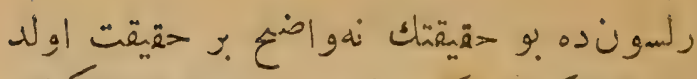

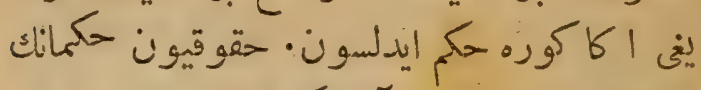

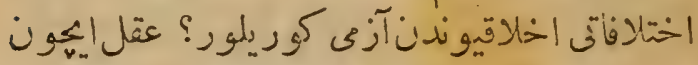

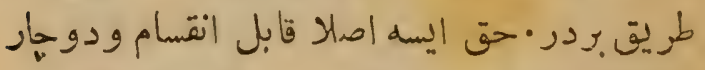
شأكا

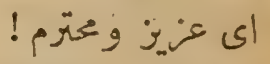

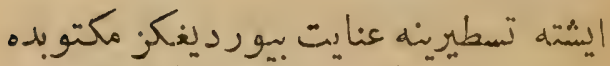

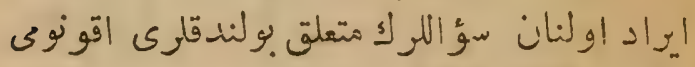

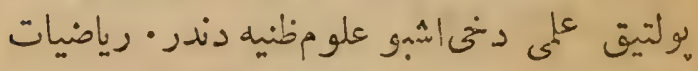

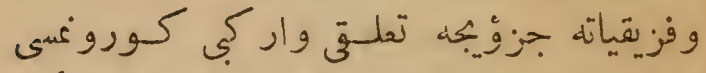

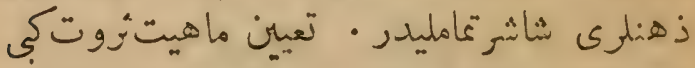

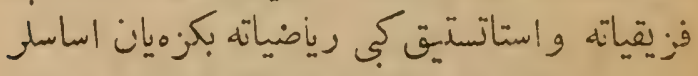

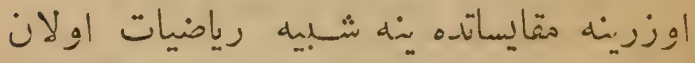

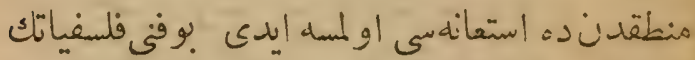

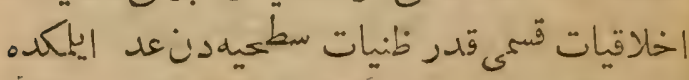

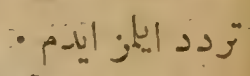

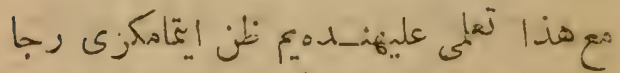

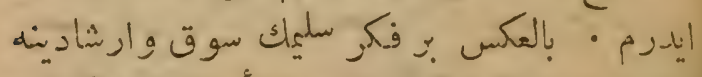

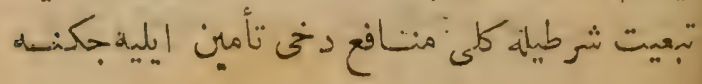


- Pr -

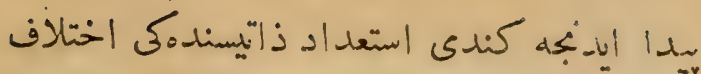

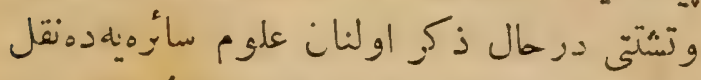

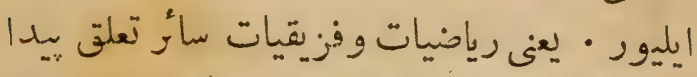

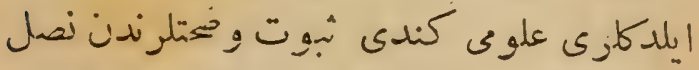

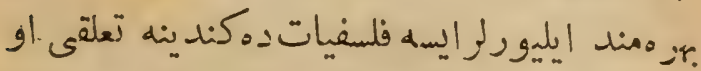

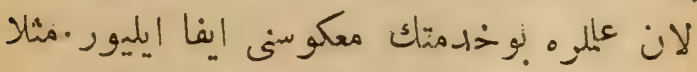

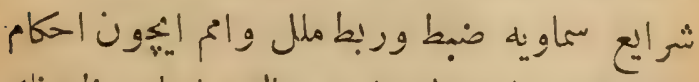

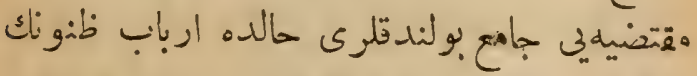

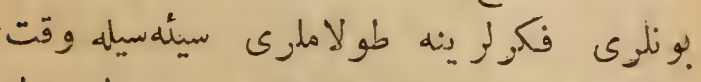

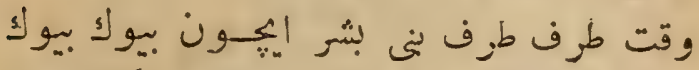

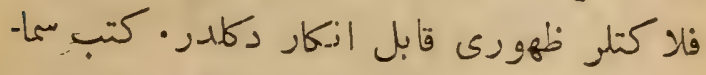

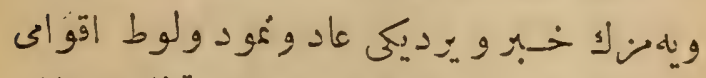

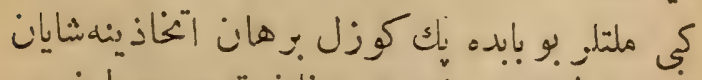

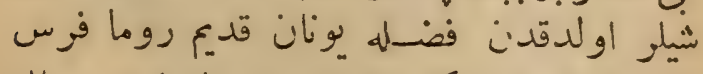

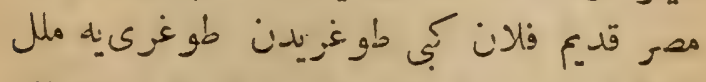

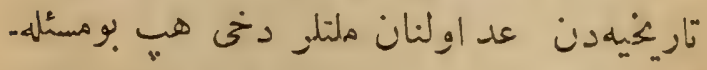

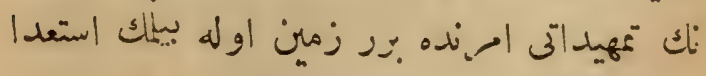

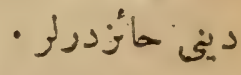

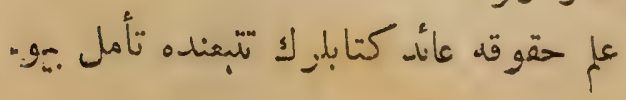




\section{-}

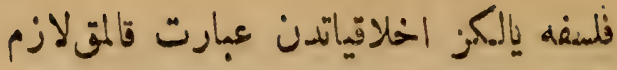

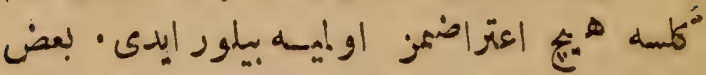

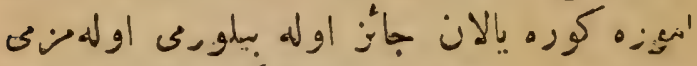

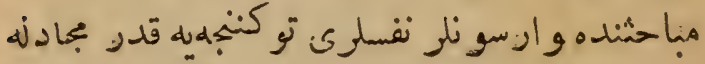

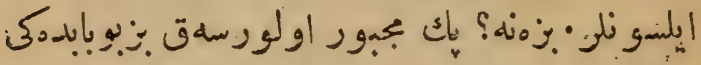

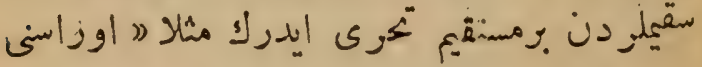

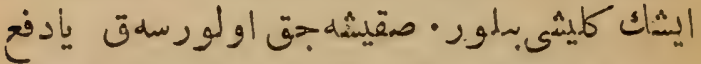
مضرت ويأخود جلب منفعت بجموديتيله بكاكاعلا

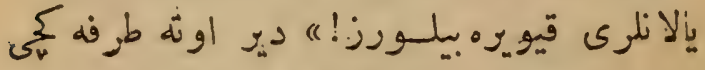

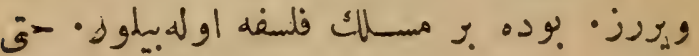

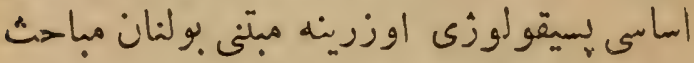

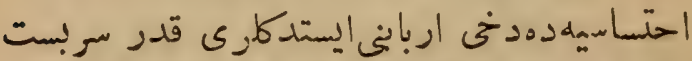

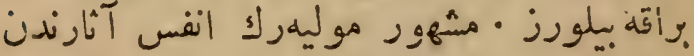

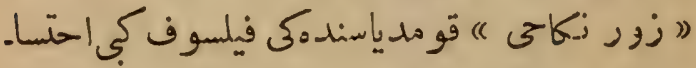

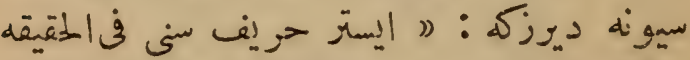

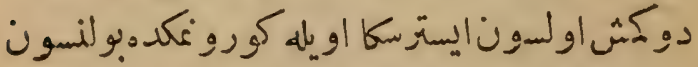

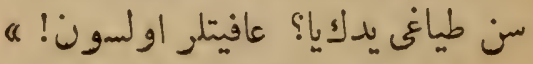

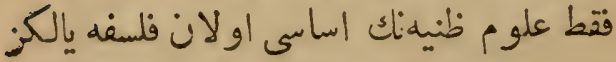

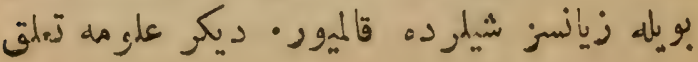




\section{- rq-}

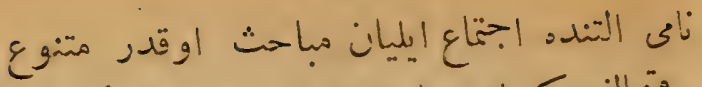

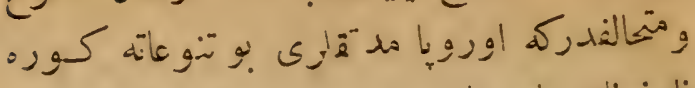

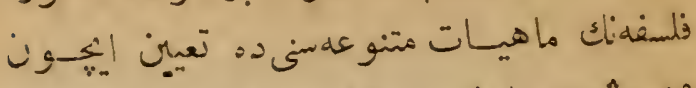

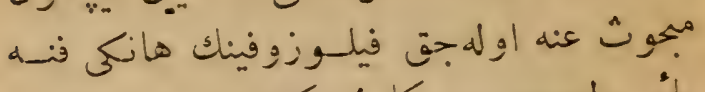

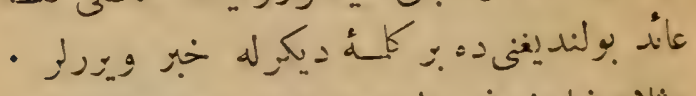

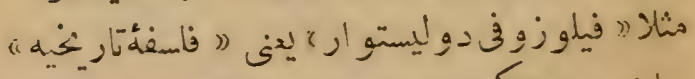

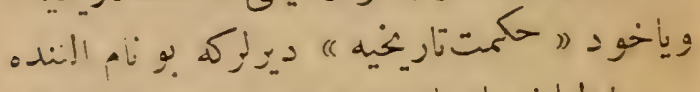

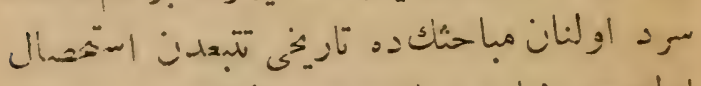

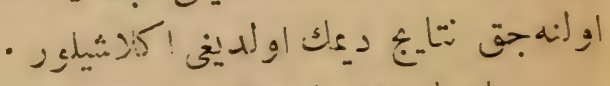

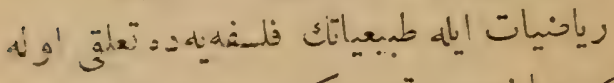

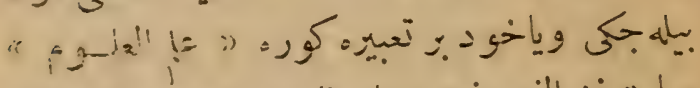

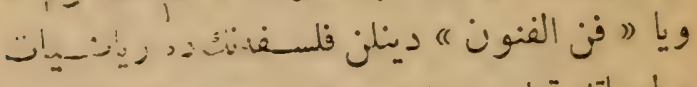

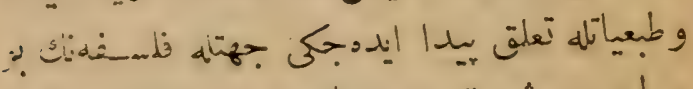

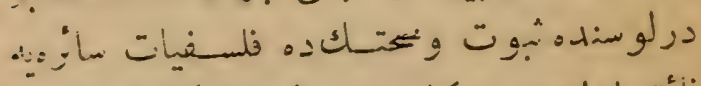

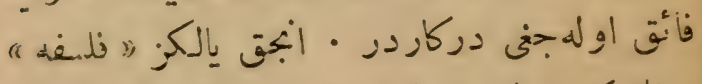

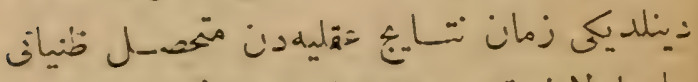

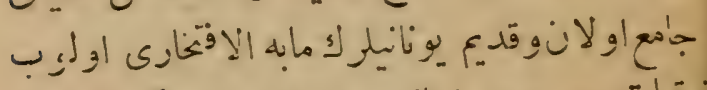

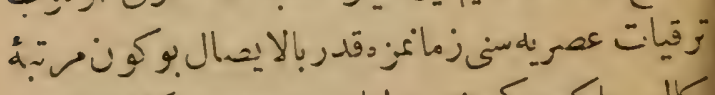

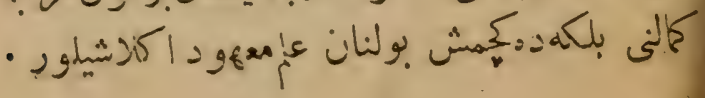




\section{- rA}

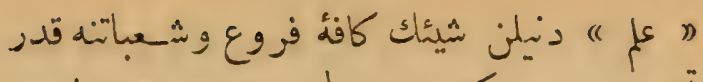

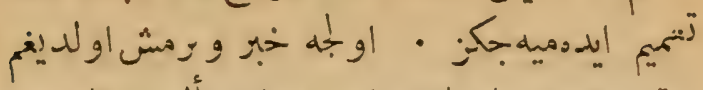

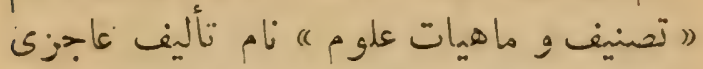

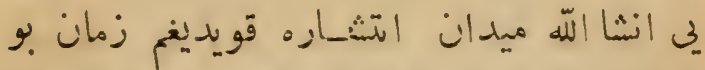

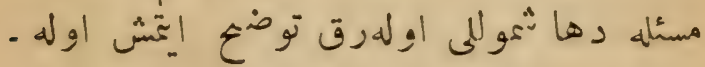

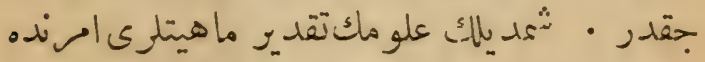

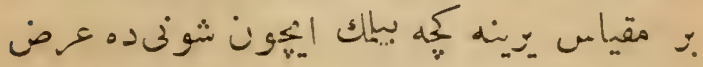
:

علو مده مثبتيت مطلقه علوم رياضيهو صكت

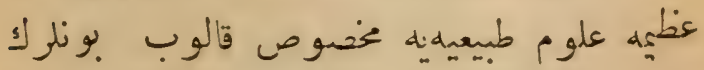

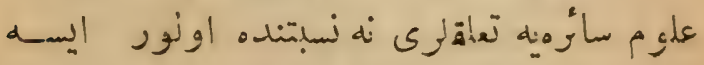

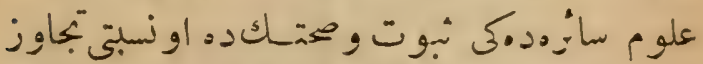

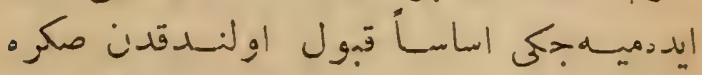

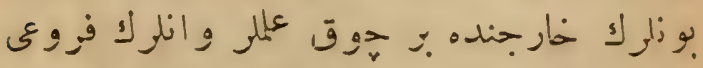

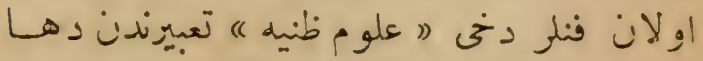

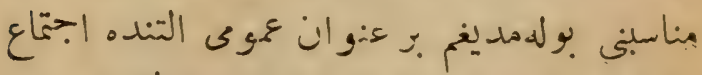

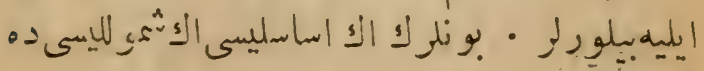

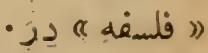

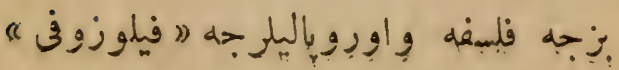




\section{- rV}

جادات ونباتات وحيو اناتاك تحريفلينه دائراتيله.

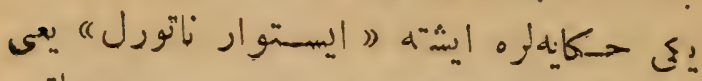

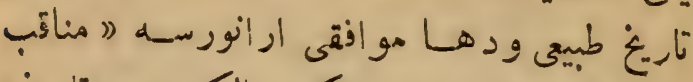

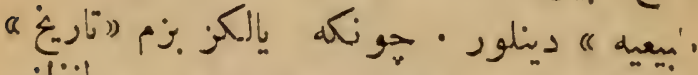

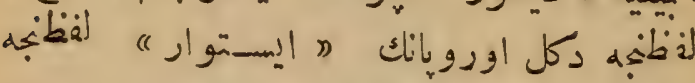

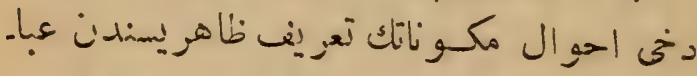

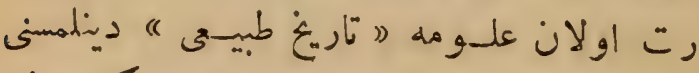

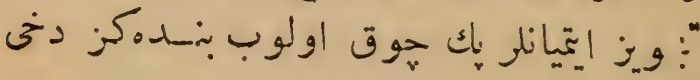

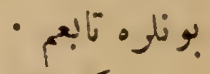

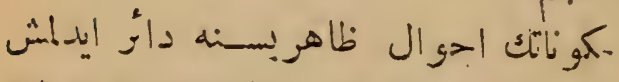

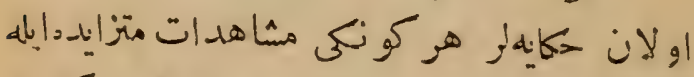

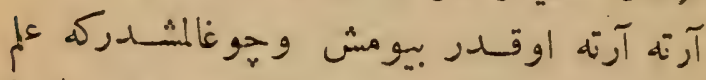

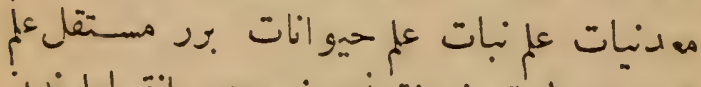

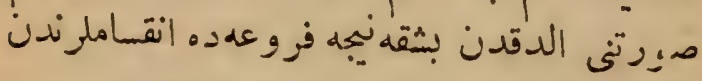

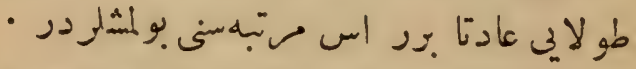

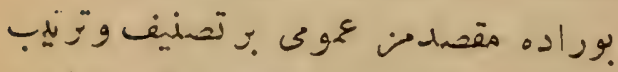

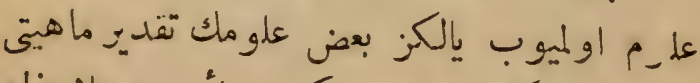

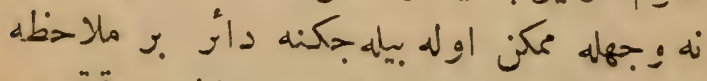

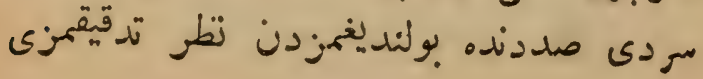




\section{- rq -}

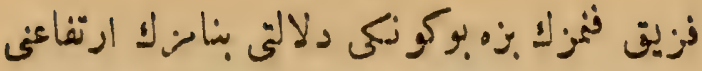

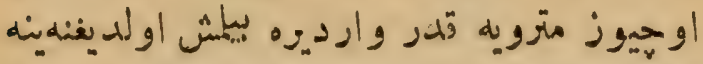

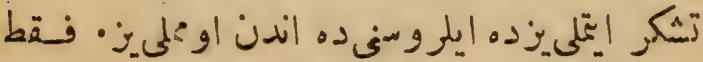

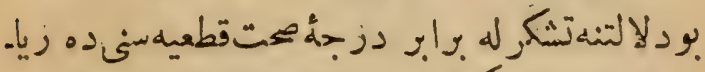

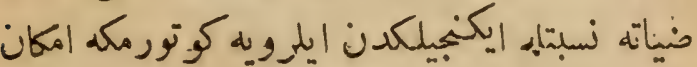

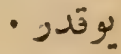

زياضيات هانكى فذه هنه نَنبتده تعلق بيندا

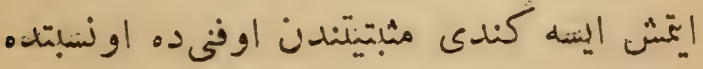

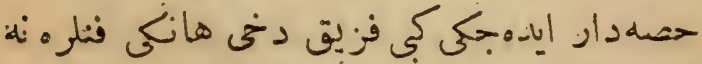

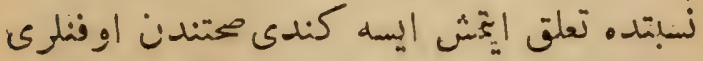

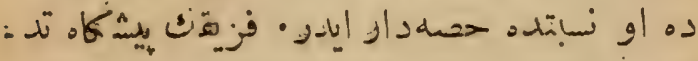

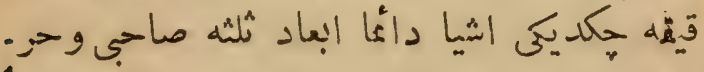

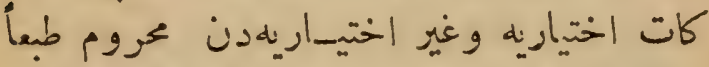

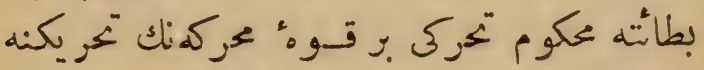

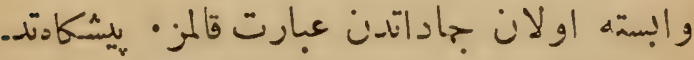

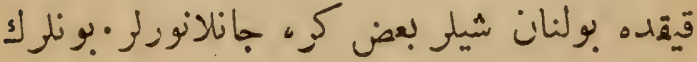

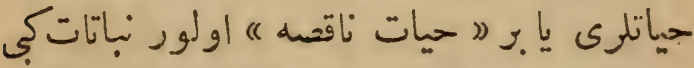

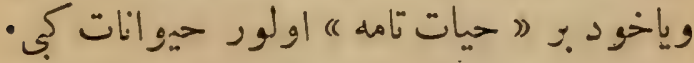

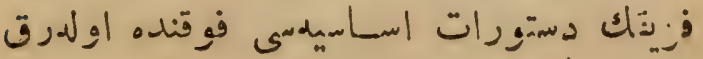




\section{$\ddot{r o}=$}

ذخى ارض طرفندن هنجنَب اولان اجسبـام سا:

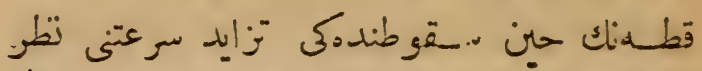

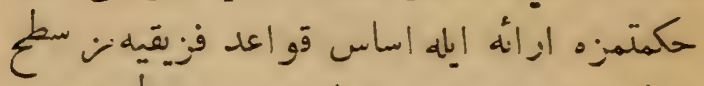

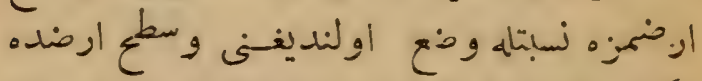

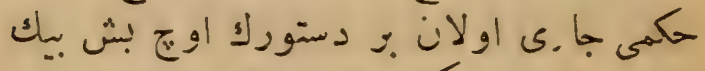

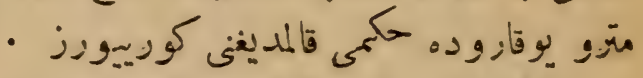

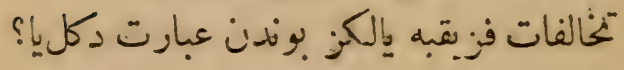

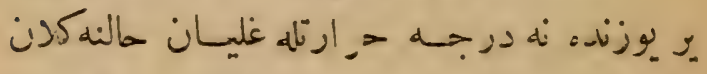

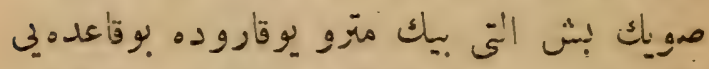

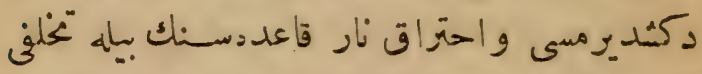

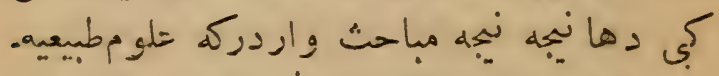

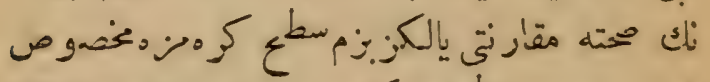

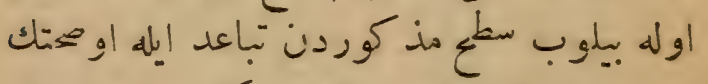

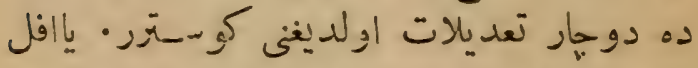

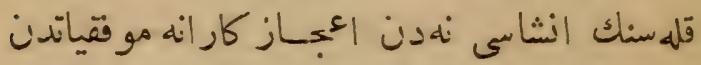

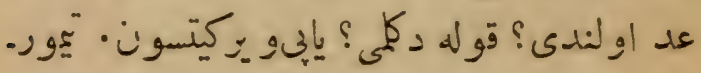

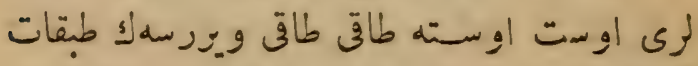

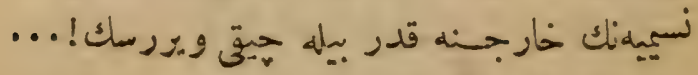

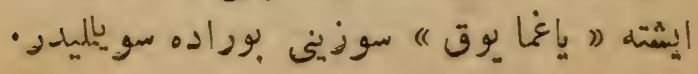




\section{- rs-}

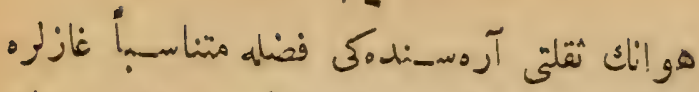

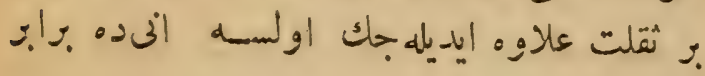

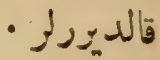

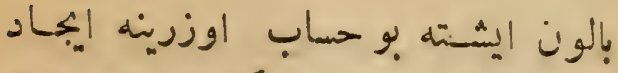

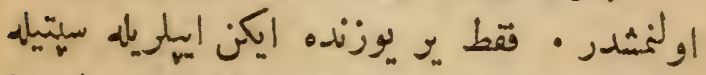

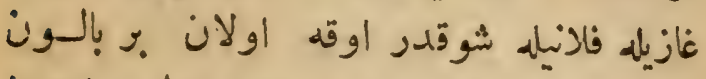

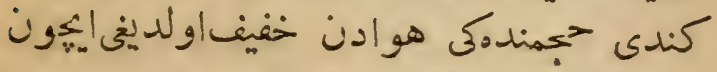

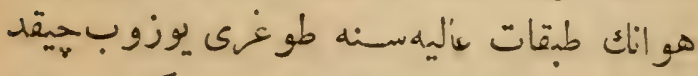

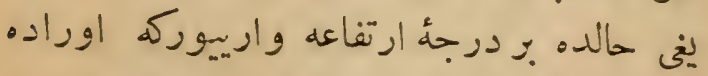

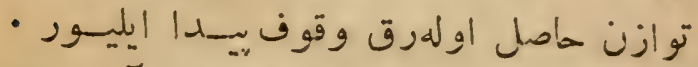

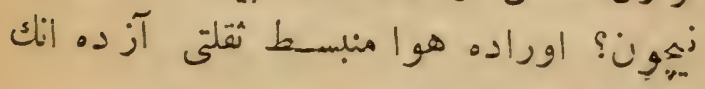

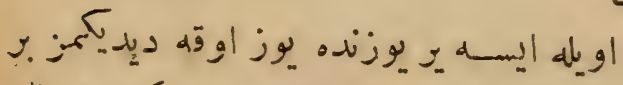
!

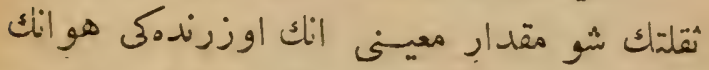

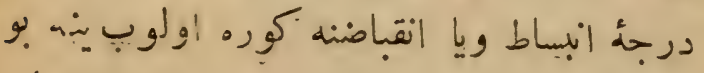

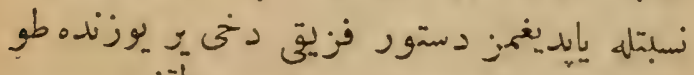

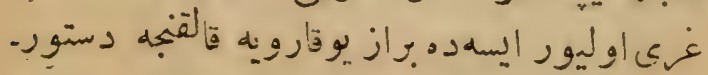

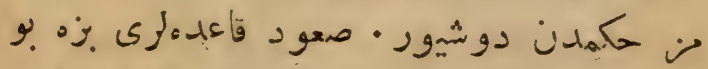

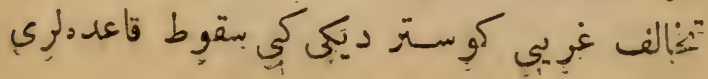




\section{$-r+$}

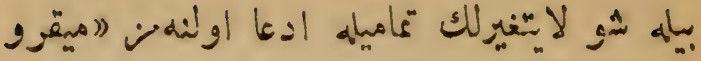

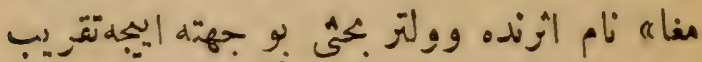

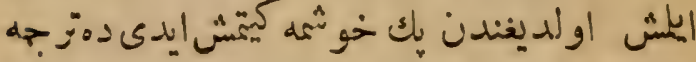

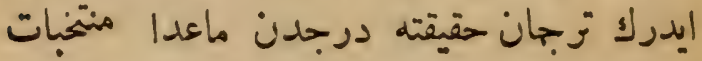

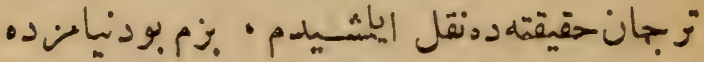

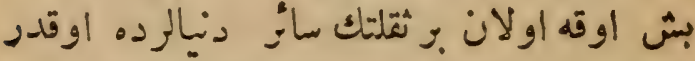

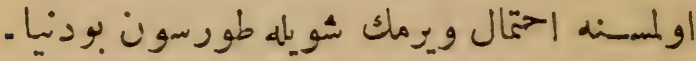

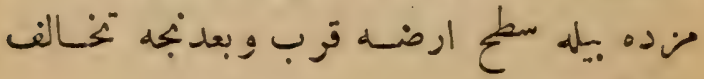

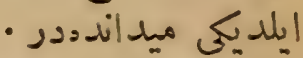

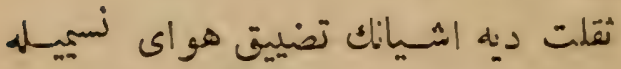

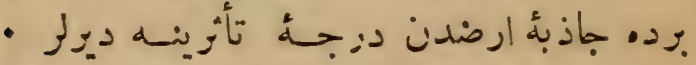

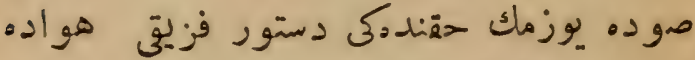

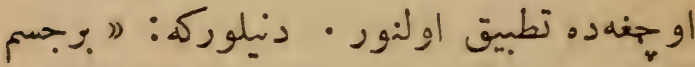

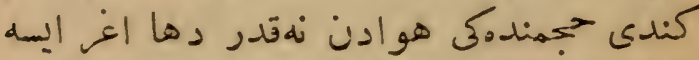

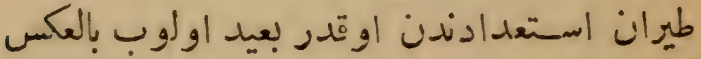

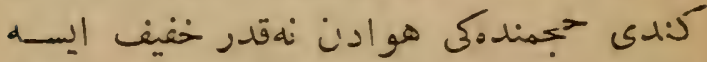
طيرانه استعدادى او نسبتده آرتّار ه غازلر

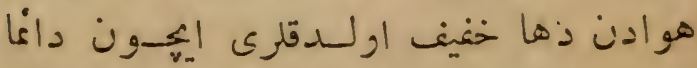

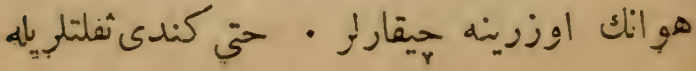




\section{- rr}

دكز صوين ايسه بورايه قدر باطهنجنسئده بيشثه

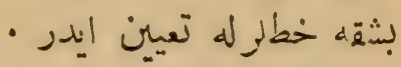

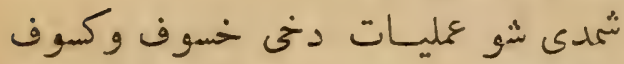

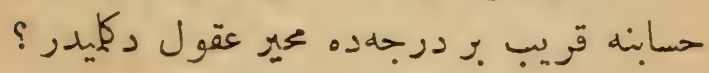

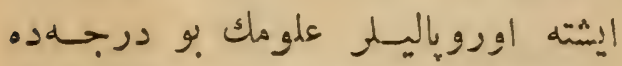

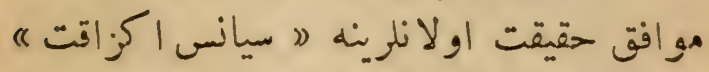

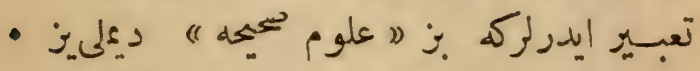

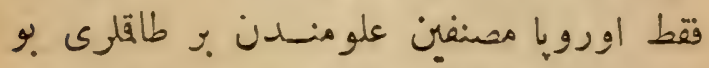

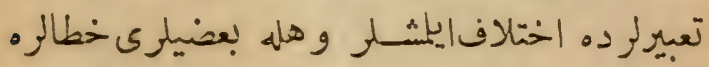

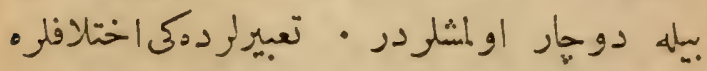

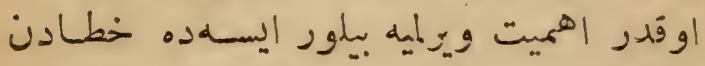

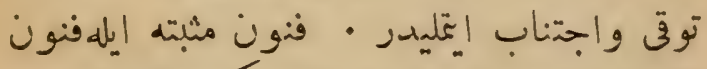

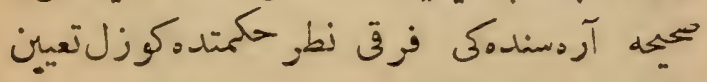

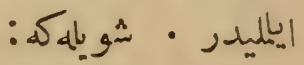

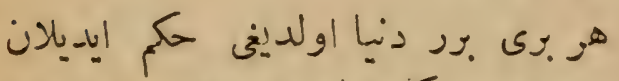

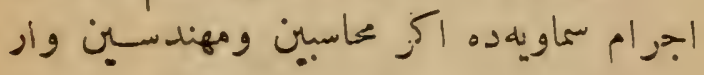

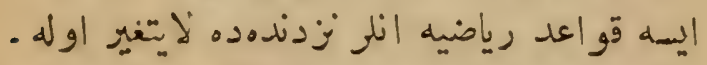

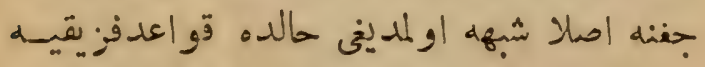

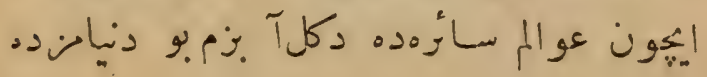




\section{- rI-}

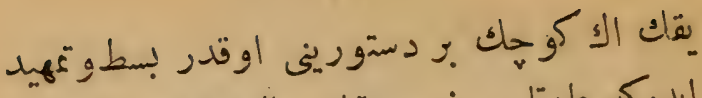

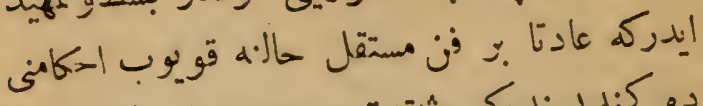

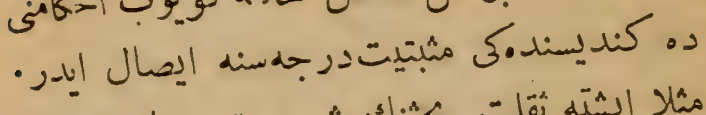

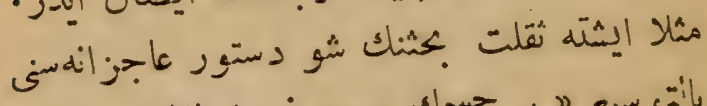

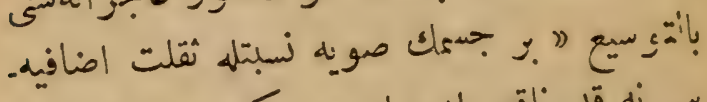

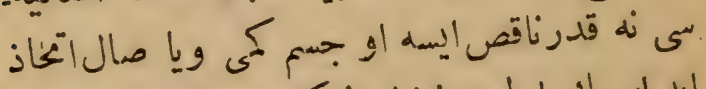

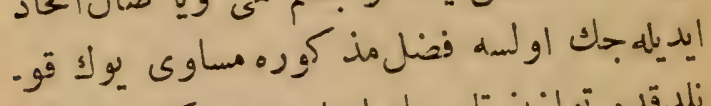

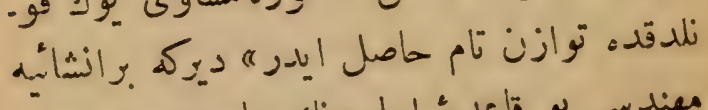

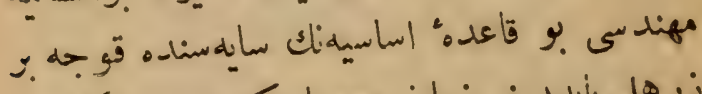

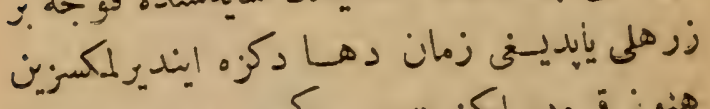

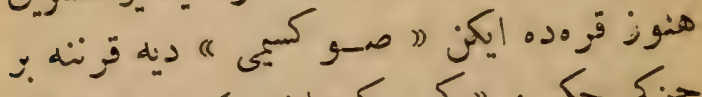

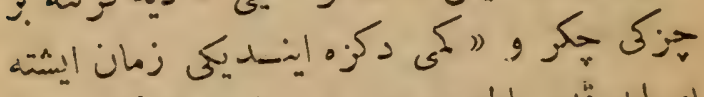

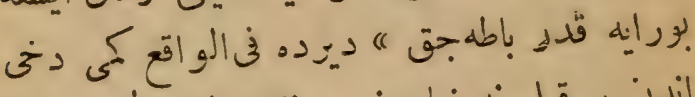

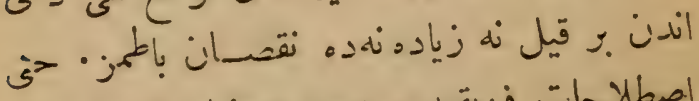

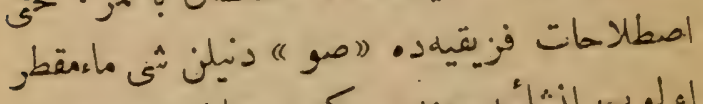

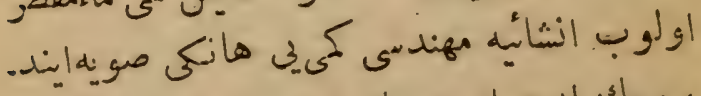

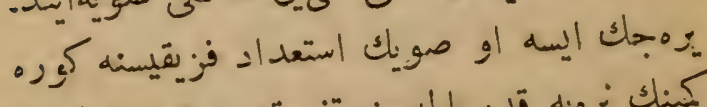

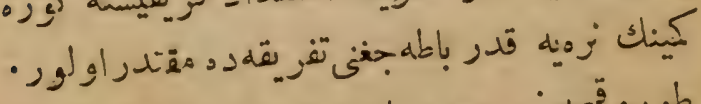

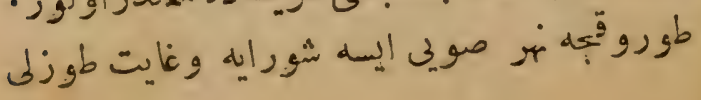




\section{- r. -}

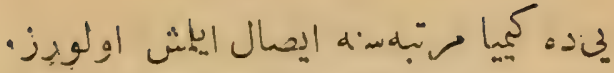

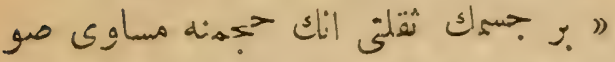

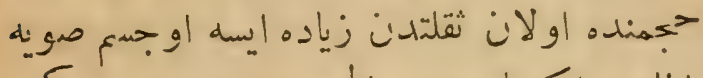

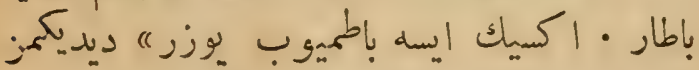

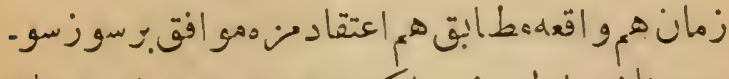

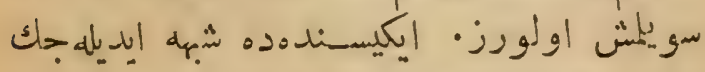

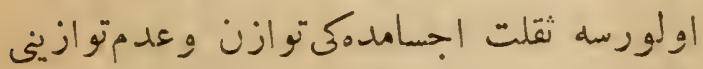

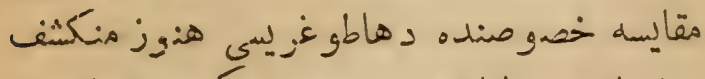

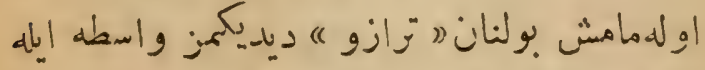

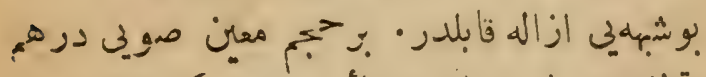

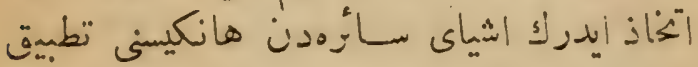

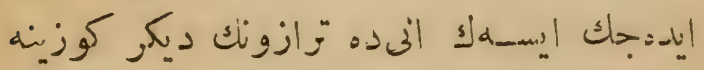

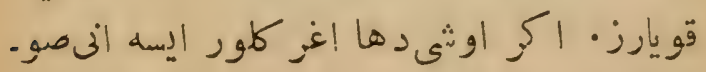

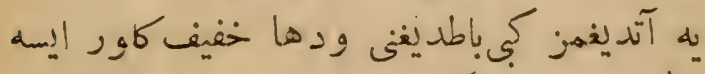

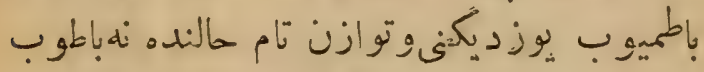

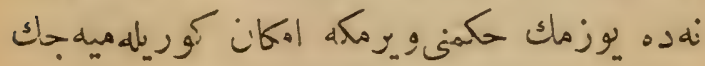

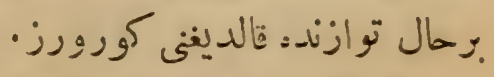

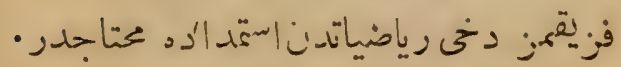

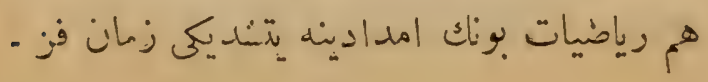




\section{$-19$}

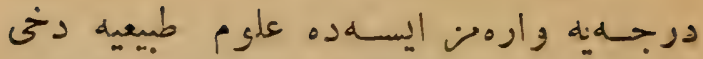

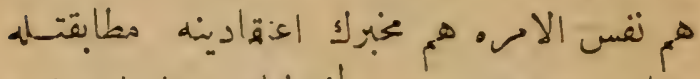

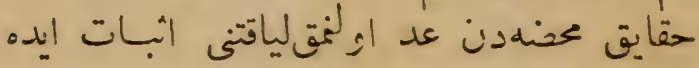
•بيلور

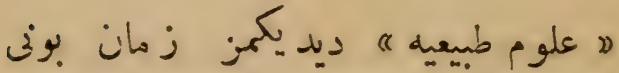

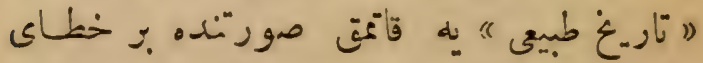

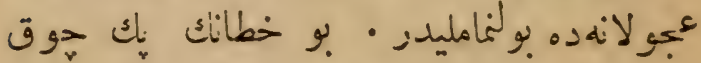

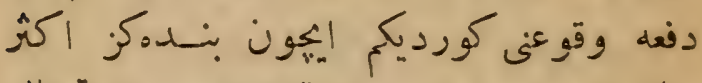

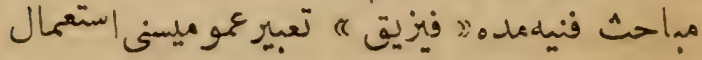

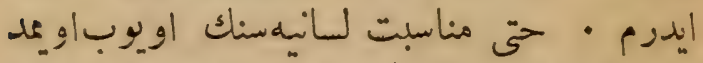

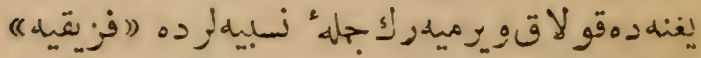

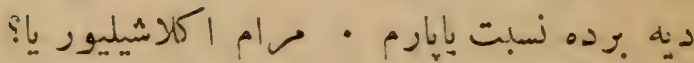

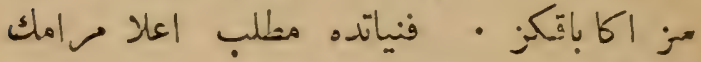

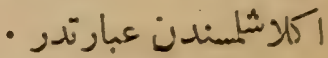

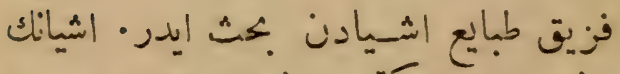

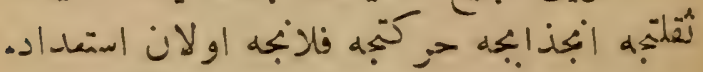

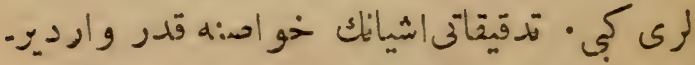

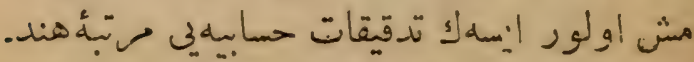

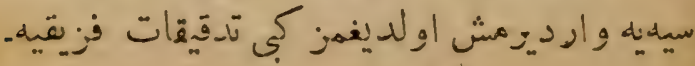




\section{$-11$}

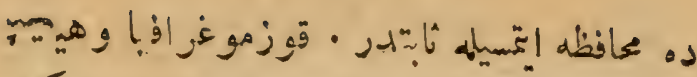

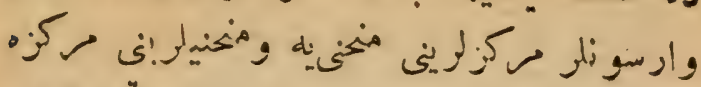

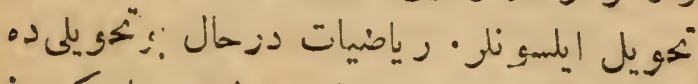

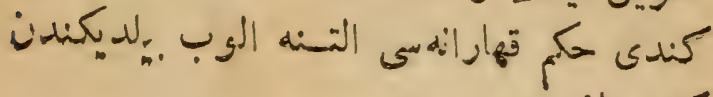
كيّو قالمز كند

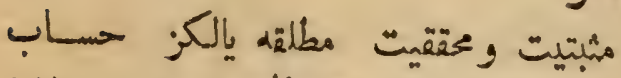

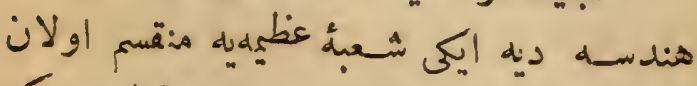

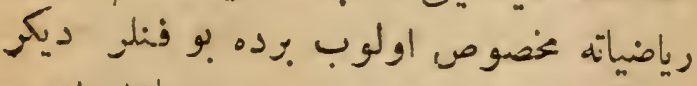

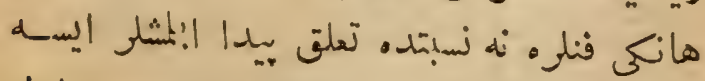

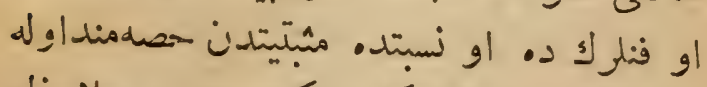

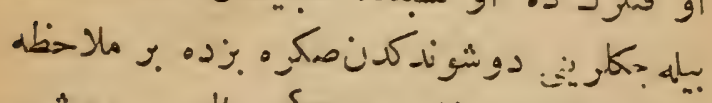

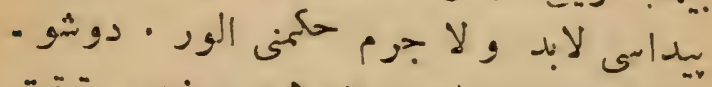

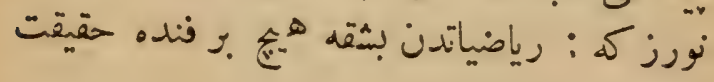

$$
\text { اولهن أورنه }
$$

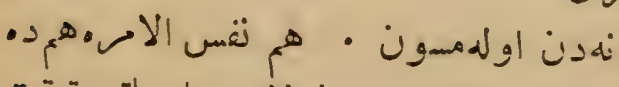

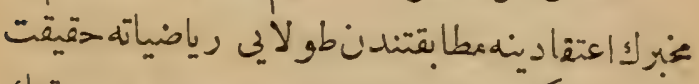

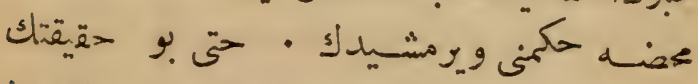

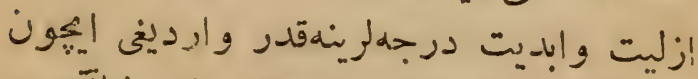

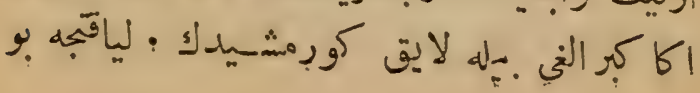




\section{$-1 V-$}

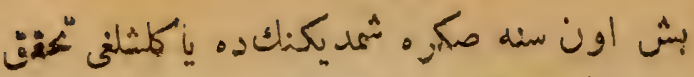

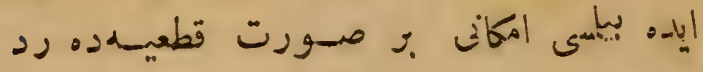
إيديلهن

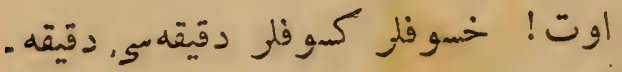

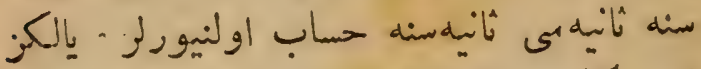

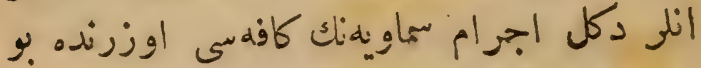

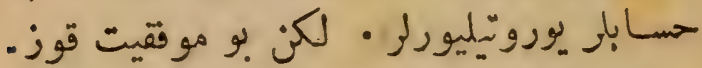

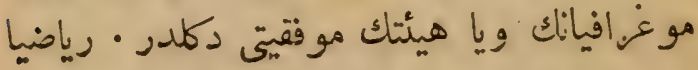

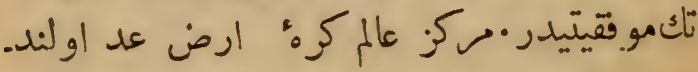

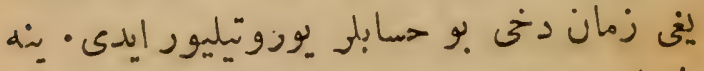

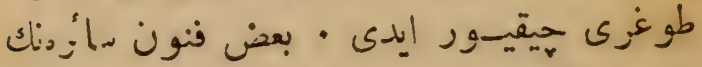

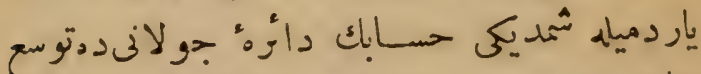

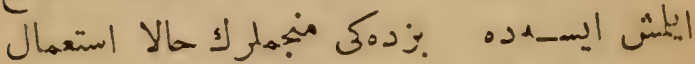

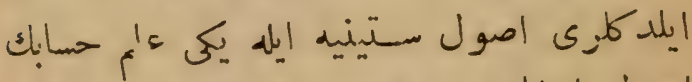

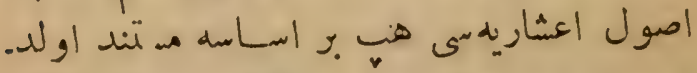

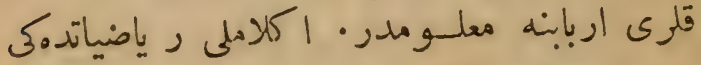

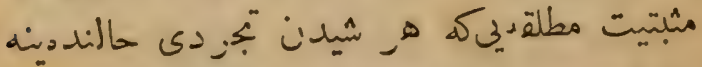

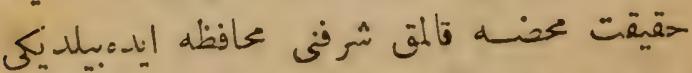

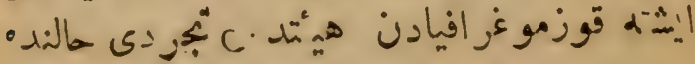




\section{$-19-$}

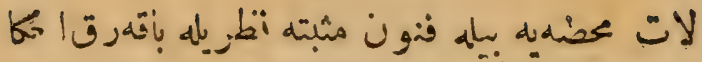

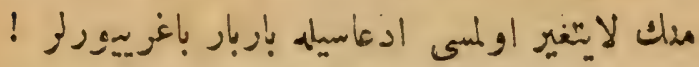

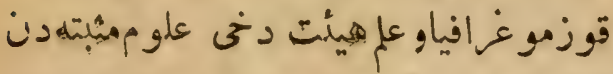

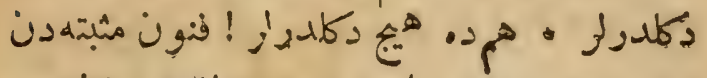

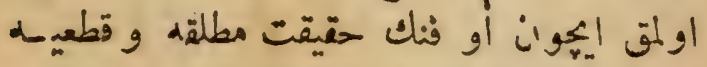

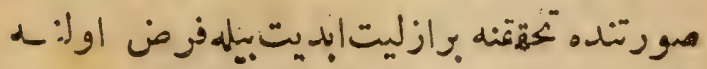

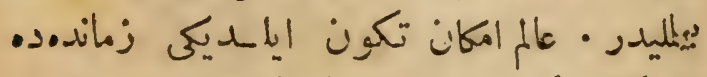

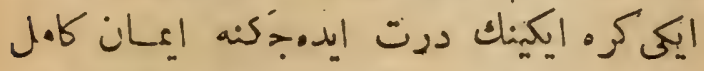

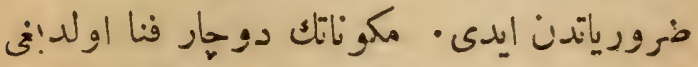

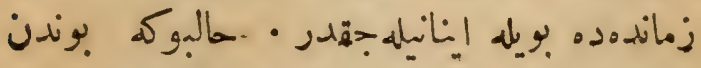

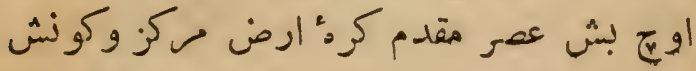

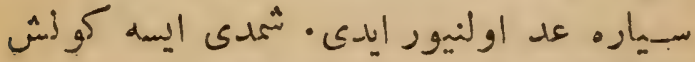

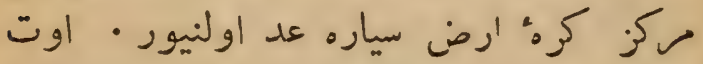

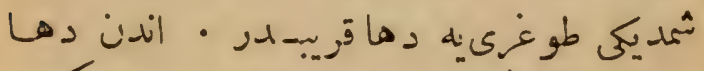

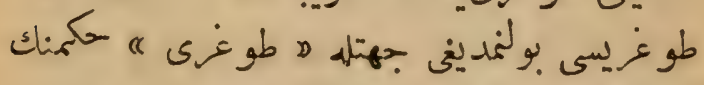

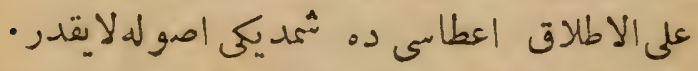

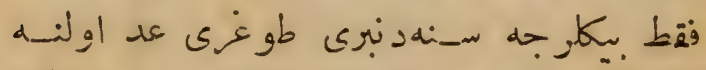

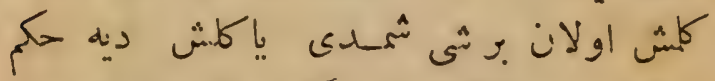

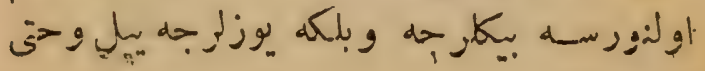




\section{$-10$}

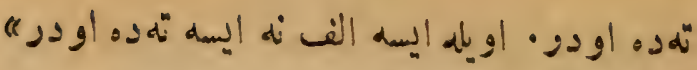

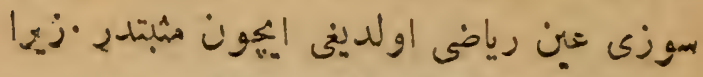

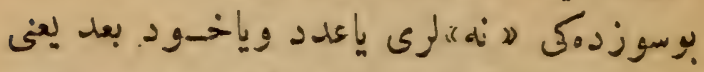

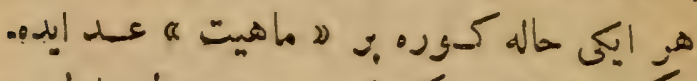

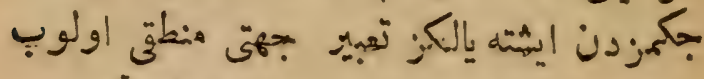

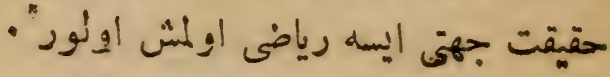

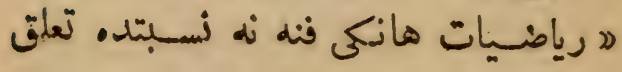

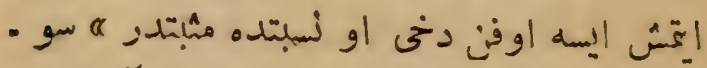

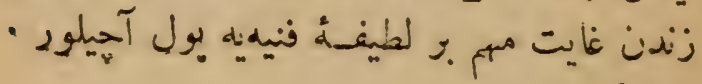

ها قوزموغز افيا ياخود هيئت ننون مثبته.

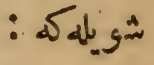

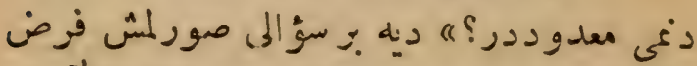

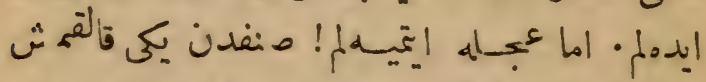

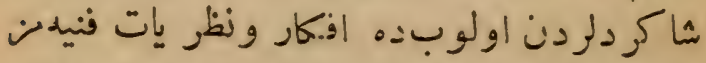

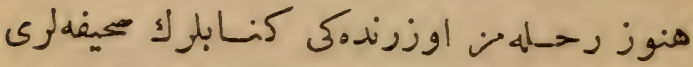

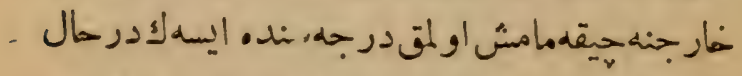

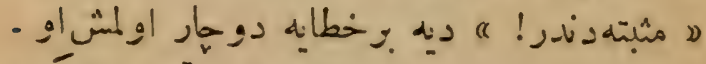

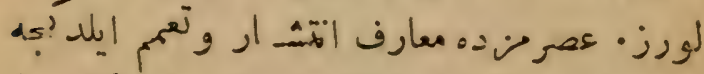

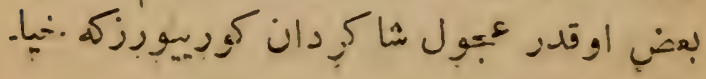




\section{- $1 \varepsilon-$}

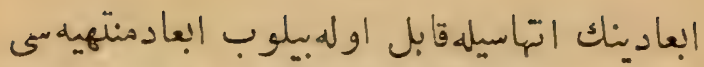

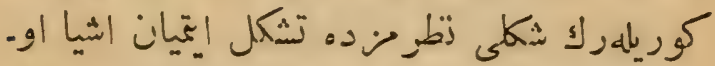

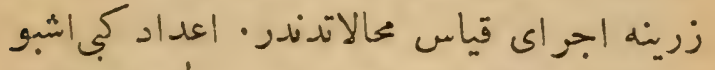

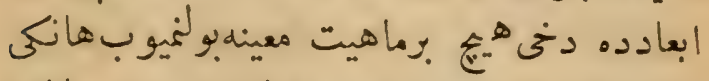

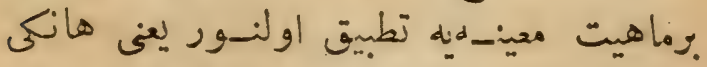

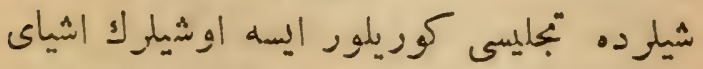

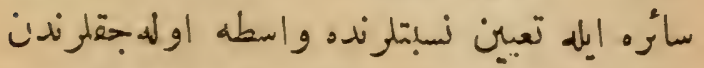

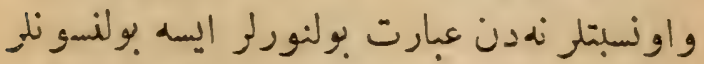

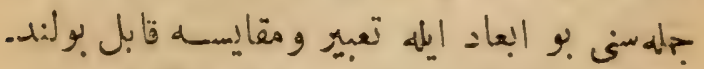

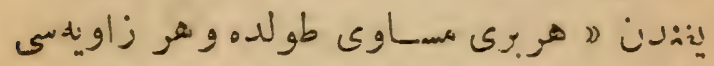

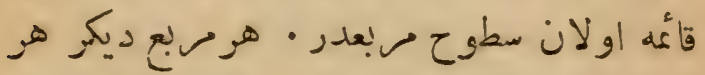

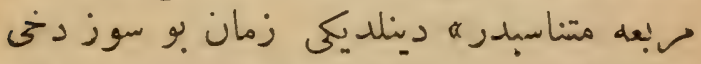

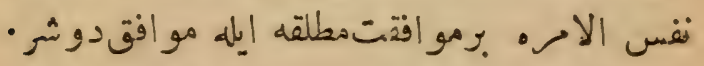

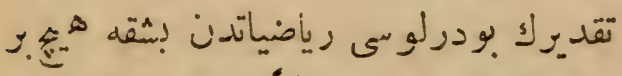

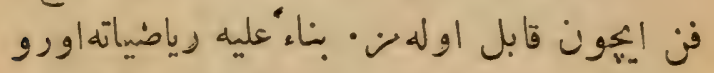

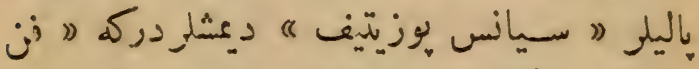

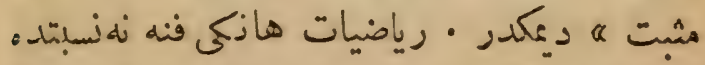

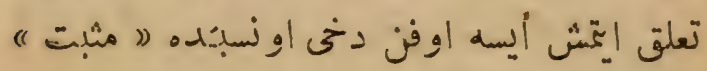

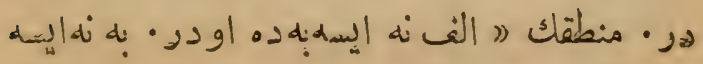




\section{$-1 \mu-$}

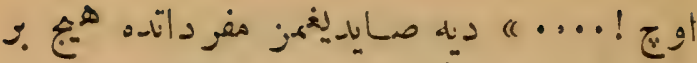

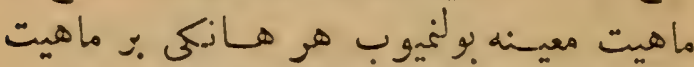

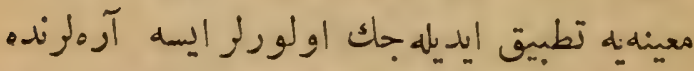

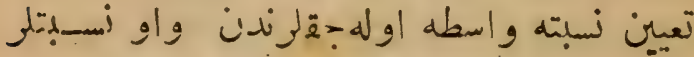

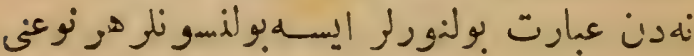

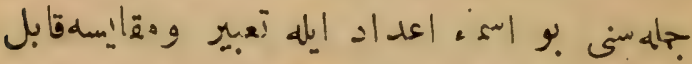

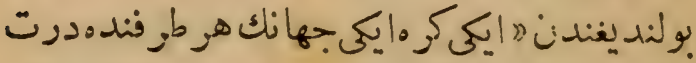

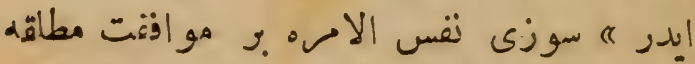

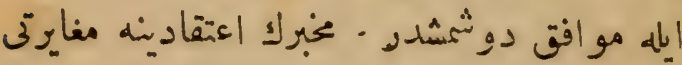

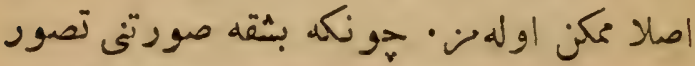

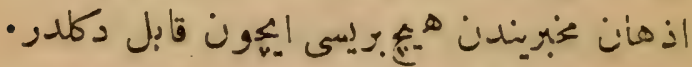

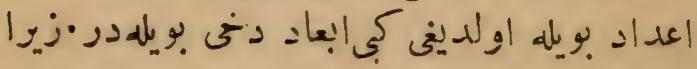

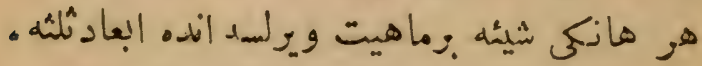

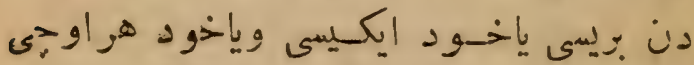

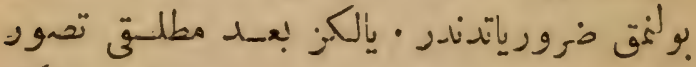

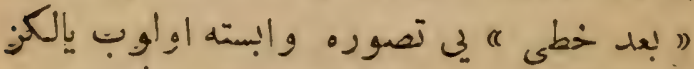

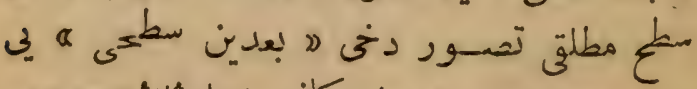

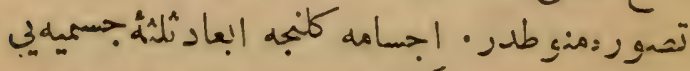

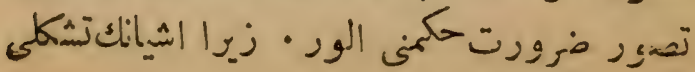


- ir -

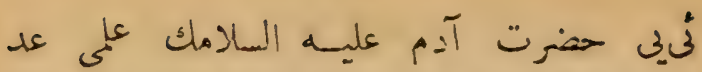

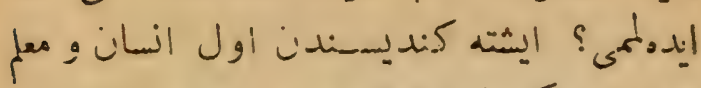

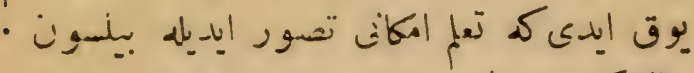

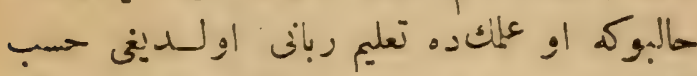

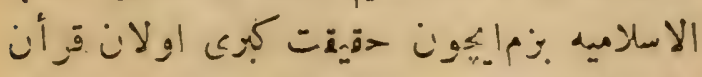

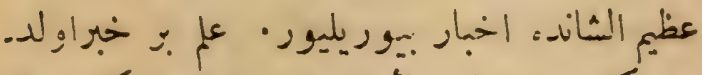

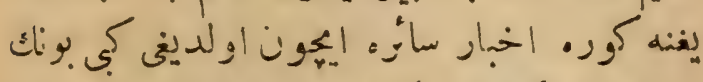

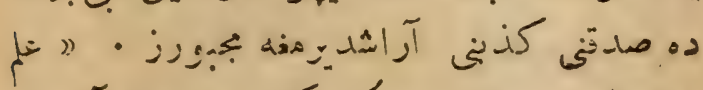

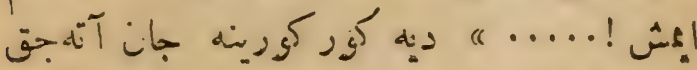
دكاز يا؟ ؟

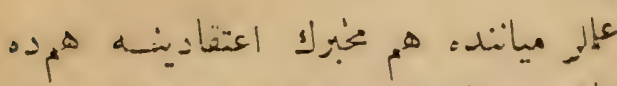

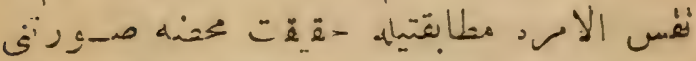

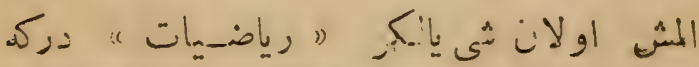

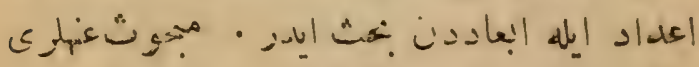

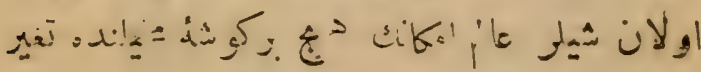

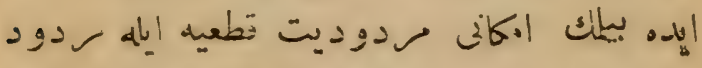

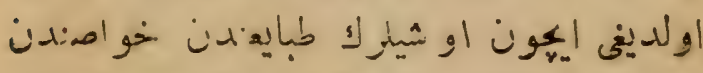

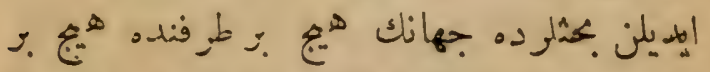

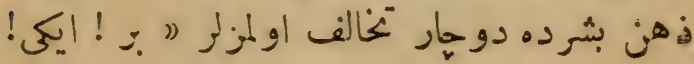




\section{$-11-$}

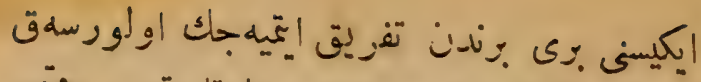

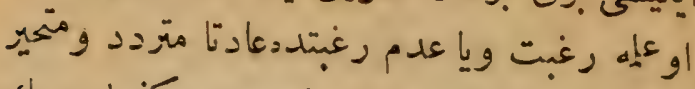

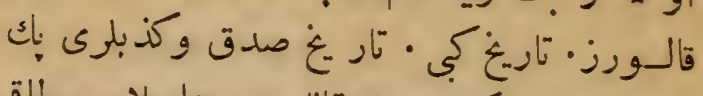

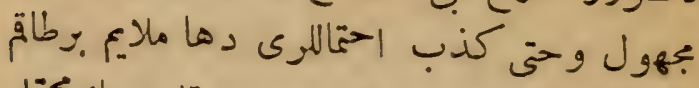

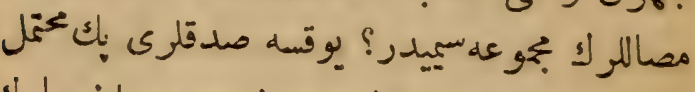

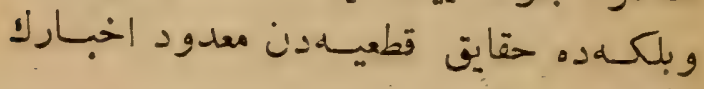

$$
\text { ؟ }
$$

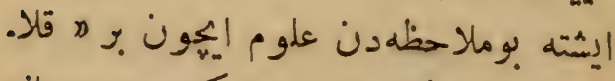

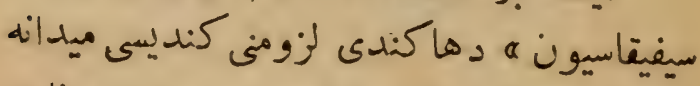

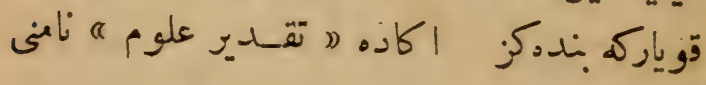

\section{ويّيבون}

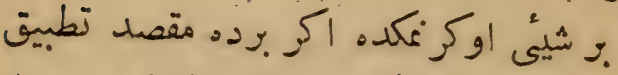

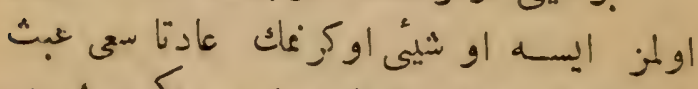

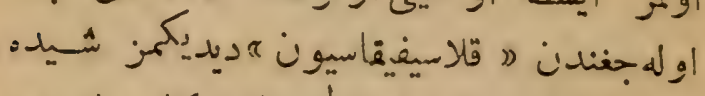

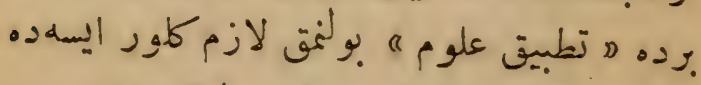

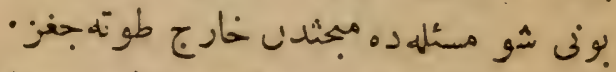

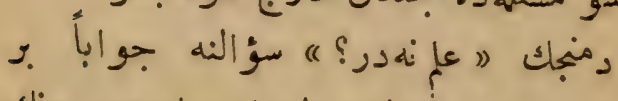

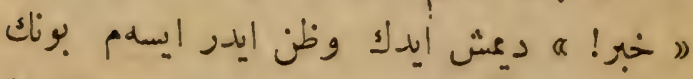

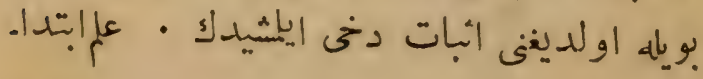




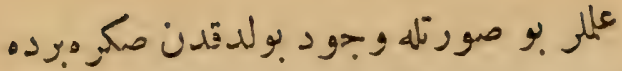

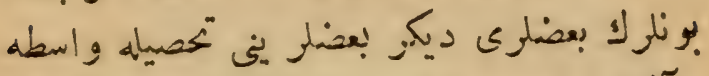

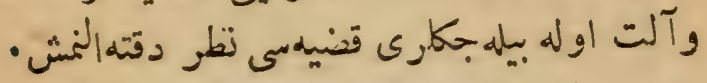

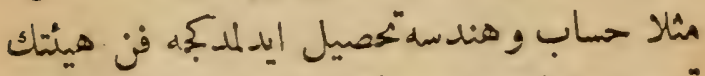

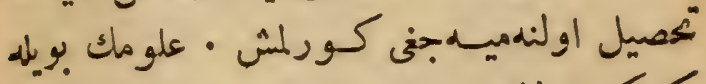

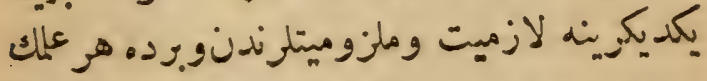

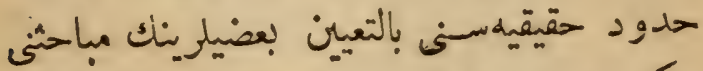

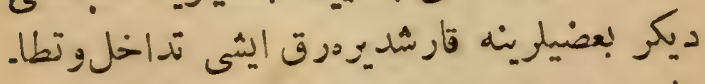

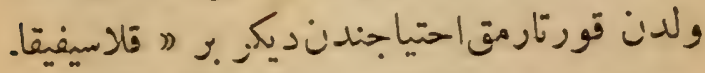

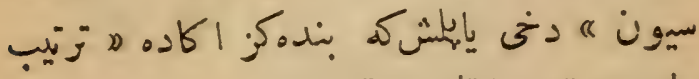

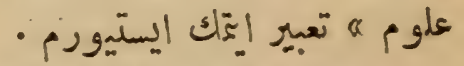

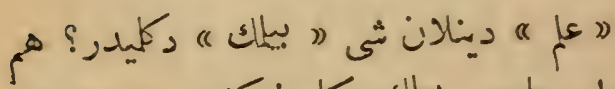

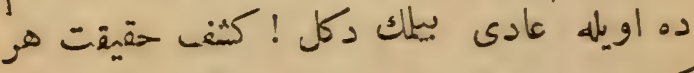

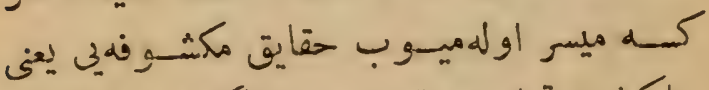

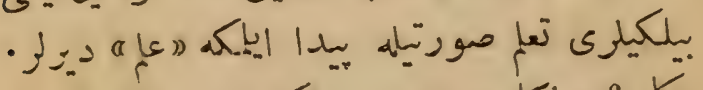

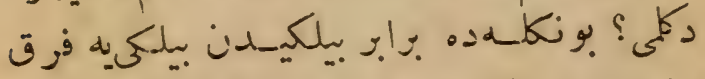

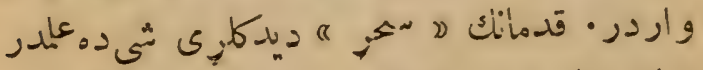

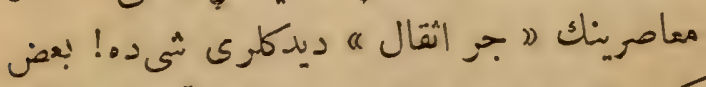

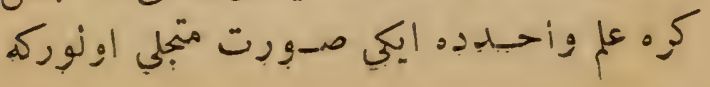




\section{- $4-$}

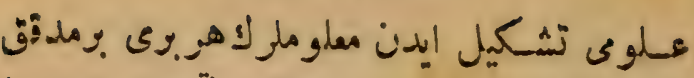

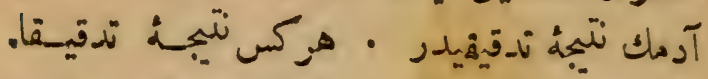

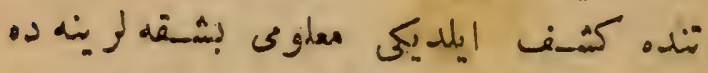

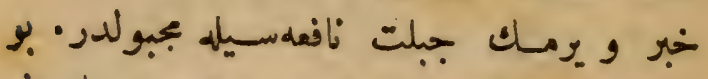

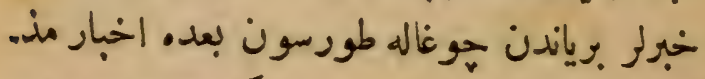

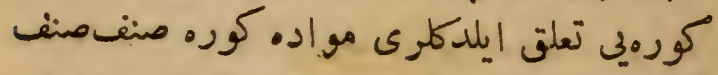

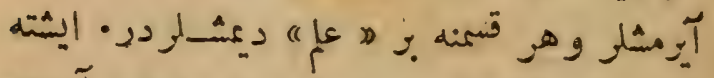

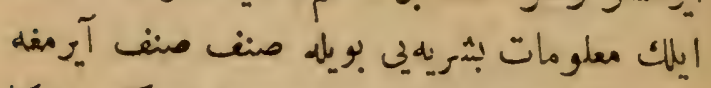

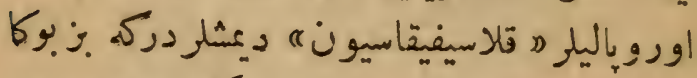

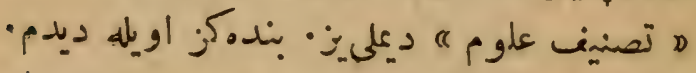

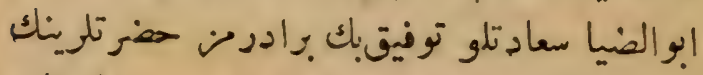

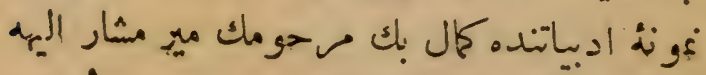

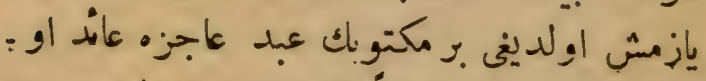

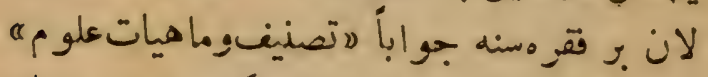

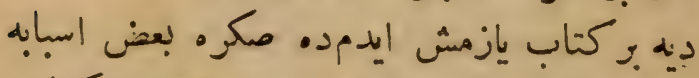

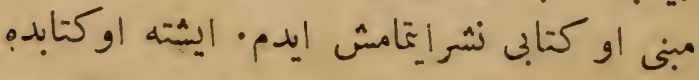

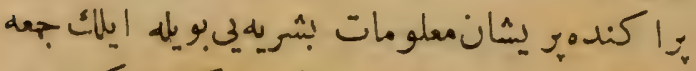

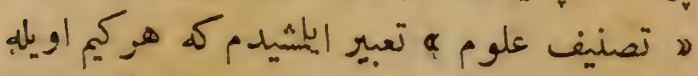

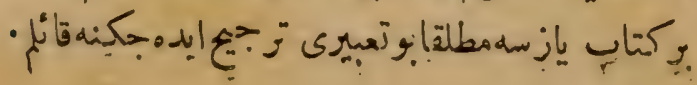




\section{$-\lambda=$}

هانيا منطق اوقور ابكن فناريدمى ايدنى

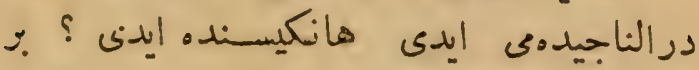

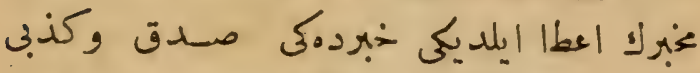

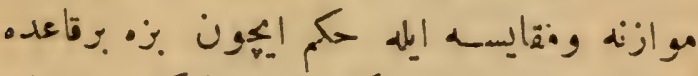

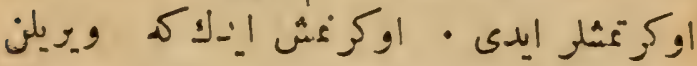

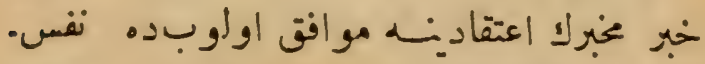

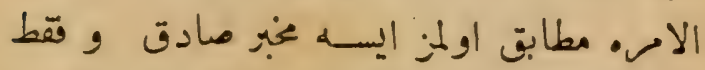

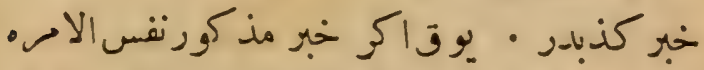

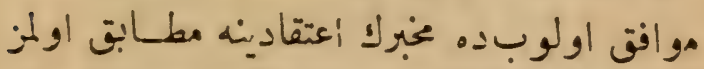

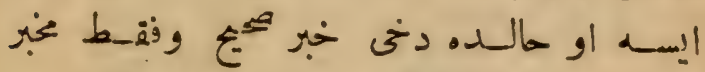

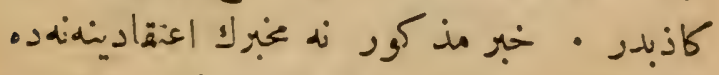

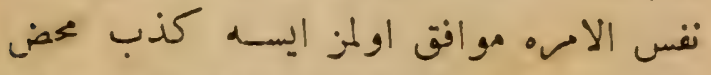

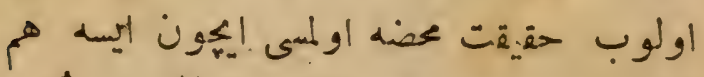

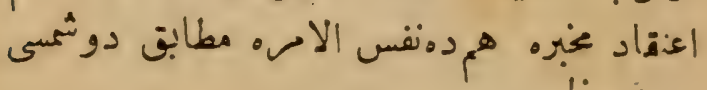

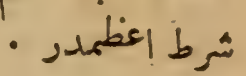

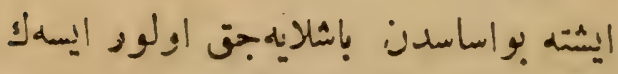

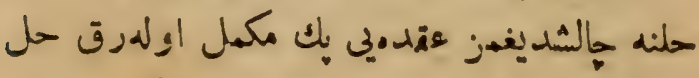
ابدهبلونوز

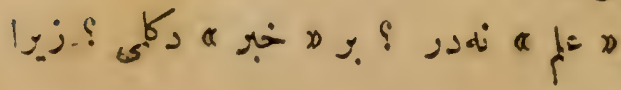




\section{$-v$}

بولنديور · باقى هميثه اولكز باقق !

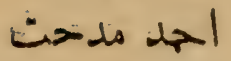

\section{站表}

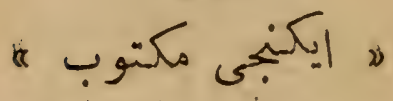

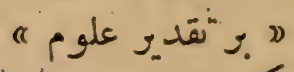

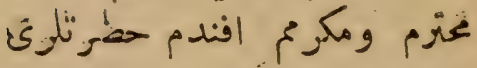

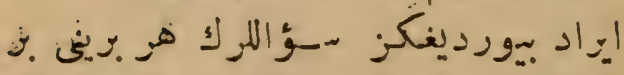

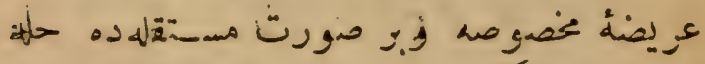

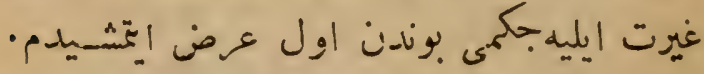

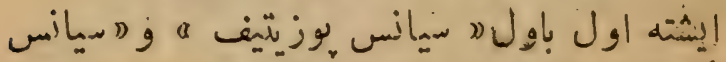

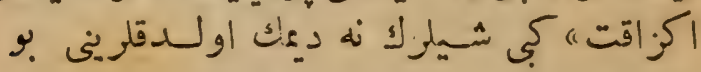

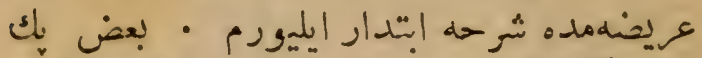

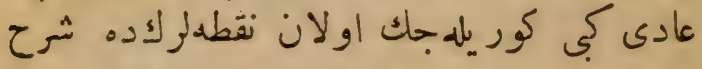

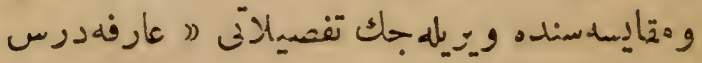

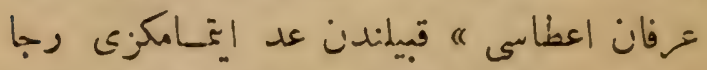

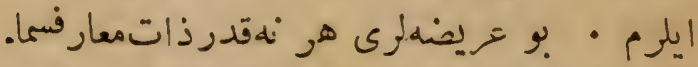

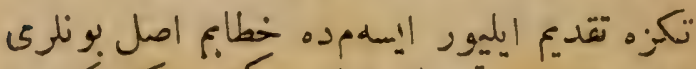

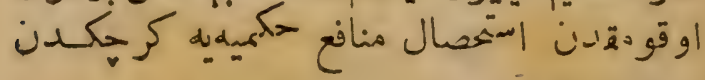

$$
\text { بكتاج إولانلزمدرد. }
$$




\section{- $-\cdots$}

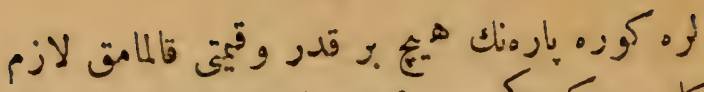

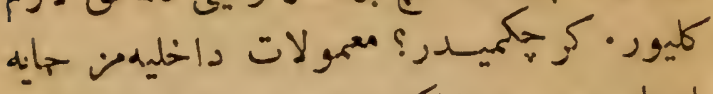

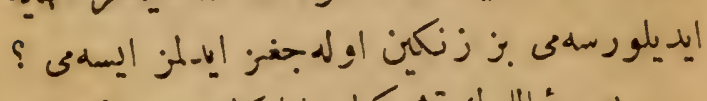

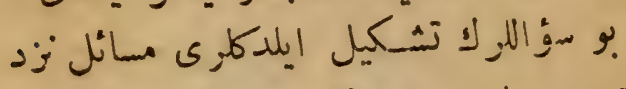

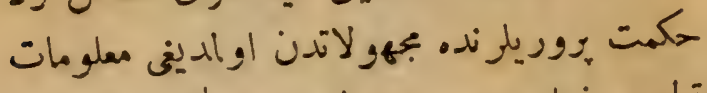

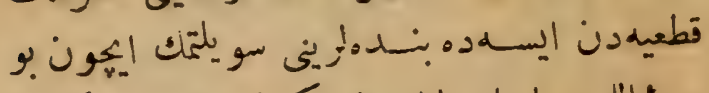

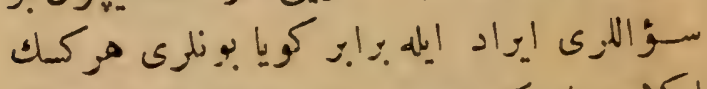

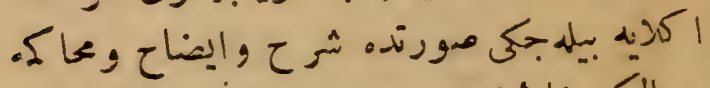

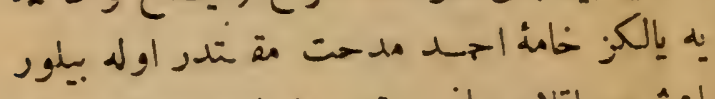

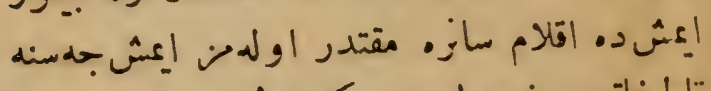

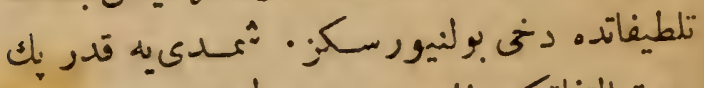

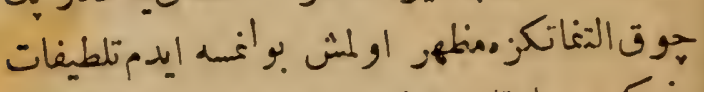

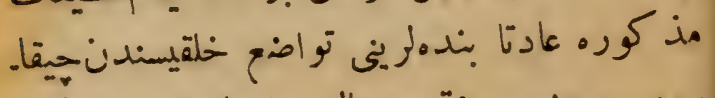

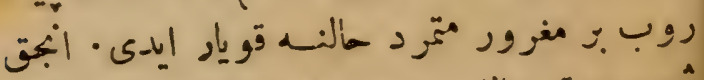

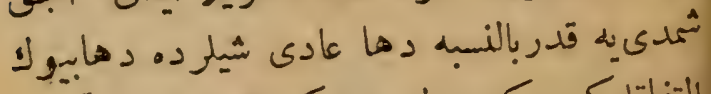

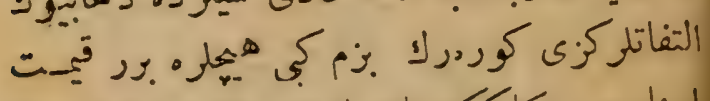

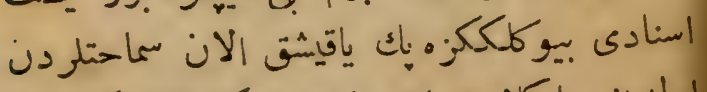

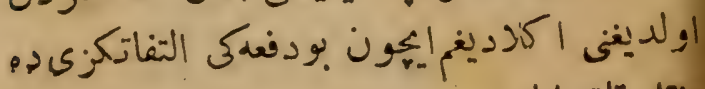

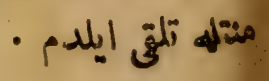




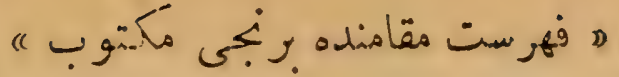

\section{عزيز وميحتر افندم حضرتلّى !}

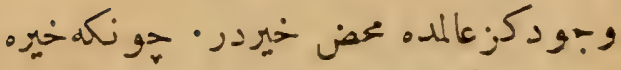

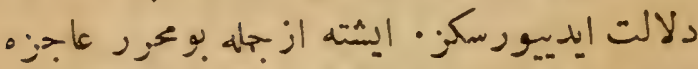

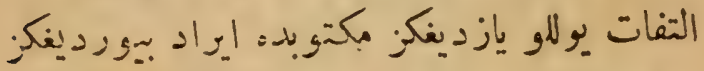

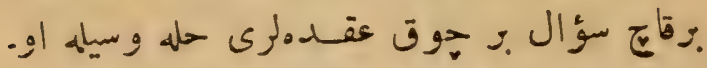

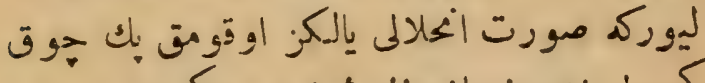

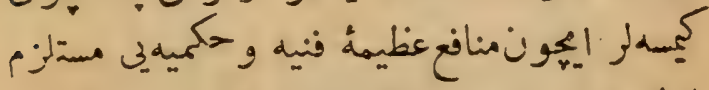

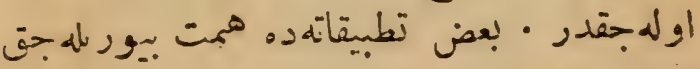

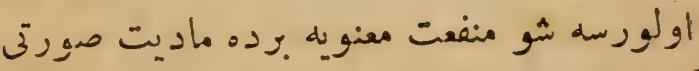

$$
\text { كسب إيدر: }
$$

$$
\text { صورييورسكزكم : صدرون }
$$

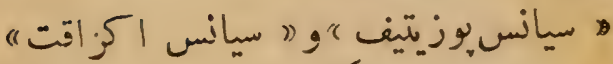

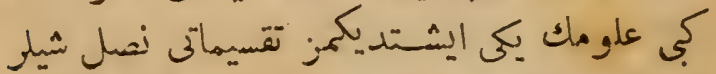

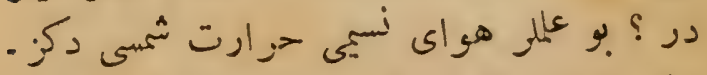

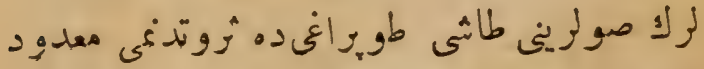

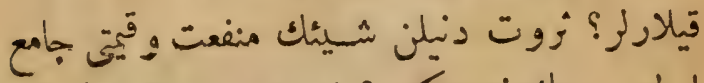

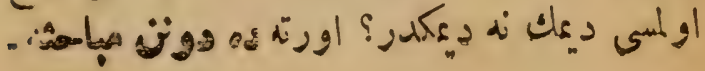


$-r-$

قدر لر ينى ميدانه هيقار من خصسورصنده

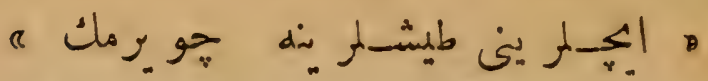

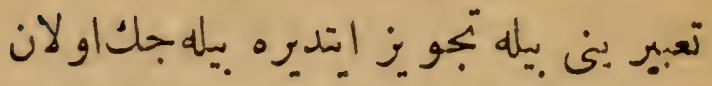

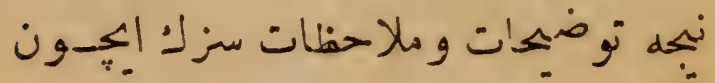

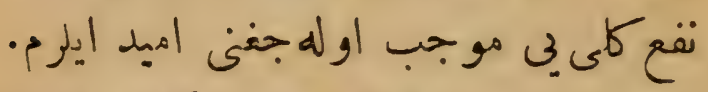

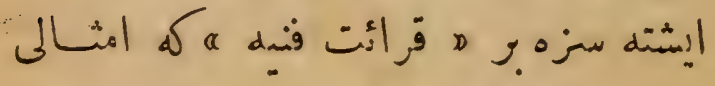

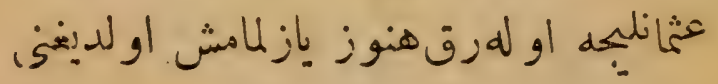

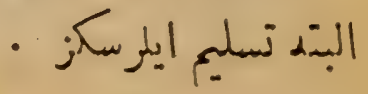

احدمدحت

$-0$ 


\section{$\frac{6}{7}$ \\ $A 25$ 1889}

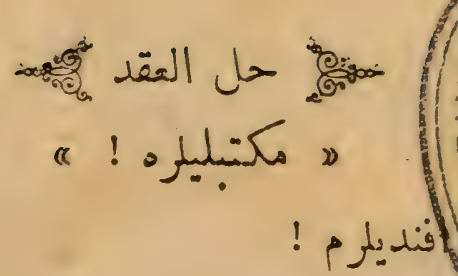

ماهيات وتقديرات علو ده دارؤاحبادن

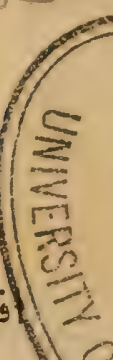

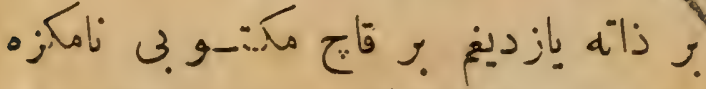

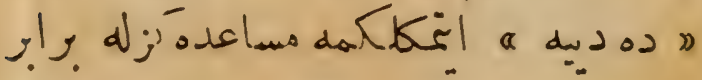

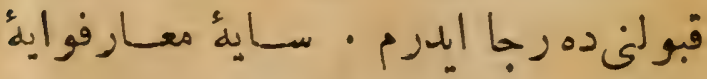

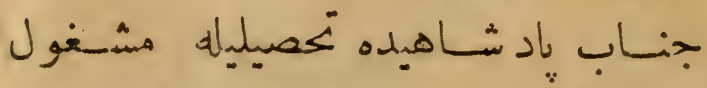

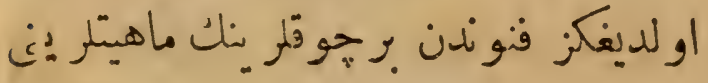




$$
\begin{aligned}
& 4036
\end{aligned}
$$

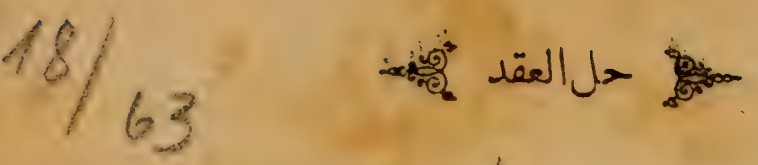

Ahmet Mithat

مر

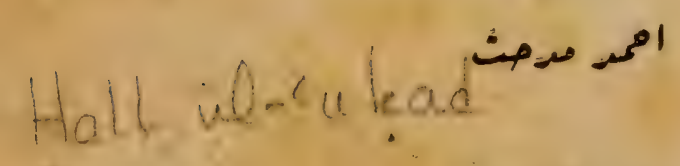

|زرجان حقيقت غنتهنه درج إدلدكدن

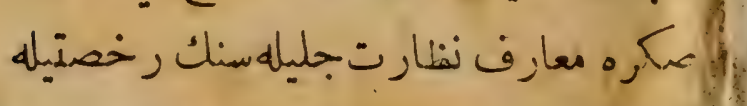

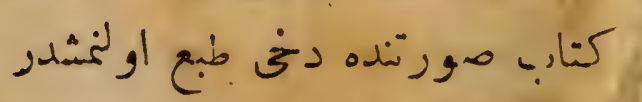

.

$$
1 r \cdot V
$$




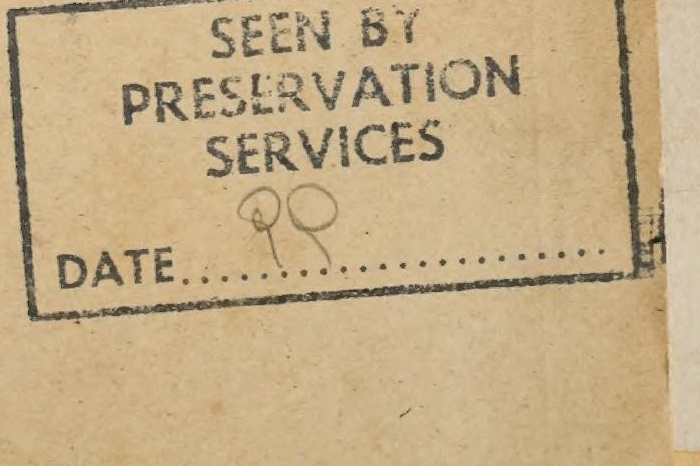





\section{PLEASE DO NOT REMOVE}

CARDS OR SLIPS FROM THIS POCKET

\section{UNIVERSITY OF TORONTO LIBRARY}

Q

171

A25

1889

P\&ASci
Ahmet Mithat $\mathrm{Hall}$ ül-'ukad

\section{SERW B}

PRESLRYATHA

SERVIEES

DATE.... 

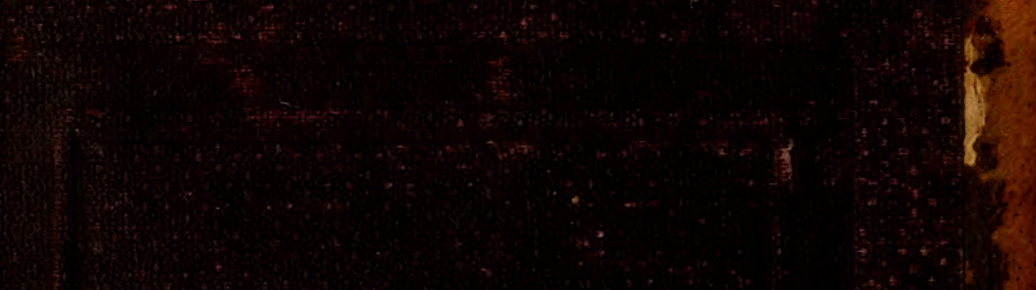

ats 